1928

\title{
History of Medicine in Nebraska
}

University of Nebraska Medical Center

Tell us how you used this information in this short survey.

Follow this and additional works at: https://digitalcommons.unmc.edu/hist_books

Part of the Education Commons

\section{Recommended Citation}

University of Nebraska Medical Center, "History of Medicine in Nebraska" (1928). University of Nebraska Medical Center: Historical Books. 1.

https://digitalcommons.unmc.edu/hist_books/1

This Book is brought to you for free and open access by the University of Nebraska Medical Center: Books at DigitalCommons@UNMC. It has been accepted for inclusion in University of Nebraska Medical Center: Historical Books by an authorized administrator of DigitalCommons@UNMC. For more information, please contact digitalcommons@unmc.edu. 


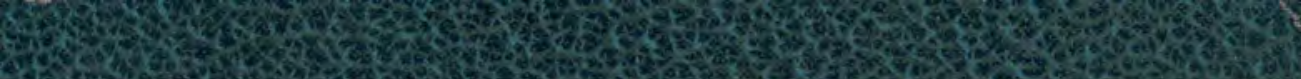

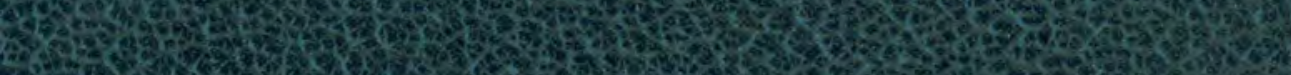


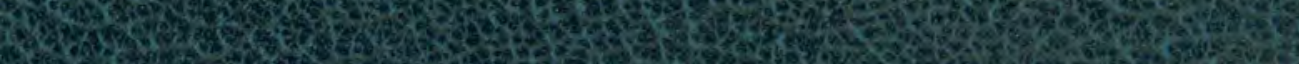
H.

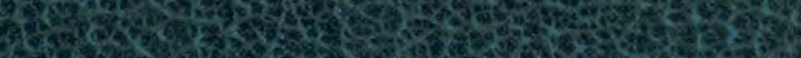

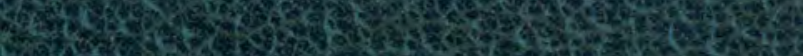

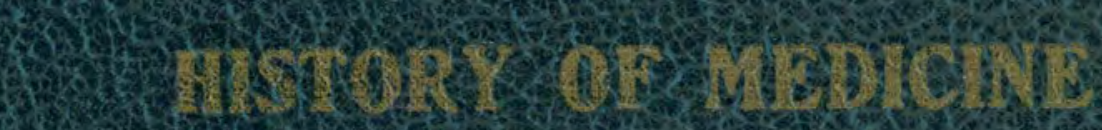
NELUBRAST:

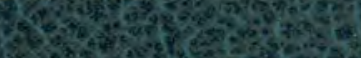
(1)

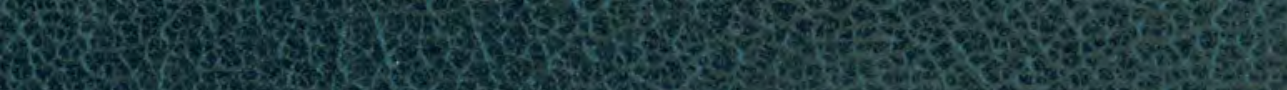

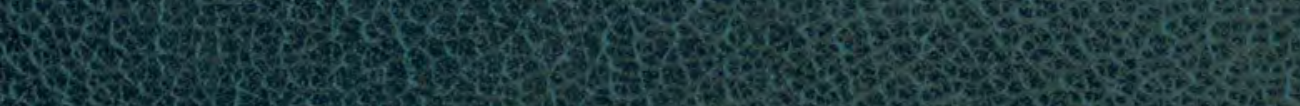
Din

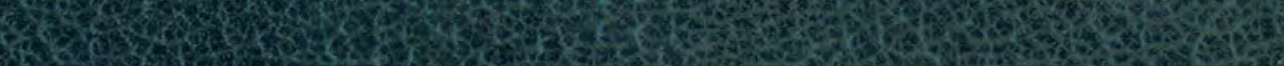

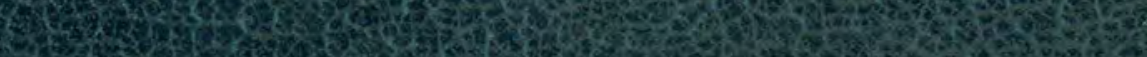

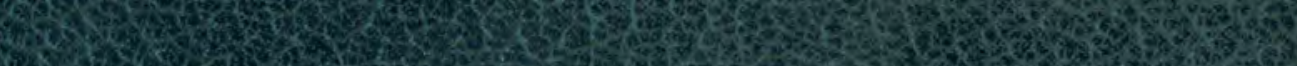

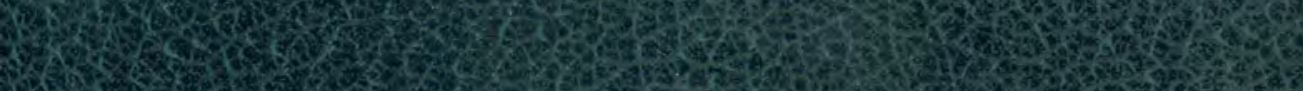

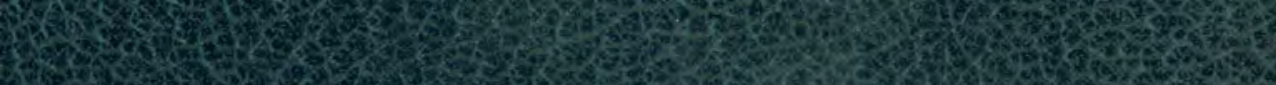

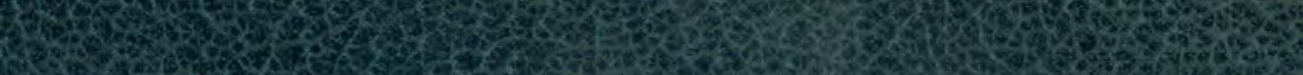
30. 



\title{
HISTORY OF MEDICINE I N \\ N E B R A S K A
}

\author{
Albert F. Tyler, Editor \\ Ella F. Auerbach, Compiler
}
Magic City Printing Co. 2421 O St., Omaha 1928

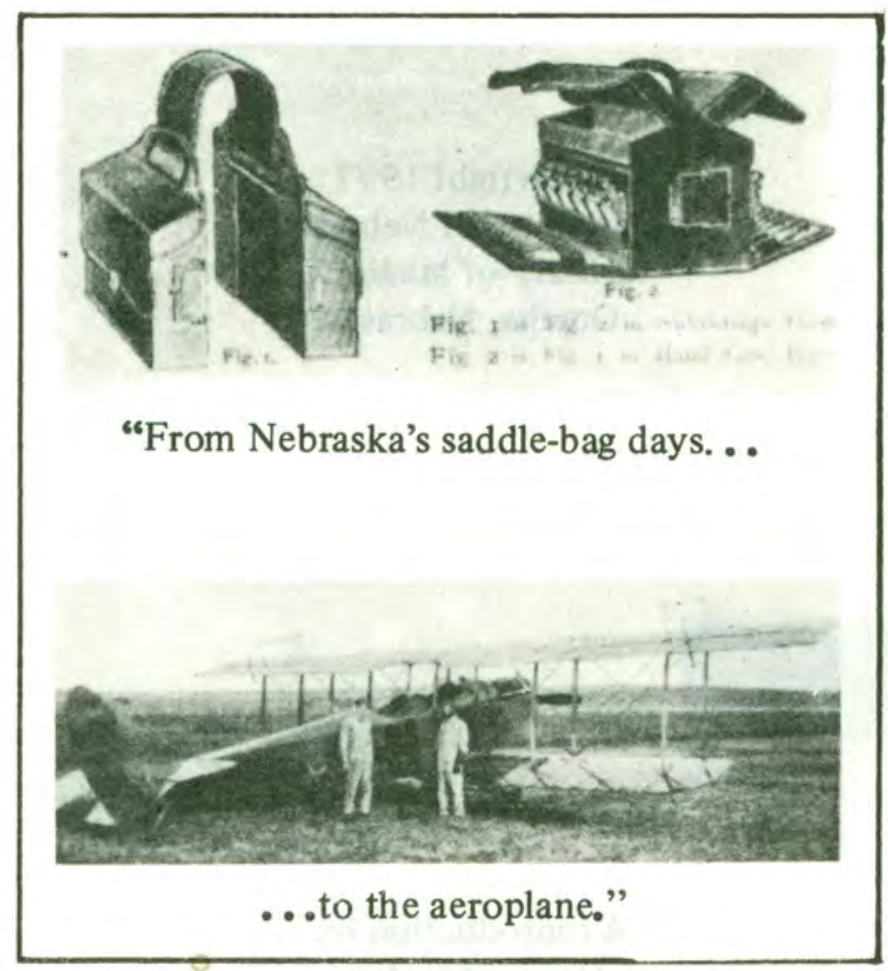

Augmented by

Bernice M. Hetzner

University of Nebraska Medical Center

Omaha, Nebraska 


\title{
Illustration of saddle-bags from The Prarie Doctor
}

\author{
By F. A. Long, 1937 \\ Courtesy of Huse Publishing Company \\ Norfolk, Nebraska
}

\author{
Copyright 1977 \\ University of Nebraska \\ Library of Medicine \\ Omaha, Nebraska
}

A reproduction by

Unigraphic, Inc.

1401 North Fares Avenue

Evansville, Indiana 47711 


\section{History of Medicine in}

Nebraska

ALBERT F. TYLER. M.D., Editor

ELLA F. AUERBACH, Compiler

Illustrated

Magic City Printing Co.

2421 O St., Omaha

1928 


\section{History of Medicine in Nebraska}

Albert F. Tyler, M.D., Editor

Ella F. Auerbach, Compiler

\section{Advisory Committee}

W. O. Bridges, M.D.

Omaha

E. A. Buchanan, M.D.

Fremont

C. B. Calbreath, i.D.

Hastings

A. N. Compton, M.D.

Valentine

E. A. Creishton, M.D.

Red Cloud

C. P. Fordyce, M.D.

Falls City

C. K. Gimbons, M.D.

Kearney

J. P. Gilligan, M.D.

ONeill

J. E. Hartwell, M.D.

Crawford

C. L. Husfead, M.D. Falls City

H. M. Hepperlen, M.D.

Beatrice

T. P. Livingston, M.D. Plattsmouth
F. A. Long, M.D. Madison

B. R. McGrath, M.D. Grand Island

D. T. Martin, M.D.

Columbus

IV. F. Milroy, M.D.

Omaha

A. R. Mrtchell, M.D. Lincoln

C. L. Mullins, M.D. Broken Bow

Morris Nielsen, M.D. Blair

H. W. ORR, M.D.

Lincoln

F. W. Plehn, M.D. Scottsbluff

J. B. Redfield, M.D.

North Platte

E. C. SAge, M.D.

Omaha

J. A. Willis, M.D.

McCook 


$$
\begin{gathered}
610.9 \\
T 97
\end{gathered}
$$

To

the members of the medical profession

of Nebraska whose heroic achievements have inspired this volume, and whose cooperation has made it possible, this book is affectionately dedicated. 


\section{TABLE OF CONTENTS}

Foreword by Dr. A. F. Tyler.

Early History.

The First Physicians and the First Scurvy Epidemic in Nebraska-Indian Contacts.

Pioneers.

Part I 1854-1880.

Part II 1880-1900.

Physicians in Politics.

Medical legislation-Organization of State Board of Health-Office-Holders.

War Service.

Nebraska Physicians Respond to Call-Pinto Yellow Fever Inoculation-Connell Gas Mask-Omaha Ambulance Company-Base Hospital No. 49.

Women Physicians.

Early Women Practitioners Encounter Indians-Hardships Incident to Pioneer Life-Achievements of Note. Publications.

Omaha Clinic-Western Medical Review-Nebraska State Medical Journal-Bi-Weekly Bulletin of Douglas County-National Magazines published in Omaha.

Scientific Achievements.

Research-Inventions-Arts and Letters-Polar Expeditions-In Foreign Climes-National Distinctions.

Colleges.

University of Nebraska Medical College - John A. Creighton Medical School-Lincoln Medical School of Cotner University-Nebraska Wesleyan.

Organizations.

Hospitals.

Omaha Medical Arts Building.

Directory of Nebraska Physicians. 


\section{INTRODUCTION}

History of Medicine in Nebraska, edited by Albert F. Tyler, M.D., and compiled by Ella F. Auerbach was, as stated in the Foreword, an effort to put on record the story of the development of medical practice in Nebraska from saddle-bag days to the aeroplane. Accordingly, all available sources were searched, and many individuals provided firsthand knowledge to the project

The title page shows the imprint: "Omaha, Nebraska, Magic City Printing Company, 1928." However the book did not appear until 1930. The spine on some copies carries the later date, and some subject areas include events transpiring in late 1928 and in 1929. When the book appeared, Francis A. Long, M.D., editor of the official journal of the Nebraska State Medical Association, published (Nebraska State Medical Journal 15:167, Apr. 1930) a review of the long-awaited volume, praising the accomplishment, but regretting the lack of an index. Dr. Long also noted that the volume contained typographical errors, some errors of dates and several transposed sentences.

The absence of an index required that the user resort to a random search based on chapter headings for information on people, places and events. Particularly frustrating to the scholar who desired to pursue a subject of interest was the omission of documentation, which might lead to more in-depth study.

This publication is an attempt to correct some of the deficiencies in the original volume, and has been issued in an attempt to provide for more efficient use of the volume by supplying an index, by correcting errors, both typographical and of fact, and by supplying documentation for 
further investigation wherever possible.

Subsequent to the distribution of the Tyler volume, many readers having personal knowledge of individuals and events covered by the book made notes and annotated their personal copies to provide additional pertinent information. Fortunately for the record, some of these marked copies as well as personal communications found their way into the Library of the University of Nebraska Medical Center. Current access to sources provided through modern methods of information retrieval has made it possible to shed new light on the events of the past. The present work is the outgrowth of information collected over a number of years by librarians who felt a desperate need for an index to a reference volume, and one librarian in particular who has a passion for accuracy and a desire to set the record straight for future students of Nebraska medical history.

No attempt has been made to update the information in the belief that that should be the content of another volume, which will carry the record from the late 1920's to some more recent date.

The corrigendum and notes which follow each chapter should be used as a page-by-page addendum to the text in order to revise the content where necessary. A source publication or manuscript is cited to verify facts as far as possible. In the instances where conflicting information has been located, the corrigendum and documentation includes the note "For other accounts, see..."

Tyler's dedication reads: "To the members of the medical professions of Nebraska, whose heroic achievements 
have inspured this volume, and whose cooperation has made it possible, this book is officially dedicated." It seems therefore, entirely fitting that the current contribution should be undertaken with the support, in part, of the Elizabeth Abbott Pioneer Physicians of Nebraska Fund.

Raw data for the indexes were compiled by Jennifer R. Harvey, with the generous support of her father, Donald A. Harvey, M. D., Nebraska '57. For the arduous task of searching for documentation and for the preparation of the manuscript, the assistance of Debra Schreiner Dimmick, Claire Gadzikowski, Cindy Home and Melanie Cimpl is hereby acknowledged.

The entire project was made possible by the support and encouragement of Robert D. Sparks, M.D., former Chancellor of the University of Nebraska Medical Center; Perry Rigby, M.D., Dean; and Robert B. Kugel, former Dean, University of Nebraska College of Medicine.

Bernice M. Hetzner, A.B., M.A.

Emeritus Professor

Librarian for Nebraska Medical History

University of Nebraska Medical Center 



\section{FOREWORD}

E2 Rom saddle-bags to aeroplane is the development that has occurred in Nebraska medicine since the state was first inhabited by white men. To put on record that story of progress is the purpose of this book. All available sources have been searched and large numbers of individuals have been interviewed so that the book might be historically accurate and at the same time an interesting tale of human achievement.

At this time when certain members of the medical profession are inclined to think that romance is no longer present in medicine, it may be of value to look into history. We learn of the cure of a scurvy epidemic among the soldiers at Camp Missouri, later Fort Atkinson and Fort Calhoun, 1819, by the eating of raw wild onions as suggested by a friendly Indian Chief. His daughter later became the wife of Dr. Gale, and his granddaughter the only American Indian woman physician.

There are still present in our midst two surgeons, J. E. Summers and A. F. Jonas, who were the first in Nebraska educated after aseptic methods were introduced. When they came, the late Victor Coffman was doing ovariatomies, wearing 
flannel sleevelets over his shirtsleeves to keep them from getting soiled. Tracheotomies were a frequent emergency operation in diphtheria cases because of the lack of antitoxin.

The search of sources reveals in an interesting manner the part taken by physicians in the community life. A long list of political offices, from a member of the school board to the legislature, have been held by physicians. In music, in art, in war, in business, the Nebraska physicians have done their bit. Since no full record of these achievements of the medical profession in Nebraska had ever been made, it seemed advisable to compile the book at this time during the evening of the life of that intermediate generation of the profession which followed the early pioneers and preceded the moderns.

When that intermediate generation began the practice of medicine, things were materially different than now. Those were the saddle-bag, bedside manner days. The family physician was not only an advisor in health matters, but was a counsellor in spiritual affairs. In many ways he stood closer to the lives of his patients than even the minister. His counsel was sought from birth to death. He helped the patient through the various illnesses of life and guided him through the vicissitudes of love and business. Microscopes were few and $\mathrm{x}$-rays were unknown, so that many things were done empirically. The doctor's skill 
reflected his sympathy and knowledge of human nature quite as much as it did his science. He was essentially a man with a big heart, ready, at all times, to help smooth the rough places in the path of life.

This book, we hope, will show the transition taking place in the practice of medicine. The various activities of the physicians sketched here reveal the intimate contact which the doctor has with the many activities of the community.

For the success of the work grateful appreciation should be rendered for the co-operation of the various librarians of the State, the State Historical Society, the county clerks, the state officials, the newspapers, the Nebraska State Medical Journal, the relatives of deceased pioneers, the officers of the various medical societies, the members of the advisory committee and the various physicians who have helped by their co-operation and suggestions. To the untiring efforts of Ella Fleishman Auerbach, the compiler, the success of this undertaking is due. Her skill as a journalist, her knowledge of sources, her fine diplomacy and unswerving loyalty deserve our highest commendation.

\section{Albert F. Tyler.}





\title{
EARLY HISTORY
}

\author{
THE FIRST PHYSICIANS AND THE FIRST EPIDEMIC IN
}

NEBRASKA-INDIAN CONTACTS

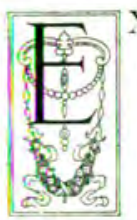

XCEPT for Indian medicine men, who undoubtedly served their people for hundreds of years before the advent of the white man, the history of medicine in Nebraska can be traced back to the week of September 26, 1819. On this memorable day, United States troops came up the Missouri river on the first steamboat to disturb the turbid waters of the "Big Muddy," and landed near the Council Bluffs, about 16 miles north of Omaha, on the present site of Fort Calhoun. They built there Major Long's Engineer Cantonment, called successively Camp Missouri, Fort Atkinson, after the general in command; and later, Fort Calhoun.

The Council Blufis got their name as the location where Lewis and Clark held two councils with the Indians in 1804-with the Otoes and Missouris on August 3 and with the Omahas, a little farther up, on August 19. It has no connection with Council Bluffs, Iowa, the sister city across the river from Omaha.

Attached to these troops, the Sixth Infantry regiment and the New Hampshire Rifle Regiment, 2nd Battalion, which landed on October 2, came two, and possibly four medical officers - the first white physicians to set foot on Nebraska soil. One of them, Surgeon John Gale of the Rifle Regiment was destined to be forever bound up with the history of this state by reason of his marriage with Ni-ku-mi, a daughter of the Iowas. Their child, Mary, grew up and married Joseph La Flesche, chief of the Omahas, and the family's importance in the medical history of Nebraska was further enhanced when Susan La Flesche, their daughter and the granddaughter of Surgeon John Gale, also adopted a medical career and was graduated from the Woman's Medical College of Philadelphiathe only Indian woman ever to have obtained the degree of doctor of medicine. She afterwards married Henry Picotte, a half-breed Sioux. 
The other three physicians mentioned above were Surgeon Thomas G. Mower of the Sixth Regiment, whose arrival was delayed until November 10, because the steamboat "Johnson" on which his men embarked, was arrested in her progress about 300 miles up the river from Belle Fontaine, their starting point; and who afterwards rose to high rank in army medical circles and was president of the U. S. Army Board of Medical Examiners when he died in New York in 1853; one Nichols, whose name first appears in company records as "surgeon's mate" Nichols, then as "Doctor Nichols"; and Doctor Presley W. Craig.

The names of Gale and Mower will go down in medical history for all time because of the splendid reports they made of the terrible scurvy epidemic which almost wiped out the regiment during its first winter in the first military post in Nebraska - then the farthest western military post in the United States. Of 788 soldiers stationed there in January, 1820, nearly 500 fell ill of the scorbutus and 157 are known to have died and lie buried beneath the sod of this early cantonment, which was abandoned in 1827.

All the details of this dread epidemic - the first record of sickness in this state - are preserved in three sources, due to the industry and thoroughness of Surgeons Mower and Gale in making their reports, both to their immediate commanding officer, and to the Surgeon General's department.

These reports were first published in 1840 by Thomas Lawson, Surgeon General of the United States and a personal friend of Mower, under the title "Medical Statistics on the Sickness and Mortality in the Army of the United States." A copy is now in the possession of Dr. J. M. Banister of Omaha. Lawson compiled them from records in his office and that of the Adjutant General for a period of twenty years, including January, 1819 to January 1839. The second article was written in 1842 by Dr. Samuel Forry of New York, of Seminole Indian War fame, in the American Journal of Medical Sciences, edited by Dr. Isaac Hays. There is a copy of this book in the library of the University of Nebraska Medical College.

Both of these articles were based on the original reports of Surgeons Mower and Gale, made to their superior officers; and on company records of the Sixth Regiment, which is still preserved as 
a military organization and is now stationed at the Precidio, at San Francisen

Photographs of these original documents--now more than 100 years old as well as copies of the r content, are now in the possession of Addison E. Sheldon of the Nebraska Historical Society, who obtained them several years ago, through the courtesy of the present commanding officer of the Sixth Regiment. These records have accompanied the regiment to many posts during the past century and are still in an excellent state of preservation.

One of these photographs of the original record is shown on the following page. Probably in the handwriting of Surgeon John Gale, since his is the last name signed, it constitutes the first medical report of the outbreak of the dread scurvy. Its phraseology and spelling lend heightened interest to the communication, which is addressed to Colonel W. Morgan, the commanding officer:

\section{Camp Missouri, Febr. 6, 1820.}

"In complyance with your order, we have the honor to remark that the Scorbutic habit has assumed a distinguished rank among numerous diseases that afflict our camp. Independent of its own bain influence on the human system, it aggravates and renders more inveterate all the other diseases to which its unhappy victim is liable. It should therefore guard against with the utmost precaution that art can suggest or experience dictate should be used to put a period to its prevalence and its influence.

It is a disease occuring after subsistence on putrescent, salted animal food with a deficiency of vegetable matter, excessive fatigue, indolence, cold and moisture and personal uncleanliness may also be enumerated among its exciting causes. It is necessary that the men be compelled to air their bedding frequently and change their flannel often, washing their hands, face, feet and even their whole bodies previous to retiring, to bathe frequently in tepid water. Wiping dry with a coarse cloth will be very serviceable. Rooms should be kept perfectly clean with a free admission of air, guarding against cold and moisture with sufficient fires.

Salted provisions should be issued seldom as possible but fresh meat and such farinaceous subsistencies as can be procured, be substituted. 
liable it thoulb therfow Guand og

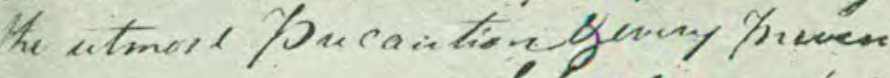

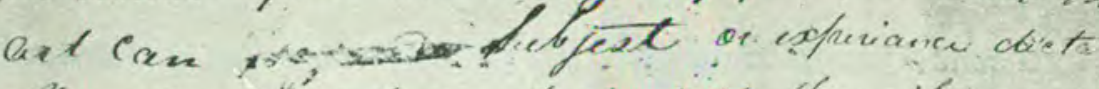
shoupd be wad to hot a frevind to its forevidence inulete its inflecance

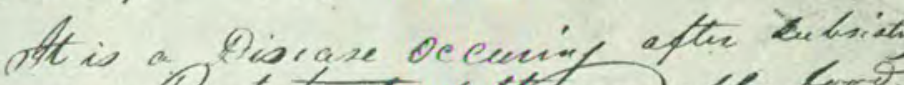
on Phustefont wathe end able hov

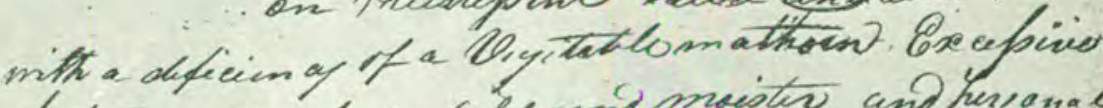

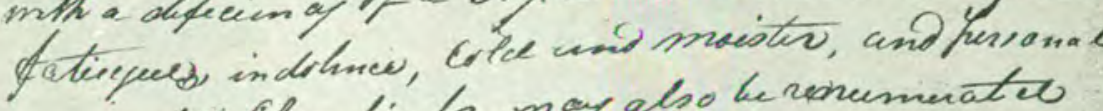
ciscleantioff, may also be renumerateo anseny its mary sciting. Causes It is ne eppay that the men be conf relled

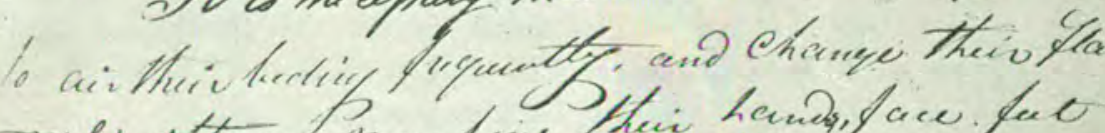

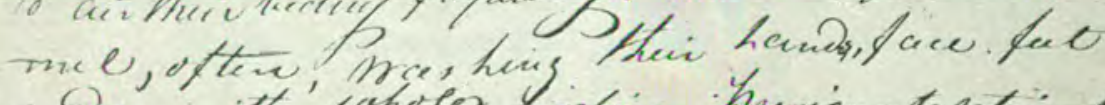

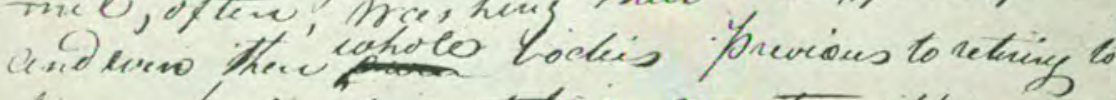
bearo frequently in tifice macter infuing dry with a Coune Clatt will be Borny dervecalle,

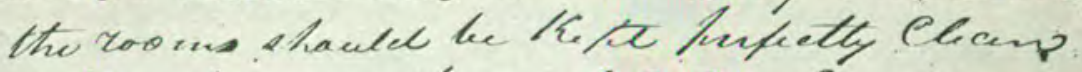

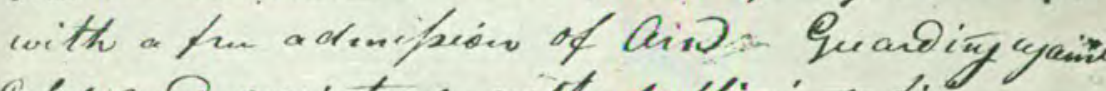

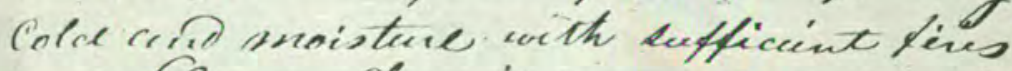
Pattie forovisions thoulce lus ifrend?

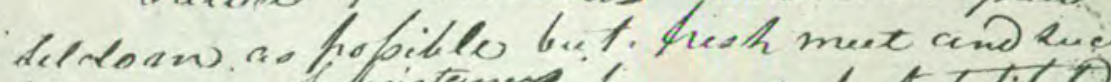

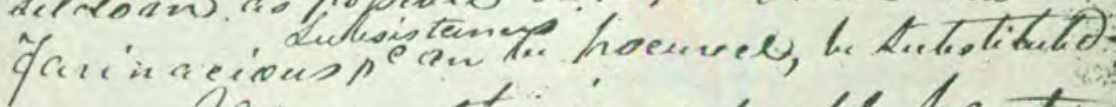
Divienar the involuable fiart

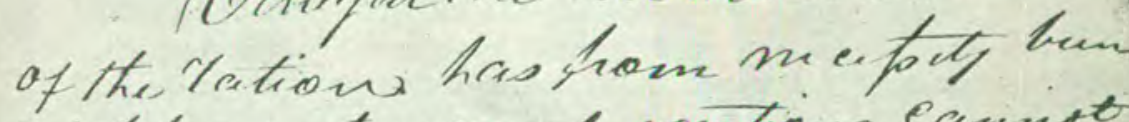
with here too mueh excition equngt beriaeres toremady this refeiciee of -

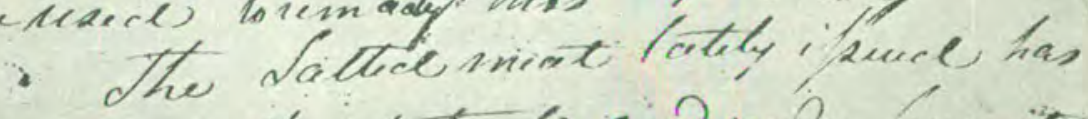

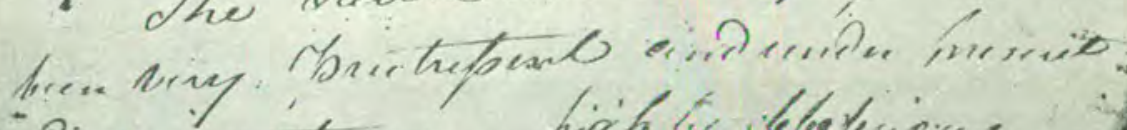

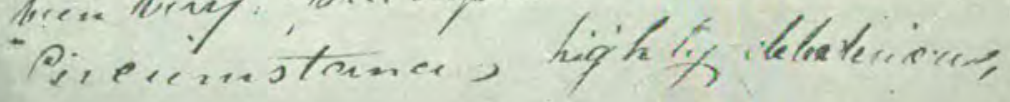

Photograph of the original report of Surgeons T. G. Mower and John Gale concerning the scurvy epidemic of $1819-1820$. 
Vinegar, the invaluable part of the ration has from necessity been withheld. Too much exertions cannot be used to remedy this deficiency.

The salted meat lately issued has been very putrescent and under present conditions highly deleterious. By divesting it of its internal impurities, boiling it in changes of water with addition of charcoal, it becomes more palatable and wholesome.

We have the honor, Sir, to be your most obedient servants,

T. G. Mower, surgeon Sixth infantry

Jno. Gale. surgeon Rifle Regiment."

To Col. W. Morgan

Another photograph, kindly lent by Dr. Sheldon, reports a relatively insignificant, though intensely human record of army life. It is the exoneration of Dr. Gale at a court martial which he himself requested. Shortly after Camp Missouri was established, under date of November 4, 1819, Dr. Gale appealed to the commanding officer for a hearing, stating that he was accused by fellow officers of "maintaining iriendly relations with Lieut. Martin Scott." What Lieut. Scott had done to merit the ostracism of his companions is not stated but 1)r. (Gale declared "it is with feelings of conscious integrity and alarm for my reputation as a gentleman that I request an inquiry to determine whether the imputation is correct."

The court martial was held on November 9, for it was on that day that the company records show that the commanding officer, either Captain M. J. Magee or Colonel Morgan, wrote that "the proceedings of the court disclose nothing which can affect his (Gale's) character. or derogative to his high standing as a gentleman."

\section{DTTSREAK OF SCURVY}

The devastating scurvy did not make its appearance until some time in January and crops up on the company's record for the first time on January 17, 1820 when Captain M. J. Magee reported "an increasing number of sick."

"Humanity dictates that the officers should exert every effort to check its progress," he declared, in exhorting the officers to take care of the sick in their command.

A week later, under date of January 25, the camp commander, IV. Morgan, "observes with concern the sick list daily augment," 


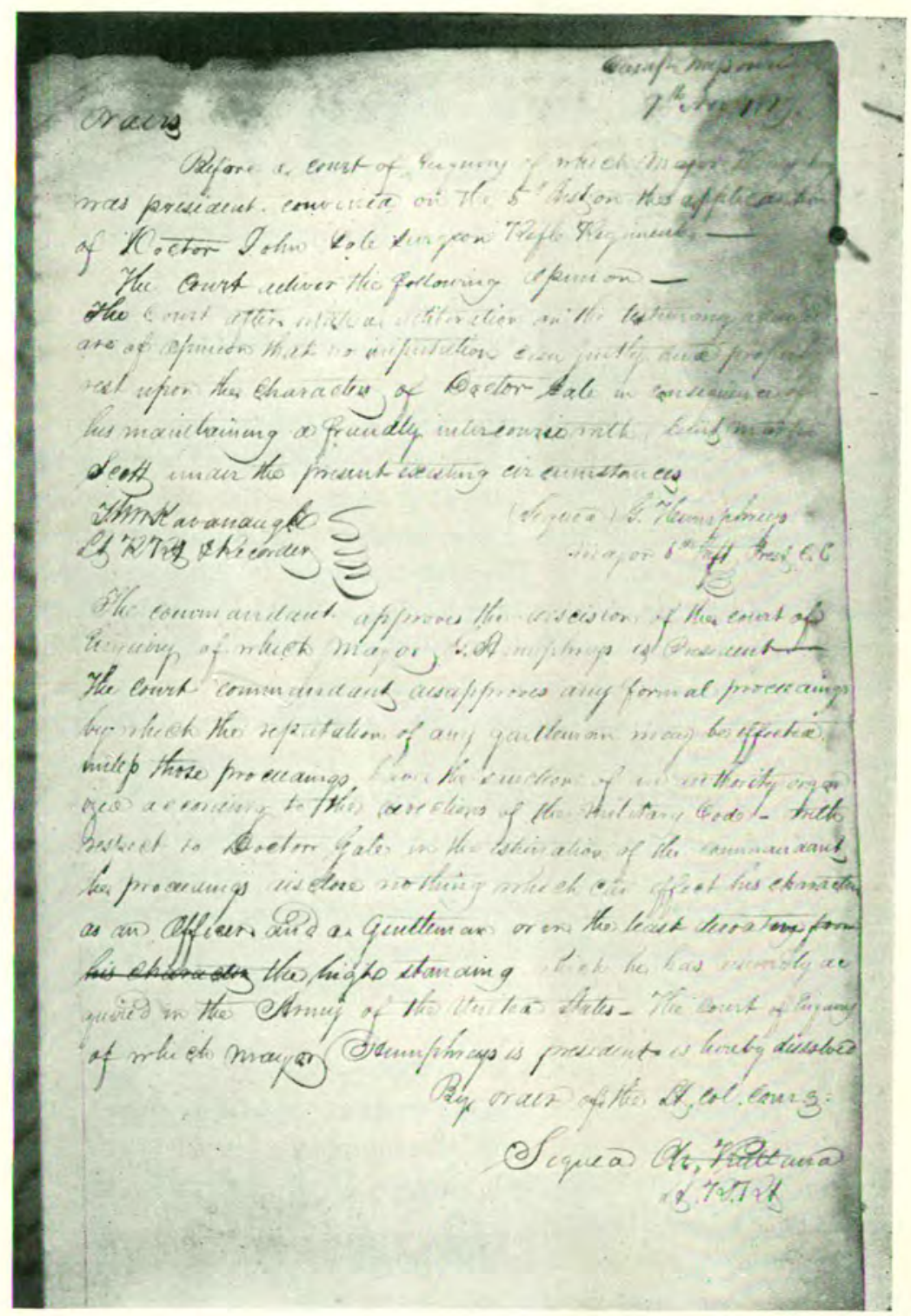

Company records reporting court martial of Surgeon John Gale in 1819. He was exonerated 
and from that time on until the appearance of early vegetables in the spring, at the same time with the arrival of a drove of cattle from Fort Leavenworth, with healthgiving fresh meat and butter, the records of a hundred years ago tell a pathetic story of the rise, span, heavy mortality and depressing effect of the scurvy epidemic and the brave attempts of the commanding officer and physicians to stem the course and lighten the spirits of the surviving men, until the milder weather of the spring brought abatement of the scourge.

An old legend told to Dr. C. W. M. Poynter of the University of Nebraska Medical College faculty, but which the compiler was not able to substantiate, has it that an Indian who came into camp while the men were dying off daily from the scurvy was the first to point out the efficacy of the wild onion (allium) which grew along the river bank, as a prime remedy for the disease, and that not another death resulted in the camp after these bulbous roots, about the size of a nutmeg, were added to the sick soldiers' fare.

If there is a grain of truth in the story, surely this unknown Indian deserves a place in the history of medicine in Nebraska! The compiler would even like to believe that he was the old chief of the Iowas, father of Ni-ku-mi, whom Dr. Gale married, for the fact of their marriage presupposes a special degree of intimacy with this particular Indian family.

To revert to stern facts, set down in the Sixth infantry records after Surgeon Mower and Gale made their recommendations for care of the sick on February 6, the commanding officer acted instantly and orders were issued the very next day with respect to sanitation, airing the bedding, changing clothing twice a week, according to the doctors orders. The small supply of fresh meat, it was ordered, was to be provided only for the sick.

Two weeks elapsed, with the sick list still increasing so that, on February 21, the commander was moved to express his regret and the further hope that "milder weather will improve" conditions. The next day, there was no celebration of Washington's birthday.

"The flour and meat are unfit for issue," was the report made to Colonel Morgan, that day.

His predicament in the next month or so and the fine soldierly manner in which he attempted to meet the sorry situation which 
confronted him, is the distinguishing feature of the next few entries in the company records.

The February 23 entry details his attempts to get wild game to furnish fresh meat for the sick. He expressed the hope that the return of water fowl will "furnish excellent feast and amusement" in the sport of hunting.

By March 6 he was desperate and sent for keel boats to take the sick to Fort Osage, where, he expressed the hope, "they will get what they need there." Seventy of the sick, in charge of Surgeon's Mate Nicoll, were transported to Fort Osage on March 25. $\mathrm{He}$ made every possible provision to raise the spirit and morale of his men who were left behind. He allowed the sick to play cards and scattered the musicians of the regimental band throughout the sick wards, so there was some one to lighten the spirits of every little group.

"The commander is alive to the situation of the sick," he wrote. "Don't get despondent. In a few days there will be warmer weather and in a short time we will be able to procure early vegetables. All soldiers not otherwise employed are on hunting expeditions."

His next statement, dated March 22, reflects the strain and torture of the commanding officer at the death of so many of his men but stresses the note of hope and encouragement for help to come. He refers to his "poignant grief at the loss of so many valuable soldiers and again voices the hope that there will soon be early vegetables, that the hunters will find fresh buffalo meat, that he expects a drove of cattle by the next month" and continues at great. length in words of cheer and encouragement to the suffering soldiers.

"Next winter we will be better supplied," he promises.

The next statement, dated April 4, is almost exultant in its good news. The tide had turned:

"The commander learns a drove of cattle will reach here by April 20, if not sooner. Boats laden with vegetables are also coming on the same date. In a few days our suffering will be ended." He calls on the officers to do their best for the men. "The gratitude of the men, approbation of our own consciences and the applause of the whole country require them to rise to this test of their ability" he emphasized, with true qualities of generalship. 
With milder weather the next day, April 5, Surgeon Mower moved the sick to a new camp in the woods three miles away, where they could have the benefit of fresh air, a change of scenery and ground for hunting. To commemorate the abatement of their sickness and the fact that the sick were beginning to show signs of improvement, it was called "Camp Recovery." Not a single death occurred here. By the end of the month, April 29, the men who were able to work had fenced and arranged a garden and field at Camp Recovery, according to an item of April 29.

With the sick now well on the road to recovery and his hard work over, Surgeon Mower was evidently relieved from duty and probably returned east for his name does not appear again in the record but the statement "Doctors Gale and Nichols will be retained at this point until further orders," appears on the record of April 28. On June 3, Doctor Presley W. Craig and other officers were ordered to proceed to Belle Fontaine without delay.

The final reference to the epidemic which proved so disastrous was on May 11 when members of the band, who had been distributed throughout the regiment to entertain the sick, were again ordered to assemble as before the scurvy broke out.

The name of Camp Missouri or Cantonment Council Bluff was evidently changed on March 15 to Fort Atkinson, for the appellation was "Cantonment Council Bluff" on March 13 and the next entry on the 15th, was dated "Fort Atkinson."

A more complete account of the conditions which caused the epidemic and some conclusions, of medical interest, reached because of it, are included in the following special reports of Surgeons Gale and Mower to Joseph Lovell, Surgeon General of the U. S. Army, at his request, shortly after the epidemic had subsided.

These are the reports Surgeon General Lawson quoted in his statistics, published in 1840 .

"The second battalion of Riflemen," says Surgeon Gale in his special report dated Camp Council Bluffs, October 1, 1820, "left Belle Fontaine and proceeded up the Missouri on the 15th June, 1819; joined the first battalion at Cow Island, on the 30th of August, and arrived at Council Bluffs, a distance of 780 miles, on the 2nd of October. 
"It will not surprise you to learn that the fatigue endured in transporting loaded boats such a distance in the peculiarly laborious manner of navigating the Missouri, and exposure to the meridian sun, the dews of evening, and the chill air of night, were productive of disease. Nearly every man had suffered severely from sickness, and many experienced relapses, before arriving at our point of destination: nor did we then cease to suffer from dysentry, catarrh, and rheumatism."

"With every exertion, our buildings were not completed until the first of January. At this period, from accumulated suffering, a disposition to despondency was manifest. Nearly all seemed to be reduced by protracted sickness and long continued labor. The sutler's supplies were exhausted, the fresh provisions were nearly all issued: and the Hospital stores were inadequate to an emergency. In this situation, when the most nutritive diet was requisite to restore our exhausted energies, the men were compelled to subsist on salted or smoke-dried meats, without vegetables or grocer.es of any description. To add to our list of sufferings, the weather in January became excessively severe; the mercury, at different periods, for several days in succession, did not rise above zero, and once fell $22^{\circ}$ below that point. Under these circumstances, about the 20th January, the scurvy made its appearance, to which all other diseases soon yielded precedence: but it proved fatal in few cases until February, when nearly the whole regiment sank beneath its influence.

"The disease continued unabated until the 7 th of April, when wild vegetables appeared. After this period, no new cases occurred, and those already affected began to recover. Of the riflemen, eighty fell victims to the malady, sixty at this place and twenty between this point and Fort Osage. None died after the arrival of the sick at the latter place.

"That debility, induced by long continued sickness, was favorable to its development, is manifest from the fact, that those who were most debilitated from previous indisposition, were first seized and numbered among its earliest victims. It may also be reasonably inferred that excessive labor and fatigue, and the severity of the weather, had an agency in the production of the disease; for the officers and non-commissioned officers, who experienced less of the former, and were less exposed to the latter, were ex- 
empt from its effects. One officer, who had been long confined by indisposition, formed an exception. This was the only case in which there was the least degree of convalescence observable prior to the appearance of vegetables; and this was probably effected by our being enabled to subsist him on eggs, chickens, milk, etc.,-presumptive evidence that a nutritive diet will produce a cure.

".Among the causes producing the diseases, may also be enumerated the residence of the men in green, damp rooms in conjunction with a faulty diet; for the riflemen, who are more expert in hunting than the Infantry, procured more wild meat and suffered far less. Our hunters detailed for that purpose, who resided in the woods and subsisted on game, were in no instance unhealthy. An officer with a detachment, who wintered in a half-faced camp, some distance below this place, and subsisted his men entirely on fresh provisions from the woods, experienced no sickness of any description."

Following is the special report of Surgeon Mower:-

$$
\text { Camp Council Bluffs, October 1, } 1820 .
$$

"Sir: I have been honored with your report of the 13 th May, requiring me to 'transmit with my next quarterly report, a detailed account of all causes, both immediate and remote, which have probably produced the unusual mortality among the troops on the Missouri; stating the situation and circumstances of the men, both in relation to the nature of the country and of the duties required of them; the quantity and quality of their supplies of all kinds, etc.'

"It may be proper to premise that the general character of the report required supposes me possessed of information, which in no wise appertains to my department, and for which I have never been clothed with authority to ask, much less to demand. With the exception that the issues of provisions fell under my inspection, it is obvious that my knowledge of the supplies, belonging to the Quartermaster's and Commissary's Department, is for the most part casual and unofficial. To remedy this embarrassment, $I$ addressed a note to the commanding officer of the regiment. requesting him to afford me information upon several subjects, with which I am imperfectly acquainted. To this note I have received no answer.

"As few cases of mortality are recorded in the regiment since its arrival on this river, in which the scorbutic taint was not predominant, our inquiries are consequently 
confined to the probable causes which produced this particular disease. It is foreign to my purpose to attempt a theoretical discussion of the nature of the disease in question, or its proximate causes. The circumstances which preceded, and which are supposed to have contributed to the production of that distressing malady, form the subject of consideration.

"The prevalence of scurvy in the Sixth Regiment of Infantry, during the last winter, may be attributed to the following causes, viz: excessive and long continued fatigue cold and dampness faulty diet.

"The Sixth Regiment of Infantry, previously to taking up its march for the Missouri had been cantoned at Plattsburgh for nearly three years, where it had experienced much of the "gay delight" of a military life with few of its hardships or privations. During this period, many foreigners had entered its ranks, who, from education and habits, were better fitted for the ordinary duties of a garrison than to undergo the laborious toils which awaited them.

"The corps left Plattsburgh on the 20th of March, and arrived at Pittsburgh the 1st of May. At this place it halted one week, when it was embarked on board transports for St. Louis. The confinement on board the boats during our passage down the Ohio, together with the use of the river water, which was extremely turbid, added considerably to the sick list.

"On our arrival at Belle Fontaine, (June 8,) the menappeared somewhat enfeebled; nor was the weather, which proved excessively warm, calculated to restore them to strength and activity. On the contrary, they seemed to. experience the same languor, which is felt by the northern man on passing into tropical climates.

"On the evening of the 4th July, the regiment was. again embarked on board of three steamboats and four barges, destined for the Council Bluffs. Without the experience of watermen, the troops had now to contend with a torrent, which, in point of rapidity and natural obstructions, is perhaps without a parallel.

"The narrow cnannel of the Missouri at low stages of water, combined with its frequent and sudden bends, precludes in a great measure the use of sails. In propelling. the barges, the cordelle and setting poles form the principal dependence. This mode of ascending the river re- 
quires of the navigator the most active and incessant exertions: while the severity of his labors is not a little aggravated by being frequently compelled to plunge into the water. After the most persevering exertions, the several companies composing the regiment reached the place of destination betwen the 3 rd of October and the 14th of November. To the failure of the steamboats this dispersed state of the regiment is attributed.

"It now remained for the troops to shelter themselves from the inclemency of the season, and to secure themselves against hostile aggressions. An alluvial bottom on the right bank of the river, about two miles above the Council Bluffs, was designated as the cantonment of the infantry and rifle regiments. The extremes of heat and cold inseparable from an inland region, are here increased by the prevalence of high winds. which are favored by the openness of the country.

"The site for the cantonment, as subsequent experience has proven, had little to recommend it, excepting the facility of procuring timber. A small lake of about three miles circumference, during the low stages of the Missouri, approaches within 600 yards of the cantonment.

"The agency of this lake in producing those diseases, which afflicted our troops while stationed in its vicinity, has been a subject of speculation. It is true, experience has taught us to guard against the exhalations arising from stagnant bodies of water, more especially if any portion of the soil recently submerged is exposed to the direct rays of the sun. When various circumstances combine, calculated to produce any particular effect, it is often difficult to assign to each its peculiar agency. In the present instance, the character of the diseases which prevailed, and the period at which they commenced, seem to lessen very much the probability that any unsalutary effects resulted from our proximity to the lake.

"Early in October, the ground having been surveyed and laid off, the regiment commenced the erection of its barracks. At this period, only five companies out of eight had arrived. The regimental hospital was prepared for the reception of the sick about the 20th of December.

"The latter part of December and the whole of January proved excessively cold, the mean of the latter month being 8 deg. $62 \mathrm{~min}$; and the barracks, hastily thrown up from green materials, opposed but a feeble barrier to the inclemency of the season. Notwithstanding the severity 
of the weather, the regiment was still constantly employed in procuring materials for the completion of the barracks, fire-wood, etc. Owing to the small number of working cattle and the feeble state of the men, it required the whole strength of the corps to accomplish these objects. It is here proper to remark that no objection can rest against the supply of clothing furnished during the last winter.

"The timber (cotton wood) which composed the greater part of the barracks, although convenient and sufficiently abundant, was particularly objectionable on account of its humidity: the quantity of water contained in this wood is almost incredible. The advanced state of the season, however, compelled the men to take shelter under their rude covers, green, damp, and unfinished as they were.

"The state of our subsistence stores had long been reviewed with concern. Fresh beef, which had been issued to the troops since their arrival, in the usual proportion, was in the latter part of January restricted to the use of a few hospital patients. The country not abounding in game, and the regiment having no expert hunters, little was derived from the chase. The important articles of beans, peas, and vinegar, contemplated to have formed component parts of the ration, failed altogether. Salted pork and beef, bacon, flour, and Indian corn, constituted the substantial part of the ration. By far the greater part of the meat was decidedly in a putrescent state and absolutely unfit for issue; the smell and taste both rejected it with disgust. The flour, although less objectionable than the meats, and originally of fine quality, had become musty previous to its issue. The corn, which was furnished in the proportion of two pints to every six rations, was soon thrown aside as a drug. Deprived of vegetables and the usual condiments of the table, the repast of the soldier was, at the same time, deficient in nutriment, unpalatable, and unwholesome.

"The medical supplies of the regiment, although suffcient for ordinary seasons, were of a very inferior quality, and by no means calculated to meet the present exigency.

"Previously to the appearance of scurvy, the men had been much enfeebled by dysentery and pulmonic inflammations; and were consequently rendered more susceptible of other ailments. The former disease commenced its attack soon after their arrival and raged with violence till the close of the year. It was then succeeded by inflammatory affections of the lungs, which prevailed with little abatement till the latter part of January. 
"Early in this month (January) a scorbutic taint was perceptible in some of our patients. who were laboring under other diseases. At first the cases were mild, and appeared to yield, in some measure, to treatment. During the whole of this month, it was noticed that the recovery of our patients was peculiarly slow and precarious: in many cases, after the acuteness of disease has been subdued, the sufferer continued to languish and decline. Early in February the progress of scurvy had become alarming: its baneful influence was rapidly extending to every form of disease. The situation of the command had assumed a serious aspect. Most of the exciting causes still existed, while the means of relief were beyond our reach. The commandant of the post having been apprised, from time to time, of the nature and extent of the prevailing malady, and of the best means calculated to arrest its progress, organized parties under the direction of officers, and despatched them up the river in pursuit of buffalo and other game. Unfortunately the success attending these exertions was very inconsiderable.

"We regret to acknowledge that the firmness of the American soldier should have been for a moment shaken by any concurrence of circumstances. We cannot conceal the fact, however, that during the prevalence of that loathsome malady which afflicted our garrison, gloomy forebodings were depicted on many a countenance; nor were the best directed efforts to counteract this despondency, by introducing diverting games, music, etc., attended with much success. On the 23rd of February, the commandant, feeling alive to the interests of the soldier, summoned together a board of war to deliberate on measures for the relief of the command. Of the result of these deliberations, I am at present ignorant. In compliance with the wishes of this board, I submitted to them a report relative to the health of the regiment, and the means best calculated to counteract the influence of the disease then unhappily existing. On the 25 th of the following month, 70 scorbutic patients belonging to the 6 th Regiment were embarked on board of keel boats, under the charge of Surgeon's mate Nicoll, destined for Fort Osage. At this place it was believed that they would more speedily obtain a regimen adapted to their condition.

"On the removal of these men, we had nearly 100 patients left, suffering under the influence of the same disorder. During the first week in April, the weather proving favorable, we removed a large proportion of our 
sick from the Cantonment, and located them on a small stream under tents, about three miles distant. Fortunately, at this period, wild vegetables began to shoot up, These powerful remedies, combined with mild weather, pure air, and change of scenery, soon banished the demon. Scurvy, and restored its victims to strength and activity. So potent was the influence of this new state of things, that patients recovered under the most unpromising aspects. Not a single death occurred at "Camp Recovery," although several persons were removed thither in a seeming moribund state. In some of them, every tooth had dropped from its socket, and even large portions of the lips had sloughed off. Among the vegetable products first discovered, and most esteemed for its remedial virtues, was the wild onion, a very diminutive bulbous root, not larger than a nutmeg.

"When we reflect on the long and arduous march performed by the 6th Regiment of Infantry, the unavoidable fatigues which awaited these troops on their arrival at the place of destination, the vicissitudes of heat, cold, and dampness, to which they were exposed, the wretched quality of provisions on which they subsisted, we cease to wonder that sickness and mortality have prevailed. Had the corps maintained its health, we might be warranted in believing that the age of miracles had returned.

I have the honor to be, very respectfully,

Your obedient servant,

T. G. MOWER, Surgeon 6th Infantry."

Joseph Lovell, Esq., Surgeon General U. S. Army.

\section{DESCRIPTION OF MOWER}

A pardonable curiosity to learn something more of the personalities of these two surgeons, Mower and Gale, who furnish the first medical history of Nebraska can be gratified through the efforts of Dr. LeRoy Crummer of Omaha who, with Dr. Irving S. Cutter, did considerable research into early records. Dr. Crummer furnished the compiler photographs of the records of the Surgeon General's department from 1849 to 1861 , which include not only a personal description of Mower, written by the latter's friend Surgeon Josiah Simpson, but his biography, written by Mower himself.

Surgeon Simpson's description of Mower is as follows:

"He was of slender figure, exact and martial in carriage, with prominent, bright blue eyes, ruddy complexion, 
and a pleasing expressive face: of delicate physical organization, in height not over five feet ten inches, in weight probably not more than one hundred and thirty pounds. Scrupulously neat in dress and person, pure and chaste in word and deed, he was a noble type of what an army surgeon should be."

Mower's own account of his career is appended, together with tributes to him at the time of his death, December 7, 1853.

"Thomas Mower was born at Leicester, near Worcester, Massachusetts, February 18, 1790. His father dying when he was seven years old, his early education was directed by an uncle. He graduated at Harvard University in 1810, and studied medicine with Thomas Babbitt, an eminent surgeon of Brookfield. Massachusetts, and formerly a surgeon in the United States Navy. Having been examined and licensed to practice medicine, he was appointed surgeon's mate in the 9 th regiment, U. S. Infantry, December 2, 1812, and immediately joined his regiment in winter quarters at Burlington, Vermont. In the spring following he accompanied the regiment to Sackett's Harbor and afterwards to Niagara: during this year (1813) he participated in the capture of Fort George, and in the actions of Chrystler's Fields. In the spring of 1814 he accompanied the 9th from its winter quarters at French's Mills to the Niagara froniier. This regiment, forming a part of Scott's brigade, was the first to land on the Canadian shore, under the fire of the enemy, on the third of July, 1814. and the writer was in the leading boat conveying the regimental field and staff, also General Scott and Stafi. In this year. June 30 , he was promoted to the surgency of his regiment, and continued on the New York frontier till the close of the war, February, 1814. He participated in the active campaign on the Niagara frontier, having been engaged in the battles of Chippewa, Lundy's Lane, and in the assault by the British on Fort Erie. At the close of the war he was one of ten regimental surgeons, out of at least forty, that was selected for the peace establishment. After nine or ten years' service on the frontier (the last two on the upper Missouri), he was placed on special duty in the harbor of New York, and charged with various duties pertaining to the station. Here, with occasional absences on duty, he has continued till the present time (1851). In 1833 and 1834 he traveled under orders upwards of 12,000 miles as a member of a medical board of examination and inspection, which visited most of our military posts southwest and northwest of New 
York. He was a member of every medical board except one, that was convened from the first organization in 1832 to the present time, and with the above exception and one other, was the presiding member. To the operation of these boards the present efficiency and high standing of the Medical Staff are mainly attributable. In the year 1818 he received the degree of doctor of medicine at the College of Physicians and Surgeons, New York, and in 1844 he was elected a member of the American Philosophical. Society of Philadelphia, an institution over which Franklin and Jefferson had pres:ded."

The record furnished by Dr. Crummer continues as follows:

"It is a statement which will be endorsed by every one who ever appeared before Mower for examination, that no one had to undergo that ordeal, without pleasant recollections of his dignity and learning, his gentleness and tenderness of character, the personal interest which he felt in every young candidate for the honor of a position in the Corps. The variety of his services was as extensive as the country. There was hardly a project, involving the exercise of more than usual judgment or foresight that was not referred to him for decision. Indeed, for the last twenty years of his life, so constantly was his advice sought for and listened to with deference, that he possessed an influence coequal with the Surgeon General, an influence which it is hardly necessary to say, was invariably exercised on the side of truth, justice and the advancement of his beloved Corps.

Doctor Lovell, who had many traits of character in common with Doctor Mower, thus spoke of him, in a letter written shortly before his death:

"I can confidently affirm, without fear of contraduction, that there is not in the whole Department a single officer who is better qualified than the present occupant (Doctor Mower) to perform the various duties which devolve upon him, either as the medical officer of the station (New York), as inspector of recruits at the largest rendezvous and depot of the army, as president of the medical board of examination which usually convenes in New York, and which devolves upon him as the senior officer but one in the Department, or as acting apothecary in purchasing and distributing the medical supplies for the various posts. In the latter capacity especially he is invaluable to the Department, and his removal from any cause would be a serious loss both to the Department and to the public service. 
"Without increase of expense the supplies have been increased in quantity and highly improved in quality, and they are so reported by the several surgeons from year to year, with scarcely an exception, as well as to have been safely and carefully packed, and to have arrived in good order; a result which is entirely due to the diligence, intelligence and fidelity of Surgeon Mower. * * * From personal observations during the war (with Great Britain), both in the field and in the hospitals and from subsequent official relations, I can with confidence add my testimony to those with whom he has served, that he is second to no officer in the Department, either as to the extent or importance of the services which have devolved on him during this period, or in the faithful and intelligent manner in which these services were performed."

Surgeon General Lawson, who was always chary in praise, in his annual report to the Secretary of War, November 8, 1854, remarks:

"Although we have been called upon to mourn the loss, not only of many of our number, but of some of our best and most distinguished officers, it will be doing no injustice to others, whether of the living or of the dead, to render a richly merited tribute of respect to the memory of Surgeon Thomas G. Mower, for many years the senior surgeon of the army, its Chief Medical Purveyor, and the presiding officer of its boards of medical examiners. During a service of forty-one years he had frequently confided to him the highest and most responsible duties, all of which were invariably performed to the satisfaction of the Department. To the judgment and discretion with which he exercised the power delegated to him as president of the army boards of medical examiners, the Medical Staff owes much of its present efficiency and reputation and it is hoped the influence of his example will not be lost."

The New York Times of January 11, 1854, contains a notice of his life and career, from which the following admirable summary of his character is taken:

"In all relations of life he was most exemplary and unexceptional; as a husband, devoted and affectionate; as a parent, kind and indulgent, and most solicitous for the honor and welfare of his children; as a friend, ardent, disinterested and unchangeable: as a man, upright, punctilious, exact in all his dealings, charitable and actively benevolent; as a gentleman, affable, polite, courteous and 
deferring to his equals, and ever considerate of the feelings and interests of those below him in position; as a soldier, jealous of the honor of his profession, firm, decided and brave, knowing no fear but the fear of a mean action, quick to perceive and prompt to execute; as a physician and surgeon, mature in judgment, sound in theory, skilful in practice, humane, sympathetic and self-sacrificing in his efforts to relieve or alleviate the sufferings of his patients; as a Christian, sincere without ostentation. believing in religion as a principle rather to be possessed than spoken of, and practicing rather than professing the Golden Rule. That he has gone to the enjoyment of that reward promised to the just made perfect, no one can doubt who knew his manly, generous nature and many virtues."

THE COLORFLL DR. GALF

A far more colorful figure, if not so admirable, at least by repute, was his colleague, Dr. John Gale. The traditional facts regarding him cannot be substantiated so well by army records, for what happened to him after he left Nebraska in 1824 or 1825 is lost to history. What information there is, was largely gleaned by Mrs. Harriet MacMurphy, dean of Nebraska newspaper women, who wrote the story of "Ni-ku-mi," from facts given her by Mary La Flesche, his daughter: Susan La Flesche Picotte, his granddaughter; and other members of the La Flesche family and Omaha Indian tribe.

Her information does not always coincide with other sources, like the army records. For instance, Mrs. MacMurphy maintains that Gale's full name was "Marion F. Gale", not "John" and that he named the child born to him and Ni-ku-mi "Mary" or "Marie," after himself. He told a tale of noble English birth and when he left here, gave out the story that he was called to England to inherit a fortune and estate, but Mrs. MacMurphy ventures the shrewd guess that this may have been one of the glib tales he was wont to tell.

He was short and thickset, according to the description Mrs. MacMurphy obtained in her girlhood from Mary and members of the Omaha tribe who recalled him, and was evidently of good birth, although his rough life and dissolute habits obscured it.

Shortly after the Sixth Infantry located at the Council Bluffs, a chief of the Ayeaways (Iowas) and his band pitched their tents 
nearby to be on neutral ground and thus protected from other hostile Indian tribes with whom they were at war.

Here enters the romantic thread destined to tie up the life of this obscure army surgeon of more than 100 years ago, with the history of this great state, for the chief of the Iowas had a beautiful daughter, Ni-ku-mi.

What more natural than that the privileged officer would be among the first to make the acquaintance of the chief and his pretty daughter?

$\mathrm{Ni-ku-mi}$ was a short, slight maiden with exceptional bright eyes, a well-formed profile and carried herselt with the dignity befitting an Indian princess, according to Mrs. MacMurphy.

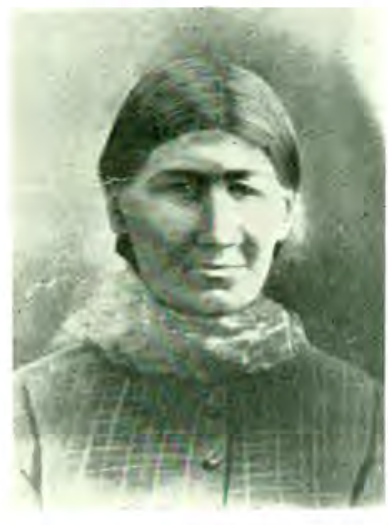

NI-KU-MI Through her influence was obtained this photograph of Ni-ku-mi, taken when she was an old woman - when the wild beauty which intrigued the army surgeon was faded and gone but when the eyes still burned with a steady fire and the mouth showed the lines of strength which characterized her whole make-up from the day she learned Gale planned to rob her of their child; through his desertion of her; through her later marriage and dominance of Peter Sarpy, the pioneer trader for whom Sarpy county was named; to the last days of her service in behalf of her beloved tribe.

And she served them well. Helped herself to Peter Sarpy's stores when they were hungry or naked; settled their disputes, denounced their wrongs and interceded for them with the whites; was friend, adviser and counselor to the whole tribe until the date of her death, March 23, 1888. She is buried in Bancroft, Nebr.

Gale's singling her out seemed like the hand of Fate, marking her a woman destined for a place in history, apart from all other women of her tribe. Nebraska Daughters of the American Revolution recognized her importance by naming their chapter at Blair, near the site of Ni-ku-mi's life romance, in her honor. 
May Allen Lazure of Fort Calhoun, historian of Ni-ku-mi chapter, emphasized the high esteem in which the D. A. R. women hold the namesake of their chapter.

"We regard her as a most remarkable woman," wrote Mrs. Lazure. "She was married to Dr. Gale according to the Indian custom, lived with him for four years and considered herself as securely wedded to him as any one could be."

When Gale received word that he had to go to Ipswich, England, to claim his inheritance (or whatever was the summons which called him from his Nebraska abode with Ni-ku-mi) he was eager to take their little daughter with him, for he "did not want her to grow up a squaw", but apparently did not care to be burdened with an Indian wife when he returned to his former mode of living.

His story, according to Mrs. MacMurphy, was that his father, James Burton Gale, had died, leaving him the estate of Burton Towers, Ipswich, England, from which he had departed ten years. earlier for America.

Mrs. MacMurphy relates that Ni-ku-mi sensed Gale's intent, and had her brother eavesdrop on a conversation between Gale and Peter Sarpy, the post trader, to discover the truth. When her suspicions were confirmed, she fled to the woods with her babe and remained there in hiding until apprised by her brother that Gale's boat had arrived, and he was forced to depart - without his child.

In justification of Gale's claim to manliness, as evidenced in his statement to his superior officers in petitioning for a hearing when he was derided by his fellow officers the first winter he was in camp here, it must be related that Gale left a generous sum of money with Peter Sarpy to care for Ni-ku-mi and instructed Sarpy to give her any supplies she required, from the post store.

There is no question of the suffering Gale brought into the life of this Indian girl. Womanlike, she waited years for him in the hope that he would return and when be did not, she accepted Peter Sarpy's proffer of marriage, probably, those with some knowledge of feminine psychology would like to believe, because he was the last link which bound her to Gale. She was a cievoted wife toSarpy, carried him on her back a long distance, it was reported, when he was ill with a fever and saved his life from hostile Ind ans. 
on several occasions. He was greatly attached to, but also feared her, some reported, or else she dominated him through some knowledge or power she possessed. Perhaps it was the respect she aroused in him because of what she had experienced and his knowledge that a white man had wronged her.

She was exceedingly generous to her people, helping herself to anything he had in his store which they might need. On one occasion when Sarpy remonstrated because she took a bolt of calico and gave it to one of her tribe, she very calmly marched into his store, carried off all the bolts of calico left there - and threw them all into the river: He never found fault with her again.

This stark bit of justice she exacted, Indian fashion, is matched by her apt handling of a situation sensed by or reported to her, that Peter Sarpy was philandering with an English widow residing nearby. When told that Sarpy had given the woman one of his horses, she ordered the black servant who was about to deliver the horse to put the horse back in the stable.

He did.

Ni-ku-mi was highly regarded by neighboring whites, both in the vicinity of Fort Atkinson and later at Bellevue, which Peter Sarpy laid out in 1854. He was of good family, a relative of the Choteaus of St. Louis, who came here in 1823 as a clerk for the American Fur Company. He was kindhearted and good to the Omahas who called him "the white chief" and since he was born in 1804, was nearer Ni-ku-mi's age probably than Gale had been.

But it was her daughter Mary, whom Ni-ku-mi gave the Indian name "Hin-nu-ga-snua," meaning "the one woman" that Ni-ku-mi's life was centered, after her desertion by Dr. Gale. When Mary was grown to womanhood, Ni-ku-mi arranged her marriage with Chief Joseph La Flesche, a half-breed of the Omahas, whose father was a French trader who came up the river from St. Louis. When Peter Sarpy died, Ni-ku-mi came to live with them.

That she made a wise choice for her son-in-law is evidenced by Chief Joseph La Flesche's record as a sage and able chief. "Iron Eye" was his Indian appellation. He is credited with having enforced the first prohibition law in this state, in 1856 when he prohibited the men of his tribe from consuming "fire water" and enforced his decree 
by whipping any man who did. Once, when the culprit was his best friend, he carried out the punishment just as sternly as he did for any one else, but when he had finished, lashed his own bare back just as severely as he had his friend's.

While they may have lived for some time in the tepees of the Indians, La Flesche later built a house for his family from lumber cut from trees along the river bank, and sawed in a mill established near Decatur by one Allen Root, and here he and Mary, the daughter of Doctor Gale, reared a large and interesting family - the most important Indian family of this vicinity, not even excepting the Fontenelles.

\section{GALE AND NI-KU-MI'S GRANDCHILDREN}

Among these children - grandchildren of Doctor Gale and Niku-mi-were Suzette, or "Bright Eyes," who became the wife of Thomas H. Tibbles, noted scout of the plains and veteran newspaper man employed by the World-Herald; and Suzanne or Susan La Flesche, afterwards Picotte, who, with Bright Eyes, was educated in the East and graduated with honors from the Woman's Medical College in Philadelphia, making the three years' course in two years; and Francis La Flesche, engaged in Indian research in the Bureau of Ethnology, Smithsonian Institute at Washington, D.C.

All of these grandchildren join in agreeing that $\mathrm{Ni}$-ku-mi was "a haven of rest to her grand-children, family and tribe who would not do anything without consulting her." Out of her rich experience in life and her association with the whites, she could advise them better than any one else. It is not without the range of possibility to believe too, that it was her influence, centered on the youngest of her daughter's children, Suzanne, in the sunset days of her life, which influenced the young Indian girl to follow her grandfather's noble profession of healing.

Both girls were educated at Father Hamilton's Presbyterian mission school, maintained on the Indian reservation near Macy during the late 70 s and the '80s by Mrs. Mary Wade and Miss Jennie Copley, two sisters who were said to be nieces of Mrs. Mary Copley Thaw, mother of the notorious Harry K. Thaw. It was through this connection that Mrs. Thaw made several beneficences to Nebraska Presbyterian institutions in past years. They were 
so impressed with the high intelligence of the girls that when one of them returned to her home in Elizabeth, New Jersey, she told Miss N. C. Read, head of a private girls' school about them, particularly about Suzette, "Bright Eyes" who was the eldest. Miss Read sent for her and she remained at the Pingree school three years. Afterwards she visited at Miss Read's home and made such a favorable impression that Miss Read asked to have Suzette's next two sisters, Rosalie and Marguerite, (now Mrs. Farley and Mrs. W. T. Diddock of Walthill) sent there to be educated. Either through a mistake, or because "Suzanne" (her parents called her by the French name rather than the American Susan) showed greater eagerness or aptitude, she was sent instead of Rosalie. Other children of Mary's seven were Lucy and Carey. They too spent three years at Miss Read's school.

Susan was only thirteen years old when she was taken from the almost nomadic life of her people to enter the Pingree school in the east, for she was born in Burt county, June 17, 1866, but she pursued her studies with unusual success, later continuing her studies

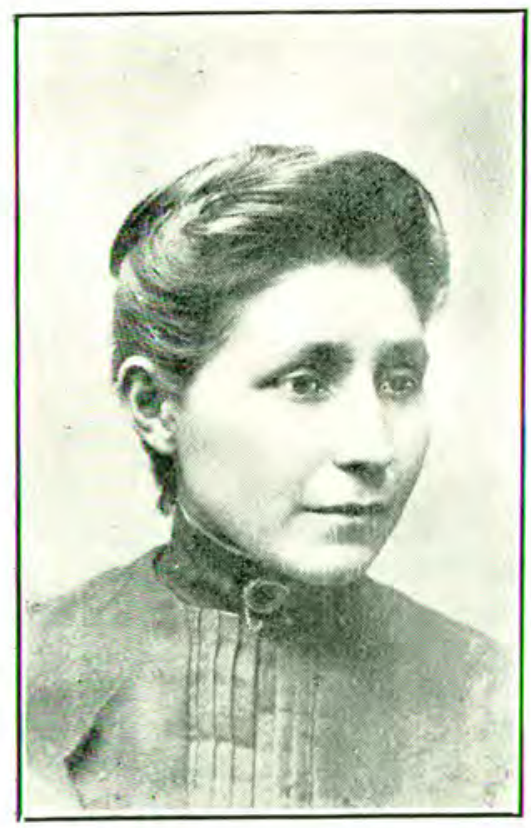

DR. SUSAN LA FLESCHE PICOTTE in Hampton Institute, Hampton, Virginia. Here she was graduated in 1886 and won a gold medal for proficiency, besides. Through the efforts of "Bright Eyes" to fi na nce it, Susan was enabled to enter the Philadelphia Woman's Medical School the next year when she was only 20 , and completed the three years' course in two years, standing at the head of her class of 100. Returning to the reservation after a year's hospital experience she was appointed government physician to her tribe, numbering 1,300 , and pursued her ministrations to the sick for six years, when she had to resign because of ill health. She then moved to Bancroft, where she lived ten years, treating both Indians and whites. 
In 1894, Dr. La Flesche married Henry Picotte, a French Sioux and two sons, Caryl and Pierre, were born to them. But even a home, husband, two children and a large practice did not suffice to contain the slender red woman's limitless energies and efforts in behalf of her people. She became the natural leader of the Omahas in all tribal and material affairs. She conducted religious services in the little mission church - she was the only Indian person ever commissioned as a medical missionary by the Presbyterian Board of Missions-and journeyed to Washington, D.C., as the delegate of her tribe, to petition for a law forbidding the sale of liquor on the Omaha and IIinnebago reservations. She was then following up the work started by her father, who foresaw this evil for the red man.

Both of Dr. Picotte's sons, Caryl and Pierre served in the army in the late war, as did their great-grandfather 100 years before them. Caryl, a second lieutenant in artillery is now a chemist in the Packard laboratories in Detroit, and Pierre is employed in the Omaha postoffice. The latter is married to a full-white woman and they have three children.

The service that Mary's children have been to their people is unbounded. Suzette or "Bright Eyes," who was the friend of Henry Wadsworth Longfellow, the poet, toured the country from 1878-80 lecturing on the wrongs and needs of her people and lobbied in Washington, D. C., for a remedy for the wrong done to Poncas by moving them off their original lands to Oklahoma, where many of them suffered and died. After her marriage to Tibbles, she did considerable writing. She died May 27, 1903 at the age of fortynine.

Susan or Dr. Picotte continued her elder sister's work in behalf of the Indians and literally "poured out her life for her people," according to Mrs. James Adams, an Omaha D. A. R. who knew her personally. She made many talks in Presbyterian churches and neighboring women's clubs, advocating some form of settlement work among the Indians.

"I do not ask for money," she pointed out, with dignity. "We have plenty, but my people do not know how to use money."

Public health and sociology were her prime interests. 
FOUNDS WALTHILL HOSPITAL

When the town of Walthill was started, Dr. Picotte and her family moved there and built a home and it was then that Dr. Picotte began to agitate that which became the dream of her lifethe establishment of the first hospital at Walthill. For five years she labored day in and day out, without any encouragement, with friends and family, church and clubs, planting the seed of the hospital idea. Today the modest little hospital is her only memorialthe Susan La Flesche Picotte hospital, pictured on this page.

Her brother-in-law gave the lot on which it was built and $\$ 500$ besides; the Presbyterian Board of Missions finally subscribed to the fund and an $\$ 8,500$ nucleus was obtained, solely by her efforts and personal solicitation.

"I get very tired of talking," was her only word of complaint.

"I believe in prevention of disease and hygienic care more than $\mathrm{I}$ do in giving or prescribing medicine and $\mathrm{my}$ constant aim is to teach these two things, particularly to young mothers," Dr. Picotte declared, in promoting the hospital. "My greatest desire in having

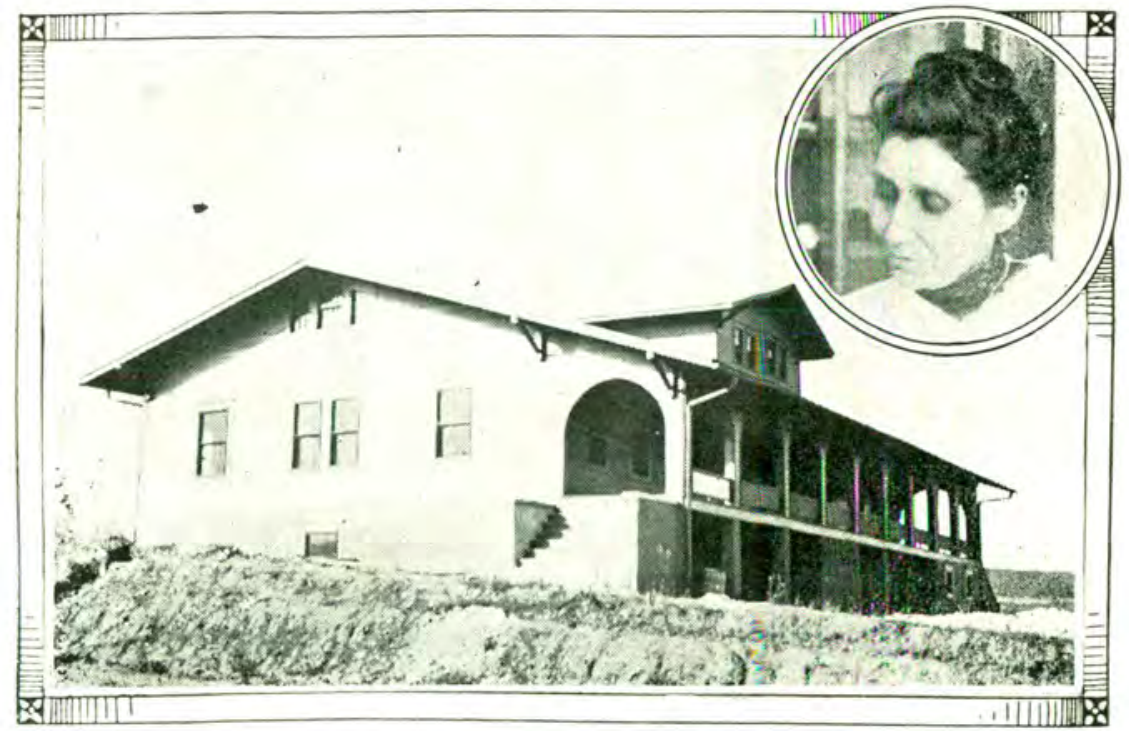

Hospital at Walthill, built by Dr Susan La Flesche Picotte (inset) 
the hospital built was to save the little children - many victims of improper care and diet, due to the change in the Indians' mode of living in the transition period. I give there lessons in how and what to cook."

She mentioned also the difficulties she encountered in getting the Indians to go to the hospital at all, at first, a struggle to which all social workers with foreign peoples can attest.

Dr. Picotte's interests were not confined to her people alone but she did an important piece of health work for the entire state as health chairman for the Nebraska Federation of Women's clubs. She lobbied for the state law requiring medical inspection of schools; for the abolishment of the public drinking cup; for sanitary ice cream dishes and spoons; for drinking fountains; advocated traveling health exhibits, and, when she found the cost prohibitive, wrote to the Russell Sage Foundation, urging the manufacture of health exhibits at a lower price so that the public could be so educated. She was active in tuberculosis prevention work, wrote articles on health for the Walthill newspaper; helped establish a playground for Walthill children, and, when there was no fund for a medical inspector, did the school inspection work herself.

Medical inspection is a great step forward, she believed, twenty years before the movement became as popular as it is today.

"I feel that what is done for the children is more important than anything else," she said, "for what you want to see in the public life, you must teach in the public school. The future fathers and mothers of our homes have a right to be educated in health knowledge."

Her long hours of steady grind, the hard drives over long distances in the country in all kinds of weather, most of the time without remuneration; her unremitting toil in establishing the Walthill hospital then began to tell on the frail Indian woman who had always been thin, almost to the point of emaciation. But though the flesh weakened, her spirit continued ardent and she was always dreaming of the things she could do, until her life was snuffed out, September 18, 1915, when she was still a young woman, in her forties. 
"She bore easily all those graces of refinement which marked her as a woman of culture, beyond the environments from which she came," was the tribute of Harry L. Keefe, prominent Walthill attorney.

What a wide gulf of civilization the little Indian woman doctor bridged, even though she was born in an humble tepee on a wild, unsettled Indian reservation before Nebraska became a state, can further be judged when one reads Dr. Picotte's account of an incident in her family history.

"My great-aunt, who died in 1894 at the age of onehundred five, remembered her grandfather, the old Chief Blackbird of the Omahas, and was an eye witness of the tragedy when the old man stabbed to death his favorite and beautiful young Ponca wife, for unfaithfulness. $\mathrm{He}$ loved her dearly and was very sorry thereafter for his deed; would not touch food for three days, and afterwards asked to be buried alive with his horse."

Close to this primitive background, it is almost incongruous to think of Dr. Picotte, health chairman of the state Federation of Women's Clubs, and concerned about the evils of a public drinking cup or anything so effete as sanitary ice cream dishes and spoons!

Before closing this chapter on the Indian phase of the medical history of Nebraska, an attempt was made to verify a report that Dr. Gale was buried at Rock Island Arsenal, Rock Island, Illinois. The commanding officer replied that post records, dating back to 1862 could not substantiate this fact. He wrote:

"During the Blackhawk War in 1831-1832, Fort Armstrong, located at the extreme western point of the island on which the Arsenal now stands, was the rendezvous for the soldiers assembled in this vicinity; at that time there were about 1500 soldiers stationed at the Fort. A year or so later an epidemic of cholera broke out and it is probable that Dr. Gale was associated with the Fort's military activities at that time and that he was one of the many who died as a result of the disease."

The sense of loss felt by the whole community is reflected in the Walthill Times of September 24 which was devoted almost entirely to an account of her full, useful life, cut off in its prime. 
The only full blood Indian now practicing medicine in Nebraska, and possibly the only one in the United States, is G. J. Frazier, a Santee Sioux, who practiced at Santee, Nebraska for twelve years as government physician

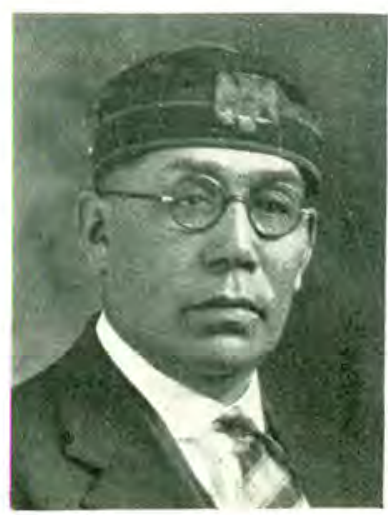

G. J. FraziER and attending physician to the Santee Normal Training school. Last Szptember, the United States Indian Field Service with which he is connected, transferred him to the Lower Brule agency, in South Dakota but the appointment is probably temporary as the Santee reservation in Knox county is Frazier's home territory.

Frazier was born on the Santee reservation Mav 6, 1876 and attended the Santee Normal school for four years, then his parents sent him also to Hampton Institute at Hampton, Virginia, where Dr. Picotte had studied. It was a normal school since raised to college standards. He was graduated at the age of 17. The Indian youth was then sent to Meriden, New Hampshire, where he attended a Dartmouth preparatory school for four years. In the fall of 1900 Frazier took the entrance examinations at the Denver Homeopathic College nearer home, which had just opened its doors, and attended school there for five years. He began his practice in the little town of Naper, in Boyd county and remained there seven years, after which he took the civil service examinations for entrance in the Indian service, Department of the Interio:. He was assigned to his home reservation and served as deputy food administrator for Knox County during the war. In the accompanying picture, Frazier is wearing the cap of the Scottish Rite order, of which he is a member.

It is appropriate to close this chapter with mention of that sturdy frontier physician, W. M. Bancroft of Lexington , who distinguished himself for his care of the wounded Pawnee and Sioux 


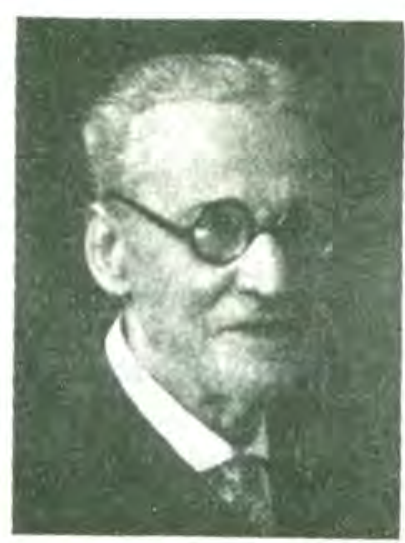

DR. W. M. BANCROFT

Indians, after their last great battle on the banks of the Republican River, in 1873. It was not only the final conflict between these two warring tribes, but marks practically the end of all the red men's wars on this continent. The young physician who participated in this thrilling experience and attended the Pawnees in many of their minor engagements, had come to Lexington in Dawson County, only the year before. Until the neighboring Custer County was established in 1877, Bancroft traveled long distances on horseback, to treat the sick in Custer County, according to Dr. C. L. Mullins of Broken Bow. A son, Jesse Bancroft, is now living in Lexington, Nebraska.

\section{Notes and Errata}

p. 2

p. 2

pp. 3-22

pp. $20-29$

p. 30
United States, War Department. Surgeon-General's Office. Statistical Report on the Sickness and Mortality in the Army of the United States. Compiled from the records of the Surgeon-General's and the Adjutant-General's Offices, embracing a period of twenty years, from January 1819 to January 1839. Prepared under the direction of Thomas Lawson, Surgeon General. Washington, J. Gideon Jr., Vol. IV, 1840.

Forry, Samuel, "Remarks on Epidemic Cholera, Inebriety, Hemeralopia, Colica Saturnina and Dengue," Am. J. M. Sc., 3:307-324, Apr. 1842.

For complete expedition records, see: Gale, John, The Missouri Expedition, 1818-1820; the journal of Surgeon John Gale with related documents. Edited and with an introduction by Roger L. Nichols. Norman, University of Oklahoma Press, 1969.

NI-KU-MI or NI-CO-MI. For other accounts, see: Morton, J. S., Illustrated History of Nebraska, Lincoln, Jacob North, 1907, vol. 2, footnotes pp. 149-150.

Frazier, G. J., M.D., Denver College of Physicians and Surgeons, 1903. Indian Service, Rosebud Reservation until retirement in 1956. 


\section{THE PIONEERS}

\section{INTRODUCTION}

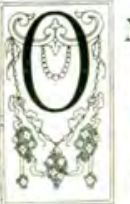

MAHA, the metropolis and once the capital of Nebraska, virtually owes its existence to two physicians, thus establishing at the outset, the important part medical men have played in her development.

One, Enos Lowe of Council Bluffs, Iowa, was president of the Iowa-Nebraska Ferry company, which in 1853-4 platted the site

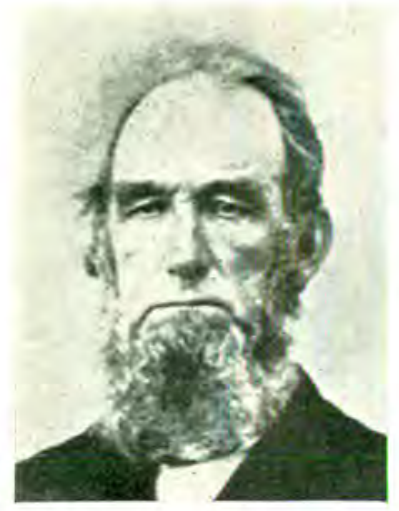

DR. ENOS LOWE of the city of Omaha, and was therefore principally responsible for the creation of the new city. The other, George L. Miller, the first physician to actualiy settle here, in 1854, was dubbed "Father of Omaha" because of his important activities in behalf of Omaha; his fight to retain the capital here; the successful battle he waged to locate the Union Pacific bridge on its present site; his editorship of the World-Herald, a powerful influence in early days, as now; and his numerous efforts to beautify the city for fut ure generations by provision for adequate parks and boulevards.

Each of those early practitioners who joined Miller and Lowe in the new little city on the banks of the Missouri-W. R. Thrall, who presided over the session of the territorial legislature when the fight to move the state capital was on and came to fistic encounter with his opponents; his partner, A. McElwee, who joined him in caring for the unfortunate victims of the Omaha Claim club's boundary differences; James H. Seymour, who also served in the territorial legislature, and who, with Dr. Lowe helped organize the First Nebraska Volunteers for the Civil War; James Porter Peck, 
a hero of the Sandusky, Ohio cholera epidemic, and a pioneer, even in those days, in advocating the cold air treatment of pneumonia; Gilbert Monell, grandfather of ex-Senator Gilbert M. Hitchcock; Samuel D. Mercer, noted as a builder of the Walnut Hill district and creator of Omaha's street railway system; even Charles A. Henry of Bellevue, who was brought to Omaha in 1855 to answer the first charge of murder preferred in Nebraska Territory-all these played an important part in the settement, politics, growth and development of the new western empire.

Their activities were not confined to the metropolis. Erastus $\mathrm{N}$. Upjohn was one of the first settlers at Bellevue in 1854, only seven or eight persons having preceded him. B. T. Shelley founded the town of Niobrara. Harvey Link homesteaded at Millard and served in the territorial legislature from there. Robert C. Talbot founded the town of Guilford by applying for a postoffice there. William Penn Brooks built the first house in Cook, Johnson county. Servetus V. Moore helped organize York county, and Melville W. Stone, veteran of the Indian warfare, helped found Lincoln county, where North Platte is located.

There are many such instances, too numerous to mention here, as they will be included in the biographies of these pioneers which follow. The explanation, however, for the preponderance of medical representation among the early builders is, probably, that since they were of the professional class, they were better equipped by education, training and experience, to see and solve the problems and conditions which confronted the early settlers.

The hardships the early physicians were forced to endure in the practice of their profession when the growing population of the state spread itself over a wide domain, reached epic proportions. And there is nowhere on record one instance that any of these pioneer practitioners ever failed in his duty, even when he knew it meant no pay: whether that duty meant riding fifty or seventyfive miles on horseback in a blinding blizzard, fording dangerous creeks, riding over trackless sand hills, providing food or clothing for the hungry and naked. Indeed, there is one instance of a Fremont doctor, Leonard Bannatyne Smith, who took the shirt off his back to cover a new-born babe when he found there was not another 
clean piece of cloth in the cabin in which to wrap the infant he had just helped into the world.

There is a similar instance recorded by Miss Rose Rosicky in her history of the Bohemian settlement in Nebraska, of the keen insight, kindly instincts and quick decision of another Fremont physician, Dr. Brunner.

The story is told by the patient herself, Mrs. Rosalie Soukup, now living in Morse Bluff, Saunders county. Mrs. Soukup came to Fremont in 1867 with her parents, Datel by name, and entered the service of the Jilek (Ellick) family. Mrs. Soukup relates:

"Their physician was Dr. Brunner, who thus came to know who I was. A few years later, after I had been married and was farming, with my husband, I became ill, felt weak and worn. My husband took me to Fremont to see the doctor, the same Dr. Brunner. He examined me, wrote a long prescription and told me to take it to the store. How surprised and delighted I was to find that the 'prescription' was an order for beans, onions, apples, rice, cheese and other provisions, which the generous doctor, noting my undernourished condition, had prescribed and paid for:"

So extreme was the poverty among many of the first homesteaders that they subsisted on corn bread and coffee made of parched grain. Some were without a cow for a year or two before they could buy one, so they had no milk or butter. Game too was scarce before the first crops were raised, for there was nothing on which the game could feed. And the doctors, more than anyone else, realized what the lack meant to their patients.

Edward Porter Peck, prominent Omaha grain man, relates that his father, Dr. James Porter Peck, who came to Omaha in 1856, drove 115 miles in a buggy to Genoa, Nebraska, in the dead of winter. When he arrived at his destination, half-frozen and weary to the point of exhaustion, he had to perform an amputation of both arms and legs on the patient with the crude surgical equipmen of those days.

Dr. G. O. Remy of Ainsworth penned an eloquent tribute to the pioneer doctors who made such long trips on horseback and by 
team, through muddy roads and all kinds of weather; and more

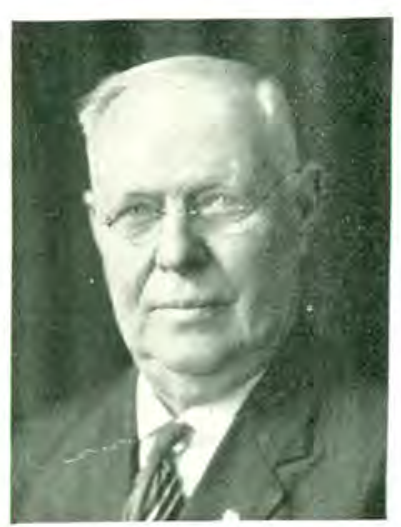

DR. G, O. REMY

particularly, through the sand hills and cattle country of northwestern Nebraska in the early days, when there were no such things as roads; merely trails through the sand hills.

"It was nothing then to be called to make a trip over these trails, little more than cattle trails, to some outlying ranch 25 to 50 miles distant," he wrote. "To make a trip like this, the doctor was forced to either go or come in the night, or give up two days to the trip. On many of these drives there would be stretches of 25 miles or more with not a house or even a post to mark the trail and every sand hill looking just like every other sand hill.

"This is a section noted for its quick-forming and severe storms. You might leave home for one of these all day and night drives on a bright winter morning with not a cloud in sight and, before noon, be in the grip of a blizzard.

"The range horse, which was the one in common use here in those days, is an intelligent little animal with traits of character all his own. His life on the range had taught him the necessity of sticking to a trail when he wanted to get somewhere and stick to it he certainly did, and it was this natural instinct in the horse which usually brought the doctor home safe, in due time.

"One thing hard for the eastern man to learn was to trust his horse; but he was forced to trust him, in the long run. If he used his lines and threw him off the trail, the horse was all at sea. He had no idea then where he was wanted to go and so just wandered around from one sand hill to another. The only hope the doctor had then, was to find the North Star and travel by that."

So the range horse, too, must have his due recognition in the history of medicine in Nebraska. 
Dr. Remy, whose pen is a graphic one, also describes most vividly one of the pioneer practitioners, Dr. William B. Loomis, who made his long circuit on horseback, as typical of the early practitioner of this period.

Transferring his mental picture to paper, Dr. Remy wrote:

"He was a man of about 60 years of age and wore a full gray beard, moderately long. He had an average sized body with legs only just long enough to reach to the ground. In other words, rather short. He was perhaps five feet six inches tall and weighed about 160 pounds. I am sure that I never saw him in a buggy, but I have seen him many times on his saddle pony. This pony was a little bald-faced brown mare with a crooked Roman nose and a nervous system strung to the highest tension. His bridle had a long-jawed curb bit which this pony knew well how to bring back against the breast so that when the doctor pulled, he was pulling against her body and not her mouth. When the doctor prepared to mount, she prepared to run. When she felt his weight in the stirrup, she was off! If the doctor lit in the saddle, all right, and if not, he could climb over to position as she ran, and run she always did!

"When you saw them coming, it always looked like a race with death or the stork. The mare running, the doctor pulling, his saddle bags standing straight out on either side, with his long overcoat flying back over the pony's tail."

Not all the men who practiced the healing art here in the early days were graduates of medical colleges, according to Dr. Remy.

"When I arrived in Ainsworth on June 24, 1884, there was one graduate doctor here, one who had had one term at Iowa City, and one who had had no medical training at all, except what he received behind a drug counter in a store in Omaha," and this description is typical of the situation in every county in the state.

"Near town, on their homesteads, were two other men engaged in medical practice, neither of whom had ever seen the inside of a medical college," Dr. Remy further stated, and this too was typical.

These men had come in with the first rush of homesteaders and took up their claims with the hope of bettering their financial 
condition. As they located they found around them sick neighbors without competent medical help and each having had experience enough in an office back east to know something of the actions of the simpler drugs, they began ministering to their neighbors' needs.

"This is said to their credit rather than discredit," Dr. Remy explains, "for I am glad to be able to say that the work they did was worthy of men with much better medical education. They were, of course, short on diagnosis and the finer action of drugs in disease, but in common with the average man who went homesteading in those early days, they were long on common sense, energy and resourcefulness and were able to recognize their limitations. When they reached that point they knew enough to stop and call for help. I wish that every modern doctor knew as much."

Thomas Henry Line, now of Central City, who plotted the original village of Marquette, Nebraska, is another pioneer whose memory spans a wide interval in his practice of medicine in this state.

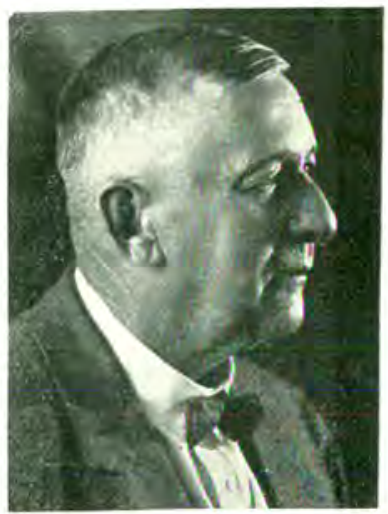

DR. THOMAS HENRY LINE
"I have seen the country of my choice develop from the dugout-sodhouse era to the most prosperous farming country in the world," wrote Dr. Line. "When I came to Marquette, it was inhabited principally by coyotes, jack-rabbits, prairie dogs and rattlesnakes, with an occasional sprinkling of Indians. I practiced medicine by going a-foot, on horseback, by ox-team, lumber wagon, spring wagon, single and double horse buggy, automobile, and who knows

but what I may yet go to see patients, 'a la Lindbergh'."

But a Nebraska physician had achieved those heights, even before the name of Colonel Lindbergh was written on the pages of history.

In April, 1919. Dr. F. A. Brewster of Holdrege, formerly in the air service in the late war, bought a Curtiss army training plane and on May 23, that year, flew to Herndon, Kansas, a distance of 
70 miles by road, and operated on a fractured skull case, establishing a world record for this small town Nebraska physician. $\mathrm{He}$ is the first physician in the world known to make a doctor's call by air. $\mathrm{He}$ and his pilot made a graceful landing, the doctor performed a delicate operation, removing pieces of bone from the skull of a man injured by an oil derrick, and flew back home the same after-

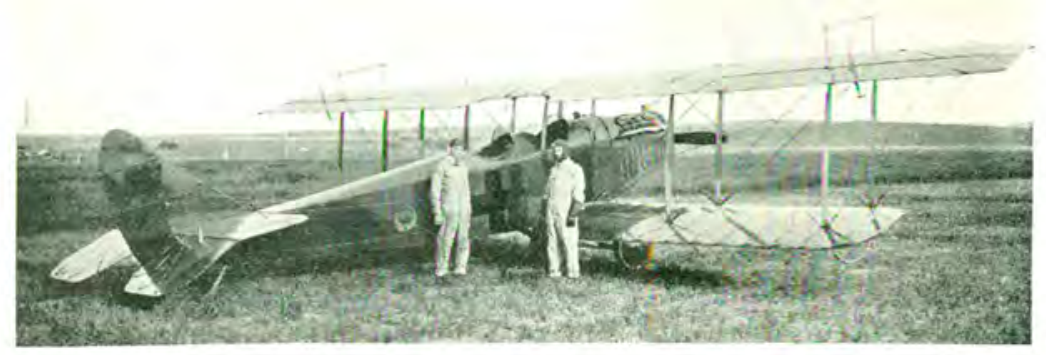

DR. F. A. BREWSTER, HIS AIRPLANE AND PILOT

noon, reaching there at $7: 50$, in almost less time than he could have arrived at his destination by auto. Several days later, he made another air-call to McCook.

His pilot was a neighbor, Wade Stevens, a former army pilot. Brewster bought the plane, a Curtiss Army training plane Model JN 4 D in April, 1919 of the Curtiss Corporation at Buffalo and made his test flight on May 21. Two days later came the emergency for which he sought to be prepared, and he was enabled to save the patient's life. The Curtiss company authorized the statement that the Nebraska doctor's airplane was the first one sold to a doctor to use in making calls, and the Herndon trip, the first physicians' air-call. He won international renown thereby.

That Brewster is progressive by nature, and especially in transportation, is evidenced by the fact that he bought the first automobile in Furnas County in the spring of 1906. It was a single cylinder Cadillac. He also built the first hospital in Furnas County, or in southwestern Nebraska, in fact-the Republican Valley hospital at Arapahoe, in the same year, 1906. Brewster was born and educated in this state and has been practicing surgery since 1900. 
There was some humor too to lighten the burden of pioneer life, according to the following story told by J. V. Beghtol of Hastings, who has practiced for more than half a century; and not a little danger, as the second story illustrates:

"I had been practicing only a few months, when I was called to the hotel to see a woman said to be very sick and in a dangerous condition," he related. "When I arrived, I found one of the maid servants lying on a bed, seemingly lifeless. Many people were in the room, gathered around the bed. The patient was lying on her back, eyes set and staring toward the ceiling: pale, unconscious and with no perceptible respiration. I made a hurried examination, found her jaws set and body generally rigid. With my limited experience, I was unable to diagnose the case and fearing death approaching, I thought it best to have council called. Accordingly, old Dr. Rogers, a pioneer physician with long experience and successful practice was sent for. He was a large, powerfully built old fellow, rough and ready in his habits and had practiced in the town for over a quarter of a century. When he came in, he threw off a large fur coat which he always wore in the winter, and with it, his fur cap and gloves. He said to me: 'Well, my boy, what is the matter here?' I replied: 'I don't exactly know, Doctor. The woman is very bad and I do not believe she will last very long.' Together we approached the bed. He took one long look at the patient and exclaimed: 'Oh, it's Sal, is it! I'll teach you how to fool this young doctor!' He threw off the bed clothes, turned her over on her abdomen and on her bare buttocks he began to smack her so terrifically that the blows could be heard all over the house, whereupon the woman jumped out of bed and ran into the kitchen. As we walked down into town the old doctor gave me a bit of advice I've followed ever since. 'I'll tell you, my boy,' said he, 'I've always made it a practice to treat the patient, instead of the disease." "

Ingratitude, sometimes encountered, was evidenced in this experience of Dr. Beghtol:

"Many years ago, one cold, dark, stormy night, the temperature about zero and a driving wind from the northwest, carrying snow and piling it up in the low places, I was called about ten miles into the country to visit a man with a broken leg. In those early days, no calls were re- 
fused on account of weather. This was before the advent of the automobile but I owned a very fine pair of bay geldings that I disliked very much to drive out on such a night. We started out though with the team and after a hard struggle with the snow drifts, arrived at our destination. The house was an old shanty, back off the road in a field. Two men came out with a lantern to assist me with the horses. We tied them on the south side of a straw shed and covered them with a pair of large, heavy blankets of fine quality which I always carried with me in the winter. The house had only one room. On entering, I found it filled with men, tobacco smoke, whiskey and profanity. The patient was lying on an old straw tick on the floor in one corner of the room. No women were in sight. Examination showed a compound fracture of both bones of the leg, near the ankle joint. It is not the aim of this story to describe the treatment of such an injury in such a place. After treating the man, the same pair of 'birds' with the lantern came out with me to get the team. We found that the blankets on the horses had been stolen and carried away. The horses were shivering with cold. A fine long whalebone whip was also missing. My fine large buffalo robe which I prized very highly was also stolen. The fellows with the lantern bewailed my loss with due profanity and I started home through the drifts without any protection from the storm whatever. The next day I reported my loss to the sheriff who informed me that the house I had visited was a den of thieves kept by my patient, his sons and other relatives. The next day he raided the premises and found much stolen property hid in the stacks. My property was never found. Having taken the case and begun the treatment of the leg, I was compelled to continue and make several visits before the fellow recovered. I never received any pay for my services. Had it not been that we got a cabinet job and a good result, I am sure the patient would have sued me for malpractice. He died several years ago in a drunken quarrel. I do not know where his soul is, but I know where it ought to be."

A record of these pioneer practitioners would be incomplete without sincere tribute to the wives of these early physicians delicately nurtured, courageous women who left their comfortable homes in the east to follow their men to a strange, hard, distant country to share and undoubtedly ease, their lot. 
Such a woman was Mrs. Luther Abbott, for instance, who made the trip from Erie, Pennsylvania, with four young children. The latter part of the journey from the end of the railroad was made in a prairie schooner. Mrs. Abbott used to sit up all night waiting for the return of Dr. Abbott when he made his long, winter rides, and would keep putting potatoes into the oven to roast at frequent intervals during the night to be sure there was a hot one ready for his supper as soon as he came in, half-frozen from his long exposure. She often accompanied him on confinement cases among the lonely farm women when there was no one else to help. But her most heroic response to duty, her children relate, was once when her husband brought home a smallpox patient, who had no one else to fook after him, for her to care for: Neglect was a word omitted from the Abbotts' lexicon.

When there was no other fuel, Mrs. Abbott burned corn to keep her large brood of children from freezing.

Another heroic woman was the wife of Dr. E. B. Graham, who settled in the cattle country, near the Wyoming state line. Mrs. Graham's nearest woman neighbor was 35 miles away. Instead of bemoaning her loneliness, as a less courageous woman might do, Mrs. Graham organized a Sunday school for cowboys, to which they rode for miles around; and planted a vegetable garden, the produce of which was the only fresh fare of its kind the ranchmen enjoyed throughout the season.

\section{"Old Doc"}

by

Dr. George O. Remy, Ainsworth, Nebr.

I've traveled o'er Nebraska's plains

Through north winds white with frost,

Through drifting snow and freezing sleet,

Nor stopped to count the cost.

I've driven miles and miles and miles

Through mud and sleet and rain,

My only recompense, a hope

To ease my fellows' pain. 
I've spent what little cash I had

For books and instruments,

That I might be prepared, when called,

To put up a defense

Against the germs that swarm around

To lay us mortals low, -

Sometimes, I hope, I've been the one

Who caused these germs to go.

I've helped the mother in travail,

Ive eased her racking pain;

And from the yawning open grave

Have brought her back again.

Ive placed her baby to her breast,

Whence it might draw its life:

I've given back to home and friends

A mother and a wile.

Ive tried to treat the people fair

And give them honest work;

Ive done my duty where twas plain

And never tried to shirk.

I've treated rich and poor alike

And never thought of gain.

The only recompense I craved

Was to relieve their pain.

All this I've done, good friends, and more;

I've even brought them food

To keep the wolf from breaking in,

As otherwise he would.

But, when good fortune smiles again.

The past is all ignored:

They pass me by without a smile

Or even a friendly word.

When I have died in poverty

These folks will gather round,

And say: He lacked good common sense;

Quick, put him under ground.

He had too much of sentiment,

If he had made 'em pay,

He might have died like real folks

And bought his own bouquet. 


\section{SETTLEMENT OF PHYSICIANS IN OMAHA}

$1854-1880$

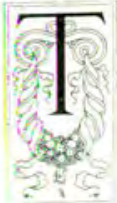

$O$ revert back to the chronological record of Nebraska settlement by men of the medical profession, the compiler gives first the account of physicians who settled in Omaha; other points in Douglas county; and then, those in other parts of the state, so far as their records can be traced.

Dr, George L. Miller was the first physician known to have practiced in Omaha. He came here in October, 1854, with his father, Colonel Lorin Miller, who was later a mayor in Omaha,

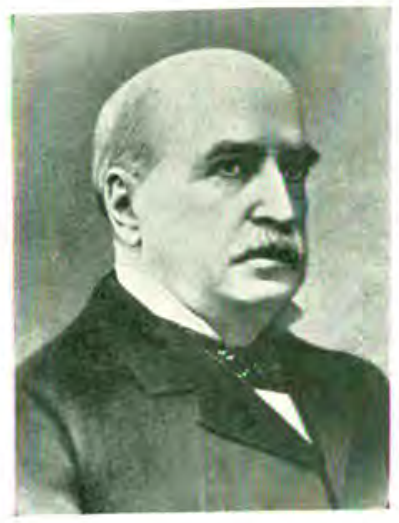

DR. GEORGE L. MILLER when the total population of the newlylocated town was about 20 persons. The Omaha Arrow, printed November 3. 1854, announces the arrival of the Millers, who were destined to play distinguished roles in its future history.

Born in Booneville, New York in 1830, Dr. Miller began the study of medicine at the age of 17 , was graduated from the College of Physicians and Surgeons in New York City in 1852 and practiced in Syracuse for two years before he came west with his father. His first office and home in Omaha was a cottonwood board cabin, with no floors or windows, set in the tall grass which abounded on the prairie, at about Eleventh and Farnam Streets now.

His first case was an Indian papoose whose father called for the doctor at his cabin and guided him through a devious trail to the north part of town where the Indians had pitched their tents, at about the present site of the Union Pacific shops. In later years Dr. Miller confessed to a great deal of trepidation during the trip. He wrote an article in which he told:

"Exactly how the brave jumped from the path and disappeared in the grass without a word of explanation, not even so much as a grunt; how moments seemed hours that 
we stood speechless and motionless, 'each particular hair' sadly agitated at the roots, waiting for his return or tor death, or for whatever else might come; how he did return, and with the wave of the hand beckoned us to follow on among the wigwams and how we followed accordingly, not daring to run, until we reached the right one; how $\mathrm{Mr}$. Indian shot through the triangular door, like the arrow from the bow; and how diligently the medicine man struggled to crawl through the little opening, by main strength and awkwardness, and finally did it; precisely how powerful was the sense of relief from ugly creeping sensations around the head and throat, when a unanimous grunt from two squaws and three bucks gave him a welcome, with smiles, to a cushion on the ground, as a seat of state; how the inevitable pipe and kinnikinnick was passed from the mouths of the aforesaid Indians (who had just dined on dog-soup), to our own; and how sweet was the taste of friendship through its fumes, we cannot stop to particularize. It was the case of a young physician, just out of city life, practicing among the Indians for the first time."

The sick child, unfortunately died, but the white "medicine man's" reputation was established, notwithstanding.

Dr. Miller was named chief clerk of the first territorial legislature on January 16, 1855 just a few weeks after he landed in Omaha, and thus began his political career and newspaper attachment, for which he later deserted the medical profession. He served four years in the territorial council, of which he became president, and was Omaha health officer in 1859. The same year he was sent to Washington, D. C., as the "special agent" of the territorial council "to get Congress to reimburse Omaha for money spent in building. the capitol." He was also commissioned to use his influence to get Congress to locate the surveyor-general's office in Omaha; to locate the Union Pacific railroad north of the Platte river and in the Platte valley; make Omaha the military depot for the Utah war; to appropriate funds to remove snags from the Missouri river; to make Omaha a port of entry and the Omaha post office a distributing office.

Quite a large order for one man to fill in Congress:

Apparently the practice of medicine in Cmaha was not very profitable then, for on his return from Washington he moved to St. Joseph, Mo., in 1860, although he did not remain there long. Those 
were exciting days on the eve of the Civil War and Dr. Miller was moved to turn his pen to stirring editorials, printed in the St. Joseph Gazette. This was the beginning of his newspaper career, which culminated in his establishment of the Omaha Herald in 1865. This newspaper merged with another and became the present WorldHerald in 1889 and Dr. Miller continued as its editor for 27 years.

In 1861, President Lincoln appointed Dr. Miller sutler at Fort Kearney. In 1864 Miller returned to Omaha and became the democratic candidate for Congress, but was defeated. It was the next year that he retired from practice entirely, and with D. W. Carpenter founded the Herald. From then on Dr. Miller became noted for his vigorous writing and a power in journalism and politics. He was president of the Western Associated Press, a news gathering agency which later became part of the Associated Press.

Miller's greatest service to Omaha was the active part he took in obtaining the location of the Union Pacific bridge where it now spans the Missouri river, instead of abiding by the engineers' decision to locate it elsewhere. When the issue hung in the balance, Miller boarded a train for New York and went in person to see President Durant and through his influence finally obtained the coveted prize for Omaha. Ezra Millard and Augustus Kountze were also instrumental in this endeavor. Miller, in the days of his early residence here, also successfully advocated the removal of the capital from Bellevue to Omaha.

Establishment of the Herndon house at Ninth and Farnam, the first hostelry in Omaha, on the site of the old Union Pacific headquarters prior to the erection of the Union Pacific's present fine building; and the development of Seymour Park, now the Lakewood Country club near Ralston, are also credited to Dr. Miller. Miller named Seymour Park for his friend, Horatio Seymour. The present system of Omaha parks and boulevards was developed during Miller's term of office as park commissioner and Miller Park was named as a tribute to him.

Some of the stone used by Dr. Miller in building his fine country place at Seymour Park, a 460 acre tract, and which home was later destroyed by fire, is included in the St. Martin church edifice on the South Side. 
Miller stood high in the councils of the national democratic party and at Cleveland's election was prominently discussed as a probable member of the cabinet. He helped organize the Nebraska Historical Society in 1878; was a member of the fire and police commission, founder of the Omaha Club, president of the Greater Omaha exposition in 1899, and head of the Humane Society. He was also collector of customs at Omaha, and was for a time general agent of the New York Life Insurance Company here. He died at the age of 90 in Omaha and was buried in Forest Lawn cemetery.

The second physician to locate in Omaha, Charles A. Henry, did so under rather unusual circumstances, yet he became one of the leading Omaha citizens; operated with Dr. James K. Ish, the first drug store and built the Pioneer block on lower Farnam street, the first three-story business block in the city.

Dr. Henry, a town lot speculator practicing in Bellevue, in April, 1855, shot and killed George Hollister, an employee of Peter Sarpy, in a dispute over a boundary line. He was brought to Omaha a prisoner and chained to the floor in the sheriff's house, according to an account in Sorenson's History of Omaha. While Henry was a prisoner there, waiting for the first grand jury in the territory's history to be impaneled to try him, Dr. Miller, the only other doctor in town, was called to accompany a flotilla of steam-

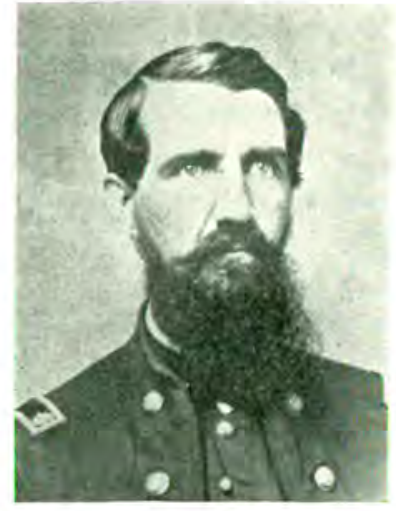

DR. ('HARIFS A. HENRY boats, carrying soldiers among whom cholera had broken out, up the Missouri river to Fort Pierre. Sickness broke out in the town during Miller's absence, so the sherriff led Dr. Henry around, in chains, to treat the sick. This won the sympathy of Omahans, especially as the doctor said he shot in self defense. Two juries, impaneled expressly for the purpose, refused to indict him, and he was exonerated. The late A. J. Poppleton and O. P. Mason were his attorneys. Henry then settled in Omaha - he was a brother-in-law of the late Governor James E. Boyd - and rendered the UnIon cause a great service during the Civil War. He was always 
reputed to be a shrewd man, of wonderful nerve and physical courage.

His reputation as an extreme democrat and pro-slavery man before the war was responsible for his choice by Colonel E. D. Webster, a former Nebraskan then aide to William H. Seward, Secretary of State at Washington, D. C., to gather much needed information regarding the rebel ram Merrimac and the southern fortifications not far from Washington.

Fitting Dr. Henry up with a full set of surgical instruments, with quinine and other rare medicines, he was given a pass through the Union lines and made a month's sojourn through the South, where he traveled unmolested by reason of his friendship with De Londe of Louisiana, John A. Parker of Virginia and W. E. Moore of Arkansas, who had been connected with Brownsville and Omaha land offices as registrars. His report, on his return, was so satisfactory that he was given a captaincy and assigned to duty as assistant quartermaster with General Steele in Arkansas. He later rose to the rank of lieutenant-colonel and died June 8, 1880, at the Boyd home in Omaha. A son, W. P. Henry, now lives in San Francisco.

Enos Lowe, the real "father" of Omaha, did not take up his residence here until late in 1855. He was born May 5, 1804, in North Carolina, but at the age of 10 moved with his parents to the Territory of Indiana. He received his medical education at the University of Cincinnati, and was a member of the Indiana legislature from Rockville until 1836, when he moved to Flint Hill, Iowa, remaining there until 1847 . He was a member of two conventions to frame a constitution for Iowa and was president of the second. His influence in politics was indicated when President Van Buren, in 1847, made him receiver of public moneys in the land office at Iowa City and in 1853, appointed him to the same position at Kanesville, or Council Bluffs. Shortly after his arrival there, Dr. Lowe helped organize the Council Bluffs and Nebraska Ferry Company which founded the city of Omaha, and it was he who ordered the purchase of the first ferry to ply between the two cities. He retained his government position in Council Bluffs for two years, moving to Omaha in 1855. His brother, Jesse Lowe, was elected the first mayor of Omaha. 
Dr. Lowe continued active in local affairs, in the Omaha Claim Club, which had much to do with settling original claims; Old Settlers' Association and other groups, though he himself did not hold office. When the Civil War broke out, he enlisted as surgeon in the First Nebraska Infantry and later rose to brigadier general. $\mathrm{He}$ was active in the profession until his death here, February 12, 1880. The nearest surviving relative left in the city is a niece by marriage, Mrs. Fred B. Lowe, all the others having moved away.

The following tribute of the Herald to Dr. Enos Lowe was printed when he died in 1880:

"The character of Dr. Lowe, like his noble and stately form, dignified and commanding, never tainted by infidelity to public or private duty, always generous in service to friends and the community; wise in counsel as a citizen; and singularly gifted as a physician with insight into disease, and of the issues of life and death, which wait upon it; is of right entitled to the veneration and perpetual remembrance of all who have made their homes in the city of Omaha, and among those founders he was one of the first for 25 years of its history."

The next year after Miller's arrival, 1855, brought an important quartet of physicians-W. R. Thrall and his partner, A. McElwee, who had been assistant physician in the Ohio Lunatic Asylum and was known as a man of parts: James H. Seymour and B. T. Shelley, all of whom won instant recognition for qualities of leadership.

Thrall was elected to the third session of the territorial legislature in 1857-8 and was chairman of the committee of the whole during the capital removal fight. Alfred Sorenson's History of Omaha quotes a vivid description and a drawing to illustrate it, of the fight which ensued when the speaker, Mr. Decker, attempted to resume his seat, which Dr. Thrall held, for the time.

"Thrall refused to let him have it. Decker grabbed for the gavel in Thrall's hand. A. J. Hanscom (donor to the city of Hanscom Park) yelled: 'Hit him over the head with it!' Decker tried to push Thrall out of his seat. Hanscom pulled Thrall back again. Others then interfered to prevent Decker from ousting Thrall and a freefor-all fight, with many bloody noses and black eyes, followed. The Omahans won. Dr. Miller, president of the 
council, sided with the Omaha faction by refusing to put a motion to adjourn to Florence."

Dr. Thrall and his partner, Dr. McElwee, also cared for some of the victims of the Omaha Claim Club members meihod of taking justice into their own hands, in the matter of establishing claims to Omaha lands, according to Sorenson's history. One of their victims, Callahan by name, was ducked into the icy Missouri river and kept there until he promised to sign a paper of relinquishment. When they fished him out, he was half drowned and frozen so that he could not stand up. The doctors took the patient into a warm room, stripped off his wet clothes, some of which were actually frozen stiff, wrapped him in dry blankets and gave him three doses of whiskey. This treatment, especially the stimulant, soon revived him and he signed the deed of relinquishment.

Dr. McElwee died about a year afterwards and Thrall did not remain here, but returned to his former home in Cincinnati, in 1858 , and was later appointed United States Marshal there.

Dr. James H. Seymour, the third of this Ohio group including Thrall and McElwee, was born in Connecticut in 1825, but was. educated, and taught school in Ohio and was graduated with distinguished honors from the Cleveland Medical College. He was then appointed resident physician at the Marine Hospital under the celebrated surgeon. Professor Ackley. The Seymours came to Omaha in 1857. The doctor had intense anti-slavery convictions and occupied himself almost at once in organizing the Republican party. $\mathrm{He}$ was elected to the Territorial legislature in 1859 and again in 1861, while he was serving with the Nebraska Cavalry in St. Louis. He returned to serve in the legislature the winter of 1862 and at its close was appointed by Governer Saunders, Surgeon to the First Nebraska Regiment, Enos Lowe having been promoted to brigadiergeneral. Shortly after he joined his regiment, Seymour was stricken with fever and died in Helena, Arkansas, September 7, 1862.

One of the countless tragedies of war marked Seymour's enddenial of his intense wish to see his young wife again before he died. Chaplain, later United States Senator T. W. Tiptin, was despatched by steamer to the nearest telegraph to notify Mrs. Seymour and accompany her to camp at Helena, Arkansas. When they arrived, nine days later, it was just one day too late. Before he died, 


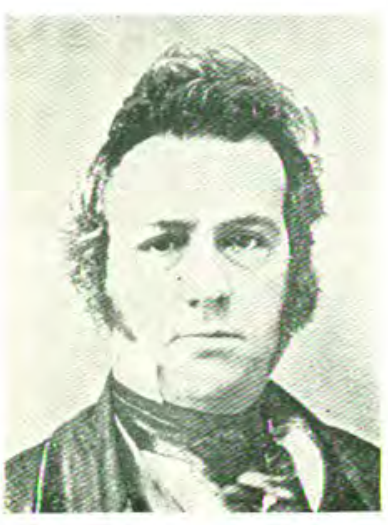

DR. JAMES H, SEYMOUR the previous day, the doctor called for the picture of his wife and children, kissed each one of the visages and then wrote in a tremulous hand: "Dear Wife and Children: I do love you but shall not see you again. I want to put full trust in God. O! It is hard. Goodbye. James."

His devoted wife, who was Lucretia Robertson, daughter of one of Seymour's preceptors, incorporated his name with Seymour addition to the city of Omaha, according to a statement in Omaha Illustrated, published in 1888.

B. T. Shelley did not remain here long, but founded the town of Niobrara. Seven other doctors must have come that year for their names are recorded as incorporators of the first Nebraska Medical Society, March 25, 1855. Dr. George L. Miller's name heads the list with B. T. Shelley and M. H. Clark of Nebraska City. The other six names are no longer familiar to present-day residents, indicating that the doctors must have drifted to other fields. Their names were Henry Bradford, J. C. Campbell, Joseph Venable, Josiah Crane, Samuel Wilson and James Stokes.

They were authorized to establish county and district societies and also to appoint an inspector "to examine and determine the quality and purity of drugs and medicines offered for sale in the territory."

This association evidently did not materialize, for two years later the legislature chartered another "Nebraska Medical Society," naming as incorporators A. Chapel, W. R. Thrall, J. P. Peck, A. McElwee, Geo. L. Miller; A. B. Malcolm, Florence; John C. Campbell and A. Bowen, Nebraska City; Andrew S. Holliday, Brownsville, and E. A. Donelan of Plattsmouth.

These gentlemen evidently realized the magnitude of the task of having an inspector examine all the drugs and medicines offered for sale in Nebraska, for the authority to appoint such an official was not given by their charter. 
A. Chapel came to Omaha in 1856, probably at the solicitation of Dr. George Miller, who turned over his practice to Chapel. They were both graduates of the New York College of Physicians and Surgeons. He was the first health officer named for Omaha, in March, 1855, one month after the Omaha charter was granted by the legislature. Dr. Chapel entered the army during the Civil War and contracted a disease from which he died, in Chicago.

Drs. Alexander B. Malcolm and James Porter Peck are the next arrivals to be considered. Malcolm arrived in Council Bluffs from Maine, in 1854 and lived there even after he opened an office in a small one-room adobe house on Harney street, in Omaha, practicing all over this district. He made himself very popular with the Indians when he gave one of them chloroform while he performed a minor operation on the red man's foot.

The story goes that when the Indian recovered, he exclaimed: "Please, Mr. God, give Indians heap sleep medicine-get all Pawnees horses. When wake up, they gone!"

When Dr. Peck arrived here, the two formed a partnership, Peck remaining in Omaha and Malcolm going on to Florence, where he opened another office. They agreed to divide their income. Malcolm lived there until his death in 1882 .

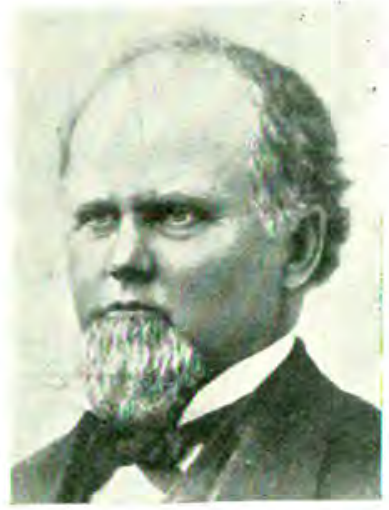

DR. JAMES PORTER PECK

Peck, who had come here from Ohio with his wife and two small sons, one of whom died shortly thereafter of diphtheria, related in after years, that the winter of 1856 was so cold he used to take a sack of potatoes to bed with him to keep them from freezing. Peck and his family experienced all the hardships and rigors of early days. He was born in Stow, Ohio, October 11, 1821, and worked at the printing trade on a Columbus, Ohio, newspaper while reading medicine in the office of D. D.

Evans, one of the leading physicians of the state. He accompanied Evans when the doctor was summoned to Sandusky during 
the fateful cholera epidemic of 1849 which raged so intensely that business was suspended and every physician fled. Evans and Peck remained at their self-imposed task of duty for seven days, when Evans contracted the disease and had to return to Cleveland. Peck was graduated from the Cleveland Medical College in 1850 and remained in Akron until striking out for the west. The little family came up the Missouri river by steamboat, arriving here July 6, 1856 .

Peck was a charter member of the Nebraska Medical Society incorporated in 1857; was elected city physician in 1858; was president of the Omaha Medical Society in 1866; and a trustee and member of the faculty of the Omaha Medical College started in 1869. Dr. Peck was a great lover of horses of the racing breed and was active in establishing the first driving club track.

His son, Edward Porter Peck, relates an interesting coincidence regarding his father, who died February 20, 1887. While traveling with the late Henry Estabrook in 1909, E. P. Peck met, in a Sandusky hotel, an old man who recalled his father's services with Dr. Evans in the Sandusky epidemic. The son also stated that the late Dr. Edward W. Lee confirmed the report of Dr. Peck's cold air treatment of pneumonia 50 years before it began to be practiced generally. Dr. Lee, a former Omahan who will be mentioned later, was practicing in New York when he made this statement to Mr. Peck.

James Kerr Ish, who later served two terms as Douglas county treasurer, should here be mentioned as an Omaha resident of 1856: some histories date his arrival in 1855 even, stating that he was associated with Charles A. Henry in opening the first drug store in Omaha in that year. In 1856 Ish opened a branch of a St. Louis drug company, Speed \& Rochelle, acquired an interest in it and later controlled Ish \& Company, the largest wholesale and retail drug business in the state. Dr. Ish also acquired large property interests here.

The year 1857 marked the arrival of two distinguished men of the profession, whose names are linked with Nebraska history. They were Gilbert C. Monell, grandfather of ex-Senator Gilbert Monell Hitchcock, and Augustus A. Roeder whose calling was also followed by his three sons, George of Grand Island, Julius and 
Gustav now of St. Louis; and his grandson, Clyde A. Roeder, Omaha surgeon. Two generations of surgeons had also preceded Augustus Roeder in Germany. Roeder served as city physician in 1862; operated one of the early drug stores here; was one of the organizers of the Omaha Medical Society in 1866 and of the Nebraska State Medical Association in 1868, of which Monell was the first president. He died in California in 1870, one year after leaving this state. His son, George, father of Clyde, was born here in 1860; was graduated in one of the first classes of the Omaha Medical College and completed his education at Rush Medical College in Chicago. He be-

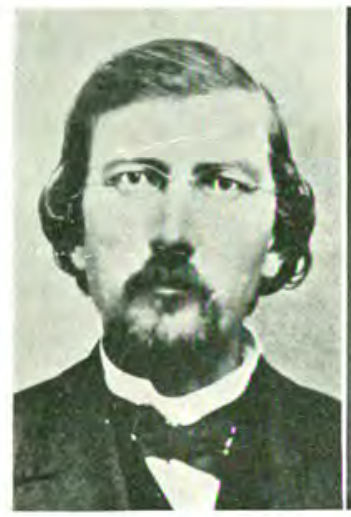

AUGUSTUS A. ROEDER

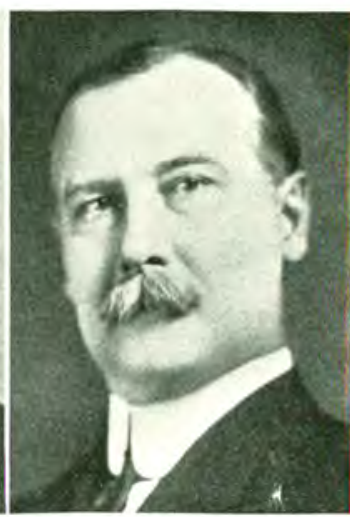

GEORGE ROEDER

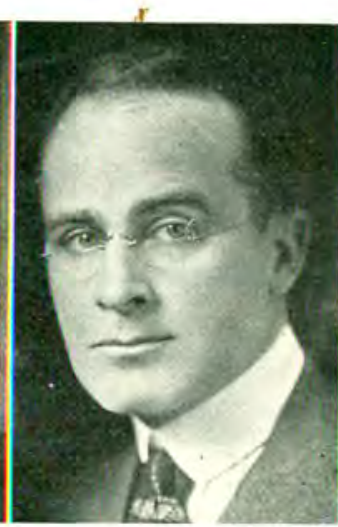

CLYDE A. ROEDER

came chief surgeon at St. Francis Hospital, Grand Island, in 1891, and in 1898 served as captain of Company M of the Second Nebraska regiment during the Spanish-American war. His brother, Julius Roeder, also practiced in Nebraska a number of years before moving to St. Louis.

Monell initiated the newspaper importance of the family by founding the Rocky Miountain News in Denver, Colorado, before he settled in Omaha in 1857. His interest in public affairs was exemplified in his efforts to found the Deaf and Dumb Institute, and his election as president of the first board of education in Omaha. Dr. Monell was born in Montgomery, N. Y., in 1816, and was graduated from Union College. He practiced medicine in Newburgh, Orange county, for a number of years and was very successful, coming west for rest and recuperation, chiefly, but with no idea 


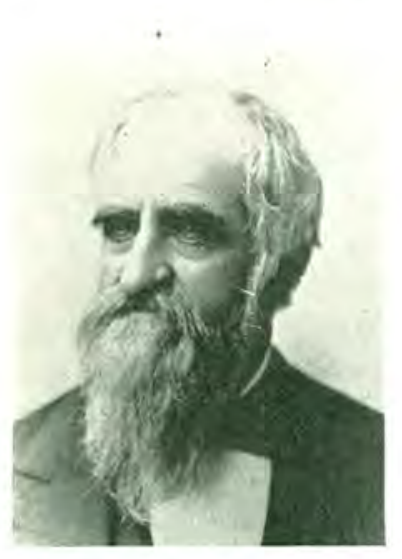

DR. GILBERT C. MONELl Hitchcock, editor of the World Herald and also senator from Nebraska and chairman of the important foreign relations committee during the recent war, acting really as representative of President Woodrow Wilson. He has also been mentioned several times as a presidential candidate possibility. The writing trend in the family is preserved in Senator Hitchcock's daughter, Mrs. Henry Doorly, great granddaughter of Dr. Monell. The Monell family home, one of the most pretentious of Cmaha's early days, was located on Dodge street, at about Twenty-first strcet on the site of the present Knights of Columbus clubhouse.

Another prominent Omaha physician of 1857 was William McClelland, who was a surgeon in the Pawnee War, unde: General Thayer. He also enlisted in the Civil $\mathbf{W}$ ar as surgeon in the First Nebraska with Lowe and Seymour. Dr. McClelland is recalled as the first local physician to use a buggy. The first set of harness made here was at his order. He died in December, 1882.

A daughter, Jennie, is now postmistress at Angel Island, the naval training station in San Francisco.

Hans Peter Jensen, who later became one of the city's best known surgeons, also arrived in Omaha in 1857 when a youth of only 13. He will be mentioned again later, as will John E. Summers, Jr., born at Fort Kearney, Nebraska, January 2, 1858, to an army surgeon and his wife, and destined to become pre-eminent as a surgeon in Omaha. 
An old business directory of the city of Omaha in 1857, found by Byron Hastings, Omaha realtor, in the rubbish of an old building on lower Douglas street, and presented to $\mathrm{Al}$ fred Sorenson, dean of Omaha newspaper men and historians, lists among the physicians those named above: A. Chapel, J. P. Peck, Gilbert Monell, McElwee and Thrall, Seymour, McClelland and one X. S. Richardson of whom no other information is available. Miller was not practicing, and Lowe was probably still counted in Council Bluffs. Henry and Ish were listed in the drug business.

From this date on, until the Civil War brought a number of army surgeons who later settled in Omaha, there is no record of important arrivals of medical men in Omaha, except Dr. A. S. Wright of Indianapolis, who introduced homeopathy in Nebraska in October, 1862, and who will be described in the section dealing with homeopaths. There were a number like the Doctors Nicholas and Luther Abbott and Jetur R. Conkling, who settled in nearby towns and later became associated with Omaha's history. No further records of the medical society or other professional meetings can be traced, except the bare mention of one meeting held in Omaha, either in 1857 or 1858 , to adopt a fee bill for mutual protection, until the organization of a new medical society, June 14 , 1866.

In the interim of almost ten years many things had happened to draw the attention of the East to Omaha, chiefly the building of the Union Pacific bridge and the ensuing boom. Then the young men, disbanded after the Civil War, many with medical experience in the conflict, had completed their medical education and were looking for new fields in which to settle. Several prominent army physicians, Dr. J. E. Summers, Sr., J. H. Peabody, J. R. Conkling, stationed in this area during the war, also saw their opportunities here and cast their lot with the growing territory, on the eve of its admission to statehood. Their record follows:

Jetur Riggs Conkling, a native of New York, came to Nebraska shortly after his graduation from Rush Medical School in 1859 with a party of friends bound for a gold hunt on Pike's Peak. 


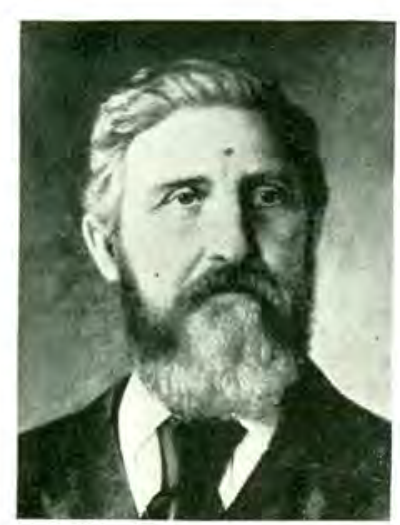

DR. JETUR R. CONKLING

They made the trip in four wagons drawn by oxen, consuming three weeks in the journey from Clinton, Iowa, to Council Bluffs. This so discouraged them that the party broke up when it reached Omaha, June 8, 1859. Conkling remained here for a few days, then went on to Tekamah, where a small group had just organized the county seat of Burt county. Shortly after, he was elected county clerk, then treasurer. Conk ling remained there in practice for four years until his appointment, in 1863, as post surgeon at Fort Kearney, where Indian raids and buffalo hunts enlivened the post atmosphere. Eight months later, when the Union Pacific site was located, Conkling moved to Omaha, soon acquiring a large practice. He became coroner in 1865, served as city physician for three years and county physician in 1881: was active in the medical society affairs of his day, and on the staff of Mercy hospital, which preceded St. Joseph's hospital. Conkling Hall, the nurses' home at the University of Nebraska Medical School, is named for him in appreciation of the first scholarship fund established in connection with school, in his memory, by provisions in Mrs. Conkling's will. $\mathrm{He}$ passed the last few years of his life in Florida. Dr. Conkling was a brother-in-law of the late A. J. Hanscom, pioneer settler who gave Hanscom Park to the city of Omaha.

James H. Peabody, ordered here from St. Louis as major of the medical district of Nebraska, July 17, 1864, was the next medical arrival of importance. Peabody, with a long list of influential friends in political circles in Washington, D. C., where he was born March 7, 1833, may well be called the "father" of the Nebraska State Medical Association, for it was in his office at 325 South Twelfth street that the organization had its inception in May, 1868, and he was the second president, in 1869. He was also a charter member of the Omaha Medical Society and the first delegate from Nebraska to the American Medical Association convention at Washington, D. C., in 1870. 
Peabody had a long and colorful career. Born in the national capital, he spent his youth near the President's mansion, served as a page in the House of Representatives for five years; was a clerk in the United States pension and land office, and was a warm friend of President Andrew Jackson, General Lexwis Cass and Schuyler Colfax. In the meantime he studied dentistry and medicine and was graduated from Georgetown University, March 8, 1860.

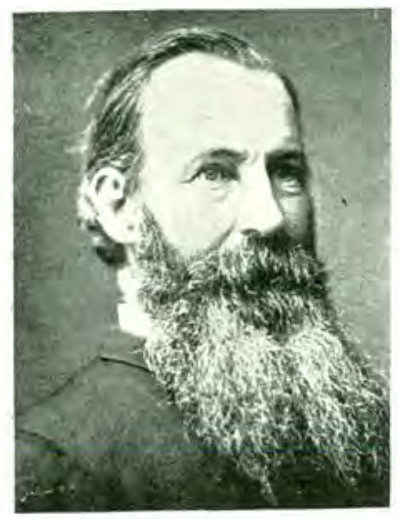

DR. JAMES H. PEABODY

In 1859, on information received from Mormon trekkers, there was a company formed to search for gold in the Black Hills. Young Peabody was interested in the project and with Dr. J. C. R. Clark of Missouri got himself appointed to vaccinate all the Indians in Nebraska and Dakota, hoping in that way to get access to the gold country and employ the Indians to aid their project. The Indians demurred and refused the white men the opportunity to prospect for gold. When war broke out, Dr. Peabody was placed in command of the Marine Hospital at St. Louis, and July 17, 1864, he was ordered to Nebraska as major in charge of the medical district of Nebraska. He occupied the old state house building on Ninth street, between Farnam and Douglas on the west side of Ninth and early evidenced his interest in Omaha by buying some land the first year he was here. After the war, he spent a year at Bellevue Hospital and the College of the City of New York, preparing himself for general practice in civil life, and returned to Omaha in 1866.

His practice extended for 50 miles around and he had many narrow escapes due to exposure in all kinds of weather, poor roads and bridges. He was nearly drowned in March, 1867, when he was washed into the Papillion river, just above Gilmore. A messenger who returned over the same route the next day with medicines, en route to Forest City in Sarpy County, was drowned in the ice with his horse, when the bridge gave way.

Mrs. Peabody's health failed in 1874 which induced the doctor to go to California for a year, but in that brief period of residence 
in the West he was made vice president of the San Joaquin Valley Medical Society. He returned to Omaha late in 1875 and continued his busy life here. He wrote many articles to give interest to the medical society meetings. He was on the staff of the first St. Joseph Hospital, called the Good Samaritan Hospital, which burned down, and the Children's Hospital, which was the forerunner of the present Clarkson Hospital.

Among the important contributions of Dr. Peabody to science was a report, printed in the Philadelphia Medical and Surgical Journal in September, 1876, in which he set forth his experience in 16 years of treatment of diphtheria and tonsilitis with oil of turpentine. This article was widely copied and brought the remedy into use in this and other countries. He was credited with originating the treatment which cut down the number of deaths to only 8 or 10 per cent, whereas otherwise it had been 20 to 30 per cent.

Dr. Peabody also wrote the "Medical and Surgical History of the War of the Rebellion;" contributed an article on surgery for the International Congress of Surgeons in Washington, September, 1887, and gave a number of pathological specimens to the Army Medical Museum in Washington. He was also one of the most popular physicians who ever practiced in Omaha, according to report. $\mathrm{He}$ took pride in tracing his ancestry to Lieut. Francis Peabody who came over in 1635. He was a brother-in-law of the late Henry W. Yates, Omaha banker. He was a charter member of the Military Order, Loyal Legion of the United States and Custer Post of the Grand Army of the Republic and other patriotic societies; contributed to the growth of all public enterprises in Omaha and dabbled a little in Populist politics, having been a candidate for mayor of Omaha and in 1894 came within two votes of obtaining the fusion nomination for Congress.

A son, Dr. John Dent Peabody, was graduated from a BrookJyn Medical College in 1881 and later practiced in Tekamah and Omaha before moving to St. Petersburg, Florida. The elder Peabody died in 1906.

Richard Channing Moore, a graduate of the Chicago Medical College and an acting surgeon in the Civil War, cast his fortune with Omaha, September 5, 1865. His qualities of leadership were 


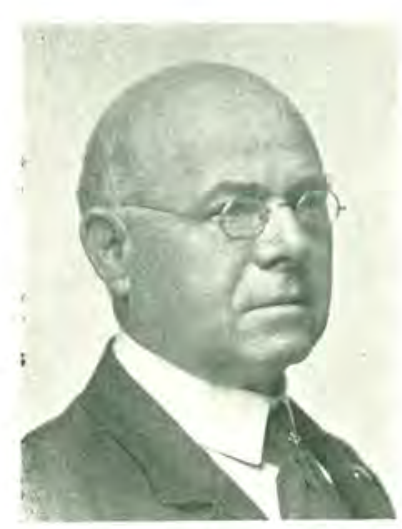

DR. RICHARD C. MOORE

at once apparent. He was city physician from 1876 to' 1879; helped organize the Nebraska School of Medicine and the Omaha Medical College, where he occupied the chair of mental diseases, and served as president of the local and state medical societies. $\mathrm{He}$ was also a vice president of the nationalassociation. He had three daughters in Omaha-Mrs. E. S. Westbrook, Mrs. Victor White and Mrs. Harry Jordan.

Sorenson's history relates an incident of 1867, when Doctors Moore and Peck were summoned to attend a railroad employe who had been scalped by a party of Indians, and left for dead. When the man, William Thompson by name, regained consciousness and found his scalp lying not far away, he managed to get back to camp, put the scalp in a bucket of water and get to Omaha by train. The scalp was a strip ten inches long at one point, five inches wide, having been cut from the center of the head, from forehead to neck. The wound was a terrible one, the knife having penetrated to the bone, and the patient was ill for a long time with a high fever. His scalp could not be sewed back by the surgeons so it was stretched on a board and tanned. When Thompson recovered and was returning to England, his native home, he presented the scalp to Dr. Moore who kept it a number of years, but eventually gave it to the Omaha Public Library Museum.

Dr. I. N. Rippey, about whom little is known except that he came here in 1865 and was one of the charter members of the Omaha Medical Society the next year, belongs also to this period.

Dr. L. F. Babcock and Emanuel H. Den must also have come to Omaha about this time for their names appear as charter members of the Omaha Medical Society, organized August 1, 1866. The name of Dr. William Eddy is also mentioned in early Omaha histories as practicing here in the early '60's, but his name was not recorded in the society. The charter list included Drs. Augustus Roeder, I. N. Rippey, J. H. Peabody, R. C, Moore, Samuel D. Mercer, L. F. Babcock, J. R. Conkling, J. P. Peck, William Mc- 
Clelland, E. H. Den, Enos Lowe and G. C. Monell. Den was still practicing here in the '70s. He was physician for the Edward Rosewater family, among others.

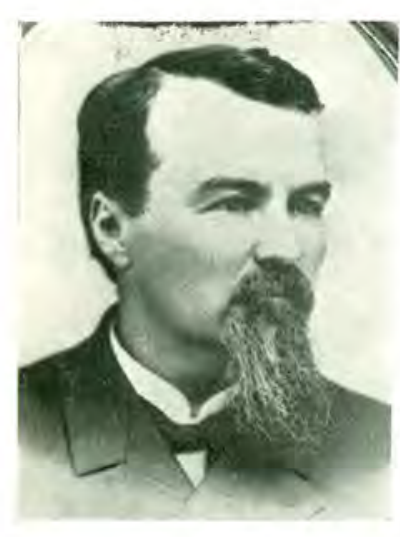

DR. C. H. PINNEY

C. H. Pinney, who was coroner here in 1867 and later assistant for several years to Dr. Coffman before moving to Council Bluffs; Samuel D. Mercer, one of the foremost builders of Omaha, and George Tilden, a leading practitioner, were a trio who settled in Omaha in 1866. The late Dr. Victor H. Coffman, one of the most colorful figures in medical history, and whose widow is still a resident of Omaha with their daughter, Mrs. E. W. Dixon; Jacob C. Denise, wh o se son, Dr. Larimore C. Denise, heads the Omaha Presbyterian Theological Seminary; and Theodore L. Baumer, whose son, T. W. is also living here, form the next group, arriving in 1867.

Denise and Baumer were active in school affairs, as well as medical society circles, Baumer serving on the first school board, of which Dr. Monell was president; and Denise on the faculty of the first Omaha Medical College.

Samuel David Mercer, who came to Omaha in February, 1866, founded the first hospital here in the winter of 1868-9, in a house

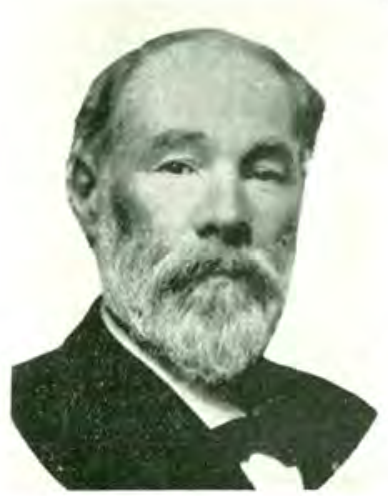

DR. SAMUEL D. MERCER near the present location of 30th and Cass streets. This hospital was soon after purchased by the city for a pest house, and later burned down. When this happened Mercer started another, known as the "Omaha Medical and Surgical Institute," according to one authority. He is also said to have founded the Union Pacific dispensary at 10th and Harney streets.

Born in Ill inois, Mercer, who spent his early life as a farm hand, became 
interested in medicine following a threshing accident and once having acquired his education in medicine at the Universities of M:chigan and Chicago, showed himself an advocate of progress. He organized the Omaha Medical College and filled the chair of clinical surgery for four years later serving as professor of surgery in the Unversity of Nebraska Medical college for two years. He was a leader in the Nebraska State Medical Association, organized in 1867, was secretary for seven years and president one term. He was also vice president of the American Medical Association in 1885-6; surgeon for the Union Pacific, Burlington and smelters, and was for ten years pension examiner for the United States. He had also a distinguished war record, having served as assistant surgeon of the 149th regiment of Illinois Volunteers at Lookout Mountain and Missionary Ridge.

But more than his fine professional record, Dr. Mercer is remembered for what he did for Omaha. He organized the company and developed the first electric railroad plant which later united with others to form the Omaha Street Railway Company. His activity in real estate was keen, netting him a large fortune. He platted the Omaha district known as Walnut Hill, named after the place in Illinois where he was born; built 75 houses thereon and sold them on easy payment. He also built the Mercer hotel, at Twelfth and Howard, one of the leading hostelries of its day, and the fine large mansion at the northeast corner of Fortieth and Cuming streets.

While chief surgeon of the Union Pacific under S. H. H. Clark and Thomas Kimball, he demonstrated his building and professional proclivities by establishing hospitals at Ogden, Laramie and Denver, and at other important railroad centers, where needed.

Mercer retired from practice in 1887 to devote himself to his vast real estate holdings, and died in 1907. A son, Dr. Nelson H. Mercer, graduate of the Omaha Medical College, now lives in England, but returns occasionally in the interest of his property holdings.

The following biography of Dr. Jacob Conover Denise, editor of the Omaha Clinic, the first medical publication in Nebraska, is furnished by his son, Rev. Larimore C. Denise. 


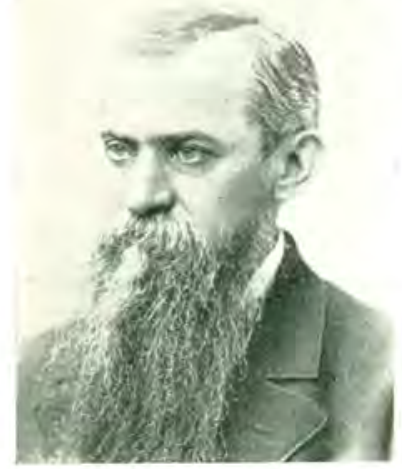

DR. JACOB C. DENISE

Denise was the son of pioneer parents who moved from Monmouth County, New Jersey, to Ohio in 1818, shortly after their marriage. The trip was made on flatboats down the Ohio, in company with a number of others who emigrated from New Jersey at the same time, and formed what is still known as the "Jersey Settlement" near Franklin, Ohio. There, on a farm 35 miles north of Cincinnati, Dr. Denise was born, December 3, 1828. His early education was conducted first at a private school in a $\log$ cabin near his home, and then from a master, from whom he learned Latin and Greek. Leaving home, he delivered the Latin oration at the commencement exercises of Franklin Academy in 1843 and received his first degree at Farmer's College, near Cincinnati, in 1849. After working for a time in the packing house of his brother at Burlington, Iowa, he began the study of medicine. His studies were pursued at Dayton, Ohio at Ohio Medical College at Cincinnati and at Jefferson Medical College in Philadelphia, from which he graduated in 1855.

After practicing medicine in Dayton, Ohio, Denise moved to Centerville, Ohio, and at the commencement of the war he was appointed assistant surgeon of the Twenty-seventh Ohio Volunteers. In 1863 he was appointed surgeon of the same regiment. He was mustered out in 1864 at his own request and returning to his home in Ohio, took a contract as acting assistant surgeon of the United States Army and was assigned as executive officer at the hospital at Columbus, Ohio. In 1865 he was transferred to the general hospital near Cincinnati, where he remained until the close of the year, when he was appointed by the governor of Ohio as surgeon of the soldiers' home at Columbus. He remained at that institution until 1867, when he came to Omaha and began the practice of his profession. In 1869 he was appointed by President Grant receiver of the land office at Grand Island and served in that capacity until 1872. He was for many years physician for the state deaf and dumb institute and was city and county physician from 1868 to 
1871. He was later examining pension surgeon and secretary of the board of the United States examining surgeons.

Denise was one of the original members of Nebraska's medical society and was its first secretary. He was also one of the organizers of the Nebraska School of Medicine, and subsequently of the Omaha Medical College and chairman of the faculty of the college. In October, 1870, he was married to Miss Mary C. Collier of Steubenville, Ohio. He died January 20, 1899.

Theodore L. Baumer came to Omaha in 1867, three years after he landed in America, and in the scant ten years of his residence here established a large following in the German settlement and was elected to the first board of education in 1869 . He was

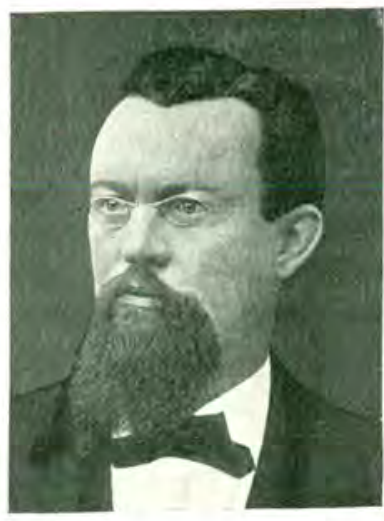

DR. THEODORE L. BAUMER came to this country in 1864 and after a brief stay in New York, practiced in Honesdale, Pennsylvania, for three years before coming west at the request of his brothers, the late John and Colonel William Baumer. Mrs. C. H. Lehmann of Omaha is a daughter.

Dr. Victor H. Coffman, perhaps the outstanding figure in Nebraska medical history for the next 40 years, certainly one whose imprint on the record of Omaha medical annals time cannot erase, was another arrival in the year 1867, after already distinguishing himself as a war surgeon. His is the distinction of having performed the first ovaritomy in Nebraska at St. Joseph Hospital; of applying the first plaster of Paris dressing for spinal curvature in this state, 


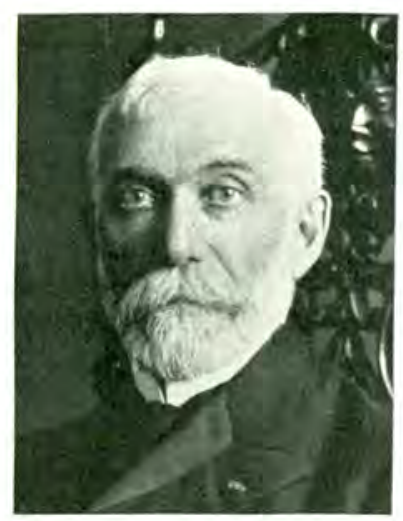

and of having performed in the early 90 s, the difficult and rare operation of removing a tumor of the thyroid gland, been done only four times, but never in this country.

This operation was done in the presence of the most prominent surgeons in the middle west and was counted, at the time, the most brilliant operation ever performed in this country. A Viennese surgeon was the only one

DR. VICTOR H. COFFMAN known to have attempted it, and his patients did not all survive. The Omaha woman, subject of this notable surgery, is still alive, according to Mrs. Victor Coffman, widow of the intrepid doctor. She was a charity patient whom Coffman not only cared for in a professional way, but for whom he provided suitable living quarters and a nurse in attendance for several months before and after the operation, at his own expense.

These successful operations gave him a reputation second to none, from coast to coast, but did not detract from his ardent devotion to the duty of allaying suffering, the chief characteristic of his long life of service to humanity.

Indeed his record in the Civil War, through which he served without a single leave of absence, gave some indication of the singular career he was to follow later. He early attracted the notice of Surgeon Burke, who was General Sherman's medical director. It was in a field hospital one day that the two doctors watched a third surgeon attempting to remove a soldier's injured arm at the shoulder joint, with a tourniquet applied. The hemorrhage was uncontrolled when Dr. Coffman, seeing the peril, placed his thumb over the subclavian artery and compressing it, told the surgeon to remove the tourniquet and amputate. He did. The medical director was so impressed that he promoted Coffman to chief of the operating staff on the spot.

Coffman seemed to bear a charmed life during his long service in the war. At one time his horse was killed and the shell riochetted, 
passing under the operating table in the field hospital where he was at work. At the siege of Mobile he operated 48 hours without rest. He chose to accompany his outfit, the Thirty-fourth Iowa, to the bottom of the Yazoo river, knowing it meant death, but fortunately the order was rescinded.

Dr. Coffman was never a man to waste words. A story typical of his terse repartee was related by Dr. John E. Summers, father of Dr. J. E. Summers, Jr., who encountered Coffman in the Mobile camp where the soldiers were laid low with dysentery. When the doctor inquired what Coffman was giving the soldiers, he replied briefly: "Wooden overcoats."

November 26, 1863, he was promoted to Surgeon of the regiment and March 13, 1865, he was breveted lieutenant-colonel for his meritorious service at Mobile. Throughout his life he devoted himself to the cause of invalided soldiers and helped widows to get pensions.

He was mustered out at Davenport, Iowa, went immediately to Philadelphia where he received his degree of medicine from Jefferson Medical College; then to Houston, Texas, as a contract surgeon and then back to New York, to the College of Physicians and Surgeons and Bellevue for additional work, before settling in Omaha, April 14,1867 .

Here his qualities of leadership were at once recognized. He was one of the organizers of the Nebraska State Medical Association shortly after his arrival; of the Omaha Medical College where he occupied the chair of principles and practice; was a member of the Fire and Police Commission and City Health Commissioner for a period in the $90 \mathrm{~s}$, when his professional and civil activities roused the city fathers to many needed and important reforms. He was also the storm center of several differences with the medical societies for he was a man of strong opinions and actions and cared little for any one's opposition.

Coffman's practice was said to be the largest ever built up by any Nebraska physician, in his day, and much of it was free to the poor, for whom his hard early life seemed to give him an unusual sympathy. Coffman was born near Zanesville, Ohio, September 10, 1839, and spent his early life breaking prairie in Illinois and Iowa. 
He walked two miles to school for the scant education he received in his youth, and worked from 4:00 a. m. to 10 and 11 o'clock at night for much of the time. At 15 years of age, the family moved to Indianola, Iowa, and here, after schooling in the Iowa Wesleyan College, he studied medicine in the office of Dr. C. W. Davis. In 1859 he went to Chicago to attend the medical college, but enlisted in the army as soon as war broke out. Coffman died October 4, 1908.

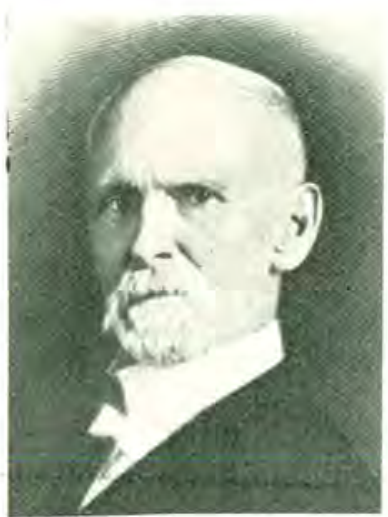

DR. GEORGE TILDEN

George Tilden, whom some state came to Omaha in 1866, probably did not arrive until 1868, soon after his graduation from Albany Medical College. He built up a large practice, became active in medical circles, and was for more than 40 years commissioner for the Douglas County Insanity Board. He was also a United States Army and pension surgeon. His wife was one of the founders of the Omaha Young Women's Christian Association. He retired from practice in 1914 and died August, 1921.

A Dr. Isaac Edwards was apparently a well-to-do practitioner in Omaha in 1867 for he then built The Edwards hotel, at the same time that George Francis Train built the Cozzens. The Edwards was framed in Chicago and cost $\$ 21,000$. In 1869, its name was changed to The Casement, in honor of the Casement brothers, contractors, who built the Union Pacific. In 1870 the name was again changed to the Wyoming. The Cozzens, located at Ninth, between Harney and Howard, in 1891 was purchased by Dr. J. W. McMenamy for the Omaha Medical and Surgical Institute, which makes both pioneer hotels part of the medical history of Nebraska. The Herndon, the first hostelry in the city was built in $1856-7$ by Dr. G. L. Miller and Lyman Richardson.

The next medical personage of importance to claim Omaha as his home was Orlando Scott Wood, recognized leader among Nebraska homeopaths, who came here with his bride July 10, 1868. Only one other homeopath, A. S. Wright of Indianapolis, had preceded him here, in October, 1862, and another came the same year, W. H. H. Sisson of New Bedford, Mass. 


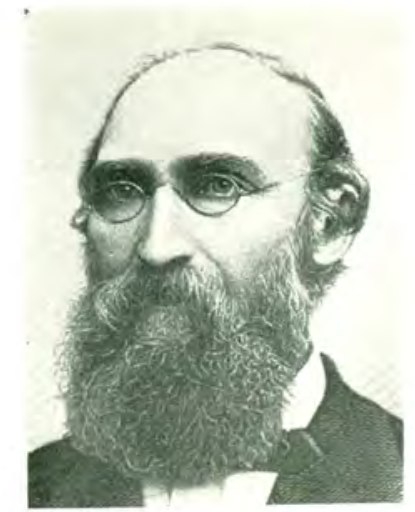

DR. ORLANDO SCOTT WOOD

Dr. Wood was born in Binghampton, N. Y., January 2, 1832. His father died early and young Wood worked heroically as farmer's boy, carpenter's apprentice and clerk in order to obtain his medical education. He was graduated from the Philadelphia Homeopathic Medical College, March 1, 1860, in debt $\$ 1,600$. He practiced in several eastern cities, attended lectures in Hahnemann College, Philadelphia, where he again graduated in March, 1868, a short time before he married and came west. He became a charter member of the Nebraska State Medical Associaation organization that year. He was also one of the organizers of the Forest Lawn Cemetery Association and one of the first advocates of cremation, in Omaha; a senior member of the American Institute of Homeopathy, and of the Northwestern Homeopathic Medical Association and Northwestern Academy of Medicine; specialized in gynecology, diseases of children and rectal diseases; and was active in the Y. M. C. A. and First Baptist Church.

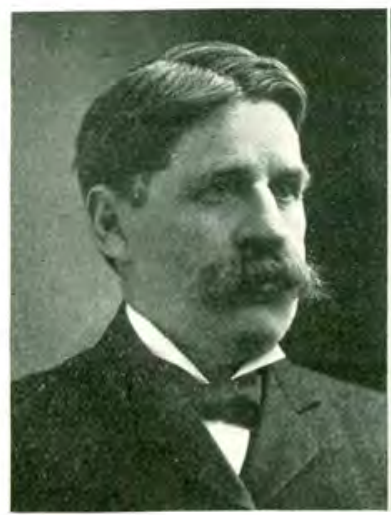

DR. HANS PETER JENSEN

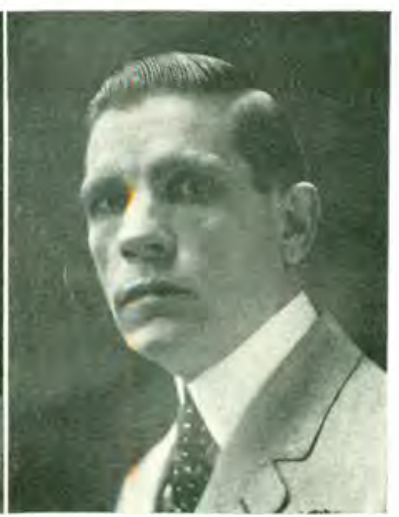

DR. ROBERT P. JENSEN

Last of the old school of pioneers to begin the practice here was Dr. Hans Peter Jensen. An intrepid youth was Jensen, a Danish boy of 13 who arrived in Omaha in a prairie schooner en route to Salt 
Lake, July 1, 1857. His father died of smallpox that very day and his sister a few days later of the same disease, so the young lad early assumed the burdens of his widowed mother, who decided to remain in Omaha. Here Jensen enlisted as a drummer boy in the Civil War, four years later, and after three years' service was honorably discharged, only to serve two additional years in Indian warfare. Discharged with the rank of quartermaster sergeant in 1866 , young Jensen, who until that time had only the scant schooling he had received in Denmark, entered the University of Michigan to study medicine, later attended the Long Island College Hospital at Brooklyn, from which he was graduated June 27, 1873. He then returned to Omaha to practice, carving a name for himself as a pioneer in the practice of therapeutics, credited with being the first physician in Nebraska to introduce a fever thermometer and also with being the first to use the $x$-ray and radium. He obtained his radium from Madame Curie herself, a personal friend, in 1905, when ne was attending European clinics.

While practicing medicine, Dr. Jensen also operated two drug stores, one at Tenth and Howard under the name of Benjamin and Jensen and the second at the northwest corner of Fifteenth and Dodge streets, Creighton Block, under the name of Allen and Jensen.

Dr. Jensen was a linguist of rare ability, having mastered seven languages, it was said, and was known for his scientific research. Comrades in the Union army related that when foraging parties were the rule, young Jensen helped himself only to books which he never destroyed, but which he left under a tree or at the side of the road when he had finished with them, hoping that some one else who could use the book would find it and benefit thereby. He was one of the organizers of the Douglas County Medical Society, held the chair of materia medica at Creighton Medical College and later, that of electrotherapeutics in the Omaha Medical College. He was also consulting surgeon for the Union Pacific. Dr. Jensen died in Omaha, after 40 years practice, June 10, 1913.

His son, Dr. Robert Percival, better known as Percy Jensen, was born in Omaha, June 12, 1875, was graduated from Creighton Medical College in 1896, served in the First Nebraska Volunteers in the Spanish-American War, as his father had done in the Civil War, was sent to the Philippines and attained a captaincy. He took post- 
graduate work in New York on his return, and accompanied his father to European clinics in 1905. On their return he practiced in Omaha until 1922, when he moved to Long Beach, California, where he was president of the federal pension board, and where he died July 31, 1926. Mrs. Henry Raapke, a sister is the only member of the Jensen family left in Omaha.

Other Omaha physicians of the pioneer period of whom little is known except as their names appear on medical society records or on the faculty of the Omaha Medical College are H. P. Mathewson, president of the state medical society in 1873 and who later moved to Lincoln; W. B. W. Gardner, J. Labree, H. R. Benjamin and M. T. Anderson and E. C. Stangland. Their names, except Benjamin and Anderson, appear as charter members of the Omaha Medical Society in 1869. Benjamin was undoubtedly the partner of Jensen mentioned above.

The record of the '70s includes also Dr. George Paul Albrecht Grossman, born in Silesia, October 2, 1846, and educated in the University of Wurzburg, where he early attracted the attention of professors, particularly Professor Spiegelberg of Breslau. His essay, "Changes of Infant's Skull in Passing through the Pelvis During Childbirth," gave him his M. D. degree, July 20, 1870. The very

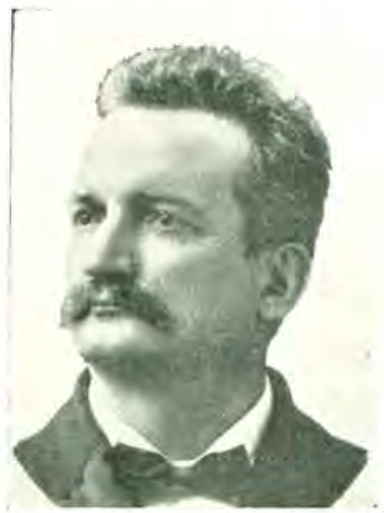

DR. GEO, P. A. GROSSMAN same day he enlisted in the FrancoPrussian war as a soldier and won the Iron Cross for bravery in the battle of Belfort. After the war he was associated with Professor Spiegelberg, the leading gynecologist of Germany, for three years and wrote for medical journals. He then apparenty enlisted for service on Hamburg-American steamships plying between Germany, the West Indies and Central America and landed in New York in 1877. He arrived in Omaha in March, 1877.

In 1880 he took charge of a department in St. Joseph Hospital. In May, 1882 he performed a Caesarian section after Porro's method. It was the sixth operation of the kind in the United States and the thirty-sixth altogether. In 
1883 he was offered the chair of surgery in the state university at Lincoln, but had to resign because it took two days a week. He was appointed surgeon for the Missouri Pacific in 1890 and continued in practice until his death here, in 1905.

P. S. Leisenring and his son, Henry George Leisenring, who also became a physician later, moved to Omaha in 1878 from Wayne, Nebraska, to which town they came in the early ' 70 s. The elder Leisenring was one of the incorporators and instructors in the Omaha Medical College in 1880 and his son was enrolled in the first class, graduating three years later. The son practiced in St. Helena, Cedar County, for a year and then again settled in Wayne, where he lived 27 years. He is the donor of the Leisenring prize at Wayne Normal College. The family moved to California in 1911.

The record of these Omaha pioneers would not be complete, however, without including some who settled in nearby points and were always associated with local medical affairs. Among them were Dr. Harvey Link who homesteaded at Millard in 1856; Dr. Heath who was mayor of Florence in 1857 , according to an account of a July 4 celebration held in the suburb north of Omaha that year, and described in Sorenson's history of Omaha; a Dr. Hardcastle, a Mexican war veteran, also of Florence, killed in August, 1857, when an iron cannon exploded at a political celebration (this is also described in Sorenson's history); Dr. Ira Van Camp, father of Dr. Lee Van Camp of Omaha, who settled in Dakota City in 1862; Dr. Luther J. Abbott, father of Keene and Ned Abbott, who settled at Pap:llion in Octobar, 1861, and Dr. Alexander S. von Mansfelde of Ashland.

Robert R. Livingston of Plattsmouth, one of the organizers of the Omaha Medical College; James Black, also of Plattsmouth; J. P. Andrews of Fort Calhoun; Cyrus Bass of North Bend, and S. A. Bonesteel of Columbus were honorary members of the Omaha Medical Society in 1869, indicating a close relationship with Omaha practitioners. Aurelius Bowen of Nebraska City is another pioneer who should be included with N. B. Larsh of the same place. Both served as presidents of the state association.

Sharing Dr. Miller's distinction as a Nebraska territorial physician in 1854 was Dr. Munson H. Clark, who must have had a small hospital or used his home at Nebraska Center, (probably 
Nebraska City) for that purpose mention is made in Morton's History of a child born to Judge and Mrs. John Fitch Kinney at Dr. Clark's hospital, the day after the Kansas-Nebraska bill became a law. For that reason they named their new son "Bill Nebraska."

Judge Kinney, who had been assistant judge of the Iowa supreme court, and his wife were then en route on a 1,500 mile trip to Utah where he had been appointed assistant justice, the preceding year. The Kinneys later returned to Nebraska City where the judge opened a law office. He was born in New York in 1816, the son of Dr. Stephen F. Kinney.

Morton's History also mentions a Dr. Finney who with Zaremba Johnson, a newspaper man, occupied the first log house built in De Soto, Washington county, May 14, 1855.

Dr. J. P. Andrews lived in Fort Calhoun as early as the spring of 1857 and was both doctor and minister for many years, practicing among the Indians as well as whites. In 1880 he moved to Blair. Mrs. E. H. Clark is a daughter.

Dr. Harvey Link, whose picturesque countenance reminds one of the poet, Walt Whitman, settled on a quarter section in the southwestern part of Douglas county, just 12 miles west of Omaha, September 22, 1856, coming here from Indiana, where he had practiced four years. He lived in the county 49 years. After proving up on his claim in 1859 , he added more

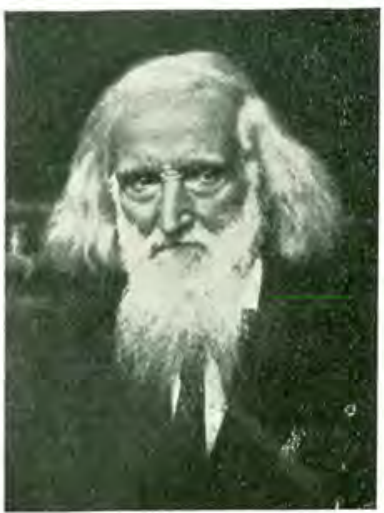

DR. HARVEY LINK land until he had 325 acres, was a member of the last territorial legislature and held many township offices, including 24 years service on the district school board. His wife and family joined him here in 1857. He was also first president of the Douglas County Medical Society, organized in 1883. Dr. Link was born in Tennessee, February 4, 1824 , of an old southern family in which were numbered many prominent physicians. He studied at Tusculum College and was graduated from the Kentucky School of Medicine at Louisville in 1852. Of his eight children, 
Mrs. William S. Collett of Bancroft and Helena, wife of Dr. Philip L. Hall of Lincoln, are the only residents in the state now. Dr. Link died at Millard, September 11, 1906.

Dr. Link was a great friend of Dr. Luther J. Abbott, who settled on a neighboring homestead in Papillion in October, 1861. Dr. Abbott was the father of Keene Abbott, distinguished Nebraska writer and dramatic critic of the World-Herald, and of Ned Abbott, superintendent of the school for the blind at Nebraska City.

Dr. Abbott and his father, Dr. Nicholas Abbott, and a brother, Ephraim, were en route back home in the East after a fruitless search of fortune in California when they stopped at a little tavern called "The Ranch" at Papillion, then known as Little Pappio, eight miles northwest of the village of Omaha. Here they expected to rest themselves and their horses before continuing east. That night the wife of the innkeeper, Mrs. W. H. Lawton, was taken seriously ill and the elder Dr. Abbott attended

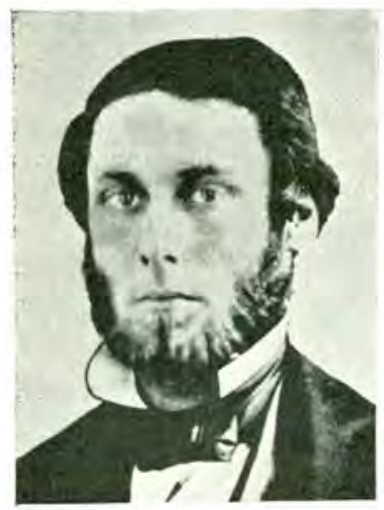

DR. LUTHER J. ABBOTT her and was forced to postpone his departure un til her recovery, for to go and leave a patient who required medical care was unprofessional. While the Abbott trio lingered, Luther and Ephraim Abbott decided to remain and take up a homestead, Luther declaring he would give up the practice of medicine. With his patient better, the elder Dr. Abbott continued his homeward journey to Troy, New York, on November 1, but soon after Mrs. Lawton suffered a relapse and Luther, who had been out of practice for five years, was forced again to minister to the sick. The fact becoming known that he was a physician, Luther was committed to practice and did so in various Douglas and Dodge county locations until his political appointment ir 1895 .

The two Abbotts rented a log cabin a half mile away from the Lawton ranch and lived here until the arrival of Mrs. Luther Abbott soon after. At that time, Mrs. Lawson, whose illness was primarily responsible for the settlement of the Abbotts in Nebraska, had 
another relapse so that Ephraim had to journey to Eddyville, Iowa, the end of the railroad, to meet her for Dr. Abbott who could not leave his patient. They made the rest of the journey in a prairie schooner.

Mrs. Abbott, fresh from the East, brought with her the first piano of which there is any record here, paying $\$ 100$ express charges for the musical instrument which was to mean so much to her in those lonely pioneer days, when the doctor made trips of 75 miles on horseback to care for the sick. Mrs. Abbott taught music lessons that year to help pay for the enormous express bill. Often she rode a pony to the home of her pupil, to give the lesson, or if the pupil came to the Abbott home, she gave the lesson with a babe on her arm.

The Abbotts remained at Pappio, now Irvington, until 1866, then lived a year at Fontenelle, for better sheep pasturage; in 1867 at Oak Grove Farm near Fremont and the Elkhorn river; and from then to 1895 in Fremont. That year Governor Silas Holcomb appointed Abbott superintendent of the Lincoln State Insane Asylum, a post he held for four years. He then moved to South Omaha to resume his practice and died there February 22, 1900, at the age of 68 .

Dr. Abbott's long years of pioneer practice were replete with thrilling experiences, encounters with drunken Indians and rough white men who overran the country. Professional colleagues reported many splendid operations he performed with the crudest equipment; and also an operation he performed on his own lip after a fight with marauders. The doctor was obliged to take three stitches in his own lip and did a very neat job, according to Dr. E. M. Whitten of Nebraska City, and A. B. Bernard, who saw it.

A Dr. Field was also located near Elkhorn in 1856, the same year that Dr. Link pre-empted his cla m at Millard and Dr. J. W. Agee settled at Waterloo in 1864. Dr. J. McLaughlin joined Agee in Waterloo in 1875; C. H. Clark in 1876; A. B. Elwood in 1878, and R. H. Huddleston in 1879. Clark and Huddleston did not remain long for they were gone in 1882. Dr. C. Howcroft settled at Elkhorn Station in 1874 , but remained only a year. Dr. T. H. Bowman then came and stayed four years. In 1879 Dr. J. Lau arrived and remained permanently. 
A former Confederate Army surgeon, J. W. Agee, settled in Valley shortly after the war and became a leader in local affairs. Of a French Huguenot family in which he traced his ancestry back to 1690 , Dr. Agee was born in Tennessee and was educated in medicine at St. Louis in 1861, after which he enlisted in the war. $\mathrm{He}$ occupied a large farm near Valley and in 1893 was appointed postmaster there by President Cleveland. He died January 7, 1907. A son, James C. Agee, graduate of the University of Nebraska in 1903, now practices medicine in Valley.

The last survivor of the "old guard" in this vicinity who made medical history in Nebraska, was the venerable Dr. Alexander S, von Mansfelde of Ashland, 82, who passed the sunset of his life dreaming of those busy, fighting days of his youth.

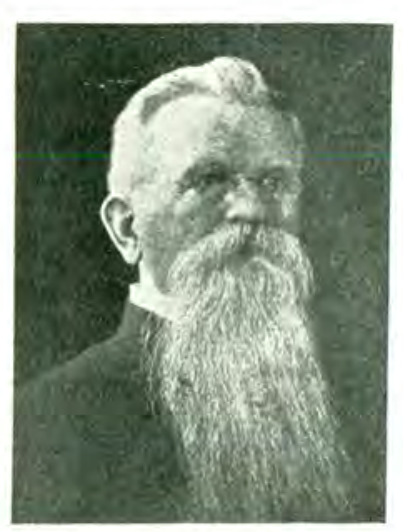

DR, A. 5. VON MANSVELDE

A rising young physician in Chicago, where he had been tendered a lectureship at Rush Medical College, Dr. von Mansfelde was called to Nebraska in March, 1875, to perform an operation for necrosis of the tibia. The field apparently appealed to him for in September of that year he formed a partnership with Dr. G. W. French in Lincoln and remained there for two years. In April, 1878, he moved to Ashland and was for a short time associated with Doctors Bonnell and Taylor.

Now began a busy life devoted to medicine, business, writing and the propagation of medical legislation. He was secretary of the state medical society from 1878 to 1889: president of the state library in 1893; active in the organization of the Nebraska School of Medicine, afterwards renamed Omaha Medical College occupying the chair of pathology and histology until 1885; associate editor of the Omaha Clinic, the first medical journal in Nebraska, from its inception in 1888 and editor in chief in 1892. He helped organize the Nebraska Railroad Surgeons' Society of which he was president; likewise the Missouri Valley Medical Society, of which he was secretary at its inception in 1888 and president in 1891-2; in 1896 president of the Nebraska Academy 
of Sciences and a member of the American Association for the Advancement of Science. In 1890 he was nominated for superintendent of public instruction by the Greenback party. He was mayor of Ashland in 1894, as well as serving on the board of education. For many years he headed the medico-legal defense committee of the state medical society, fostering all the beneficial legislation sought by the physicians. To crown his record, which excels that of any other physician in the state in the matter of personal service for organized medicine, Dr. von Mansfelde was the first to advocate government pensions for widows and children of Drs. James Carroll and Jesse W. Lazear, heroic victims of the yellow fever inoculation in which A. S. Pinto of Omaha shared, after the Spanish War. Pictures of the two doctors hang in the von Mansfelde home, "Quality Hill," at Ashland.

Von Mansfelde also advocated the passage of the national pure food law; revision of the medical regulations of the United States Army which he did during President Taft's administration; and by his personal efforts prevented a split in the state medical association in 1880 when suit was instituted against it in the national organization. He was also a pioneer in the present method of treating tuberculosis.

For many years, Dr. von Mansfelde devoted part of his large home in Ashland to care for those who needed hospital treatment. With his wife as anaesthetist and assistant, he performed many difficult operations, among them one of the first successful ovariotomies. He always spoke with warm enthusiasm of his wife as a helper. There was nothing she could not do to assist him better than anyone else, he frequently asserted. His library is one of the most extensive and interesting medical book collections in the state. Two daughters, the Misses Belle and Jo von Mansfelde, teach in the Omaha High School and one in the Ashland $\mathrm{High}$ School. On the death of his wife, Dr. von Mansfelde remarried, about ten years ago. The present Mrs. von Mansefelde was a faithful nurse in his invalid days.

Dr. von Mansfelde was born in Neumark, Prussia, in 1845, came to the United States in 1862 and was in the drug business at Fort Wayne, Indiana, when he began to read medicine with doctors there. He entered Rush Medical College in 1866 and received his 
degree in 1871, the year of the great fire. He specialized in obstetrics. Dr. von Mansefelde died June 17, 1928.

Next to von Mansfelde in the list of survivors of pioneer days was Wellington Smith Gibbs, an arrival of the late '70s, who died in Omaha, November 12, 1926. Dr.

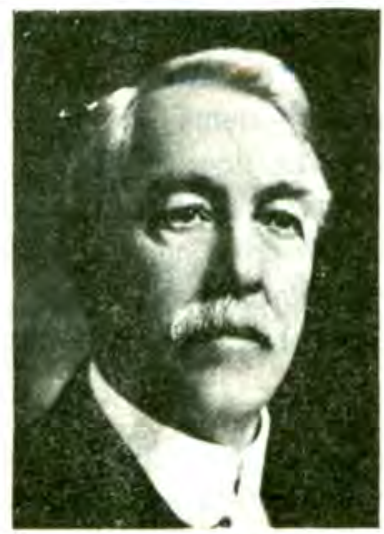

DR, WELLINGTON S. GIBBS Gibbs was the first to propose and one of the last survivors of the incorporators of the Omaha Medical College, on which faculty he served for 25 years. This dates from its first quarters on the third floor of the Hellman Block at Thirteenth and Farnam streets, when 13 students enrolled; to its new building at Eleventh and Marcy, with 50 pupils; through its brief affiliation with Bellevue College, when Gibbs was a director there, to its final affiliation with the University of Nebraska, while it was located in its Gibbs was also one of the founders of the University of Omaha.

\section{THE PIONEERS}

\section{SETTLEMENT OF PHYSICIANS IN OMAHA}

$$
1854-1880
$$

\section{Notes and Errata}

pp. 43-76 For contributions of Nebraska physicians to medical literature, see: Orr, H.W., "Bibliography of Nebraska Medical Literature," West. Med. Rev., 9:340-356, 385-393, Nov., Dec., 1904: 10:10-20, Jan. 1905.

Henry, Charles A. See Sorenson, Alfred, The Story of Omaha ... . Third Edition, Omaha, Nebraska, National Printing Co., 1923: p. 92.

\section{p. 48 Enos Lowe died February 12, 1880.}

pp. 52-53 Augustus A. Roeder died June 17, 1869: age 45. Buried, Prospect Hill Cemetary, Omaha. See Proc. Nebraska St. Med. Soc., 2nd Annual Meeting, Omaha, Nebraska, June 7 \& 8 , 1870:pp. 36, 37: See also ...1st Annual Meeting, Nebraska 
City, June $1 \&$ 2, 1869; p. 5 and Proc. St. Med. Convention of Nebraska, Omaha, June 24, 1868: p. 5.

p. 55

p. 58

p. 60

p. 61

pp. $63-64$

p. 70

p. 70

p. 72

p. 75

p. 76

p. 76
"Doctor Nicholas" unable to further identify.

Peabody, J. H., "Treatment of Diphtheria with Oil of Turpentine," Omaha Clinic, 1:247-254, Jan. 1889.

Dr. Mercer's hospital was the American Surgical Institute, not the Omaha Medical and Surgical Institute. See Records of the Omaha Medical Society, 1867-1871, Ms. in the Library of Medicine, University of Nebraska Medical Center.

Dr. Nelson H. Mercer should read Nelson S. Mercer.

Coffman, Victor H. See Morton, J. Sterling, Illustrated History of Nebraska, Lincoln, Jacob North Co., 1907; v. 2, pp. 609-11.

"Dr. Heath, Mayor of Florence, 1857." See p. 32 of Sorenson, Alfred, The Story of Omaha ... op. cit, p. 46.

"Dr. Hardcastle" unable to further identify.

". . . his homeward journey to Troy, New York. . ." should read ". . . his homeward journey to Troy, Ohio. .." See History of the State of Nebraska, Part I, Chicago, The Western Publishing Co., 1882: p. 615.

von Mansfelde, A. S., "Ovariotomy," Proc. Nebraska M. Soc., Omaha, Nebraska, Sixteenth Annual Session, May 13-14, 1884 ; pp. 313-320.

"Eleventh and Marcy" should read "Eleventh and Mason"

Matriculants, 1880-1881: 14 students. See Omaha Medical College, Record of the Secretary (of the Board of Trustees) April 13, 1869 to March 9, 1886 inclusive. Ms. in the Library of Medicine, University of Nebraska Medical Center, Unpaged. 



\title{
PIONEER NEBRASKANS OUTSIDE OF OMAHA
}

\section{AND DOUGLAS COUNTY}

\author{
$1854-1880$
}

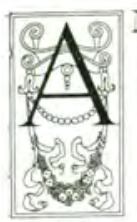

MONG the other pioneer physicians who settled in points outside of Douglas county but whose careers touched closely upon the metropolis, was Dr. Erastus N. Upjohn, who settled in Bellevue in 1854. He was the father of Dr. William C. Upjohn, who with his wife, Dr. Mary L. Upjohn, practiced in Papillion and Omaha. The elder Dr. Upjohn was one of the first settlers in Bellevue, only seven or eight persons having preceded him. He was born in England in 1811 and came to this country in 1829. He was graduated from Bellevue

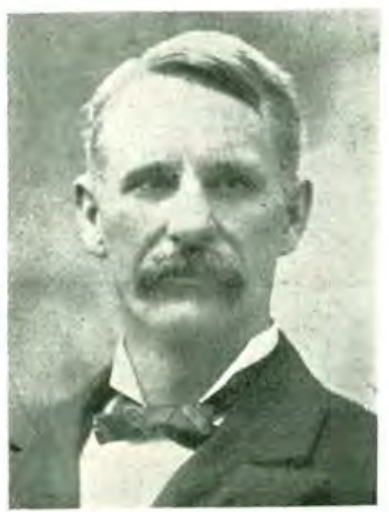

DR. WILLIAM C. UPJOHN

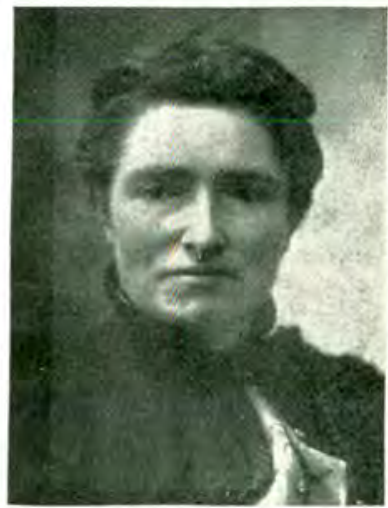

DR. MARY L. UPJOHN

College in New York City in 1835 and practiced in Michigan until news of the new territory lured him westward. Dr. Upjohn brought his family to Bellevue the following year after his own arrival. He served as surgeon in the Second Nebraska Volunteer regiment in 1863 and returned to his practice after the war. After his death, March 10, 1880, his widow married Richard Hogeboom of Sarpy County. William Upjohn died several years ago and his widow, Dr. Mary L. Upjohn, passed away in December, 1927 in Sierra Madre, California, at the age of 75. Se was an aunt of Mrs. Fred Rohring, Omaha. 
Another pioneer physician of Bellevue was William Jackson Rice, who came there in 1856.

William Jackson Rice settled in Bellevue in June, 1856, according to his daughter, Mrs. Lillie Jackson Ailesworth of Kansas City, who was the second white child born in Sarpy County and the first native white woman married there. Peter Sarpy was Dr. Rice's first patient and Mrs. Stephen Decatur, the second, Mrs. Ailesworth reports. Dr. and Mrs. Rice came up the Missouri river in a steamboat from St. Louis, where Rice had been associated in practice with the father of Dr. Jabez N. Jackson, now president of the American Medical Association, and they had to spend the night on the steamer because there was no hotel in Omaha. The next day H. T. Clarke, pioneer settler at Bellevue, accompanied Dr. Rice to Bellevue, promising to erect a home for him. The doctor did settle there, remaining until his death. He was an excellent violinist, sang well and when occasion required, occupied the pulpit in the Methodist church. He was also a 33rd degree Mason.

Rice was born in Richmond, Virginia, in 1815, studied medicine in New York, Ohio and St. Louis and operated a drug store and hotel in Washington, Missouri, before sett ling in Bellevue. His practice frequently called him as far as Nebraska City.

Many of these whose biographies will be sketched in the following pages will also be mentioned in the county histories, but are here given as among the outstanding medical men in the state.

Aurelius Bowen settled in Nebraska City in 1856 after a year's exciting residence in Kansas, where he helped organize the new state. He was born in Vermont in 1817, the son of Silas Bowen, a physician of Welsh descent; and was graduated from Castleton Medical School in 1851. He served with the Second Nebraska in the Civil War. Returning to Nebraska City after the war, he was one of the incorporators of the Omaha School for the Deaf in 1867, and served on its board until 1875. He joined the state medical society in 1869 and was elected president in 1872 . The following year he was elected to the state senate for the session 1873-4 and was author of the bill providing for a state institution for the blind at Nebraska City. Ned Abbott, son of Dr. Luther J. Abbott, pioneer Nebraska physician, is the superintendent. 
N. B. Larsh is another Nebraska City pioneer, having arrived in 1859. He served in the Territorial legislature of 1861-2; in the state senate in 1872-3; and was mayor of Nebraska City. Larsh was one of the organizers of the state medical society which he served as its third president in 1870, and was at one time superintendent of the state insane asylum. He died in December, 1887, succumbing to a severe chill received in crossing the river to see a patient. He died two days after his last call to duty. Larsh was born in Ohio in 1835 and was graduated from Miami College in 1857.

An early arrival in Auburn was Charles F. Stewart, who settled in Nemaha county in 1857. Stewart was a native of Indiana, born August 28, 1832, and received his medical education in Cincinnati. He served in the Civil War as assistant surgeon and was a United States examining surgeon for 20 years. He was superintendent of the state hospital for the insane from November, 1871, to January 1,1875 , and was a member of the state board of health for seven years.

Robert Ramsay Livingston of Plattsmouth, who settled there in October, 1859, is one of the outstanding figures in Nebraska medicine. With J. H. Peabody he shares the distinction of having founded the Nebraska State Medical Association, for it was the renewal of his correspondence with Peabody in the spring of 1868 which resulted in the organization meeting in the latter's office on May 11. He was president in 1871.

Livingston was a man of imposing stature, about six feet tall, weighed more than 200 pounds and had worked as superintendent of a copper mine in Houghton, Michigan, before he came west. He started life with many handicaps, however, chief of which was the death of his father, a veteran of the War of 1812 , before young Robert was born. Montreal was his birthplace, August 10, 1827. He was graduated from Magill University in 1849, attended the College of physicians and Surgeons in New York, and wandered from place to place before settling in Plattsmouth ten years later. Soun after, he became editor of the Platte Valley Herald and he was at this post when the momentous word came in May, 1861, that the "Star of the West" had been fired on. With instant decision which characterized his whole life, Livingston stopped the press and rewrote his front page, issuing a call for volunteers for Company $\mathrm{A}$, the 
colonel in command. He served at Donaldson and Shiloh, rose to colonel and was mustered out of the service in 1866 with the brevet rank of brigadier general. After the war he commanded the district of Nebraska on the plains during the Indian warfare.

Just before entering the service, in the April, 1861 number of the American Journal of Medical Sciences, Livingston published a paper "Ether in Laryngitis with Exudation of Lymph," in which, so far as known, he used for the first time inhalation and internal administration of ether, in this case resulting in recovery.

Until the close of his busy life, September 28, 1888, Livingston was a power in Nebraska affairs. He was mayor of Plattsmouth three terms; president of the state fish commission; surveyor general of the state; chief surgeon of the Burlington; several times a democratic candidate for congress, and organizer and professor of the Omaha Medical College and the medical department of the University of Nebraska at Lincoln. Three sons succeeded him in the medical profession.

Dr. Carl Ernest Louis Golding is said by a son to have come to Plattsmouth in 1856, combining the practice of medicine, for which there was little demand, with Indian trading. He was born in Germany, received his medical education at Koenigsburg and afterwards practiced in Stettin. He left Germany for England when a young man, but tarried there only a short time, setting sail for New York in 1850. From there he undertook a trip to California in the wake of the "forty-niners," but on reaching Leavenworth, Kansas, about 1852 , he decided to remain with relatives who were living there. He located in Plattsmouth about 1856, but left for St. Louis to enlist in the army during the Civil War, after which he returned to Plattsmouth permanently. He then became a merchant until 1888 when he retired. He died October 31, 1903. His son, Dr. D. G. Golding, born in Plattsmouth in 1870 and educated first in the Plattsmouth schools, was graduated from Jefferson Medical College in Philadelphia in 1890, served as head physician and surgeon in the Connecticut Soldiers' Home and Hospital in 1890-91 and did post graduate work in New York City. He is now practicing in Santa Monica, California.

The two Doctors Bullard, father and son, of Pawnee City, were the next arrivals of whom there is record, in 1863. The father was 
Dr. Ezekiel W. Bullard and the son, John IV. Bullard. They came from Ohio, rowed across the Missouri river which was filled with ice, to Brownsville and there hired a man to take them to Pawnee City. The younger Bullard was then a child of six. The Bullard family experienced many hard turns of luck in their many years' residence at Pawnee. Their home was washed away in a flood, June 17,1883 , and the whole town was then moved to a higher level. In 1886 the younger Bullard who had taken some work at the Northwestern Medical School in St. Joseph, left for St. Louis and took his degree from the Missouri Medical College. He then located at Dubois, where he remained until 1889 when he returned to Pawnee to form a partnership with Dr. A. B. Anderson. In 1892 the young Dr. Bullard took another degree from Jefferson Medical College in Philadelphia and again returned to Pawnee to practice until his death, July 2, 1906.

He was promoter of the Pawnee Telephone Company, president of a bank and on the examining board for pensions, secretary of the state medical society, president of the Nebraska State Medical League, member of the county medical society, A. M. A., Western Medical and Gynecological Society and American Academy of Ophthalmology and Otolaryngology.

John R. Brook who came to Salem, Richardson County in 1860 , was the only doctor in the vicinity and was often forced to ride 50 miles on horseback to care for the sick. Frequently after such a ride there was no pay, for the early homesteaders had barely enough food on which to subsist. Brook was once a democratic candidate for Congress. A Dr. Hanna of Falls City is also claimant of the honors for first physician in Richardson County, according to John W . Towle of Omaha, who formerly lived there.

I. W. Snowden was a pioneer physician who practiced in Nebraska City from 1863 to 1870 . His son, C. C. Snowden, who grew up there, followed his father in the profession and was graduated in May, 1882, since which time he has been practicing at Davenport, Nebraska. He is a charter member of the Thayer county society.

Dr. Alexander Bear, who came to Nebraska in 1866, was destined to play an important part in the upbuilding of Norfolk, 
Tebraska. Born in Warrenton, Virginia, February 4, 1840, of

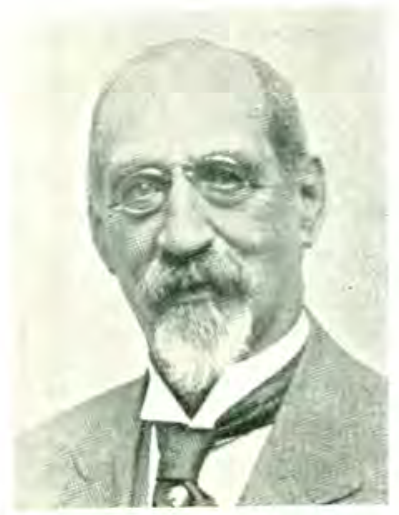

DR. ALEXANDER BEAR Bavarian parentage, Bear was educated in the Universities of Virginia and Maryland and was graduated in medicine in 1860. He practiced a short time in Marion, but when the war broke out, enlisted in the Confederate army as lieutenant in Company D, Fourth Virginia Infantry. After one year's service he was made a surgeon and served throughout the war. He came west at the close of hostilities and in 1867 settled in Fremont for two years. In 1869 he moved to West Point, and in 1872 to Norfolk where he practiced for nearly 40 years.

Highly successful as a physician and surgeon, Bear rose to prominence in politics, too. He was mayor of Norfolk for many years; president of the Board of education, member of both houses of the legislature, 1874-76; and in 1875, a republican legislature elected him a regent of the Lniversity, although he was a democrat. Known as the "pioneer physician of the Elkhorn valley," he was elected first president of the Elkhorn Valley Medical Society when it organized in 1908 and he was also vice president of the Nebraska State Medical Association. He was vice president of the Norfolk National Bank and built some of the finest business blocks in the city. He retired from active practice at 70 , and his eyesight having failed, returned to the home of his youth to pass the remaining days.

Dr. George W. Collins of Pawnee City was another arrival in April, 1866. Dr. Collins had first studied law in Illinois, where he was born in 1837 , and had been admitted to the bar when he changed his mind and took up the study of medicine in the Hahnemann College in Chicago. He came to Pawnee with the intention of practicing law apparently, for he was associated with Judge A. H. Babcock for eight years, during which he was elected to the legislature from Pawnee county in 1870 and speaker of the house the following year, but there were few doctors in the county and soon his medical practice grew so large he had to abandon the law. 
Dr. Collins presided over the house when Governor Butler was impeached, though he himself protested the impeachment. He was also a Garfield elector and chairman of three republican state conventions. He was the first superintendent of the State Industrial School in Kearney, from 1881-3.

Dr. William Penn Brooks of Cook, Johnson county, was another interesting arrival in 1867. A graduate of the Western Homeopathic College at Cleveland in 1865, he traveled through the South, then to St. Joseph where he went by boat to Brownsville, a six-day trip on account of the large amount of ice in the river. From there he drove overland to Helena, three miles southwest of the present town of Cook, entered a homestead and built himself a house.

During his first years in Johnson county, Dr. Brooks rode a saddle horse a circuit of ten or twelve miles and was frequently called a distance of 30 miles to visit the sick. After 1876 he drove a team. Dr. Brooks built the first house in the town of Cook in 1888, when the Missouri Pacific railroad went through. He directed his public life to questions of reform, and frequently contributed to the press. Among his pamphlets are "Popular Fallacies of Homeopathy Examined and Refuted," in 1878; "Hard Times and the Way Out," second edition, 1888: "Our Government, What Is It?" in

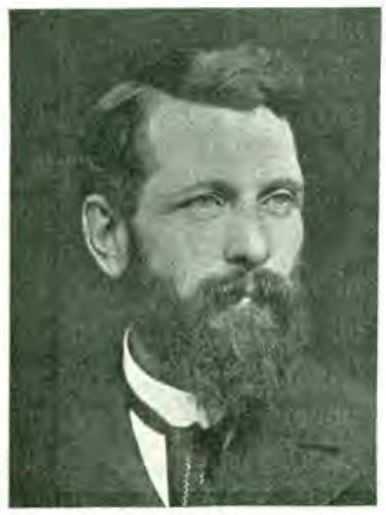

1892, and "Sixteen Escaped Criminals to One Conviction" in 1902. This latter was along temperance lines. He frequently shocked his little community by his radical religious views, according to Dr. W. L. Curtis of Lincoln, who was born at Cook and knows Brooks well.

Leander Bannatyne Smith, father of Victor B. Smith of Omaha, came to Fremont in 1867 from Pennsylvania as a youth of 21 to work in his uncle's drug store. In the maentime he studied DR. LEANDER B. SMITH medicine and was graduated from the Keokuk Medical College in 1878. During his long years of practice he served persons so poor that, as related in the introduction to this chapter, he took the shirt off his back to wrap a newborn babe whose 
mother did not have a clean cloth in the home. Dr. Smith was city physician, county coroner, and served on the United States pens.on examining board. A son, Floyd, died while a med cal student at the University of Nebraska, after serving in the World War. There was another Fremont doctor, J. H. Crebbs by name, with whom Dr. Smith was friendly.

James White Thomas, a Civil War veteran, settled in Weeping Water in 1867 and practiced there until his death in 1908.

Silas H. Fawcett settled in Blair in 1868. He was born in Virginia in 1821 of parents who freed their slaves and were among the early settlers in Kokomo, Indiana. Here young Fawcett grew up, was educated at the Cincinnati Medical College and practiced in Louisville, Ill., before coming west. He was one of the best known men in the county and died there in 1896 .

Eli M. Wilson, a post surgeon in the army, came to Falls City in 1868, after his graduation from Cincinnati College in 1864. He died in November, 1886.

Dr. Melville W. Stone, who helped organize Lincoln county in 1868 , achieved fame for his part in Indian warfare in the western part of the state. His family moved to Iowa in 1853 from Ohio,

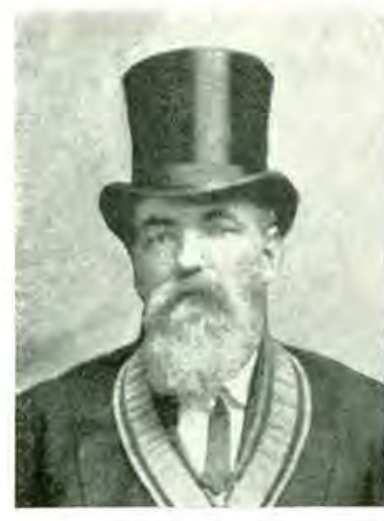

DR. J. H. CREBBS where he was born in 1837, was graduated from Bellevue Medical College in 1861 and immediately enlisted in the Civil War. He was still in the service April 7, 1866, when he was ordered to report to the commander of the Department of the Platte, due to the bloody Indian warfare. Stone was the medical officer with General Carr's expedition sent out to quell the Brule and Ogallala Indians and was present at the battle of Summit Springs, Colorado, the last Indian battle in the Nebraska-Colorado division of the West.

He was stationed at North Platte, where he helped organize the county and was the first Union Pacific surgeon appointed there in 1868 , a post he held for 22 years. He was also county judge that year. When he resigned from the army he moved to Wahoo, in. 
Saunders county, practicing there from 1877 to 1888 . In 1891 he moved to Osceola and helped organize Polk county.

Dr. Stone was surgeon general for Nebraska under Governors Nance, Dawes and Thayer; superintendent of the Hastings Insane Asylum for two years, medical director of the G. A. R. from 1878 to 1890 and in the early '90s was called to Omaha to take charge of the Union Pacific surgical work at St. Joseph hospital.

Dr. William Arnold, a surgeon in the Thirty-seventh Ohio Volunteers during the Civil War, settled in Brownsville, Nebraska, in March, 1868. His daughter, Fannie, was in later years supervisor of music in the Omaha public schools. Dr. Arnold was a native of Kent, England, and was a cousin of the famous Dr. Thomas Arnold, head master at Rugby.

Two doctors were instrumental in organizing York county in 1869-70, both of them serving as the first commissioners. They were Dr. Servetus V. Moore and Dr. Thomas L. Myers of Aurora. Dr. Myers came to York in 1869 with his

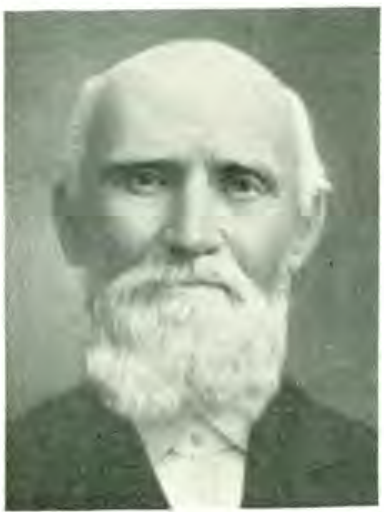

DR. SERVETUS V. MOORE parents, who homesteaded there, and was named postmaster that year. At 15 he enlisted in the Civil War and was held in Andersonville prison for nine months. After the war he studied medicine at Keokuk. After several years in York he settled at Aurora in 1873, one of the first to make his home there and the first to practice medicine. He died in 1888 , at the age of 43 .

Dr. Moore also came to York at the same time from Ohio where he was graduated in medicine in $1857 . \mathrm{He}$ took an active part in the political life of the community, serving in the legislature from 1876 to 1880 , and was a nominee for Congress in 1882. His son, Dr. Orville M. Moore, joined him in the practice of medicine at York, having been graduated from the Cincinnati Eclectic College in 1884. He was for two terms president of the Nebraska State Eclectic Medical Society and is still practicing at York. 


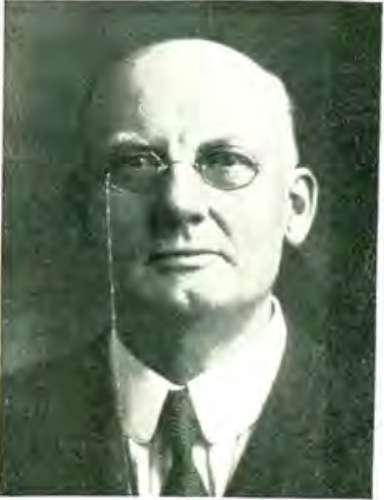

DR. ORVILLE M. MOORE

The elder Moore had no intention to practice medicine when he came west, but did so at the solicitation of the new settlers from 1870 to 1880 , according to his son, Dr. O. M. Moore. He was born in Ohio in 1835, studied medicine in Fulton County, Indiana, and with preceptors in Brown County, Illinois, before coming to York in 1869. He died March 28, 1914, at the age of 81 .

James Luther Gandy, veteran of the Civil War and son of a Virginia doctor, Owen Gandy, came to Humboldt in 1870, three years after his graduation from Rush, and grew to prominence as one of the most extensive land owners in southeastern Nebraska. The Gandy ranch near Barada, Nebraska, is a 10,000-acre ranch, and he owned other Kansas, Texas and Colorado land, for the management of which Dr. Gandy retired from medical practice. His son, George G. Gandy, succeeded him in practice at Humboldt. The elder Gandy, who was born in 1844, was elected the second mayorof Humbcldt in 1879, and was a delegate to the state democratic convention. He died May 21, 1924.

Carleton K. Chubbuck of Tecumseh settled in Johnson county in 1871, serving as county coroner and secretary of the board of examining surgeons. He was born in Pennsylvania and read medicine with two uncles before he was graduated at Binghampton, New York, in 1859. He practiced in various places before settling in Nebraska where he became a member of the state eclectic medical association. He died November 25, 1907.

Charles F. Ballard, first mayor of Havelock, Nebraska, cameto Fillmore county with his parents, October 4, 1871, from Indiana. He taught school and was coroner in Fillmore county before completing his medical studies at the University of Indiana and in Chicago. He moved to Havelock in 1892, served as mayor three terms and for 12 years as member of the school board.

Dr. James G. Brenizer, pioneer of Custer county at Broken Bow, first settled at Nebraska City on his arrival in 1872 . He 
was one of the most successful breeders of registered Shorthorn cattle in Nebraska. Brenizer studied medicine in North Carolina and practiced in Freeport, Illinois, before coming west. In 1879 he practiced at Phillips in Hamilton county, but located permanently at Broken Bow in 1884 .

Jaspar P. Norcross settled in Lincoln in 1872 after his graduation from St. Louis Medical College, remaining there for seven years until he moved to Aurora. In 1885 he lived for a time at Sweetwater in Buffalo county and the next year at Sartoria, where he remained for ten years. In 1899 he moved to Miller where he opened a drug store. Norcross was active in republican politics from 1885 on.

Major Thomas Edward Mitchell, with a distinguished Civil War record as surgeon-in-chief of the 3rd Division, First Army Corps, with the Army of the Potomac, was an early pioneer physician, settling in Columbus, Nebraska, in 1873. He remained there until 1881 when he became division surgeon of the Union Pacific railroad at Ogden, Utah, where he had charge of the railroad hospital. While in Columbus, Major Mitchell, who had been wounded and taken prisoner during the Civil War, was associated in practice with Dr. D. T. Martyn, another early physician there. Mitchell's death occurred in Pasadena, California, February 7, 1888. Two daughters, Miss Elizabeth Mitchell, school teacher, and Mrs. Mary Mitchell Hulst, one of the first local women to engage in the advertising field, are residents of Omaha. Mitchell was a graduate of the University of Maryland in 1853.

George W. Johnston, the first resident physician in Fillmore county, came to Fairmont in 1873 , where he was active in assisting the early settlers in tiding over their first hardships. In 1891 Governor Boyd appointed him superintendent of the insane asylum at Hastings for four years, after which he took postgraduate work in Chicago and then settled in Geneva. Johnston was born in Virginia in 1851 and took his first medical training at Bellevue, graduating in 1872. He was a railroad and pension board surgeon.

George Frederick Laubach, whose son, Herbert George Laubach, is now practicing at Mitchell, Nebraska, was another pioneer settler of 1875 . He took up his first practice in a new town called Sarpy Center, where he remained a year and married the village school 
teacher, Mattie Sexson. He then received the appointment of army surgeon at Lower Brule agency, South Dakota. Late in 1879 he removed to Watertown, Minnesota, where his son, Herbert G. Laubach, was born, March 30, 1879. The Laubachs did not remain there long, but moved back to Sarpy County, Nebraska, and opened a drug store and office at Papillion. He died of typhoid a short time later, December 26, 1881. The elder Laubach traced his ancestry to a German family originating in the quaint old town of Laubachon-the-Main, who emigrated to this country in 1738 , settling on the

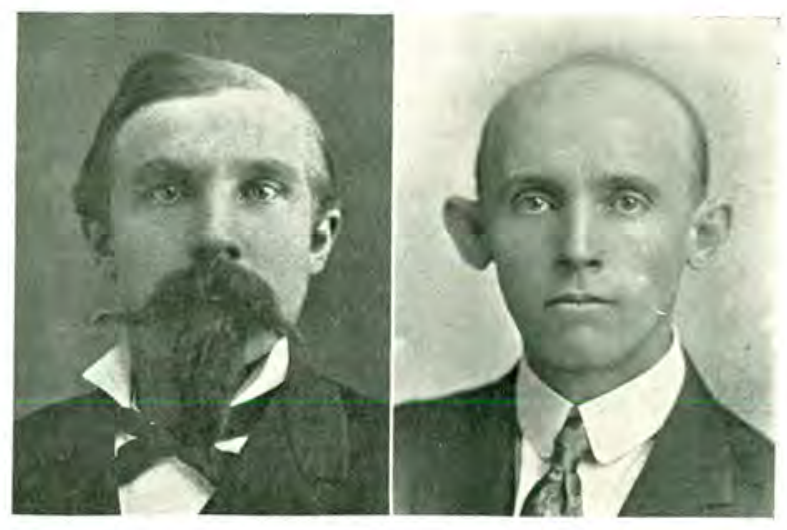

DR. GEORGE F. LAUBACH DR, HERBERT G. LAUBACH

banks of a small stream which is today still called Laubach Creek. It is about two miles from Bethlehem, Pennsylvania. Born there June, 1853, Laubach gained all the schooling he could in a country classroom and academy and at the age of 18 enrolled in the medical department of the University of Pennsylvania where he made a fine record and was graduated March 12, 1875. He had the distinction of studying with such prominent medical pioneers as Drs. Alfred Stilley, Hayes Agnew, Francis G. Smith and R. A. G. Penrose, from whom he received personal letters of recommendation on his application for an army appointment. His son, H. G. Laubach, still has the original letters.

Hiram L. Smith was another early physician who came in 1875 to Geneva, Fillmore county, where he was mayor four terms, and from where he was elected to the state senate in 1885 . He invested heavily in farm lands and at one time was reputed to own 4,000 
acres. He was also president of the bank. Smith was born in New York in 1828 and was graduated from Granville, Ohio, Medical College in 1855. He practiced 20 years in Indiana and served in the Civil War before coming to Nebraska. He established and gave to Geneva the Hiram L. Smith Library.

C. B. Stillman was the first physician in Platte county, practicing there before 1876 .

Dr. Henry Y. Bates of Belgrade also began the practice of medicine in this state in 1876, though he came to Nebraska with

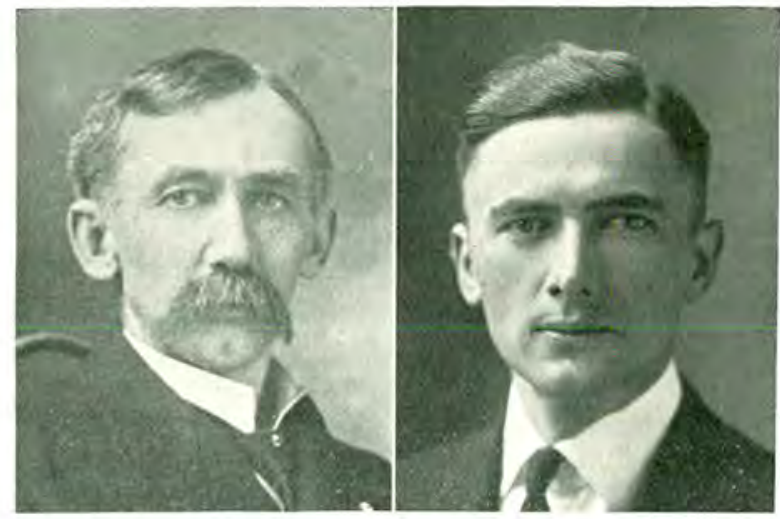

DR. ALLAN B. ANDERSON ALLAN BYFORD ANDERSON

his father, Joseph Bates, from Illinois in 1859, taking up a large Sarpy county homestead. Bates attended the Sarpy school, Peru Normal and the Eclectic Medical Institute in Cincinnati, from which he was graduated in January, 1876. Except for three years, from 1889 to 1892 when he ran a drug store in Council Bluffs, Dr. Bates has practiced in this state ever since. He settled at Belgrade soon after the town started in 1894.

Allan B. Anderson has been practicing in Pawnee City since 1877, the year he was graduated from the Louisville Medical College, and is now succeeded by his son, Allan Byford Anderson. The elder Anderson experienced all the hardships of country practice a half century ago and distinguished himself for his emergency surgery, without any of the equipment today thought necessary for an operation. With oniy a few instruments, soap and hot water, he per- 
formed in 1880, the first successful laparotomy for ectopic pregnancy that had ever been performed in Pawnee County.

"The worst diseases fought with in early years were the gastroenteritis in children and typhoid fevers and malaria among adults," wrote Dr. Anderson. "These diseases are now shorn of their terrors in present ho:seho!ds, better instructed in sanitation and with a betier water supply."

Dr. Anderson values particularly the friendships he formed on his arrival in Pawnee and which, he said, have continued uninterruptedly for half a century. He was born near Quincy, Illinois, Narch 25, 1851, and after his graduation from Louisville, took postgraduate work in Chicago with Moses Gunn, Charles L. Parkes and W. H. Byford, for whom he named his son.

An important arrival in York, Nebraska, in 1879 was George W. Shidler, father of George P. Shidler, now vice president of the York Clinic and Hospital. The elder Shidler was one of the first surgeons west of the Mississippi river and among the first to use a local anaesthetic. He performed the first appendicitis operation in York county and became so widely known in his profession that he received a request from Germany for a picture of himself to be placed with the noted surgeons of that country. The elder Shidler was born in Pennsylvania in 1849 and received his medical education at Ann Arbor and Keokuk, a graduate in 1875. He practiced at Swedesburg, lowa, before moving to York to form a partnership with Dr. Porter. In 1897 he joined O. M. Moore in practice and in 1909 his son joined the firm. The York Clinic, which they head, was formed in 1915 .

Carl Hullhorst, later of Lincoln, practiced in Columbus in 1876, shortly after his graduation from Iowa State Medical school. He was born in Germany in 1847, taught music and was church organist in Tiffin, Ohio, when he came to this country in 1865. After Columbus, he practiced in Gibbon and Hastings, where he was president of Hastings College one year, then settled in Lincoln in 1889. Here he founded the Third Presbyterian Church. He practiced little after 1891, interesting himself in theology, music, history and literature until his death in 1908 . 
Winfield Ackley, an Ohioan, came to Juniata in July, 1877, a graduate of the Keokuk Medical School the preceding year. He took post graduate work at Rush in 1880. Ackley was Adams county coroner in 1877 and served as United States examining surgeon. W. W. Phar came to Ayr in Adams county in 1879, also a graduate of Keokuk in 1878. He opened a drug store there in 1880.

Other arrivals in 1877 were Ellis Passmore Hamer (graduate of Jefferson Medical College, Philadelphia, in 1851 and who had practiced in Illinois) who engaged in farming and financing, but did not practice medicine; and William A. Hampton, physician and lawyer, who had first become acquainted with Nebraska seven years

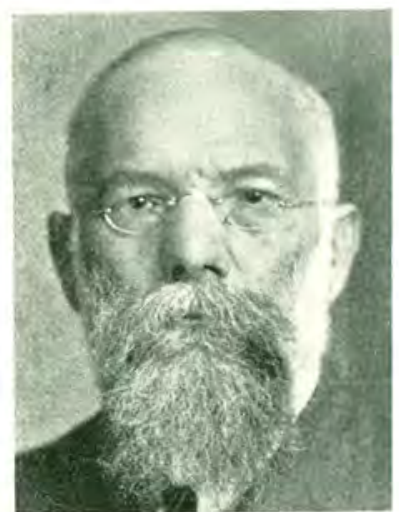

DR. FRED HOFFMEISTER

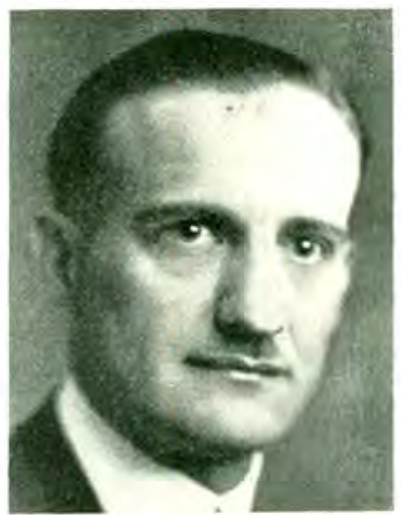

DR. GEORGE HCFFMEISTER

before when he drove a herd of 1,600 cattle from San Anton.o, Texas, to Nebraska City. Hampton had a varied career. He was born in Oh:o in 1851, was a Texas cowboy in his youth and was graduated from Keokuk in 1877. He settled at Humphrey, Platte county, in 1883 and was later president of a bank at Alliance.

Charles I. Krickbaum of Hampton, Hamilton cotnty, also settled in Nebraska City in 1877 where he became a warm friend of $\mathrm{J}$. Sterling Morton. He was born in Pennsylvania and received his medical training at Bellevue before serving in the Civil War as major. He moved to Lincoln in 1879 and to Hampton in 1900, dying there January 6,1912 . 
Fred A. Hoffmeister of Imperial, Chase county, was an important arrival in 1878, when he settled at Odell, Gage county. Dr. Hoffmeister was born in Germany in 1853 in a house built and occupied by his family since the year 1712. He was graduated from the University of Goettingen in $\mathbf{1 8 7 7}$ and came to America shortly thereafter. He remained in Odell for five years, then moved to Ainsworth in Brown county, remaining until 1885, and the next year to Imperial where he became one of the leading citizens. $\mathrm{He}$ was elected county treasurer in 1898 and to the legislature, where he was active in promoting medical legislation, in 1912. He did much to induce the German population to settle in Chase county and was himself an extensive farmer and breeder, besides operating a drug store. A son is now engaged in the practice of medicine at Imperial.

William H. Babcock, veteran of the Civil War in the Vicksburg campaign, settled in Hamilton county in 1878 and practiced there until 1886, when he moved to Chappell and opened a drug store. He was a native of New York and a grandson of Theodosia Prevost, who, after the death of her first husband, married Aaron Burr. Dr. Babcock died June 18, 1895.

John Cooke, native of Scotland and descendant of a long line of Scottish physicians, settled in Hastings in 1878. He was graduated from the University of Glasgow in 1867 and practiced in New York and Illinois before coming to Nebraska, where he served as Adams county coroner for two terms. A son, Charles F. N. Cooke, who followed him in the study of medicine, died in 1902, and the elder Cooke, February 13, 1904.

Elisha Barker Graham and his wife, who located in 1879 on a cattle ranch in Sioux county on the Niobrara river, 14 miles east of the Wyoming line, are a couple whose memory will long linger with the ranchers and cowboys of that vicinity. Dr. and Mrs. Graham, who was the only woman in the neighborhood, except at Fort Robinson, 35 miles away, conducted a Sunday school class to which the cowboys came for miles around, using their guitars as accompaniments for the Sunday school hymns. Mrs. Graham also planted the first vegetable garden, the products of which the cowboys too enjoyed mightily. The nearest railroad was at Cheyenne. The Grahams were originally New Yorkers, but Dr. Graham was gradu- 
ated from Cleveland Medical College in 1866. In later years they lived in Los Angeles.

Two physicians who came to Nebraska in 1879 came primarily to enter the cattle business. One was Robert C. Talbot of Broken Bow and the other, Hudson Josiah Winnett, who engaged in the sheep business at Sidney, Cheyenne county, but later settled in Lincoln.

Talbot homesteaded in Custer county, where he was drawn into practice among his neighbors and was appointed postmaster at Guilford in 1881. In 1893 he opened an office in Broken Bow, was elected to the city council, county treasurer two terms, on the school board eight years, and in 1896 was defeated for state senator. He was president of the Custer County Medical Society several terms. Talbot was born in Indiana in 1847 , served in the Civil War and was a graduate of the Miami Medical college of 1870 .

Winnett remained in the sheep business until he moved in 1884 to Lincoln, where he became one of the most influential men, both in his profession and politics. He was secretary and president of the Lincoln Medical Society; elected to the Lincoln city council in 1897 and president in 1898, and mayor of Lincoln from 1899 to 1903. In 1903 he was elected chairman of the state railway commission, serving till 1906. Winnett was born in Pennsylvania and studied at Jefferson and Long Island College, from which he was graduated in 1870 and practiced nine years in Pennsylvania before coming west.

A resident of Douglas county in 1877, although he did not practice in Nebraska until 1883, was Thomas Henry Line, now of Central City, who was one of the founders and prominent citizens of the town of Marquette that year. Line, born in Maryland, April 21,1858 , taught school there before coming west to Omaha in 1877 . He obtained a teacher's certificate from J. J. Points, then superintendent of schools, and taught a term in a log schoolhouse where Bennington now is.

"I boarded and roomed in a house which was a combined residence and hog and cattle barn," Line recalls. "I slept next to the hogs with only a wooden partition separating. After finishing this 
term I returned to Illinois where I taught again and studied medicine in the office of Dr. D. Newcomer of Mt. Morris, Illinois. The following winter I studied at Ann Arbor and finished at Rush Medical College, graduating from there February 22, 1881. I spent some time in Cook County Hospital and practiced in Adeline, Illinois, before locating in Marquette, Hamilton county, Nebraska, February 3, 1883.'

Dr. Line was made county coroner the next year, edited the Independent, the village newspaper, for two years, platted and laid out the boundaries of the village and was chairman of its first board of trustees. He remained at Marquette until 1917 when he moved to Central City, where he has been city and county physician. Line also served as physician for the Indian school at Genoa, on the exemption board during the late war, and as secretary to the United States pension examining board, 1888-1893. Dr. Line has always been active in politics and writes considerably on public health topics, education and the prevention of crime.

John T. Hay, former superintendent of the hospital for insane at Lincoln in 1908-11, was on the staff there from 1879 to 1892. He was a graduate of Cornell in 1872 and was professor of mental diseases in the Nebraska Medical School, later affiliated with $\mathrm{Ne}$ braska Wesleyan University. He was a member of the American Psychological society and the American Medical Association, and died in 1911. 
$1854-1880$

Notes and Errata

pp. $77-94$

For contributions of Nebraska physicians to medical literature, see: Orr, H. W., "Bibliography of Nebraska Medical Literature," West. Med. Rev., 9:340-356, 385-393, Nov., Dec., 1904; 10:10-20, Jan. 1905.

p. 77

Portrait identified as "Dr. Mary L. Upjohn" should read "Mary H. Upjohn."

p. 77

Last line should read "She was an aunt of Mrs. Fred Rohring, Omaha."

p. 82

"Elkhorn Valley Medical Society ... organized in 1908 ..." should read ". . . organized in 1896 ..." See p. 361.

p. 83

Brooks, William Penn. See also Morton, J. S., Illustrated History of Nebraska, Lincoln: Jacob North, 1905, vol. 1, p. 602.

p. 83

"In the maentime ..." should read "In the meantime..."

p. 84

"Fremont doctor ..." and portrait should be identified as Dr. J. H. Crabbe.

p. 89

Portrait on the left should be identified as Dr. Allen B. Anderson.

p. 90

Anderson, A. B., "A Report of Section on History of Medicine," Proc. Nebraska M. Soc., Omaha, Nebraska, Sixteenth Annual Session, May 13-14, 1884, 335-343. 

PIONEERS-PART II

IN OMAHA $1880-1900$

The decade of the $80 \mathrm{~s}$ ushers in a period of perhaps the greatest importance in the medical history of Nebraska. It marks the arrival of the greatest number of practitioners; and those of the finest type - men whose names stand highest in the professional world today, like Harold G. Gifford, W. O. Bridges, J. E. Summers, A. F. Jonas, W. F. Milroy, B. B. Davis, F. S. Owen, H. M. McClanahan, and others; and the period when the local physicians were most active in a three-fold direction: first, in promoting effective medical legislation; second, in organizing medical societies of various names and periods of existence; and third, in establishing medical schools, hospitals and publications.

It is also of prime interest in that it marks the beginning of the revolution in medical practice, aseptic surgery: the opening of the era of preventive medicine; and scientific discoveries too numerous to mention, so that the last 40 or 50 years have proved more important in medicine than all the centuries which preceded it, as Dr. Morris Fishbein, editor of the Journal of the American Medical Association, pointed out in his talk at the Omaha Chamber of Commerce, in December, 1927.

Locally it is further distinguished by the interest in civic affairs manifested by Omaha physicians, many of whom occupied posts as health commissioners, presidents of the school board and in every public capacity possible, for the development of city and state.

Of those who settled in Omaha in the early ' 80 s and helped make medical history here, many have passed on after active, useful lives. Included among these are Doctors Lynn Graddy, Robert M. Stone, Samuel K. Spalding and Ralph W. Connell, health commissioners; Charles Rosewater, Oscar S. Hoffman, Benjamin F. Crummer and F. E. Coulter. Other practitioners including those named at the head of this section, and the following, J. B. Ralph and A. B. Somers, deans among the practitioners since both are past 80 years of age; D. C. Bryant and W. J. Galbraith, founders of Creighton Medical College; J. P. Lord, pioneer in the ortho- 
pedic field: William H. Christie, J. H. Vance, and Elias Holovtchiner, of the school board group; Robert Gilmore, J. M. Aikin, former secretary of the state association and Joseph C. Moore, C. C. Impey and Robert S. Knode, whose sons succeed them in the practice of medicine, must be mentioned as outstanding members of the profession, who came here in that ten year period.

An attempt is made in the following pages to mention them in chronological order, as to their arrival in Omaha:

Lynn B. Graddy, perhaps the first oculist and aurist to specialize in Omaha, came here in November, 1880. When Dr. Harold Gifford, present dean in this specialty first came to Omaha six years later, he and Graddy established a small eye and ear hospital, the forerunner of the present fine Methodist Hospital, mention of which will be made in another section. Graddy was born in Kentucky, April 11, 1852 and was educated at the University of Tennessee, completing his medical training in London and Paris before settling in Omaha. With Doctors Robert S. Stone, who came the next year, Joseph Neville, S. A. Merriam, Paul Grossman and R. S. Hyde, he organized the Omaha Academy of Medicine and Surgery, in 1881. It enjoyed a brief span of life.

He presented to the medical profession the Stone mask for the Homeopathic school in 1874. The younger Stone experimented in anesthetics for 18 years and in 1918 took this up for special study.

Robert Marsena Stone, active in organizing the Omaha Medical Society, the above-mentioned Academy and the Missouri Valley Medical Association in the first decade of his residence here, had practiced a year in Hastings before settling here in 1881. He was born in New York in 1847, of a family which traced its ancestry to Governor Bradford. His father was a surgeon in the navy during the Civil War and the son was graduated from the New York Schleich solutions, and administered them in hospitals in Omaha, Chicago and Denver.

Dr. Samuel Kennedy Spalding, distinguished for several political posts he held-member of the Omaha school board five years and president one year; city health commissioner in 1898-9; state 


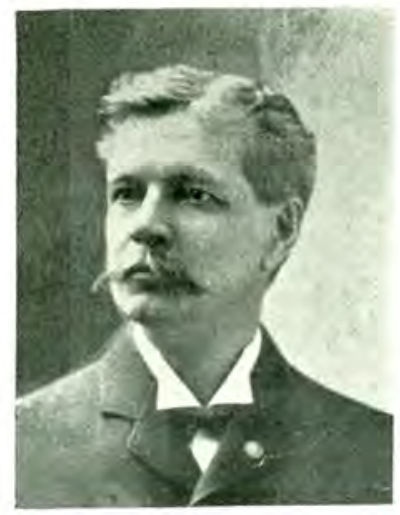

DR. SAMUEL K. SPALDING toxin in the city of Omaha. Dr. Spalding made a specialty of nervous and mental diseases and did scientific research in the field of mental disorders. He was a charter member of George Crook post, G. A. R.; and a member of the G. A. R. national council; and helped build the North Presbyterian church at 24th and Wirt Streets. He died in Washington, September 29, 1915. A daughter is the wife of Dr. A. S. Pinto, present city health commissioner and Spanish-American war hero.

Aaron Edmiston, graduate of Rush Medical College in 1880, came here three years later and has practiced here for 44 years. He was an instructor in the Omaha Medical College, and one of the founders of the University of Omaha. $\mathrm{He}$ is also on the Clarkson hospital staff.

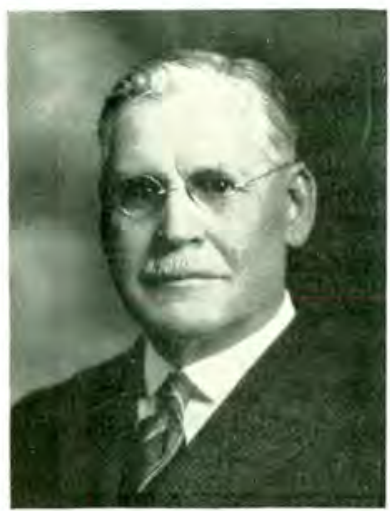

DR. AARON W. EDMISTON

When Ak-Sar-Ben governors, in 1927, named Dr. Willson Orton Bridges, King of Quivera, the first time in history that a member of the medical profession was so honored, many were curious to know the reason for the choice, barring Dr. Bridges' engaging personality and eminent standing in the profession. But few knew the wonderful service Dr. Bridges had given to Omaha and 


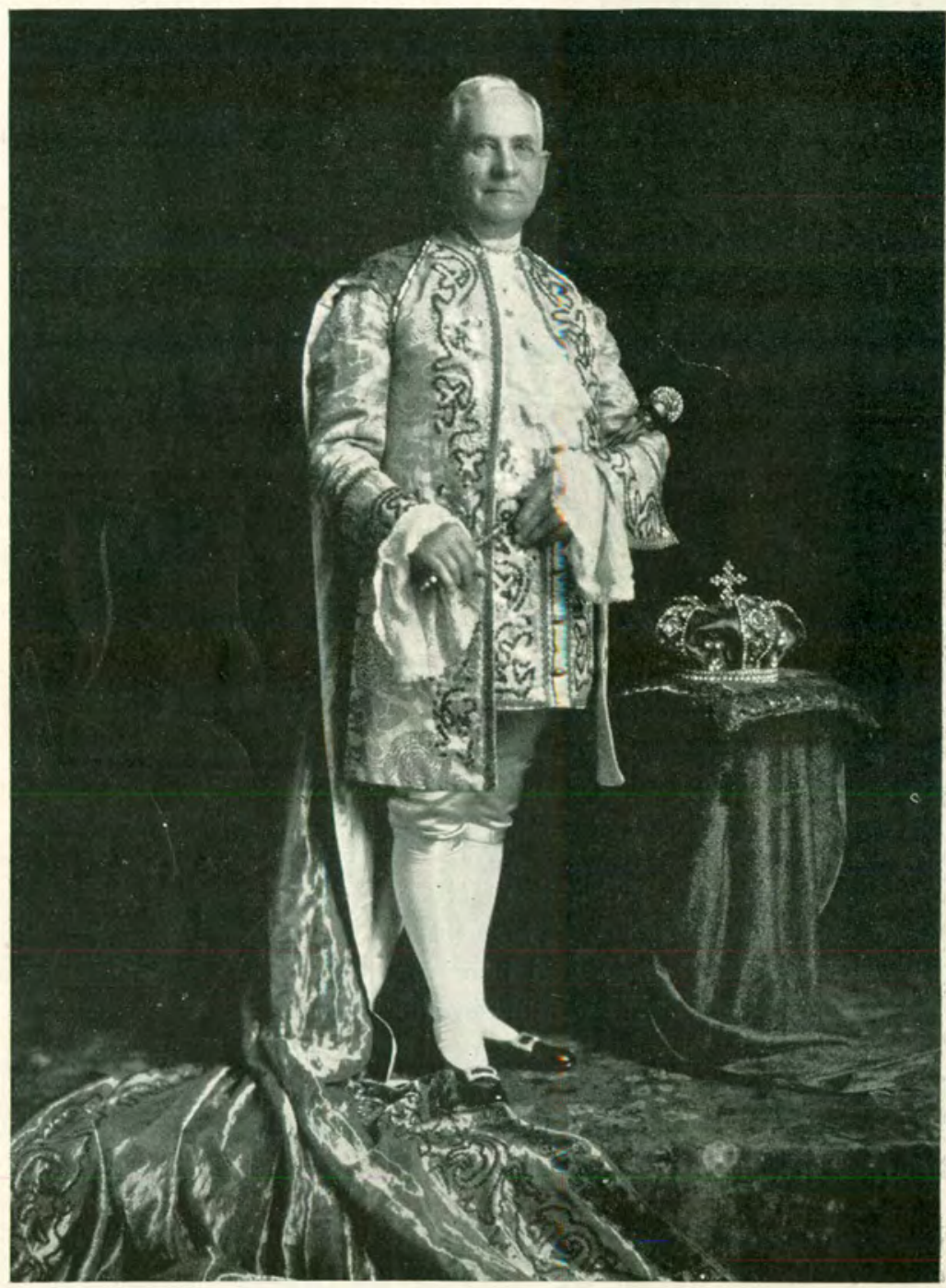

DR. W. O. BRIDGES, XXXIV KING OF AK-SAR-BEN 
the state, since the many yea:s of his active work were done so quietly and so unostentatiously.

"Now the truth can be told," it develops that Omaha owes largely to Dr. Bridges, the location of the University of Nebraska Hospital and Medical College and all the splendid buildings which, one by one, have been pledged by sometimes unwilling legislatures, through the persistent efforts, lobbying and watchfulness of quiet, dignified Dr. Bridges.

It was I)r. Bridges who first perceived and diagnosed the source of opposition to removing the medical department of the University of Nebraska to Omaha, its logical seat. It was he who planned a course of action which completely routed the opposition. Sitting in his office, he outlined a campaign of fight which extended into every part of the state. He entertained governors and regents, called on and interviewed every candidate for political office and learned where each one stood in the matter, pledging every possible vote. So was the fight for the local medical college-now the equal of any in the United States - won, thanks to Dr. Bridges and his helpers.

Dr. Bridges was born in the east; educated at New York University and practiced at Ogdensburg, where he was health officer and attached to the Marine Hospital, before coming to Omaha in 1883. He was dean and professor of medicine at the Omaha Medical College and University of Nebraska and past president of the county, state and Missouri Valley societies. He is a director and past medical director of the Bankers Reserve Life Insurance Company.

Important papers of Dr.Bridges include "Report on Hemolytic Jaundice," Typhoid Periostitis," "Typhoid Spine," "Gastric Analysis in Stomach Disease," "Essential Anemias," "Digitalis in Heart Disease," "Vaccine Therapy" and many others. His brother, Edson L. Bridges, associated with him in practice, is professor of medicine in the University of Nebraska Medical College; served with Base Hospital 49 in France and has done post graduate work in Vienna, Munich, Berlin and London.

Dewitt Clinton Bryant, later dean of Creighton Medical College for 23 years during the important period of its expansion, came to 
Omaha in 1884, after extensive study both in this country and abroad. He was born in Eton, Ohio in 1849, educated at Oberlin, and graduated in Medicine from Wooster in 1875 and Western Reserve in 1882. He spent one year, 1879-1880, in the Royal Ophthalmic Hospital in London and in 1899-1900, four months each in the schools and hospitals of London, Berlin and Vienna. He was an oculist and aurist, establishing the firm of Bryant, Burrell and Bushman, prior to assuming the deanship of Creighton, more of which will be mentioned in the chapter dealing with Creighton. Bryant was a founder of the American College of Surgeons and of the Omaha Academy of Medicine, with which Creighton men were allied in 1888, and president of the Omaha and Nebraska State Medical societies and of the Physician's Casualty Association. He was also a member of the American Association Railway Surgeons. Failure of his wife's health in 1916 forced him to resign and move to California where he is located at Claremont and identified with the Los Angeles and California State Medical societies.

Dr. W. J. Galbraith, closely associated with Dr. Bryant in Creighton and St. Joseph Hospital affairs and at one time on the faculty of the Omaha Medical College, is also located in California at Inglewood, although he is away most of the time as a ship surgeon. He came to Omaha in 1883, a graduate of New York University. Still another Californian is Ewing Brown, now assistant health commissioner at San Pedro. Brown was a contemporary of Bryant and Galbraith but was connected with the Omaha Medical College, rather than Creighton. He was born in Illinois in 1858; finished at Jefferson Medical College in 1883 and came to Omaha the next year. He was a Union Pacific surgeon and was active in medical circles until he removed to the west ten years ago.

William Forsyth Milroy, who is mentioned at great length in another chapter as the only Nebraska practitioner to enjoy the distinction of having a disease named for him, also settled in Omaha in 1884; as did the late Oscar S. Hoffman and Edward Everett Womersley, active in city and county medical societies and on the faculty of Omaha Medical College. Womersley first came to Nebraska to visit, when a lad in 1865 , from Massachusetts where he was born in 1852. In 1870, after being educated at Dartmouth, he enlisted in the U.S. Army and was stationed at Fort Leavenworth, 
Kansas. He was a clerk in the War Department and filled various jobs until he was graduated in Medicine from the Columbia University in New York, in 1883. The next year he came to Omaha and resided here until his death in 1906 . Dr. Womersley was a charter member of Hanscom Park Methodist Church, organized in 1886.

Hoffman was not quite twenty-one when he was graduated from the College of the City of New York and interned at Blackwell Island before going abroad for several years of post graduate

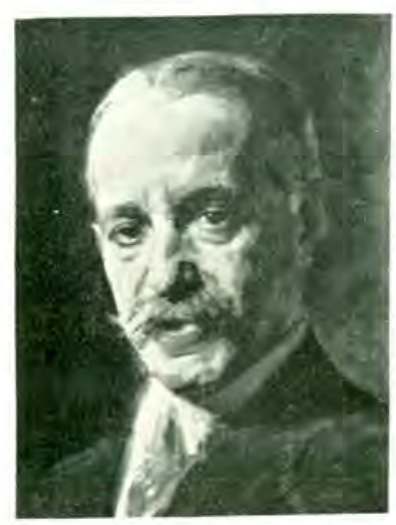

DR. OSCAR S. HOFFMAN work under Cohnheim, Weigert, Kaposi and Sanger. At the instance of Max Meyer, prominent Omahan of the ' 80 s, Hoffman came west to Omaha in 1883 and associated himself with Doctors Mercer and Galbraith, in the Union Pacific service. He taught dermatology in Omaha Medical College for 25 years; was active in founding Wise Memorial Hospital of which he was the chief of staff from its organization in 1899 until his death, July 23, 1926. Hoffman was a highly educated gentleman, well read, both in medicine and outside of medicine, noted for his ready wit and fastidious appearance, he made annual trips to Europe for many years. He was a New Yorker by birth, February 14, 1856. The accompanying photograph is from a painting by J. Laurie Wallace.

Charles Impey, center of another three-generation-group of physicians came to Omaha in 1885 from Graham, Missouri, where he practiced after his graduation from the University of Kentucky medical school in 1874. He also took post graduate work in New York and Chicago. Many years after taking up his residence here, Impey conducted a private hospital called the Central Hospital, at 22 nd and Seward streets, where he was associated in surgery with his son, Chester C. Impey, now on the staff of Wise Memorial Hospital. The latter is a Creighton graduate in the class of 1903, and served his internship at the Post Graduate Hospital in Chicago. 
The first of the Impey line of surgeons was Francis Impey, an army surgeon who was stationed in Memphis, Tennessee, and Fort Leavenworth, Kansas during the Civil War. He was born in County

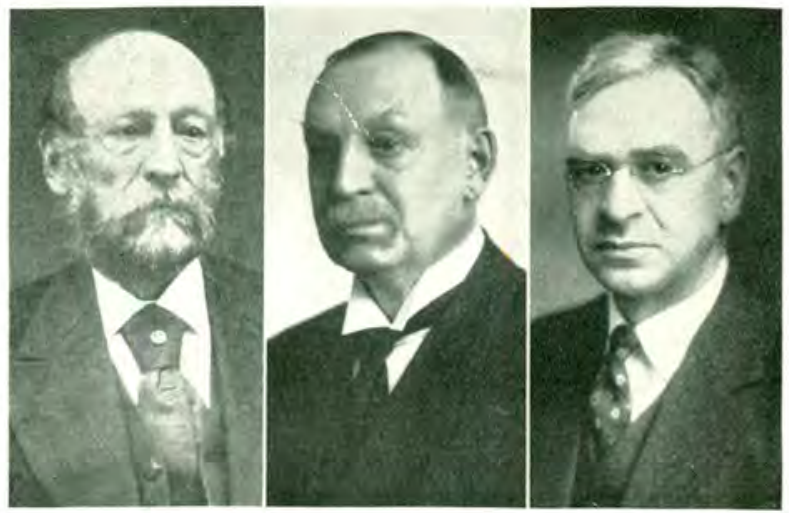

DRS. FRANCIS, CHARLES AND CHESTER C. IMPEY

Roscommon, Ireland, in 1800, came to this country as a youth and lived for a time in Pennsylvania. He was graduated in medicine from the St. Louis college, moved to California during the gold rush of 1849, practiced there for several years, but returned to

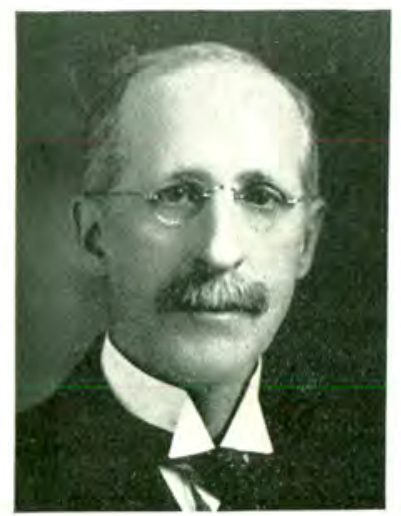
DR. RALPH W. CONNELL ing in Omaha. January 10, 1916. northwest Missouri, where he died in 1883. His son Charles, born in Miscuri, January 6, 1853, died in Omaha,

Ralph W. Connell, for many years nealth commissioner in Omaha, and uncle of Karl Connell, who won international renown for his inventions in connection with the gas mask during the late war, came to Omaha in April, 1884. His widow, a son James and a daughter, Mrs. H. M. Baldrige, are liv-

Another Nebraska-bred surgeon is Byron Bennett Davis, who came to Salem, Richardson County, Nebraska, in 1869 at the age 
of ten with his parents, who hailed from Wisconsin where he was born, June 14, 1859. He received Phi Beta Kappa honors from the University of Nebraska and was later graduated in medicine from the Minnesota College Hospital in 1884, with the grade of 98. He then attended the New York Polyclinic before locating in McCook, Nebraska in 1885, practicing there until 1893. Dr. and Mrs. Davis then spent a year in Europe where their son, Dr. Herbert Haywood Davis was born, March 24, 1894 and on their return in September, 1894, settled in Omaha. Here he became professor of surgical pathology at the Omaha Medical College; president of the state, county and Western Surgical associations, and chief surgeon in several local hospitals.

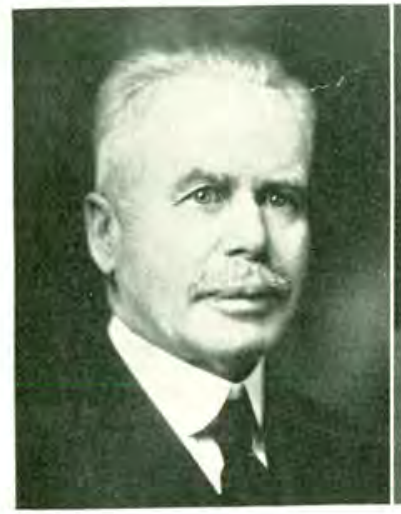

DR. BYRON BENNETT DAVIS

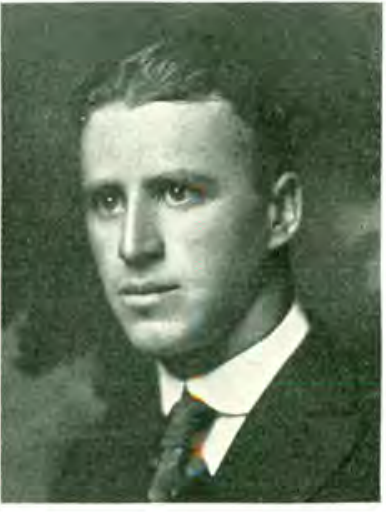

DR. HERBERT H. DAVIS

Two papers by Dr. Davis have won wide attention. One was "Contribution to the Surgical Treatment of Gastroptosis and Enteroptosis," (using an original method largely quoted and practiced to some extent by others) and the other, "Surgical Treatment of Epilepsy." Other papers of note are: "Unusual Contents in the Hernial Sac," "Hernia in the Linea Alba," "Surgical Diseases of the Biliary Passages," "Choice of Operation for Stone in the Bladder," "Surgical Treatment of Peritoneal Tuberculosis," "Gastro-Enterostomy-Indications and Report of Cases," "Preparation of the Patient for Operation," "Some Mechanical Problems in the Cure of Inguinal Hernia," "Malignant Diseases of the Kidneys," "Outlook for Surgery of Gastric Cancer," "How Can Mortality of Cancer of 
Uterus be Reduced?," "New Method of Repair of the Injured Ureter."

While still living in McCook, Dr. Davis was in 1887 elected a regent of the University of Nebraska and served six years. He was also on the faculty of the University and surgeon of the Burlington Railroad. His son, Herbert, graduate of Cornell and the University of Nebraska, recently returned from more than a year's study abroad and has joined his father in the practice of surgery.

The name of Dr. Harold Gifford occupies the pinnacle of national renown for his work in opthalmology. As a public spirited citizen and humanitarian, he has no peer. He gave to the city of Omaha, Gifford Park, a pretty breathing space in the center of a thicklypopulated section; and his gift of Fontenelle Forest Reserve near Child's Point, as a bird sanctuary, indicate his love for nature and his desire to see her beauties brought close to the people. Camp Gifford, the Boy Scout recreation spot is located in the heart of the forest, as is the Omaha Walking Club's shack.

Dr. Gifford was editor of the Opthalmic Clinical Record from 1897 to 1925, is the author of numerous articles and textbooks, chairman of the ophthalmological section of the American Medical Association in 1898. His scientific achievements will be treated in another chapter.

Gifford was born in Milwaukee, October 18, 1858, was graduated from Cornell in 1879 and from the University of Michigan Medical School in 1882. He received an honorary M. A. from this school in 1912. He pursued his post graduate studies in New York, Vienna and Zurich and was married in Switzerland, December 30, 1890 to Miss Mary Millard of Omaha. He settled here in 1886 and was for a time associated with Lynn B. Graddy in a small eye and throat hospital. Gifford early became associated with the Omaha College of Medicine, later the University of Nebraska School of Medicine and is today emeritus professor at this institution. His son Sanford is associated with him as are James Patton, John Potts, W. F. Callfas, W. A. Cassidy, Nora Fairchild and others. 
Dr. Charles Rosewater, youngest brother of Edward Rosewater, came to Omaha in 1886. He took his first medical course in Cleveland where he was born; then Vienna, Prague and WurzBurg, Bavaria, where he was graduated in 1870. He practiced in Cleveland and New York City and then made a second trip for special study in Vienna and Prague, before settling in Omaha. $\mathrm{He}$ held the chair of professor of obstetrics in Creighton Medical College and was secretary for the U. S. Board of Examining Surgeons for Pensions. He was active in all medical societies, serving

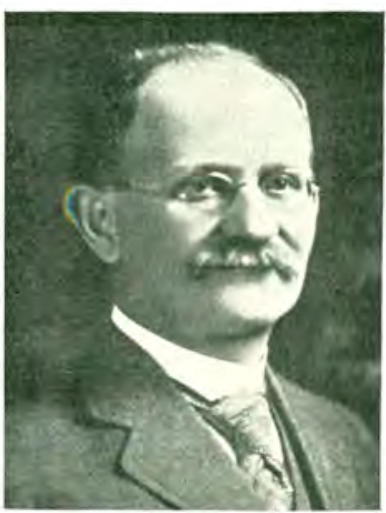

DR. CHARLES ROSEWATER as secretary of the Omaha-Douglas County and Missouri Valley Associations.

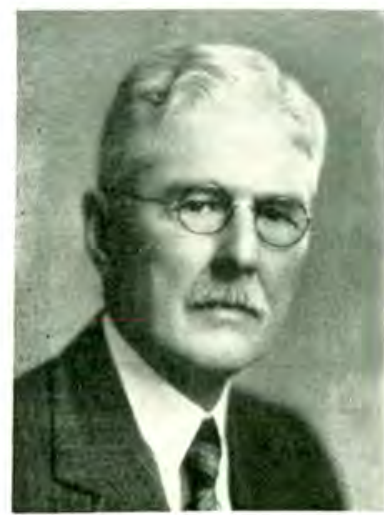

DR. J. H. VANCE

J. H. Vance, member of the School Board from 1905 to 1910 , and one of the founders and trustees of the University of Omaha, also came in 1886 . He was one of the organizers of Nebraska Base Hospital No. 49 in the late war. He has been a member of the staff of Swedish Immanuel Hospital for many years. His son Brookes is now practicing in New York. He was named for Governor Brookes of Wyoming, a family friend.

Dr. August F- Jonas occupies a preeminent place among Omaha surgeons for his skill, experience and many original contributions to medical journals in the past 40 years. His leadership is attested by the number of medical and surgical organizations he has headed. Beside his standing in the profession, Dr. Jonas is highly esteemed for his own personal characteristics and is a lover and collector of objects of art, more of which will be noted in another chapter. 
Dr. Jonas was born in Wisconsin in 1858 and at 14 was employed as a bookkeeper in a small Iowa town where he read medicine with Dr. A. T. Koch. At 17 , he entered Bennett Medical College in Chicago, from which he was graduated in 1877. He first practiced in Sauk City, Wisconsin, and then in 1882 went abroad for four years, studying at Halle, Ludwig Maximillian University in Munich, Bavaria, from which he was graduated in 1884; and then took postgraduate work in Vienna, Berlin and Paris. He came to Omaha from Madison, Wisconsin in 1887 and has been a leader ever since in every movement affecting the medical profession here. He is chief surgeon of the Union Pacfic since 1898, one of the founders and chief of the surgical staff of the Methodist Hospital whose organization he made possible by a gift of $\$ 30,000$ in the early ' 90 s, on condition that the hospital board raise an equal amount. Friends assert that Dr. Jonas pledged every cent he owned to this venture. During the war he was instrumental in organizing Nebraska Base Hospital No. 49 for service in France and also the Omaha Ambulance company. He is also professor of surgery at Nebraska University. It was in Dr. Jonas' office that there was founded in the late '80s, the Omaha Medical Club, forer unner of the Omaha-Douglas County Medical Society. This club was made up of the newer medical men just arriving in Omaha in the $80 \mathrm{~s}$, as distinguished from the Omaha Academy of Medicine, an alleged exclusive body. The two units were harmoniously merged in the new society of which Dr. W. F. Milroy was the first president in 1890 .

The list or Dr. Jonas' presidencies includes Omana-Douglas County Medical Society: Nebraska State Medical, 1905; Missouri Valley, 1894; Pan-American, 1897; Western Surgical and Gynecological, 1899, American Railroad Surgeons, 1901. He was an American Medical Association delegate to an international convention in Paris in 1900 and two years later, was elected vice-president of the American Medical Association. He was professor of clinical surgery in the old Omaha Medical College before it merged with the state university. He is also a member of the American College of Surgeons, Nebraska Division; of the American Surgical Association and a former president of the Omaha Surgical Club as well.

Two more important arrivals of 1887 were Andrew Bartholomew Somers and John Prentiss Lord. Dr. Somers is today Omaha's 
oldest active practitioner, having celebrated his eightieth birthday

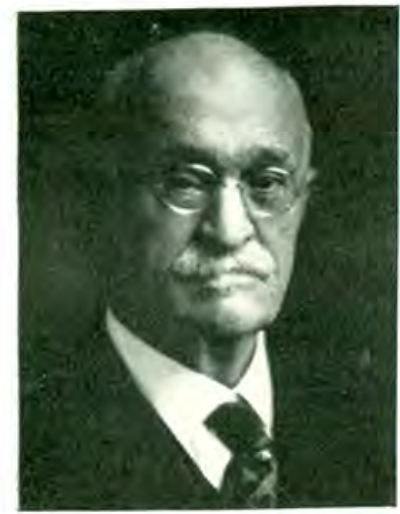

DR. ANLREW E. SOMERS May, 1928. With mind keenly alert, his humor never failing, the tall, spare New Englander reports to his office every morning, sharing offices with his protegee, Willis $\mathrm{H}$. Taylor, whom he regards with the same affection "as if he were my son." Dr. Somers was educated at the University of Vermont, and Columbia, from which he was graduated in 1872 and practiced in his native state, Vermont, for 15 years before he came west. His activity was apparent immediately upon his arrival. He was a charter member of the Missouri Valley Medical Society organized in 1888 and an ex-president; one of the organizers and an ex-president of the Omaha-Douglas County Medical Society; served as city health commissioner in 1892-1893 and on the State Board of Health from 1900 to 1905. A member of the Creighton faculty from 1895 to 1900, he became professor of obstetrics at the Omaha Medical College, now the University of Nebraska School of Medicine, that year. and continued until 1917, when he was made professor emeritus.

To listen to Dr. Somers philosophize on the changes in times and medicine since he began to practice is a liberal education.

"I never spoke into a telephone until I came to Omaha in $1887, "$ he declared.

As a member of the Union Pacific medical staff, Dr. Somers had an interesting experience when he was summoned to attend the late E. H. Harriman, when the railroad magnate suffered an attack of acute appendicitis in Grand Island a number of years ago. The party was rushed to New York by special train, superseding the Twentieth Century Limited. Dr. Somers said he made the round trip from Grand Island to New York in 70 hours, with a seven hours' wait between trains in Chicago, on the return trip, a record, even today.

To observe Mr. Harriman in action, even on a sickbed in a speeding railroad train, was a lesson in business efficiency, according to Somers. 
Somers is the oldest practicing physician in Omaha, having a record of more than 55 years, and has been a Mason for more than 50 years. J. B. Ralph, retired, who is now 86 , is said to be the oldest living graduate of Rush Medical College. He was also medical director of the Grand Army of the Republic, at one time. He makes his home with a son, Roy Ralph in Dundee.

John Prentiss Lord is the dean of orthopedic surgeons in the state, and the second in the x-ray field, Dr. H. P. Jensen being credited the first. Lord has been on the staff of the Nebraska Orthopedic Hospital in Lincoln since it was established in 1905 and was on the

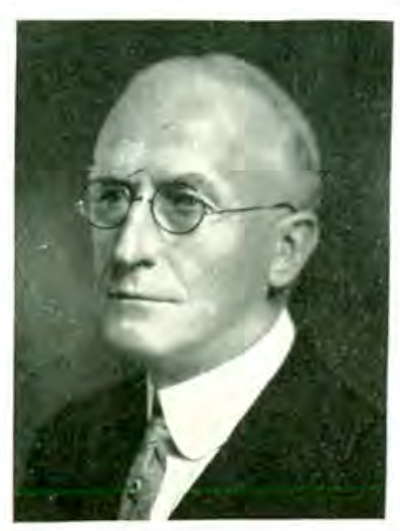
editorial staff of the Western Medical Review. He has headed many medical societies, including the Omaha-Douglas County in 1899; Western Surgical, 1910: state association, 1911; and the Missouri Valley, 1915. He was born in Illinois, April 17, 1860; was graduated from Rush Medical in 1882; practiced in Creston four years and took post-graduate work in New York in 1886 before settling in Omaha. He began to specialize in surgery in 1893. He has been on the staff of both Creighton and Nebraska and has written many valuable papers. In one, he was the first to call attention to skin grafting in bone cavities. He is affiliated with the National Railroad Surgeons, American Orthopedics, American Association for the Advancement of Science, and national tuberculosis societies. Robert D. Schrock and H. F. Johnson are now associated with him.

Edward Wallace Lce, who left Omaha in 1905 was another important physician who came to Omaha in the late $80 \mathrm{~s}$. He was chief physician during the TransMississippi Exposition and was connected with the Burlington Railroad. He left Omaha to become chief physician of the Erie Railroad in New York. In the late war, he established a government hospital at Porta Rico and while there contracted a tropical fever from which he never entirely recovered. He died in the fall of 1927 at Randolph, New York. Dr. Lee's 
wife was May Dundy of Omaha, second queen of Ak-Sar-Ben. Dr. Lee was said to be the first physician to reach the side of President McKinley, when the latter was shot.

Active in politics and public affairs was Dr. William H. Christie, president of the Omaha School Board for two terms, and delegate to the republican national convention in 1884, voting for James G. Blaine. Dr. Christie, who was born in New Jersey, March 31, 1844 , enlisted in Company $\mathrm{K}, 75$ th Illinois, in the Civil War and

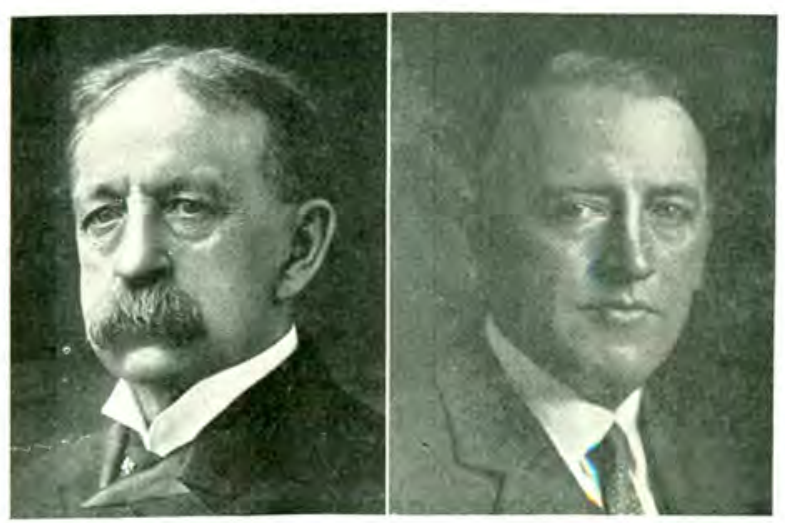

DR. WILLIAM H. CHRISTIE DR. BURTON W. CHRISTIE

was wounded in his first battle, having been shot three times. He was in poor health for several years as a result. When he felt better, he became interested in the study of medicine, and enrolled at Rush Medical College in Chicago. He practiced for a time in Illinois and Iowa and finally located permanently in Omaha in 1887. He was professor of materia medica and therapeutics in the old Omaha Medical College and was president of the county society, in 1907. He was also active in Masonry and established many lodges in southwestern Iowa. A son Burton W. Christie, is following in his father's professional footsteps.

Another physician who served as president of the Omaha Board of Education is Elias Holovtchiner, born in Russia in 1880. He was graduated from the University of Berne, Switzland, in 1881; Zurich in 1885 and took post graduate work in Berlin, Leipsic and other European cities. He then engaged as surgeon on the Hamburg- 


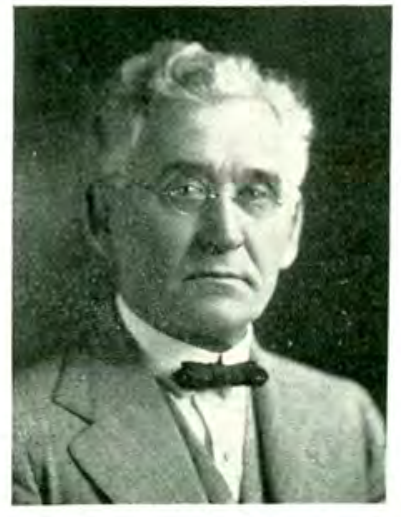

DR. ELIAS HOLOVTCHINER

American steamship line and in that fashion he came to America. His advent to Omaha was September 29, 1887. Hclovtchiner is a contributor on political and economic subjects to many publications. He was elected to the board of education in 1909.

Dr. Joseph C. Moore, father of J. Clyde Moore, one of the leading child specialists in the city, first settled in Oakland, Nebraska, in 1882 and came to Omaha in 1887. He was born in Ohio in 1851 and rece.ved his medical education in St. Louis, where he was graduated in 1882.

Robert F. Gilmore, native of Ireland, where he was boin in Belfast in 1856, cast his lot with Omaha in 1887. After obtaining

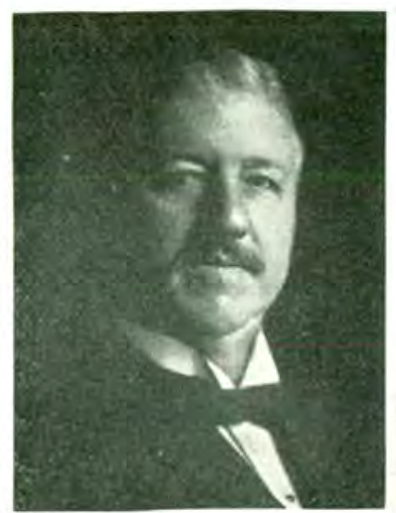

DR. ROBERT F. GILMORE

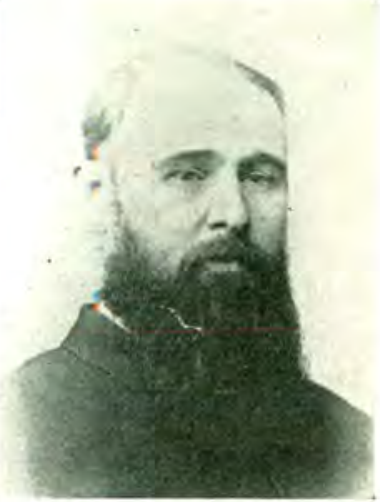

DR. C. D. SPRAGUE

his medical education there he practiced several years in the Emerald Isle before coming to America. He is chief of staff of Wise Memorial Hospital.

Samuel Mount Campbell settled in Omaha in 1886 or 1887. C. D. Sprague, a former county physician at Parkman, Maine, also settled in Omaha in 1887, after completing a postgraduate course at Rush Medical College. He practiced here until his death, April 7, 
1898, at the age of 49. A son, Charles H. Sprague, is a Benson druggist,

Jchn C. Davis, whose son, Calvin Dav's, is now practicing in Omaha, belongs also to this decade. The elder Davis was a member of the old city council. His office was for many years located on Cuming street, between Twenty-first and Twenty-second.

Dr. Benjamin F. Crummer, prominent in the state society, which he headed in 1903, and in the Creighton faculty, and father of LeRoy Crummer, one of the leading Omaha internists today; Joseph Melanchton Aikin, for many years secretary of the state medical society and editor of the Nebraska State Medical Journal: and Andrew W. Riley, identified with Creighton Medical College since its inception, came to Omaha in 1888.

The elder Dr. Crummer came here from Warren, Illinois, where he practiced a number of years after his graduation from the University of Michigan in 1869. He early won recognition in Omaha

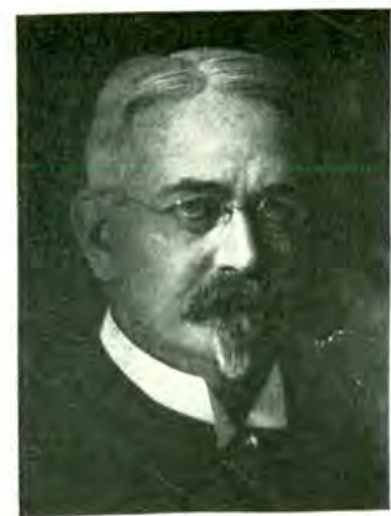

DR. B. F. CRUMMER for qualities of leadership and built up a large practice. He died January 23, 1907. His son LeRoy is a specialist in diagnosis and heart disease, the author of "Clinical Features of Heart Disease," published in 1925; and has written various monographs on the History of Medicine. He is best known as a collector of rare old medical books, prints, anatomical fugitive sheets, and antiques relating to the history of medicine, many of which he has presented to the University Library. $\mathrm{He}$ is also interested in rare prints and book bindings, which he collects on numerous trips abroad. He was born at Warren, Illinois, was graduated from Central High School, Omaha, in 1889; Michigan, 1893; Northwestern in 1896 and took post graduate work in Vienna, Berlin, London, Zurich and Frankfortam, Main. He was on the Creighton staff before affiliating with Nebraska University, where he is professor of clinical medicine. Crummer was president of Omaha-Douglas County Medical Society in 1911. His father served in 1891. 
Dr. J. M. Aikin, whose practice was for the last 20 years of his life limited to nervous and mental diseases, was born in Ohio, July 18, 1857; taught school in Iowa while he attended the state

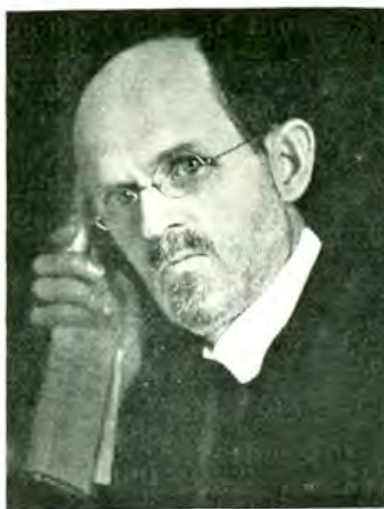
medical college and was assistant physician at Mt. Pleasant and Clarinda asylums, after his graduation in $1887 . \mathrm{He}$ came to Omaha the next year, associated in offices with J. C. Moore. He was professor of diseases of the nervous system in both local colleges and was secretary of the state society from 1911 until he died, November 18, 1920. He was named editor of the state Journal in 1918 and a member of the House of Delegates, American Medical Association, 1917-20.

DR. JOSEPH M. AIKIN

Andrew W. Riley, on the faculty of Creighton Medical College from its inception in 1892 until he died in 1908, came to Omaha in 1888 after extensive siudy abroad, where he was interested in colleges and management of hospitals. He was born in New York Nov. 2, 1858 , studied at McGill and Dartmouth and taught school before applying himself to the medical profession. He held the chair of theory and practice at Creighton and belonged to all medical organizations.

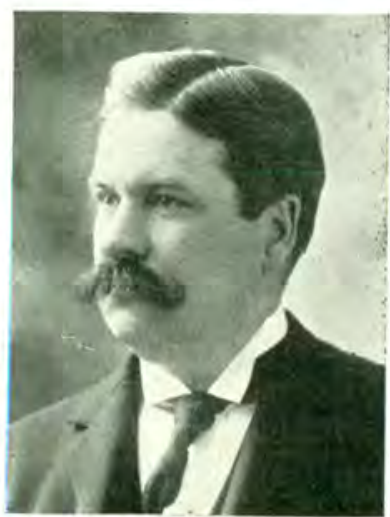

DR. ANDREW W. RILEY

Dr. H. M. McClanahan, pioneer pediatrician between Chicago and San Francisco, cast his fortune with Omaha, April 13, 1889 , shrough the influence of Dr. McKean, noted missionary to China and a warm friend of McClanahan, who was taking away from Omaha one Dr. Stock to accompany him to China. Shortly after his arrival here from Illinois, where he practiced seven years, Dr. McClanahan bought the stock of the late Dr. C. R. Moore in the Omaha Medical College and thus became a member of the faculty and active 


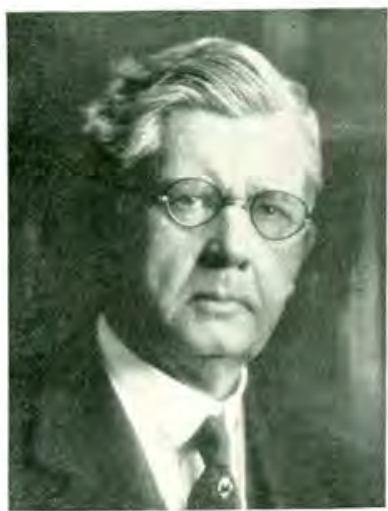

DR. H. M. MC CLANAHAN showing that the Indians understood the principle which makes gauze useful, the spider web serving the same purpose.

Dr. McClanahan is now engaged in writing a book on Children and Their Diseases, in which he hopes to crystallize the manifold experiences of 40 years' extensive practice among them.

"I am not writing about a thing which I have not myself seen or experienced," he declared. He has more than 45 other papers to his credit. He did post graduate work in London and Vienna prior to 1908. Dr. McClanahan has served as president of both county and state medical sccieties. His son-inlaw, Dr. J. A. Henske, is associated with him in practice.

Robert Samuel Knode also came to Omaha in 1889, specializing in diseases of the nose, throat and ear, in which practice he is today succeeded by his son, Dr. A. R. Knode. Born in Maryland, April 16, 1842, the family moved to Indiana in the elder Knode's youth. He volunteered in the Eighth Indiana regiment and attained the rank of assistant surgeon. After the war he entered

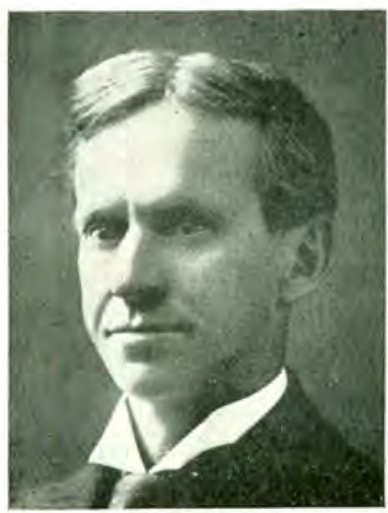
Miami Medical College and was grar-DR. ROBERT SAMUEL KNODE 
uated March 1, 1867. He practiced in Indiana before moving to Omaha, where he was active in the early advancement of his specialty. Knode retired in 1915 and died January 26, 1920. The younger Knode, educated at the University of Nebraska, is on the staff of several Omaha hospitals.

Dr. Walter O. Henry, brother of Dr. Edwin C. Henry, settled in Omaha in 1890, after ten years' practice in Pawnee City, where he was in partnership with A. B. Anderson. The father of the Henrys, Dr. Samuel Henry, was a physician at Louisville, Kentucky, and here the elder Henry brother studied before attending Rush and graduating from Bellevue in 1870. On moving to Omaha, Henry established the Presbyterian Hospital and was elected to the chair of gynecology in Creighton University. In 1897 he formed a partnership with his brother, E. C. Henry, who was a Creighton graduate and took work at the Medico-Chirurgical College of Philadelphia. The younger Henry was also head of the anatomy department of Creighton, was in the service in the late war, first commander of Douglas County post of the American Legion on its inception in 1919 and is now owner and chief surgeon of Lord Lister Hospital, Omaha.

Walter Henry was a delegate from the Missouri Valley society to the International Medical Congress at Buda-Pesth in 1909. He founded the Omaha General Hospital, located for a number of years at 14 th and Capitol Avenue.

Frank Styles Owen, emeritus professor of ophthalmology and oto-laryngology at the University of Nebraska, came to Omaha in 1891, to become one of the leading men in his specialty. He was recently elected president of the Nebraska State Medical association. A son, Donald R. Owen, and Clarence Rubendall are associated with him.

Dr. Reuben Robinson, born near Wilna, Russia, came to Omaha in 1894 after being graduated from Russian universities and took his degree from Omaha Medical College in 1896. He practiced here for two years when poor health caused his removal to Texas, where he died in 1915.

Dr. Edward E. Sloman of Detroit practiced in Omaha from about 1890 to 1892 , as did Dr. Isidor Gluck, according to records 
of the Omaha Medical Society. Sloman was drowned in Lake Manawa a year or two later.

Elmer J. Updegraff, noted among his colleagues as a general surgeon especially skilled in the treatment of fractures, came to Omaha in 1895 and enrolled in the Omaha Medical College, from which he was graduated in 1899. In his senior year he was lecturer in anatomy. Updegraff joined the Union Pacific staff and was for 25 years division surgeon. He was also a charter member of the American College of Surgeons. He died in California, July 9, 1925, at the age of sixty-eight.

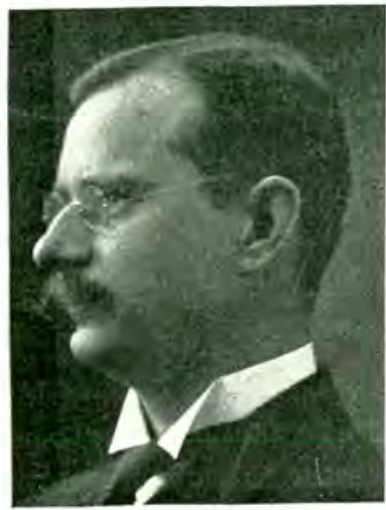

George H. Bicknell, dead now for fifteen years, was one of the most popular physicians who came to Omaha in the early '90s, probably about 1894 . He had a personality which endeared itself to every one who knew him and the memory of which still lingers, according to J. M. Patton, associated with Harold Gifford, as was Bicknell. The latter was on the staff of the Kankakee and Glenwood, Iowa, Institutions for the Feeble-minded, and on the County Hispital staff here, before invited by Gif-

DR. GEORGE H. BICKNELl ford to join with him. He was a student of languages and a musician of ability, according to Patton and A. C. Stokes.

Dr. Fred R. Teal, late superintendent of the hospital for insane at Norfolk, should here be mentioned, although he came to Omaha when a babe in arms from Council Bluffs. His parents had lived in Omaha as early as 1857 , then crossed the river. Teal was born in Council Bluffs in 1873, was graduated from Omaha and Norfolk schools and from the Chicago Homeopathic Medical College in 1896. Two years after his return to Omaha to practice, in 1898, he was elected to the Board of Education. In 1900, Governor Dietrich appointed him to the Norfolk post.

Dr. Millard Langfeld was called to Omaha in 1898, after receiving his degree from Johns Hopkins Medical School in Baltimore, 
where he was born, to become professor of bacterology and clinical medicine in Cre ghton Medical College. He is also bacteriologist for the Omaha Board of Health and is on the staff of the Nebraska Institute for the Deaf. He is now superintendent of Cudahy laboratories. Langfeld is author of "Infections and Parasitic Diseases," published in 1897.

\section{THE NEW CENTURY}

The opening of the new century brought to prominence James S. Goetz, who died in 1927, and a group of native sons whose attainments will be enumerated in other chapters; and a group of newcomers, among them Palmer Findley, who came here in 1906.

James Goetz, who moved to Omaha with his family from Cincinnati in 1881 when he was a babe in arms, was graduated from Miami College, Cincinnati and studied in Vienna and Berlin before

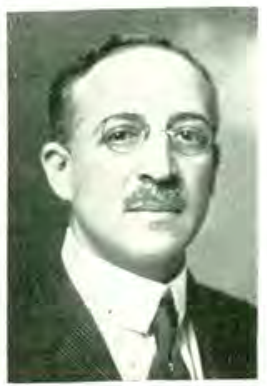
he returned to Omaha in 1902 to join Dr. O. S. Hoffman in practice. "Jimmie" Goetz, as he was familiarly known, became one of the most popular men in the medical profession in Omaha, counting his friends in a wide circle in many strata of society, before his death, June 7, 1927. He was lecturer on internal medicine in the University of Nebraska, occupied the chair of therapeutics and was on one of three major medical services. He also published a number of broDR. JAMEs GoEtz chures. In 1918, he was made a life member of the Surgeon's Club, Rochester, Minnesota.

Palmer I indley, gynecologist and obstetrician, is author of two texts, "Diagnosis of Diseases of Women" and "Diseases of Women" and is associate editor of the American Journal of Obstetrics. $\mathrm{He}$ was educated at Iowa and Northwestern Universities and is now on the faculty of the University of Nebraska and a trustee of the University of Omaha. He was president of the state medical, of the American Association of Obstetrics, a fellow of the American Gynecological Society, College of Surgeons, Omaha Surgical Club and head of the Nebraska section of the Society for Control of Cancer. In civic organizations he is president of the Professional Men's Club. 
Findley is the middle of a three-generation group of physicians which includes his father, the late David Findley who practiced in a 50-mile radiunf of Lewis, Iowa, for 47 years, closing his years of

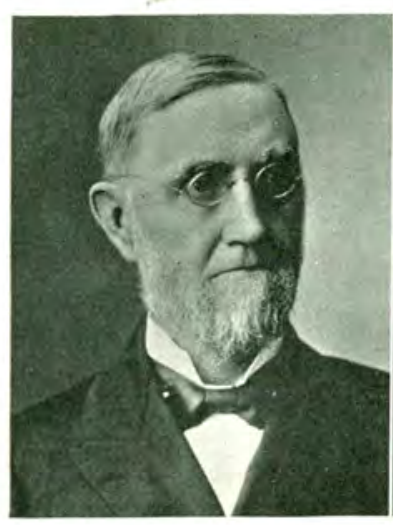

DR. DAVID FINDLEY

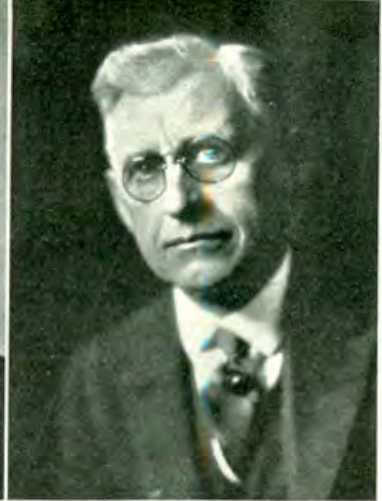

DR. PALMER FINDLEY

service on his golden wedding anniversary. The senior Dr. Findley made his rounds on horseback over the trackless prairie with his saddlebags slung across his horse. He was reputed to be the first

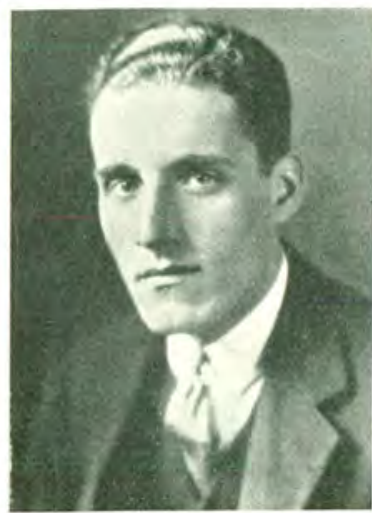

DAVID P. FINDLEY

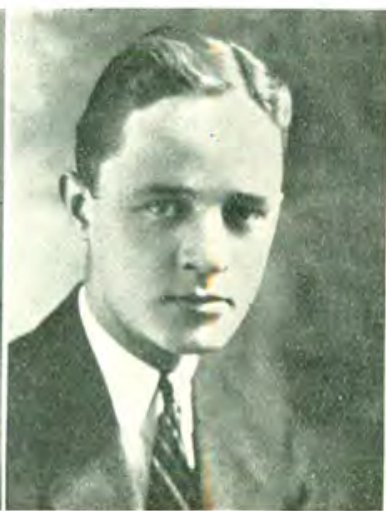

THOMAS P. FINDLEY, JR.

physician to introduce the stethoscope and obstetrical forceps in Iowa and the first to use a top buggy.

Both of his sons followed him in the practice of medicine-Dr. Palmer Findley in Omaha and Dr. William J. Findley in Sac City, 
Iowa. Now the two sons of Dr. Palmer Findley, David Pressley and Thomas Palmer Findley, Jr., are following in their father's and grandfather's steps. Dr. Thomas P. Findley is a graduate of Princeton and Rush Medical College and is now serving his internship in the University of Pennsylvania Hospital. David studied at the University of Minnesota and is now at the Jefferson Medical College, Philadelphia.

Dr. Palmer Findley took his B. S. degree from the University of Iowa and his M. D. from Northwestern, finishing his studies in Berlin, Vienna and Paris.

Findley was associated for eight years with Dr. Clarence Webster in Chicago at Rush Medical College and Presbyterian Hospital and came to Omaha in 1906 to accept the chair of gynecology at the University of Nebraska College of Medicine.

\section{IN NEBRASKA, OUTSIDE OF OMAHA \\ 1880-1900}

With a rapidly growing population and wider settlement of the agricultural and cattle-raising districts, many physicians came out of the east to seek their fortunes in the new settlements. Many, like James L. Gandy, Hiram L. Smith and Jackson B. Whittier, acquired vast tracts of farm and ranch lands; others organized banks, lumber yards and other financial interests, or entered politics.

Calvin F. Moranville of Guide Rock, mentioned especially in the Webster County history, came there from Iowa where he had already practiced two years. He was born in Vermont in 1858 and was educated at the Nebraska Medical School, which then had thrce departments, homeopathic, eclectic and allopathic; and finished at Hahnemann College in Chicago. His brother, James W. Moranville, settled at Red Cloud. Both served in the Spanish-American War.

William G. Houtz, son of a Pennsylvania physician and a veteran of the Civil War, when he was the first doctor on the field after the Battle of Corinth, came to Lincoln in 1850 but did not practice much, limiting his services to old soldiers and friends. He was a personal friend of General John Thayer and General Victor Vifquain, He was born in 1830 and was a graduate of Girard. 
David A. Hungerford, another retired physician, lived in Grand Island after practicing in McPherson, Kansas, and Julesburg, Colorado. He too was a Civil War veteran.

Jackson B. Whittier, a cousin of the poet, John Greenleaf Whittier, and a paymaster in the Union Army by appointment of President Lincoln during the Civil War, settled in Decatur, Burt County in 1881. The aged physician, who became a capitalist and extensive land owner in his many years' residence here, spent most of last winter in Immanuel Hospital in Omaha, having suffered a broken hip early in the fall. Born in New Hampshire and educated at Dartmouth, Whittier, who was early left an orphan, crossed the plains in a prairie schooner and spent a year mining in Colorado before the war. He attempted dentistry after the war, but changed to medicine, and was graduated from Hahnemann College, Chicago, in 1877. He is one of the heaviest land holders in this section; one of the original stockholders of the First National Bank of Tekamah and has been president of the First National Bank of Decatur for many years. Though Dr. Whittier has composed some verse himself he has never attempted to have it published. He is ninetyseven years old, the oldest physician and banker in the state.

The year 1882 brought F. W. Winter of Adams County to Wymore. He practiced there until 1922 when he retired. Robert Damerell of Red Cloud came to Webster County in March, 1882, one month after his graduation from Rush Medical College. He was a Burlington surgeon until 1895, when Governor Holcomb appointed him superintendent of the insane asylum at Hastings for four years. Damerell, who was born in Illinois in 1852, taught school first to earn money for his medical course.

Daniel Samuel Woodard of Aurora, Hamilton County, began his practice in this state in 1882, after finishing at the Ensworth Medical College at St. Joseph, Missouri, although he had resided on a Saline County farm since 1879. Woodard practiced at Hampton until 1897 when he bought a drug store at Aurora. He was active in the county medical society, served two terms in the state legislature, was assistant superintendent at Hastings Insane Hospital, 1899-1901, and superintendent at Lincoln Insane Hospital, 1909-1911. 
Robert S. Anglin, a Canadian by birth, practiced in Papillion and Springfield from 1882 to 1888 when he decided to specialize in eye, ear, nose and throat work and went abroad to study at Vienna, Heidelberg and Edinburgh. On his return he settled in Omaha and practiced 30 years until his death in Tekoa, Washington, January 19, 1927 while visiting a sister, He was educated at the Royal Military College at Kingston, Ontario.

Carroll Dandola Evans, prominent physician of Columbus, had won his spurs as lieutenant of the Pennslyvania National Guard, quelling the coal strikes and railroad riots of 1877 , before he settled at Columbus in May, 1883. Because of this experience he was made colonel on Governor C. H. Dietrich's staff and surgeon-general of the Nebraska National Guard by Governor E. P. Savage. In 1902 he was made a member of the Association of Military Surgeons of the United States. Evans was born in Tarentum, Pennsylvania, May 26, 1856, of early American descent, was graduated at Baltimore in 1882 and took post graduate work in New York and Chicago before coming west. He was state delegate to the American

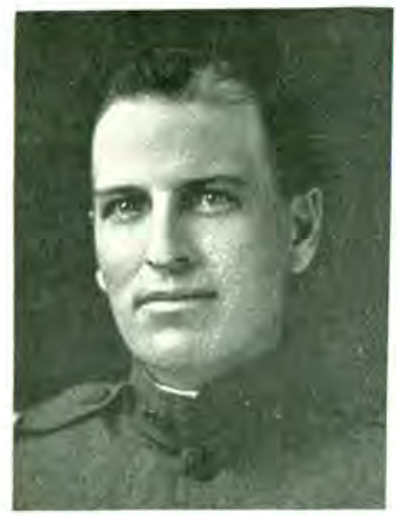

DR. HERBERT COPSEY Medical Association in 1903 and active in Masonry.

Herbert Copsey of Alliance came to Custer County from Wisconsin in 1883 with his parents, who homesteaded there, but was not graduated from the Lincoln Medical College until 1906. He was president of the staff of St. Joseph's Hospital for six years until last year, when succeeded by Charles S. Slagle. He was a captain in the late war.

Dr. James M. Alden of Pierce, a member of the legislature, both houses in 1903, came to Pierce County in 1883. He was born in New York, September 7, 1848 and was graduated from Jefferson Medical School in 1871, practicing in Michigan before he journeyed west to this state.

An interesting survivor of the old school is Cyrus Monroe Easton of Davenport, Nebraska, now more than 85 years old. $\mathrm{He}$ came to Nebraska in 1884 and practiced 17 years in Gardner and 


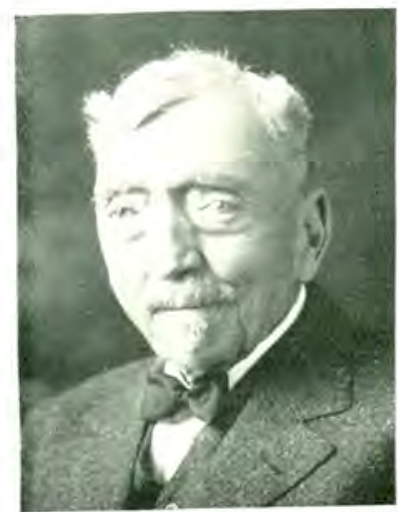

CYRUS M. EASTON

37 years in Hebron, before spending his declining years at Davenport. Easton was born on a farm in Ohio, October 23, 1842, and moved to Illinois in 1858 where he taught school for several years and attended Rush Medical College, being graduated January 17, 1872. He had previously served in the Civil War with Company F, 14th Illinois Volunteers. He took some work at the University of Michigan before attending Rush Medical College. Dr. Easton was for 20 years Pension examiner at Hebron.

George Oliver Remy of Ainsworth, the oldest practitioner in northwestern Nebraska, author of "Old Doc" and more than 50 other poems, and who has expressed himself eloquently on the hardships endured by the pioneer doctors, also came to this state in 1884. His son, Charles E. Remy, is now superintendent of the Michael Reese Hospital Dispensary in Chicago.

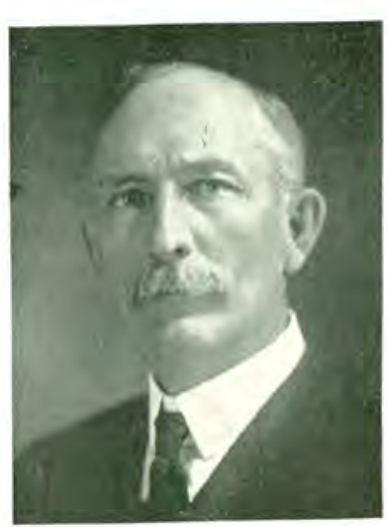

H. HAPEMAN

H. Hapeman of Minden, oldest practitioner in Kearney County, whose practice extends to Colorado and Kansas, also arrived in 1884, after his graduation from Rush Medical College.

John Henry Fochtman settled in Cozad in May, that year, opened a drug store five years later and in 1904 built a ine new building to house the drug store and his office. Fochtman was born in Maryland in 1862 and was forced to make his way largely on his own initiative because of the death of his father when he was only nine years old. $\mathrm{He}$ was only 17 when he entered the College of Physicians and Surgeons in Baltimore and was graduated in 1883, after spending a year at Pennsylvania. His son has succeeded the elder Fochtman at Cozad. 
J. H. Mackay of Norfolk, superintendent of the insane asylum there and active in Democratic politics, was a resident of Madison County since 1884. He was born in Nova Scotia and educated in Chicago. He was secretary-treasurer of the League of Physicians and Surgeons of Madison, Pierce and Stanton Counties.

Benjamin Franklin Lorance of Auburn, attended the University oi Nebraska in 1879-1880 and read medi-

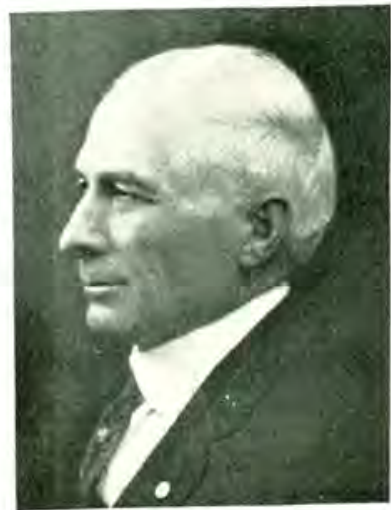
DR. BENJAMIN F. LORANCE in republican politics. cine with D. A. Walden at Beatrice in 1884 before receiving his degree from the Iowa college in 1887. He also practiced in Beatrice with Dr. Walden and Bates, serving as a principal of the school there, and as superintendent of the Hebron schools at the same time. Since 1894 however, he has practiced medicine exclusively, first at Brock, then at Auburn, and has taken post graduate work in Chicago. He is ex-president of the Nemaha County society, a member of many teachers' organizations, and active

The year 1885 brought to this state George Frederick Keiper of Pierce, later superintendent of the Insane Hospital at Norfolk from 1896-1900, and active in democratic politics; Harold B. Miller of Lincoln; Ben F. Farley of York; C. B. Little of Bloomfield and E. A. Benton of Central City.

Keiper served in both houses of the legislature, during which time he was author of a bill providing that the state care for the insane and in 1893 was nominee for Congress in the Third District, polling the largest democratic vote ever cast. He was born in Pennsylvania in 1836, was graduated from Rush Medical College the year he came here, and died in Los Angeles, December 3, 1909. He was a member of the American Psychological Society, as well as other medical organizations. Miller first practiced at Rushville for four years, then went east for post graduate work in Pennsylvania, his native state, then moved to Lincoln in 1903. He was professor of materia medica in Nebraska Medical College and chief of staff at Tabitha Hospital, organized in 1907 by the Lutheran Synod. 
Farley, a veteran of the Civil War, took his degree at Ann Arbor in 1870, was proprietor of the Hillside Hospital in York, director of the German-American bank there and vice-president of the state medical society.

Clement Botsford Little of Bloomfield, Knox County, who now lives in Portland, Oregon, first practiced in Clarks, Merrick County, in 1885; then Osceola, 1888; before moving to Bloomfield in 1890. He was superintendent at Norfolk Insane Hospital from 1893 to 1895. A son, T. Coe Little, practiced in Bloomfield and Omaha, where he held the chair of neurology at Creighton Medical College for four years.

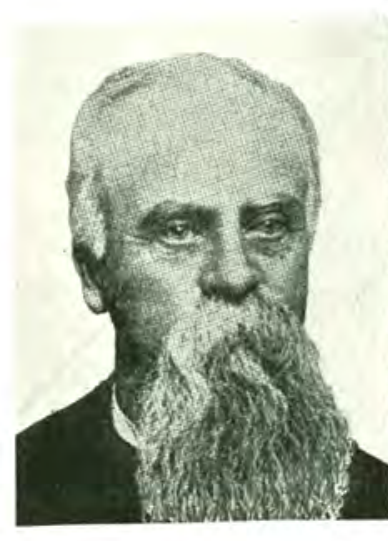

DR. EUGENE A. BENTON

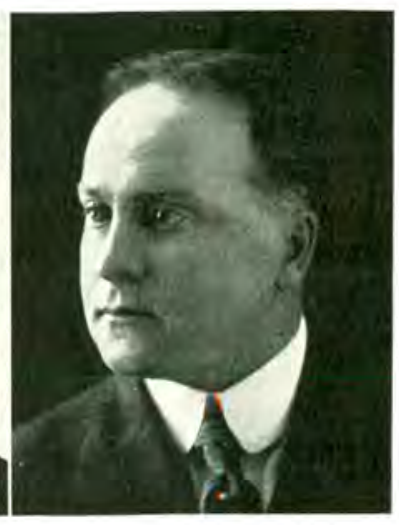

DR. JOSEPH E. BENTON

Eugene A. Benton came to Central City from Illinois in 1885 and is today succeeded by his son, Joseph E. Benton. The elder Benton, in 1887, took Wilson B. Thurton, just arrived from Wisconsin, as his partner and the firm continued so until 1891, when Thurston went on to Idaho. Benton was active in the Merrick County Medical Society and served as vice-president of the state association. He died in 1912. Joseph Benton has been secretary of the Merrick County society for years.

The list for 1886 is an important roster. It includes the names of Benjamin F. Bailey of Lincoln, president of Green Gables Sanitorium; Thomas Hutchinson Ashton of Syracuse, ex-president of 


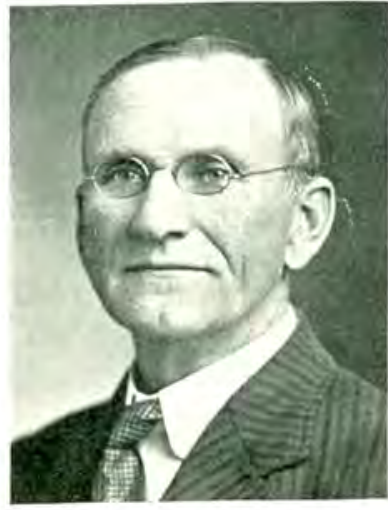

ALEXANDER L. MATTHEWS

the Lnited States Examining Surgeons; Angelo Prentiss Welles of McCook, president for two years of the American Institute for Homeopathy and president in 1905 of the Nebraska society; Nicholas McCabe, mayor of North Platte in 1906; Benjamin F. Gay of Stockville, Pierce County; Alexander L. Matthews, eclectic practitioner at Gallaway, who organized the bank, helped build a roller mill, served on the village and school board and was president of the pension board in Custer County and an unsuccessful candidate for the legislature in 1912.

Bailey was president of the Nebraska State Board of Health for ten years; a former president of the state society and active in all medical circles. He was born in New Hampshire, June 2, 1860, and educated in Boston and at Hahnemann in 1881. Ashton, a Civil War Veteran with a distinguished record was confined to the Johnson Island prison for a time. He served with an Ohio regiment after graduating from Michigan in 1862. Welles, also a Civil War prisoner at Andersonville, attended Rush and Hahnemann Medical Colleges in Chicago, after the war, practicing in Illinois twelve years before he formed a partnership with Dr. B. F. Stutzman in McCook in 1886. Stutzman left McCook the next year. McCabe, born in Ireland in 185-, was made Lincoln County Physician the same year he arrived and served 12 years. He was also coroner and Union Pacific surgeon and made many improvements in the town during his three terms in office.

B. B. Baker of Norfolk, now assistant medical director for the Elkhorn Life Insurance Company, was an interesting arrival in 1886, at Curtis, as physician for a firm of contractors who were building the Burlington high-line from Holdrege to Cheyenne, Wyoming.

"I came to Nebraska as a tuberculosis suspect," wrote Baker, "my trouble having been so diagnosed. But the energy and pep required to deal with the people on a frontier railroad construction job, where the labor employment 
agencies sent anybody they could get on to the road, where many characters, who wanted to escape from the sight of man and the police in particular, for a time sought refuge; eating the working man's diet as furnished in the camps, sleeping in the open, driving a pair of bronchoes to a buggy and over trails and breathing Nebraska ozone, was sufficient to fully restore my health when we completed the road into Cheyenne in November, 1888."

Jonathan J. Evans of Ainsworth, late of Springview, Nebraska, first settled at Norden in 1886, opening a drug store too. He remained five years before moving to Springview. Evans was a graduate of Ohio schools of which state he was a native, born in 1854 .

Harry H. Grosback of Wauneta was the first physician in Chase County in 1886. He is a graduate of the Cincinnati Eclectic school.

Frank Lincoln Wilmeth of Lincoln, active in advancing Eclecticism and the Lincoln Medical School, and in 1913 president of the national Eclectic society, settled in Furnas County in 1887 and taught school there, before he was graduated from the Lincoln Medical School in 1894. He took postgraduate work in Chicago and practiced four years at Eagle, Cass County, before his appointment as superintendent of the college hospital at Lincoln. He was active in the medical center at Cotner as president of the board and dean until 1911 and now conducts a sanitarium known as Esther's Hospital.

Edward F. Dodd located at Saronville in 1887, opening a drug store too, after having studied medicine with Dr. J. P. Norcross in Aurora since 1882 and finishing at St. Louis University. He remained at Saronville only three years, then moved to Newport, where he became a member of the town council, acquired farm lands, started a creamery, lumber yard and even engaged in general merchandise. A son, Dr. Clinton Dodd is a graduate of Creighton, class of 1910 .

With a fine scientific record in England behind him, George James Haslam, surgeon, settled in Fremont, Dodge County in 1889. Born in England in 1858, Haslam was educated at the Universities of Ireland and Manchester, where he won distinction for his superior ability. He was a member of the Royal College of Surgeons and was for two years sectional secretary of the British Association for 
Advancement of Science, beginning in 1883; and received the honorary degree of Bachelor of Science from Victoria University, Manchester. He also spent two years in Zurich. He published a book, "Anatomy of the Frog," issued by the Oxford University Press in 1889 , the year he came to Fremont. Here he became city physician, railroad surgeon and was a member of many societies organized for research.

Peter Harold Salter of Norfolk was an important arrival in 1889, after extensive study abroad. He was the founder with Dr. F. A. Long and Alexander Bear of the Elkhorn Valley Medical Society in 1895, and in 1910 was elected president of the Nebraska State Medical Association. Salter, a Canadian, born Sept 8, 1862, first practiced as surgeon on Clan Line Steamship company between England and India in 1885-1886; then for three years at Fort Hope, Ontario before settling in Norfolk.

Frank E. Coulter was practicing in Waterloo in 1889. Shortly thereafter he moved to Omaha, went into the specialty of neurology, which subject he taught at Creighton and was considered one of the leading psychiatrists in the city until he moved to California in about 1922 . He died in 1927 , in the west.

Everett B. Finney, leading homeopathist in Lincoln, located there in May, 1889 and although he does not affiliate with the local medical societies, is highly regarded as a surgeon by the "regulars." He was born near Weeping Water, May 8, 1867.

John Marshall Neely, who settled in Elmwood in 1889, was the son of a pioneer Indiana physician, Joseph Neely, who later entered the ministry; and was followed in the profession by his son, John Marshall Neely II, now in Lincoln, and a grandson, J. M. Neely III, now a junior in the University of Nebraska Medical School. This makes four generations of Neely physicians, three of them in this state.

The first Neely to practice in Nebraska was born in Indiana in 1835, was graduated from Cincinnati Medical School in 1858 and was surgeon for the 120th Indiana Volunteer Infantry during the Civil War. After the war, he began practice at Owensville, Indiana, where he was married to Ellen Smith and where their son, John M. Neely II, now of Lincoln, was born in 1870. The father continued 
practice here until 1882 when his wife died and the son was sent to live with relatives on a farm near Vincennes. He attended a country school part of each winter, taught school three years, and was graduated from Kentucky Medical School at Louisville in 1896. His father had come west in the 80 s, locating at Elmwood, Nebras$\mathrm{ka}$ in 1889, so the son followed him into this state and located at Alvo in September, 1896. He remained there only until the following spring, May 18, 1897 when his father died and he took up
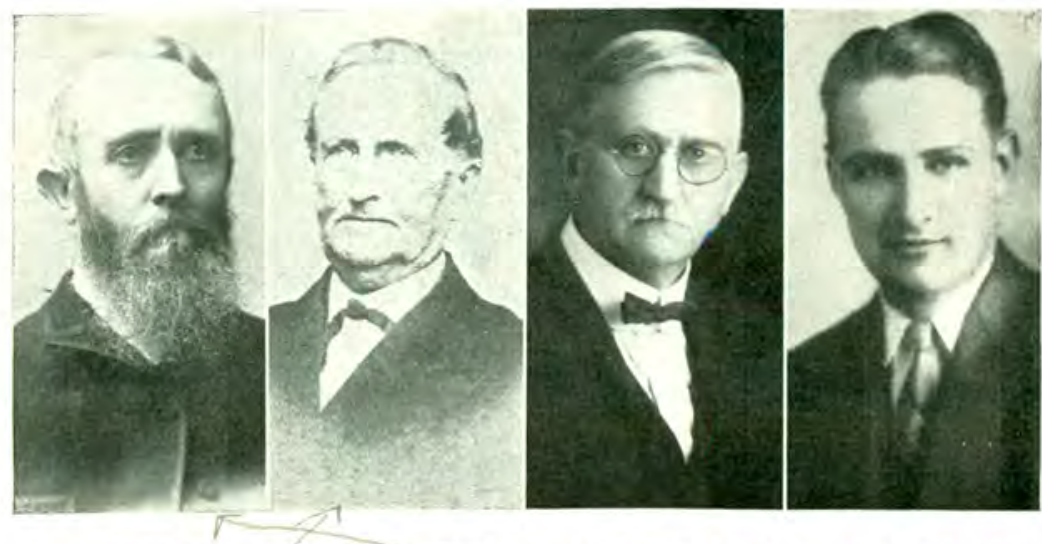

DRS. JOSEPH NEELY, J. M. NEELY I, J. M. NEELY II, J. M. NEELY III

his father's work at Elmwood, remaining there 23 years. In 1919 he moved to Lincoln to afford his six children better educational advantages and has been in general practice there since.

Harry M. Hepperlen of Beatrice came west when a boy, in 1880, from Pennsylvania and settled in Jefferson County. He attended Keokuk in 1891, then Jefferson Medical College and spent the years of 1897-1898 at the University of Vienna. He located at Harbine, Nebraska, in 1891 but on his return from abroad he moved to Beatrice and established the first hospital there. In nine years it grew from 6 to 50 beds. In 1908 the institution was acquired by the United Brethren Church with Hepperlen as chief surgeon. It is now housed in a three story structure, and has a nurses' training school.

Dr. Andrew Johnson, superintendent of the state institution for feeble-minded at Beatrice in 1901, came to America from Sweden in 1870 and settled in Osceola, Polk County, in 1876. He attended 
the Lutheran academy at Wahoo, Augustana College, and was graduated from Omaha Medical School in 1890. He was a member of the Omaha Medical Society, became a Union Pacific surgeon and a member of the National Association of Railroad Surgeons.

George A. Ireland of St. Edward is a native of Nebraska. He was born in Papillion, educated at Peru Normal, the state university and a graduate of Omaha Medical College in 1897. He practiced at Papillion before settling in St. Edward.

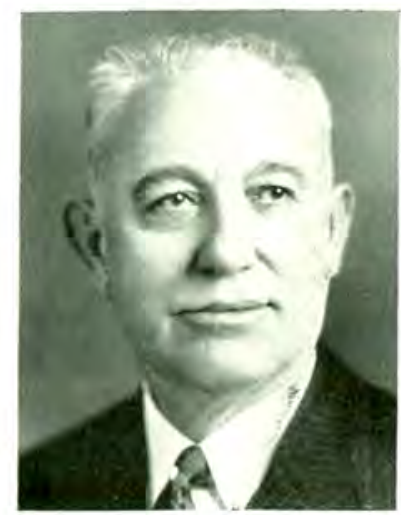

H. M. HEPPERLEN, SR.

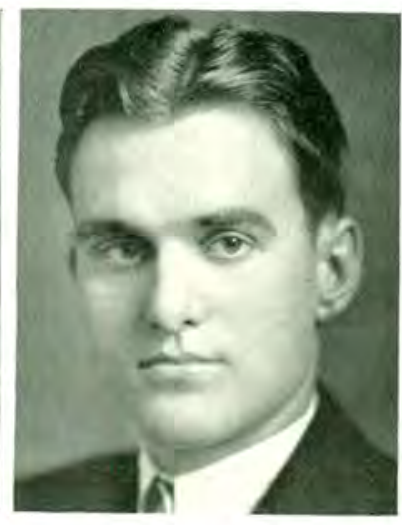

H, M. HEPPERLEN, JR.

Ernest S. Case of Stockville was born in Nebraska City, May 14, 1872, the son of Dr. Sackett C. Case, a native of New York. Mrs. Case was also a practicing physician. The younger Case was graduated from Omaha Medical College in 1895, and was coroner of Frontier County. He was elected to the state legislature in 1909.

James L. Greene, superintendent of the State Insane Hospital at Lincoln in 1901-1907 and formerly assistant at the Norfolk institution, came to University Place in 1890 from Vermont. He is now located in Little Rock, Arkansas.

Albon E. Bartoo of Arcadia, a member of the 1902 legislature, came to Westcott in 1890, a graduate of the University of Buffalo. $\mathrm{He}$ also opened a drug store in Arcadia.

R. R. Loughbridge, later of Lincoln and Milford, settled in Plattsmouth in 1878 when a child of five. He was graduated from 
Cotner Medical College in 1894 and took post graduate work in Chicago and Philadelphia, under Christian Fenger before practicing in Pleasant Dale, near Milford, Seward County. He established the county hospital at Milford in 1900. In recent years he opened an office in Lincoln for the practice of surgery and has been on the staff of the state industrial school at Milford for years. He is a student of history and active in the Nebraska State Historical Society. 


\section{Notes and Errata}

p. 96

p. 99

p. 100

p. 102

p. 103

p. 108

p. 109

p. 111

Schleich Anesthesia and the Stone mask. See Stone, R. M., "Schleich Anesthesia," Proc. Nebr. St. Med. Soc., ThirtyFourth Annual Session, 1902: pp. 206-224.

Bridges, Willson Orton, "Hemolytic Jaundice with Report of Cases,” Nebraska St. M.J., 3:361-369, Dec. 1918.

- "Post-typhoid Periostitis," N. York M. J., 46:492-494, Oct. 9, 1897.

- "Modern Aids to Diagnosis of Diseases of the Stomach," Iowa M.J., 2:9-16, 1896-1897.

- "Digitalis Therapy in Heart Disease," M. Herald and Phys. Therapist, 44:293-296, Dec. 1925.

- "Present Status of Serum and Vaccine Therapy," Med. Herald, 31:1-9, Oct. 1912.

All references to "Creighton," "Creighton College," and "Creighton University" in this book may be assumed to refer to one of the following, depending on the contextual date of the reference:

1892-1908: The John A. Creighton Medical College of the Creighton University.

1909-1926: The Creighton University College of Medicine 1926 to the present: The Creighton University School of Medicine.

Exception: Entries under "Creighton University" in the index actually refer to the University as a whole.

". . during the late war . . " should read ". . .during World War I..."

Byron B. Davis. A complete bibliography is available in the Library of Medicine, University of Nebraska Medical Center.

". . . in the late war..." should read "... in World War I..."

"Elias Holovtchiner, born in Russia in 1880 . . ." should read ". . . born in Russia in 1860 ...."

Crummer, LeRoy, Clinical Features of Heart Disease, New York: Hoeber, 1925. 
First, second and third lines should read " ... in its affairs, and subsequently the University of Nebraska. After graduating from Jefferson Medical College in Philadelphia, and before taking up his practice ..."

McClanahan, Harry M., "The Practice of Medicine Among the Indians," Med. \& Surg. Reporter, 44:338-341, Mar. 19, 1881.

- "Surgery, as Practiced by the Indians," Med. \& Surg. Reporter, 44:458-460, Apr. 23, 1881.

- "Medical Knowledge of the North American Indians," Med. \& Surg. Reporter, 44:539-541, May 14, 1881.

- Pediatrics for the General Practitioner, Philadelphia: Lippincott, 1929.

p. 115 "... on the County Hispital staff here ..." should read "... on the staff of the Douglas County Hospital ..."

p. 116 Langfeld, Millard, Introduction to Infectious and Parasitic Diseases, Philadelphia: Blakiston, 1907.

Findley, Palmer, The Diagnosis of Diseases of Women, Philadelphia: Lea, 1903.

- A Treatise on the Diseases of Women, Philadelphia: Lea, 1913.

p. 117 Portrait labeled "David P. Findley" should read "Thomas P. Findley, Jr."

p. 117 Portrait labeled "Thomas P. Findley, Jr." should read "David P. Findley."

David Findley first used the stethoscope and obstetrical forceps. See Sheldon, A. E., Nebraska: the Land and the People, Vol. 2, Chicago: Lewis, 1931, p. 472.

"Calvin F. Moranville . . . was educated, University of Nebraska, College of Medicine, Lincoln."

“... Benjamin F. Gay of Stockville, Pierce County ..." should read "... Benjamin F. Gay of Stockville, Frontier County..."

p. 127 Portrait labeled "J. M. Neely I" should read "Joseph Neely".

p. 127 Portrait labeled "Dr. Joseph Neely" should read "Dr. J. M. Neely I". 


\section{PHYSICIANS IN POLITICS}

Medical Legislation-State Board of Health-Office-holders

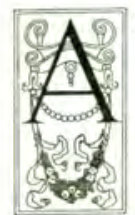

MEN of education, with qualities of leadership, Nebraska physicians have played an important part in the political life and development of the state. At least nine are known to have served in the Territorial Legislature and a large number when statehood was accomplished. That their interest in holding office was civic, not selfish, is evidenced by the fact that practically no medical legislation of benefit to themselves was attempted until 1881. All were imbued with the hope of building up this great, new commonwealth.

Minutes of the state medical society of 1872 reveal that Dr. James H. Peabody, of Omaha, at that early date advocated a state board of health and suggested as an argument to the legislature that it would increase the population of the state.

"Such a state board could give publicity to the healthful conditions of this state and our land offices would be crowded with immigrants," Dr. Peabody declared. Victor H. Coffman of Omaha seconded Peabody's statements.

S. D. Mercer, R. R. Livingston and D. W. Hershey were a committee appointed to gather information on health conditions and their report indicated that the climate of Nebraska was healthful for lungs and skin, that it was free from malaria and that the land had good drainage. The committee was also instructed to learn the effects of the railroad (the Union Pacific had been completed a short time before) on public health. George Tilden of Omaha also extolled the healthful condition of the state. Luther J. Abbott was probably the first to recognize this fact for in the Fremont Tribune in July, 1868, Abbott published an article on dis- 
eases of Nebraska, stating that it was free from phthisis. In 1889 he reported to the state society that pulmonary consumption originating here was unknown

Physicians ran the gamut of political office, as the list appended to this chapter will show. Their services were versatile, too. Hudson J. Winnett of Lincoln served on the state railway commission in 1906, and Philip L. Hall, also of Lincoln and a son-in-lawof Harvey Link, pioneer physician at Millard, was on the state banking board from 1897 to 1901. Hall has written many

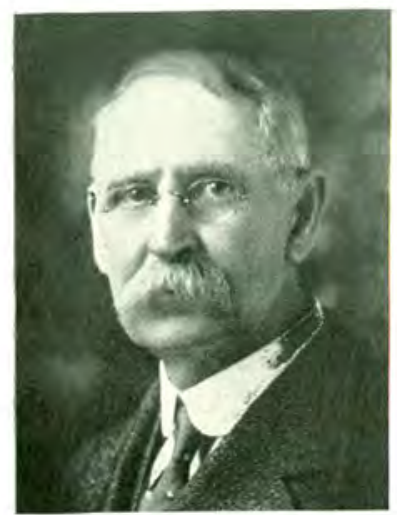

H. J. WINNETT

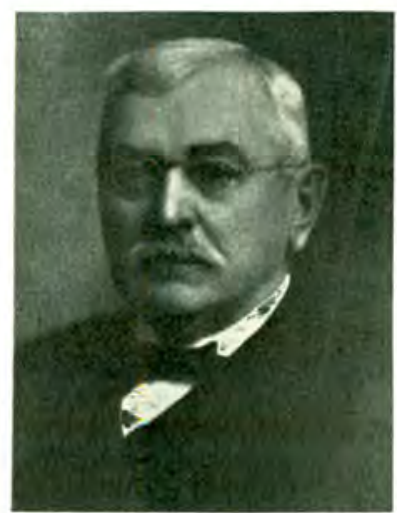

PHILIP L. HALL

articles on banking. James Kerr Ish was county treasurer of Douglas in 1861-3-5 and F. A. Hoffmeister at Imperial in 1898. James E. Hartwell of Crawford was a deputy sheriff in Virginia before locating in this state and Joseph A. Albro is police judge and justice of the peace at Albro. Robert R. Livingston of Plattsmouth was president of the state fish commission and surveyor general of the state while chief surgeon of the Burlington. Postmasters were J. W. Agee of Valley, Thomas J. Chidester of Western, Saline County, Anson L. Root at Eight Mile Grove and Thomas L. Meyers of York in 1869.

Their efforts, however, in behalf of medical legislation, are recorded by William H. Wilson of Lincoln, Chief of the state Bureau of Health, in a recent issue of the Nebraska State Medical Journal. 


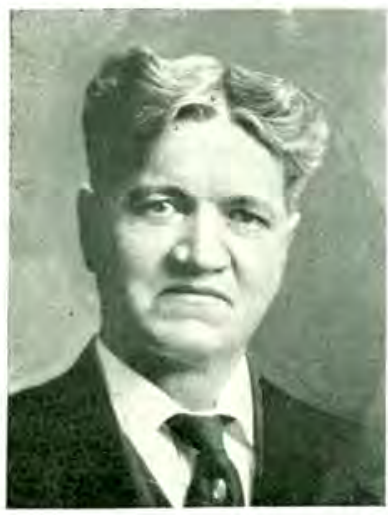

WILLIAM H. WILSON

Wilson formerly practiced medicine at Table Rock, from which district he served in both houses of the legislature and has been actively identified with public health in this state for the past 25 years. He served on the state board of health for 16 years, as health inspector, state epidemiologist, on the special committee which drafted the pure food and drug act in 1907; promoted the vital statistics law and has worked in season and out to raise the standards of medical practice, to reorganize town and county boards of health and to give the state board sweeping powers in sanitation and quarantine.

"From the time Nebraska was organized as a territory up to the time it was fourteen years old as a state it had no medical laws of any kind," Wilson relates in the January, 1923, number of the State Medical Journal. "Any one who had the nerve could call himself 'doctor' and prey upon the credulity of the sick and afflicted. There were many so engaged in the state. With legislation in the older states driving out the quacks and charlatans, naturally $\mathrm{Ne}$ braska got her full share of them, so that the state would soon have been overrun with quacks and charlatans plying the healing art, had a barrier not been raised. The medical profession of the state at that time called public attention to this danger. It prepared a bill to meet the conditions and went to the legislature in 1881 and the measure was enacted into law." It disqualified 14 per cent of the "doctors" practicing then, according to J. V. Beghtol, first president of the board.

"This first law regulating the practice of medicine providedFirst, that all persons holding a diploma from a legally chartered medical school could register this diploma with the county clerk, and receive a certificate to practice; Second-all comers thereafter were required to have a diploma; Third - anyone having attended one course of lectures in a chartered medical college and having practiced in the state three years could register and receive a cer- 
tificate: Fourth - those who had been engaged in practice for a living continuously for ten years, the last two having been in this state, could register. This law may now seem rather crude, but for the times was a good beginning and made a foundation on which to build.

"Ten years elapsed before additional legislation was enacted. Then the profession decided that for the public good and the interest of professional advancement, the state should have a state board of health and the standards of practice be raised. A measure to this end was presented to the legislature and secured enactment into law in 1891. It provided for a state board of health composed of the governor, attorney general, and superintendent of public instruction. Owing to the provisions of the constitution, it had to be composed of state officers. It provided that the board should appoint four medical men of at least seven years practice, to be known as secretaries, to act for the board and in reality to be the de facto board of health. Two of such secretaries were required to be of the regular school of practice, one of the eclectic and one of the homeopathic schools. The law repealed the practice of 1881 and provided that all newcomers must possess a diploma from a legally chartered medical college requiring three terms of lectures of nine months each, and submit their credentials to be passed upon by the secretaries of the State Board of Health.

"Again in 1897 the profession went to the legislature and asked to have its qualifications raised still higher by requiring applicants for a license to practice, to hold a diploma from a medical college of standing, requiring a four-year graded course of nine months each. The request was granted and the law was amended.

"In 1899 the osteopaths made a strong plea to the legislature to pass a bill legalizing them to practice, but the medical profession, in what it believed the interests of the public, was able to convince the lawmakers that the bill should not be passed. Two years later the effort was again made with greatly renewed vigor. The medical profession made a gallant stand against the bill in the interests of the public weal and scientific medicine, but the bill was enacted into law. The law limited the practice, as was requested by the osteopaths, to a drugless healing. It required the applicant for license to practice to hold a diploma from a legally chartered osteo- 
pathic school. This and other credentials were required to be submitted to the state board of health to receive a certificate for practice."

Is early as 1902 the medical profession took cognizance of the fact that medical colleges having become so numerous and competition for students so great, there was a tendency of some schools to

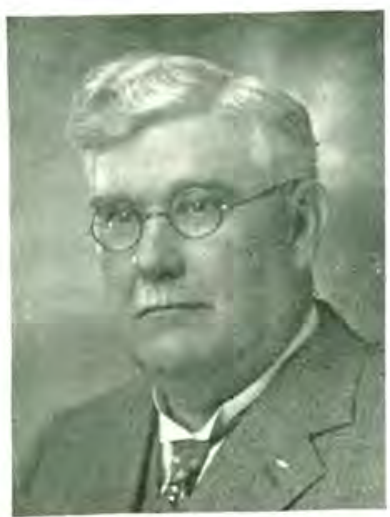

DR. E. T. M'GUIRE graduate students who were rather poorly qualified. To meet this contingency representatives of the profession through IV. H. Wilson, then a member of the house of representatives, drafted a bill creating the state board of health and examining board, thereby assuring the public of higher qualifications in its practitioners. At that session, Wilson also put a bill through both house and senate to form a more uniform standard of qualification for all who were engaged in the healing art, exempting drugless healers from qualifying in materia medica and surgery, but this bill was vetoed by the governor. A bill was also passed giving the state board of health sweeping powers in the matter of quarantine and sanitation throughout the state, and providing for the appointment of a state health inspector. That was an important step in preventive medicine.

In 1905 Wilson, again a member of the house, at the instance of the state board of health and representatives of the profession, put through a bill creating the state board of health registrar of vital statistics, and as a result of that act a movement was started which eventually put Nebraska in the United States registration area. Aside from its record and commercial value to the laity, it was an important step toward laying the foundation for scientific preventive medicine.

In 1907 the osteopaths made a powerful effort to have the legislature grant them a state board of their own. The state board of health and leading members of the medical profession just as strenuously opposed the passage of the measure. Wilson, at that time 
a member of the state senate, led the fight against the passage of the measure. The osteopathic leaders came to him and offered to compromise and stop the fight if they were given representation on the state board of health. The senator believed it wise to accept and so advised other medical workers, arguing that while the bill could be defeated, it only meant postponement, as the fight would undoubtedly be made at a later session, and probably with success. The advice did not meet with favor, the fight was made, and the bill killed. Two years later the effort was on again, the same compromise offered, the same advice given, and again refused by the other workers, and at that time all workers had the disadvantage of having to work from the outside, with the result that the osteopaths won and got their separate board.

"It seems to me even at this late date that a mistake was made in not accepting the proferred compromise, and holding the control of medical practice under one board," Wilson believes.

"In 1911 and again in 1913 the chiropractors made vigorous efforts to have the legislature legalize their practice, but representative members of the medical profession were able to convince lawmakers that the theory of disease entertained by the cult was erroneous and that they were wholly unqualified to be entrusted with the health of the people. In 1915 the chiropractors were again in evidence with their bill for legalization, armed with seemingly ample funds to pay skilled lobbyists. Their bill was enacted into law notwithstanding vigorous efforts made by the medical profession, but the bill was materially amended, so that when passed it required the attendance at a chiropractic school requiring three years of nine months each. It is a question if this improves the quality much, but it does lessen the quantity.

"In 1916 Dr. E. W". Rowe, then president of the State Medical Association, inaugurated a movement for the creation of a real state health department, which movement was endorsed quite generally by members of the profession. The governor was appealed to and he requested the United States Public Health Service to send a man to make a survey of the state. Dr. Carrol Fox from the Public Health service was sent and put in two months in such survey. He submitted plans and recommendations. Using his recommendations as a basis, a bill was drafted providing for 
a very complete and modern health department, and continuing without material change the medical examining board. At a legislative session of 1917 this measure was submitted to the legislature, and after energetic efforts on the part of the medical profession, enacted into law. The legislative session of 1919 carried over into the Department of Public Welfare, under the code law, all laws bearing on medicine and public health. During that session the osteopaths had their law rewritten and materially liberalized from a law providing for drugless and manipulating practice exclusively to one which permits the use of certain drugs and the practice of surgery. To a candid mind it may seem difficult to make excuse for the continuation of a separate law and board for a practice which permits almost everything in which the profession engages."

The most recent and important piece of medical legislation promoted by Nebraska physicians was the passage of the Basic Science law of 1927. This places Nebraska in the vanguard, as only three other states in the Union now have this law. It provides that all who wish to be licensed to practice the healing art must pass an examination in the basic sciences, viz: chemistry, physiology, anatomy, bacteriology, pathology and hygiene. Provision is also made for the annual registration of all practitioners.

In addition to Dr. Wilson's very complete history of medical legislation, several minor additions can here be noted. The Medical Practice act of 1891 to 1897 was amended in 1909, taking the appointive power from the constitutional board of health and vesting it exclusively in the governor. Again in 1911, the Act was amended by the legislature, on the request of the medical profession, to again raise the standards of the medical colleges and providing for inspection of the same by the state board of health. This act served a few years later to eliminate poorly equipped medical schools, according to Dr. Wilson.

In 1913, the legislature passed an act creating a laboratory for the state board of health.

In addition to their efforts to raise the medical standards of the state by adequate legislation, Nebraska physicians have tried their political mettle in securing appropriations from the legislature to finance the Nebraska University College of Medicine and University Hospital; for the state orthopedic hospital, school for the 
blind, insane asylums and other state institutions; and the Nebras$\mathrm{ka}$ State Medical Association maintains a medical defense committee, mentioned in the Chapter on Organizations. Roy W. Fouts of Omaha is the present chairman.

\section{State Board of Health}

The first law creating a State Board of Health in Nebraska was passed by the legislature, March 27, 1891, and became operative August 1. There being no constitutional provision for such a body, this difficulty was overcome by creating a board of health out of state officers already provided for by constitution, or by a statutory act.

The State Board of Health (proper) consists of three members, the governor, attorney general and superintendent of public instruction, who are ex-officio members; four secretaries, who are the active members and are appointed from three schools of medicine, for a term of four years. Two of them are regulars, one a homeopath, and one an eclectic.

The first board of secretaries consisted of James Vance Beghtol, regular, of Friend, Nebraska; Charles F. Stewart of Auburn, eclectic; Frederick E. Haldeman, regular, of Ord, now of Berkeley, California; Edmund Turney Allen, homeopath, of Omaha, who issued to themselves the first certificates, August 13, 1891. Beghtol was named president. Governor John M. Thayer; A. K. Goudy, superintendent of instruction and Geo. H. Hastings, Attorney-General, were the other members.

Any person is regarded as practicing medicine who shall operate or profess to heal or prescribe for or otherwise treat ailments of another. The exceptions to this act of the legislature are gratuitous service in case of emergency, administration of ordinary household remedies, and does not apply to commissioned surgeons in the U. S. Army or Navy, nor to nurses engaged in their legitimate occupations.

The records show that by December 1, 1892, 16 months later, 1,445 physicians were granted certificates, entitling them to practice in this state. Of this number, 1,029 were so-called "regulars"; 127 eclectics; 127 homeopaths and 159 were unclassified. More 
than 50 were women. A total of 1,284 were graduates of medical colleges and 158 were found to be entitled to certificates, having registered under the law of 1881 and 1883. Three negro physicians were licensed.

Approximately 2.000 physicians are today licensed to practice in Nebraska.

As first appointed, the state board of health was merely a licensing board but had no sanitary powers. Since then, all its present power and scope have been added by successive legislatures.

James $\mathrm{V}$. Beghtol, the first president, recently celebrated his 50 th year in the practice of medicine. He was born in Illinois in 1851; graduated from Keokuk in 1877 and practiced in Iowa, before he settled in Nebraska, at Friend, Sa-

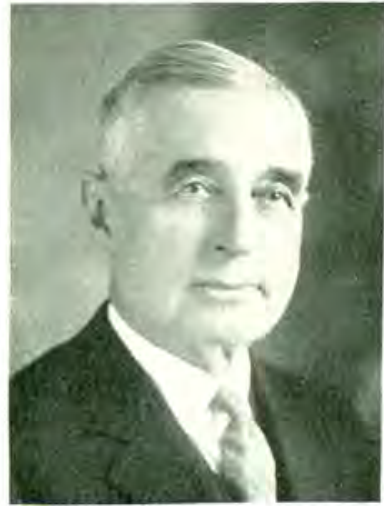

JAMES V. BEGHTOI, line County, in 1884. After 18 years at Friend, he moved to Hastings where he has lived for 25 years, and is at present the oldest active practitioner, specializing in medico-legal work.

"One thing Ive learned and that is to treat the patient, not the disease," Beghtol declared at the testimonial dinner given in his honor on his golden anniversary.

He is on the staff of several railroads, was city physician of Hastings, a medical advisor in the late war and contract surgeon to students at Hastings College. Beghtol holds certificate No. 1 among Nebraska doctors, having issued the first license to himself as president of the state board in 1891. He was president of the Adams County and Republican Valley medical associations.

Benjamin F. Bailey, who served twelve years on the state board, part of his time as president, is now head of the public policy and legislation committee of the state medical association, of which he is also an ex-president. During his term with the state board, Bailey often adopted heroic measures to enforce the regulations on 
quarantine. During one of the smallpox epidemics when small towns along the Burlington road neglected to fulfill the disease prevention regulations, Bailey went to the head official of the railroad and influenced him to issue an order that Burlington trains would refuse to stop at these towns, unless

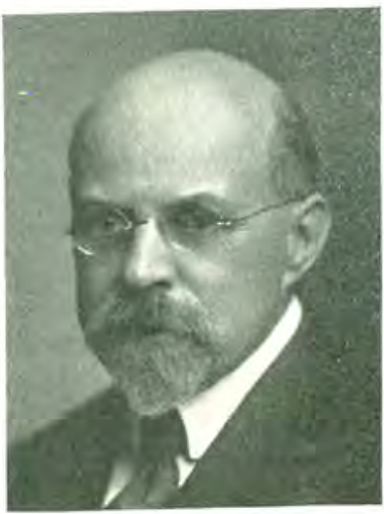

BENJAMIN F. BAILEY all health regulations were carried out. Bailey was also influential in retaining the services of S. R. Towne as health inspector, during Governor Dietrich's regime.

Bailey's civic interests are many and varied in addition to his professional life which is bound up in Green Gables Sanitarium, mentioned in the Chapter on Hospitals. He is on the Lincoln School Board, was president of the Lincoln Chamber of Commerce, president of the Sons of the American Revolution and is active in the Red Cross, Boy Scout and Rotary organizations. He came to Lincoln in 1886 from Littleton, New Hampshire, where he was born in 1860. He practiced in New England for several years before ill health caused his removal to the west. He was at first identified

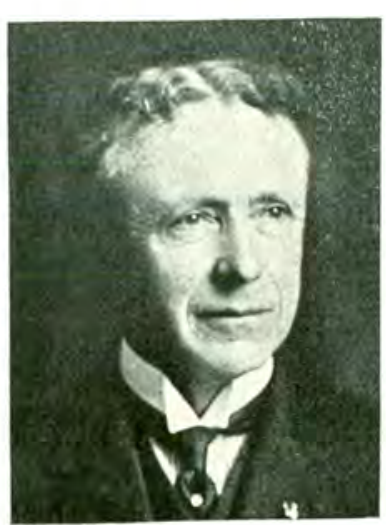

DR. OLE GROTHAN with the homeopathic school of medicine, but is now a regular.

On the first board besides J. V. Beghtol, were C. F. Stewart, E. T. Allen and F. D. Haldeman. All continued in office from 1891 until 1904, when O. S. Wood of Omaha replaced Allen. The next year, B. F. Bailey was appointed to succeed Beghtol; Ole Grothan of St. Paul, for Haldeman and H. B. Cummins of Seward, for Stewart. When Grothan enlisted in the Spanish-American War and was sent to Cuba in 1899,

George H. Brash of Beatrice was appointed to serve in his place. 


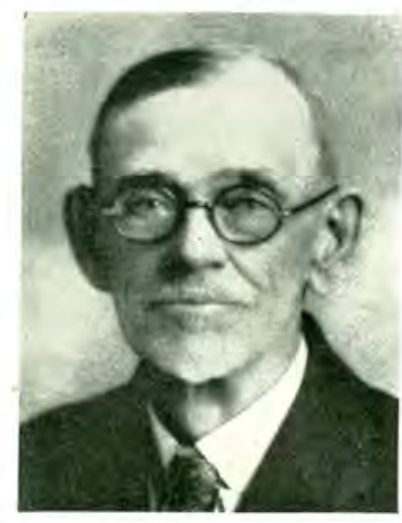

S. R. TOWNE

Two high points of interest in the board's history during the above period was in 1893 when the board denied recognition to Cotner Medical College because of the absence of hospital and clinical facilities, engaging in a hot fight with Lincoln Eclectics; and in 1899, when strong measures were advocated to control a smallpox epidemic in the state. S. R. Towne of Omaha was named health inspector, the first one to so serve.

Towne, a Dartmouth graduate of the class of 1875 , instituted the control of contagious diseases while health officer of Omaha in 1892 and continued his work as state health official later. He instituted the state quarantine law, also the census of births and deaths, during the years 1898-1899.

W. T. Johnson of Pawnee City replaced Cummins in 1901 and A. B. Somers served in place of Grothan. The next year the U. S. Marine Service sent C. P. Wertenbaker to help the state board of health combat the smallpox epidemic. Dr. Wertenbaker was at-

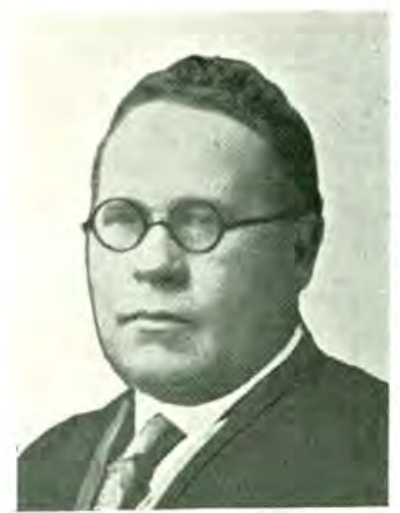

J. D. CASE tached to Governor Savages' staff. S. R. Towne was given formal appointment of state health inspector in 1903, and was succeeded in later years in this post by S. K. Spalding of Omaha; W. H. Wilson of Table Rock, now chief of the state Board of Health in 1907 and J. D. Case in 1915 .

Ernest J. C. Sward of Oakland was made one of the state board secretaries in 1905, after a spirited contest between Robert McConaughy of York, J. A. Andrews of Holdrege and himself, which necessitated three meetings and the casting of about 200 ballots before he was named. Two years later, S. F. Ashby of Fairmont was selected to succeed B. F. Bailey, who 
served more than ten years. In 1909, A. L. Muirhead of Omaha was named for Brash. The latter died in 1924, after 30 years' practice in Nebraska. The year 1909 was the year that the law was passed, requiring a board of nurse secretaries, and the Misses Anna E. Hardwick of Lincoln, formerly of the New York Orthopedic Hospital; Catherine Wollgast of University Place and Victoria Anderson of Omaha were appoint-

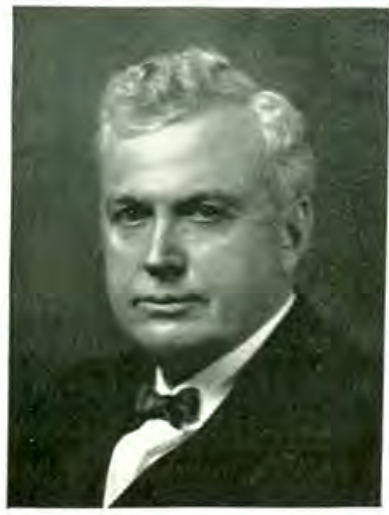

C. P. FALL ed. The 1911 members of the state board were P. F. Dodson of Wilber, $\mathrm{H}$. B. Cummins of Seward, C. T. Burchard of Falls City and E. Arthur Carr of Lincoln. C. P. Fall served at one time for Burchard in 1913. Carr was president of the board in 1914, with C. T. Burchard and Cummins. The next year Burchard was president, Carr, vice-president; Cummins, secretary and Lucian Stark of Hartington, now of Norfolk, as treasurer. Stark succeeded Dodson.

In 1916 a bill was passed to reorganize the health department, the bill legislating out of office the men then in the posts. The newly commissioned board met with C. T. Burchard, the outgoing president, in 1917, and organized as follows: W. P. Johnson of Pawnee City, President; C. L. Mullins of Broken Bow, vice-president: J. E. Spatz of Fairfield, treasurer and J. J. Hompes of Lincoln, secretary. This was the year war was declared and the state engaged L. D. Bristol of Boston as special public health officer. Bristol never appeared, whereupon E. S. Tenney, another Harvard University man was appointed in his place. William F. Wild later served.

A government health officer, S. J. Crumbine was assigned to Nebraska during 1918, in the interest of venereal disease prevention.

Still another reorganization of the health board took place on November 13, 1919 under the Code Bill, when the department of Public Welfare came into existence, providing for three secretaries on the state board instead of four. The officers were J. E. Spatz, president; E. T .McGuire, vice-president and H. 
J. Lehnhoff of Lincoln, secretary-treasurer. The same board is,

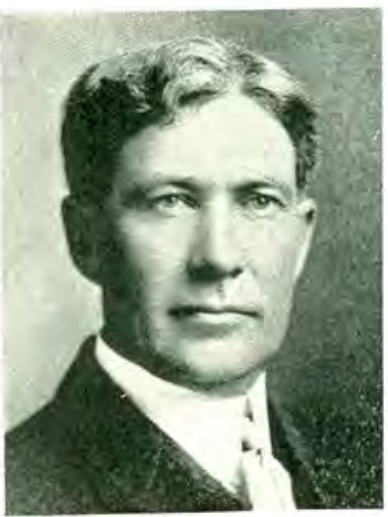

H. J. LEHNHOFF still serving, with the exception of a period during 1925 when Lehnhoff was ill and E. W. Rowe acted in his place. Rowe is a member of the Lincoln School Board and ex-president of the Lancaster county medical society. Lehnhoff was state president in 1926.

To complete the record of the n u rse board secretaries, when the first board resigned after a year's service, the following trio were named in 1910 to serve in their place: Misses Nan Dorsey of Omaha, Lillian B. Stuff and Bessie Bixby of Lincoln. The next year Miss Ellen Stewart of Omaha was named president of the nurses board. Gertrude Reid Smith was appointed in 1913 and Katherine Wollgast of Lincoln in 1917 but Miss Wollgast declined and Miss Margaret McGreevy was named in her place. In 1918 appointees were Misses Marie Weich, Huldah Anderson and Louise Brockhan of Omaha, the latter to succeed Gertrude Smith; and Elsa Boyd of North Platte to succeed M.R. Swan.

In line with this effort to raise the standard of nursing education, the post of director of nursing education was created in 1927 and Miss Phoebe M. Kandel of Canton, Ohio named for the office. Nebraska is the fourteenth state to establish this position. maintenance of which is made possible by a voluntary increase on the annual fees of registered nurses from $\$ 1.00$ to $\$ 2.00$. It therefore imposes no cost on taxpayers. The director is under supervision of the department of public welfare. She will act in an advisory capacity with the superintendents of the 27 accredited schools of nursing in this state, five of which are affiliated with universities or colleges. These are Nebraska University Hospital; St. Joseph's, affiliated with Creighton; Bryan Memorial at Lincoln, with Nebraska Wesleyan University; Mary Lanning Hospital at Hastings, with Hastings College and Methodist Episcopal Hospital in Omaha, with Wesleyan University. 
A state committee on nursing, aimed to improve nursing standards in Nebraska, and whose services will be voluntary, since the health department has no funds from which to pay them, was announced in May, 1928 by Judge Lincoln Frost, secretary of the state department of public welfare. Members of the committee, who will work with Miss Phoebe M. Kandel, the new director of nursing education, are: Miss Florence McCabe, Omaha, president of the Nebraska State Association of Graduate Nurses; Miss Lulu Abbott, Lincoln, president of the Nebraska State League of Nursing Education; Miss Harriet Patterson, Seward, president of the Nebraska Public Health Association: Miss Hazel Tubbs, Lincoln, president of the Nebraska Private Duty Nursing Association; Rev. Emil G. Chinlund, president of the Nebraska Hospital Association; Father Bernard L. Sellmeyed, Omaha, director, Creighton Memorial School of Nursing: Miss Charlotte Burgess, Omaha, University Hospital: Harvey L. Freeland, Lincoln, bureau of vocational education, and Dr. E. W. Rowe, Lincoln.

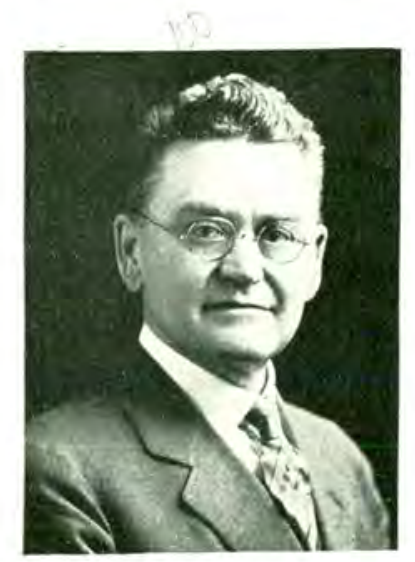

DR, F. W. PLEHN

The state board of health has fostered many needed reforms and added many functions since the early years of 1900, largely through the efforts of Wilson, who is now chief of the Bureau of Health. This Bureau, which is included in the Department of Public Welfare under the Code Bill, has four divisions: venereal disease, vital statistics, child hygiene and laboratories. There is also a child welfare and examining boards department. William $\mathrm{R}$. Boyer of Pawnee City was added to the medical examining board in January, replacing Spatz of Fairfield and Lulu Abbott of Lincoln, to the nursing board.

F. W. Plehn of Scottsbluff served on the Kansas State Board of Health before moving to Nebraska.

\section{State Department of Health and Welfare}

Judge Lincoln A. Frost, Secretary. 


\section{Bureau of Health}

W. H. Wilson, Chief, State House, Lincoln.

Divisions:

Venereal Diseases-P. H. Bartholomew, Director.

Vital Statistics-Miss Hattie M. Summers, State Registrar and Director.

Laboratories - Mr. L. O. Vose, Director.

Child Hygiene-Miss Louise Murphy, Director.

\section{Bureau of Examining Boards}

Mrs. Clark Perkins, Director, Lincoln.

E. T. McGuire, President, Mead; E. W. Rowe of Lincoln, Secretary.

\section{Omaha Board of Health}

Functioning in the metropolis of the state, the Omaha Health Department is an important adjunct to the city government. While his name does not appear on the list of Omaha health commissioners furnished by A. S. Pinto, present incumbent, it is known that George L. Miller, the first physician of Omaha, busied himself in public city health matters as early as 1855 , one year after the city was laid out.

A. Chapel, named health officer in 1857 is the first whose name is recorded officially. Others are as follows:

\begin{tabular}{|c|c|}
\hline 858 & J. P. Peck \\
\hline 361 & Geo. L. Miller \\
\hline $862-1863$ & Augustus Roeder \\
\hline $1864 \ldots . .$. & G. C. Monell \\
\hline $1865-1866$ & J. R. Conkling \\
\hline $\begin{array}{l}1867 \text {.... } \\
\text { and }\end{array}$ & $\begin{array}{l}\text { A. Roeder resigned Mar. 20, } 1867 \\
\text { was appointed. }\end{array}$ \\
\hline $1868-1870$ & J. C. Denise \\
\hline $1875-1878$ & R. C. Moore \\
\hline $1879-1886$ & Peter S. Leisenring \\
\hline $887-1889$ & J. B. Ralph \\
\hline $1890-1891$ & Clark Gapen \\
\hline
\end{tabular}


1892-1893

A. B. Somers

1894-1895

J. J. Saville

1896

J. W. Blythin and

S. K. Spalding at election on April 20, 1897.

1898-1899

S. K. Spalding

1900

Victor H. Coffman

1903

John B. Ralph

1906-1915

R. W. Connell

1916-1919

E. T. Manning

1919-1921

J. F. Edwards

1921 to date

A. S. Pinto

Edgar L. Holyoke was city physician in Lincoln from 1889 to 1903 .

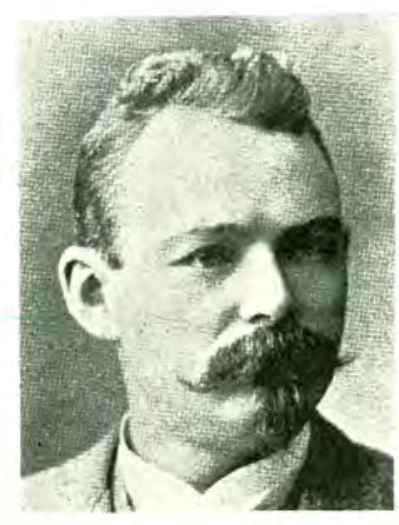

CLARK GAPEN

Clark Gapen, appointed city physician by Mayor Cushing, was an interesting arrival of 1889 , having combined the study of law with the practice of medicine. A Virginian by birth, he was graduated from the Chicago Medical College in 1875 and practiced in Cook County for more than ten years. He was professor of medical Jurisprudence at the University of Wisconsin for a time and served as special attorney in the celebrated Carter divorce suit in Chicago and the King murder trial in Omaha, when the head of the Browning-King Company was shot down by a cast-off sweetheart. Gapen was active in the Omaha Medical Society, organized in 1890 .

In addition to these health officers, a list of early coroners includes the names of:

E. Dallow

Emerson S. Seymour 1860-1862

J. R. Conkling. 1865

C. H. Pinney 1867

Jacob Gish 1869

J. R. Conkling 
Jacob Gish

Joseph Neville

J. C. Jacobs

The first diphtheria anti-toxin in Omaha is said to have been inoculated by Doctors J. J. Saville and S. K. Spalding, Omaha city health commissioners. The first ambulance was purchased by the city in 1899 . Water supply, garbage removal, sanitary plumbing, disease prevention and quarantine restrictions as well as generaf sanitation and the collection of vital statistics is in the province of the city health department.

\section{County Health Officers}

\section{County}

Adams-E. B. Hamel. Address

Hastings

Antelope-Gordon Fletcher. Orchard

Arthur-

Banner-

Blaine-R. J. Williams,

Boone-J. E. Davis,

Box Butte-C. E. Slagle,

Boyd-J. R Beatty,

Brown-G. W. Lambley

Buffalo-J. W. Laughlin.

Burt-Harry W. Benson,

Butler-C. E. Palmer,

Cass-J. W. Brendel,

Cedar-F. P. Dorsey,

Chase-George Hofimeister, Imperial

Cherry-A. N. Compton, Valentine

Cheyenne-R. E. Roche,

Clay-J. O. Latta,

Sidney

Colfax-P. H. McGowan,

Cuming-J. J. Kiefer,

Clay Center

Schuyler

Westpoint

Custer-Theo. Koefoot, Broken Bow

Dakota-C. H. Maxwell, Dakota City

Dawes-George W. Demmer, Chadron

Dawson-

Deuel-D. E. O'Connor,

Dixon-J. M. O'Connell,

Dodge-S. A. Preston,

Douglas-Lee Van Camp,

Dundy-J. F. Premer,

Fillmore-J. Bixby,

Chappell

Ponca

Fremont

Omaha

Benkelman

Geneva

Franklin-M. L. Sparks, Bloomington

Frontier-E. S. Case,
County

Address

Furnas-

Gage-G. L. Roe,

Garden-G. H. Morris,

Beatrice

Oshkosh

Garfield-E. D. Thurston, Burwell

Gosper-George Clark, Elwood

Grant-William Howell, Hyannis

Greeley-J. L. Brannen, Greeley

Hall-L. Phelan,

Grand Island

Hamilton-E. A. Steenburg, Aurora

Harlan-W, C. Bartlett, Alma

Hayes-

Hitchcock-A. H. Thomas, Trenton

Holt-J. P. Gilligan, O'Neill

Hooker-D. A. Walker, Mullen

Howard-E. C. Hanisch, St. Paul

Jefferson-H. E. Potter, Fairbury

Johnson-G. J. Rubelman, Tecumseh

Kearney-H. S. Andrews, Minden

Keith-H. A. Vandiver, Ogallala

Keyapaha-W. D. Lear, Springview

Kimball-E. L. Rolph, Kimball

Knox-W. H. Britt, Creighton

Lancaster-R. H. Sawyer, Lincoln

Lincoln-G. B. Dent, North Platte

Logan-H. W. Hubbell, Gandy

Loup-

Madison-Edward L. Brush, Norfolk McPherson-Harriet McGraw, Tryon Merrick-J. Hutchison, Central City Morrill-C. Palmer,

Nance-F. W. Johnson, Fullerton

Nemaha-B. F Lorance, Auburn 
County

Address

Nuckolls-V. A. Thomas, Nelson Otoe-C. P. Crudup, Nebraska City Pawnee-Paul J. Flory, Pawnee City Perkins-F. M. Bell, Phelps-Paige Palmer, Pierce-F. G. Salter, Platte-A. A. Bald, Polk-L. M. Shaw,

Grant Holdrege Pierce Platte Center Osceola

Redwillow-

Richardson-Wm. Boose, Falls City Rock-C. H. Root, Saline-R. C. Panter, Sarpy-O. H. Margaret, Saunders-Frank Tornholm, Seward-H. D. Clarke,

\section{County}

Address

Scottsbluff-N. H. Rasmussen,

Scottsbluff

Sheridan-

Sherman-A. E. Wanek, Loup City Sioux $-W, H$. Priest, Harrison

Stanton-O. C. Hopper, Stanton Thayer-Arthur Bowles, Hebron Thomas-J. L. Pennington, Thedford Thurston-John Buis, Pender Valley-C. C. Shepard, Ord Washington-G. A. Langstaff, Blair Wayne-C. I. Ingham, Wayne Webster-Robert Damerell, Red Cloud Wheeler-S. A. Osheroff, Ericson York-J. C. McKinley, York

Health Officers in Cities of 2,500

Population and Over.

$\begin{array}{lrlr}\begin{array}{l}\text { Alliance, } \\ \text { Auburn, } \\ \text { Aurora, } \\ \text { Beatrice, }\end{array} & \text { Geo. J. Hand } & \begin{array}{l}\text { Holdrege, } \\ \text { Kearney, }\end{array} & \begin{array}{r}\text { Wm. Robertson } \\ \text { Henry Farrell }\end{array} \\ \text { Blair, } & \text { Roy C. Noble } & \text { McCook, } & \text { Chauncey F. Chapman } \\ \text { Broken Bow, } & \text { G. A. Langstaff } & \text { Norfolk, } & \text { R. R. Reed } \\ \text { Columbus, } & \text { W. E. Talbot } & \text { North Platte, } & \text { J. B. Redfield } \\ \text { Fairbury, } & \text { E. Koekke } & \text { Omaha, } & \text { A. S. Pinto } \\ \text { Falls City, } & \text { T. J. Andrews } & \text { Plattsmouth, } & \text { E. G. Dovey } \\ \text { Fremont, } & \text { E. R. Hayes } & \text { Schuyler, } & \text { P. H. McGowan } \\ \text { Gering, } & \text { Grant Reeder } & \text { Sidney, } & \text { R. E. Roche } \\ \text { Grand Island, } & \text { W. E. Shike } & \text { Superior, } & \\ \text { Hastings, } & \text { F. D. Ryder } & \text { University Place, } & \text { Roy Crook } \\ & \text { J. V. Beghtol } & \text { Wymore, } & \text { Francis Elias } \\ & & \text { York, } & \text { J. N. Plumb }\end{array}$

F. A. Sedlacek of Omaha, assistant health commissioner.

Millard Langfeld, city bacteriologist.

TERRITORIAL LEGISLATURE

George L. Miller of Omaha, four years; president of Territorial Council in 1857; secretary in 1855.

W. R. Thrall of Omaha, acting president of Council, 1857-1858; later U. S. Marshal at Cincinnati.

J. H. Seymour of Omaha in 1857.

Augustus Roeder of Omaha in 1857.

E. A. Donelan of Plattsmouth, president of council in 1859. 
J. H. Seymour of Omaha in 1861.

Napoleon B. Larsh of Nebraska City in 1861-1862.

Harvey Link of Millard, 1866.

Luther J. Abbott of Irvington, 1866.

STATE LEGISLATURE.

According to the 1915 Blue Book of the Nebraska Legislature, there were 62 physicians serving in the legislature between the years of 1875 to 1913 . The largest number, seven served in the year 1907; there were six in 1897 and five in 1877. A complete roster of these physicians would be hard to assemble today as the occupation of legislators is not listed in the records, for each year but some of the outstanding names are enumerated below. Some served in both houses. N. B. Larsh of Nebraska City served in the Senate in 1872-1873 and Aurelius Bowen of the same town supplanted him in 1873-1874. Alexander Bear of Norfolk served in both houses, in the legislature in 1870; senate, 1875 and thereafter. George W. Collins was in the legislature in 1870 and was elected speaker of the house in 1871. John Ahmanson of Omaha served in the late '70's. Servetus V. Moore of York was in the lower house from 1876 to 1880 .

The record for the ' 80 's includes J. R. Buffington of Liberty, J. W. Thomas of Weeping Water and Hiram L. Smith of Geneva in the senate in 1885; and S. W. McGrew of Auburn, George F. Keiper of Pierce, both houses, and Charles C. Gafford of Wymore, for 1887.

C. W. Baldwin of Elkhorn was in the lower house in 1896 and A. H. Sowers of Adams and Ole Grothan of St. Paul in the senate in 1897. J. E. Hathron of Bartley, D. S. Woodard of Aurora and M. T. Zellers of Hooper were in the house in 1899.

The records for 1901-1902 show in the senate, H. B. Cummins of Seward; G. W. Meredith of Ashland and A. E. Bartoo of Acadia; in the house, J. A. Andrews of Eustis, W. Y. R. Gawne of Central City and J. E. Hathorn of Bartley. James M. Alden of Pierce in 1903; John P. Gilligan of O'Neill in the 1905 senate; J. Martin Talcott of Crofton in both houses, 1909 and 1910; Ernest S. Case of Stockville in 1909; Fred A. Hoffmeister of Imperial in 1912 and Charles W. Doty of Beaver Crossing in 1916-1917. Daniel S. Woodard of Aurora served two terms in the legislatude in this period 


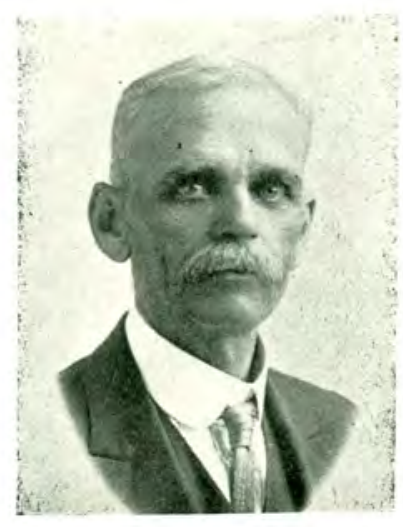

ANDREW J. JENISON

and William H. Wilson, formerly of Table Rock, now chief of the bureau of health at Lincoln, served in both houses. Porter F. Dodson of Wilber was also a solon about the same period, as was John Charles Malster of Stromsburg and Andrew Jenison of Harvard. Emory I. Whitehead of Alliance served in the 1923 legislature. George W. Collins was chairman of three republican state conventions as well.

R. C. Talbot of Broken Bow, Custer County, was county treasurer two terms, beginning 1884 .

Edwin W. Cook, Plattsmouth, city treasurer.

\section{MAYORS}

Dr. Heath of Florence in 1857.

James Luther H. Gandy of Humboldt in 1879 , second mayor.

A. S. von Mansfelde of Ashland in 1894.

Alexander Bear of Norfolk in 1896.

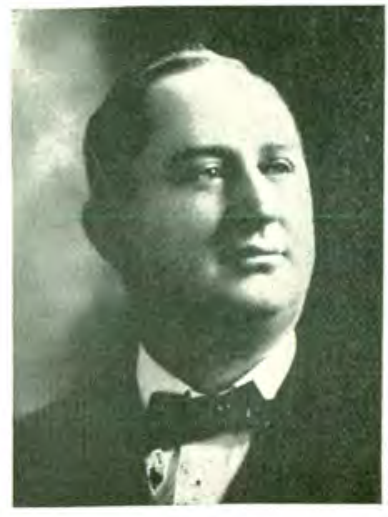

THOMAS H. ENSOR

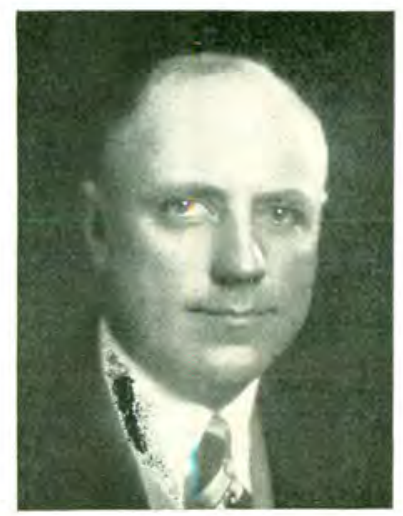

CLELAND G. MOORE

Charles B. Stillman of Columbus.

Thomas H. Ensor of South Omaha, 1896-1900.

Hudson J. Winnett of Lincoln in 1899. 
Nicholas McCabe of North Platte, in 1906, three terms.

J. P. Gilligan of O'Neill, four years.

C. F. Ballard of Havelock, first mayor there, three terms.

Hiram L. Smith of Geneva, four terms.

Milton M. Butler, Weeping Water.

John C. Malster of Stromsburg.

Frank Frink of Newman Grove.

Emanuel F. Carr of Stapleton, six years.

Andrew J. Jenison of Harvard.

Carl J. Verges of Norfolk, 1912-1914.

Cleland G. Moore of Fremont, 192 7-1929.

William H. Pruner of Kennard.

R. J. Murdock of Blair.

N. B. Larsh of Nebraska City.

R. R. Livingston at Plattsmouth, 1874-1877.

E. T. MsGuire of Mead.

Wm. E. Donelan of Plattsmouth, second mayor in 1858-1859. Is iah Lukens of Tekamah.

Wi liam J. Birkofer of Gothenburg.

CITY COUNCILS

Samuel C. Panter of Dorchester.

J. E. Hartwell of Crawford.

EDUCATIONAL

Alexander Bear of Norfolk, Willson O. Bridges and Byron B. Davis of Omaha are physicians who have served as regents of the University of Nebraska. A. S. von Mansfelde of Ashland was nominated for state superintendent of instruction on the Greenback Ticket in 1880 .

B. F. Lorance of Auburn, president of the Nebraska Association of School Boards and Executives, 1928. He has been a member of the Auburn School Board for more than twenty years.

Serving on the Board of Education in Omaha, several of them as presidents of the board, have been:

Gilbert C. Monell, president of the first board, was also one of the incorporators of Brownell Hall Girls' School in 1868; Theodore L. Baumer, a member, 1872 . 
S. K. Spalding, member five years, president in 1894 .

John H. Vance, member 1905-1910.

W. S. Gibbs.

Fred R. Teal, 1900.

William H. Christie, president two terms.

Elias Holovtchiner, president, 1909-1917.

F. W. Faulk, South Side, 1922.

C. W. Mason, 1928.

Jennie Callfas, 1928.

In the State:

B. F. Bailey and E. W. Rowe in Lincoln.

Sydney S. Wilson of Nebraska City, 16 years,

Alfred H. Thomas of Trenton.

Edwin W. Cook, Plattsmouth.

Joel Anderson, Gothenburg.

C. C. Barr, Tilden.

W. S. Wiggins, Exeter, president.

A. E. Buchanan, Fremont.

Edward O. Wilson of Madison, president.

James E. Hartwell, Crawiord.

P. A. Sundbury, Holdrege.

E. F. Carr, Stapleton, secretary 15 years.

A. J. Jenison, Harvard, president.

Alexander Bear, Norfolk, president.

Samuel G. Panter, of Lincoln, on Dorchetser board.

J. P. Gilligan of O'Neill, 18 years.

Lew A. Carter, O'Neill, president.

Charles D. Eby of Leigh.

Edgar S. B. Geesaman, Fort Calhoon.

Antony Parsons of Valley, secretary of Board of Education sor 13 years.

Henry R. Miner of Falls City, president of School Board, 1911, William E. Shook of Shubert, on School Board 18 years.

George W. Egermayer of Shubert.

R. C. Talbot of Broken Bow.

T. P. Livingston of Plattsmouth.

Wm. E. Donelan of Plattsmouth, later on St. Joseph, Missouri School Board. 
DELEGATES TO NATIONAL POLITICAL CONVENTIONS

William $\mathrm{H}$. Christie was a delegate to the republican meeting in 1884, voting for James G. Blaine.

W. J. McCrann of Omaha, was a delegate to the democratic national meeting in 1908. Dr. Jennie Callfas is at present democratic committeewoman from Nebraska and Dr. Olga Stastny was. elected an alternate to the 1928 national democratic convention.

\section{NOMINEES FOR CONGRESS}

S. V. Moore of York in 1882.

G. F. Keiper of Pierce in 1893.

Robert R. Livingston of Plattsmouth, several times.

\section{STATE INSTITUTIONS}

Benjamin F. Williams of Lincoln is chairman of the state board of control of state institutions. He has received recognition for developing a library for insane patients at the state institution, of which he was the superintendent from 1908-1918, and his method

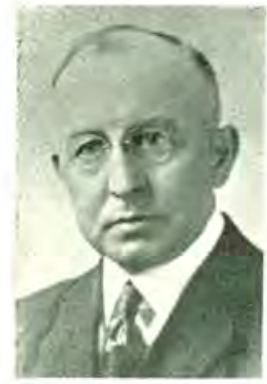

J. S. FAST of establishing the library was discussed at the Chicago meeting of the American Medical Association in 1917. Several Eastern institutions have since copied his method.

Charles F. Stewart of Auburn was said to be the first superintendent of the Nebraska Hospital for the Insane from November, 1871, to January 1, 1875. He was also appointed to the first state board of health in 1891 and served seven years. He was born in Indiana in 1853 and settled in Nemaha County in 1857 . He was educated in Cincinnati and was a Civil War veteran.

Among other superintendents there were Mark W. Baxter, D. S. Woodard of Aurora, Luther J. Abbott of Fremont, N. B. Larsh of Nebraska City and J. S. Fast of Hastings.

Aurelius Bowen of Nebraska City, a state senator in 1873 was author of the bill creating the state institution for the blind in his town. He was also one of the incorporators of the school for the deaf in Omaha in 1867 and was a member of its board of trustees until 1875 .

J. V. Beghtol of Hastings was superintendent of the State Industrial School for boys at Kearney in 1902 . 


\section{PHYSICIANS IN POLITICS}

Notes and Errata

p. 130

State Board of Health. Memorial and Petition for State Board of Health. See Proc. Nebraska St. Med. Soc., 4th Ann. Mtg., June 4-5, 1872, p. 31.

Committee appointed to gather information on health conditions should include M.W. Wilcox. "Report of Committee on Climatology and Prevailing Diseases," Trans. Neb. St. Med. Soc., Sixth, Seventh and Eighth Annual Meetings, pp. 209-221, 1877, Appendix G.

pp. 131-133 Wilson, W. H., "Medical Legislation, the Public and the Doctor," Nebraska St. M.J., 8:14-16, Jan. 1923.

p. 133 Senate File 116, 1891.

p. 137 Medical legislation. See Orr, H.W., "Medical Legislation in Nebraska," West M. Rev. 5:180-183, June 15, 1900.

p. 141 Code Bill. See "Civil Administrative Code of 1919," Nebraska Blue Book, 1920, p. 187.

p. 147

"Augustus Roeder of Omaha in 1857 . . ." should read "1858" since he was in the Fifth Territorial Legislature. 



\section{WAR SERVICE}

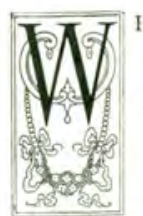

HEN war is declared, the importance of doctors jumps to first rank. Whatever their peace time missions of mercy may be, their need during bloodshed is as inexorable as fate. And it was the army service of Surgeons T. G. Mower and John Gale with the Sixth Regiment in 1819, as described in the first chapter, which virtually began the history of medicine in Nebraska.

The army brought also to Nebraska during its early days, John E. Summers, medical director in charge of the Department of the

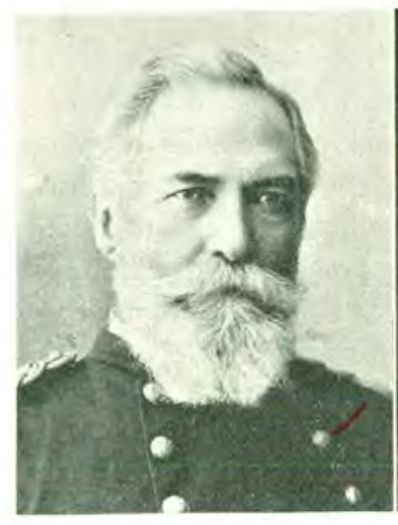

JOHN E. SUMMERS

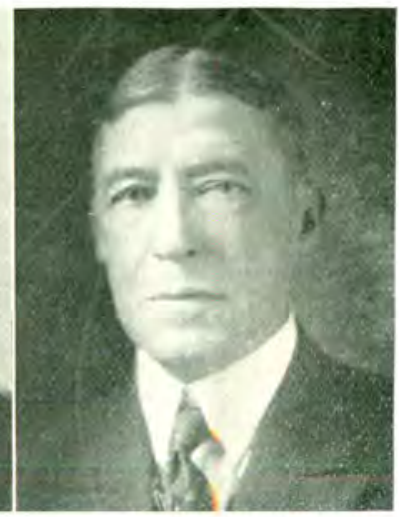

JOHN E. SUMMERS, JR.

Platte, who was stationed at the frontier post of Fort Kearney, January 2, 1858, when his son, John E. Summers, Jr., now dean of Omaha surgeons, was born. Further mention of him will be made in the section on the University of Nebraska College of Medicine, which recently conferred upon him the honorary degree of doctor of laws, for distinguished service to the school and as a pioneer in aseptic surgery. He was the first Nebraskan educated in the new theory. 
The elder Summers came of a distinguished family in Virginia, where a county is named for them. He was educated in the Universities of Virginia and Pennsylvania and was connected with the army medical department for 38 years, prior to his retirement in 1886. He was given the rank of Brigadier General, Retired, by act of Congress, May 23, 1904.

The son followed his father's army career to the extent of a West Point cadetship for several years, then attended Columbia University from which he was graduated in 1881. He then entered the United States army, spent two years as an assistant post surgeon in Wyoming and then resigned to spend two years in study at Vienna and other European centers. He returned to Omaha in 1885 to assume a pre-eminent place in local surgery; was made professsor of surgery in Omaha Medical College; and served as president of the Nebraska, Omaha, Missouri Valley and Western Surgical and Gynecological associations, the latter the leading surgical society in the west. He also became chief surgeon on several hospital staffs and for the railroads.

Dr. Summers wrote a book "Modern Treatment of Wounds" which ran through several editions and received praise from the medical profession throughout the country; and contributes to many medical journals. He is also a member of the American College of Surgeons, fellow of the American Surgical Association; and a member of the Societie Internationale de Chirurgie, to which A. F. Jonas of Omaha also belongs. There are only a few members in the United States.

Of the few doctors in Nebraska before the Civil War, they volunteered almost to a man when Fort Sumter was fired on. R. R. Livingston of Plattsmouth stopped the printing press of the Plattsmouth Herald to issue the first call to arms, and organized the First Nebraska company of volunteers. Of the Omaha surgeons, J. H. Seymour, one of the first to go, died in the service at Helena, Arkansas, September 7, 1862. William McClelland, who saw service in the Pawnee War under General Thayer; Enos Lowe, with the First Nebraska Infantry, A. Chapel, who died in Chicago of illness contracted in the service; J. H. Peabody, major in charge of the medical district of Nebraska; J. R. Conkling, post surgeon at Fort Kearney in 1863 ; R. C. Moore, a Union surgeon, and J. W. Agee 
of Valley, who served as a Confederate surgeon, were among them.

The first state capitol building, then in Omaha, was used as a post hospital during the war. It was located on Ninth street between Farnam and Douglas streets, was 33 by 75 feet in size; cost $\$ 3,000$ and was considered a very fine edifice at the time. It is reproduced on this page.

The end of the war and the building of the Union Pacific railroad brought an increase in population, and also in physicians - most of whom had served in the Civil War-which gave the state and particularly Omaha some of its outstanding practitioners. Victor

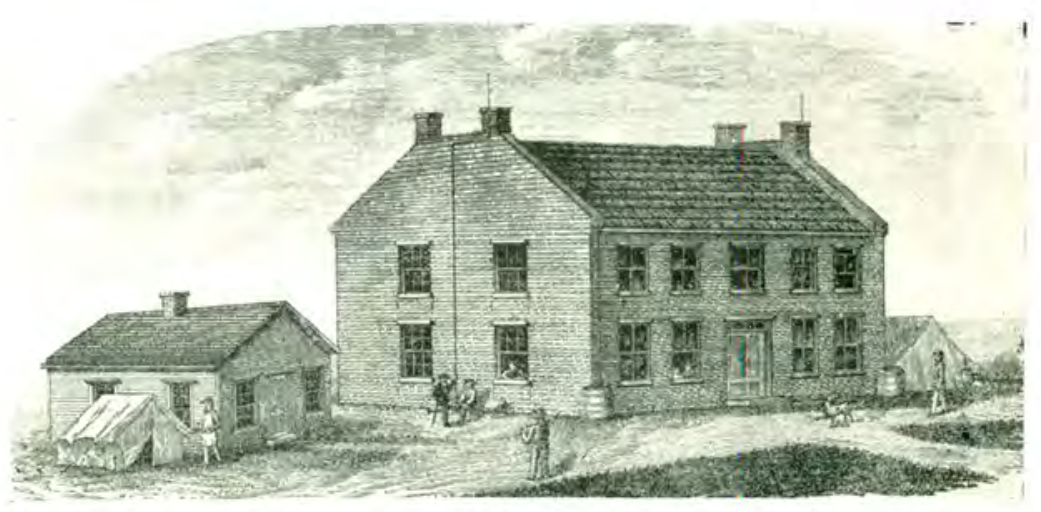

STATE CAPITOL-USED AS POST HOSPITAL

H. Coffmann was one of these as was Thomas H. Ashton who settled in Syracuse in 1886.

Carroll Dandola Evans of Columbus, Colonel on Governor C. H. Dietrich's staff and surgeon general of the Nebraska National Guards by appointment of Governor E. P. Savage, had an unusual military experience as second lieutenant in the Pennsylvania National Guards in 1877 , when he was called out to quell coal strikes and railroad riots. He was born in Tarentum, Pennsylvania, in 1856, was graduated from the College of Physicians and Surgeons in Baltimore in 1882 and practiced for a short time in Bradford, Pennsylvania before he located in Columbus, Nebraska, May 16, 1883. He is a member of the Association of Military Surgeons of the United States and has attended a number of meetings by appointment of various governors. 
The next conflict, the Spanish-American war, brought the usual response from state physicians. Burton W. Christie of Omaha, Guy Seward of Fremont, J. R. Cameron of Bennett, W. H. Nelson of Ruskin, G. W. Strough of Garland, Arthur Lawrence Smith of Lincoln, Ole Grothan of St. Paul and A. S. Pinto, now health commissioner of Omaha, who saved the life of his commander, Lt. Col. G. L. Townsend in the Philippines, and who submitted to yellow fever inoculation in the interests of science, in Cuba, as described in another section, are among the enlisted officers.

C. L. Mullins of Broken Bow, captain and assistant surgeon with the First Nebraska Volunteers in the Spanish-American war, was a member of the first board of health in Manila, after the occupation by the United States Army. Willis A. Talbot, also of Broken Bow, served with this regiment too in the Phillipines, and made a splendid record by stamping out the small pox. When he enlisted in the World War, he was sent directly to the first line in France, because of his previous war experience.

The last call to arms in the World war in 1917 enlisted every available medical man that could be spared. Two distinct war medical units, University of Nebraska Base Hospital No. 49 and Omaha Ambulance Company No. 335 were organized, recruited and financed here in this state. Besides these units, many Nebraskans were attached to other organizations and rose to high rank. P. H. Bartholomew. Czar C. Johnson and H. Winnett Orr were among the

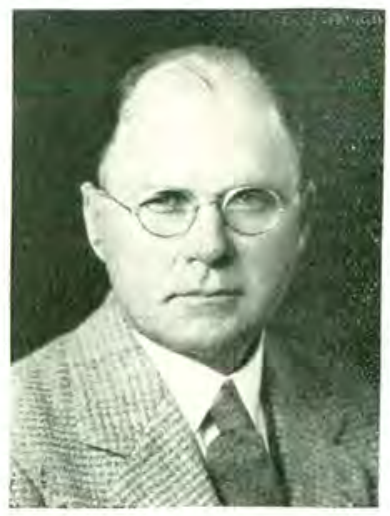

W. J. REDFIELD Lincoln men who rose to the rank of Lieutenant-colonel. Miles Standish' Moore of Gothenberg, president of the Nebraska State Medical Association in 1921 , served for two years with the Imerican Expeditionary Forces, after service on the Mexican border. Ralph G. Cressman of Hastings went through the St. Mihiel drive. He rose to the rank of lieutenant-colonel and was in charge of an aviation hospital. FF. A. Brewster of Beaver City and T. E. Riddell of Scottsbluff gave two years in the air service. C. D. Hustead of Aurora 
was also in the air service. G. A. Harris of Valley was on the Mexican border in 1916. E. E. Koebbe of Columbus was in the navy six years and Roy E. Peters of Wymore, four years. Harmon P. McKnight of Virginia was in the regular army five years. W. J.

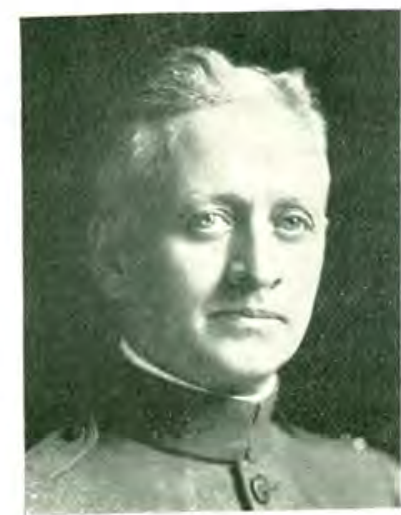

E. C. HENRY

Redfield of Omaha served as a major and at present is on the staff of Lord Lister Hospital.

After the war physicians were leaders in the organization of the American Legion. Edwin C. Henry of Omaha was the first commander of Douglas County post, which grew to be the largest in membership in the world. E. E. Boyd organized the post at Central City and Harry McFadden was commander and adjutant of the Greenwood post.

Because of his long and active service in the United States army medical corps, John Monro Banister, Colonel, U. S. A. (retired), was the most-sought medical officer in Omaha during the

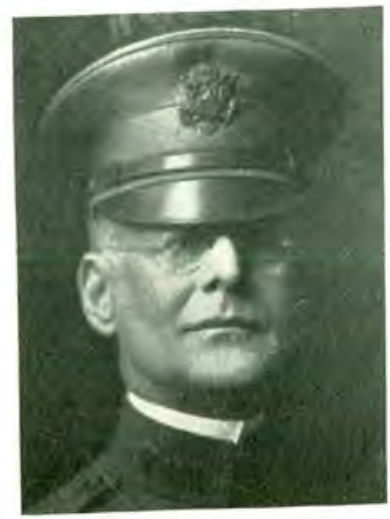
period when the Nebraska Base Hospital and Omaha Ambulance Company were being formed in the late war, and was president of the state medical society, that year. He was born in Alabama of distinguished Virginia Revolutionary ancestry. He was a member of the Virginia Society of the Cincinnati, Sons of American Revolution and was on duty under orders of the War Department as surgeon and in command of the Medical Department at the West Point Military Academy from 1898 to COL. JOHN MUNRO BANISTER 1902. He had an important record in the Philippines, as surgeon at the post of Manila and at the general hospital for the entire archipelago. On his return, he was chief surgeon for the Department of the Missouri, at Omaha. His military record from 1879 until 1910, when he retired at his own re- 
quest, includes service in the Spanish-American war, three years in the Philippines and reassignment to duty in the late war. He was professor emeritus of tropical diseases at the University of Nebraska Medical College. Professionally, he was a member of many medical societies, the usual and honorary ones, especially in his specialty, which was ophthalmology and oto-laryngology, such as the American College of Surgeons, American Academy of Ophthalmology and Oto-Laryngology and the American Laryngological, Rhinological and Otological Society. He was also a member of the Association of Military Surgeons of the United States.

His contributions to professional literature include: "Lateral Lithotomy with the Successful Removal of a Calculus and Seven Pieces of Necrosed bone from the Bladder of an Indian Scout Nineteen Months after the Reception of a Gunshot Wound." (American Journal of Medical Sciences, 1880 or 1881 .) "The Radical Cure of Inguinal Hernia" (Journal of Association of Military Surgeons of the U. S., 1897.) "Hints in Relation to the Dynamics of the Extrinsic Ocular Muscles with Suggestions as to Treatment of States of Muscular Imbalance," read before the Colorado Congress of Ophthalmology and Oto-Laryngology, June 23, 1920, and published in the American Journal of Ophthalmology. "A Plea for Conservatism in the Treatment of Frontal Sinus Affections," read before the Sioux Valley Eye and Ear Academy, July 9, 1923 and printed in Eye, Ear, Nose and Throat Monthly,August, 1923.

Besides his distinguished military record, Colonel Banister has made important contributions to the physiology of the eye and has indicated numerous surgical means for correcting defects of the eye.

CONNELL WINS D. S. M.

Twice cited for distinguished service in the American Expeditionary Forces in France, Major Karl Connell of Omaha was awarded the Distinguished Service Medal of the United States, on recommendation of General Amos A. Fries, chief of the chemical warfare service.

The Omaha physician developed the first protection against the penetrating German smoke gases and placed several hundred thousand defensive respirators in the field in time to meet the German smoke gas attack in the battle of the Somme in 1918 when 
the British front was being crumpled. He perfected the only allAmerican gas mask which saw service in France. It was officially known as the Connell mask.

Connell's war service preceded America's entrance into the conflict. He established an Advance Hospital Unit in France and in 1915, toured Germany and Austria as accredited sanitary observer for the National Guard of New York. On his return, he

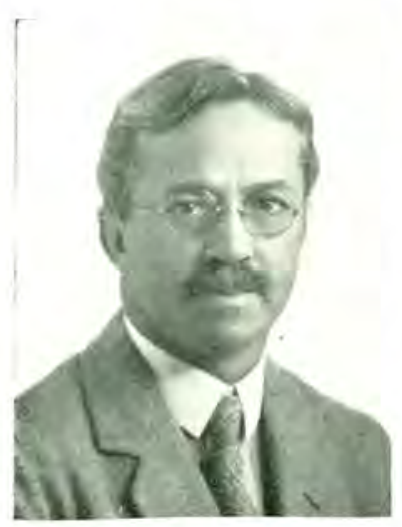

MAJOR KARL CONNELL took part in the campaign for national preparedness and on entry of this country into the war, he was assigned by the Surgeon General to the problems of wound treatment and standardization of the surgery in the Advance Zone. From this he was called overseas on account of previous achievement in the science of anesthesia, to be placed in charge of gas mask development in the war zone. He accomplished his first objectiveproviding a defensive respirator for the men in the trenches - and then set to work to make a better gas mask. Hampered by lack of supplies and workmanship in a war-torn country, he returned to America, where the chemical warfare service placed all its facilities at his command. He had perfected the Connell gas mask and was at work on similar problems when the Armistice was signed.

Dr. Connell was born in Omaha, July 4, 1878, the son of W. J. Connell, prominent Omaha lawyer, and the nephew of R. W. Connell, late health commissioner. He was educated in Creighton University Medical College and the College of Physicians and Surgeons at Columbia University in 1900. After his war service, Dr. Connell returned to Omaha to be with his father in the declining years of the latter's life and was professor of surgery at his old alma mater, Creighton, from 1919 to 1923. At the same time, he conducted the Presbyterian Hospital, on South Tenth street. Since severing his connection with the hospital Dr. Connell has spent much time in the east, and the past winter at Santa Barbara, California. Mrs. Edward Creighton of Omaha is a sister. 


\section{YELLOW FEVER HERO}

Pursuing his quiet, busy way as health commissioner of Omaha since 1921, Alva Sherman Pinto, veteran of two wars, is deserving of the caption "hero" in two notable instances.

While in the medical service in the Spanish-American war and thereafter, he was one of the first group of volunteers to be bitten by infected mosquitos at Havana, Cuba, proving the manner of infection of yellow fever. Walter Reed, Jesse W. Lazear and James

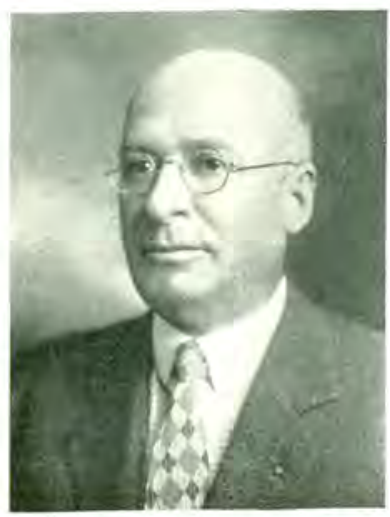

A. S. PINTO Carroll of this group died. Walter Reed Hospital in Washington, D. C., is a memorial to the first; Lazear and Carroll, who submitted to the infection at the same time with the Omaha Pinto, also died and were accorded a nation's honor as heroes. Pinto and a Cuban, Dr. Aristides Agramonte, were thought to be the only survivors until the Literary Digest of January 14, 1928, reported another, John R. Kissinger of Indiana, who has been disabled since then. He was a hospital orderly under Pinto.

The Omaha physician was the one chosen to accompany the invalid Carroll back to his home and family in New York. Lazear died at once. Dr. A. S. von Mansfelde, a friend of both young physicians, was the one who originated the efforts in Congress to establish a pension fund for the widows and orphans of the two self-sacrificing physicians. Photographs of Lazear and Carroll hang in the von Mansfelde home at Ashland.

Official recognition to Pinto's heroic service with the other better-heralded victims is given in Macrae's edition of Osler's Practice of Medicine, Volume II.

Pinto's second exhibition of valor took place the next year in July, 1901 at Hermani, Samar, Philippine Islands, when the Omaha doctor killed the assailant of his commanding officer, Lt. G. L. Townsend, (now colonel U. S. A.), thereby saving 'Townsend's life.

Pinto was graduated from Creighton College of Medicine in 1898 and enlisted the same year as a private in the Spanish Amer- 
ican war. After serving in both Cuba and the Phillippines, he resigned, captain in the medical department, in 1903. He returned to the army as a major, August 7,1918, serving in France until July, 1919. He was commanding officer of Camp Hospital No. 48 at Recy sur Orce. Pinto was born in Chilicothe, Ohio, May 29, 1872 but came to Omaha as a youth. He is a son-in-law of the late Dr. S. K. Spalding, who preceded him as health commissioner of Omaha in 1898-1899.

Erskine M. Barnes of Omaha, veteran of two wars, is a full colonel in the medical corps, one of the four ranking medical officers in the state. The others are H. Winnett Orr, David C. Hilton and Czar Johnson, all of Lincoln. He

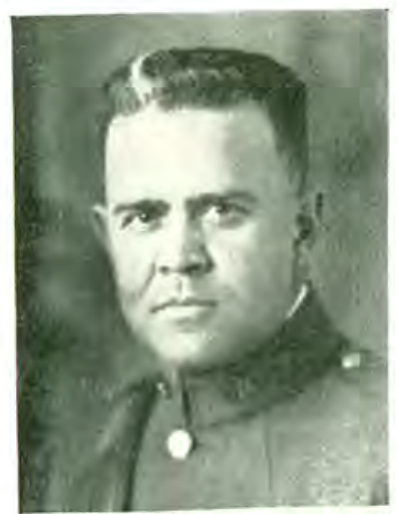

ERSKINE M. BARNES is also on the reserve advisory board of Major-General Smith, of this corps area. Barnes enlisted as a private in Company $\mathrm{H}$, Second Nebraska Volunteers in the Spanish-American war but was later transferred to the First Division Hospital, where he served throughout the conflict. He was commissioned a captain in the world war and was discharged as major of the 355th infantry, 89th Division. He was promoted to lieutenant-colonel in 1923 and full colonel in 1926, commanding the 372 nd medical regiment, 6th army. Barnes is a graduate of the University of Nebraska and Cotner and is on the staff of Wise and Immanuel Hospitals. His brother, Chester D. Barnes, is a physician at Tecumseh.

Wesley L. Curtis of Lincoln, president of the Lancaster County Medical Society, was surgeon for the coast and geodetic survey in the Philippine Islands.

Ralph Luikart of Omaha, formerly superintendent of the Creighton Medical dispensary and assistant professor of obstetrics, served with the Serbian Red Cross during the typhus epidemic in 1915, before the entrance of the United States in the war. When Serbia was captured he returned to this country. 
Captain George Richardson Gilbert, former post surgeon at Fort Omaha, did an important piece of work in the late war by organizing hospital trains at Fort Riley, the medical officers' training camp. After a year of this work, he embarked for France with a hospital train and on his arrival there, was surgeon on an ammunition train, also Base Hospitals 67 and 44, and later, at Fort Monroe. Gilbert, born here November 18, 1873, is a grandson of the late O. D. Richardson, member of the first Territorial Legislature in Nebraska in 1854. He has had a varied experience in the west as physician for the Union Pacific Railroad, coal mines and beet sugar factories, and while living in Morrill, Nebraska in 1910-1911, was president of the Scotts Bluff County Medical Society.

Roy W. Fouts of Omaha was instrumental in organizing the Army Medical School at Chattanooga, Tennessee, during the World War.

F. A. Sedlacek, assistant health commissioner of Omaha served with the Reci Cross in Siberia, in the late war.

Perry Allerton was commander of the Tilden American Legion.

The late Arthur A. Conrad of Crete was a lieutenant of cavalry in the German army during the Franco-Prussian war of 18701871. He came to Crete in 1880.

OMAHA AMBULANCE COMPANY, NO. 335

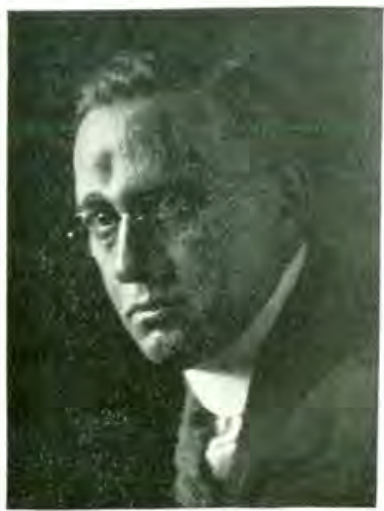

A. L. LINQUIST

Red Cross Ambulance Company, No. 335 was organized shortly after war was declared, in the months of May and June, 1917, by Omaha Chapter, American Red Cross, headed by Gould Dietz. G. W. Wattles, chairman of military relief, appointed an organization committee of the following doctors: A. F. Jonas, chairman; Charles A. Hull, secretary; Colonel J. M. Banister (Med. Corps, retired); J. H. Vance, B. B. Davis, LeRoy Crummer and O. S. Hoffman. This organization and committee furnished funds and equipment for the company of volunteers, the 
personnel of which was headed by First Lieutenant A. L. Linquist, commander, and Lynn T. Hall, Otis Martin and J. A. Fleischman, also first lieutenants.

The company's service record as furnished by Lynn T. Hall is as follows:

Ordered into service August 22, S. O. 185 W. D. Par. 55. Company proceeded to Camp Taylor, Louisville, Kentucky entraining under orders 68 Par. 7 W. D. September 13, 1917 Par. 16 S. O. 218 Hdqrs. Central Dept. Chicago, Illinois on September 26. Second ambulance company to arrive at camp, being among the first troops to arrive there. Upon organization of the 84 th Div. number was changed to No. 335, 309 San. Train. Ambulatory service for the entire camp to base hospital handling approximately 6000 patients. Called upon to assist in train wreck on the L \& N. RR. December 22, 1917 at Shelbyville, Kentucky, transporting dead and injured from relief train to hospital.

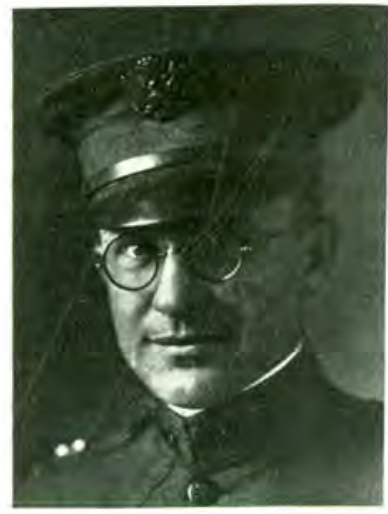

OTIS MARTIN

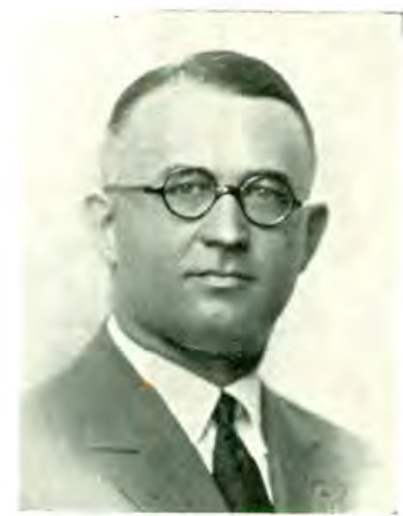

LYNN T. HALL

Forty-nine dead and 60 injured. Received letter of commendation from Surgeon General and Railroad Co. Acted as provisional ambulance company for 309th Engineers on seven day hike under full pack. Performed necessary work handling 44 heat exhaustion cases, erecting temporary hospital on roadside. Under verbal orders from Comdg. Genl. 84th Div, as per instructions W. D. entrained for Camp Sherman, Chillicothe, Ohio, June 7, 1918. Ambulatory service to base hospital about 100 patients. Entrained for Camp Mills August 25, 1918 verbal orders Comdg. Genl. 84th Div, per instructions W. D. Boarded boat September 
8th, sailing early September 9. Landed at Liverpool on September 21 after an uneventful trip across. Entrained at once for Camp Woodley, Romsey, England. Crossed English channel September 23 landing at LeHavre, France Entrained for back area September 26 in northern France, arriving at Mussidane, Dordogne, France, September 27. Continued training and ambulatory service for troops in area evacuating to hospitals at Montpont and Chateau La Rouche. Entrained November 11, verbal orders C. O. 309 San. Train for Sanitary Schools at St. Aignan. S. O. 314 Hdqrs. 1st D. Div. Par. 3 moved to Theizee, Verbal orders C. O. San Schools moved to Pouille, France. Entrained for Longchamps December 11, arriving December 14. Verbal orders C. O. 5th Corps moved in trucks to Favorelles, Haute Marne, France, December 20, 1918. Received orders for 22 men and 1 N. C. O. with 10 ambulances to report to Capt. Taylor director 101st San. Train, 26 th Div. to evacuate sick and injured for entire 26 division, the division being billeted throughout the greater part of the province of Haute Marne. Eight ambulances were stationed in various parts of the area occupied, two being held at Hdqrs. at Garry. Each car cared for 5 or 6 towns evacuating to base hospitals No. 90 at Chaumont and Nos. 53 and 88 at Langres. The area covered extended to Bourdons and Consigney on the north, Foulain on the west, Damrimont on the east and Champigny on the south. The number of patients grew continually, pneumonia and bronchitis being prevalent. The roads were bad and broken axles and springs were common, making it difficult to maintain service. Drivers and orderlies aIternating at the wheel to rest each other. Broken down cars made the addition of 5 C. M. C. ambulances necessary. Period of evacuation covered 42 days and patients numbered in excess of 4000 . January 3, 1919 Amb. Hdqrs, moved from Sarry to Bannes and remained until 36 were entrained for LeMans area. During entraining period a car followed each regiment to pick up stragglers. Cars were on the go during entraining period which covered 3 days and nights. This completed our work with the 26th Division. Conduct and efficiency of men being commended by General Hale, Div. Commander and by Corps. Surgeon 5th Corps relieved from duty on the 29 of January, 1919, reporting to Corps Surgeon 5 th corps for duty.

Ambulatory service for 57 th Pioneers and 603 and 604 Engineers during period from January 30 to March 3, 1919, caring for about 2000 patients. Entrained at Foulain for 
Mezeray S. O. 62 Par. 1 Hdqrs. 5th Corps March 4, 1919 on March 5 arriving next day. Spent time in concentration area. On order 22 Hdqrs. A. E. C. March 17 movement from Mezray to Brest. Entrained at LaSuze March 23, arriving at Brest March 24. Camp Pontanazen from March 24 to April 10.

Boarded Von Steuben for home on the 10 of April, landing at Hoboken, April 19. Camp Merritt usual routine. Entrained for Camp Dodge, April 28, discharged May 1, 1919.

Following officers attached at various times transfer records not available: First Lieutenants D. R. Kline, M. C. Smith, Panitch; Captains H. C. Wilson and D. W. Davis. Fifteen men were promoted to lieutenants in various branches through training schools.

Traveling over northern France in railroad truck convoys, the Omaha lads' knowledge of that country is not exceeded by any American organization that went across. On Christmas day they saw President Wilson in the big review at Humes, and on April 4, at Brest, took dinner with Secretary of the Navy Daniels, who visited their mess hall and consumed corned beef like a veteran.

The company personnel included.

$\begin{array}{lll}\text { Abrahamson, C. A. } & \text { Dineen, M. J. } & \text { Hager, R. } \\ \text { Alexander, H. W. } & \text { Dragoo, C. } & \text { Haglin, J. E. } \\ \text { Alleman, W. R. } & \text { Dugdale, J. F. } & \text { Harper, R. G. } \\ \text { Armstrong, H. G. } & \text { Durkee, S. } & \text { Harral, C. E. } \\ \text { Bailey, H〉 } & \text { Farly, R. J. } & \text { Hart, Fay } \\ \text { Barta, L. C. } & \text { Fauble, E. } & \text { Hatch, Kenneth. } \\ \text { Beisel, C. } & \text { Fauble, G. } & \text { Hart, H. } \\ \text { Broman. E. } & \text { Fern, H. } & \text { Hart, K. } \\ \text { Boyle, L. J. } & \text { Fitzgerald, J. T. } & \text { Harte, H. D. } \\ \text { Carlsan, T. J. } & \text { Foley, J. J. } & \text { Hodgins, V. M. } \\ \text { Calley, J. W. } & \text { Foley, S, J. } & \text { Horne, H. } \\ \text { Chizum, G. } & \text { Gates. C. F. } & \text { Howell, G. R. } \\ \text { Cizek, G. J. } & \text { Gerstein, Harry. } & \text { Howley, H. } \\ \text { Cochrane, A. P. } & \text { Gerstein, Hime } & \text { Huth, A. } \\ \text { Curtis, P. } & \text { Gilligan, F. } & \text { Ingraham, W. } \\ \text { Czerwinski, V. J. } & \text { Glynn, L. M. } & \text { Inkster, G. } \\ \text { Dailey, R. } & \text { Goetz, Harry } & \text { Jenks, H. } \\ \text { Davis, L. } & \text { Gooding, Jos. } & \text { Jensen, A. } \\ \text { Dent, H. } & \text { Goldsmith, H. } & \text { Jensen, Anton } \\ \text { Deuel, L. } & \text { Gould, R. M. } & \text { Jesse, R. } \\ \text { Devin, R. M. } & \text { Gray, E. } & \text { Johnson, A. } \\ \text { Dierking, H. } & \text { Haffner, H. } & \text { Johnson, R. B. } \\ & & \end{array}$




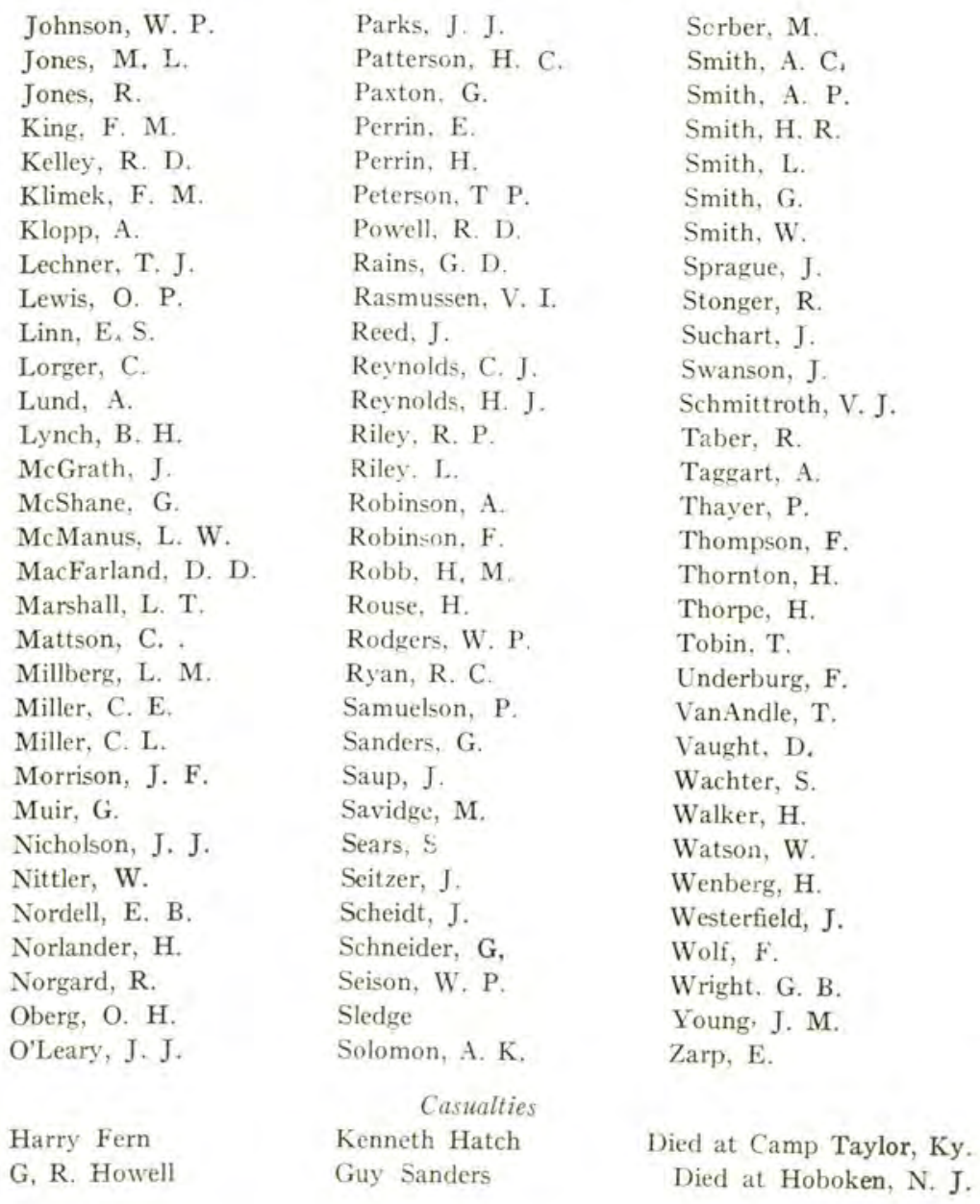

UNIVERSITY OF NEBRASKA BASE HOSPITAL NO. 49

Pursuant to a telegram received by Gould Dietz, Chairman of Omaha Red Cross chapter on October 8, 1917 from LieutenantColonel C. H. Connor of the U. S. Army Medical Corps, stating that a base hospital formed around the medical department of the state university might be accepted for war duty, if the $\$ 50,000$ or $\$ 60,000$ necessary to finance such a unit could be raised, local patriotism reached a high pitch. Dietz immediately conferred with local medical school authorities and replied: "Think we can handle a base 


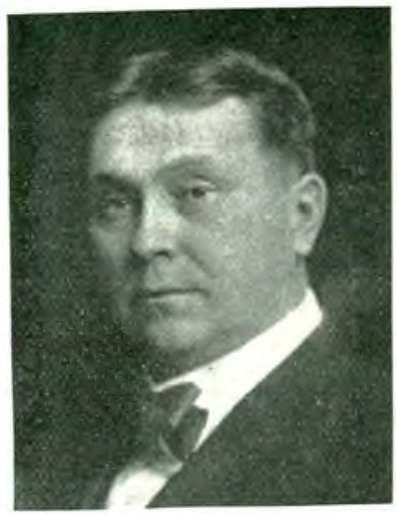

ARTHUR C. STOKES

hospital. Dean Irving S. Cutter and Chief Surgeon A. F. Jonas of University Hospital and I recommend Arthur C. Stokes, professor of clinical and experimental surgery of medical department of state university to head unit. Jonas agrees to head advisory committee of doctors here to help me organize unit. Please send all information and instructions."

On receipt of this recommendation, Stokes received a major's commission and was placed in command of the unit. The organization was later perfected as a state-wide affair, sponsored by the Nebraska Red Cross.

This record of Nebraska Base Hospital No. 49 was taken from the work entitled "Medical Department of the United States Army in the World War," prepared under the direction of Major. General George M. Ireland, Surgeon-General of the United States by

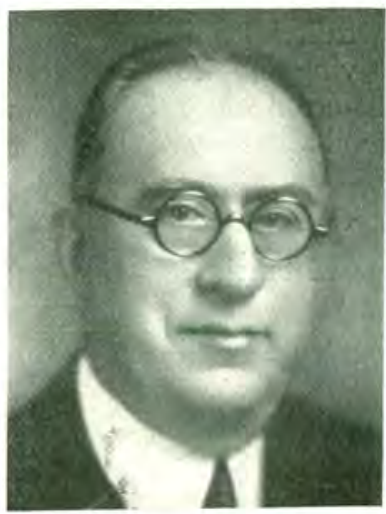

CHARLES A. HULL

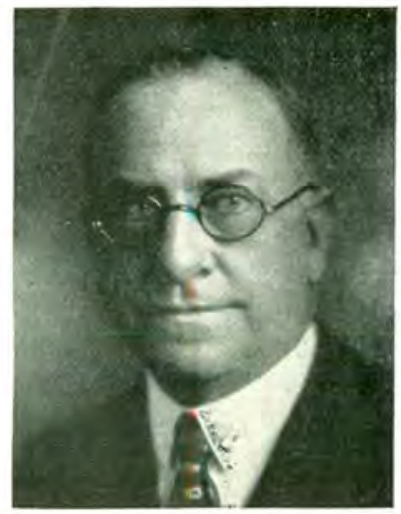

EDSON L. BRIDGES

Colonel Joseph H. Ford, who was stationed at Allerey and is known to Dr. Stokes:

Base Hospital No. 49 was organized in September, 1917, at the Nebraska University, Omaha, Nebraska. The unit was mobilized in Omaha, Nebraska on March 25, 
1918, and was transferred to Fort Des Moines, Iowa, where it trained until July 4, 1918. It then proceeded to Camp Mills, New York, and sailed July 14, 1918 for Liverpool, England, on the Karmalia, arriving there July 31. Thence it traveled by rail to Southampton and, crossing the channel, arrived at Cherbourg, France, August 3, 1918. It entrained for Allerey, Department of Soane et Loire, in the intermediate section, and arrived there August 5, 1918 being the third medical organization to arrive at that center. At Allerey the unit occupied a section of type A wooden barracks, which were found very incomplete, but by August 2.3 the hospital was ready for patients, and on August 26 received its first convoy of sick and wounded.

The normal bed capacity of the hospital was 1,000, with an emergency expansion of 1,000. The largest number of patients in hospital under treatment was on November 10,1918 when 1,950 were being cared for.

Base Hospital No. 49 was designated by the commanding officer of the center as a special hospital for mental and nervous disorders. During its period of activity, August 26, 1918 to January 20, 1919, the hospital cared for 2,562 surgical cases (with 506 operations), 1,902 medical, and 430 gassed cases.

Base Hospital No. 49 ceased to function on January 20, 1919, and the organization sailed from Brest on the Manchuria, April 12, 1919, arriving in New York, April 23, 1919. The unit was transferred May 4, to Camp Dodge, Iowa, where it was demobilized May 7, 1919.

\section{Commanding Officer}

Lieutenant-Colonel Leopold Mitchel, M. C., March 30, 1918, to March 15, 1919.

Major Charles A. Hull, M. C., March 16, 1919, to May 7, 1919.

\section{Chief of Surgical Service}

Lieutenant-Colonel Arthur C. Stokes, M. C.

\section{Chief of Medical Service}

Major Edson L. Bridges, M. C.

On his return to this country, Stokes was assigned to United States General Hospital No. 1 in New York City and did considerable surgery for returned soldiers. 
When the unit landed at Liverpool, according to Stokes, it marched nine miles to Camp Knotty Ash, Britishers greeting them all along the way. It was a long march. Persons along the way encouraged them by giving assurance that the camp was "Ten minutes on bicycles," but the phrase failed to carry weight after endless repetition. They reached camp shortly after midnight and after only the few short hours rest till dawn, entrained for Southhampton where they took boat for Cherbourg, August 3. Arriving in France, they entrained for the final lap of the journey. Not until a trainman chalked the word "Allerey" on their car as they moved south, did they know their destination. Men and officers reached there August 7, nurses arriving a month later.

Allerey was the largest American hospital center in France, and in fact, in all America's history. It was prepared to operate on a great scale, with eight units and equipment for 20,000 beds. Military authorities had anticipated heavy casualties and had done their best to be prepared.

One night three trainloads of wounded men rolled in between sunset and dawn, the work of unloading one section usually lasting about four hours. With morning came another trainload, so the Nebraska men kept right on with their errand of mercy. The skill of the surgeons and nurses and the patient care and devotion of enlisted men displayed during that eventful October, 1918 should be a source of lasting satisfaction to citizens of this state who donated $\$ 70,000$ to equip this unit. Base Hospital No. 49 was said to have ranked second in France. Pennsylvania was accorded first place.

The commander, Major Stokes, who rose to the rank of Lieutenant-Colonel, returned from France shortly after the hospital ceased to function on January 20, 1919, having evacuated 450 patients. The unit then became disintegrated, the portion which remained intact, returning to the United States under command of Major C. A. Hull. After a short stay in Camp Merritt, the unit proceeded to Camp Dodge, where it was demobilized May 7. The Chamber of Commerce tendered a welcome-home dinner on May 17. Majors Hull and E. L. Bridges were recommended for lieutenantcolonelcies but the commissions did not arrive before demobilization. 
Other officers of the unit were Major James M. Patton; Captains John B. Potts, Oliver Chambers, James C. Waddell, G. W. Dishong, Edward W. Rowe, John R. Nilsson, Leonard O. Riggert, Justus E. Olsson, George H. Walker, John C. Moore and Clyde C. Moore and Lieutenants J. E. M. Thomson, Miles J. Breuer, George W. Covey, Henry E. Flansburg, F. W. Webster of Lincoln; Abraham Greenberg, Sanford Gifford, Edwin C. Davis, George N. Boehler of Omaha; John S. Simms of North Platte; Durard B. Parks of

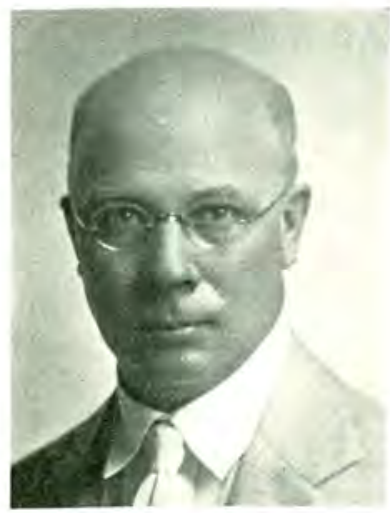

JOHN B. POTTS

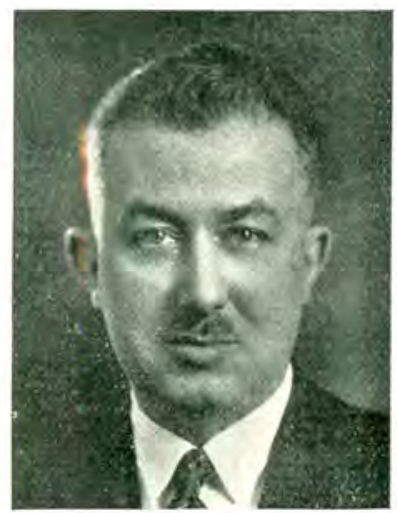

ABRAHAM GREENBERG

Laramie, Wyoming; Robert C. Panter, Dorchester; Willian L. Sucha, William R. Peters, Fred W. Buckley, Willian A. Delaney, Joseph L. Campbell, John W. McDonald and Theodore L. Shaffer; Herbert L. Machol, second lieutenant and quartermaster; Edwin J. Whalen, attached and Chaplain J. A. Tancock.

Doctor Stokes, who organized and headed Nebraska Base Hospital No. 49, now continues his Red Cross activity as chairman of Omaha chapter, a post he has held since shortly after his return from the war. This is second only to his interest in the University of Nebraska College of Medicine, for which he has done yeomen service; first, in helping to bring about the $\$ 100,000$ appropriation for the first building erected on the campus in 1911; second, in recommending the establishment of a scholarship fund to the late J. R. Conkling and third, in the gift of a lot adjoining the campus, to the school--all of which is mentioned at greater length in the chapter on Medical Schools. He has been vice-president and librarian of the 
state medical society, and is affiliated with the local, American Medical, Western Surgical and American Urological Associations. Born in Canada in 1869, he came to Rock Rapids, Iowa in 1885, was graduated from Iowa State College in 1892, spent two years at the College of Physicians and Surgeons in Chicago and was graduated from Omaha Medical College in 1899. He taught chemistry here for seven years. He interned one year in the Methodist Hospital and did post graduate work in Roosevelt Hospital, New York, after which he spent two years in study in Halle, Kiel and Berlin, Germany, and in England. He returned in 1904 and has practiced surgery ever since. He was professor of surgery at Nebraska University, is on the staff of Clarkson Hospital and is now medical director of the Guarantee Fund Life Insurance Company and consulting surgeon for the Missouri Pacific Railroad.

Nurses with Base Hospital No. 49 included:

Ida L. Gerding, Head Nurse Clara Crouse

Clara Baker, Assistant

Florence M. Albrecht

Lillian Albrecht

Katherine B. Andrews

Sadie L. Anderson

Bess M. Anson

Beatrice E. Arthur

Lelia E. Batie

Edith Banwell

Victoria B. Beachley

Alice M. Bixby

Mabel Blomberg

Emma A. Blome

Thyra L. Brandt

Edith M. Brannian

Josephine C. Braun

Minnie K. Braun

Ida A. Brecks

Harriet M. Brenenstall

Mildred I. Brown

Marie T. Budler

Mary Chalmers

Josephine Chamberlain

Cecile R. Champney

Mildren Chapin

Juliet E. Cherry

Anna M. Conley

Florence M. Conway
Eva L. Crowell

Pearl R. Culp

Edna O. Dickinson

Alberta E. Dill

Martha C. Doege

Emma M. Duguay

Mabel Eckstrom

Florence E. Edgecombe

May Elliott

Irena M. Ellison

Hilda C. Fleetwood

Carolyn A. Glammeier

Myrtle H. Hamerland

Nell E. Hawk

Sarah E. Jamison

Ellen Marie Johnson

Emily A. Johnson

Huldah D. Johnson

Lillian R, Johnson

Irene $\mathrm{H}$. Jess

Elizabeth Kalal

E. Georgia Kavon

Carrie M. Kolle

Martha Krausnick

Maybelle Lippincotte

Pearl W. Larson

Hildegard M. Lindstedt

Mildred M. MacLaughlin
Gertrude B. MacRae

Nellie H. McKinnon

Mary A, McKay

Lilian Mang

Mary J. Marshall

Selma M. Martin

Pearle Meiklejohn

Mayo G. Morisette

Ethel Murray

Anna C, Nasstrom

Martha Nicholson

Margaret E. Oliver

Lilly Olson

Mollie O'Malley

Bess Polansky

Elizabeth Pugh

Esther E. Quist

Eva M. Rogers

Anna L. Roggensees

Emma H. Rudat

Muriel Rusland

Elizabeth H. Sandman

Alma L. Schurman

Ethel M. Sconce

Elfrieda L. Seeck

Anna L. Sheibley

S. Julia Shepard

Nellie H. Smart

J essie Smith 
Zella A. Smith

Minnic M, Sullivan

Enma L. Svitak

Martina C. Thode

Evangelyne F. Vance

May Melle Wagner

Hospital Sergeant Jorgensen, William A.

Sergeants, First Class

Withrow, Taylor N.

McFayden, Grant L.

Otoupalik, Hugo M.

Storz, Louis $\mathrm{H}$.

Patterson, Chester L.

Micek, Joseph F.

Herbert, Walter M.

Swanson, Myrl R.

Levy, Ike

\section{Sergeants}

Peterson, Victor E.

Garrison, Everett J.

Finch, Walter M.

Spearman, Harry $\mathrm{H}$.

Sanders, Frank B.

Gronstal, Knute S.

Fuller, Merlin $\mathrm{H}$.

Bierman, Edward A.

O'Connell, John L.

Garlow, Samuel A.

White, Robert M.

Stevenson, Waldo W.

Limos, Walter P.

Hazen, John T.

Kuebler, Leon A.

Arendt, Daniel C.

Kerlin, Lloyd W.

\section{Corporals}

Tanner, Howard $\mathrm{H}$.

Schata, Karl D.

Redelfs, Lommert H.

Jindrich, George W.

Vanderpool, Merrill M.

Johnson, Carl A.

Smith, Vern

Johnson, Julius H.
Hedwig Weller

Viva E. Westerdahl

Grace E. Wilkinson

Connie Windmeyer

Irene L. Wishart

\section{ENLISTED MEN}

Creutz, Fred J.

Daugherty, James A.

\section{Cooks}

Alkire, Irvan D.

Bettencourt, Joseph L. Bullock, Willard E.

Fanton, Herschel A.

Kocum, Joseph

Koehler, Albert

McKellips, Ward

Potter, Laird I.

Rathke, Carl A.

Rohlff, Oscar B.

Stellate, Martin J.

Wright, James $\mathrm{H}$,

Privates, First Class

Almquist, Carl O. G.

Anderson, Oscar B.

Anderson, Paul F.

Arkin, Julis

Arnold, Edward S.

Austin, Jack W.

Baca, Harold W.

Bastian, Henry E.

Bauer, Peter L.

Blome, Ernest R.

Brown Joe R.

Buffington, George $\mathbf{M}$.

Burnham, Philip S.

Conner, Paul

Conrad, Paul E.

Copeland, Harold T.

Dally, Mike H.

Davies, Stanley B.

Davison, Almond D.

Drake, Marlin K.

Driver, George D.

Falck, Paulus F.
Dorothy Wooster

Ethel M. Wright

Laboratory Technicians

Eva F, O'Sullivan

Patricia L. Naughtin

Fitzgerald, Roger

Fluhr, Robert

Frew, James V.

Fuchs, Gustave O.

Goddin, Gilbert W

Grant, Richard S,

Hardy, William E.

Harrington, Lewis A.

Hauser, Byron T.

Henning, G. Russell

Housh, Charles R.

Hlair, Peter J.

Hunt, Loren E.

Hunter. James D.

Jewett, Lawrence B.

Johnson, Leland A.

Jungclaus, William N.

Jurgensen, Nohne C.

Kantor, Dominik B.

Kohn, Frank

Korach, Leo

Kraybili, Harold M.

Kring, Orlen R.

Lawric, Mason C.

Lesh, Charles W.

Little, Ralph B.

Loomis, Gilbert. C.

Loomis, Maurice M.

McCall, Henry B.

McClintick, Howard B.

McMillin, John $\mathrm{H}$.

Meadows, James W

Meduna, Lloyd R.

Morris, George E.

Munger, Alfred C.

Neal, John D.

Newcomb, Arthur P.

Nicholson, Clyde G.

Nilson, Nils G. 
Olson, Fred

Ostertag, Frank S.

Petersen, Alvin A.

Prouty, Edgar L.

Redells, John W.

Reese, Alfred I.

Rubin, Lewis A.

Ruth, Gordon A.

Rutherford, Charles

Schlosser, Cecil T.

Sherman, Rollin G.

Simanek, Edward J.

Steavenson, Leigh C.

Taylor, Harold H. R.

Truelsen, Emil E.

Vasina, Anton F.

Warshawsky, Morris M.

Wandborg, Carl M.

Wertman, Willard

Wetherbee, Harlow F. Privates

Akeson, James E.

Barbati, Phillip

Black, Benjamin $\mathrm{H}$.

Bowen, Charles R.

Bramon, Marcus D., Jr.

Brennan, Thomas J.

Browne, Jesse P.

Burley, Robert C.

Carlson, Carl

Carter, Guy D.

Connolly, Charles R.

Connolly, James J.

Czeslawski, Casimer

Dana, Irving $\mathrm{R}$.

Dillon, Edward M.

Ericksen, Edward M.

Frederickson, Vernie

Fuller, Edgar M.

Gallinger, Ralph

Garwyliw, Wasyl
George, Oscar

Gill, John P.

Graper, Frank

Hanson, Carl P.

Hash, Berthal R.

Heater, Olin

Herman, Walter T.

Hervey, David S.

Hickman, Hortie

Higgins, John M.

Hoaglund, Earnest A.

Hoffman, Paul H.

Hoffman, Wayne W.

Holbrook, Myron

Hopper, William N.

Hosking, Milton C.

Hoskinson, Joseph E.

Hrbeck, Cyril J.

Hugg, Thomas

Hull, Everett B.

Hutchison, William N.

Ince, Guss.

James, Louis A.

Jeter, Calvin D.

Johnson, Myron V.

Kenney, James

Kennon, Olen A.

Keyton, Russell S.

Kirshenbaum, Jacob

Klass, Henry

Koch, Earnest

Krafit, Arthur A.

Kugler, Earnest F.

Kuss, Joseph A.

Lang, Mathew S.

Lewis, Carl A.

Lewis, William B.

Lundholm, Martin C. O.

McGrath, Mathew P.

McNamara, Gerald A.

Minikus, Edward
Morey, Claris B.

Moylan, Joseph

Nelson, Jesse W.

Newman, Julius M.

Nystrom, Harry R.

Olson, Stanley O.

Parker, David W.

Payne, William N.

Peace, Charles P.

Peterson, Royal F.

Pierce, Russell K.

Purcupile, Benj. H.

Ramos, Frank

Reed, Sanford P.

Remillard, Louis O.

Reus, John

Rhodes, Frank V.

Robb, Howard H.

Roberts, Jack

Roberts, Harry Wi

Robertson, Richard

Roedel, John C.

Root. Ralph R.

Sauer, Lesslie E.

Schmitt, Henry J.

Scudder, Chas. R.

Shirey, Ralph W.

Sickinger. Chas. E.

Smith, Carl W.

Spiegel, Emil R.

Starkey, Roy D.

Stocktill, Henry B.

Swambom, Alaric R.

Way, Chester F.

Webb, Walter E.

Wegner, Andrew J.

Werner, Walter A.

Wohlner, Paul

Worley, Ivan $\mathrm{H}$.

Worrall, Lowell D.

Yard, Alfred G. 


\section{WAR SER VICE}

\section{Notes and Errata}

p. 153

p. 154

p. 156

p. 158

pp. 158-159
John E. Summers, Jr. See Nebraska St. M.J., [Issue honoring Dr. John Summers] 27:133-152, Apr. 1932.

Summers, J.E., The Modern Treatment of Wounds, Omaha: Medical Publishing Co., 1899.

Alva Sherman Pinto. See p. 160.

Banister, John M., "Lateral Lithotomy with the Successful Removal of a Calculus and Seven Pieces of Necrosed Bone from the Bladder of an Indian Scout Nineteen Months after the Redeption of a Gunshot Wound," Am. J. M. Sc., $80: 409-414$, Oct. 1880 .

- "The Radical Cure of Inguinal Hernia from the Standpoint of the Military Surgeon," Proc. of the Seventh Annual Meeting of the Assn. Mil. Surg. U. S., 7:478-496, 1897.

- "Hints in Relation to the Dynamics of the Extrinsic Oscular Muscles with Suggestions as to Treatment of States of Muscular Imbalance," Am. J. Ophth., 3:878-883, Dec. 1920.

- "A Plea for Conservatism in the Treatment of Frontal Sinus Affections," Eye, Ear, Nose, Throat Mon., 2:357-360, Aug. 1923.

Karl Connell. See U. S. Adjutant-General's Office. American Decorations. A List of Awards of the Congressional Medal of Honor, The Distinguished Service Cross and the Distin. guished Service Medal Awarded Under the Authority of the Congress of the United States, 1862-1926. Compiled in the Office of the Adjutant General of the Army and Published by Order of the Secretary of War. Washington, U.S. Government Printing Office, 1927, p. 690.

p. 160

A. S. Pinto. See Osler, Sir William and McCrae, Thomas, Eds., Moder Medicine, Its Theory and Practice. Philadelphia: Lea and Febiger, 1913, Vol. 1, p. 938.

p. 161

"Barnes is a graduate of the University of Nebraska and Cotner

and ..." should read "Barnes is a graduate of the University of Nebraska and Cotner University Medical Department and..." See pp. 311-313. 
p. 166

University of Nebraska Base Hospital. See [Sheldon, A. E.], Base Hospital 49, Nebraska History and Record of Pioneer Days. 2:2-5, Apr.-June 1919.

p. 170

“... John C. Moore and Clyde C. Moore..." Delete "... and Clyde C. Moore." 


\section{WOMEN PHYSICIANS}

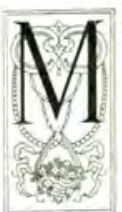

EDICINE was one of the first professional fields to attract woman when her emancipation from home duties only, began to be agitated. Perhaps it was because ministering to the sick was long her province. In scanning the list of early Nebraska women practitioners, it is interesting to rote that many of them were wives of physicians and many, also, mothers of large families, proving that a home and career are apparently compatible in this profession. Curously ênough too, several did not take up the study of mediçine until after their marriages . and rearing their childpen.....

Mrs. Sallie Dodge, according to Edwards' History of Richardson County, was the first physician there. A Mary Quick came to Richardson County, 1867, and was one of the leading physicians of the vicinity for twenty-five years.

Real pioneer honors - both in the profession and in the westbelong to Dr. Phoebe A. Oliver Briggs, native of South Danville, New York, who came west in 1872, when a young woman just out of the first class of the Women's Medical College of Philadelphia, to act as post doctor for the Otoe Indians at Maryville, Kansas. She was the only white woman among eight men and about 800 Indians.

Young Dr. Oliver (she married John S. Briggs, the post trader, later) first came to Nebraska in the Summer of 1873 with the Otoes on their annual buffalo hunt and was in western Nebraska at the time of the Indian massacre near the present site of Trenton, Nebraska. The Otoes' horses were all stolen at that time by the Sioux and the Otoes were left on the buffalo range, fat from home, on foot. While the men were out hunting for their horses, one day, a band of Sioux came into camp and proceeded 


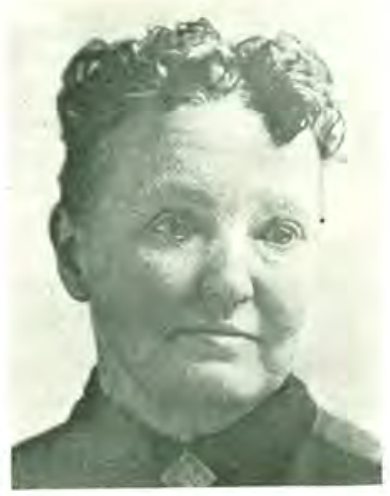

PHOEBE A. OLIVER BRIGGS

to gather up the blankets and whatever else was lying around handy and loose.

The young white doctor minced no words with the intruders. She just walked up to the first Indians and jerked her blankets away from them and, womanlike, shooed them out of camp! They left her unmolested, probably more awed than she was frightened.

There are many other stories of the brave young woman doctor, in which she showed equal courage, according to Dr. R. D. Green of Beaver City, who gathered much of the available data regarding Dr. Briggs from her nephew, W. T. Collings of Beaver City, himself an old plainsman.

Later her fame grew so among the Sioux that she was invited to one of the tribal feasts and was escorted there by none other than Wisler, the Sioux war chief. He presented her with a ring, now in the possession of Collings.

It was on this memorable hunting trip with the Otoes that Dr. Briggs and her husband, highly impressed with their first introduction to Nebraska, decided to cast their lot with the new country. On returning to Brownsville, they resigned their government appointments and the next year took up land under the homestead law in Furnas County, settling about seventeen miles southwest of the present site of Beaver City, in the Sappa Creek valley.

Dr. Briggs was the first physician to locate in Furnas County and was for several years the only doctor in southwestern Nebraska and northeast Kansas.

Her feats in practice were most remarkable for courage and endurance. She made trips of 100 miles or more on horseback, in all kinds of weather, over all sorts of roads or no roads at all, whenever called, collecting for her services whatever she could, or nothing at all. She was a competent practitioner, if stories are true, both as a physician and in surgery, such as it was. When needed, she even stayed and nursed her patients for days at a time. 
Dr. Briggs weathered all the pioneer catastrophies, droughts, grasshopper plagues and Indian scares, with other early Furnas County settlers and continued her practice in the vicinity of Beaver City and Norton, Kansas until about 1895 when she and her husband moved to Troy, Kansas, where he died in 1910. She then returned to her old home in South Danville, New York, where she died in 1922 .

Additional data regarding Dr. Briggs gleaned from the History of Norton County, Kansas, does not coincide altogether with the information given by her nephew, Wr. T. Collings. The Kansas record gives her residence in Furnas County, Nebraska only from 1879 to 1884 . According to this data, Dr. Briggs was born in Rockford, Illinois, Octobed 6, 1841 and was educated in Union Seminary at Rogersville, New York. She was teaching school at the age of fifteen. In the summer of 1866 she went into a drug store in Philadelphia, at the same time continuing the study of medicine. She entered the first class of the Female Medical College in October and received practical instruction in the Women's Hospital. From September, 1867, to September, 1868, she was junior assistant at the New York Infirmary for Women and Children under Dr. Elizabeth Blackwell, the first woman to receive a diploma from a regular medical college in the Lnited States.

The next year, Dr. Briggs was admitted to lectures in Bellevue and Charity hospitals, took a course in practical anatomy and received a certificate in chemistry in the free night scientific lectures at Cooper Union. A little later she was senior student assistant in the New England Hospital for Women and Children at Boston; was admitted to lecture in the Massachusetts General Hospital; to Lowell courses in anatomy and practical chemistry in the Institute of Technology and a course in the Boston Society of Natural History.

All of the above is related to show with what pertinacity the young woman pursued every chance to obtain a scientific education. Against what odds can be realized when it is known that this pioneer Nebraska doctor was a member of the class of 39 women who were so disgracefully received at the Pennsylvania Hospital on November 6, 1869, after they had registered in the Women's Medical College. 
The decision to admit women having been published, male students from all of the medical colleges in Philadelphia gathered in the amphitheatre until there was no standing room left, hissing and yelling and making worse demonstrations. When adjourned, they flew to the exits, formed in line and compelling the women to take the car track, marched them down Chestnut street.

It took more than this adverse demonstration, however, to discourage the courageous women and the first class, of which Dr. Briggs, then Oliver, was a member, was graduated in March, 1870. She then served as assistant physician at the hospital until 1871 when she accepted an appointment by the Society of Friends of Philadelphia to be physician to the Otoe and Missouri tribes of Indians. Her appointment was approved by A. L. Green, U. S. Indian agent and Samuel Janney, superintendent of Indian Affairs on April 30, 1872.

Some records give this date too as the day of her marriage to J. S. Briggs, Indian trader, in the Otoe agency school house, with the Otoe tribe, to whom Briggs gave a feast, as the guests. But Dr. Briggs' nephew, W. T. Collings, asserts there is a mistake in the date, as the couple did not meet until the young doctor's arrival at the post. It is within the range of possibility, however, that the couple may have met in the east and that there was a romantic reason behind the doctor's seeking a western appointment, her wedding taking place the day she arrived.

Her first patient, according to record, was $\mathrm{W}$. E. Case, who was sick at Mott Woods dugout. Dr. Briggs was also a guest at the first wedding in Norton County, the only other guest being one Dick Felton. The wedding repast included ham, coffee and corn bread, Dr. Briggs furnishing the ham and coffee.

A child was born to Dr. Briggs and her husband on September 19. 1881 in the Maternity Hospital at Philadelphia (apparently during a visit to the east) but the child, whom they named Clara Ray, died of diphtheritic croup October 30, 1889, at Troy, Kansas.

The death of her only child renewed the doctor's zeal for service to suffering humanity, the darkest nights and the severest blizzards never causing her to falter for one moment in answering the call to duty. 
Sharing many of the same pioneer hardships in a new country although the Indian peril had been eliminated, was young Dr. Georgia Arbuckle (later Fix), of Scotts-

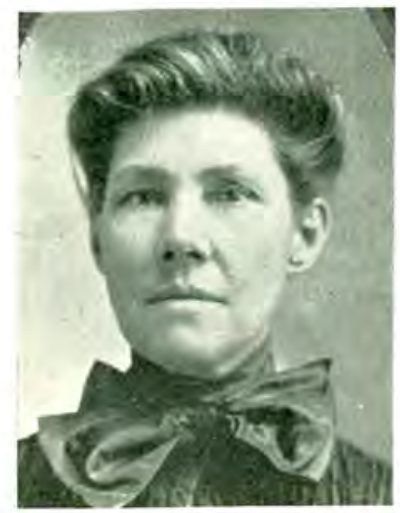

GEORGIA ARBUCKLE FIX bluff, who enrolled in the first class of the Nebraska School of Medicine, preparatory, in 1880, and was graduated from this institution, which became the Omaha Medical College, in its first class in 1883. After practicing in Omaha about a year, during which time she was given the recognition of clection a: vice-president of the Douglas County Medical Society, Dr. Arbuckle homesteaded on a tree claim in 1886 in Scottsbluff, in the sparsely settled western part of the state where she found herself seventy-five miles away from any other doctor in the North Platte Valley.

Left an orphan in Mercer County, Missouri, where she was born, and thrown on her own resources at an early age, the young physician's life seemed mapped out for strength and courage and all the virtues of hardihood which, together with the exigencies of her situation, developed in her unusual skill as a surgeon.

The young woman made many long and lonely rides traveling through the sand hills and fording the treacherous North Platte river and was fairly idolized by the lonely ranch women whom she understood, perhaps pitied, and whom she befriended, as well as she cared for them in sickness.

"Dr. Fix is most surely entitled to a place in the medical history of Nebraska," wrote Dr. Frank W. Plehn of Scottsbluff. "Under most strenuous conditions, often enduring great hardship, she was a helper and friend indeed to the early settlers of the Valley. She is borne in greatful memory in the minds and hearts of many of the 'elders' of this region. Not one but gives her credit for the greatest energy and courage, as she was ever conscious of her duty to those who depended upon her, without thought of personal comfort or emolument." 
In 1888 she was married at old Fort Sidney to N. Guin Fix and the couple began their home life at Minatare, soon after moving to Gering, where Dr. Arbuckle-Fix opened a private sanitarium. She was active in procuring a library and other modern features for the town. She was also active in church work and in 1908, was elected delegate to the great Pan-Anglican Episcopal Congress in London. She died in San Diego, California, July 26, 1918.

Pioneer colleagues agree that her professional record was a remarkable one for a woman, in those days.

Mrs. Sackett C. Case, wife of a Nebraska City physician, is also named among the early women practitioners. She is mentioned, in one record, as tending the sick in 1872. A son, Ernest S. Case, was a physician in Stockville, Nebraska. Another instance of mother and son practitioners was Dr. Jennie Foster and her son, Wendell Foster, of Plattsmouth. Mrs. Foster came there in 1881 and enjoyed an extensive practice until her death in 1887.

The first record of a woman practitioner in Omaha discloses Amelia Burroughs, a homeopath, who moved to this city in February, 1883, from Council Bluffs, where she had been in practice for a year or more. A half dozen or more quickly followed in the remainder of the decade, most of them also homeopaths. State board of health records for December 1, 1892, when all were required by law to register, show 56 women licensed to practice in this state. This fact is a surprising one, to all whose attention has been called to the fact, as it far exceeded the impression of even the best informed medical men in the state, today.

Dr. Gertrude Jones-Cuscaden is the only surviving pioneer woman physician in Omaha, for she came here in 1884, as did Dr. Mary J. Breckenridge, who died in 1924. Dr. Cuscaden was a regular, and Dr. Breckenridge a homeopath. Both women exemplified the fact that home-making and motherhood were compatible with the practice of medicine, for both of them reared large families, the children of which became prominent in professional and artistic circles here.

Dr. Cuscaden was born near Chillicothe, Ohio, May 20, 1849, of distinguished ancestry and attended the country schools only three or four months a year until September, 1865, when she entered Ohio Wesleyan College at Delaware, Ohio, for a five years' course. 
She wanted to study medicine, even at this early age but the family opposed it so strongly that she taught school instead, but mana ged to read medicine with Dr. T.

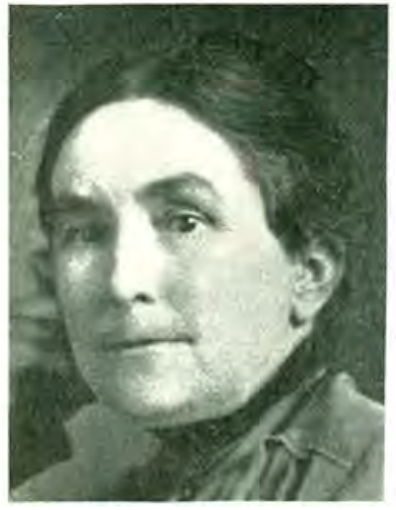

GERTRUDE JONES-CUSCADEN B. Williams, a leading physician, at the same time. In 1872, the young woman won her father's consent to attend the University of Michigan Medical college from which she was graduated in March, 1874, as a doctor of medicine; and in June, the same year, as pharmaceutical chemist. She interned in a Boston Women's and Children's hospital and then returned home to practice medicine from 1875 to 1884 . That year Dr. Jones married John A. Cuscaden and the couple came to Omaha to make their home. One son, Alexander Cuscaden, is a California newspaper man of prominence. Another son, Robert, is a talented Omaha violinist who studied abroad and now plays with the Omaha Symphony orchestra.

Mary Foster Breckenridge, wife of Charles F, and mother of the late Ralph II. Breckenridge, both prominent Omaha attorneys, did not bagin the study of medicine until her sixth child was two

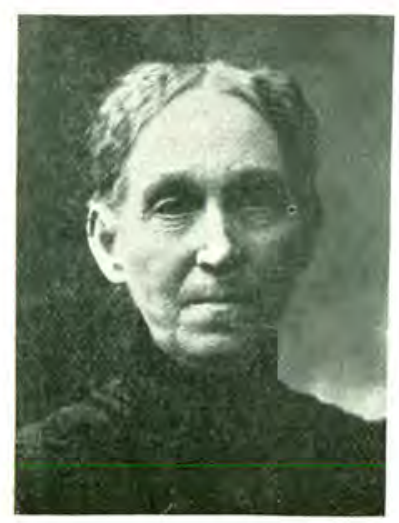
years old. Then she committed her baby to the care of her eldest daughter and left for Hahneman College, Chicago, where she obtained her doctor's degree. Returning to Omaha she built up one of the largest practices ever held by any woman physician, and because of her wonderful character and personality, endeared herself to her large following for over 25 years. She then gave up her practice to accompany her husband, who was ill, to California. Dr. Breckenridge was a native of New York but MARY FOSTER BRECKENRIDGElived in Milan, Ohio, where she was married in her youth. They lived in Cresco, Iowa, and Grand Island, Nebraska, before settling in Omaha, December 1, 1884. 
Something of what these frail pioneer women physicians endured is further indicated in the March, 1928 issue of the American Magazine, which featured Dr. Harriet Goodman Kurtz McGraw of Tryon, only

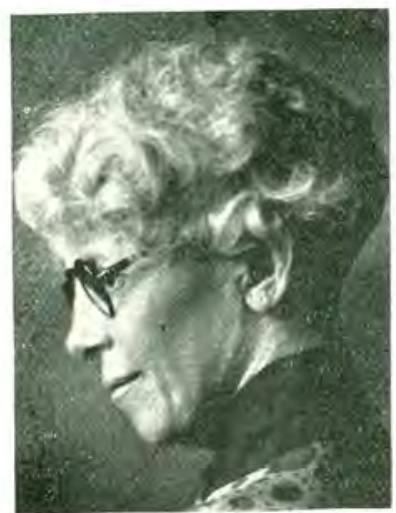

HARRIET G. K. M'GRAW physician in the whole of McPherson County, which includes a territory of 800 square miles.

Going west for her health after working her way through the Lincoln Medical College, Mrs, McGraw battled loneliness and prairie blizzards for eight years until she won the complete confidence and admiration of every one in the county, where she is now health officer. Her husband, Joseph McGraw, the only lawyer, is county attorney.

"Ask any rancher or cowboy or sand hill farmer-men whose broken bones she has set, whose cuts she has sewed by lamplight, whose wives and children she has doctored and nursed and saved-ask them of her. They will tell you that 'the Doc's all right, even if she is a woman,' and more than one will add with respectful emphasis, that she is the best doctor in Nebraska," "according to the magazine tribute.

Dr. McGraw formerly practiced in Chicago and in Lincoln, Nebraska, in 1918 .

The record of Dr. Susan La Flesche Picotte, Indian woman physician who founded the hospital at Walthill, was given in the opening chapter.

Other women physicians in Omaha in the 80 s were Doctors Eleanor S. Dailey, graduate of the Women's Medical College in 1878, who came here in 1886 and Emma J. Davies, graduate of Hahnemann College, Chicago, who also came the same year. In March, 1888, the latter's mother, Dr. H. B. Davies, moved here from Nebraska City and joined her daughter in partnership. Another woman physician, Freda M. Lankton, graduate of Iowa State University at Iowa City, joined her former preceptor, Mrs. Burroughs, here in May, 1888. 
Metha Helfritz Jonas, wife of Dr. August F. Jonas, came to Omaha as a bride in 1889, the year of her graduation from the Women's Medical College at Chicago. She specialized in diseases of women and few, if any, could excel her as assistant in the operating room, or in microscopy, according to an account in the Western Medical Review, when she died, October 28, 1895, in Baltimore. She was born in 1857, attended the University of Iowa, and taught school before beginning the study of medicine. She also served as secretary of the Omaha Medical Society in 1894.

The name of Mary Strong also appears in the Omaha Medical Society records of that year.

Dr. Sophonia Lane, wife of Dr. Milton Lane, practiced with her husband in Lincoln in the carly '80s, helped organize the first Lincoln Medical Society and was its secretary for several years. She was a graduate of the Northwestern University Women's Medical School and did considerable surgical work together with her husband. According to Dr. Marie Lois Grote of Lincoln, who knew her, Sophronia Lane was a lovable woman, possessing a remarkable mind. She was especially interested in selecting, encouraging and helping young women embarking upon a medical career and a lasting credit to the women in the profession. After her husband's death, Dr. Lane was for a time on the staff of the Lincoln State Hospital and later moved to Ohio to live with a daughter.

Dr. Grote, mentioned above, practiced in rural districts for 23 years, the only woman doctor to continue country practice for so long a period.

Dr. Charlotte Norton, pioneer physician in Lincoln from 1886 to 1893 , pursued her medical career against the greatest obstacles. Left a widow with two small children to support, Mrs. Norton decided to study medicine, as she had always wanted to do, even though she was past forty at the time. None of her family approved of women doctors so they refused to help her. Finally an old family friend loaned her enough to go to college. Taking with her a family servant who would not leave her in her adversity, Mrs. Norton settled in Ann Arbor, engaging one room, and entered the university. Sometimes oatmeal and milk was their only food. Sometimes she had to take one or both of the children to class with her. And 


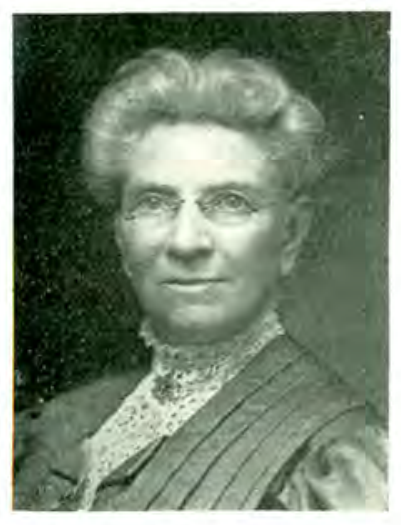

DR. CHARLOTTE NORTON

then she became very ill with typhoid fever, but in spite of all this, Mrs. Norton finished the four year course in three years and was graduated in 1885. A year's interneship in the New England Hospital at Roxbury, Massachusetts. preceded her residence in Lincoln, where she began her practice in 1886, numbering among her patients, the family of William J. Bryan. Her sister, Sarah Woll Moore, was then head of the art department in Lincoln schools, serving from 1884 to 1892 .

In 1893 Dr. Norton moved to Florida where she was resident physician in a sanitarium on the Indian river. Her outside practice took her miles up and down the river, which she traveled by sailboat, as the roads were very poor. Both in her practice in the west and in the south she was called out at night to travel through blizzards or torrential rains, through sticky clay roads or dry, sandy ones, but her self sacrifice and her devotion to her work never failed, according to her daughter, Christine Hazel Norton, now a teacher in Brooklyn, New York schools. One morning, having been on a case all night, she was driving home behind a half-broken colt which ran away, threw her out and dragged her for some distance. She lay at the point of death for a long period but recovered, dividing her time thereafter between Brooklyn and Florida, where her son Christopher lives at Merritt's Island. She died there December 25, 1923, at the age of eighty-three.

Dr. Norton was a woman of culture and refinement, a member of Sorosis, the Woman's club of Lincoln at that time. Her kindness to young physicians was especially marked.

Mary Ryerson Butin, wife of Dr. S. L. Butin of Dorchester, was practicing there in 1888. Mrs. Butin was the only woman doctor elected first vice-president of the state medical association and presided at a session in 1888 with such grace and power that the men commented on it most favorably. Dr. Inez Philbrick of Lincoln was named second vice-president of the state society in 1900 . 
The late Dr. Julia C. Starr, resident of Beatrice, Nebraska, ior 44 years, did not study medicine until after her second marriage in 1879, to Dr. Calvin Starr, a widower of Muscatine, Iowa. She then took up the study, first with her husband and later in the homeopathic department of the Iowa State Medical College. The couple then moved to Beatrice in 1883 where both of them practiced until his death in 1914. She died June 8, 1927 at the age of eightyone. Her skill and faithful ministrations were highly extolled at that time.

Dr. Starr's early life was full of pioneer adventure. Born in Muscatine, January 20, 1846, Julia Cornelia Candee, she was first married to Horace Scudder in 1866 and with him set out for their wedding journey to Denver, Colorado, in a stage coach. Two sons, Sheldon who died in infancy, and Horace, well-known in Beatrice where he was prominent until his death in 1906, were born of this union. The elder Scudder died in 1876, which occasioned her return to her home town. She was the last survivor of all her family with the exception of three children of Dr. Calvin Starr.

Eleanor Capitola Reed, of a medical family, is a pioneer practitioner in Peru, Nebraska, where she settled in 1887. Dr. Reed is a graduate of the Woman's Hospital Medical College of Chicago in 1885 and practiced for one year in Fort Worth. Texas, before settling in Peru. Dr. Reed was born in Cass County, where she practices, and where both her father and uncle were early practi-

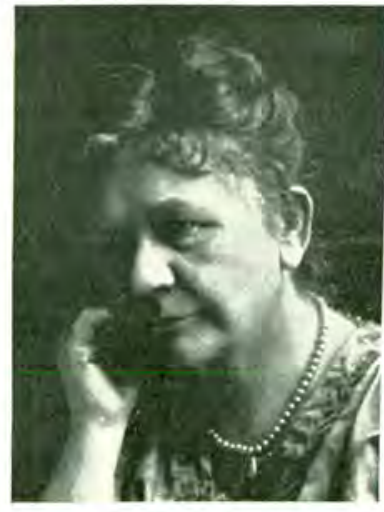

LENORE PERKY WEBSTER tioners. They suggested that she study medicine.

The Nebraska Orthopedic Hospital in Lincoln is a monument to another outstanding pioneer woman practitioner, Lenore Perky Webster, wife of Joseph R. Webster of Lincoln. Lenore Perky, born in Ohio in 1857, was the daughter of Dr. J. F. Perky, a Civil War veteran who moved to Lincoln in 1880 . Four years later the family moved to Wahoo in Saunders County where Lenore went into the photograph business, and began to read medicine. She was graduated 
from the Hahnemann College in Chicago in 1890, after which she helped her mother open the state industrial home for girls at Milford, where Mrs. Perky was matron. The young woman physician practiced a short time in Fremont and then moved to Lincoln, where in 1897, Governor Holcomb appointed her physician to the Home for the Friendless. She served until 1901. Here began Dr. Perky's interest and work for the crippled which culminated when she read a paper before the Nebraska State Homeopathic Convention in Omaha in 1904, which so stirred the membership that the convention made her chairman of a legislative committee which drafted a law providing for a state orthopedic hospital and lobbied it through the next session of the legislature.

Dr. Perky continued her practice in Lincoln - the W. J. Bryan family among her patients - until November 29, 1906, when she was married to J. R. Webster, an attorney, and they are now living in Washington, D. C. She was active in suffrage circles.

Another Lincoln physician of the early '90s was Louisa Boyer Smallwood MacDonald, graduate with honors of the Women's Medical College of Pennsylvania at Philadelphia in 1889. Dr. Smallwood was born in Canada in 1848 and since childhood evidenced a desire to study medicine. She served a year as assistant physician in the Philadelphia Women's Hospital before she came to Lincoln, to practice with marked success until 1907. She had been married in 1884 to Alexander Smallwood and a daughter was born to them. His death, shortly after, induced her to take up her medical work. In 1894 she married Norman A. MacDonald, whose son still lives in Lincoln. She died in 1919 after a long illness.

Lina M. Rosat, educated in Switzerland and in this country, and a member of the school board in Grenville, Illinois, before she moved to Lincoln, has practiced there 19 years.

"The first time I attempted to use the forceps to deliver a woman in confinement was in 1895," said Dr. Rosat, describing some of the situations the early women doctors met. "It was a first confinement and the woman was thirty years old. She was progressing nicely when all at once she fainted and I found myself in a 


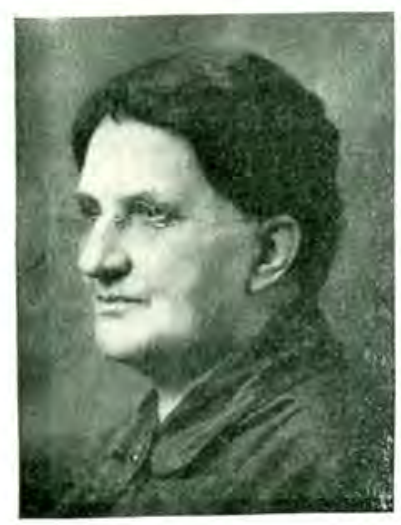

LINA M. ROSAT

bad predicament ten miles away from any other doctor. I thought at once that there was a detached placenta and the only thing to do was to apply the instruments, which I did and brought a fine baby girl 'alive.' As I suspected, placenta and clots of blood came after the feet. The mother had recovered consciousness and made an uneventful recovery. It was hard on the nerves but a woman doctor must have a good supply of nerves and initiative if she wants to succeed."

Dr. Rosat now specializes in electrotherapeutics.

Then came the law of 1891 , requiring all physicians in the state to register before December 1, 1892. Records of the state board of health for that year disclose the 56 women practitioners registered under the law. In the 30 odd years that have intervened the list has barely doubled itself, indicating that the appeal to enter the medical profession is not so great, in the present day, apparently, as it was in the early ' 80 s.

The women who registered in 1892 and their place of residence follow:

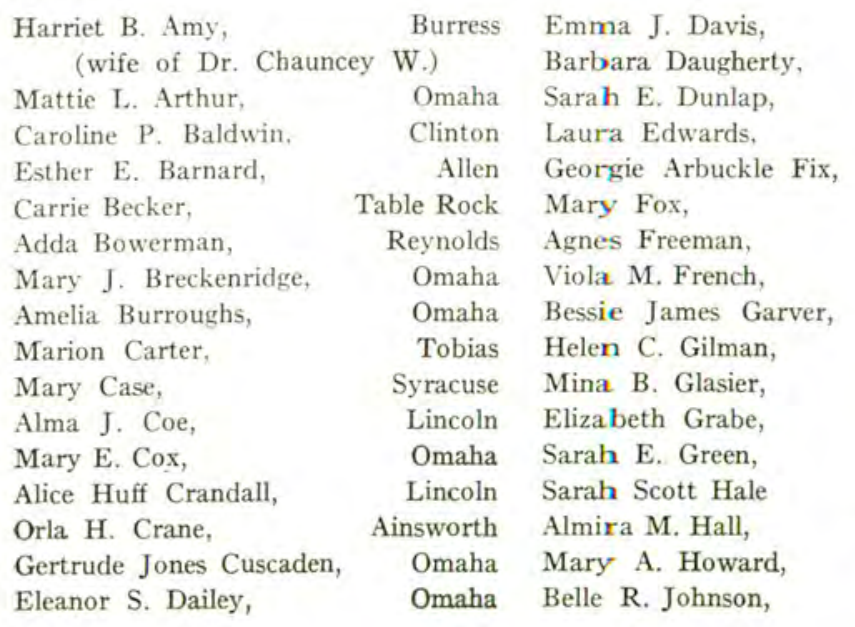

Omaha

Lincoln

Albion

Hastings

Gering

Table Rock

Beatrice

Plattsmouth

Pender

Hemingford

Omaha

Beatrice

Lincoln

Edgar

Broken Bow

Hastings

Randolph 
Metha Helfritz Jonas,

M. Addie Kester,

Elizabeth B. King,

Sophronia M. Lane, (wife of Thomas H.)

Freda M. Lankton,

Hannah C. McCahan,

M. Josephine McChesney,

Mrs, E. H. Birch Mills, (wife of George M.)

Charlotte M. Norton.

Eleanor C. Reed,

Margaret L. Sabin.

Lizzie White Sawyer,
Omaha

Lincoln

Du Bois

Lincoln

Omaha

Axtell

Osceola

Kearney

Lincoln

Peru

Lincoln

Sparks
Margaret E. Simmons,

(wife of George H.)

Louise B. Smallwood.

Lincoln

Mary M. Song,

Julia C. Starr,

Omaha

Beatrice

(wife of Calvin)

Ora S. Stephensen,

Bennington

Emma Watkins Stever, Juanita

Nancy J. Stewart, Spring Bank

Agnes D. Swetland, Omaha

( wife of James M.)

Mary E. Tanner,

Mary H. Upjohn,

Omaha

(wife of Dr. Wm. C.)

Sylvia M. Ward,
Papillion

Lincoln

Following the licensing law, the class of 1894 of the Omaha Medical College was distinguished by a group of seven women students: Mrs. Emma Warner DeMaree; Mrs. M. A. Quincy; Ella P. Summer, Mary L. Tinley, now practicing in Council Bluffs, Iowa; Dora M. Judkins of Hastings, who married a Dr. Davies, who later died; Mrs. M. Mead and Mrs. M. M. Van Nuys.

Emma Warner DeMaree served on the school board of Roca, Lancaster County, where she practiced from 1895 until her retirement, eight years ago, and was the mainspring of community life and politics in the little village. She was the daughter of Dr. Warner, pioneer physician who settled in Roca in 1864 and married a physician, H. C. DeMaree in 1881. Two children born to them died in their childhood, after which she decided to enter Northwestern Medical School at Chicago. She then joined her husband in practice until 1921, when she moved to Buhl, Idaho.

Dr. Emma DeMaree's mother, Mrs. Esther Warner, was an unusual woman who gave the address for women farmers at the Washington meeting of the National Council of Women in 1888. Her husband was killed in a runaway accident, after which she managed the farm herself.

Lincoln, the capital city, boasted a number of interesting women practitioners in the '90s. Among them were Ruth Wood and Margaret Sabin, a homeopath, whom older residents recall in connection with a big white horse she always drove. Dr. Sabin had a large practice and was active in suffrage circles. Another was Georgiana 
Grothan, divorced wife of Dr. Ole Grothan, now of St. Paul. Dr. Georgiana Grothan was said to be a beautiful woman. She had a private hospital in Kearney, which is now the state tuberculosis hospital. Still another was Margaret Simmons, first wife of Dr. George H. Simmons, for many years editor of the Journal of the American Medical Association. They too were divorced and he remarried.

But the outstanding woman physician in Lincoln, as she is in the state, by common agreement of both men and women in the medical profession, is Dr. Inez Celia Philbrick. She is in general practice, chiefly obstetrics, and is in charge of the women students' dispensary and health work at the University of Nebraska, where she teaches sex hygiene and nutrition classes.

Dr. Philbrick is a leader in public life, not only among women, for whom she headed a successful suffrage campaign as president of the Nebraska Women's Suffrage Association, but in social service, educational circles and politics. She is

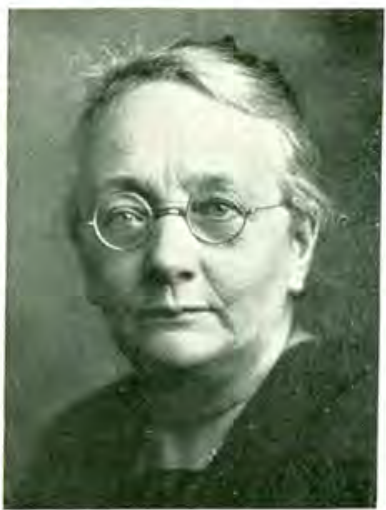

INEZ CELIA PHILBRICK on the board of many charitable organizations, secretary of the Lincoln city library board and chairman of the Woodrow Wilson Foundation. Dr. Philbrick organized the first medical women's club in Lincoln, as well as the state medical women's organization, a n d served as first president of each. Besides all these activities, she has educated a girl protegee through the university; finds time for many a quiet, good deed which none but the recipient knows and sometimes not even he or she; and finds time also to write many splendid articles for medical societies, journals, and for other organizations. She is a graduate of the Women's Medical College of Philadelphia in 1891 and has practiced in Lincoln ever since. She is also active in the Unitarian church.

Always zealous for the interests of women in the medical profession, Dr. Philbrick believes they are, on the whole, better fitted for public health work, rather than general practice. 
"Women are not adapted for commercial medicine," is the way she expresses it. She is a warm advocate of state medicine, has written many papers and spoken in its favor, and is strongly of the opinion that state medicine is the next development of the profession.

Other women practicing in Lincoln in 1907 when a second attempt to organize proved successful were Eva Shivley of College View, now of Osceola; Lyra H. George; Hallie Ewing, then at the state hospital; Daisy Hanson; Mabel Dunn; Amy R. Humphrey, Laura J. Brown, who was elected president; and May L. Flanagan of Green Gables, now president of the

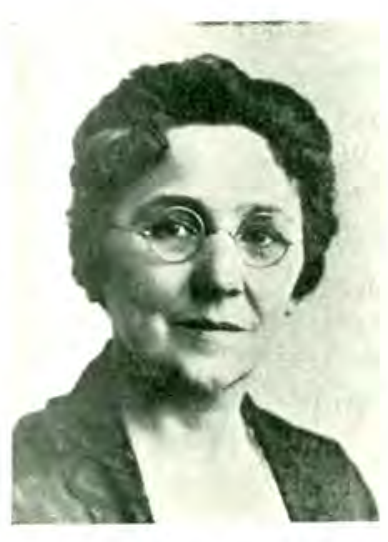

KATHERINE BRANDT WOLFE Lincoln Altrusa Club. Dr. Flanagan was at first, physician at the Home for the Friendless but has been at Green Gables for 27 years. She is ex-president of both state and Lincoln medical women's societies.

More recently added to the Lincoln profession is Ruth Ashley Warner, now president of the Lincoln medical women; resident physician at the state agricultural college and for women students at Wesleyan, where she is also instructor in hygiene; and Margaret Hammond, secretary of the Lincoln society.

A fine record as supervisor of school health in the Lincoln public schools belongs to Katherine Brandt Wolfe, who was appointed to this post in 1918 and served seven years. Dr. Wolfe introduced nutrition work in the Lincoln schools, established the first free school clinic for the removal of tonsils and adenoids and correction of eye defects for children of poor parents; carried on successful campaigns against trachoma and tuberculosis and brought about many reforms in school architecture.

Dr. Wolfe, then Miss Brandt, was graduated from the Women's Medical College in Philadelphia, her home city, in 1887 and practiced for two years in San Luis Obispo, California, until her marriage in 1889 to Professor Harry K. Wolfe of the University of Nebraska. She practiced her profession in Lincoln at intervals until her husband's death in 1918, after which she was appointed to the Lincoln 
school post. She has three children: Isabel, wife of Professor Ansel Hemenway of the University of Arizona at Tucson; Katherine, first assistant in the department of Physical Education in one of the Seattle High schools and Harry, senior in the University of Washington, specializing in architecture. Dr. Wolfe now makes her home in Seattle. She has written numerous papers for medical and school publications.

With less years of practice in Nebraska to her credit than Dr. Philbrick, but having achieved international recognition for her post-war service is Dr. Olga Stastny of Omaha, designated as

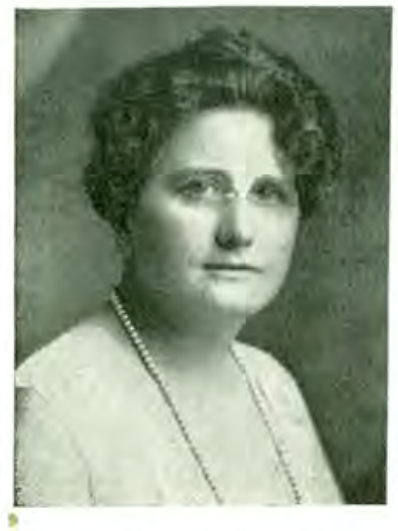

OLGA STASTNY the "heroine of that hour" by Dr. Esther Pohn Lovejoy, chairman of the American Woman's Hospitals, in her recent book, "Certain Samaritans," published by MacMillan Company. Dr. Lovejoy referred to the time of the Turks' banishment of the Christians.

"The presence of Dr. Stastny had more influence in quelling disorder than the Greek military guard," was her tribute to the plucky war worker from Nebraska.

The story of the stately Omaha woman physician's career reads like a thrilling bit of fiction. Born of immigrant parentage, one of nine children, in the little Czech stronghold of Wilber, Saline County, Olga Sadilek was equipped with only a high school education when she married Dr. Charles S. Stastny, a Wilber dentist. Two children were born to them when he died suddenly at the age of 28 .

Left with two children to support, young Mrs. Stastny decided to follow an early leaning toward medicine. With her little life insurance money, she registered in 1908 for the pre-medic course at the University of Nebraska, making up a necessary year of high school and preparatory work before she was finally graduated in medicine from Omaha Medical College in 1913. After a year's internship in the New England Hospital for Women and Children in Boston, Dr. Stastny hung up her shingle in Omaha in 1914, built 
up a large practice among her own nationality and was active in local war work, when she enlisted in Unit No. 1 of the American Women's Hospitals. She served first in France, then in Czecho-Slovakia and after the great Smyrna fire was sent to lonely Marconissi Island, off the coast of Greece, to establish "medical order" among hordes of Greek and Armenian refugees fleeing from the Turks, out of Asia Minor.

One lone woman on an island which had never before been inhabited! No trees, village or town, except the remnant of an attempt to establish a quarantine station a few years before. Scant food or medical provisions and the knowledge of thousands to come, needing medical attention! Later she had seven civilians and 26 soldiers to help.

Here was a situation to fairly stampede a whole medical organization. But not one indomitable Nebraska woman. Her splendid handling of the situation is what Dr. Lovejoy records in her now famous book. It was an heroic achievement in the annals of medical relief work.

"Before more than meager rations and equipment for caring for the refugees had been provided on the island, a pest ship with normal carrying capacity of about eight hundred persons brought to the island nearly 5,500 men, women and children," Dr. Stastny related. "You can imagine what a horrible sight it was. They were literally packed like sardines on the ship, and those who were not suffering from typhus and small pox were weak from lack of nourishment. Because of our limited equipment, we began landing them a few at a time-taking the more healthy first. It just seemed an impossible task to care for them all. We had only a limited supply of water, milk and bread, and all we had to eat for five days was beans.

"Finally, I was sent 250 soldiers to keep order, we segregated 415 cases of typhus and 135 of smallpox in our makeshift hospitals. Truly it was the survival of the fittest. I often thought it would be a blessing if none of the refugees were saved, because I saw no future for them. But later we had 40 nurses, six doctors and 220 workers on the island, and five months after I arrived there, we had cared for nearly 12 thousand people."

For this service Dr. Stastny was rewarded with the Cross of St. George, conferred by the Greek government. Her unit of the American Women's Hospitals in Luzancy, France, was also awarded 
the Medaille de Reconnaissance. She then, at the request of Dr. Alice Masaryk, daughter of the president of the Czech republic, engaged in Y. W. C. A. work in Prague, establishing soup kitchens and child medical stations. Then, under the Young Men's Christian Association, she undertook the unusual and difficult task, for a woman, of giving health and social hygiene talks to men in 43 soldier camps, speaking to groups of 600 to 700 men at a time.

"Talk to those boys as if you were their mother," was her only instruction, and she did.

"I appealed to them as citizens of a new republic who were expected to return to civilian life with vigorous bodies and clean minds and I appealed to them as potential fathers who must safeguard the welfare of their race," said Dr. Stastny.

Tragedy entered Dr. Stastny's life when her only son, Robert met death in an airplane accident in the summer of 1921 when he and other relatives journeyed to Prague to join her there for a visit. Dr. Stastny met the blow like a true soldier, only redoubling her efforts for suffering humanity.

She remained abroad until she completed her sixth year of labor in reconstruction of the war-ridden peoples of Europe, returning to Omaha and resuming her practice in 1924. Today her practice is not limited to her own people, and she is much in demand as a public speaker.

Dr. Mary L. Upjohn, who died in November, 1927, in Sierra Madre, California, practiced at Papillion for many years and in Omaha for fifteen years with her husband, the late Dr. William C. Upjohn. Both were graduates of the University of Michigan. They were in general practice until their retirement and removal to California. Dr. Upjohn was 75 at the time of her death. A niece, Mrs. Fred Rohring, is the only Omaha relative.

The most recent list of women practitioners in the state includes:

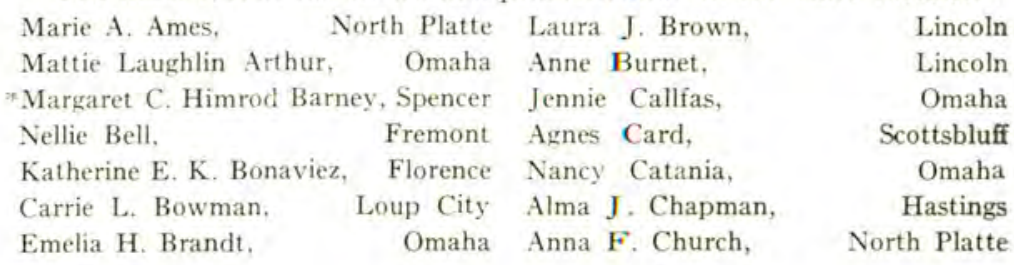


Frieda Clark,

Martha E. Clark,

Lillian E. Coates,

Anna M. Cole,

Susan R. Cooper,

Anna M. Cross,

Clara G. Cross,

Gertrude Cuscaden,

Eleanor S. Dailey,

Dora M. Judkins Davies, Tecumseh

Ida P. Davis,

Nellie G. C. Deffenbaugh, Fairmont

Emma W. Demaree,

Sadie C. Doran,

Grace M. Bliss DuVall,

Emma M. Easterday,

Dora B. Eckles,

Hallie L. Ewing,

Nora M. Fairchild,

Jean P. Fease,

May L. Flanagan,

Alice W. G. Graham.

Marie Lois Grote,

Anna M. Griffith,

Bess Hasom Hahn,

Margaret E. Hammond,

Daisy M. Hansen,

* Clara M. Hayden,

Edna E. Heeren,

Mary A. K. Hendrickson,

Etta E. Hewett,

Abby Virginia Holmes,

Stella F, C, Jacobi,

Agnes M. Johnson,

Agnes H. Jones,

Sarah B. Kalar,

Alace M. Kani,

Mary Kirkwood,

Margaret W. R. Koenig,

Vera M. Lee,

Cora Dell Lindberg,

Harriet L. Lindt,

Johanna E. Logan.

Elizabeth C. Lyman,

Delia A. Lynch,

*Louisa B. S. MacDonald,

M. Josephine McChesney, Isabel McDonald,
Omaha

Omaha

York

Minitare

Aurora

Crawford

Omaha

Omaha

Omaha

Syracuse

Roca

Falls City

Steele City

McCook

York

Lincoln

Omaha

Franklin

Lincoln

Lincoln

Lincoln

Omaha

McCook

Lincoln

Lincoln

Ingleside

Carroll.

Loup City

Bristow

Omaha

Omaha

Neligh

Greenwood

Bloomfield

Omaha

Lincoln

Lincoln

Omaha

Ord

Omaha

Central City

Omaha

Omaha

Lincoln

Osceola

Lincoln
Harriet Goodman K u rt z McGraw, Tryon

Ethel M. McKinley,

Oconto

M. Martha McVean, Nebraska City

Anna M. Mares,

Omaha

Bessie P. Mason,

Omaha

Hilma C. Swanson Miller, Omaha

Marie H. Morse,

Wisner

*Elizabeth B. K. Munson, Waterbury

* Minerva M. Newbecker, Ord

Marie A. Nielson, Blair

Lorene Painter, Lincoln

Edna Smith Pells, Grand Island

Inez C, Philbrick, Lincoln

Ada Platz,

Madge J. Potts,

*Mary A., Quincy,

Eleanor C. Reed,

Amy R. Robinson,

Lina M. Rosat,

Margaret L. Sabin,

Charlotte P. Sevier,

Mary Sheldon,

Virginia B. Shiveley,

Emma McG. Shiveiy,

Lydia Schaum,

Clara M. Schunk,

Altha Sloss,

Azalia Smith,

Nina R. Smith,

Edith H. S. Spence,

"Julia C. Starr,

Olga F. Stastny,

Eunice R. Stoops,

Beatrice

Broken Bow

Ashland

Peru

Hastings

Lincoln

Lincoln

Fremont

Fullaway

Edgar

College View

Omaha

Hastings

Blue Springs

Omaha

Homer

Grand Island

Beatrice

Omaha

Mitchell

Kathleen O'Connor Sullivan, Omaha

H. Rathben Sullivan, Omaha

Ella P. Sumner, Hastings

Agnes V. Swetland,

Omaha

Agnes C. Thorpe,

* Mary W. T. Ward,

Brayton

Hampton

Emma A, Warner,

Butte

Ruth A. Warner, Lincoln

Myrta A. Wells, Omaha

Ada Whaley, Omaha

Mildred C. Williams, York

Amelia T. Wood, University Blvd.

Marcia L. Young, Omaha

Sophia Warner,

Kearney 
Dr. Inez Philbrick of Lincoln was president of the Nebraska Women's Suffrage Association, secretary of the public library board, chairman of the Wilson Foundation and serves on the board of many charitable institutions.

Dr. Olga Stastny of Omaha is president of the Women's Overseas Service League and was chosen as the most representative business or professional woman of Nebraska, in a national contest held last year.

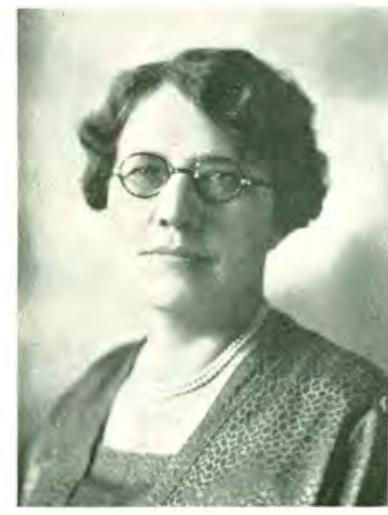

EMELIA H. BRANDT

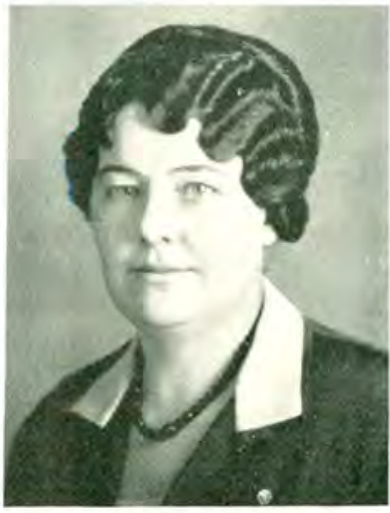

ADA PLATZ

Dr. Emelia H. Brandt was president of the Women's Division of the Omaha Chamber of Commerce.

\section{POLITICAL POSTS}

Alma J. Chapman of York was for seven years superintendent of the sttae reform institution for women.

Harriet McGraw is health officer at Tryon.

Ella Pearson Sumner of Hastings was coroner of Franklin County from 1902 to 1917.

Ada Platz of Beatrice is physical examiner for Beatrice school girls and examiner of the "better babies" show at the state fair for 12 years. 
Charlotte P. Seiver of Fremont was school physician from 1916 to 1920 .

Katherine H. K. Wolfe of Lincoln was supervisor of Lincoln school health for seven years, establishing a fine record.

M. Martha MacVean of Nebraska City is city health and juvenile court officer; interested in all welfare work.

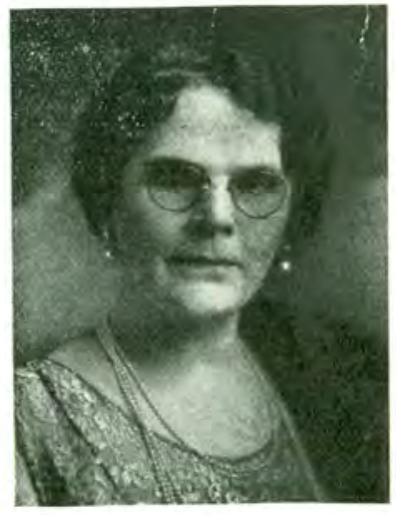

JENNIE CALLFAS

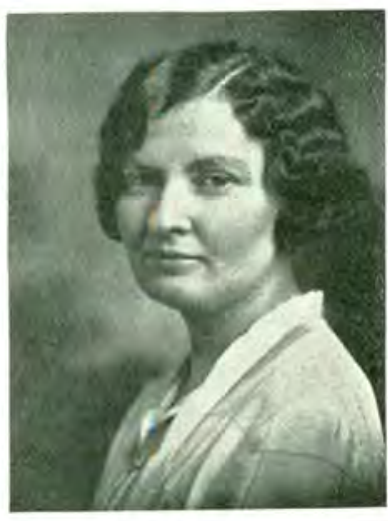

CHARLOTTE P. SEIVER

Marcia L. Young, born in Illinois January 18, 1884, and graduated from the Hahnemann College, Chicago, in 1916, was examining physician of Douglas County juvenile court.

\section{NOTES OF INTEREST}

\section{LITERARY}

Anna Robinson Cross of Crawford, Nebraska, wrote the "Legend of Crow Butte Indians," for the Daughters of the American Revolution's compilation of historical narratives. Azalia Smith, lung specialist in the South Side, Omaha, writes poems and songs. "Life's Toils and the Cool Timbers" is one of her poems. Her songs are "Lovelight and Moonlight," "Corn Time in Nebraska," and "Step Easy Blues." 


\section{LECTURERS}

Olga Stastny, lecturing on social hygiene to Czecho-Slovakiar soldiers after the war; Emelia Brandt, touring the country for the national Young Women's Christian Association board in 1919, speakin gon public health, and the late Adda Wiley Ralston, in the same work established their ability along these lines.

Margaret Koenig of Waterloo spent five years in public health work and with the Children's Bureau, touring chiefly through Arkansas and other southern states.

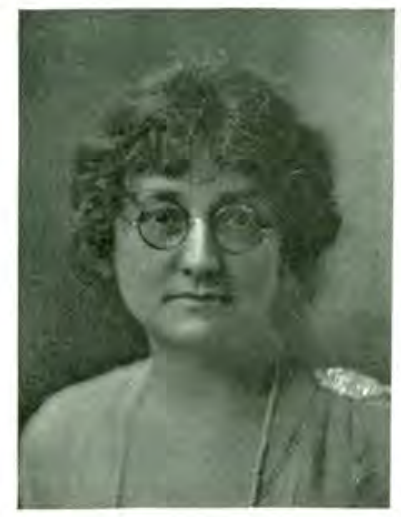

MARGARET KOENIG

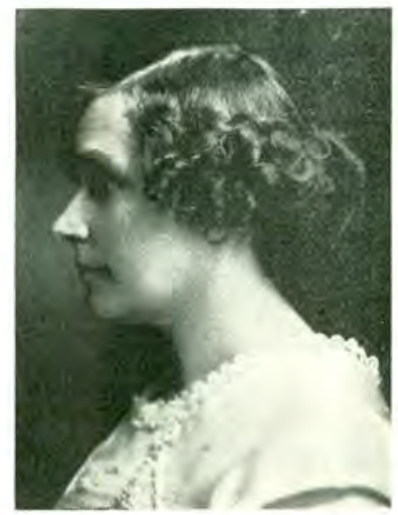

AZALIA SMITH

\section{INSTRUCTORS}

Nora Fairchild of Omaha is instructor in ophthalmology at the University of Nebraska College of Medicine. Stella Chapman Jacobi, formerly of Omaha, held the chair of diseases of women in Dunham College, Chicago, Illinois, before coming to this city. She was a graduate of the University of Michigan in 1885 and practiced 40 years. Her husband was also a physician.

\section{SPECIALISTS}

\section{PSYCHIATRISTS}

Dr. Marie Lois Grote, on the staff of the Lincoln State Hospital, is one of two Nebraska women physicians to specialize in psychiatry, which, she believes is a splendid field for women. "I 


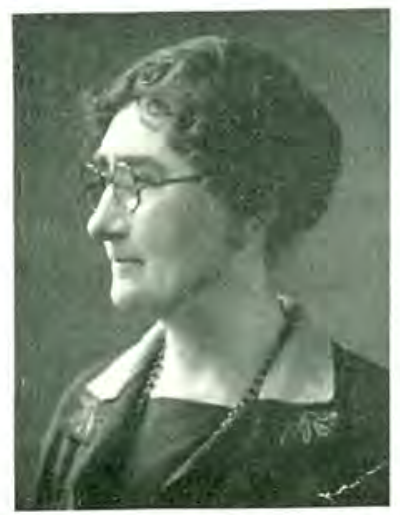

MARIE LOIS GROTE

believe nervous women unbend and will tell more to a woman physician than they will to a man," she says. Dr. Grote has practiced for 33 years. She is a graduate of the Northwestern University Women's College in 1894, practiced four years in Chicago and 23 years in rural practice in Ponca, Dixon County, Nebraska. She was the only woman member of the Dixon County Medical Society.

Agnes Cecilia Thorpe, born in Brayton, Greeley County, July 26, 1890, and graduate of Hahnemann College, Kansas City in 1914, also the Mayo Clinic, is a neuro-psychiatrist. She practiced in Scottsbluff from 1916 to 1918 and then served at the state hospitals for insane in Kansas and North Dakota. She married Dr. John D. Carr in 1921 and has one son.

\section{SURGERY}

Margaret Himrod Barney, formerly of Homer, Nebraska, but now located at Hot Springs, South Dakota, is a very good surgeon, in the opinion of no less an authority than Dr. J. E. Summers, Omaha surgeon who watched her work. "She was not afraid of anything," Dr. Summers reports.

Georgia Arbuckle Fix, member of the first graduating class of Omaha Medical College, established a fine reputation for skill in surgery, in Scottsbluff County, where she was 75 miles away from any other doctor. Phoebe A. Oliver Briggs, pioneer woman physician of Furnas County, near Beaver City, also enjoyed fine repute for medical and surgical skill.

\section{ROENTGENOLOGY}

Margaret Hammond of Lincoln is a roentgenologist and specializes in electro-therapeutics. Lina M. Rosat of Lincoln is also in this branch of the profession.

\section{HOSPITAL STAFFS}

May L. Flanagan is vice-president and assistant chief of staff at Green Gables, Dr. Bailey's sanitarium in Lincoln. Isabel C. 
MacDonald, internal medicine, is now on the staff. She recently arrived in this country from Scotland. A very fine young doctor was Lorene Painter, assistant physician, who died in 1924, of miliary tuberculosis.

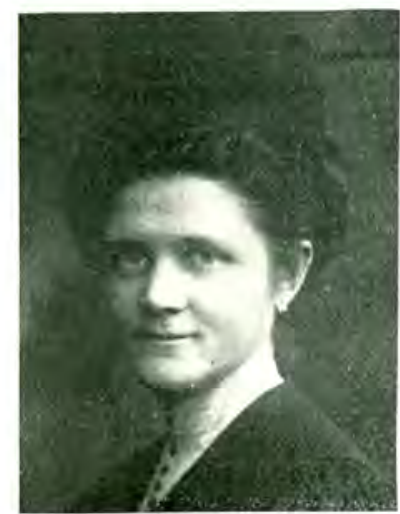

CLARA B. CROSS

Clara B. Cross of Omaha worked in J. B. Murphy's laboratory in Chicago until shortly before she died.

Mary A. Quincy was the first secretary of the Saunders County Medical Society.

There were eight women charter members on the Omaha Medical Society when it organized in 1890. Among them were Hannah C. McCahan, afterwards Fleming of Falls City; Eleanor S. Dailey, who had served as second vicepresident of the old Douglas County Medical Society in 1886, and Mary Strong, both of whom read papers before the society in the early '90's; and Metha Helfritz Jonas, who was secretary in 1894. Minerva Newbecker was a member in 1897 but later joined her brother-in-law, Dr. F. D. Haldeman in practice at Ord. She was one of the organizers and vice-president of the Valley County society. She died several years ago.

Dr. Nina Ream Smith was practicing in Dakota and Thurston Counties prior to 1898, when she married and retired. Emma J. Lawrence, Sadie Doran and a Mrs. Johnson appear on Falls City lists about this time or shortly thereafter.

Mary Winifred Ward, a young physician practicing in Lincoln, died March 12, 1916, after childbirth.

Susan Wilson Field, daughter of a Lincoln family, and graduate of the University of Nebraska in 1901, pursued her medical course at the Woman's Medical College in Philadelphia in 1907 and has served in various eastern women and children's hospitals and colleges ever since. She is now resident physician at the State Teachers' College, Farmville, Virginia, where she was appointed in 1921 but spends all her vacations in Lincoln. 
Other women doctors were S. B. Kator in Bloomfield, Cedar County: Marie H. Morse at Wisner and Mary E. Rosenberg.

\section{NEBRASKA ASSOCIATION OF MEDICAL WOMEN}

This organization, at first known as the Nebraska Medical Women's League, was formed at Lincoln, December 8, 1917, "for the purpose of advancing medical knowledge and science among women in the profession and guarding and fostering their interests."

Dr. Inez Philbrick of Lincoln was elected president; Dr. Olga Stastny of Omaha, vice-president; and Dr. Lorene Painter of Lincoln, now dead, secretary-treasurer.

Other charter members included Laura J. Brown, Hallie Ewing, Ruth Warner, Daisy Hanson, May Flanagan and Margaret Hammond of Lincoln; Minerva Newbecker of Ord, now dead; Sadie Doran of Falls City; Ada Platz of Beatrice; Emma Warner De Naree of Roca; and Nina Smith of Homer.

The second meeting took place the following spring, May 19, 1918 also at Lincoln when Dr. Margaret Koenig of that place was named president: Ada Platz of Beatrice, vice-president; and Dr. Painter was re-elected secretary. On account of the war, no further meetings were held until May 11, 1921 when the women physicians again assembled at Lincoln and voted that the same set of officers should hold over another year.

The next meeting of which there is any record was held November 17, 1923 when Dr. Emelia Brandt of Omaha was named president; and Dr. Alace Kani was elected to fill the unexpired term of Dr. Rose Wohl, indicating that there had been a 1922 meeting, of which the minutes are missing. The women also voted to change the name of the organization to "Nebraska Society of Medical Women."

This name was short-lived for at the next gathering, May 13, 1924, the name became "Nebraska Association of Medical Women." Dr. Inez Philbrick of Lincoln was again named president; Martha E. McVean of Nebraska City, vice-president ; and Margaret Hammond of Lincoln, secretary and treasurer. 


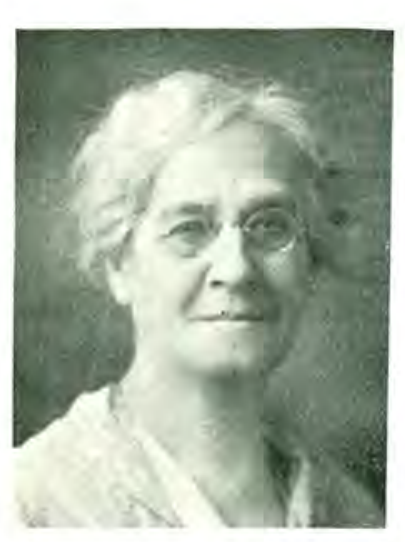

MATTIE L, ARTHUR

November 28, at meeting in Omaha, Dr. Nora Fairchild of Omaha was elected president; Susan Rachel Cooper of Aurora, vice-president and Katherine M. Hunt of Omaha, secretary. At the May 11, 1926 meeting, May Flanagan of Lincoln was elected president; Charlotte Siever, vice-president and Ruth Warner of Lincoln, secretary.

Present incumbents are Mattie $\mathrm{L}$. Arthur of Omaha, elected president at a meeting May 11, 1927, in Lincoln; Ada Platz of Beatrice, vice-president; and Emelia Brandt of Omaha, secretary.

Dr. Alace Kani of Omaha was elected president of the Nebraska Association of Medical Women for 1928-29 at the annual meeting held in May, in Omaha. Other officers include Dr. Mildred Johnson Clarke, Omaha, vice president, and Dr. Marie Grote, Lincoln, secretary-treasurer.

\section{MEDICAL WOMEN'S CLUB OF LINCOLN}

Inez Philbrick, dean of women practitioners in the state, organized and headed the first gathering of medical women in Lincoln in the late ' 90 's but the society died out and was not revived until Thursday, June 16, 1907. On this date, Dr. Philbrick, Louisa Smallwood MacDonald now dead, and May Flanagan of Green Gables were instrumental in again organizing the women, at a meeting at the home of Laura J. Brown. Besides these four, Amy R. Humphrey, Lyra H. George and Mabel Dunn, who was connected with Sunlight Sanitarium, attended the first meeting. Doctors Brown and Dunn are now in California.

Dr. Brown was elected president, Inez Philbrick, vice-president and Mabel Dunn, secretary-treasurer. Dr. Houser, Emma De Maree, Bertha Reynolds, Susan Field, Lina M. Rosat, Hallie Ewing, Lenore Perky Webster and Daisy Hanson, now married and living elsewhere, joined at subsequent meetings. 
Medical papers were read and the women took an active part in the campaign for a state health inspector and other public health work.

The next year the officers were Emma DeMaree, president; May Flanagan, vice-president and Daisy Hanson, secretary; in 1909. Dunn, Rosat and Hanson, in the order named; 1910, Flanagan, Philbrick and MacDonald; in 1911, Hanson, Rosat and Brown and this latter set of officers were retained for eight years. In these years, Doctors Margaret Hammond, Sabin, Koenig, Lenore Painter and Kathryn Wolfe joined the group.

Ruth A. Warner was elected president in 1919 and has continued in office ever since. Susan Field was named vice-president at that time and Alma Chapman, then at the state hospital, for secretary. The next year, 1920, Margaret Hammond became secretary and is still serving.

The Lincoln women doctors helped Lenore Perky Webster wage a winning fight to obtain the establishment of the state orthopedic hospital and it was through their efforts that the women's state organization was effected.

\section{OMAHA WOMEN'S MEDICAL SOCIETY}

A preliminary meeting to discuss the organization of an Omaha group was held November 7, 1922 in the office of Dr. Kathleen

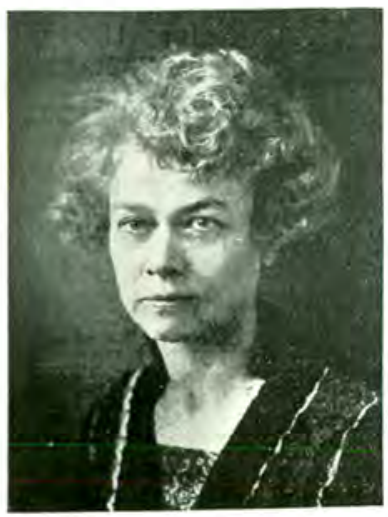

M. ALACE KANI

O'Connor Sullivan. Five present were Nora Fairchild, Rose Wohl, Mattie Arthur, Emelia Brandt and Mrs. Sullivan. Dr. Brandt was made president pro tem and Dr. Sullivan, secretary. A second meeting was held November 24 and a third meeting, November 28, 1922, at the University Club, when the constitution was adopted and the following officers were elected: President, Emelia $\mathrm{H}$. Brandt; vice-president, Nora Fairchild; secretary-treasurer, Rose Wohl. Charter members included the foregoing three and Mattie L. Arthur, M. Alace Kani, Kathleen O'Sullivan, Ada Wiley Ralston, Azalia Smith and Mary Taylor Bissell, associate member. 
Erickson-Hill of Council Bluffs, and Katherine Hunt in the other two offices. Dr. Kani is also the new state president.

Dr. Olga Stastny was elected president in 1927 but resigned shortly thereafter in favor of Dr. Erickson-Hill. Azalia Smith is vice-president and Mattie Arthur, secretary-treasurer.

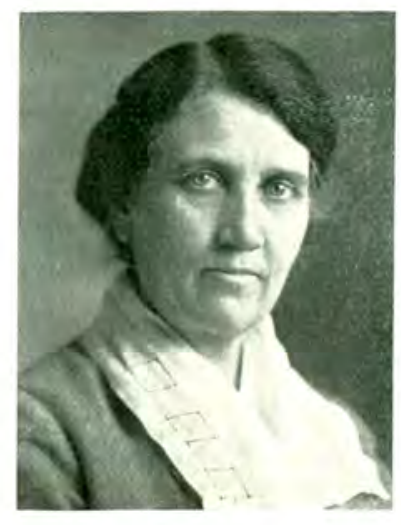

DELIA LYNCH

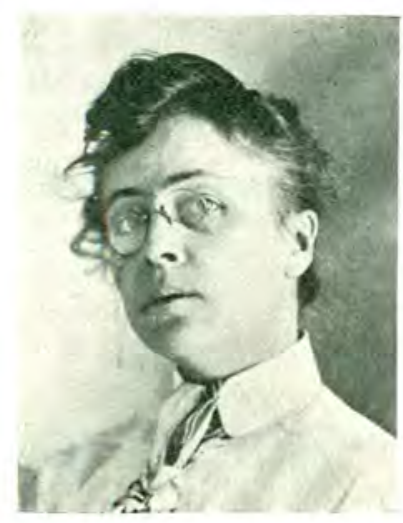

EDNA PELLS

\section{NURSES}

Hettie Painter, an army nurse but never graduated from any medical school, operated a small hospital in Lincoln before 1893.

Mathilda Anna Lueninghoener of Fremont was the first trained nurse in Dodge County. She was born in Fontenelle, Washington County, where her parents homesteaded in 1855 , and when a young woman was operated for tumor. She became so interested in surgical nursing at this time that when she recovered she studied for this profession under the direction of her surgeon, Dr. George J. Haslam of Fremont. She was employed in his office for 19 years. 


\section{WOMEN PHYSICIANS}

\section{Notes and Errata}

pp. 174-177

Phoebe A. Olive Briggs. See Lockard, F. M., History of the Early Settlement of Norton County, Norton, Kansas: Champion, 1894 : pp. 4-5, 81-85.

p. 176

“. . Octobed 6, 1841 and ..." should read ". . October 6, 1841 and ..."

p. 178

Georgia Arbuckle Fix, Omaha Medical College, 1883, 1st class to be graduated, 1881; (Nebraska School of Medicine), 2nd class: Omaha Medical College, 1882: 3rd class, 1883.

p. 182

Metha Helfritz Jonas; West. M. Rev., 1:40-41, June 15, 1896.

p. 190

Olga Stastny. See Lovejoy, Esther (Clayson Pohl), Certain Samaritans, New York: Macmillan, 1927.

p. 194

". . . superintendent of the sttae reform . .." should read ". . . superintendent of the state reform ...."

p. 196

“. . Speakin gon public..." should read "... Speaking on public..." 



\title{
PUBLICATIONS
}

\author{
THE OMAHA CLINIC
}

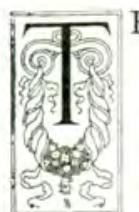

HE first medical journal in the state was the Omaha Clinic, which appeared April 10. 1888, although it was considered and discussed as early as March, 1887. Jacob C. Denise of Omaha, one of the founders of the Omaha Medical College, was the editor, and H. J. Penfold, owner of an Omaha surgical supply house, the founder. Associated with Denise as editors were J. E. Summers of Omaha; A. S. von Mansfelde of Ashland: James Carter of Red Oak, Iowa, for the Missouri Valley Medical Association and M. L. Hildreth of Lyons, to act for the Nebraska State Medical Association.

The first article in the publication was by Harold Gifford and dealt with mastoid operation. There was also an article by W. F. Milroy. Mention is made of the establishment of the Presbyterian Hospital; the Omaha Medical Club and the seventh commencement of the Omaha Medical College.

The second number carried the news of the death of $F$. G. Fuller of Lincoln on April 13, 1888 as a result of a buggy accident while en route to call on a patient; gives the name of N. F. Donaldson of North Platte as the first subscriber for the new medical publication; and reports a meeting of the Nebraska Railroad Surgeons' Association, held in Lincoln, June 27, 1888. J. C. Moore of Oakland was elected president; D. C. Bryant and E. W. Lee of Omaha, vice-presidents; A. S. von Mansfelde secretary; and G. H. Peebles of Lincoln, treasurer.

Subsequent numbers - a complete file of which is owned by $\mathrm{H}$. Winnett Orr of Lincoln - announce progress of lobbying in the legislature for a bill to provide for a state board of health. The committee in charge, headed by J. F. C. Bush of Wahoo, included 
H. B. Lowry, W. M. Knapp, M. L. Hildreth, A. S. von Mansfelde and Milton Lane.

Penfold continued publishing the "Omaha Clinic" for five years until March, 1892, when he withdrew, announcing it to be his opinion that the publication should be entirely in the hands of the medical profession.

A. S. von Mansfelde was named editor-in-chief that year. Under his management it made steady advancement and was a useful organ during the period of agitation for medical legislation. The issue of February, 1893, contains the brief of the state case against the Chinese practitioner, C. G. Wo of Omaha, submitted as a test case to the supreme court on January 31 .

George Wilkinson succeeded to the editorship in 1899 and continued the publication for a time until it apparently died out, due to the popularity of a new journal.

\section{THE WESTERN MEDICAL REVIEW}

The Western Medical Review, founded by George H. Simmons, and destined to supplant the Omaha Clinic, made its first appearance as a 24 page paper, on May 20, 1896. The opening number con-

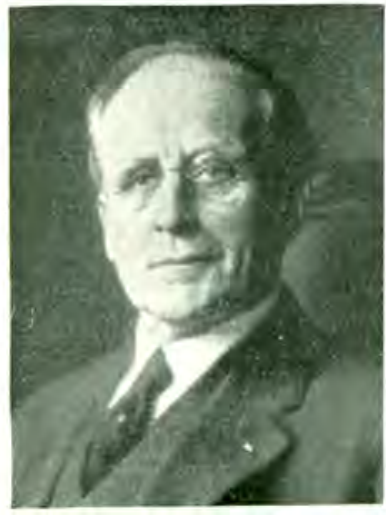

GEORGE H. SIMMONS tained articles by A. R. Mitchell, S. E. Cook, MI. H. Everett, W. L. Dayton and J. F. Stevens, all Lincoln physicians who had purchased stock in the venture. In the September number, that year, was an article by Georgiana Grothan of St. Paul on "Chloroform in Labor."

Simmons continued as editor of the publication until 1899 when the editor of the Journal of the American Medical Association resigned and Simmons determined to enter the race for the post.

As preparation for the big job he was to tackle, Simmons had the benefit of experience gleaned during vacations from his medical course - at Hahnemann College, supplemented by Rush - when he worked as assistant city editor on the Lincoln State Journal, acting 
editor of the Nebraska Farmer, and correspondent for Omaha Republican and Kansas City Journal. He was an Englishman by birth (1852) and entered the University of Nebraska shortly after his arrival in this country, when he was eighteen years old. His first public notice was when he carried off the prize for the best essay of the freshman year. In addition to his editorial experience, Dr. B. F. Bailey of Lincoln relates that Simmons went into the plant of the Nebraska State Journal and familiarized himself with every mechanical phase of newspaper publication, before he took the competitive examination and was selected for the new editor.

How well Simmons filled the post can be judged by the fact that he was retained for 25 years and at the conclusion of this quarter century of service, was tendered a testimonial dinner in Chicago, attended by the leading medical men in the country. A handsome portrait of himself, reproduced here, was presented to Simmons at the time. Speakers on this occasion, June 9, 1924, were Harvey Cushing, professor of surgery at Harvard; Frank Billings, dean of Rush Medical College; William J. Mayo of the Mayo Clinic; Will Owen Jones, editor of the Nebraska State Journal; Hubert Work, Secretary of the Interior and William Sidney Thayer, professor of medicine at Johns Hopkins, Baltimore.

Each of these speakers lauded Simmons as editor, publisher, writer, organizer, executive and administrator in medical education, as a citizen and as a man. As editor of The Journal and general manager of the American Medical Association enterprises, he is credited with complete reorganization of the Journal until it today takes its place as the leading medical publication in the world. While Morris Fishbein, who lectured in Omaha last December is the active editor today, Simmons is retained as editor emeritus.

The present system of organization in the American Medical Association, including the board of trustees, house of delegates, and state and county units plan, is said to have been originated largely by Simmons and effected at St. Paul in 1901, shortly after he took the post. The circulation of The Journal leaped from 12,000 in 1900 , to more than 90,000 in the quarter century he was at the helm. Hygeia, published for the laity, and many other scientific publications and directories, are also included in the American Medical Association publications, edited by Simmons. 
Simmons divorced his first wife, Dr. Margaret Simmons and married a Mrs. Hurlbut of Lincoln.

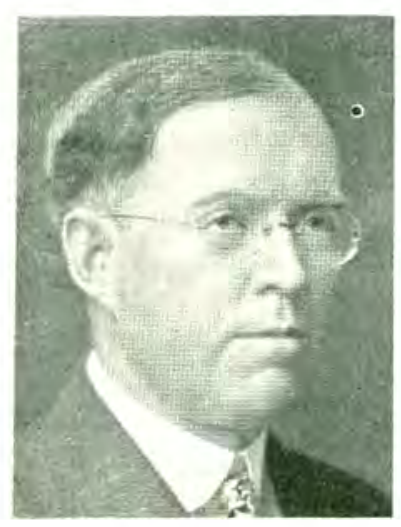

H. WINNETT ORR

When Simmons severed his connection with the Western Medical Review, his place was taken by S. E. Cook and H. Winnett Orr of Lincoln. Cook became editor and Orr, whose interest in the publication was bought for him by his uncle, H. J. Winnett, former mayor of Lincoln, became managing editor. Shortly after taking charge, these men asked the state association to make the Western Medical Review its official organ and this was practically accomplished.

Orr, who is now chief surgeon of the Nebraska Orthopedic Hospital at Lincoln, has been a prolific writer ever since; was editor of the Journal of Orthopedic Surgery and has a distinguished war record. He wrote "An Orthopedic Surgeon's Story of the Great War," in which conflict he served as lieutenant-colonel overseas. $\mathrm{He}$ is a good organizer as well; has been president of several Lincoln medical societies, as well as the state president in 1920; secretary of the national American Orthopedic Association from 1914 to 1917 and chairman of the orthopedic section of the American Medical Association in 1920.

While editor of the Western Medical Review in January, 1905, he first agitated the matter of placing replicas of five famous surgeons in the Hall of Fame in New York and wrote a letter to those in charge. The Journal of the American Medical Association took up the matter, printed a ballot, which resulted in the choice of Benjamin Rush, J. Marion Sims, William T. G. Morton, Oliver Wendell Holmes and Valentine Mott. Three of these were the same names that Orr originally proposed. Among Orr's important papers are: "Rights of the Patient;" "Fundamental Principles of Orthopedics, Reconstruction and Industrial Surgery;" "Epidemic of Acute Anterior Poliomyelitis in Nebraska" (1909) and "Treatment of Osteomyelitis." He collaborated in 1902 with Dr. A. S. von Mans- 
felde in writing a history of the Nebraska Medical Society for the first one-third of a century and in 1905 compiled a Nebraska medical biography with the help of his students at the university.

Dr. Orr, who has one of the finest medical libraries in Lincoln, among which are many old books, one of them, dated 1657 being earliest commentaries in Greek and Latin on Hippocrates, has given a fine collection to the Lincoln General Hospital, as a memorial to his uncle, the late Dr. H. J. Winnett.

Orr in 1908 operated the Sunlight Sanitarium in Lincoln, in cooperation with Doctors C. W. M. Poynter, Irving S. Cutter, later dean of the University of Nebraska College of Medicine and now dean at Northwestern; George Brash of Beatrice and L. M. Shaw of Osceola. Dr. Mabel Dunn, Northwestern, 1896 and formerly second assistant physician at the Nebraska Insane Hospital was in charge of the department of obstetrics and gynecology in this sanitarium.

Cook and Orr continued the publication of the Western Medical Review until about 1909 when they sold out to Henry Gehring of Omaha, owner of a surgical supply company similar to Penfold's. Either under Gehring's control, or as an independent enterprise, Dr. A. L. Muirhead of Omaha, late dean of Creighton, became editor in October, 1909. P. G. Woolley was associate editor and E. G. Barnhardt, business manager. The board of directors included A. F. Jonas, F. E. Coulter, H. L. Aikin, H. L. Burrell and Harold Gifford.

This publication was not wholly satisfactory and members of the profession cast about for a change. J. P. Lord and other local men raised a fund to take it over but Gehring's demands were prohibitive so nothing was done, for the time.

\section{NEBRASKA STATE MEDICAL JOURNAL}

A state association-owned medical publication was first proposed by Francis A. Long of Madison, present editor of the Nebraska State Journal, in his presidential address before the state association in 1907. He had made a study of the 16 medical publications then in circulation. Nothing further was done until 1913 when Dr. Long was made chairman of a committee to investigate the contract with 
the existing journal, which was printing news of the society's activities. B. F. Bailey of Lincoln and W. O. Bridges of Omaha served with Long. The following year, Dr. Long was again named chairman of the committee, to serve for two years, and empowered to establish a journal in 1916 .

The first issue of the Nebraska State Medical Journal, therefore, appeared in July, 1916, with Irving S. Cutter of Omaha, dean of the University of Nebraska School of Medicine as editor; Albert

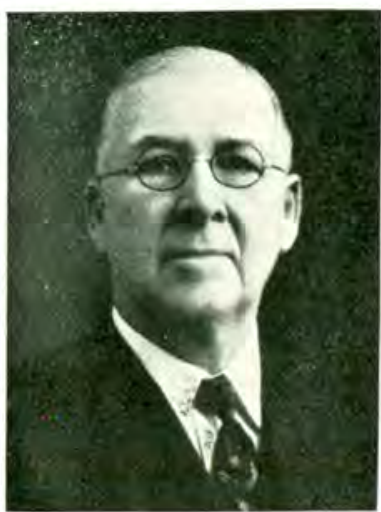

FRANCIS A. LONG F. Tyler of Omaha, associate editor; J. M. Aikin, secretary of the state association as business manager and a publication board including Drs. Long, Bailey, Bridges and Aikin. Cutter continued as editor until 1918 when Aikin assumed the duties, serving until he died, November 18, 1920.

Dr. Long then took over the editorial post and R. B. Adams of Lincoln is business manager. The committee on publication still includes Long, Bridges and Bailey who underwrote the initial expense of the Journal. It is now self-supporting.

The Journal aims to publish the best scientific papers possible and its editor asserts that no favoritism of any kind will be shown.

Francis A. Long of Madison, editor of the State Journal, taught. school in West Point, Nebraska in March 1879 and near Oakland in the summers for several years, while he studied medicine at the Iowa University in the winters. After his graduation in the spring of 1882 , he spent several months with his former preceptor at Moulton, Iowa, but seeing no future for himself there, came to Madison, Nebraska, June 27, 1882 and has resided there since that date.

He probably did the first operation for the removal of the appendix done in north Nebraska in December, 1892, and was the first physician to administer antitoxin for diphtheria in north Nebraska, January $31,1895$. 
Early in his professional career he became interested in organized medicine. He was president of the Nebraska State Medical Association in 1906 and 1907, delegate to the American Medical Association meeting at Atlantic City in 1907, in Chicago in 1908 and in Los Angeles in 1911. He was Nebraska delegate to the American Medical Association Council on Medical Education and Medical Legislation in Chicago in 1909 and 1910 and represented Nebraska at the Second Conservation Congress at St. Paul, Minnesota in 1910. A fellowship in the American College of Surgeons was conferred on him at the Boston meeting in 1915.

He has been very much interested, from its inception, in the Good Roads Movement and gave liberally of time and money to further the work. He assisted in putting the Meridian Highway on the map and has been vice president of the International Meridian Highway Association since 1923. He originated, organized, named and mapped the Upland Highway. He was married to Miss Maggie E. Miller at West Point, Nebraska, December 2, 1884 and to this union three children were born-Frances L. Long, botanist with the Carnegie Institution of Washington, now stationed at Santa Barbara, California; Harriet C. Long, librarian, Chief of the Traveling Library Service for the State of Wisconsin, Madison, Wisconsin, and Margaret, (Mrs, J. W. Whisenand) Peoria, Illinois.

Dr. Long was born near Kreidersville, Pennsylvania, February 16, 1859 and worked as a common laborer about the coal mines, in car shops, and as accountant in a lumber yard in Carbon County, Pennsylvania, before he came west with his family in December, 1876 , to Moulton, Iowa.

BI-WEEKLY BULLETIN

OF THE OMAHA-DOUGLAS COUNTY MEDICAL SOCIETY

This six-page leaflet, edited by Herman M. Jahr, is the newest publication to serve local physicians. It notes county society affairs and events of interest to the medical profession of the vicinity; carries a few ads and may grow to greater size and strength in the future. Dr. Jahr, a young pediatrician, is investigator for the U. S. Children's Bureau to study maternal mortality. He is also assistant in bio-chemistry at the University of Nebraska Medical College, 


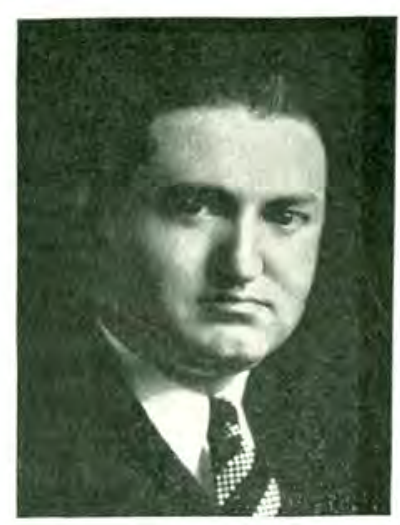

HERMAN M. JAHR

from which he was graduated in 1923.

He was, preceding this, assistant in pathology at the University of Arkansas where he took his B. S. degree.

The idea for the Bulletin issued since last November originated with Frank M. Conlin, then president of the Omaha-Douglas County Medical Society. He also started the agitation for the new county hospital.

The Pulse, a student publication, was the official journal of the Omaha Medical College from 1897 to 1901.

\section{NATIONAL MAGAZINES PUBLISHED IN OMAHA}

Archives of Physical Therapy, X-Ray and Radium, official monthly publication of the American College of Physical Therapy, is published in Omaha, with Albert F. Tyler as managing editor. It was founded in January, 1924. Disraeli Kobak and J. S. Coulter of Chicago; J. C. Elsom of Madison, Wisconsin and David Willmoth of Louisville, Kentucky, are the publication committee.

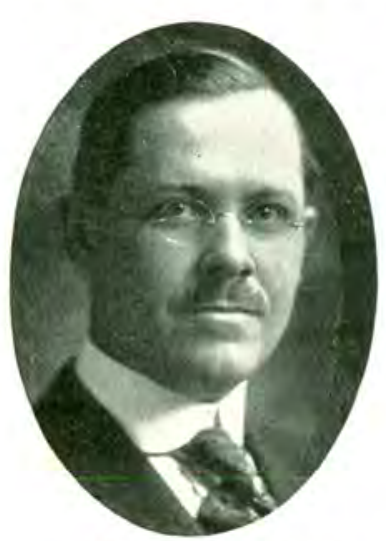

ALBERT F. TYLER

This is the second national publication in Omaha, with which Tyler has been associated. He was editor of the Journal of Radiology, official organ of the Radiological Society of North America from 1921 to 1924 , taking it shortly after its inception in Iowa City, where it was previously published only several times a year. Under his direction the circulation was increased ninefold. Dr. Tyler was president of the Radiological Society of North America in 1920 and performed for this organization much the same service that Dr.

George Simmons did for the American Medical Association. He built it up from a middle western society to its present proportions, 
and organized it into districts, besides his service in developing the Journal. He was the first to describe the "Effect of Heavy Radiation on Pleurae and Lungs," which was published in the Journal in November, 1922.

Tyler is on the Creighton faculty, a member of the British Roentgen Ray Society, the International Association of Teachers of Radiology of Vienna, Austria and was recently invited to membership in the American Medical Editor's Association. He was president of the first Omaha Roentgen Ray Society and of the OmahaDouglas County Medical' Society in 1918 and is still a member of its council. He is treasurer of the state Young Men's Christian Association.

Dr. Harold Gifford was formerly editor of a national ophthalmic publication. Palmer Findley is associate editor of the American Journal of Obstetrics. 


\section{PUBLICATIONS}

\section{Notes and Errata}

p. 203

p. 203

p. 203

p. 204

p. 204

p. 206

p. 206

Omaha Clinic, v. 1-10, Apr. 1888 to Sept. 1897. Omaha, Nebraska, H. J. Penfold. Edited by J. C. Denise, 1888-1892; G. Wilkinson, 1892-1897 and later continued under title Chicago Clinic.

Gifford, Harold, "A Report of Eight Mastoid Operations with a Slight Modification in the Method of Procedure," Omaha Clinic, 1:1-3:18-21, Apr. 10; May 10, 1888.

Milroy, W. F., "Diagnosis of Tubercular Meningitis," Omaha Clinic, 1:11-13, Apr. 10, 1888.

Gee-Chung Wo v. State. 36 Nebr. 241.

West. M. Rev., (Nebraska State Medical Association) Lincoln: Omaha, Nebraska, v. 1-36, no. 9-12, May 1896-Sept./Oct. 1930. Editors: George H. Simmons, 1896-99: S. E. Cook, 1900-1903: H. W. Orr, 1903-1906: A. L. Muirhead, 19061916: No editor listed after 1916.

H. Winnett Orr, Editor, J. Orthop. Surg., Lincoln, Nebr.: H. Winnett Orr, Vol. I, 1919 - Vol. III, 1921. Superceded by J. Bone \& Joint Surg. Editor: E. G. Brackett, 1921+

Orr, H. W., An Orthopedic Surgeon's Story of the Great War, Norfolk, Nebr.: Huse Publishing Co., 1921.

- The Rights of the Patient and Other Medical Essays, Lincoln, Nebr.: Dr. H. Winnett Orr, Publisher, 1920.

- "The Fundamental Principles of Or thopedic Reconstruction and Industrial Surgery," JAMA, 79:255-57, July 22, 1922.

- "Epidemic of Acute Anterior Poliomyelitis in Nebraska," West. M. Rev., 14:497-98, Oct. 15, 1909.

- The Treatment of Osteomyelitis and Other Infected Wounds by Drainage and Rest, Chicago: R. R. Donnelly \& Sons, 1927.

Orr, H. W. and Mansfelde, A. S. v., "The Nebraska State Medical Society: its history for the first one-third century," West. M. Rev., 7:127-140, May 1902.

p. 207

". . . medical biography ..." should read ". . . medical bibliography ..." 
p. 207 Orr, H. W., "Bibliography of Nebraska Medical Literature," West. M. Rev., 9:337-357, Nov. 1904: 9:385-393, Dec. 1904: 10:10-20, Jan. 1905.

F. A. Long, M.D. copy of Tyler is in the Library of Medicine, University of Nebraska Medical Center and contains Long's corrections.

p. 208

Nebraska St. M. J. (Nebraska State Medical Association), Norfolk, Nebr., Omaha, 1916+, Editors: Irving S. Cutter to 1917; Joseph M. Aiken, Managing Editor, to Dec. 1920: F. A. Long to 1930 .

p. 208

Fifth paragraph should read: "Francis A. Long of Madison, editor of the State Journal, came to West Point, Nebraska in March 1879, taught school near Oakland in the summers..." Note: F. A. Long correction, see Notes on p. 207.

First appendectomy. See Long, F. A., A Prairie Doctor of the Eighties, Norfolk, Nebr.: The Huse Publishing Co., 1937, pp. 84-87.

p. 208

First diphtheria antitoxin. Ibid., p. 115.

p. 210

p. 210

The Pulse continued as the official journal of the University of Nebraska College of Medicine, 1902-1921.

Tyler, A. F., editor, Arch. Physical Therapy, American College of Physical Therapy, Omaha: Radiological Publishing Co., 1926-1944. Preceded by J. Radiol., 1920-26. Editors: A. R. Hollander, 1926-27; Disraeli Kobek, 1928-30. See Nelson, P. A., "History of the Archives," Arch. Physical Med. Rahab., 50:367-405, 414.

p. 211 Tyler, A. F., "Effect of Heavy Radiation on Pleurae and Lungs," J. Radiol., 3:469-75, Nov. 1922. 


\section{SCIENTIFIC ACHIEVEMENTS}

RESEARCH-INVENTIONS-ARTS AND LETTERS - POLAR EXPEDITIONSIN FOREIGN CLIMES - NATIONAL DISTINCTIONSNOTES OF INTEREST

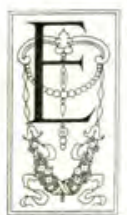

NUMERATION of the contributions of Nebraska physicians to the progress of medicine and science is one of the satisfactory features of compiling the History of Medicine in this state. From the late '50s, when James Porter Peck pioneered the cold air treatment for pneumonia, down to the present day, the record is marked by important work of local and state practitioners.

James H. Peabody, organizer of the Nebraska State Medical Association, is credited with being the first to advocate the use of oil of turpentine in the treatment of diphtheria cases, later almost axiomatic. This was in an article in the Philadelphia Medical and Surgical Journal of September, 1876. He contributed an article on surgery to the great International Congress of Surgeons held in Washington, D. C., in September, 1887, and gave to the Army Medical Museum in the nation's capital, a most valuable collection of pathological specimens. His son, John Dent Peabody is now practicing in St. Petersburg, Florida.

The late Victor H. Coffman performed one of the first successful ovariotomies in the country; and Paul Grossman, the third Caesarian section performed in this country. John Prentiss Lord was the first to call attention to skin grafting in bone cavities. Hans Peter Jensen obtained from Madame Curie in France in 1905 some of the first radium used for medical purposes here and was the first Nebraska physician to use the $x$-ray coil. Dr. Lord was the second. Only five or six other physicians in the United States had any radium when Jensen procured his, while attending European clinics. Jensen was also said to be the first to use a fever thermometer here. 
John E. Summers was the first Nebraska surgeon to introduce aseptic surgery here and S. K. Spalding and J. J. Saville, health commissioners, the first to use diphtheria anti-toxin. F. J. Schaufelberger of Hastings, now of Los Angeles, was the first to administer the serum there in 1892. He imported it from Dr. von Bering in crystalline form. The patient was a daughter of the Rev. $\mathrm{H}$. J. Kirschstein.

More recent achievements of importance, together with several brief accounts of special distinctions of Nebraska physicians in the fields of art, music, literature, in foreign missions and in other paths of interest or adventure, are included in the following pages.

If a poll were to be taken on the most important personage in Nebraska medicine, there would be but one answer, inside the profession or out. The name of Harold G. Gifford occupies this eminence. Of international renown in eye surgery and pure laboratory research - a brief account of which work is here appended for the first time in Dr. Gifford's long and useful career, through the courtesy of his son Sanford, and his colleague, James M. PattonDr. Gifford is best known and loved, at home in Omaha, for the simple virtues which made Abraham Lincoln great; for a brand of citizenship public-spirited to the highest degree; and for a farreaching philanthropy, which includes a gift of Gifford Park, a children's playground in a thickly-settled portion of the city; and the reservation of 1,500 acres in beautiful Fontenelle Forest, along the Missouri river southeast of Omaha, as a bird sanctuary and retreat for nature lovers.

Harold Gifford took the degree of bachelor of science from Cornell University in 1879. He then took his medical degree from Michigan University, remained there as Assistant in Pathology for a year, and then having become interested in Ophthalmology, went abroad for further study. In the laboratories of the Universities of Erlangen, Heidleberg and Zurich, he conducted some of the earliest experimental work on bacteriology of the eye, and on that disease which has ever since been such a puzzle to ophthalmologists, sympathetic ophthalmia. He was fortunate enough to be appointed first assistant to Horner, then Professor at Zurich, and one of the foremost clinical ophthalmologists of Europe. Returning to America, first in the New York Eye and Ear Infirmary, and later in 
Omaha, he put his training in scientific principles, which was unusual for that time, to good use in continued laboratory research, and in the application of his findings to the problems of a busy practice.

In pure laboratory research, his early work on the experimental production of sympathetic ophthalmia, with his demonstration of the fact that organisms may travel from the inoculated eye along the lymph paths into the orbit, and thence to the nerve and suprachoroidal spaces of the second eye, and his work on the drainage of the anterior chamber, will be remembered. In bacteriology his contributions have perhaps been most important. He was the first

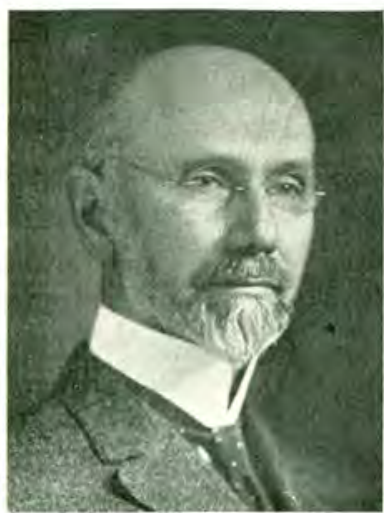

HAROLD G. GIFFORD

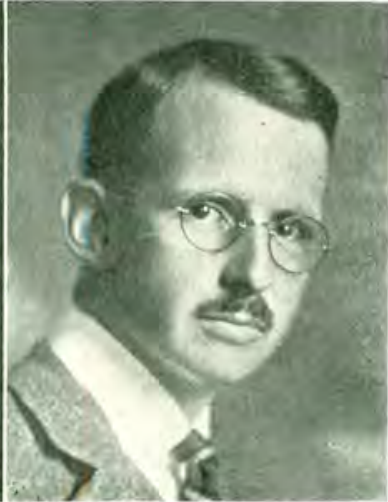

SANFORD R. GIFFORD

to bring out the fact that the normal conjunctival sac contains numbers of organisms, some of which may become pathogenic when they are carried into the eye by trauma or operations. In 1896, he gave the first description in English of the acute conjunctivitis caused by the pneumococcus, and first demonstrated that this organism is the cause, at least in Omaha, of this disease, commonly known as pink-eye, by inoculation of secretion containing the organisms on his own conjunctiva and that of an assistant, with production of the typical disease, and by inoculation of an infant with a pure culture obtained from a case. Two years later, he published the first description in English of the Morax-Axenfield Bacillus as a cause of chronic conjunctivitis and of corneal ulcer. In 1910, he was the first writer in English to describe involvement of the eyelids by the sporothrix, a member of the lower fungi which causes 
sporotrichosis, and the first in any language to describe a peculiar form of involvement of the ocular conjunctiva with this organism.

As a clinical observer, his name is attached to two eye symptoms which are of value in the diagnosis of exophthalmic goitre, and which he first described in 1906. In 1898, he reported the first American cases of Parinaud's conjunctivitis, a rare condition which had previously been described by only a few observers in France and Austria. He was one of the earliest reporters of the Juvenile form of Family Amaurotic Idiocy, and his name has sometimes been associated with this disease.

In therapeutics, probably his most important contribution was the use of large doses of sodium salicylate in sympathetic ophthalmia, which has become the classical treatment of this disease in most countries.

In ophthalmic surgery, he made many practically important modifications of operations described by others, notably in the correction of ectropion by the use of Thiersch grafts, in the correction of cicatricial entropion by the use of mucous membrane from the lip, and in the method of carrying out the Machek operation for ptosis. The procedure of destroying the lachrymal sac with trichloracetic acid as a substitute for the troublesome excision of the sac in dacryocystitis, which has found wide acceptance, is original with him. He devised a form of trachoma forceps for expression of the folds, which presents decided practical advantages over previous instruments, and his brain-knife, for exploring the brain for brainabscess, though less known, is a valuable instrument.

His writings have appeared chiefly in the form of articles for the various Ophthalmological journals in this country, England and Germany. His most extensive works are the complete reviews of the subjects of sympathetic ophthalmia in the American Encyclopedia of Ophthalmology, and of Congenital Paresis of the Abducens, published in part in the American Journal of Ophthalmology. $\mathrm{He}$ also wrote the chapter on Diseases of the Optic Nerve in De Schweinitz' System of Ophthalmology and External Injuries of the Eye in Posey and Wright's System. He was one of the editors of the Ophthalmic Record during its existence, and upon its fusion with other journals into the American Journal of Ophthalmology, became a collaborator in that journal. 
As an educator, he was one of the founders of the Omaha Medical College, and served that institution as Professor of Ophthalmology and Otology, and for a time as Dean of the Faculty. He was one of those most interested in the absorption of that school into the Nebraska University College of Medicine in Omaha, and headed the departments of ophthalmology and otology in that college when the fusion was affected, and until his appointment as Emeritus Professor.

In recognition of his scientific and clinical work, ne was granted the Honorary degree of M. A. by the University of Michigan and of LL. D. by the University of Nebraska, and was chosen as chairman of the Ophthalmological Section of the American Medical Association for its meeting in Cleveland.

The degree conferred by the University of Nebraska was the first honorary degree ever conferred by this institution and was followed, early in 1928, by similar honors to Doctors A. F. Jonas, W. O. Bridges and J. E. Summers, also former deans.

Associated with Dr. Gifford professionally are his son Sanford R. Gifford and James M. Patton, the latter for more than 25 years. Sanford Gifford and Patton are joint authors of a paper describing a

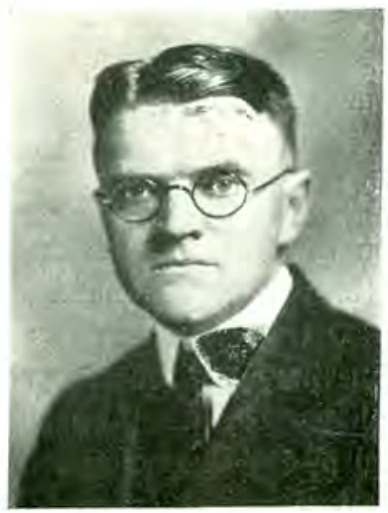

JAMES M. PATTON previously unknown condition which was called agricultural conjunctivitis, with the isolation of a gram positive anaerobic bacillus as the probable cause. The younger Gifford is author of various other articles in ophthalmic journals, several on bacteria of the eye, including a report of two cases of ocular sporotrichosis and a complete report of the occurrence of leptothrix in ophthalmology. He has also reported experimental work on the occurrence of sodium salicylate in the eye after its therapeutic use; on the actions of lens protein and on the experimental production in rabbits of a condition resembling sympathetic ophthalmia by the use of herpes virus. For his investigations, the younger Gifford has fitted out his own private laboratory in the University of Nebraska 
Medical College, where he was given the honorary degree of Master of Arts in 1923. He was graduated from there in 1918 after receiving his Bachelor of Arts degree at Cornell in 1913. His postgraduate work was at the University of Freiburg and other foreign centers.

Patton is chairman of the department of ophthalmology and Sanford Gifford, associate professor, at the University of Nebraska. Both served with Base Hospital 49 at Allerey, France, in the late war. The younger Gifford was also elected president of the Sioux Valley Eye and Ear Academy, at its last meeting in Omaha, February 15 .

Others associated with the Harold Gifford Office are Nora M. Fairchild in the eye department; and W. F. Callfas, J. B. Potts and W. A. Cassidy in ear, nose and throat work.

\section{MILROY'S DISEASE}

William F. Milroy is the only Nebraska physician who has the distinction of having a disease named for him. The great Osler himself, in his "Practice," was the first to designate as "Milroy's

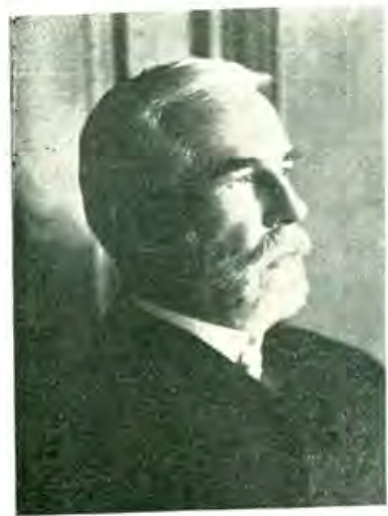

WILLIAM F. MILROY Disease," a hitherto undescribed variety of hereditary oedema, which the Omaha physician described for the first time in a paper published in the New York Medical Journal, November 5, 1892.

Since that date, Milroy's disease is mentioned in every medical textbook that has been printed and it has been accorded international recognition. A distinguished Italian physician is now engaged in some endocrine research, in an effort to learn what causes this particular disease, which manifests itself by great enlargement of one or both legs, without causing any discomfort or functional symptoms in any way.

Milroy traced the history of the disease through six generations of the family of the original Omaha specimen, a former Baptist minister now serving in the Burma, India, mission field. On consulting a 
London physician several years ago, this gentleman was told he had "Milroy's disease." Irving S. Cutter, former dean of the Nebraska College of Medicine, heard Milroy's disease described by an Edinburgh professor, when he happened to attend a lecture in the Scottish city.

The Omaha physician has had correspondence with Osler, Dr. Welch of Baltimore and other leading men all over the world, who are interested in this disease.

Dr. Milroy performed another distinct service by writing the first and only complete record, prior to this date, of pioneer Omaha medical history. It was written in 1894 and is included in Savage and Bell's "History of Nebraska."

Dr. Milroy was president in 1885-1887, of the old Omaha Medical college. When the Omaha-Douglas County Medical Society was reorganized in 1890, after the stormy schisms of the late 80 s when the Omaha Medical Club was lined up against the Omaha Academy of Medicine, Dr. Milroy was chosen president.

"They told me I was the only doctor in Omaha who had no enemies - that's why I was elected," said Dr. Milroy, "and now, for 37 years I've pondered whether that was not a doubtful compliment. They say a man isn't worth much if he has no enemies."

In recognition of the importance of Dr. Milroy's contribution to science, Dr. LeRoy Crummer of Omaha had a beautiful and rare binding made for one of Milroy's reprints on this subject and presented it to the University of Nebraska Medical College library. Both Milroy and Crummer are on the faculty.

Another important paper by Dr, Milroy was on "Typhoid Fever and Water Supply of Omaha." He was president of the state medical society in 1916 and of the Missouri Valley society in 1918. He was born in New York, December 28, 1855, attended the University of Rochester and Johns Hopkins and was graduated from the College of Physicians and Surgeons in New York City in 1882. He came to Omaha two years later. He was vice-president of the American Therapeutic Society in 1923 and president of the Nebraska Children's Home Society. 
Father W. P. Whelan of Creighton university credits C. F. Crowley, professor of chemistry there for 34 years, with taking the first perfect $\mathrm{x}$-ray in Omaha early in 1896 but the first medical use of this important discovery, so far as known, redounds to Omaha telephone company employees in the summer of 1896.

According to Father Whelan, Crowley, who had been experimenting with the Roentgen ray, discovered in December of 1895 , took his first x-ray picture February 12, 1896, two months after the first one in the world had been taken in Wurzburg, Germany. To the modern student his arrangement of the Ruhmkorff cone shaped coil, Geisler and Crooke's tubes, would be singularly amusing. Over this apparatus Dr. Crowley spent hours of fruitless labor. His first exposure, a failure, lasted three hours. By accident he found, that with a shorter exposure he would have better results. On February 12 , a thirty-five minute exposure of a mouse produced a perfect picture.

On March 12, 1896, Professor Crowley, with the aid of Father Mara and Professor Otten demonstrated the Roentgen Rays in a public lecture at the administration building. By this time the length of exposure had been decreased to twenty minutes. Even that was long as contrasted with the one-second exposure of today. The following year he had skiagraphs of fractures taken by means of the Tuppler Holtz machine. That summer in Detroit University he produced the first $\mathrm{x}$-ray in Michigan.

In 1915 he was appointed chemical engineer of Nebraska on the Preparedness Committee by the United States Navy Consulting Board. The first method of purifying Omaha's water supply is also due to Crowley, also city chemist, who suggested it to the Water Board. He accomplished the chlorination for the destruction of bacteria and the alum process, for purification.

Dr. Crowley also volunteered to complete and prepare for publication the important scientific work of the late J. S. Foote, his colleague at Creighton, on bone structure. Further mention of this book, to be brought out this spring by the Smithsonian Institute, will be made later. It entailed endless, painstaking research - sometimes a week to find the name of one bird, mentioned in the 
manuscript, under an abbreviation, as reported by the Omaha WorldHerald of Nov. 6, 1927:

"Dr. Foote, one of the most careful of writers, in listing birds by their scientific names, had written with 50 or 60 others "clor (sp)."

No such name appeared in the lists of bird species ordinarily to be found, and as scientific men do nothing halfway, Dr. Crowley, head of the Creighton department of chemistry, began to hunt what "clor (sp)" stood for. $\mathrm{He}$ read the notes from which Dr. Foote had written but none of these would help him. He dug among the author's personal effects and projected 2,000 slides on a screen to see if by chance the name would appear. There was no information.

Then Dr. Crowley began reading books on birds, spending hour after hour in a maze of scientific nomenclature that beat chemistry several laps to the mile. No result. He enlisted the efforts of the librarians in Creighton and at the city library and bird lovers generally in Omaha.

Meanwhile Dr. Crowley had written to the Smithsonian Institute for more bird lore and back came a whole shipment of pamphlets. Glancing them through he found several by Dr. Foote himself. In one of these appeared the list that he was laboring over and the solution of his problem. While he had been prepared to find the name of a rare bird, the one that fitted belonged to the common every day swan.

\section{"Clor (sp)" should have been "cygnus olor (sp)."}

The letters "(sp)" were used by Dr. Foote to denote species when no further separation of type was made.

"Many times I was tempted to draw my pen through the word and let the list go,' Dr. Crowley said, 'but that's not the way to treat matters of this kind. If the books were to have scientific value some question might hinge on the one thing omitted." "

Crowley also delivered a course of lectures to the Post-Graduate Chemical Institute at Wichita, Kansas, which elicited high appreciation.

To revert to the telephone company officials' claims to the first honors in the medical use of $\mathrm{x}$-ray, the story is as follows: 
The late E. B. Smith, superintendent of the telephone company's engineering department, had followed with interest the news of Roentgen's discovery and purchased and rigged up an amateur outfit, with which the men in his department experimented, as boys do nowadays with wireless. Smith was very friendly with the late Dr. Ralph W. Connell, health commissioner for many years in Omaha, with whom he indulged in an occasional game of poker, and had told the doctor of the success of his amateur outfit.

Not long after, the small daughter of Dr. Connell, Regina, (now Mrs. H. M. Baldrige) ran a needle into her heel and her father quickly got in touch with Smith to learn if the $\mathrm{x}$-ray would help locate the needle. It did.

Smith, Paul H. Patton and other men of the telephone company were called in. Patton operated the tube and exposed the plate. W. A. Pixley, then in the auditing department, developed the plate and the picture was made, showing the needle imbedded in the heel clearly enough so that it could be removed with very little difficulty.

The Omaha telephone company group had proved the sensitiveness of photographic plates to Roentgen rays!

Several years ago, Paul Patton presented a set of the original pictures taken to Albert F. Tyler, Omaha radiologist, who is writing a book on the subject.

Harry A. Holdrege of Omaha, former chief engineer of the Nebraska Power Company, was another pioneer experimenter in the $x$-ray field, having proved Roentgen's theory while a laboratory assistant in the Massachusetts Institute of Technology in Boston in the winter of 1895-1896. Roentgen's discovery was not given to the world until January, but during the preceding months there had been enough published on Roentgen's theory to make it interesting enough for technologists to work at it.

In acknowledging that he had helped make some of the first $\mathrm{x}$-ray pictures in this country, Mr. Holdrege related the circumstances. "A Professor Norton, now head of the physics department at Massachusetts Tech, was assigned to investigate the new discovery and I helped make those pictures," said Mr. Holdrege, who is a son of G. W. Holdrege, of the Burlington railroad. 
John P. Lord is said to be the first Omaha physician to employ the use of $x$-ray in his practice, as did H. P. Jensen, the first Omaha practitioner to own and use radium. D. T. Quigley of Omaha, formerly of North Platte, who operates the Radium Hospital, one of the few exclusive radium institutions in the country, is now recognized as an authority on the subject. His book on radium will soon be off the press.

\section{RESEARCH IN BONE STRUCTURE}

The late Dr. James Stephen Foote, whose last work on bone research will be brought out in 1928, posthumously by the Smithsonian Institute, originated the theory that bone structure of ani-

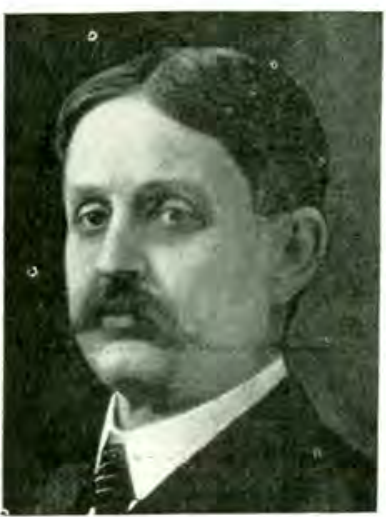

JAMES STEPHEN FOOTE mals is a measure of their development. He proved his point by examination of old Egyption mummies and other relics. He also was a specialist on teeth and one section of the forthcoming book will tell "How We Got Our Teeth." For his knowledge along this line, he was. honored by the American Dental Association.

Dr. Foote was on the Creighton University faculty for 33 years as research professor. He died in 1925.

Foote's "Comparative Histology of the Femur," published in the Smithsonian Contributions to Knowledge, 1909-1916, was his largest work, until his last, but other important writings include: "Constructive Method of Histology," 1907; "Outlines of Pathology," 1908; "Circulatory System of Bone," Smithsonian publication, 1921; 'Bone as a Measure of Development", 1923; and papers on compartive histology on the bones and teeth of the primitive vertebrates.

Through the kindly offices of Dr. Hrdlicka, head of the Smithsonian department of anthropology, Foote obtained numerous specimens of mummies to pursue his research. As a return favor, Foote sent Hrdlicka a collection of skulls so that he might continue his 
favorite specialty. He traveled extensively abroad, studying in the laboratories of England and Germany with Virchow.

Later on when Foote, owing to illness, discontinued teaching for two years he devoted himself entirely to research work on teeth. His books on the subject are "Bone Structure as an Index of Development-How and When we Get Our Teeth," making a comprehensive study of fish, amphibians and reptiles. The last work he had just completed when he died suddenly in a heart attack.

A violinist of note, Foote was also devoted to the muse of poetry. In 1883 in Boston he published a lengthy poem in blank verse on Joan of Arc.

Foote was born in Connecticut in 1851, was graduated from Yale in 1877 and from Columbia and the College of Physicians and Surgeons in New York in 1880. He spent a few years in Wichita, where he acted as director for a group of doctors organized into a student body for the purpose of learning to use the microscope. They met every night. He made the original contribution for the largest hospital in Wichita today. Shortly after the opening of Creighton University, he was called here in 1893 and remained until his death. He was a member of many scientific organizations: The American Microscopical Society; American Association for the Advancement of Science and was an invited speaker at the Pan-American Congress held in Cuba.

High tribute to Dr. Foote's 34 years' research is expressed by Dr. Arthur D. Black, dean of Northwestern University Dental School, in his introduction to Dr. Foote's posthumous work, "Bone as a Measure of Development," which was issued in May, 1928. It is the first volume ever published by the American Dental Association and was prepared for the press largely through the efforts of Dr. E. H. Bruening of Creighton Dental College faculty, who worked with Dr. Foote for many years. Dr. Bruening holds the copyright for the book.

\section{WRITES ON WAR SURGERY}

Captain George Peyton Pratt of Omaha, who served with Evacuation Hospital No. 1 at Sebastopol, France, was the only Nebraska physician invited by the Surgeon General to assist in collecting 
and preparing material for the medical history of American participation in the European war. The topic of "Thoracic Surgery" (War Wounds of the Chest) was assigned to him.

The invitation came to Dr. Pratt in April, 1920 and the result of Pratt's work, together with George J. Heuer and Verne R. Mason, both of Johns Hopkins at Baltimore was printed in the Annals of Surgery for September, that year. An interesting feature of the published work is a series of composite pictures of all chest wounds treated in this important hospital center, prepared by Dr. Pratt.

Ira M. Lockwood, Lincoln roentgenologist, was the only other Nebraskan connected with Evacuation Hospital No. 1 and is credited with painstaking localization work especially valuable to the three surgeons who completed this important piece of war wounds history. Captain Pratt served for ten months at this hospital, before the Armistice was signed.

\section{DENTAL SURGERY}

William Lete Shearer, Omaha physician and oral surgeon, has won renown for the operations he designed in 1905, known as the Shearer methods of alveolectomy and partial alveolectomy, and for

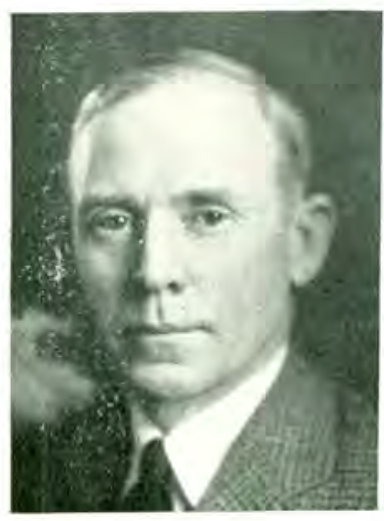

WILLIAM L. SHEARER the instruments he also designed and which bear his name. Among them are the open-faced forceps and the chickenbill. He presented his operations for the removal of imbedded and impacted teeth, known as the flat principle of managing problems of the jaw, to the medical profession in a paper before the Tri-City Dental Society in 1906. In the 22 years intervening, these methods have gradually been adopted all over the world. He was given an honorary membership in the Wisconsin Dental Association, since he is a native of that state.

Besides the usual societies, Shearer holds membership in the American College of Surgeons, in the American Association of Oral Surgeons and Exo-dontists; was one of the organizers and is a mem- 
ber of the board of American Association of Oral and Plastic Surgeons; on the faculty as special lecturer of the International Post Graduate School of Orthodontia at Kansas City, where he goes twice a year to give a series of lectures; and is assistant professor of surgery and head of the oral and plastic surgery department of the University of Nebraska College of Medicine. He was for many years on the Creighton College faculty. He is also on the board of trustees of the University of Omaha; chairman of the health committee and a member of the executive board of the Omaha Chamber of Commerce, and is oral surgeon at the Nebraska Methodist, Immanuel, Evangelical Covenant and Clarkson Hospitals. $\mathrm{He}$ is past president of the Nebraska State Dental and Tri-City Dental Societies.

\section{MUIRHEAD TREATMENT OF ADDISON'S DISEASE}

A story of great heroism in the interest of medical science marks the page of the late A. L. Muirhead, former dean of Creighton University, who, while dying of Addison's disease, assisted the Mayo

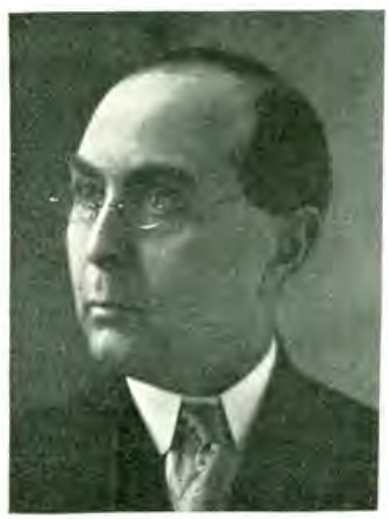

A. L, MUIRHEAD Clinic in diagnosing his case and who worked out a treatment known as the Muirhead Regime for Addison's Disease, which will go down in medical history for the benefit of future unfortunate sufferers of this rare disease, who may now receive a cure that he was denied, thanks to his final efforts.

The principle of the treatment Muirhead mapped out, too late for his own use, is the frequent administration of adrenalin hypodermically and by rectum and of the whole gland or suprarenal cortex by mouth to the point of tolerance.

Dr. Muirhead wrote up the history of his case and his own very careful clinical observations in the Journal of the American Medical Association in 1921 (Volume 76, page 652) in an article entitled "An Autograph History of a Case of Addison's Disease," concluding with this simple statement, fraught with the high purpose of serving humanity: 
"Although the writer is the patient, he believes that observations made by a physician who is also a teacher of pharmacology will be of greater value to those who have patients with Addison's disease under their care, than would the usual observations."

Dr. L. G. Rowntree of the Mayo Clinic continued the Muirhead treatment on other patients, after the death of Muirhead, and reports gratifying results. He considers it the best treatment yet available and has published the following articles concerning the Muirhead treatment: "Subsequent Course of a Case of Addison's Disease," Journal of the American Medical Association, in 1922, (Volume 79, page 556); "Treatment of Three Cases of Chronic Addison's Disease," in Medical Clinics of North America in 1923 (7:177); and "Studies in Addison's Disease," Journal of the American Medical Association in 1925 (84:32).

Muirhead was a graduate of the University of Michigan and instructor in pharmacology in his alma mater, joined the Creighton faculty in 1904 as professor of pharmacology, which position he held until his death in the spring of 1921.

From 1913 to 1915 he was Dean and for several years was editor of the Western Medical Review. He contributed largely to medical journals, especially to those of his own specialty and was the author of a text-book on "Physiology for Nurses."

\section{RESEARCH IN URINARY ANTISEPSIS}

The synthesis of mercurochrome resulted from an investigation originally carried on by Edwin Davis, Omaha urologist, during 19161918. This research was conducted in the laboratories of Johns Hopkins Hospital in Baltimore, until interrupted by the war. Before leaving for the service, however, Davis summarized the results of his research to that date, in a preliminary report printed in the Journal of the American Medical Association, March 2, 1918, entitled "Urinary Antisepsis - a study of the antiseptic properties and renal excretion of compounds related to phenolsulphonephthalein."

Cooperating with the Omaha urological surgeon during the second year of these experiments was a Baltimore chemist, Dr. Edwin C. White, who continued the research after Davis left, with Doctors 
Hugh H. Young and E. O. Swartz, with the result that within a few months, they announced a new germicide "mercurochrome-220." This report was published in 1919 .

The original purpose of this investigation was the discovery of the ideal internal urinary antiseptic - one which would be chemically stable, non-toxic and non-irritating and which would be elim-

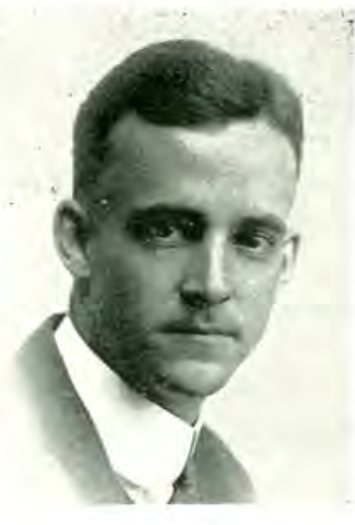

EDWIN DAVIS inated unchanged by the kidneys, to exert an antiseptic action in the urinary tract. Mercurochrome does not accomplish this specific purpose. This drug has been shown, however, to be of value in general sepsis, and the number and variety of its uses as a local antiseptic have so multiplied that mercurochrome has come to be almost a household remedy.

While at work on this problem of urinary antisepsis, Davis and White and one Robert Rosen announced another step in their research progress: the secretion of antiseptic urine following intravenous administration of an organo-mercury phthalein derivative. This was printed in the Journal of Urology, also in 1918.

The Omaha specialist then made another important discovery-the value of acriflavine as an internal urinary antiseptic, as well as in the local treatment of a social disease.

Dr. Davis investigated more than 200 synthetic compounds during this piece of research, noting that some of them possessed the property of rapid diffusibility through the tissues. B. E. Harrell collaborated with him in the completion of this report, which was also printed in the Journal of Urology, that year.

All of these reports were available and were used as a basis for the final synthesis of the now popular mercurochrome.

But this work is not yet completed. The ideal urinary antiseptic has not yet been found and Davis is still searching for it. On his return to Omaha after the war, he resumed his experiments in the laboratory of the University of Nebraska Medical College, with 
the aid of an appropriation made by the U. S. Inderdepartmental Social Hygiene Board. He studied the antiseptic properties and renal excretion of 204 anilin dyes and gave the results of his experiments in a paper published in 1921. Further important research in the oral administration of acriflavine were published by the young Omaha specialist in 1924.

Dr. Davis is also writing chapters in two systems of surgery. One is Dean Lewis' Practice of Surgery and the other is Nelson's Loose-Leaf Surgery.

\section{NUTRITIONAL EXPERT}

Victor E. Levine, professor of biological chemistry and nutrition at Creighton University, is regarded as one of the three leading clinical nutritionists. The other two are Alfred F. Hess of New York and William McKim Marriott of

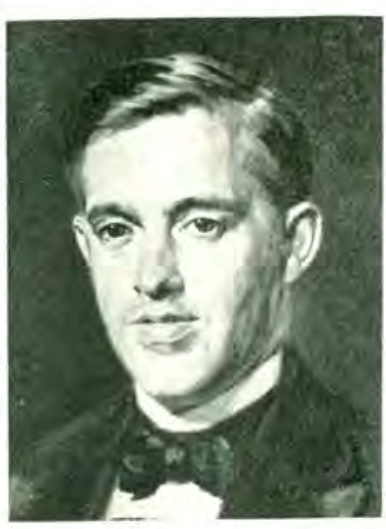

VICTOR E. LEVINE

St. Louis. He is a co-worker of Elmer V. McCollum of Johns Hopkins University, in the isolation of vitamin $\mathrm{B}$, and of C. H. Best, who, with F. G. Banting, discovered insulin, an important research in carbohydrate metabolism. McCollum, in recent publications, accords the Omaha professor high praise.

McCollum and Levine are responsible for the latest theory that the visceral organs, like liver, are rich in vitamins and iron and therefore a preventing factor in anemia; and that these organs are superior to muscle meats, like steak and chops. Levine's research took him to the Arctic regions in 1922 in an effort to discover how the Esquimos, who eat no fresh vegetables or fruits (then thought to be the only sources of vitamins) could live. He discovered that the Esquimos eat all the inside organs of animal food, and from this investigation, ascertained that the visceral organs supply all the vitamins required. This expedition was a Johns Hopkins undertaking. 
The Omahan's research is along three lines: analytical biochemistry, toxicology, and metabolism and nutrition. In the first field he discovered a general test for carbohydrates, a specific test for reducing sugars, a specific test for ketone sugars, two tests for phenols, and a re-agent for reducing enzymes. He has worked on a method for differentiating boiled or pasteurized milk from raw milk, living bacteria from dead bacteria, and paratyphoid "A" from paratyphoid "B." He has also worked out a biologic method for detecting selenium in the body, and has reported a new quantitative method for the estimation of peroxidase. In collaboration with Dr. W. M. Barry, he described a method for the preparation from bile of the green pigment, biliverdin.

In the field of toxicology he worked out the symptoms of selenium poisoning and has discovered the antidote. During 1910 1912, selenium and some of its compounds began to be used in the treatment of cancer. Levine pointed out that many patients receiving this treatment, died, not because of the cancerous condition but as a result of symptoms occasioned by selenium poisoning.

More recently Levine has confined himself to the study of opium alkaloids. He found that many convictions for murder were based on toxicological conclusions that are no longer correct. In one of his papers he states: "The study presented leads to the conviction that many of the analytical procedures for organic poisons used in toxicologic examination and offered in legal evidence, are in dire need of thorough revision and critical re-valuation. They were introduced into toxicology twenty-five to fifty years ago, when analytical methods in organic chemistry and in bioligical chemistry were in their infancy. Where human life is at stake medico-legal safeguards should stand firmly on a basis of undisputable scientific facts."

In the field of metabolism Levine has been interested in carbohydrates. He described several new substances besides insulin that have the power of producing hypoglycemia. Together with Charles H. Best, he discovered the presence of insulin in bacteria. Scott and Best published experimental data showing that insulin was found not only in the pancreas, but also in the organs of the body as well as in blood and urine. Collif, Scott and Best also demonstrated the existence of insulin in plants. The presence of insulin 
in bacteria was a gap that had to be filled in order to draw the general conclusion that all forms of life contain insulin. Levine was the first one to show that insulin was dialyzable and that it was probably simple in chemical structure.

In his work on nutrition, which he seeks always to apply to clinical medicine, Levine also studied the effect on growth of the rarer biologic elements such as manganese, nickel, cobalt and arsenic. He has the training of both laboratory and clinical nutritionist. His book "Applications of the Science of Nutrition to Clinical Medicine" will be off the press in 1928 .

Levine is a fellow of many distinguished scientific organizations. His portrait is hung on the walls of the School of Hygiene and Public Health of Johns Hopkins University. The accompanying cut is from a painting by $\mathrm{J}$. Laurie Wallace.

\section{THIRD SOURCE OF URIC ACID}

A third source of uric acid in the body is the important discovery of James Francis McDonald, for the past seven years professor of physiology at Creighton University. It was favorably

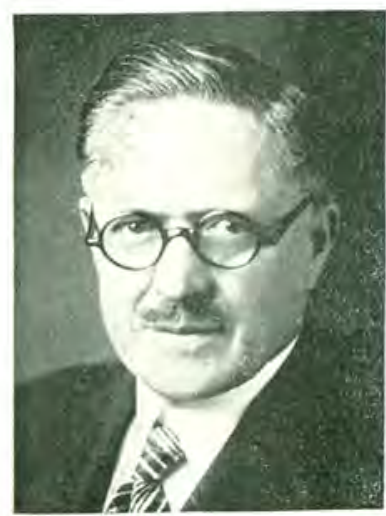
JAMES FRANCIS M'DONAID activity of various kinds of bacteria which inhabit the intestine and other regions of the body.

Victor E. Levine, professor of biochemistry and nutrition and Michael Gleason, who gave technical assistance, collaborated with McDonald in this discovery. 
McDonald has established further important scientific facts. One is that several varieties of bacteria contain nuclei. Working with him in this discovery were John T. Little of Omaha, assistant professor of chemistry and Ernst Ruckensteiner of the department of Pathology, Creighton Medical College, now in Rochester, New York. This discovery shows that the structure of bacteria, so long a mooted question among the authorities, follows the plan long known to underlie in the structure of the cells of all vegetables and animal organisms, in that bacterial cells are made up of structures like nuclei, cytoplasm, and cell wall which are definitely separated from each other in an organized manner.

McDonald also discovered that ciliated epithelium, which is an automatically-acting tissue located in various parts of the human body, is subject to acceleration and retardation by neural and chemical controlling agencies just as are the other visceral tissue of the body like plain muscle, heart muscle, and glandular cells. Formerly it was considered that ciliated epithelium was lacking in these correlating mechanisms, which are known to regulate the rate of activity of all other visceral organs and tissues. He also established that ciliated epithelium is paralized in the absence of a film of moisture which normally lies upon its surface. Since this type of epithelium lines the respiratory tract and has the task of making possible the filtering of a pure stream of oxygen from an abundantly dust- and germ-polluted atmosphere, and since, further, the air of American homes and offices during cold weather is known to contain less humidity than that of desert air, this discovery is held by physicians and sanitary engineers to be of the utmost importance from the point of view of the cause and treatment of various types of respiratory infections, including the common cold. Further, since ciliated epithelium is the means of propulsion of the ovum along the Fallopian tube down to the uterus, a disturbance in the controlling agencies of this cilia, is believed to be an important causative factor in the occurrence of various grave and frequently fatal conditions, like placenta previa and ectopic pregnancy. (In collaboration with C. E. Leisure and E. E. Lenneman, class 1928, Creighton Medical College.)

McDonald also believes that the semicircular canals in the human body have important physiological relations, hitherto over- 
looked. This work, now in process of publication, was done in col'aboration with Frank Neisus, class 1928, Dr. L. L. Wilson and Dr. J. A. McCarthy, 1927.

McDonald is also writing a book on "The Mechanism of Referred Pain." The subject of pain reference is in a rather chaotic form as stated in medical textbooks and literature. His wide experience in lecturing upon basic medical subjects as embryology, histology, gross anatomy, physiology and neurology, and his clinical experience at the Mayo Clinic and elsewhere have enabled him to correlate, simplify and reinterpret the entire subject, bringing it into relation with known anatomical, physiological and pathological facts and principles and making this subject more orderly and more easily intelligible.

Dr. McDonald is interested in criminal psychology. His clinical and psychological study of Frank Carter, the "Sniper," (in collaboration with the various specialists, Victor E. Levine, B. Carl Russum, John R. Kleyla, J. A. Borghoff, B. M. Kully, and C. M. Swab) has been praised by the Laura Spellman Rockefeller Memorial, established by John D. Rockefeller. The Omahan's findings have been incorporated in the international study which this institution is making of crime and the psychology of the criminal.

McDonald was born in Copenhagen, New York, was educated at Syracuse (1911) and has done extensive graduate work in biology at Columbia University, under Professor Gregor; in neurology, under Judson C. Herrick at Chicago University; and in Europe where he studied the intimate structure of the brain in the private laboratory of Professor Brodmann, of the University of Tubingen, Germany; and in organic chemistry with Professor Pickel at Creighton.

Before coming to his Omaha post, McDonald was on the faculty of Bellevue and Fordham Universities in New York; spent three years at the Mayo Clinic, and was a graduate lecturer in embryology and clinical neurology to special groups, in New York City. His scientific affiliations include the American Association 'for the Advancement of Science, Nebraska Academy of Science, American Chemical Society, Annual Biological Conference and the usual medical groups. 


\section{PALEONTOLOGISTS}

Frank B. Young and A. L. Cooper of Gering are rapidly forging to the front for their original studies in paleopathology. They have given papers, with exhibits, at the 1926 meetings of the American Medical Association in Dallas, Texas, and the Radiological Society of North America, at Milwaukee.

The impetus for their study of diseased piehistoric bone came about through their proximity to the celebrated fossil beds at Agate Springs Fossil Quarry, in Sioux County, and their friendship with Captain James Cook and Harold Cook who first discovered them.

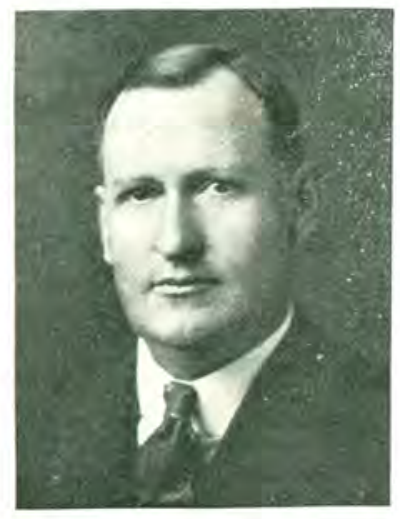

FRANK B. YOUNG

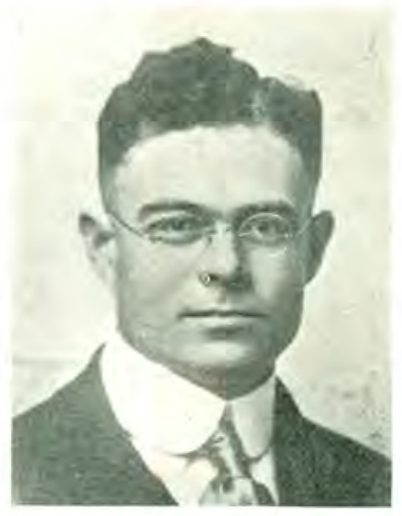

I. L. COOPER

One of the important results of their search and discovery of evidences of diseased teeth of prehistoric animals is to prove the opinion held by nearly all laymen, many physicians and most dentists, that diseases and deformities of teeth and jaw are due to improper diet and other conditions of modern civilization. Future results of continued research along these lines is incalculabe in benefits.

Before settling in Nebraska, Young was prominent in Arkansas medical circles, was president of the Arkansas state medical society in 1913-1914, president of state board of health and state health officer and superintendent of the state hospital for nervous diseases. While health officer, he established the first anti-malarial work in the history of the South and while head of the institution, promoted general medical and surgical treatment of insane patients in a man- 
ner which had never been attempted before. Young believes such care will result in much good for these unfortunates. Since locating in Gering in 1916, Young was president of the Scotts Bluff County Medical Society and it was largely due to his efforts that the West Nebraska Methodist Hospital was established in Scottsbluff. He was a member of the committee of the Nebraska State Medical Association which placed an exhibit at the State Fair in Lincoln, last year - the first exhibit of its kind in the history of organized medicine.

The use of roentgen rays has enhanced the importance of Young's research work.

Young was born in Kansas in 1878; was educated at the University of Arkansas and was graduated in medicine at the Kansas City Medical College in 1900. He is continuing his research and will shortly publish some articles in the Annals of American History. $\mathrm{He}$ and his colleague were given honorable mention for their exhibit by the American Medical Association convention at Cleveland.

\section{ARCTIC FXPLORERS}

An Arctic explorer in 1871, an intrepid northern adventurer, was Noah Hayes, retired physician living in Lincoln, Nebraska. He celebrated his 84th birthday in June, 1927.

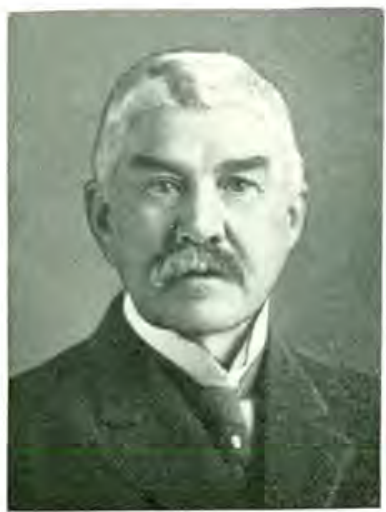

NOAH HAYES

Hayes was a member of the Polaris expedition which reached the farthest northern point ever attained until Peary reached the pole. The vessel was lost in the ice and the crew was rescued by a whaling vessel from Liverpool.

The Polaris was captained by Charles F, Hall, a veteran of several Arctic dashes who spent eight years among the Esquimos, learning their language, and who induced Congress to appropriate $\$ 50,000$ for the expedition. The Polaris sailed from Washington, D. C., June 10,1871 and from New London, Connecticut, July 3. She never returned and her commander lies buried where his ship was crushed in the ice, his 
only monument being a large crowbar stuck at the head of his grave. His death and burial are described in a journal kept by young Hayes from July 27, 1871 to May 24, 1873 when he ran out of paper and couldn't buy any more in latitude 82 degrees, 16 minutes - the farthest north ever achieved up to that time.

The record as far as it goes, is a thrilling document, relating the encounter with ice floes, scarcity of food, hunting and exploring parties and finally, the destruction of the ship off the shore of Lifeboat Cove, below Renassalaer Harbor, on the coast of Greenland, near enough to Littleton Island that the crew of fourteen were able to make the distance afoot, over new ice. Many valuable instruments were left on the ice because they were not among the first essentials which were all the men could carry.

A day later the party was discovered by Esquimos who assisted them in building a shelter, Polaris House, from the lumber taken from the ship. Here the Americans stayed from October to June, fashioning boats from selected timber. When the ice was out, the party set adrift on May 30 with provisions for two and one-half months and on June 3 the two boats were actually under way. June 22 they were sighted by the Ravenscraig, a Scotch whaler which rescued the crew and transferred half of them (among them Dr. Hayes) a few days later to the whaler Arctic, aboard which they enjoyed a two month whaling cruise and finally landed in Edinburgh, where they were extensively entertained.

The British government brought the shipwrecked mariners home in state and the government provided easy posts for most of them. After several years in Washington young Hayes decided to study medicine and was graduated from Georgetown Medical College more than fifty years ago. His first office was in Fairbury, Nebraska. He later moved to Seneca, Kansas, where he practiced 33 years. He was on the staff of the Soldiers' home at Burkett, retiring more than ten years ago to make his home in Lincoln.

Hayes recruited a company for service in the Spanish American War and mustered them in at Topeka, Kansas, but was unable to serve himself because he was fifty-four then and had a bad heart. He first came to Nebraska in 1878 and shortly moved to Kansas, where he practiced for 33 years. He returned to this state in 1915 and practiced desultorily for a few years at Wilcox and McCool. 
A daughter, Miss Helen Hayes, is on the staff of the Lincoln State Journal.

More recently, in about 1922, Victor Levine of the Creighton University faculty accompanied an Arctir expedition to Labrador to study nutritional problems of the Esquimos and another Omaha lad, Earl K. Langford, a Creighton graduate, is now in the frozen north with the Donald MacMillan Arctic expedition for the Field Museum, Chicago. Langford's expedition sailed in June, 1927, and made its winter headquarters at Nain, Labrador. The party is not expected back until October, 1928.

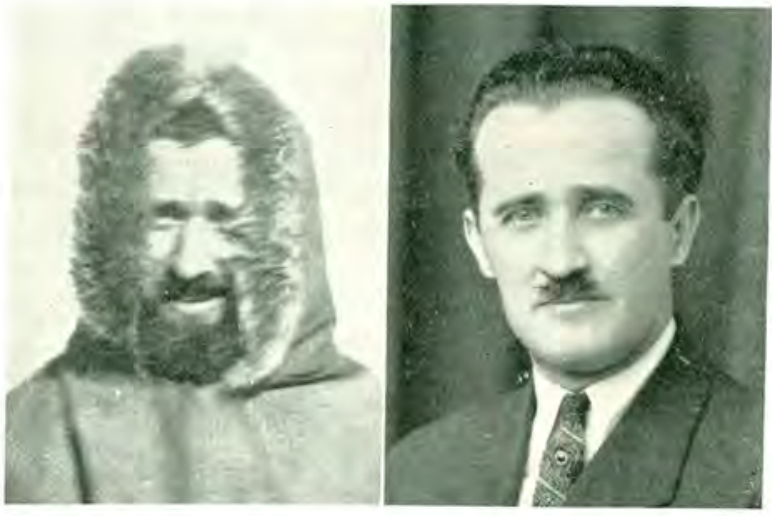

EARI, K. LANGFORD, IN ARCTIC ATTIRE, AND AS HE LEFT THE STATES

Langford's letters to his parents, Mr. and Mrs. W. I. Langford, 3409 South Twenty-first street, although few and far between, are replete with interesting experiences. He told of a 100-mile journey made in a small boat to check an epidemic of influenza among the Esquimos at Hopedale, Labrador. Arriving in the settlement, the doctor found nearly every one sick, and without medical care of any kind. He got the village "on its feet" again, without a death, and did considerable business as a dentist before leaving.

"There are enough bad teeth here to keep several dentists busy for a lifetime," he wrote. He also reported a strange epidemic among the dogs at the Esquimo settlement.

There are 12 in the party, and all are dressed in Esquimo clothes, lined with sealskin. To protect their faces against the cold they let their beards grow, and pictures of Dr. Langford received at 
home brought a laugh. In addition they must shave their heads that the hoods may fit tightly.

The Omaha physician received national prominence through mention of him made by Donald Macmillan, commander of the expedition, in a radio interview with the party in the far north, by the Associated Press through the Massachusetts Institute of Technology radio station on February 16, 1928.

"Our physician and surgeon, Dr. E. K. Langford, is of great help on a coast where there is not a single doctor for 200 miles," MacMillan radio-ed. "He has left by dog team to attend a broken leg 30 miles south."

The Field expedition established winter quarters and a permanent scientific station at Bowdoin harbor, Field Bay, northern Labrador, for the purpose of studying the meteorology, geology, botany, zoology and anthropology of this region, which is unknown scientifically.

Langford attended Benson High School, Creighton and the University of Nebraska, and was graduated from Loyola College of Medicine in Chicago. He practiced in Omaha with Stuart MacDiarmid, before serving 23 months overseas, as a captain. In France, he formed the friendship of Howard Savage, later commander of the American Legion through whose influence he joined the Field expedition. He was surgeon with the Edison Electric company in Chicago just before leaving for the north.

FIRST AIRPLANE

Frank A. Brewster of Beaver City and Holdrege, Nebraska, is the first physician in the world to buy and operate an airplane for use in making professional calls. He made his first air-call the afternoon of May 23, 1919, by answering an emergency call to Herndon, Kansas, flying the 55 miles in 50 minutes. He and his pilot made a graceful landing, the doctor performed a delicate operation, removing pieces of bone from the skull of a man injured by an oil derrick, and flew back home the same afternoon, reaching there as $7: 50$, in almost less time than he could have arrived at his destination by auto. Several days later, he made another air-call to McCook. 
His pilot was a neighbor, Wade Stevens, a former army pilot. Brewster bought the plane, a Curtiss Army training plane Model JN 4 D in April, 1919 of the Curtiss Corporation at Buffalo and made his test flight on May 21. Two days later came the emergency for which he sought to be prepared, and he was enabled to save the patient's life. The Curtis company authorized the statement that the Nebraska doctor's airplane was the first one sold to a doctor to use in making calls, and the Herndon trip, the first physician's air-call. He won international renown thereby.

That Brewster is progressive by nature, and especially in transportation, is evidenced by the fact that he bought the first automobile in Furnas County in the spring of 1906. It was a single

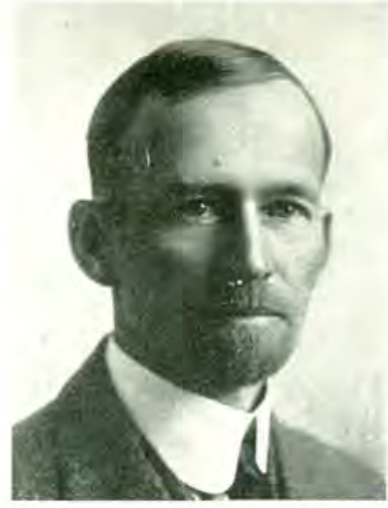

F. A. BREWSTER

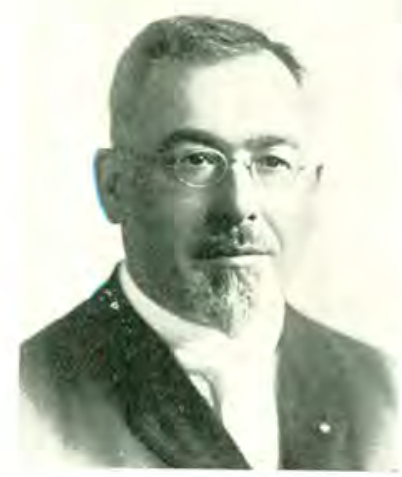

FREDERICK H. MILLENER

cylinder Cadillac. He also built the first hospital in Furnas County, or in southwestern Nebraska, in fact, the Republican Valley Hospital at Arapahoe, in the same year, 1906.

Brewster was born and educated in this state and has been practicing surgery since 1900 .

\section{ELECTRICAL EXPERIMENTER}

Frederick H. Millener, for thirty years connected with the Union Pacific, was a veritable electrical wizard, though none of his inventions were sufficiently perfected to be accepted.

"He was far ahead of his time in many respects," said W. H. Guild, Union Pacific official, commenting on the loud-speaking mega- 
phones which Millener installed in various parts of the Union Depot, during the war, to announce incoming and departing trains, and aimed to do away with the necessity train announcers.

Millener had the right idea, as evidenced by the later perfection of the radio loud-speaker horns, but had not perfected his conception when he died in California four years ago, and the megaphones were dismantled at the depot. He made many experiments with wireless talking equipment, and on one occasion, with little material or equipment, manufactured a phonograph record to be used by Miss Henrietta Rees in the production of a prize play for the Omaha Woman's Press Club.

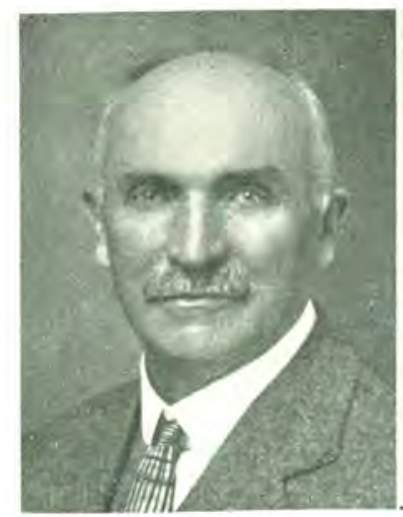

CHARLES HUGH BREUER

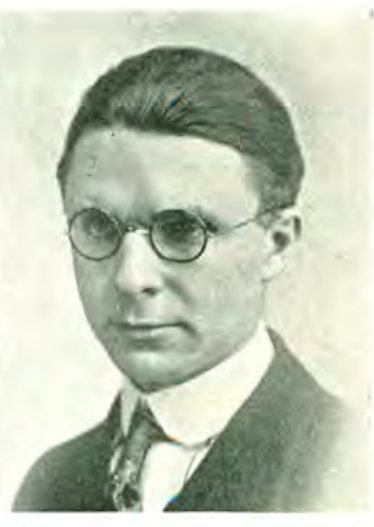

MILES J. BREUER

Little is known of his medical career except that he told Dr. T. P. Livingston of Plattsmouth that he was a graduate of the medical department of the University of Buffalo and had practiced there. Employees of the Union Pacific, where he was employed as custodian in the latter years of his life, say he received degrees from German universities. Another old friend is authority for information that Millener attended Jefferson Medical College in Philadelphia.

\section{LITERATURE}

Outside the field of medical literature, as well as in it, Nebraska physicians have made names for themselves. One, "Doc" A. L. Bixby of the Lincoln State Journal, is credited with being the first newspaper columnist in the country. $\mathrm{He}$ rounded out more 
than 35 years on the Journal. Another young Lincoln physician, Miles J. Brever, has written a novel, not yet published, "The Man with the Strange Head," "The Stone Cat" and other thrilling stories for "Amazing Stories" and "Wierd Tales," as well as many articles of medical interest in professional magazines. He compiled an index of physical therapy, wrote articles on sociology and photography and some poetry. His father Charles Hugh Breuer wrote "Popular Hygiene."

\section{LINES TO LIFE}

We've traveled far together, Life. From childhood to old age;

We've climbed the hills of barren rock, And played upon your stage.

Our friendship's never had a jar, I ve loved you all the way;

No one has come between us, Life,

To cause this love to stray.

Of all who started with us, Life,

But few are left today;

They started with as fair a chance

But some have lost the way.

They loved you just as well as I,

Their prospects just as bright,

But somewhere in the swamps we crossed

They dropped from out our sight.

I'm growing somewhat tired, Life,

My step is not so strong

As when we stood upon the heights

Or mingled with the throng.

Some day I know you'll leave me, Life,

It won't be very long,

As you have left those other friends,

But still my love is strong.

I'm not bidding you good-bye, Life,

You've been too true a friend;

I'm just a little tired, that's all,

And can't tell where 'twill end.

But when we reach the journey's end,

Where all earthly ties are broken,

Then, may the good-byes that we say

Be gentlest ever spoken.

Dr. G. O. Remy, A insworth, Nebr. 


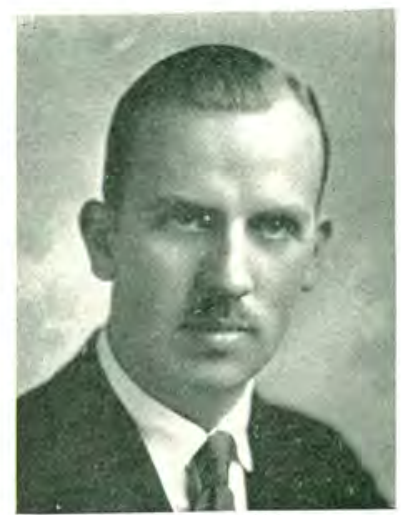

CLARENCE F. BANTIN

George Oliver Remy, pioneer physician of Ainsworth, has written more than 50 creditable poems. Clarence F. Bantin, young Omahan, wrote a oneact play, "Memory Rose," which won first prize in the Omaha Woman's Press Club statewide contest in 1927. It was published by Samuel French of New York and has since been produced by the Drama League. A second play of young Bantin won honorable mention in the Press Club contest of 1928. A scientific article, "Diabetes Lipemia Retinalis," was printed in the Journal of the American Medical Association in February, 1926.

George Harrison Gilmore of Murray, who has practiced medicine for 32 years in a town near where his parents homesteaded and where he was born in 1867, wrote "Away from the Mountains," a short story, and "The Hidden Village," an archeological work, besides articles on "The Home Trained Nurse," "Split Fee," and "Influence of La Grippe on Pregnancy."

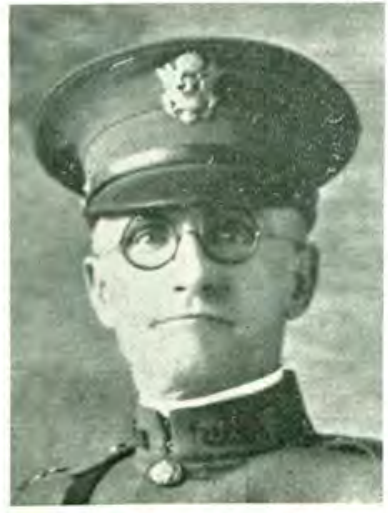

GEORGE H. GILMORE

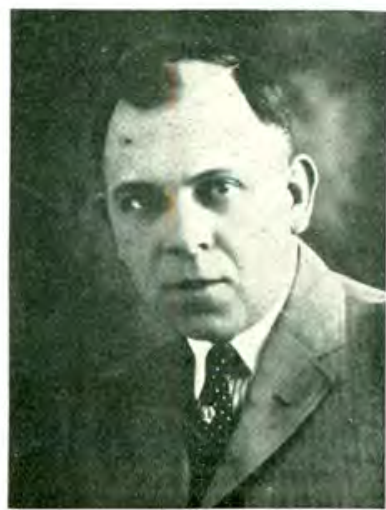

CLAUDE FORDYCE

Claude Powell Fordyce of Falls City has written prolifically on sports and outdoor life and is travel editor of "Outdoor Life and Recreation Magazine," of Denver. His output includes six books 
and over 100 articles on recreational activities and health topics in national magazines. His books include "Trail Craft," "Touring Afoot," "Auto Camps and Tours," "Keeping Well Outdoors," "Camps and Kits" and "Outdoor Life." He writes for Adventure magazine as well.

Benjamin F. Lorance of Auburn, interested in educational problems, wrote three books, "Medi-Cult, "The A-B-C of the Medical Profession" and "Religious Instruction and the American Public School," besides medical articles. Joseph Milton Curtis of Tecumseh translated "Origin and History of the Aryan Race" and other books from the German of Karl Zuchallzech.

In the scientific and medical field, Charles W. M. Poynter of the faculty of the University of Nebraska Medical College has made important contributions to anthropology, teratology, embryology, neurology and anatomy and belongs to many scientific societies; Le Roy Crummer wrote "Clinical Features of Heart Disease" and various monographs on the history of medicine; John E. Summers, Jr., "Modern Treatment of Wounds;" Palmer Findley, "Diagnosis of Diseases of Women," "Diseases of Women" and he was also associate editor of the American Journal of Obstetrics; Alfred Schalek, graduate of the University of Prague in 1890 and formerly a professor at Rush Medical, wrote a book on skin diseases; Arthur Bruce Walker of Lincoln wrote articles on chemistry; Roy W. Fouts on "X-Ray Diagnosis and Therapy and Physical Therapy;" and George J. Haslam of Fremont, a book on "Anatomy of the Frog," which won him recognition from British scientific organizations. John Barr Learned, father of Myron Learned, Omaha attorney, wrote a book on insomnia. He was a native of New England and died here January 24, 1910. Charles P. Crudup of Nebraska City wrote "The Autobiography of a Physician." He and his brother, S. Jones Crudup, formerly of Julian, Nemaha County, are sons of Edward A. Crudup, pioneer physician.

The chapter on "Amputations" in McKeen's book on "Surgery" was written by W. J. Galbraith, formerly of Omaha, chief surgeon of the Union Pacific, and one of the organizers of Creighton Medical College, according to Father W. P. Whelan, regent of Creighton. After leaving Omaha, he was medical director for the Chihuahua, Mexico, mining companies of the late John A. McShane of Omaha, 
in about 1907 and when last heard from was a surgeon on a Pacific ocean steamship. His home is in California.

Daniel Thomas Quigley of Omaha, owner of the Radium Hospital, is author of a 600-page book "The Conquest of Cancer, by Radium and Other Agents," scheduled for publication in April, 1928.

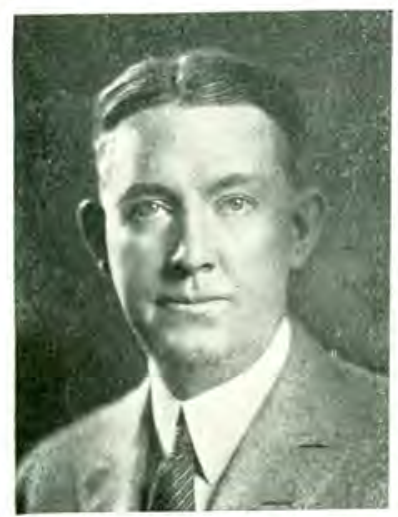

Since 1913 he has devoted himself almost exclusively to tumor and cancer study. Quigley has written on various phases of surgery, pathology and radium therapy, some of which were among the first papers written on these subjects: "Focal Infection as a Cause for Rheumatism," 1907; "Treatment of Surgical Tuberculosis by Sunshine," 1908; and the same year, "Use of the Sphygmomanometer by the General Practitioner and Surgeon," in which he recommended a general use of blood pressure instruDANIEL THOMAS QUIGLEY ments and the checking up of blood pressure in surgical operations and obstetrical cases. He is on the faculty of the University of Nebraska; a member of the American Association for the Advancement of Science; American Radium Society, College of Surgeons and Radiological Society of North America. He formerly practiced in North Platte, Nebraska, after his graduation from Rush Medical College, but settled in Omaha in 1913, following extensive study in Europe.

ART AND BOOK COLLECTORS

The genial "Doc" Bixby, philosopher-columnist of the Lincoln Journal, loves to tell the story that the first medical practice law in the state, passed in 1881 , legislated him out of practice.

"I was one of the 'quacks' the law was aimed at," he is fond of relating, but it is more probable that the smell of printer's ink proved the most potent with him.

Bixby came to Nebraska in 1878 and settled on the Pawnee reservation, now Nance county, where he was the first practitioner to locate. He lived in a "soddy" for a year, moved to Minnesota for a year, and then returned to practice two years in North Platte, 
where his tin shingle decorated the corner of the Tracy and Le Fils drug store. A Dr. Longley and Dick Dullard were the only other doctors there. Caught by the newspaper lure a little later, he estab-

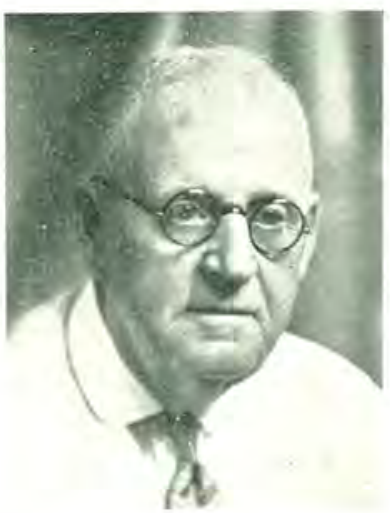

"DOC" BIXBY

lished a paper in Fullerton, served four years with the Western Newspaper Union at Denver and three years in Columbus before joining the State Journal staff in August, 1892. Only one man in the United States has served a longer period as special writer on one publication, according to "Bix," and that is Frank Stanton on the Atlanta Constitution.

Bixby has written several books, among them "Bix' in America" and " 'Bix' Abroad" and much verse, besides his daily column in the Journal. His medical training was received at Rush Medical College, Chicago.

"By consulting the calendar, I note that I am getting along in years," wrote Bixby, who was born in Potsdam, New York, in 1856. "Youth departed when I wasn't looking," he continues in his own inimitable style. "The journey will end just over the hill yonder. Life hasn't been easy for me by any means but has yielded much of satisfaction. I'm glad it happened, but have no desire to travel the road again. One trip's enough for me. I begin to feel toward the earth as Hiram Johnson does toward the Japs - when I am incompetent to tread on it, I want it out from under my feet."

August F. Jonas, whose residence at 31st Avenue and Dodge streets, Omaha, includes an art gallery and museum which is a treasure house of rare manuscripts and fine paintings, has presented many valuable gifts to the University of Nebraska Medical College and Library. Among them were original surgical instruments used in Hippocrates' time. He also owns a medical manuscript of Egyptian papyrus made in the year 1552 B. C. He showed it at a meeting of the Omaha Surgical Club several years ago. His collection of rare books includes a first copy of the Guttenberg Bible and his mineral collection is one of the finest private mineralogy showings in the country. 
Dr. LeRoy Crummer's library of rare medical books is considered one of the three finest medical libraries in the country. It includes 442 medical books printed before the year 1640. One of

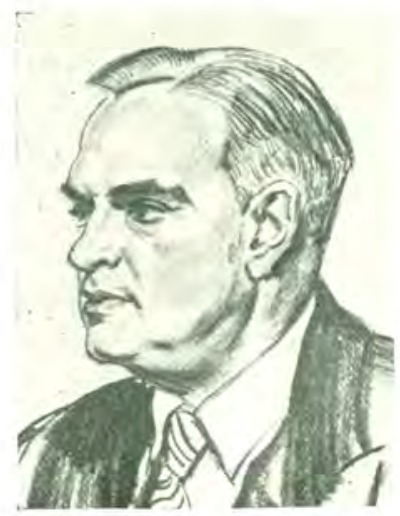

LEROY CRUMMER the most valuable volumes is a first edition of William E'Tarvey's book, published in Frankfort in 1628, announcing the discovery of the circulation of the blood. There is said to be only five of these books in the United States. Another rare volume in the possession of Dr. Crummer is one of the four known copies of Pare's anatomy. Sir William Osler, Dr. E. C. Streeter and Dr. John F. Fulton, all of Boston, own the other three. Dr. Crummer found it in a Paris bookshop.

Of his rare bindings, one is a German manuscript of the year 1280 , made of old board, covered with deer leather. He also collects old prints.

Crummer's medical library represents only one-fourth of his collection. This hobby has given him membership in the Grolier Club of New York, which includes the best known book collectors in the country. He is also a fellow of the Royal Medical Society of London.

The accompanying cut of Dr. Crummer was made from a charcoal drawing done by the celebrated English artist, Laura Knight, who with her husband are close friends of Dr. and Mrs. Crummer and have visited them here in Omaha, as well as entertained them in London on the Crummers' frequent trips abroad. The Knight sketch of the Omaha physician was made into a monotype by Emory Walker, the leading artist in this work.

Alfred J. Brown, Omaha surgeon, is an artist of national reputation in the design and execution of book plates and was one of the few American physicians who exhibited book plates in the exhibit of physicians' artistic works recently held in the New York Public Library, following the example for such exhibits set by Lon- 


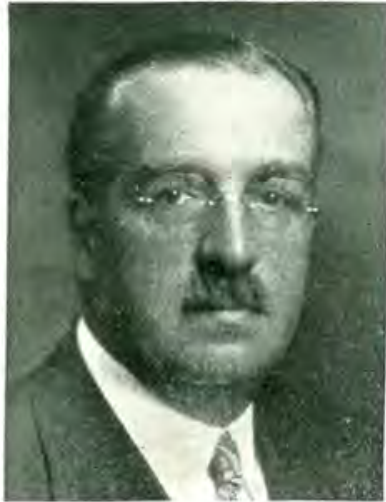

ALFRED J. BROWN don and Paris. According to Crummer, Brown is regarded as the successor of French, a distinguished book plate artist with whom Brown worked at Saranac Lake. He has made more than 40 , one of them in use at the University of Nebraska Medical College library. Brown has also written a history of surgery, and various monographs in anatomical and surgical magazines. A graduate of Yale and Columbia Medical College, he served as instructor in war surgery in Bellevut Hospital in 1917-1918.

The late H. B. Lowry of Lincoln owned a fine collection of art treasures and $\mathrm{H}$. Winnett Orr, also of Lincoln, has an extensive library, including many rare tomes.

Mrs. Charles C. George, president of the Omaha Society of Fine Arts, found in the old Lininger art collection recently put on sale, an old parchment diploma issued by the University of Naples in 1651, conferring the degree of doctor of medicine upon one Dominic Anthony Vendittolus. Translated from the Latin by Professor John J. Wellmuth of Creighton University, it reveals that the candidate "had finished seven years' study and that he underwent a public, severe and fearful examination," before the precious degree was granted. The framed parchment hangs in the Fine Arts galleries in Aquila Court.

Willson O. Bridges is the possessor of several rare old prints of distinguished European physicians, which hang in his private office.

\section{FOREIGN MISSIONARIES}

A Nebraska physician, Clarence C. Drummond, now at Norfolk State Hospital, was in 1921 honored with the Kaiser-I-Hind Medal by the British government for his 28 years' public service in India. Drummond was in medical mission work in India from November, 1897, to February, 1926, when he and his wife were compelled to return home because of ill health. They worked among the Hindus, Mohammedans, Parsees and Christians, giving hospital and dispensary care. 
"The first twenty-five years I was stationed at Harda, in the Central Provinces," Drummond relates. "Harda is a town of 16,000 population, and is about four hundred miles northeast of Bombay. The last four years I spent at Mahoba, a very ancient and more primitive town of 12,000 population in the United Provinces of Agra and Oudh, not far from Cawnpore.

During the time of my service India passed through two severe famines, and for twenty years arinual recurrent epidemics of bubonic plague, and one great epidemic of influenza, at the time of the World War. Epidemics of Asiatic Cholera and other tropical diseases recur so constantly as to excite no comment. For several years I had charge of a leper asylum of twenty to thirty patients."

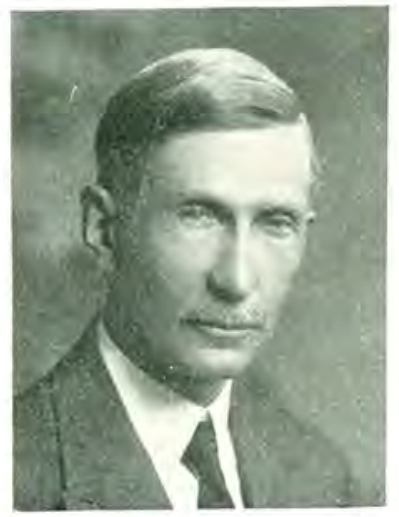

CLARENCE C. DRUMMOND

Drummond was born at Mount Pleasant, Iowa, February 14, 1867 and moved to Arapahoe, Nebraska, with his parents in 1879. He received his B. A. degree from Cotner and was graduated in 1896 from the Lincoln Medical College of Cotner. He practiced for a year, then was married and with his wife departed for India in October, 1897. Since his return he has been on the staff of the Hastings State Hospital but was recently transferred to Norfolk. He is a member of te Indian Medical Missionary Association.

Francis F. Tucker, twice decorated by the Chinese government for famine relief and disease prevention, is a graduate of the University of Nebraska College of Medicine. Under auspices of the American Red Cross, he employed 50,000 Chinese laborers in the construction of highways, thus enabling them to support their families without the stigma of charity. At the end of seven months, the famine was over and a highway system of 485 miles was handed over to the government.

In 1920 a pneumonic plague broke out, threatening Snabtung and Chihi provinces. Dr. Tucker and his Techow Hospital staff stopped the spread of the disease. In the last exciting months of his seven-year term of service, Dr. Tucker cared for thousands of soldiers, erecting hastily organized hospital units, and receiving all the seriously wounded of both sides. 
At one time a thousand refugees filled the corridors and chapel of his hospital for men. A flood came and the medical staff kept on at their work with 10 feet of water on the first floor of the building.

Perhaps the best known medical missionary from this state was James W. McKean who left Omaha in 1889 to establish a hospital at Chiengmai, Siam, where Claude M. Mason, member of the Omaha Board of Education also spent the eleven

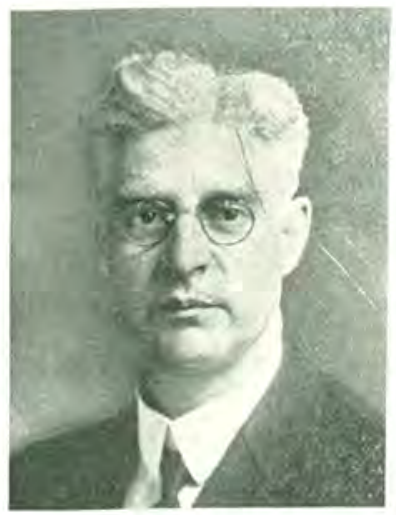

CLAUDE M. MASON year period between 1906-1917. McKean rendered Omaha too a distinct service when he induced H. M. McClanahan, then practicing in Illinois, to come here and take over his practice, when he went to Siam. It was in this manner that the local dean of child specialists happened to settle in this city. McKean, like McClanahan, was active in the Lowe Avenue Presbyterian church before he began his work abroad.

Mason, who is now instructor in tropical medicine at the University of Nebraska, besides serving on the board of education, also spent the seven years of 1918-1925 at Kiu Lung Kiang. Yunnan, China, where Curtis M. Gault, also a Nebraskan, served too.

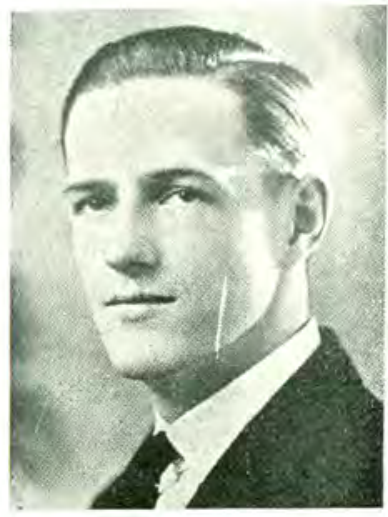

WALTER JUDD Mason took a post graduate course in tropical medicine in London in 1912. Antony Parsons of Valley was a medical missionary in the Belgian Congo in Africa for the past 13 years. Max Gentry of Scottsbluff and Walter Judd of Rising City have been in China for the past two years.

Ernest Joel Constantine Sward of Lincoln, formerly a secretary of the State Board of Health, was born in Turkey, where his parents were Swedish missionaries, in 1873. He was educated in the Universities of Minnesota 
and Nebraska and in 1896 settled in Oakland, Burt County, where he was coroner for six years.

Arthur I. Lovell of College View was ordained to fill a church elder's position.

Howard R. Murphy and Bertha Mangon Thomson, graduates of Cotner University Medical Department in 1912 and 1913, are now serving in Midnapore and Mahoba, India, respectively.

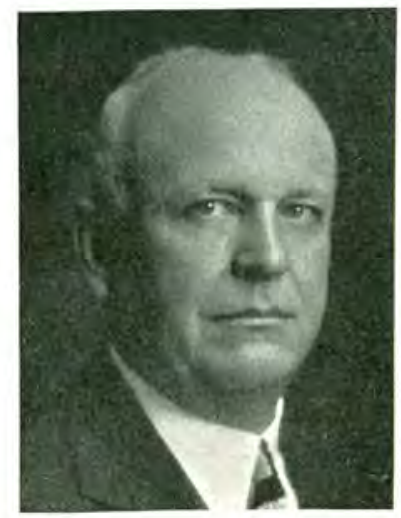

HERBERT C. SUMNEY

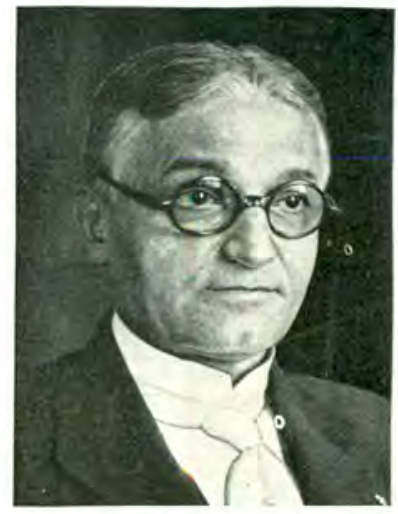

JOHN BAPTIST

\section{IN FOREIGN CLIMES}

Otto Albin Kostal spent more than a year on the staff of the Ancon Hospital in the Canal Zone, Panama.

Grove Baldwin, Creighton graduate, has been practicing in Honolulu for eight years.

Owen Stuart Townsend of York circled the globe in 1902, spending six months in southern China. He was a surgeon at the Soldiers' and Sailors' Home at Grand Island in 1911-1913.

P. H. Salter of Norfolk was a surgeon on a steamship line between England and India in 1885-1886, and saw much of the world at that time.

Herbert C. Sumney is a big game hunter, choosing the wilds of northern Canada for his sport. 
John Baptist of Omaha was the court photographer to Abdul Hamid II, sultan of Turkey and while holding that post, photographed most of the crowned heads of Europe.

Two Syrian and two Filipino physicians are numbered among Nebraska physicians. The Syrians are S. B. Koory of Schuyler and Avedis H. Sissakian of Verdel; and the Filipinos, graduates of the University of Nebraska, are Juan Racines of Palmer and Felix Sucgang of Bushnell.

\section{PRACTICE LIMITED TO INSURANCE}

Augustus David Cloyd of Omaha, medical director of the Woodmen of the World and Globe Insurance Companies, believes he has passed on more applications than any one else in the country, since he began his duties 30 years ago. He passes on between 100,000 and 150,000 applications a year in 43 states and Mexico. Cloyd, W. F. Milroy, Arthur C. Stokes and C. C. Criss are among other Omaha physicians whose practice is limited to the insurance field. Cloyd has written extensively on medical insurance topics.

C. A. Selby of North Platte originated a group insurance plan.

\section{GENEOLOGISTS}

A. D. Cloyd of Omaha wrote a complete geneology of the Cloyd, Basye and Trapp families to which he belongs, tracing his line back to 1680 when his Scotch ancestor, James Cloyd, settled

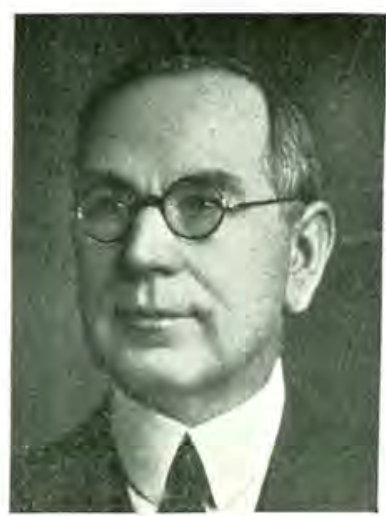

AUgUSTU'S DAVID CLOYD in Chester County, Pennsylvania. It took Cloyd 15 years to complete the book which is a volume of several hundred pages. $\mathrm{He}$ originated a unique family square, instead of the usual family tree, to show the lines of descent. Wesley L. Curtis of Lincoln, now president of the Lancaster County Medical Society, also wrote a geneology of the Curtis family, his research taking him on several eastern trips. He was born on a homestead near Cook, Nebraska, in 1870 and practiced there and at Fairbury a number of years before moving to Lincoln, and instituted there twenty years ago an annual lecture course which is still an annual event. 
Josiah B. Martin of Plattsmouth is another Nebraska physician to compile a geneology of his family. His daughter, Miss Edith Martin, is completing the task.

BIRD LORE

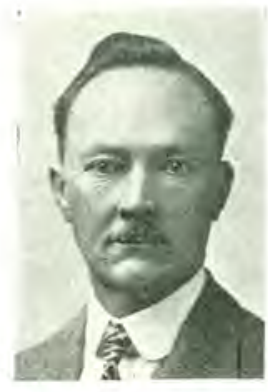

DAVID CI HILTON

David Clark Hilton of Lincoln, former president of the Nebraska Ornithological Union, wrote "Birds of the Fort Leavenworth Military Reservation," published in the Wilson Bulletin in 1919. He was in the medical field of service, was a colonel in the state guards and was a delegate from this country to the fourth international congress of military medicine held in Warsaw, Poland, in 1927. He also wrote" Morphogenesis of the Liver," in the Journal of the American Microscopical Society in 1903.

Solon R. Towne, aged Omaha physician and former city and state health officer, has had a lifelong interest in the birds and their habits, and Harold Gifford, Omaha philanthropist, besides many public benefactions, reserved Fontenelle Forest, southeast of Omaha, to the state of Nebraska as a bird sanctuary.

\section{RADIO OPERATORS}

Sidney A. Lutgen owns and operates radio station $\mathrm{KGCH}$ from the Wayne Hospital, which he also owns. The program always includes an educational talk by one of the faculty of Wayne State Teachers' College and includes talks by a physician, dentist or nurse on some phase of health.

Charles W. Keith of Edgar is a radio operator under the Seventh Army Corps Area.

\section{ADMITTED TO BAR}

A. J. Faulk of Mitchell, who organized the Scotts Bluff Medical Society, was admitted to the bar in 1881 and did not obtain his medical degree until 1901. He was born in Pittsburgh in 1858 and settled at Mitchell in 1903.

Clark Gapen, health commissioner of Omaha during the ' 90 s, also had a legal as well as medical training. 


\section{MUSICIANS}

Arthur D. Dunn and Mrs. Dunn are patrons of music in this city, Mrs. Dunn having served as president of the Tuesday Musical Club. W. J. McCrann was formerly president of the South Omaha Conservatory of Music and E. A. Van Fleet was active in the Apollo Music Club. J. M. Mayhew of Lincoln is a professional organist and plays the piano, as well. He has traveled extensively abroad. F. A. Sedlacek, assistant health commissioner of Omaha, is a vocalist, linguist and had an interesting war record with the Red Cross in Siberia. D. C. Bryant, former dean at Creighton, and the late J. S. Foote were talented violinists. Egbert G. Johnson of Broken Bow has written two songs, "Choice of Flower" and "Island Home."

HEAD CHAMBERS OF COMMERCE

Benjamin F. Bailey of Lincoln, for many years president of the Nebraska State Board of Health, was head of the Lincoln Chamber of Commerce. William J. McCrann was president of the South Omaha Commercial Club for five years. Ralph Luikart of Omaha is chairman of the Goodfellowship committee of the Chamber of Commerce and he, Herman Schulte and A. F. Tyler are on the executive committee.

\section{INVENTORS}

Josiah Beckley Redfield of North Platte patented a mouth gag which is used in the removal of tonsils.

Joseph Adolphus of Lincoln invented the Adolphus height gauge and wheel wrench, after his graduation from Creighton Medical College in 1908. His father, Joseph Adolphus, Sr., was founder of the Georgia Eclectic College, and served on the faculty of the Lincoln Medical College in 1905 . He was a linguist of ability and a Mexican War veteran. He died in 1927.

Godfrey J. Kadavy of Omaha invented a "dropper" used on ether cans when giving an anesthetic. This simple device not only saves time and makes accurate dosage easily attained, but when the can is not in use, prevents waste by evaporation. This device has been universally adopted, even in missionary hospitals in China. Its operation is so simple that it could be entrusted to a novice, if 
emergency demanded; it eliminates the danger of overdosing the patient and does away with the primitive safety pin or grooved cork methods.

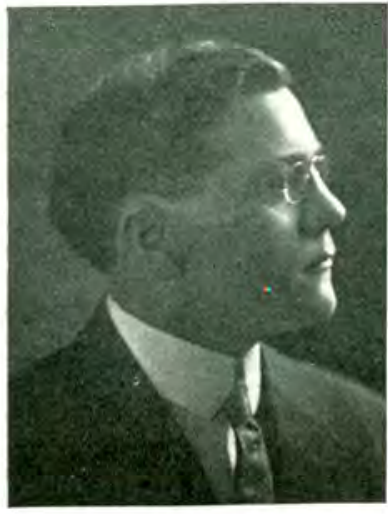

GODFREY J. KADAVY

Kadavy made his first ether can dropper through sheer disgust with the old method, culminating when he had to administer ether to a patient whose shoulder had to be set. Recalling a certain soda water attachment he had cbserved while working in a drug store, he experimented successfully with it. In the five years since he made the first dropper by hand, orders for these improvements have been filled in gross lots. Kadavy is a graduate pharmacist as well as physician. Creighton is his alma mater.

John H. Thomsen, owner of Frederick Hospital, invented the Nesmoht portable obstetrical table. It is said to fill a great need in providing hospital facilities of clean delivery in the home. It

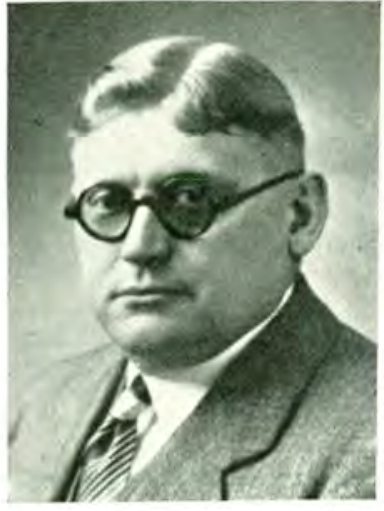

JOHN H. THOMSEN

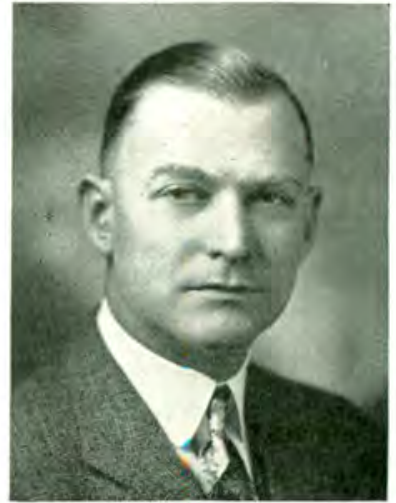

F. H. KINYOUN

weighs only twelve pounds, is carried in a 28 -inch golf bag and can be set up over the usual bed in just a few minutes. Its designer ventures the belief that the table will do much to lower the mortality and cases of child-bed fever, due to carelessness in deliveries in the 
home, or in country cases remote from hospital care. More than 1,200 of these portable table-beds have been sold in this and foreign countries, according to Thomsen. It has been advertised in the Journal of the American Medical Association. Thomsen's technique also includes an original medication producing twilight sleep without ill effects for mother or child. He is a Creighton graduate and president of the Omaha branch of the International Association of Inventors.

F. H. Kinyoun invented in 1924 an electrical bone surgery set, three of which are now in use by surgeons in the Mayo Clinic at Rochester, Minnesota. The invention of the young Omaha Creighton graduate is said to be a distinct improvement on the old circulatory electric bone saw.

Edwin C. Henry of Omaha is credited with rigging up a set of radio-earphones for detecting the presence of bullets in the human body. In one case which Henry operated he was able to detect the location of a bullet in the head of a woman who had been shot.

Dr. Harold Gifford's designs of a trachoma forceps and a brainknife for exploration for brain-abscess have been mentioned in another section, as were Dr. Karl Connell's improvement of the gas mask and Dr. W. L. Shearer's dental forceps and chickenbill.

E. Willard Powell, Omaha surgeon, had several inventions to his credit. In 1915 he designed a silver tracheotomy tube with a removable cap for cleaning, to be worn and to supply the lost part

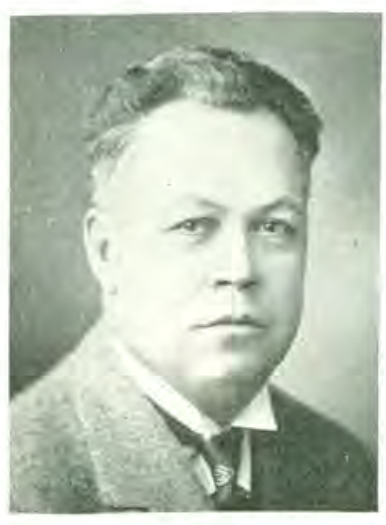

E. WILLARD POWELL of the trachea, from malignancy; and for relief in operating malignant growths of the upper air passages. In 1910 he devised a circular flap for the removal of varicose veins. It is so designed that it catches and exposes all the superficial veins from knee to ankle, as well as the communicating branches to the deep veins. In 1915 he also designed an operation with a " $U$ " shaped skin flap for draining the pleural cavity for empyema of the chest and changed the drainage from the old type rubber tubing to that of a flat rubber 
drain the shape of two heels of an inner sole, or the open center in the figure 8 . The advantage of this over rubber tubing drainage is that it drains as well and also acts as a valve, opening on expiration or coughing and closing on inspiration. Powell died in June, 1928.

\section{NOTES OF INTEREST}

The first shorthand notes of any court proceeding in this state we: taken in Fremont, April 7, 1870, when Dr. Alexander Bear was testifying in a case in which Lorenzo Crounse of Omaha was the examining attorney.

John R. Nilsson of Omaha was a surgeon in the mines of the Black Hills.

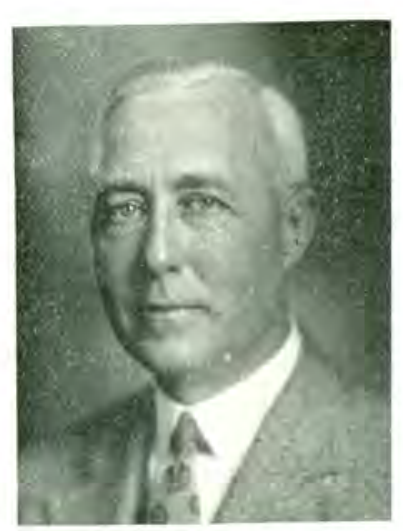

MAX EMMERT

Max Emmert inherits an organizing talent from his father who helped organize the Missouri Valley Medical Association at Council Bluffs in 1888. He was then practicing in Atlantic, Iowa. The younger Emmert organized the Omaha Surgical Club, the Nebraska branch of the American College of Surgeons and the Omaha Lions' Club.

Palmer Findley is prouder of his record as a sprinter than he is of his medical achievements. He tied for national honors in the 50-yard dash while in college in 1890 and 26 years later, was awarded the much-coveted letter by Iowa University.

D. S. Trigg of Broken Bow is the most recent martyr to duty in this state. He died in November, 1927, from pneumonia contracted while driving half way across Custer County to give first aid to a young girl of Oconto who was thereafter kept alive for many days by means of artificial respiration.

William Edward Shook of Shubert was a court reporter for the First Judicial District of Nebraska for two years, before taking up the study of medicine.

Lysander Tower Burbank served as both doctor and minister in Custer County in the early '80s. 
A. S. Von Mansfelde was local weather observer at Ashland.

The father of Joseph A. Henske, Omaha pediatrician, and two of his brothers are practicing medicine in St. Louis. A third brother is a dentist.

Landscaping is the hobby of Carl J. Verges at Norfolk, who has a private park surrounding his sanitarium.

E. Willard Powell traced his ancestry to Dr. Powell, a physician to Queen Victoria of England. Another grandfather, Eagles by name, planted the first seed and started the first bed of celery at Kalamazoo, Michigan, according to Powell. A great industry grew from this start. The Omaha Dr. Powell was associated with Edward Wallace Lee as physician for the Trans-Mississippi Exposition, helped organize the Council of Boy Scouts in Nebraska and helped organize and was secretary in 1919 of the Medical Building Association which initiated the movement for the present Medical Arts Building.

\section{CATTLE RANCHERS}

James G. Brenizer, pioneer physician of Custer County in 1872 was one of the most successful breeders of registered Shorthorn cattle in Nebraska.

James Luther Gandy owned a 40,000 acre ranch in the '70s and ' 80 s, and Elisha B. Graham owned a Sioux County ranch in 1879. Georgia Arbuckle, just out of medical school, took up a claim just west and south of Minatare in 1886. A few years later she moved onto a tree claim near the mouth of the Red Willow Canyon, seven miles east of what is now Bayard, Nebraska.

Joseph H. Hall of Plattsmouth breeds prize chickens, Jersey cattle, horses and racing dogs. He brought a heifer from Alabama during the war, paying $\$ 60$ expressage. It brought second prize at the state fair, competing with New York.

Louis Swoboda, who practiced for 28 years in Omaha, is now retired to a Sarpy County farm whose products have won many prizes at county exhibits. 
Dr. and Mrs. A. P. Condon, owners of Nicholas Sen hospital, also operate a dairy and chicken farm, rifle range and stable for riding horses, north of Florence.

\section{NATIONAL HONORS}

American Medical Association: A. R. Mitchell of Lincoln is trustee, S. D. Mercer of Omaha was vice-president in 1885-1886, R. C. Moore of Omaha was second vice-president in 1891, A. F. Jonas of Omaha, vice-president in 1902 and Harold Gifford of Omaha, chairman ophthalmological section.

John P. Lord of Omaha, president of the Western Clinical and Orthopedic Association during the late war.

Palmer Findley of Omaha, president of the American Association of Obstetrics.

A. F. Jonas, president W'estern Surgical and Gynecological Association and American Railway Surgeons' and Pan-American Medical Society.

Radiological Society of North America: A. F. Tyler of Omaha, President in 1920 and E. Wr. Rowe of Lincoln, president in 1927.

Roy W. Fouts of Omaha, secretary of the American College of Physical Therapy, 1921-1928.

W. F. Milroy of Omaha, vice-president of the American Therapeutic Society in 1923.

Angela Prentiss Welles of McCook, president of the American Institute for Homeopathy for two years.

Frank Lincoln Wilmeth of Lincoln, president of the National Eclectic Medical Association in 1913.

William L. Dayton of Lincoln, president of the American Academy of Ophthalmology and Oto-Laryngology in 1917.

Francis A. Long of Madison, vice-president of the International Meridian Highway Association since 1923.

George J. Haslam of Fremont, Honorary degree, British Association for the Advancement of Science. 
Frank Styles Owen of Omaha, vice president of the American Academy of Ophthalmology and Oto-Laryngology, is the 1929 president of the Nebraska State Medical Association.

\section{SCIENTIFIC ACHIEVEMENTS}

\section{Notes and Errata}

p. 212

p. 212

pp. 213-216 Gifford, Harold. A complete bibliography is available in the Library of Medicine, University of Nebraska Medical Center.

p. 215

p. 216

p. 216

p. 217

p. 217

Peck: cold air treatment for pneumonia. See Tyler, A.F., "Master Omaha Physicians: James Porter Peck," Bull. Omaha-Douglas Co. Med. Soc., $3:(3), 8,1930$.

Peabody, J. H., "Oleum Terebinthinae in the Treatment of Diphtheria and Tonsilitis," Med. \& Sur. Reporter, 35: 206-07, Sept. 9, 1876.

Lord, J.P., "Anthroplasty of the Inter-Phalangeal Joints," Am. J. Orthop. Surg., 14:212-217, Apr. 1916.

Summers, J.E., Jr., "Antiseptics in Surgery," Proc. Nebraska St. Med. Soc., 18th Annual Session, June 1 - 3, 1886. 1887 , pp. 363-369.

- The Modern Treatment of Wounds, Omaha: Medical Publishing Co., 1899.

- "Rubber Gloves or Gauntlets: their use by Physicians," JAMA, 33:63-64, July 8, 1899.

p. 215 is mis-numbered " 213 ".

Dr. Harold Gifford was not one of the founders of the Omaha Medical College. He came to Omaha in 1886. The Omaha Medical College began in 1881. See p. 104.

Patton, James M. and Gifford, Sanford R., "Agricultural Conjunctivitis,” Am. J. Ophth., 5:623-37, Aug. 1922.

Milroy William F., "An undescribed Variety of Hereditary Oedema,"N. York M.J., 56:505-08, Nov. S, 1892.

Osler, Sir William, "Persistent Hereditary Oedema of the Legs (Milroy's Disease)," The Principles and Practice of Medicine, New York: D. Appleton, 8th ed., 1912: pp. 1124-1125. 

of Omaha, Nebraska and South Omaha by Savage, James W. and Bell, John T. New York and Chicago: Munsell \& Co., 1894. Chapter XXXCIII, pp. 353-365.

- "Typhoid Fever and Water Supply in Omaha," Omaha Clinic, 2:1-11. Apr. 1889.

Foote, J. S., Bone as a Measure of Development; (and) When and How We Acquired Our Teeth. Published by the Scientific Foundation and Research Committee of the American Dental Association. Omaha: Douglas Printing Co., 1928. Foote died in 1925 and this was published in 1928, and prepared by Dr. C. F. Crowley.

p. 222

Lord, J.P., "The X-Ray Treatment of Cancer," West. M. Rev., 7:246-248, Aug. 15, 1902.

Quigley, D. T., The Conquest of Cancer by Radium, Philadelphia: F. A. Davi กา., 1929.

Foote, J. S., "A Contribution to the Comparative Histology of the Femur," Smithson. Contr. Knowl., Vol. 35, Washington: Nov. 3, 1916.

- A Constructive Method in Histology, Naugatuck, Conn.: F. L. Bradbury, 1907.

- The Circulatory System in Bone, Washington: Smithsonian Institute publication, 1921.

Foote, J. S., Bone as a Measure of Development, Chicago: American Dental Association, 1928.

- When and How We Acquired Our Teeth, Intro. by Dr. Arthur D. Black, Chicago: American Dental Assn., 1928.

Pratt, G. P.: Heuer, George J. and Mason, Verne R., "Penetrating War Wounds of the Chest," Ann. Surg., 72:352-69, Sept. 1920.

Muirhead, A. L., "An Autograph History of a Case of Addison's Disease," JAMA, 76:652-653, Mar. 5, 1921. Disease,"JAMA, 79:556-57, Aug. 12, 1922.

- "The Treatment of Three Cases of Chronic Addison's Disease," M. Clin. North American, 7:177-87, July 1923.

- "Studies in Addison's Disease," JAMA, 84:327-35, Jan. 31, 1925. 

1916.

Davis, E. G., "Úrinary Antisepsis - A Study of the Antiseptic Properties of the Renal Excretion of Compounds Related to Phenolsulphonephthalein," JAMA, 70:581-85, Mar. 2, 1918.

Davis, E. G.: White, Edwin C. and Rosen, Robert, "Urinary Antisepsis - The Secretion of Antiseptic Urine Following the Intravenous Administration of an Organo-Mercury Phthalein Derivative," J. Urol., 2:277-97, Aug. 1918.

Davis, E. G. and Harrell, B. E., "Acriflavine in the Treatment of Gonorrhoea - an Experimental and Clinical Study," J. Urol., 2:257-76, Aug. 1918.

p. 228

Davis, E. G., "Urinary Antisepsis: A Study of the Antiseptic Properties and the Renal Excretion of 204 Anilin Dyes," Am. J. M. Sc., 161:251-67, Feb. 1921.

- "Urinary Antisepsis: Clinical Results Following the Oral Administration of Acriflavine," J. Urol., 11:29-44, Jan. 1924. Knowledge of Nutrition, New York: Macmillan, 3rd ed., 1925 :p. 251.

pp. 229-230 Levine, Victor E. A complete bibliography is available in the Creighton University Health Sciences Library.

p. 234

"Noah Hayes. . . celebrated his 84 th birthday ..." should read "Noah Hayes . . . celebrated his 83rd birthday ..." Note: Dr. F. A. Long correction.

p. 236

p. 236

p. 240

Noah Hayes. Add to the first sentence: "A son, Lucius B., also lives in Lincoln." Note: Dr. F. A. Long correction.

“. . accompanied an Arctir expedition . . ." should read ". . . accompanied an Arctic expedition..."

Breuer, M. J., Index to Physiotherapeutic Technic, Omaha: American College of Radiology and Physiotherapy, 1925.

p. 241 Bantin, C. F., Memory Rose: a Play in One Act, New York and London: Samuel French, Ltd., 1927.

- "Diabetic Lipemia Retinalis and Fat Embolism," JAMA, $86: 546-48$, Feb. 20, 1926. 

Boston: R. G. Badger, 1924.

p. 242

p. 242

p. 242

p. 242

p. 243

p. 244

p. 244

\section{- Religious Instruction and the American Public School,} Boston: R. G. Badger, 1925.

Poynter, C. W. M. A complete bibliography is available in the Library of Medicine, University of Nebraska Medical Center.

Crummer, LeRoy, Clinical Features of Heart Disease, New York: Hoeber, Inc., 1925.

Summers, J. E., Jr., The Modern Treatment of Wounds, Omaha: Medical Publishing Co., 1899.

Findley, Palmer, The Diagnosis of Diseases of Women, Philadelphia: Lea, 1913.

- A Treatise on the Diseases of Women, Philadelphia: Lea, 1903.

Dr. Palmer Findley is also the author of Priests of Lucina; The Story of Obstetrics, Boston: Little, Brown and Co., 1939. The Story of Childbirth, Garden City, N.Y.: Doubleday, Doran and Co., Inc., 1933.

Shalek, Alfred, Diseases of the Skin, Philadelphia: Lea, 2nd ed., 1910.

Crudup, C. P., The Problem: The Autobiography of a Physician, (pseud.) New York: The Shakespeare Press, 1913.

Galbraith, W. J., "Amputations" in Surgery: It's Principles \& Practice by Keen, William Williams, cannot be verified.

Quigley, D. T., The Conquest of Cancer by Radium and Other Methods, Philadelphia: F. A. Davis Co., 1929.

Bixby, A. L., Driftwood: A Modest Collection of Random Rhymes, Written at Odd Times for Odd People. Lincoln: State Journal Co., 1895.

". . . original surgical instruments . . " not originals. "Exact Reproductions of Surgical Instruments Excavated at Pompeii" were presented to the College of Medicine, University of Nebraska, by A. F. Jonas. Now in the Library of Medicine, University of Nebraska Medical Center. 
LeRoy Crummer library. See ... A list of old medical books, books on the history of medicine and medical bibliography, and a list of medical portraits, in the possession of LeRoy Crummer, Omaha, Nebraska. Together with some bibliographic notes, catalogued and compiled by Myrtle A. Crummer, Mar. 5, 1925, (Omaha, 1925), Mimeographed. See also ...A catalogue, manuscripts, and medical books printed before 1640 in the library of LeRoy Crummer. Omaha, Nebraska. Omaha: Priv. print, April 15, 1927.

Brown, Alfred Jerome, Old Masterpieces in Surgery, Omaha: Privately published, 1928.

French, Edwin Davis, Grolier club, N. Y., Edwin Davis French: A Catalog of his Engraved Work, Grolier club, 1909.

A Catalogue of the H. Winnett Orr Historical Collection and Other Rare Books in the Library of the American College of Surgeons, Chicago: A merican College of Surgeons, 1960. This collection is now in the Library of Medicine, University of Nebraska Medical Center, Omaha.

Hilton, D. C., "The Early Morphogenesis and Histogenesis of the Liver in Sus Scrofa Domesticus, including Notes on the Morphogenesis of the Ventral Pancreas," Tr. Am. Micr. Soc., 24:55-88, 1903.

J. H. Thomsen, Nesmoht portable obste trical table, see: Sheldon, A. E., Nebraska, the Land and the People, Chicago and New York: The Lewis Publishing Co., Vol. III, 1931, p. 216.

"... during the late war..." should read "... during World War $1 . .$. 


\section{COLLEGES}

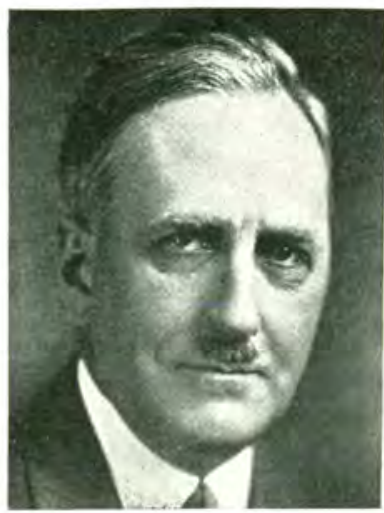

IRVING S. CUTTER

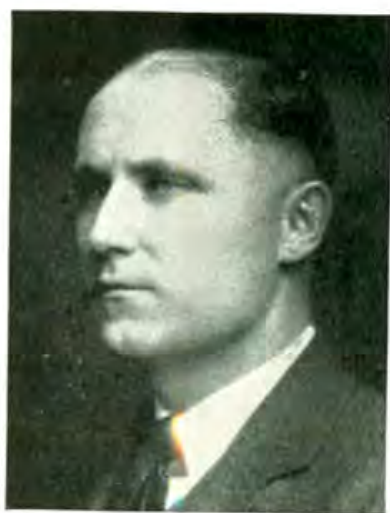

J. JAY KEEGAN

J. Jay Keegan, A.M., M.D., (University of Nebraska) former dean of the University of Nebraska College of Medicine, is a young man, born in 1889 at Axtell, Kansas. He is a specialist in neurological surgery, having studied in the clinic of Harvey Cushing in Peter Bent Brigham Hospital in Boston. He was in charge of the laboratory of the United States Naval Hospital, Chelsea, Massachusetts, during the war in which he served three years as a lieutenant in the navy reserve corps, senior grade.

He made the first scientific report of the influenza epidemic in this country, and with Dr. M. J. Rosenau of the Harvard medical school, conducted a series of experiments on 60 human volunteers to determine the cause and spread of influenza. Following his war service he studied brain surgery under Cushing at Boston.

Keegan was instructor in anatomy and professor of clinical pathology at the University before he was named dean, in 1925, to succeed Irving S. Cutter, who left to become dean of the Northwestern University Medical School. His publications are in the fields of cerebral morphology, cerebrospinal fluid, brain surgery, 
epidemic respiratory disease, vascular nephritis, and medical education. He has published treatises on the subjects of the Negro and American Indian brain, the bacteriology, pathology and epidemiology of influenza and other respiratory diseases and has contributed to the literature of brain surgery.

Besides the usual organizations, he is a member of the American Societies of Neurological Surgeons, Clinical Pathologists, Bacteriologists and Anatomists and the American Association for the Advancement of Science.

Dr. Keegan resigned as dean, effective September 1, 1929, in order to devote his entire time to the practice of neurological surgery. Dr. Charles Wm. M. Poynter was chosen by the board of regents as acting dean.

Cutter, the former dean, is credited with much of the growth and development of the present University campus at 42nd and Dewey Avenue. He was a graduate of the University of Nebraska when 23, taught in the Beatrice High School and sold books for a time, before studying medicine 12 years later. Upon his graduation, he practiced in Lincoln with C. W. M. Poynter, present dean, of the medical school, and the son of former Governor Poynter of Nebraska. Cutter was appointed dean of the local medical school when it was moved to Omaha, by the chancellor of the University, over the protest of all the Omaha medical men because he was a Lincoln man, but Cutter was successful in winning their approval in his program of developing the Omaha school. Cutter was born in New Hampshire and served as a captain in the late war. He was a professor of chemistry when elected dean of the medical school.

Charles W. M. Poynter, Omaha; anatomist, University of Nebraska, B.Sc., M.D., 1902; post graduate work at Vienna and Harvard, chairman and professor of anatomy department, University of Nebraska.. Member of County, State, American Association for the Advancement of Sciences, American Association of Anatomy, Society of Anatomy of Great Britain, American Association of Anthropologists, American Medical Association, Sigma Xi, Alpha Omega Alpha, Phi Rho Sigma. Contributions to anthropology, teratology, embryology, neurology and anatomy. 


\section{UNIVERSITY OF NEBRASKA, COLLEGE OF MEDICINE}

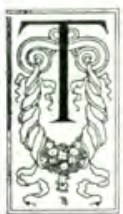

HE University of Nebraska College of Medicine at Omaha owes its splendid existence today to two, or more properly three, medical schools, which preceded it: two in Omaha and a short-lived one in Lincoln, from the years 1883 to 1888.

The first school of medicine in Nebraska was incorporated May 22, 1869 as the Omaha Medical College. This was only

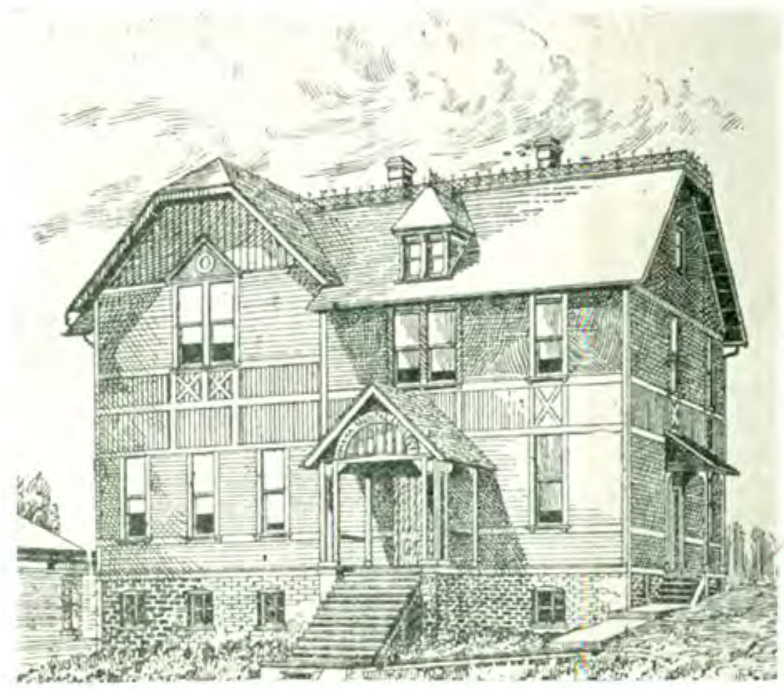

FIRST OMAHA MEDICAL COLL 玉GF.

three months after the state university was founded. Jacob C. Denise, H. P. Mathewson, Samuel D. Mercer, James H. Peabody and James Porter Peck, five of the outstanding local practitioners, were the trustees. The chairs they established and the men chosen to occupy them were as follows:

Anatomy, descriptive and surgical, H. P. Mathewson, M. D.; Physiology and histology, Richard C. Moore, M. D.; Principles and practice of surgery and clinical surgery, S. D. Mercer, M. D.; principles and practice of medicine and clinical medicine, J. P. Peck, M. D.; materia medica and therapeutics, James H.Peabody, M. D.; chemistry and toxicology, George Tilden, M. D.; obstet- 
rics and diseases of puerperal women and children V. H. Coffman, M. D.; general pathology and morbid anatomy, C. H. Pinney, M. D.; medical and surgical diseases of women, Jacob C. Denise, M. D.; physical diagnosis and diseases of the chest and throat, vacant; medical jurisprudence, James W. Savage, Esq.

A good deal of work was done by the trustees in arranging the preliminary details looking to the opening of the college; but owing to various obstacles in the way, and a growing feeling among those thus occupied that the enterprise was premature, it was abandoned.

Ten years later, a few of the same intrepid spirits again revived the project, under the name of the Nebraska School of Medicine, Preparatory. The following statement taken from the records of the institution, expresses briefly the object and aim of the institution.

"It is the mature judgment of our leading physicians, as well as prominent citizens of other business pursuits, that the time has arrived for the establishment of a medical school in our State. After deliberate consultation as to demands and the available means of conducting such an enterprise, the school has been organized unde: the name and title of the Nebraska School of Medicine, and located at Omaha, a city of upward of 32,000 inhabitants, and growing rapidily, supported by a state with 500,000 people, and with well established commercial relations existing between it and adjoining States and territories.

"The school for the present will be preparatory simply, but the instruction given will be thorough in all branches. Each chair will be represented by a man of experience and ability in his respective department. A number of eastern schools of medicine have established graded courses and allow students who are far enough advanced to enter higher classes; hence, students in the West can attend our school for one or two terms and then be admitted to advanced classes of other schools, when their proficiency will warrant such advancement."

The course of instruction continued for twenty weeks, begin. ning the middle of October. The instruction was by didactic, clinical and practical work. The following prominent physicians constituted the faculty: George B. Ayres, J. C. Denise, W. S. Gibbs, P. S. Leisenring, R. R. Livingston, A. S. von Mansfelde, S. D. Mercer and Richard C. Moore. 
The school opened, as proposed, in rooms on the third floor of the old Hellman block, then located at Thirteenth and Farnam streets, with fourteen students in attendance. Two of them were women, a Mrs. Whipple and Mrs. J. F. L. D. Hertzman, whose husband was also in the class. Another student was H. G. Leisenring, son of Dr. P. S. Liesenring on the faculty; and another was F. D. Haldeman, later a prominent practitioner at Ord. Other
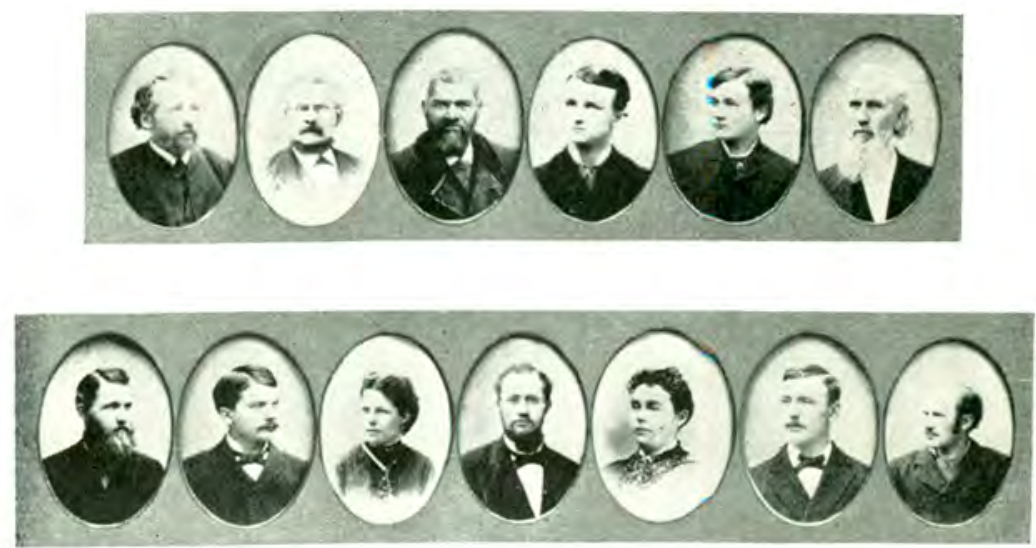

FIRST CLASS OF OMAHA MEDICAL COI.LEGE

students, whose pictures are preserved, with the original faculty, in a photograph of 1880, include W. H. C. Stephenson, Robert Monteith, Andrew P. Johnston, C. F. Webb, James E. Hadley, E. D. Diedrich, S. H. Witte and R, C. Elvin.

The success of the Nebraska School of Medicine encouraged those who engaged in it to go a step farther, and they organized, upon this foundation, the Omaha Medical College. The board of trustees included Drs. R. R. Livingston, V. H. Coffman, G.B. Ayres, S. D. Mercer, P. S. Leisenring, J. C. Denise, R. C. Moore, G. H. Peebles and W. S. Gibbs.

At the request of these men, the stockholders of the Omaha Medical College incorporated in 1869, surrendered their charter and the same name was assumed by the new corporation. It was effected June 14, 1881. Professorships established were: Dr. R. R. Livingston, principles and practices of surgery; Dr. G. B. Ayres, anatomy, descriptive and surgical; Dr. S, D. Mercer, clinical sur- 
gery; Dr. P. S. Leisenring, obstetrics and diseases of women; Dr. G. H. Peebles, diseases of children; Dr. J. C. Denise, physiology, ophthalmology and otology; Dr. R. C. Moore, materia medica and therapeutics; A. S. von Mansfelde, histology and general pathology; Dr. James Carter of Ottumwa, Iowa, chemistry and toxicology;

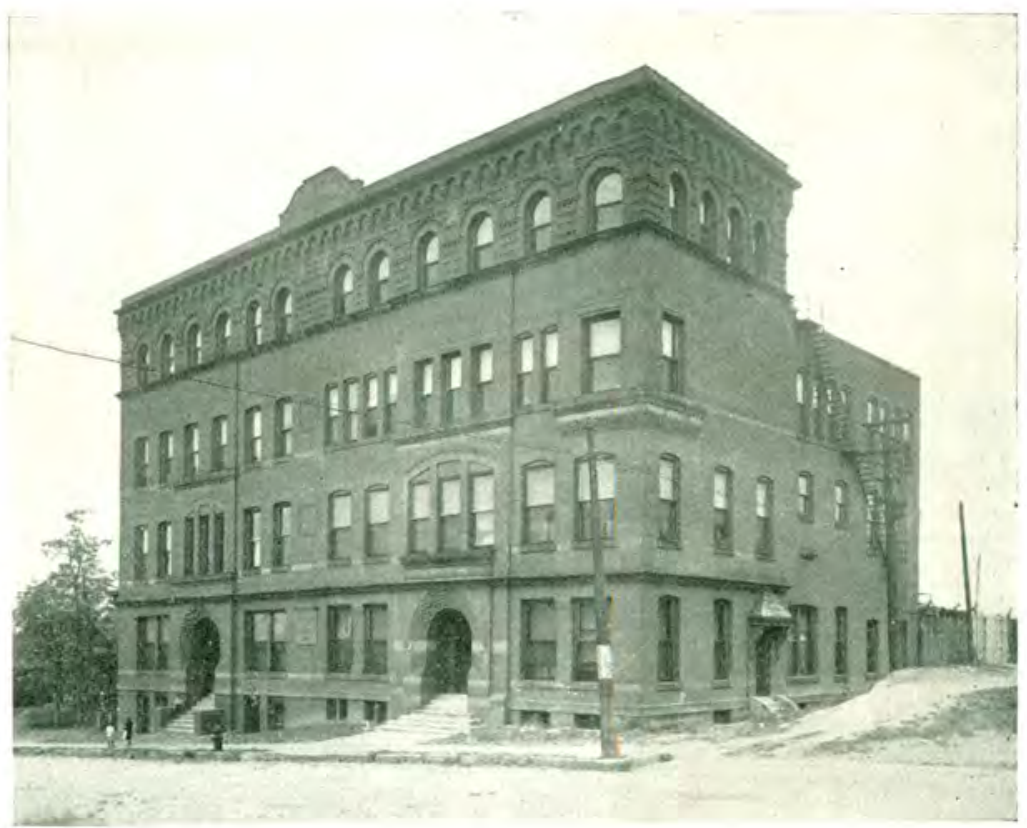

SECOND OMAHA MEDICAL COLLEGE

H. P. Mathewson, dissases of the mind; W. S. Gibbs, demonstrator of anatomy and J. C. Cowin, medical jurisprudence. Donald Macrae of Council Bluffs, father of the practitioner of this name in Council Bluffs today, was head of the gynecology department and one of the first professors of surgery. He became dean of the school in 1890, said to be the first named to this office. Macrae was a Scotchman by birth who settled across the river in 1867 , became mayor of Council Bluffs and one of the organizers of the Missouri Valley Medical Society, of which he was president. He died in August, 1907. His son, Donald Macrae, Jr., born January 24,1870 , followed in his father's footsteps as a physician, as professor in anatomy at the Omaha Medical College from 1892- 
1898; as mayor of Council Bluffs and head of the Missouri Valley Society. He has a distinguished war record besides, in the Spanish-American conflict, on the Mexican border and in the late war, when he received the D. S. M. and croix de guerre.

Convinced that the rapidly increasing population of this vicinity actually demanded a well-equipped medical college, R. R. Livingston, the president, and George B. Ayres, the secretary, arranged for the purchase of two lots at the southwest corner of Eleventh and Mason streets and the two-story building here pictured to house the first Cmaha Medical College was erected at a cost of $\$ 4,500$. Doctors on the faculty provided the funds. The location was probably determined by the fact that it adjoined the old St. Joseph Hospital, where arrangements were made to admit students to the hospital wards for clinical practice.

"The new building contained two large lecture rooms, a laboratory, library, museum, patient's room, dissecting and anatomists' room and is filled with every convenience of a well-equipped medical college," according to the second annual announcement, issued in 1882-1883, a copy of which is preserved in the archives of the medical school's library. "The faculty recommends the graded course but will give a diploma after three years' study, including two full courses of lectures," it announced. Requirements were only that one be eighteen years of age, possessed of a creditable English education and of good moral character. Women were admitted under the same conditions as the men. Professor Ayres gave a gold medal for the best student in anatomy that year. Charles F. Webb of Denver was the winner.

Graduates in the 1882 class were James W. Search and Edward Diedrich of Omaha, George V. Ellis of Gothland, Dakota Territory; James E. Hadley of Bell Creek; F. D. Haldẹman, then of Iowa City, Iowa; Werner Hemstead of Papillion; Robert Monteith of Seward and Urban H. Norris of Greenwood. They formed an alumni association with Hemstead as the first president and Haldeman as secretary. Among the 35 students who matriculated in 1881-1882 from eight nearby states, two were women. They were Alice Huff and Georgia A. Arbuckle, later Fix, who, after practicing a short time in Omaha settled in Scotts Bluff County and became 


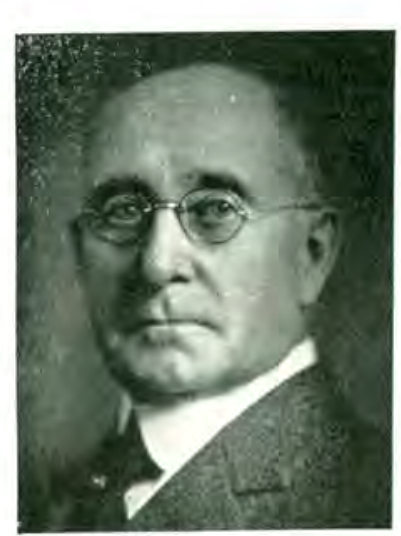

DR. EWING BROWN

one of the finest women practitioners of that western country. More will be told about her in the chapter on women physicians.

Ewing Brown was added to the faculty in 1883 as professor in anatomy and Mary E. C. Gydeson was another woman student. Graduates that year were Howard D. Brothers, A. H. Keller, Harry G. Leisenring of St. Helena, L. R. Markley, J. S. Shaw, C. F. Webb, Josephus Williams and G. F. Lloyd of Hastings. The exercises were held in Boyd's Opera House.

FIRST LINCOLN MEDICAL SCHOOL

With the Omaha Medical College thus launched on a successful career and proving a boon to local practitioners, a group of Lincoln physicians, headed by A. R. Mitchell and H. B. Lowry cast about to see what they could do about organizing a similar institution in Lincoln, affiliated with the state university. They succeeded in obtaining a $\$ 2,000$ appropriation from the legislature of 1883, for incidental expenses toward establishing such a school, on condition that the services of the faculty would be gratuitous. Mitchell was made the first dean, June 14, 1883. Homeopaths and eclectics immediately put in a bid to be represented as well as the regulars and this was adjusted by the appointment of B. L. Paine and B. F. Righter of Lincoln and C. L. Hart of Omaha for the homeopaths and W. S. Latta of Lincoln and J. H. Woodard of Seward for the eclectics.

Prematurely established, with no hospital, teaching equipment or even suitable classrooms, the Lincoln Medical School originated in the basement of the old University hall. It was heated by stoves and subjects for teaching were kept in a preserving vat, Mitchell recalls. Hospital facilities were the greatest need, even though antiseptic surgery was in its infancy and aseptic surgery was unknown. There were no trained nurses either, Mitchell further recalled in his talk at the dedication of the fine new wing of the University Hospital in Omaha, last November. Henry B. Ward, an- 
other dean of the old Lincoln School, also spoke. He is now on the Illinois faculty.

Considerable rivalry then developed between the Omaha and Lincoln schools but the latter was doing fairly well for the start until dissension between the homeopaths and eclectics so upset the institution that in 1885 the legislature prohibited the use of any further funds for a medical school. The brave faculty hung on another two years, without pay, until 1887 when the regents finally closed the school.

While the Lincoln school situation hung in the balance, the Omaha Medical College increased in size, equipment and standing until in 1887 when the college building was moved to the northwest corner of Twelfth and Pacific streets and was enlarged by the addition of another story. It now had fifty students. The college had, for the preceding year, been affiliated with the Methodist Episcopal institution at York, Nebraska, as the medical department of the latter school, and a free dispensary had been established. There were also numerous changes in the faculty. L. F. McKenna was named professor in clinical medicine in 1884 and held this chair until 1889, when he resigned and $\mathrm{W}$. O. Bridges succeeded him. In 1884 also W. F. Milroy accepted the position of demonstrator of anatomy. After two sessions he was transferred to the professorship of histology, general pathology and hygiene. In 1891 he was assigned to a new chair of clinical medicine, retaining the subject of hygiene. General pathology and histology were given by H. L. Hewetson and W. R. Lavender. L. J. Abbott of Fremont, Nebraska, was in 1884 elected professor of theory and practice of medicine and occupied that position for two years. In 1886 Joseph Neville was elected professor of clinical surgery. In 1887, J. E. Summers, Jr., was elected to and still occupies the chair of principles and practices of surgery.

In 1890 a number of changes were made. W. H. Christie was elected to the chair of materia medica and therapeutics made vacant by the resignation of Carter. Dr. H. C. Van Gieson was chosen professor of physiology while Gibbs was associated with Macrae in the chair of theory and practice of medicine- C. M. G. Biart was appointed lecturer on dermatology and Dr. Harold Gifford, lecturer on bacteriology. Laboratories were established this year also for the 
purpose of affording practical instruction in histology and pathology. The next year, 1891, also witnessed material changes in the faculty. George Wilkinson succeeded Van Gieson in the chair of physiology; F. S. Thomas of Council Bluffs, having previously assisted Macrae, was elected professor of diseases of the mind and Oscar Hoffman assumed the chair of dermatology.

The addition of several new hospitals about this time did much to enhance the importance of the Omaha Medical College since it furnished additional opportunities for clinical teaching. Among these were the new Methodist Hospital, outgrowth of the Eye and Ear Infirmary; Clarkson, formerly Children's Hospital; the Immanuel Hospital and St. Bernard's in Council Bluffs, which had just been connected to Omaha by the new electric railway bridge. The college catalogue for the year 1890-1891 lists all these new hospital facilities and notes that "Omaha and South Omaha, with a combined population of 150,000 is rapidly advancing as a medical center." That year the faculty made obligatory the three-year course. Shortly before, they decided "not to admit ladies any more, but advise them to attend female medical colleges."

Creighton Medical College was established May 30, 1892, largely, so it is said, through the efforts of William J. Galbraith, chief of the Union Pacific staff, who joined the Omaha Medical College faculty in 1887 as professor for the treatment of injuries peculiar to railroad accidents, but apparently came to some disagreement with the board later. The election of A. F. Jonas, who succeeded him as chief surgeon of the Union Pacific, to the school faculty was said by old timers who recall the difficulty, to have been the cause. Three incorporators of the Omaha Medical College who had been among its most active workers, also withdrew. These were R. C. Moore, P. S. Leisenring and G. H. Peebles. They were succeeded by H. M. McClanahan, E. W. Chase and Sherman Van Ness, who bought their stock. Further changes included the assignment of Wilkinson to the new chair of electrotherapentics, C. E. Allison assuming that of physiology, A. F. Jonas succeeded Neville as professor of clinical surgery, Gifford on the duties of clinical professor of ophthalmology and otology and D. Y. Graham and C. L. Mullins were made assistants to the demonstrator of anatomy.

A new situation foliowed this break and the establishment of Creighton University. St. Joseph Hospital no longer permitted 
Omaha Medical College students to use the hospital, which became an adjunct of the Creighton school; so it was necessary to have another hospital. W. (). Bridges and J. E. Summers are the men who then went out to the county commissioners and urged the establishment of a county hospital, at the poor farm. This was done, and a $\$ 160,000$ building with a capacity for 300 patients, including a pavilion for maternity cases and for the care of the insane, was shortly erected. A new building, to replace this more-

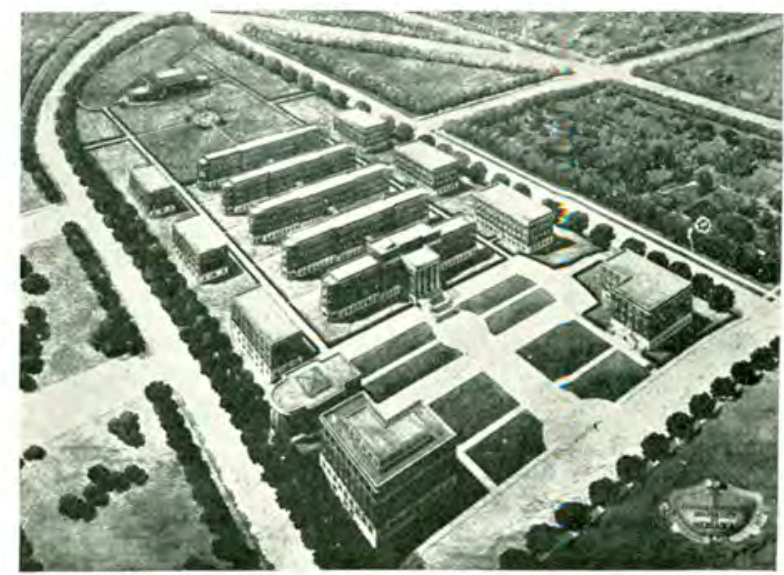

BIRDSEYE VIEW OF UNIVERSITY OF NEBRASKA COLLEGE OF MEDICINE

than-thirty-year-old edifice is now advocated by the Omaha-Douglas County Medical Society in a strong campaign initiated over a year ago by Frank M. Conlin, then president. The bond issue will be voted on at the next election.

The college also tried another experiment with affiliation, that year with the University of Omaha, (Bellevue College) with the Rev. David R. Kerr as chancellor, an arrangement which lasted for several years. The legislature of 1891 having enacted certain requirements for medical practitioners, the standards of the school were raised, and new departments and instructors were added, as the needs arose. Apparently the regulation denying women entrance was not enforced, as women were enrolled each year, particularly in the year 1894 when Emma W. DeMaree, Mary Tinley, now a successful physician in Council Bluffs; Ella Pearson Smith, Ada Whaley, Maud Mead, Mary Quincy of Ashland, Dora Judkins of 
Hastings, Mathilda Maria Schmidt and Mrs. M. M. Van Nuys enrolled. George and Julius A. Roeder, sons of Augustus Roeder, pioneer Nebraska surgeon, were in the class of 1892. George is now in California. He is the father of Clyde A. Roeder, a leading Omaha surgeon.

The catalogue for 1896-1897 announced that a four year course would thereafter be required (the legislature passed this law in July, 1898). Women still sought medical training in greater numbers than today for the freshman class that year included Nellie L. Clark, Libbie Fitch, Frieda A. Phillips of Fremont, Imogen L. Roby, Libbie McNerny Searles and Florence Neal of Villisca, Iowa. Alma J. Chapman of Hastings, Mary Elizabeth Rosenberg and the first Chinese student ever enrolled were included in the 1897 class.

A constantly growing student body, and competition in the form of the new Creighton medical school, brought about the erection of a fine new brick building, four stories high, in 1893, on the same site, furnishing much better facilities. The school grew so rapidly that even these quarters were outgrown and in 1899-1900 an addition to the building was erected.

\section{MEDICAL LIBRARY STARTED}

With the beginning of the new century and established in splendid quarters, the school began the nucleus of its splendid library, with a beginning of 1,000 volumes. It now numbers 35,000 volumes, and is considered one of the finest in the country, according to Miss Madeline Hillis, librarian. When the college of medicine became part of the state university in 1913, all medical volumes in the Lincoln university library were moved here and combined with the Nebraska State Medical and Douglas County society libraries too. Several valuable private collections have also been given to the college, including those of Drs. Frank Billings, Richard C. Moore, S. D. Mercer and Harold Gifford.

In its new location in the second wing of the University Hospital, the library consists of a large reading room on the main floor with seating capacity of 100 and racks holding 1,500 books. The rackroom, located on the floor below, now holds approximately 33,000 volumes, but its capacity may be doubled through the installation of a mezzanine floor. The library has its own bindery, fully 
equipped to repair and to bind the 290 different medical periodicals received.

Great care is exercised in selecting books, considering first their value as reference and second, the historical value. Reprints of old works rather than originals are preferred, since students are allowed to handle reprints but not originals. Agents located in Berlin, London, Paris and other foreign cities have secured many of the most valuable volumes in the library, some in foreign languages.

Dean Keegan credits LeRoy Crummer, a recognized authority on books of medical and historical interest, with developing the historical section of the medical library. He too has made some valuable additions to it.

Recognizing the advantages accruing to a medical college by reason of affiliation with a state university, promoters of the Omaha Medical College had for several years been negotiating with regents of the University of Nebraska toward that end. It was conceded by Chancellor E. Benjamin Andrews and even Dean Robert $H$. Wolcott of the Lincoln faculty from 1909 to 1913, that Omaha afforded better clinical facilities as a city of the metropolitan class. An agreement of affiliation was therefore completed in 1903 between the two institutions, under which the Nebraska University gave the first two years of instruction in Lincoln and the Omaha Medical College was responsible for the last two years in Omaha. This agreement was terminated in 1913, when the University formally took over instruction in all four years of medicine.

The action of the Board of Regents in undertaking responsibility for the full course of medicine constituted a revival of the College of Medicine of the University which was established on the Lincoln campus in 1883 and discontinued in 1888, the present dean, J. Jay Keegan, pointed out in an article printed in the November, 1927 issue of the Nebraska State Medical Journal. Coincident with this act, the full four years of instruction in medicine was established in Omaha, on the present campus at Forty-second and Dewey Avenue.

But this latter was not accomplished without a strong fight, the memory of which will linger long in the minds of all the participants. 
Chief among them were Willson O. Bridges, August F. Jonas and J. E. Summers - all former deans - and the trio upon whom the University of Nebraska conferred its highest mark of respectthe honorary degree of doctor of laws, in January, 1928.

"We would not have had the University medical college and hospital in Omaha, if it had not been for these men," John R. Webster, a regent, acknowledged on this occasion.

Several others who rendered distinguished service in this connection were Harold Gifford, the first to receive an honorary degree; Byron B. Davis, former regent; W. F. Milroy, first president of the Omaha Medical Society and Arthur C. Stokes, who headed the Nebraska University Base Hospital No. 49 in France in the late war.

Another contribution of this group of men, including Stokes, Bridges, Summers, Jonas and several others, was the gift of certain lots adjoining the medical college campus, which they held in fee simple and which the legislature never appropriated the money to buy.

These men not only labored incessantly to bring about the removal, but they went into their own pockets to the extent of thousands of dollars to pay for the expense incidental thereto. It was the knowledge of this fact which was instrumental in the choice of W. O. Bridges as Ak-Sar-Ben King in the fall of 1927, shortly before the dedication of the second wing of the Universnty of Nebraska Hospital.

Bridges, who was dean of the Omaha Medical College from 1910 to 1914 , when the campaign first started to get a $\$ 20,000$ appropriation from the legislature with which to purchase an Omaha site, is credited with management of the affair from Omaha. Frank Ransom of Omaha introduced the bill. Stokes conducted the campaign in the legislature, spending more than two months in Lincoln, lobbying for the subsequent $\$ 100,000$ to erect the first building. A. P. Fitzsimmons of Tecumseh was an able assistant. This was in 1911.

"They sent me down from Omaha on a joking motion made by Palmer Findley of Omaha," Stokes related, "but after a hard fight we won the $\$ 100,000$ appropriation." 
Opposition, in addition to the natural reluctance of the solons to appropriate such a large sum of money, came from two sources: Lincoln, which opposed removal of the medical department of the University to Omaha, and from Creighton Medical College supporters, who urged that one medical school was enough for the city. Stokes' bill was killed on nine successive occasions but was revived each time by herculean efforts, aided and abetted by a powerful fraternal organization which threw its strength against a democratic legislature, friendly to Creighton. Even after the bills passed the House, where it was sponsored by John H. Grossman of Omaha and the Senate, where Phil Cole of Wayne and Fritz Volp of Scribner fathered it, T. P. Mahoney, influential Omaha attorney, headed a large delegation which made an unsuccessful appeal to the governor to veto the bill. The fight was even carried to the supreme court on the grounds that the regents had no authority to move any part of the University to Omaha.

Since then, subsequent appropriations were not so hard to obtain, the school and hospital having established their value. The next legislature will be asked to provide a maintenance fund for the hospital, in a separate appropriation from that for the university proper, E. A. Burnett, acting chancellor of the University at Lincoln, announced recently. Maintenance funds for the University of Nebraska, he pointed out, are insufficient to operate a hospital of 240 beds properly. The hospital serves the whole state, patients who cannot afford to pay are cared for there and it is not fair or practical to charge hospital maintenance to the medical school, according to Burnett.

The first building on this campus was the present North Laboratory Building, erected in 1913 at a cost of one hundred thousand dollars, and housing all departments of the College, according to a history prepared by Dean J. J. Keegan. The total enrollment this first year was 84, compared to 301 in 1927. Clinical facilities were obtained by affiliation with the Douglas County Hospital and several private hospitals of Omaha, and by maintenance of a Dispensary at 1716 Dodge Street. It soon became evident that proper bedside clinical instruction could not be maintained without a University Hospital under the supervision and control of the College of Medicine. Accordingly the Legislature of 1915 appropriated $\$ 150,000$ for a teaching hospital which would care for the worthy 
sick poor of the state. This first unit of the University Hospital was completed in 1917.

The College soon outgrew the North Laboratory Building, and in $1917, \$ 180,000$ was appropriated to erect the South Laboratory Building. This was completed in 1919 and the dispensary, which had been maintained down town, was transferred to the ground floor of this bulding.

The Nurses' Home was added in 1923, since the nurses had been housed in a temporary wocden dormitory and a fire on December 22, 1922, destroyed the building. Th's gave impetus to the University Training School for Nurses, which, with the beginning class of September, 1927, had an enrollment of 108, and is no small part of the educational service of the College of Medicine. It was organized in October, 1917. Charlotte Burgess is the suparintendent.

Faculty members include:

Myra Tucker, R.N., Assistant Superintendent of Nurses and Educational Director.

Mercedes Breen, R.N., Assistant Instructor in Nursing.

Alice Amen Heinz, A.B., R.N., Instructor in Obstetrical Nursing and Supervisor of Obstetrical Department.

Frieda Deterichs, R.N., Instructor in Surgical Technique and Supervisor of Operating Department.

InA Townsend, R.N., Instructor in Surgical Nursing and Supervisor of Surgical Floor.

Lucy Leigh, R.N., Assistant Instructor in Surgical Nursing and Assistant in Operating Rooms.

Loneta Klavon, R.N., Assistant Instructor in Medical Nursing and Supervisor of Medical Floor.

Irma Anderson, R.N., Night Supervisor.

Josephine Chamberlain, R.N., Superintendent of Dispensary.

Winifred Hyde, Ph.D., Professor of Psychology.

Matilda Katherine Peters, R.N., Instructor in Home Economics.

Beatrice Hodge, Director of Medical Social Work.

Helen Wyandt, B.Sc., Instructor in Clinical Pathology.

Alice OrR, Matron of Nurses' Home.

The increased emphasis on clinical teaching, and the increased enrollment from 143 in 1917 to 301 in 1927 , made the first unit of 
the University Hospital insufficient to provide clinical cases for bedside study by the senior and junior students who had increased from 46 in 1917 to 120 in 1925 . To remedy this situation the Board of Regents allowed from the University building appropriation of 1925 an item of two hundred thousand dollars to erect a second unit of the University Hospital. This is the building which was completed and formally opened last November.

The grounds and buildings of the Medical College and Hospital have been excellently planned by Irving S. Cutter, former dean, and John Latenser and Sons, architects of Omaha. The entrance to the grounds is one of the beauty spots of Omaha, and the buildings present an impressive harmony of arrangement and architecture. The buildings now on the Medical College campus are the North and South Laboratory buildings, the two units of the University hospital, the Nurses' Home, a Nurses' Dormitory, the power plant, greenhouse and carpenter shop.

Future expansion of the hospital is planned in serial unit additions westward with added nurses' homes along the south side and laboratory buildings along the north side, a recreational park for ambulent patients and an athletic field for students west of the hospital.

The University also owns a considerable amount of land bordering the Medical College Campus, this being planned for adjoining private hospitals which will be affiliated with the University Hospital. The Clarkson Memorial Hospital is planning to build across the street at Forty-second and Dewey Avenue; the Child Saving Institute is located at Forty-second and Emile Streets and a new children's hospital is being considered at Forty-fourth and Dewey Avenue overlooking the recreational park. The Douglas County Hospital is but seven blocks to the south on Forty-second Street, easily accessible from the Medical College Campus. Recent action by the Board of County Commissioners has begun the separation of the County Hospital and the County Poor Farm, and plans are drawn for the development of a modern County Hospital at its present site. The centering of many medical activities about the State Medical College is a logical procedure, and future growth is more likely to be underestimated than overestimated. 


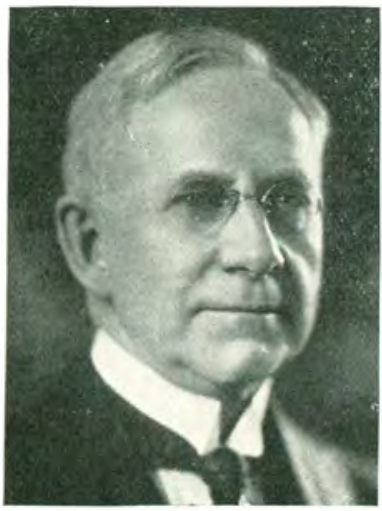

W. O. BRIDGES

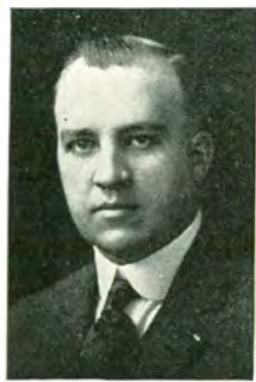

E. W. BANTIN

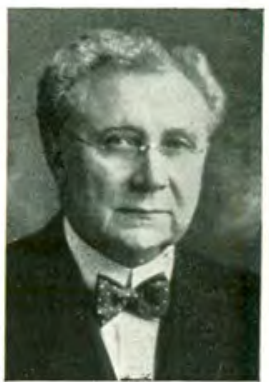

W. F. CALLFAS

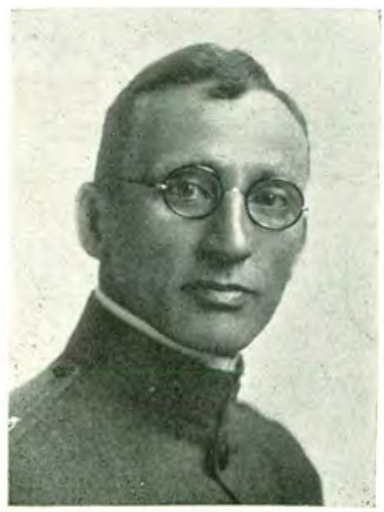

H. B. LEMERE

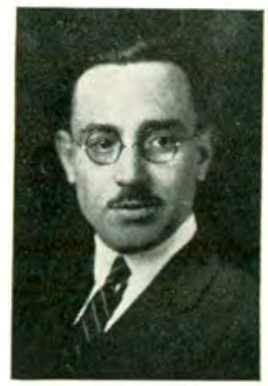

W. A. GERRIE

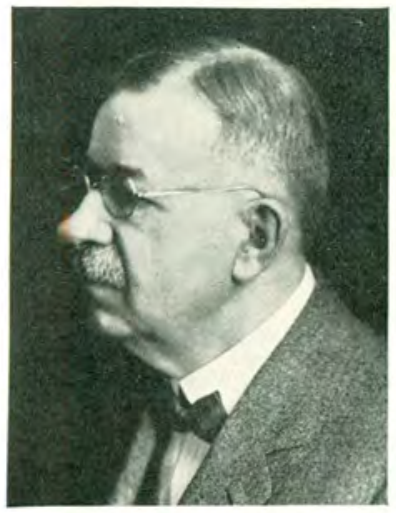

A. F. JONAS

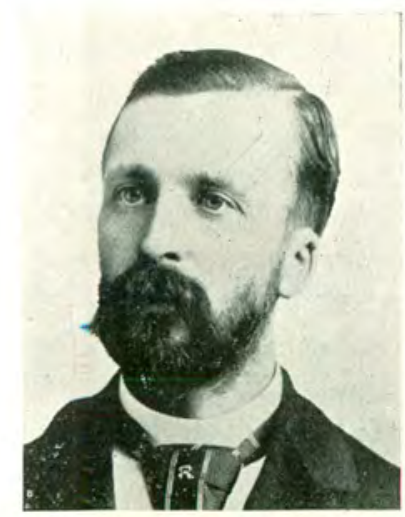

W. R. LAVENDER 


\section{Faculty of the College of Medicine}

\section{Charles W. M. Poynter, Dean}

John Frankin Allen, M. D., Assistant Professor of Medicine.

Maine C. Anderson, M. D., Clinical Assistant in Medicine.

William Nance Anderson, B. Sc., M. D., Associate Professor of Medicine.

Paul Martin Bancroft, B. Sc., Fellow in Clinical Research.

John Monroe Banister, A.B., M.D., Professor of Tropical Medicine, Emeritus.

Clarence Frederick Bantin, B.Sc., MI.D., Clinical Assistant in Pediatrics.

Elmer William Bantin, B.Sc., M.D., Instructor in Pediatrics.

Meyer Beber, Ph.D., Assistant Professor of Biochemistry.

Abram Elting Bennett, B.Sc., M.D., Instructor in NeuroPsychiatry.

Gordon Newall Best, B.Sc., M.D., Clin ical Assistant in Medicine.

Russell Rolland Best, B.Sc., Instructor in Anatomy and Clinical Assistant in Surgery.

Rodney Waldo Bliss, B.Sc., M.D., Associate Professor of Medicine.

Edson Lowell Bridges, M.D., Professor of Medicine. (Chairman of Department.)

Willson Orton Bridges, M.D., Professor of Medicine, Emeritus.

Alfred Jerome Brown, A.B., M.D., Associate Professor of Surgery.

Lauren Fletcher Busby, A.M., Instructor in Anatomy.

William Frederick Callfas, C.M., M.D., Assistant Professor of Oto-Rhino-Laryngology.

Waldron A. Cassidy, A.B., M.D., Assistant Instructor in OtoRhino-Laryngology.

Josephine Chamberlin, R.N., Superintendent of Dispensary.

Frank Matthew Conlin, M.D., Assistant Professor of Medicine.

Otis Merrian Cope, A.B., M.D., Associate Professor of Physiology and Pharmacology. 


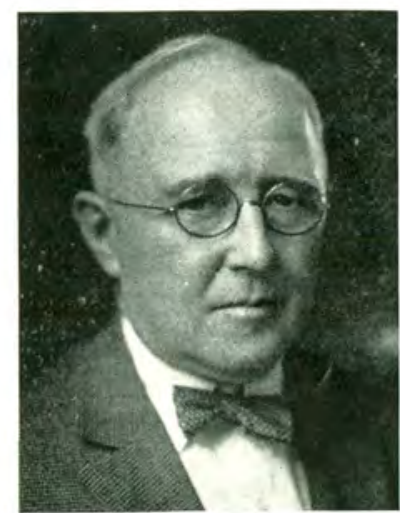

C. W. POLLARD

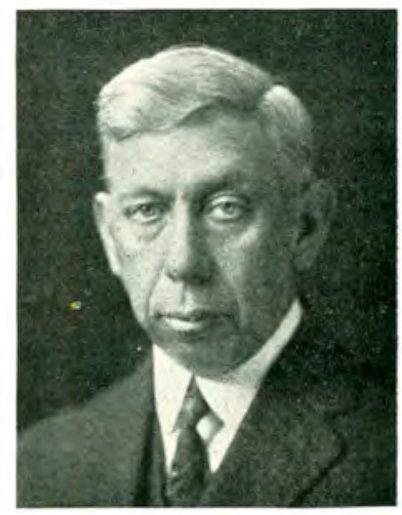

R. H. WOLCOTT

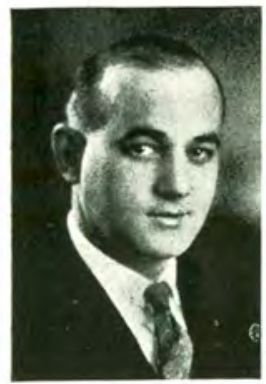

M. GRODINSKI

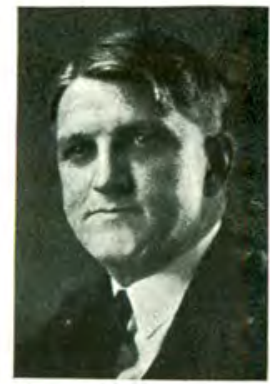

C. R. KENNEDY

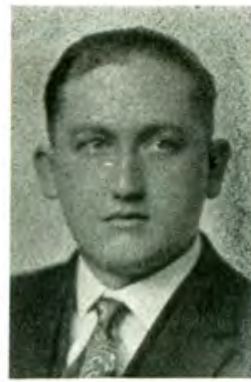

A. C. STELNBERG

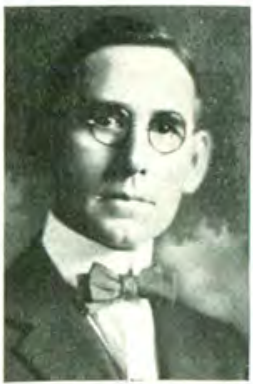

G. A. YOUNG

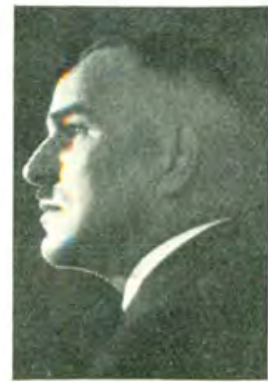

C. C. TOMLINSON 
Leroy Crummer, B.Sc., M.D., Professor of Medicine, Emeritus. Byron Bennett Davis, A.B., M.D., Professor of the Principles of Surgery and Clincal Surgery.

Edwin Davis, A.B., M.D., Professor of Urology. (Chairman of Department.)

- Herbert H. Davis, A.B., M.D., Instructor in Surgery and Director of the Laboratory of Surgical Research.

John Calvin Davis, Jr., A.B., M.D., Clinical 4ssistant in OtoRhino-Laryngology.

James Charles Dickson, B.Sc., M.D., Assistant in Clinical Research.

Arthur D. Dunn, M.D., Instructor in Clinical Research and Director of the Laboratory of Medical Research.

Harold E. Eggers, A.M., M.D., Professor of Pathology and Bacteriology. (Chairman of Department.)

Orrin Cecil Ehlers, B.Sc., Fellow in Anatomy.

Robert Bruce Eldrege, M.D., Assistant Instructor in Pediatrics.

Nora M. Fairchild, M.D., Clinical Assistant in Ophthalmology.

Wallace A. Gerrie, B.Sc., M.D., Clinical Assistant in Medicine.

Harold Gifford, A.M., M.D., LL.D., Professor of Ophthalmology, Emeritus.

SAnford Robinson Gifford, A.M., M.D., Assistant Professor of Ophthalmology.

James Samuel Goetz, M.D., Professor of Medicine (deceased).

Manuel Grodinsky, B.Sc., M.D., Instructor in Anatomy and Clinical Assistant in Surgery.

August Ernest Guenther, Ph.D., Professor of Physiology and Pharmacology. (Chairman of Department.)

Lynn Thompson Hall, B.Sc., M. D., Assistant Professor of Medicine.

Howard Brownlee Hamilton, A.B., M.D., Professor of Pediatrics. (Chairman of Department.)

Vincent Charles Hascall, Ll.B., Instructor in Medical Jurisprudence.

Madelene S. Hillis, Librarian of Medical College Library,

Beatrice P. Hodge, Director of Medical Social Work. 
Charles Aaron Hull, M. D., Assistant Professor of Surgery, in charge of Fractures.

Herman Milton Jahr, M.D., Clinical Assistant in Pediatrics.

Charles Stanton James, M.D., F.M., Instructor in Ophthalmology.

Herman Frank Johnson, M.D., Assistant Instructor in Orthopedic Surgery.

August Frederick Jonas, M.D., Professor of Surgery. (Chairman of Department.)

J. Jay Kefgan, A.M., M.D., Dean of the College of Medicine, Professor of Clinical Pathology and Instructor in Surgery, in charge of Neuro-Surgery.

Charles Rex Kennedy, M.D., Professor of Clinical Surgery.

Clifford Foster Kent, Fellow in Physiology and Pharmacology.

Wendell A. Killins, M.D., Instructor in Medicine.

Archibald Roy Knode, M. D., Assistant Professor of OtoRhino-Laryngology. (Secretary of Department).

John Stephens Latta, Ph.D., Associate Professor of Anatomy.

Henry Bassett Lemere, M.D., Professor of Oto-Rhino-Laryngology. (Chairman of Department.)

Ernest Verdon Lewis, A.M., Fellow in Pathology.

John Prentiss Lord, M.D., Professor of Orthopedic Surgery. (Chairman of Department.)

James S. McAvin, Ph.G., M.D., Instructor in Anesthesia and Roentgenology.

Harry Monroe McClanahan, A.M., M.D., Professor of Pediatrics, Emeritus.

ERnest Lynn MacQuiddy, B.Sc., M.D., Instructor in Medicine.

Otis Wallace Martin, B.Sc., M.D., Clinical Assistant in Urology.

Claude W. Mason, M.D., Instructor in Tropical Medicine.

William Rudolph Mechtenberg, B.Sc., Fellow in Physiology and Pharmacology.

Aura James Miller, M.D., Professor of Clinical Pathology.

- Glen Miller, B.Sc., M.D., Clinical Assistant in Surgery.

William Forsyth Milroy, M.D., Professor of Clinical Medicine, Emeritus.

Willson B. Moody, B.Sc., M.D., Assistant Instructor in Medicine. 
Charles Frank Moon, M.D., Instructor in Obstetrics.

John Clyde Moore, Jr., B.Sc., M.D., Associate Professor of Pediatrics.

Clifford Veryl Morgan, A.B., M.D., Fellow in Clinical Research.

Sergius Morgulis, Ph.D., Professor of Biochemistry. (Chairman of Department.)

R. Allyn Moser, A.B., M.D., Instructor in Medicine.

Floyd J. Murray, B.Sc., M.D., Assistant Instructor in Medicine.

John Tennyson Myers, Ph.D., Associate Professor of Bacteriology.

Frederick W. Niehaus, B.Sc., M.D., Instructor in Medicine.

John Rudolph Nilsson, M.D., Instructor in Surgery.

Donald R. Owen, B.Sc., M.D., Instructor in Oto-Rhino-Laryngology.

Frank Styles Owen, M.D., Professor of Oto-Rhino-Laryngology, Emeritus.

Charles Austin Owens, M.D., Instructor in Urology.

James McDowell Patton, A.M., M.D., Professor of Ophthalmology. (Chairman of Department.)

Carleton B. Pierce, M.S., M.D., Assistant Professor of Roentgenology and Physiotherapy.

Emil Carl Peterson, B.Sc., M.D., Supervisor of Clinical Clerks.

Charles Whitney Pollard, A.B., M.D., Professor of Obstetrics and Gynecology. (Chairman of Department.)

George Benjamin Potter, M.D., Instructor in Ophthalmology.

John BeEkman Potts, M.D., Assistant professor of Oto-RhinoLaryngology.

Charles William McCorkle Poynter, B.Sc., M.D., Professor of Anatomy. (Chairman of Department.)

George Pratt, B.Sc., M.D., Assistant Professor of Medicine.

George W. Prichard, M.D., Assistant Instructor in Medicine.

Daniel T. Quigley, M.D., Instructor in Surgery.

- Roy Raymond Ralston, D.D.S., Clinical Assistant in Oral Surgery.

Sol E. Ravitz, B.Sc., M.D., Clinical Assistant in Urology. 
Charles O'Neill Rich, B.Sc., M.D., Assistant Professor of Surgery.

- Clyde Augustus Roeder, M.D., Associate Professor of Surgery.

Phillip Romonek, M.D., Clinical Assistant in Oto-RhinoLaryngology.

Clarence Rubendall, B.Sc., M.D., Assistant Professor of OtoRhino-Laryngology.

Abram S. Rubnitz, B.Sc, M.D., Clinical Assistant in Medicine.

EARL C. SAGe, B.Sc., M.D., Instructor in Obstetrics.

Alfred Schalek, A.M., M.D., Professor of Dermatology and Syphilology. (Chairman of Department.)

Elvin F. Scheidegger, B.Sc., M.D., Resident Physisian in Pathology.

Robert D. Schrock, A.B., M.D., Assistant Professor of Orthopedic Surgery.

Ralph Leonard Schroeder, B.Sc., Fellow in Physiology and Pharmacology.

William Lete Shearer, M.D., D.D.S., Assistant Professor of Surgery, in charge of Oral and Plastic Surgery.

Eugene Eari Srmmons, B.Sc., M.D., Clinical Assistant in Medicine.

Andrew Bartholomew Somers, M.D., Professor of Obstetrics, Emeritus.

Olga Frances Stastny, M.D., Clinical Assistant in Medicine.

Robert James Stearns, M.D., Assistant Instructor in Urology.

Abraham Steinberg, M.D., Clinical Assistant in Ophthalmology.

John Edwards Summers, M.D., Professor of Clinical Surgery.

Willis Harvey Taylor, B.Sc., M.D., Associate Professor of Obstetrics.

Amos Thomas, LL.B., Instructor in Medical Jurisprudence.

Chester Quay Thompson, M.D., Assistant Instructor in Medicine.

Theos Jefferson Thompson, Ph.D., Associate Professor of Chemistry, Advisor to Pre-Medic Students.

WarRen Thompson, B.Sc., M.D., Instructor in Medicine.

Charles Creighton Tomlinson, M.D., Assistant Professor of Dermatology and Syphilology.

Solon Rodney Towne, A.M., M.D., Professor of Hygiene, Emeritus. 
Jack Vernon Treynor, B.Sc., M.D., Assistant Instructor in Pediatrics.

Chester Hill Waters, B.Sc., M.D., Assistant Professor of Surgery.

Joseph A. Weinberg, B.Sc., M.D., Instructor in Pathology and in Surgery.

William David Wessley, B.Sc., Fellow in Anatomy.

William Penaluna Wherry, M.D., Assistant Professor of Oto-Rhino-Laryngology.

Harrison Alonzo Wigton, B.Sc., M.D., Assistant Professor of Neuro-Psychiatry.

William Albert Willard, Ph.D., M.D., Clinical Assistant in Dermatology.

Helen Wyandt, B.Sc., Instructor in Clinical Pathology.

G. Alexander Young, M.D., Professor of Neuro-Psychiatry. (Chairman of Department.)

\section{Committees of the Faculty}

Executive - Chairmen of Departments.

Evaluation of Credits-Dr. Poynter (Chairman), Dr. Myers, Dr. Willard.

Delinquency - Dr. Eggers (Chairman), Dr. Guerther, Dr. Latta.

Course of Study and Schedule-Dr. Guenther (Chairmen), Dr. Myers, Dr. Pratt.

Scholarships and Research Prizes-Dr. H. Gifford (Chairman), Dr. J. E. Summers, Dr. McClanahan.

Student Activities-Dr. Pollard.

Pre-Medic Advisor-Professor. H. W. Manter.

Library-Dr. Latta (Chairman), Dr. Morgulis, Dr. Crummer, Dr. Brown, The Librarian.

Summer Session-Dr. Willard (Chairman), Dr. Conlin, Dr. Moser.

Graduate Studies-Dr. Morgulis (Chairman), Dr. Poynter, Dr. Dunn.

Dispensary-Dr, Moser (Chairman), Dr. Kennedy, Dr. Tomlinson.

Publications-Dr. Brown (Chairman), Dr. A. D. Dunn, Dr. Cope.

University Hospital-Dr. E. L. Bridges (Chairman), Dr. Roeder, Dr. Young, Dr. Patton, Dr. A. J. Miller. 
Staff Clinics-Dr. Pratt (Chairman), Dr. Hamilton, Dr. E. Davis.

Internships - Dr. A. J. Miller (Chairman), Dr. E. L. Bridges, Dr. Hamilton.

Examinations-Dr. A. D. Dunn (Chairman), Dr. E. L. Bridges, Dr. Roeder.

THE UNIVERSITY OF NEBRASKA HOSPITAL

The University of Nebraska Hospital was established in Omaha by an act of the Legislature of 1915 to provide a teaching hospital for the College of Medicine and to furnish hospital care to the worthy sick poor of the state. The first unit was opened in 1917 and during the past ten years has cared for over twenty-five thousand patients who otherwise would have been unable to obtain needed hospital and medical treatment.

The second unit of the University Hospital, opened November 30,1927 , was very much needed to provide additional clinical facilities for the rapidly growing College of Medicine and to meet the increased call for state service. Of particular interest are the department of roentgenology and physical therapy, the central purchasing and supply department, the medical amphitheatre, special children's wards, psychopathic wards, and wonderful solaria on each floor for convalescent patients. The solarium in the third floor has been furnished for occupational therapy by the Women's Auxiliary of the Nebraska State Medical Association and by the Faculty Women's Club of the College of Medicine.

More than 5,500 patients were cared for in the hospital dispensary last year, according to figures of Dr. Keegan. Other interesting figures show more than 3,000 admitted as patients, representing 42,159 hospital days. More than 1,800 minor surgical operations, and more than five hundred major surgical operations were performed. There were 334 babies born at the hospital during the year.

More than 2,300 x-ray examinations and treatments were given, 1,700 anesthetics administered, 10,000 prescriptions filled and 10,000 special laboratory tests made.

In fact for 1926 service currently appraised at more than threequarters of a million dollars was given at the University Hospital to the needy people of Nebraska. 
The University Hospital now has a capacity of 250 beds, arranged on a sixteen bed ward plan in north and south wings, with central service and quiet rooms and a connecting corridor on all floors between units. The ground floor contains the admitting department, kitchen, dining rooms, clinical pathology laboratories, zecropsy amphitheatre, pur basing and supply department, store rooms, library stack room, linen and sewing rooms and the department of roentgenology and physical therapy. The first or main floor contains the College and Hospital offices, three medical wards with adjoining isolation rooms, diet kitchens, laboratories, work rooms, etc., the library reading room, the medical amphitheatre and the hospital record room. Each floor has, on the connecting corridor between units, a spacious solarium, with south exposure, and each ward a sun porch. The second floor contains the resident physicians' quarters, four surgical wards and a photographic ronm. The third floor contains the internes' quarters, two wards for obstetrics and gynecology, a children's orthopedic ward and a psychopathic ward.

There are several special features worth noting. The admitting department at the ground floor entrance consists of a waiting room, admitting office and completely equipped examining room with the admitting physician in charge. All patients must enter the hospital through this department, and are referred to the proper service with a brief case record and diagnosis. Accident cases and minor surgery are cared for in this department, and the hospital follow up clinics and records maintained. The clinical pathology department is ideally situated in the north wing of the first hospital unit, adjacent to the necropsy amphitheatre. The purchasing and supply department on the ground floor is ideally located in central space with an extensive storage basement under the second unit. All purchases are made by competitive bids and a perpetual inventory maintained of all supplies received. The department of roentgenology and physical therapy occupies the south wing of the second unit of the hospital and is fully equipped to do all work in this field. Two children's wards in the south wing of the new unit, third and fourth floors, are especially divided for isolation of infants and infectious cases. The two psychopathic wards in the north wing of the new unit, third and fourth floors, are divided into nine single rooms, five of which are sound isolated, and two three-bed wards for observation and recovery. An occupational 
therapy room and hydrotherapy facilities are provided. This limited provision of the University Hospital for the care of curable psychopathic patients partially meets a great state need. The State Hospital for the insane at Lincoln is overcrowded and many curable patients do not need to be committed to this institution. Colorado, Iowa, and other states, have established such psychopathic hospitals in connection with their State Medical Colleges and when the value of these two wards of the University Hospital is demonstrated, Nebraska also probably will make such provision. The out-patient department is intimately connected with the hospital, located in the first two floors of the South Laboratory Building on the Medical College Campus. Thirty-five thousand visits were made by 5,533 dispensary patients last year. This furnishes an excellent teaching clinic for senior medical students, and permits selection of instructive cases for hospital admission.

\section{INTERNSHIP}

The internship in the University Hospital is a rotating eighteen months' service, a new intern beginning duty every two months throughout the year. The services advance as follows: (1) Pathology - two months, responsible for all special laboratory tests, surgical tissue examination, dressing of infected wounds, and assistant at necropsies; (2) Drug Room and Anesthetics - two months, maintenance of drug stock, for hospital orders and over one thousand prescriptions per month for outpatients' department, is first assistant on anesthetics; (3) Roentgenology and Physical Therapytwo months, full time work in this department, and responsible for emergency work outside of regular hours; (4-5) Medicine-four months, including neurology and dermatology; (6-7) Surgery - four months, including orthopedic surgery, urology, fractures, neuro-surgery; (8) Pediatrics - two months, including oto-rhino-laryngology and ophthalmology, assistant pediatrician to Child Saving Institute; (9) House Physician - two months, obstetrics and gynecology, admitting physician in the receiving department. This internship is not excelled anywhere in the country in the general training given and opportunities offered by a service in a teaching hospital.

\section{ADMISSION OF PATIENTS}

Patients are admitted to the University Hospital from all counties of the state on the basis of county population quota in so far 
as is possible. This does not mean that any county can force the admission of incurable or institutional cases into the hospital because its county quota has not been used. Such patients are ineligible and have to be sent home at considerable unnecessary expense if they are not admitted. The University Hospital must serve first the purpose for which it was established and is maintained,- that of medical teaching, and patients, who remain a long time and cannot be benefited or require only bed care, not only are of no value for teaching but fill beds which might be used by patients who could be benefited. Certain hospital services, as the acute illnesses, infectious diseases, obstetrics, accidents, and minor surgery, all extremely valuable and necessary in medical teaching, can be maintained only by admitting patients from nearby counties in excess of their quotas. The reason for the College of Medicine was to provide such facilities for teaching, and fully justifics a disproportionate service to Douglas County patients. However, a stricter requirement is maintained that Douglas County patients pay the cost of board and nursing while in the hospital. Exceptions to this rule are made only when it is desired to admit an instructive teaching case or when the University Hospital is able to render a hospital service badly needed and not available elsewhere. The hospital is very desirous of rendering serice to outstate counties and patients will be admitted promptly without question unless they are quite evident senile institutional patients. The hospital is glad to admit even those if there is any question concerning diagnosis or treatment which a thorough study might clear up.

The cost of maintaining patients in the University Hospital is between three and four dollars per day, depending upon the separation of medical college expense from hospital maintenance. $\mathrm{Pa}$ tients who receive this excellent service of the University Hospital, which includes detailed case study superior to most private hospitals, with consultation and treatment by the foremost physicians of Omaha, are expected to pay at least the cost of board and nursing which is three dollars per day. This applies to all patients who are not established county charges.

\section{SCHOLARSHIPS}

Three scholarships are available at the University of Nebraska Medical College for worthy students who need financial assistance. 
One is the Jennie Hanscom Conkling Endowment, made a gift to the institution June 7, 1920 by her husband, the late Jetur Riggs Conkling, pioneer Omaha physician. The Nurses' Home is called Conkling Hall in their honor. The late Mrs. Conkling was a sister of A. J. Hanscom, pioneer Omaha settler who gave Hanscom Park to the city.

Other scholarship loan funds have been provided by the Omaha Medical College Foundation and the Nebraska Federation of Women's Clubs. Principal of the first-named fund is more than $\$ 10,000$.

The Women's Overseas Service League of Omaha, made up of women who served in France, established a $\$ 5,000$ trust fund for the hospitalization of ex-service men or women, or their dependents. It is a memorial to the late May Burns Kountze, prominent Red Cross worker during the late war.

Dr. A. C. Stokes, whose recommendation Conkling followed in the matter of establishing the scholarship; and Gifford, Jonas, Bridges and F. S. Owen administer the Conkling trust.

SENIOR CLASS OF 1927-1928

UNIVERSITY OF NEBRASKA COLLEGE OF MEDICINE

$\begin{array}{lll}\text { Albertson, Leland C. } & \text { Hopkins, Howard L. } & \text { Prescott, Kenneth E. } \\ \text { Anderson, Chauncey L. } & \text { Katsuki, David I. } & \text { Preston, Robert Louis } \\ \text { Arkwright, Richard M. } & \text { Konterwitz, Harry K. } & \text { Pyle, Bert W. } \\ \text { Baker, Kenneth C. } & \text { Kuncl, Joe } & \text { Rasgorshek, Robert H. } \\ \text { Beach, Glen O. } & \text { Leavitt, Ruben D. } & \text { Rigg, James P. } \\ \text { Bennett, Clyde R. } & \text { Lanspa, Joseph A. } & \text { Sabin, Clarence W. } \\ \text { Bennett, William E. } & \text { Lewis, James T. } & \text { Saiki, Arthur K. } \\ \text { Borre, Helge } & \text { Linsley, Claude H. } & \text { Smith, Jerome H. } \\ \text { Burlingame, Donald L. } & \text { Martin, John K. } & \text { Sorenson, Regnar M. } \\ \text { Cram, Roy S. } & \text { Miller, Mrs. D. E. } & \text { Taggart, Samuel R. } \\ \text { Christliebe, John M. } & \text { Miller, D, H. } & \text { Thompson, Ralph M. } \\ \text { Crozier, Henry C. } & \text { Moritz, John R. } & \text { Valentine, Linville F. } \\ \text { Dean, Joe. O. } & \text { Morrison, Arlo } & \text { Van Valin, James C. } \\ \text { Dewey, Leonard A. } & \text { Morse, Esther M. } & \text { Wagner, Carl P. } \\ \text { Edstrom, Alice D. } & \text { Mossman, Thomas M. } & \text { Webster, William W. } \\ \text { Endres, Gregory L. } & \text { Mulligan, Arthur M. } & \text { Wells, Thos. } \\ \text { Engel, Earl H. } & \text { Musgrave, Rhoda U. } & \text { Willmarth, Edwin H. } \\ \text { Everette, Arthur R. } & \text { Nilsson, Gustav N. } & \text { Wilmoth, Marion E. } \\ \text { Geomoets, Henry N. } & \text { Pelikan, Charles Carl. } & \text { Wynegar, David E. } \\ \text { Graham, James W. } & \text { Peterson, Arthur E. } & \text { Zahorchak, Joseph A. } \\ \text { GreenBerg, Ben } & \text { Peterson, John C. } & \text { Zierott, Leroy L } \\ \text { Heinz, Theo. E. } & \text { Pfeiffer, Eric P. } & \end{array}$


Arthur D. Dunn, chairman of the department of clinical research at the University of Nebraska Medical College, came to Omaha in 1907. He was a graduate of Rush Medical College in 1902, and served one and one-half years as house phy-

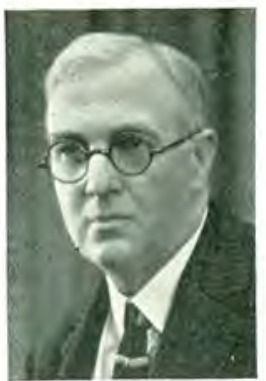

ALTHUR D. DUNN sician in Cook County Hospital, Chicago, and six months as private assistant to the late Dr. John B. Murphy of Chicago. He spent a year in post graduate work in Vienna and a year in a mining hospital in Idaho. Both Dr. and Mrs. Dunn have identified themselves with musical development of the city, notably the Tuesday Musical Club and the Omaha Symphony Orchestra. He has served on the faculty of Creighton Medical College and of the University of Nebraska and the staff of several hospitals. He was born in Pennsylvania in November, 1873 and attended Alleghany College and the University of Chicago.

Sergius Morgulis, professor of biochemistry at the University of Nebraska College of Medicine since 1921, is the author of "Fasting and Undernutrition" (E. P. Dutton and Co., 1023), which was at once translated into German and Russian. It was the first attempt to treat the subject, of great significance to the practice of medicine, from a strictly scientific viewpoint.

With an interesting record behind him, Morgulis has spent the past ten years in the study of enzymes, the chemistry of blood, various problems of metabolism, including bones, urea and mineral metabolism, and a series of methodological interest. More than 40 original papers on these subjects appeared in

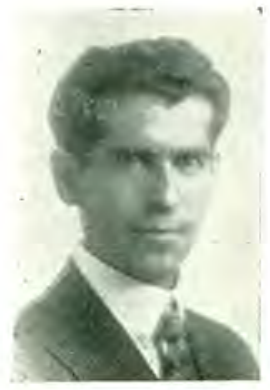

SERGIUS MORGULIS leading scientific and medical journals. In conjunction with Dr. George Pratt and Dr. Herman Jahr, a study on kidney function tests was published from his laboratory.

Born in Russia in 1885, Morgulis was educated at the University of Odessa, and at Columbia, where he received his M. A. in 1907 and worked for two years at the same desk with professor T. H. Morgan, the greatest living biologist, it is said. He then taught in the Ohio State University and at Harvard, where he received 
his doctorate, and in 1910, appointment as Harvard representative for two years' study in Vienna, Berlin and Naples. On his return, he accepted the post of associate in animal metabolism at the Carnegie Nutrition laboratory and in 1914, associate in biochemistry at the College of Physicians and Surgeons, Columbia. At the same time the U. S. Bureau of Fisheries gave him a substantial grant to conduct special researches on the problem of nutrition of fish and a laboratory was built for his use in the New York Aquarium.

Morgulis work at this time received for him the Bowdoin Medal, a gift of $\$ 200$ for research on fasting, and a prize of $\$ 100$ from the American Fisheries Society for his studies on fish nutrition. He also published 30 scientific papers in leading American and German periodicals, representing original researches in regeneration; effect of drugs on development, fasting from the morphological and biochemical standpoints and researches in metabolism under a variety of conditions. He was elected to the American Biochemical society, Society of Zoologists, Society of physiologists and is a Fellow of the American Society for the Advancement of Science. His first affiliation in Omaha was with Creighton University.

\section{JOHN A. CREIGHTON MEDICAL COLLEGE.}

Hermann von Wechlinger Schulte, dean of Creighton University School of Medicine since 1918, had a distinguished record in the fields of embryology and comparative anatomy before coming to Nebraska and has since evinced a strong interest in social service and the social aspects of medicine. He was associate professor and member of the faculty of medicine and pure science of Columbia University from 1904 to 1917 . He is now president of the Omaha Council of Social Agencies; vice-president of the Nebraska State Conference of Social Work; president of the University and Professional Men's Clubs; on the city library board and chief of staff at St. Joseph's Hospital. He was educated at St. Paul's school, Trinity College, 1897; was graduated in medicine at Columbia in 1902 and studied in Berlin in 1904. He is active in the OmahaDouglas County Medical Society, Chamber of Commerce, Catholic Hospital Association, Harvey Society and is a member of the American Medical Association committee for the study of Internal Secretions. 
Other affiliations include: New York Academy of Sciences (Fellow-Vice-President 1915-1917), Nebraska Academy of Science (Vice-President, 1923, President, 1924), Association American Anatomists, American Association for the

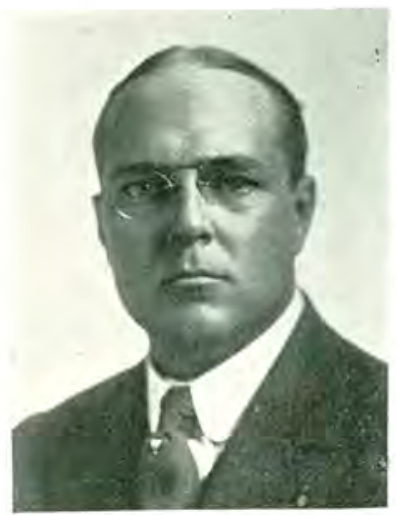
Advancement of Science (Fellow), New York Zoological Society (Fellow), Society of American Mammologists, Eugenics research Association, American Museum of Natural History, American Gsographical Association, American Forestry Association, John Burrows Association, American Academy of Political Science, Nebraska State Anatomical Board (1917), Trustee of Omaha Orthopedic Society, Lieutenant-Colonel in Medical Reserves, Commanding Officer of General Hospital No. 55 (1922), ReHERMANN VON WECHLINGER serve Officers Association of the United SCFILLTE States.

Notable publications of Dean Schulte include: "Range of Variations in Monotremes and Australian Marsupials", Journal of Anatomy, Vol. VI, 1907; "Further Communication on the Venous System of Marsupials," Anatomical Record, Vol. II, 1906; "The Development of the Human Salivary Glands Studies in Cancer and Allied Subjects," Columbia University Press, Vol. VI, 1913. "The Development of the Salivary Glands in the Cat," Idem.; "The Mahhalia Avolingual Salivary Aea," Idem.; "Early Stages of Vasculogenesis in the Cat (Felis domestica, with especial reference to the Mesenchymal Origin of Endothelium," Mem. Wistar Inst. of Anatomy and Biol., No. 3, 1914; "Anatomy of a Foetus of Balaenopteia Borealis" (Lesson), Mem. American Museum of Natural History N. S., Vol. I, part VI, 1914; "The Fusion of the Cardiac Anlages and the Formation of the Cardiac Loop in the Cat" (Felis domestica), American Journal of Anatomy, Vol. 20, 1916; (with Frederick Tilney) "The Development of the Neuraxis in the Domestic Cat to the Stage of Twenty-one Somites," Annals of New York Academy of Science, Vol. XXIX, 1915; "The Early Stages of the Development of the Great Veins and of the Hepatic Circulation in the Cat," (abstract), Anatomical Records, Vol. II, 1917; "The 


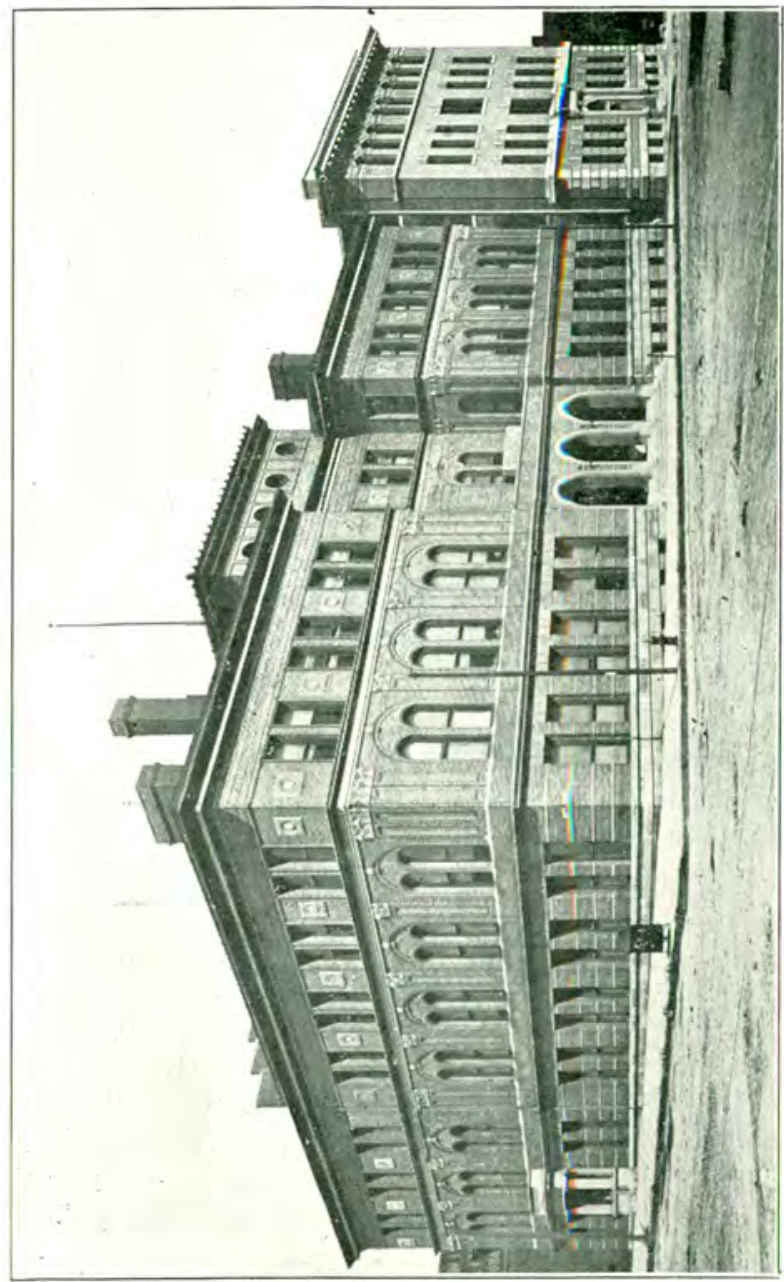

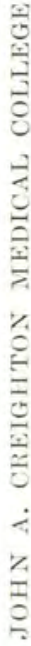


Skull of Kogis Breviceps" (Blainville), Bulletin of American Museum of Natural History, Vol. XXXVII, 1917; "A Note on the Lumbar Vertebrae of Scutisorex" (Thomas), Idem; (with M. de Forest Smith) "The External Character, Skeletal Muscles and Nerves of Kogia Breviceps" (Blainville), Idem., Vol, XXXVIII, 1918; (with John D. Kernan, Jr.) "Memoranda Upon the Anatomy of the Respiratory Tract, Foregut and Thoracic Viscera of Foetal Kogia
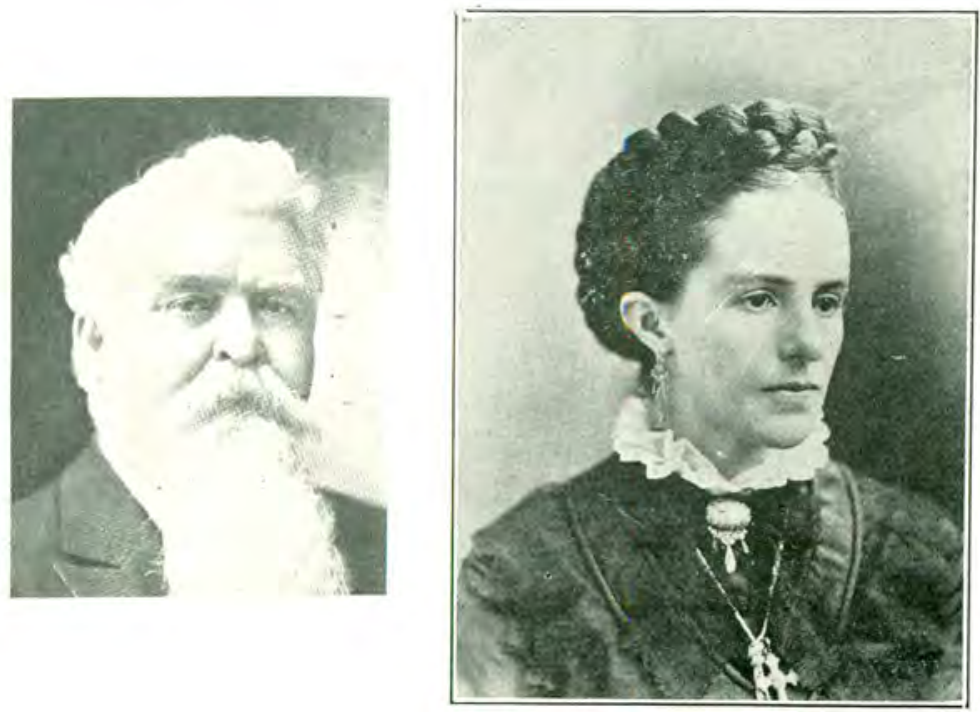

COUNT AND MRS. JOHN A. CREIGHTON

Respiratory Tract, Foregut and Thoracic Viscera of foetal Kogia Breviceps," Idem., Vol. XXXVIII, 1918; "John Hunter," The Creightonian Chronicle, Vol. 9, 1918; "The Spirit of Professionalism," American Institute of Architects, Vol. XII, 1924 and Association of Professional Men's Quarterly, Vol. 1, 1925; "Hospital Social Service," Hospital Progress, Vol. 6, 1925; "The Physician and His Community," Nebraska State Medical Journal, 1927; "Fear and the Physician," Shadows, January, 1928; "Building of New Hospital," Omaha Bee-News, November 20, 1927.

Creighton University, with which the Creighton School of Medicine is affiliated, owes its origin to the bequest made by Mrs. Mary Lucretia Creighton, widow of the late Edward Creighton, who died 
in 1876. The school opened its doors September 2, 1878 on its California street site, The Right Rev. James O'Connell, first Catholic bishop of Omaha, a trustee, called in the Jesuits to conduct the school.

A brother of Edward, Count John A. Creighton and his wife, Sarah Emily, are responsible for the establishment of the medical school at Fourteenth and Davenport Streets, and St. Joseph Hos-

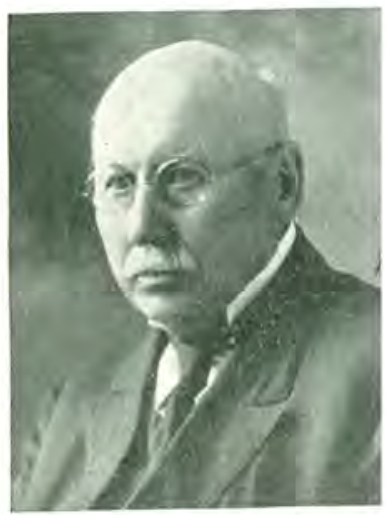

DE WITT C. BRYANT pital, its teaching institution on South Tenth street.

The following letter is from DeWitt C. Bryant, now residing at Claremont, California, who was for 17 years dean of the John A. Creighton Medical College, as well as one of its organizers. He was also one of the organizers of the American College of Surgeons. Bryant here gives an account of the inception of the present great school, where, he states, he spent the most enjoyable years of his life, teaching.

"I have avoided all personalities," wrote Dr. Bryant, "although I would have liked to say some good things about a number of the old faculty. In the spring of 1892 , the Hon. John A. Creighton requested Dr. Patrick S. Keogh, Dr. W. J. Galbraith and myself to meet with him and the president of Creighton University to discuss and decide as to the wisdom and feasibility of founding a new medical college in Omaha. Mr. Creighton stated that all his life he had been very deeply interested in medical and hospital work and even much more so after the death of his wife which had occurred a few years before. He said that the memorial to his wife, the new St. Joseph's Hospital, the largest and best-equipped hospital in the middle west, at that time, was just being completed and now he wanted to build a medical college, as a monument to himself, to be known as the John A. Creighton Medical College, the medical department of the Creighton University.

"He emphasized the fact that he wanted the college to be one of the best medical schools in this whole country and that the equipment for teaching should be up to date and 
of the very best for all of which he was not only willing but anxious to supply the funds. He wanted the school to open its doors and begin teaching the first of October following this first meeting if we believed, as he did, that the venture would prove to be a success.

"With his promise of financial support and the new hospital to furnish material for clinical teaching, there seemed to be no shadow of a doubt of certain success following the undertaking. As no voice from a 'doubtful Thomas' in our group was heard, plans were immediately adopted for selecting a faculty and assigning to each member some branch of medicine which he should prepare himself as well as possible, in the short time before the opening of the school, to teach.

"Fortunately, Omaha at that time, had a goodly number of medical men well trained and well fitted for the undertaking, so little time was lost in making the selection. Only two, for teaching some of the scientific branches in the first and second year work, were brought from the east. All the other members of the faculty were residents of Omaha or Council Bluffis.

"The work accomplished and the results obtained afterwards proved the wisdom of the selections made. As it required some time for the erection and equipment of the new building it was decided to use the old St. Joseph's Hospital, then vacated, for teaching purposes until a site could be selected and a building erected for the new college. As a matter of fact it was two years before the school was housed in its new domicile.

"The first class consisted of nineteen students. This number rapidly increased, year by year, as the college's exceptional facilities for teaching both didactic and clinical medicine became known, until at the time of the founder's death there were more than one hundred and fifty students enrolled in the school and later this number was increased to two hundred.

"After the first two years, the college required four years didactic and clinical instruction to entitle the student to a diploma, the same as the best eastern medical colleges demanded.

"The success of the college has been due, first, to the personal effort of each individual member of the faculty and the personal contact with the students in the 
every day routine teaching; and, second, to the combined efforts of the original faculty to make the founder's dream come true. As one of the presidents of the university often said, the original faculty by its untiring zeal, labor and energy erected an enduring monument not only for the founder of the college but also for themselves."

The men included Galbraith, formerly chief surgeon of the Union Pacific, who is generally credited with having first interested Count Creighton in the project, after he, Galbraith, had resigned from the Omaha Medical College; Dr. Bryant, Dr. Keogh, the father of Frank S. Keogh of Omaha, who was elected the first dean of the new medical school; and Doctors W. M. Barritt, G. H. Brash, H. L. Burrell, Frank E. Coulter, Benjamin F. Crummer, Paul Grossman, H. P. Jensen, A. Johnson, J. P. Lord, W. R. Martin, J. H. Peabody, J. D. Peabody, A. W. Riley, W. S. Robinson, Charles Rosewater and S. K. Spaulding.

Rev. W. P. Whelan, S.J., who has been connected with the institution longer than any other person, sets May 30, 1892 as the day that the board of trustees of Creighton University voted to accept the offer of Count Creighton, who guaranteed the funds necessary to maintain the new school of medicine. The school did not open until October 1.

The curriculum provided for three years of instruction. The graduates of high schools were eligible for admission. In addition to the usual departments there was a chair of military surgery and one of electro-therapeutics. Thirty-six students representing six states were registered the first year. The total charge for instruction, inclusive of laboratory or hospital fees was $\$ 55.00$ a year with a "liberal reduction for the sons or brothers of professional men."

In June, 1892 was opened the Creighton Memorial Hospital at 10th and Castelar streets on land donated by John A. Creighton, who added largely to the building funds of the hospital with the purpose of providing clinical facilities for the Medical College. The old St. Joseph's Hospital at 12th and Mason Streets, erected in 1870 afforded temporary quarters for the College until the present building at 14th and Davenport streets was completed in October, 1898.

In 1893 Professor J. S. Foote joined the faculty and began a life long service to the College. 


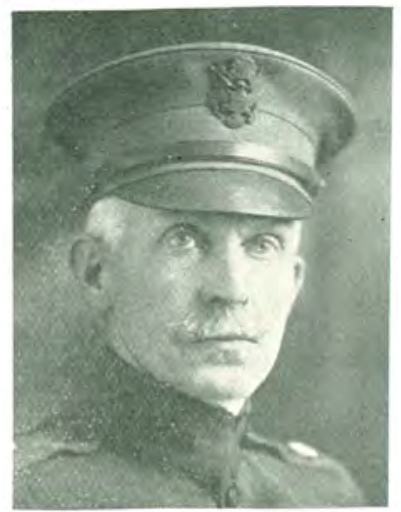

J. R. CLEMENS

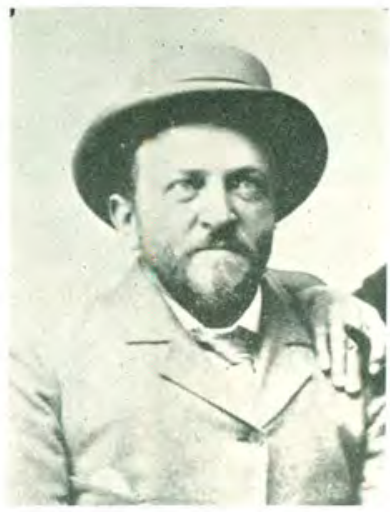

W. G. GALBRAITH

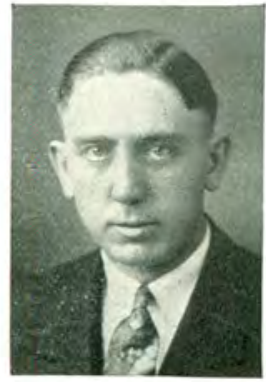

F. M. DUFFY

M. J. FORD

G. W. DISHONG

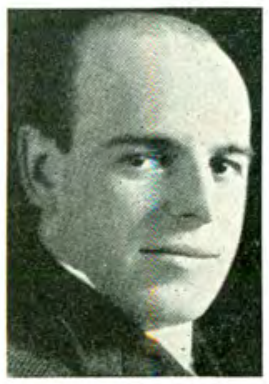

T. J. DWYER

J. F. LANGDON 
In 1894 the Faculty "decided to adopt a better and more thorough course of instruction and established a four-year curriculum. As the laws of Nebraska require only three years study of medicine, students of this institution for the present, will be required to pay no fee for the fourth term." In this same year Professor C. F. Crowley was appointed professor of chemistry. In 1897 Dr. Bryant, who had been secretary of the faculty since its formation succeeded Dr. Keogh as Dean, an office which he held until 1913.

Father Whelan's long and useful career as regent to the college began in 1904. He supplied the following additional information:

"The school opened the first fall with an attendance of thirty students representing six states. This number increased steadily until it was determined to restrict the number of admissions.

"In 1896 Creighton lengthened the course to four years, and was the first school west of the Mississippi to do so. Pending the erection of suitable quarters the school found a temporary home at 12 th and Mason Streets in the old St. Joseph's Hospital. This hospital was founded in 1888 by Mrs. Sarah Emily Creighton, who bequeathed to the Franciscan Sisterhood $\$ 50,000$ towards its construction. John A. Creighton furthered the project begun by his wife by donating the ground on which the hospital is located and by increasing twofold the amount of the original legacy.

"After his death, the sisterhood fell heir to four times the amount already given. This sum was chiefly expended on the construction of the present north wing and chapel and not a little of it in the building of the Nurses' Home. By an arrangement made with the sisters in charge of the hospital through the good offices of the founder of the Medical School, all clinical material and advantages have from the beginning been reserved and will continue to be devoted in perpetuity to the exclusive use of the Faculty and students of the Creighton Medical School. This agreement was entered into by John A. Creighton and Mother Xavier of the Franciscan Sisterhood in presence of Father James F. X. Hoeffer, President of the University. It had long been the cherished hope of John A. Creighton to build a permanent home for the medical school, and thus forever unite the two institutions dear to him, The Creighton University and The Creighton Memorial Hospital." 


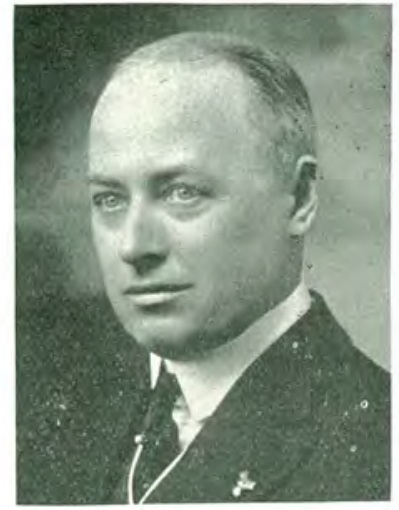

B. M. RILEY

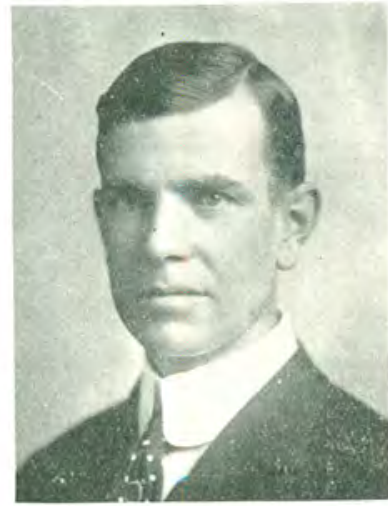

ROBERT RETZER

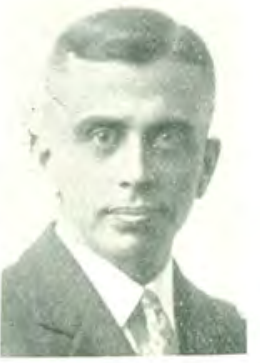

MAURICE HOWARD

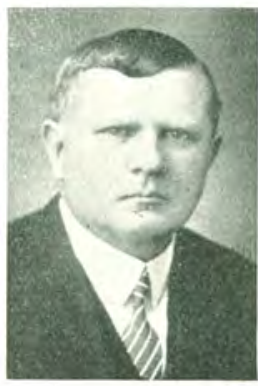

CHAS. MC MARTIN

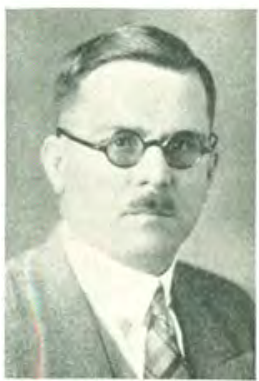

FRANK P. MURPHY

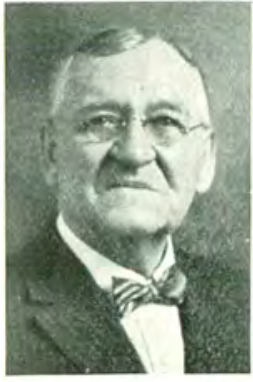

A. J. WILSON

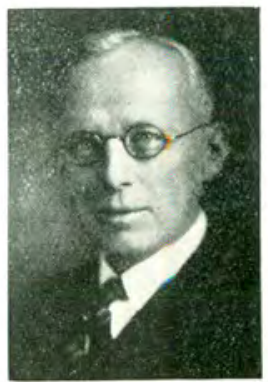

G. E. NEWHAU'; 
"Such a building was erected and ready for classes in the fall of 1898. Later on the laboratory building, north of the original building and connected with it on the second floor by a bridge across the alley was constructed.

"The site for the school was selected because it was so readily accessible by three railways from every part of the city, thus affording a convenient center for the outdoor clinic and free dispensary.

"The Creighton Medical Bulletin, a student's enterprise, made its first appearance in 1898 and was published under the direction of the Faculty. Michael J. Ford of Omaha was on the staff. For years it afforded the students a splendid opportunity of testing their ability as authors and was also a happy medium of publicity until the various student publications were merged into one college magazine.

"The appointive power to professorships in accordance with the express wish of the Founder, rests with the Board of Trustees of the University, though it has been the uniform practice to defer greatly to the wishes of the Administrative Board of the Medical School, so that the selections may result in a congenial and harmonious faculty To this Board ultimately belongs the determination of all important points relating to the course of studies, discipline, schedule of hours, proper methods of instruction and the internal government of the school.

"Deans have been Drs. P. S. Keogh, D. C. Bryant, A. L. Muirhead, Robert Retzer, J. R. Clemens and the present incumbent Dr. H. von WV. Schulte.

"For seventeen years Dr. Bryant was the soul of the school," according to Father Whelan. "His ability as an executive, his deep insight into character as well as his recognized scientific reputation among his confreres made him an assured success as Dean. He was dear to professors and students alike; his genial manners and unaffccted simplicity had an irresistible charm, he was in very truth a magnetic personality. But with all these outstanding qualities of mind and heart he could not have achieved such success had he not been ably seconded by a devoted and loyal faculty. Drs. Andrew Riley, Crummer, Spalding, T. B. Lacy of Council Bluffs, C. F. Crowley and J. S. Foote were his reliable consultants. Drs. Foote and Crowley served the institution for more than thirty years. The latter is still head of the department of Chemistry. 
"Dr. Foote was a scholar, student and teacher and a lover of scientific research. In the retired life he led, he was ever on the alert to wring from nature her most profound secrets. His various publications attest his deep penetration into the subjects of which he was an acknowledged master."

Officers include Rev. William J. Grace, S.J., President of Creighton University; Father Whelan, regent; Dr. Schulte, dean; Dr. Bryan M. Riley, secretary and Dr. Charles F. Crowley, emptor. The administrative board includes Schulte, Whelan, Riley and Doctors George F. Simanek, Adolph Sachs and Herbert F. Gerald.

Creighton Medical College, though young in years, early attracted to itself men of distinction in the scientific world, notably the late James S. Foote and A. L. Muirhead, mentioned in another chapter, with C. F. Crowley, James F. McDonald and Victor E. Levine of the faculty today and another, a gifted surgeon, the late Charles C. Allison.

Arthur Julian Wilson and E. C. Henry of Omaha were among the first students to enroll in Creighton University. Wilson, whose father, J. N. Wilson, was a physician in Hamilton County, Pennsylvania and had befriended W. J.Galbraith in his youth, was urged to take up medicine by Galbraith, who later made him his assistant in the Union Pacific service.

Wilson recalled many interesting stories of Galbraith's service as chief surgeon of the Union Pacific during the caisson disease epidemic among the Missouri river bridge builders, and of the early St. Joseph Hospital at Eleventh and Mason Streets, which was used as the first Creighton Medical College building when the hospital moved into its present edifice; and of Galbraith's subsequent service in Honolulu and in Mexico, and reported that the former prominent Omaha surgeon and founder of Creighton, is now chief surgeon aboard the Leviathan. A son, William J. Galbraith, is now practicing law in Tucson, Arizona. Wilson also recalled the names of a number of his classmates, who were graduated in 1895. Among them were one Bratt, M. E. Bush, now dead; Ralph Casterline, Max Cornelius of Kearney, a talented pianist who also died; Ed. S. and C. E. Furay (the latter dead) George A. Harris of Valley, H. E. Miller, Murphy of St. Louis, Charles Rowland, now in Oklahoma and Frank P. Sinclair, who gave up the practice of medicine to enter the govern- 
ment meat inspection department. Clifford Walden, son of D. A. Walden, a Beatrice doctor, was also a member of the class. Doctors Rudolph Rix, A. S. Pinto and F. J. Wearne of Omaha finished in the next class, in 1896.

Doctors Galbraith, J. S. Foote, who was a member of former President Taft's class and an anatomist from Chicago and Dr. Harris, were greatly beloved by the early Creighton students, according to Wilson. The latter was physician for the Hanna Wyoming coal mines, and practiced seven years in Knox County, where he was a coroner two terms, before returning to Omaha to practice. He has been here 23 years.

\section{CREIGHTON MEN OF DISTINCTION}

Though it was acknowledged when he died June 19, 1918, that he had few peers in his field, there was considerable opposition to Allison's appointment to the chair of surgery, in 1898, only seven years after he located in Omaha. His youth - he was only thirty-

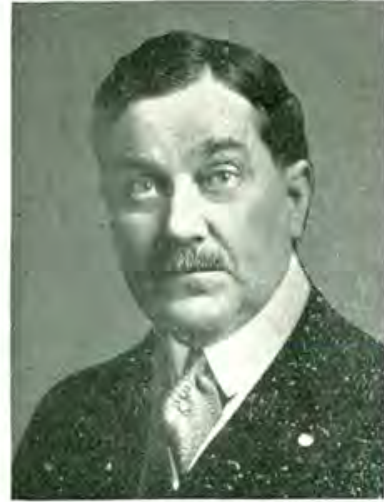

CHARLES C. ALLISON two-and comparatively short residence here and the natural competition of other surgeons, contributed to the opposition but the record of Allison's twenty years' service at Creighton and as chief surgeon at St. Joseph, St. Catherine and Presbyterian Hospitals, as well as on the Wise Hospital staff, proved the wisdom of his choice.

Allison was born in Hillsboro, Ohio, December 6, 1866, was educated at St. Mary's College, St. Mary's Kansas and at the Lou isville, Kentucky Medical College; after which he spent a year as ship's surgeon on a vessel sailing between New York and Rotterdam. Ohio friends who settled in Omaha induced him to come west in April, 1891, and it was not long before his natural ability and deft surgery brought him speedy prominence. Difficult cases were sent to him from long distances and remote places, and the extraordinary amount of work he accomplished, often as many as fourteen serious operations per day, soon taxed a frame robust in appearance, but not actually strong. He suffered from a tuberculous affection anc 
was further weakened by an attack of blood poisoning, the result of infection from a patient, the combination of which brought on his untimely death at the age of fifty-two, even though he husbanded his strength by a total lack of social life or other activities outside his profession.

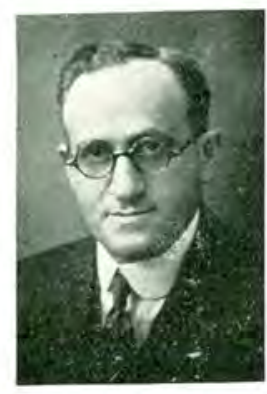

ADOLPH SACHS

Allison's greatest monument is, however, in the hearts of Omaha's pcor, whom he served to a remarkable degree, with no thought of pay. He literally poured out his strength in personal service, as evidenced by the tr.butes, at his passing. He did much to establish Omaha as the ackncwledged medical and hospital center of this section of the middle west, for his name was a household word. Allison is survived by his widow, a member of Count Creighton's family: a son, Charles Creighton Allison, and a daughter, Mrs. Albert Sibbernsen.

Adolph Sachs, Creighton graduate and professor of medicine, who completed his studies abroad, has done some important experiments in mechanical drains of the gall bladder, in which he was assisted by Maurice C. Howard. Sachs is ex-president of the OmahaDouglas County Medical Society and has also written for the Ameri-

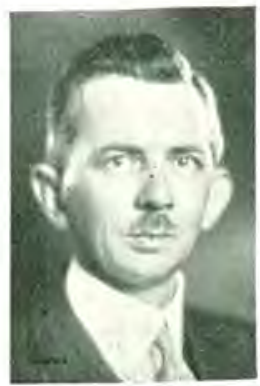
can Journal of Sciences and other publications. George F. Simanek, chief of the surgical staff at St. Joseph Hospital, has attained more than local distinction for his ability. The removal of a bullet from the heart of a patient is one of the rare operations he performed, according to Father Whelan. Bernard M. Kully, instructor in oto-laryngology, is prominent in this field.

Francis Wenger Heagey, assistant professor of medicine, was graduated from $\mathrm{Co}-$ DR. F. W. HEAGEY lumbia University and came to Omaha in 1916.

His important papers are "Cerebellar Manifestations of Epidemic Encephalitis," "Smyptoms of Colonic Disturbance," "Development of Neural Tube in a Chick," "Epidemic Encephalitis, including review of 115 American Cases," "Cervical Adenitis," "Epi- 
demic Encephalitis in Relation to Anterior Poliomyelitis" and "Relation of the Internist to General Practitioners."

Besides the usual professional affiliations, Dr. Heagey is a fellow of the American College of Physicians. A member of the Chamber of Commerce and various other civic clubs.

Of the younger men on the faculty today, in addition to those mentioned above, are Carl Russum and Francis M. Duffy in the department of pathology and bacteriology, the latter having published two important papers.

Among the distinguished graduates, Karl Connell who perfected the gas mask in the late war, and A. S. Pinto, who volunteered in the yellow fever experiments, are mentioned in the chapter on War Service.

The newest acquisition of Creighton University is Nicholas A. Michels, a young priest who studied abroad and has already achieved a brilliant record in science, who is professor of the de-

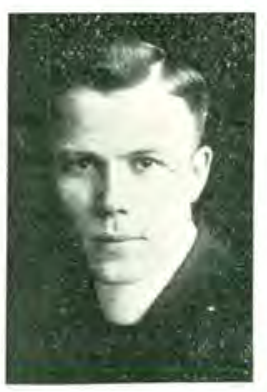

REV. A. MICHELS partment of histology and embryology. His research is chiefly in the field of haematology. It includes a comparative study of the origin, distribution and morphology of the mast cell in the lower vertebrates; origin of the easinophil granules; morphology and significance of prehepatic embryonic blood cells; morphology of tissue culture cells; origin and nature of perivascular infiltrations in polioencephalitis and acute encephalitis. He is a collaborator in the work, "Biological Abstracts."

Michels received his M. A. in biology and microscopic anatomy under Downey at the University of Minnesota in 1920 and his D. Sc. in the medical natural sciences under Gregoire, University of Louvain, Belgium, in 1922. He worked in the Marine Biological station at Friday Harbour in 1921. In 1923 he studied at the Sorbonne in Paris, in Naples, and also did private research in haematology with Ferrata at Sienna, Italy; worked with Maximow in Chicago in 1925 and with Globus, the neuropathologist in New York University and Mt. Sinai Hospital, in 1926. Before coming to Omaha, he was professor of biology at St. Thomas college and biology and histology in St. Louis University Medical School. $\mathrm{He}$ 
is a member of the Societe Scientifique de Bruxelles; Societe d'An thropolgie de Bruxelles, Association of Anatomists, American Association for the advancement of Science, Nebraska Academy of Science and Sigma XI.

\section{CREIGHTON FACULTY}

Bryan M. Riley, A.B., M.D., F.A.C., Professor of Medicine and Head of the Department.

George F. Stmanek, M.D., F.A.C.S., Professor of Surgery and Head of the Department.

Albert F. Tyler, B.Sc., M.D., F.A.C.P., Professor of Roentgenology and Physiotherapy.

Adolph Sachs, M.D., F.A.C.P., Professor of Medicine.

Charles McMartin, Ph.B., M.D., F.A.C.S., Professor of Dermatology and Urology. Chairman of Senior Council.

Hermann von W. Schulte, A.B., M.D., Professor of Anatomy.

Gustav W. Dishong, M.D., F.A.C.P., Professor of Nervous and Mental Diseases.

Victor E. Levine, A.M., Ph.D., Professor of Bio-Chemistry.

Louis B. Bushman, A.B., M.D., F.A.C.S., Professor of Opthalmology.

Claude T. Uren, M.D., F.A.C.S., Professor of Otology and Rhinology.

Herbert F. Gerald, Ph.G., M.D., Professor of Pharmacology. Chairman of Junior Council.

James F. McDonald, B.S., M.D., Professor of Physiology.

Floyd S. Clarke, M.D., Professor of Pediatrics.

Edward E. Chaloupka, M.D., Professor of Gynecology and Obstetrics.

B. Carl Russum, A.B., M.D., Professor of Pathology and Bacteriology.

Frederick J. Langdon, A.M., M.D., F.A.C.S., Associate Professor of Surgery.

Frank J. Schleier, M.D., Associate Professor of Surgery.

Joseph M. Shramek, M.D., Associate Professor of Surgery.

John W. Duncan, M.D., F.A.C.S., Associate Professor of Surgery.

William L. Sucha, M.D., Associate Professor of Surgery, Orthopedics.

Charles J. Nemec, M.D., Assistant Professor of Surgery.

John R. Kleyla, A.B., M.D., Assistant Professor of Medicine. 
Francis W. Heagey, A.B., M.D., F.A.C.P., Assistant Professor of Medicine.

Maurice Howard, A.B., M.D., Assistant Professor of Medicine.

Harry J. Murphy, A.B., M.D., Assistant Professor of Pediatrics.

Ernest Kelley, M.D., Assistant Professor of Nervous and Mental Diseases.

Frank P. Murphy, A.M., M.D., Assistant Professor of Obstetrics.

Nicholas Michels, D. Sc,, Assistant Professor of Anatomy.

James F. Kelley, M.D., Assistant Professor of Roentgenology and Physiotherapy.

John K. Muldoon, M.D., Assistant Professor of Obstetrics.

John J. Warta. M.D., Assistant Professor of Ophthalmology.

William Porter Haney, M.D., F.A.C.S., Assistant Professor of Otology and Rhinology.

Raymond Traynor, A.B., M.D., Assistant Professor of Medicine.

Eugene Noonan, A.B., M.D., Assistant Professor of Anatomy.

William P. Whelan, S.J., Lecturer on Medical Ethics.

Donald Burke, LL.B., Lecturer on Medical Law.

Charles M. Walson, Major M. C., U. S. A., Lecturer on Hygiene.

Harry Boyne, D.D.S., M.S., Lecturer on Oral Surgery.

Edw. R. Hayes, M.D., Special Lecturer.

Clarence B. Molseed, Ph.G., M.D., Assistant Professor of Surgery.

Maurice E. Grier, M.D., Assistant Professor of Gynecology.

Harry J. Jenkins, M.D., Assistant Professor of Surgery.

John J. Gleason, M.D., Instructor in Surgery.

Vernard A. Lanphier, M.D., Instructor in Medicine.

Thomas W. Torpy, M.D., Instructor in Surgery.

Thomas J. Boler, M.D., Instructor in Urology.

ADOLPH SRB, M.D., Instructor in Surgery.

Earl Connolly, A.B., M.D., Instructor in Surgery.

Louis E. Moon, M.D., Instructor in Surgery.

Bernard Kully, M.D., Instructor in Oto-Laryngology and Anatomy.

Andrew G. Dow, M.D., Instructor in Pediatrics.

John T. Little, A.B., A.M., Instructor in Chemistry. 
William T. Rance, B.S., M.D., Instructor in Surgery. Charles F. Swab, M.D., Instructor in Ophthalmology. John J. Freyman, A.M., M.D., Instructor in Surgery. John J. OHEARn, M.D., Instructor in Medicine. George E. Neuhaus, M.D., Instructor in Neurology. John J. Borghoff, M.D., Instructor in Dermatology.

Fred J. Schwertley, M.D., Instructor in Anatomy and Sur. gery.

Louis D. McGuire, B.S., M.D., Instructor in Surgery.

Francis J. DufFY, B.S., M.D., Instructor in Bacteriology.

Arthur J. Offerman, M.D., Instructor in Medicine.

Elizabeth Moyer Swab, M.D., Instructor in Ophthalmology. Silas Hopkins, M.D., Instructor in Surgery and Anatomy.

E. Emmet McMahon, A.B., M.D., Assistant in Medicine. Benjamin F. Ewing, B.S., M.D., Assistant in Medicine. Thomas F. Houlton, B.S., M.D., Assistant in Neurology. James Iwerson, M.D., Assistant in Pediatrics.

John J. Chaloupka, B.S., M.D., Assistant in Medicine.

James W. Martin, A.B., M.D., Assistant in Orthopedics and Anatomy.

Wrlliam H. Schmitz, B.S., M.D., Assistant in Urology.

Ernest W. Landgraff, M.D., Assistant in Surgery.

Julius G. Bartek, B.S., M.D., Assistant in Medicine.

Charles F. Ulrich, M.D., Assistant in Medicine.

Frank J. Casey, B.S. M.D., Assistant in Medicine.

William J. Adams, A.B., M.D., Assistant in Medicine.

William Barry, A.B., M.D., Assistant in Roentgenology.

Arthur C. Johnson, B.S., M.D., Assistant in Surgery.

Fred M. Watke, B.S., M.D., Assistant in Oto-Laryngology.

\section{DISPENSARY}

Medicine: Drs, Kleyla, Heagey, Traynor, Ulrich, McMahon, Offerman, Chaloupka, Bartek, Adams and Casey.

Pediatrics: Drs. Murphy and Dow.

Nervous and Mental Diseases: Drs. Houlton and Neuhaus.

Surgery: Drs. Srb, Jenkins, Molseed, Connolly, Schwertley, McGuire, T. W. Torpy, Rance, O'Hearn, Johnson and Landgraff.

Orthopedics: Drs. Sucha and J. Martin.

Proctology: Dr. Moon.

Urology: Drs. Boler and Schmitz. 
Dermatology: Dr. Borghoff.

Obstetrics: Drs. F. Murphy and Muldoon.

Gynecology: Drs. E. Chaloupka, Grier and Freyman.

Roentgenology: Drs. Kelly and Barry.

EyE: Drs. Warta, C. Swab, Elizabeth Swab and Young.

EAR: Drs. Uren, Kully, Haney and Watke.

Laboratory: Drs. Gerald and Duffy.

The graduates numbering about one thousand are located in practically every state, but chiefly in the middle West. The Army, Navy and the Public Health Service also claim their quota. In Omaha a hundred or more are successful practitioners.

A splendid medical library which subcribes to eighty scientific periodicals, is a feature of the college.

A student loan fund, established by John R. Webster and John Potter Webster has proved exceedingly useful.

Interesting figures in connection with Creighton University School of Medicine: Faculty-Total 85-

Professors $\quad 15$ Instructors $\ldots \ldots \ldots .22$

Associate Professors ……....... 5 Assistants _.....................23

Assistant Professors …...15 Special Lecturers _.............. 5

CREIGHTON MEMORIAL ST. JOSEPH HOSPITAL

St. Joseph's or Creighton Memorial is the largest hospital west of the Mississippi river, occupying two square blocks. Surrounding the big hospital buildings at Tenth and Castelar streets, which house 420 beds and a fine six-story Nurses' Home, are beautiful recreation grounds, overlooking the Missouri river. The staff includes sixty physicians and surgeons and a training class of 100 nurses. It is connected with the Creighton College of Medicine, and shared with it the philanthropy of the late Count John A. Creighton and Mrs. Creighton. Its present value is $\$ 1,250,000$.

The hospital was established in 1870 by the Sisters of Mercy. In 1880 , it passed into the hands of the Franciscan Sisterhood, by whom it is still conducted. There is no denominational descrimination however, and the hospital does the biggest share of charity work of any institution in the city. Of 6,908 patients receiving medical care there in 1925, the free patients numbered 2,562 and 1,451 partpay patients, or more than half charity work. 
Rules of the American College of Surgeons and the Catholic Hospital Association are strictly adhered to. A free dispensary and out-patient department was inaugurated in 1919. Surgical cases, discharged from hospital, report here for dressings, when needed, thereby shortening their hospital stay. A follow-up system, which already is operative among forty per cent of discharged patients, has proved of inestimable value to both physician and patient. A clinical research division has also been established. The training

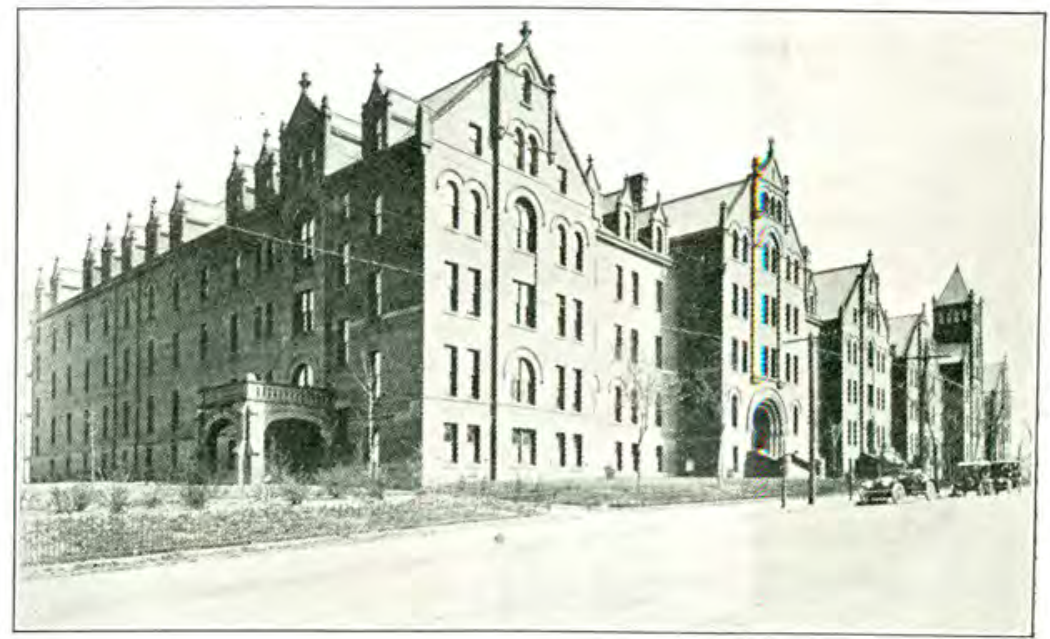

school for nurses is a valuable asset to the community, because its graduates, skilled in nursing, support themselves by helping others. Besides the usual course given in other hospitals, these trainees have the advantage of practical instruction in physical culture, anaesthesia, laboratory, roentgenology and pharmacy by instructors from Creighton University, so that later they may specialize in these departments, if they desire. Candidates must have high school education. Two classes yearly are formed.

The top floor of the Nurses' Home may be used for ballroom or gymnasium, as desired.

A Romanesque chapel, seating 300, with three magnificent Carrara marble altars, imported from Italy, with beautiful stained glass windows and a large pipe organ is one of the features in connection with the hospital. 
More than 3,000 operations were preformed in the seven operating rooms, last year. A fulltime anesthetist is employed. Beaded necklaces and footprints establish baby's identity in the nursery.

A complete $\mathrm{x}$-ray and physiotherapy department and a 20-room annex for mental and nervous diseases deserve special mention. Provision has also been made for occupational- and hydrotherapy. A trained instructor is to be employed. A dental room, with a corps of dental surgeons in daily attendance was provided last year.

Miss Helen Murphy of St. Joseph's Hospital is president of the Omaha chapter of the International Guild of Catholic Nurses. Other officers are Miss Mary Sueper of St. Joseph's, vice-president, and Miss Carmelita Kellogg of St. Catherine's Hospital, secretarytreasurer. The chapter, which was formed recently has 65 members. Rev. Bernard Sellmeyer, S. J., of Creighton is spiritual director.

SENIOR CLASS OF $1927-1928$

THE CREIGHTON UNIVERSITY SCHOOL OF MEDICINE

Baldwin, Earle Creighton Henrich, Melvin C. Berens, Sylvester N.

Christie, Joseph W.

Clarke, Edward John

Carnazzo, Sebastin John

Dawson, Terence Thomas

Dunham, Lawrence Hilton

Doyle, J. Lyman

Dill, Francis

Dallal, Joseph M.

Eckrich, Jerome Andrew Finocchiaro, Maynard M. Hale, Albert E.

Hand, Harold M.
Houzvicka, Otto August

Hazlett, Joseph D.

Havlicek, Theo. Leo

Hartendorp, Paul Van H.

Hildinger, Albert Leo.

Holleran, George C.

Keenan, Leo W.

Leisure, Clyde E.

Lenneman, Ernest

Lowe, DeWitt Stratton

Malloy, Ellsworth Francis

Malloy, Floyd James

Maloney, EdwardStephen

Wolf, Clifford Robert
Moran, Clarence S.

McDermott, Alza Stewart McKnelly, William Von McTaggart, Wm. Bernard Murphy, William Keon Neisus, Frank Anthony O'Neill, Raymond Thomas O'Brien, Edward James Pellettiere, E. Victor Plank, Joseph Raymond Robinson, Adrian M.

Rose, Robert William Stuckart, Theodore

Srb, Gilbert J.

constantly under the supervision of the senior and junior councils. These are composed of the Heads of departments of the clinical and laboratory years.

Students are distributed into small groups, each of which is directed by a faculty advisor. It is the latter's duty to check up regularly on the work of his group and report back to the Council. In this way the students' scholastic standing is ever under observa- 
tion, and kept up to the required standard. Both councils have frequent meetings. The chairman of each council makes his report to the entire faculty at their semi annual sessions.

For outpatient calls the city's districts are manned by one or other professor or instructor living in or near said district, whose duty it is to answer the call of the student, when he is sent out on a case. Thus the work of the student is supervised and the health of the patient protected.

GENERAL HOSPITAL NO. 55

In 1922 at the invitation of the Surgeon General, a reserve medical unit was established as Creighton Medical Unit of the organized Reserves. This unit is the 55th General Hospital. It has an officer personnel of 43 , a capacity of 1,000 beds, and an emergency expansion of 2,000 beds, It is a second phase unit, that is, its mobilization is scheduled to be complete 120 days after mobilization day. The medical officers are faculty members and graduates of the Creighton School of Medicine, the dental staff are from the faculty of dentistry, and some of the officers of the reserve medical administrative Corps are graduates of other departments of the University. Reserve Officers are expected to fit themselves by availing themselves of the correspondence courses offered by the Army and attending training camps for a period of two weeks in summer. at Fort Snelling, Fort Omaha and Fort Leavenworth.

Last year seven members of the unit attended training camps.

\section{COTNER UNTVERSITY MEDICAL DEPARTMENT 1890-1918}

After the demise of the old Lincoln Medical College connected with the University of Nebraska, in 1887, Lincoln physicians of the Eclectic school staged another strong battle to establish a medical school in the capital city. Their efforts were recorded by Leon A. Moomaw, M. A., in his "History of Cotner University," published in 1916, as follows:

"Doctors W. S. Latta and R. L. Bentley, a committee from the Nebraska Eclectic Medical Society met with the Board of Trustees May 27, 1889, to discuss the feasibility of establishing a medical department in Cotner University. It was not until the following March, however, that definite 
action was taken. A number of leading Lincoln doctors including W. S. Latta, R. L. Bentley, J. R. Keys, A. I. Root, Wm. McIntyre and J. H. Woodward had formulated a plan which was presented to the trustees. The essential points of their plan were:

1. That the Medical College should be a department of Christian University.

2. That the Medical department should be self-sustaining.

3. The trustees should provide suitable rooms fully equipped for medical work.

4. The university trustees should be given the privilege of removing any professor and should have the authority to elect a successor upon the nomination of the Medical College faculty. This plan was accepted, and the Medical School was opened in the fall of 1890 , in rooms on the fourth floor of the university building. A few years later, having outgrown its original home, the Medical College was moved to Lincoln. At the close of the year 1911 its name was changed from "Lincoln Medical College of Cotner University" to "Cotner University Medical College."

During its early years the Medical College was handicapped because it was an eclectic institution. This was something new to the western medical world and men of the old school opposed it. It was impossible to fill all positions on the faculty with men holding the new view. This caused more or less friction. Jealousy among the medical men has often constituted a disturbing influence. The school has had many "ups and downs," but with all its difficulties, many men of unquestionable character and distinction in the medical world, give this institution credit for making them what they are.

Many changes have been made in length of time required for graduation from the medical school. At the beginning it consisted of a three year course of six months each. The following year the term was increased to seven months, instead of six. Another change was made in 1896, when it became a four year course of six months each. Still there seemed to be need of more time and in 1900, the school year was extended to seven months. Later the professional degree was given only upon completion of satisfactory work for four years of eight months each." 
The school underwent several changes of names during its period of life from 1890, when it was organized as the Cotner University Medical department, until it became extinct in 1918. In 1896, the name was changed to Lincoln Medical College of Cotner University; the original name was restored in 1911 and the name Lincoln Medical College resumed in 1915. The first graduating class was in 1891. Deans were Doctors W. S. Latta, 1889-1902; Jerome M. Keys, 1902-1905; Frank L. Wilmeth, 19061911; Richard argrave Spradling, 1911-1913 and Frank L. Wilmeth, 1914-1918. There were over 275 graduates.

The alumni association of the medical school numbers 249, including physicians practicing in 19 states; one Sanky Bacon in the U. S. Navy; and two in India, Howard R. Murphy, 1912, in Midnapore and Bertha Mangon Thomsen, 1913, in Hahoba. C. C. Drummond, 1896, mentioned in another chapter of this history, also served in India.

Cotner College was named for Samuel V. Cotner of Omaha, who by a generous gift saved the school from being closed in its early days.

\section{NEBRASKA COLLEGE OF MEDICINE OF WESLEYAN UNIVERSITY}

A third attempt to foster a medical school in Lincoln was organized by James Franklin Stevens of Lincoln in 1905, in connection with the Nebraska Wesleyan University, according to Dean F. A. Alabaster. The catalog for the years 1908 and 1909 contained the following statements with reference to it:

"The Nebraska College of Medicine was organized in 1905 under the laws of the State of Nebraska for the purpose of teaching medicine and allied sciences, including dentistry, pharmacy and nursing. At first a Patron College, in the spring of 1907 it was made the Affiliated Medical School of Nebraska Wesleyan University, and hence the medical department of the institution. It offers to a limited number of acceptable students excellent opportunities for the pursuit of medical knowledge, not only in laboratory and research work, but also in didactics and clinics. Owing to the restriction in numbers, students are enabled to receive the personal direction and instruction of the professors, a privilege not always enjoyed in large institutions." 
The period of active affiliation with Wesleyan University covered the collegiate years of 1907-1908 and 1908-1909. A four year course was outlined in the catalog and a medical catalog was published. Thirty-four students were enrolled in 1907-1908 and twentysix students in 1908-1909. Three were graduated in 1908 and nine in 1909 . There were thirty-seven members of the faculty, including the following doctors and Wesleyan professors:

Doctors J. F. Stevens Charles C. Moyer, J. M. McLeod, W. L. Dayton, H. B. Lowry, David C. Hilton, H. B. Miller, J. T. Hay, O. C. Reynolds, E. J. Angle, J. P. Williams, F. A. Graham, F. Eiche, E. L. Holyoke, J. S. Welch, Oliver Everett. Professors Charles Fordyce, Albert T. Bell and B. S. Hopkins. Claude S. Wilson of Lincoln was professor of medical jurisprudence. 


\section{COLLEGES}

\section{Notes and Errata}

pp. 259-260 Keegan, J.J., M.D. A complete bibliography is available in the Library of Medicine, University of Nebraska Medical Center.

p. 260 Charles William M. Poynter named Dean, University of Nebraska College of Medicine in 1929. He was Acting Dean during Dean Cutter's service in World War I.

For discussion of Cutter appointment, see Orr, H. W., Selected Pages from the History of Medicine in Nebraska, Lincoln; Privately printed by Orr, 1952: pp. 101-105.

See Omaha Medical College. Record of the Secretary (of the Board of Trustees), April 13, 1869 to Mar. 9, 1886, inclusive. MS in the Library of Medicine, University of Nebraska Medical Center. Unpaged. See also Hetzner, B. M., "The Development of the Omaha Medical College, 1869-1902," Bull. Med. Library Assn., 47:105-116, Apr. 1959.

pp. $261-266$

See also Omaha Med. Col. Bull., 1882-1901. (Various Publishers).

p. 261

Omaha Medical College history, University of Nebraska College of Medicine history. See Poynter, C. W. M., MS in the Library of Medicine, University of Nebraska Medical Center.

p. 262 Nebraska School of Medicine, Preparatory. For a complete statement, see Record of Secretary, Omaha Medical College MS in the Library of Medicine, University of Nebraska Medical Center.

p. 263 Photograph should read "First Class of Nebraska School of Medicine."

p. 264 Jacob C. Denise: Dean, 1885-1889.

Donald Macrae: Professor of Gynecology, 1882-1885: Professor of Surgery, 1885-1887: Professor of Medicine, 1887-1893: Dean, 1889-1893.

p. 264

The Omaha Medical College building photograph is of the remodeled Omaha Medical College building opened in 1893.

p. 265 Omaha Medical College building "here pictured" refers to the illustration on p. 261. 

the University of Nebraska, MS in the Library of Medicine, University of Nebraska Medical Center.

Dedication of the New Wing of University Hospital (Omaha) in Nov. 1927.

Omaha Medical College moved to 12 th \& Pacific in 1886 . See Sixth Annual Announcement, Omaha Medical College . . . Session 1886-7, p. 5 .

Seventh Annual Announcement, Omaha Medical College . . . Session $1887-8$, p. 12. "The Trustees and faculty have concluded for the present not to admit lady students as matriculants but advise all female applicants to attend a regular female medical school." The Eighth Annual Announcement, 1888-1889, carried the same notice, p. 5 . In the Ninth and Tenth Annual Announcements, 1889-90 and 1890-91, the notice was omitted. The Matriculants, $1887-88,1889-90$, included feminine names. Women are listed as matriculants in all classes according to $\mathrm{OMC}$ Bulletins.

For outcome of bond issue for Douglas County Hospital, see pp. $483-4$.

Omaha Medical College Affiliations:

1885-1887: Medical Department of Nebraska M(ethodist)

E(piscopal) College of Nebraska, York, Nebraska.

1887-1891: Unaffiliated.

1891-1902: Medical Dept. of University of Omaha. The "University" included Bellevue College, Bellevue, Nebraska, as its Arts and Science College, and Omaha Medical College as the Medical Department. Management of the Medical College remained unchanged. A Dental Department was added in the 1895-96 academic year.

View of Univeristy of Nebraska College of Medicine is an architect's conception of the University of Nebraska College of Medicine plan and is not an actual aerial photograph.

p. 270 First Chinese student: Chung Chi Chan, Canton, China.

p. 271

"Dean Robert H. Wolcott of the Lincoln faculty from 1909 to 1913 ..." should read "Dean Robert H. Wolcott of the Lincoln faculty from 1910 to 1914 ..."

"An agreement of affiliation ..." should read ". . . agreement entered into in May 1902 as an integral part of the University. 1902-1904: work of the first and second years taken either at Lincoln or Omaha. All last two years done exclusively in Omaha. After Sept., 1913, all four years in 

Nebraska M.J., 12:406-411, Nov. 1927.

p. 271 University of Nebraska College of Medicine. See Poynter, C.W.M., "A Review." The Pulse, 11:5-11, Jan. 18, 1917.

p. 272

". . . second wing of the Universnty of . .." should read "... second wing of the University of ..."

pp. 273-275: See Keegan, J.J., "The University of Nebraska Hospital at Omaha." Nebraska M.J. . . . op. cit., p. 271.

p. 278

Portrait A. C. Steinberg should read A. C. Steinberg.

p. 288

Jetur Riggs Conkling and Jennie Hanscom Conkling Foundation, established by the will of Clementine C. Conkling. See Univ. Neb. Col. Med. Cat., Aug, 2, 1920, p. 23.

p. 289

Morgulis, Sergius, Fasting and Under-nutrition, New York: E. P. Dutton \& Co., 1923.

p. 290

Morgulis, Sergius, See Who's Who in America, Chicago: The A. N. Marquis Company. London: Stanley Paul \& Co., Ltd., 14:1393, 1926-27.

pp. 290 \& 293 Schulte, Hermann von Wechlinger. A complete bibliography is available in the Creighton University Health Sciences Library.

p. 291

p. 293

Delete line 7. Repeated in line 8.

p. 303

Sachs, Adolph, "Medical Biliary Drainage," Am. J. M. Sc., 167:368-92, Mar. 1924.

Heagey, F. W, "The Cerebellar Manifestations of Epidemic Encephalitis," New York M. J., 116:321-25, Sept. 20,1922.

- "Symptoms of Colonic Disturbances," The J. of Radiol., 5:261-64, Aug. 1924.

- "Epidemic Encephalitis" (including a review of 115 American cases), Nebraska M.J., 9:3-9, Jan. 1921.

- "Epidemic Encephalitis in Relation to Anterior Poliomyelitis," Nebraska M.J., 7:304-312, Sept. 1922. 
- "Relation of Internal Medicine to the General Practice of Medicine," J. Iowa Soc, 17: 233-36, July 1927.

p. 311

Moomaw, L.A., History of Cotner University, including the early religions and educational movement of the Christian Church in Nebraska. Bethany, Nebr., 1916. 


\section{ORGANIZATIONS}

NEBRASKA STATE MEDICAL ASSOCIATION

[Compiler's note: Credit is largely due to Dr. W. F. Milroy for the following data.1

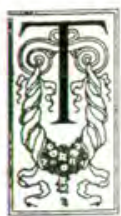

HE first medical organization in the territory of Nebraska was the Nebraska Medical Society, incorporated March 25, 1855, with the following members: George L. Miller, B. T. Shelley, M. H. Clark, Henry Bradford, J. C. Campbell, Joseph Venable, Josiah Crane, Samuel Wilson and James Stokes. They were authorized to establish county and district societies and also to appoint an inspector "to examine and determine the quality and purity of drugs in medicines offered for sale in the territory."

[Compiler's note: So many medical societies-state, district, county and local - have been formed, and so many specialized groups, as well, that it was hard to hit upon a good sequence to follow. For the convenience of the reader, there is here appended an outline of the sequence finally adopted. It was dictated by a somewhat arbitrary judgment of their relative importance.

Nebraska State Medical Association

Omaha-Douglas County

Lincoln-Lancaster County

District Organizations

Missouri Valley

Elkhorn Valley

Loup Valley

Republican Valley

Miscellaneous-state, Lincoln, Omaha, specialty groups and women's auxiliaries.

County societies and registrations.] 
This association evidently did not function any further, for two years later, the legislature chartered another "Nebraska Medical Society," naming as incorporators: Doctors A. Chapel, W. R. Thrall, J. P. Peck, A. McElwee and George L. Miller of Omaha; A. B. Malcom of Florence; John C. Campbell and Aurelius Bowen of Nebraska City; Andrew S. Holliday of Brownsville and E. A. Donelan of Plattsmouth.

These gentlemen evidently realized the magnitude of the task of having an inspector examine all the drugs and medicines offered for sale in Nebraska, for the authority to appoint such an official was not sought nor given by their charter.

There is no further record of the state society activities until February 10, 1868, when, pursuant to a call made by the Omaha Medical Society, delegates from several counties met in the rooms of Dr. James Peabody, 325 South Twelfth Street, on May 11, 1868 to form a state organization. This third attempt to organize was completed at a subsequent meeting, June 24, 1868 and has survived ever since.

The purpose of the society, it was stated, was "to give frequent united and emphatic expression to the views and aims of the medical profession in this state, which must at all times have a beneficial influence and supply more efficient means than have hitherto been available here for cultivating and advancing medical knowledge, for elevating the standard of medical education, for promoting the usefulness, honor and interests of the medical profession, for enlightening and directing public opinion in regard to the duties, responsibilities and requirements of medical men; for exciting and encouraging emulation and concert of action in the profession and for fostering friendly intercourse between those who are engaged in it."

This foreword practically forecast the society's activities up to the present time, a period of more than 60 years.

Three classes of membership were established: delegates, members by invitation and permanent members. The time for the annual meetings was set for the first Tuesday in June. A code of ethics was also adopted. 
Charter members of the society included Gilbert C. Monell, who was elected the first president; Robert R. Livingston of Plattsmouth, Cass County, vice-president; Napoleon B. Larsh of Otoe County, second vice-president; S. D. Mercer of Omaha, secretary; Jacob C. Denise of Omaha, corresponding secretary; Daniel Whittinger of Otoe County, treasurer; H. P. Mathewson and James Peabody of Omaha; J. P. Andrews of Fort Calhoun and August Roeder of Washington County. An old record of 1882 quotes the names of "W. B. Lamb," and "Preder of Hastings," probably Roeder.

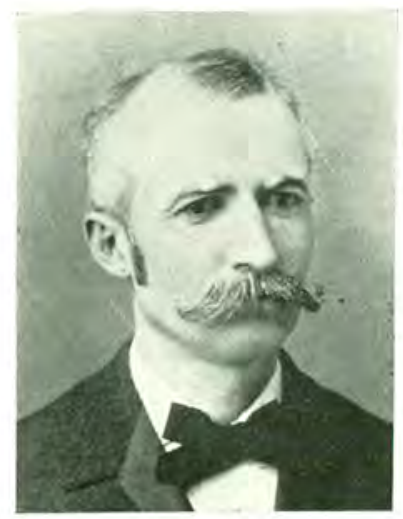

M. L. HILDRETH

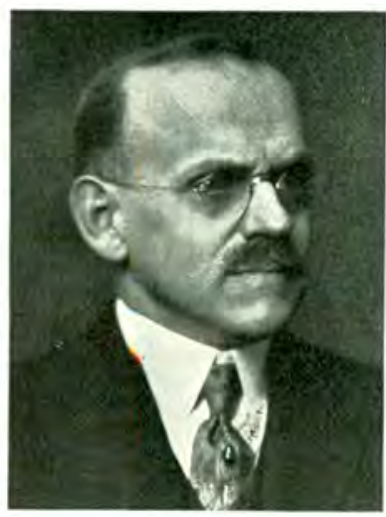

E. W. ROWE

The first annual convention after the state society was formally organized, was held in Nebraska City, June 1 and 2, 1869, when interesting reports were made by the sections on surgery, anatomy, physiology and materia medica. James H. Peabody of Omaha was named president to succeed Monell; N. B. Larsh and F. Renner, vice-presidents; and D. F. Hershey, treasurer. There was no change in secretaries.

Omaha was the meeting place for the second annual convention June 7 and 8, 1870 when N. B. Larsh of Nebraska City became president; John Black of Plattsmouth and L. H. Robbins of Lincoln, vice-presidents; and H. P. Mathewson, treasurer. Resolutions of highest respect were adopted on the death of Augustus Roeder, pioneer physician and grandfather of Clyde A. Roeder of Omaha. Dr. Peabody was also named the first delegate from $\mathrm{Ne}-$ 
braska to the American Medical Association convention held in Washington, D. C., that year.

R. R. Livingston of Plattsmouth was elected president at the third session held in Lincoln in 1871. A. Bowen of Nebraska City and V. H. Coffman of Omaha were named vice-presidents; and George Tilden of Omaha, corresponding secretary. The fourth session was held in Plattsmouth in 1872 when the retiring president gave a lengthy address on "The Medical Profession." Bowen then succeeded to the presidency; William McClelland of Omaha and L. J. Abbott of Fremont were named vice-presidents; and V. H. Coffman, secretary.

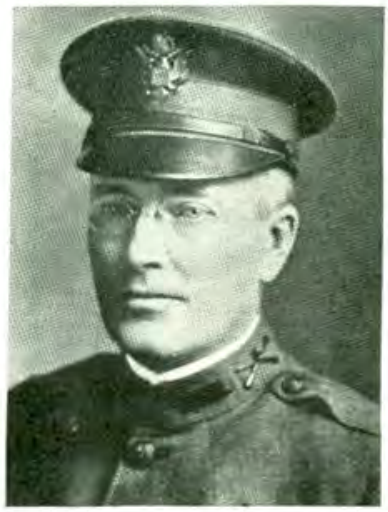

M. S. MOORE

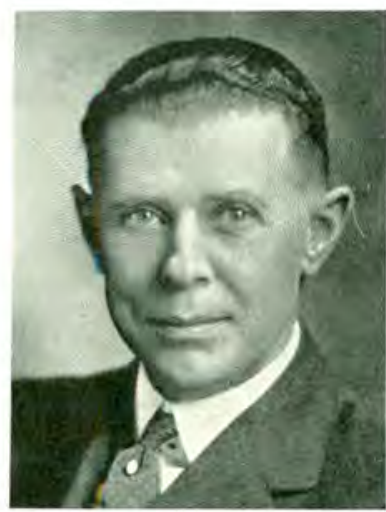

MORRIS NEILSEN

On June 3 and 4, 1873, the society convened for the the fifth time in Nebraska City. H. P. Mathewson was named president; D. W. Hershey and F. G. Fuller, vice-presidents; R. R. Livingston, corresponding secretary and James $\mathrm{H}$. Peabody, treasurer.

At the sixth session in Omaha, June 2 and 3, 1874, John Black was elected president; William English and Harvey Link of Millard, vice-presidents; F. G. Fuller, permanent secretary. At the seventh meeting in Plattsmouth, June 1 and 2, 1875, L. H. Robbins was named president; E. Van Buren and George Tilden, vice-presidents and $\mathrm{A}$. Bowen, treasurer.

For some reason, the eighth annual session was not held until September 26 and 27, 1876, in Lincoln. J. P. Peck of Omaha was 
elected president; A. Woolsey and H. D. Gilbert, vice-presidents and L. H. Robbins, treasurer. Offices not mentioned above were retained by their former incumbents.

The ninth session was held in Omaha; the tenth in Fremont and the eleventh in Nebraska City. At the first of these meetings, L. J. Abbott of Fremont was named president; E. M. Whitten and Harvey Link, vice-presidents. In 1878 , E. M. Whitten was promoted to the presidency: Alexander Bear of Norfolk and M. W. Stone were vice-presidents; A. S. von Mansfelde of Ashland, recording secretary and R. C. Moore of Omaha, treasurer. In 1879, Harvey Link was

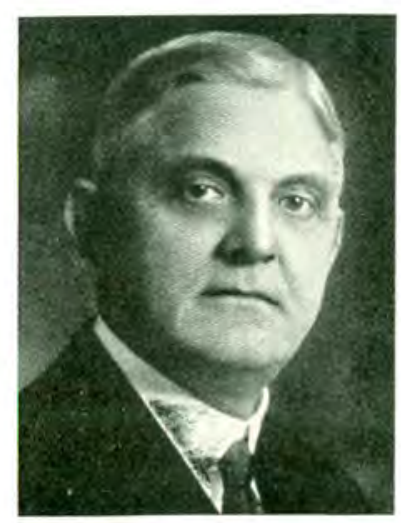

H. E. POTTER

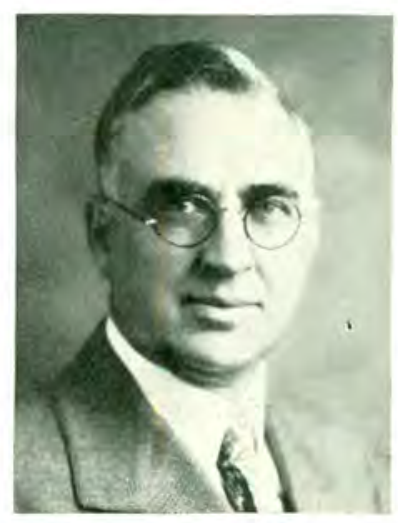

B. R. M'GRATH

president; F. G. Fuller succeeding Alexander Bear as first vice-president.

The 12th regular convention was held in Kearney, June 1 and 2, 1880. Resolutions of respect were passed upon the deaths of William E. Donelan and Enos Lowe of Omaha, both identified with the early settlement of Nebraska; and upon that of D. H. O'Linn, a younger practitioner and one of the finest surgeons in the state. S. D. Mercer of Omaha was elected president; W. M. Knapp and F. B. Reed, vice-presidents.

The 13th annual meeting at Norfolk, June 7 and 8, 1881, elected M. W. Stone of Wahoo, president; A. H. Sowers of Hastings, first vice-president; A. H. Jackson of Cincinnati, second vice-president; A. S. von Mansfelde of Ashland, recording secretary; R. R. 
Livingston of Plattsmouth, corresponding secretary and R. C. Moore of Omaha, treasurer. These constituted the board for 1881 and 1882 .

During the decade of the ' 80 s the population of Nebraska and the number of practicing physicians grew by leaps and bounds and the state was flooded by practitioners, many of whom were said to be poorly or inadequately trained in the profession. "Regulars" in the state association agitated and succeeded in passing the law of 1881 , requiring each one to register. This was followed by other legislation and finally the establishment of the state board of health,

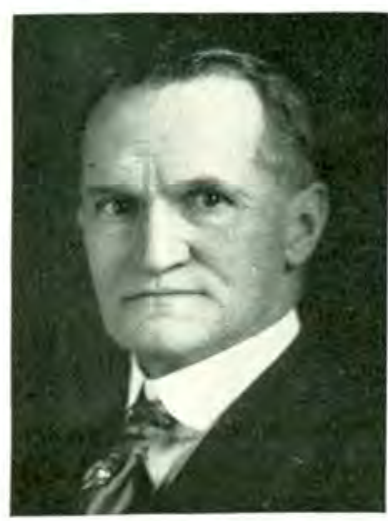

F. S. OWEN

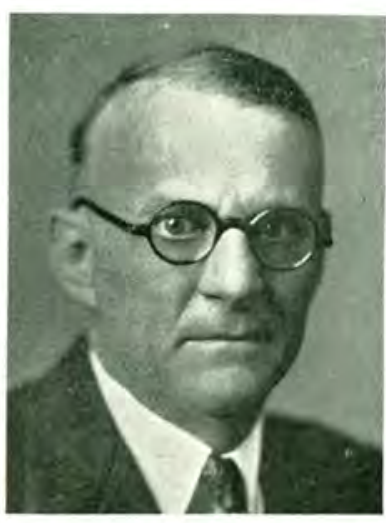

R. B. ADAMS

in 1891 to regulate the licensing. These activities, which will be discussed further in the chapter dealing with the political life of Nebraska physicians, brought into existence a new organization, the Nebraska State Medical League, a separate adjunct of the state society, whose main function was to lobby for medical legislation. This organization, and the medico-legal defense committee which succeeded it and now handles all proposed medical legislation, will also be treated in another section.

To continue with the list of state meetings and officers, at the 1883 session in Lincoln, A. H. Sowers of that city was named president; W. M. Knapp, C. T. Dildine, A. S. von Mansfelde, A. R. Mitchell and R. C. Moore, the other officers. Victor Coffman headed the set of officers elected in 1884, in Omaha. They included G. W. Johnson, E. Van Buren, von Mansfelde, Livingston and Moore. 
The next year at Grand Island, F. G. Fuller, G. H. Peebles, M. J. Gahan, and the trio, von Mansfelde, Livingston and Moore were named. At Lincoln in 1866, W. M. Knapp, James Carter, N. F, Donaldson and "the trio" were elected. In 1887, R. C. Moore of Omaha who had been treasurer for nine years, was elected president and the retiring president took over the treasurership. Milton Lane, N. F. Donaldson, von Mansfelde and H. B. Lowry were the other officers. The next year, when G. H. Peebles was named president at a Lincoln meeting, marked the only time a woman was elected to the office of first vice-president. She was Mary R. Butin. C. O. Reynolds, von Mansfelde, L. A. Merriam and Knapp, who continued as treasurer for the next ten years, were the other officers. Milton Lane, O. C. Reynolds and M. L. Hildreth were the 1889 officers, elected at Kearney. The opening of the ' 90 s found J. C. Denise president, elected at a Beatrice meeting. His colleagues were D. A. Walden, G. L. Humphreys and M. L. Hildreth. For the ensuing years, the natural succession of vice-presidents to the office of president was instituted so the complete list of officers will no longer be here set down but the presidents' names will be found in the following complete list of presidents of the Nebraska State Medical Association:

1868 Gilbert C. Monell. Omaha 1869 James H. Peabody, Omaha 1870 N. B. Larsh, Nebraska City 1871 R. R. Livingston, Plattsmouth 1872 Aurelius Bowen, Nebraska City 1873 H. P. Mathewson. Omaha 1874 John Black, Plattsmouth 1875 L. H. Robbins, Lincoln 1876 J. P. Peck, Onaha 1877 L. J. Abbott, Fremont 1878 R. M. Whitten, Nebraska City 1879 Harvey Link, Millard 1880 S. D. Mercer, Omaha 1881 M. W. Stone, South Omaha 1882 A. H. Sowers, Lincoln 1883 Victor H. Coffman, Omaha 1884 F. G. Fuller, Grand Island 1885 W. W. Knapp, Lincoln 1886 Richard C. Moore, Omaha 1887 George H. Peebles, Lincoln 1888 Milton Lane, Kearney 1889 J. C. Denise, Omaha
1800 D, A. Walden, Beatrice 1891 Charles Inches, Scribner 1892 M. L. Hildreth, Lyons 1893 A. S. von Mansfelde, Ashland 1894 H. B. Lowry, Lincoln 1895 J. E. Summers, Jr., Omaha 1896 F. D. Haldeman, Ord. 1897 Willson O. Bridges, Omaha 1898 A. R. Mitchell, Lincoln 1899 Robert McConaughy, York 1900 H. M. McClanahan, Omaha 1901 William B. Ely, Ainsworth 1902 A. B. Anderson, Pawnee City 1903 B. F. Crummer, Omaha 1904 R. C. McDonald, Fremont 1905 A. F. Jonas, Ornaha 1906 F. A. Long, Madison 1907 Harold Gifford, Omaha 1908 L. M. Shaw, Osceola 1909 P. H. Salter, Norfolk 1910 J. P. Lord, Omaha 1911 A. D. Nesbit, Tekamah 
1912 I. H. Pickett, Odell

1913 D. C. Bryant, Omaha

1914 J. P. Gilligan, O’Neill

1915 E. W. Rowe, Lincoln

1916 W. F. Milroy, Omaha

1917-8 C. L. Mullins, Broken Bow

1919 J. M. Banister, Omaha

1920 H. W. Orr, Lincoln
1921 M. S. Moore, Gothenburg

1922 B. B. Davis, Omaha

1923 B. F. Bailey, Lincoln

1924 Morris Nielsen, Blair

1925 Palmer Findley, Omaha

1926 H. J. Lehnhoff, Lincoln

1927 H. E. Potter, Fairbury

1928 Benj. R. McGrath, Grand Island. 1929 F. S. Owen, Omaha.

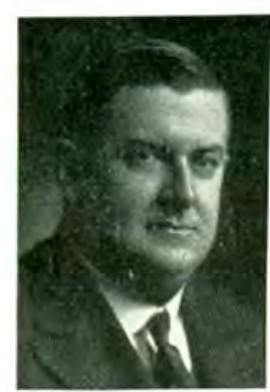

W. P. WHERRY

William P. Wherry of Omaha served as librarian for the state society for the 20-year period between 1906 and 1926. He is also past president of the Omaha-Douglas County Medical Association and head of the Evangelical Covenant Hospital staff.

B. R. McGrath of Grand Island was the 1928 president of the Nebraska State Medical Association, succeeding Harry E. Potter of Fairbury. C. A. Selby of North Platte and A. P. Overgaard of Omaha, vice-presidents, and R. B. Adams of Lincoln, secretary-treasurer. The committee on Journal publication includes F. A. Long of Madison, W. O. Bridges, Omaha; B. F. Bailey, Lincoln and R. B. Adams.

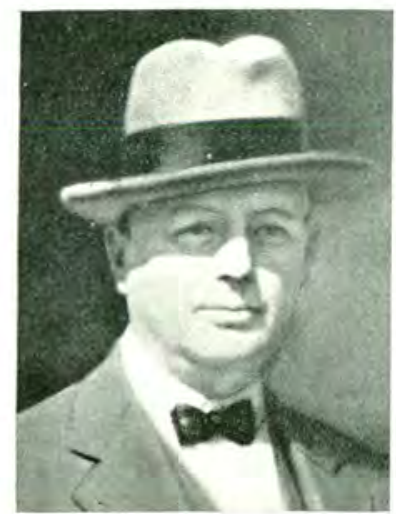

J. P. GILligAN, SR.

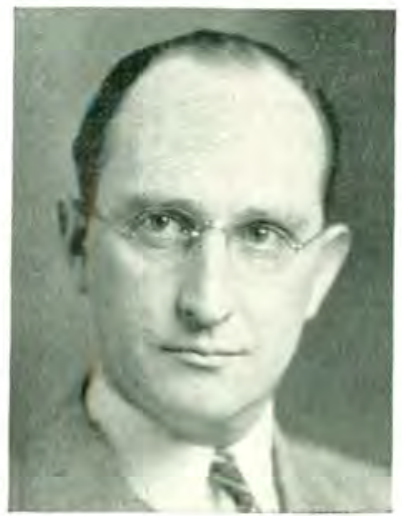

J, P. GILLIGAN, JR.

John P. Gilligan of O'Neill is one of the pioneer physicians of the state. He has always been active in medical association work, 
being president of the Nebraska State Medical Association in 1914. His interest in politics is shown by his service as state senator in 1905. His son is also a physician and is practicing at Nebraska City.

F. S. Owen of Omaha was elected president of the Nebraska State Medical Association, at the 1928 meeting held in Hastings. Vice-presidents were W. R. Boyer, Pawnee City; E. L. Brush, Norfolk; councillors, F. Tornholm, Wahoo; Morris Nielsen, Blair; H. E. Potter, Fairbury; W. J. Douglas, Atkinson; delegate to the American Medical Association, R. W. Fouts, Omaha, and alternate, J. M. Mayhew of Lincoln.

\section{OMAHA-DOUGLAS COUNTY MEDICAL SOCIETY}

\section{Merger of Omaha Medical Society, Douglas County Medical Society, Omaha Medicai Club and Academy of Medicine.}

The first two gatherings of physicians in Omaha, one in 1855 and another in 1857, were really not local in character, since they included physicians from points outside the metropolis. Indeed the two organizations then formed were known as the Nebraska Medical Society. Record of the very first meeting of Omaha practitioners exclusively, therefore, dates back to about 1857 or 1858 when a conference was held to adopt a fee bill for mutual protection. A local organization was not contemplated however until June 14, 1866, when the close of the war and the activity in connection with the building of the Union Pacific bridge attracted a large number of physicians to the new country, just opening up.

Dr. Enos Lowe was chairman of this preliminary meeting and Dr. I. N. Rippey was secretary. The following preamble and resolution was adopted:

"Whereas, the regular practitioners of medicine in the City of Omaha, Nebraska, feel the importance of some organization for the advancement and promotion of medical science, as well as for the mutual protection and welfare of its members; be it

"Resolved, that we, the undersigned, do agree to form among ourselves (and the regular practitioners of medicine who may from time to time be admitted) - an association to be known as the Omaha Medical Society, of Omaha." 
Formal organization of the Omaha Medical Society was completed later in the summer, August 1, 1866, to be exact, when a constitution prepared to meet every emergency for the next fifty years, was adopted. The members numbered thirteen including L. F. Babcock, J. R. Conkling, E. H. Den, Enos Lowe, William McClelland, Samuel D. Mercer, G. C. Monell, R. C. Moore, James H. Peabody, James P. Peck, C. H. Pinney, I. N. Rippey and Augustus Roeder. Some lists omit the name of Pinney, but he was a resident of Omaha and coroner the next year so he undoubtedly was included.

Election of officers did not take place until November 12, 1866, when Dr. Peck was named president; Roeder, vice-president; Rippey, secretary; and Peabody, treasurer.

A list of members of the Omaha Medical Society in 1869, three years later, includes the names of Theodore Baumer, Victor $\mathrm{H}$. Coffman, J. C. Denise, W. B. W. Gardner, J. La Barie or Labree, H. P. Mathewson, C. H. Pinney, E. C. Strangland and George Tilden (see frame on Nebraska University Library wall) and the following honorary members: J. P. Andrews of Fort Calhoun; James Black of Plattsmouth; Cyrus Bass of North Bend; S. A. Bonesteel of Columbus; George Miller of Omaha (who had retired from the profession to go into newspaper and political life) and R. R. Livingston of Plattsmouth. E. H. Den, who was a charter member in 1866, was not included in this list. William Eddy, H. R. Benjamin, M. T. Anderson and H. P. Jensen are the next group whose names appear in medical records of the '70s.

The next record of the Omaha Medical Society after the election of officers in November, 1866, was December 17, 1866, when a very comprehensive fee bill was adopted, not only setting forth the prices to be charged for ordinary professional services, but also naming the remuneration for various simple surgical operations and the treatment of venereal diseases. No mention was made of capital operations, such as abdominal sections, which were then unknown.

This action was an important factor in binding together the profession for mutual protection, for the fee bill really established the basis for pay in those days, and was accepted by both regular and irregular physicians. 
A copy of the fee bill, printed in 1871, was preserved by Mrs. Victor H. Coffman, who loaned it for reproduction herewith. Fortunately enough, when Mrs. Coffman's home was practically destroyed during the Omaha tornado of 1913, this old document and photographs of Dr. Coffman were miraculously preserved from destruction. A comparison of the fees of those early days, with what is charged today, reveals interesting changes in standards. Some fees, such as that for life insurance examination, are the same, even though more than 50 years have elapsed.

Following is a reprint of the fee bill and list of members of the Omaha Medical Society in 1871 .

"Anderson, M. T.

Baumer, Theodore

Benjamin, H. R.

Coffman, V. H.

Conkling, J. R.

Denise, J. C.

Gardner, W. B. W.

Lowe, Enos

Livingston, R. R., Plattsmouth

\section{Honorary Wembers}

Andrews, J. P., Fort Calhoun

Black, James, Plattsmouth

Bass, Cyrus, North Bend

Bonesteel, S. A., Columbus

Miller, G. F., Omaha
Moore, R. C.

Mathewson, H. P.

McClelland, Wm.

Mercer, S. D.

Monell, G. C.

Peck J. P.

Pinney, C. H.

Tilden, George

Whereas, The Omaha Medical Society feeling the importance of a perfect uniformity in the prices for professional services, in order to avoid litigation and other difficulties, deem it important and proper that there should be a mutual understanding upon the subject;

Therefore, we, the members of said society do solemnly agree that we will hereafter be governed by the following bill of charges for professional services, as far as it is practicable:

Office prescription and advice, (ordinary)

Officers in 1871

Victor H. Coffman, President

Theodore Baumer, Vice-President

H. R. Benjamin, Recording Secretary

R. C. Moore, Corresponding Secretary

C. H. Pinney, Treasurer

For ordinary visit within the city limits

$\$ 1.00$ to $\$ 3.00$

Visit to country, per mile, additional,

Night visit to country, per mile additional...

Visit to Steamboat

Night visit to Steamboat.

Night visit from 9 P. M. to 6 A. M. within city.

Consultation within city 
Consultation within city at night

10.00

Subsequent joint attendance with attending Physicians.

Obstetrical fee, ordinary case of not over six hours...

3.00

For each hour's attendance over six hours $\quad 1.00$

Cases requiring turning or forceps (additional)

20.00 to 30.00

Embryotomy (additional

25.00 to 50.00

Caesarian section (additional)

50.00 to 100.00

For delivering retained Placenta $\quad 10.00$

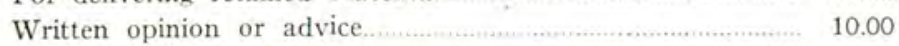

Services or opinion involving questions of law, or attendance at court

$\begin{array}{lr}\text { Opinion upon life insurance } & 5.00 \\ \text { Signing medical certificate in case of insanity } & 10.00\end{array}$

$\begin{array}{lr}\text { Signing medical certificate in case of insanity } & \\ \text { Venesection } & \end{array}$

Cupping or leaching, each application $\quad 3.00$

Vaccination, first case $\quad 3.00$

Each additional case at same time and place $\quad 1.00$

Gonorrhoea, first prescription, in advance …................. 10.00

Stricture operation, in advance

25.00 to 100.00

20.00

10.00 to 100.00

Cases of sudden poisoning

$\begin{array}{ll}\text { Each introduction of catheter or bougie } & 5.00 \\ \text { Each introduction of seton or issue } & 5.00\end{array}$

Physical examination of chest or uterus $5.00 \mathrm{t}$

10.00

$\begin{array}{llr}\text { Administration of Anaesthetics } \ldots x & 5.00 \text { to } & 10.00 \\ \text { Post-mortem examinations } & 25.00 \text { to } & 50.00\end{array}$

Chemico-legal post-mortem examinations $\quad 100,00$

Additional charges may be discretionally made for night traveling in inclement weather, or over bad roads; also, in cases involving risk to the Physicians, as in infectious, or contagious diseases; in the examination of putrid subjects, and especially in the following diseases: Malignant Cholera, Malignant Erysipelas, Malignant Puerperal Fever, Malignant Scarlatina, Malignant Rubeola, etc.

In Variola and Varioloid, double ordinary charges.

Extra fee for advice in cases involving extreme solicitude, responsibility, attention and skill, as in the following:

Cases of Uterine or other Hemorrhage dangerous to life.......\$10.00 to $\$ 50.00$

Cases of threatened abortion ........................ 100 to 30.00

Acute or Chronic Ophthalmia, threatening loss of vision........ 10.00 to $\quad 50.00$

Cases of Malignant disease or Cancer, etc. $\quad 10.00$ to 50.00

Cases of Chronic Cutaneous diseases................................... 10.00 to 50.00

Cases of Chronic Constitutional diseases, as Scrofula,

Syphilis, etc.

20.00 to 100.00

For reduction of Fractures 20.00 to 100.00

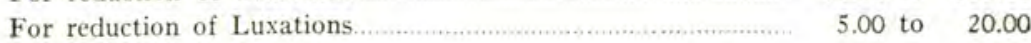


For reduction of Hernia by Taxis

$\begin{array}{rr}15.00 \text { to } & 50.00 \\ 10.00 \text { to } & 25.00 \\ 100.00 \text { to } & 500.00 \\ 25.00 \text { to } & 50.00 \\ 50.00 \text { to } & 100.00 \\ 100.00 \text { to } & 200.00 \\ 50.00 \text { to } & 150.00 \\ 25.00 \text { to } & 75.00 \\ 5.00 \text { to } & 20.00 \\ 25.00 \text { to } & 200.00 \\ 10.00 \text { to } & 30.00 \\ 25.00 \text { to } & 100.00 \\ 25.00 \text { to } & 100.00 \\ 10.00 \text { to } & 25.00 \\ 5.00 \text { to } & 10.00 \\ 2.00 \text { to } & 5.00 \\ 5.00 \text { to } & 10.00 \\ 3.00 \text { to } & 5.00 \\ 3.00 \text { to } & 5.00 \\ 3.00 \text { to } & 10.00 \\ 50.00 \text { to } & 200.00 \\ 50.00 \text { to } & 100.00 \\ 25.00 \text { to } & 200.00\end{array}$

For reduction of Prolapsed Anus or Uterus

For removing stone from bladder

For amputation of arm or forearm

For amputation at Shoulder joint

For amputation at hip joint.

For amputation of thigh

For amputation of leg or foot

For amputation of finger or toe

Extirpation of large and complicated Tumors ...........................

Extirpation of other tumors

Extirpation of Mamma

Extirpation of Testicles

Extirpation of Tonsils

Extirpation of Uvula

For Scarification of the Gums

For Scarification of the Tonsils

.

For Scarification of the Conjunctiva

For Dividing Fraenum Linguae

For Cauterization of the Fauces, Larynx, etc.

Operation for Cataract

Operation for Strabismus

Operation for Ligature of Arteries

100.00 to 500.00

Aneurysm.

100.00 to 500.00

Operation for Strangulated Hernia

25.00 to 75.00

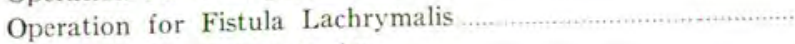

Operation for Fistula in Ano

Operation for Hemorrhoids

25.00 to $\quad 75.00$

20.00 to 50.00

50.00 to 15000

Operation for Imperforate Anus

50.00 to 200.00

Operation for Imperforate Urethra

10.00 to 20.00

Operation of Tapping Hydrocele

Operating for Phymosis and Paraphymosis ..........................

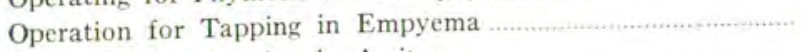

Operating for Tapping in Ascites

20.00 to 30.00

20.00 to 60.00

20.00 to $\quad 50.00$

25.00 to 75.00

Operation for Club Foot, single

50.00 to 150.00

Operation for Club Foot, double

25.00 to

75.00 to

Operation for Cleft Palate

Operation for Trephining

50.00 to

100.00

150.00

100.00

50.00 to 100.00

50.00 to 100.00

25.00 to 75.00

Operation for Recto-Vaginal Fistula

25.00 to 100.00

20.00 to 100.00

Operation for Stricture Esophagus Rectum, etc.

Operation for removal of Sequestra.

100.00 to 150.00

Operation for removal of Inferior Maxillary.

200.00 to 500.00

Operation for removal of Superior Maxillary. 
Plastic Operations

50.00 to 200.00

For opening Abscesses

2.00 to $\quad 50.00$

For Tracheotomy

50.00 to 100.00

For Puncture of the Bladder 25.00 to 100.00

Excision of Joints 25.00 to 250.00

For dressing wounds, Ulcers, etc. 2.00 to $\quad 10.00$

For Extracting Foreign Bodies from Ear, Nose, Eye Throat,

Urethra and Gun Shot Wounds

5.00 to 50.00

For Ophthalmoscopic Examinations

10.00 to 30.00

For Laryngeal Examinations

10.00 to 30.00

All Subsequent Attendance in Surgical cases to be charged at usual rates.

\section{Annual Contracts}

Resolved, That the members of this society agree not to attend families or individuals by annual contract.

\section{To Regulate the Collection of Bills}

All medical bills being due at the time the services are rendered, and it being the custom in the city to settle all accounts monthly; therefore,

Resolved, That we, the members of this society adopt and adhere to the Rule of Monthly Collections.

\section{Black List}

Whereas, Many persons are in the habit of employing a Physician until he presents his bill for payment, then discharging him, and calling another; thus going the rounds of the profession, without ever paying or making an effort to pay their bills; therefore,

Resolved, That we, the members of this Society, adopt a Black List, wherein the name, number and street of every such person shall be kept, the preliminaries of which shall be hereafter regulated, and that we decline to render service, until they pay their previous attending Physician or Physicians.

Approved and adopted March 28, 1871.

\section{V.H. Coffman, President.}

H. R. Benjamin, Recording Secretary,"

At a meeting February 10, 1868, preliminary steps were taken to again organize a state medical society which was perfected the following June. This association, still flourishing, has held annual meetings since and ranks with the best in the Union. Its history is given in another section. A special meeting was held February 12, 1868 to take measures for procuring the body of Ottway G. Baker, who was to be hanged for murder, February 14. A committee was appointed to petition the judge for the purpose. On February 24, the committee made a lengthy report, stating that the judge had at 
first acceded to the request and then revoked the order, when Baker's spiritual advisor, a Catholic priest, objected. The society condemned the action of the judge, who thus denied to science an opportunity to investigate an important matter. The priest, Father Egan, was also criticized. March 9, 1868, the society voted $\$ 25.00$ to defray expenses of acquiring a certain skeleton. What connection this action may have had with the removal of the body of Baker, which the society claimed, or the bones of some other individual, there is nothing in the records of the society to indicate.

Meetings of the Omaha Medical Society were held with regularity and the scientific work accomplished was quite commendable up to about 1876 or 1877 , when, through internal dissension and the withdrawal of more active members, it became practically moribund and finally expired about 1881. The last meeting was held July 18, 1881; and another attempt was made toward a meeting, September 5, 1881, but no quorum could be assembled.

In this interval, two new organizations sprang up, functioned for several years, but were probably abandoned when the Douglas County Medical Society was organized in 1883. These two were the Omaha Pathological and Sanitary Society, formed in 1876 by Doctors H. P. Mathewson, A. A. Parker, Victor Coffman, William McClelland,R. C. Moore and William Arnold. The second was the Academy of Medicine and Surgery, organized October 22, 1881. Membership included Doctors L. A. Merriam, Joseph Neville, L. B. Graddy, Paul Grossman, H. W. Hyde and R. M. Stone.

This period of schism continued for nearly two years more until the need for a strong, united organization again manifested itself.

\section{Douglas County Society Formed}

On the evening of April 11, 1883, Drs. James Carter, J. M. Swetman, J. B. Ralph and George B, Ayres met in the parlors of the Creighton House, for the purpose of organizing a Douglas County medical society. A committee was appointed to publish a call to all county physicians to meet for the above purpose. Twentyeight responded to the call, met in the Millard Hotel, April 18, 1883, and the organization was perfected with the following officers: president, Harvey Link of Millard; first vice-president, J. M. Swet- 
man; second vice-president, J. H. Peabody; secretary. James Carter; treasurer, L. B. Graddy; board of censors, G. B. Ayres, J. B. Ralph, L. A. Merriam, R. C. Moore and A. A. Parker.

Charter members, in addition, were: V. H. Coffman, Ewing Brown, O. S. Wood, S. K. Spaulding, L. F. McKenna, P. S. Leisenring, R. W. Colville, W. O. Bridges, Paul Grossman, S. D. Mercer, Joseph W. Search, W. S. Gibbs, Harry Durham, M. A. Rebert, H. P. Jensen, J. C. Denise and J. M. Woodburn.

For almost three years, meetings were held semi-monthly or monthly and valuable papers were read. In the spring of 1884 , the Nebraska State Medical Society held its annual meeting in Omaha and was entertained at a banquet by the Douglas County society, the sum of $\$ 360$ being collected for the purpose.

Officers of the county society in 1884 were: President, J. H. Peabody; vice-presidents, G. B. Ayres and Georgia A. Arbuckle; secretary, James Carter; treasurer, M. A. Rebert: censors, W. O. Bridges, L. A. Merriam, S. K. Spaulding, L. B. Graddy, J. M. Swetman.

In 1885 the officers were James Carter, president; J. B. Ralph and W. P. Wilcox, vice-presidents; W. O. Bridges, secretary; M. A. Rebert, treasurer; L. A. Merriam, L. B. Graddy, J. M. Swetman, W. O. Bridges and E. E. Womersley, censors, In 1886, R. C. Moore was chosen president; E. E. Womersley, first vice-president; Eleanor S. Dailey, second vice-president; E. A. Kelly, secretary; L. A. Merriam, treasurer; and the board of censors, J. M. Swetman, James Carter, L. B. Graddy, M. A. Rebert and E, A. Kelly.

During the early part of 1886 , attendance began to dwindle. Some withdrew, having taken offense at remarks during the discussion of papers. Many of the older practitioners had allowed their business affairs to interfere with their duties in the society and were rarely present. So little interest was shown that at the meeting of May 4, 1886, at which the above officers were elected, a motion was carried that "when we adjourn, we adjourn sine die." Nevertheless, meetings were held from time to time and a strong effort was made in the fall to revive the organization.

The greatest obstacle was that they could not drop a large number of inactive members, or those in name only, because the 
constitution required the vote of a larger number of members than they could assemble at that time, at one meeting. Several vain efforts were made to reorganize until the final meeting was held March 1, 1887, "at which time no essayist responded to the call" and the Douglas County society died out.

Two rival societies again arose. The first of these was the Omaha Medical Club, made up chiefly of the newcomers to the city, and organized in the office of A. F. Jonas, January 4, 1888. Its chief characteristic was its simplicity. During the first year it had no constitution or by-laws. It was mutually agreed that it existed for scientific work solely and the discussion of personal differences and of all questions of medical ethics was prohibited. Membership was open to any reputable graduate of a "regular" medical college but no one was regarded as a full-fledged member until he had read a paper before the club. Meetings were held at the office of the essayist, who also presided, semi-monthly. A quorum of at least several always responded, and only once, did an essayist fail to do his part. Following are those who joined the first year: A. F. Jonas, R. M. Stone, J. E. Summers, Jr., Harold Gifford, S. R. Towne, A. B. Somers, T. W. Hyde, W. F. Milroy, L. A. Merriam, W. L. Ross, Eleanor Dailey, B. F. Crummer, C. M. C. Biart, Mary Strong, James Carter, Robert Gilmore and L. B. Graddy.

At the end of the first year, the members decided to formulate into writing, the hitherto unwritten rules of the club and 23 were drafted. These rules specified that failure to provide a paper at one's turn, or absence from four consecutive meetings would terminate one's membership. Sickness or absence from the city alone excused non-attendance. Candidates for membership were required to have lived in the city for one year, unless a full-fledged member could vouch for his good character, and two negative ballots could exclude from membership.

Papers were, as a rule, meritorious, and the discussions spirited and interesting. At the end of the second year, January, 1890, a banquet was given at the Murray Hotel. The following were additional members: Clark Gapen, H, C. Van Gieson, W. H. Slabaugh, M. Helfritz Jonas (first wife of Dr. A. F. Jonas); J. P. Lord, A. W. Riley, W. H. Christie and J. F. Presnell. 
Conditions surrounding the Omaha Medical Club were not favorable to ever securing a large membership, nor was this the design of originators. Owing to these facts and possibly to a healthy spirit of rivalry, a new society appeared in the field, early in 1888 . This was the Omaha Academy of Medicine, patterned after the New York Academy of Medicine, and including most of the later Creighton College group. It was organized in May with these officers: president, D. C. Bryant; first vice-president, George B. Ayres; second vice-president, James H. Peabody; secretary, C. P. Harrigan; treasurer, Ewing Brown; board of trustees, John O. Jones, A. P. Ginn, W. F. Milroy, J. P. Lord and Charles Rosewater. Membership was limited to 30 . Besides the officers, it included B. F. Crummer, A. W. Edmiston, Wm. H. Galbraith, Oscar Hoffman, M. A. Hughes, H. P. Jensen, P. S. Keogh, W. G. Kemper, R. C. Moore, L. F. McKenna, H. M. McClanahan, A. A. Parker, J. B. Ralph, George Tilden, W. C. Reeves, J. E. Summers, Jr., H. G. Van Gieson, J. H. Vance and E. E. Womersley.

The Academy struggled along for a year with seldom a quorum of ten present at its semi-monthly meetings, until finally it too died.

Even prior to the organization of these last two societies in 1888, a feeling existed that there should be in Omaha an organization to include all reputable practitioners in the city. These latter two societies did not fill the need as they were alleged to be too exclusive. The desired organization was one which should first, give tone and standing to individual practitioners; second, promote harmony and community of interest in the profession and discourage rivalries; third, to enforce existing laws relating to the practice of medicine and improve them, where deficient; and fourth, and most important of all, to stimulate the scientific work of the members.

This feeling continued to gain ground, despite the two new organizations until March 18, 1890, when 65 of the leading physicians, representing both factions, met in the Paxton Hotel, in response to a post card invitation and effected a temporary organization by the election of B. F. Crummer, president and Charles Rosewater, secretary. A committee was named to draft a constitution and to report one week later. April 1, the committee reported, the Omaha Medical Society organization was effected and the following officers elected: president, W. F. Milroy; first vice-president, B. F. 
Crummer; second vice-president, August F. Jonas; secretary, Charles Rosewater; treasurer, S. K. Spaulding; board of censors, D. C. Bryant, W. H. Christie and J. P. Lord.

This organization was the direct fore-runner of the present Omaha-Douglas County Medical Society, which name it took in February, 1903.

The members were DeWitt C. Bryant, C. M. G. Biart, Bennett C. Anderson, Frederick Bacon, W. O. Bridges, H. L. Burrell, Benjamin F. Crummer, E. W. Chase, Howard Cook, W. H. Christie, J. C. Denise, A. W. Edmiston, Harold G. Gifford, Clark Gapen, Robert Gilmore, W. S. Gibbs, C. P. Harrigan, H. P. Hamilton, H. P. Jensen, A. F. Jonas, his wife, Metha Helfritz Jonas: John C. Jones, L. J. Kohenstamm, P. S. Leisenring, J. P. Lord, W. F. Milroy, L. A. Merriam, Joseph Neville, A. A. Parker, Alfred Raymond, M. A. Rebert, M. O. Ricketts, A. W. Riley, Charles Rosewater, A. B. Somers, S. K. Spaulding, J. E. Summers, Jr., S. R. Towne, H. C. Van Gieson, W. P. Wilcox, George P. Wilkinson, E. E. Womersley, E. E. Sloman, R. C. Moore, R. S. Knode, S. B. Gillett, J. M. Aikin, W. R. Lavender, J. T. Presnell, Eleanor S. Dailey, F. E. Coulter, John D. Peabody, Mary Strong, Robert McDonald, W. O. Henry, J. A. Kelley, Thomas Kelley, W. L. Ross, Hannah C. McCahan, E. Holovtchiner, Paul Grossman, W. O. Rodgers, J. T. Mathews, H. W. Hyde, Andrew Crawford, Wm. M. Davis, G. S. Milnes, A. H. Jago, C. C. Allison, Gertrude Cuscaden, W. M. Brown, H. M. Mc Clanahan, C. F. Clark, C. Riis, W. M. Barritt, L. F. McKenna, F. S. Owen, Sherman Van Ness, Joseph McDonnell, B. F. Whitmore, Fred Swartzlander, J. E. Claussen and H. L. Hewetson.

From this beginning, the Omaha Medical Society went forward in its scientific work and took an active part in securing the enactment and enforcement of the medical law of 1891 , requiring all physicians to obtain a license from the state board of health. This activity was in addition to the efforts of the Douglas County MedicoLegal Association, organized July 31, 1891, which will be mentioned hereafter.

B. F. Crummer succeeded Milroy to the presidency in 1891 and J. P. Lord was secretary, according to a report in the Omaha Clinic. W. O. Bridges was elected president April 12, 1892, the officers serving with him including Harold Gifford and Eleanor S. 
Dailey, vice-presidents; George Wilkinson, secretary and S. K. Spalding, treasurer. E. E. Womersley, H. P. Hamilton and A. B. Somers were the censors.

The officers who followed Bridges for the next three years, until A. F. Jonas was elected president in 1896, it has not been possible to trace, for the records have been lost or destroyed, and those active in the association like Doctors Milroy, Bridges and Jonas cannot remember positively. J. E. Summers, Jr. is known to have served one year, and S. K. Spalding, who was city health officer.

Dr. A. F. Jonas ventures the guess that Dr. L. A. Merriam, prominent Omaha physician in the early '90s, may have served as president during one of the years for which the record is missing.

"I recall that Dr. Merriam acted as secretary at one time and may have been elected president shortly thereafter," said Dr. Jonas. Dr. D. C. Bryant, on a recent visit to Omaha, was of the same opinion.

Perusal of available minutes of the Omaha Medical Society, now in the hands of Earl C. Sage, secretary of the Omaha-Douglas County Medical Society, bring to light many interesting notations. Metha Helfritz Jonas was secretary in 1894. Two other women members presented papers in 1895 . They were Eleanor S. Dailey who spoke on "The Bicycle for Women" and Mary Strong on meningitis cases. January 12, 1897, the meeting was devoted to a discussion of the inefficient handling of insane persons in the city jail, accordng to the minutes of Henry B. Wilson, secretary. Resolutions petitioning the city council to bring about more humane treatment of the insane, were adopted. Harold Gifford also brought up the matter of subscriptions to the Pasteur memorial.

At another meeting in the spring of 1897 , J. P. Lord moved that smoking be abolished at meetings "because it is obnoxious to non-smokers, especially the ladies, and detracts from the dignity of the body." "After quite a little discussion, the motion was adopted" is reported in the beautiful penmanship of R. M. Stone, but the action was probably forgotten, present members declare, judging by the amount of smoking done at today's meetings.

A little later, the health commissioner's post was the object of consideration, and the mayor was petitioned to make that a full- 
time position, "not a sinecure or political snap for two hours a day." Newspaper reporters were also barred from medical society meetings, indicating that perhaps the discussions were becoming pretty lively.

"The word 'appendicitis' has not been heard, this year," reports R. M. Stone, secretary in 1898. The following year, B. F. Crummer opposed the law legalizing midwifery and the organization followed suit but later rescinded its action, probably for reasons of policy.

In 1900 when Harold Gifford was president, the society waged a strong fight, opposing two legislative candidates from Omaha, Frank T. Ransom and Fred M. Youngs, said to favor the osteopaths, whose bill was to come up in the next session. When it passed, the local physicians carried the fight to Governor Dietrich, who, however, refused to veto the bill. The society also opposed the employment of an undergraduate medical student as assistant to V. H. Coffman, then health commissioner, precipitating a lively tilt, and there is further evidence of it in mention made in the minutes that O. S. Hoffman replied to an attack on Creighton.

In 1901, H. M. McClanahan, who opposed the practice of feesplitting was widely quoted in the World-Herald and the doctor had to submit a letter from the editor, stating that he did not seek and had no knowledge of the publicity to be given the matter, whereupon the society voted to "exonerate him from any participation in this flagrant violation of professional honor."

Another doctor was censured for indulging in a newspaper ad, whereupon he resigned.

In February, 1903, the society was reorganized according to the plan adopted by the state and national medical associations and became known as the Omaha-Douglas County Medical Society, which is its present appellation.

That year the organization opposed a proposed cut in the health commissioner's salary from $\$ 2,000$ to $\$ 1,500$ a year; took action to enforce the state laws for registration; advocated a change in the location of the pest hospital, supplied medical literature for the city library and agitated for a safe and sane Fourth of July. The following year, it petitioned the Douglas County commissioners to erect tents for tubercular patients at the county hospital, or to permit 
patients or their friends to erect them. Committees also interviewed A. S. Barnes, N. P. Dodge and H. S. Clarke, Jr., then candidates for the legislature, to learn how they stood on medical bills pending, and denounced patent medicine and fake ads.

The county society has continued its activity along these lines, lobbying for the removal of the medical department of the University of Nebraska from Lincoln to Omaha, which was accomplished; for the acquisition of the present site for the University medical school and hospital at 42nd and Dewey Avenue; and for the successive construction there of hospital and school building units, the last one of which was dedicated last November.

With the state organization, it led in the fight for the passage of the Basic Science bill, last year. Nebraska is said to be the third state in the Union to pass it.

Dr. A. S. Pinto, health commissioner, has also enlisted the efforts of the society in an attempt to wipe out diphtheria before 1930 by inoculation of present school children.

Since the opening in 1926 of the present fine Medical Arts building in Omaha, with provision on the second floor for a splendid auditorium for medical society meetings, headquarters have been established here and a paid secretary is in constant attendance. Portraits of all pioneer Omaha practitioners which can be obtained, hang in the auditorium, through the eftorts of the secretary, Dr. Earl C. Sage. The society, years ago, had an auditorium on the 16th floor of the City National Bank Building.

The society's library totals more than 800 volumes, many of which have been presented to the University of Nebraska Medical School Library.

Membership today totals about 300. Average attendance of meetings is better in proportion than any other city in the United States, according to a report of the American Medical Association in 1916.

Presidents of the Omaha-Douglas County Medical Association:

Temporary president 1866 Enos Lowe 1866 Jame P. Peck 1867 James H. Peabody
1883 Harvey Link

1884 J. H. Peabody

1885 James Carter

1886 R. C. Moore 
1887

1888 D. C. Bryant

1889

1890 W. F. Milroy

1891 B. F. Crummer

1892 W. O. Bridges

1893 S. K. Spalding*

1894 J. E. Summers*

1895 L. A. Merriam*

1896 A. F. Jonas

1897 D. C. Bryant

1898 R. C. Moore

1899 J. P. Lord

1900 Harold Gifford

1901 Byron B. Davis

1902 F. E. Coulter

1903 W. H. Christie

1904 H. P. Hamilton

1905 J. H. Peabody

1906 W. H. Slabaugh

1907 A. B. Somers
1908 E. C. Henry

1909 Ewing Brown

1910 J. M. Aikin

1911 LeRoy Crummer

1912 H. M. McClanahan

1913 B. W. Christie

1914 F. S. Owen

1915 J. M. Aikin

1916 Charles A. Hull

1917 J. H. Vance

1918 A. F. Tyler

1919 W. P. Wherry

1920 P. H. Ellis

1921 A. D. Dunn

1922 Palmer Findley

1923 J. M. Patton

1924 G. W. Dishong

1925 Rodney Bliss

1926 Adolph Sachs

1927 Frank Conlin

1928 A. P. Overgaard

*The order is doubtful; J. E. Summers may have served in 1893 and Spalding in 1894.

Officers of the Omaha-Douglas County Medical Association for 1928 include: president, A. P. Overgaard; vice-president, J. F.

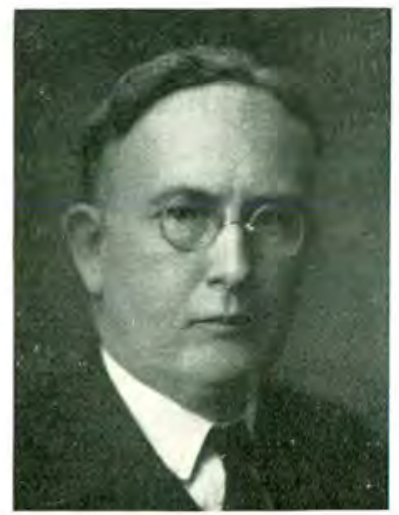

A. P. OVERGAARD

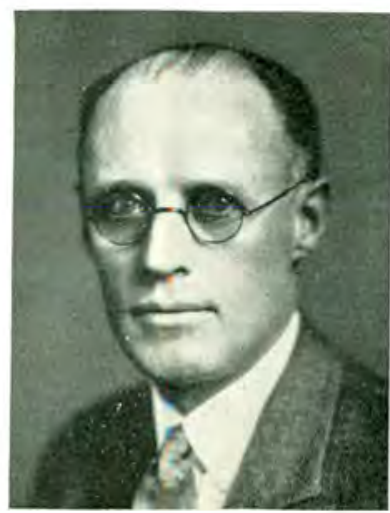

FRANK M. CONLIN

Langdon; secretary-treasurer, Earl C. Sage; council, Rodney W. Bliss, Frank M. Conlin, G. W. Dishong, A. E. Bennett, J. Frederick Langdon, A. P. Overgaard, Adolph Sachs, Earl C. Sage and A. F. 
Tyler; advisory members, J. Jay Keegan, Herman von W. Schulte and Herman Jahr.

Committee chairmen and personnel are: Preventive MedicineJ. M. Banister, chairman; B. C. Russum, A. J. Miller, J. R. Kleyla and William Melcher. Public Affairs-J. Jay Keegan, chairman; G. A. Young, J. F. Langdon, F. W. Heagey, Chas. W. Hickey and A. Parsons. Educational-H. von WV. Schulte, chairman; J. W. Duncan, S. R. Gifford, H. M. Jahr, H. B. Lemere. B. W. Christie, Thomas L. Houlton, B. M. Kully and Emily Brandt. LegislationJ. W. Duncan, chairman; Geo. F. Simanek, John F. Allen, Paul H. Ellis and F. W. Heagey. Entertainment - C. C. Tomlinson, chairman; Lowell Dunn and Thomas L. Houlton. Program-L. D. McGuire, chairman; George Pratt and R. W. Fouts.

NAMES OF REGISTERED PHYSICIANS IN DOUGLAS COUNTY SINCE 1881

Abundi, Rolli

Abbey, O. L.

Aikin, J. M,

Alexander, E. I.

Allen, E. T.

Altenburg, M. A.

Anderson, B. E.

Anglin, Robert Stephen

Arnold, Wm.

Arnold, E. L.

Arbuckle, Georgia A.

Armstrong, J. T.

Atkinson, M. A.

Ayres, George B.

Azee, James. W.

Bodelson, Helen B.

Bockme, Mastelle

Burrough, Amelia E.

Bigger, D. P.

Borglum, F. M.

Brown, Ewing

Brosins, F. C.

Bridges, Wilson $\mathrm{O}$.

Benson, Anna L.

Brown, Thomas D.

Biart, C. M. G.

Berg, A.

Buschman, Elisa

Bryant, D. C.

Ballard, W. H.

Breckenridge, Mary J.

Beyerman, Louis

Baldwin, Cyrus

Barrett, Edward D.

Blackburn, R. A.

Baldwin, Charles W.
Barnsdall, J. W.

Baldridge, S. T.

Bricker, F. J.

Bradway, William

Bullard, Jas. H.

Beerstler. George W.

Brown, William P.

Bacon, Fredic

Burges;, Frank D.

Beckett, Jas.

Berry, William

Brown, W. M.

Bracelin, M. Patrick

Berry, John L.

Burr, Chauncey S.

Bair, IVm. M.

Birkhauser, Joseph E.

Betts, William Hy.

Beard, J. R.

Bruner, Jas. F.

Blythin, J. W.

Boyd, Jay

Binney, Bascon Henry

Bumiz, Frederick

Burrell, Henry L.

Coffman, Victor $\mathbf{H}$.

Chadwick, P. M.

Conkling, Jetur R.

Coffroth, H. J.

Christiansen, Sophia

Coulter, Frank E.

Crowell, G. M.

Cross, E. D.

Cuscaden, Gertrude

Carter, James

Connell, R. W.
Colville, A. W.

Coe, Chas. M.

Croll, Mercer B.

Chapman, Mary B.

Cook, A. J.

Chase, Edward W.

Cole, Arthur W.

Crofton, Frank Everett

Cosman, Ethelbert O.

Campbell, S. M.

Cornish, J. V.

Crain, Charles $\mathrm{H}$.

Compton, G. W.

Claybough, W. W.

Christie, W. H.

Cox, Mrs. May E.,

Cummings, Edger D.

Cook, Howard

Dinsmoor, Charles M.

ivarrow, R. H.

Denise, Jacob C.

Dopita, Maria

Diedrich, Edward

Den, Emanuel Henry

Davis John C.

Durham, Henry

Dysart, Joseph W.

Dimmitt, Frank W.

Dailey, Eleanor $\mathrm{T}$.

Denton, W. A.

Dymenberg, W.

Dunn, W. G.

Davis, Jacob W. E. K.

Deveris, J. S.

Dayton, G. M.

Davies, E. J. 
Dutton, C. E. Dauns, C. W. O. Edwards, Isaac Ebener, F. W. Edmiston, A. W. Elvin, R. C. Elliot, R. M. Ernhouse, E. L. Ensor, Thomas Hayden Flaner, T. Jackson Fishblatt, Albert S. Fiegenbaum, G. A. Fisher, Waldo French, B. F, Fernland, P. O. A. Fish, W.

France, John M.

Foote, D. A.

Fellenstein, David W.

Foster, Miss Ursilla

Galbraith, Wm. James

Gilmore, Robert

Gluck, Isadore

Glasgow, J. M.

Geutsch, F. H.

Graham, W. H.

Glick, M. S.

Gifford, Harold

Ginn, Arthur

Gibbs, D. C.

Gee, Hoddard R.

Geutsch, D. C.

Gapen, Clark

Gibbs, W. T.

Gillette, Leslie B.

Gilman, D. L.

Giles, A. P.

Gluck, Hanna S.

Graddy, L. B.

Greene, J. Alonzo

Grossman, Paul

Gulick, Henry

Hyde, H. W.

Hart, C. L.

Hansen, Maria

Huddleston, R. H.

Huelff, John

Hostetter, Peter

Hanchett, W. H.

Hinz, A. F.

Hamilton, H. P.

Hanigan, C. P.

Hagglund, Maris C.

Harris, Chester F.

Hughson, James A.

Henderslott, Willie W.

Howe, M. F.

Hoffman, E. H.

Hoge, W. B.

Hewitson, $\mathrm{H}$.
Hertzman, J. F. Holovtchiner, E

Henry, C.

Holiman, Oscar S.

Hayes. Charles W.

Hanchett, J. C.

Howes, J. C. V. D.

Humphrey, W. A.

Hensley, J.

Huston, Irvin E.

Hashaw, J. B.

Hear, Henrietta

Impey, Chas.

Jensen, H. P.

Jonas, Francisced

Jones, John C.

Jubel, Hette

Joy, Douglas A.

Jonis, A, F.

Jenkins, John E.

Jordan, Charles M.

Jespersen, Thomas

Johnson, B. F.

Jacobs, Chas. W.

Johnson, M. A. D.

Jonas, M. Helfritz

Kinusland, Samuel

Knowles, H. S.

Kelley, E. A.

Knowles, S. H.

Kral, Marie

Keogh, Patrick S.

Kinsler, J. T.

Keenan, George, Jr.

Kensington, Milo L.

Kelly, James A. A.

Kelso, James

Kelly, Thomas

Kemper, W. G.

Knox, W. W.

Kirkpatrick, M.

Kuntza, Margaretha

King, Sophia

Kuhlman, Chas. G.

Knode, R. S.

King, John D.

Karten, Joseph W.

Lanyon, Willian $\mathrm{H}$.

Link, Harvey

Leisenring, P. S.

Lewis, F. Stanton

Lieber, P.

Laws, John

Lee, E. W.

Ludington, Horace

Lane, James

Lenz, Minna

Lucke, Robt. S.

Larimer, J. F.
Lavender, William R.

Liljeroth, Anna

Lord, J. P.

Larrabee, J. M.

Lewis, J. A.

Lankton, Frieda M.

Moore, Richard C.

McCleliand, Wm.

Merriam, L. A.

McLaughlin, James

Mercer, Samuel D.

M cCoy, Emily

Miller, Ruben Lewis

McKenna, L. F.

Murray, F. X.

McDonald, Chas. M.

Mattice, Richard Ira

Morguer, D. Omar

McMenarry. J. W.

Macua, F. M.

Mathews, I. F.

McCoy, John Cresop

$\mathrm{McCoy}, \mathrm{H}, \mathrm{F}$.

Maxwell, William C.

Malter, Alfred

Meade, Hamilton

McManizal, J. M.

Miller, Henry Gratton

McClanahan, W. S.

Mohr, Mrs. Lauisa

McKean, James K.

Murphy, Francis Paul

Merrill, $\mathrm{S}$.

Miller, J. C.

McGrew, J. E.

Meyers, F. A.

McClanahan, H. M.

McDonald, Robert

McKibbin, Harriet A.

McGovern, H. S.

Milner, George S.

Moore, J. C.

Neville, Joseph

Nunn, Richard

Noon, Joseph Edward

Nordstrom, S. G.

Neilson, Amelia

Nickerson, E. J.

Nichols, G. L.

Odell, Chas. M.

O'Leary, Arthur

Orr, A. C.

Parsell, Geo, H.

Parker, Arthur A.

Peabody, James H.

Peck, James P.

Panter, Judson C.

Peabody, John D.

Philpott, C. H. 
Pagelsen, M. Emily

Pettit, H. W.

Pulek, Geo. J.

Pangle, G. W.

Provencher, Norbert

Porter, Bowen

Parsons, Wm. H.

Potts, J. W.

Potts, Franklin

Patee, H. E.

Presnell, Jas, F.

Pagler, J. H.

Rose, W. C.

Ralph, Jno. B.

Robert, M. A.

Ross, George W.

Richetts, M. O.

Raymond, E. A.

Rutherford, W. G.

Randa!I, Maxin

Ries, Christian

Reeves, Labon P.

Ross, IV. L.

Roemer, C. O.

Reevis, Wm. C.

Rosewater, Charles

Roe, J. W.

Ris, Josefa

Rich, Josephine Agnes

Riley, Andrew W.

Reller, Dr.

Rodgers, W. O.

Randall, H. R.

Runner, Frank F.

Reymond, Alfred

Rafter, Martin B.

Scherer, Frederick

Stephenson, W. H. C.

Search, James W.

Speres, Conrad

Siggins, E. L.

Stone, Robert W.

Starkie, Caraline

Straub, Caroline

Shaeffer, L. A.

Spencer, E. S. B.

Swetman, James M.

Saville, F, F.

Spalding, Sam K.

Spira, Moritz

Shelley, H. A.

Solomon, F. F.

Shipman, Alfred

Smith, Henry F.

Schneckenburger, E.

Stout, J. K.

Sprague, Chas. G,

Spalding, W. Clyde.

Summers, Jno. E., Jr.

Simons, L. A.
Smith, J. E.

Scanlan, William

Spinney, A. B.

Sawyer, A. H.

Svenson, E. O.

Shriver, J. M.

Smith, Franklin B.

Sinclair, Isaac

Smith, Elmer E.

Sherwood, Ephriam

Sorenson, Carl Gustaf

Slabaugh, Warner $\mathrm{H}$

Suzsdorf, Gustave E.

Sloman, E, E.

Somers, A. B.

Swartzlander, Fred

Strong, Mary

Shorts, Philip R.

Stoddart, Archibold C.

Slomiuski, Ladislaus

Smiley, Jonathan

Starner, Gettis E.

Schemel, H. K.

Sprague, C. D.

Staring, Jennie

Smith, J. W.

Stevens, Henry M.

Scott, L. M.

Tilden, Geo.

Trumbower, J. W.

Tarner, Wm.

Toney, S. C.

Turner, Louis

Tracy. Jonathan

Towne, Solon R.

Thomlon, John Davis

Tilden, L. C.

Ullrich, C. W.

Ulber, Hattie

Van Camp, Ira.

Van Doren, S. H.

Verporten, M. H.

Van Alta, Eleanor

Van Grisen, Henry C.

Vance, J. H.

Van Hummell, D.

Van Ness, Isaac T.

Von Locukun, Peter

Watson, John

Watson, Amanda C.

Wood, O. S.

Willberger, J. L.

Woodburn, John Martin

Wood, Ch. T.

Wilcox, Wm. P.

Waite, F. W.

Womersley, E. E.

Worley, H. A.

Wier, David K.

Wirth, Edward
Ward, T. R.

Wentz, Anna E.

Williams, G. W.

Wuso, H. G.

Wilkins, Theoda

Wilkinson, Geo. P.

Wilson, William A.

Worthy, Mrs. Melvina

Weber, H. R.

Williams, Jno. A.

Walker, R. C.

Willson, Hugh McG.

Willard, Wm. G.

Warren, Mannie V.

Warren, Hamilton

Williams, J. P.

Wo Gee Chung

Wengard, Edw. V.

Weaver, John B.

Angle, S. D.

Auspacher, Carrie F.

Arnold, H. J.

Ahmanson, John

Arthur, Mattie L.

Allison, Chas C.

Bennett, Alice

Burbank, F, E.

Berwick, Thos. A.

Barritt, W. M.

Bolin, E. C.

Bryson, W. G.

Bowerman, Adda

Conway, H. O.

Cronk, Harvey R.

Chambers, W. C.

Cakl, Franklis Ka

Childs, Mary E. D.

Claussen, J. E.

Cram, C. W.

Chamberlin, Míyron $\mathrm{H}$.

Doolittle, M. C.

Dillings, F. C.

Dodge, J. B.

Davis, William

Dean, Frank Wilson

Drake, W. E.

Emmons, J. H.

Eddy, E. H

Epps, Franklin

Feurt, Wm. Henry

Freeman, Geo.

Foster, Wm. B.

Groux, Benjamin

Grebe, William

Gran, Albert O.

Glasier, W. H.

Goerss, Franz C. A.

Graham, Dales Young

Golding, Daniel G.

Gahan, Myles J. 
Gunn. W. H. Howe, R, M. Hayes, D. D. Harrison, J. C. Hensel, L. M. Hopkins, C. M. Holmes, H. P. Henry, W. O. Hopkins, Alfred G. Heilmann, Hans Hadfield, E. J. Holmquist, G. Holmquist, Anna S. Henderson, Thomas Ingham, George W. Johnson, D. W. Johnson, Andrew Jones, R. H. Jonas, A., F. Jonson, Elin Jago, Arthur $\mathrm{H}$. Kelman, W. J. Kiezekova, Josephine King, John S. Keys, J. M.

Kensington. M. L. Longshore, Anna M. Lavender, W. R. Lewis, M. D. Lonsdale, James A. Mangin, John M. Miller, A. j. Merrill, C. S. Maiken, W. H. Messenger, H. E. Muller, Von Otto Mason, W. T. Moore, Edwin B. Martin, W. R. Moore, W. F. McCahan, Hannah C. MacConnell, C. W.

Nelson, Charles

Nichols, G .L.

O'Rourke, M. J.

Ohlenschlaeyer, M. Pageler, J. H. Parsons, J. W. Paynter, Horace M. Pearson, Orlando Peck, Geo. Wm. Phelan, Leopold Richardson, L. Richards, James Riebe, Mrs. P. Siggins, John J. Shriver, F. M. Sears, H. Thatcher Stone, Robt. M. Sumney, H. C.
Straight, Jno, W.

Swenson, Carl G.

Swetland, Agnes V.

Simpson, S. R.

Schmidt, Mrs. Rosa

Taggart, Arthur T.

Terry, P. A.

Von Egert, Albert

Walsh, M. W.

Williamson, Geo. W.

Warren, Hamilton

White, J. W.

Webb, C. I.

Werrick, G. A.

Allen, E, T.

Aikin, J. M.

Arnold, Wm.

Alexander, E. L.

Agee, Jas, W.

Aberly, H. J.

Adams, W. E.

Allison, Chas. C.

Abbott, H, A.

Arthur. Mattie L.

Arnold Harry L.

Anderson, John C.

Brown W. M.

Borglum, J. M. H.

Breckenridge, Mary $\mathrm{J}$.

Baldwin, Chas. N.

Birney, B. H.

Barrett, Wm. M.

Birkhaenser, J. E.

Burroughs, A.

Bryant, D. C.

Burrell, H, L.

Bridges, W. O.

Bacon, F.

Beecher, R.

Blythin, J. W.

Bell, W. J.

Bruner, Jas. F.

Blair, Saml. F.

Barron, Thomas E.

Brownrigg, W. J.

Bump, Lewis W.

Burnett, Jas. T.

Blackburn, Robt. A.

Burns, Guy W.

Brewer, Chas. H.

Bridges, Edson L.

Blair, Samuel

Baker, Lewis L.

Bishop, James, C.

Baker, A. J.

Clark, Chas. F.

Chadwick, P. M.

Claussen, J. E.

Chamberlin, M. H.

Christie, W. H.
Cook, Howard

Claybaugh, Wm. W.

Cornish, Jas. B.

Crummer, B. F.

Cox, Mary E.

Cullimore, Grant

Chase, E. W.

Cuscaden, G. G.

Connell, R. W.

Ca rriker, N. J.

Cram, C. W.

Coulter, F, E.

Campbell. S. M.

Clayton, W. A.

Combs, M. R.

Crooks, Chas. V.

Carradine, Jas. S,

Capell, W. L.

Carpenter, E. M.

Cook, A. J.

Clark, Martha E.

Crummer, Henry LeRoy

Curtis, W .L.

Cloyd, A. D.

Coffman, Victor $\mathrm{H}$.

Carter, A. H.

Conlan, P. J.

Campbell, Stuart A.

Downs, Chas. M.

Davis, J. C.

Davis, Jacob W. E. K.

Denise, J. C.

Dunn, Wm. G.

Daily, E. S.

Davis, Wm.

Davis, S. T.

Davis, Edwin Van Ness

Dean, Frank W.

Douglas, Elmer E.

Davis, L. L.

Davis, B. B.

D riscoll, McKendree

Duncan, Chas. M.

Davis, W. M.

Dippell, Emil T.

Davis, Ida P.

Dill, J. W.

E.dmiston, A. W

Ensor, Thos. H.

Eddy, E. H.

Eiis, Jens C. D.

Eskeldson, Robt. E.

Edwards, Laura H.

Edgington, Avington

Elmore, Chas. G.

Foote, Dellizon

Freeman, Geo.

France, John M.

Friedman, A.

Fleckenger, Jos. 
Flock, C. W.

Furay, Chas. E.

Fisher, Oliver

Fenner, H. B.

Gilmore, Robt.

Grossman, Paul

Gahan, M. J.

Galbraith, Wm. J.

Graham, Dales Young

Gibbs, W. S.

Gluck, Isidor

Ginn, A. P.

Gwin, Howell B.

Golding, D. G.

Gilbert, Geo. R.

Glasgow, John M.

Gulick, Henry

Griffith, Anna M.

Hewelson, H. L.

Holmquist, H. L.

Hoffman, O. S.

Hyde, W. W.

Hayes, C. W

Hertzman, J. F.

Hoffman, E. H,

Henry, Walter O.

Henderson, Thos.

Hopkins, C. M.

Holliday, J. V.

Hirchman, J. V.

Hobb, W. R.

Hoxie, Frank

Himrod, Margaret C,

Harrup Jens Sorenson

Hinchey, Frank

Hoffman, Carl A.

Hopkins, Salein A.

Hill, J. G.

Holden, Horace T.

Hostetter, W. A.

Henry, C. E.

Horton, W. H.

Harrison, George E.

Hopper, Oscar C.

Hayes, Hezekiah

Hunter, Chas.

Hoyt, S. W., Jr.

Hall, E. T.

Hopkins, A. G.

Hull, Charles A.

Hutton, Jesse H.

Holmes, Abbie V.

Impey, Chas.

Jago, Arthur Herbert

Johnson, Andrew

Jones, J. C.

Judkins, Dora M.

Karten, Jos. W.

King, J. W.

Keys, Jerome M.
Kensington, M. L.

Kirkpatrick, Milo

Kelly, Thos.

Kinsler, Jas. I.

Kindred, Homer L.

Kenner, Chas. A.

Kelley, Jas. A, A.

Kelley, John F.

Lavender, W. R.

Liensenning, P. S.

Lankton, Freeda

Lane, James

Lucke, R. S.

Ludington, $\mathrm{H}$.

Lee, E. W.

Link, $\mathrm{H}$.

Lord, J. P.

Laird, J. W.

Lannon, W. H.

Lee, R. C.

Leard, Saml. E.

Langel, A. M.

Love, Geo. S.

Lillerahl, Frank E.

Lieber, Philip

Ludington, Paul H.

Mathews, Jno. T.

Moore, Jos. C.

McClanahan, H. M.

McCrea, F. M.

Merriam, L. A.

Mason, W. T.

Milnes, Geo. J.

McCahan, $\mathrm{H}$

McCoy, H. F

Moore, R. C.

Milroy, W. F.

Metz, Phillip. H

Mann, Nettie Holden

Martin, W. R.

Moriarity, Pierre C.

Millen, W. M.

McGavern, H. S.

Millen, W. M.

McGavren, H. S.

Millen, S. C. H.

Mercer, Saml. D.

McDowell, Chas, $\mathrm{H}$.

Malster, R. M.

Monroe, B. F.

Morton, Robt. B.

Munk, Eric

Mosses, E. Neff

Millen, W. M.

Mack, Alonza E.

Miller, Hjalmer R.

Mason, Rufus D.

Melchers, F. W.

Montgomery, Chas. F.

Mercer, Wilson S.
McCrea, F. M.

McCoy, H. F.

McGrew, J. E .

McDonnell, Jos.

McKenna, L. F.

McCann, W. J.

McGovern, H. S.

McDowell, Chas. H.

Neville, Joseph

Nichols, G. L.

Newbecker, M. Minerva

Nichols, Chas. L.

Owen, F. S.

Overholt, F.

Oxford, Chas.

Offerson, Kristine

Parsons, J, W.

Parker, A. A.

Peck, Geo, W.

Putman, Seymour

Parcell, Geo. H.

Park, E. M.

Pries, Rudolph F.

Powell, Ernest W.

Potts, Anna M. L.

Porter, E. R.

Peterson, Alfred $\mathrm{O}$.

Pollard, Chas. W.

Purnell, W. W.

Quinby, S. J.

Rosewater, Chas.

Roe, Jno. W.

Riley, A. W.

Rebert, Michael

Ralph, J. B.

Rodgers, W. O

Richardson, Louis

Ross, W. L.

Reed, Thos. A.

Rosenberg, Jacob

Roeder, J. A.

Race, Wm. F.

Renwick, Robt. W.

Robertson, Reuben, L.

Robinson, Reuben

Rasnom, Penn W.

Rosenberg, Mary E.

Rosenthal, Geo. W.

Rainey, James M.

Swartzlander, Fred

Strong, Mary

Stone, R. M.

Straight, Jno. W.

Sprague, Chas.

Searles, Frank L.

Swenson, C. G.

Sprague, Chas. G.

Sherwood, E.

Somers, A. B.

Sloman, E. E. 
Sussdorf, Gustave E. Summers, Jno. E. Spaulding, S. K. Swetman, J. M. Stephenson, W. H. C. Search, Jas. W. Swetland, Agnes, Satterfield, C. E. Slabaugh, W. H. Stout, James K. Shepard. C. I. Saville, J. J Solomon, J. J. Simons, Levi A. Siggins, Ernest L. Sturdevant, C. L. Stephenson, O. L. Schafer, Louis A. Shepman, Alfred Schettler, G. O.

Sweaney, Leverett Stephens, F. E. Searles, Austin D. Schindel, C. M

Stark, C. V.

Sigel, C. H.

Stack, Thos. E.

Sedwick, Wm. A.

Saffold, Benj. W.

Stone, Thos, W.

Swoboda, Louis

Smith, John G.

Shaw, B. F.

Sapp, Clinton E.

Taggart, A. T. Thompson, Wm. A.

Tracy, Fred. F.

Tische, J. M.

Teter, Daniel P. Tolson, Benjamin F. Upjohn, Mary $\mathrm{H}$. Upjohn, Wm. C. Vance, Jno. H. Van Camp, Ira Van Gieson, H. C. Von Leckum, Peter Van Dyke, James Wood, O. S.

Wirth, Ed.

Weaver, Kno. B.

Warren, Hamilton

Worley, H. A.

Weise, Heinrick

Walker, Robt. C.

Williamson, G. W.

Warner, Chas. J.

White, W. S.

Weber, Howard R. West, Benjamin F. Weber, Geo. Carl
Ward, T. R.

Ward, Joseph D.

Wilson, A. J.

Womersley, Ernest A.

Wearne, Fred J.

Walsh, Jno. E.

Yager, Wm. Seth

Alexander, J. S.

Agee, James C.

Adair, Ladie B.

Akin, Henry L.

Andrew, G. M.

Abbott, Edward C.

Adams, Arthur B.

Akers, Wm .O.

Aitken, Charles C.

Anderson, William Nance

Bogen, Louis I.

Buel, W. C.

Brown, Arthur C. F.

Boyd, Jay.

Blake, Benj. F. M.

Burdick, J. R.

Burkard, Adrian F.

Barakat, M. E.

Brown, Ewing

Barns, Frank M.

Bushman, Lewis B.

Branaman, Geo. M.

Bickwell, George H.

Ballard, Carl Hardin

Brancht, F. E.

Beinre, C. J. P.

Benz, Ferdinand L.

Bunce, Arthur C.

Black, Axel J.

Bailer, Lloyd E.

Britton, J. E.

Burke, W. A.

Browne, Alfred M.

Bourne, Joseph W.

Britt, Leonard Edward

Beck, Frederick Oswald

Boler, Thomas Daniel

Babcock, H. C.

Buol, George

Barnhardt, Edgar G.

Battendieri, Domenico O.

Bowser, William Wolf

Cox, William C.

Condon, A. P.

Canet, Ernst

Cummings, John A.

Chenowith, W. S.

Callender, J. A.

Chilcoat, Julius J.

Conaway, Aaron C.

Chambers, Oliver

Christie, B. W.

Conaway, H. O.
Chedeck, Benj. H.

Childe, E. P.

Curry, William

Claybaugh, Wm R.

Cox, Harry O.

Collins, Cornelius R.

Cran, George W.

Callfas, Jennie

Collelmo, Ugo A. D.

Cochran, Francis Bruce

Chaloupka, Hugo R.

Crockett, H. E.

Disbrew, A.

Dahlstrom, Anton S.

Dott, L. H.

Dallal, Joseph J.

Dandy, George Brown

Dummer, I.

Davies, James F.

DeLangle, Chas. P.

Duncan, J. K. L

Davis, Deane D.

Decker, Jay C.

Dassler, P. H.

Dume, Arthur D.

Dermody, Leo. A.

DeWitt, Charles H.,Jr.

Davis, William Windle

Davis, Delmer L.

Dermody, Louis Arthur

Dunham, F. S.

Eghiaan, Setrak

Edmonds, C. A.

Ellis, Paul $\mathrm{H}$.

Ewing, H. L.

Edwards, Augustus G.

Evans, Edward Benj.

Edwards, F, A.

Edwards, Lee. W.

Falk, F. W.

Fulton, Harry A.

Fensch, Albert

Ford, M. J.

Francisco, D. E.

Fitzgerald, F. E.

Fitch, Libble M.

Florer, Mauricio

Foote, William R.

Fowler, Fred $\mathrm{H}$.

Fuller, John A.

Fairchild, Nora May

Findley, Palmer

Fuester, Richard

Findley, Park A.

Friffen, Elmer J.

Gist, F. J.

Grantham, Elizabeth A.

Gordon, William

Gage, E. E.

Grebs, Elton B. 
Galloway, Harry S.

Gordon, Frank Earl

Gunn, J. A.

Gardner, Charles A.

Hea!d, H. C.

Headrick, Charles M.

Hanchett, Alfred P.

Hutchinson, W. F.

Hamilton, Geol L.

Henshaw, E. E.

Hall, B. W.

Hamilton, H. P.

Hahn, Gustav

Hunter, Montgomery.

Houghton, F. W.

Harrison, Edwin M.

Hall, Stacy B.

Hirschmann, Herman

Hickey, Chas. W.

Hellwig, John W.

Harris, Robley D.

Hauslien, Chas. M.

Hyde, John Fay

Holtman, Amadens A.

Hopkins, J. C.

Hammond, J. C.

Hart, Leonard

Harris, Roy B.

Hayman, Edward C.

Hall, G. H.

Hover, Hugh

Hill, J. Stanley

Hench, John Madison

Hull, $A^{1}$ va Rufus

Harris, Tenny Tennyson

Hamilton, Howard B.

Hutchison, Joseph W.

Humpal, Joseph Tohn

Hanson, Marius

Impey, C. C.

Iwerson, John C.

Isaacs, David

Jackson. Bernard M.

James, Peter E.

Jack, John Barnes

Johnston, Wm. R.

Jefferson, Alfred

Janso, Herman

Jones, Newell

Jones, Lauren

Jones, McMillan

Keith, James B.

King, F, L.

Koch, Wesley A.

Klussman, M. Pauline

Koutsky, John W.

Koenig. Albert $\mathrm{H}$.

Kucera, Frank $\mathrm{H}$.

Kelley, H. D.

Knode, Ray A.
Kennedy, Charles R.

Kenner, William C.

Klick, John Jos.

Kinsey, Ben W.

Kruse, F, W.

Lyman, Henry S.

Lemere, Harry Bassett

Lindquist, Adolph B.

Long, Louis C.

Leechner, Wm. H.

Lake, Fred W.

Lee, Daniel F.

Lewis, Edwin

Long, John $\mathrm{H}$.

Lyman, Rufus A.

Lyman, Mrs. C. E.

Lightfoot, Frank

Ludden, James L.

Langfeld, Millard

Littlejohn, J. Mart in

Langdon, John F.

Larson, Andrew G.

Little, P. J.

Lynch, Edward C.

Leary. William J.

Lieber, Charles

Lynch, Delia Adalene

Lombard, M. D.

Lingenielder, Julius

Lewis, William F,

Loney, James Stephen

Lundby, John L.

Leonard, Edw. F.

Middleton, John I.

Magaret, $\mathrm{O} . \mathrm{H}$.

Merager, O. S.

Mack, Lucinda C.

Moore, P. L.

Medill, J. W.

Morris, A. B.

Miller, James E.

Muck, William $\mathrm{H}$

McCarthy, M. S.

Mares, Anna M.

Morison, Chas. C.

MacDiarmid, S .B.

Martin, William P.

Muirhead, A. L.

McDermott, Bernard A.

Mullen, Thos. R.

Miller, Jas. P.

Marble, Robert E.

Morsman, Leslie W.

Medders, David Albert

McPherson, Joseph B.

McSlay, Jas. H.

Mathew, Zellmond B.

Milen. Theo.

Manning, Ernest T.

Miller, Leonard N.
Moffet, Villa Gatley

McCaw, Hugh E.

Nilsson, John R.

Nystrom, J. Oscar

Neal, B. E.

Nielsen, Marie Anna

Nelson, Fred A.

Neal, W. T.

Nemec, Charles J.

Neff, Enoch

Nason, William C.

Nusbaum, David $\mathrm{H}$

O'Connor, H. K.

O'Rielly, Robert

Parchen, H. W.

Phillips, W. H.

Park, B. F.

Pospisiel, Joseph

Pierce, Albert L.

Powels, Ella

Pinto, A. Sherman

Patton, David H. R.

Pass, M. D.

Prouty, S. B.

Pete Francis

Perkins, Philip M.

Porter, E. J.

Pickett, W. E.

Peckham, Anna P.

Pruner, William H., Jr.

Pinkerton, W. J.

Prendergast, James F.

Pi ichard, George W.

Parker, John A.

Pike, Frank

Rich, Chas, O'N.

Ramsey, William $\mathrm{H}$.

Richards, James

Rohlff, E. L.

Ryan, Willis J. R.

Richardson, C. T.

Riley, Bryan M.

Rix, Rudolph

Ruzuka, D. J.

Rhode, Margaret W.

Romm, Abraham

Robinson, W. Clark

Robinson, Chas. O.

Robertson, Edw. U.

Rooney, Chas. E.

Ramsey, A. J.

Rice, Rose $\mathrm{H}$.

Rubendall, Clarence

Ryman, Eugene Miles

Renny, Charles E.

Richardson, Delmar D.

Staples, Louis H.

Schueller, E.

Steiner, W. F.

Shaffer, George $\mathrm{H}$. 
Stockdale, B, A.

Sinclair, Isaac P.

Smith, Geo. W.

Smith, H. C.

Strouse, H. G.

Snyder, Chas, W.

Smith, Seymour H.

Sommer, Christian N.

Seeman. W. O.

Sher, Philip

Scott. Michael J.

Staade, S. W.

Schleier, Frank J.

Singer, Harold D.

Swaney, L. Alice

Sabin, A. C., Jr.

Smithheisler, James R.

Searles, Libbie McMerny

Seybert, F. T.

Swartzlander, Louis C.

Sachs, Adolph

Stokes, Charles S.

Slocumb, M. G.

Simpson, John E.

Stivers, Charles C.

Skeen, Earl D.

Simanck, Geo. F.

Shanahan. Edmond F.

Scott. Frank Waldo

Sigafoos, James Frank

Sedlacek, Frederick A.

Standeren. John F.

Sommer, Edward Adam

Thulin, Herman F.

Truelson, Thomas

Tanner, Willis C.

Tyler, Albert F.

Tany, Edward R.

Tomlinson, Charles C.

Taylor, Thos. L.

Updegraff, E. J.

Upton, E. J.

Van Camp, Lee B.

Van Fleet, Edward A.

Van Lackum, Herman J.

Van Keurew, Jno.

Van Buren, Frederick A.

Webster, Ralph F.

White, Alexander L.

Williams, Henry C.

Wisner, William $\mathrm{O}$.

Walker, W. H.

Wilmeth, W, L.

Whitmyre, John P.

Wherry, W. P.

Wilson, M. A.

Whiteside, Geo. H. W.

Woitishek, Frank J.

Waggoner, Hewitt A.

Wells, Myrle A.
Whitman, Frank S.

Ward, Wm. W.

Wyatt, Merlin B.

Wray, Frank $\mathrm{H}$.

Williams, Mattheu A.

Yeakele, William K.

Zaworsky, Edward A.

Allen. John F.

Anderson, James C.

Atha. J. Frank

Banister. John M.

Beniamin. Herman P.

Bridges, Edson L.

Conlin. Frank M.

Cheeneegavzyan, H. M.

Callfas, Wm. F.

Clark, Charles E.

Corell. Walter W

Chaloupka, Edward

Coats. Charles C.

Edmiston, Aaron W.

Fricke Albert A.

Foster, Robert Hale

Fitzgibbon, Henry M.

Hoffziger, Armand

James, Chas. S.

Kardss, Hubert D.

Kelley, Ernest

Kani, M. Alice Mantz

Kuegele. Frederick $\mathrm{H}$.

Larson, Jonathan. M

Lundy, Fred L.

Ling, Frank $\mathrm{B}$.

McMartin, Chas,

McCleneghan, Samuel

McArthur, Hector

Moore, John C.

Munro, Henry S.

Myers, Benjamin L.

Mantor, Harry L.

Munson, Herbert $\mathrm{O}$.

Moore, Cleland G.

Murphy, Wm. M.

Newell. Charles H.

Nordwall, C Olaf $\mathrm{H}$.

Nye, Mark A.

Potts, John B.

Pugsley, George W.

Pulve, John E.

Paddleford, James F.

Parks, Tlbert L.

Potter, George B.

Robinsun, Richard F.

Rice, Moses R.

Raber, Donald D.

Roeder, Clyde A.

Stewarci, P. LaFayette

Sweeney, Edward E.

Soper, Joseph

Stevens, George A.
Torjuson, Theodore B.

Woolley, Paul G.

Waiters, Hamlin J.

Wordwall, C. Olaf $\mathrm{H}$.

Willis, Bennet G.

Warder, W. Scott.

Winterson, George C.

Allingham, $H$. T.

Angus, George Alexander

Adcock, Lee Campbell

Allen, William E.

Avery, Hiram Henry

Abel, Nellie E. H.

Atzen, Chas. R.

Akers, William O.

Anderson, Earzye Harry

Atwood, Norman H.

Brown, Charles Phillip

Brumley, Samuel Henry

Borglum, Francis L.

Boone, Abner E.

Burns, Hiram D.

Breengardt, B. A.

Buck, Frederick W.

Barry, Augustus C.

Bennett, W. S.

Barr. Arthur L.

Barclay, Arthur O.

Barnes, Erskine M.

Burlingame, L. R.

Bleiweiss, Martin $\mathrm{H}$.

Banghart, Edgar B.

Barnes, Charles E.

Bleick, Louis C.

Brown, Elmer W.

Brandt, Amelia $\mathrm{H}$.

Block, Max

Byrne, James R.

Criss, N. L.

Criss, C. C.

Clark, Harry Douner

Cramer, Lloyd

Cross, Clara Glines

Caughlan, Gerald V.

Chiles, Jesse Henry

Covey, George W.

Cassidv, George Alvin

Condon, Charles Emmet

Crosby, P. F.

Clemens, James Ross

Cook, Lyman Joseph

Connelly, Earl A.

Crady, C. C.

Clark, Freda M. P.

Cooper, Albert L.

Christensen, C. H.

Connell, Karl Albert

Cassidy, Waldran A.

Chain, Leo William

Collins, Floyd M. 
Dickson, Wm. Harrison Duncan, John William Dwyer, John R.

Durham Cecil B.

Dihel, T. E. K.

Lelfs, Clans G.

Day, Charles M.

DeVore, Samuel F.

Davis, John Calvin Jr.

Draney. T. L.

Detwiler, Augustus K.

Douglas. William James

Dow, Andrew G.

Dav's. Edwin Green

Davis, Herbert $\mathrm{H}$

Dansky, Nathan

Frskine. Errl B.

Ensor. Rolland R.

Emmert. Miy

Edstrom, Andrew J.

Erman, Jacob Martin

Eqen, Lothar F.

Everitt, Neill J.

Edler, William

Emerson, Arthur G.

Edwards. Jas. T.

Foster, E. W.

Foltz, Clarence B.

Follman, John C.

Fields. L. Seymour

Franklin, Daniel

Farrington, Owen P.

Fletcher, Asa E.

Folsom Shirley Dair

Gleeson, John Joseph

Gooden, Dav'd Wendell

Gebhardt, Albert A.

Gramlich, Ralph C.

Goreham, Salem E.

Greenburg. Abraham

Gillespie, Floyd Burke

Giragosian, Veham H. J.

Grier, Maurice E.

Geetz, James S.

Gerish, Albert E.

Gerish, Nettie L.

Grudinsky, Manuel

Giever, John C.

Gerrie, Wallace A.

Hamilton, Hariet S.

Hastead, Edwin Louis

Heumann, Johann M. F.

Holst, John, Jr.

Hall Lym Thompson

Haines, Frances E.

Heusie, Joseph Aloysins

Hill, J. Besten

Harms, Chas. W. W.

Herne, Brcse S.

Hyland, Clarence M.
Hoffmeister, George W.

Holke, Henry J.

Heagey. Francis W.

Hahn, Frederick M.

Haney, Wm. P.

Hanisch, E. C.

Heise, Carl G.

Hollenback, Carl F.

Hough. J. Waiter

Howard, Maurice C.

Harvey, Harry Evans

Hebenstreitt, Austin J.

Hunt, Katherine Moran

Hawkins, Anthony L. R.

Johnson, Aldis Adelbert

Johnston, Raymond S.

Jones, Vincent Leo

Johnson. Julius A.

Johnson, Rudolph E.

Jenkins, Harry J.

Jones, Glenn Albert

Johnson, Ernest D. L.

Johnson, Iven Godfrey.

Kinsey, Katherine E.

Kalal, F. J. B.

Kee, Azalia

Knyoun, Floyd $\mathrm{H}$.

Kauffman, A. J.

Kleyla, J. R.

Kline. Phillip

Fory. James Francis

Lipe, Wilbur P.

Lurvey, Homer D.

Loughridge, William K.

Long, William E.

Levy, Philip

Lawrenzana, D. Antonio

Laffler, Gilbert D.

Lemley, George

Linquist, Arthur L.

Lynch, Lawrence A.

Lake, Lilburn B.

Lichtenwallner, John

Landgraf, Ernest W.

Larsen, Carl Edward

Maxwell, James F.

Moen. Louis Edwin

Morian, Clarence $\mathbf{H}$.

Miller, Lucins V.

Martin. Wm. C.

Mack, Alonzo E.

Moen, Charles Franklin

Marble, Robert Eugene

Mocrehead, Harold B.

Moere, Jchn E.

Moser, R. Allyn

Meyer, Carl A.

Molsead. C. S.

Miller, H. C.

Maxwell. T. Meredith
Millener, Frederick $\mathrm{H}$.

Murphy, Francis P.

Murphy, John Harry

Miller Harry C.

Miller, Irving

Meredith, Geo, W.

Mesraprian, Messiah

Martin, Otis

Miller, Glenn Henry

Madison, Amos B.

Melchiorsen, Wm.

Murray, Floyd Joshua

Merriam, Sidney Addison

McAvin, James D.

McCraw, W. Joseph, Jr.

McArdle, LeRoy

McGrew, W. R.

McIsaac, Fred C.

McLean, Edward H,

McCarthy Joseph D.

McGuire, Louis D.

McCrann, Patrick M.

McGee, Harry Edwin

MicArdle, George M.

McMahon, Edward E.

McGowan, Patrick $\mathrm{H}$.

Needham, Charles T.

Nichols, Robert

Nutting, Will Wallace

Nigro, Dominie M.

Neilson, Arthur L.

Northcross, Stephen B.

Niehans, Freiderich W.

Norman, Eugene F.

Nolan, William J.

Niederst, Richard $\mathrm{H}$.

O'Connor, Wm. E.

O'Connor, Thomas P.

Overgaard. Andrew P.

Owen, Donald R.

Offerman, Arthur J.

Osherhofi, Samuel A.

B. Pinckncy, Chas. E.

Parsons, Antony

Putman, Lynn J.

Patten, James McD.

Park, Durward Belmont

Pratt, Gecrge P.

Philbrick, Guy Sterling

Prince, Norman C.

Puris, Abram M.

Pruner, A. Caskie

Quigley, Willard $\mathrm{H}$.

Rasmussen, N. H.

Ryder, Frank D.

Reihart, Oliver $\mathrm{F}$.

Rogers, H. Stanley

Reed, Stanly G.

Rasmussen, Henry A.

Russum, Benj. Carl 
Rubnitz, Abraham S.

Ross, William Lytle, Jr.

Ross, Colin $\mathrm{H}$.

Rieth, George R.

Reichstadt, Emil

Riggert, Leonard $\mathrm{O}$.

Redfield, Willis J.

Ross, Arthur J., Jr.

Riddle, Roscoe Conklin

Rance, William Thomas

Rarritz, Sol E.

Rusche, Carl F.

Shouse, Edwin

Smeroff, Louis Noah

Sauders, Jno. A.

Shillington, Maurice A.

Strickland, William R.

Snow, John E.

Sheehy, Joseph P.

Shook, Charles F.

Sheets, Charles H.

Shearer, William L.

Srb, Adolph F.
Sullivan, John P.

Sage, Earl C.

Schrock, Robert D.

Sherwood, R. G.

Swobodia, Joseph Phillip

Stodden, Frank J.

Stearns, Robert J.

Stapleton, H. B.

Schanm, Lydia L.

Shields, Wm. D.

Sullivan, Harry $\mathrm{T}$.

Schwertley, Frederick

Schaller, Frank W.

Shipley, H. McGregor

Thomsen, John Henry

Thompson, Warren Y.

Thorpe, Agnes Cecelia

Tamisea, John A.

Thompson, Kenneth L.

Torpy, Thomas W.

Talcott, Vernon V.

Tobin, Frank J.

Tipton, G. Dean
Van Orsdel, Samuel A.

Vercoe, Walter L.

Warta, Joseph J.

Weiss, Rudolph Otto

Wren, Claude

Wheeler, Clayton E.

Wood, Leonard S.

Wilson, Jesse D.

Woodward, J. C.

Whitcomb, Glen D.

Way, Charles W.

Whittaker, J. B.

Weyer, Stephen M.

Weigand, G. L.

Wohl, M. G.

Walker, Harold Hill

Weinberg, Joseph A.

Wiggins, Herbert

Wear, John W., Jr.

Young, Marcia Louise

Young, Alexander G.

Yates, Walter Sidney

Zalazowski, Frank L.

\section{DOUGLAS COUNTY SINCE 1921}

Ernest S. Wegner

John Jay Keegan

Theodore M. Agnew

John Aloysius Borghoff

Alford Clifton Graham

Edward J. Mulholland

L. A. N. Delanney

Claude W. Mason

Barney Maurice Kully

John Joseph O'Hearn

Thomas Leo Houlton

Frank Gailford Crandall

Byron Howard Baer

Ernest Lynn MacQuiddy

Albert David Davis

Harry Overton Drew

Eugene Earl Simmons

King Chee Chock

Oliver Clarke Nickum

Ervin I. Finkenstein

Ralpin I.eslie Troup

Linford L. Lee

Joseph Francis Malloy

Gerald H. Beck

Michael Joseph Lipp

Ernest Madison Burns

Ralph M. Fouch

Elmer Louis Barr

Harry Ferdinand Hartje

Leo Dow Rose

Erwin Phelps Miller

Charles Francis Little

John I'hilip Cogley
Searl Henry Lanyon

Barbara Churchill

James William Koutsky

Bernard J. Gilshannon

William Henry Melcher

John J. Freyman

Harry Gusten Huffman

Wendell A, Killins

Joseph Satolli McCarthy

Clarence Edward Rice

Joseph William Ebert

Raymond K. Hoover

Stephen Thomas Parker

Joseph John Kane

Dickinson C. Richards

Jerome VanH. Pace

Richard Otto Lucke

Charles B. Huestis

Henry Ambrose Kildee

Bradford J. Murphy

George P. Nicholson

Wesley B. Jones

Bernard E. McGovern

Grove Baldwin

John Francis Cross

Freeman E. McConoughey

Thomas E. Sample

Charles A. Weymuller

Richard C. A. Jaenike

Merle F. Warner

Joseph R. Sample

Charles G. Weeth
Nathan Muskin

Walter Sidney Yates

Charles M. Swab

William T. Werber

Otto Maxwell Husted

Elias George Camel

Clyde Clarence Hardy

George Banks Lennox

John Godfrey Chaloupka

Raymond James Brennan

Homer R. Palmateer

Jerald Joy Bruce

Richard Kenneth Collins

Alex F. J. Hansen

William A. Bunten

Felix Oliver R. Kolda

John Stephen Broz

Jay Reed Dewey

David Enrique Algorta

C. Raymond Anderson

Edward Janus Hotz

S. J. Randall

Bernard Vincent Kenney

Grover G. Goodwin

Martin L. Minthorn

James William Martin

Anthom A. Foster

James George Better

George E. Neuhaus

Leo Williams Chain

William Howard Echmitz

Robert Lyman Sands

Bradford J. Murphy 
Fritz Rosenbladt

James Gwynne Folwer

Henry Francis Bougardt

Carl F. Rusche

Walter Cyril Nalty

Benjamin F. Ewing

Emmett Francis Hoctor

Phillip Romonek

Roland W. Dahlgren

Lambert Krahulik

Lyle William Doran

James Richard Condon

Matthew Joseph Severin

William J. Reeder

Walter Henry Judd

Wilfred Anthony Ash

Francis M. Duffy

Clifford John Mullen

Edwin August Reils

Frank Arleigh Nelson

Charles Austin Owens

Chester Quay Thompson

Guy Hart Moates

David Leo Rater

Michael Aloysius Welbes

George A. Bendiage

Albert J. Schwedheim

Willson Bridges Moody

Herbert Eric Stroy

James Timothy Moriarty

Henry Smith Atwood

Herman Charles Bodemer

John Ernest Jackson

Willard Max Gentry

Ted Eugene Riddell

Harry Hamlin Kretzier

Julius George Bartek

Cedric Henry Nelson

Ernest Robert Reinsh

Neil J. Dau

Harold Vincent Dwyer

Claude Ferdinand Peters

William Wayne Graham

Bretisiaw Sedlacek

Ward Caldwell Fenton

Otto Albin Kostal

Conrad J. Baumgartner

Godfrey J. Kadavy

Clement Leon Martin

Craig Wilson Munter

Carl A. Hoefer

Clarence F. Bantin

Thomas Powell Haslam

James Gilian Allen

Bernard Charles Burns

Paul Ancil Reed

Clarence Joseph Goebel

Charles Ramsey Price

John Wessel Ortman

Derrick Antill Hoxie
David Michael Bloch

William James Adams

Frank Joseph Casey

Ozro Theo. Woods

William Brooks Vance

Charles Raymond Canty

Max Eugene Wonders

Freman S. Collen

Charles Bernard Hayes

William Dale Lear

Fletcher Clark Stewart

Julius M. Moskovitz

Milton E. Beitennan

Martin Joseph Ryan

Melvin N. Newquist

Abram Elting Bennett

John E. Kestel

Frank Joseph Mnuk

Chester Trimble

John Joseph Malee

Walter Benthack

Kenneth Lawrence Roper

George Murray Lynch

Earl Edgar Miller

Milton Henry Carrig

Henry Jeptha Sealey

William Thomas Johnson

Luyl Clare Bedwell

Ralph W. Shirey

Arthur L. Linquist

Arnold Larson Jensen

Otto Paul Ludwig

Demetric C. Macasa

Herman Frank Johnson

Aaron M. McMillan

Robert Bruce Eldredge

Laird W. Elwood

Irwin Isaac Boehr

Herman Mandel Jahr

Abraham Abe Steinberg

William Peter B. Nemzek

Charles B. Huest is

David Harrison Dale

Morriss DeWitt Kelley

Charles Richard Bates

Thomas Yule Dorwart

Paul Herbert Priest

Lawrence E. Crowney

Francis Edgar Shoulain

James Phillip Lovely

Fritz Vennemann

Joe Goldstone

Louis Franklin Curtis

Morris Margolin

Carl Robert Carlson

Ara Fay Peebler

Elvin F. Scheidegger

Julius Philip Brown

James Harvey Turner

William C. Kenner, Jr.
Dwight Otis Hughes

William F.McCarthy

Lyle L. Wood

Paul Edgar Conrad

Price Terrell

Richard C. Henderson

Wade H. Peyton

Max Fleishman

Guy W. Goodrich

Leslie Earl Sauer

William D. Harris

Harry A. Collins

Eugene W. Kenney

Joseph Markey Grace

George W. Doran

Thomas J. Kargacin

Jean Thomas Lapierre

Frank J. MeDonough

Roland T. Rohwer

Noal W. Spencer

Raymond M. Wallerius

Joseph Hogn Hovocka

Joseph I. Fitzsimmions

Anthony George Carroll

Leo James Hombach

Mason Earnest Lathrop

Daniel LeRoy Delehant

Louis Bladimir Bilon

Richard Randall Brady

Thomas James Hartford

Harley E. Anderson

Frederic: W. Kuhlmann

Rudolph H. Sundberg

Mildred Joy Buzza

Zeno N. North

George Marcus Hansen

Francis Kirk Burnett

Reginald A. Gary

Fred M. Watke

Edwin Albin Kilbride

Estelle A. Magiera.

Donald James O'Brien

Eugene C. Grau

Michael William Barry

Emil Carl Petersen

William Sarold Scoins

Richard A. Smith

Clyde Gordon Nicholson

Paul Albert Brehm

Chester F. Johnson

Irving Rabkin

Donald Jasper Wilson

William John Shaw

Francis Joseph Abts

Victor Ernest Berchtold

Richard D. Furnish

Walter W. Carveth

Carryl William Wiggins

Clarence Hugo Folsom

John William McGee 
William Newton Nelson

Ralph Swisher Russell

Dionisie Mathew Sirca

Samuel E. Light

Lyle Stephenson Powell

Louis Ernest Weymuller

Herbert Lester Phillips

Magnus C. Petersen

Donald L. Drummond

Elmer Burkett Reed

Francis Joseph Berney

Joseph Bernard Pankau

Arthur Charles Antony

Robert C. Kirchman

Thomas G. Fitzgibbon

Julius Albert Weber

Earl R. Crowder

Joseph Leo O'Rourke

Joseph Lafe Ash

James J. Duffy

Francis Elmer Toomey

F. W. Franz

Leo P. Coakley

Thomas J. Murphy

Francis Irving Powers

Thom:s J. O'Brien

Edward Alonzo Lebold

Juul C. Nielsen

Ladd E. Hoover

Charles John Shramek

Lucas H. Lucic

Lawrence L. Davidson

Smith C. Kirkegaard

Gerald M. Kunkel

Kirby Clayton McGrew

J. F. Lukowsky

E. J. Conner

Victor Johannes Weiss

George P. Sims

Louis Luster Robinson

Burn Thompson Stout

Stanley James Walters

Carl R. Wegner

Walter M. Herrmann

Roland A. Jefferson

Max Himmelfarb
Clarence Lorimer Bain

L. B. Rowley

Carl Fletcher Ward

Walter Robert Wegner

Paul S. Read

George E. Robertson

C. M Oakes, Jr.

Eugene B. Maxwell

Charles Mandel

Niels Marius Hansen

Edwin Katskee

Daniel J. Hurley

Leander Herman Schafer

David N. Deering

William Elza Wright

Charles M. Murphy

Harley James Hotz

Herschel B. Morton

Robert Andrew Kroehler

Peter Percy Bell

John C. Harrington

Edwin Perle Deal

Charles Bishop Beymer

Reuben Carl Matson

George L. Clark

Mildred T. Clark

John Philip Gilligan, Jr.

Robert Alexander Steven

Harry Joseph Arnald

Raymond J. Primasing

John Ralph Vasko

F. Howell Dunn

Earl Alexander Harris

George L. Roark

Joseph John Michalak

Robert Alan Phillips

Purl Elmer Reed

Joseph Cullen Root, 2nd.

Aura D. Miller

Carmelo DiStefano

Meyer Smernoff

George A. M. Eychaner

George M. Fredericks

Donald M. Pillsbury

Albert J. Rettenmaier

A. A. Blum
A. David Cloyd

Raymond Alan Lower

James A. Cleary

Isidore Soifer

M. E. Jacobsen

Charles J. Fogarty

Ferold D. Lovejoy

Furman Paul Ralston

Leo J. Hand

Joseph W. McNamara

Frank B. Hand

T. S. Tracy

William J Feehan

L. Daniel Dieter

Austin Gibbons Dunn

Nevill Joyner

Lawrence D. Lee

Maine C. Andersen

Eugene William Pape

Herbert M. Every

Frank Charles Svoboda

Elizabeth M. M. Swab

Paul Vincent O'Rourke

William Marcus Korth

Carleton B. Peirce

Virgil S. Glass

Francis J. Homback

Joseph F. Whalen

William Joseph Egan

Elmer Marion Hansen

Harry M. Murdock

J. C. Dickson

Edgar Pearl Benedict

Charlotte Ann Mitchell

Charles L. Nutzman

Miles F. Daubenheyer

George W. Ainlay

O. Clair Kreymborg

Leo L. Wilson

Raymond L. Traynor

James P. McGowan

Roscoe P. Luce

Otto L. Munch

Claire Addison O'Connor

Meade Mohun

Owen S. O'Neil

\section{LINCOLN MEDICAL SOCIETY}

A. R. Mitchell, at present one of the nine trustees of the American Medical Association, and W. L. Dayton are the two oldest practitioners in Lincoln, in point of years of service there. Mitchell came in 1879 and Dayton, in 1882. Both men were active in founding the Western Medical Review of George H. Simmons, further mention of which will be made in another chapter. 
According to Mitchell, the very first gathering of medical men in Lincoln was conceived and started by F. G. Fuller, the first physician to practice in Lincoln, and himself (Mitchell) as they "sat at the table drinking beer in the old Klutsch saloon in Lincoln." "It was a good saloon, good beer and a good society," Mitchell declared. "I cannot give the exact date, except that it was a presidential year, probably 1880, and our first meeting was on the night we were awaiting returns from the election," he recalled.

There were a lot of interesting things connected with the Lincoln men, according to Mitchell. Dr. J. D. Leslie went from there to

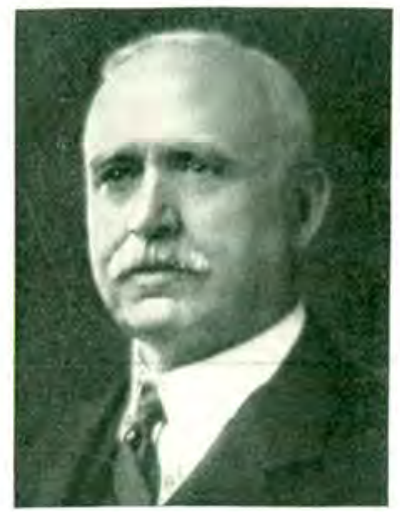

A. R. MITCHELL

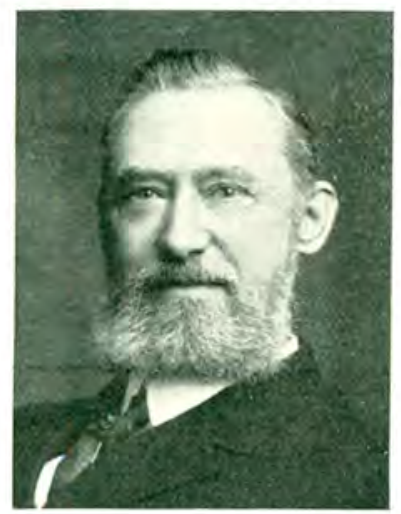

W. L. DAYTON

Memphis to work through the yellow fever epidemic of 1878; George H. Simmons became editor of the Journal of the American Medical Association, a post he held for 25 years; and J. O. Carter distinguished himself in the conduct of medical affairs in the state penitentiary. Other men in Lincoln as early as 1872 were Jasper P. Norcross, in 1875, G. W. French, with whom A. S. von Mansfelde associated himself when he came to Lincoln that year; and L. H. Robbins, who was president of the state society then. French later moved to Humboldt, Kansas.

Horace Chapin also came to Lincoln from Massachusetts in 1879, the same year as Mitchell. He died in 1887. There was another doctor by the name of Rudmore practicing in Lincoln at the 
It is probable that F. G. Fuller was the first president as he was the first doctor, and the most influential one in Lincoln, but a new chairman was chosen for each meeting. Fuller came to Lincoln from Galesburg, Illinois, in 1868, the year he was graduated from Ann Arbor, after service in the Civil War. He was the first superintendent of the state insane asylum when it was opened, serving in 1875-1877; was city physician, on the board of health and was president of the state society in 1884. He died April 13, 1888 at the age of forty-seven, after a buggy accident while enroute to Saltillo to see a patient. Mrs. H. F. Sidles of Lincoln is a relative. Mitchell states he himself was the first secretary and he is of the opinion Leonard $\mathrm{H}$. Robbins was the first treasurer. A son of Robbins is now a New York newspaper writer. J. O. Carter, when he died, left his splendid library to the University of Nebraska.

Leslie, who was the Burlington surgeon at Lincoln when he volunteered for the yellow fever service, was an exceptionally handsome man and was tendered a brilliant reception by citizens of Lincoln when he returned from his heroic service in 1878. He lived on the site of the present Lincoln Chamber of Commerce.

Mitchell, now regarded as dean of the Lincoln men, was a graduate of Rush Medical College in the class of 1879, of which the famous Dr. John B. Murphy of Chicago was a member. He is a Burlington surgeon, on the staff of a number of insurance companies, and taught clinical surgery at the University medical school, which he helped to establish, while it was located in Lincoln. Mitchell relates that he fired an engine for the Burlington before he decided to study medicine and later became a member of the road's surgical staff. N. J. Beachley was another early member of the Lincoln society, he recalls.

This early group also adopted a fee bill, according to MitchelI. He recalls that the fee was something like $\$ 1.50$ for a visit; 50 cents extra for each additional patient; $\$ 3.00$ for a night visit and 50 cents a mile for trips into the country. There were about 20 members of the society and the meetings were held on 11 th and $\mathrm{O}$ streets, upstairs, above what is now Harley's drug store.

The first formal records of the Lincoln Medical Society, now in the possession of Dr. Winnett Orr, date back to April 26, 1887, when a special meeting was held in the office of Dr. Milton Lane, 
at the request of H. B. Lowry, Milton Lane and N. J. Beachley, to elect delegates to the state convention, and name a committee to confer with the city council about a city hospial. Dr. Sophronia M. Lane, wife of Milton, was secretary. W. L. Dayton was in the chair, a new presiding officer still being chosen for each meeting.

At the next meeting, May 10, a report was given on sanitation at the poor farm.

Attendance record for the year indicates these members: $\mathrm{N}$. J. Beachley, Anne Burnett, J. V. Beghtol of Friendville; Horace Chapin, who died that year; J. O. Carter, W. L. Dayton, H. C. DeMaree, J. W. Emery, F. G. Fuller, A. L. Hoover, J. H. Hay, Milton and Sophronia Lane, H. B. Lowry, D. H. Muir, Charlotte M. Norton, William Protzman, L. H. Robbins, H. J. Ruel, A. R. Mitchell, Alice E. Huff, formerly of Ashland, and C. B. Manning.

The next year, 1888, the Lincoln society engaged in several lively sessions due to the appointment of Doctors M. H. Everett and Haggard as Burlington surgeons, by R. R. Livingston of Plattsmouth, then chief surgeon. A special meeting of protest was held June 2, 1888 at which time it was asserted that Everett had recently been refused admittance to the Lincoln society because of unprofessional conduct. A letter was sent to Livingston, asking him to reconsider the appointments.

Livingston acted with his usual prompt dispatch. In a letter signed "Livingston and Sons" (three of his sons eventually followed him in the practice of medicine in Plattsmouth) he asked the Lincoln society "to prove its charges and tell how many were present when the 'bill of condemnation' was passed."

The society then adopted resolutions assuring Livingston that no personalities had actuated them, only the good of the profession. "The last incumbent was no good and to approve men like him was placing a premium upon charlatanism," they averred.

It developed that the charge against Everett was that he consulted with A. H. Dorris, a homeopath, and also consulted "with one G. H. Simmons, an advertising homeopath who lives in open violation of medical ethics" and also with W. S. Latta, an eclectic; and that "Everett recommends Dr. Garten, an eye and ear specialist in preference to our educated regular specialists." Dr. Garten 
had been refused admission. Charges against Haggard were "that he associated in business with Everett and fraternized chiefly with irregular practitioners."

Evidently the above action was not wholly endorsed for on June 23 another special meeting was held to reconsider the action taken against all these men. The call for the meeting was signed by $\mathrm{D}$. H. Muir, A. L. Hoover, George E. Andrews and C. B. Manning.

A little later in the year, sentiment against the homeopaths and eclectics evidently underwent a change for all the men attacked were admitted to the society. G. H. Peebles, Frank B. Crims, W. M.

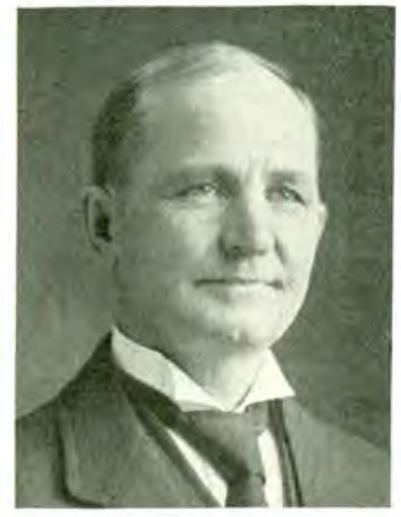

E. L. HOLYOKE

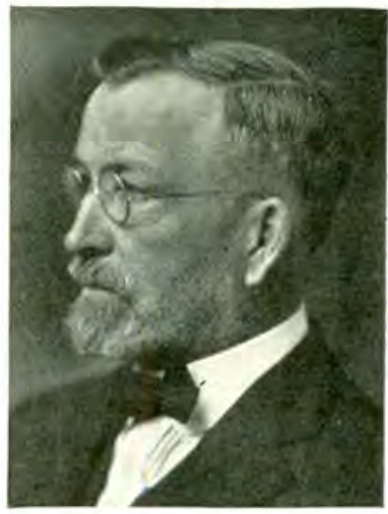

W. L. CURTIS

Knapp, H. M. Casebeer, Griffen, H. J. Winnett, later mayor of Lincoln; E. L. Holyoke, who came in 1884; Dawson, M. B. Newhouse and D. D. Gorman were all admitted before the end of the decade.

The minutes for October 13, 1891 show Margaret Simmons, first wife of George Simmons, elected to membership. Milton Lane was then secretary in place of his wife, who was ill. A. D. Wilkinson also joined that year.

The minutes for October 11, 1894, have special interest for they reveal that Dr. Mitchell apparently incurred the displeasure of the society for his name was dropped. He was reinstated, however, and today holds one of the highest honors in medical ranks as a trustee of the national association. L. G. Rhodes and Stevens were elected members and Mrs. Ruth Woods, reinstated. 
The 1895 minutes disclose great activity in medical legislation and is featured by the appearance of the first typewritten report, prepared by Dr. G. H. Simmons. The members in good standing that year were: J. R. Haggard, Simmons, A. D. Wilkinson, M. H. Everett, J. O. Dawson, H. M. Casebeer, L. G. Rhodes, J. H. Tyndale, M. H. Garten, Ruth M. Woods, H. J. Winnett, J. F. Stevens, F. D. Crim, A. R. Mitchell, H. B. Lowry, William Green, W. M. Knapp, J. T. Hay and A. I. McKinnon.

This was the first year that a regular set of officers was elected. H. J. Winnett was chosen president: J. F. Stevens, vice-president; A. D. Wilkinson, secretary: H. M. Casebeer, treasurer; and L. G. Rhodes, J. R. Haggard and George H. Simmons on the executive committee.

On May 12, 1896, Dr. Inez Philbrick and Louise Smallwood McDonald, the best known women practitioners in Lincoln were admitted to membership. M. H. Garten was president that year. At the December 26, 1897 election, S. E. Cook was named president; A. I. McKinnon, vice-president; J. R. Haggard, secretary and William Greene, treasurer. Greene was president in 1898; A. D. Wilkinson in 1899 and since there is no record in 1900 of an election and Wilkinson was still in office in 1901, he must have held over. H. Winnett Orr was named president and Inez Philbrick, secretary, on December 19, 1901. Shortly after, the society reorganized according to the state plan and became the nucleus for the Lancaster County association.

\section{LANCASTER COUNTY MEDICAL SOCIETY}

While H. W. Orr was president of the Lincoln Medical Society in 1902, the group reorganized as the Lancaster County Medical Society and $\mathrm{O}$. W. Farnam was elected the first president. Through the efforts of J. C. Thompson, present secretary, and A. D. Munger, the following list of subsequent presidents was compiled:

1903 J. L. Green

1904 J. M. Mayhew

1905 A. I. McKinnon

1906 W. L. Dayton

1907 M. H. Everett

1908 H. H. Waite

1909 J A. D. Wilkinson
1910 J. T. Hay

1911 J. M. Mayhew

1912 O. W. Everett

1913 J. S. Welch

1914 H. J. Lehnhoff

1915 F. B. Hollenbecik

1916 W. L. Dayton 
1917 H. H. Everett

1918 R. B. Adams

1919 A. I. McKinnon

1920 H. E. Flansburg

1921 B. F. Bailey

1922 J. J. Hompes
1924 K. S. J. Hohlen

1925 D. C. Hilton

1926 F. F. Teal

1927 E. W. Rowe

1928 W. L. Curtis

Physicians registered in Lancaster County since 1881 include:

Charles M. Headrich

Samuel W. Thurber

Chas. Seymour Hart

Hettie Kersey Painter

Arthur Hosmer Bowen

Ruth M. Wood

Horace Chapin

William L. Dayton

Abraham L. Hoover

Luciss J. Bumstead

James Cotter

Wesley Queen

Mellvile Cox Keith

George W. Howard

Daniel H. Muir

Milton Lane

E. P. Childs

Frederick B. Righter

Albert Roscoe Mitchell

Wm. F. Myers

Jesse Holmes

James O. Carter

William Gibbon

Robert Lyon

Samuel C. Cooley

Richard S. Grimes

Nathaniel J. Beachley

Evert Jan Brethower

Harley P. Mathewson

Alfred Jackson Shaw

James C. Wm. Oviatt

Milton B. Deck

Minerva Lewis

James Vance Beghtol

John O'Herbin Mote

Augustus M. VanDerslice

John F. Wayman

James L. McKee

Byron Bennett Davis

Robert Peter

Orin Everett Mulmane

Francis M. Ackley

Stephen R. Blizzard

Franklin Spears

Edgar Loomis Holyoke

Wm. H Lincoln

Henry John Ruben

John W. Bowman

H. J. Winnett
Otto Hottelmann

Benjamin F. Vandolah

James B. Lumner

Wm. Wilson Ralston

Milo Leonard Kensington

Mary Alice Lutz

Sarah Elizabeth Green

James H. Woodward

Mary L. Blackman

Anne Burnet

Don Frank Morris

Charlotte Moore Norton

John Kinion Maxson

John O. Dawson

James E. Anderson

Redington Stanhope

Albert S. Fishblatt

William T. Mozee

Emerson K. Kellenberger

Elijah D. Buckner

P. W. Hayes

Benjamin B. Mozee

Austin D'Arcy Standish

Louis C. Long

Sophronia McC. Lane

James R. Haggard

Paul Stockfeld

Catherine Volkmann

Hannt Fredberg

Joseph DeG. McClane

Jerome Burt Tomblin

James Andrew Scott

Melchert H. Garten

Mrs. Rebecca A. Clark

Mary A. Howard

Wm. Preston Browne

James Erwin Reed

Stephen S. L. Morris

Cassins C. Kenny

Grant J. Ross

Ralph J. Bentley

Samuel E. Latta

Edwin Miles Butler

James Madison Wood

Hermann Andrew Fick

Otto H. Dogge

Isiah Ransom Cooke

George L. Jackson

William Story Latta
Joshua A. Kettring

Henry Clay Demaree

Lurton Franklin Polk

Leonard H. Robbins

Margaret Loomis Sabin

William Fulton

A. C. M. Smith

John T. Hay

Dugald C. Winship

Barlett Lewis Paine

John Wesley Stouffer

George A. Pogue

John J. Turner

Frederic Gurley Fuller

Edward Fiffin Piper

James D. Leslie

John H E. Huelff

Jonas Hoover

Stephen A. Mecham

Willis Peek Sperry

Harry Mervin Price

Charles P. Felshaw

Mary Mills Michael

Nathaniel Steel

Geo. E. Bragg

Hamilton B. Lowry

George H. Simmons

Eugent B. Appleget

Jacob Simonson

Charles L. Sturdevant

Jasper P. Norcross

William Protzman

William McC. Clark

J. Carl Krause

Nora Diamantenberg

Charles E. Spahn

John S. Gallison

Isaac Sinclair

Amon Thatcher Noe

Charles F. Goodell

Chas. G. A. Hullhorst

Thomas H. Lane

Allen P. Furgason

Johann Malok

Russell L. Moore

Wm. Henry Hatch

William Grieg

Sylvester D. Skidmore

J ulian E. Phinney 
Emilie Krause A. H. Dorris

John Sinclair Leonhardt Howard M. Casebeer

Katharine Brandt Wolfe Marija Van DeWege

John Jacob Siggins

Lyman White Soper

Ladislaus Slomanski

Hector Sinclair Alley

Dudley Carlton Spencer

Daniel Matson

James Green

Edwin Miller McGee

Peter H. Garretson

Louisa Boyer Smallwood

Alma J. Coe

Gertrude H. Trommholz

Chas. M. Williams

Frederick Burbank

Benjamin F. Lang

Milton Phillipi Guy

Jerome O. Everett

William Green

Lenore Perky

Louise A. W. Geoglein

Ernest A. Hancock

Hugh McGregor Willson

Alice Emily Huff

Thomas E. Hosman

Daniel D. O'Gorman

Jesse J. P. Marsh

G. Hial Peebles

Frederic L. Riser

L. G. Canfield

Franklin Collingswood

Charles T. Parker

James Seaton Kelso

Magntus Youngstedt

Herbert William Adams

Marshall B. Newhouse

T. H. Woodward

George R. W. Paugh

Frank Davis

William McGregor

Francis Andrew Graham

Everett B. Finney

William M. Bair

F. W. Tucker

Peter James

Orson W. Green

Benjamin Franklin Bailey

Thomas F. Butt

Morris Edward Jones

H. J. Rueb

Milton $\mathrm{H}$. Everett

J. Hamilton Gray

Aurelius P. Taylor

John Price Nelson

William Henry Dickee

John William Blizzard

Louis Was

Thomas Charles Fenton
Norman R. Hook

Thomas O'Connor

Oliver C. Link

Alexander C. Sabin

Louis Turner

Snyden R. Dalby

Henry C. Victor

J. M. Cunningham

James William Kessinger

Almer Lee Sabin

Anna Mary S. Potts

Joel Edward Walker

George Emory Andrews

Claudius B. Coleman

Charles B. Manning, Jr.

Andrezeja Nowickiyo

Robert Emmett Giffen

Arthur O'Leary

William Thomas Nichols Lucius J. Bumstead William Henry Snook

Joseph Sylvester Eaton

Augustus A. Tyler

Johanna M. Brandt

Benjamin F. French

Frank Dwight Crim

Morris M. Aaron

Benjamin F. Hart

Barbara F. Dougherty

Will K. Johnson

Belle R. Johnson

Charlotte M. Norton

Wm. Green

Wm. M. Knapp

Charles F. Ballard

John W. Hitchcock

Charles P. Hill

James Cotter

H. P. Lowry

John D. Hare

Uric D. Stone

A. P. Taylor

William S. Latta

Joseph S. Eaton

F. E. Stephens

C. C. Kenney

E. A. Collins

James L. McKee

G. B. Ward

Wm. D. Shields

Alma J. Coe

M. E. Jones

Edward H. Allen

Seymour Putnam

Howell B. Given

F. L. King

Inez C. Philbrick
W. L. Carlyle

W. L. Dayton

George A. McCandless

Wm. Tanner

James F. Stevens

T. M. Triplett

A. S. McKinnon

Ira G. Stone

M. H. Garten

Joseph Croggs

Sheldon E. Cook

Wm. H Johnson

Sarah L. K. Hovey

S. S. Skidmore

Wesley Queen

A. O. Faulkner

Stephen W. Jacobs

Thad $\mathrm{H}$. Woodward

Francis A. Graham

G. H. Peebles

F. D. Crain

Margaret E. Simmons

F. L. Riser

Benjamin J. Alexander

Richard S. Grimes

Chas. Edward Spahs

Chas. H. Sigler

J. O. Dawson

Everett B. Finney

Benjamin F. Bailey

Wm. Green

Ruth M. Wood

Frank Davis

Alice Huff Crandall

Lenore Perky

Samuel C. Cooley

L. C. Long

Milton B. Deck

C. A. Shoemaker

F. W. Tucher

Chas. G. Hullhorst

Jonas Hoover

G. M. Smith

Everet J. Brethower

H. C. Temaree

Milton Grey

John S. Leonhardt

J. C. Brubaker

Asbury N. Loper

Russell L. Moore

L. G. Rhodes

Marshal B. Newhouse

A. P. Furgason

Daniel Matson

Alvah H. Dorris

William G. Houtze

William Proutzman

T. J. Merryman

William H. Seip

William G. Houtz 
Charles Warren Dennis W. W. DeWolf

J. B. Imhoff

William W. Welch

Sidnar Morgan

Charles F. Collins

Charles H. Simmons

J. O. Carter

Geo. 0. W. Farnham

J. R. Haggard

C. A. Flippin

M. B. Flippin

J. Stewart McCullough

Thos. H. Lane

H. M. Casebeer

George O. W. Farhorn

William G. Safford

Margaret E. Simmons

A. D. Wilkinson

E. E. Faulkner

H. W. Rosensteel

Daniel D. O'Gorman

Lee W. Edwards

Hector S. Aley

Lafayette W. Blanchard

T. J. Mayers

Julius Martin McLeod

W. N. Ramey

Ralph L. Bentley

John T. Hoy

H. C. Manary

John A. Haggard

Hudson J. Winnett

P. R. Madden

R. D. Push

Benjamin F. West

J. F. Hackett

E. J. Angle

August Anderson

M. Minerva Newbecker

Douglas H. Roberts

Francis H. Young

James E. Waller

Charles Eugene Coffin

Luther J. Abbott

Clarence C. Drummond

J. K. L. Duncan

Chas. D. Chandler

H. H. Stretton

Robt. E. Fiffin

Henry E. Johnston

Marshall P. Ketchum

F. A. Snyder

Cornelius E. Sotterfield

Charles Gilchrist

E. Arthur Carr

Wm. S. Butterbaugh

I. C. Stephens

George W. Strough

Edward J. Cowles

R. N. Miller
Frank L. Searles

Libbie McNerny Searles

Emma M. Demaree

Joseph A. Vance

John P. Williams

Sarah A. Scott Hale

William T. Slone

William Curry

Barton Willard Johnson

F. S. McKibbin

William H. Dearing

Oren O'Neal

William $\mathrm{H}$. Loughridge

Alfred M. Browne

Hiram Winnet Orr

John M. Birkner

Samuel J. Smith

C. C. Moyer

David W. Reed

Eva A. Reed

C. C. Reynolds

Abraham Poska

J. L. Sturdevant

Milton Morrow

Anna M. L. Potts

Edward M. Sherman

James E. Hadley

Fletcher Gardner

William C. Cox

H. C. Mudding

Chas. A. Kenner

Austin R. Allen

Albert W. Kelley

Wm. E. Gassett

James Perry Romine

William F. Race

C. H. Temple

John Victor Beachley

Henry C. Williams

Isaac P. Sinclair

J. C. Masshart

May Louise Flanagan

H. B. Farnsworth

H. M. Earel

P. L. Moore

F. J. W. Stoney

Jay Boyd

Frank Earl Gordon

F. B. Hollenbeck

A. R. Waters

Mary E. B. Hutchinson

James B. Cole

Edgar Bigsby

Charles B. Hutchinson

Wm. Milliken

Chas. W. Little

John Demand

Albert D. Brewer

Elbert A. Hall
Catherine M. Bowers

Ralph M. Morrill

Andrew J. Baker

E. J. Austin

James D. Case

Emma Hoye

Samuel Methany

Roy H. Sawyer

Essie H. Boudurant

F. A. Lemar

Amy Robinson

Samuel J. Stuart

Chas. W. M. Paynter

Lyra H. George

Wm. A. George

Wm. H. Slattery

P. E. T. Anderson

F. L. Wilmeth

Wallace C. Davis

Josephus G. Bullett

Carrie S. Stowes

Howard E. Truex

J. A. Hodam

Joanna Disbro Crawford

Clarence R. Smith

M. U. Thomas

Walter L. Davis

Charles Milliken

Josephine Morelock

Evans M. Myers

Warren H. Sherman

Wm. Grant Bixler

John F. Spealman

William J. Adamson

C. DeWitt King

Geo, A, Droll

Geo. E. Spear

W. T. Torbitt

Harold B. Miller

Jacob B. Baruch

P. N. Fenger

David C. Hilton

Elight Treadgald

Laura J. Brown

Robert W. Hufman

Charles M. Swartz

C. A. Protzman

Edwin R. Vanderslice

W. M. Cowgill

Henry Campbell

Wm. J. Martin

W. J. James

Alva Wilson

Frederick Eiche

Lawrence B. Pilsbury

F. E. Falrymple

David G. Olson

Chas. W. Jester

William F. Dugan

Wm. T. Davis 
B. W. Ganoing Geo. H. Bentz Hiram R. Palmer L. A. Lansing Richard E. Howard A. L. Emery Chas. W. Little G. G. Douglas Lydia E. K. Parmele Thos. V. Davis Charles E. Drelup Huldah Davis Harold M. Brown Grove W. Bartlett Wm. J. Wells Louis I. Bogen C. H. Rush Oliver W. Everett Edwin R. Ryerson Isiah Irvin Omar Cox Hulda Davis Wesley G. Rickard J. Stanley Welch Androse N. Howley Edward T. Jones William M. Barrett William E. Chamberlain John F. Bradshaw

Earl E. Boyd

Seth L. Hubbard

George J. Goodsheller

Otto E. Longacre

Robert W. Reynolds Orville Rockwell Park A. Findley Amy R. Humphrey Roy O. Hummel James M. Kent Agnes H. Jones Ira E. Atkinson S. D. Henry Adolph B. Lindquist Ben W. Hensey Theo. Milen W. P. Mongtomery Almeron 0 . Skinner Rufus A. Lyman Ira K. Humphrey H. A. Abbott Harriet G. Hurtz Frank T. Wright Alfred C. Ames Wm. T. Putt Mabel Dunn Hubert H. Waite Lina M. Rosat Ambrose H. Hawley Charles C. Stivers Walter N. Ramey
Samuel Matheny

Henry P. Wekesser

Ernest F. Harrington

A. B. Morris

J. E. Brittan

Carl E. Herren

Joseph J. Hompes

Wm. H. Rupert

Geo. H. Walker

Martin F. Harman

Timion L. Taylor

James F, C. Kergan

Gustave A. DesJardien

Edward W. Rowe

George E. Seng

Harry A. Taylor

Harrison A. Longdon

James F. Stevens

Walter L. Albin

Alice W. Goldberry

Cecilia B. Riddell

Olle Olson

Daniel W. Thompson

Ernest J. C. Sword

Ada Platz

Clarence Rubendall

Vera M. Lee

Lazelle B. Stintevant

Wm. Wilte

Arthur B. Moss

Frank B, Ling

Francis F. Malone

R. O. Early

Lillian L. Snow

Harry H. Blodgett

Artie Folsom

Stacy B. Hall

Roscoe L. Smith

W. H. Garrison

Allan M. Lafferty

Willie Edgar Lamb

J. E. Morrill

Francis L. Borgliner

Milton G. E. Bennett

J. A. Philipson

Erasmus M. Hill

Dorotha T. Harbaugh

Bloom W. Ganoung

Carl D. Nelson

James Johnston Snipes

Wm. H. Wilson

Andrew Jackson Smith

William Henry Henschele George Dexter Hoschouer Laura Hunt

Irving Samuel Cutter

Timothy F. McCarthy

John W. Greenfield

Charles M. Duncan

L. R. Thornton
Roy B. Adams

Messiah Mesropian

D. W. Miller

George Harris Searcy

Samuel Metheny

Alphonse R. DesJardien

W. G. Griffith

Ira Hiram Lockwood

William Alfred Myers

William Clay Jones

Rea Buchanan

G. I. Reeves

H. S. Brevoort

Delbert J. Bowman

Fenton Noah Goodson

Edward Ramah Ryerson

Charles C. Aitken

Leopold Frankel

C. B. Edmunds

Roy William Davey

Chauncey F. Chapman

Alfred E. Reeves

Charles Archibald Walton

George M. Doran

William Willis Worster

Josiah Young

Arthur Andrew Smith

Frank P. Dwiggins

Karl S. J. Hohlen

Jay Daw Shively

Jesse Day Taylor

Wm. W. Claybaugh

Thomas H. Ashton

Nathan Oyler keynolds

Charles W. Thomas

William McIntyre

Charles William Parks

William S. Wiggins

Albert C. Colman

Clarence Emerson

Harry L. Mantor

John Waller Carrothers

Charles Percy Charlton

Harry Ernest Flansburg

Edward C. Hayman

Jesse Carl Cummings

Charles Harrison Arnold

Iven Jesperson

Lydie Jesperson

Chester Elmer Lewellan

William L. Cameron

George Wilson Pringle

Charles A. Shoemaker

Eva McGee Shiveley

Ralph Thomas Knight

Charles H. Beaver

Ward Willard Hedlund

Albert Lincoln French

Wm. Byron McCoy

Arthur Irving Lovell 
J. Beattie

John Henry Long Joseph Joseph Rizk Torrence C. Moyer Arthur B. Walker Miles John Breuer Frederick O. Buck Frederick M. Andrus Ernest Wilberforce J. K. EIms James MacWoodward George W. Covey Frederick F. Teal Frank Alonzo Wilmot Noah Hayes Clark Dwight Spivey Paul A. Royal Henry Benard Frosh John L. Thomas Sammie E. Bumford Elbert J. Latta William C. Colburn A. R. Mitchell Ernest Capek Harry Bohn Metheny Andros W. Hoyt Albert J. Boren M. Robert Byrnes James M. Thomson Hilborn C. Crabtree Margaret E. Hammond Isabel Proctor Mary B. Kirkwood Edmund M. Geesman Harry H. Stiles David D. Sanderson Henry S. Munro Edgar D. Cummins Elden Marshall Findley H. M. Bonniwell James A. Burford Carl Wagner Sherfey George Edward Mason Wilford H. Crutcher

A. B. George Carl H. Bastron Veteran Smith Barkey Arthur L. Smith James Franklin Johnston Charles Avery Hansen Lawrence T. Sidwell Walter T. Garfield F. B. Jehnson Jecrene Painter Ruth Ashley Warner Irvia C. Munger George W. Meredith Charles F. Stocker Miten F. Arnhett W. T. Mozec Stanley Gillium Zemer
L. Sidney B. Robinson

W. L, Curtis

Jerome G. Pace

J. D. Guttery

Eugene Miles Ryman

George Alvin Cassidy

Beverly A. Finkle

Philip H. Bartholomew

Edgar A. Pickens

Roland George Breuer

Clarence J. Rogers

Arbor Day Munger

Paul K. Howard

Charles W. W. Harms

Roy Crook

Earl Betheny

George McClare Cultrt

Czar C. Johnson

Wesley Charles Becker

J. F. Moell

Fred Ray Metheny

Frederick W. Shank

Truman Young Stelle

Horace Teal Haverstock

Nathan Hall Blakeley

Robert Charles Olney

James B. Williams

Jchn M. Neely. Jr.

Albert James Coats

Ira Ot is Church

Alma J. Chapman

Eugene E. Rider

Harris Carrahan Moore

Charles Oris Casey

William P. Hannicutt

Benn Eugent Nicola

Guy Virl Forney

Sidney O. Reese

Jchn Clark Thompson

John Clark Thomuson

Elizabeth Jameison Davis

Harold F. Morrison

Paul Block

H. B. Stapleton

I. Hugh Dillen

Irving W. Churchill

John W. Thompson

Laird W. Elwood

Matthitis Henry Horn

Edward J. Fleetwood

Leonard J. Ower

Freemsn E.

$$
\text { McCenoughes }
$$

Susan Wilson Ficla

James Orvil Murphy

Jeremiah C, Wilson

C. L. Fahnestock

Stanley Curtis Clements William Henry Clary Russell W. Johnson

F. D. Carpenter
Delmar Bryant Sollis

Ernest G. Jarmin

Charles S. Grabin

Catherine M. Goodson

Otto i. Asher

Earl B. Brooks

Aaron S. Peier

Williant A. Campbell

Leonard A. Swanson

John Julius Loom's

Warren Herbert Eller

Edwin Sartain Gault

Earl Neagley Deppen

Flovd Lesslie Rodgers

Burt Thomas Church

Percy Elmore Milbourne

Walter John Connor

Ernest Alfred Everett

Clayton F. Andrews

Edwin Adam Sommer

Geno. Ethel Beery

Cleveland James White

John Dudley Lutton

Harry Sophus Stahr

George Grassel McKhann

Everett Edward Angle

Glenn S. Everts

Frank Russell Anqurson

Royal Woods

Mabel A. Runyan

Jay Blaine Babcock

Albert Waite Bryan

Emmett C. Dolan

Alíred Edward Mailliard

Gecrge Everie Lewis

Virgil Sprague McDaniel

Alired Filder

George Stephen Johnson

W. H. Caulk

Clarence Elmer Frey

Hans B. Mueller

Larry Dewey Rider

Jcseph R. Cameron

Luther Vernon Gibson

J. Frank Atha

Gecrge Harold Misko

Charles Rollin Williams

Cecil Walker Dingman

James W. Thomas, Jr.

Ernest S. Wegner

Rcy Hcrbert Whitham

Zelimsnd E. Matheny

Raymond Brandt Kepner

Albert R. Hornbeck

F. A. Wells

Edwin Katskee

Samuel G. Panter

William E. Dickinson

Isobel C. McDonald

Edward H. Stahly

C. C. Drummond 
The Missouri Valley Medical Society was organized in Council Bluffs, September 27, 1888 by a group of eastern Nebraska and western Iowa physicians who, in their call to the first meeting, expressed the hope that the society "would be worthy of the two great states" it was to represent. J. M. Emmert of Atlantic, Iowa, father of Max Emmert of Omaha; J. C. Denise of Omaha and Donald Macrae of Council Bluffs, father of the present physician of this name, were the organization committee.

Macrae was elected temporary president; A. S. von Mansfelde of Ashland, secretary: L. A. Merriam of Omaha on the credentials committee.

Of the 75 charter members, the following were listed from Omaha, in addition to the above named: R. M. Stone, B. F. Crummer, J. S. Summers, Jr., A. F. Jonas, J. B. Ralph, D. C. Bryant, W. O. Bridges, C. M. G. Biart, Charles Rosewater, W. L. Ross, Fred K. Bacon, W. J Galbraith, W. F. Milroy, Ewing Brown, James H. Peabody, Joseph Neville, H. G. Gifford, C. P. Harrigan, P. S. Leisenring, A. B. Somers, L. A. Merriam, J. E. Noon, R. C. Moon, L. F. McKenna: and from South Omaha, W. F. Slabaugh, M, Kirkpatrick and William Berry.

The object of the society was "to foster, advance and disseminate medical knowledge, to uphold and maintain the dignity of the profession and encourage social and harmonious relations within the profession."

Donald Macrae was named first president; J. M. Emmert of Atlantic, first vice-president; J. C. Denise of Omaha, second vicepresident; James Carter of Omaha, secretary and T. B. Lacey of Council Bluffs, treasurer.

At this meeting the late B. F. Crummer of Omaha, father of Le Roy Crummer now practicing here, read a paper: "Foreign Body in the Rectum."

The next meeting was held December 20, 1888 when the following new members were added from Omaha: Eleanor S. Dailey, Mary Strong, E. O. Svenson, Solon R. Towne, George P. Wilkinson and W. P. Wilcox. The following papers were read by Omaha physi- 
cians: A. F. Jonas, "Etiology of Neoplasm," with case; J. E. Summers, Jr., "Extirpation of Tongue," with case; J. H. Peabody, "Diphtheria, Its Treatment by Turpentine," H. G. Gifford, "Treatment of Penetrating Wounds of the Eye."

The first meeting of the Missouri Valley association in Omaha, was the second annual meeting, September 19 and 20, 1889, in Metropolitan Hall. J. M. Emmert was elected president, P. S. Leisenring of Omaha and W. H. Hildreth, vice-presidents; James Carter was continued as secretary and T. B. Lacey, treasurer.

All the above facts were gleaned from a book of early minutes of the society now in the possession of the secretary, Earl C. Sage in Omaha. They are beautifully written, with pen, in the meticulous handwriting of the late James Carter, the first secretary.

The society flourished, conducting successful annual meetings until reorganized for better post-graduate study, at the last meeting held in Des Moines, Iowa, September 14, 1927. Headquarters were voted to be established in the Medical Arts Building in Omaha, with the idea of forming a clearing house for all medical matters in this vicinity. The 1928 meeting was held in Omaha in November.

Nebraska presidents of the organization since its inception include:

$\begin{array}{llll}\text { 1891-2 } & \text { Alexander S. von Mansfelde } & 1906 & \text { John E. Summers, Jr., Omaha } \\ & \text { Ashland } & 1908 & \text { W. F. Milroy, Omaha } \\ 1894 & \text { August F. Jonas, Omaha } & 1910 & \text { A. B. Somers, Omaha } \\ 1895 & \text { Ewing Brown, Omaha } & 1916 & \text { John P. Lord, Omaha } \\ 1897 & \text { H. B. Lowry, Lincoln } & 1918 & \text { A. I. McKinnon, Lincoln } \\ 1899 & \text { B. F. Crummer, Omaha } & 1921-2 & \text { W. O. Bridges, Omaha } \\ 1902 & \text { Richard C. Moore, Omaha } & 1924 & \text { H. J. Lehnhoff, Lincoln } \\ 1904 & \text { A. D. Wilkinson, Lincoln } & 1926 & \text { A. D. Dunn, Omaha }\end{array}$

\section{ELKHORN VALLEY MEDICAL SOCIETY}

The Elkhorn Valley Medical Society, composed of physicians practicing around Norfolk, was organized December 29, 1896, at the Oxnard Hotel. P. H. Salter of Norfolk and F. A. Long of Madison, who has been secretary of it many terms in the 30 years, were the organizers. Alexander Bear of Norfolk, pioneer physician of Elkhorn Valley, was the first president. He retired at the age of 70 when he became blind, and returned to the home of his early youth in Richmond, Virginia, where he died. 
Long, who was elected the first secretary, became the third president and Salter, the fifth president. Of late there has been a movement to amalgamate this organization with the Fourth Councillor district.

Present at the first meeting were Alexander Bear, George F. Keiper, W. H. H. Hagey, D. R. Daniels, F. A. Bryant, G. B. Richards, A. D. Tashjean and P. H. Salter of Norfolk; F. A. Long of Madison; W. T. Bason of Humphrey; E. W. Minton of Oakdale, J. O'Keefe and E. Tanner of Battle Creek; W. F. Conwell of Neligh, William C. Campbell of Creighton; B. F. Gay and I. M. Alden of Pierce; R. J. Chrystal of Osmond: William Corgum of Newman Grove: A. E. Scofield of Tilden and W. O. Lea of Hoskins.

Dr. Bear called the meeting to order in the dual capacity of the oldest practitioner in the Elkhorn Valley, and mayor of Norfolk. He was elected temporary chairman and F. A. Long of Madison, secretary. Constitution and by-laws were presented and the following physicians, unable to attend, were elected to membership: Charles Inches of Scribner; H. G. Leisenring of Wayne; F. H. Nye of Plainview: T. E. Stack, Humphrey and J. A. Clark, Albion.

Dr. Bear was elected president for the ensuing year; J. M. Alden, vice-president: P. H. Salter, second vice-president; F. A. Leng, secretary and G. B. Richards, treasurer. Other presidents to date have been:

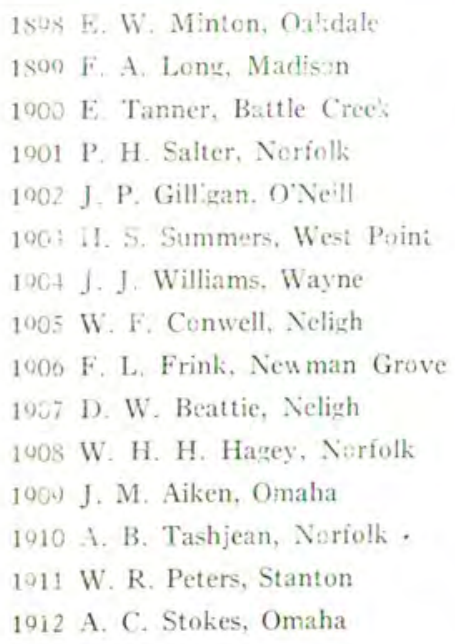

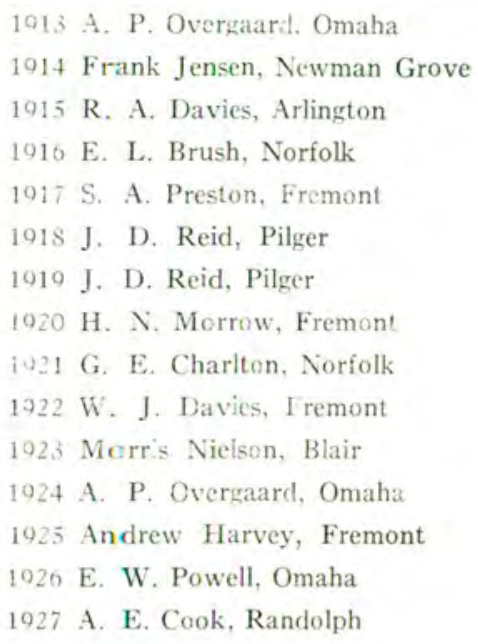


In response to a call issued by Dr. C. E. Coffin of North Loup, the following physicians met at the office of Dr. F. D. Haldeman, Ord, Nebraska, on December 14, 1892: Coffin, Eugene Thurston, Neal Cameron, Daniel R. Lee, J. B. Waynick, F. D. Haldeman and A. E. Bartoo of Arcadia. Coffin briefly stated the objects and benefits of an organization of Loup Valley physicians, in which all concurred. Coffin was named temporary president and Haldeman, secretary. Membership fees and quarterly meetings were decided. Election of officers for the ensuing year was as follows: President, C. E. Coffin; vice-presidents, N. Cameron and J. B. Waynick; secretary, A. E. Bartoo; treasurer, D. R. Lee. Dr. Cameron read an original paper "Antiseptic Obstetrics in the West."

\section{REPUBLICAN VALLEY ASSOCIATION}

The old Republican Valley Association, organized more than 20 years ago, recently changed its name to the Tenth Councillor District of the Nebraska State Medical Association. It performed a useful function in the southwestern part of the state. J. V. Beghtol was an early president and served again in 1925, when the annual meeting was held in Hastings. L. F. Egan and J. M. Willis of McCook and L. W. Rork of Hastings are among the active members and ex-presidents.

\section{NEBRASKA STATE HOMEOPATHIC MEDICAL SOCIETY}

|Compiler's note: Much of the following data was collected by Dr.W. H. Hanchett and printed in the Magazine of Western History in 1889; and Sarage and Bell's History of Nebraska in 1894.1

Organization of the Nebraska State Homeopathic Society was perfected in Lincoln, September 2, 1873 by the election of E. T. M. Hurlbut as president; A. S. Wright of Omaha and J. H. Way, vicepresidents; A. C. Cowperthwait, secretary: O. S. Wood, treasurer; and W. A. Burr, Way, D. H. Casley, Emlen Lewis and Wright as a board of censors.

The next meeting was held in Omaha, June 19, 1874 when all officers were re-elected, except that Lewis and H. S. Knowles replaced Way and Wright, as vice-presidents. 
Wright, who came to Omaha in 1862 from Indianapolis, is credited with introducing homeopathy in Nebraska, and urging the formation of the state society. He established a fine practice in Omaha, then the capital with a population of 2,500 ; bought considerable property and remained there until 1874 , when he moved to California.

Nebraska City was host for the next meeting, May 18, 1875, when O. S. Wood was elected president. The next five annual sessions convened in Omaha and the presidents were, successively, Drs. Cowperthwait, C. L. Hart and B. L. Paine.

Subsequent meetings were held (except one, that of May, 1884, in Omaha) in Lincoln with the following presidents, in turn: Chas. M. Dinsmoor, Carscadden, A. R. Van Sickle, F. B. Righter, C. L. Hart and J. H. Gray.

A record of the year 1894 reveals W. H. Hanchett of Omaha as state president; W. A. Humphrey of Plattsmouth, vice-president; Willis Buck of Minden, secretary and O. S. Wood of Omaha, treasurer.

Omaha too had a successful local society, that year, of which the officers were C. G. Sprague, G. H. Parsell, Freda Lankton and D. A. Foote.

Besides the Nebraska State Homeopathic Society, there was another - the Northwestern Homeopathic Medical Association, composed of eastern Nebraska and western Iowa practitioners, organized at Council Bluffs in 1877 by W. D. Stillman, of Council Bluffs, P. W. Poulson, T. A. Bragg, A. C. Cowperthwait and B. L. Paine of Lincoln and C. L. Hart of Omaha. The second meeting, the following year, was held at Lincoln and Dr. Paine was elected vice-president.

Wright was the sole homeopathist in Omaha until 1868 when Dr. W. H. H. Sisson of New Bedford, Massachusetts, and O. S. Wood of Philadelphia, later one of the most prominent practitioners here, arrived. Sisson died in 1873. Drs. W. J. Earhart and Marsden, partners, came here from Philadelphia in 1869 but did not remain long. Earhart went on to Fremont and Marsden, back east. 
Dr. F. Saxenberger was here from 1871 to 1874 . In October, 1872 , D. E. F. Hoyt arrived from Grand Rapids, Michigan, practiced with Wood for a time; then went to New York. When Sisson died, January 25, 1873, his pupil, Emlin Lewis of Papillion took over his practice for two years, then moved to Iowa.

James M. Borglum, father of the world-famous sculptors, Gutzon and Solon Borglum, came next

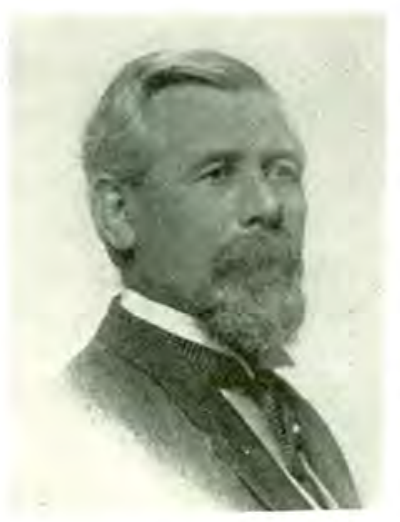

J. M. BORGLUM in 1874, practiced at Fremont for awhile, he and Earhart exchanging places, then returned to Omaha. Borglum was a student with Sisson at the Hahnemann College in St. Louis. Earhart afterward returned to Philadelphia. Dr. H. C. Jesson of Chicago was here for two years, 1875-1877; Dr. H. S. Worley of Davenport from 1875 to 1879 ; and C. M. Dinsmoor arrived from Missouri in March, 1878. He opened a sanitarium here the same year and became most active in promoting the interests of homeopathy in the medical legislation of the day.

In the spring of 1879 John Ahmanson, for many years one of Omaha's business men and an ex-member of the Nebraska legislature, finished at the Hahnemann Medical College in Chicago and in April, established himself in Omaha. Dr. Willis B. Gifford of Attica, New York, came to Omaha August, 1880 and entered into a partnership, previously arranged, with Dr. Dinsmoor. He remained only until the next February, when he returned to Attica.

Very early in 1880 , Dr. C. S. Hart moved here from Onawa, Iowa. June 12 he and Dr. Wood formed a partnership for a few months but they separated by mutual consent and Dr. Hart opened another office. March, 1881 brought Dr. G. H. Parsell from Weedsport, New York. In 1882, Dr. Francis M. W. Jackson and Dr. E. Stillman and D. B. Spencer came but remained only a year.

In February, 1883, Dr. Amelia Burroughs moved over from Council Bluffs where she had been in practice for a year or so. Dr. W. H. Hanchett, fresh from Hahnemann College, Chicago, also came at the same time. In July, 1883, Dr. J. M. Borglum moved back 
from Fremont, remaining until the spring of 1885, when he moved to California. The following October he returned.

In the winter of 1883-1884, Dr. P. W. Poulson of Council Bluffs opened an office with Borglum and practiced in both cities for a short time.

Dr. Ralph W. Connell, later health commissioner of Omaha, began the practice of medicine in April, 1884. Dr. H. S. Knowles from Avoca, Iowa, came about the same time, remained a year or two and went on to California. In June, H. A. Worley returned from Davenport, Iowa, and went into partnership with Dr. Dinsmoor for a year. Then Worley established his own office. In October, Dr. C. C. Sprague of Elizabeth, New Jersey, who had been in Ogden, Utah, for a short time, bought out Dr. C. L. Hart's practice, when the latter moved to Grand Island. Hart remained there until 1889, when he returned to Omaha to look after his real estate interests, not to practice.

Dr. Mary J. Breckenridge settled in Omaha, December 1, 1884. Wm. H. Parsons of Glenwood, Iowa, came in October, 1885 and in 1886 there came Dr. E. T. Allen, eye and ear surgeon; Dr. Emma J. Davies, of Hahnemann College and Dr. G. W. Williams of Marshalltown, Iowa. On Sunday morning, December 16, 1888, Dr. Williams was found dead in his office in the Arlington Block.

Some time in the same year, 1886, Dr. C. W. Hayes came also from Marshalltown. On account of poor health, he engaged in real estate business in 1887, hung out his shingle again. Dr. C. M. Campbell arrived in 1887, as did Dr. J. W. Narnsdall, and Dr. E. L. Alexander of Guthrie Center, Iowa. In February, 1888, Dr. J. P. Hanchett, also of Hahnemann College, formed a partnership with his brother, Dr. W. H. Hanchett but it lasted only till the end of the year, when J. P. Hanchett left the city.

In March, Dr. H. B. Davies, mother of Emma J. Davies, moved up from Nebraska City and joined her daughter in partnership.

Another woman physician, Dr. Freda M. Lankton, graduate of Iowa State University at Iowa City, joined her former preceptor, Mrs. Burroughs, in May, 1888.

August 13, that year, Dr. Dinsmoor formed a partnership with Dr. W. A. Humphrey of Wahoo. Dr. W. G. Willard and Dr. D. A. Foote both arrived in November that year and opened offices. 
A flourishing eclectic society, in which F. L. Wilmeth and Samuel Metheny of Lincoln and E. T. McGuire of Meade were active, and contemporary with the homeopathic society, disbanded several years ago and the old records cannot be traced. Five years ago, a reorganization took place, sponsored by the younger men who had some interest in Eclectic Medicine, and was backed and joined by the older men, many of them former members of the original society.

"Most of the younger men who now belong are also members of the Nebraska State Medical Association," C. Elmer Frey of Lincoln, retiring 1927 secretary of the Eclectic society explains, "and have no antagonism nor opposition to the so-called regular school. We do, however, believe that there is much of value in the Eclectic practice, or rather in the Eclectic materia medica and, therefore, believe that it is worth while for us to maintain this additional organization of those who have some mutual views and interests in this line.

"The purpose of the present organization is to further study and investigate principally, the native plant remedies and to place their use on a sound, scientific basis; also for the mutual social benefit to be derived. For this purpose meetings are held once yearly. There are 154 actively practicing Eclectic physicians in Nebraska (possibly more of whom I do not know)."

The president is E. T. McGuire of Meade, Nebraska. Before the present officers were elected, Harry W. McFadden of Greenwood was president and Fred Metheny of Lincoln was secretary. Annual meetings are usually held in Lincoln in May. In 1927 the headquarters were in the Cornhusker Hotel and about 50 attended.

\section{NEBRASKA STATE MEDICAL LEAGUE}

A Nebraska State Medical League, an organization separate from the state medical society, was formed during the '90s, to carry on necessary propaganda and lobbying for medical legislation, a feature of this decade. John W. Bullard was at one time the president.

The work of the league was probably later assumed by the Medico-Legal Defense Committee of the state society, under the able 
direction for many years of A. S. von Mansfelde of Ashland. B. B. Davis also served on this committee. R. W. Fouts of Omaha now heads the medico-legal defense work, to carry on which service each member of the state association contributes two dollars a year.

DOUGLAS COUNTY MEDICO-LEGAL ASSOCIATION

The Douglas County Medico-Legal Association was organized in Omaha on July 31, 1891. The officers of the association were: president, Dr. Joseph Neville; vice-president, Dr. E. E. Womersley; secretary, Dr. George Wilkinson; treasurer, Dr. C. G. Sprague.

This association was not intended to take the place of the authorities established by the new law for its enforcement, but only to second their efforts. Shortly before the enactment of the new law, a strong effort had been made by the Omaha Medical Society to enforce the then existing law of 1881 and 1883. It was the special design to ascertain, by its practical application, wherein this law was defective. The result of this effort was that many of the quacks were driven from the State; and yet many points were discovered at which there was great room for improvement in the laws. After the organization of the medico-legal association, the work of the Omaha Medical Society in this direction received the attention of the former organization. It was through its agency that proofs were furnished and prosecutions carried to successful issue in Omaha, and the army of quacks completely routed. Mere show of force was in many cases enough, but others fought it out and were defeated.

\section{AMERICAN COLLEGE OF PHYSICAL THERAPY}

Organized in Omaha in 1921 as the Inter-state Physiotherapy Society, with membership in several nearby states, the American College of Physical Therapy is today a rapidly growing international organization with members in Australia, South America, Canada, Cuba, the Philippines and several European countries. C. L. Mullins of Broken Bow, Nebraska, was the first president and Roy W. Fouts of Omaha, the first secretary-treasurer. A. F. Tyler, Fouts and T. T. Harris, all of Omaha, were appointed to draft a constitution for adoption at the next annual meeting. This was held in Omaha in September, 1922, when the proposed constitution was adopted with a change in the name of the association to "American College of 
Physiotherapy." The present name was decided at the 1926 meeting held in Chicago.

Among the purposes of the society are: to alleviate suffering and prolong human life through the study, promotion and scientific development of physical therapy; to sponsor and finance scientific research: to promote a registry of technicians and to conduct schools or colleges for those desiring further study in this subject.

Mullins and Fouts were re-elected

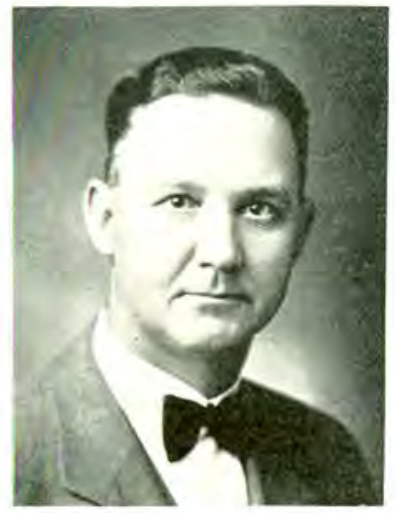

ROY W. FOUTS for the second year, with the addition of F. H. McCabe of Cambridge, Nebraska, as vice-president. Fouts has been continued as secretary ever since. The 1924 efficers included: S. B. Childs of Denver, president; Edwin A. Merritt of Washington, D. C., president-elect; B. B. Grover of Colorado Springs, vicepresident, and R. W. Fouts of Omaha, secretary. Curran Pope of Louisville, Kentucky was elected president in 1925; John Stanley Coulter of Chicago, president-elect; Harry Eaton Stewart of New Haven, Connecticut, first vice-president W. Scott Keyting of Salt Lake City, Utah, second vice-president; Disraeli Kobak of Chicago, third, and Warren B. Chapman of Carthage, Missouri, fourth vice-presidents. Edwin C. Henry of Omaha was named treasurer.

At the 1926 meeting held in Chicago, John Stanley Coulter was president; Disraeli Kobak, president-elect; J. C. Elsom of Madison, Wisconsin, Frank Walke of Shreveport, Louisiana, Arthur E. Joslyn of Lynn, Massachusetts and Fred B. Moor of Loma Linda, California, vice-presidents and E. C. Henry of Omaha was re-elected treasurer. The 1927 officers were Disraeli Kobak, president; J. C. Elsom, president-elect; F. H. Walke, Norman E. Titus of New York J. U. Giesy of Salt Lake City and F. J. Novak of Chicago, vice-presidents; and John Stanley Coulter of Chicago, treasurer. At the sixth annual meeting, held in Chicago last fall, J. C. Elsom of the University of Wisconsin, at Madison, presided. Frank Walke of Shreveport, Louisiana, was named president-elect; Norman E. Titus of New York, J. U. Giesy of Salt Lake, F. H. Ewerhardt of St. 
Louis and A. E. Schiller of Detroit, vice-presidents and Fouts of Omaha and Coulter of Chicago were re-elected secretary and treasurer.

Archives of Physical Therapy, X-Ray, Radium, the nat:onal publication of the society, is printed in Omaha under the direction of Albert F. Tyler, managing editor, as indicated in the Chapter on Publications. The publication committee includes Kobak, Roswell T. Pettit, A. R. Hollender of Chicago, A. David Willmoth of Louisville, Kentucky, and Tyler of Omaha.

AMERICAN SOCIETY FOR THE CONTROL OF CANCER, NEBRASKA SECTION

Since its national organization in Washington, D. C., Dr. Palmer Findley of Cmaha has headed the Nebraska section of the American Society for the Control of Cancer, and has directed the educational work of the organization in this state. The executive committee working with him includes Drs. Max Emmert, Albert F. Tyler, D. T. Quigley and J. M. Banister in Omaha; J. Stanley Welch in Lincoln; B. R. McGrath in Grand Island; C. E. Slagle in Alliance and F. H. Morrow in Columbus.

In addition to this committee, practically the whole medical profession in the state is lined up in this fight, with representatives in practically every county and town.

\section{COILEGE OF SURGEONS}

Nebraska section, American College of Surgeons, is the only such formal state organization in the country. Other Fellows of the American College of Surgeons hold membership merely in the national.

The Nebraska section was organized February 18, 1924, in Omaha, largely through the efforts of Max Emmert and William L. Shearer. August F Jonas of Omaha was the first president; J. Stanley Welch of Lincoln, vice-president; W. L. Shearer of Omaha, secretary-treasurer, an office he still retains; and councillors, P. H. Salter of Norfolk; C. A. Allenberger of Columbus; Max Emmert of Omaha; F. B. Hollenbeck of Lincoln; Delmar Davis of Omaha and $\mathrm{H}$. Winnett Orr of Lincoln. 
One of its most important functions is to gather information about Nebraska hospitals for the national organization, which sets the standards for hospital classification.

The same officers were retained for 1925. In 1926, Welch succeeded to the presidency; Allenberger was made vice-pnesident and Welch and Emmert named councillors. The 1927 officers include Allenberger, president; K. S. J. Hohlen of Lincoln, vice-president; J. E. M. Thomson of Lincoln and B. R. McGrath of Grand Island.

K. S. J. Hohlen of Lincoln was elected president at the fifth annuel meeting held in Hastings, in May, 1928. Max Emmert of Omaha was named vice-president; William L. Shearer, Omaha, secretary-treasurer; and James M. Patton of Omaha and George Dent of North Platte, councillors for three years.

Nebraska members of American College of Surgeons include:

\section{Alliance}

Charles Eyster Slagle

\section{Aurora}

Donald B. Steenburg

\section{Beatrice}

Harry M. Hepperlen

\section{Columbus}

Christian Alexander Allenburger

Charles H. Campbell

Carroll D. Evans

William S. Evans

Frank H. Morrow

David City

Harry Edwin Burdick

Charles Edward Palmer

\section{Fairbury}

Albert Lynch

Grand Island

Earl George Johnson

Benjamin R. McGrath

\section{Hastings}

Charles L. Egbert

Arthur Andrew Smith

\section{Kearney}

William B. Banister

Charles H. Fox

Lester M. Stearns

\section{Lincoln}

Clayton Farrington Andrews

Paul Black

Earl B. Brooks

Wesley L. Curtis

Clarence Emerson

Harry Harding Everett

Everett B, Finney

C. C. Hickman

David Clark Hilton

Karl Siegfried J. Hohlen

Frank Bradbury Hollenbeck

Joseph J. Hompes

Czar Clinton Johnson

Artemas I. McKinnon

Albert Roscoe Mitchell

Arbor D. Munger

H. Winnett Orr

Frederick F. Teal

James E. M. Thomson

J. Stanley Welch

McCook

James M. Willis

Madison

Francis A. Long

Minden

Harry Hapeman 


\author{
Norfolk \\ Edward Lewis Brush \\ Stuart Avery Campbell \\ Peter Harold Salter \\ North Platte \\ George B. Dent \\ Omaha \\ Jehn Monro Banister \\ Alfred Brown \\ Louis B. Bushman \\ William F. Callfas \\ Byron B. Davis \\ Edwin Davis \\ John W. Duncan \\ Max Emmert \\ Palmer Findley \\ Dellizon A. Foote \\ Harold Gifford \\ Sanford R. Gifford \\ Herschel P. Hamilton \\ William Porter Haney \\ Samuel R. Hopkins \\ Charles A. Hull \\ Charles S. James \\ August F. Jonas \\ Charles R. Kennedy \\ J. Frederick Langdon \\ Henry B. Lemere
}

J P. Lord

Ralph Luikart

Charles McMartin

Harry C. Miller

Louis Edwin Moon

John Rudolph Nillsson

Frank S. Owen

James M. Patton

John Beekman Potts

Daniel T. Quigley

Charles O. Rich

Clyde Augustus Roeder

Earl Cuddington Sage

William Lete Shearer

George F. Simanek

Arthur Charles Stokes

John E. Summers

Herbert C. Sumney

Claude T. Uren

Chester H. Waters

William P. Wherry

Sidney

Hugh E. Mantor

Superior

Charles Gilbert McMahon

Tekamah

Isaiah Lukens

AMERICAN COLLEGE OF PHYSICIANS, NEBRASKA SECTION

The Nebraska section of the American College of Physicians, of which Adolph Sachs of Omaha is governor, is an honorary society, corresponding in ideals and requirements with the American College of Surgeons. It was organized in 1915 to (1) uphold and maintain high standards in medical education and practice; (2) encourage research, especially in clinical medicine; (3) foster measures for the prevention of disease and for improving public health; (4) perpetuate the history and best traditions of medicine and to maintain the dignity of the profession in its relationship with patients.

Members in this state include:

\author{
Beatrice \\ James Clyde Waddell \\ Genoa \\ Homer Davis \\ Lincoln
}

\author{
Miles J. Breuer \\ John Mills Mayhew \\ Arthur Lawrence Smith \\ Edmund G. Zimmerer
}




\section{Omaha}

Julian R. Blackman

Rodney W. Bliss

Burton W. Christie

Floyd S. Clarke

Frank M. Conlin

LeRoy Crummer

Gustave W. Dishong

Arthur D. Dunn
Francis W, Heagey

H M. McClanahan

William F. Milroy

Goorge E. Neuhaus

George P. Pratt

Bryan M. Riley

Adolph Sachs

thliert F. Tyler

\section{NEBRASKA-IOWA PEDIATRIC SOCIETY}

The first organization of pediatricians in the state was effected in about 1916 with H. M. McClanahan, dean of children's specialists as president, and continued until about five years ago, when it ceased to function. Last fall, the society was re-organized as the Nebraska-Iowa Pediatric Society and has about twenty members. Floyd S. Clarke is president; H. B. Hamilton, vice-president and R. B. Eldredge, secretary-treasurer. Omaha members include Clarence F. and Elmer Bantin, Andrew Dow, J. A. Henske, J. C. Iwerson, Herman Jahr, H. M. McClanahan, Clyde Moore, William Berry and George Clark: J. V. Treynor of Council Bluffs, E, R. Hayes of Falls City; W. O. Colburn, E. V. Wedeman and Wegner of Lincoln.

Meetings, with scientific programs, are held once a month.

FOR EYE, EAR, NOSE AND THROAT SPECIALISTS

Three of these special societies claim Nebraska members. They are the Omaha-Council Bluffs Ophthalmological Society, the Nebraska Academy of Ophthalmology and Oto-Laryngology, and the American Academy of Oto-Laryngology.

\section{UNIVERSITY MEDICAL SOCIETY OF LINCOLN}

To promote the interests of the medical profession (really the students) at the University of Nebraska, in 1894, J. P. Rowe called a meeting to order April 16. W. C. Hall was named temporary chairman and J. W. Funk, clerk. A second meeting, when formal organization was effected, took place April 26. J. P. Rowe was elected president; Miss R. Corr, vice-president; H. Winnett Orr, secretary and Miss Anna Fossler, treasurer. 
At the next meeting, June 8, the club voted to appoint a committee to interview the chancellor with respect to introducing a course in physiology the next year.

Charter members of this organization, which continued for some time were Will C. Hall, R. Corr, H. Winnett Orr, George A. Flippin, Mary Horne, Ira L. Riggs, G. B. Ira, Vernon Craig, Alfred O. Peterson, H. H. Everett, J. P. Rowe, J.W. Funk, Anna Fossler, Belle Beachley, T. J. Kemp, Mae Rhodes, Charles H. Platz, R. L. Meier, H. B. Hubbard, Sherman A. White and F. S. Culver.

In 1897 another student organization, called Nu-meds, was organized on the Lincoln campus.

\section{LINCOLN PATHOLOGICAL CLUB}

The Lincoln Pathological Club was organized at the University of Nebraska College of Medicine, then at Lincoln, in 1908-1909. C. W. M. Poynter was the first president; A. E. Guenther, secretary; and R. G. Clapp, treasurer. Members who read papers that year were H.Winnett Orr, H. H. Waite, H. J. Lehnhoff, Dean Henry B. Ward, A. E. Guenther, J. M. Mayhew, H. H. Everett, W. A. Willard, R. A. Lyman, Pilsbury, R. H. Wolcott, J. Stanley Welch, F. D. Barker, Paul G. Woolley and A. C. Stokes.

\section{OMAHA PATHOLOGICAL AND SANITARY SOCIETY}

This society was organized in 1876 by Dr. H. P. Mathewson, who afterward moved to Lincoln; A. A. Parker, Victor Coffman, William McClelland, R. C. Moore and William Arnold. Mathewson was the first president; Parker, secretary and Moore, treasurer. Meetings were held every Monday night. The organization was still flourishing in 1882 when Dr. Moore was president, Jacob C. Denise, treasurer and Parker, still secretary.

\section{ACADEMY OF MEDICINE AND SURGERY}

This society was organized October 22, 1881, for the purpose of hearing professional papers from members every week. Papers were limited from 30 to 60 minutes. Membership included L. A. Merriam, Joseph Neville, L. B. Graddy, Paul Grossman, H. W. Hyde and R. M. Stone. 
OMAHA MICROSCOPIC SOCIETY

The Omaha Microscopic Society was formed in April, 1892, by Prof. W. R. Lighton, Prof. Leviston and Dr. George Wilkinson, secretary, according to a report in the Omaha Clinic of that month. Its membership of 30 consisted almost entirely of physicians. Its object was perfecting members in the use of the microscope in the study of normal and diseased structures, in connection with the practice of medicine.

\section{OMAHA SURGICAL CLUB}

At the suggestion of Dr. Max Emmert, a group of surgeons including William L. Shearer, Palmer Findley, Delmar L. Davis, now in California, Chester Waters and Robert D. Schrock met with Emmert about the middle of October, 1922, to discuss the organization of the Omaha Surgical Club.

Palmer Findley was elected president pro tem at a meeting held December 7. Emmert was named vice-president and W. L. Shearer, secretary-treasurer, an office he still retains. At this meeting it was decided to invite the following surgeons to join, membership being limited to 20: C. A. Roeder, C. A. Hull, L. E. Woon, J. J. Keegan, J. P. Lord, J. E. Summers, B. B. Davis, A. F. Jonas, Karl Connell, C. R. Kennedy and W. E. Wolcott.

The next year Emmert was named president and B. B. Davis, vice-president; in 1924 B. B. Davis and J. P. Lord succeeded them; and in $1925 \mathrm{~J}$. P. Lord and J. W. Duncan were elected for these offices. This set of officers is still serving, since few meetings have been held of late.

Present membership includes: Alfred J. Brown, B. B. Davis, J. W. Duncan, Max Emmert, Palmer Findley, C. A. Hull, A. F. Jonas, J. Jay Keegan, C. R. Kennedy, J. P. Lord, L. E. Moon, C. O. Roeder, C. O. Rich, R. D. Schrock, W. L. Shearer, C. H. Waters, J. E. Summers, Edwin Davis, Herbert Davis and J. F. Langdon.

OMAHA X-RAY SOCIETY

The Omaah X-Ray Society was organized in 1907 by a group of pioneer specialists in this branch, including Dr. H. P. Jensen, who 
had shortly before returned from Europe where he obtained the first radium for medical use in Nebraska; J. P. Lord, R. D. Mason, W. H. Mick, W. L. Ross and A. F. Tyler. Either Jensen or Mason was elected president (memories differ as to the first official); but Ross was elected secretary and continued in this post until two years ago, when he was succeeded by Dr. James F. Kelly, the present secretary. Dr. Tyler served as president for three terms and W. L. Ross is now in office.

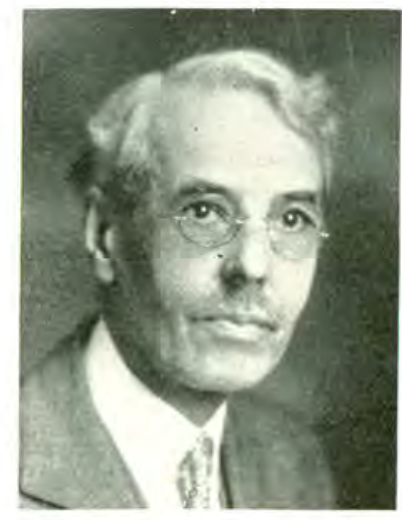

W. L. ROSS, SR.

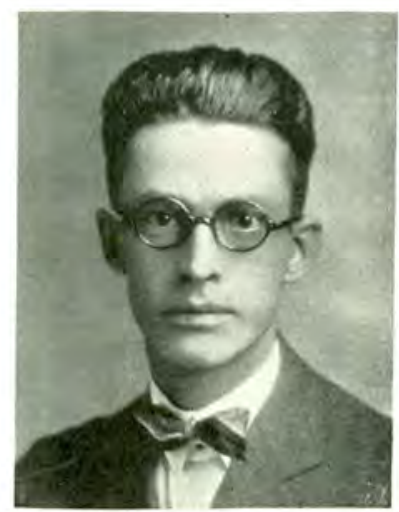

W. L. ROSS, JR.

A state organization, the Nebraska Radiological Society, was organized in Dr. Ross' office in 1924, with Roscoe L. Smith of Lincoln as president and R. W. Fouts of Omaha, secretary. It was active for two years but is now dormant.

\section{AMERICAN SURGICAL ASSOCIATION}

Three Omaha surgeons, Alfred Brown, A. F. Jonas and J. E. Summers, are the only Nebraskans who hold membership in the American Surgical Association, composed of 150 of the leading surgeons in the United States and Canada.

\section{NEBRASKA TUBERCULOSIS ASSOCIATION}

Shortly after the national association was formed in 1905, Dr. Solon R. Towne, former state health worker, interested a group of Omaha Woman's Club members, including Mrs. Draper Smith and Mrs. K. R. J. Edholm, in the effort to eradicate tuberculosis through 
a system of education. The Nebraska unit incorporated in 1908, held various exhibits and put on an annual Christmas seal sale but it was not until the year of the war, 1917-1918, that a downtown office was engaged and the work put on a permanent basis. Miss Alice Marshall is the office secretary. Dr. Towne has long been president of the organization; Dr. William N. Anderson, vice-president; Thomas C. Woods of Lincoln, second vice-president; Dr. F. W. Heagey, secretary and C. J. Claassen, treasurer. Dr. A. D. Cloyd and Mrs. H. C. Sumney, wife of Dr. Sumney and Mrs. F. W. Carmichael, Red Cross worker, are on the executive committee.

WOMEN'S AUXILIARY TO THE NEBRASKA STATE MEDICAL ASSOCIATION

Through an invitation extended in the State Medical Journal in April, 1925, a large number of Nebraska doctors' wives met at luncheon at the Lincoln Country Club, May 13 to discuss the forma-

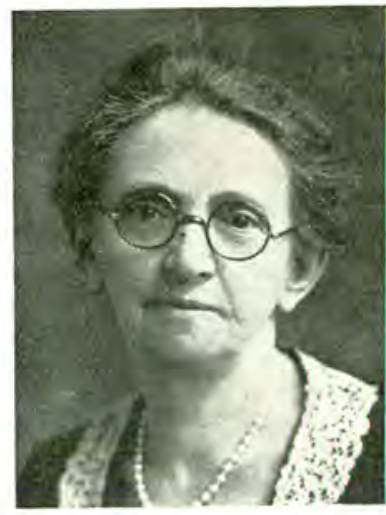

MRS. F. A. LONG tion of an auxiliary to the state medical association. Mrs. J. E. M. Thomsen of Lincoln called the meeting to order. Mrs. E. W. Rowe of Lincoln was named secretary pro tem. After voting to organize, Mrs. F. A. Long of Madison, wife of the editor of The Journal, was named president and Mrs. Clarence Rubendall of Omaha, secretary-treasurer. Mrs. J. P .Lord of Omaha was appointed to represent the new organization at the American Medical Association Auxiliary meeting in Atlantic City in June.

A membership drive in October, conducted in each county, brought in 225 members. Three county organizations have since been formed and several are in the process of organization, although memberships are held by women in at least 25 counties.

Mrs. W. R. Boyer is president and Mrs. Byford Anderson, secretary of the Pawnee County club. Mrs. H. L. Kindred of Meadow Grove heads and-Mrs. Perry Allerton of Tilden is secretary of a group which includes Madison, Stanton, Antelope and Pierce Counties. 
An Omaha-Douglas County organization was effected at a meeting in the new Medical Arts building auditorium, April 21, 1927, preliminary to the state convention in May. Mrs. A. P. Overgaard was elected the first president; Mrs. Frank Conlin, wife of the county society president at that time, honorary vice-president; Mrs. H. C. Sumney, vice-president; and Mrs. A. F.

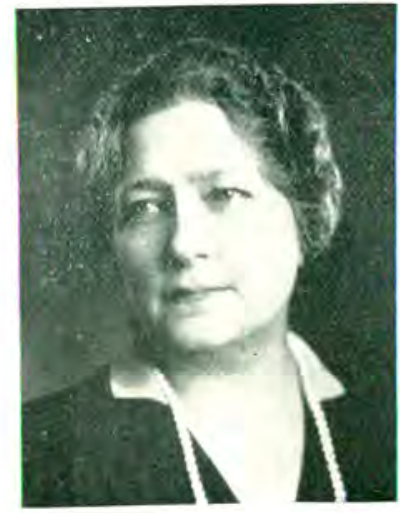

MRS. H. C. SUMNEY Tyler, secretary-treasurer. Directors chosen were Mesdames William L. Shearer, George E. Neuhaus, John Allen and A. S. Pinto. The 1928 officers include Mrs. H. C. Sumney, president; Mrs. B. B. Davis, vice-president; and Mrs. J. Harry Murphy, secretary-treasurer. Mrs. J. J. Keegan and Mrs. Clarence Rubendall are directors. This auxiliary takes part in the annual Needlework Guild activity; has offered its services in the diphtheria education program and helps entertain women visitors to the state meetings.

Officers of the state auxiliary, elected in 192i, and who held over in 1927 are Mrs. Clarence Rubendall of Omaha, who succeeded Mrs. Long to the presidency; Mrs. Harry Flansburg of Lincoln, secretary and Mrs. S. A. Preston of Fremont, treasurer. Mrs. G .H. Walker of Lincoln recently succeeded to the presidency.

\section{DOCTORS' WIVES' CLUB}

The Doctors' Wives' Club, the only social one of its kind known in the Enited States, was organized in 1913, by Mrs. A. L. Muirhead, wife of the dean of Creighton Medical College, and Mrs. Albert F. Tyler, following a social meeting at the home of Mrs. Muirhead. Mrs. Tyler was chosen the first president.

Most of the women were mothers of small babies and had few respites for sewing and visiting, which made these friendly social afternoons, especially welcome. The club took into its group from time to time wives of newcomers, welcoming these women and brides who were strangers to Omaha, and creating for them a nucleus around which many friendships were formed. 
When the United States entered the war, the Club numbered sixteen members, and this group obtained government allotments of materials, knitted and made other supplies for the army, helping in no small way to furnish needed articles for the Red Cross.

There are at present fifty-nine members in the club. Meetings are held once each month, and there are nine meetings in the club year. The Doctors' Wives' Club is interested in all of the projects which are sponsored by the Omaha-Douglas County Medical Society.

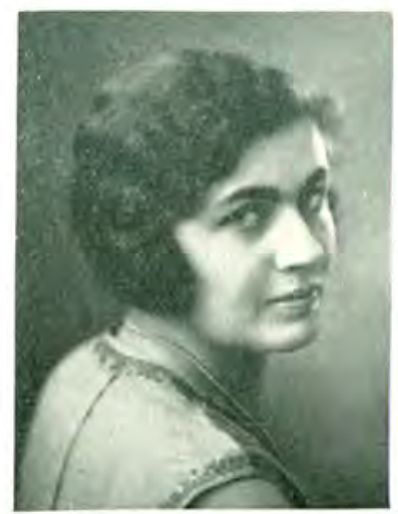

MRS. ADOLPH SACHS

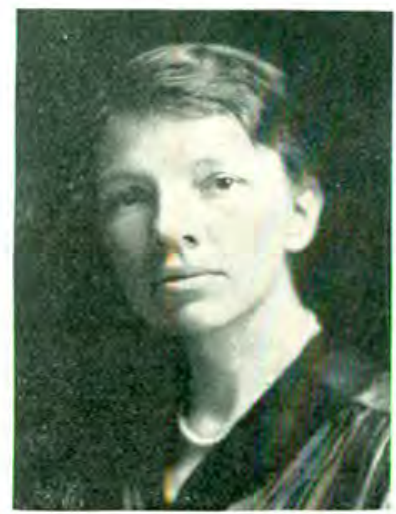

MRS. A. F. TYLER

The club contributes annually to the community chest, Father Flanagan's Boys Home, and the Nebraska Children's Home Society. The club has also sponsored benefits for the Nebraska Tuberculosis Association, and the Douglas County Hospital.

The Doctors' Wives' Club members are prominent in Omaha's civic and social life. Past presidents are: Mesdames Albert F. Tyler, Arthur David Dunn, A. P. Overgaard, D. T. Quigley, Gustav W. Dishong and Rudolph Rix.

Mrs. Adolph Sachs is th present president, Mrs. Wm. H. Pruner, vice-president; and Mrs. J. Harry Murphy, secretary. Members are Mesdames:

\section{H. Ballard}

Rodney W. Bliss

Julian R. Blackman

J. A. Borghoff

Jennie Callfas
Floyd Clarke

Frank M. Conlin

L. A. LeLanney

A. K. Detwiler

Gustav W. Dishong
Andrew G. Dow

T. J. Dwyer

R. Bruce Eldredge

Paul H Ellis

Max W. Flothow 


$\begin{array}{lll}\text { C. B. Foltz } & \text { Charles McMartin } & \text { Wm. H. Pruner } \\ \text { J. J. Freymann } & \text { D. A. Medders } & \text { D. T. Quigley } \\ \text { Herbert F. Gerald } & \text { Harry C. Miller } & \text { Rudolph Rix } \\ \text { Wm. P. Haney } & \text { W. F. Milroy } & \text { B. C. Russum } \\ \text { Francis W. Heagey } & \text { Clyde Moore } & \text { Adolph Sachs } \\ \text { David Isaacs } & \text { Frank P. Murphy } & \text { W. H. Schmitz } \\ \text { Aldis A. Johnson } & \text { J. Harry Murphy } & \text { Wm. L. Shearer } \\ \text { Newell Jones } & \text { George E. Neuhaus } & \text { A. C. Stokes } \\ \text { Ernest Kelley } & \text { C. H. Newell } & \text { Elizabeth Moyer Swab } \\ \text { C. R. Kennedy } & \text { Wm. J. Nolan } & \text { Albert F. Tyler } \\ \text { J. Frederick Langdon } & \text { A. P. Overgaard } & \text { Claude T. Uren } \\ \text { Ralph Luikart } & \text { J. M. Patton } & \text { W. P. Wherry } \\ \text { Samuel McCleneghan } & \text { A. S. Pinto } & \text { Glenn D. Whitcomb } \\ \text { Jas. F. McDonald } & \text { E. W. Powell } & \text { G. Alexander Young } \\ \text { Louis D. McGuire } & \text { G. W. Pritchard } & \end{array}$

\section{NEBRASKA STATE NURSES' ASSOCIATION}

Twenty-two years ago, in 1906, Miss Nan Dorsey, in charge of the Visiting Nurse Association of Omaha, and Miss Brobson, superintendent of nurses at Clarkson Hospital, called a group of ten nurses together for the purpose, quoting from the minutes of that meeting, "of organizing a State Nurses' Society to eventually work for state registration, for raising the standards of the profession and promoting fellowship among nurses of the city and state." They adopted the name of The Nebraska State Association of Graduate Nurses.

This little group met again January 28, 1907 and adopted the first constitution and by-laws. They agreed to meet monthly the first year. The first officers were: president, Miss Nan Dorsey; first vice-president, Miss Gene Anderson; second vice-president, Miss Carrie Louer; secretary, Miss Harriet Borglum; treasurer, Miss Irish; directors, Misses Mary Dueker, Churchill, Minnie Ericson and Florence Chambers.

After a few months spent in developing the organization, they sent invitations to their meetings to nurses throughout the state and appointed an entertainment committee to plan for public speakers. Their programs show interest in the work of the Juvenile Court, of the Social Settlement, of the progress in the elimination of tuberculosis. 
At the end of two years they were affiliated with the National Associated Alumni Graduate Nurses and the Nebraska State Federation of Women's Clubs. In 1908 Miss Carrie S. Louer was elected president. The organization was incorporated and the legislative committee was carefully framing their first Nursing Bill. This bill became a law in 1909. They sent a delegate to the national convention. Their meetings had an attendance of twenty to thirty.

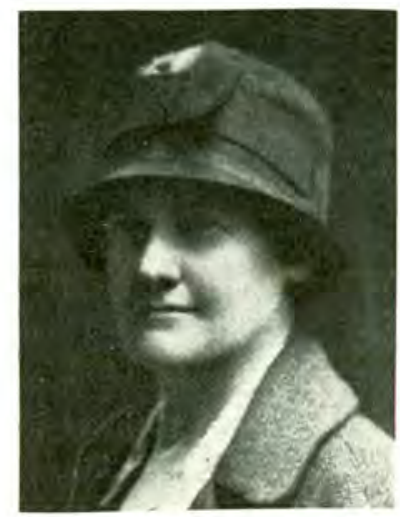

MISS NAN DORSEY

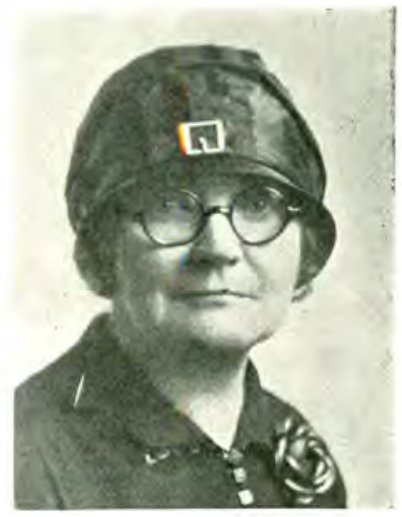

MISS FLORENCE MC CABE

After five years they held quarterly meetings lastiıg one day. The organization of a central registry was under way in Lincoln and Omaha.

Fifteen years after organizing, the name was changed to The Nebraska State Nurses' Association. The state was divided into three districts; meetings were two-day sessions and the membership reached 434. Today, the membership is 750 out of 1,600 registered nurses in the state. The first bulletin has been published.

The aims of the nurses advocated in the last legislative session were not realized. The fees for reciprocity have been raised to $\$ 15.00$ and renewal license fee is $\$ 2.00$. This increase in funds made possible the financing of a State Educational Director of Schools of Nursing. In January, 1928 Miss Phoebe M. Kandel of Canton, Ohio, came in that capacity. Officers for 1928 were Florence McCabe, R. N., president; Edith M. Salin, R. N., first vice-president; Clara Rhodes, R. N., second vice-president; Mary O'Neill, R. N., secretary and Vida Pickard, R. N., treasurer. Second district officers include: 
Miss E. Beryl Cornell, president; Sister Olive Cullenberg, vice-president; Miss Josephine Chamberlain, vice-president; Miss Helen Tomkins, secretary and Miss Hazel Drake, treasurer.

\section{GRADUATE NURSES' OFFICIAL REGISTRY}

The Official Registry was organized in 1911 by ten nurses, mostly superintendents of hospitals, who gave $\$ 10.00$ each to start it functioning. Miss Gertrude Smith was the first registrar and conducted the work from her home.

In 1915, the William Wallace home at 2420 Harney Street was obtained as a clubhouse and the name was changed to the Nurses' Central Club and Official Registry. Funds were raised, the clubhouse was filled and there was a waiting list for rooms. Then came the war, and the nurses were called to the colors. Dr. C. W. Pollard took over the clubhouse for a maternity hospital. Mrs. Eyman was engaged as registrar and the registry moved to her home.

The Club and Registry reopened in the Harney Street location on December 1, 1919, but moved to its present location, the old Coad home at 3718 Farnam street, on March 1, 1924. It became the property of the Second District, Nebraska State Nurses' Association, on January 21, 1926. The registry furnishes graduate registered nursing service only, including hourly service to all parts of the city. More than 20 of the nurses enrolled, make their home at the Nurses' Club.

Miss Nan Dorsey, organizer and first president of the Nebraska State Nurses' Association, is now in charge of a school of public health nursing maintained by the Red Cross at Bedford College, in London, England. Princess Arthur Connaught, herself a registered nurse, is head of the school, which enrolls students from 13 countries, including Austria, Germany, Czecho-Slovakia, India, Iceland, South Africa, Holland and others. Graduates do district nursing and child welfare work when they return to their own lands. Miss Zaidee Dorsey, a sister, is employed in the federal building, Omaha.

\section{VISITING NURSE ASSOCIATION}

Mrs. Herbert M. Rogers, nee Miss Anna Millard, is honorary president of the Visiting Nurse Association of Omaha, which she 
founded 31 years ago, after completing a nurse's course at Johns Hopkins Hospital in Baltimore. Mrs. W. R. Adams was her co-

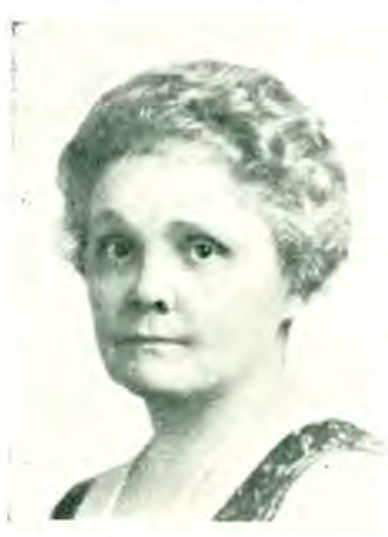

MRS. HERBERT M. ROGERS worker. From the personal efforts of these two women, the V. N. A. has developed to a staff of 30 graduate nurses. who do bedside nursing, give pre-natal and post-delivery care, do infant welfare and nutritional work: and educational and preventive work in orthopedic cases and in communicable diseases. Six infant welfare stations, with the leading pediatricians of the city in attendance, are maintained.

Student nurses in loc al training schools receive two months' experience in public health nursing with the V. N. A. The 1927 annual report showed 11,660 patients cared for during the year. Miss Florence McCabe is superintendent.

\section{NEBRASKA LEAGUE OF NURSING EDUCATION}

The first meeting of the Nebraska State League of Nursing Education was held October 19, 1920 in Omaha, with Miss Clara Baker, superintendent of Clarkson Hospital, temporary chairman. Charter members present were: Miss Clara Baker, Ethel Odegard, Edith J. Moody, Jessie King Lockwood, Mabel Dimock, Lula Hollar, Myra Tucker, Marie Wiek, Nell Webster, Theresa Keller, Fannie Kelley, Gene Keyes, Sister M. Humbarta, Bertha Bryant, Stell Burch; Mrs. Louise Waterman and Mrs. Alberta Stump. Miss Ethel Odegard was the first president.

The object of the organization is: (1) To consider all questions pertaining to the education of the student nurses; (2) to bring about greater interest in questions of public welfare; (3) to encourage more cordial professional relations and (4) to develop and maintain the highest ideals in the nursing service.

The League meets annually in conjunction with the Nebraska State Nurses' Association. The State League under the new 


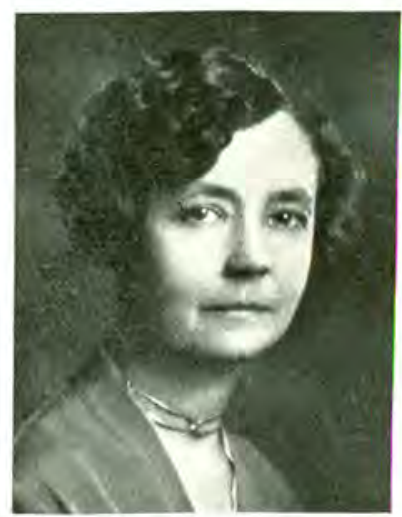

MISS HOMER HARRIS

re-organization plan became affiliated with a National League in 1926. It now has a membership of forty. It has been active in promoting nursing legislation and through its efforts has received the co-operation of the Vocational Education Bureau in securing High School and College instructors for some of the subjects taught in schools of nursing. The League has also been active in presenting to the Department of Public Welfare, the necessity for an Educational Director in the Schools of Nursing. Miss Phoebe Kandel was appointed State Educational Director of the Schools of Nursing, January 1, 1928.

Present officers are: Homer C. Harris, president; Arta Lewis, vice-president, Hastings, Nebraska; Helen Rusk, secretary, Methodist Hospital; Leta Holdrege, treasurer, Visiting Nurses Association. Directors are Vida Nevison, Myrtle Dean and Ada Charleton.

\section{ETA CHAPTER OF PHI RHO SIGMA}

The establishment of Eta chapter of Phi Rho Sigma at Creighton University Medical College, Omaha, marked the beginning of fraternity life upon the campus of that institution, and the establishment of the first medical fraternity in the state. E. W. Foster, J. V. Beachley, W. P. Haney and E. L. Morill were the organizers.

Just before Christmas of 1897 they held a smoker in their little back parlor on Cass Street. The freshmen were rather timid at first in approaching the upper classmen but food, drinks and tobacco being plentiful it was not long until all fell into the spirit of the occasion. After the holidays they met and formed a permanent organization which, for the lack of a better name, was christened Gamma Sigma. The members of the first order were as follows: Paul Ellis, J. W. Thornton, F. C. Pinkerton, L .E. Rex, E. L. Morrill, J. V. Beachly, E. W. Foster, J. H. Ganey, E. L. P Delanney, E. W. Hammond, H. D. Dudley, H. T. Harris, O. C. Deihl and W. P. Haney. 
The officers elected at this time were: E. W. Foster, Occipitus Magnus; J. V. Beachly, Occipitus Parvus, E. L. Morrill, Cul de Sac and W. P. Haney, Scribe.

This organization continued until the end of the school year, giving an occasional smoker to stimulate interest.

At this time Morrill began correspondence with a friend, Harry H. Everett, attending Northwestern and a member of Phi Rho Sigma, about the possibilities of establishing a chapter at Creighton. Morrill was referred to D. E. W. Wenstrand, who was at that time secretary of the grand chapter, and in the fall of 1898 began correspondence in regard to a chapter. Upon the recommendation of F. W. Miller of Red Oak, Iowa, H. W. Orr of Lincoln, Nebraska and L. R. Packard of Kearney, Nebraska, to their respective chapters, the charter was issued. On the evening of March 3, 1899, they were formally installed into the shrine of Phi Rho Sigma, the installation taking place in the parlors of the Henshaw Hotel. Drs. H. H. Everett of Chicago, Miller of Read Oak and Orr of Lincoln came to Omaha for the installation.

Foster continued in his official capacity until 1899 when Ernest E. Hammond was elected the first president of Eta Chapter. New men were pledged, initiations being held on the top floor of the old Bee Building. At the conclusion of this year, 1900, H. L. Akin was elected president.

Among the initiates of 1901 was M. J. Ford, who in November of that year, became the proud father of a boy, the first child born into Eta Chapter, who was pledged to Phi Rho Sigma on his birthday.

On March 2 ,1901, just two years after the installation of Eta Chapter, the latter helped establish Iota Chapter at the University of Nebraska Medical School.

In 1902, Stuart B. MacDiarmid was elected president. C. E. Rooney, A. V. Rock and Ernest Kelley later guided the fraternal interests of the chapter.

In 1908 the first step toward real fraternalism was made in the opening of the first Eta Chapter house, due chiefly to the efforts of $\mathrm{H}$. A. Johnson. The maintenance of a home was not found 
feasible, so after one year the house was discontinued, and the meetings were held in various downtown hotels. In 1910 Eta essayed a second chapter house. It was at this time that Eta and Iota jointly succeeded in holding a successful national convention here. J. V. Moore was president.

A period of inactivity marked the years of the war but in 1922 another fraternity house was opened, and the doors have never been closed since that time.

HONORARY MEMBERS

Chas. C. Allison
James M. Barstow
D. C. Bryant
Henry L. Burrell
Peter T. Conlan
Frank E. Coulter
Benj. F. Crummer
L. A. Dermody
Arthur D. Dunn
T. J. Dwyer

\author{
Milton H. Everett \\ James S. Foote \\ H. P. Hamilton \\ Geo. A. Harris \\ Edwin C. Henry \\ Walter O. Henry \\ Henry B. Jennings \\ Thomas C. Little \\ John P. Lord
}

\author{
Charles McMartin \\ Alonzo E. Mack \\ Chas. O. Rich \\ Rudolph Rix \\ Michael J. Scott \\ Frank T. Seybert \\ Harold T. Singer \\ John E. Summers, Jr. \\ H. Clayton Sumney
}

\title{
MEMBERS ON FACULTY
}

Wm. J. Adams, A.B., M.D.

Thos. J. Boler, M.D.

L. B. Bushman, A.B., M.D., F.A.C.

Frank J. Casey, B.S., M.D.

G. W. Dishong, M.D., F.A.C.P.

Andrew G. Down, M.D.

John W. Duncan, M.D., F.A.C.S.

Herbert F. Gerald, Ph.G., B.S., M.D.

John J. Freymann, A.M., M.D.

Wm. P. Haney, M.D., F.A.C.S.

Harry J. Jenkins, M.D.

Arthur C. Johnson, B.S., M.D.

Ernest Kelley, M.D.

James F. Kelley, M.D.

John R. Kleyla, A.M., M.D.

Frederick J. Langdon, A.M., M.D., F.A.C.S.

Vernard E. Lamphier, A.B., M.D.

Louis B. McGuire, B.S., M.D.
Chas. McMartin, Ph.D., M.D., F.A.C.S.

James W. Martin, A.B., M.D.

Clarence S. Molseed, Ph.G., M.D.

John K. Muldoon, M.D.

Harry J. Murphy, A.B., M.D.

Frank P. Murphy, A.M., M.D.

Geo. E. Neuhaus, M.D., F.A.C.P.

Eugent F. Noonan, A.B., M.D.

Wm. T. Rance, B.S., M.D.

B. M. Riley, A.B., M.D., F.A.C.P.

B, C. Russum, A.B, M.D.

Adolph Sachs, M.D., F.A.C.P.

Frank J. Schleier, M.D.

Fred J. Schwertley, M.D.

Wm. L. Sucha, M.D.

Chas. F. Swab, M.D.

A. F. Tyler, A.B., M.D., F.A.C.P.

James G. Vetter, M.D. 
PRESIDENTS OF PHI RHO SIGMA

$\begin{array}{lll}\text { Ernest D. Hammond } & \text { J. S. McAltee } & \text { F. J. Tobin } \\ \text { Henry L. Akin } & \text { T. V. Moore } & \text { F. O. Kolda } \\ \text { Charles R. Mowery } & \text { Max W. Flothow } & \text { H. A. Vandever } \\ \text { Stuart B. Mac Diarmid } & \text { Thos. H. Thornton } & \text { Herbert A. Sohm } \\ \text { Charles E. Rooney } & \text { C. O. Moore } & \text { H. Mell Robbins } \\ \text { Andrew V. Rock } & \text { B. Carl Russum } & \text { Leo. W. Graff } \\ \text { Ernest Kelley } & \text { Fredric O. Wilson } & \text { S. Dale Porter } \\ \text { Henry A. Johnson } & \text { C. O. Little } & \end{array}$

PHI CHI

Phi Chi medical fraternity was formed as a result of a consolidation of the Phi Chi society founded at the University of Vermont on March 31, 1889 and the Phi Chi medical fraternity founded in Louisville, Kentucky, on October 26, 1894. It took place March 5, 1905 in Baltimore, Md. This consolidation gave the fraternity twenty-six active chapters. At the present time the fraternity has fifty-six chapters. A chapter exists in a majority of "A" class medical schools in the United States and there are two chapters in Canada. The total membership of the organization amounted to 13,567 in July, 1927.

The local chapter, Chi Upsilon of Phi Chi, was founded at Creighton Medical School, January 29, 1916, by Eben J. Carey, M. D., then assistant professor of anatomy at Creighton and now acting dean of the Marquette Medical School. Charter members are: J. R. Leibee, J. M. Heacock, M. C. Howard, W. B. Phillips, J. C. Mounsey, J. J. O'Connor, P. B. Gillespie, E. H. Monolley, G. Baldwin, J. W. Libert, B. Williams, J. J. Carrol, H. A. Johnson, T. F. O'Toole, F. E. Lovely, T. W. Torpy, G. C. Scanlon, R. S. Johnson, J. T. Sullivan, H. T. Haverly, J. T. O'Connell, F. Landgraf, B. Kully, E. Lighty, C. Zimmerman, F. A. Celozowsky, C. R. Marshall, W. A. Grossand G. C. Philerick.

The above members are only a few of the many prominent alumni practicing in Nebraska and elsewhere.

The first house of the chapter was established in 1924. A house is now maintained by the 37 active members, at 3635 LaFayette Avenue. Its capacity is 22 . 
PHI BETA PI

The first chapter of Phi Beta fraternity was organized in 1891 in the state of Pennsylvania. The first charter to be issued in the state of Nebraska was to a group of students at Creighton Medical School, February 7, 1907. It is Alpha Alpha chapter. Charter members were Harry Loftus, A. L. Dermondy, A. P. Kimball, W. A. Bloedorn, T. G. Barnhart, H. P. Benjamin, R. L. Ivins, F. Emmet Leahy, F. L. Putman, Fredric L. Barbour, T. Tennyson Harris, and M. G. O'Keefe, M. D.

The chapter is a member of the Pan-Hellenic Council of Creighton University. For the past five years the local Chapter has enjoyed a house at 3224 Dodge Street.

The present membership is forty-four active and three pledges. In this group there are fifteen states represented and one member comes from Belize, British Honduras. In 1924 the National Convention was held in Omaha, attended by members from every chapter in the United States, thirty-nine chapters being represented.

\section{ALPHA CHI OF PHI DELTA EPSILON}

The Phi Delta Epsilon national medical fraternity installed Alpha Chi chapter of Creighton University College of Medicine on December 20, 1925, at the Fontenelle Hotel. The charter members initiated at that time were: Dr. Victor E. Levine of the faculty, Irvin Soifer, Stanley Freedman, Meyer Greenberg, Isaac Sternhill, Maynard M. Greenberg and David Gross. The first pledges were Ben Slutzky and Samuel Z. Faier.

One of the first official acts of the chapter, manifesting its spirit, was the gift of $\$ 100.00$, subscribed by the members, to the Library Fund of the medical school. The Dean of Men announced that Alpha Chi led all the fraternities on the campus, both social and professional, for the year 1926-1927, with an average of 91 per cent.

The national fraternity, twenty-five years old, numbers among its membership 42 active chapters, all in class "A" medical schools, twelve graduate clubs in various medical centers throughout the United States and a total membership now approaching 4,500. Its motto, "Facta non Verba," is a guide in its aspirations. 


\title{
Fraternities at Nebraska Universits
}

\author{
PHI RHO SIGMA, IOTA CHAPTER
}

Iota chapter of Phi Rho Sigma was granted to twelve men who were in attendance at the Omaha Medical College on February 16, 1901. These men were A. B. Lindquist, H. A. Reichenbach, S. B.. Hall, H. W. Heffinger, M. B. McDowell, B. W. Christie, M. A. Tinley, D. F. Lee, A. H. Cooper, C. W. Poynter, W. P. Wherry and C. F. Avery. Iota chapter continued its existence as a chapter of $\mathrm{Phi}$ Rho Sigma when the Omaha Medical College was absorbed by the University of Nebraska. In 1904 six men, A. A. Arnold, J. F. Allen, A. B. Cotes, J. B. Potts and G. R. Walker, who were taking their first two years of medicine in Lincoln organized a sub-chapter known as Iota-Beta. This chapter was united with Iota when the four years of medicine were given in Omaha in 1913.

The present chapter is composed of fifty men, thirty-five of whom reside in the chapter house at 4120 Dewey Avenue, immediately across from the Medical College campus. The present officers of the fraternity are: J. R. Moritz, president; A. A. Morrison, vicepresident; F. M. Karrer, secretary; J. C. Petersen, recorder and J. M. Sheldon, treasurer.

The original house was built in 1914. A wing nearly equal in size was added in 1921. It is valued at sixty thousand dollars.

\section{UPSILON NU OF PHI CHI}

Upsilon Nu chapter of Phi Chi medical fraternity was organized October 7, 1916, to "secure a closer fellowship in university life." It was the third professional fraternity on the University of Nebraska Medical College campus. Among the founders was Dr. Eben J. Carey, at that time assistant professor of Anatomy at Creighton. The nucleus of students included E. L. McQuiddy, J. W. Wear, E. H. Morris, W. A. Gerrie, M. L. Minthorn, J. B. Eyerly, H. I. Freidell, and R. O. Griess. The first two men were initiated at Creighton Chapter of Phi Chi.

The charter was granted on November 6, 1916. Charter members consisted of sixteen men: G. H. Lamphere, E. S. Wegner, W. F. Deal, F. E. Rogers, G. H. Misko, L. L. Edmesten, H. C. Church, and A. C. Graham, together with those students mentioned above. 
E. L. McQuiddy was named presiding senior; I. W. Wear, Jr., presiding junior; E. H. Morris, secretary; I. O. Church, treasurer; G. H. Lamphere, judge advocate and S. B. Brown, steward.

The first chapter house was located on west Farnam, at 38th Street and during the first few years of the new organization, there were about a dozen students in the house. Later, new quarters were found on Harney near 38th Street, and still later on 42nd, near Dewey Avenue. The membership gradually increased and after living at 34th and Dewey for two years, the fraternity purchased the home of Dr. H. G. Gifford at 420 South 36th Street. This has been the chapter house since 1923. The membership has shown a steady increase from the original sixteen to the present forty-two active members - twenty-six of whom live in the chapter house. A total of one hundred fifty men have been initiated since its founding.

Present officers are: Clarence W. Sabin (1928), presiding senior; Ralph L. Schroeder (1929), presiding junior; E. F. Bruning (1929), secretary; W. W. Webster (1928), treasurer; J. F. Smith (1928), judge advocate; Omer L. Seng (1930), sentinel; Chas. E. Gurney (1930), chapter editor.

Associáte members include Drs. H. A. Wigton, J. T. Maxwell, J. R. Nilsson, J. T. Meyers, R. W. Fouts and J. W. Iwersen.

\section{PHI BETA PI}

Alpha Psi chapter of Phi Beta Pi medical fraternity was established May 28, 1920, with the following charter members: Guy Hart Moates, Wilmer O. Lewis, Leo D. Rose, Donal H. Morgan, R. Perry Allerton, Ralph M. Fouch, Charles Langhorn, Herman C. Bodemer, Earle E. Miller, Ray T. Thomson, H. S. Stahr, Lyle L. Wood, George R. Metzinger, D. B. Kantor, Bretislav Sedlacek, Guy W. Goodrich, Ernest R. Reinsh and Harry H. Kretzler.

The first officers were Guy H. Moates, archon, and Ernest R. Reinsh, secretary. Present set of officers are L. L. Zierott, archon; D. E. Hanson, secretary; E. H. Engel, vice archon; A. W. Glathar, treasurer, and Henry Blum, house manager.

The first Phi Beta Pi house was located at 414 No. 39th Street, just north of the Joslyn Castle. In the spring of 1924, was pur- 
chased the present home at 116 South 38 th Street. The membership includes forty active members, besides the faculty and staff men.

\section{BETA EPSILON OF NU SIGMA NU}

Students in the College of Medicine of the University of Nebraska organized the Phi Beta Rho Society in the fall of 1905. One year later, through Nu Sigma Nu members of the faculty, Beta Epsilon chapter was chartered December 21, 1906. H. E. French, W. Ar., of Zeta, assisted by H. J. Prentiss of Xi Chapter, a member of the executive council, conducted the installation in the Lindell Hotel in Lincoln.

Owing to the location of the school at the time, Beta Epsilon chapter had necessarily comprised two divisions - one at Lincoln and the other at Omaha. Since but a small group lived at Lincoln, it was found unnecessary to maintain a chapter house there, though quarters were at the residence of Dr. A. T. Peters, at 2438 W. Street. In Omaha a chapter house was maintained at 1509 South 26th street. Coincident with the time when the University established the full four years of instruction in medicine at the present location, 42nd and Dewey Avenue, Beta Epsilon chapter maintained but one headquarters. The present home is located at 201 South 33rd street. It was acquired in July, 1922.

Organizers of Nu Sigma Nu fraternity are Claude Powell Fordyce, Harry Allen Taylor, Brownlow P. Miller, Geo. Winthrop Prichard, Albert Theodore Peters, Charles Henry Willis, Merlin B. Wyatt, Lozell B. Sturdevant, Cecil Floyd Charlton, Frank Henry Morrow, George Webster Sullivan, Henry Peter Wekesser, Lawrence B. Pilsbury, Rufus Ashley Lyman, Charles Whitney Pollard, Robert R. Hollister.

The first officers were Merlin B. Wyatt, president; Lozell B. Sturdevant, vice-pres.dent; Harry Allen Taylor, secretary-treasurer; Frank Henry Morrow, custodian. The present officers are Kenneth Baker, president; Thomas Gairdner, vice-president: Frederick F. Teal, secretary; William H. Hay, treasurer; Raymond G. Lewis, custodian; Otis L. Anderson, historian.

There are now 25 active members and $\mathbf{1} 6$ pledges in the fraternity. The alumni committee includes R. W. Bliss, C. C. Tom- 
linson, C. W. Pollard, C. R. Kennedy, C. H. Waters, Donald Macrae, H. A. Taylor, Palmer Findley, F. H. Morrow, G. W. Pritchard and A. B. Anderson.

BETA GAMMA OF ALPHA KAPPA KAPPA

The Beta Gamma chapter of the Alpha Kappa Kappa was organized November 7, 1921. Through the efforts of Frank M. Conlin of Nu chapter, Rush Medical School and Father Bernard L. Sellmeyer, M. D. of Epsilon Chapter of Jefferson Medical School that charter was secured. Grand Primarius George Cook of Concord, New Hampshire and Grand President John Perley Sprague were present at the installation, also Frank M. Conlin and Ernest L. Manning. Charter members were; Harold Frank, Herrick Antil Hoxie, Fletcher Clark Stewart, Richard Walter Hille, Emmet Albert Pearson, Willard Munson Pratt, John Ernest Jackson, Howes Martin Barron, Henry Jeptha Sealey, Thomas Blair Protzman.

The first officers were J. Stanley Welch, district deputy; Frank M. Conlin, primarius: Thomas Blair Protzman, president; Richard Walter Hille, vice-president; Willard Munson Pratt, treasurer; Henry Jeptha Sealey, recording secretary; John Ernest Jackson, corresponding secretary; Emmet Albert Pearso, chaplain, Homer Martin Barron, historian: Derrick Antil Hoxie, marshal; Harold Frank, warden.

The present officers are Frank M. Conlin, primarius; Kenneth Eugene Prescott, president; James Perry Tollman, vice-president; Cyril Leland Slown, treasurer; Henry Napoleon Genoets, recording secretary; James Paul Rigg, corresponding secretary; Harvey Daniel Runty, chaplain; Edwin Blair Banister, historian; Harold Eastman Coder, marshal; John Warner Malzacher, warden; William Duncan Turner, steward; Leland C. Albertson, house manager.

The fraternity home is located at 132 North 38th Avenue, Omaha. At present the members include: 30 active, 7 faculty, 10 pledges and 38 alumni.

COUNTY ORGANIZATIONS AND REGISTRANTS

ADAMS COUNTY

James V. Beghtol of Hastings was the first president of the Adams County society in 1903 and has served three or four times 
since then, in addition. C. V. Artz was vice-president and Fred Schaufelberger, now in California, was secretary-treasurer. The records from that time until 1914 have been lost but Dr. Beghtol supplies from memory the information that J. T. Steele was president in 1904; C. V. Artz in 1905; Dr. Linn in 1906; and Dr. Ackley in 1907. The record of presiding officers from 1914 to the present time includes J. T. Steele, M. W. Baxter, E. Dolphus Haysmer, S. R. Hopkins, W. S. Fast, S. J. Jones, E. C. Foote, O. H. Hahn, R. D. Martin, E. B. Hamel, A. A. Smith, H. R. Mulligan, Dr. L. W. Rork, Calbraith, Mullinax and Pinney. Beghtol, who was president of the first state board of health in 1891, recently completed 50 years of practice and was given a testimonial banquet.

Members of the Adams County Medical Society are named by J. V. Beghtol in the following list:
H. T. Andrews
R. O. Griess
J. V. Beghtol
O. M. Hahn
A. J. Boren
J. W. Brown
E. B. Hamel
S. J. Jones
C. B. Calbreath
W. E. Kelly
R. C. Cressman
E. J. Latta
P. A. Chandler
J. B. McPherson
L. J. DeBacker
C. C. Drummond
F. L. Marsteller
R. D. Martin
L. F. Egen
J. P. Feese
E. C. Foote
J. L. Mace
W. E. Nowers
G. L. Pinney
L. W. Rork
A. A. Smith
Ella P. Sumner
C. B. Spicer
Frank Schauffelberger
L. K. Strate
L. A. Swanson
F. N. Townley
J. E. Uridil
M. B. Wilcox
G. M. White
H. J. Pittock

The list of physicians registered in Adams County, under the Act approved March 27, 1891, includes:

W. Ackley
Charles V. Artz
Ardelle Mabel Alcorn
F. C. Brcsius
Frederick J. Bricker
Hugh M. Bailey
M. W. Baxter
Charles Bruce
J. O. Bruce
James Vance Beghtol
Samuel E. Bamford
Geo. A. Blair
William M. Blair
H. S. Brevoort
Julian R. Blackman
Guy L. Brillhart
Joseph Wesley Brown
Albert J. Boren
E. Bollinger
Daniel LeRoy Burgeson
Edna F. P. Burgeson
W. A. Chapman

W. Ackley

Charles V. Artz

F. C. Bresius

Frederick J. Bricker

Hugh M. Bailey

M. W. Baxter

Charles Bruce

J. O. Bruce

Samuel E. Bamford

Geo. A. Blair

William M. Blair

H. S. Brevoort

Julian R. Blackman

Guy L. Brillhart

Joseph Wesley Brown

Albert J. Boren

E. Bollinger

Edna F. P. Burgeson

W. A. Chapman

E. T. Cassell

Grant Cullimore

W. T. Carson

Alma J. Chapman

Chas, E. Corbin

C. F. N. Ccoke

W. H. Chapman

Ora M. Caldwell

Andrew J. Chamberlain

C. B. Calbreath

Ralph Gates Cressman

John Francis Cross

Earl R. Crowder

Paul A. Chandler

Geo. W. Doran

Floyd Chapin Dean

Abner B Dunn

Char!es Roy Dever

Clarence C. Drummond

Taura A. Edwards

H. L. Ewing

Charles L. Egbert
Albert Adolf Ehrke

Wellington A. Franklin

Wm. Mann Follette

Joseph Fleckinger

Eugene C. Foote

James H. Fargher

Robert Hale Foster

Joseph A. Fleishman

Quillin Pearl Fairchild

Geo. G. Fischer

Mattie A. Furman

Harlan J. Foster

Howell B. Gwin

Sarah S. Green

John W. Greenman

Oscar S. Gray

Hiram Adelbert Green

Margery Jane Gilfillan

A. Galloway

Ethed L. B. Gray

John Worth Gray

Charles W. Gooden 
Mary A. Howard

Edgar Rea Holmes

H. Hartwig

C. S. Hubbard

Charles M. Headrick

Luther H. Howland

E. B. Hamel

Karl S. J. Hohlen

Seth L. Hubbard

Hugh Hover

Oscar Herman Hahn

Walter Burris Hudson

Glenn C. Harper

Clara May Hayden

Elam Dolphus Haysmer

Charles S. Hershner

Ward Willard Hedlund

Charles Hayes

O. H. Hahn

R. J. Irwin

Geo. W. Johnsen

Geo. Jones

Dera M. Judkins

Lewellyn L. Jones

Sherman J. Jones

Raymond S. Johnston

W. B. Kern

F. L. King

Wellingten W. Keith

James M. Kent

Frederick H. Kuegle

Ben W. Kinsey

Clarence E. Kidder

W. H. Lynn

Elbert J. Latta

Charles Lucas

Allan B. Lafferty

Joseph S. Leisure

Frank B. Ling

O. T. Leftwich

Daniel Mack Lsaming

Clay Eli Mullinax

Orville C. Mastin

Mary Mills Michael

John J. Moreland
W. T. Mozee

R. R. Marble

Albert Morefield

J. F. McNulty

Charles N. Merriweather

Herman Gustave Maul

Zellmond E. Matheny

Henry S. Munro

Jeseph B. McPherson

Harold Rowe Mulligan

Frederick A. McGrew

Rebert C. Miller

Samucl Gerald McI ane

Walter E. Nowers

Francis Naulteus

Howard R. Newkirk

Sylverston H. O'Neill

Albert S. Pierce

W. M. T. Putt

Seymsur Putman

M. A. Perkins

T. J. Piersoll

Fioyd Pierce

A. A. Potterf

Harry J. Pittock

Wm. H. Pearson

Joseph Bernard Pankau

Bert C. Pease

Chester A. Pierce

Geo. LeRoy Pinney

F. W. Rose

Benjamin Rea

W. D. Rea

J. G. Roberts

Jeseph P. Riddle

Emma E. Robbins

Amy Robinson

Lee W. Rork

Orville Clinton Reed

J. T. Steele

Fimma Watkins Stever

Charles C. Stivers

Henry Mc. Swigart

Arthur E. Smith
S. Scruggs

C. S. Shepard

A. J. Shrimp

Carl K. Struble

Alexander C. Sabin

Joseph R. Sample

Geo. E. Spear

Jchn W. Straight

A. C. Sabin, Jr.

Flerence P. Sims

John W. Smith

Lesslie B. Sims

Samuel J. Stuart

Franklin Schaufelberger

Frederick Schaufelberger

Wm. L. Sucha

Arthur Andrew Smith

Clara Margaret Schunk

Sharles Ralph Spicer

Lawrince T. Sidwell

Edward Adam Sommer

Ella P. Sumner

Bertha E. Smith

Elmer Burton Smith

Lester Kenneth Strate

Louis Turner

Fred L. Taylor

A. L. Talbot

Frank Newcomer Townly

Thomas H. Urquhart

Abijah R. VanSickle

I. M. Voerhees

Thomas J. Vanderhoof

Frank Ray Vieregg

Jcseph Williams

G. A. Weirick

Wm. M. Wegmann

James E. Warwick

Edward A. Wier

M. L. Wilson

Geo. M. White

Henry C. Williams

Bernard John Weigel

Jeremias Calfe Wilson

Geo. L. Wagner

\section{ANTELOPE COUNTY}

Physicians registered in Antelope County include:

Albert E. Collyei

Eli A. Watson

Hugh Hover

Hubert D. Karass

H. L. Brevoort

George A. Clark

Luther Alan Howes

Stanley Curtis Clements

Robert Hale Foster

Leopold W. Wuestehoff

Gertrude F. Crane
Ambrose H. Farnsworth

W. A. Peterson

H. M. Cox

Wm. F. Conwell

Gilbert A. McMillan

Mercer B. Croll

Edward W. Minton

Guy H. Hildebrand

Joseph H. Thompson

W. F Whitmore

J. M. Miller
Robert McAdam

Robert P. Elwood

A. J. Sanders

John S. Livingston

E. J. Austin

Frank H. Nye

Isaac Bowden

H. Melerian

Edward T. Julian

A. A. Webster

David W. Beattie 


\section{W. A. Lee}

Charles V. Crook

Ida P. Davis

Wm. G. Fletcher

Charles M. Headrick

A. F. Conery

Etta M. Dought

Marshall Petitt

J. C. Walton

Ora M. Caldwell

Max Kcelter

M. Freeman Hall

L. C. Johnson

Roy Crook

Frank Bartley

Archibald G. Fletcher

Robert W. Chamberlain

J. P. Jensen

A. C. Sabin, Jr.
Lauren Jones

Charles C. Stivers

Paul L. Conwell

E. L. Robinson

Chas C. Barr

Ben W. Kinsey

A. A. Potter

J. C. Walton

Roscoe L. Smith

James Walter Bennie

C. L. Davidson

David L. Fletcher

William F. Race

F. D. Carpenter

Lawrence Monau

U. Samuel Harrison

Pierre R. Schlumberger

George W. Connelly

Neill J. Everett
Walter S. Payne

Joseph Daniel McCarthy

William Lester Davis

Park A. Lillie

W. T. Craft

George M .Doran

Charles Elmer Sheets

Frank N. Saville

Roy Milo Cox

Bernard J. Macauley

W. V. Kennedy

Elmer E. McClelland. Jr

Bennett A. Melgaard

Elton B. Grubs

Emery Oliver Gonterman

Adelbert Townsend

Lloyd Leslie Nelson

Elmer Elsworth Curtis

Edward Adam Sommers

BANNER COUNTY

The county clerk at Harrisburg, Banner County, wrote there were no physicians registered there.

\section{BLAINE COUNTY}

Physicians registered in Blaine County since 1881 are:

\author{
William S. Irwin \\ Joseph M. Klinker \\ Aras B. Cox \\ Charles C. B. W. Cox \\ Charles Joseph Kelley \\ C. T. Owings \\ Cyrus Pickett \\ Richard J. Williams \\ Allen V. Sheridan \\ Thomas C. Ashton \\ Edwin J. Mitchell \\ James L. Pennington
}

\author{
Jchn W. Wear, Jr. \\ Henry F. Hewitt \\ F. E. Keep \\ Albert S. Warner \\ F. E. Loomis \\ Emma A. Warner \\ W. B. Bridgman \\ William F. Lewis \\ H. S. Brevoort \\ Margaret Himrod \\ A. A. Webster \\ G. B. Ira \\ Will:am Kingsly Clark
}

\author{
Chas. F. Zimmerman \\ Wesely Queen \\ Frnest F. Rondet \\ C. Homer Newell \\ Charles V. Crooks \\ J. C. Walton \\ E. Schueller \\ Ray H. Burrell \\ W. E. Bridgman \\ H. W. Parchen \\ W. T. Craft \\ Elizabeth Martin
}

\section{BOONE COUNTY}

Early records of the Boone County Society have been lost and later ones are incomplete. Apparently the first organization was in 1902 when F. D. Burgess of Cedar Rapids was elected president; and F. M. Barns of Albion, secretary-treasurer. The present officers are G. W. Sullivan of St. Edward, president; J. E. Davis of Albion, vice-president; and F. M. Barns of Albion, secretary-treasurer. 


\section{BOYD COUNTY}

Registered in Boyd County since 1891:

Abner D. Neeley Chelsea M. Erb E. F. Collins John R. Beatty Etta E. Hewett Henry F. Hewett Paul R. Howard Geo. J. Frazier George W. Ira George E. Armour Grundy E. McDonald Josiah Young

\author{
A. C. Sabin, Jr. \\ James W. Sifton \\ George E. Darrow \\ George P. Wilkinson \\ A. A. Potterf \\ Edward R. Seasongood \\ Ray Alex Alexander \\ F. A. Bryant \\ Harry Frederick Diers \\ Clifford Leon Hooper \\ A. L. Stiers \\ Edwin Bruce Bradley \\ Frank Wesley Vaughn
}

\section{BOX BUTTE COUNTY}

\section{In Box Butte County since 1891:}

Frank M. Knight

Helen C. Gilman

E. E. Barr

William K. Miller

Wm. H. Smith

W. R. Lewis

George H. Brash

F. A. Maples

Frank Doennebrink

A. L. Muirhead

A. C. Lucas

Robert A. Blackburn

H. H. Belwood

L. W. Bowman

Will S. Bellwood

Charles A. Holbrook

F. L. Riser

John E. Moore

E. A. Sommers

W. L. Bowman

G. M. Smith

L. L. Davis

G. N. Mitchell

Charles V. Crooks

Lee W. Edwards
Harold B. Miller

W. T. Eikner

George Hand

George W. Collins

Ralph Smith

Francis E. Clough

U. H. Norris

John R. C. Carter

Herbert A. Copsey

A. A. Potterf

Charles C. Stivers

Elton C. Grubs

Charles H. Churchill

Albert H. Thornton

W. R. Scott

Ben W. Kinsey

Charles E. Slagle

Thomas W. W. Little

Charles L. Weber

Fred B. Quincy

Wm. T. Eikner

Wm. S. Bellwood

Harry H. Bellwood

Oliver McEwen

H. S. Brevoort

Forest Lee Parsons
Einer V. Blak

Almerin Webster Baer

Clement Leon Martin

Robert R. Seasongood

Clarence M. Hyland

John I. Limburg

George M. Doran

William Joseph Matousek

Harry Alexander Skelton

Fritz Vennemann

Robert C. Hawkins,

R. E. Kriz,
A. C. Sabin, Jr.

Blake S. Allison

Charles E. Herschman

C. F. Moranville

Charles B. Jackman

J. M. Willis

John H. McCoy

C. E. Teter

William Samuel Howard

Einar V. Blak

Morris J. Baskins

Asa Lee Woolis

Marcus Charles Hurd

Minor Morris

Joseph Peter Weyrens

Andrew C. Schoch

Abram Elting Bennett

Lee Roy Farmer

James E. Duncanson

Edgar Paul Murdock

Donald A. Graham

Lawrence E. Sleeper

Elmer E. McClelland, Jr.

Emery Ira Whitehead

Henry Charles Walker

\section{BROWN COUNTY}

In Brown County since 1891 .

\author{
William B. Ely \\ Thomas J. Farleigh \\ H. P. McKnight \\ James Scott \\ A. A. Webster \\ George O. Remy
}

Orla H. Crane

W. B. Loomis

Douglas B. Young

William S. Irwin

George W. Lambley

Charles V. Crooks
John Laws

T. F. Campbell

Marshall Petitt

H. A. Brown

A. C. Cameron

M. S. Chenowith 
Archibald Murphy

Emil Black

Charles V. Holsclaw

H. C. Smith

A. A. Potterf

Charles C. Stivers

Ben W. Kinsey

A. C. Sabin, Jr.

Thomas J. Lawson

Henry F. Hewitt

E. J. Upton

J. A. Jelinek

Joseph J. Srb

Zellmond E. Matheny

John T. Staward

Levi M. Asbury

Arthur T. Robertson
Adelbert Townsend

H. S. Brervort

Etta E. Hewitt

James C. Tucker

Charles E. Remy

John R. C. Carter

Tyre K. Jones

William F. Race

Sam Hardeman

Oscar E. Coleman

\section{BUTLER COUNTY}

George Edward Masau

J. G. Marran

H. C. Burdick

Clark E. Beede

Laird W. Elwood

Otto E. Langaere

BURT COUNTY

\section{Milo J. Gilkerson}

M. L. Hildreth

Mattie L. Arthur

Andrew D. Nesbit

Edgar A. Sears

A. T. Hill

Thomas W. Leeper

W. L. Pierce,

William B. Gregg

Walter Lewis

C. E. Clark

Perry J. Clark

Frank Simon

Peter G. Grimm

L. Phil Ross

James A. Johnston

M. J. Kenyon

A. L. Muirhead

Ernest J. C. Sword

O. B. Bowers

E. J. Austin

Isaiah Lukens

John E. Moore

John I. Clark

Caroline LaM. Rolph

George O. Remy

Benjamin Rea

Brice X. Corbin

A. G. Hopkins
F. C. Clark

Adolph Lagerkrans

Charles Samson

George P. Wilkinson

Charles M. Headrick

James B. Keith

Edwin M. McGee

John J. Kiefer

Augusta B. Engstedt

Edward B. Oliver

W. N. Morrow

Ora M. Caldwell

W. C. Keetel

Geo. L. Blanchard

John D. Reid

Marshall Petitt

A. A. Potterf

I. S. Stevens

Guy Seward

N. P. Hansen

Merit Wood

James F. Paddleford

E. Bollinger

Alice W. Goldsberry

William F. Race

Frederick W. Luhman

Charles C. Stivers

Frank Earl Gordon

Axel E. Hedlund
Arthur J. Griot

Alfred G. Rasck

William Van Doren

Stephen M. Weyer

Freeman S. Coolen

Chester A. Johnson

Marcus Hoops

Walter C. Zulauf

Irwin Isaac Boehr

Bennie R. Farner

Frederick David Coleman

Edwin August Reils

Edward Robert Pelikan

Frank Swarthout Agler

Arthur A. Arehart

Sçuire Oliver Harris

\author{
Henry A. Johnson \\ Herbert Cooper \\ George M. Doran \\ Harry W. Benson \\ Richard F. Robinson \\ James C. Anderson \\ Wm. J. Luxford \\ H. S. Brevoort \\ William M. Bair \\ Alired Elder \\ Encich Neff \\ A. Galloway \\ Bernard M. Jackson \\ Andrew Harvey \\ Erick M. P. Sward \\ Emma M. Ackerman
}

A. B. Morris

William Charles Keettel

Frank D. Ryder

Samuel August Swenson

Chas. J. Logan

H. P. McKnight

C. A. Cummings

Earl B. Erskine

Arthur L. Barr

Roy E. Hall

J. M. Tische

Glenn W. Briggs

\section{CASS COUNTY}

Cass County, which early in its history numbered some of the leading practitioners in the state, notably General Robert Ramsey 
Livingston, one of the organizers of the Nebraska State Medical Association, had a strong county medical society two years before the state organization was formed. Records of this early county organization, together with perhaps the most complete history of pioneer physicians within its county limits which it was possible to procure, have been obtained through the untiring efforts of General Livingston's son, T. P. Livingston, and another pioneer physician, Joseph H. Hall. They spared no efforts to make the following account as complete as possible.

The first Cass County Medical Society was organized December 20, 1866, with John Black as president; F. B. Reed, corresponding

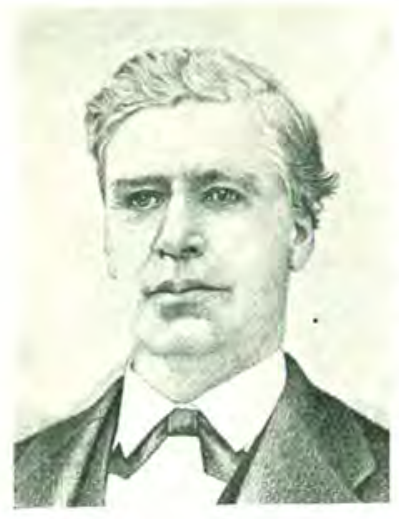

JOHN BLACK

secretary; R. R. Livingston, recording secretary and W. E. Donelan, treasurer. A few meetings were held but no other election took place until 1882, six years later, according to the records. The society did, however, entertain one of the early meetings of the state organization in the spacious home of Dr. Black, when, it is said, the choicest of imported liqueurs were dispensed by the host. His daughter stated that at her 50th wedding anniversary, celebrated recently, she uncorked some that was "left over" from that notable meeting.

Dr. Black was born in Northumberland County, England, November 4, 1821, and came to America with his parents in 1838, locating in Knox County, Ohio. He was graduated from Cleveland Medical College in 1847 and moved with his parents to Mayville, DeKalb County, Missouri in 1852, practicing there until 1863, when he moved to Plattsmouth, where he died November 21, 1895. He was not, however, the first to practice there.

The Donelan cousins, William E. and Edmund A., were the first regular physicians to settle in Plattsmouth, having opened an office on Main Street in the fall of 1855. After a few years, E. A. Donelan moved to St. Joseph, Missouri, where he became a member of the board of education. He died a few years ago. William E. Donelan, who remained, became the second mayor of Plattsmouth, serving in 
1858-1859, and was iffuential in the upbuilding of the community. He was born Nov. 20, 1828, inin Cincinnati, studied with a pre-

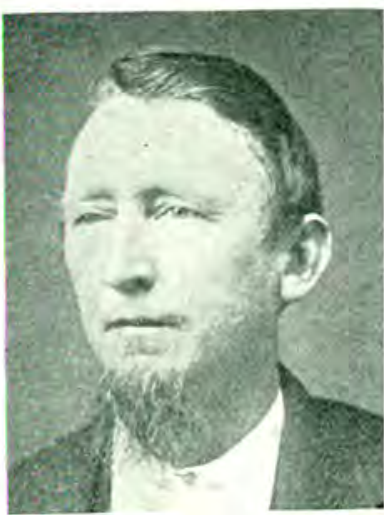

WILLIAM E. DONELAN cepior, Dr. Casterline of Liberty, In$\mathrm{d}$ ana, and at Ohio Medical College in 1854 and practiced two years in Savannah, Missouri, before settling in Plattsmsuth. He died April 22, 1879. Another practitioner, who arrived in about 1856 or shortly thereafter, was "Levi" Golding, graduate of Koenigsberg, Germany, medical college, who combined the practice of medicine with Indian trading. His real name was Carl Ernest Lcuis Golding. He left for St. Louis to enlist during the Civil War and on his return, devoted himself exclusively to business. A son, D. G. Golding, born in Plattsmouth and graduated from Jefferson Medical College in 1890, is now a physician in Santa Monica, California. The elder Golding died October 31, 1903.

The next physician to choose Plattsmouth for his home was R. R. Livingston, who became an outstanding figure in political life, as well as in medical circles. Born in Canada and having worked in the mines of northern Michigan, as described in the Chapter on Pioneers, Livingston settled in Plattsmouth in 1859 and practiced there until June, 1861, when he organized Company A, First Nebraska Volunteer Infantry. He returned to Plattsmouth at the close of the war with the rank of general, became mayor of the town; helped organize the Cass County and Nebraska State Medical Societies; and the Omaha Medical College, as well. When a medical school was organized in Lincoln, he was also on the faculty there. When the Burlington railroad was built he was named chief surgeon of the road. Many vivid stories are still told of the life and activities of this powerful figure in Nebraska medicine; how he stopped the printing press of the Plattsmouth Herald to issue the first call for volunteers in the Civil war; how he challenged his friend, J. Sterling Morton of Nebraska City, father of "Arbor Day," to a duel, and other colorful tales. 
Three of Livingston's sons followed him in the profession and two of them, Theodore Philip and John Stuart Livingston are now practicing in Plattsmouth, the elder having succeeded his father as med cal d rector of the Burlington lines. west. Robart R. Livings-
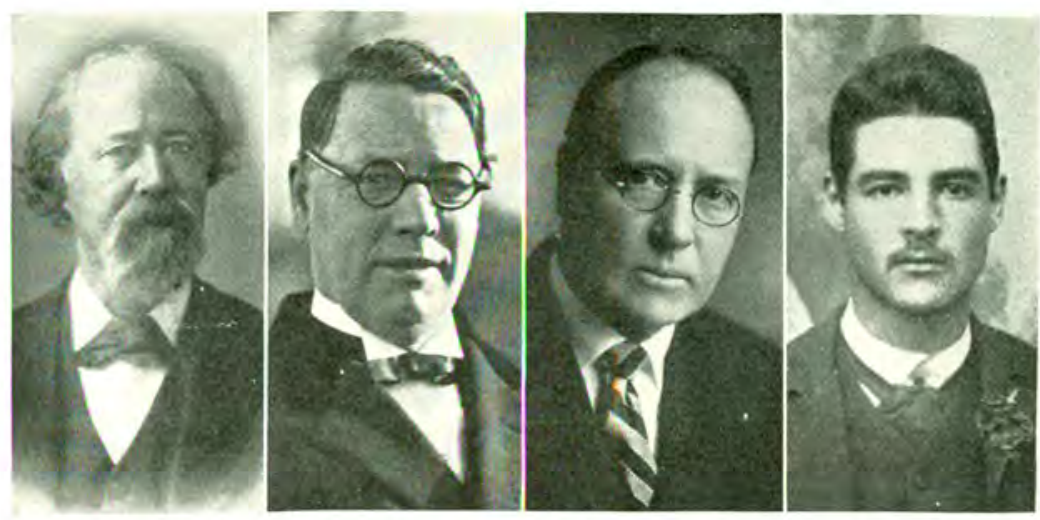

ROBERT R., JOHN S., THEODORE P., AND R. R. LIVINGSTONE, JR.

ton, Jr., graduate ci the Omaha Medical College in 1887, practiced in Cedar Creek: was on the staff of the state hospital at Ingleside; and then in 1902 entered the service of a gold mining company in Quito, South America, from which he returned broken in health, and died July 2O, 1906, not yet forty years

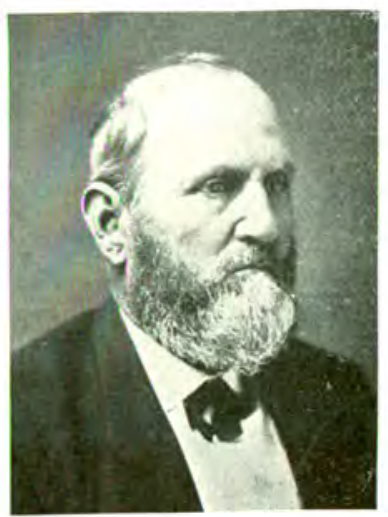

GEORGE HUFFMAN BLACK of age. T. P. Livingston was graduated from Omaha Medical College in 1885 and took post graduate work in Chicago. His service with the Burlington dated from his father's death, September 28, 1888 to 1907 . His brother Stuart received his medical training at the University of Michigan.

Francis B. Reed, who settled in Rock Bluffs in 1859 and whose daughter, Eleanor Capitola Reed, is now practicing in Peru, Nebraska; Wm. Henry Schildtknecht, who came to Plattsmouth in 1861 and the Blacks, George $\mathrm{H}$. "Ohio" Black who also came in 1861 and John "Missouri" Black, mentioned above, who came in 1863, are the next group of practi- 
tioners. The two Doctors Black were not related to each other and were distinguished by the old residents, by the state from which each came. George Huffman Black was born in Huntington, Pennsylvania, November 22, 1817, and lived in Delaware, Ohio, until he came to Plattsmouth November 1, 1861. He practiced there until he retired in 184. His death occurred February 6, 1890.

Schildknecht was born in Dayton, Montgomery County, Ohio on May 28, 1836 of Pennsylvania Dutch stock and came to Ne-

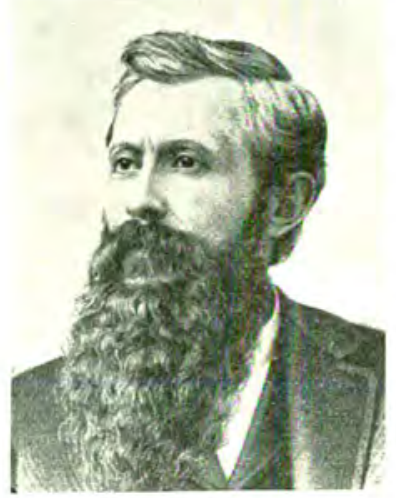
braska in 1859, locating first on a farm four miles south of Plattsmouth for a few years, before he began the practice of medicine. He had studied with a preceptor, Dr. Brewster, in Henry County, Indiana for three years, afterwards attending the Eclectic college at Cincinnati and practiced in Indiana two years before coming west. Dr. Schildknecht was said to be well adapted to his profession, kindly, sympathetic, jovial and friendly so that he won his way into the hearts of those he served until his William H. Schildknecht death, February 27, 1907. He practiced both homeopathic and eclectic methods. None of his three daughters survive.

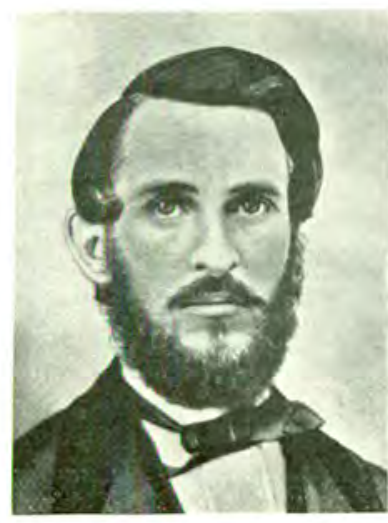

FRANCIS REED

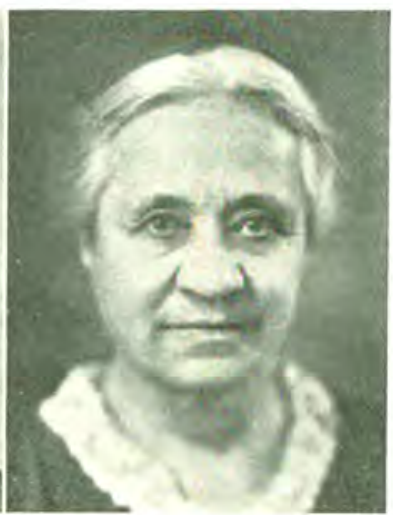

ELEANOR CAPITOLA REED 
Francis Reed, who joined Livingston in the First Nebraska Volunteers in the Civil War, was born in Reedville, Ohio, December 26, 1828 and studied medicine in Ohio and at Keokuk. He practiced in St. Charles, Iowa, from 1856 to 1859 before settling in Rock Bluffs, Cass County, Nebraska. He also published the Plattsmouth Herald in 1881 and practiced for a half century in this state, before his death. His daughter, Eleanor Capitola Reed, is still practicing in Peru, near the place where she was born December 21, 1861. She is a graduate of the Women's Hospital Medical College of Chicago in 1885 and took short courses in Johns Hopkins and New York City. She is active in the Nemaha County society. The Reeds furnish the only instance of father-and-daughter-physicians in the state.

John Windsor Rawlins, a distinguished gentleman, for four years surgeon in charge of the Army of the Potomac, was the next important medical personage in the Cass County seat. Rawlins crossed the Platte on April 24, 1869 coming from Florence, Nebraska, where he lived

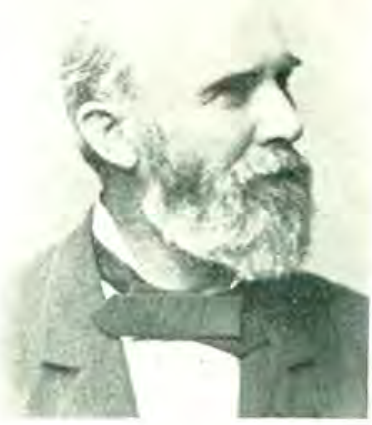

JOHN WINDSOR RAWLINS with both typhus and typhoid fever and was thoroughly sick of war and bloodshed so that he attempted to give up the practice of medicine, but drifted back into it. He died in Williamsburg, Virginia, in 1906 when he was 85 years old and was buried in Arlington cemetery. A daughter, Mrs. Flora F. Waugh, lives in Lincoln, Nebraska.

Samuel S. Miller, who had been practicing in Bellevue, Sarpy County, as early as 1856, spent some time in Plattsmouth in the 
early '60s. He was a licentiate of the Toronto School of Medicine and it is said all of his six sons are now practicing medicine in the east.

Jacob Alfred Hasemeier, born in Franklin County, Pennsylvania, September 20, 1849, Practiced in Louisville, Nebraska, for the 30-year period between 1872 and 1902, when he moved to California. He was a graduate of the Ohio Medical College at Cincinnati in May, 1878, and died in the west in 1913. His widow, a son John who served in the Rainbow Division in France, and a daughter in Chicago survive him. Mrs. James Robertson of Plattsmouth is a sister.

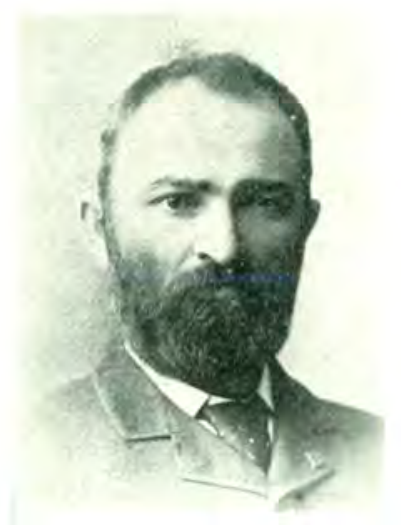

JACOB A. HASEMEIER

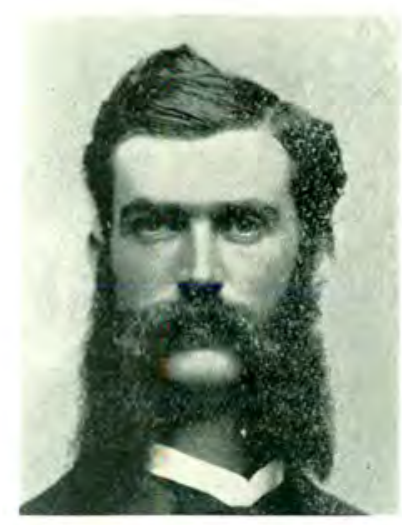

NOAH R. HOBBS

Noah R. Hobbs, born in Livingston County, Missouri, February 16,1852 , came to Rock Bluffs, Nebraska, with his parents when he was eight years old. He attended Naomi Institute there and began the study of medicine in Missouri Valley, Iowa, under the tutelage of E. F. Chapman, remaining there three years. He was graduated from Rush Medical College in February, 1876, and that summer, located in Elmwood, where he practiced for almost a quarter of a century, until his death, July 10, 1900. A daughter, Miss Grace E. Hobbs of Portland, Oregon, is the only surviving member of his family.

Hobbs was preceded at Elmwood by James A. Kenaston, an ordained elder who came to Nebraska as a missionary in 1864 and again in 1868, after service with a Polk ounty, Iowa, regiment in 
the Civil War. He filed pre-emption on a homestead at Elmwood in 1869 , and in 1871 was elected a member of the state constitutional convention. Kenaston was born in Cabot, Caledonia County, Vermont, April 2, 1826, was licensed to preach in 1857, read law and medicine, completed his medical studies in 1860 and was ordained an elder in 1864. He practiced in Elmwood from that years until 1881 when he moved to Sherman Heights, Tennessee, where he died, June 30, 1911.

Robert Bruce Wallace, who practiced at Factoryville in Cass County from 1873 to 1887 , came to Nebraska in 1864 from Sheridan

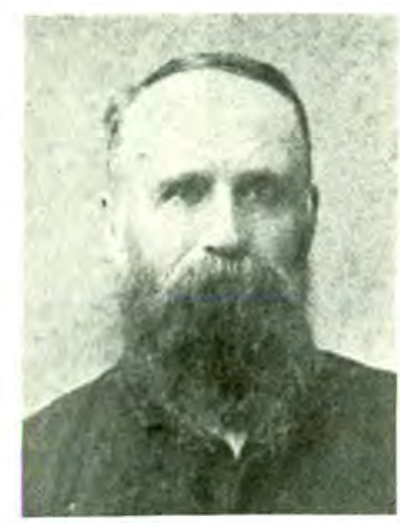

JAMES A, KENASTON

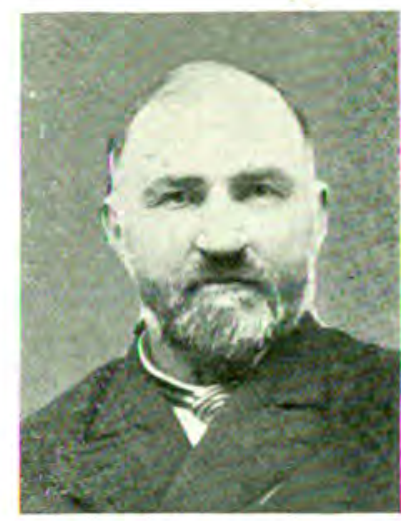

ROBERT BRUCE WALLACE

County, Missouri, where he was born March 10, 1846. He taught school for more than a year, then attended Jefferson Medical School, Philadelphia, from which he was graduated in 1868. Returning to Nebraska City, he was employed in the drug business for a few years and then located in Wyoming, Otoe County, until 1873, when he moved to Factoryville. When the opst office was moved to Union in 1887 , he moved too, continuing his practice there until his death, September 16, 1901. He was active in the Otoe County Medical Medical Society.

Joseph H. Hall, still living, is the next of the old school of physicians to move to Cass County in 1864 with his parents, when only a lad of eleven. His father, James Hall, had been sheriff of Clark County, Iowa, and was later elected to the state legislature from 
Cass. Young Hall, who was born March 24, 1853, in an Indiana $\log$ cabin, hewn and built by his father before their removal to

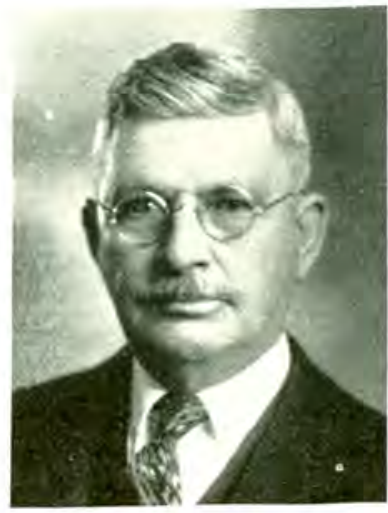

JOSEPH H. HALL Iowa, was graduated from Peru Normal and studied medicine with General R. R. Livingston as his preceptor, from 1876 to 1882 , although he was graduated from Rush Medical College in 1878. This was about the time the germ theory in medicine was first agitated, and Hall came back after postgraduate work at Bellevue in 1882 , with many new-fangled ideas in surgery, for those days.

The veteran practitioner, by whom most of this cass County historical material was collected, relates the story of an operation he performed for ovarian cyst, in a woman's home, there being no hospital facilities in Plattsmouth at the time. A daughter of the patient scrubbed the walls and sprayed the room with the proper solution, under Dr. Hall's instructions. The operation was entirely successful. At another time, Dr. Hall and his preceptor, Dr. Livingston, performed a simultaneous operation, amputating two legs of a man inịred in a railroad accident.

Of all his pioneer experiences, Dr. Hall recalls that the mud and the snowdrifts were the worst.

"Sometimes they were so deep my horse couldn't go through, but the call on the sick had to be made," said he.

Hall joined the Nebraska State Medical Association in 1878 and is perhaps one of the oldest living members, together with Dr. A. S. von Mansfelde of Ashland, who proposed his name. Hall was health officer at Plattsmouth during a virulent outbreak of smallpox in 1881; served on the advisory draft board during the late war, and was the first grand medical examiner of A. O. U.W. in Nebraska.

Anson L. Root, who settled in Eight Mile Grove in March, 1873, was the son of a doctor, and himself had hwo sons, one of whom became a physician and the other a druggist. His mother, Sally Brooks, was the daughter of an officer in the Continental army. Root was born in Trumbull County, Ohio, February 5, 1831 and studied with his father until he was 21 ; with : Dr. Bradley 
in Johnstown, Ohio, and then took a course at the Cincinnati Eclectic college. He began to practice in Ohio n 1851 and followed his profession in Indianna and Michigan before coming to Nebraska, where he was appointed postmaster. After eight years at Eight Mile Grove, he moved to Weeping Water, where he died a few years later.

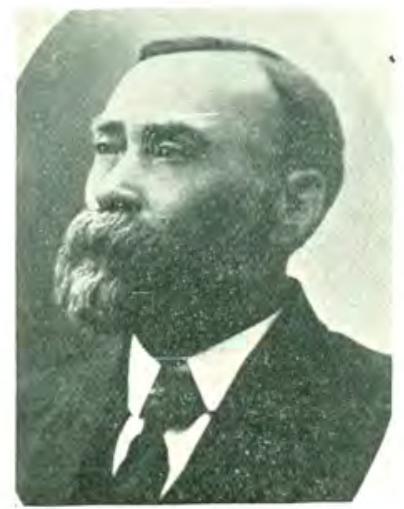

Milton Micajah Butler, who practiced in Weeping Water for more than 40 years, came to Plattsmouth in 1870 , to form a partnership with W. H. Schildknecht, which lasted until Butler moved to Weeping Water in 1873. Butler came from Indiana where he read medicine with his brother, who was also a physician; and studied in Cincinnati and at Rush Medical College in 1869. In his new post, Butler attained local distinction when he treated 300 cases of smallpox which broke out in the broom Milton micajah bUtLer corn fields near Alvo, and enforced a quarantine even though threatened with shotguns by irate neighbors. He was elected mayor of Weeping Water and was president of the local academy for ten years. He died July 20, 1915.
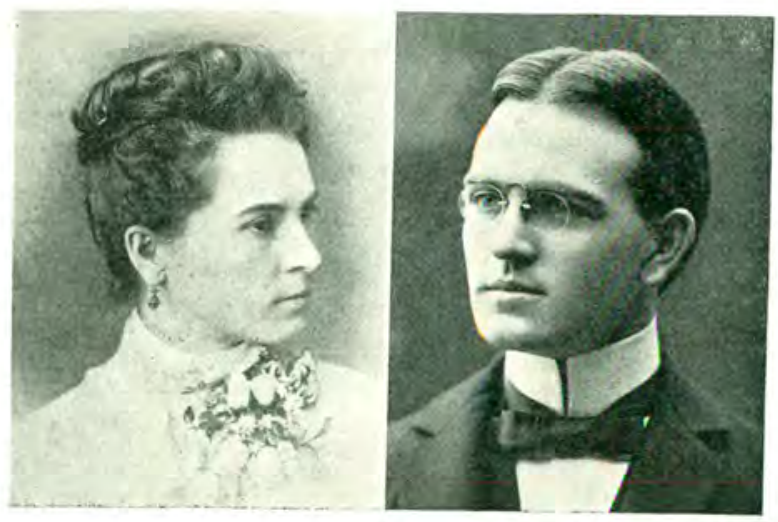

DR. JENNIE FOSTER AND SON, WENDELL FOSTER

The opening of the decade of the ' 80 s brought to Plattsmouth in 1882, Dr. Jennie Foster, who, with her physician-son, E. Wen- 
dell Foster, were a tragic couple who furnish the only instance of a mother-and-son-physicians in the state. Dr. Jennie Foster was born in Almakee County, Iowa, March 19, 1856 and attended Keokuk Medical College from 1880 to February 28, 1882. She registered in Cass County May 18, 1882 and practiced there until her death, April 1, 1887, when she was still a very young woman. She specialized in diseases of women and children. Her son, E. Wendell, a Creighton graduate, practiced in Cedar Creek for four years, then at Hastings; and in 1902, drove muleback through the Big Horn mountains to the Hospital. Additional equipment was added and it opened to the

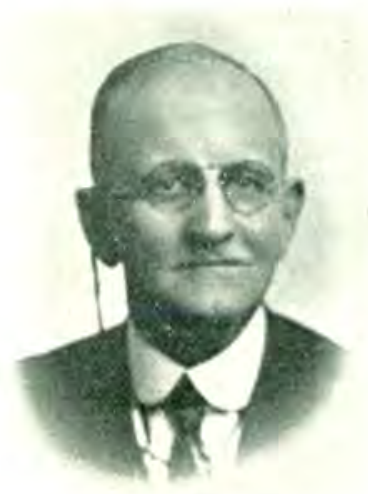

EDWIN WESTBROOK COOK

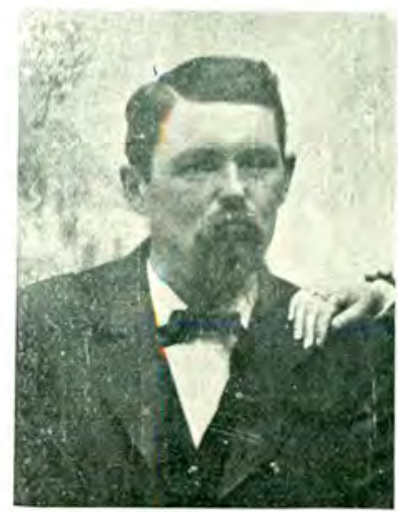

JOHN BROWN DUFF

new town of Worland, Wyoming, where he was the first physician to practice. He killed himself in Omaha in 1906.

John Brown Duff came to Nebraska in $\mathbf{1} 882$ and practiced at Cedar Creek until his death, March 21, 1822. He was a Civil War veteran, a graduate of Ann Arbor and Keokuk Colleges and practiced at Winterset, Iowa, before settling here. During the typhoid epidemic of 1887 , it was reported he lost only three out of 36 cases.

Alfred Shipman, native of Ontario, Canada, came to Plattsmouth in October, 1884, having previously practiced in Johnson County, where he was president of the county society. He was graduated from Keokuk in 1875, and practiced for 20 years in this state, before moving to New York, where he died April 14, 1920, at the age of 78. A son is living in California. 
Edwin Westbrook Cook, member of the board of education and city treasurer of Plattsmouth, settled there in 1884, after his graduation from the Iowa State Medical College, and post graduate work in Chicago. He was active in public affairs, was medical examiner for many fraternal organizations and for the Rock Island railroad, until his death at Rock Island, Illinois, October 14, 1920. He was born near Salem, Iowa, in March, 1857.

George H. G.Imore of Murray was born on a ranch seven miles from there, August 20,1867, and, since attaining manhood, has practiced in this vicinity for more than 30 years. He organized a company during the Spanish-American War, and is of a literary turn. His publications will be enumerated in another chapter.

E. D. Cummins, now of Lincoln, and Patrick J. Flynn of O'Neill, Creighton graduate, whose son Allison Flynn later moved to Pittsburgh, were other early practitioners. Other early registrants, revealed by county records after the law of 1881 went into effect, show, besides the above named, Hamilton Mead, S. W. Richmond, John L. McCrea and Julius Ploof of Plattsmouth; Henry D. Root of Elmwood; W. D. Gibbon, George D. Sitzen and J. W. Thomas of Weeping Water; R. B. Mullen of Factoryville; John M. Waterman and Chester F. Harris of Louisville: Claiburn D. Davis of Union; George Stewart, Enus Orin Darling and Nathan Kirk of South Bend; Urban H. Norris of Greenwood; William A. Packard of Avoca; E. E. Reynolds of Rock Bluff; and Jennie Coleburn and J. Alonzo Green, out in the county - all of whom registered in 1881 . Hyacynthum Schmidt of Plattsmouth, Benjamin J. Alexander and W. A. Palmer of Greenwood, and Josiah Sylvester Sturdivant of Eight Mile Grove registered in 1882; Alvin H. Keller and Grant J. Ross of Plattsmouth, and George R. Salisbury of Weeping Water in 1883; William F. Whittemore of Plattsmouth, John Marshall Neely of Bushbury, Wesley DeGarnau of Louisville, George W. Miller of South Bend and Alfred H. Cross in Cass County in 1884; Theodore Philip Livingston of Plattsmouth, son of R. R.; Benjamin F. Brendel of Murray and Robert Bruce Wallace of Weeping Water in 1885; Orthelo Waters and Alex Van Gant Robinson, both of Louisville, William Kirk of South Bend, R. H. Rhodes of Greenwood, Bowen Porter of Eagle and Benjamin F. Lang of Weeping Water, in 1886: Ernest L. Siggins of Plattsmouth, John P. Williams of Weeping Water and Isaac Sinclair of Eagle in 1887; W. H. Dear- 
ing of Wabash, Winifred A. Alden of Rock Bluffs, Julius A. Schulke of Louisville, J. N. Emmons of Plattsmouth and John McConnaha of Cass County in 1888; R. R. Livingston, Jr _, Frank D. Burgess and W. A. Humphrey of Plattsmouth, L. Guy Ramaly of Nehawka. Martin L. Thomas of Union, Robert Baird of Elmwood, Edgar Dean Cummins, now of Lincoln and John F. Brendel in 1889; James B. Hungate of Weeping Water, Norval Eddy Presnell of Avoca and Isaiah W. Haughey of Elmwood and Sidney J. Tabor of Murray in 1890 ; Julian A. Pollard of Nehawka, Jerome B. Taublin of Greenwood and john R. W. Lages of Alvo, William Henry Maikin of Eagle and Viola M. French of Plattsmouth in 1891; John M. Neely, Jr., of Eagle, now of Lincoln, in 1896; Norris D. Talcott of Greenwood and M. U. Thomas of Weeping Water, son of J. W. Thomas, in 1897; J. P. Flynn of Plattsmouth in 1899; Edward W. Northman of Louisville, 1900; Thomas H. Gilmore of Murray, 1901: E. W. Foster of Cedar Creek and J. B. Martin of Plattsmouth in 1902; J. B. MARTIN Jacob F. Brendel of Murray in 1903; Uren Morrow of Louisville in 1916; and John Stewart Livingston of Plattsmouth, third son of R. R., in 1918. Raymond P. Westover is a recent registrant.

Records of the Cass County society throughout this whole period are missing until April 16, 1903, when a reorganization, according to the state plan, was effected in the office of J. M. Neely at Elmwood. I. D. Jones of Murdock was elected president. E. W. Cook was named president at the 1905 meeting held with Dr. Hungate at Weeping Water; J. B. Hungate at the 1907 meeting in Louisville; T. P. Livingston at the 1908 meeting; J. M. Neely of Elmwood in 1910; M. M. Butler in 1915; F. P. Reed of Weeping Water in 1917; and Dr. Neely re-elected in 1918, when all county doctors were asked to volunteer for war service. H. W. McFadden of Greenwood and J. W. Thomas of Nehawka were already on duty. At the 1921 meeting, G. H. Gilmore of Murray was elected president; J. W. Thomas was the 1922 leader. He was re-elected the next year and A. R. Hornbeck of Murdock took the office in 1924. 


\section{CEDAR COUNTY}

Physicians registered in Cedar County are:

Robert A. Allen

A. A. Potterf

Samuel L. Brown

A. C. Sabin, Jr.

Eli M. Morehouse

M. A. Flouersch

Marshall Petitt

W. Y. Jones

Gilbert D. Loffler

Q. A. Kerley

Jno. Van Keuren

John J. Kiefer

John W. King

Edw. T. Anderson

John B. Joyce

L. J. Townsend

J. A. Clark Busby

Harold Van Lammers

John Dudley Lutton

Earl Edgar Miller

Jeremiah A. O'Connor

Frank Lane Ready

Walter Zulauf

Edward S. Furay

Archibald C. McPhaden

Paul John Hermsen

Ray B. McNamara

James Muir

John M. Johnson

A. D. Field

Leslie A. Johnson

Ralph M. Ryan

Augustus Hamilton

Avery C. Hancock

Mary B. Hancock

F. P. Dorsey

W. W. Van Velson

William Herbert Coney

Austin Smith

Beecher B. Baldwin Charles Ferd Ulrich Alonzo A. Ward James F. Warrick George WV. Doran William Patrick Hynes Arthur C. Smith Jno. J. Williams Walter Sidney Yates A. C. Salvie
D. D. Barr

H. B. Arnold

Arthur N. Sloan

J. A. Copeland

Morris Nielsen

Fletcher Gardner

Arthur E. Cook

Almer L. Sabin

E. Schneller

W. A. Burke

Chas. D. Chandler

C. C. Sackett

Jacob C. Hay

Sallie F. Kennedy

Francis J. Goulding

Charles C. Crowl

Hugh Hover

Lucien Stark

P. J. Little

Thomas C. Hinkle

Charles C. Tellesen

F. E. Barucht

C. Bernard Nagelmann

H. S. Brevort

Fred G. Dewey

Isaac Bowden

Bert L. Bleason

Arthur E. Oberman

H. H. Bryan

Frank A. Paden

Paul W. Gibson

Frank Earl Gordon

Charles C. Stivers

Alfred Eddy

John Gould

Henry Van Velsor

Fred A. Bayer

\section{CHASE COUNTY}

F. L. Krampert

C. Robert Carlson

\section{CHERRY COUNTY}

Walter H. Vanden

Rollin G. Rothe Elto

Elton B. Grubs

T. Nelson Duncan

M. E. Barakat

Joseph John Dallal

H. S. Brevoort

George P. Wilkinson

Homer F. Fort

Ben W. Kinsey
E. J. Austin

Charles E. McChesney

Eli M. Williams

C. T. Ingham

Allen F. Miller

Belee R. Johnson

C. H. Steele

J. A. Dales

M. M. Wilson

Will K. Johnson

J. Will Presnell

William G. Ziegler

W. G. McCohn

G. M. Morton

Charles E. Ballard

Alfred Eddy

Wm. T. Tanner

Daniel J. Van Velsor

John Scott Ward

William W. T. Gerisch

George B. McFree

H. E. McKenzie

Henry V. Van Velsor

W. E. Wolfgang

J. W. Hitchcock

William C. Bundy

Frederick A. Bayer

Hector Sinclare Aley

George Julius Puhek

George Hartford Smith

Joseph F. Smith

Edward C. Mosteller

Henry G. Liesenring

J. D. McClane

Charles O. Seaman

S. H. Knowles

Charles Arthur Sharp

George Hoffmeister

Chester Arthur Johnson John W. Archerd

A. N. Compton

Dr. Cornelius

Dr. Tische

A. A. Potterf

Hal R. Cohee

Robert P. Hoxsey

Milton B. McDowell

Jennie A. McCullach 
G. H. Hall

Francis J. Baldwin

H. A. Brown

L. Clyde Davis

Mrs. S. M. Steward

J. Elmer Snyder

Lauren Jones

Edward S. Furay

Judd A. Strong

W. R. Sparling
Ernest Roone Downs

Willis G. Tanner

Blaine Augustus Young

Adam R. Ray

William A. Moore

Wm. T. Davis

Ida P. Davis

William G. Estee

M. J. Gahan

Edward H. Dwyer
T. F. Campbell

Charles V. Crooks

Julius L. Goodrich

Johnathan J. Evans

Alfred Lewis

Charles V. Holsclaw

Edward T. Julian

Lizzie White Sawyer

James C. Dwyer

\section{CHEYENNE COUNTY}

Cheyenne County society was organized in October, 1925, with H. L. Mantor of Sidney, president; R. E. Roche of Sidney, vicepresident and G. F. Zarbaugh of Dalton, secretary treasurer. Other members were A. L. Miller, E. L. Rolph ard P. C. Mockett, all of Kimball; W. T. Sloan and A. J. Ames of Potter; Roche, J. R. Taylor and Mantor of Sidney and A. E. Hedlund and Zarbaugh of Dalton. R. E. Roche of Sidney is president now and G. F. Zarbaugh, secretary.

\section{CLAY COUNTY}

Isaac D. Howard O. P. Shoemaker F. A. Butler John F. Edgar James H. Conrad John T. Fleming Sarah A. Scott Hale J. A. Philipsen G. A. Wierick

A. J. Jennison

C. A. Fiippin

T. F. Campbell

Sarah E. Green

F. L. King

Henry C. Williams

A. J. Kaufman

S. Scruggs

James O. Latta

Messiah Mesropian

Charles L. Egbert

Bruno J. F. Getzlaff

Jerome G. Pace

Charles C. Stivers

David J. Reynish

Oran C. Osa

William M. Bair

George E. Egloff

Vernard A. Lamphier

F. C. Eakins

Henry Hamblin Seeley

Lucius Gould Wright

\section{A. L. Stiers}

Edwin M. McGee

Roy David Martin

W. M. Thomas

Louis J. Storkan

Herbert William Adams

Andrew Jackson Smith

Gilbert D. Laffler

James G. Stone

Joseph M. Welch

William H. Gibbon

John M. Birkner

D. F. Anderson

Hugh M. Bailey

T. E. Casterline

James K. Whiteman

Joseph E. Spatz

George M. Prentice

Victor Anderson

Henry R. Miner

Jos. R. Sample

A. Disbrow

Robert A. Blackburn

W. D. Rea

John W. Thompson

Charles Lucas

F. H. McCabe

Wellington W. Keith.

Andrew J. Chamberline

S. Harper Corran

George B. Walford
C. J. P. Beirne

Clinton L. Ayers

Chas. L. Bohanxan

William T. Putt

George D. Wertz

George M. Doran

John M. Triplett

John Larence Mace

H. S. Brevoort

J.eander Z. Skinner

Wm. J. Breckenridge

Roy D. Bryson

Enoch Neff

Wesley Queen

James R. Bell

Eugene Miles Ryman

J. E. Ingram

Henry S. Munro

Robert F. Jones

Rudolph Otto Griess

Chas. W. Gooden

Laird W. Elwood

H. L. Vradenburg

O. B. Canfield

J. C. Brubaker

M. A. Perkins

Adam R. Ray

Alfred C. Ames

William A. Lusk

John S. Winston

J. L. Patton 
Herman Bening

Herman H. Schultz

F. E. Dalrymple

R. W. E. Casterline

Alexander C. Sabin

Virginia A. Bradley

Charles A. Holbrook

Wm. Cornwell

Frederick L. Beck

Peter G. Grimm

Frank E. Stoaks
A. A. Potterf

J. W. S. Martin

Dennis Neville

Frank Earl Gordon

Geo. D, Sitzer

Allan M. Lafferty

John W. Mechan

Joseph S. Leisure

Charles Herbert Atwood

John W. Archerd

Geo. H. Bentz
Charles C. Aiken

M. L. Rich

Alfred E. Reeves

Fletcher A. Butler

H. Y. Bates

Lester Kenneth Strate

George L. Carlson

A. J. Kaufman

Lothar F. Egen

William A. Campbell

\section{CUMING COUNTY}

The Cuming County society was organized at Beemer, February 22, 1904, on call of $\mathrm{E}$. Tanner of Battle Creek, then district delegate. H. W. Francis of Bancroft was elected president and has continued in this post for 17 of the 24 years which have elapsed, thereby probably establishing a state record for years in office. W. L. Crosby of Beemer was named vice-president and H. L. Wells of West Point, secretary-treasurer. Present at this meeting were also R. H. Morse and Pritchard of Wisner; T. D. Thompson and H. S. Summers of West Point.

The next meeting was held April 18, 1905 when Francis was re-elected president and Irwin C. Sutter of Bancroft was elected to membership. Francis continued in office until June 14, 1917 when H .S. Summers succeeded him. New members admitted in the interim were J. H. Tobkin, Lincoln Riley, J. J. Kieffer, George V. Allen, Charles S. Grabin, F. Kuegle, I. L. Thompson, K .E. Thompson, Marie Morse, E. S. Thompson, F. J. Kotlar, J. F. Smith and A. W. Anderson. Summers held office until November, 1920, when the late T. D. Thompson was elected president, serving until 1924 when Francis, who is still the presiding officer, was again named. Additional new members include L. F. Chapman, F. M. Heacock, W. K. Riley, B. V. Kenney and C. A. Pierson, who conducts a hospital at Beemer. There is also a hospital at West Point, in connection with the home for the aged. It is called St. Joseph's Hospital. Present membership includes Francis and Heacock of Bancroft, W. K. and Lincoln Riley and M. H. Morse of Wisner, Pierson of Beemer, Irwin L. Thompson, Chapman, Kieffer and A. W. Anderson of West Point. Thompson is secretary-treasurer.

Around West Point, local residents would scarcely know how to say "Mr." Thompson, they are so accustomed to prefixing "Dr." 
Thompson. Residing there have been five Doctors Thompson, four of them sons of the late Thomas D. who came to the county about 1874, after his graduation from the University of Pennsylvania, and practiced there until his death, about two years ago. Two of his

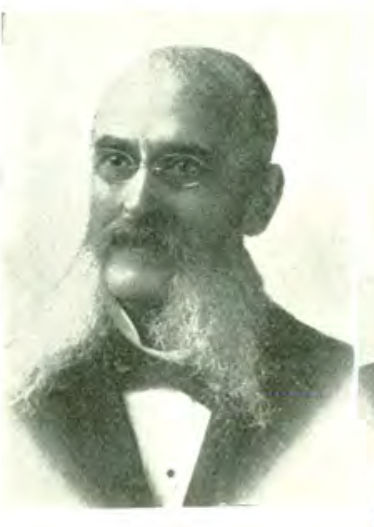

THOS. D.
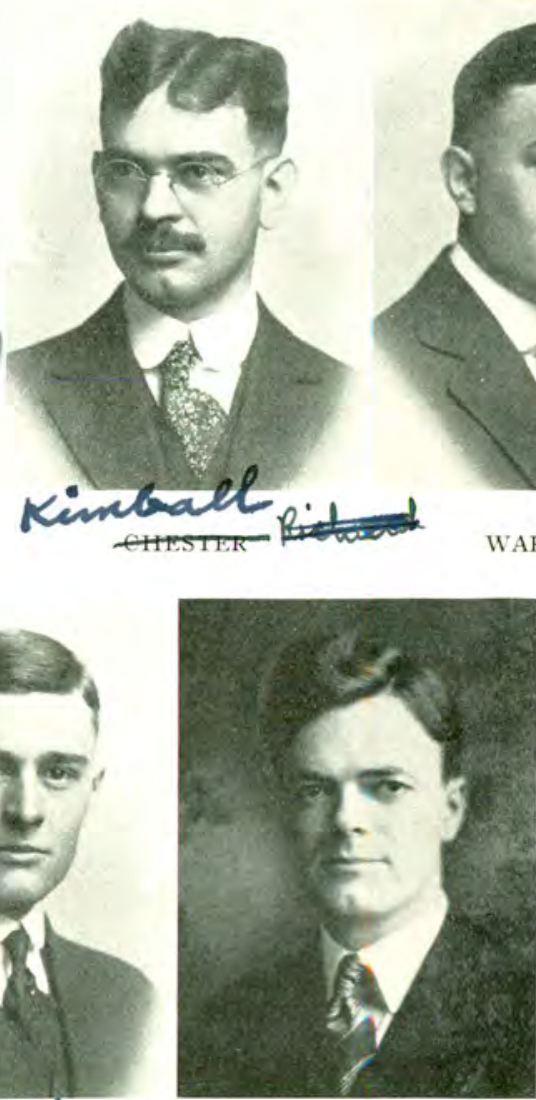

chester

sons, Warren Y. and Chester Quay are now practicing in Omaha and are on the faculty of the Nebraska University College of Medicine. Richard Yoder settled in Seattle, Washington. Kimball E. died a few years ago while still a young man. Each of the four selected different schools of medicines to attend. Warren was gradnated from Rush; Chester, from Harvard; Richard, from Cornell and New York College of Medicine; and Kimball, from Creighton. 
Lending additional interest and numbers to the Doctors Thompson, were his father, Levi H., and the four brothers of Thomas D. Thompson, who practiced in the east; and his grandson and namesake, Thomas Thompson of West Point, son of Charles, the only one of old Dr. Thompson's sons who did not elect a medical course. The young Thomas is now attending the University of Nebraska School of Medicine, where his two uncles teach. Dr. Levi Thompson practiced for 49 years in Reading, Pennsylvania. The family has been given national publicity, due to the number of doctors among them.

Cuming County physicians since 1891 have been:

$\begin{array}{ll}\text { George V. Allen } & \text { Henry J. Holk } \\ \text { Emma M. Ackerman } & \text { Max Jany } \\ \text { Albert Wilfred Anderson Julius Lingenfelder } \\ \text { Edwin Buzick } & \text { John J. Kiefer } \\ \text { Davis Beswell } & \text { W. D. Karass } \\ \text { Grove W. Bortlett } & \text { Frederick W. Kuegle } \\ \text { Rodner Beecher } & \text { Frank J. Kotlar } \\ \text { H. S. Brevoort } & \text { Allen M. Lafferty } \\ \text { W. M. Biarr } & \text { J. C. M. Murphy } \\ \text { Charles Cadwallader } & \text { Edwin M. McGee } \\ \text { Mercer B. Croll } & \text { Theo Milen } \\ \text { William M. Crosby } & \text { R. H. Morse } \\ \text { Charles V. Crooks } & \text { S. A. Preston } \\ \text { J. K. L. Duncan } & \text { Enoch Neff } \\ \text { William G. Estee } & \text { Charles Oxford } \\ \text { C. W. Flock } & \text { Owen S. O'Neill } \\ \text { Henry W. Francis } & \text { Harry Prichard } \\ \text { W. A. Gervais } & \text { G. G. Pratt } \\ \text { W. D. Gibbon } & \text { A. A. Potterf } \\ \text { D. G. Griffith } & \text { Lincoln Riley } \\ \text { Charles S. Grabin } & \text { M. L. Rich } \\ \text { Frank Earl Gordon } & \text { James P. Remiur } \\ \text { A. E. Hill } & \text { William F. Race } \\ \text { Marian Hansen } & \text { Wilber K. Riley }\end{array}$

A. C. Sabin
Karl Schiemel
Erwin C. Sutton
Charles C. Stivers
Hy. S. Summers
Irwin L. Thompson
Thos. I. Thompson
Richard J. Tanner
Kimball E. Thompson
C. T. Seevers
Joseph N. Tobkins
Edgar Samuel Thompson
Walter Christian Zulauf
Frederick Van Akereu
George Carl Weber
H. L. Wells
Lille Forrest Chapman
Frank Mills Heacock
Clarence A. Pierson
John Francis Smith
Leo. M. Wagner
S. A. Sammons
Almer L. Sabin
Thos. B. Smiley

CUSTER COUNTY MEDICAL SOCIETY

Through the good offices of C. L. Mullins of Broken Bow, the oldest member of the profession still in active practice in Custer County and who made long drives through the county, one day traveling 90 miles, to gather historical data, some information regarding the early medical history of Custer has been gleaned.

Governor Garber declared the county an entity on June 17, 1877 , naming it for the lamented Indian fighter, but it was not until almost two years later that homesteaders began to straggle in. The largest influx of settlers came in 1882-1883. Two doctors came 
with the very earliest settlers in the late 70 s. The name of the first has been forgotten but the second, Robert C. Talbot, is still living at the age of 81 and his son, Willis E. Talbot, is now practicing in Broken Bow.

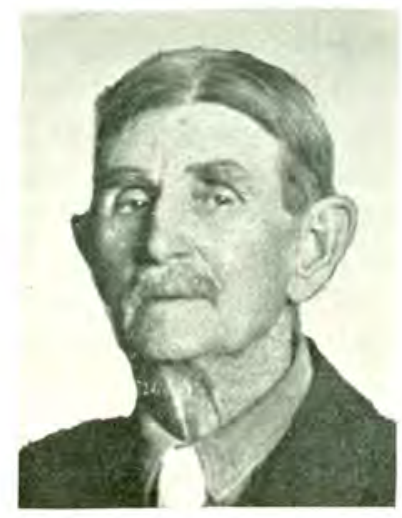

R. C. TALBOT

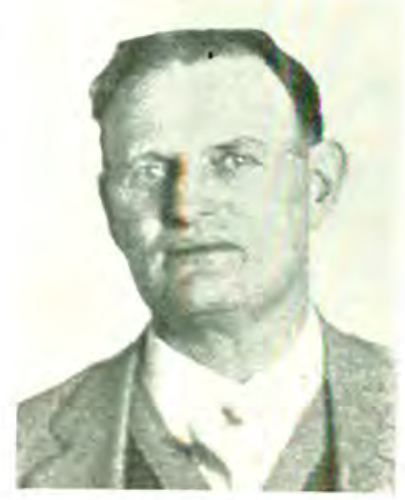

W. E. TALBOT

The elder Talbot, who settled on government land near what is now the village of Berwyn, in the fall of 1879 , still has large land holdings there. He was born in Danville, Indiana, March 16, 1847, was graduated from Miami Medical College in Cincinnati in 1870 and practiced in several Indiana towns before comirg west. He had no intention of practicing medicine, planning to take up farming and stock raising, Talbot informed Dr. Mullins, in a recent interview, but the settlers, learning that he was a physician, came long distances to consult him and he was gradually forced back into the profession, though he gave his attention largely to stock raising. He remained on his homestead until 1884, when he was elected county treasurer on the republican ticket, and moved to Broken Bow, where he served for two years. After this, he engaged more regularly in the practice of medicine. He was a man of strong character, fine mental qualities, served on the school board and was one of the organizers of the Custer County Medical Society. The exact date cannot be determined for the records are gone and Dr. Talbot's memory is not reliable but it was in the early ' 80 s, about 1883. It is probably one of the oldest county medical societies in the state.

"It took courage and real interest to main tain a society in the then sparsely-settled county of large size (the county is 48 by 54 
miles in area)," is the comment of Dr. Mullins, who came to Custer

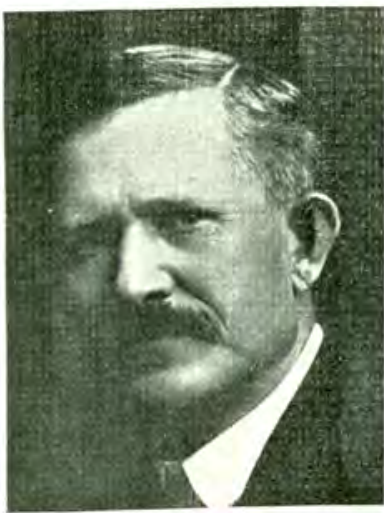

C. L. MULLINS

himself in 1894, "for the roads were nothing but trails and going to medical meetings meant traveling a long distance either on horse-back or at best, by team and buggy. This fact should serve as a stimulus to present day physicians in maintaining active county societies, when we have such wonderful roads and comfortable automobiles. In 1894 the society agreed to meet bimonthly. After several years, a quarterly plan was adopted, and still later, the plan for spring, mid-summer and fall meetings. No meetings have been omitted in all these years, except three or four, due to severe storms. With no telephones and no automobiles, the early doctors frequently drove 60 miles to attend a meeting, getting home along toward morning, after driving most of the night. One of these early meetings proved so interesting, the discussion lasted all day and

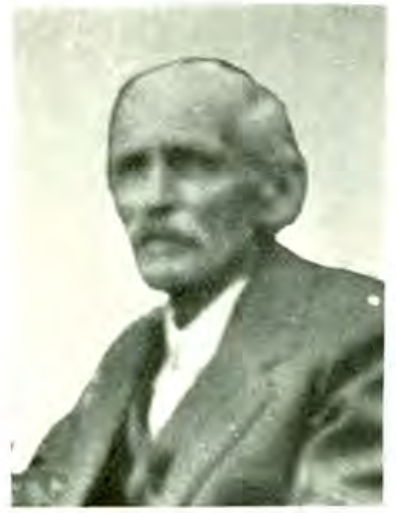

L. L. CRAWFORD all of the following night! The interest shown would do credit to a district meeting.

"Early in its history the society had let down the 'bars' and eclectics and homeopaths were admitted on an equal footing, which added enthusiasm to the discussions. Nothing but good came of this action, which was not popular at that time in most regular societies."

The drought of 1894 discouraged a number of the pioneer Custer doctorhomesteaders, some of whom then departed for new places to settle. Among the early physicians who remained were Lysander Tower Burbank, a former missionary to Turkey who served as a minister as well: T. N. Waterbury and L. L. Crawford. 
Crawford located on a homestead near where Merna now stands, probably about 1881 or 1882 and removed to Merna when it was founded in 1886. He practiced while on the farm and rode over a large territory. He was graduated from the Cincinnati College of Medicine and Surgery in 1876 and practiced in Ohio for a time. He was of the pioneer type, for after this county became fairly settled, he left a good practice at Merna and went to Paonia, Colorado, where he still practices. He contributed largely to the early development of the county.

Burbank was born in Fitz William, New Hampshire and graduated from both theological and medical schools in New York, fitting himself for medical missionary work.

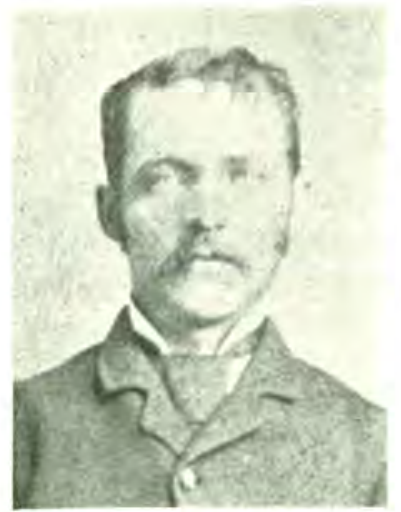

T. N. WATERBURY He married Susannah Val Vlech in New York in 1860, and went, that year, as a medical missionary to Bitlis, Turkey, in Asia where he lived for ten years and where several of his children were born. One of them was Dr. Fred Burbank, who was graduated in medicine at the Omaha Medical College and practiced in Custer County. On their return to America the Burbanks resided in Herndon, Virginia, until 1880 when they came to Georgetown, Nebraska, a small inland trading point and he took charge of the Burr Oak Church (Presbyterian). He was engaged as a minister but because there was but one physician in the county he made calls over a large territory, going mostly horseback, his daughter told Dr. Mullins. "He was a man large both physically and mentally, of many attainments, being versed in Greek and Turkish, a fine English scholar and a student of literature. His principal remuneration for his medical services from 1880 until 1892 was that satisfaction that comes from a knowledge of work well done for the needy poor, as nearly all the settlers were then poor. He removed to Denvr in 1892 and later to California where he died a few years ago."

T. N. Waterbury settled on government land near where the village of Westerville is now located, on July 12, 1880. He was not a graduate in medicine, but had taken a course, and again attended 
a medical college about 1881-1882. On his return he resided on a farm in the vicinity, but when Westerville was founded, moved into the town. He was the first physician to devote all of his time to practice, as Dr. Talbot tried to keep out of it, and Dr. Burbank devoted part of his time to the ministry. Old settlers still recall Waterbury's name with reverence, relating that he literally worked himself to death on his long horseback rides, probably covering the largest territory of any physician in the county. He was so devoted to his work that when he developed typhoid fever, he still insisted on being taken to see his seriously-ill patients, on a bed. This probably contributed to the untimely death of the fine young physician, September 21, 1884.

C. H. Morris succeeded Waterbury at Westerville in 1884-1886, then he went to Ansley; then to Broken Bow in 1892 for two years, and then to Texas, where he died. Frank Vinsonhaler was the next doctor to settle in Westerville, about 1885, remaining until 1891 , when he moved to Little Rock, Arkansas. A. J. McArthur arrived in 1891, practiced a few years and then removed to a farm in the county. He retired recently and now lives in Broken Bow. In 1884, Luther Michael located at a small trading point named Olax, situated near where Oconto now is. He remained until the spring of 1885 when he moved to Callaway, living there until 1893 or 1894. $\mathrm{He}$ is now in California. Another prominent physician at Callaway is Alexander L. Mathews who came in 1886 and still lives there. $\mathrm{He}$ is mentioned in the Chapter on Pioneers.

The first physician in Mason City was C. J. Caldwell who came there in July, 1886 and remained until February, 1887, when be moved to Minneapolis. J. W. Miller, a graduate of Rush Medical College, then moved there from the older town of Algernon, located a few miles west, which was abandoned when the Burlington Station was built in Mason City. Miller was an active and capable physician, interested enough, even in that day, in scientific medicine to do experimental work on dogs. He removed to Gibbon about 1896 and is still there. A. E. Robertson succeeded Miller or took over his practice in 1895 . He died May 31, 1911. A. C. Rumery lived in Mason City from 1903 until his death, August 26, 1926. He was an active member of county and state societies. There were a few more doctors in Mason City during these years but they remained so short a time they left no impression. P. H. J. Carothers, who 
came in 1911, moved to Broken Bow in 1924 and now owns and conducts a hospital and is engaged in general practice. L. W. Forney and Dr. Hubbard are now practicing in Mason City also.

L. B. Wamsley came to the old inland town of West Union in 1883, probably, and conducted a drug store for many years. He was the only doctor there. He was not a graduate in medicine, but had taken one course in the old College of Physicians and Surgeons in Keokuk, Iowa, and was active in the county society, probably one of its first members. He retired fifteen years ago and spent the rest of his life in the state of Washington.

Arnold was laid out in 1884 and hence is one of the oldest towns in the county. Of the physicians there Dr. Stimson was the first, locating there in 1884 but he practiced only six months, dying of typhoid fever. J. H. Murray succeeded him in 1885 and remained there until 1890. A Doctor Bennett succeeded Murray and remained one year. S. W. Anderson succeeded Bennett and remained two years, then returning to Ohio. B. E. Robinson, a graduate of McGill University of Montreal came to Arnold from Canada in1892 and practiced there until until his death, December 19, 1913.

Robinson was one of the most capable physicians Custer County ever had, modest to the point of diffidence, industrious, a fine character who became an American citizen in the best sense of that term. When he located at Arnold and for many years following, there was no railroad there. His territory was only limited by his ability to get to patients for his trips took him into and beyond the present town of Stapleton, all over the sand hill country. Even after a chronic interstitial nephritis undermined his health, his interest in his beloved profession remained. He typified the best of a passing class of medical men, the family physician.

Frank A. Burnham came to Arnold as a. partner of Robinson a year or two before the death of the latter. He was graduated from the medical department of Nebraska University and served as intern at the Clarkson Hospital. He came, one of the best equipped men of the county, is active in the county and state society and does considerable surgery. J. E. Dunn came to Arnold a few years later than Dr. Burnham.

Ansley was established in 1886 upon completion of the Burlington, and C. H. Morris, as mentioned, was the first physician there, 
coming from the oldest town in the county, Westerville. Dr. Haynes and Dr. Thomas were also there early and later S. E. Hawes who removed from there to Fairbury in February, 1894. T. B. Anderson of the University of Pennsylvania who later removed to Broken Bow and entered the army during the Spanish-American War, came next, then C. L. Mullins in February, 1894. The latter, in November, 1895, removed to Broken Bow, where he has practiced since. Following was a Doctor Eyeman who remained but a short time, then W. R. Young of the University of Iowa, who remained for several years. Young removed to California where he took up eye, ear, nose and throat work. He died several years ago. E. A. Hanna of Ensworth Medical College, St. Joseph, followed Mullins at Ansley, locating there in the fall of 1895 . Physicians at Ansley at present are, besides Hanna, R. P. Higgins and J. C. Stadden.

Oconto was established when the Kearney and Black Hills railroad went through that part of the country, on its way to Callaway which was the end of the line for many years. Later it was built on to Stapleton. Before Oconto there was a small trading point with post office about a half mile north of Oconto named Olax. Luther Michael came there in 1884 and practiced among the settlers until about 1890 when he removed to Callaway. Following Michael at Oconto was David Wise, who practiced there for two or three years. Oconto was without a physician for a few years except for a student practitioner who spent one summer there and another who spent the next summer there until 1897, when J. C. Wade of the Sioux City Medical College arrived. He is still there and was a medical officer in the World War.

Luther Michael, before mentioned, seems to have been the first physician to practice in Callaway where he remained until 1893 or 1894 when he went to California. A. L. Mathews came in the fall of 1886. F. J. Davies of the old Omaha Medical College came about 1889 and has been there since. He helped build that part of Custer County. J. F. McNulty spent a few years there. He was one of the very best general practitioners the county has had. F. L. Greer was there for several years in the ' $90 \mathrm{~s}$. He was a licentiate in medicine, active in county medical society matters although getting along in years. R. D. Bryson, present councillor of the ninth district and vice-president of the state association, is an outstanding physician of this county. 
A Doctor Renneck was the first physician in Sargent, located in the northern part of the county, but nothing further can be gleaned regarding him. I. W. Waynick was another early practitioner, who also conducted a drug store. He had great native ability and took an active part in the development of Sargent, but never joined the medical society. He left several years ago.

Dr. Stack was the first practitioner at Anselmo, remaining several years. He came from the nearby trading point, Dale. A Dr. Williams also was there for a short time. Then, for several years, the town was without a doctor, calling on Merna or Broken Bow, when there was need. Later R. J. Williams, a Canadian physician arrived, but after a few years, moved to Blaine County. Next was C. L. Willis, graduate of Nebraska Medical College, who remained several years and was twice elected president of the county medical society, the only member to be so honored. He now lives in Parco, Wyoming. Dr. Ward of Ohio lived in Anselmo for short periods two or three times and C. D. Spivey has lived and practiced there for many years.

Two more doctors, besides L. L. Crawford, at Merna, are A. R. Downing, a graduate of the Quincy, Illinois, Medical College in 1886, who practiced at Waco until June 19, 1895 when he located at Merna. The other is J. H. Morrow of the Lincoln Medical College class of 1902 .

First physicians in Broken Bow, which takes its name from a broken ox-bow, not the bow of the red man, and which was a trading point on a stage route and a postoffice station long before the railroad was built in 1886, were a Dr. Hull, who also ran a hotel; Dr. Reyner, who remained several years; a Dr. Baum, Sanders, two Mercereaus, father and son; Luckey, Bush, Langston, J. J. Pickett, long secretary of the county society; Cyrus Pickett, M. C. Blystone, C. H. Morris, T. B. Anderson and C. L. Mullins, besides the Talbots, R. C. and Willis E., mentioned above.

Mullins, the 50th president of the state association, also served as vice-president; was the first president of the American College of Physical Therapy; one time member of the State Board of Medical Examiners; secretary and president of the county society, county coroner and a veteran of the Spanish-American War. He was born in Winchester, Missouri, January 27, 1867, attended the North- 
western School of Pharmacy, was graduated from the Omaha Medical College in 1891 and practiced in Gretna and Eagle before settling in Custer County.

Men in the profession in Custer at the present time are Hubbard and Forney at Mason City; E. A. Hanna, R. P. Higgins and J. C. Stadden at Ansley; Billings at Comstock; D. B. Kantor, C. H. Fenstermacher and Taylor at Sargent; A. R. Downing and J. H. Morrow at Merna; F. A. Burnham and J. E. Dunn at Arnold; R. D. Bryson, F. J. Davies and A. L. Mathews at Callaway; J. C. Wade at Oconto; C. D. Spivey and J. R.

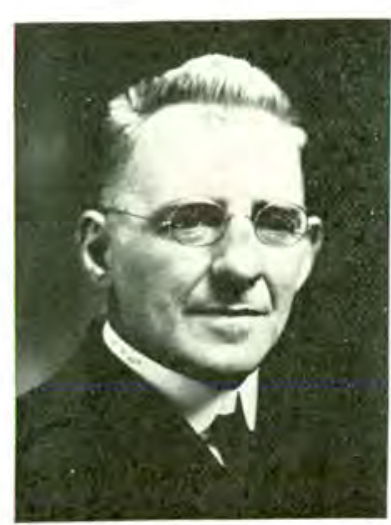

J. S. DEVRIES Kalar at Anselmo T. H. Koefoot, W. E. Talbot, G. E. Pennington, H. B. Landis, P. H. J. Carothers, C. L. Mullins and A. J. McArthur, who is retired, at Broken Bow.

No account of the early medical history of Custer County would be complete without memntion of William M. Bancroft, who came to old Plum Creek, now Lexington,, Nebraska, in Dawson County, in 1873, four years before the organization of Custer County. He was a sturdy pioneer and very capable for a young man just out of medical school. He rode horseback most of the time, often swimming his horse over swollen streams, no obstacle ever stopping him from ministering to the isolated cattle men and Indians in both counties. He died August 19, 1926, at Lexington, which he saw grow from a small village to the present beautiful town it is, in the 53 years of his residence there. His photograph is included in the first chapter of this book.

Physicians registered in Custer County since 1891 include:

Clinton Day

Claudius H. Morris

A. L. Mathews

Cyrus Pickett

Flavius J. Greer

Thomas E. Stack

Lafayette B. Wamsley

A. J. Sanders

Julius L. Goodrich

J. J. Pickett

R. O. Smith
Lysander T. Burbank

A. J. McArthur Willis S. Anderson

Hiram H. Wirt

J. Philip Gilligan

Samuel E. Hawes

J. W. Miller

Almira M. Hall

Eli M. Williams

L. L. Crawford

Byron E. Robinson
Thomas B. Anderson

John E. Nickerson

David Wise

M. C. Blystone

I. S. Stevens

J. W. Waynick

C. L. Mullins

Albert Rizin Downing

Geo. M. Jones

Joseph L. Eyman

Edgar A. Hanna 
Joseph H. Graham J. M. Jennings George Carl Weber Edmund T. Allen Don Frank Morris
T. F. Campbell Edgar Paul Murdock

C. A. Yoder

Harry Weber McFadden

George H. Morris
A. Jelbert Townsend

Austin R. Alien

L. E. Vandiver

Clinton H. Smith

\section{DODGE COUNTY}

The Dodge County society was organized October 31, 1901, with Dr. L. B. Smith of Fremont, president and Dr. A. P. Overgaard, now of Omaha, secretary. Members from Fremont were E. W. Martin, R. C. McDonald, W. J. Davies, George Haslam, J. J. Metzinger, Nellie Bell, N. H. Brown, T. N. Morrow, T. C. Sexton, J .S. Devries, F. E. Calkins, From Scribner there were O. C. Hopper, C. W. Hauslein and Charles Inches; B. S. Perlee and R. A. Davies of Arlington; F. Wiggelworth, B. B. Hauser and M. T. Zellers of Hooper: C. O. Eigler, C. M. Carr, J. M. Doan and Thomas Grant of North Bend; I. E. Atkinson of Dodge and J. H. Crabbs of Fremont was an honorary member.

Since that time Smith, Martin, McDonald, Haslam, Brown, Inches, Davies, Zellers, Doan and Crabbs have passed away.

Present officers are W. H. Heine of Fremont, president and J. S. Devries, secretary-treasurer. The membership includes:
Fremont
L. J. Putnam
C. D. Heine
J. G. Allen
G. S. Reeder
Scribner
A. E. Buchanan
S. A. Preston
E. L. Hustead
R. C. Byers
C. Seivers
W. J. Davies
G. Seward
J. S. Devries
R. T. Van Metre
North Bend
Geo. Byers
A. O. Fasser
Arlington
Geo. Haslam, Jr,
D. M. Bloch
A. E. Hoft
A. Harvey
W. H. Heine
R. A. Davies
J. J. Metsinger
Snyder
Howells
L. J. Homan
H. D. Meyers
C. G. Moore
A. J. Callahan
Dodge
H. N. Morrow
S. P. Wallin
B. V. Kenney
Hooper
Cedar Bluffs
A. E. Stuart
H. C. Pedersen
B. B. Hauser

Physicians registered in Dodge County are:

John Francis Smith

John C. Giever

Charles Samson

Robert C. Kirchman

George Harold Misko

F. E. Braucht

Guy Seward

George M. Doran
Joshua Shipley Devries Frank J. McDonough William John Davies Joseph I. Fitzsimmons Stanley P. Wallin James Gillan Allen Alexander Otto Fasser Karl E. Krueger
J. H. Crabbs

Luther J. Abbott

George J. Haslam

Leander B. Smith

Samuel F. Blair

J. M. Hardy

Moses Theo. Zellers

Ira Doan 
Willis E. Talbot

William R. Young

Chas. W. Hakes

R. B. Mullin

James F. Davies

R. M. Minter

W. D. Rea

Grace M. Lewis

A. E. Robertson

A. A. Potterf

W. R. Pennington

John C. Wade

R. W. McKenzie

Harry E. Potter

Marshall Petitt

J. F. McNulty

F. A. Wells

Marie A. Ames

Albro J. Ames

John W. Morrow

Geo. F. Barthalomew

Geo. E. Pennington

A. M. Earel

Chas. L. Egbert

Clatilla B. Job

Joseph J. Warta

William J. Birkefer

C. J. Christiansen

John E. Prest

A. C. Sabin, Jr.

Jcseph Pestal

Arthur C. Rummery

Frank E. Stokes

Claud Leroy Willis
Charles E. Taylor

Charles C. Stivers

Jhanna E. Logan

Ora M. Caldwell

Edward Dodd

Ben W. Kinsey

James M. Graham

Frank Earl Gordon

Earl F. Ward

H. S. Brevoort

Dempsey L. Trowbridge

Frederick W. Buckley

John L. Moore

Chas. L. Housel

John H. Morrow

Allen V. Sheridan

Seth P. Hubbard

Clark Dwight Spivey

Joseph B. Schrock

Claude Powell Fordyce

Robert Henderson, Jr.

Franklin H. Redmond

C. H. Fenstermacher

Michacl E. Shriver

George O. Gordon

Robert T. Jones

Clinton L. Ayers

Harry Carl Nichols

Henry Bruce Landis

M. L. Rich

John L. Sears

Alonzo A. Ward

Frank Ashael Burnham

George I. Sellon

Roy D. Bryson
Warren Thomas Hurst

James L. Pennington

S. S. Harriman

Ralph P. Higgins

William F. Race

Ethel May McKinley

Madge Potts

John Emmett Leahy

Frank Joseph Parizek

Frederick W. Buck

Fred A. McGrew

James R. Kalar

Gilbert D. Loffer

J. Erman Dunn

John C. Stadden

Jesse Lee Paine

Alfred Johnson

Robert A. Billings

Charles E. Pinckney

L. E. Vandiver

Harry Arthur Briggs

Jesse D. Wilson

Richard Walter Hille

$\mathrm{Wm}$. T. Engleman

Dominic B. Kantor

Adda Mae Whaley

Egbert Guy Johnson

C. S. Hubbard

Rex Leo Murphy

Frank Kohn

William G. Williams

C. W. Edmonds

Geo. M. Doran

Howard R. Murphy

\section{DAWSON COUNTY}

Doctors registered in this county are:

\author{
Burton T. Norall \\ Ray S. Wycofi \\ Theodore A. Peterson \\ John H. Millhouse \\ Lewis A. Koch \\ Orville C. Reed \\ Arthur W. Anderson \\ Hugh R. McMeekin \\ E. L. Meredith
}

Joel Anderson

Orville D Johnson

J. M. Chesshir

Charles H. Sheets

Willis C. Tanner

B. F. Stewart

Jonas Larson

C, E. Teter

Guy R, Taylor

\section{DEUEL COUNTY}

\section{Registered in Deuel County are:}

Hosea Hudson

Hiram R. Palmer

W. H. Babcock

Russeil Dayton Root

James I. Allen
Themas Dale Dorwart

Heward R. Murphy

T. J. Mason

Harry H. Haugh

R. W. Mullen
Lsuis I. Bogan

E. J. Porter

Gso. O. Dunseth

Clyde N. Moore

Ernest B. Downs

Henry M. Harvey

Farl A. Harvey

E. W. Edmonds

Edwazd Wirth

Frank Earl Gordon

W. W. Sadler

G. H. Hall

Marion B, Patty 
F. L. Burbank

D. J. Ruzika

Ira E. J. Atkinson

Robert E. MacDonald

Edwin W. Martin

Chas Inches

E. L. Colburn

Nathan $\mathrm{H}$. Brown

J. S. Mortlock

E. Person

Thos. C. Sexton

Ludwig Hannawald

A. J. Sanders

Jacob Simmons

Frank Simon

Sherman J. Hadley

H. W. Parchen

David J. Bartlet

Gustave Nieman

F. Engelhard

William $\mathrm{O}$. Wisner

Milo Bloomer

Alfred Shipman

Mercer B. Croll

Chas. H. Sigel

W. H. McCan

E. N. Leake

Frank Bell

Benjamin F, West

Nellie Isell

Chas. Oxford

Geo. F. Moore

Chas. O. Eigler

Charles V. Crooks

Louis N. Andersen

M. J. Gahan

Jens Sorensen Haarup

Frank Carrall

J. M. Jessen

Almer L. Sabin

John W. S. Howeil

J. W. Dill

Thomas Grant

Metta E .Davis

Anna M. L. Potts

James B. Keith

John F. Kelley

James F. Premer

Nelson Hiram Lewis

Albert Ciegle Armitage

Sylvia M. Ward

T. F. Campbell

W. W. Sadler

E. F. Fuqua

C. Neef

B. F. Jeffers

James W. Moranville
J. J. Metzinger

Samuel J. N. M. Byers

Chas. M. Carr

W. D. Guttery

J. M. Doan

Andrew P. Overgaard

Frank W. Brown

Tandy Wiglesworth

Chas. M. Haslein

H. N. Morrow

Jno. N. Byers

James F. Davies

A. E. Hoff

Oscar C. Hopper

F. E. Calkins

A. A. Potterf

Ira F. Richardson

Otto G. Smersh

E. O. Weber

Chas E. Furay

Elton B. Grabs

Arthur W. Fees

J. H. Griffin

Tupper Kirby

Amos F. Johnson

Johann F. E. Weiland

Karl Schemel

Chas. O. Robinson

Wm. B. Munford

Ernst Capek

Harold M. Brown

Byron L. Perlee

Owen S. Oneil

Paul R. Howard

D. G. Golding

Wesley Queen

Charles C. Stivers

John A. Fuller, Jr.

Grove W. Bartlett

Frank Earl Gordon

Geo. D. Sitzer

S. A. Preston

A. J. Clark

Harry H. Thompson

Allan M. Lafferty

George M. Doran

Edwin J. Oxford

\section{DUNDY COUNTY}

Morton G. Welch

William McC. Roberton

Nelson Ward

S. P. McPhery

B. E. Neal

Arthur K. Turner

Robert W. Hansen

Albert C. Welch

Edgar A. Pickens

William Floyd Deal
Louis J. Townsend

Robert C. Byers

Cleland G. Moore

Frederick H. Kuegle

Franklin Patterson

Hugh Horer

Richard J. Tanner

William Elder Doane

H. S. Brevoort

William H. Heine

Enoch Neff

William M. Bair

Joseph Soper

Edward C. Lynch

Charles M. Headrick

Richard T. Van Metre

G. H. Rathbun

Henry George Hurtig

Jesse Lee Cook

Thos. J. Nolan

William F. Race

Vahan H. J. Geragosian

T. F. Campbell

Charlotte P. Seiver

John Habenicht

Andrew Harvey

Grant S. Reeder

Vilvoy M. Connelly

Charles H .DeWitt, Jr.

James C. Agee

H. Y. Bates

William H. Knollenberg

Clinton David Heine

Walter Sidney Yates

Albert E. Buchanan

Frederick B. Patterson

R. B. Mullins

H. P, McKnight

George A. Byers

Ambrose J. Callaghan

Andrew Sinamark

Frank T. Lovely

Lynn J. Putnam

Anthony Parsons

Effie A. Current

J. E. Dalrymple

Frederick W. Buck

George Sibbald

John G. Watthall

Willis E. Stewart

William W. Johnson

Chas. W. Oaks

J. K. L. Duncan

A. C. Sabin, Jr.

Royal Woods

J. H. Jessen 
W. S. Shields of Holdrege organized the county society in 1903 at Bloomington and adopted the constitution and by-laws provided by the state association. Ella P. Sumner was named president; W. H. Byerly, vice-president; and N. H. Maulick, secretary-treasurer. J. B. Sumner was elected delegate to the state convention. The society has remained active ever since, holding quarterly meetings.

\section{FRONTIER COUNTY}

\author{
Chas. D. Blair \\ Wm. M. Bair \\ Louis $\mathbf{i}$. Bogen \\ Wm. P. Clathner \\ Ernest D. Case \\ Mary C. Case \\ G. E. Charlton \\ D. J. Duncan \\ Robert H. Easton \\ Chas. E. Finch \\ Frant. W. Fochtman \\ J. A. Fleischmann \\ Benjamin F. Gay \\ Geo. W. Hardesty \\ A. C. Harlan \\ R. A. Hanthorn \\ John W. Hitcheock
}

Wellington W. Keith
K. M. Kreecorian
E. J. Kirk
Bernard Mills
Henry Miller
Henry C. Madding
Clarence Minnick
Van Hooper Magill
J. H. Nettleton
C. Neff
E. F. Purdum
Geo. H. Parkinson
Marshall Pettit
A. A. Potterf
S. R. Razee
Chas. R. Stewart
B. F. Stewart

\author{
A. C. Sabin \\ A. O. Skinner \\ Louis Noah Smernoff \\ Fannie H. Wiedeanders \\ E. F. S. Wideanders \\ Edward Wirth \\ Geo. W. Wilson \\ E. R. Walizer \\ Willis Wilson \\ Ira W. Waite \\ Baker Woodruff \\ John S. Winston \\ Ely Hoge Waters \\ Johannes Weiss \\ R. S. Stuckey \\ John W. Straigh \\ Dawl Stevens
}

\section{FURNAS COUNTY}

The Furnas County Medical Society was organized in the summer of 1893, probably at Oxford. T. R. Butler of Beaver City was elected president and E. E. Cone of Oxford, secretary-treasurer. There are no records of this meeting, the only source of information being Dr. C. C. Cone. So far as he can recall, practitioners in the county at the time were L. M. Brady of Oxford; Hitchcock and Aiken of Cambridge; C. C. Cooper and Buller of Arapahoe; C. C. Green and T. R. Butler of Beaver City, but he does not know which ones joined the society. Dr. Johnson of Wilsonville and Dr. Shoemaker of Hendley came about this time. The Furnas County society has continued in existence ever since and now includes in its membership every physician in the county, with one exception. W. C. Miller of Arapahoe is president; F. W. Shank of Oxford, vicepresident; and R. D. Green of Beaver City, secretary-treasurer.

Dr. Phoebe A. Oliver Briggs, the first woman of whom there is record of practicing in Nebraska, was also the first doctor in Furnas County, in 1872 , according to some reports. Other records give the 
years of her practice there as 1879-1884, when her husband, J. S. Briggs, homesteaded on Sappa Creek. Later they moved to Troy, Kansas, but Dr. Briggs continued her practice in this county, even after her removal.

\section{Registered in Furnas County are: .}

\section{S. A. Aiken}

Frank Leroy Allen

G. C. Armstrong

Edmund Tunney Allen

A. C. Butler

L. M. Brady

T. R. Butler

Isaiah Bennett

F. A. Brewster

R. A. Blackburn

J. O. Bruce

William M. Bair

Elizabeth Brewster

Harry Arthur Briggs

Marry Bratt

Butler Cooper

Elbert E. Cone

A. M. Cowden

Cecil C. Copeland

Joseph R. Cameron

Charies E. Dean

Charles M. Dunan

Harry W. Davis

Thomas Louis Doher

George Halley DeMay

Jno. W. Earle

Homer F. Fart

J. A. Gunn

J. T. Goode

Charles W. Gooden

Delinzo A. Walden

Joseph L. Webb

Lorentz Andreas Claussen

John Valentine Roop

James Delzon Minkler

S. G. Huff

William J. Sisson

George Lowny Roe

John Blythe Fulton

John Alsbach

Daniel Freeman

Samuel S. Hoffman

O. O. Wells

Agnes S. Freeman

Thomas John Farleigh

Lewis B. Boggs

J. H. Quinn
Frank Earl Gordon

Albert E. Gerish

Clarence C. Green

Ralph Dennis Green

John W. Hitchcock

Girard R. Hart

H. R. Hayden

A. B. Hardin

Edward A. Hudson

G. H. Hall

Henry J. Holke

J. M. Jennings

Frank B. Johnson

C. T. Keickbaum

J. D. Konestrick

A. L. Kee

Frank Kohn

Charles W. Lyons

Gilbert D. Liffler

W. W. Newsome

Raymond A. Newton

Walter L. Morrill

W. T. Mozee

C. J. Mosshart

F. W. McCabe

Carl William Morrow

Waiter C. Miller

Howard R. Murphy

Chas. A. Oaks

William Plank

Thomas D. Tibbetts

Joseph R. Buffington

Mary Bewick Bridges

William W. Jones

Charles C. Gafford

Henry Allen

Moses Atwood

Fred A. Hoffmeister

James Wesley McKibbon

John Ellis Kehler

Josiah Roop

James Ira Gumaer

Z. E. Beemblosom

Phoebe Foster

Harry M. Price

Charlie A. Starr Sims

F. B. Elwood

J. G. Pace
A. A. Potterf

Willam E. Packwood

Roscec P. Pierce

Robert F. Raines

W. D. Rea

Lee Wallace Rork

Nellie A. Runyan

David J. Reid

Wm. H. Rupert

McDonald Ryan

Robert M. Riggs

A. L. Trout

Adelbert Townsend

Thomas E. Stack

Geo. P. Shoemaker

R. S. Stuckey

A. C. J. Sabin

David Finley Smith

Charles S. Stivers

Dan La Motte Smith

Wilber A. Staley

B. F. Stewart

Henry $J$. Walsworth

G. A. Weirick

Eli Hoge Waters

Harvey S. Watson

J. M. Willis

Joseph E. Waller

Alonzo A. Ward

J. W. Youngman

J. D. Dickerson

Frederick Wm. Winter

George W. Howard

Ezra Wonder

Greene McClure Smith

Willard D. Clark

Mark Davis

Geo. W. Randall

Geo. Rightmire

Albert S. Fishblatt

Davis Williams

Robert T. Arbuthnot

John Collins Jones

Calvin Starr

Geo. Angus Wood

John W. Sanders

Ira N. Pickett 


\section{GAGE COUNTY}

Chas. O'Ferrall

Wm. Armine Humphrey

Julia Cornelia Starr

Alexander C. Sabin

John C. Anthony

Stillman Marion Benner

Robert S. Albright

Grant J. Ross

Edward Bates

Delbert A. Clark

Chas. Summer Boggs

Arthur Augustus Milligan Elizabeth Grabe

Geo. W. LaFollette

Christian Moeller

Mina Fimerson

John O. Mote

Frank Mead Sommers

Byron Bathrick

David J. Turner

Augustus A. Tylee

Bloom Warren Ganoung

Phillip M. Hobbs

William J. Harris

Robert Morgan Carr

Geo. Julian Puhek

Almer Lee Sabin

James Elwood Anderson

Isador A. McClellan

John M. Fowler

W. J McCrann

John Marion Waters

Elon Stafford

Edwin S. Patterson

Thomas Henry Fulton

M. Wilson Walton

Mary Foster Brinton

Edward D. Barrett

$\mathrm{Wm}$. Todd

Wm. Kirke

Ehme E. Aukes

Geo. O. W. Fainham

Clarence Austin Bradley

John M. Welsheimer

Harrietta Bottsford-Amy

Theron Root Hall

Alvin J. E. Clark

Louis Turner

A. M. Pickett

N. Spalding Smith

Lorenzo R. Thornton

Chauncey Willard Amy

Milo Leonard Kensington

Alman N. Pierce

Butler Presson

Cliffor-1 P. Fall

Franklin Hunt Broyles

Chas. Fremont Kennedy
Thomas W. Warnock

Willis G. Morris

Peter Janss

Chas. M. Williams

Mathew H. Blackburn

Allen Poff Ferguson

Geo. Almerian Dean

John M. France

Frank Warnock Beard

A. L. Guy Ramaly

Leopold F. Saxenburger

Wm. Adams Johnson

Mary C. Farnum

Hardin B. Redman

D. F. Morris

James A, Paddock

Orlando Harran

Chas Marion Hollopeter

Jonathan H. Baker

Elmer Grant Dennis

Ferdinand Brother

Albert H. Felch

Lyman A. Webster

Emil Prochazka

Wm. F. Lee

Chester Ernest Hunter

Geo. Henry VanDyke

Johnston A. Hawt horne

James T. Armstrong

D. A. Waldon

George Leroy Roe

Don Frank Morris

John B. Fulton

Wm. H. Wilson

O. O. Wells

Julius Martin McLeod

R. S. Jeffreys

Wm. Ross Lee

A. V. Robinson

Grant Cullimore

Geo. D. Sitzer

Rabley Hackett

W. R. Alexander

Benj. H. Warren

A. F. Kaup

John G. Kneely

Ezra E. Reynolds

Samuel J. Smith

Edwin Buzıck

J. W. Turner

Lucien L. Noble

Grant E. P. Freeborn

Omar L. Cox

Chas. H. Zieler

J. L. Patton

Urlic D. Stone

James L. Pennington

Allen T. Rice
Newton N. Bunsback

Herbert H. Smith

Mary B. White

W. N. Ramey

Chas P. Hill

Geo. W. Strough

C. W. Baird

Warren H. Sherman

John Ervin McGirr

Thomas M. Cullimore

Jans Sorenson Haarup

Wm. Mann Follett

Fred J. Woods

S. Alexander

A. A. Potterf

W. J. Harris

W. P. Montgomery

Byron L. Pampel

Chas. P. Proudfoot

Seth L. Hubbard

Aetha Sloss

Herbert J. Slop

E. W. Fisher

John S. Curtis

Frank L. Lewis

Benj. Rea

Geo. H. Brash

H. M. Hepperlen

Artie Folsom

W. D. Gibbon

Barton Williard Johnson

Frank W. Krieg

Wm. A. Harper

Geo. A. Sloss

T. E. Macy

B. M. Deardorf

Wm. H. Johnson

Anna M. L. Potts

John Barnes Jack

Warren L. Seaman

Pearle K. Drummond

Wm. H. Dearing

J. S. Sturdivant

Andrew Johnson

U. H. Morris

Louis W. Studley

Chas S. Curry

Edward B. Oliver

Clifford W. Waldon

F. A. Wells

Mable A. Nickel

John J. Williams

Geo. A. Harris

Olin C. Diehl

F. C. Hoops

Albert O. Harms

Marion B. Patty

C. A. Love 


\section{A. L. Emery}

Oscar C Swope

Stillman Woodward

Wm. T, Sloan

Walter L. Albin

Peter L. Gillespie

Claude S. Castle

Frank E. Osborn

Chas C. Paxton

Chas. H. Campbell

A. E. Walker

G. G. Douglas

A. Galloway

W. W. Thomas

Chas. V. Crooks

F. M. Tripplett

Park A. Findley

Chas. C. Stivers

Dempsey L. Trowbridge

Chas D. Eby

Arthur L. Kinseley

Edward P. Bachle

Louis E. Penner

Ben W. Kinsey

Nillis H. Flamm

Geo. E. Seng

Chas. H. Willis

H. Guy Schooling

Edward E. Sweeney

Edward R. Keen

Joseph L. Webb, Jr.

Richard J. Gasslein

Geo. M. Doran
Milton G. E. Bennett

Ada Platz

Walter M. Jones

John Wesley Neigh

H. S. Brevoort

John Barr Trutcher

Bryant Robert Simpson

Amsbury Lee

Lucius Gould Wright

Robert P. Jensen

E. J. Upton

Marie McGravey (Peak)

Francis Leander Elias

Harry Edward Diers

Frank T. Schowengerdt

Claude Chas. Lull

$\mathrm{Wm}$. S. Fast

Frederick W. Buckley

William John Hawes

Walter Chas Purviance

Gilbert D. Loffler

Frederick W. Buck

John Todd Waggoner

J. E. Claussen

V. A. Mokler

Harry R. Brown

A. B. George

Henry S. Munro

Jonathan J. Evans

L. A. Powell

Edward M. Ware

Earl Renshaw Leonard

Chas. J. Reilly

Marion T. Sigler
A dolph N. Thoms

W. T. Mozee

Dale E. Haworth

Wm. W. Claybaugh

Levi M. Asbury

F. Scott Salibury

Wm. T. Wildhaber

Chas Glenn Baird

James Clyde Waddell

Weaver Aldus Rush

Roy Elliott Peters

Earl A Warner

Chas W. Thomas

David Leonard Anderson

Clarence Edward Rice

Lafayette M. Blanchard

James E. Tucker

Roy Cecil Noble

Almeron O. Skinner

Lawrence T. Sidwell

Harold Harrison Woods

Chas. C. Stivers

Robert P. Hoxsey

Salmon A. Cassidy

John Hewitt Judd

Frances Crothers Knapp

H. P. McKnight

Dallas D. Davis

J - R. Liebee

Louis Robert Lorke

Ellsworth W. Cutshall

Wm. Patton Garrison

Louis Robert Lorkee

\section{GARDEN COUNTY}

George H. Norris and Everett Ostling are the only two physicians registered in Garden County.

\section{GOSPER COUNTY}

George C. Clark and David McCoy Saylee are the only two physicians registered in Gosper County.

\section{GRANT COUNTY}

Thomas J. Holcomb

Leona $\mathrm{P}$. Vaughn

John H. Cowles

J. E. Anderson

H. S. Aley

Wm. Arrasmith

W. W. Arrasmith

Mary J. Breckenridge
William Milliken

T. F. Campbell

Albert David Brewer

George W. Hogle

\section{HALL COUNTY}

J. C. Brubaker

Edward D. Barrett

Frederick J. Bricker

Ira N. Barker

Wm. J. Bonesteel
Lucien Stark

Albro J. Ames

Marie Antoinette Ames

Henry D. Boyden

Chas. E. Brown

Andrew J. Baker

H. S. Brevoort

W. C. Buel 
Chas, E. Barnes

Frederick W. Buck

Frank H. Bent

Wm. A. Carter

Nichlas Child

E. Christensen

Martin L. Carter

John S. Curtis

J. A. Coffman

J. C. Cave

G. W. Gorman

Wm. H. Caulk

Alma J. Chapman

Ora M. Caldwell

Chas. V. Crooks

Fay E. Cramer

H. O. Conaway

David H. Carson

G. M. Dixon

Frederick E. Dalrymple

Sumner Davis

J. P. Dullard

Chas. B. Dyde

Edward S. Dungan

Martin H. Deffenbaugh

Nelle G. C. Deffenbaugh

Edward Dodd

Wm. F. Dugan

Geo. M. Doran

Juan R. Y. Del Puerto

Thos. J. Eaton

Albert Eisenbiess

Louis H. Engelken

Bell English

Chas. D. Eby

John W. Earel

C. B. Edmonds

Wm. T. Engleman

Wm. T. Eikner

John M. Fitch

A. S. Fishblatt

Geo. B. M. Free

G. M. Freeman

A. W. Fleming

Frederick W. Fochtman

Wm. M. Follett

A. H. Farnsworth

Earl E. Farnsworth

Jos. Flickinger

C. A. Flippen

Claude P. Fordyce

Godfrey C. Fritschel

Irvin I. Finkelstein

C. A. W. Gibson

M. J. Gahan

John H. Galligan

Josiah B. Grinnell

Frank Grabel

A. Galloway

Howell B. Givin
John E. Gelow

John M. Gahringer

Frank E. Gordon

Edgar S. B. Geeseman

D. G. Griffiths

Albert J. Grist

Geo. A. Grist

S. G. Hurford

Jas. N. Harrison

Jonathan B. Hawk

L. W. Hammer

Wilmer B. Hoge

C. J. Horton

J. M. Hardy

Etta C. Hewitt

Wm. H. Hombach

Albert G. Hartensen

Chas. S. Hershner

E. C. Hayman

Jos. E. Higgins

Stacey B. Hall

Jos. V. Hinchman

Henry J. Holtke

Seth F. Howes

Wm. J. Heflin

Peter Janss

John Janss

Annie D. Jackson

John D. Jackson

Henry Janss

H. M. Julian

F. V. Johnson

Earl G. Johnson

Royal F. Jester

Chas. W. Jester

H. A. Krick

W. B. Kern

Nilo L. Kensington

F. L. King

Peter C. Kelley

Ben. W. Kinsey

F. J. B. Kalal

Frederick W. Kuegle

Horace Lashler

Thos. H. Line

Chas. Lucas

Julius Lingenfelder

Gilbert D. Liffler

Johanna E. Logan

Elbert E. Linn

Jas. McLean

Wm. McGregor

Benj. R. McGrath

Wilmer D. McGrath

J. R. McKirahan

P. L. Moore

Michacl Luther

Wm. Milliken

F. L. Murphy

Earl Matheny
Zellmond E. Matheny

Alfred F. Naultens

Harry C. Nichols

Francis M. Osborn

M. A. Otterbourg

Caswell T. Poe

G. J. Puhek

Albert Puringer

Leopold Phelan

A. A. Potterf

Marcus R. Piersol

C. W. Pittman

E. J. Jorter

Anna M. L. Potts

Wm. T. Putt

Solles C. Pitts

Edna S. Pells

Hogan J. Ring

W. T. Royce

Joseph P. Riddile

C. M. Robinson

George Rocder

Clyde A. Roeder

M. L. Rich

W. D. Rea

Willis J. Redfield

Benj. A. Root

Edward W. Rowe

Wm. F. Race

John H. Regan

John $V$. Reilly

Willis J. Raynor

Franis D, Ryder

A. L. Stevenson

A. J. Sanders

William Smith

B. M. Shockey

Emanuel Stringfellow

Wellington A. Thomas

Henry J. Smith

P. I. Scallon

Edwin L. Smith

Arthur D. Smith

Samuel D. Smith

C. D. Severe

J. Lue Sutherland

Almond B. Sage

Almer L. Sabina

L. F. Saxenberger

Clement A. Stone

Geo. D. Sitzer

Chas. C. Stevens

Jas. Soper

John C. Stadden

Frank E. Stoaks

Harvey L. Starkey

Eugene M. Stansbury

Felipe Sucgang

Anthony J. Smith

$\mathrm{Wm}$. Tanner 
Louis Turner

Jennie E. Tarbox

Jas. H. Thomas

B. T. Trueblood

John S. Tiffany

Hachel M. Cooper

J. M. Tische

D. L. Trowbridge
C. W. Porter
D. B. Steenburg
E. K. Steenburg
G. H. Marvel
P. O. Marvel

John M. Triplett

Oscar J. Vallicolt

John T. White

Frank J. Wright

Jos. Wyerhorst

C. H. Waldschmidt

George Weeter

G. H. Weirick

\section{HAMILTON COUNTY}

Hachel M. Cooper

J. M. Woodard

C. D. Hustead

H. P. McKnoght

O. M. Troester
E. O. Weber

Johannes Weiss

Geo. L. Wagner

Dare Woodruff

Rolland C. Woodruff

John G. Woodin

Frank H. Wray

Eli A. Watson

\section{HARLAN COUNTY}

The Harlan County society was organized January 21, 1903 at Orleans, with Doctors Collins, Banwell, Pennington, Hoffman, Baker, Waggoner and Campbell present. W. H. Banwell was elected president; S. M. Baker, vice-president; J. N. Campbell, secretary; Waggoner, treasurer; Collins, Pennington and Hoffman, censors. Those who have served as president successively since then include: S. M. Baker, J. O. Hoffman, J. L. Pennington, W. C. Bartlett, A. J. Gardner, J. N. Campell, T. E. Mossey, C. H. Munger, O. J. Vallicott, W. L. Sucha, W. G. Rundle for two terms, A. J. Gardner for four terms. S. M. Baker was secretary-treasurer for 15 years. W. C. Bartlett, the present incumbent, was a captain in the medical corps in the late war and V. V. Talcott served as first lieutenant.

\section{HAYES COUNTY}

Physicians in Hayes County since 1892 are:

John A. Vogel

E. P. Child

W. C. Fisher

R. S. Stuckey

Andrew B. Fellers

\section{T. S. Hunt}

Mercer B. Croll

William A. Sallen

Chas. O. Eigler

Wm. A. McClelland

Milton B. Deck

Chas. S. Grabin

E. J. Bild

Herman H. Johnson

Herbert D. Krass

A. A. Potterf

William J. Nolan
A. A. Potterf

Frank H. Bent

Selmon A. Cassady

James C. Anderson

B. J. Dodge

\section{HOLT COUNTY}

Albert Townsend

H. S. Brevoort

Alonzo L. Bushby

Albert C. Coleman

James Ward Gill

Charles Edwin Legg

Henry Carl Nichols

Neal P. McKee

B. V. McDermott

John Thomas O'Connell

Charles Thayr Needham

Hugh Joseph O'Donnell
Clay Eli Mullinax

Raymond A. Young

Hugh Allan McDonald

Harold C. Hume

John Francis Gardener

James L. McDonald

Henry Connally

J. Phillip Gilligan

Edward F. Furay

P. J. Flynn

C, J. Waltor

H. H. Byrn

Wm. James Stephenson

A. C. Sabine

Ernest Sapert.

Ben. W. Kinsey 


John A. Devine
Hugh Hover
Edward Walker
Guy Walter Townsend
Edwin J. Oxford
C. L. Sturdivant
George Earl Mukel
William T. Race
Walter P. Hornbach
L. Arthur Carter
Frederick L. Wilson
Oscar W. French
J. D. Watson

Cary M. Hopkins

H. F. Kohler

Chas. V. Crooks

Geo. J. Hess

Wm. J. Douglas

W. H. Brigs

Wm. C. Colburn

Egerten E. Wilson

Charles C. Stivers

William W. Noyes

Henry J. Talboy

Franklin Patterson

William M. Blair
Ora M. Caldwell

Bernard M. Jackson

G. O. Sturdivant

James Henry Hale

Harry George DeGarzon

Charles R. Gannaway

Arthur E. Smith

Herman P. Benjamin

William O. McDermott

George M. Doran

John Philip Brown

B. T. Trueblood

\section{JEFFERSON COUNTY}

The Jefferson County Medical Society was organized at Fairbury in May, 1888, with five members. It reorganized in November, 1902 with seven members. G. L. Pritchett was named president and Warren Perry, secretary. Members at the time that the society affiliated with the state association were the two just named, S. E. Hawes, T. J. Andrews, S. W. Dodge, H. E. Potter, state president in 1927 , and George A. Heath, now president of the county society.

Physicians registered in the county include:

Wm. S. Ammerman

J. E. Anderson

A. C. Ames

T. J. Andrews

Luther L. Ames

H. S. Aley

James R. Armstrong

Clinton L. Ayers

Donald Bitzer

Hollis Lee Brownson

Byron Bothrick

Edwin T. Black

H. N. Bradshaw

Wm. M. Bair

E. L. Barrett

E. Adda Bowerman

Harry R. Brown

G. A. Birdsall

David L. Baker

Henry R. Burner

Thomas E. Barron

Frederick Buck

John P. Bishop

T. C. Canine

Harvey L. Clarke

Arthur L. Carter

Harry Bauguess

Geo. H. Bentz

H. E. Bollinger

John Vawter Beachley
H. O. Conway

Albert James Coats

W. L. Curt is

Willford $\mathrm{H}$. Crutcher

Corwin Stanton Clarke

W. H. Caulk

Ora M. Caldwell

Andrew J. Chamberlain

Charles V. Crooks

Hayes H. Culbertson

George W. Doran

Chas. M. Duncan

S. W. Dodge

Franklin K. Dabney

Fred Edward Dargatz

George R. DuVall

Frank Davis

Ida P. Davis

Olin C. Diehl

Guy L. Dodge

Martin L. Eaton

L. M. Foster

Charles M. Ferry

Geo. B. M. Freem

Wm. Farmer

A. Friedman

Artie Folsom

Lester Wayne Forney

W. S. George

L. E. George
C. T. Gritzka

Jacob Grebe

Dwight Otis Hughes

O. A. Hall

Noah Hayes

O. O. Harris

I. Humphrey

C. G. Hubbel

H. M. Hepperlen

Charles E, Hunter

Samuel E. Hawes

George A. Heath

R. C. Harris

R. S. Humphrey

Hugh Hover

Hall H. Humphrey

William John Hawes

Harry E. Harvey

Reuben S. Jeffrys

Wm. Thos. Jeffrys

John C. Jones

P. Jauss

Herbert C. Kimberling

A. M. Kinnamon

David G. Kling

James W. Kessinger

A. T. Kaupp

Herman Kunze

John J. Kiefer

Tupper Kirby 
Frank W. Kreig

Ben. W. Kinsey

Chas. H. Lutes

Emil Lange

F. B. Lovell

Gilbert D. Laffler

Albert Lynch

Joseph M. Larabee

George M. Lynch

A. J. Lappens

W. T. Mozee

Geo. L. Madison

Jas. D. Minkler

Jas. W. Moody

J. W. Miller

Chas, B. Masser

Elizabeth A. Moss

P. L. Moore

G. W. Meisenbach

Irvia C. Munger

Carolyne E. Maxwell

Ralph Whitman Murray

Enoch A. Montgomery

Theo. Milen

B. F, McElwee

John H. McCoy

Marie McGarvey

George H. Newton

L. A. Nowickige

John G. Neely

Francis Naulteus
Owen S. O'Neil

H. M. Ochiltree

Francis Petr.

G. L. Pritchett

Francis J. Pearce

A. M. Pickett

Warren Perry

Harry E. Potter

Milton J. Powell

L. A. Powell

Henry G. Penner

Louis E. Penner

A. A. Potterf

Jennie B, Rozell

L. Rick

Charles G. Rankin

G. W. Randall

L. Guy Ramalay

Ezra E. Reynolds

Benjamin Rea

James Perry Romine

Lewis P. Rich

Lee Wallace Rork

William F. Race

M. L. Rich

Edwin W. Shearburn

J. E. Sherrill

Philip T. Sydenham

Levi Nelson Smith

Cornelius E. Satterfield

George Franklin Spence
G. W. C. Truitt

Andrew Texley

H. J. Turner

F. B. Thompson

Louis Turner

J. A. VanCamp

Fred William Voos

Rebecca B. Wolcott

William A. Wilson

H. Whiebe

Peter Miens

J. G. W. Westerhoff

Lucins Gould Wright

Victor Juble Wall

Dare Woodruff

Joseph Sterling Waldman

Johannes Weiss

Warren H. Sherman

Henry B. Shull

Herbert J. Sloss

Altha Sloss

Milton Howard Spangler

H. C. Smith

George K. Stites

Thomas E. Stack

Charles C. Stivers

Robert Lyman Sands

J. S. Taylor

William A. Thompson

\section{JOHNSON COUNTY}

Alfred Shipman was president of the Johnson County society in the early '80s. C. M. Headricks of Tecumseh was secretary in 1892.

J. Frank Atha John W. Archerd

Charles Aitken

Turner Brown

E. T. Black

W. P. Brooks

Marshall P. Bauserman

Chas. D. Barnes

J. E. Brittan

H. S. Brevoort

Frederick W. Buck

C. K. Chubbuck

C. M. Coe

John C. Cochran

H. H. Boburn

Edgar M. Cramb

R. W. E. Casterline

P. T. Corbin

W. L. Curtis

Joseph M. Curtis

P. V. R. Dafoe

W. L. Downing

A. Desbrow
Allie M. Day

James F. Davies

T. E. K. Dihel

John W. Douglas

Dora M. Judkins Davies

T. E. Fairall

A. P. Fitzsimmons

Artie Folsom

Park A. Findley

Benjamin F. Gay

Elton B. Grubs

Charles M. Headrick

William L. Heilmann

Sullivan Howard

N. P. Hansen

H. P. Jelsma

Charles L. Kerr

Ben. W. Kinsey

F. W. Kruse

L. F. Lattan

Anson S. Lutgen

Gilbert D. Laffler

Edwin M. McGee
Thomas D. Miller

P. L. Moore

T. E. Massey

Walter L. Morrill

Erroch Neff

Ralph V. Overton

J. L. Patton

C. L. Pickett

A. A. Potterf

Owen D. Platt

Cory Allen Philpot

C. W. Prettyman

I. Rathburn

C. F. Roh

G. J. Rubelmann

David James Reed

Edwin R. Ryerson

Grover Cleveland Rice

M. Stewart

Warren Sherman

F. A. Snyder

Ulric D. Stone

Herbert H. Smith 
Alexander C. Sabin W. B. Shepard A. C. Sabin, Jr. Alfred Shipman Chas. C. Stivers Charles R. Snell Alva C. Truitt J. W. Turner Louis Turner

Wm. H. Johnson Hannah C. McCahan James A. Martin Franklin Shoff Sherman J. Jones Edmund M. Glessner Harry Hapeman John D. England J. M. Jennings W. E. Buck James McClean Oscar F. Shoff Wm. C. Kenner Frank B. Slusser B. F. McElwee Alexander A. Sabin John R. Macgregor Fred W. Whiting W. D. Rea James E. Duncanson James A. Burtord L. S. Stewari

Sollis C. Pitts Simon A. Levey
John Thompson D. L. Trowbridge Thos. L. Taylor Frank N. Townley Charies M. Williams B. F. West

Alonzo A. Ward J. W. Youngman John Youngerman Charles H. Ziegler

\section{KEARNEY COUNTY}

F. L. King

James B. Keith

W. R. Townsend

J. Stanley Hill

J. R. McKirahan

J. W. Craig

C. W. Edmonds

C. J. P. Beirne

Chas. E. Abbott

Martin H. Deffenbaugh

Martha A. Hamilton

Niels C. J. Stebsgaard James J. Smith

J. H: Griffin

G. S. Reeves

A. A. Potterf

Ora M. Caldwell

Charles C. Stivers

David G. Olsen

Frank Earl Gordon

Arell L. Marsteller

Charles V. Crooks

William M. Blair

\section{KEITH COUNTY}

Alonzo A. Ward

Earnest Louis Meredith

Howard A. Vandiver
Irwin Isaac Boehr Arthur Benj. Cramb Charles Conlee Ora M. Caldwell John F. Luepke Percy E. Milbourn John B. Rogers Howard Coke Stewart H. S. Thompson

James W. Craig

Theo. Milen

Effie A. Current

Seth L. Hubbard

Enoch Neff

M. L. Rich

Ward Hughes Powell

N. P. Hansen

F. A. Wells

Pierre LaFayette Stewart

Harry S. Andrews

Charles S. Hershner

Frederick W. Buck

G. M. Andrews

Clarence A. Rathbun

Jonas Larson

Guy Elmer Burman

George L. Wagner

Charles Harold Frank

Ernest G. Jarmin

Hodson A. Abbott

Neville Joyner

\section{Clyde Newton Moore}

George W. Doran

\section{KNOX COUNTY}

Registered in Knox County since 1881:

Jacob M. Miller

Van N. Swan

Benneville Y. Shelley

Albert Lincoln Clark

John F. Quinten

George Westley Ira

Andrew Joseph Caulfield

George Roberts

John Bower Hoover

William Hazen

William Elijah Moore

William C. Campbell

Carl Muller

Edward C. Mosteller
John \&. Strain

William Franklin

Frank Elbert Burbank

William Henry Britt

Wm. J. Bonesteel

William Frederick Ward

Lewis Faulkner

Otto Hottelmann

Peter Janss

A. J. Emerson

William Lowe

Dane Perry

George Sweeney

William Breene Estee
Ellery G. Fuller

Charles B. Carveth

Otto Von Muller

Gustave A. Nieman

Clement B. Little

Columbus Delano Severe

John B. Bates

Wm. S. Butterbaugh

F. C. Gening

Myron Penney

M. J. Bagley

W. A. Lee

W. W. Van Velsar

E. J. Vaxton 
W. E. Bridgman John Habenicht J. Harvey Mettlin Willard Kingsley Clark James Martin Falcott Thomas Coe Little Edson L. Bridges Frank E. Liliedahl A. J. Wilson J. F. McNutty A. Disbrow Almer S. Sabin Fletcher Gardner J. C. Walton Edward B. Oliver A. H. Sissikian Charles V. Crooks Roy H. Burrell I. S. Stevens Ralph V. Overton Chas. W. Oaks James R. Kalar Sarah B. Kalar Geo. J. Frazier Allen Bell James C. Sappington George P. Wilkinson Benj. H. Chedeck Otto T. Hansen A. C. Sabin, Jr. Gilbert D. Laffler A. A. Potterf Edward Dodd E. J. Austin E. P. Childe Louis C. Bleik Francis W. Boland Roy Crook

$\begin{array}{ll}\text { Charles C. Stivers } & \text { Melvin N. Newquist } \\ \text { Adelbert Townsend } & \text { Ralph Emerson Moyer } \\ \text { Frank Earl Gordon } & \text { Charles Northfield Olsen } \\ \text { Albert Orton Cormack } & \text { Max Robert Pope } \\ \text { H. S. Brevoort } & \text { Marcus Albin Peterson } \\ \text { Hugh Hover } & \text { Frederick C. Bornschein } \\ \text { Samuel August Swenson } & \text { Elias Alexander } \\ \text { Herbert D. Karass } & \text { E. H. Milady } \\ \text { James R. Smithheisler } & \text { Harry Crandall } \\ \text { Charles Henry Swift } & \text { Seth Mossman } \\ \text { William M. Blair } & \text { Frederick Otto Lundberg } \\ \text { Bernard M. Jackson } & \text { J M. Canfield } \\ \text { Ray Olson Dunn } & \text { Hyman W. Gardner } \\ \text { Charics Robert Mullong } & \text { Francis Paul Burke } \\ \text { Glen Eimo Peters } & \text { Margaret Frazier } \\ \text { Darley Garfield } & \text { Elna Laura Kiessling } \\ \text { Ernest V. Neumann } & \text { Elfie Viola Spurrier } \\ \text { Thomas N. Fleming } & \text { Elsie Muriel Fosterman } \\ \text { Andrew Leon Berggren } & \text { Kathleen Montgomery } \\ \text { P. J. Little } & \text { Irene Aphelia Anderson } \\ \text { Frank Wesley } & \text { W. H. Cabble } \\ \text { Lawrence Morrow } & \text { J. O. Bruce } \\ \text { Walter Sidney Yates } & \text { John De Fox } \\ \text { Wren Morrow } & \text { tnna Isabelle Thompson } \\ \text { Dietrich L. Bartling } & \text { Grank E. Gamble } \\ \text { Bernard S. Kelley } & \text { Isador S. Trostler } \\ \text { John Patton Kimmel } & \text { Frank M. Blazek } \\ \text { Cecil B. Durham } & \text { Marion S. Elliott } \\ \text { M. James Stech } & \text { Henry L. Wilson } \\ \text { Arthur G. Emerson } & \text { Dan De R. Talcott } \\ \text { Rudolph E. Johnson } & \text { F. D. Finch } \\ \text { Raymond E. Robinson } & \text { Frank H. Kucera } \\ \text { Ray B. McNamara } & \text { Czar C. Johnsor. } \\ \text { Vernon Vivoldo Talcott } & \text { Raleigh A. Buckmaster } \\ \text { John Russell Newman } & \text { Allan M. Lafferty } \\ \text { Grace Dowler Horner } & \text { Carl D. Nelson } \\ \text { H. W. Parchen } & \text { Carl Raymond Green } \\ \text { Albert J. Schivedhelm } & \text { George Kenneth Lewis } \\ & \end{array}$

\section{LINCOLN COUNTY}

Melvin N. Newquist

Ralph Emerson Moyer harles Northfield Olsen

Robert Pope

Frederick C. Bornschein

Elias Alexander

Frederick Otto Lundberg J - M. Canfield

Elna Laura Kiessling

Elfie Viola Spurrier

Elsie Muriel Fosterman

W. H. Cabble

J. O. Bruce

Inna Isabelle Thompson

Grank E. Gamble

Isador S. Trostler

an De R. Talcot

Raleigh A. Buckmaster

Lafferty

Carl Raymond Green

Lincoln County society was organized in North Platte in 1903 by Doctors G. B. Dent, D. T. Quigley, now of Omaha, Voorhees Lucas, N. McCabe and F. H. Longley. Dr. Dent was named president; Lucas, vice-president; Quigley, secretary-treasurer; Longley, censor; and McCabe, delegate to the state society.

Since its organization, this western Nebraska unit has been extremely active and has assisted in many ways in building up the standing and morale of the profession. The society, in 1910, favored Senate Bill 4069, advocating the creation of a national board of health; in 1913, attempted the organization of a Western Nebraska Medical Association; in 1914, investigated and exonerated a member from charges of unprofessional conduct; and about this 
time, helped organize and equip the Good Samaritan Hospital, ai Episcopal church institution now serving North Platte and vicinity. In 1921, the society cooperated in the employment of a school nurse, which service is still continued. An attempt was also made in 1924 to immunize school children against diphtheria but it failed because of lack of cooperation of the public. During the legislative session of 1926-1927, members sent many telegrams and letters favoring the Basic Science bill.

Serving in the late war were the following members: E. W. Fetter, T. J. Kerr, J. B. Redfield, C. A. Selby, J. S. Simms, F. J. Wurtele, all of North Platte, and J. C. Newman of Wallace.

Record of officers for 1904, 1905 and 1906 are missing but it is probable that Dr. Dent was retained, since he was still president in 1907. In 1908, Dr. N. McCabe presided; 1909-1912, F. H. Longley; 1913, A. J. Ames; 1914, J. B. Redfield; 1915-1921, V. Lucas; 1922-1923, T. J. Kerr; 1924-1927, H. H. Walker. Dr. J. B. Redfield is now vice-president; H. A. McDonald, secretary-treasurer; T. J. Kerr, censor; G. B. Dent, delegate to the state society and B. C. Pease, alternate.

Doctors registered in Lincoln County, from September 1, 1891 to December 21, 1927, include:

$\begin{array}{lll}\text { F. H. Longley } & \text { David A. Rundstrom } & \text { Chas. V. Crooks } \\ \text { Nicholas McCabe } & \text { D. T. Quigley } & \text { J. B. Redfield } \\ \text { Frederick N. Dick } & \text { Ora M. Caldwell } & \text { A. L. Ambrose } \\ \text { N. F. Donaldson } & \text { John W. Twinem } & \text { E. J. Porter } \\ \text { William Eves } & \text { Wm. J. Berkofer } & \text { John S. Simms } \\ \text { Chas. W. Duncan } & \text { Agnes Swetland } & \text { Frederick W. Buck } \\ \text { P. R. Wood } & \text { A. C. Sabin } & \text { C. C. Wallingford } \\ \text { William. O. Wisner } & \text { A. O. Potterf } & \text { S. J. Richardson } \\ \text { Elmer Y. Lawrence } & \text { Frank B. Slusser } & \text { Geo. O. Gordon } \\ \text { Geo. B. Powell } & \text { M. D. Pass } & \text { D. W. Vanderhoff } \\ \text { Homer B. Hatch } & \text { Albro J. Ames } & \text { J. C. Newman } \\ \text { Voorhees Lucas } & \text { Marie E. Ames } & \text { F. J. Wurtele } \\ \text { Chas. V. Bedell } & \text { Charles C. Stevens } & \text { L. E. Vandiver } \\ \text { Frank F. Dennis } & \text { Edmund T. Allen } & \text { Claude A. Selby } \\ \text { Wm. G. Eester } & \text { Elton B. Grabs } & \text { Theo. J. Kerr } \\ \text { Chas. W. Thorp } & \text { Ben. W. Kinsey } & \text { Frank H. Bent } \\ \text { Hugh E. McCaw } & \text { S. A. Sassady } & \text { Earl W. Fetter } \\ \text { W. J. Pinkerton } & \text { Clyde E. Kennan } & \text { Edward B. Evans } \\ \text { Geo. B. Dent } & \text { B. C. Elms } & \text { E. T. Carr } \\ \text { J. P. Dullard } & \text { J. K. Elms } & \text { Z. E. Matheny } \\ \text { W. D. Rea } & \text { Wm. M. Blair } & \text { Homer F. Fort } \\ \text { H. C. Hannah } & \text { Stacy B. Hall } & \text { Chas. F. Heider } \\ \text { T. F. Campbell } & \text { E. G. Cooper } & \text { Clyde N. Moore } \\ \text { Annie F. Church } & \text { Paul R. Siberts } & \text { Joel Anderson } \\ \text { Alonza A. Ward } & \text { W. J. Redfield } & \text { Walter W. Covell } \\ \text { F. W. Kruse } & \text { H. S. Brevoort } & \text { W. W. Solder } \\ & & \end{array}$


Bertha E. Morgan

C. E. Vandiver

B. M. Jackson

Thomas E. Sample

H. B. Schofield

Agnes H. Jones

Edward G. Dovey

H. L. McLeay

W. T. Shawley Julius L. Goodrich

Eugene D. Thurston

D. W. C. Smith

Luther D. Scherer

A. Jackson Dern

J. H. Nettleton

Lincoln G. Simon

E. E. Barr

Charles W. Stewart

P. C. Mockett

J. P. Dullard

Edmun Tuney Alien

George E. Darrow

Arturo Garcia
Malcom B. Wilcox

Chas. L. Swift

Bert C. Pease

Geo. W. Doran

Frank Kohn

John R. Montgomery

Harvey L. Clarke, Jr.

LOGAN COUNTY

E. F. Carr

LOUP COUNTY

Albro J Ames

Milan S. Moore

J. F. MeNulty

Charles V. Crooks

A. A. Potteri

KIMBALL COUNTY

Stacy B. Hall
H. S. Brevoort
Homer F. Fort
George P. Wilkinson
Albert Fremont Barfoot
Enoch Neff
Hugh M. Bailey
Clyde Yeager Beard
Wilber K. Mylar
Earl George Clegg
Riley Edward Roche

Stacy B. Hall

H. S Brewoort

Gecrge P. Wilkinson

Albert Fremont Barfoot

Enoch Neff

Hugh M. Bailey

Clyde Yeager Beard

Riley Edward Roche
Townsend E. Dent C. F. McReynolds Ot is R. Platt H. H. Walker Andrew C. Schoch E. Dillard

H. W. Hubbell

Robert Glen Miller Austin Edgar Ripperton Frederick K. Woltman William F. Race

Frederick W. Buck

Edward L. Rolph

Frank W. Wieland

A. A. Potteri

Eugene F. Noonan

John R. C. Carter

Arthur Lewis Miller

W. W. Sadler

Felipe P. Sucgang

Joseph Bernard Pankau

\section{PHERSON COUNTY}

Harriet G. McGraw is the only physician registered at Tryon, McPherson County. Further mention of Dr. McGraw, who was featured in a recent number of the American Magazine, is included in the chapter on Women Physicians.

\section{MADISON COUNTY MEDICAL SOCIETY}

Including Madison, Stanton, Pierce, Antelope and Knox Counties.

The Madison County Medical Society was organized in 1903 by Dr. F. A. Long of Madison, and from 1903 until 1916 meetings were held once a year. These records have been lost.

In 1916 it was decided to have monthly meetings to be held in the various towns of the county. Each meeting was to be a round table discussion of various diseases, taking one disease for each meeting and assigning etiology, pathology, diagnosis and treatment to different members. This was so successful and created so much interest that surrounding counties, who had no meetings, asked to be taken in to the society and as a result, Pierce, Antelope, Stanton and 
Knox Counties were elected to membership. This has continued up to the present time and now the society is known as the Madison, Stanton, Pierce, Antelope, and Knox Counties Medical Society.

In 1926 a change of the style of program was inaugurated in that each month's program was assigned to two members who, in turn, could put on any kind of a program that they wished, and since that time they have been having outside speakers.

The society has steadily grown until now it has become the best society of its kind in the state and has done wonderful work in harmonizing the medical profession in this vicinity.

Presidents since 1916 include A. E. Gadbois, A. N. Howley, Frank Jensen, G. E. Charlton, E. L. Brush, W. R. Peters, L. L. Nelson, A. M. Sonneland, J. D. McCarthy, P. R. Allerton, F. G. Salter and A. C. Barry.

A colorful historical sketch of practitioners in Madison County since 1875, prepared by F. A. Long of Madison in 1925, is here appended:

Previous to 1875 there was no real physician at Madison. Three men known as "doctors" homesteaded or timberclaimed in the community and seem to have done some neighborhood practice.

One was "Doc" Webster, who had a claim on North Taylor Creek. It appeared that he dispensed some homeopathic remedies, but never pretended to do regular practice.

"Dr." John Quincy Adams Harvey lived three miles up Taylor Creek on what is now the Alex. Graves farm. He seems to have accommodated his neighbors when ill, by the use of "roots and yarbs" and by giving calomel and quinine. He was the first coroner of Madison County and an early day story was that when called to the cabin of a settler who was found dead, down Union Creek, he opened the door, looked in and gave the verdict-"Deader'n hell!"

Dr. John L. Willberger, who had been a practitioner in eastern Iowa but not a graduate settled on Union Creek about three miles south of the Lutheran Church in Green Garden. He appears to have done considerable practice before the advent of a regular physician. In the early eighties he was in Omaha for several years and afterward returned to Madison and opened an office and died here. 
Dr. S. J. Bridenstine, a graduate of the Iowa State University Medical School, located in Madison in 1875 and remained here 14 years, leaving in 1889 for the Puget Sound country and is now in practice at Ballard, a suburb of Seattle, Washington. He had a very large practice and was probably the best liked of all of Madison's physicians. He early took up the study of electricity in medicine and had some very fine apparatus.

Dr. Charles Fleischman came to Madison in the latter part of 1880 and remained until the early part of 1882 when he left somewhat surreptitiously, leaving his medical and surgical equipment at the hotel where he had lived.

Dr. F. A. Long (the writer) came June 27, 1882, with a diploma under his arm, but with very little knowledge of the world and its ways and without money. He got very little business during the first few years, but no less than he deserved. It took about five years to get on a living basis, after which the fates were kinder to him. He has now been here almost forty-three years and his later career is known to many people. He is now editor of the $\mathrm{Ne}$ braska State Medical Journal.

A Doctor Cox came to Madison from Battle Creek in the fall of 1882. He was a minister-doctor who came from North Carolina, near the Virginia border. He was an elderly man who had ridden the bridle paths in the Southland and had ministered to both soul and body. $\mathrm{He}$ was neither an educated doctor nor educated minister, but he was faithful to his patients and had a large following, especially among Virginians in this county. After a few years he moved to Blaine County, Nebraska, where he died.

A Doctor Collins came here from southwestern Iowa about 1883. He bought a farm four miles east of Madison, now owned by the Weiland estate and lived there a part of the time but kept an office in town. He was not a graduate nor a registered physician, but practiced in spite of the law. He was originally from Indiana, had been a soldier in the Civil War. He never acquired much of a practice and after a few years he returned to Iowa.

Dr. J. H. Mackay came here from Illinois either in 1883 or 1884 . He was a recent graduate of a Chicago homeopathic medical school. He was in some respects a brilliant but an erratic character. He lived here a number of years and acquired a large practice. He was 
married to a Madison girl, a Miss Sylvia Johnson. At one time he was the editor of the Madison Reporter, a Democratic organ. Through the infunence of the late Senator Allen he was appointed Superintendent of the Norfolk State Hospital for the Insane in 1906, a position which he resigned under some pressure a year or so later. He later practiced in Norfolk and finally went to Texas where at Houston he died in January, 1922.

A Dr. J. B. Hawk came here from Emerson, Iowa, in 1884. He remained only about six months and moved to Grand Island. I understand he died many years ago.

A "Dr." Hutchinson came to Madison from Bridgeport, Connecticut, about 1886. Previous to coming here he had been a fulminate mixer at the Union Metallic Cartridge Co., works at Bridgeport, and no record ever turned up to indicate that he was a graduate physician. He claimed to be a specialist in diseases of women. He became associated with Dr. Bridenstine and later purchased Dr. Bridenstine's home and office. He left Madison about 1890 and went to Minneapolis, where he died.

Dr. Chas. E. Gossard, a half-brother of the late Senator Allen, succeeded to the business office of Dr. Mackay when the latter became head of the Norfolk State Hospital. He practiced here a number of years and is now located at Topeka, Kansas.

About 1890 a German named Weber came to Madison to practice medicine. He gave himself out as a specialist in diseases of women. After a rather colorful career of about two years he moved west.

Dr. E. N. Smart came to Madison from Humphrey in 1893 and has been in continuous practice here since that time. Like the writer, the doctor was quite a while 'catching on,' but since then he has always held a large clientage.

Dr. Smart died suddenly of organic heart disease, in April, 1927.

Dr. Robert Johnson came to Madison from Norfolk, where he had family connections, sometime in the late ' $90 \mathrm{~s}$. He remained but a short time and gave up the profession for a mercantile career.

Dr. S. A. Preston, a recent graduate, came to Madison in the early fall of 1900 , and opened an office in the opera house block. He remained only a few months, then lo- 
cated at Beemer. $\mathrm{He}$ is now one of the leading physicians of Fremont.

About 1904 or 1905 appeared Dr. John R. Montgomery, in many respects the most dramatic character ever had in the practice of medicine. He was well educated - as one of his classmates said, "not any better than he let on"- -had a lot of courage and an insinuating manner that brought him a considerable business in a short time. His downfall occurred a few years later through too great a fondness for the flowing bowl. He went to Denver, got into trouble with The Colorado Exanining Board, was next heard from at Smith Center, Kansas, and later at Minneapolis. Still later he was said to have been connected with a traveling concern such as the "United Doctors" or the "German Doctors." Within the past year he billed several towns in south eastern Nebraska as "Dr. John R. Montgomery, Specialist of St. Louis." He was arrested for practicing without a license and served some time in the Falls City jail. With several others he broke out of jail but was captured in Kansas and brought back.

Dr. A. E. Gadbois located at Madison in March, 1907, coming from the neighboring town of Humphrey. He enjoyed a large practice while here. He sold his Madison interests in 1917, took special work in eye, ear, nose and throat work, served some time in the army, then located at Norfolk.

Dr. Thos. H. Long came to Madison to practice in cooperation with his brother in 1907 and remained about 15 months when the lure of the west took him to Tacoma, Washington, where he now is located.

Dr. Mlan D. Baker (a Tilden product), fresh from college, located at Madison about 1908 and for a time was dssociated with Dr. Montgomery. He later moved to Tilden, became associated with Dr. S. A. Campbel! and with Dr. Campbell moved to Norfolk, where he died an untimely death of cancer of the kidney in 1920.

Dr. W. E. Shike came to Madison from Lincoln about 1912 where he had graduated shortly before from the Lincoln Medical College. He acquired quite a business, but after about two years he located at Gering, Nebraska.

Dr. E. O. Wilson located in Madison in 1912. The need of conservation of some property interests caused him to move on the farm about four miles from town, where he 
lived several years. He served in the medical corps of the Army during the latter part of the war. Since disposing of the farm he has devoted himself to a growing practice.

Dr. L. W. Wuesthoff came to Madison from Elgin, when Dr. Gadbois sold his property to him in 1917. He moved to Atascadero, California, in the fall of 1923.

Dr. H. R. Palmateer came to Madison in the early spring of 1923 to become associated with Dr. E. N. Smart.

Dr. Claude Wills, a native son of Madison, came here during the summer of 1923 from Casper, Wyoming, where he had been in practice for some time.

\section{MERRICK COUNTY}

The Merrick County Medical Society was organized January 13, 1903, by J. E. Benton of Central City, acting on authority of the reorganization committee of the state medical society. E. A. Benton was elected president; E. L. Robinson, vice-president; and J. E. Benton, secretary-treasurer.

Following is a list of the members since inception: W. J. Arrasmith, E. A. Benton, J. E. Benton, E. E. Boyd, J. L. Brannon, A. D. Brown, G. M. Brown, C. H. Campbell, R. C. Christie, George Clark, R. R. Douglas, H. O. Drew, F. Fouts, C. H. Fox, W. Y. R. Gawne, H. E. Glatfelter, R. A. Hamil, S. L. Hull, J. W. Hutchison, R. C. Jaenike, N. Jones, H. E. King, T. H. Line, L. Little, G. E. Martin, C. S. Minnich, A. L. Muirhead, C. C. Paxton, Juan Racines, E. L. Robinson, W. C. Robinson, Senelick and J. M. Triplett.

Doctors registered here since September 16, 1891 include:

Howard C. Adams

G. M. Andrews

William Arrasmith

E. A. Benton

J. W. Brakett

C. A. Barnett

J. E. Benton

Schuyler C. Borien

G. M. Brown

J. Baird

H. S. Brevoort

A. D. Browne

Fredericis W. Buck

Geo. F. Bartholomew

Chas. H. Campbell

Charles Crooks

F. E. Dalrymple

James F. Davies

Robert R. Douglas

Elwood W. Laird
H. E, Glatfelter

Sarah E. Green

J. H. Griffin

Frank E. Gordon

Sullivan Howard

Wilbur N. Hunt

James Hadley

Newton J. Hoagland

Adolph H. Holm

Solomon L. Hull

Clarence M. Hyland

Joseph N. Hutchison

Thomas J. Jones

Newell Jones

Johanna E. Logan

Frederick Fouts

Artie Folsom

C. H. Fox

W. Y. R. Gawn

H. L. Gregg
C. D. D. M. Langrall

Lorrell Little

C. S. Minnich

A. L. Muirhead

Robert E. McCracken

J. E. Martin

J. J. Pickett

Charles C. Paxton

Sollis C. Pitts

E. L. Robinson

W. C. Robinson

M. L. Rich

William F. Race

A. J. Sanders

Frank Simon

Alfred Shipman

I. S. Stevens

J. S. Sturdevant

John Stoddard

A. C. Sabin, Jr. 
A. L. Stiers Charles C. Stivers W. B. Thurston Adelbert Townsend
Thomas Vallier J. B. Whittaker Augustus Ward

R. C. Walker Geo. M. White
Percy Alberton

H. O. Drew

E. Ruth Hull

L. L. Wood

\section{NANCE COUNTY}

John F. Johnson of Fullerton, pioneer physician and charter member of the Nance County society, practiced in Hamilton County across the reservation from Lone Tree (now Central City) from 1874 until 1881, when he settled in Fullerton. He had read medicine in a doctor's office in Minnesota until the Civil War, through which he served in hospital details, and at its close, practiced in Cloud County, Kansas, until 1874. He was active in the G. A. R. until his

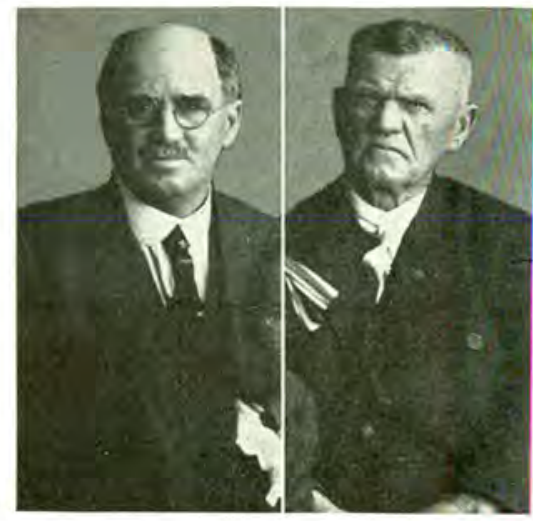

F. W. JOHNSON J.F. JOHNSON

death in 1924. A son, Frank W. Johnson, joined him in practice in Fullerton after his graduation from Omaha Medical College in 1894. The younger Johnson helped reorganize the Nance County society under the new plan in 1903; was the city and county health officer and a member of the insanity commission for 30 years. He is a member of the Union Pacific Old Timers' club.

Henry E. King of Fullerton is now president of the Nance County Medical Society.

The list of doctors registered in Nance County includes:

Henry S. Andrews

John W. Brackett Alma S. Bennett

Gilbert P. Bennett.
H. Y. Yates

Bret V. Yates

Oley A. Britell

William Henry Barber
Cyrenins S. Barnes

S. Byron Buckley Joseph H. Binney Edw. D. Barrett 
G. R. Barringer

Edward D. Balcom

Charles V. Cook

Robert L. Cosner

Ora M. Caldwell

Tracy R. Clark

A. J. Emmerson Clark

James A. Cleary

Homer Davis

L. A. N. DeLaney

Kenneth Davis

John Dwight Davis

Sydney Eastman

Lee W. Edwards

Paul J. Flory

John H. Faucett

Chas. J. Fogarty

Wm. H. Gray

Edward James Gillespie

Paul B. Gillespie

Charles E. Goodwin

Adolph Oppermann

V. M. Boal

Lorenzo Rounds

Eleanor C. Reed

H. L. Mathews

James Kay

W. W. Kieling

John F. Neal

W. T. Neal

Chas. Stewart

Richard H. Welfley

S. B. Lutgen

Thos. S. Gant

J. H. VanCamp

E. C. Mostelles

Joseph W. Bourne

Harrison I. Shull

Eugene M. Tyler

Alfred Elder

Columbus L. Cook

Thad. L. Loofbourrow

J. W. Epler

William M. Daily

E. W. Schirmer

Seth J. Crudup

Alfred Shipman

Ulrich D. Stone

Hilary Gaither

B. F. Lorance

Allen T. Rice

A. S. Halladay

Edward E. Fauver

J. S. Wilson

Herbert H. Smith

J. L. Melvin
M. M. Hazle

Roy E. Hall

John F. Johnson

Frank W. Johnson

Dora M. Judkins

Johann H. Jessen

J. F. Johnson

Edward Johnson

P. Janss

John J. Keifer

H. E. Kinyon

E. Eugene King

Milton Elder Kirkpatrick Edward Emmet Sweeney

Gilbert D. Laffler

Thos. H. Line

Edward C. McMillan

T. C. McMillan

F. A. Malick

D. B. McMahon

E. C. Mc Millan

Paul C. O'Haver

A. E, O'Key

\section{NEMAHA COUNTY}

John Barnes Jack

Albert Townsend

Jens Sorensen Haarup

Chas. P. Crudup

Lafayette W. Blanchard

J. Hugh Dillon

John W. S. Howell

Almer L. Sabin

Daniel Freeman

G. M. Andrews

E. Schneller

B. F. Shellhorn

T. E. Fariall

F. L. King

U. H. Norris

Walter L. Morrill

Clifford A. Lutgen

Ira F. Harlan

Fred L. McLeod

J. Luther Glasgow

W. E. Shook

Guy R. Taylor

D. W. Starbuch

C. W. Edwards

A. A. Potterf

L. A. Fairchild

I. S. Stevens

Willis J. Raynor

Albert E. Gerish

Halbert F. Neal

V. Veone Vance

Emil Raben

Hal Clark Smith

Anson S. Lutgen

Chas. W. Jester
A. A. Potterf

Austin W. Peppers

Benjamin Rea

M. L. Rich

Palmer W. Roberts

E. H. Smith

L. F. Saxenberger

Alexander C. Sabin

C. S. Sheppard

Chas. C. Stivers

E. H. Smith

A. J. Saunders

Joseph H. Thompson

Jno, VanKuren

N. A. Williams

Henry C. Williams

Alonzo A. Ward

C. D. Williams

N. A. Williams

Edward Franklin Zoerb
Joseph V. Hinchman

A. L. Stien

Lottie Stephens

Charles I. Stephenson

Asen H. Kent

W. W. Frazier

Francis F. Malone

W. S. Butterbaugh

Isaiah Irvin

Athenus L. Asa

Park A. Findley

Godfrey C. Fritchel

H. A. Abbott

George W. Doran

J. E. Brittan

Wm. S. Yager

H. S. Brevoort

Perry A. Kelly

Elijah C. Williams

Enoch Neff

Johannes Weiss

Samuel Arthur VanOsdeI

Artie Folsom

N. P. Hansen

Frank C. Thompson

John Harvey Nicol

Edgar Cline

Piere LaFayette Stewart

Louis Arthur Dermody

C. A. Brown

Webster Tanner

C. Herbert Munger

Asa E. Fletcher

Clyde A. Meddar
Charles Ray Dever - 
Alonzo A. Ward

J. M. Callender

Carl William Morrow

Herbert O. Munson

Francis W. Boland

Ora M. Caldwell

Raymond A. Young
Bert A. Smith

James H. Hylton

Gilbert D. Loffler

Paul Henry Stappenbeck

Nathan Holl Blakesley

David D. Stonecypher

Dwight Otis Hughes
Alfred Clifton Graham

A. Jackson Dern

Leander Z. Skinner

David A. Hewit

Joseph F. Moell

Charles C. Steen

\section{NUCKOLLS COUNTY}

Following are the names of physicians registered in Nuckols

\section{County:}

Charles McMahan

J. E. Brainard

J. M. 5. Chesshir

J. A. Trowbridge

\author{
W. F. Mitchell \\ J. E. Ingram \\ W A. Cate \\ Y. A. Thomas
}
W. H. Nelson
A. M. Pedersen
J. B. Dierker
E. Kauffman

\section{PHELPS COUNTY}

Phelps County society was organized in 1903 by a quintet including Doctors P. A. Sundbury, S. F. Sanders, W. D. Shields, W. A. Schreck of Bertrand and F. J. McRae of Loomis. S. F. Sanders of Holdrege was elected president and served two years; F. J. McRae of Loomis was the first vice-president and P. A. Sundbury of Holdrege, secretary-treasurer. In 1905, W. A. Schreck of Bertrand was named president; in 1906, W. D. Shields; in 1907, C. O. Geise; in 1908, P. A. Sundbury; in 1909, S. F. Sanders, the first president, served again. W. D. Shields, elected in 1911, held office six years. In 1917, J. L. Magill was president; 1918, Schreck of Bertrand; 1919, E. I. Whitehead; 1920, P. K. Palmer; 1921, R. W. Long; 1922, Guy Clark of Bertrand; 1923, R. D. Green; 1924, W. M. Robertson; 1925, S. F. Sanders again and in 19261927, P. A. Sundbury, again. All presidents are Holdrege physicians, unless otherwise stated.

\section{Registered physicians in Phelps County are:}

H. E. Harrington Geo. N. Whittier

L. C. Holms

Geo. F. Walker

James T. Miller

N. McKechnie

John D. England

Samuel F. Sanders

Edward E. Whitehorn

Wm. D. Shields

Hannah C. McCahan

George W. Wilson

P. A. Sundbury

Jacob S. Shields

John Blood

Daniel S. Palmer
Wm. A Shreck

G. A. Weirick

F. V. Johnson

Alexander C. Sabin

Almer L. Sabin

W. D. Rea

James L. S. Stewart

F. L. King

Dennis Neville

B. E. Neal

Arthur Hale Gilmore

Chas. W. Oaks

Henry E. Marselus

James A. Anderson

Charles V. Crooks

Charles O. Giese
A. A. Potterf

James E. Warrick

David G. Olson

Bert E. Marrow

Charles C. Silver

Eugene E. Rider

Willington A. Thomas

Ben. W. Kinsey

John E. Caneen

William M. Bair

Frank Earl Gordon

Frank E. Stoaks

Seth L. Hubbard

Frank N. Loveley

William H. Blakemare

Theo. Milen 
Eugene M. Stansbury

Ward Willard Hedlund

Wm. T. Eikner

J. L. Magill

Beecher B. Baldwin

James C. Anderson

Louis Noah Smernoff
Jonas Larson

E. I. Whitehead

H. P. McKnight

Dare Woodruff

Geo. M. Doran

Ora Caldwell

Wm. W. Frank
Paul B. McCanley

T. A. Peterson

King P. Palmer

Radiel Watkins-Long

Ralph D. Green

Wm. B. Banister

Guy W. Clark

\section{PLATTE COUNTY}

C. B. Stillman was the first physician in Platte County, practicing there before 1876. Physicians registered there since 1891 are:

Henry Eugene Ayars

L. C. Voss

A. J. Sanders

Edward Hoehen

Charles B. Stiliman

John C. Willy

Mary B. Clark

J. W. Knie

Jenkin W. Davis

W. T. Mason

Julius S. McAllister

J. L. Patton

Alfred Michel

Thomas E. Stack

A. C. Kennel

C. T. O. Miessler

Homer A. Hansen

Phillip H. Metz

Thomas E. Barrow

John WV. Brackett

Sylvester Gwaltney

Charles J. Alger

Batholdi Tiesing

Jens Sorensen Haarup

W. L. Downing

$\mathrm{Wm}$. H. Vose

Andrew J. Baker

Harry J. Arnold

Frank Grabel

William W. Frank

Geo. F. Pugh

Almer L. Sabin

Daniel G. Walker

J. S. Sturdevant

Peter L. Benthack

Henry C. Williams

P. H. Dassler

Carroll D. Evans

\section{F. H. Geer}

David T. Martyn

Charles V. Crooks

Charles A. Stevens

Isaac P. Sinclair

D. T. Martyn, Jr.

Wm. R. Cornelius

Edwin A. Moore

Hans Peterson

E. R. Jones

Ora M. Caldwell

James F. Davies

A. A. Fotterf

J. C. McKinley

Chas, H. Platz

A. E. Gadbois

Josiah Young

William S. Evans

Alvin G. Lueschen

Gertrude H. Frommholtz

Edward Benjamin Evans

Lew Paul Murphy

James R. SmithheisIer

C. Nefi

W. H. Norris

Anthony Cauley

Harry Elmer Lamb

A. C. Sabin

H. J. Brink

James G. Stone

Charles C. Sivers

Ben W. Kinsey

Frank H. Morrow

William F. Kace

Charles H. Campbell

Geo. A.Ireland

George M. Doran

Allan M. Lafferty

William F. Putt

POLK COUNTY
M. J. McChesney

L. M. Shaw

D. J. Smith
C. L, LeMar

L. Myers

J. C. Malster
W. Richard Neumarker

Richard J. Tanner

Stacy B. Hall

Hugh Hover

H. S. Brevoort

Bret Verne Bates

E. W. L. Weideranders

Fannie D. Henderson

Adelbert Townsend

Charles M. Headrick

C. A. Allenburger

John Francis Loosbrock

Ralph M. Ryan

Richard H. Jones

Frederick W. Buck

Gilbert D. Laffler

Piere LaFayette Stewart

Arno Albert Bald

Charles E. Barnes

Vohan H. J. Giragosian

Theo Koefoot

Joseph H. Thompson

Mahlon Bluford Peterson

P. E. V. Boerber

Carroll D. Evans, Jr.

F. A. Lemar

Johann H. Jessne

George H. Morriss

Fred B. Cyphers

Maurice Clayton James

W. A. Burke

Anthony J. Smith

Harry Richard Elston

Julian E. Meyer

Roscoe Conklin Kory

Ezra Edwin Koebbe

Henry J. Holke

Charles H. Davies 


\section{RED WILLOW COUNTY}

Chas. H. Jones

B. B. Davis

W. A. DeMay

John E. Hathorn

F. W. Eskey

Allen F. Rice

William Plani

I. M. Brown

L. J Spickelmier

W. V. Gage

Andros W. Hoyt

R. B. Campbell

Ely Hoge Waters

J. A. Gunn

Emma T. Meinhardt

A. C. Harlan

Samuel C. Beach

Chas. J. Logan

Charles M. Duncan

W. D. Rea

W. R. MacKechnie

C. L. Fahnestock

John D. Hare

Ole E. Robinson

Albert Morefield
J. K. L. Duncan

Chas. W. Oaks

Wm. S. Albright

John F. Hart

Orville C. Mastin

C. Neef

William E. McDivitt

A. A. Potterf

Clarence Minnick

Frederick W. Buck

Devilo P. Simons

Julius A. Toren

Ben. W. Kinsey

Johanna E. Logan

James F. Premer

Othello Waters

Effie A. Current

Frank Earl Gordon

Roland Ray Reed

John W. Conard

Charles Mansfield Worth

Charles C. Aitken

Warren M. Phillips

Griffith Alonzo DeMay

James C. Anderson

Evan Ardie:
Charles C. Stivers

William S. Bartholomew

Edmund Turney Allen

Dare Woodruff

B. B. Simmons

A. B. Hardin

McDonald Ryan

Jacob S. Rinehart

Bessie P. Mason

John S. Forsen

Charles B. Calland

Charles F. Lyle

Donald H. Morgan

J. M. Willis

Raymond B. Kepner

Walter E. Knox

A. I) Shapere

Earl F. Leininger

J. Stanley Hill

John R. Montgomery

George W. Doran

Dewey F. Brown

Howard R. Murphy

Laird W. Elwood

Walter C. Purviance

\section{PHYSICIANS AND MEDICAL HISTORY OF RICHARDSON COUNTY}

$$
\text { by C. L. Hustead, }
$$

Secretary of Richardson County Medical Society.

The author of this history is especially indebted and grateful to two physicians, C. T. Burchard, who a few years ago passed to the great beyond, and J. A. Waggoner of Humboldt, who has practiced medicine in this community for over fifty years and wha is still in active practice. In 1917, these two physicians, having passed through the trying years of the pioneer days, resolved to compile a history of the medical profession in this county from its very beginning and for this reason, the writer of this article wishes to give Doctors Burchard and Waggoner credit for having foresight in making for us a record which we could not have procured in any other way.

\section{Physicians of Arago}

Before Doctor Burchard's arrival at Arago in 1864, there had been a resident doctor, with a French name, which Doctor Burchard could not recall, as he remained for only a short time. St. 
Stephens, a mile to the north, supplied the medical wants of Arago for a time in the persons of Doctors Whitmire and Shepherd. David Whitmire came to St. Stephens in 1855 and removed to Rockport, Missouri in 1866, where he died. J. T. Shepherd came to St. Stephens in 1865 and later removed to Arkansas City, Kansas in 1875. Doctor Burchard states that these were both graduate physicians.

Russel Peery came from Peru, Nebraska in a covered wagon, associated himself with Doctor Burchard's father, F. W. Burchard,
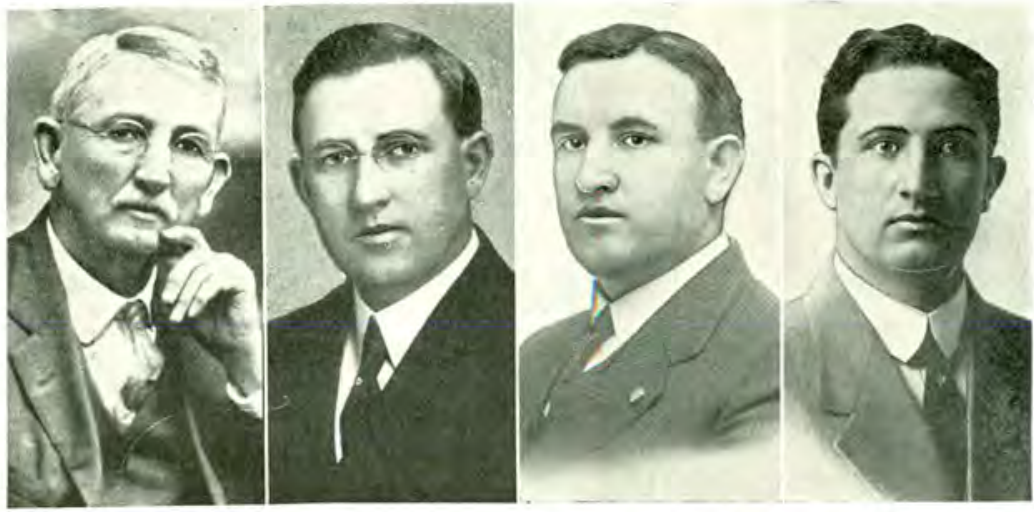

J. A. WAGGONER OF HUMBOLDT AND THREE SONS-ALL PHYSICIANS

in the drug business, remained for only a short time and departed. The only trace that history gives of his subsequent movements is that one of his sons, Matt Peery, became a doctor and located at Elk Creek, Nebraska.

The next physician to arrive was C. F. Luja in 1866. He was a German physician, educated in Europe. He removed to Rockport, Missouri in 1875 and returned to Falls City in 1899, where he died in September, 1900.

In 1868, F. P. Seclor, a graduate of Ann Arbor, Michigan, came to Arago from Detroit, after service as an army surgeon in the Civil War. He removed from Arago to Cheyenne, Wyoming, where he was re-assigned to military service at an army post of that place. Later he moved to Tampa, Florida. 
The next physician coming to Arago was W. F. Conwell, who practiced there from 1873 to 1879 , after which he located at Neligh, Nebraska.

Doctor Meinhardt was a resident doctor during the fall of 1876 and the spring of 1877 and at that time, George Koenig located in Arago and resided there for two years, when he retired to a farm two miles out, which he worked, continuing a more or less intermittent practice, up to the time of his death in 1912.

J. D. Hunter came to Arago from Highland, Kansas in the summer of 1875 , an undergraduate, practiced for a short time and then went to Keokuk, Iowa, where he was graduated in 1876 . He then came to this county, locating in Falls City where he practiced until the time of his death in 1883.

Dr. C. T. Burchard in 1876, at the age of nineteen, went to Chicago, matriculating in Rush Medical College. After taking the winter course in 1876-1877, and the spring course in 1877, he returned to Arago, July 4, 1877, for the purpose of spending his vacation. A widespread and malignant diphtheria epidemic m ning ng up in Arago and vicinity, he was pressed into service on account of a shortage of doctors and he continued there in general practice until October, 1878, when he returned to Rush Medical College, was graduated in February, 1879, at which time he returned to Arago where he practiced until 1884. He then located in Falls City and permanently resided there until his death in the year 1920. Doctor Burchard bears the distinction of having brought the first fever thermometer, the first hypodermic syringe, and the first obstetrical forceps to Arago, also having done the first tracheotomy in this section of the country.

\section{Physicians of Falls City}

At the time C. T. Burchard located in Falls City in 1884, there had resided there, Drs. H. O. Hanna, the first physician to settle in Richardson County, according to John R. Towle of Omaha, whose family were pioneer settlers there: W. W. Shaw, J. D. Hunter, A. B. Newkirk, Sr., all of whom had died and Drs. Wing, Wood, Woods and W. W. Campbell, all of whom had recently moved away, prior to 1884. The resident doctors of Falls City were A. B. Newkirk, E. M. Wilson, J. B. McConnell, D. W. Campbell, H. L. Ran- 
dall, George H. Neal, McCoy, C. W. Bryson and Wesselowsky. Later in the year, A. Kellar and W. H. Kerr located in Falls City, making an even dozen resident physicians in the year 1884, all of whom have since moved away or died.

Since that time, many have come and gone: Dr. I. M. Houston, F. C. Wiser, Hannah Flemming, W. Parcell, C. L. Kerr, C. C. Keeler, D. G. Griffiths,W. S. Fast, P. W. Hays, Emma Lawrence, C. H. Rush, W. M. Trotter, Hazard, Hershey, William J. Wells, G. C. Paxton, J. V. Hinchman, C. A. Brink, Johnson and Mrs. Johnson, Sadie Doran, Lee Cowan, H. M. Harvey and C. T. Burchard.

Among the above mentioned, our records show that the following physicians died: Drs. W. W. Campbell, E. M. Wilson, George H. Neal, W. H. Kerr, I. M. Houston, P. W. Hays and A. Kellar. H. O. Hanna and E. M. Wilson were regimental surgeons during the Civil War. The following physicians moved away: A. B. Newkirk and C. W. Bryson, locating in Los Angeles; and D. W. Campbell, in Atchison, Kansas in 1866 and was Burlington surgeon for a considerable time. H. L. Randall a number of years ago located at Grand Island and served in connection with the Soldiers' and Sail-

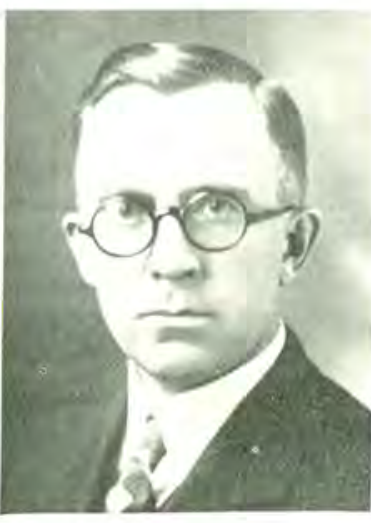

C. L. HUSTEAD ors' Home. G. C. Paxton moved to Idaho. G. W. Griffiths moved to Lincoln and later was appointed superintendent for the Feeble-Minded Institution at Beatrice. W. F. Fast was appointed superintendent of the Institution for Feeble-Minded in 1913 and was later placed in charge of Ingleside Hospital at Hastings in 1916 which place he occupied up to the time of his death. C. T. Burchard died in the year 1920 .

The following physicians are practicing medicine in Falls City at the present time: M. L. Wilson, H. D. Burchard, C. P. Fordyce, H. R. Miner, J. C. Gillespie, Edward R. Hays, O. F. Lang, G. W. Reneker, R. G. Henderson, S. D. Cowan, J. M. Gren, W. R. Boose and C. L. Hustead. 
Rulo

Physicians known to have practiced medicine in Rulo are Moses Jeffries, J. S. Jones, J. B. Samuels, Neal, Knic, J. G. Walker, J. C. Shepherd, F. C. Wiser, R. G. Henderson and William Shepherd. J. C. Shepherd is one of the early pioneer physicians, having located in Richardson County and practiced here for over a period of fifty years. He is still active and progressive and is at the present time, associated with his son, William Shepherd. They are the only two physicians practicing at Rulo at this time. On May 7, 1927, Doctor Shepherd was presented a gold medal by the Richardson County Medical Society in honor of his fifty years' service in this county. $\mathrm{He}$ is on the staff of the Falls City Hospital.

\section{Barada}

Physicians known to have practiced medicine at Barada are the following: I. N. Williamson, G. C. Paxton, W. S. Fast, G. W. Reneker, S. A. VanOsdel, Wiltse, D. D. Leeper, Maust, J. F. Strong, J. H. Bloomenkamp and W. I. Hinkle, all of whom have either died or moved away.

\section{Shubert}

Physicians known to have resided at Shubert are as follows: A. D. Cloyd, I. C. Sutton, J. F. Strong, W. E. Shook, J. M. Willis and G. W. Egermeyer. Cloyd achieved distinction after leaving Shubert by being chosen as medical director of the Woodmen of the World with offices at Omaha. W. E. Shook and G. W. Egermeyer are the present medical representatives in this city.

\section{Cottage Grove}

Cottage Grove, a rural cross-roads lying about four miles north and east of Verdon, was at one time represented in the medical profession by C. R. Baker and Ira Baker, father and son; Doctor Rockwell, who resided there in 1867 and H. L. Randall. There are no medical representatives at Cottage Grove at this time.

\section{Humboldt}

The first physician to locate in Humboldt was J. L. Gandy, a graduate of Rush Medical College in 1867, who located in Humboldt in 1869 . In connection with his practice, he operated a drug store. The doctor had a very extensive practice for a number of 
years which called him over the greater part of Nemaha, Johnson, Pawnee and Richardson Counties. Several years ago, he retired from practice to devote his time to his extensive real estate holdings. $\mathrm{He}$ was one of the largest land owners in this section of the state Doctor Gandy died a few years ago at Humboldt.

P. F. Pattrick, a graduate of Keokuk Medical School, practiced medicine from 1872 to 1883 up to the time of his death.

J. Russell Morris came to this county in 1879 and located on a farm and for a number of years did a large practice. He moved from his farm to Humboldt in 1892 and remained there until the time of his death in 1913.

J. G. Cox, a native of Humboldt, born in 1814, received his literary education at Hanover College, Indiana and was graduated from the University of Kentucky at Louisville in 1852. In 1872, Doctor Cox located at Humboldt. He saw service in both the Mexican and Civil Wars and died in Humboldt in 1911.

A. L. Williamson located in Humboldt after graduating from the College of Physicians and surgeons at Keokuk, Iowa in 1883 and continued to practice at this place to the time of his death in 1903.

P. W. Hays was graduated from Jefferson Medical College, Philadelphia in 1877. Two years later he located at Humboldt. $\mathrm{He}$ later removed to Falls City, remaining there in active service until the time of his death in November, 1896. The doctor was regarded by his colleagues as one of the leading members of his profession. Dr. E. R. Hays of Falls City, is the son of the late P. W. Hays.

J. A. Waggoner was graduated from the University of Louisville, Kentucky, in 1876. He located in Dawson, Nebraska in the spring of 1879 where for six years he practiced his profession and operated the first drug store in that city. In 1886, he came to Humboldt, practiced for four years, then he moved to Bern, Kansas and four years later returned to Dawson. Here he remained until 1907, when he located in the city of Humboldt and is practicing there at this date. Doctor Waggoner is the best known physician of the profession and has a wider circle of acquaintances than any other doctor in the county. He is not only an alert physician, but 
a gentleman in every sense of the word. He is loved and respected by all who know him and has had more to do with the building of the medical profession in the county and the Richardson County Medical Society than any other physician now living. On May 7, 1927 , Doctor Waggoner was presented a gold medal by the Richardson County Medical Society as a token in honor for his fifty years' practice in this community.

The above named doctors are the ones mostly identified with the early history of medicine of Humboldt. L. T. Peterson, now connected with Pottinger Sanitarium, practiced medicine at Humboldt a few years. N. H. Blakley, now of Auburn, Nebraska, was located a short time recently at Humboldt. W. R. Waggoner, J. T., and Hewitt Waggoner, son of J. A. Waggoner, at one time were associated with their father. At the present time, W. R. Waggoner enjoys an extensive practice in Denver, J. T. Waggoner at Adams, Nebraska, and Hewitt Waggoner at Los Angeles, California.

The physicians practicing medicine at Humboldt today are as follows: J. A. Waggoner, F. A. Nelson, G. G. Gandy, son of the late James L. Gandy, and C. E. Novak.

\section{Dawson}

J. D. Terry was the first doctor to locate in Dawson in 1873. Terry remained for only a short time and was followed by W. G. Hanlan who enjoyed a large practice for a time, and was killed in 1886 in a pistol duel.

J. A. Waggoner who is now located at Humboldt, practiced at Dawson from 1879 to 1885 and located at Humboldt in 1886.

T. H. Emerson practiced at this point from 1886 to the time of his death in 1894 .

G. C. Paxton, another physician of Dawson, a graduate of Louisville, Kentucky, first located in Barada, then Dawson and finally Falls City. After being in Falls City a number of years, he located at Rigby, Idaho.

A. E. Burgher started practicing at this place in 1902 and continued for ten years, after which he moved to St. Joseph, Missouri.

Following Doctor Burgher to Dawson, came R. W. Fouts and later J. F. Kelly, both of whom have specialized in $\mathrm{x}$-ray and are now located in Omaha. 
Dr. W. S. Fast was a resident physician of Dawson for a short time and is now located at Atchison.

W. S. Wood, who was graduated from Marion Simms Medical School, now the University of St. Louis, in April, 1896, came to Dawson recently from Oregon, Missouri. $\mathrm{He}$ is the only doctor there now.

\section{Salem}

A history of the doctors in Richardson County would not be complete without reference to the late John R. Brook, who located in Salem in the year 1860. At that time, he was the only doctor for miles around and much hard work was entailed in reaching his patients, for he traveled altogether on horseback. He frequently made trips from thirty to forty miles and often with no hopes of ever getting remuneration for his services. He was a man of fine mental attainments and possessed a powerful physique. In the early history of the state, he was a candidate on the Democratic ticket for Congressman. His death occurred when he was past the age of eighty, at Salem, after a residence of more than forty years. He left behind him much to be recorded in commemoration of a very useful life.

C. Kinney located in 1871, later moved to Lincoln and engaged in the practice of medicine up to the time of his death 28 years ago.

J. W. Heskitt located in 1884 and remained to the time of his death in the year 1924 .

Other physicians who have practiced in Salem are: Pollard, A. J. Smith, Clinton Day, J. T. Waltemeyer, L. A. Delanney and J. E. Waller, all of whom have either died or moved away.

The present practicing physician of this place is G. M. McArdle who was graduated from Creighton University in 1914.

\section{Verdon}

The first practicing physician of Verdon was J. T. Webster, who after a few years moved to Emporia, Kansas and died in the year 1866.

Doctor Callison in the early years, practiced and operated a drug store at this place. He died many years ago. 
I. M. Houston did his initial practicing in Verdon and married the daughter of Doctor Callison and afterwards moved to Falls City, Nebraska.

D. M. King, another physician to locate at this place in the early history of the town, was a soldier in the Civil War and died at Verdon years ago.

I. H. Phillips practiced for a while at Verdon, coming to that place from Iowa, later moving to Wyoming. His last location was Seneca, Nebraska.

D. G. Griffiths practiced in Verdon, his native town, for a few years before locating in Falls City.

Doctor Thomas, J. H. Bourne, Geb Hall and Doctor Hurka were other physicians who practiced in Verdon.

C. A. Meadler is now the physician located at this place.

\section{Stella}

J. A. W. Hull, the first doctor in Stella, also built and operated the first drug store. He died in the year 1913.

B. B. Andrews was one of the leading physicians and surgeons in this part of the state and was considered one of the leading surgeons in the middle west. In the early ' 90 s, he operated his own hospital and was doing considerable major surgery. Later he moved to Oklahoma and after several years residence there, returned to Nebraska, locating at Brownville, later at Nemaha City, Nebraska, where he died in 1915 .

Dr. A. W. Montgomery started practicing medicine at this place in 1898. He was a vice-president of the Nebraska State Medical Association and served as president of the House of Delegates.

G. M. Andrews, a son of the late B. B. Andrews, located at Stella a number of years ago and together with A. W. Montgomery, are the two practicing physicians at the present time.

G. W. Egermeyer, who is now associated with W. E. Shook of Shubert, was at one time a practicing physician of Stella.

\section{History of Medical Societies in the County and the Richardson County Medical Society}

The earliest history of any attempt to form a medical society in this section is related by Dr. J. A. Waggoner of Humboldt, who 
states that in the year 1879 , there was an attempt made to organize a medical society at Humboldt in which he and a Doctor Pattrick were especially interested. This society was called the Nemaha Valley Medical Society. In 1879 at Falls City, the society was called to order and the doctors present were: J. A. Waggoner, C. T. Burchard, H. O. Hanna, W. W. Shaw, J. D. Hunter and Pattrick.

C. T. Burchard, in his history of the county, relates that the next medical meeting which he remembers attending, was called the Southeast Nebraska Medical Society. It was supposed to include some four counties in this corner of the state. Dr. A. B. Newkirk was its organizer. This was in the year 1883 .

Spasmodic efforts were made from time to time to start and maintain medical societies but failed for one reason or another until the year 1903 when there was organized in Falls City, the Richardson County Medical Society, in affiliation with the Nebraska State Medical Association. The charter members of the Richardson County Medical Society were: Drs. J. A. Waggoner, A. Kellar, F. C. Wiser, I. C. Sutton, A. E. Burgher, R. G. Henderson, Howard Marsh, W. S. Fast, F. A. Kellar, C. T. Burchard, I. N. Williamson, I. M. Houston, W. H. Kerr, D. D. Leeper, Hanna C. Flemming, M. L. Wilson and J. E. Waller. Those subsequently elected to membership were the following: Drs. J. R. Morris, W. E. Shook, J. M. Willis, Clinton Day, G. M. Andrews, C. A. Brink, C. C. Keeler, C. C. Wittwer, A. W. Montgomery, G. W. Reneker, Thomas, S. A. Van Osdel, G. G. Gandy, E. R. Hays, W. R. Boose and W. M. Trotter.

\section{Re-Organization of the Richardson County Medical Society}

The record, as presented in the history of Richardson County, states that in the spring of 1010, some undesirable members had gained admission to the socety which caused dissatisfaction and threatened its disruption. It was deemed best to permit the society to die a natural death from non-payment of dues, thus forfeiting its charter with the view of re-organization under a new charter. This was done April 9, 1912 at a meeting held at Humboldt in the office of Drs. Waggoner and Waggoner, with the following physicians present as charter members: J. A. Waggoner, Anthony Kellar, W. E. Shook, C. T. Burchard, M, L. Wilson, W. R. Waggoner, C. A. Brink and A. W. Montgomery. 
In their previous experience in conducting the medical society, regular licensure had been the only test for eligibility. Realizing that this test proved inadequate, it was resolved that in conducting the society in the future, they would make character, integrity and ethics the test as to eligibility and the censors were duly instructed to approve applications only of those who measured up to these requirements.

The Richardson County Medical Society at the present time includes: S. D. Cowan, G. W. Egermeyer, C. P. Fordyce, J. C. Gillispie, J. M. Greene, G. G. Gandy, C. L. Hustead, R. G. Henderson W. I. Hinkle, E. R. Hays, O, F. Lang, G. M. McArdle, C. A. Meadler, H. R. Miner, C. E. Novak, G. W. Reneker, W. E. Shook, William Shepherd, J. C. Shepherd, J. A. Waggoner, M. L. Wilson and N. H. Blakley, A. W. Montgomery, F. A. Nelson and G. M. Andrews.

Past presidents of the Richardson County Medical Society have been the following physicians: 1912, J. A. Waggoner: 1913, C. T. Burchard; 1914, M. L. Wilson; 1915, W. E. Shook; 1916 , A. W. Montgomery; 1917, J. A. Waggoner; 1918, E. R. Hays; 1919, Lee Cowan; 1920, G. W. Reneker; 1921,C. P. Fordyce; 1922, H. R. Miner; 1923, C. L. Hustead: 1924, M. L. Wilson; 1925, A. W. Montgomery; 1926, C. P. Fordyce; 1927, William Shepherd.

List of physicians registered in Richardson County since 1881:

James Luther Gandy

James Guthrie Cox

Adolph Blumer

C. R. Baker

Ira R. Baker

Russell Morr's

John Greenleaf Walker

Meses Jefferies

P. F. Patrick

David Selery Livingston

P. W. Hays

Geo. H. Neal

Eli Millikau Wilson

Adamson B. Newkirk, Jr.

Iram N. Williamson

Hiram L. Randall

John R. Brooke

E. William Shirmer

Jeseph Add'son W. Hull

George Koenig

William Waring Shaw

Jno. W. Waggoner

Mrs. Mary S. Quick

J. D. Hunter

Arthur N. Long
Frank S. Hoffmeier

Jered Alcnzo Greene

Cassius C. Kenney

R. S. Malony, Sr.

Daniel W. Campbell

Caroden Leroy Swartz

Hiram Foster McCoy

Charles T. Burchard

Charles W. Bryson

Price William Hughs

Henry William Parchen

Edward DeWitt C. Wing

Joshua D. Woods

John B. Summers

Jchn B. McConnell

Robert Liston Wood

L. S. Munsell

Elmere Y. Munsell

Daniel Edgar Foristall

Marion S. McCormick

Eugent Ferron

J. S. Shepherd

Edwin Miller McGee

J. B. Samuel

Horace P. Porter
Josephus M. Callison

Green C. Paxton

Andrew McNeny

Danicl McCaughn Craig

James Thomas Webster

Albert S. Fishblatt

Frank Edgar Samson

Thomas Ryall

Eurene Lewis Fridenberg

Lewis Edward Thorp

James Albert Gafford, Jr.

Adamson B. Newkirk

Alexander L. Williamson

L. C. Goodrich

David Harris

L. B. Allen

Vespasian Stookey

Antheny Keller

Thomas E. Jefferson

William H. Kerr

Hugh K. McClelland

Leopold F. Saxenberger

John Elder

Chas. L. Brooks

J. M. Zielie 
Harden B. Redman

J. W. Haskett

I. M. Huston

Chester F. A. Harris

Julius Wesselowski

Samuel Wesley Johnson

Thomas Laughlin Martin

John H. Lucas

James E. Anderson

Louis Beyermann

George W. Randall

William B. Cook

J. W. Heckler

John Farley Secrest

Augustus David Cloyd

James A. Houser

Joseph V. Hinchman

John H. Patty

Albany J. Emerson Clark

David Morgan King

James William Kessinger

Milton F. Wells

C. F. Walther

Thomas Henry Emerson

Chas. Wm. Uilrich

N. Spaulding Smith

Bezaleel Bell Andrews

Thomas Hayden Ensor

John Tassey Waltmeyer

Isaac M. Huston

Peter Janss

John William Kine

Wm. M. Bair

J.M. Cecil

A. M. Pickett

L. Guy Ramaley

Geo. A. Clark

James Franklin Stevens

John M. France

Napoleon B. Ray

Edward C. Mosteller

Samuel D. Whitney

Charles Lemoire Kerr

Henry Redmond

Thomas E. Hosman

Peter W. Schlotterleach

Thomas H. Emerson

George Koenig

Anthony Keller

Charles L. Kerr

W. H. Kerr

David M. King

Ira R. Baker

Joseph A. M. Hull

L. B. Allen

C. T. Burchard

Wm. Neil

Isaac M. Huston

F. C. Wiser

T. S. Martin
B. B. Andrews

J. C. Shepherd

Will K. Johnson

Belle R. Johnson

Charles E. Browne

G. C. Paxton

William J. Wells

J. C. Patton

Peter M. Hays

Joseph W. Bourne

Alfred Elder

A. L. Williamson

Hannul C. McCahan

Homer L. Kindred

W. W. Wertenberger

Irwin C. Sutton

A. L. Stires

William S. Fast

M. L. Wilson

Jos. S. Waller

J. B, Herschey

A. W. Montgomery

Charles W. Prettyman

Kelon H. Long

G. M. Andrews

H. W. Garrett

Almer L. Sabin

Geo. W. Reneker

Henry R. Miner

U. H. Norris

Robert G. Henderson

W. A. Burke

Ira F. Harlan

C. P. Shaffer

Jesse $F$. Strong

Howard Marsh

E. Bollinger

G. H. Hall

Edward B. Oliver

Sarah M. Walker

Geo. V. Allen

H. M. Morrison

F. A. Keller

S. Arthur Van Osdel

Dwight Leeper

H. H. Coburn

C. H. Rush

C. L. Pickett

D. G. Griffiths

George G. Gandy

A. E. Burgher

Wm. Cornwell

W. H. Kenney

A. A. Potterf

Charles A. Campbell

I. S. Stevens

Angus Matherson

Elton B. Grubs

Robert H. Hufman

John W. Tiffany
W. E. Shook

J. W. Heskett

A. R. Waters

Mary R. Bower

Guy R. Taylor

J. Willard Caldwell

Arthur E. Wolfe

A. E. Walker

Fred G. Hall

Oren H. Kent

Charles 1. Stephenson

William R. Waggener

Edward C. Wittwer

Clinton Day

J. M. Willis

G. A. Lacert

Warren H. Sherman

Park A. Findley

Eben C. Clopper

Charles C. Stivers

John M. Green

Ben. W. Kinsey

Isaac H. Phillips

Harry D. Burchard

Ferdinand Damour

Josephine Printy

L. A. Delanney

Edward E. Sweeney

Julian A. Pollard

Millar L. Wilson

Henry S. Andrews

Chartes W. Thomas

Leverett Sweany

Chester A. Brink

William M. Trotter

Chas E. Novak

Edward R. Hays

Ino A. Waggener

H. D. Brevoort

Russell Morris

James Garfield Janney

William R. Boose

Frank Earl Gordon

John DeFox

Claude P. Fordyce

E. J. Lpton

John T. Waggener

Sam David Cowan

Garfield A. Reutter

Charles M. Hazard

Roy W. Fouts

J. A. VanCamp

Edward H. Wiltse

Charles Luke Hustead

Ora L. Stephenson

Sadie Cecelia Doran

Emery Ira Whitehead

Oscar F. Lange

Robert Hurka

Pierce LaF. Stewart 
William Kirk Fast

LeRoy Thermon Peterson

Lee Cowan

James Francis Kelly

George W. Egermeyer

Charles Powell Fordyce

Henry M. Harvey

Andrew Jackson smith
Henry J. Holke

James C. Gillespie

Francis P. Murphy

Clyde A. Medlar

Arthur Haislet Haynes

F. D. Carpenter

George M. McArdle

Ora M. Caldwell
Nathan Holl Blakeley

George W. Doran

Walter S. Wood

Frank Arleigh Nelson

Warren Irl Hinkle

Charles Bernard Hayes

Virgil Ross Hamble

\section{SALINE COUNTY}

L. E. Goodell of Wilber was the first president of the Saline County society, organized at Crete in 1904. William H. Pallett of Crete was named vice-president: Mackenzie Brown of Friend, secretary; Hamilton W. Hewitt of Friend, treasurer; censors, Porter

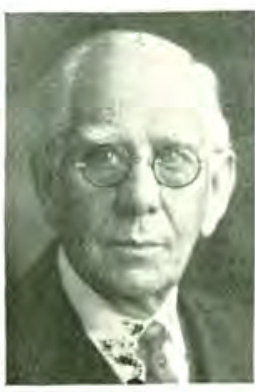

S. G. PANTER

F. Dodson, Wilber; William S. Wiggins, DeWitt and Edward Bates of Crete. Other active members were S. G. Panter of Friend; Arthur C. Conrad, A. D, Root, Dr. French, and John B. Foss of Crete; Thomas J. Chidester, Western; Dr. Cross, father of Dr. Guy B. Cross, recently deceased, of DeWitt; Joseph Cerny and William S. Love of Wilbur. Dodson served several terms as state examiner and was elected to the legislature. Since 1906, active members are Drs. Hamilton, Fletcher Farwell of Friend; Dodson, Hein and Cerny of Wilber; Panter of Dorchester, Guy Cross of DeWitt; Byrnes, Pallett, Stejskal, A. A. Conrad and H. W. Quirk of Crete, present secretary-treasurer.

The society holds monthly meetings, secures excellent papers and has done much toward educating the public to higher health standards.

Thomas J. Chidester, mentioned above, came to Western in 1880 from Pennsylvania where he had practiced several years, after being graduated from the Cincinnati Medical College in 1873. He also served as postmaster at Western, besides caring for the sick.

John A. Habenicht, the first Bohemian doctor to practice in Nebraska, came to Wilber for the first time in 1880. He remained here until 1887, when he moved to Schuyler but three years later returned to Wilber, where he lived until 1898. This time he left permanently for Chicago, where he died February 14, 1918. 
Dr. Habenicht was an unusual character, an ardent lover of literature and the dramatic art, according to Miss Rose Rosicky, editor of the Bohemian newspaper in Omaha, who devotes considerable space to Dr. Habenicht in her history of the Bohemian settlement in Nebraska. He was born in 1840 in Caslav, Bohemia, his father being a German army physician. After attending school in his native town and later in Litomerice, where his father was transferred, he studied medicine in the University of Prague and later in Leipsig, Germany. He engaged in medical practice and in 1869 came to Chicago, Illinois. Dr. Habenicht devoted thirty years of his life to writing a history of the Bohemians in the United States, which was published in 1904 by the publishers of the Catholic paper "Hlas" in St. Louis, Missouri. In 1897 he published, at his own expense, "Reminiscences of an Old Physician," dealing mainly with the history of the Bohemian settlement in Chicago. He revised and brought to date an edition of a popular medical book in Bohemian, written originally by Dr. Pecirka in Bohemia. $\mathrm{He}$ was a great admirer of Napoleon and in his large library were to be found any books of which he had ever heard concerning his favorite hero.

Other Bohemians to be graduated in medicine in this state among the first of their people are Louis Swoboda, Charles H. Breuer and Joseph P. Percival, who were graduated in 1896. J. R. Jicinsky received his degree in Chicago.

Arthur C. Conrad settled in Crete, Saline County, also in 1880, and is today succeeded in his practice by a son, Alexander A. Conrad. Though only seventeen years old when his father died, the younger Conrad recalls many of the unusual and competent services his father performed in those early days.

"A twelve-year-old lad slipped off a hay stack and ran three prongs of a pitchfork into his abdomen," the son reports. "Father, with the help of two farm hands, opened the belly, sutured the punctured intestines and the boy, now grown to manhood, is a farmer living near Claytonia, Nebraska. Another time, Father operated a man from Dorchester who had fallen from a hay loft window and fractured his sacrum. Father wired this with silver wire and the man made a good recovery. Dr. A. F. Jonas of Omaha saw this case later. Another case at Wilber showed good surgery for those days. 
During a fight at a dance, a man was struck across the clavicle with a beer bottle, fracturing and splintering the clavicle. No Wilber doctor would touch the case or even assist my father when he was called. He secured a dentist to give the anaesthetic and he wired the clavicle with silver wire, with very satisfactory results. It is claimed that he grafted chicken skin on the leg of a boy who had been bitten by a rattlesnake. An ulcer had formed which would not heal. Father killed a chicken and at once grafted skin from its

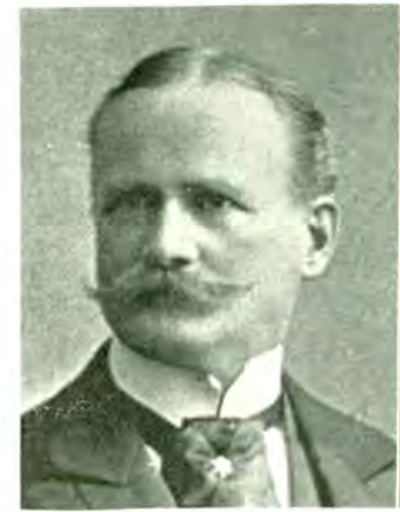

ALEXANDER A. CONRAD

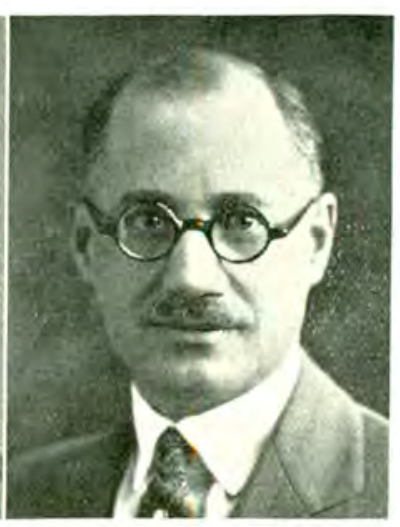

ARTHUR C. CONRAD

breast onto the area and I am told it grew, or took. It is claimed he later asked the boy's father whether feathers grew on the skin graft. It was told to me as the truth. I have never heard of it being done before, or since. Father also performed an operation for cleft palate and harelip on a child, with excellent results. He used shoe buttons as a means of clinching his silver wire sutures."

The elder Conrad was a finished horseman and owned the fastest horse in the county, one which won many prizes at the county fair. He died in 1907.

Saline County had a society as early as 1892 , when J. K. L. Duncan of DeWitt was secretary.

\section{SAUNDERS COUNTY}

The Saunders County society was organized in 1903 with A. S. von Mansfelde as president and Mary A. Quincy as secretary. At her death, Frank Tornholm of Wahoo was named to succeed her. After serving as president, von Mansfelde was also treasurer for 
many years. Since he is in poor health, this office too now devolves on Dr. Tornholm, who is also councillor for the Sixth District, state ussociation. C. H. DeWitt, Jr., is now president of the Saunders County society. Membership includes sixteen active and one honorary member.

Registered in the county are:

H. A. Abbott

P. E. T. Anderson

Charles P. Aitken

Wm. M. Bair

Andrew Leon Berggren

James L. Braimen

Louis L. Bleick

Thomas E. Barron

Albert E, Buchanan

Frederick W. Buck

W. C. Buel

Roy D. Burrell

J. H. Bowman

John Vawter Beachly

John C. F. Bush

Russell D. Bush

M. S. Bias

H. S. Brevoort

Frank Lawrence Baker

Roy D. Bryson

Ralph Christer

J. H. Crabbs

Ernest Capek

B. H. Clark

H. C. Cushman

Joseph M. Curtis

A. M. Cowden

Seneca Deane

Fred G. Dryden

T. Nelson Duncan

William E. Dixon

Walter L. Davis

Clinton Quincy Dodd

Herman C. DeWitt, Jr.

Joseph H. Downing

F. E. Dalrymple

Laird W. Elwood

Homer F. Fox

Clarence L. Frey

L. R. Forgrave

Elmer E. Fisher

F. D. Finch

Park A. Findley

C. O. Fletcher

William Mann Follett

W. W. Frazier

Louis S. Frieday

William G. Frieday

Albert Fess

F. E. Gordon
Charles W. Gooden

Orville Floyd Gillispie

John W. Gorder

J. D. Gultery

Richard Gray

James E. Hadley

Charles A. Helvie

R. S. Humphrey

Jens Sorrenson Haarup

John W. S. Howell

A. E. Hoff

Fredrick Hullhort

Phillip L. Hall

Alfred P. Haynes

Mary E. B. Hutchinson

Charles W. Hickey

Hugh Hover

William D. Heaton

John Carl Hubenbecker

Benjamin F. Jones

William Burton Johnson

William H. Johnson

F. W. Kruse

W. H. Keeney

Ben. W. Kinsey

Archie P. Kimball

Robert C. Kirchman

Hubert D. Karass

Edwin R. Keene

E. C. Keyes.

Joseph F. Kaspar

Charles R. Kickbaum

C. F. Kirkpatrick

James B. Keith

P. E. Koeber

Elizabeth B. King

J. E. Lamb

F. E. Loomis

E. E.Long

Joseph F. Lauvetz

William A. Lusk

Allen M. Lafferty

William J. Luxford

Johanns E. Logan

A. S, von Mansfelde

J. F. Morning

Robert B. Morton

George W. Meredith

H. E. Miner

Ernest Louis Meeredith
Andrew D. Mahaffey

John W. Moore

Theo, Milen

Fred Warren McCaw

Orville C. Mastin

Herman R. Miller

Milton Morrison

Charles D. Marrow

E. T. McGuire

F. S. McGibbon

M. A. Nye

John M. Neely

John A. Percival

W. J. Pinkerton

Isaac H. Phillips

A. A. Potterf

Walter S. Payne

Joseph Pestal

John McKinley Packer

Mary A. Quincy

Benjamin D. Rupp

A. L. Stiers

Edward Adam Smmers

Peter A. Slattery

Frank Lee Spraelling

B. A. Stockdale

Chas. E. Stivers

E. Schneller

Alexander C. Sabin

John G. Smith

F. E. Stephens

Chas. H. Sigel

M. W. Stone

C. Frederick Stockert

A. J. Sanders

Isaac Soule

A. F. Stuart

I. C. Stephens

George L. Smith

Ira G. Stone

Albert Thomas

Daniel W. Thompson

M. W. Thomas

Frank Tornholm

J. M. Willis

Ernest Owen Weber

Frank T. Wright

M. L. Wilson

Henry C. Williams

Ephraim A. Gager 
Frank E. Way

Byron Howard Baer

David Michael Block
Charles H. DeWitt, Sr.

C. L. Davidson

Benjamin F. Gay

John J. Lancer
C. E. McReynolds

Ralph Emerson Moyer

William W. Noyes

\section{SCOTTS BLUFF COUNTY}

Six physicians met in the office of Dr. Andrew J. Faulk at Mitchell, August 28, 1906, to organize the Scotts Bluff County society. Faulk was named temporary chairman and Dr. Edwin Buzick, secretary. Four committees were also named, as follows; Drs. Buzick, Tobias and Emerson, constitution; Emerson, Stewart and Sheldon, censors; Faulk, Sheldon and Stewart, program; Buzick, Stewart and Emerson, fees.

The next meeting was held November 7 in the office of Dr. Sheldon at Scottsbluff. Dr. Faulk being absent, Dr. Emerson pre-

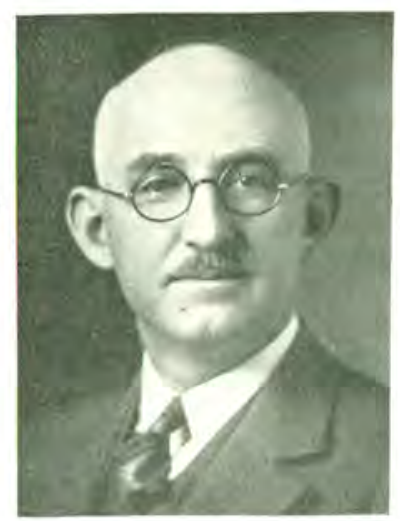

sided. The constitution outlined by the state organization for county societies was adopted. Election was set for January 28 in the office of Dr. Sheldon. On this date, Dr. Tobias called the meeting to order and these officers were named: president, Andrew Crawford; vice-president, A. I. Stewart; secretary-treasurer, Dr. Buzick; board of censors, Drs. Emerson, Stewart and Sheldon: delegate to state society, Dr. Emerson. Meetings were to be held quarterly.

T. J. VANDERHOOF

Presidents of the society in succeeding years include: for 1908, H. P. Sheldon; 1909, A. J. Stewart; 1910, G. R. Gilbert; 1911, F. W. Plehn; 1912, C. H. Platz; 1913, C. A. Boyd; 1914, J. N. Stoops; 1915, C. E. Vandiver; 1916, C. P. Fox ; 1917, R. P. Stoops; 1918 and 1919, C. N. Moore; 1920, C. R. Watson; 1921, F. B. Young; 1922, A. L. Cooper; 1923, W. E. Shike; 1924, N. H. Rasmussen; 1925, T. J. Vanderhoof; 1926, W. C. Harvey.

The 1927 officers are W. P. Hodnett, president; E. J. Mitchell, vice-president; and J. B. Schrock, secretary-treasurer. Other members of the society besides those named above are Ted Riddell, 
F. M. Collins, E. E. Griggs, F. B. Young, R. V. Witter, W. S. Franklin, A. J. Ross, E. F. Zoers, G. W. Pugsley and W. C. Harvey.

Registered in the county are:

Georgia A. Fix

Elias B. Lonquest

E. E. Barr

L. R. Craig

Andrew V. Stevenson

Frank Ed. Gordon

Edwin Buzick

William H. Packard

A. A. Potterf

Edwin Nichols, Jr.

Willis G. Morris

C. E. Vandiver

James Norval Stoops

R. A. Grigsby

Clarence P. Fox

Joseph B. Schrock

Clyde Newton Moore

John R. Montgomery

Frank Booth Young

William Perkins Hodnett

Silas Charles Rand

Thomas J. Vanderhoof

Arthur J. Ross, Jr.

Mary Josephine Sheldon

Claude R. Watson

Harry Bohn Metheny

Charles H. Laughran

P. G. H. Vander Wyst

Ted Eugent Riddell

Harry H. Thompson

Orville Clinton Reed
William H. Johnson

Joseph H. Miller

Marshali Petitt

Andrew Crawford

Andrew J. Faulk

Henry Dexter

Arthur G. Emerson

Georze R. Gilbert

Elten B. Grubs

C. D. D, M. M. Laugrall

William C. Berry

Carl L. Fairbanks

Arthur M. Faught

R. C. Knode

Rcy Philson Stoops

Alonzo A. Ward

William Francis

Agnes Cecelia Thorpe

Frazk B. Evans

Nelson H. Rasmussen

S. G. Allen

George W. Cramm

E. J. Mitchell

Edwin Franklin Zoerb

John J. Kiefer

George Oliver Dunseth

William G. Williams

Floyd M. Collins

Wliliam A. Moore

Charles Harold Frank

Lyle L. Wood
Athemus L. Asa

Byron G. Bailey

Charles Albert Boyd

J. K. Elms

Edwin A. Beard

Enoch Neff

$\mathrm{Wm}$. T. Eikner

William Earl Shike

George P. Wilkinson

Adelbert Townsend

Highland Z. Dean

Leroy R. Jones

Judd A. Strong

Albert Lloyd Cooper

Earl E. Griggs

Walter Carlton Harvey

S. A. Sammons

Herbert G. LauBach

Elwood Miller Farquhar

George M. Doran

Joseph Peter Weyrens

George E. Hart

H. G. Stalcrop

William Milliken

R. B. Mullins

Herbert P. Shelton

Anna A. Cole

Edward Wirth

John M. Tobias

Frank W. Plehn

\section{SEWARD COUNTY}

No exact date of organization for the Seward County society is known, but 30 years ago is the probable time, recalled by older members. The society, like all pioneers, had its struggles. Earlier modes of travel hampered many meetings but the society with changed membership, kept forging ahead until now 95 per cent of county physicians are members. With autos, meetings are frequent, in different towns of the county, and often are held with neighboring counties. At the county seat are modern hospitals, maintained with full equipment for care of sick and injured. The Morrow Hospital and the more recent Seward Hospital, also Ragan Sanitarium are at Seward. At Milford a small hospital takes care of the needs of that flourishing community. The state of Nebraska has a hospital for 
veterans of all wars, their wives and widows at Milford. County physicians, in order of their residence, since 1885, include:
H. B. Cummins
C. W. Doty
Joseph Morrow
E. S. Kagan
J. G. Muir

\author{
H. J. Wertman \\ J. E. Meisenbach \\ Homer Houchens \\ P. D. Deogny \\ Bert Morrow \\ Wm. Sandusky
}

H. D. Clark

J. B. Williams

O. C. Nickum

Strough

J. W. Neville

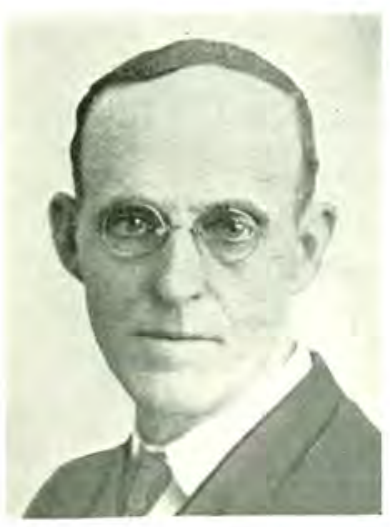

C. W. DOTY

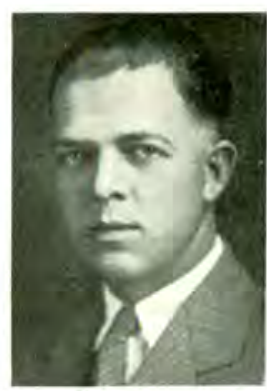

P. A. DOTY

\section{SHERMAN COUNTY}

Physicians registered in Sherman County are as follows:

Hiram R. Palmer

John L. Goff

John W. Archard

A. J. Kearns

J. W. Jones

Sumner Davis

A. E. Robertson

Mary A. K. Hendrickson

P. E. Koerber

Herman Kunze

Amos S. Main

Sullivan Howard

Benjamin Rea

Louis I. Bogen

John H. Long

L. W. Bowman

W. B. Bridgman

E. E. Barr

Albro J. Ames

Clyde Davis

Julian E. Phinney

Geo. J Shafer
Chas. A. Rydberg

Anton E. Wanek

Charles C. Crooks

Frederick W. Buck

A. A. Potterf

Louis E. Dickinson

Otto E. Longacre

Charles C. Stivers

Frank E. Stoaks

Frank Carl Gordon

Charles E. Paul

Homer F. Fort

Seth L. Hubbard

H. S. Brevoort

M. L. Rich

\section{SIOUX COUNTY}

\section{F. D. Burgess}

Jacob L. A. Ziegenhagen Richard L. Ivins

A. A. Potterf

George A. Mathews

Wendell H. Priest

Charles Avery Hansen
John E. Bowman

Garner F. Parker

Carrie Luella Bowman

William F. Race

A. W. Frisbie

Gilbert D. Loffler

W. C. Buei

Charles S. Hershner

Alfred Johnson

William H. Pearson

Lawrence Barret

Emeral J. Culver

Harry Carl Nichols

Edward S. Furay

Carl Gideon Amick

Francis L. Borglum

Lloyd Cramer

Frank M. Barns

Willis C. Tanner

Paul Herbert Priest

Earl Emanuel Dale

George Oliver Dunseth 
STANTON COUNTY

Following is a list of all Stanton County Physicians:
E. C. Underberg
Syl Person
William H. Person
Almer L. Sabin
W. L. Bowman
Charles M. Headrick
Andrew Texley
Edward B. Oliver
Charles V. Crooks
J. C. Walton
W. D. Guttery

John D. Reid
Edwin A. Beard
William Robert Peters
A. A. Potterf
Herbert D. Karass
A. C. Sabin, Jr
Joseph B. Hardy
Charles C. Stivers
Frank Earl Gordon
Allan M. Lafferty
Richard Tanner
Adelbert Townsend

H. S. Brevoort Theo. Whilen Luther W. Bowman Francis J. Moffatt Jehn Dick Reid Bret Verne Bates James R. Kalar H. Y. Bates Louis Richardson S. G. Allen Francis Edgar Manning

THAYER COUNTY

The Thayer County Medical Society was organized April 14, 1903, at Hebron, pursuant to a call by J. V. Hinchman of Hebron. Eleven physicians met, including J. V. Hinchman, U. H. Squires, Jos. H. Boyes, C. M. Easton and M. F. Reynolds of Hebron; C. C. Snowden of Davenport; G. A. Birdsall of Alexandria; A. Herney of Deshler; H. H. Stretton of Chester; H. S. Hickok of Carleton and J. L. Magill of Gilead. G. S. Pritchett of Fairbury, councillor of the district, was present to aid in the organization. Hinchman, Boyes, Easton, Reynolds, Snowden, Birdsall, Herney and Stretton became charter members. Snowden and Stretton still belong. One other charter member still resides in the county. He is C. M. Easton, now at Davenport, retired from active practice. Membership has varied from eight to eighteen in the years since organization. The first officers were: president, J. V. Hinchman; vice-president, G. A. Birdsall and secretary-treasurer, Jos. H. Boyes.

In common with other county medical societies in the rural districts and with small membership, the society has had its ups and downs and its difficulties in furnishing programs. The first paper read before the society was by G. S. Pritchett, on "The Modern Treatment of Diphtheria." Men of prominence in the profession of the state have appeared on its program but mostly the program has been furnished by members. Occasionally the society has sponsored lectures for the general public, especially on cancer.

List of presidents since 1903 includes: J. V. Hinchman, Hebron, 1903-1904; G. A. Birdsall, Alexandria, 1905-1907; Charles Henry, Hebron, 1908; C. M. Easton, Hebron, 1909; W. E. Kelly, Belvidere, 1910; Jos. H. Boyes, Hebron, 1911; J. L. Magill, Gilead, 
1912; Rudolph F. Decker, Byron, 1913-1914; H. J. Newell, Alexandria, 1915; F. E. Dargatz, Gilead, 1916; Charles Henry, Hebron, 1917; A. Herney, Deshler, 1918-1919; H. J. Newell, Alexandria, 1920; C. C. Snowden, Davenport, 1921: E. A. Bowles, Hebron, 1922; P. E. Milbourne, Davenport, 1923; G. R. Taylor, Hebron, 1924; U. H. Squires, Hebron, 1925; H. W. Saylor, Bruning, 1926; J. G. W. Westerhoff, Carleton, 1927.

List of physicians registered in Thayer County since 1881:

Charles M. Arbuthnot Jacob Arthur Fulton Leroy Dobyns Thomas Jonathan McGee James G. Van De Walker Samuel Morrow Charlie M. Sutherland William Janssen Stephen L. Evans Hugh E. McCaw Benjamin R. Smith James F. Thomas Seneca F. Deane George Wesley Munk Charles Wesley Walker James C. Wm. Oviatt Sidney A. Lake Thomas Deloss Bristol Joseph C. Mosshart John Z. Hills George Manly White Joshua Depoits Woods Cyrus Monroe Easton Fred Wilcox Charles T. Lawrence Urias S. Musser Charles B. Mosser Henry C. Manary Ira Willis Waits A. L. Elder George W. Randall William L. Bowning George W. McConnell A, Jackson Dern Wesley Smallew Charles C. Snowden Theo. Blenkner F. P. Van Valkenburg Jno. W. Thompson A. M. Pickett Louis Turner G. M. Smith N. E. Wood James D. Pitts James E. Anderson George Asa Birdsall John Collins Jones
Almer Lee Sabin John Jonas Kessel Peter Janss

Alfred C. Ames

George E. Gray S. Guy Ramaly Milo Leonard Kensington Thomas H. Jamieson Alvin Henry Keller J. J. Ardeney R. S. Humphrey Eliza A. Moss

A. T. Hinz William H. Dempster G. W. C. Truitt Alvis F. Hintz Forrest M. Mingus Thomas B. Stutzman Luther L. Ames Edwin M. McGee George McKenzie Joseph V. Hinchman Clarence E. Skidmore Orra Iona Latta Joseph H. Boyes H. S. Hickok G. A. Weirick Adam Herney M. W. Spohn

E. Schneller August Anderson I. C. Stephens Alexander C. Sabin A. C. Dunn John W. S. Howell Benjamin Rea Ida P. Davis Geo. F, Boone J. S. Sturdivant Andrew J. Chamberlain Caroline Reed H. W. Saylor John J. Kiefer H. H. Stretton Seth C. Reagan W. R. Townsend William T. Reynolds
Charies A. Holbrook

Guy L. Dodge

Henry J. Newell

Albert L. Grubb

H. E. Bollinger

W. E. Kelley

Sylvester R. Toothaker

Charles Henry

Henry Wimer

Charles H. Cronke

J. W. Youngman

Geo. H. Bentz

E. B. Hamel

Homer D. Morris

A. A. Potterf

L. A. Powell

Clyde A. Medlar

Arza J. Roush

Joseph L. Webb

Walter S. Cherry

Charles C. Stuvers

Joseph F. Moell

Artie Folsom

U. H. Squires

J. K. Elms

J. L. Magill

Grace Bliss Du Vall

Rudolph F. Decker

George R. Du Vall

Carl E. Richards

Geo. D. Sitzer

Alfred Johnson

Jesse Hartman

Rex. B. Stratton

Arthur E. Oberman

Hugh Hover

Guy R. Taylor

Percy E. Milbourne

Charles C. Aitken

Pierre Lafayette Stewart

Fred Edward Dargatz

Joseph T. Antony

James Andrew McDevitt

Clarence Raymond Atzen

Otis R. Platt

Justiv J. Young

Earl A. Harvey 
Arthur E. Smith

William R. Waggener

William J. Adamson

Johannes Weiss

J. G. W. Westerhoff

Arthur Lewis Miller

Samuel G. Panter, Jr.

E. Arthur Bowles

C. B. Edmunds

Julius L. Goodrich

Martin V. B. Clark

Rufus K. Langston

George Carl Weber

J. M. Callender

James E. Duncanson
Robert Lyman Sands

Doyle B. Mullikin

Frederick C. Armstrong

Iris Otis Church

Gerge L. Wagner

Fredk A. McGrew

Edward Adam Sommer

Otto Friedrich Dierker

THOMAS COUNTY
Loetta Beamer Bowles Forrest Alton Mountford Millard Franklin Schafer Paul Ancil Reed Frederick W. Krueger George M. Doran James Marvin Wallace

Talbert Webb Hughes Samuel E. Overmass David McCoy Sayles Henry Charles Hansen James L. Pennington Samuel L. Keller Joseph Cadleigh Johnson

\section{VALLEY COUNTY}

The Valley County society was organized January 14, 1903 at Ord, by a group of ten physicians, including one woman, Minerva Newbecker. The others were Doctors F. D. Haldeman, C. A. Brink, C. C. Shepherd, Coffin, M. S. Moore, Warta, D. S. Hogan, E. D. Thurston, and D. R. Lee. Dr. Haldeman was elected president, C. A. Brink, vice-president and Hogan, secretary-treasurer. Four meetings were held that year. In 1904, Brink was elected president, Lee, vice-president; and Hogan retained. The next year, Lee was president; Minerva Newbecker, vice-president and Brink, secretary. Since 1907, membership in the state society has been kept up but the local society is inactive.

Registered in the county are:

$\begin{array}{ll}\text { Charles E. Pinckney } & \text { Frank Earl Goodon } \\ \text { J. A. Phillipsen } & \text { Artie Folsom } \\ \text { Francis Thomas Read } & \text { Corydon D. Bundy } \\ \text { George Harold Misko } & \text { Charles C. Stivers } \\ \text { Phillip I. Cromwell } & \text { Osa M. Caldwell } \\ \text { Pierre Lafayette Stewart } & \text { Clinton J. Miller } \\ \text { Gilbert D. Loffler } & \text { A. A. Potterf } \\ \text { Frederick W. Buck } & \text { Emma E. Robbins } \\ \text { William F. Race } & \text { Joseph E. Higgins } \\ \text { Royal Schudder } & \text { T. F. Campbell } \\ \text { Frank Elbert Barta } & \text { Chas. Milliken } \\ \text { James Burns Anderson } & \text { Charles C. Shepard } \\ \text { Cosa Dell Haskell } & \text { Wm. Hemphill } \\ \text { James Stogsdill } & \text { Joseph J. Warta } \\ \text { Merle F. Warner } & \text { Henry Wilson } \\ \text { S. Langrall } & \text { Chas. V. Crooks } \\ \text { Silverston H. O'Neill } & \text { M. Minerva Newbecker } \\ \text { John L. Sears } & \text { D. S. Hagan } \\ \text { Allan M. Lafferty } & \text { Sarah E. Green } \\ \text { Amos F. Johnson } & \text { John C. Brockett } \\ & \end{array}$

Charles E. Pinckney

Phillip I. Cromwell

Gilbert D. Loffler

Frederick W. Buck

William F. Race

Royal Schudde.

Frank Elbert Barta

Cosa Dell Haskell

James Stogsdill

Merle F. Warner

Silverston H. O'Neill

John L. Sears

Amos F. Johnson
Chester A. Brick

Edwin S. Wilson

Ora L. Stephenson

Robert A. Billings

Elizabeth B. King

Frank O. Burdick

Elizabeth J. Bond

William G. Estee

M. C. Blystone

Sumner Davis

Almire M. Hall

H. B. Shirley

Romain H. Palmer

Frederick D. Haldeman

Joseph M. Klinker

Daniel R. Lee

Joseph B. Waynick

Charles Eugent Coffin

Albon E. Bartoo 
W. H. Pruner, Sr., an early physician of Washington County, was induced to come to Nebraska by Dr. Thomas Sexton of Fre-

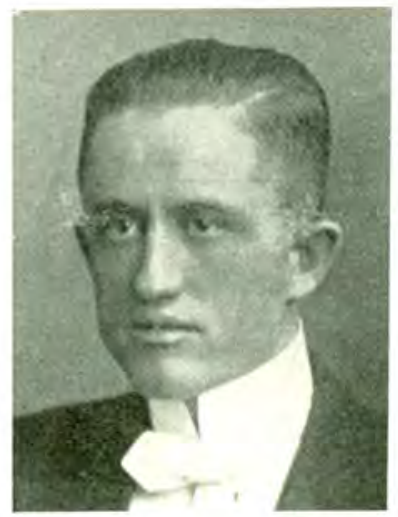

A. C. PRUNER mont, who located at Fontenelle, following the Civil War. Pruner arrived from Virginia in the spring of 1890 and located at Kennard where he remained until his death in 1915. His pre-medical work was taken in the Polytechnic Institute of Blackburg, Virginia, where he was secretary to the president of the college. He was graduated from the College of Physicians and Surgeons of Baltimore in 1881 and for $\mathrm{n}$ in e years, practiced in Virginia. He was a member of Phi Kappa Alpha fraternity and active in Masonic circles. Two sons, W. H., Jr. and A. C. Pruner, practiced in Omaha. W. H., Jr., died July 3, 1929.

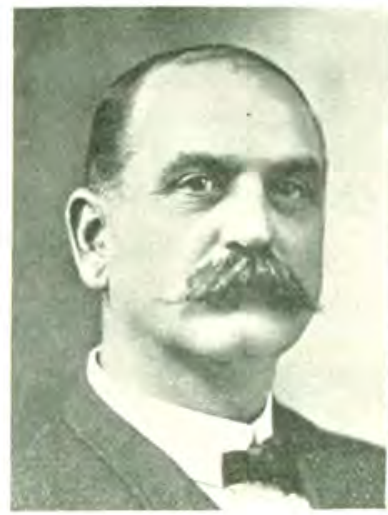

W. H. PRUNER

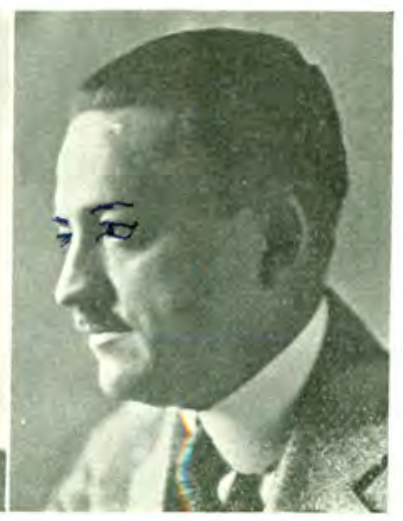

W. H PRUNER. JR.

Registered in Washington County since 1881 are:

Samuel G. Gloverl

Somers Pettingill

Seaman L. Dart ${ }^{\prime}$

Marsha! D. Bedal

A. S. Pendry

S. H. Fawcett
Thomas C. Sexton'

J. F. Bakert

Paris G. Cooper

William H. Palmet

Samuel B. Taylor

Buron F. Monroe
Almon James Ryan

O. V. Harris

Jesse Lyman Conant

Henry W. Parchen

Hiram Noble

James C. Wickersham 
Henry G. Chamberlain William Robert Hanna

J. Marion Brown

James M. Davidson

James Elmon Hadley

Frederick W. Houghton

J. T. Wade

William W. Buck

Henry Cushman

Quinby A. Woodward

Edward Verran Brown

Sherman J. Hadley

H. L. Burrell

Louis Turner

George W. Nichols

Wm. H. Pruner

Charles Webster McDade

R. M. Howe

Zeoria Owen McDade

Isaiah Lukens

E. R. Stewart

Jonathan F. Tracy

J. M. Hardy

Andrew Crawford

F. E. Stephens

John McConnaha

J. S. Mortlock
Thomas E. Stack

I. L. Compton

Peter G. Grimm

Rodner Beecher

Joseph M. Curtis

Adda Bowerman

Thomas A . Reed

Perry J. Clark

L. R. Brown

Chas. A. Raver

J. S. Devries

W. A. Burke

Samuel L. Brown

E. Schneller

P. H. Dassler

Fredericka A. Phillips

Chas. A. Robinson

James B. Keith

Rupert A. Davies

Henry A. Fulton

Geo. A. Langstaff

Andrew P. Overgaard

A. J. Cameron

Byron B. Hanser

William F. Race

George J. Wenzlick

J. W. Kine
Alice Cherry

A. A. Potterf

W. H. Horton

Marie Anna Nielsen

S. A. Sammons

Joseph V. Hinchman

Byron L. Perlee

R. J. Murdoch

Francis N. Young

George S. Love

Arthur W. Fees

William R. Waggener

Marion Orr Wilson

William G. Orr

Richard F. Robinson

James D. Jones

Morris Nielsen

Louis Lancelot Burstein

Edgar S. B. Geesaman

G. Frederick Howes

Chas. J. Logan

Leo. Julius Kilian

Henry Y. Bates

Floyd Leskey Newcom

Gerald Henderson Beck

Gilbert D. Loffler

Ralph Atherton Gilify

\section{WAYNE-CEDAR-DIXON-THURSTON-DAKOTA GROUP}

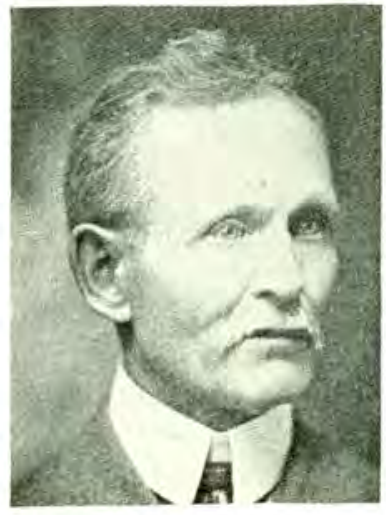

E. S. BLAIR

Almer L. Sabin

A. E. Gregg

Charles V. Crooks

Charles M. Headrick

W. H. Phillips

Andrew Texley

Edward B. Oliver

S. J. Scruggs

E. J. Austin

Because of the few physicians in the above counties, they hold membership in one society. Wayne County membership includes E. S. Blair, C. H. Ingham, G. J. Hess and S. A. Lutgen of Wayne; Drs, Neely and McIntyre at Winside and Dr. Andrew Texley at Carroll.

Wayne County registrants include:

H. G. Leisenring

William C. Wightman

M. R. Regan

J. J. Williams

E. Bradford

W. A, Love

Charles F. Thompson

C. H. Steel

Ora M. Caldwell

S. Scruggs

Byron McIntyre

David Isaacs

Roy P. Dempster

C. D. D. M. M. Langrath

Backus M. McIntyre

H. D. Karass

William F. Edmonds
Ralph B. Crawford

G. W. Williamson

Allan B. Cherry

Edward S. Blair

Gustave Nieman

A. L. Muirhead

A. A. Webster

Benjamin Rea

Charles C Stivers

Karl Sciıcmel

Armand Naff́ziger

Thomas O. Lovig

Geo. J. Hess

11 H. S. Brevoort

William M. Bair

Edna Susanna Heeren

Frank C. Zoll 
H. W. Parchen

W. H. Caulk

Richard J. Tanner

John G. Neely

Victor Lamont Siman
Earl B. Erskine

Hugh Hover

C. L. Davidson

Stephen M. Weyer

C. T. Ingham
Homer David Lurvey

Paul F. Siman

Frank Earl Gordon

Anson S. Lutgen

\section{WEBSTER COUNTY}

Through the efforts of E. A. Creighton of Red Cloud, it has been established that I. W. Tulleys, who came from Clinton, Iowa,

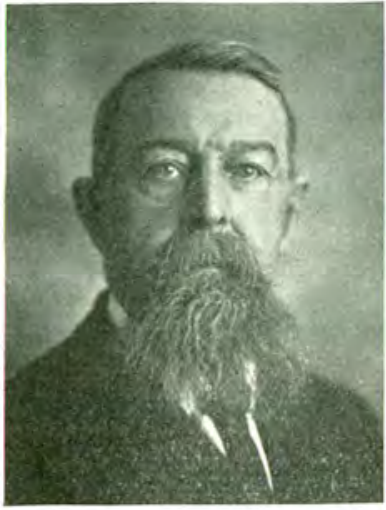

CASPER WEGMANN

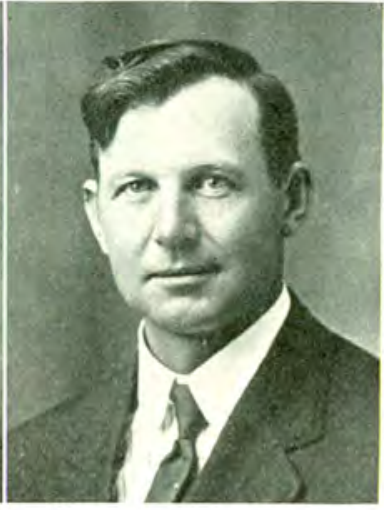

WM. M. WEGMANN

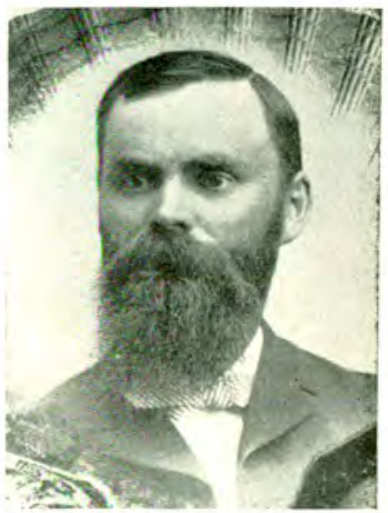

ROBERT DAMERELL

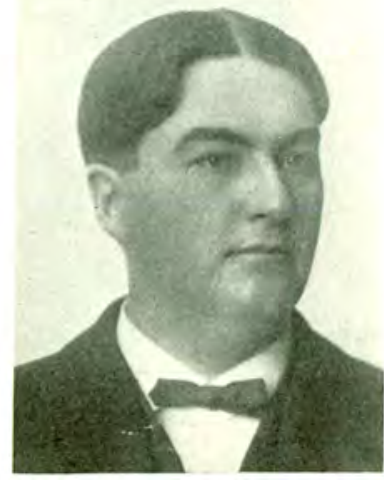

E. A. CREIGHTON

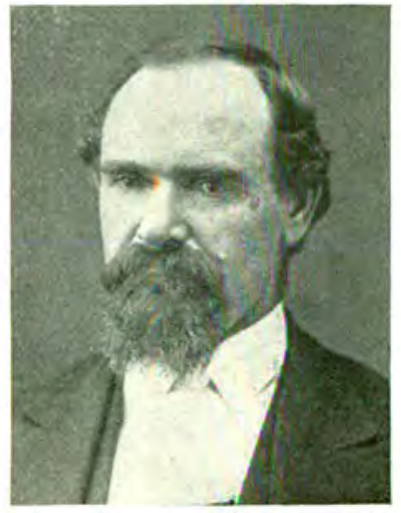

I. W. TULLEYS

was probably the earliest practitioner in Red Cloud, in 1872 . He died in 1909. Tulleys was a man of commanding appearance, kindly disposition and tenacious of purpose. Other physicians in Webster 
County during the '70s were Drs. Williams, Head, McCullough, Butler, Hall and Moszena. Casper Wegmann came to Blue Hill in 1879. He, with I. W. Tulleys and Robert Damerell were the rec-

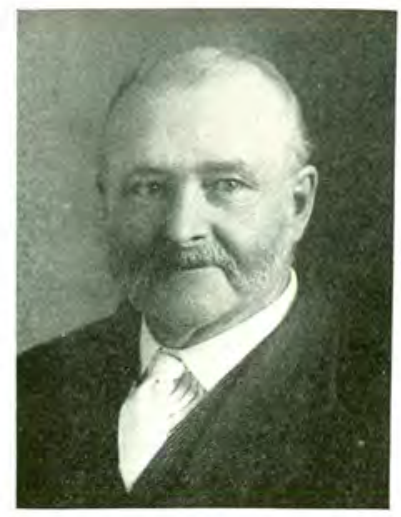

HENRY COOK

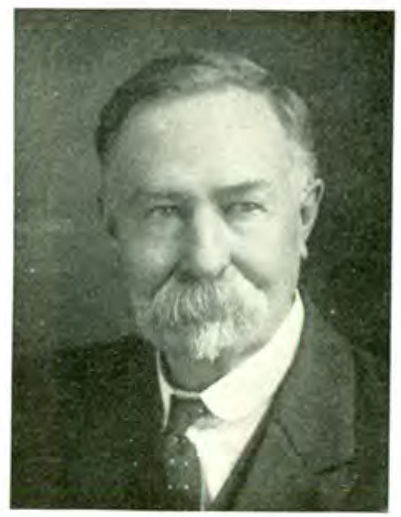

A. L. AMBROSE

ognized leaders in the profession during their lifetime. His sudden death, September 2, 1924 while attending a case of childbirth, was a distinct shock to the community, rich and poor alike.

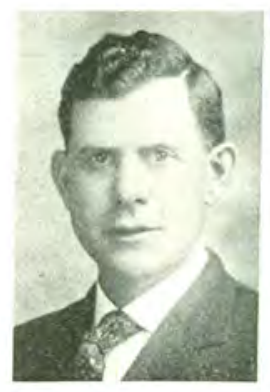

J. W. STOCKMAN

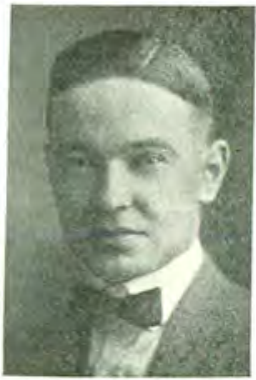

R. S. MARTIN

Robert Damerell, who came from Illinois in 1882, was the outstanding personage of that decade. He was the first president of the county medical society and was superintendent of the state hospital at Hastings for a number of years. He was keen in his profession, noted as a wit, always a gentleman, ever ready to help his fellow-man, and a man to be kindly remembered by his 
brother practitioners. Damerell was a stockman and farmer, as well as a physician. He died in Red Cloud in 1927. George E. McKeeby also practiced in the county during the ' 80 s.

Physicians in Webster County during the 90 s were Wm. T. Johnson, Denney, L. H. Beck, F. E. McKeeby, now of Colorado; and G. C. Winterson, now of Omaha.

The Webster County society was organized in 1902 or 1903 by a group including Robert Damerell, Henry Cook, Cal Moranville, Ira A.Pace, Robinson, Beck and E. A. Creighton. Dr. Damerell was elected president and Creighton, secretary. The organization flourished for a few years, then lagged until Dr. B. F. Bailey of Lincoln visited it and revived the spirit. Dr. H. S. Reed was then elected secretary. Drs. Harry Everett and Palmer Findley of Omaha have also visited the society. A. L. Ambrose was the 1926 president. Present officers are A. L. Ambrose, E. A. Creighton, R. S. Martin, J. W. Stockman and William Wegmann.

Dr. Creighton, the first secretary, compiled the following list of county physicians, in each of the towns:

\section{Bladen}

Charles F. Kehler, licensed in 1891, died in 1909.

William M. Wegmann, licensed in 1901, in active practice.

\section{Blue Hill}

Casper Wegmann came here in 1879, licensed in 1891, died September 2, 1924.

Silverton H. O'Neill, licensed in 1911, general practice, surgery, manager of his private hospital.

Claude Ross Laird, licensed in 1913, general practice, served with distinction in world war, in Russian campaign.

Dr. Fulkerson, in practice several years, later manager of a sanitarium in Illinois.

W. A. Franklin, in general practice, now in Magnolia, Illinois.

Joseph E. Uridell, licensed in 1914, general practice but now in surgery in Hastings, Nebraska. 
Philip H. Bartholomew general practice, now in Public Health Service at Lincoln.

\section{Cowles}

Wm. T. Johnson, general practice in the early '90s. Moved to Pawnee City, died there a few years ago.

A. J. Boven, licensed in 1906, general practice a few years; now limits to eye, nose and throat at Hastings.

W. E. Devers, in Cowles a short time; served in World War; remained in the service as a major.

\section{Guide Rock}

John W. Robinson, licensed in 1891. After years of faithful service, died there a few years ago.

A. L. Ambrose, licensed in 1910. President of County Medical Society; in active practice.

Cal. Moranville, after a few years moved to Hemingford.

Ira A. Pace, licensed in 1898. Active practice and manages a drug store.

Hugh S. Reed, licensed in 1907. Secretary of county society.

\section{Inavale}

T. B. Myers, practiced several years. Present address not ascertained.

\section{Red Cloud}

Henry Cook, licensed in 1899, though seventy-seven years of age, is still in practice and manages a drug store.

E. A. Creighton, licensed in 1899, in general practice, was captain in medical corps during the World War.

Robert Hoxsey, licensed in 1906, practiced here a number of years, is now on staff of State Hospital at Beatrice.

Robert S. Martin, licensed in 1919. General practice. Attached to the medical corps during the late war and is now lieutenant in the reserves. 
Robert S. Mitchell, licensed in 1906. Practiced here thirteen years. Captain in late war. Removed to Appleton, Wisconsin. Died there in 1926.

J. W. Moranville, licensed in 1891, died here ten years ago.

J. W. Stockman, licensed in 1903. General practice. Lieutenant in medical corps, World War.

Robert F. Raines, general practice, 1903-1910. Died here.

Marion W. Thomas, licensed in 1897, was a partner with Raines for a short time, then moved to Weeping Water.

List of all physicians registered in Webster County since 1881:

Isaac W. Tulleys
William F. Lee
James M. Mosena
James M. Callender
Elbert A. Hall
John E. Smith
Charles F. Kehler
J. L. Elliott
H. P. Schunk
Napoleon B. Ray
J. L. Patten
Cyrenins Schenk
J. W. Robinson
C. W. Oviatt
E. Sutton
M. E. McGray
Robert R. Sherer
L. J. Spickelmier
John B. Fisk
Robert Damerell
L. D. Denney
C. T. Lawrence
J. W. Moranville
Charles M. Williams
Alfred A. Naultens
Thos. H. Brown
H. K. McClelland
Louis W. Wells
A. D. Stapleford
G. E. McKeeby
Enos O. Darling
John G. Walker
Henry P. Monroe
William Tanner
Louis H. Beck
William T. Johnson
George H. Chaffie
C. W. Shelleck
A. J. Rogers
G. E. Rollins

Isaac W. Tulleys

James M. Mosena

James M. Callender

Elbert A. Hall

John E. Smith

Charles Kehle

Napoleon B. Ray

J. L. Patten

Cyrenins Schenk

C. W. Oviatt

E. Sutton

M. E. McGray

Robert R. Sherer

John B. Fisk

Robert Damerell

L. D. Denney

C. T. Lawrence

J. W. Moranville

Charles M. Williams

Thos. H. Brown

H. K. McClelland

Louis W. Wells

A. D. Stapleford

G. E. McKeeby

John G. Walker

Henry P. Monroe

William Tanner

Louis H. Beck

William T. Johnson

George H. Chaffie

A. J. Rogers

G. E. Rollins
Allen T. Rice

John M. France

Hattie C. Bon

C. T. Moranville

Edward L. Sheldon

Robert A. Hawthorn

Charles E. Vandiver

A. M. Pickett

Edward D. Barrett

J. M. Miner

Orville C. Mastin

Casper Wegmann

Jas. E. Anderson

P. James

George B. M. True

Milo L. Kensington

W. H. Snook

George A. Winick

Forest M. Mingus

Seth M. McCollester

A. B. Greenlich

Andrew W. Hoyt

Walter C. Fulkerson

Fred E. McKeeby

S. O. Netharton

John R. Pardum

R. W. Casterline

Herman R. Muller

William M. Follett

D. L. Trowbridge

Benjamin Rea

E. A. Creighton

J. F. Goode

W. A. Franklin

Ira $\mathrm{T}$. Pace

Henry Cook

J. S. Sturdevant

C. S. Shephard

John F. Bradshaw

Henry McSwigart
Wm. M. Wegmann

C. T. Owings

Robert F. Raines

A. C. Sabin

Jhn Thompson

A. L. Stiers

A. B. Philips

A. A. Potterf

M. U. Thomas

Robert S. Mitchell

Arthur L. Nichols

Sarah J. Boland

Charles C. Stivers

H. S. Reed

E. T. Allen

P. H. Bartholomew

Ben. W. Kinsey

J. W. Stockman

Charles S. Hershner

George C. Winterson

W. M. Bair

John R. Caster

Jesse Hartman

Scott L. Hubbard

Arthur Reeves

H. S. Brevoort

A. J. Boren

D. D. Sanderson

A. L. Ambrose

A. C. Ames

J. C. Caldwell

R. P. Hoxsey

C. R. Laird

A. B. Harden

W. E. M. Devers

A. J. Chamberlain

C. F. Moranville

Henry C. Williams

S. H. O. Neill 


\section{WHEELER COUNTY}

George F. Wells H. F. Roehler William F. Wilson
Robert W. Hansen Ambrose A. McDonald Edwin R. Keene J. H. Long YORK COUNTY
B. A. Root

F. G. Snyder J. N. Plumb W. F. Eckles O. S. Townsend F. W. Karrer Geo. Morrison
Lucius Gould Wright

Alonzo A. Ward

Samuel A. Osheroff
H. O. Bell
J. S. Bell
E. B. Hanna
R. E. Harry
D. D. King
J. C. McKinles
O. M. Moore

York and Hamilton societies were combined in 1892 with McConaughey of York as secretary.

\section{ORGANIZATIONS}

\section{Notes and Errata}

p. 315-321 Nebraska State Medical Association. See Mansfelde, A. S. v. and Orr, H.W., "The Nebraska State Medical Society; its history for the first one-third of a century" West. M. Rev., 7:127-140, May 1902.

Nebraska State Medical Society. See Proceedings of the Convention of the Organization of the Nebraska State Medical Society. Omaha, Nebraska, June 24,1868 in the Library of Medicine, University of Nebraska Medical Center. Library of Medicine, University of Nebraska Medical Center. in 1869 are in the Nebraska Medical History collection, Library of Medicine, University of Nebraska Medical Center. the Library of Medicine, University of Nebraska Medical Center. Society Minute Book, 1890-1905, n.p., MS. Office of Society. As a secondary source, see Seeley, Mary, History of the Omaha Douglas County Medical Society, M.A. Thesis, University of Nebraska at Omaha, 1969. 

sity of Nebraska Medical Center.

Omaha Douglas County Medical Society. See Sage, E. C., "Presidents I Have Known" Bull. Omaha Douglas County Medical Society, 3:5-14, Nov. 23, 1928.

Basic Science Law enacted 1927. See Waite, H. H., "Basic Science Laws," Nebraska M.J., 13:175-179, May 1928.

These portraits of pioneer Omaha practitioners are in the Library of Medicine, University of Nebraska Medical Center.

Invert the last word on the last line of the page.

Lincoln Medical Society. See Orr, H. W., "The Lincoln and Lancaster County Medical Society" in Selected Pages from the History of Medicine in Nebraska, Lincoln: H. W. Orr, 1952, pp. 49-50.

Column 3, fif th name from the bottom reads as follows: "William G. Houtze." This name should be deleted.

Column 2, first name reads as follows: "Samuel Matheny." The name should be deleted. It appears correctly in Column 3 , fifth name on the same page.

"John Clark Thompson" appears twice in Column 2. Delete one. of the City of Omaha, Nebraska, New York and Chicago: Munsell and Company, 1894:pp. 363-365.

"Carscadden" refers to Dr. Richard Carscadden of York, Nebraska. May 1942.

Eben J. Carey acted as an installing officer at the induction, Nov. 4, 1916. Omaha Bee, Nov. 5, 1916. old as community," Kearney Daily Hub, June 29, 1973.

". . . was inffuential in . . ." should read ". . was influential in..." 
". . . his brother Stuart received ..." should read ". . . his brother John Stuart received ..."

p. 401 George Huffman Black. “. . . he retired in 184." should read "... he retired in $1884 . "$

p. 403

“. . . with a Polk ounty, Iowa . . ." should read ". . . with a Polk County, Iowa ..."

"... from that years until . . " should read " . . from that year until ..."

"When the opst office..." should read "When the post office

A. O. U. W. (Ancient Order of United Workmen).

p. 405

p. 406

p. 408

“. . . himself had hwo sons, ..." should read ". . . himself had two sons,..."

“. . . practice in Ohio n 1851 ..." should read "... practice in Ohio in 1851 ..."

Gilmore, George H., born August 20, 1866. See Genealogical Record of James Gilmore and Peter Massie and Their Descendents, 1963: p. 34. For publications, see p. 241.

“. . Thomas H. Gilmore of Murray . . " should read “. . . George H. Gilmore of Murray ..."

Portrait labeled "Kimball (Thompson)" should read "Richard (Thompson)".

Portrait labeled "kichard (Thompson)" should read "Chester (Thompson)".

“... removed to Denvr in 1892 ..." should read "... . removed to Denver in 1892 ..."

“. . . remained until 1893 or 1894 . . " should read ". . . remained until 1894 ..."

"... memnition ..." should read "... mention . .."

Dr. Harriet G. McGraw, A merican Magazine, Mar. 1928.

p. 440 "A "Dr." W. F. Hutchinson ...": Dr. F. A. Long correction. See Notes on p. 207.

p. 441 Shike, Dr. W. E., Lincoln Medical College, May 11, 1911. See Thompson, Loyd and Winfield Scott Downs, Who's Who in American Medicine, New York: Who's Who Publications, Inc., 1925: p. 1352. 


\section{HOSPITALS}

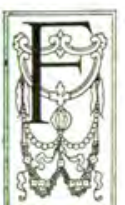

OR a record of the first hospital established in Nebraska, one must revert again to the reports of Army Surgeon $\mathrm{T}$. G. Mower, who accompanied the Sixth Regiment to Camp Missouri, in the fall of 1819. In one of these documents included in the Surgeon-General's published reports of 1840, Mower states that the "post hospital was ready to receive the sick on December 20, 1819." Shortly thereafter, when the scurvy epidemic broke out, there was great need for these quarters.

The next mention of a hospital in this state occurs in Savage and Bell's History with reference to a Dr. Munson H. Clark who operated a hospital, undoubtedly in his own home at "Nebraska Center," probably Nebraska City, in 1854. Dr. Clark was one of the incorporators of the first Nebraska Medical Society in 1855.

A child was born in the hospital to Judge and Mrs. Kinney who were on their way to Salt Lake City.

During the Civil War, the state capitol building in Omaha, shown in the chapter on war service, was used as a post hospital, according to local histories. Other than this the first hospital in Omaha was said to have been built by the pioneer physician, Samuel D. Mercer, near the present site of Thirtieth and California, in 1866 but it burned down shortly thereafter. Later in the early '80s, Mercer was in charge of a small hospital of three or four beds, called "the Union Pacific Dispensary," located on Harney street, between 10th and 11th streets. W. J. Galbraith was in charge of the Union Pacific Dispensary during his residence here. As chief surgeon of the Union Pacific, Mercer established many small hospitals, chiefly for railroad use, throughout the state. Catholic orders made several attempts to establish hospitals in Omaha before the present fine St. Joseph's Hospital, the largest institution in the state, was put on a permanent footing. Perhaps the second early hospital in Omaha 
was the Good Samaritan, started in 1869 , in a six-room cottage at Twenty-third and Webster streets. It was destroyed by fire in 1877 and for a time, the work was wholly abandoned. The Sisters of Mercy, in 1870, founded a small hospital which was turned over tothe Franciscan Sisters a decade later. It was the first St. Joseph's Hospital. In 1880 a building was erected between 11th and 12th on Mason street.

The Child's Hospital and Home, forerunner of the present Clarkson Memorial Hospital, superseded it in October, 1881, at a meeting of Trinity Cathedral women, called by Bishop Robert H. Clarkson, then head of the Episcopal diocese of Nebraska. By December a six-bed hospital was opened in a rented cottage at 1716 Dodge Street. Mrs. Clarkson was the manager, Mrs. Frances A. Moore, the matron and Mrs. A. J. Poppleton, secretary-treasurer. Directors were Mesdames H. W. Yates, Herman Kountze, C. H. Frederick, J. M. Woolworth, S. S. Caldwell, J. E. Summers and W. O. Bridges were early physicians on the staff. When Bishop Clarkson died, the Rev. George W. Worthington succeeded him as head of the institution. In the spring of 1883 , it was decided to buy the lot and erect a permanent building, the corner stone of which was laid June 12, the same year.

To build such a hospital and furnish it was considered a daring enterprise in that day, but Bishop Clarkson entered upon it with the confidence which characterized him in all his work. The first subscriptions were made by Mrs. Clarkson and Mrs. James M. Woolworth of $\$ 500$ each, and were followed by a gift of $\$ 5,000$ from Mrs. Mahlon D. Ogden of Chicago, a member of a family whose benefactions can be traced through all Bishop Clarkson's work in Omaha. When completed in 1883, the hospital cost $\$ 14,000$.

In 1885 the constitution was amended to permit the treatment of adults. The patients treated that year were 132 children and 38 adults. Later history of the institution will be included in the Clarkson Memorial section.

Another institution for the sick, established in January, 1881 was the Nebraska Medical and Surgical Institute, of Doctors Ira Van Camp and E. L. Siggins, located on the second floor of a building at Fourteenth and Dodge Streets. It had nine wards and as full a hospital equipment as the times demanded. 
The first Douglas County Hospital was built in 1887, but perhaps the most impressive healing institution in the late '80s and early '90s was the Omaha Medical and Surgical Institute, located in the former Cozzens Hotel, pioneer hosterly, built by George Francis Train in $\mathbf{1 8 6 7}$, but which fell into great disrepute later.

Dr. J. W. McMenamy, founder of the Institute, first opened in commodious quarters at the corner of Thirteenth and Dodge

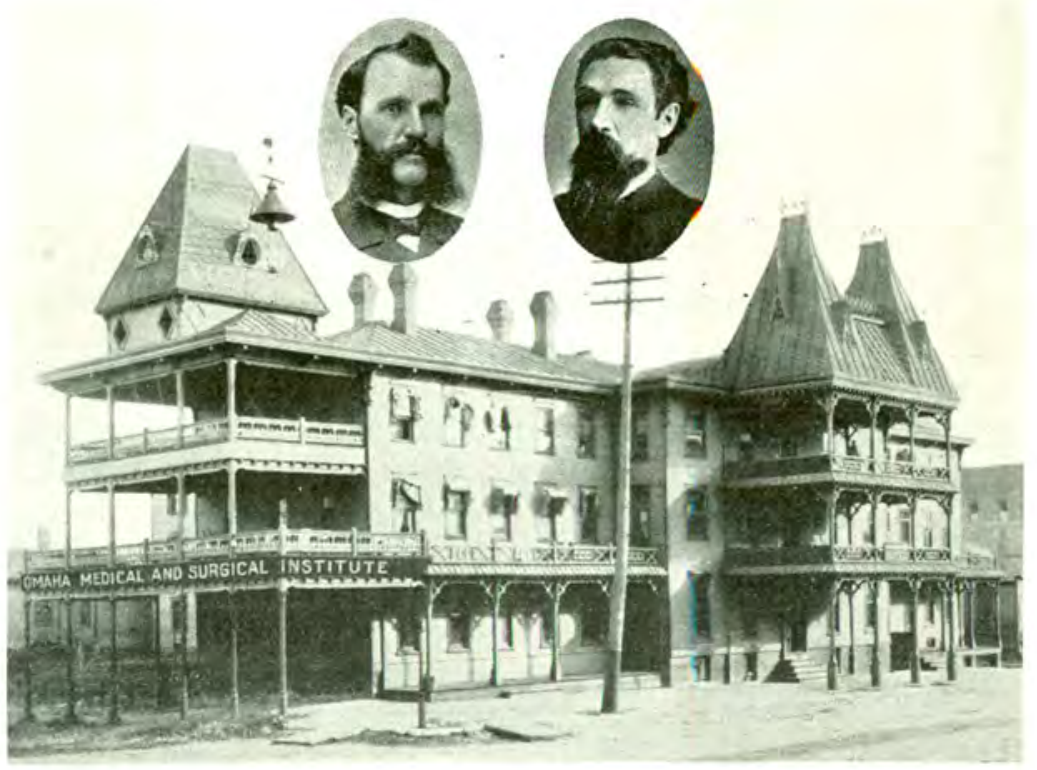

OMAHA MEDICAL AND SURGICAL INSTITUTE

Streets, but early in 1891, bought and completely remodeled the Cozzens' Hotel at a cost of $\$ 150,000$. It was pronounced the finest and most completely equipped institution west of Chicago, containing 150 rooms, steam heated and perfectly ventilated; offices, consulting rooms, operating rooms, a department for the manufacture of surgical appliances and braces, drug department and boarding department for guests and patrons. The staff included six physicians, three druggists, three bracemakers and nurses and other personnel totaling 40. Its management undertook the treatment of all chronic and surgical cases and the cure of many human deformi- 
ties. Patronage grew for five years until patients came from every state in the union and its founder, Dr. McMenamy, who was said to have a thorough medical education and who had practiced here for several years in the usual way before he opened the Institute, was lauded on every hand. When he died, he left the Institute to his co-laborer, Dr. A. T. McLaughlin. The latter, credited with the successful management of the institution until then, was a great believer in electricity as a curative agent, and after his inauguration as head of the Institute, spent thousands of dollars on electrical appliances and engaged in an elaborate work on electricity and electro-magnetism.

His institution continued in popularity for several more years until local newspapers attacked it for alleged questionable transactions, after which its reputation failed, business fell off and it finally rlosed its doors. It then became the Jennings Hotel.

Reputable Omaha physicians, including L. A. Merriam, who was then secretary of the county medical society were on the staff, in its hey-day according to Dr. W. F. Milroy, who could not recall any of the other names. Milroy stated that the Omaha Medical College bought from the Institute, when it went out of existence, expensive lifesize wax figures imported from France, and designed for medical study, but the figures melted the following summer. Other expensive equipment was part of the furnishings of the illfated Institute.

The decade of the '90s was marked by great additions to the hospital facilities of Omaha. The Eye and Ear Hospital, established by Doctors Lynn Graddy and Harold Gifford in an old frame house on South 20th Street, about Howard, and which had been operated by them for about ten years with a capacity of 25 beds, became the nucleus in 1891 for the present fine Nebraska Methodist Episcopal institution, which will be described later. Dr. A. F. Jonas was said to have contributed $\$ 30,000$ with the provision that the Methodist Church would match it with a like sum, for the first new building. Jonas and Gifford have been on the Methodist staff ever since.

Another hospital established in the '90s was the Presbyterian Hospital at Thirteenth and Dodge Streets, started in 1893, chiefly for emergency cases. Four years later it moved into a three story building near 26 th and Leavenworth streets, where it had a capac- 
ity for 75 patients. Immanuel Hospital was founded in 1890 with seventy beds and Wise Memorial in 1899.

A private hospital of 20 beds maintained during this period was the Central Hospital at Twenty-second and Seward Streets, operated for over 20 years by the late Dr. Charles Impey, pioneer Omaha surgeon. His son, Chester C. Impey, now practices here and is on the staff of Wise Memorial Hospital.

A record of the more recent institutions is included hereafter.

Nebraska has 69 hospitals, of which 44 have more than 25 beds, according to figures printed recently in the Nebraska State Medical Journal. Omaha has 17 and Lincoln, five. Of these, there are 35 first class hospitals under the survey of the American College of Surgeons, of which 14 are fully approved and three, conditionally approved as meeting all requirements for Class A hospital standardization. Seven of the approved hospitals are in Omaha. This includes certain required organization, equipment, records, personnel and procedures which insure the most accurate diagnosis and best possible treatment. They are Clarkson, St. Joseph's, Methodist Episcopal, Nebraska University, Swedish Mission, Immanuel and Wise. Other hospitals in Nebraska on the approved list are Lincoln General, Nebraska Orthopedic, St. Elizabeth's and Bryan Memorial in Lincoln; St. Francis, Grand Island; St. Mary's, Columbus; St. Joseph's, Alliance; West Nebraska, Scottsbluff ; Falls City Hospital, Falls City.

Members of the Nebraska section of the American College of Surgeons, decided at their annual meeting held in Omaha in February to enter a campaign to bring all hospitals of 25 beds and over, up to the requirements of this hospital standardization. Fifty-eight counties are without hospital facilities.

A Nebraska Hospital Association was organized in 1927 as a result of an informal meeting called by Miss Homer Harris, superintendent of Clarkson, to discuss pending legislation which affected hospitals in this state. The meeting was held at St. Joseph's. Rev. E. G. Chinlund of Immanuel was named president; Miss Blanche Fuller of Methodist, vice-president; Miss Ida Isaacson of Evangelical Covenant, secretary and Miss Harris, treasurer. 


\section{Bishop Clarkson Memorial Hospital}

Having its inception as a children's hospital, as described at the beginning of this chapter, Clarkson Hospital, a memorial to the late Bishop Robert H. Clarkson of the Episcopal Diocese of Nebraska, took its name in 1881. The first training school for nurses was established in 1886. The hospital now has 100 beds, a training school of forty-five nurses; eleven graduate nurses and a surgical and medical staff which numbers twenty-nine. Homer C. Harris, superintendent, retired a short time ago. Martina C. Thode is the present incumbent.

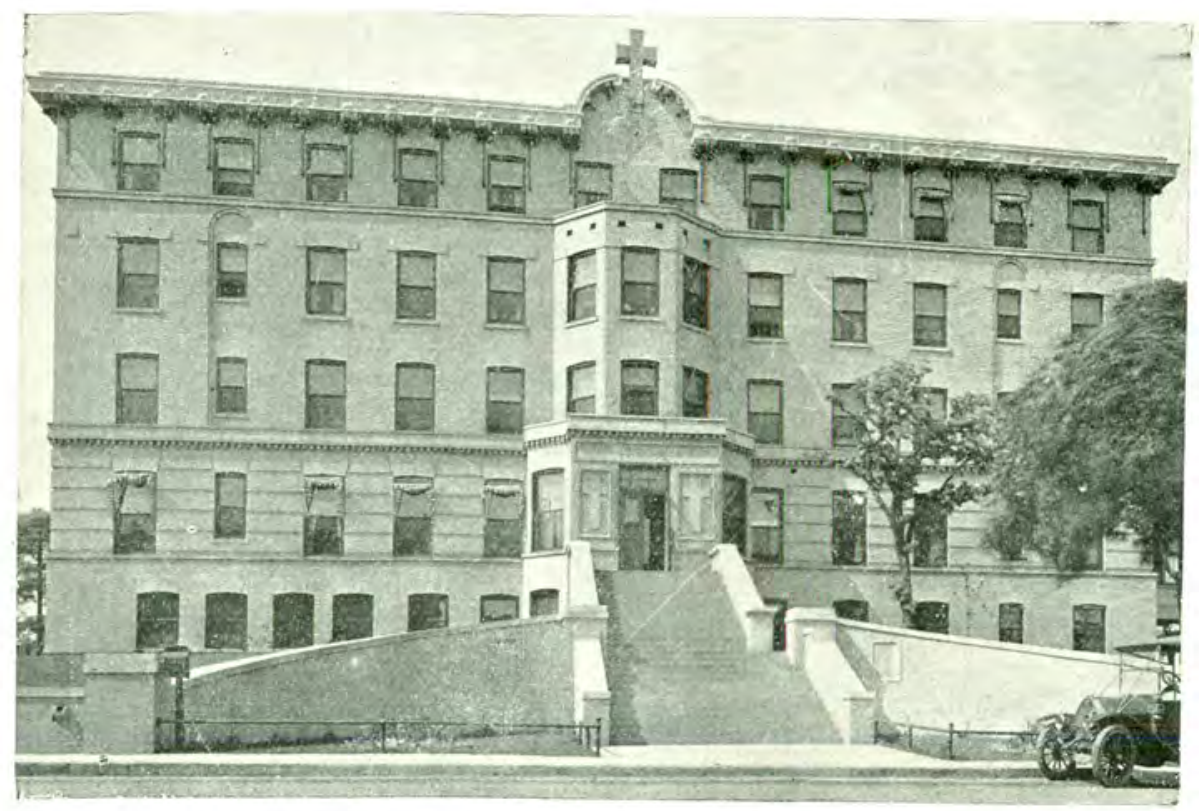

BISHOP CLARKSON MEMORIAL HOSPITAL

It is an interesting fact that a daughter and a granddaughter of Bishop Carkson are at present serving on the house committee of the hospital. They are Mrs. Frederick H. Davis and Mrs. T. L. Davis. Other members are Mesdames Theodore Ringwalt, W. C. Shannon, Milton T. Barlow and F. H. Cole.

The board of trustees includes Bishop Ernest V. Shayler, Rt. Rev. George Allen Beecher of Hastings, Dean Stephen E. McGinley, 
F. H. Davis, Walter T. Page, William Ritchie, Jr., W. Farnam Smith and Mesdames Shannon, Ringwalt and Davis.

The present building in which the hospital is housed at 2100 Howard Street, was erected in 1907. The hospital has always been proud of its reputation as a training school for nurses. It affords a thorough course in medical, surgical, obstetrical, gynecological, orthopedic and pediatric nursing and competent instruction in the operating room, laboratory and diet kitchen.

A new 200-bed hospital to cost about $\$ 300,000$ and located at 42nd and Howard, in proximity to the University of Nebraska Col-

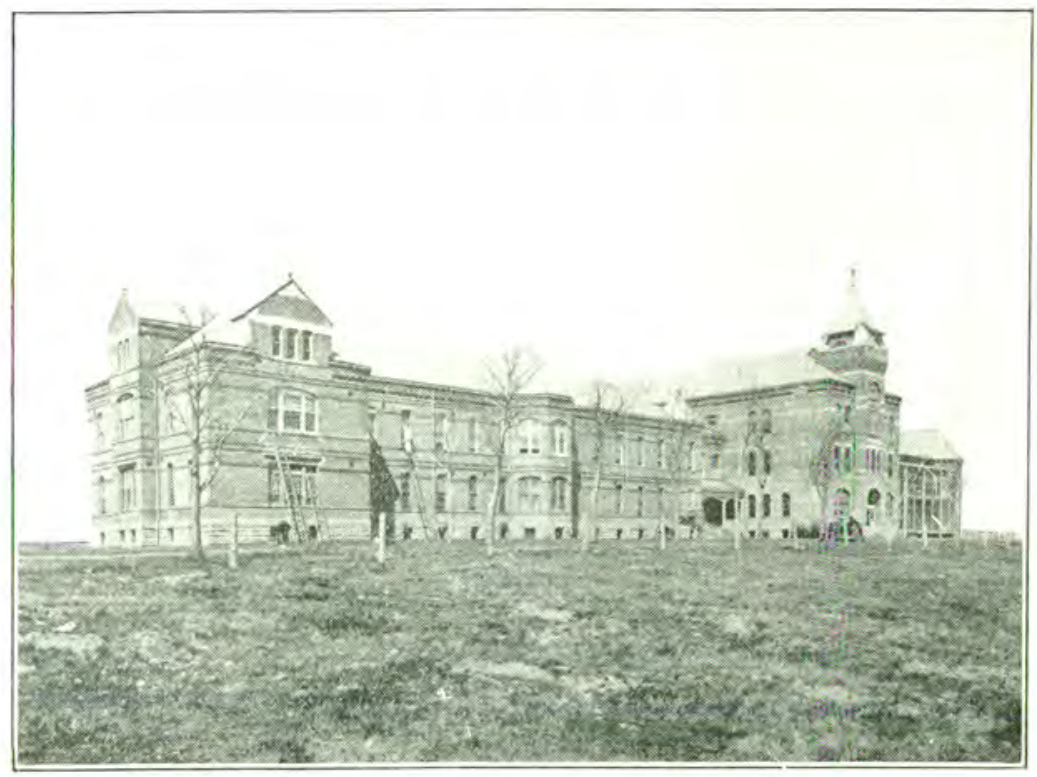

DOUGLAS COUNTY HOSPITAL

lege of Medicine, is planned for the near future. Trustees have already purchased 12 city lots opposite the University Hospital, just north of the Child Saving Institute.

\section{Douglas County Hospital}

A campaign for a new $\$ 750,000$ county hospital to replace the antiquated institution at 40th and Poppleton Avenue, built in 1887, was launched in 1927 by Dr. Frank M. Conlin, then president 
of the Omaha-Douglas County Medical Association, and was completed in 1928.

A pavilion of 100 beds for the care of the tuberculous; a 150bed pavilion for the insane; an obstetrical department and some provision for children suffering from venereal disease are some of the necessary additions sought. Separation of the County Hospital and poor farm is also advocated. There are at present 188 beds in the hospital but the average daily population is much larger.

J. E. Summers is head of the staff of twenty physicians and fourteen graduate nurses. Mason E. Lathrop is the superintendent.

Situated on 180 acres of land, the hospital, according to Dr. Conlin, has a normal capacity of 110 beds. The average working capacity through crowding beds into rooms and corridors is two hundred beds. In a similar manner the poor farm, with a normal capacity for 128 patients, cares for 238 as a winter capacity. A cheaply constructed frame unit was built in 1913 for care of tubercular patients.

\section{Immanuel Hospital}

This hospital, which entered its new $\$ 250,000$ building in May, 1926 , is only one part of the vast scheme of relief work housed by the Augustana Synod and the Swedish churches of America in the five-block tract adjacent to Thirty-fourth and Meredith Avenue. The group includes a home for incurable invalids and defectives, housed in the old hospital building a home for the aged, an orphan home, a Deaconess, a nurses' home and sundry buildings like chapel, garages, heating plant, greenhouse, gardener's home, director and assistant pastors' homes, laundry, etc., totaling fifteen buildings and representing a value of $\$ 750,000$.

The origin of this vast institution of mercy dates back to October 8, 1887, when the Rev. E. A. Fogelstrom, Rev. J. S. Detweiler, Rev. A. M. Anderson, J. F. Heflin and S. V. Gustavson, met in the study of the Immanuel church in Omaha to organize a charitable and benevolent society under the name of "The Evangelical Lutheran Immanuel Association for Works of Mercy." Subsequently, G. A. Lindquist, John Johnson, Dr. George L. Miller, Alfred Millard, Fred Drexel, Wm. L. McCague, Peter Colseth, Anthony 
Johnson, Joseph Barker and Guy C. Barton were added to the board.

Twelve lots were secured between Meredith and Fowler Avenue, upon which was erected the first wing of a hospital building. A little later three lots were bought on the east side of Thirty-fourth Avenue, upon which was built the first Deaconess Home. In the next decade the society underwent several reorganizations and merged in its present form, under the control of the Augustana Synod. Rev. Fogelstrom continued as its head until his health broke and

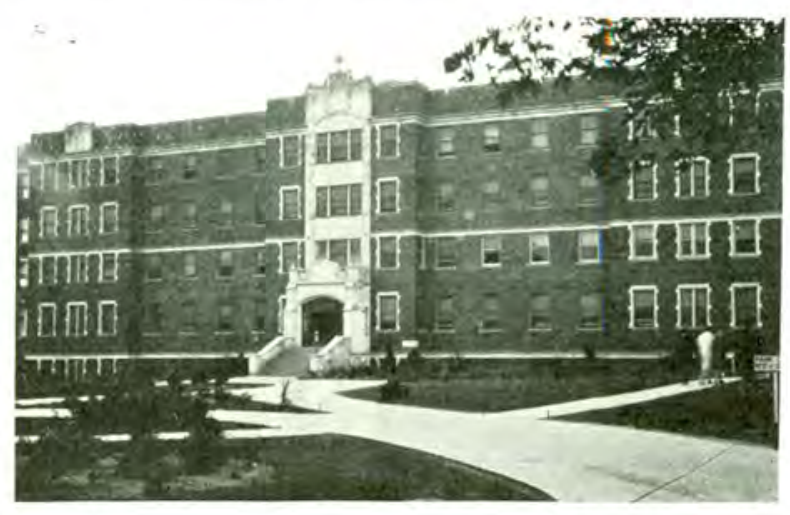

IMMANUEL HOSPITAL

he died in Wahoo, Nebraska, October 4, 1909. Rev. E. G. Chinlund is today the managing director, not only of the hospital, but the auxiliary units.

The new hospital wing has a capacity of 130 beds, one of the finest medical and surgical staffs in the city, a complete $x$ ray definest medical and surgical staffs in the city, a complete $x$-ray department, and has a training school for forty nurses - not all of them

This does not include the invalids' home, where sixteen men and twenty-six women patients are now receiving kindly care. This institution cares for more incurables, paralytics and cripples and mentally defective than any other local institution except the county hospital.

Deaconess Elna Johansson is directing sister and Sister Olive Cullenberg, superintendent of the nurses' school. A two months' course with the Visiting Nurse Association gives the senior student a practical and beneficial insight into public health nursing. 
The chronological history of the institution since the first hospital building and frame Deaconess Home were erected in 1890 and 1891 is as follows:

In 1901, the Children's Home, a two-story frame building, and a parsonage were erected. In 1902 a small frame house was secured, which in 1903 became the first quarters for invalid and aged, and which has now for many years been used as a home for the engineer and his family. In 1903 a central heating plant was built, and in 1905 an additional story was added above the boiler room in which a modern steam laundry was installed. In 1904, a wing was added to the hospital building, and in 1905 the Deaconess' Home was considerably enlarged. In 1909-1910 a new fifty-five bed hospital was erected north of the former hospital, and the same year a parsonage for the assistant pastor was built and an underground tunnel constructed, connecting the heating plant with all of the buildings. Additions have been made to the tunnel as further buildings were erected. In 1912 a large greenhouse was built, and in 1916 a home for the gardener was secured.

From 1910 to the present time, additional property has been purchased from time to time, so that the institution now owns sixty city lots, covering an area of five square city blocks. A frame building, secured in these purchases, was moved to a lot east of the Children's Home and converted to a home for older children in 1918. In 1922, a modern, fireproof and commodious Deaconess' Home was erected at a cost of $\$ 100,000$, and the climax of the building plan to date was the erection of the fine new hospital building erected this year to take care of the growing demands in hospital work, and also to provide room in the other vacated buildings for more invalids and aged.

A valuable addition to the grounds was the grant by the city council to vacate Fowler Avenue between Thirty-fourth and Thirtysixth Streets and the alleys in the block between Fowler and Meredith Avenues. It affords privacy and an opportunity to beautify the grounds, which the officers state will go forward with despatch. Concrete walks and driveways have been laid out.

The crowning achievement in the scheme is the chapel erected at the same time as the new hospital building, and financed by the Women's Missionary Society. 
The total number of inmates, deaconesses, nurses and employees of this little city is 307 persons.

\section{Lord Lister Hospital}

Lord Lister Hospital is privately operated by Mrs. Margaret A. Henry, whose husband, Dr. Edwin C. Henry, is the chief surgeon. The hospital was established in 1912 at Fourteenth and Capitol

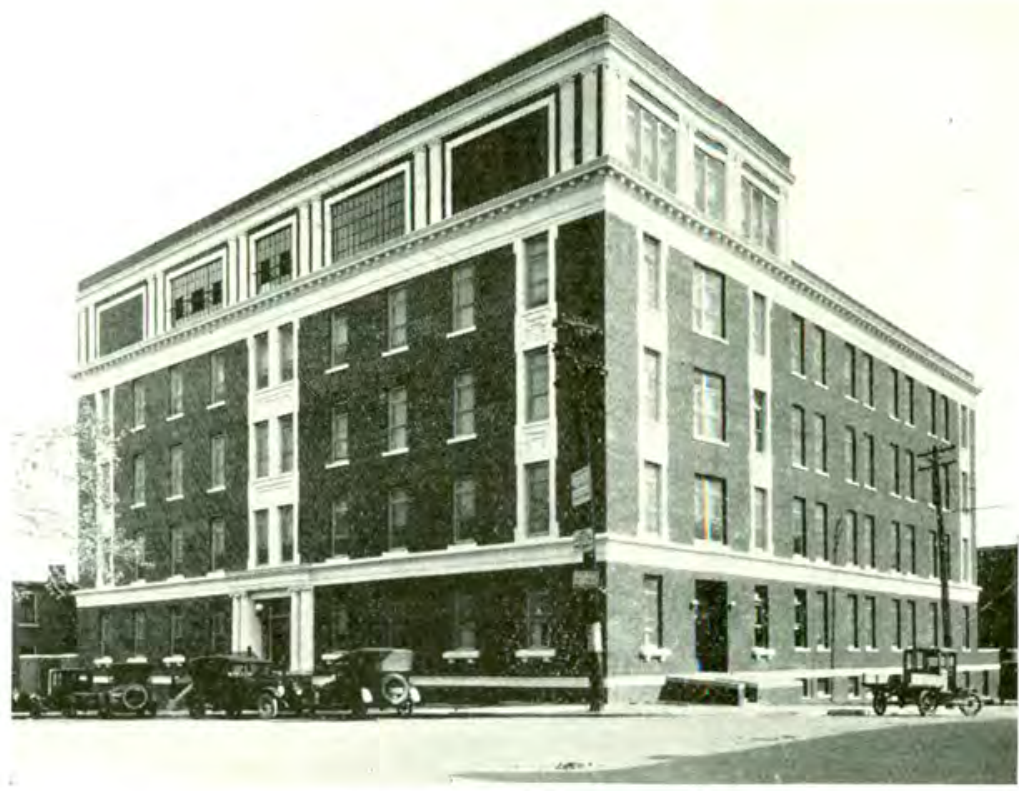

LORD LISTER HOSPITAL

Avenue, named for the great scientist, discoverer of antiseptics; and moved to its present splendid quarters at 26th and Dewey Avenue, in 1921. There are 130 beds.

A large percentage of Lord Lister patients are surgical cases from many surrounding states, hence the surgical department is equipped with every modern convenience. There are two large rooms for general surgeons and a dark room, fittcd with artificial lights for nose, throat and kidney work. All new methods of anaesthesia, such as spinal, sacral, rectal, gas, ether or any combination of these methods, are herein provided. 
The hospital employs a full-time pathologist and visitors are permitted to view the pathological museum on the fifth floor. The $\mathrm{x}$-ray and physiotherapy departments of this hospital are said to be the first completely equipped departments of this kind in any middle west hospital. The equipment includes $\mathrm{x}$-ray for diagnosis and superficial treatment; large 200,000 volt machine for deep x-ray treatment for tumors, etc.; radiant lights, air and water cooled actinic rays, diathermy, sine wave currents, galvanic and faradic currents.

A completely equipped dentist's office with a dentist in charge, is another novel convenience to patients. The Omaha Public Library also maintains a branch library of 100 volumes here. A large training school for nurses is also maintained. The nurses have an alumni association of over 100 members, who hold monthly meetings.

\section{Lutheran Hospital}

The Lutheran Hospital, formerly known as the Presbyterian Hospital, was taken over in April, 1928, by the Missouri Synod of the German Lutheran Church. Many improvements have been made in the equipment so that now there are two surgical operating rooms and complete $\mathrm{x}$-ray equipment for diagnosis and therapy, as well as laboratory facilities. The hospital has a capacity of about 60 patients.

Dr. Louis E. Hanisch was instrumental in bringing about the reorganization.

It is planned to have an open staff made up of the leading physicians and surgeons and specialists in Omaha. Not only is it the plan of the authorities to enlarge and improve the hospital, but later it is hoped that an Old Peoples' Home and a Children's Home may also be established.

\section{South Side General Hospital}

South Side General Hospital, located at 2420 G street, is a thirty-bed, privately owned hospital with an excellent equipment, capable staff and graduate nurses. Sadie F. Larson is superintendent. It was established in 1894 by the South Omaha Hospital Association.

\section{Nebraska Methodist Hospital}

The second largest hospital in Omaha is the Nebraska Methodist Episcopal institution, located at 36 th and Cuming streets, 
which recently dedicated a new $\$ 175,000$ nurses' home. A new $\$ 250,000$ wing is planned for next year. Owned by the Nebraska Methodist Conference, it maintains 325 beds, a large training school for nurses, and has treated close to 100,000 patients in its 37 years' existence.

The Methodist hospital is an outgrowth of the Eye and Ear Hospital started by Dr. Lynn Graddy in 1881. Miss Blanche Fuller, superintendent for the past twelve years, supplied the following history of the hospital, from the first meeting, held in January 19, 1891 in the parlors of the Y. M. C. A., to "discuss ways and means of establishing a Methodist hospital in Omaha. R. R. Ball was elected chairman and D. A. Foote, secretary.

Permanent organization was completed February 25, 1891, and officers elected as follows: R. R. Ball, president; P. E. Cowgill,

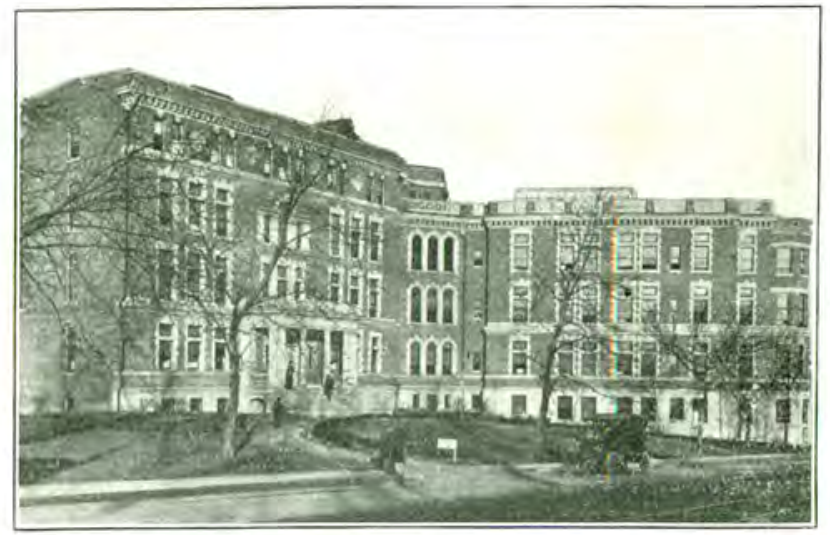

NEBRASKA METHODIST HOSPITAL

secretary and Frank Hills, treasurer. A. H. Davis. S. W. Lindsay, Rev. Alfred Hodgetts, James J. McLain, Rev G. M. Brown, John Dale, Rev. W. E. Beans, Rev. H. A. Crane, Rev. John W. Shank and John M. Hazelton were present,

In March, 1891, the hospital was opened in a building situated on the east side of Twentieth street, south of Howard. This building was purchased of Dr. Harold Gifford, and in part donated by him. This building stood upon leased ground which was never owned by the hospital, and held 35 beds. It was soon apparent 
that the building and equipment were not adequate, so on February 18, 1898, the Board passed a resolution permitting the deaconesses to go out and raise funds for a new site and a new hospital which should cost altogether not to exceed $\$ 50,000$.

On March 16, 1900, the present site on the northwest corner of Thirty-sixth and Cuming Streets was purchased. The first purchase consisted of two and one-half acres and cost $\$ 15,000$. On November 13, 1903, the first contract for the first unit of the hospital was let. In February, 1906, a campaign was inaugurated and $\$ 80,000$ was raised for the hospital. The usual troubles and delays incident to every building were theirs, but on June 12, 1908, they moved into the first unit of the present hospital. This unit contained 75 beds.

The hospital was soon crowded with patients and in 1914 they occupied the first addition, a new wing which cost $\$ 80,000$ and gave additional space, bringing the capacity of the hospital to 150 beds.

In 1916 the operating room pavilion was enlarged and now contains six operating rooms, with necessary service rooms, and three rooms for the $\mathrm{x}$-ray department.

They were again not able to care for all the sick who came to their doors, and in September, 1918, another wing was opened at approximately the same cost, $\$ 80,000$, bringing the bed capacity of the hospital to 225 .

The School of Nursing has kept pace with the increase in patients and now numbers 100 students with 16 supervisors and instructors. During the years from 1915 to the present time, the hospital has purchased property in the square, using the houses as dormitories for nurses, until the hospital now owns approximately 5 acres in the square where the building is located and two large lots on the opposite side of the street.

In September, 1927 the first unit of the Home for the School of Nursing was dedicated. It houses 120 people and cost $\$ 170,000$.

From the beginning the hosp.tal has been served by a staff of eminent physicians and surgeons. It is standardized by the American College of Surgeons and accepted by the American Association for Training of Internes. 
There have been two superintendents during this period. Mrs. Allie P. McLaughlin was the first superintendent, serving for twentysix years. The present superintendent, Miss Blanche Fuller, has been in charge for the past eleven years.

The latest addition to the hospital is a free cancer ward for women, made possible by a $\$ 50,000$ bequest from the late Miss Belle Dewey, Omaha newspaper woman, who died of that disease at the hospital on June 18, 1925. The hospital board voted the same amount and two rooms on the second floor of the hospital are provided and as soon as the new hospital wing is finished a ward will be set aside to be known as the Belle Dewey Memorial ward. It is one of the first endowments for this work in the country and hospital officials hope that extensive research may result.

Applications for admittance to the ward will be made through physicians in the Omaha-Douglas County Medical Association. Creed or race is to play no part in acceptance of patients. The arrangement was sanctioned in county court after conferences between hospital officials and the executors, Joseph Polcar and Mrs. A. J. Love.

Ford Hovey is president; C. W. DeLamatre, vice-president; M. L. Stone, secretary and B. A. Wilcox, treasurer of the hospital board.

\section{Wise Memorial Hospital}

Wise Memorial Hospital, named for the late Rabbi Isaac M. Wise, founder of Reform Judaism in America, was organized in 1899, through the efforts of the late Edward Rosewater, founder of the Omaha Bee; Mrs. Jonas L. Brandeis, grandmother of E. John Brandeis and Mrs. Arthur D. Brandeis, his mother; Rabbi Abram Simon, then head of Temple Israel, Rev. Esau Fleishman, Mrs. J. Sonnenberg, Mrs, Charles Schlank, Mrs. Louis Levy, Adolph L. Brown, Isaac Kohn, Sam Newman and Mrs. J. Rosenstein. Rabbi Simon was the first president; Rev. Esau Fleishman, the first vice-president and Mrs. A. D. Brandeis, secretary, according to old hospital records.

The first location was a ten room house at 3208 Sherman Avenue, occupied for two years; after which the hospital moved into the old J. J. Brown mansion at 2225 Sherman Avenue, with a 30- 
bed capacity, where they remained until the present edifice was built at Twenty-fourth Avenue and Harney, in 1908. A gift of $\$ 15,000$ from Abraham Slimmer of Waverly, Iowa, and $\$ 10,000$ from

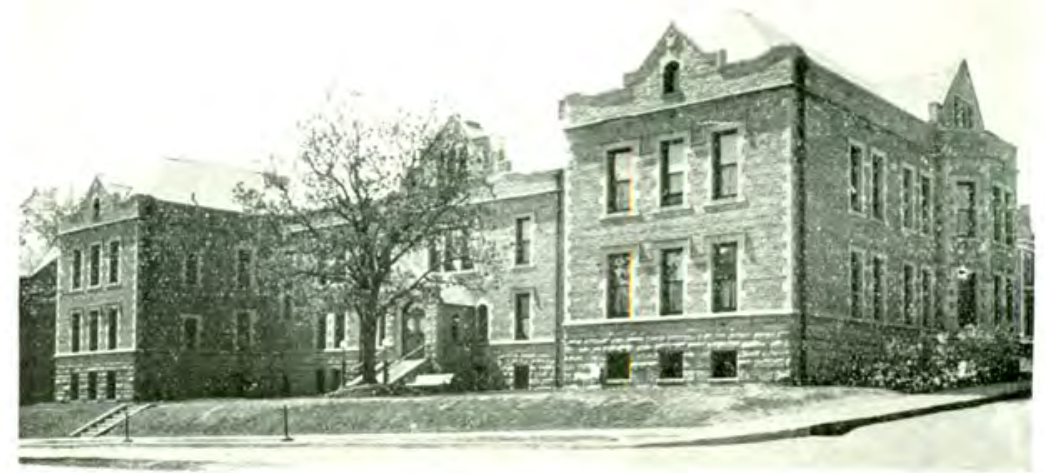

WISE MEMORIAL HOSPITAL

the late Guy C. Barton made possible the new building. The Nurses' Home, memorial to Emil and Hugo Brandeis, was added later.

First staff doctors included B. B. Davis, Oscar Hoffman, J. E. Summers, Robert Gilmore and James Goetz, and later A. F. Jonas,

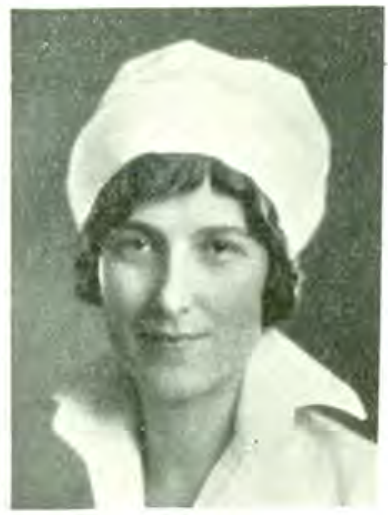

MRS. RUTH ALGORTA

C. C. Allison, W. O. Bridges, Charles Rosewater, F. J. Wearne, Paul Ludington and F. S. Owen. Gilmore is now chief of the medical and Clyde A. Roeder, chief of the surgical staff. The late O. S. Hoffman was chief of staff from its inception until his death, last year.

Mrs. Jane Wheeler Pinkerton, graduate of Clarkson Hospital, organized the nurses training school in 1899. It became an accredited school in 1908. Mrs. Pirkerton was superintendent from 1901 to 1903; Miss Carrie Louer in 1906-1907; Mrs. Lillie Myers, 1908-1911; Miss Pearl Larson, 1924- 
1925, and Samuel Frank and Mrs. Margaret Owene for short periods until the appointment in 1927 of the present superintendent, Mrs. Ruth Algorta.

Remodeled in 1927 at a cost of $\$ 50,000$, Wise Hospital is accredited by the American College of Surgeons and is affiliated with the department of medicine, University of Nebraska. It has a capacity of 60 beds and maintains a nurses' training school of 40 . Though maintained by Jewish subscriptions, augmented by a few

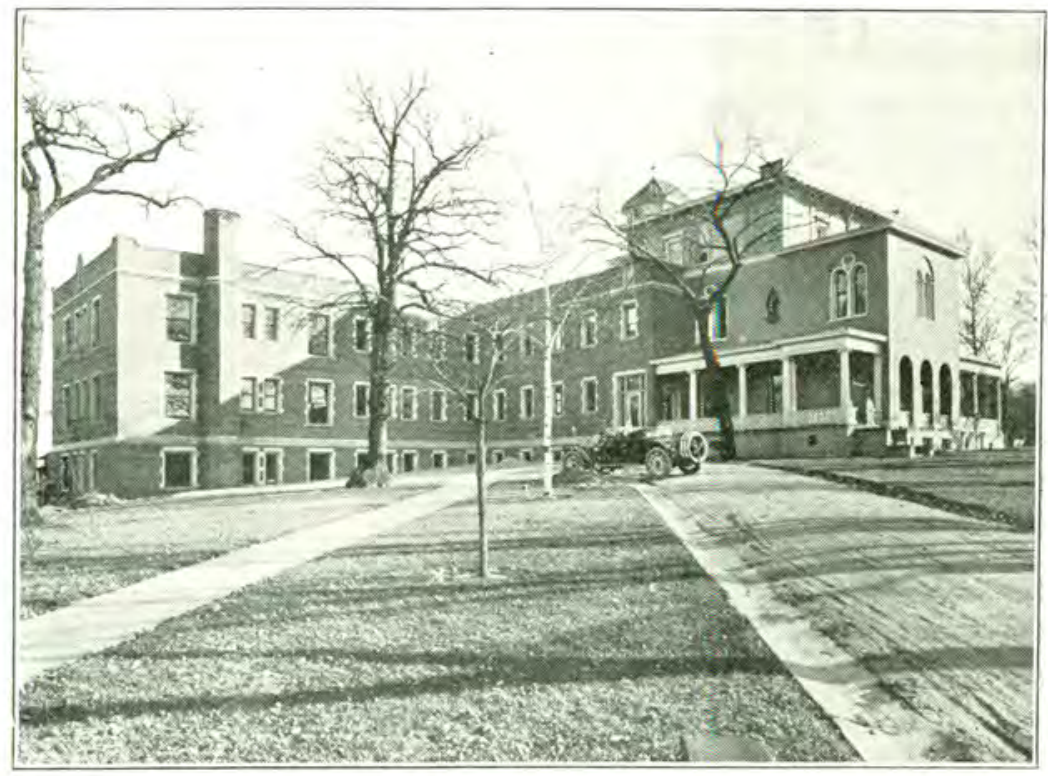

ST, CATHERINE'S HOSPITAL

gifts from non-Jewish friends, the institution is entirely non-sectarian in its admission of patients and free work. Samuel Wertheimer, Isidor Ziegler and N. P. Feil are officers.

\section{St. Catherine's Hospital}

St. Catherine's Hospital, located at Ninth and Forest Avenue, in the old Herman Kountze mansion, was organized in 1910 as a small, thirty-bed hospital, by the Sisters of Mercy, an order founded in Ireland in 1778. So fine is its record that the institution has made two enlargements in the brief span of years and it now numbers 190 beds. 
The most recent wing, completed in 1927 with a capacity of 118 beds, has excited the admiration of every visitor to the building. Every known practical or utilitarian improvement in equipment or building was included, after the architect and Sisters had studied the best hospitals in this country and abroad.

Unusual attention was given to sanitary fixtures, many of which were specially designed to meet hospital requirements. Instead of bare white walls, cheerful, colored walls, aimed to brighten the invalid's stay in the hospital; and a unique electric call system for nurses was installed. Doors separating each patient's room from the corridor are also unique. They are door frames with casement cloth centers, thus insuring privacy for the patient without removing him entirely from the sound of human life about him.

The surgical unit is at the north end of the top floor. It consists of two major operating rooms, one septic operating room and one operating room for eye, ear and throat, with dark room and waiting room adjacent. Most of the rooms have private bath or toilet facilities. Fine obstetrical and $\mathrm{x}$-ray departments are also provided.

The twelve Sisters in charge are all registered nurses, besides which there is a staif of six graduate nurses and a training school of sixty-seven nurses is maintained. The hospital plant is valued at $\$ 350,000$.

Sisters of Mercy first began their hospital work in Nebraska sixty-one years ago, in fact, were the first order to undertake nursing here. Their initial effort was with the present St. Joseph's Hospital, later taken over by the Franciscan Sisters.

\section{Evangelical Covenant Hospital}

The Swedish Mission Hospital, now known as the Evangelical Covenant Hospital, is endeavoring to enlarge its capacity from ninety to 125 beds, to provide a nurses' home, and to permit it to carry on the large amount of charity work done in this institution. Organized in 1905, it early acquired its present location at Twenty-fourth and Pratt Streets, where the proposed new structure will be erected. 
In the twenty years of its existence, the hospital has cared for 24,000 patients and done charity work equaling the value of its present building, according to the Rev. Albin N. Osterholm, superintendent. Rev. P. A. Nelson is now chairman of the board.

Rev. Osterholm assigns the following reasons for the need for increased hospital facilities: Increase in population, modern methods of living in apartments and kitchenettes, extra hazards from

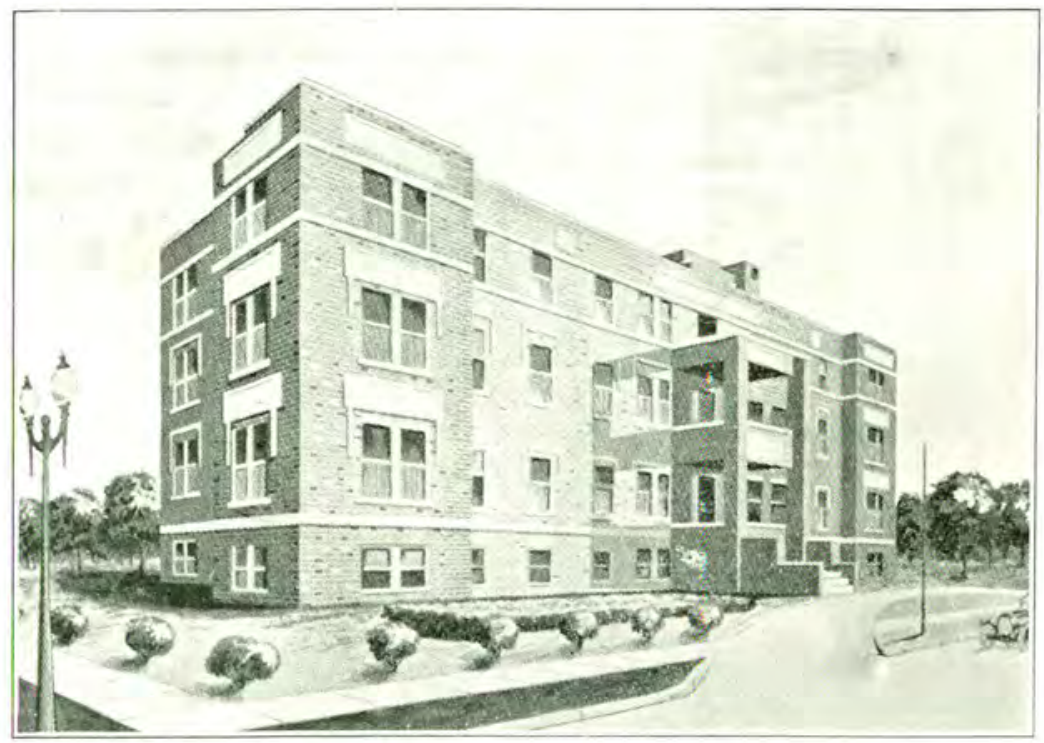

EVANGELICAL COVENANT HOSPITAL

automobiles, demand for higher class, scientific medical and surgical treatment, and also development of hospitals as centers for prevention of disease and promotion of public health.

Special features of the proposed new building contemplated will be sun parlors on the roof for convalescing patients, as well as observation rooms for suspected tubercular patients.

Founders and benefactors of the institution were the late Rev. Emanuel Berg, Olof B. Johnson, Mr. and Mrs. Peter Bergman of Polk, Nebraska, Nels Erickson and J. O. Wilson of Scandia, Kansas, who made possible the nurses' home. The executive committee includes: Carl Johnson, president; N. J. Peterson, treasurer; Axel 
E. Olson, the superintendent; Rev. Osterholm, and the highest officers of the Nebraska and Iowa conferences of the Evangelical Covenant Church.

The staff of doctors organizes its own body and elects the officers. The hospital is open to all doctors of recognized skill and professional character. Monthly scientific meetings are conducted and the work done is recognized by the American College of Surgeons.

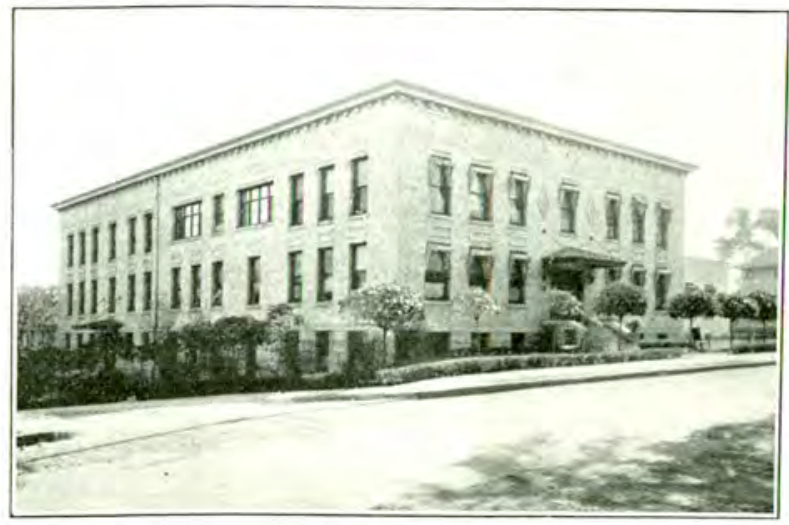

NICHOLAS SENN

The school of nursing is under state supervision and both theory and practice, as well as conduct, is under close supervision. There

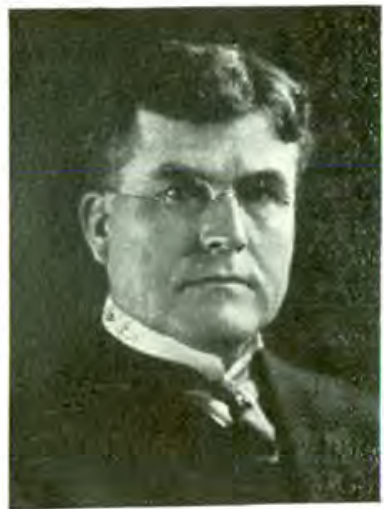
are at present forty pupils. Classes are formed in September and in February. Young women from eighteen to thirtyfive years are taken, preferably two-year high school girls. All subjects taught, including practical demonstration classes for probationers, in 1927 required a total of 826 class hours. An average of twenty-one teachers are engaged in the school of nursing. There is no tuition charge, and the students are granted a monthly stipend. Some of them get hrough on this without outside help.

A. P. CONDON

The hospital has cared for over 25,000 patients, fully one-third of whom have been entirely or in part dependent upon charity. 
The property and equipment represents approximately $\$ 200,000$. The annual business totals $\$ 100,000$ in caring for an average of 2,000 patients. Miss Ida C. L. Isaacson of Minneapolis was engaged last year as manager of the institution.

\section{Nicholas Senn Hospital}

Nicholas Senn Hospital, located at Park Avenue and Dewey, was incorporated in 1912 by its present owner, Dr. A. P. Condon and now has a capacity of 96 beds. The nurses' training school has upward of 50 members. A $\$ 25,000$ swimming pool, where nurses and undergraduates are taught to swim, is a feature of the hospital. It is open to classes outside the hospital. A. B. Griffith is superintendent.

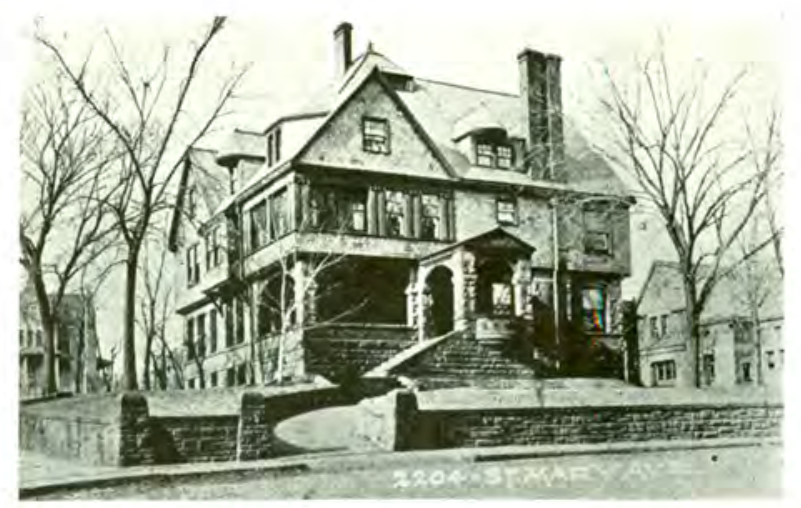

()MAHA MATERNITY HOSPITAL

\section{Omaha Maternity Hospital}

The Omaha Maternity or Dr. Pollard's Hospital, located at 2204 St. Mary's Avenue, in the old Hamilton mansion, is devoted exclusively to maternity cases. Its equipment is the last word in needs along these lines, including two Hess incubators for prematurely born infants, and the newest anaesthesia as well as various modern devices. It is privately owned by Dr. Charles W. Pollard, dean of local gynecologists, who holds the chair of obstetrics and gynecology in the University of Nebraska College of Medicine.

Prior to 1924 when Dr. Pollard took charge, this hospital was known as the Stewart Maternity Hospital. It was opened in 1916 by Miss Nellie E. Stewart, who formed a partnership with Dr. Pol- 
lard in 1919. This continued for five years. The hospital was then enlarged and opened to all physicians and surgeons in good standing. It has a capacity of 22 beds and a well-equipped nursery. All nurses employed are graduate nurses.

\section{Danish Lutheran Hospital}

The Lutheran Hospital, under Danish auspices, was organized in November, 1927, to take over the former Presbyterian Hospital, in the old Iler home at 1240 South Tenth street, which was operated by Karl Connell. It has a capacity of 52 beds. Dr. F. Rosenbladt is chief of the surgical staff. Miss Sophia Pieper is superintendent.

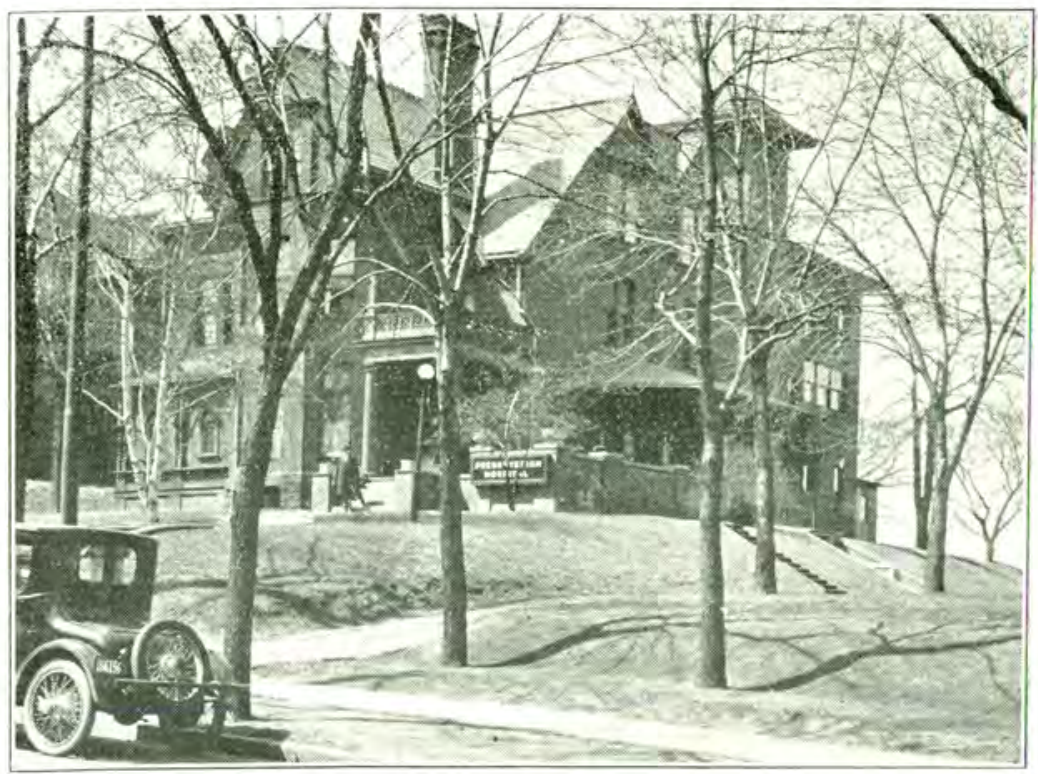

DANISH LUTHERAN HOSPITAL

Danish residents of this vicinity have long cherished an ambition to erect a great hospital as a memorial to pioneers of their extraction who helped build up America. They favored its location in Omaha because of this city's central position and established reputation as a medical center. Promoting the cause are Rev. A. O. Soholm, formerly of Omaha (now of Mason City, Iowa); Dr. James A. Miller, professor of pathology at the University of Nebraska College of Medicine; Prof. X. F. Hansen of Dana College, 


\section{Radium Hospital}

Blair; C. L. Rawson of Omaha and Fred Petersen of Council Bluffs. Plans for development and expansion will soon be put into effect. This hospital was recently purchased by the German Lutherans.

One of the few exclusively radium hospitals in the country is located in Omaha, in the old Turner mansion at 34th and Farnam Streets. When established eight years ago by its present owner, Dr. Daniel T. Quigley, it was one of the few institutions in the United States where radium treatment was at all obtainable. It has

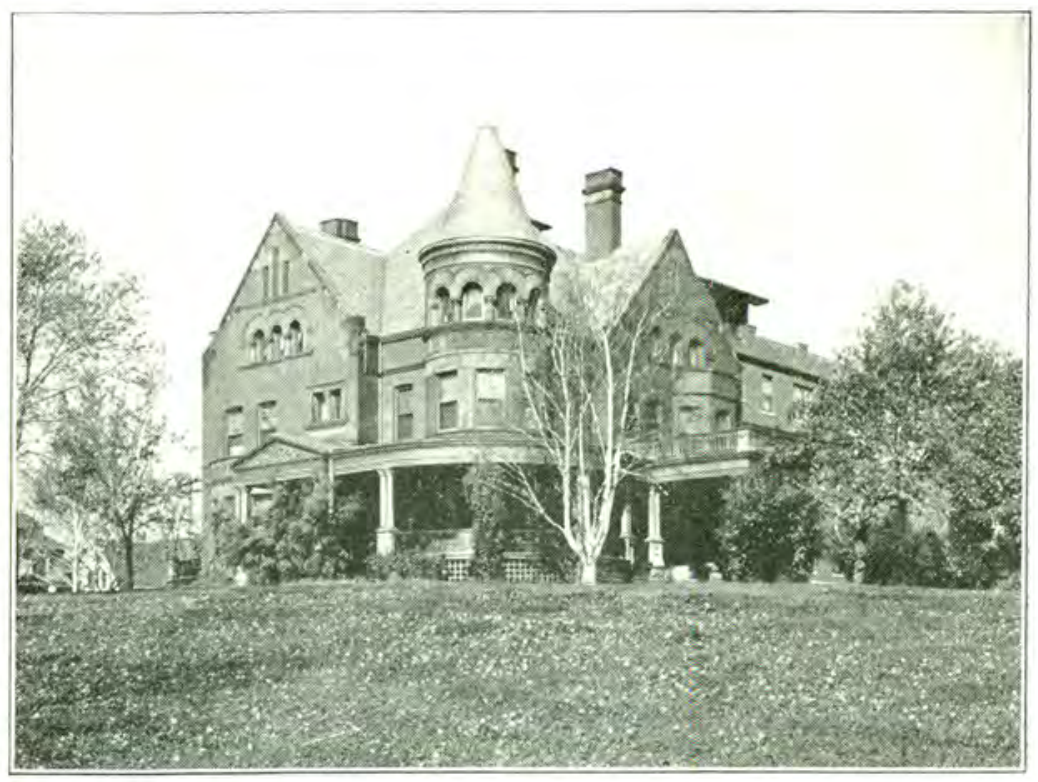

RADIUM HOSPITAL

a capacity of thirty beds. This hospital is equipped with modern facilities for radium treatments of all kinds.

This precious substance, radium, is more costly than diamonds and is worth 180,000 times it weight in gold. A ton of ore must be refined in order to produce one milligram of radium, and one milligram is only one sixty-sixth of a grain. The ore is obtainable in Colorado, but Belgium now has a monopoly on its production, due to the discovery of fertile sources of the ore in the Belgian Congo, Africa, where it can be mined more cheaply than in America. 
Dr. Quigley recently completed a book on radium which will be off the press soen. He formerly practiced in North Platt, coming to Omaha about 1917, following extensive European study. He is on the faculty of the University of Nebraska College of Medicine.

\section{Ford-Paxton Hospital}

Paxton Memorial, founded as the Ford Hospital by Dr. Michael Ford more than ten years ago, suspended operation in 1927.

\section{Salvation Army Women's Home and Hospital}

A haven of refuge for unwed mothers is the Salvation Army Women's home and Hospital, located at Sherman Avenue and Grace Streets, Omaha. A new building erected in 1921 at cost of $\$ 75,000$, has accommodations for 40 mothers and 40 babies. The average

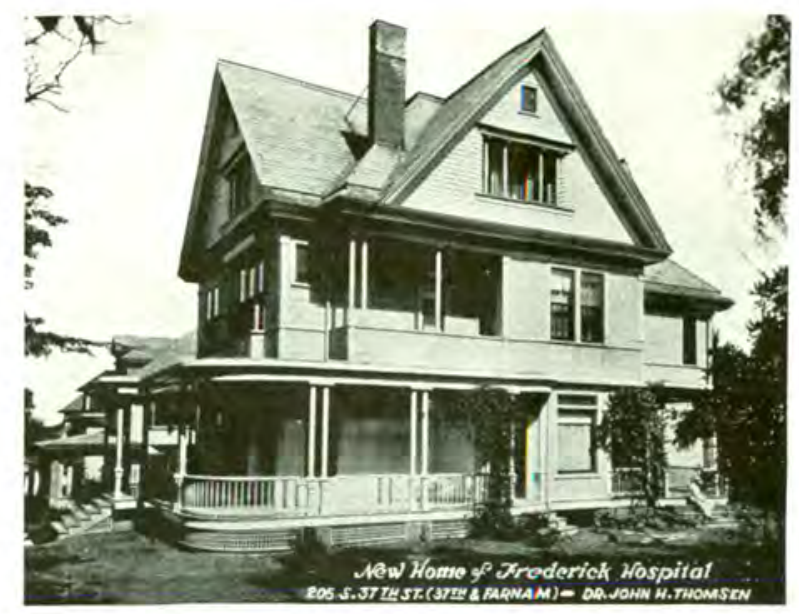

FREDERICK HOSPITAL

yearly number of patients is 200. Two trained nurses and a staff of eight in help are employed. Commissioner Frederike French is manager of the institution. The work was established in Omaha over 36 years ago and is now one of the constituent agencies of the Community Chest. Dr. Samuel McCleneghan has been on the staff for 16 years.

\section{Frederick Hospital}

Frederick Hospital, located at 205 South Thirty-seventh Street, was established eleven years ago by Dr. John H. Thomsen, its pres- 
ent owner. It has eight beds and a staff of two nurses in regular attendance. The hospital recently moved to this new location from its old home at 1425 North Seventeenth Street, Dr. Thomsen, a Creighton graduate, invented an obstetrical table, mentioned in another chapter.

\section{City Emergency Hospital}

Through the bequest of the late Anne Wilson, the City Emergency Hospital, located at 912 Douglas Street, was opened for contagious diseases under the supervision of the late R. W. Connell, health commissioner, October 8, 1912. It has a capacity of 40 beds, and cared for 3,500 cases up to the present time. The number varied from none to 66 at one time.

Diphtheria, scarlet fever and erysipelas have been cared for with gratifying results. During the past few years, the number of cases has greatly decreased. Since April, 1926, small pox cases have also been treated.

Nurses are paid a regular salary as there is no training school. Their number varies according to the need. During the epidemic of scarlet fever in 1917 and 1918, a separate house was rented to accommodate the great number of patients. No serious contagious case has been refused, although there is no provision for the minor contagious diseases, such as measles, chicken pox, mumps, etc. A great number of these have been admitted, however, at times when there have been only a few of the more serious diseases and it has been possible to accommodate them.

The City of Omaha appropriates a sum which is adequate to conduct affairs of the institution as very few patients are able to pay. The medical care of patients has always been under the direction of the health commissioner and his assistants. All physicians may send patients at their discretion.

The hospital was at one time under the Police department but at present it is under the Health Department and A. S. Pinto, Commissioner. The nurse in charge at the opening of the hospital is still on duty.

\section{Bethany Hospital}

Bethany Hospital, 2102 Wirt Street, is maintained by Swedish churches of Nebraska. It has no regular staff but is open to all 
practitioners of good standing, for treatment of all cases except contagious ones. It has 30 beds, three graduate nurses and maintains a nurses' training school.

\section{St. Luke's Hospital}

St. Luke's Hospital, located at 2121 Lake Street, was established in 1912. This hospital has fifteen beds, a staff of four doctors and two graduate nurses. It is privately owned.

\section{City Detention Hospital}

The City Detention Hospital for contagious diseases was established in 1901, with a capacity of 22 beds. Thomas D. Boler is medical superintendent. The Women's Detention Hospital for

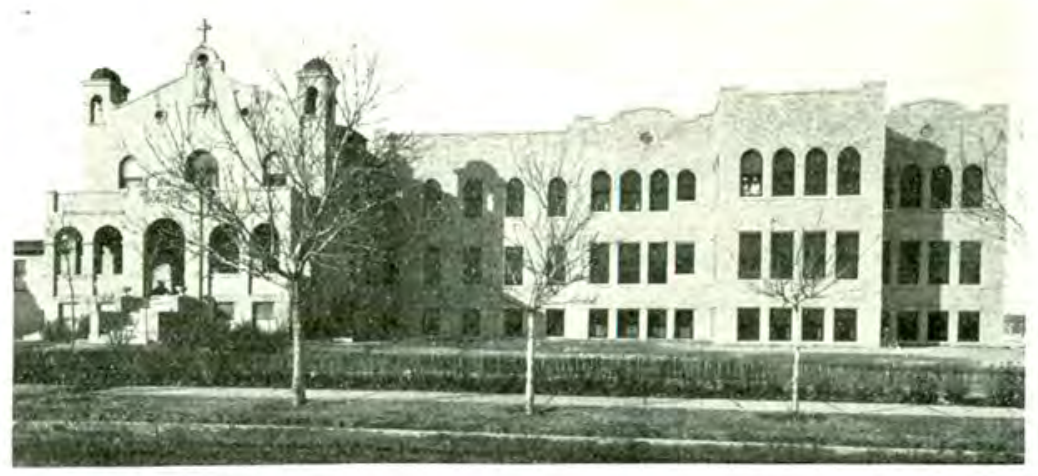

S1. JOSEPH'S HOSPITAL

the treatment of venereal disease was established in 1918, also under the superintendency of Boler. Miss Tresa Keller is the nurse in charge.

\section{Hospitals Outside of Omaha}

\section{AINSWORTH}

A. G. Rasch established a hospital of 27 beds in Ainsworth, Brown County, in 1922. It is called the Ainsworth Hospital.

\section{ALBION}

The Physicians' Hospital at Albion, with ten beds, was established in 1920. James W. B. Smith is the owner and superintendent. 


\section{ALLIANCE}

The original St. Joseph's Hospital at Alliance was built in 1910 by the Sisters of St. Francis, who have their motherhouse in Stella Niagara, New York. Due to the small number of Franciscan Sisters at that time, the Sisters of Mercy of Omaha began the work in 1911. One year later it was returned to the Sisters of St. Francis who have since conducted it. Mother M. Agatha McMullen was its first Superior. It was a modest building with room for twenty-three patients and had a staff of five doctors: Drs. H. H. Bellwood, now in California; H. A. Copsey, G. J. Hand and C. E. Slagle of Alliance; and C. E. Hershman of Alliance, deceased.

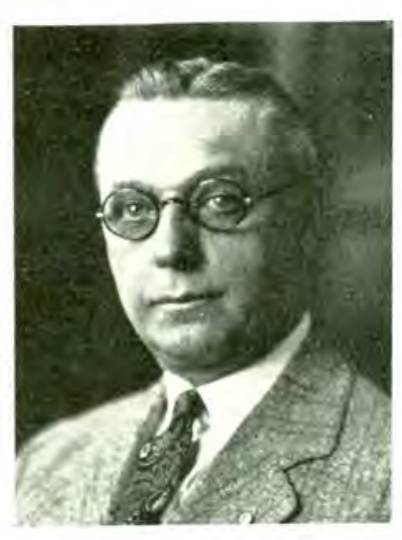

C. E. SLAGLE

During the first year eighty-four patients were recorded. In 1912 already two hundred thirty; and as every year the number of patients increased, it was an urgent necessity to erect a larger building. In the year 1916 an Executive Committee consisting of R. M. Hampton, C. A. Newberry, J. W. Guthrie, and Doctors C. E. Slagle and H. A. Copsey, appealed to the citizens of Alliance to assist in the erection of the new building to the hospital. In December the new part was finished and the additional rooms were immediately occupied.

The enrollment steadily increased until it became necessary to build again. Consequently, in June, 1925, the east wing was added, providing twenty-five more beautiful rooms, a department for maternity cases, a nursery, two sunporches, and classrooms, recreation room and library for nurses. The next building project will be a nurses' home, the plans for which are now under consideration. In 1920 a training school for nurses was opened, in 1921 it was accredited and in 1923 the first graduation took place.

Since 1926 the hospital is on the list of approved hospitals. It has 70 beds.

Former members of the staff, now located elsewhere, are: Drs. J. P. Weyrens of Scottsbluff; E. V. Blak of San Francisco, Calif.; 
M. J. Baskin of Denver, Schoch, who left for North Platte; P. Murdock of Lodgepole; J. A. Willis of McCook; Ted Riddell and Moore of Platte Valley.

Deceased members of the staff are Drs. Minor Morris who died in 1926 and A. L. Woolis, 1927.

The present staff includes Drs. Chas. S. Slagle, President; Lee Farmer, vice-president; Henry Walker, Secretary; H. A. Copsey, George. F. Johnston, John McCoy, George J. Hand, L. W. Bowman and E. I. Whitehead.

On the visiting staff are Drs. Howell of Hyannis and Gray of Broadwater. The laboratory is under the supervision of Dr. Philip Hillkowitz of Denver, pathologist. To date the patient enrollment is 1,356 , cared for by twelve Sisters and twenty nurses. Mother M. Theresa Rohrbach is the superintendent.

ALMA

Robert H. Kerr is owner and physician of the Alma Hospital of 12 beds, started in 1919. It has an out-patient department.

ARAPAHOE

The Republican Valley Hospital at Arapahoe, founded in 1906 by Dr. F. A. Brewster of Beaver City and Holdrege, was the first one in Furnas County, or in southwestern Nebraska.

ARNOLD

A ten-bed hospital was established at Arnold in 1917. F. A. Burnham is the medical director and Jane Burnham, R. N., superintendent.

\section{ATKINSON}

The Atkinson General Hospital of 14 beds was organized as a community hospital in October, 1925, by Dr. W. J. Douglas Atkinson, who, with Dr. N. P. McKee, have constituted its staff since then. Two nurses are in charge and more are employed as needed. Eighty-three patients were received the first year, 32 of whom came from outside the town, showing the need for it and the community asset. Mrs. A. Collamer is the superintendent and Mrs. Brown, R. N., the nurse in charge. 
The Atkinson Sanitarium of eight beds was started in 1903 by C. L. Sturtevant, physician and owner.

AUBURN

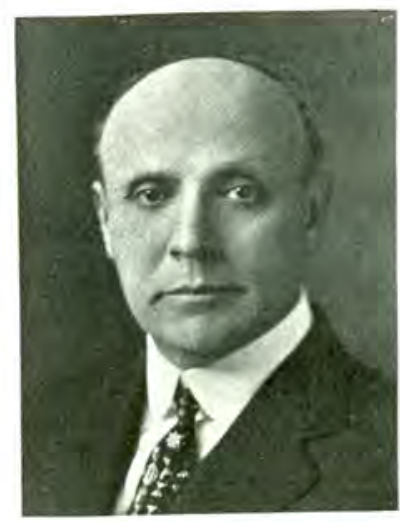

C. A. LUTGEN

The Auburn Hospital, owned and operated by Dr. C. A. I.utgen, was established October 10, 1909 in a private dwelling and continued to function in this house until 1914, when it was removed to its present home. This is a stucco and frame building erected especially for a small 10-bed hospital, equipped with modern $\mathrm{x}$-ray and laboratory, modren operating room, steam pressure sterilizer, also with elevator and food lift, drug room and chemical laboratory.

The hospital is available to any physician or surgeon. The following doctors are on its staff:
B. A. Smith
V. V. Vance
C. Graham
Edgar Cline
S. A. Van Osdel
E. M. Tyler
I. W. Irvin
A. J. Ramsey
C. A. Lutgen
Paul Sioppenbeck
N. H. Blakely

AURORA

A 25-bed hospital and out-patient department was established in Aurora in 1916. Mrs. Kathryn Shaneyfelt is the superintendent.

AXTELL

\section{Bethpage Mission}

The Bethphage Mission is a private institution owned by the Bethphage Inner Mission Association, consisting of Lutherans belonging to the Augustana Synod with headquarters at Rock Island, Illinois. Its purpose is to provide a Christian home for epileptics, feeble minded, or otherwise destitute. It was founded by Rev K. G. Wm. Dahl, February 19, 1913, at Axtell, Nebraska, where its first cottage, Tabor, was completed in the year 1916. Founded on the principle that only by following the cottage system, could a 
Christian home preserve its home-character, it has added new buildings, and intend to do so in the future, according to available funds. It has no regular endowment, and is dependent for its upkeep on free-will offerings. The institution now owns 203 acres of land and the following buildings: Tabor, for women (capacity 35); Emmaus, for men (capacity 45); Sarepta, for deaconesses (capacity 25); Garage (capacity 12 cars).

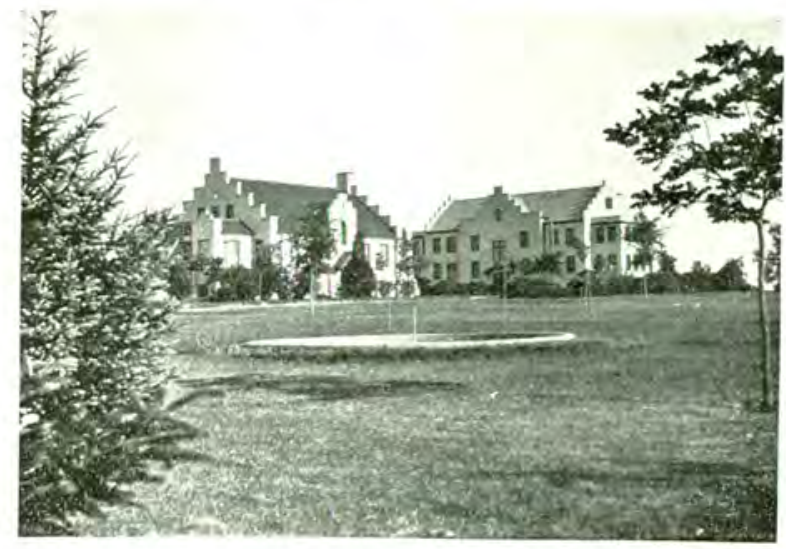

BETHPAGE MISSION

Besides these substantial cottages it owns two wooden buildings for women (capacity 21), one for children (capacity 23), a chapel, home for men workers, home for the superintendent, one for the janitor, one for Mrs. Dahl, office building, horse barn, and fine dairy barn, as well as other necessary structures. The monetary value of the mission is estimated at nearly half a million.

It has developed to be an institution of the poor and for the poor. It is mainly the poorer class of the Augustana Synod that support it. The aim has come to be to serve those for whom the state has no homes, or who would be out of place in the state asylums. They are admitted regardless of nationality or creed. Their work is carried on mainly through Deaconesses.

The Rev. Dahl died September 9, 1927, and the Rev. C. A. Lonnquist has since filled the suparintendent's office. The physician of the home is H. S. Andrews of Minden, who is assisted by E. G. Jarmin of Minden and Navill Joyner of Axtell. 


\section{BEATRICE}

Harry M. Hepperlen established the first private hospital in Beatrice in 1899, shortly after moving there from Harbine, Nebraska, where he had practiced eight years. From six beds, the hospital grew to a 50-bed institution in nine years. In 1908 it was acquired by the United Brethren Church, which built a three-story structure and added a nurses' training school. Hepperlen was retained as chief surgeon. Born in Pennsylvania, Hepperlen came to Jefferson County in 1880, was graduated from Keokuk in 1891 and has done post graduate work in Jefferson Medical College and the University of Vienna, in 1897-1898. J. C. Waddell was associated with him for a time in the Beatrice Hospital.

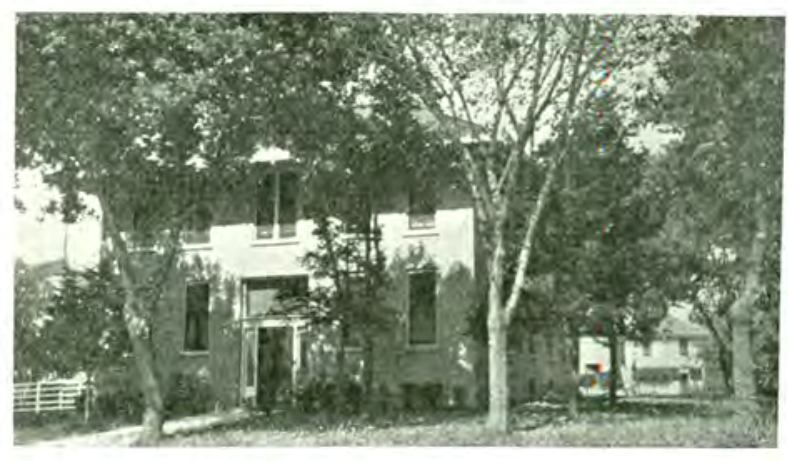

BEATRICE SANATARIUM

The Lutheran Hospital and training school superseded this institution in 1913. It now maintains 65 beds. Miss Celina Rohlfing is superintendent.

The Mennonite Deaconess Home and Hospital was established in 1911. There are 40 beds in the hospital department. Sister Magdaline Wiebe is superintendent.

Clifford P. Fall, member of the State Board of Health from 1910 to 1914, organized the Beatrice Sanitarium in 1901, in company with Dr. George Harris, now of Valley. Dr. Harris remained in the partnership for two years, since which time Dr. Fall has been sole owner. It is a private hospital, but open to all doctors of good standing. It employs eight full time nurses and has had as many as 15. A nurses' training school is also maintained, with Miss Clara Rhodes, R. N. in charge. Instructors include C. P. Fall, C. S. Curry, 
Ada Platz, Roy Noble, F. W. Buckley, Krine and Misses Clara Rhodes and Elizabeth Sandman.

The Institution for Feeble-Minded was established at Beatrice by act of the Legislature approved March 5, 1885. An appropriation of $\$ 50,000$ was made at the same time for the erection of proper buildings. The city of Beatrice donated forty acres of land to the state.

The institution received its first patients May 25, 1887. During that year sixty-five were received. Of these, two women and one man remain. He, Orion Rossman, came on the day it was opened. Total number admitted to December 1, 1927, 2,438. Of these 862 remain. One hundred fifty applications received within the past two years cannot be accepted because of lack of room.

The first superintendent was Doctor Armstrong, followed by Doctors C. P. Fall, C. W. Sprague, Emil Lang, W. H. Deering, A. Johnson, Frank Osborne, G. L. Roe, W. M. Thomas, W. S. Fast, D. G. Griffiths, S. J. Stewart, L. T. Sidwell and J. A. Burford, present incumbent.

This institution along with the other state penal and charitable institutions was originally under the control of the Board of Public Lands and Buildings, but by amendment to the Constitution in 1912 these several institutions were placed in the custody of the Board of Commissioners of State Institutions (changed to Board of Control in 1920), consisting of three members.

The first Board consisted of: Silas A. Holcomb, Howard Kennedy and Henry Gerdes. Since that time the following have served on the Board: Eugene Mayfield, Dr. B. F. Williams, Carrie M. Peterson, L. C. Oberlies, Kathryn F. Worley, A. E. Allyn, Mrs. Carrie A. Birss, E. T. Westervelt and Harry S. Thorp.

The institution farm consists of 512 acres. There are nine ward buildings, a hospital building, and the infirmary building, a general dining hall and kitchens, a school building, besides power plant, store room, barns, etc.

BEAVER CITY

The Beaver City Hospital, formerly Dr. F. A. Brewster's private hospital, was established in 1914 with ten beds and an out- 
patient department. F. A. Brewster of Holdrege is the medical director and R. D. Green, son of a pioneer Gage County physician, the resident doctor.

\section{BEEMER}

C. A. Pierson is medical superintendent of the Beemer hospital of six beds, started in 1908 .

\section{BLAIR}

A 15-bed hospital was started in Blair in 1906. Mrs. F. A. Washburn is superintendent.

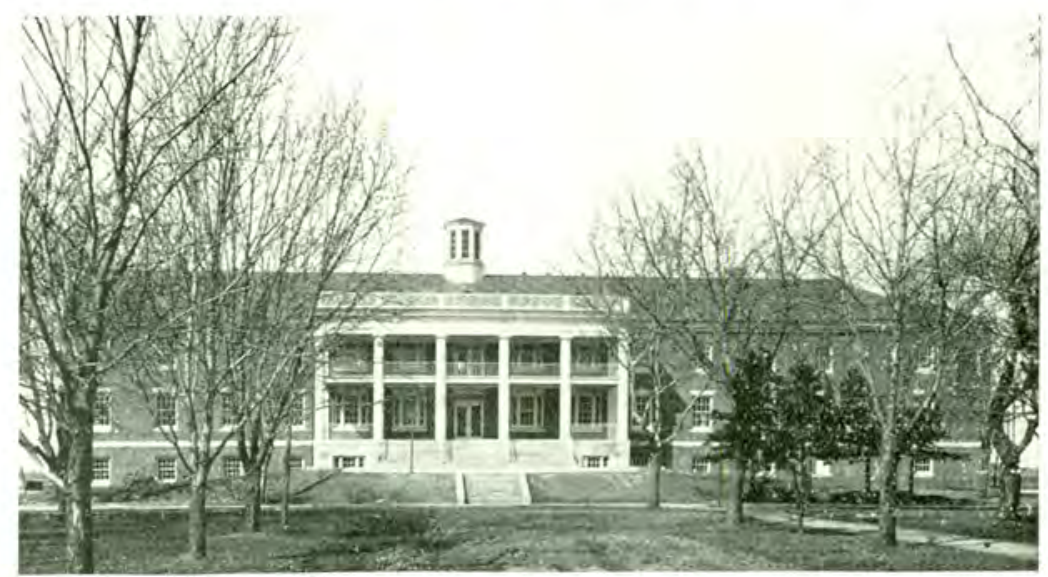

NEBRASKA SOLDIERS' AND SAILORS' HOME HOSPITAL

BROKEN BOW

The Broken Bow Hospital of 35 beds was established in 1923, with an out-patient department. Paul H. J. Carothers is the medical superintendent.

\section{BURKETT}

Nebraska Soldiers' and Sailors' Home Hospital

The first Nebraska Soldiers' and Sailors' Home Hospital, a frame building, was built in 1887. It consisted of three or four wards of ten single beds each, for men only. The whole building was primitive, without pipe water, heated with stoves and no proper ventilation in cold weather. Modern fixtures have since ben in- 
stalled, rooms partitioned and it is now used as quarters of very old men and convalescents.

The second hospital was erected about 1900. It had rooms for 60 patients, there being two single beds in 20 rooms, also four wards of four beds each, with hot and cold water. The building now contains the doctor's office, the drug dispensary and store-room for the various hospital supplies, together with rooms as a hospital annex. The balance of the building is occupied as quarters for members.

The new hospital was constructed in 1923. Modern in every respect, capacity 104 beds; hot and cold water in each room. The basement story contains two mental wards of 12 beds each. The kitchen and dining room, both models of up-to-date construction with tile floors. A diet kitchen in each story above. A day and night force of attendants is maintained.

For almost 15 years the medical service was let by contract to medical men residing in Grand Island, since which time a resident physician has been maintained. The names of all physicians who have been there can not be traced. Since 1901 there have been 15 on service for two years or less: Doctors Randall, the first, Swygert, Gordon, Griffiths, Fordyce, Wagoner, Hinchman, Chapman, Putt, Powell, Deaver and Willis J. Raynor, the present incumbent, since 1924.

\section{CAMBRIDGE}

The Republican Valley Hospital at Cambridge was started in 1906 with 27 beds. A. L. Kee, B. F. Stewart and C. Minnick are on the staff and Alice Kilburn is superintendent.

\section{CENTRAL CITY}

The J. E. Benton Hospital at Central City is operated by Dr. J. E. Benton. It has ten beds and an out-patient department.

\section{COLLEGE VIEW}

Benjamin E. Nicola is medical superintendent of the College View Sanitarium and Hospital of 40 beds, established in 1922. It was formerly the Nebraska Sanitarium, started thirty years ago. 
St. Mary's Hospital at Columbus is one of the oldest and largest hospitals in the state. Established in 1879 by the Sisters of St. Francis, it now has 218 beds. C. A. Allenburger is chief of staff, Sister M. Hubertina is superintendent.

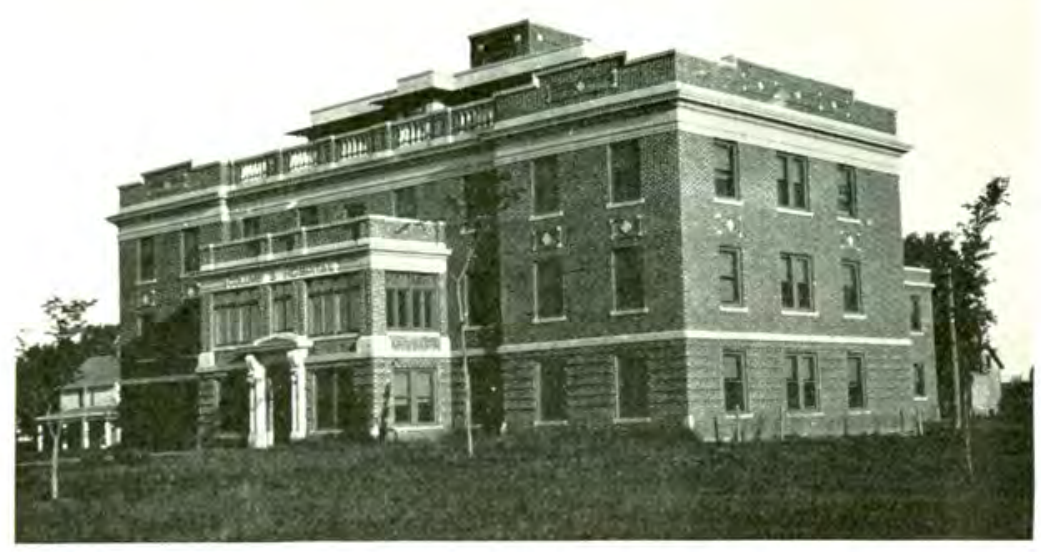

COLUMBUS HOSPITAL

The Columbus Hospital at Columbus was organized in 1922 by the Misses Emma and Mayme Matzen, both trained nurses of wide experience. The institution has a capacity of 40 beds and is open to all reputable physicians and surgeons.

CRAWFORD

R. L. Ivins Hospital at Crawford was established in 1918 by the physician whose name it bears. It has ten beds.

\section{DALTON}

PIONEER MEMORIAL HOSPITAL

The Dalton Hospital is dedicated to the memory of the pioneers of the west, who, through their hardships and by their efforts, transformed the wide, desert plains into a fertile expanse, now marked by productive farms, modern homes and numerous cities and villages.

The staff includes A. E. Hedlund, chief surgeon; R. E. Roche, C. Palmer; L. H. McNaught and Leonard Freeman of Denver, con- 
sultants; G. F. Zarbach, chief of internal medicine; Harry L. Mantor and Arthur Dunn of Omaha and J. N. Hall of Denver, consultants; George L. Strader of Cheyenne, ophthalmology; F. L. Beck of Cheyenne, oto-laryngology; and C. C. Tomlinson of Omaha, dermatology. Mrs. H. R. Zarbaugh is matron.

\section{DAVID CITY}

Started in 1901, David City Hospital now maintains 25 beds. Ottilie Schrumpf is the superintendent.

FAIRBURY

Taylor Hospital at Fairbury, started by Dr. J. S. Taylor in 1914, has 22 beds.

\section{FALLS CITY}

The Falls City Hospital is the outgrowth of a plan originated in 1916, when Dr. C. L. Hustead contemplated the building of a small private hospital which would accommodate ten patients. A conference was held with Rev. J. A. Mathiesen, the Lutheran minister of Falls City, when Dr. Hustead was persuaded to discontinue his plans in order to establish a larger institution which would be sponsored by the Lutheran churches surrounding Falls City in the states of Missouri, Iowa, Kansas and Nebraska. The organization was perfected through the aid of the Inner-Mission Board of the United Lutheran Churches of America at which time the organization was granted the privilege of soliciting funds in these states, among 252 churches.

On September 22, 1918, the corner stone for this hospital was laid with proper ceremonies. The hospital, together with the equipment and grounds, cost $\$ 120,000$. The Hospital Board was organized and the first superintendent, Miss Maude Howell, employed. It received patients early in 1919.

At this time the money for completion of the building had not been raised and due to difficulties with the management as well as professional jealousies, the financing failed. The institution was forced into bankruptcy and was sold at public auction in the fall of 1920 to the Lincoln Trust Company of Lincoln, which purchased the institution for the protection of a first mortgage which they held. It was also necessary for them to spend several thousand dollars to 
take up first mechanics' liens. The hospital title was finally cleared through the efforts of C. C. Carlson, president of the Lincoln Safe Deposit Company. Later, several attempts were made in this community to take over the institution and operate it as a community hospital, until June 1, 1921, when the institution was purchased by Dr. C. L. Hustead, who has successfully operated it since that time.

The Falls City Hospital is an institution of forty beds, is one of the most modern hospitals in the state and is the first hospital in the state under fifty beds to meet the requirements of hospital standardization. It is fire-proof, and contains fifty-three rooms. There is installed, an automatic elevator, complete sterilizing equipment, clinical laboratory, $\mathrm{x}$-ray, physiotherapy and dietetic departments. It has two well-lighted operating rooms, large modern kitchen, equipped with sterilizing dish-washing machine and other electric equipment. There is also a complete laundry.

From June 1, 1921 to June 1, 1927, more than two thousand patients had been cared for. The hospital is open to all ethical physicians and surgeons.

\section{Officers of the Staff}

$\begin{array}{lr}\text { C. L. Hustead } & \text { Director } \\ \text { Wm. Shepherd } & \text { President } \\ \text { C. P. Fordyce } & \text { Secretary-Treasurer }\end{array}$

\section{Staff Divisions}

General Surgery Consultants and Visiting Dental

C. L. Hustead

H. R. Miner

Wm. Shepherd Medicine

W, E. Shook

M. L. Wilson

G. W. Egermayer

C. A. Meadlar Pediatrics

E. R. Hayes Obstetrics

C. P. Fordyce

N. H. Blakley
Staff

J. A. Waggoner

J. C. Shepherd

G. G. Gandy

A. W. Montgomery

G. M. Andrews

Orthopedic Surgery

H. R. Miner

$X-R a y$

C. L. Hustead Pathologist

Wm Shepherd
R. D. Cole

Fred Hoffman

Urology and Diseases of the Skin

H. D. Burchard

F. A. Nelson

G. M. McArdle

Eye, Ear, Nose and

Throat

S. D. Cowan

G. W, Reneker

C. E. Novak 
The Reeves Memorial Hospital at Farnam was built in 1925, by Dr. Albert E. Reeves, surgeon who served in France, as a memorial to his mother, who died November 2, 1923. There are 18 rooms in the modern semi-fire-proof building, it has a modern operating room, electric sterilizers, a full $x$-ray and physical therapy

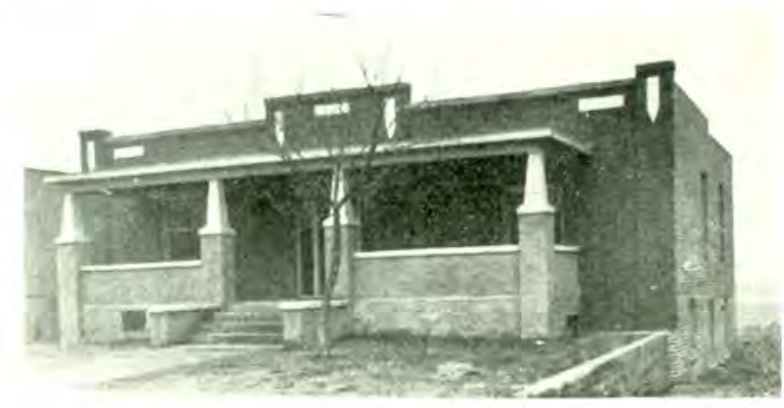

REEVES MEMORIAL HOSPITAL

equipment. The staff includes R. H. Easton of Eustis, obstetrics and gynecology; W. J. Birkoffer of Gothenberg, consulting surgeon; J. M. Liggett of Farnam, consulting physician and Alfred E. Reeves, surgeon.

\section{FREMONT}

The Military Avenue Hospital at Fremont, started in 1924, has 30 beds. Nora O'Connor White is the superintendent.

Richmond Hospital, established a year later, has 12 beds. Laura Wilson Lyman is superintendent.

GENOA

The Genoa Indian School Hospital of 30 beds, maintained for use of the 500 pupils of the school, also includes a dispensary where pupils and employees come for minor treatment and dressings. A graduate nurse is in charge. Ten student Indian girls assist halftime, in connection with their school work. A large amount of trachoma treatment is given. R. D. Balcom is the physician in charge of the hospital and health work. Sam B. Davis is superintendent of the school. 
Grand Island General Hospital, established in 1913, has 25 beds. H. B. Boyden is superintendent.

St. Francis Hospital at Grand Island was founded in 1886 under the direction of Sister Magdelene, representing the Franciscan Sisters of LaFayette, Indiana. It was conducted under her management until 1905 when Sister M. Blanche came to Grand Island and the hospital was her direct supervision until 1919. Dur. ing the years 1919 to 1925 Sister M. Huberta was Superior of the institution, and at present the hospital is managed by Sister M. Eugenia.

The original building has accommodations for twenty-five patients and is still standing. In 1911 it became necessary to increase the capacity for patients and fifty more rooms were provided for private patients, with every modern facility.

On February 1, 1920, St. Francis Hospital School of Nursing was established and offers to women qualified for the nursing profession a three year course, both theoretical and practical, which is fully accredited by the Department of Public Welfare of the State of Nebraska. At present there is an enrollment of forty-two students.

In order to meet the needs of the public the Sisters were again obliged to add another wing in 1924. All rooms are equipped with private bath, toilet and closet. Modern and well equipped operating rooms and maternity department were provided for, as well as the clinical laboratory and $\mathrm{x}$-ray department. It has 216 beds, making it one of the largest hospitals in the state.

Physicians on the staff are:
W. D. McGrath
A. H. Farnsworth
B. R. McGrath
E. E. Farnsworth
W. J. Arrasmith
F. D. Ryder
J. V. Reilly
Wm. Hombach
E. A. Watson
J. E. Giggins
$\mathrm{E}_{4}$ G. Johnson

J. E. Gelow
$\mathrm{H}$. Hatfield
Leo Phelan
R. C. Woodruff
George Leschinsky

HARTINGTON

St. John's Hospital at Hartington, with 16 beds, is directed by J. M. Johnson. 


\section{HASTINGS}

The Glasco General Hospital at Hastings has seven beds. Mrs. Anna Glasco is superintendent.

Mary Lanning Memorial Hospital at Hastings has 75 beds. It was started in 1915. J. M. Davis, president; Mrs. Edythe D. Merritt, superintendent.

The Nebraska Sanitarium was established in 1908 by the Nebraska Sanitarium and Benevolent Association. A. F. Kirk is manager. It has 30 beds.

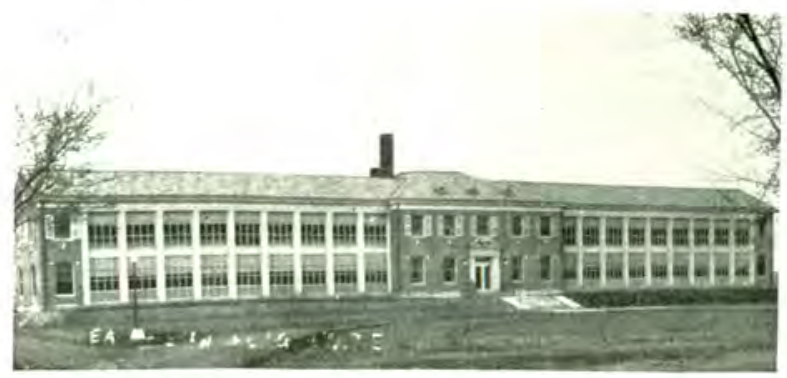

NEBRASKA STATE HOSPITAL FOR TUBERCULOSIS

HEBRON

Blue Valley Hospital at Hebron has 35 beds. It was organized in 1905. E. A. and L. B, Bowles are surgeons and owners. Kathleen Sisler is superintendent.

\section{KEARNEY}

Good Samaritan Hospital at Kearney was established in 1924 by the Sisters of St. Francis. It has 60 beds. Sister M. Hubertina is the superintendent.

St. Luke's Hospital, established in 1912, has 26 beds. It is under Episcopal control. Mrs. Myrtle B. Greene is superintendent.

A hospital for the State Industrial School for Boys was established by an act of the legislature in 1920. Surgeons to the school since its organization in 1879 include Doctors Dildine, the first; C. V. Basten, J. L. Bennett, H. S. Bell, F. A. Packard, and again J. L. Bennett, the present incumbent who has held the post for 22 years. There are on an average of 220 inmates. Only three 
deaths occurred in the past 21 years and no boy was ever sent home to avoid responsibility, according to Dr. Bennett.

The Nebraska State Hospital for Tuberculous at Kearney was established by an act of the 1911 Legislature and was opened for the admission of patients on January 22, 1912.

At the outset the home which formerly belonged to the Franks and at one time was used by Dr. S. Grothan as a hospital, was purchased together with twelve acres of ground. Shortly afterwards a pavilion of wood construction which at the present time accommodates twenty girls and twelve boys, besides a school room for them and a second story, which houses sixteen employees, was built. Following this a brick building was built. This accommodates fifty-three men and has a kitchen for both this building and the pavilion. In 1923 a two-story brick building was added. This has accommodations for forty-five patients besides kitchen and diningrooms, x-ray rooms, laboratory, etc., and is occupied by women. In addition to these buildings there also is a home which is used to house nurses, one of the doctors, and office help. Chicken houses, hog sheds, vegetable cave, coal shed and ice plant have been added. There is also a brick building which houses a boiler plant and laundry. Land at the present time amounts to 37 acres.

Superintendents who have been in charge are: Pearl F. Barker, resigned September 1, 1913; Nellie C. G. Daffenbaugh, from September 1, 1913 to November 1, 1914; Dr. E. R. Vanderslice; Dr. L. S. B. Robinson, January 14, 1916; Dr. L. T. Sidwell, June 1, 1918; Dr. J. A. Burford, September 1, 1923; Dr. L. T. Sidwell, from July 1, 1927. Assistant physicians have been Doctors Painter, Schneider, A. G. Hartenstein and Harry C .Smith. Dr. Smith has been in this position since May, 1923.

L. M. Stearns and W. E. Rose, who practice in Kearney, have acted as examining physicians. They are not connected with the institution at the present time.

The following have been second assistant physicians: Adrian L. Breen, James Fleming, Harold H. Theis, R. C. Kirkwood and J. B. Stanley.

The population at the present time is 104. The capacity is 130. Patients admitted since the hospital opened total 1,982 . 


\section{KIMBALI}

The Kimball Hospital of 20 beds was started in 1919. A. L. Miller is the physician and Mrs. Uda M. Miller, R. N. is superintendent.

\section{LINCOLN}

Frank L. Wilmeth is in charge of Esther's Hospital of 25 beds, established in 1008 .

Green Gables Sanitarium was established in 1901 by Dr. Benjamin F. Bailey, formerly president of the state board of health. It has 119 beds and an out-patient department. A large staff is maintained.

Lincoln Hospital, at 315 North 14th Street, was established in 1904, with an outpatient department. It has 34 beds.

Lincoln Sanitarium, 1401 M Street, was established in 1893 and has 100 beds. O. W. Everett is medical director.

The Roeder Maternity Home and Hospital in Lincoln has 14 beds. It contains a home for the aged and maternity cases. Mrs. H. T. Roeder is superintendent.

St. Elizabeth's Hospital, established in 1889 by the Sisters of St. Francis is perhaps the oldest hospital in Lincoln. It has 200 beds. E. G. Zimmerer is the medical director and Sister M. Hedwig, superintendent.

The Isolation Hospital, started by municipal authorities in 1900 for the care of small pox patients has 16 beds. Chauncey F. Chapman is the superintendent.

Dr. Shoemaker's private hospital was established in 1908 with 15 beds. C. A. Shoemaker is the owner.

\section{Lincoln General Hospital}

Lincoln citizens interested in the idea, met December 6, 1910, at the Lindell Hotel to consider the establishment of a public hospital. Present were: J. E. Miller, W. E. Hardy, C. W. Bryan, A. L. Candy, Don L. Love, Charles Mayer, J. J. Teeters, C. E. Prevay, C. J. Bills, W. H. Ferguson, T. M. Shipherd, A. L. Weatherly, Rev. H. R. Chapman, and doctors H. I. Lehnhoff, I. 
S. Cutter, J. S. Spealman, H. W. Orr, S. E. Cook, A. D. Wilkinson and H. J. Winnett.

At a meeting held December 29, 1910, the first permanent officers were elected as follows: C. J. Bills, president; J. E. Miller, vice-president; A. L. Weatherly, secretary; S. H. Burnham, treasurer.

Articles of incorporation were prepared and filed in due time. A bond issue of $\$ 100,000$ was voted by the city, with the provision that when the Lincoln Hospital Association raised $\$ 100,000$, the bond should be issued by the city to aid in the building of said hospital.

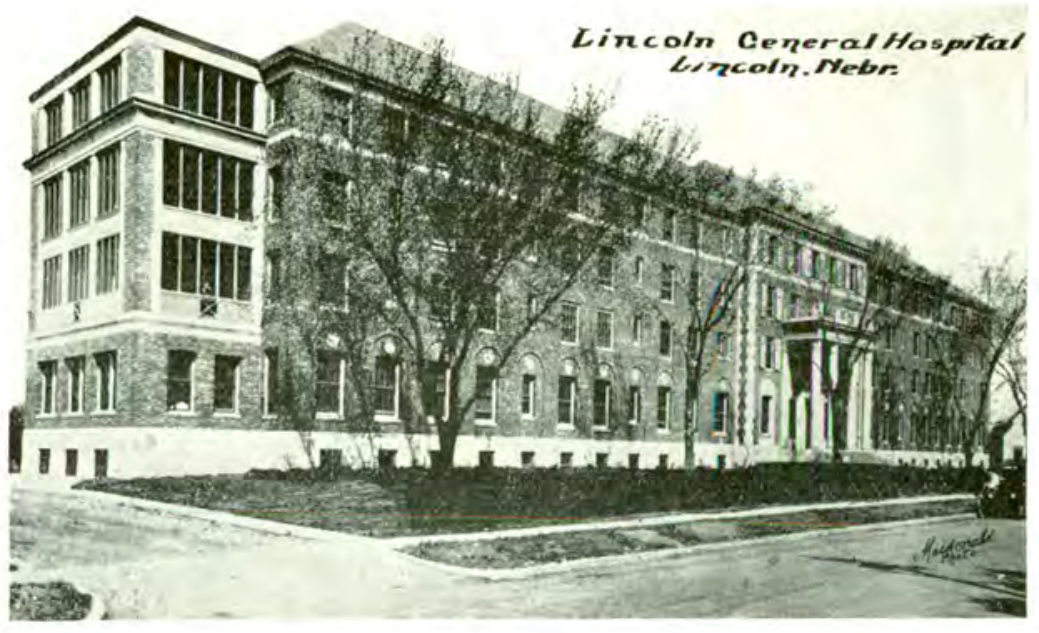

LINCOLN GFNERAL HOSPITAL

At that date the Lincoln Hospital Association had raised in round numbers $\$ 125,000$, not including the bequest of $\mathrm{R}$. E. Moore who left $\$ 100,000$ for the Emily J. Moore Annex.

On February 28, 1921, the City Council appointed the following persons as members of the Hospital Board: For the term of six years: Miss Ida Robbins, W. E. Barkley. For the term of four years: Mrs, Louise Westerman, Mrs. Pauline F. Wessels, H. B. Grainger. For the term of two years: Mrs. W. H. Ferguson, Robert E. Moore, W. R. Mellor. 
On January 18, 1922, the following officers were elected: L. L. Teeters, President; W. E. Barkley, vice-president; Ida L. Robbins, secretary; W. R. Mellor, treasurer.

In January, 1922, Mrs. Emily Moore was appointed a member of the board to succeed her deceased husband, Mr. R. E. Moore.

Mrs. W. H. Ferguson resigned as a member of the board in March, 1922. Mr. J. E. Miller was appointed to fill the vacancy.

The board in January, 1923, was as follows: J. L. Teeters, Miss Ida Robbins, W. E. Barkley, Mrs. Louise Westerman, H. B. Grainger, Mrs. Pauline F. Wessels, W. R. Mellor, J. E. Miller, Mrs. Emily Moore. O. J. Fee, who had been secretary of the Lincoln Hospital Association for some time, was made secretary of the Lincoln General Hospital.

This board continues the same to the present time, excepting that Joseph Grainger was appointed to fill the vacancy caused by the death of H. B. Grainger. J. L. Teeters was re-elected. He has been president ever since the board was organized in 1922.

The present location of the hospital was decided on May 25, 1922. The hospital was complete and open to receive patients March 24, 1925. The cost, fully equipped, was $\$ 400,000$ and it has accommodations for 149 patients. The total number of patients admitted up to December 13, 1927, was 6,366.

Mrs. Gladys G. Smits was chosen superintendent in November, 1924, her term to begin January 1, 1925. A training school for nurses was established and at the present time there are 42 students enrolled, and 10 graduate nurses are employed as heads of different departments.

The hospital has an organized staff of 24 menibers, which is made up of the following: Doctors J. M. Mayhew, Chief of Staff; F. F. Teal, Secretary and Treasurer; C. F. Andrews, W. O. Colburn, George Covey, Earl Deppen, Clarence Emerson, H. Flansburg, M. O. Frazier, C. C. Hickman, T. Moyer, A. D. Munger, I. C. Munger, H. W. Orr, S. O. Reese, F. L. Rogers, E. W. Hancock, E. S. Wegner, Roy Whitham, J. M. Woodward and Stanley Zemer.

The staff holds semi-monthly meetings on the first and the third Monday in the month, following a staff dinner at the hospital. 
A round-table luncheon is held every Friday noon at the hospital for staff members and any other visiting doctors who wish to attend the meeting.

\section{Bryan Memorial Hospital}

William Jennings Bryan deeded his beautiful home at Fairview, with ten acres of ground, to the trustees of the Lincoln Methodist Hospital early in the spring of 1923. In October, architects were employed and the study of plans begun, which resulted in the adoption of the ground floor plan and unit system of construction.

Following the death of Bryan, who in this gift made the largest single contribution he ever gave to any institution, the name of the hospital was changed from Lincoln Methodist to Bryan Memorial Hospital of the Methodist Episcopal Church.

The Bryan home has been repaired and redecorated and is used as a home for the nurses and personnel. Five acres additional land have been purchased on the east, adjoining the original tract and home site, where will be located additional buildings as dormitories and training school for nurses as soon as available funds can be secured.

The following Lincoln business men comprise the officers: A. R. Talbot, president; Geo. E. Hager, vice president; A. W. Miller, secretary; Eli Shire, treasurer. Physicians on the staff include:

\begin{tabular}{|c|c|c|}
\hline Chief of Staff & J. J, Loomis & J. S. Welch \\
\hline E. W. Rowe & O. Olson & C. C. Hickman \\
\hline Internal Medicine & F. T, Wright & E. E. Rider \\
\hline G. W. Covey, Chairman & G. H. Walker & R. C. Olney \\
\hline H. J. Lehnhoff & Jesse Taylor & C. H. Arnold \\
\hline F. L. Rogers & E. R. Ryerson & Ophthalmology and Oto- \\
\hline H. E. Flansburg & J. M. Neely & Laryngology \\
\hline T. C. Moyer & R, Crook & E. Brooks, Chairman \\
\hline S. C. Clements & E. N. Deppen & F. F. Teal \\
\hline R. B. Adams & Ruth Warner & J. J. Hompes \\
\hline E. B. Reed & W. G, Rickard & J. M. Woodward \\
\hline J. C. Thompson & Surgery & Paul Black \\
\hline General Medicine & D. C. Hilton, Chairman & W. $\mathrm{L}_{1}$ Curtis \\
\hline H. A. Taylor, Chairman & C. F. Andrews & W. L. Albin \\
\hline E. D. Cummins & E. B. Finney & Stanley Zemer \\
\hline C. L. Fahnestock & K. S. J. Hohlen & W. M. Elliott \\
\hline Chas. Harms & F. B. Hollenbeck & Pediatrics \\
\hline F, B, Johnson & Clarence Emerson & E. V. Wiedman, Chair. \\
\hline
\end{tabular}



A. D. Munger
Orthopedics
Neuropsychiatry
E. M. Hanock
J. E. M. Thompson,
E. S. Wegner
Chairman
B. F. Williams, Chairman
Obstetrics
Urology and Dermatology
$X-R a y$
W. C. Becker, Chairman
E. E. Angle, Chairman
J. J. Snipes
E. W. Rowe
D. J. Bowman
Acting Superintendent
Myrtle Dean

A. D. Munger

\section{Nebraska State Orthopedic Hospital}

The first agitation for a state hospital for crippled children was started by Dr. Lenore Perky, (afterwards Webster), of Lincoln, in a paper read before the State Homeopathic Medical Society at Oma-

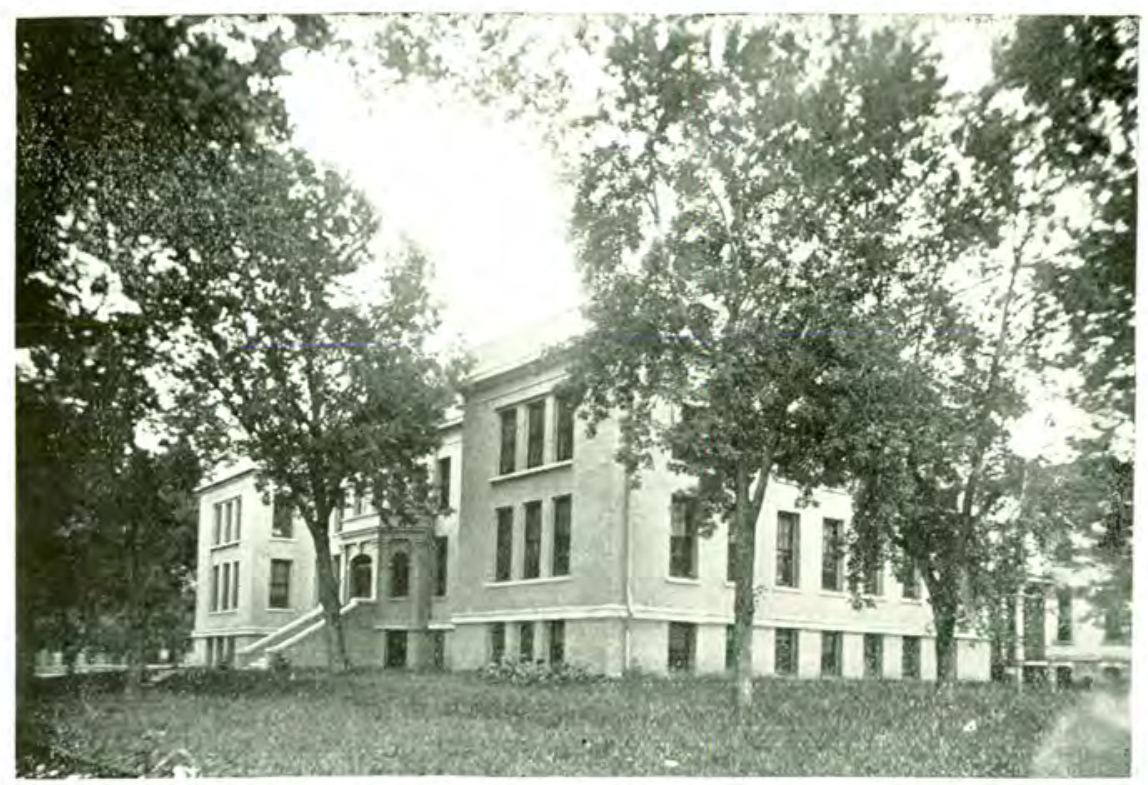

NEBRASKA STATE ORTHOPEDIC HOSPITAL

ha in 1902. Friends of such a measure were soon found and a bill drawn which was presented by Hon. J. H. Casebeer of Blue Springs to the legislature of 1905 . The bill named $\$ 25,000$ as a sum to be appropriated for the establishment and maintenance at the Home for the Friendless, a hospital for crippled, ruptured and deformed children. In his message, Governor Mickey recommended that the Home be moved to Milford, where there was plenty of land, adequate buildings and room to spare for the orphan children, wards of the 
state. This proposal did not meet with favor and the home was retained at Lincoln. Various influences combined to reduce the proposed appropriation to $\$ 10,000$ for two years, and the bill passed. John Prentiss Lord of Omaha, orthopedic surgeon, was chosen superintendent May 18, 1905 and he chose H. Winnett Orr of Lincoln as his assistant. Lord continued as orthopedic consultant until 1917. The building was not ready for patients until October, 1905, though the first patient was admitted September 21, 1905. Miss Anna E. Hardwick, a graduate of, and for five years employed in, the Hospital for Ruptured and Crippled in New York City, was secured as head nurse, on the recommendation of four prominent physicians. Having so experienced a person to carry on this important work of the institution was a great factor in rendering the work efficient from the start. The number of patients grew from six on October 1 to 28 the following May 1. The number of cases treated and the character of the work compared favorably with two other state orthopedic hospitals in Minnesota and New York.

Orthopedic appliances, a school and industrial department where children can be taught simple occupations has been added in the years since then. Nebraska was the third state in the Union to establish an orthopedic hospital.

According to Dr. Inez Philbrick, Dr. Lenore Perky first became interested in institution problems while her mother was superintendent at the Industrial Home at Milford and later, as a physician at the Home for the Friendless. Here she hecame greatly concerned for the needs of two crippled children in that institution. She discussed these needs with Mrs. L. W. Pomerene, a member of the board, also with a Mr. Davis, secretary of an advisory committee, who reported to the governor that there were 73 cripples in the poor farms of the state, unable to attend school and receiving no treatment.

Learning of the New York Orthopedic Hospital, the first of its kind in the country, she determined she would visit the hospital on a contemplated trip east, which she did, and came back filled with enthusiasm. She then wrote to Dr. Gillette, superintendent of the Minnesota Orthopedic Hospital at St. Paul and received a very helpful pamphlet giving the results of its work with photographs before and after treatment. Dr. Perky and Mrs. Pomerene then got to- 
gether a committee which roughly drafted the bill, At first the institution was put under the regents of the state university but when this was found illegal, control was vested in the Board of Public Lands and Buildings. An attorney was engaged to prepare the bill in proper form and Casebeer introduced it.

The committee which drafted the bill included Dr. Perky, Dr. E. A. Carr, J. H. Casebeer, Cora Garber and latterly, H. W. Orr. Dr. Perky and Mrs. Pomerene lobbied early and late before committees in both houses of the legislature, aided by Miss Garber, Dr. Carr and Dr. E. B. Finney until the bill passed. The next session of the legislature, they lobbied still further, obtaining an appropriation of about $\$ 50,000$ for the next two years.

Miss Hardwick, the superintendent of nurses, was not only a capable executive, but a mother to the children and undoubtedly a very great aid to the surgeons of the hospital, engaged in, to them, a new field, according to Dr. Philbrick.

The legislature of 1913 appropriated $\$ 45,000$ for the erection of a new building, which was occupied the following year. This increased materially the facilities for the rehabilitation of hundreds of crippled children.

Today the hospital has a capacity of 100 beds and due to improvements under way, will have a capacity of 125 beds.

Officers who served up to this date are: H. W. Orr, superintendent, 1905 to 1917; John P. Lord, chief surgeon, 1905 to 1917; W. H. Crutcher, superintendent, 1917 to 1918; A. I. McKinnon, orthopedic surgeon, 1918 to 1919; B. A. Finkle, superintendent, 1918 to 1921 ; H. W. Orr, orthopedic surgeon, 1919 - still holds position; Jay H. Matthai, superintendent, 1921 - still holds position.

LYNCH

The Lynch General Hospital was established in 1922. It has 20 beds. R. E. Kriz is the owner and medical director.

$\mathrm{MC} \mathrm{COOK}$

\section{St. Catherine's Hospital}

Urged by the necessity to aid suffering humanity and knowing the worth and loyalty of Dominican Sisters in his parish as teachers, Father Kunz, then pastor of St. Patrick's Church, McCook, appealed 
to St. Catherine's, the motherhouse of the order for laborers to take up the work of nursing and management of the newly proposed hospital.

A council was held by the Sisters and the proposition decided on and finally accepted. On August 12, 1921, Sister M. Pius, with a companion Sister, was sent to take charge of the work, arriving in McCook on August 13 and assuming charge of the hospital on August 15, 1921.

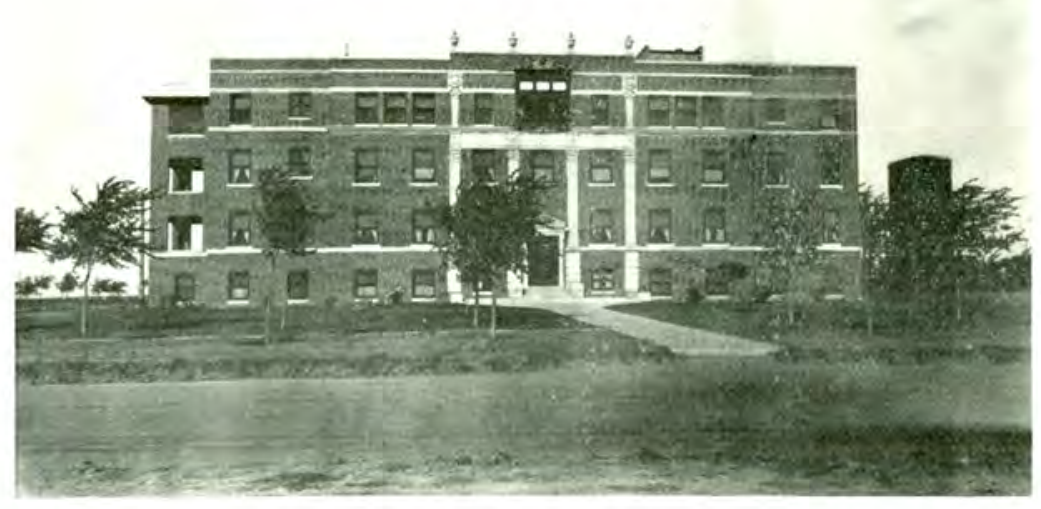

ST. CATHERINE'S HOSPITAL

An old residence which had been serving as a hospital was rented to serve temporarily until the new buildings could be erected. This was a two-story frame structure and some of the rooms were not even plastered but lined with paper. There were six rooms on the first floor to be used as Chapel, dining room and kitchen and the remaining three for maternity cases. The second floor consisted of an operating room and five rooms for surgical and medical cases. The sisters put twelve beds in these rooms and at times had to put up a cot to accommodate a patient.

The doctors practicing in the hospital at the time of the opening were:
C. L. Van Stock
L. B. Swaggert
W. E. Knox
R. R. Reed
Elizabeth Hohl
J. M. Willis
F. Demay
Z. L. Kay
G. A. DeMay
Shappierre
Curtis 


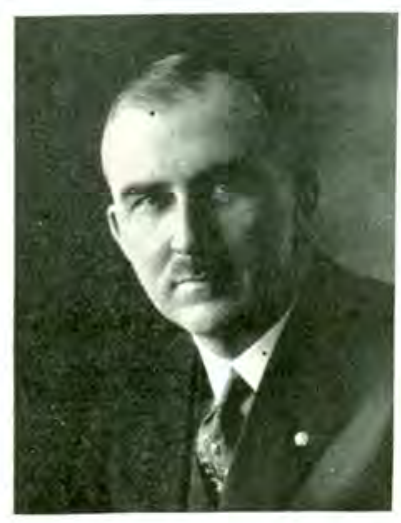

J. M. WILLIS

The new hospital was completed July 25, 1923, and the formal opening took place on September 23. It contains eighty rooms and a capacity for fifty beds. There are three operating rooms, one for major operations, one for minor opsrations and a third for eye, ear and nose work. The $x$-ray installation is the very best in its line.

Formal dedication of the hospital tock place on October 18 at 10 o'clock followed by Pontifical High Mass in the Chapel.

On February 21, 1924, Father Moulinere addressed the Chamber of Commerce. In the evening the doctors held a meeting for the purpose of organizing a staff. The officers elected were:
R. R. Reed, President Sr. M. Pius
Nursing Committee
G. A. DeMay, Secretary Sr. Odilia
Z. L. Kay
Executive Committee
Records
E. M. Easterday
W. E. Knox
Dr. Elizabeth Hohl
L. B. Swaggart

J. M. Willis

The training school opened in September, 1924 and the first graduation exercises were held September 9, 1827. The school became affiliated with St. Elizabeth's Hospital in February, 1927. Doctors practicing in the hospital at present include:
J. M. Willis,
Brown
Morgan
W. E. Knox
G. A. DeMay
Z. L. Kay
Hill
R, R. Reed, Record
Folsom
Leininger

Three thousand patients have been cared for in the six years since the hospital was established.

MILFORD

The Milford Hospital was established in 1914 with eight beds. Frank Wilsey is superintendent.

\section{NEBRASKA CITY}

The Community Hospital at Nebraska City has 16 beds. Charlotte A. Ganzel, R. N., is superintendent. 


\section{St. Mary's Hospital}

The new St. Mary's Hospital at Nebraska City, opened February 13, 1927, is a fine example of community enterprise, citizens having raised one-half of the $\$ 150,000$ building fund. Franciscan Sisters furnished the other $\$ 75,000$ and conduct the institution, in which rooms have been furnished in honor of Nebraska City pio-

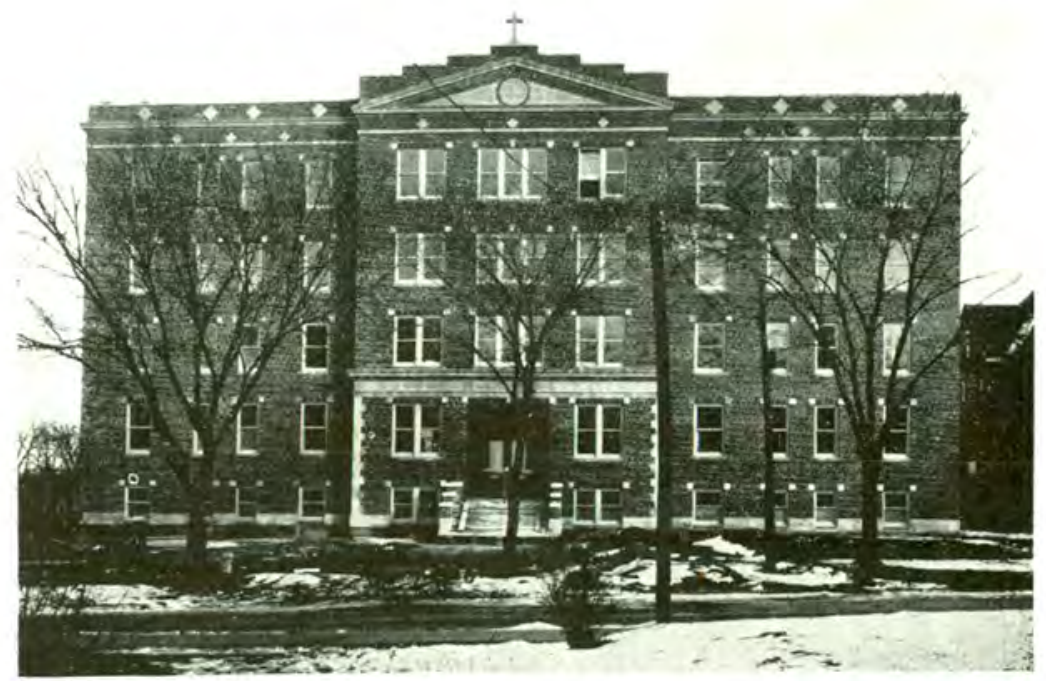

ST. MARY'S HOSPITAL

neers like J. Sterling Morton. It is a five-story, fireproof edifice, modern in every respect, and equipped to meet all requirements of the American College of Surgery. The bed capacity is 35 and 740 patients were cared for, during the first year of operation.

Sisters of St. Francis, whose mother house is at Maryville, Missouri, also built hospitals in Hanniball, Missouri and Oklahoma City, Oklahoma. They incorporated under Nebraska law, for the purpose of founding the Nebraska City Hospital. No medical staff or training school has yet been organized, the institution being open to all reputable practitioners. Sister M. Ursula is the resident Superior. William H. Pitzer and J. H. Sweet of Nebraska City were active in the movement to found the hospital. 
NEWMAN GROVE

The Community Hospital at Newman Grove, started in 1920, has 11 beds. Frank Jensen and G. H. Morris are the physicians and owners.

\section{NORFOLK}

\section{Norfolk City Hospital}

The Norfolk City Hospital was established in 1914 with 26 beds and an out-patient department. C. R. Mullong is medical director and E. G. Mullong, R. N., superintendent.

\section{Lutheran Hospital and School of Nursing}

The Lutheran Hospital is located in a beautiful section of the city of Norfolk, and has a capacity of fifty beds. A nurses' train-

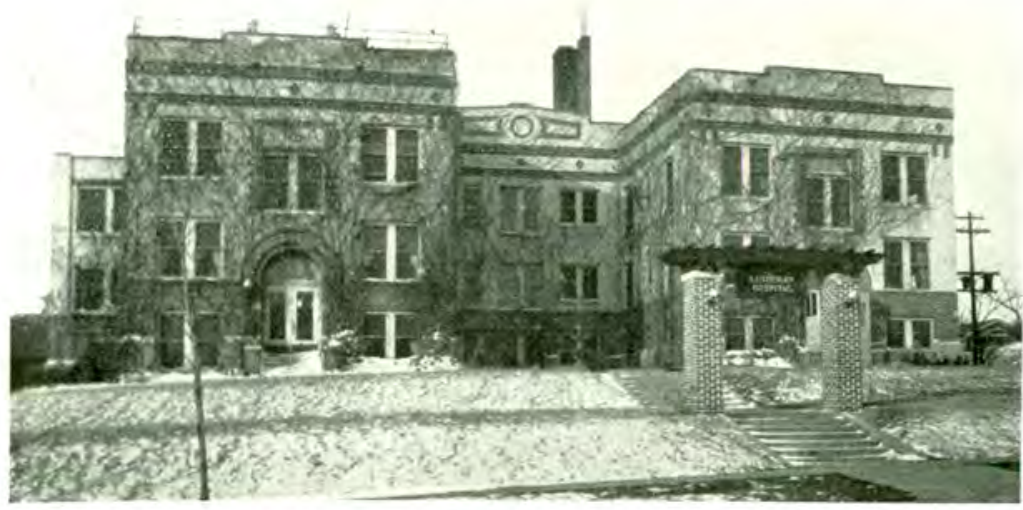

LUTHERAN HOSPITAL, NORFOLK

ing school is conducted in connection with it, and young ladies be tween the ages of eighteen and thirty-five who have finished a course of two years at high school (graduation is preferred) may apply for admission. The hospital is controlled by the Lutheran Hos pital Association of Norfolk and vicinity.

The institution was built by Dr. S. A. Campbell in 1919 at a cost of $\$ 200,000$ and the Association assumed control in the year 1923 with the purpose of providing a general hospital open to all patients (except those afflicted with contagious disease) and to all reputable physicians and surgeons. It has three operating rooms, 
a well-equipped laboratory, $\mathrm{x}$-ray, an obstetrical department with delivery room and nursery, a nurses' home which can accommodate thirty students, and a laundry sufficiently large to meet the demands of the hospital.

Miss Marie Waechter, R. N., is the present superintendent, and the executive board includes Rev. M. E. Mayer, C. F. W. Filter and Fred Bruhn.

\section{Norjolk General Hospital}

The Norfolk General Hospital was organized in 1897 by Doctors P. H. Salter and F. G. Salter, as a private institution. It was first located on Norfolk Avenue in a double house which was ar-

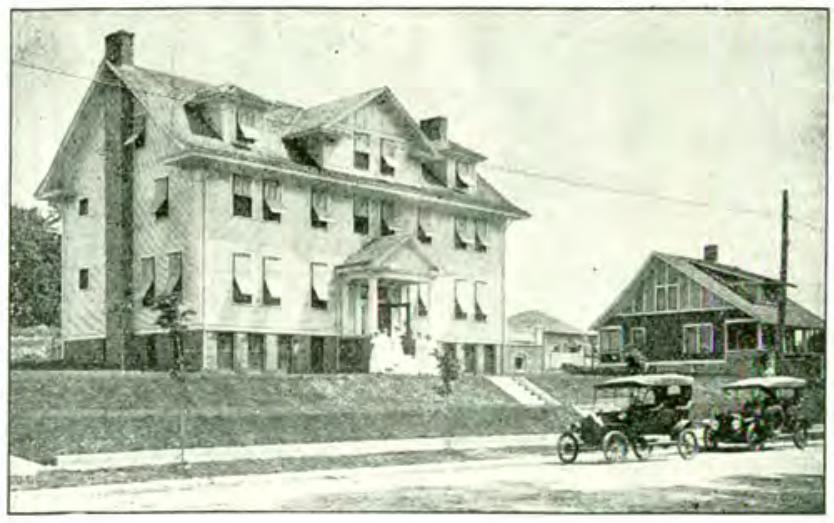

NORFOLK GENERAL HOSPITAL

ranged for hospital purposes. In 1900 it moved to Koenigstein Avenue where a new hospital building was erected; and later moved to Norfolk Avenue and 10th Street where it was maintained until 1914, when the present building at 1502 Norfolk Avenue was erected. In 1913 Dr. E. L. Brush was taken into the partnership.

Miss Jean E. Keyes was the first superintendent and served 10 years. Miss Margaret Wakeman is the present superintendent. A training school of twelve nurses was maintained from 1914 until January, 1927. Now, graduate nurses only are employed.

\section{Verges Sanitarium}

Carl J. Verges operates a ten-bed private sanitarium at Norfolk, equipped for hydro- and physical therapy, surgery and obstet- 
rics. He completed his medical studies in Germany. He was formerly mayor of Norfolk and has been city physician since 1925 .

\section{NORTH PLATTE}

The Platte Valley Hospital was established at North Platte in 1913 , by E. W. Fetter, the owner and physician. It has 14 beds.

Wurtele Hospital was established by Dr. Fred J. Wurtele in 1922. It has 12 beds.

The Redfield-Dent Hospital was established in July, 1925, by Doctors J. B. Redfield and .. B. Dent. It is open to the medical profession and has no definite staff. The hospital has 14 beds, is

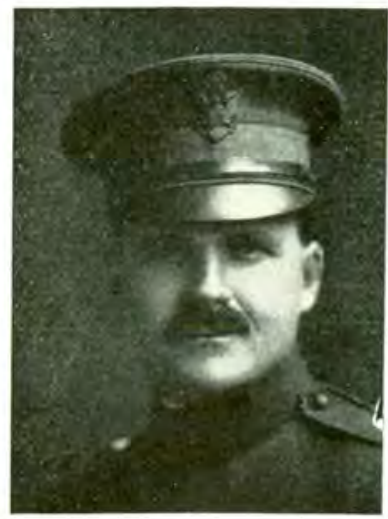

J. B. REDFIELD

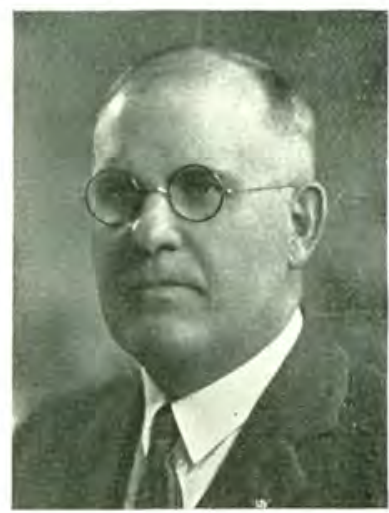

C. J. MiLleR

modern in every particular and is equipped with the latest sterilizing equipment, apparatus for treating fractures and $x$-ray. Both doctors are the superintendents.

\section{ORCHARD}

Dr. David Livingstone Fletcher operates his own hospital at Orchard, Nebraska. It is called the Orchard Hospital and has 11 beds. Mary Clemens, R. N., is superintendent of the institution, which was started in 1918.

ORD

The Ord Hospital was started by Dr. Clinton J. Miller in the Spring of 1917, when he equipped a large residence in the center of town. This building was soon outgrown. In 1919 a new, modern 
brick building was erected on the location of the old, the first patients being admitted in July, 1920. The hospital is three stories high and has a capacity of 20 beds. It is owned entirely by Dr. Miller and the work is mostly surgical. Equipment includes an $\mathrm{x}$-ray laboratory and all modern needs. Phyicsians active in the development of the hospital include F. A. Barta, H. S. O'Neill, E. E. Clark, E. J. Smith, C. E. Pinkney, Lawrence Barrett, D. R. Lee, S. A. Osheroff, P. G. Howes and Henry Norris.

Robert A. Billings of Comstock maintained a hospital at Ord for 12 years.

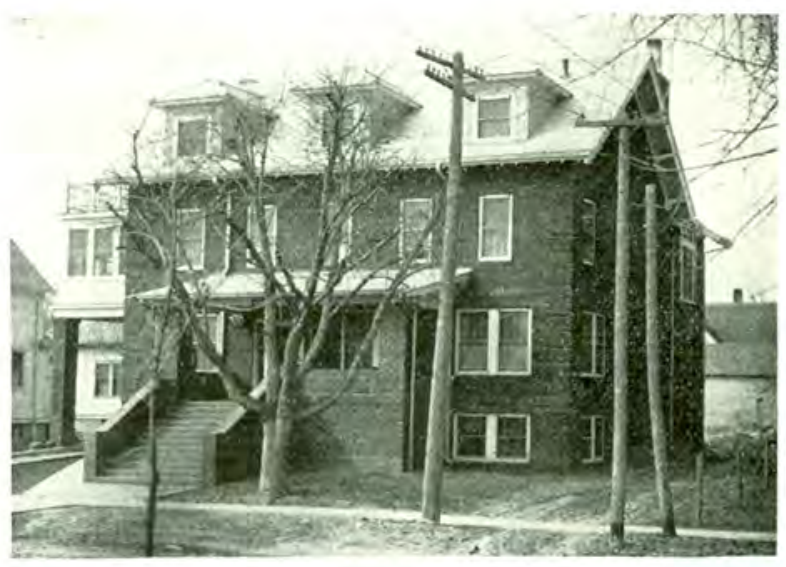

ORD HOSPITAL

PALMER

Coolidge Hospital, located in Palmer, was founded in 1916 by Charles Coolidge, a local philanthropist. Much assistance was given to him by Dr. C. S. Minnich, T. R. Lambert, Alfred Nicholas, Perry Gage and many other prominent citizens of Palmer and vicinity, both in work and money.

Coolidge then devoted the greater part of his fortune to founding an endowment fund for the hospital to insure its proper care and development.

The hospital is now equipped with a splendid x-ray machine of latest design and pressure sterilizers of the most modern design. It is open to all physicians and is under the management of a board of 
directors, including: Alfred Nicholas, president; M. V. Lambert, secretary-treasurer; Perry Gage, Lafe Simonson and Lee Nicholas.

PAWNEE CITY

The Pawnee Hospital had its inception November 22, 1913, when an organization made up of the physicians of the city was or-

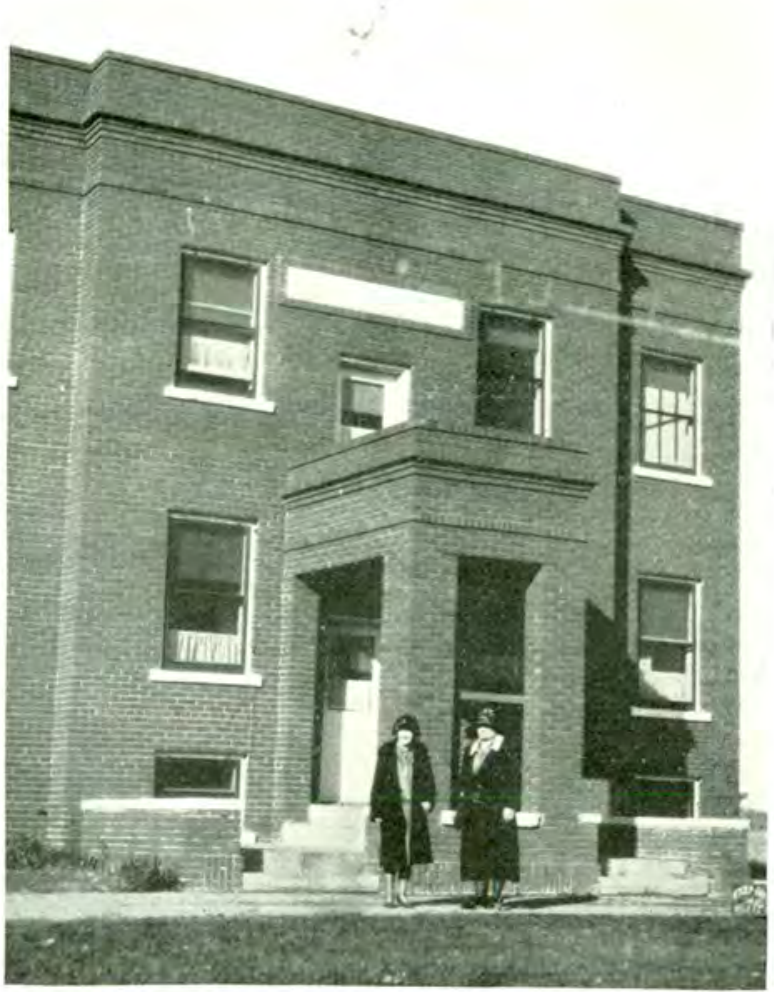

COOLIDGE HOSPITAL

ganized under the name of The Pawnee Hospital Association, with J. C. Waddell, president; W. T. Johnson, vice-president; Earl V. Brooks, secretary and W. R. Boyer, treasurer.

A suite of steam-heated rooms which had been occupied by the public library was secured, and an operating room outfit, together with furniture to equip three rooms was installed. Diets were pre- 
pared at a nearby cafe.. No regular nurses were employed, each case being taken care of by a special nurse secured at the time of entrance.

This arrangement was continued with fair satisfaction until the fall of 1916, when a hotel building was altered into a fairly modern hospital. Additional equipment was added and it opened to the public as the Pawnee Hospital.

Since that time, various additions in rooms and equipment have been made until now there are 23 patients' beds in the main hos-

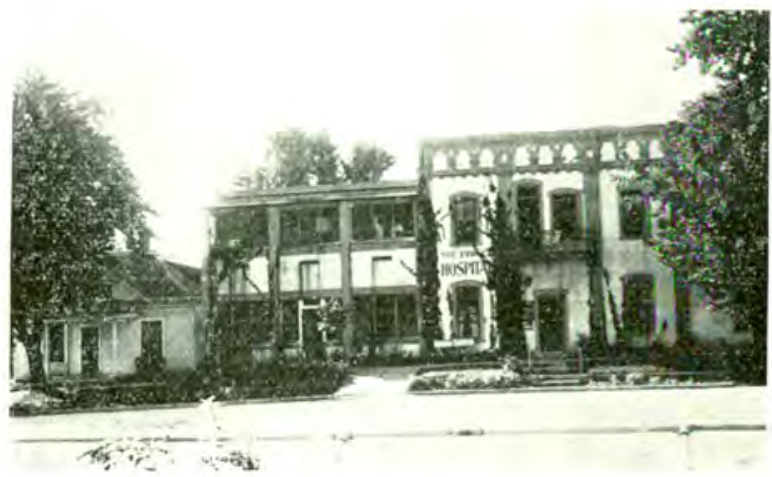

PAWNEE HOSPITAL

pital building. Through the beneficence of Miss Bessie Loch who presented to the hospital during the past year an adjoining cottage, a maternity annex with five beds is conducted.

With the advent of the World War, Brooks and Waddell enlisted returning after a year or more of service in France with the rank of major. Neither returned to Pawnee City, however, Waddell going to Beatrice to become identified with the Hepperlin Clinic and Brooks to Lincoln where he is a prominent oculist and aurist. During the war, Drs. Johnson and Boyer, being the only members of the profession left in the city, conducted the work of the hospital as best they could until December 16, 1918 when there occurred the lamentable death of Johnson in his car while on the way to see a patient in the country. Boyer then secured the assistance of F. S. Salisbury, a recent graduate from the University of Nebraska College of Medicine at Omaha, and Dr. Dodds from the nearby town 
of Summerfield, who remained until the following spring, at which time Paul J. Flory, recently out of the naval service, and a few months later, A. Byford Anderson, just finishing an internship in the University Hospital, became members of the firm then organized under the name of The Pawnee Medical Unit, which supplanted the original Pawnee City Hospital Association.

The personnel of this firm remained the same until 1926 at which time Dr. Leo D. Harman of Table Rock, who had also returned from France and been discharged from the A. E. F. with a major's commission, was added to the firm and these, together with Dr. Boyer, the only remaining member of the original association, make up the present membership.

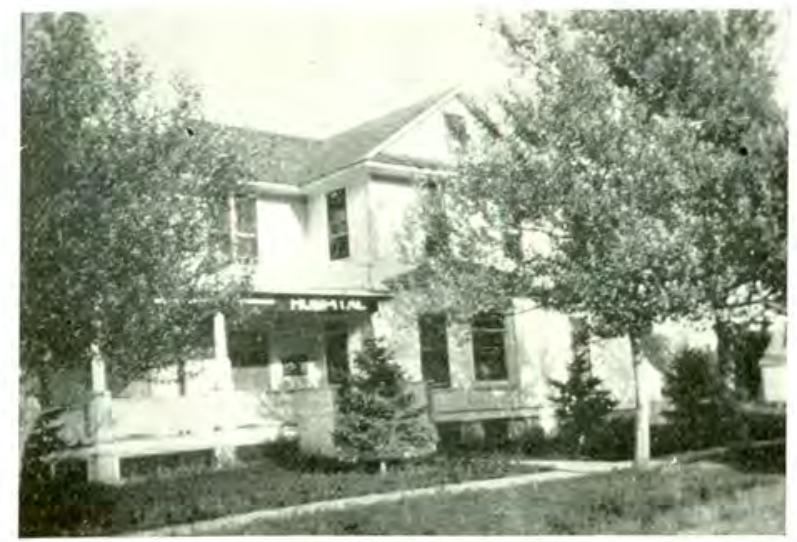

W. H. CRAWFORD HOSPITAL

The patronage of the hospital has gradually increased until during the past year 854 patients were admitted. Twenty-one full time employes are required, fourteen of whom are on the nursing staff under the supervision of Mrs. Alta Leonard, R. N., Omaha Methodist, 1919.

\section{PENDER}

Logan Valley Hospital was established at Pender in 1912. It has eight beds. John Buis is medical director.

PLAINVIEW

Plainview General Hospital has nine beds. Etta Falconer, R. $\mathrm{N}$., is superintendent. 
PLATTSMOUTH

The Nebraska Masonic Home at Plattsmouth, established in 1903 for dependent Masons and their families, has 40 hospital beds. R. P. Westover is the attending physician and W. F. Evers, superintendent.

RED CLOUD

The Red Cloud General Hospital was started in 1925 with seven beds. Mrs. W. H. French is superintendent.

RUSHVILLE

Crawford Hospital owned and founded by Dr. W. H. Crawford.

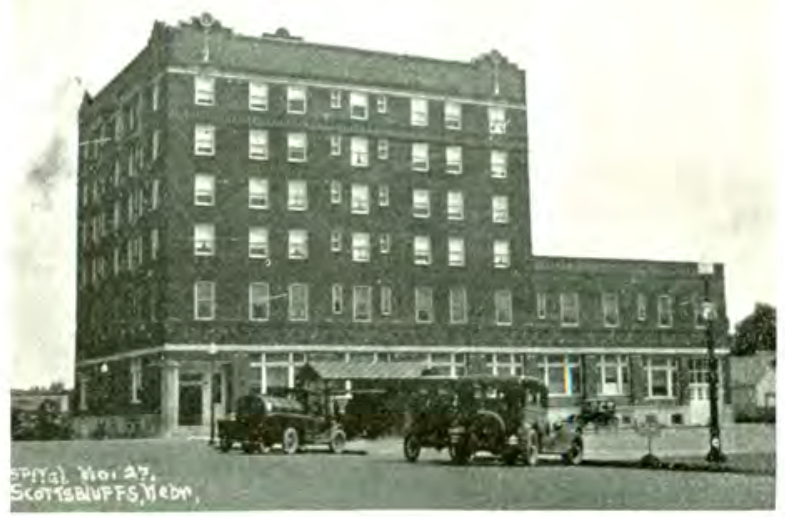

WEST NEBRASKA METHODIST EPISCOPAL HOSPITAL

\section{SCHUYLER}

Dr. F. G. Kolouch established the Kolouch Hospital in 1922 for surgical use. It has 14 beds.

\section{SCOTTSBLUFF}

The West Nebraska Methodist Episcopal Hospital of Scottsbluff was organized in November, 1921 and dedicated April 15, 1924, since which time 4,000 patients have been cared for. A nurses' training school was opened September 1, 1924 with Mary Jane Fuller, R. N., as principal. Of the first class of five, two were graduated in October, 1927. 
Miss Lydia H. Keller, R. N., the first superintendent, was succeeded by Miss Martha E. DuBois, who served until May 1, 1926. Mrs. Maud E. Kellison is now superintendent. Only graduate nurses are employed. There are now 21 girls in the training school.

The medical staff includes:
C. R. Watson
E. E. Griggs
A. B. Kerns
C. G. Steen
L. J. Swanbom
W. C. Harvey
T. J. Vanderhoof
T. J. Anderson
W. P. Hodnett
T. E. Riddell
A. G. Ross
C. H. Frank
J. B, Schrock
F. W. Plehn
H. F. Maika
A. L. Cooper
W. P. Weyrens
E. Nichols
E. J. Micchell
H. G. LauBach
W. E. Shike
N. H. Rasmussen
R. V. Witter
G. W. Puglsey
J. N. Stoops
F. B. Young
George Robertson
W. S. Franklin

The Executive Board consists of Rev. E. C. Fintell, D.D., District Superintendent; F. S. McAffree, president; A. N. Mathers, vicepresident; Beach Coleman, secretary; Fred D. Tailon, treasurer; Rev. J. M. Wingett, executive secretary; J. C. McCreary, J. M. Carr, C. H. Westerveld, Rev. E. D. Gideon, Rev. M. Allen Keith, Rev, E. H. Mainard,T. L. Green,M. B. Quivey, J. T. Whitehead, George W. Wilcox and H. S. Stark.

\section{SEWARD}

The Morrow Hospital at Seward was started in 1900 by Dr. Joseph Morrow and was then the only hospital in the state west of Omaha and Lincoln. It was first called the Seward Hospital. It has 28 beds and Anna M. Shook is superintendent.

Hillcrest Hospital and Sanitarium at Seward was started in 1918. It has 15 beds.

\section{SPENCER}

The Spencer Hospital, started in 1905, has 15 beds. J. I. Limburg is medical director and Mrs. Murray, superintendent.

\section{STRATTON}

Dr. Stewart's private hospital at Stratton was established by Dr. W. E. Stewart in 1902. It has 14 beds.

STROMSBURG

The Mawood Hospital at Stromsburg was established by Dr. G. A. Flippin, formerly of Lincoln. 
The Home Hospital at Stromsburg was established in 1926 with nine beds. A. J. Edstrom is medical director.

\section{STUART}

Wilson Hospital at Stuart was started in 1920. It has 12 beds. Marie Kozisek is superintendent.

\section{SUPERIOR}

The first hospital in Superior was opened by Dr. Wilson in 1912 in the building known as the Brown property, on which site is now situated the new Brodstone Memorial Hospital.

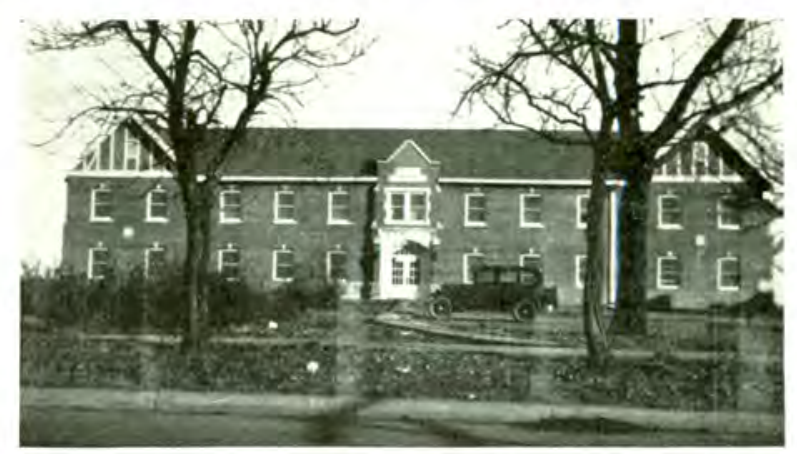

BRODSTONE MEMORIAL HOSPITAL

In 1916 Dr. Wilson sold his interest to Drs. E. K. and D. L. Hirsch, who came from Louisiana. The hospital was soon moved down town to the R. K. Hill property, which was remodeled to suit the growing needs of the organization. In 1917 Dr. D. L. Hirsch severed his connections. His interests were taken over by Drs. Mitchell and Mitchell, local physicians, and this partnership remained in force until Dr. E. K. Hirsch engaged in Red Cross work in 1918. At this time the equipment was sold and the hospital closed. Superior was again without a hospital until May, 1919, when about 40 citizens subscribed money through the sale of stock with which to purchase equipment and open a new hospital which was also located in the Hill building and Dr. E. K. Hirsch returned as surgeon. This was known as the Superior Hospital. The same year the name was changed to The Taylor E. Lewis Memorial Hospital, in memory of one of the World War heroes but, because of some difficulties in securing the payment of endowment to the Taylor E. Lewis Fund this last name was changed to Memorial Hospital. 
In 1921 Hirsch sold his private surgical practice to Charles G. McMahon, a graduate of the Medical School of the University of Minnesota, who has since been staff surgeon.

The regular capacity of the Memorial Hospital was eight beds and many times it was necessary to make additional room for patients by the use of office, reception room and dining room.

Realizing the need of more commodious quarters and, wishing to present to the city of Superior as a memorial to their mother, Mrs. Mathilde Brodstone, something long to be remembered by its people, Evelyn Brodstone, now the Lady Vestey of England, and her brother Lewis have given to the community the splendid new

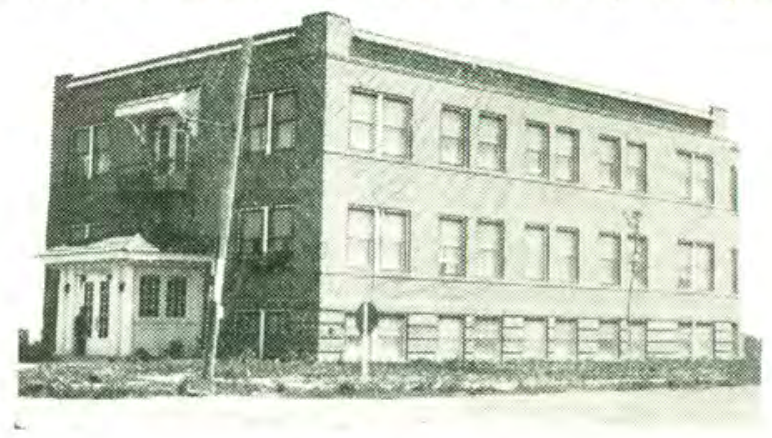

TAYLOR HOSPITAL

building known as the Brodstone Memorial Hospital. The new building is 38 by 116 feet, two stories and basement, strictly modern in every way and fireproof throughout. There are 17 patient rooms and two large parlors, one of which is specially designed as a sun parlor for convalescing patients.

This building was opened to receive patients on January 2, 1928.

The superintendent is Miss Margaret Grandy, on duty since 1921. The board of managers consists of six members: Mrs. C. E. Shaw, president; Mrs. C. H. Hodges, secretary; Mrs. C. G. Jensen, treasurer, Mrs. Mabel Duwe, Miss Mary Felt and Miss Nelle Allison. Presidents of banks of the city constitute the finance board.

SIDNEY

The Taylor Hospital was completed August 1, 1927. It has a capacity of $20-25$ beds. 
The McCrea Private Hospital was built in 1907 by Dr. E. L. McCrea of Table Rock to take care of the surgical needs of that part of the state, where there was no other hospital. He still owns and controls it. Affiliated with the institution are Doctors W. R. Boyes, E. B. Brooks, G. G. Gandy, L. D. Harmon, Charles Novak, A. B. Anderson, John Bullard, W. S. Cherry, Johnson, Byford Anderson, Paul Flory and J. C. Waddell.

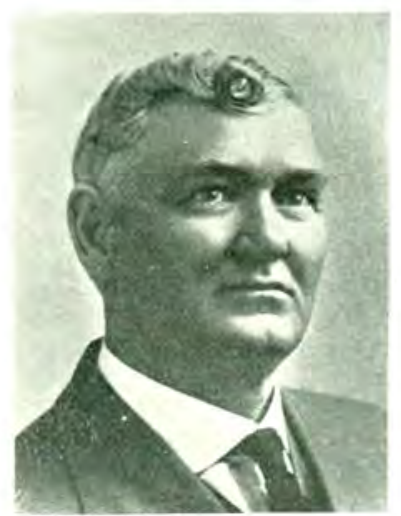

E. L. MC CREA

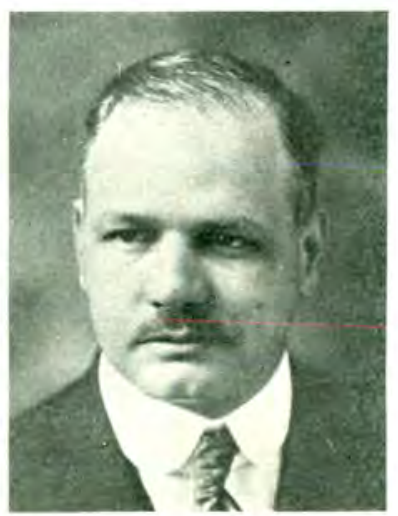

D. L. KING

TEKAMAH

Isaiah Lukens was the physician of Fraternity Hospital at Tekamah, established in 1909 until his death in June, 1928. It has 15 beds. Anna Morran is superintendent.

\section{TILDEN}

The Tilden Hospital was organized by Dr. C. C. Barr in 1920, with a capacity of ten beds. He was chief of staff and Perry Allerton, associate. Mrs. Raemer, R. N., was the first superintendent and was followed by Lucy Stimson and T. M. Tyler. The hospital draws patients from a radius of 25 miles. Five is the average number of patients cared for.

The Wilder Hospital preceded this institution. 


\section{WALTHILL}

The Dr. Susan La Flesche Picotte Memorial Hospital, an Indian Mission Hospital of 18 beds, was established by the Indian woman physician for whom it was named, several years before her death in 1914. Presbyterian funds supplemented the money she raised. Hilma C. Carlson and E. Pitzer are superintendents. It is under Presbyterian control and maintains an out-patient department.

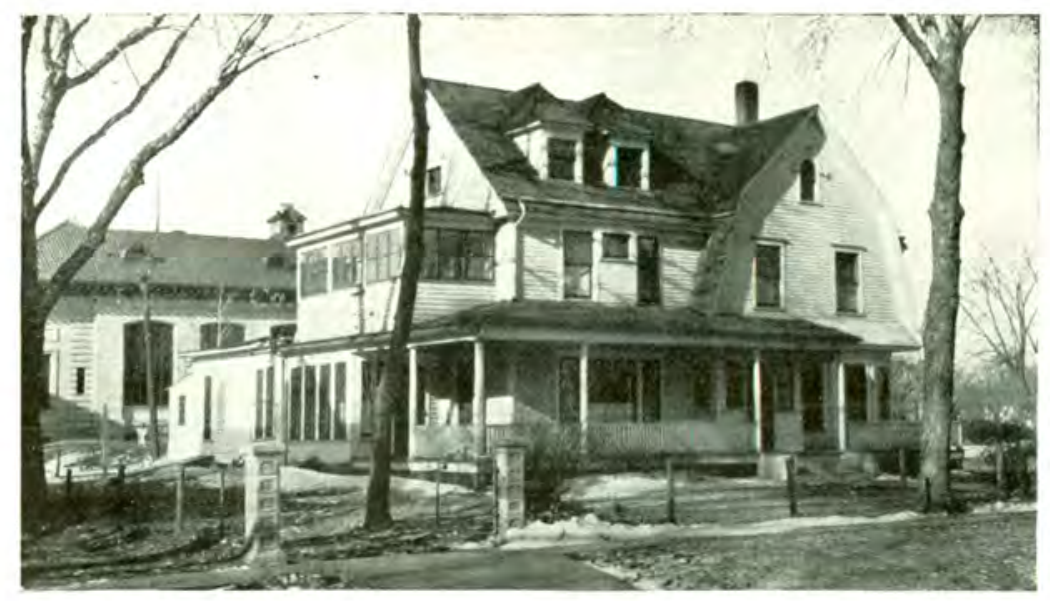

YORK CLINIC HOSPITAL

WEST POINT

St. Joseph Home for the Aged, and Hospital at West Point is under the control of the Sisters of St. Francis and has 17 hospital beds. Joseph Ruesing is superintendent.

\section{WAYNE}

Dr. Sidney A. Lutgen built the first Wayne hospital in 1914, fitted with seven beds. Five years later he built the present 25-bed hospital, complete in every essential, from laboratory to $\mathrm{x}$-ray equipment. In 1921 a nurses' training school was instituted, the nurses taking part of their work at the Teachers' College. The hospital affiliates with Mt. Sinai and Frances Willard Hospital in Chicago, where nurses complete their courses. Radio station $\mathrm{KGCH}$ is operated by Dr. Lutgen in connection with Wayne Hospital. 


\section{WINSIDE}

Victor L. Siman is medical director of Winside Hospital established in 1920. It has six beds.

\section{YORK}

The York Clinic and Clinic Hospital was organized in May, 1920, by Doctors O. M. Moore, George P. Shidler, who moved to Torrance, California in 1924, and Dexter D. King. It opened for patients on June 1 with Mrs. Mary Thompson, R. N., as superintendent. She is still in this post. Ernest E. Wegner, now of Lincoln, joined the staff in March, 1921 and April 6, that year, the firm incorporated under the laws of Nebraska, with the intention of selling stock to erect a new hospital building. This corporation dissolved, however, in 1923 and a partnership was resumed. L. V. Bilon was with the clinic from June 1926 to February, 1927 and Robert E. Harry joined it July 1, 1927. The present hospital staff includes therefore, Doctors Moore, son of a pioneer York physician; King and Harry as owners, and J. C. McKinley of York, on the visiting staff. Only gradıate nurses are employed. Any ethical physician has the privileges of the hospital.

Evangelical Lutheran Hospital at York was established in 1914 and has 60 beds. Miss Emma Schuelke, R. N., is superintendent.

Notes and Errata

pp. 477-541 For an accurate and more complete listing of Nebraska hospitals, see (a) "Registered Hospitals," JAMA 90:951-52, Mar. 24, 1938. (b) American and Canadian Hosptials: A Reference Book of Historical, Statistical, and Other Information ... . Edited by James Clark Fifield with the cooperation of the American Hospital Association. Minneapolis: Midwest Publishing Company, 1933; pp. 698-712. (c) American Medical Directory . . . a register of physicians . . . Nebraska section on "Hospitals, Sanitaria and Charitable Institutions:" Chicago; Press of the American Medical Association, 1906 -

p. 477 "Post hospital." For a complete expedition record, see: Gale, John, The Missouri expedition, 1818-1820: the joumals of Surgeon John Gale with related documents. Edited and with an introduction by Roger L. Nichols. Norman: University of Oklahoma Press, 1969. 
Clark hospital. Unable to verify in Savage, James W. and Bell, John T., History of the City of Omaha, New York and Chicago: Munsell and Company, 1894. Bound in the same volume with Butterfield, Consul W., History of South Omaha.

p. 478 Child's Hospital and Home. For a more complete history, American and Canadian Hospitals .... op. cit., pp. 477-541.

"... pioneer hosterly ..." should read "... pioneer hostelry ..."

pp. 479-80 "Omaha Medical and Surgical Institute." See the advertising circular in the Library of Medicine, University of $\mathrm{Ne}$ braska Medical Center entitled Omaha Medical and Surgical Institute . . . Omaha, Nebraska, 1891 - ?. See also The Western Metropolis .... an index of the progressive business institutions. H. N. Blood and Company under the auspices of the Omaha Board of Trade and Daily Bee, 1891: pp. 88-89.

p. 485 Delete third line, second paragraph.

p. 485 The last five words, second paragraph should read ". . . not all of them Deaconesses.' See Auerbach, Ella F., “Omaha, A Real Medical Center" Omaha's Own Magazine, 1 (10): 17-30, Dec. 1926.

p. 487 Lord Lister Hospital opened in 1914. See p. 708, American and Canadian Hospitals... op. cit., pp. 481-541.

p. 488 Lutheran Hospital information should be combined with information on p. 498, Danish Lutheran Hospital, as a single organization which, in 1931 , leased the Wise Memorial Hospital building, pp. 491-492. See Jourdan, H. M., History of the Lutheran Hospital unpublished MS, Library of Medicine, University of Nebraska Medical Center.

p. 489 Nebraska Methodist Hospital. See also Morton, J. S., Illustrated History of Nebraska, Lincoln: Jacob North, 1907; Vol. 2, p. 548 .

pp. 491-492 Wise Memorial Hospital building was leased to the Lutheran Hospital Association in 1931. See pp. 488, 498 errata.

Charles W. Pollard, University of Nebraska College of Medicine faculty: 1904-1937.

p. 498 Danish Lutheran Hospital is the same as Lutheran Hospital, p. 488. See Jourdan, H.M., History of the Lutheran Hospital unpublished MS ... op. cit., p. 488. 
The subtitle "Radium Hospital" should be inserted before the first complete paragraph.

p. 500

Quigley, Daniel Thomas, The Conquest of Cancer by Radium and Other Methods, Philadelphia: F. A. Davis Company, 1929.

p. 500

p. 504

p. 505

p. 509

p. 522

"He formerly practiced in North Platt . . ." should read "He formerly practiced in North Platte..."

Ford Paxton Memorial Hospital, 25th and Douglas Streets, Omaha. Private, general, 65 beds.

City Emergency Hospital. "The nurse in charge . .." identified as Lillie A. Myers.

Illustration: St. Joseph's Hospital, Alliance, Nebraska.

Atkinson General Hospital staff: William J. Douglas, M.D. not W. J. Douglas Atkinson.

“. . laboratory, modren operating . .." should read ". . . laboratory, modern operating ..."

". . . have since ben installed . . ." should read ". . have since been installed ..."

Nebraska Orthopedic Hospital. See U. S. Works Project Administration, Nebraska Writers' Project: History of Nebraska Orthopedic Hospital, 1941: Mimeographed, 62 pages. See also Orr, H. Winnett, M.D., The Nebraska Orthopedic Hospital, 1905-1955: a personal account . . .

p. 526

p. 535

West Nebraska Methodist Episcopal Hospital, Scottsbluff (not Schuyler of Rushville).

p. 536

Morrow Hospital, Seward. See p. 710, American and Canadian Hospitals . . . op. cit., pp. 477-541. According to this source, the Morrow Hospital opened in 1902. Its establishment was preceded by the following hospitals: Norfolk, 1897 (Ibid., p. 529): Grand Island, 1886 (Ibid., p. 515); Columbus, 1879 (Ibid., p. S11): Burkett, 1887 (Ibid., p. 509). 


\section{OMAHA MEDICAL ARTS BUILDING}

\section{Notes and Errata}

p. 543

“. . . a separate incorporation . .." should read ". . . a separate corporation..."

p. 544

Blue Sky Law. See Session Laws of the State of Nebraska, 1921: Chapter 308. See also Sheldon, A. E., Nebraska, the Land and the People, Chicago: Lewis Publishing Company, Vol. 1, p. 974.

p. 544

Paintings and photographs of pioneer physicians are now in the Library of Medicine, University of Nebraska Medical Center. 


\section{OMAHA MEDICAL ARTS BUILDING}

As a climax to the history of medicine in Nebraska, it is fitting to mention the fine, 17-story Medical Arts Building-an imposing feature of Omaha's skyline. It is also a monument to the progressive spirit of the Omaha medical and dental fraternity, who early recognized the advantages and benefits to be derived from centering under one roof, all the professional attention a patient might require, be it doctor, dentist, drugs, $\mathrm{x}$ ray, braces, optical or surgical supplies.

Conceived in May, 1919, by Dr. William P. Wherry, then president of the Omaha-Douglas County Medical Society, it was at first proposed to erect an office building for doctors and dentists exclusively as a medical society project, but because of professional objections, a separate incorporation, the Medical Building Association, was chartered in the fall of that year, and stock was sold to local practitioners. Dr. Wherry was the first president; the late W. H. Sherraden, dentist, vice-president; the late Dr. E. Willard Powell, secretary and Leonard Schiebel, then connected with a local bank, treasurer. George Brandies, who contributed $\$ 150,000$ to the building fund; William Schall, John Madden, Dr. Paul Ellis, Dr. James M. Patton, Dr. A. D. Dunn, Dr, F. F. Whitcomb, Drs. Hunter and Neilsen and W. A. Piel, druggist, were among the directors. Dr. Charles W. Pollard was subsequently president of the company during the trying days of its many negotiations.

A spirited contest ensued prior to the location of the building on the southeast corner of 17 th and Dodge Streets. Many sites both north and south of Farnam Street were suggested but a three-to-one vote of the membership decided the issue. Financing had been arranged with the Peabody-Houghteling Company of Chicago, architects' drawings made, when a series of unfortunate circumstances caused a long delay in the completion of the building. Chief among 
them was the passage of a new blue sky law which interfered with the stock-selling campaign; failure of the plans to raise money and lack of delivery of pledged contributions, and other disappointments which made refinancing imperative. This Benjamin Kulp of the Madison-Kedzie bank of Chicago agreed to do, furnishing a loan of $\$ 1,200,000$ because of his supreme confidence in the future of Omaha as a medical center, and in the professional men who were behind the proposition.

The Kulp interests reimbursed all doctors who had purchased stock in the original company with the same amount of stock in the rew company.

Building operations were resumed in 1924 on the steel framework which had long been a distressing sight to loyal Omahans, and the completed building was ready for occupancy November 1, 1926. It was formally opened to the public in April, 1927, at the time of the Nebraska State Medical Association meeting here.

With few exceptions, the Medical Arts Building now houses the leading professional men in the city, all applicants for space being passed on for desirability and professional standing by committees of their colleagues, before offices are leased to them. A first class drug store is operated in the corner store and a tea-room on the top floor.

An auditorium seating 300 , with a special stage, balcony, excellent lighting, and provision for motion picture projection, is provided on the second floor for the meetings of the Douglas County Medical Society and other meetings and lectures. The walls are hung with paintings and photographs of pioneer Omaha physicians, gathered largely through the efforts of Dr. Earl C. Sage, secretary of the county society and also of the Missouri Valley Medical Association, which also maintains its headquarters, with a paid secretary in attendance, in the pleasant clubrooms of the building on the 17th floor. Here the doctors may gather for a few rounds of bridge or social intercourse, snatching a brief respite from their labors at any time of the day. Visiting physicians may register here, learn whatever clinics are scheduled for the period of their stay, and receive any information or professional courtesy which may be extended to them. 
Located in the center of the downtown district, the Medical Arts Building is accessible to any part of the city by proximity to the most important street car lines. Ample parking space is available to the north and west. It is of fireproof, steel frame and concrete construction, towers 225 feet above the street level, its exterior of Indiana limestone with light colored terra cotta and gray face brick.

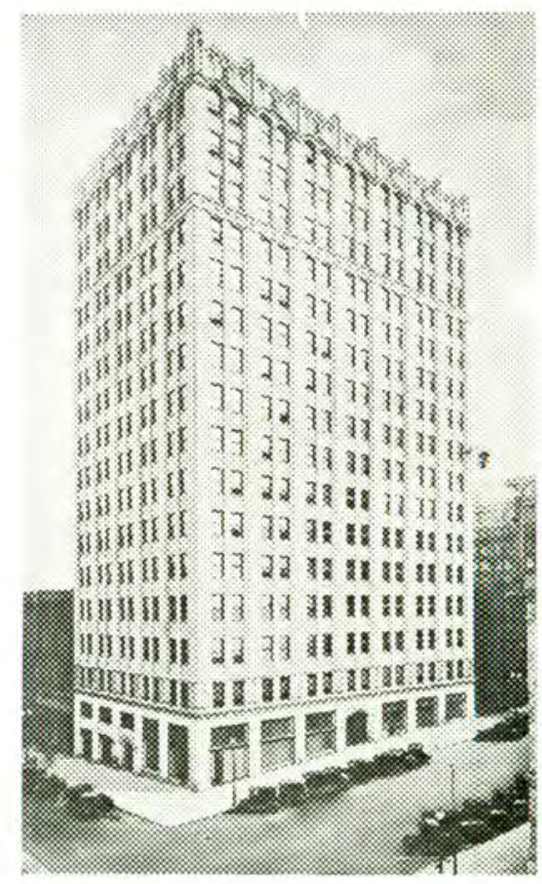

OMAHA MEDICAL ARTS BUILDING

The interior finish is of foreign and domestic marbles with selected wood work and hard maple floors. Fireproof tile and plaster partitions separate the various tenant spaces from each other and the corridors, which are broad, light and well ventilated are furnished with terrazzo floors and marble wainscotings seven feet high.

Four electric signal elevators of the latest type-the first to be installed in Omaha - make for complete and efficient passenger service. The elevators are all automatic, with double doors to eliminate any chance of accident and are "manned" by attractive, white- 
garbed elevator girls whose unfailing courtesy and efficiency in a building where transportation of the sick, often stretcher cases, the lame and the blind, the old and babes in arms, is a daily problem, occasions universal commendation.

Two entrances, on Seventeenth and on Dodge Streets, provide easy access to the inner store space and elevators.

The building is so designed that all offices are assured excellent light and ventilation at all times. Offices have an unusual advantage of breadth, rather than depth, thus providing a wide frontage for light, air and window space. Each office is equipped with lavatory, hot and cold water, electricity, compressed air and gas for professional work. Separate electrical mains are provided, to which $x$ ray apparatus may be connected. There is a compartment on every floor for refrigerated biological cabinets with separate locked compartments for the tenants.

Alfred Kennedy of the Heyn-Kennedy Company, building managers, maintains his office here also, giving his personal attention to any suggestions which may arise.

The directory of tenants follows:

Allen, Jchn F., M.D.

Anders. Chas. G.. D.D.S.

Anderson, Harley E., M.D

Andersen, M. C.. M.D.

Arries. Byren E.. D.D.S

Banister. J. M., M.D.

Barry, M. WHllam, M.D

Bennet. A. E., M.D.

Berry, Wm., M.D

Best. R. Russell. M.D

B ndewald, G., D.D.S.

Black man, Julian R., M.D.

Bl'ss. Rodney W., M.D.

Beehler, George M., D.D.S.

Boler, Thos. D., M D.

Borghoff. J. A., M.D.

Brandt, Emelia H., M.D.

Brown, Alfred, M.D.

Brawn, C. E., D.D.S.

Brown, Harold E., D.D.S.

Callfas, William F.. M.D.

Carman Frazk D., D.D.S.

Carney. Ralph B., D.D.S.

Cascy, Frank J., M.D.

Cass dy, W. A., M.D

Clayten, J O., D.O.S

Con'ey, D. E., D.D.S
Conlin. Frank M.. M.D

Cook Lyman J., M.D.

Crandell, A. A., D.D.S.

Dailey, Edmund J., D.D.S

Davis, B. B., M.D.

Dsvis, C. J., D.D.S.

Dav's Edwin, M.D.

Dav's, Herbert H. M.D.

Derby, Gladstone, D.D.S.

Dind inger, J. W., D.D.S,

Dunn. A. D., M.D.

Denn, Arlo M., D. D, S

Dunn. F. Lowell, M.D.

Eggers, H. E., M.D.

Eldredge, Robt. Bruce, M.D.

Ewing, Ben F., M.D.

Fairchild, Nora M., M.D.

Farrell, Robt. F.. M.D.

Fouts, Roy W., M.D.

Freyman, J. J., M.D.

Fritz, Glenn H., D.D.S.

Gardiner, J. F., M.D.

Gar Iner, Themas A. D.D.S.

Gifford, Harold, M.D.

Gifiord. Sanferd R., M.D.

Greenberg, A., M.D.

Grier, M. E., M.D. 
Griffin, E. J., M.D.

Grodinsky, M., M.D.

Haney, W. P., M.D.

Hanisch, Louis E., M.D.

Hanson, Harold G., D.D.S.

Hardlannert, E. F.. D.D.S.

Hardy, C. C., M.D.

Hauslein, Charles M., M.D.

Heazey, Francis W., M.D.

Healey, M. J., D.D.S.

Henske, J. A., M.D.

Hipple, A. Hugh, D.D.S.

Hoffman, L. O., M.D.

Hollister, Robert R., M.D.

Howard, M. C., M.D.

Hughes, A. L., D.D.S.

Hull, Chas. A, M.D.

Hunt, Katherine M., M.D.

Impey, C. C., M.D

Iwerson, J. C., M.D.

Jahr, Herman M., M.D.

James, Chas. S., M.D.

Johnson, H. F., M.D.

Keegan, J. Jay, M U.

Kelly, James F., M.D.

Kelly, John, Jr., D.D.S.

Killins, W. A., M.D.

Kleyla, John R., M.D.

Knode, A. R., M.D.

Kully, B. M., M.D.

Langdon, J. Frederick, M.D.

La Porte, E. J., D.D.S.

Lawsen, Ray, D.D.S.

Lemere, H. M., M.D.

Litchfield, E. A., D.D.S.

Lord, John P., M.D.
Luikhart, Ralph, M.L.

McClanahan, H. M., M. D.

McCrane, H. F., D.D.S.

McKenna, F. J., D.D.S.

McMullen, J. J., D.D.S.

Manning, Ernest T., M.D.

Martin, James Wm., M.D.

Martin, Otis W., M.D.

Masn, Ernest A., D.D.S.

Mason. Walter E., D.D.S.

Maxwell, J. T., M.D.

Mellinger, F. S., D.D.S.

Mercer, Nelson S., M.D.

Merchant, H. A., D.D.S.

Miller, Harry C., M.D.

Mlaska, L. J.

Moon, Charles F,, M.D.

Moon, Louis E., M.D.

Moore, Clyde J., M.D.

Moser, R. Allyn, M.D.

Muldoon, J. V., M.D.

Murphy, Frank P., M.D.

Murphy, J. Harry, M.D.

Muskin, Nathan, M.D.

Myers, J. T., Ph.D.

Myers, L. E., D.D.S.

Nelsen, H. A., D.D.S.

Neuhaus, George E., M.D.

Niehaus, Frederick W., M.D.

Noonan, E. F., M.D.

O'Sullivan, Margaret J., M.D.

Overgaard, A. P., M.D.

Owen, D. R., M.D.

Owen, F. S., M.D.

Owens, C. A., M.D.

Parker, Jos. S., D.D.S. 
$+$ 


\section{DIRECTORY OF NEBRASKA PHYSICIANS}

Abbott, Chas. E.; Minden; Gen. Prac,; b 1876; Uni. of West Ontario, London, 1902; Kearney Co.; A.M.A.

Abbott, Edward Carson; Omaha; Eye, Ear, Nose and Throat; Uni. of Iowa and New York Ophthalmic Hosp., N. Y.

Adams, Arthur Benedict; Omaha (Florence); Phys. and Surg.; Creighton Med. Col.; former prof, diseases of Children, Creighton; Park Board; Health officer; Staff, Lord Lister and Nicholas Senn Hosps.; Co.; State; A.M.A.

Adams, Howard Chalfient; Wolbach; Gen. Prac,; b 1873; Rush Med. Col., 1898; Greeley Co

Adams, R'oy Bennett; Lincoln; School Physician; Uni. of Nebr., 1902; Rush Med. Col., 1907; secretary, Nebr. State Med. Assn.; National Educational Assn.; Nebr. Teachers' Assn.; Lancaster Co.; State; A. M. A.; Lincoln University Club.

Adams, William James; Omaha; Gen. Prac.; Creighton Med. Col., A.B., M.D.; surg. staff, Lord Lister Hosp.; med. staff, St. Joseph's Hosp. and Col,; Lieut., Inf., U.S.A.; Omaha-Douglas Co; Elks Club; General Clinic.

Adamson, Wm. J.; Lincoln; Gen. Prac.; Lincoln Med. Col., 1903; Lancaster Co.

Adcock, Lee Campbell; Omaha; Gen. Prac.; b 1878; Jefferson Med. Col., 1903; Douglas Co.

Agee, James Clarence; Fremont; Gen. Prac.; b 1876; Uni. of Nebr., 1903; Dodge Co.

Agler, Frank Swarthout; Surprise; Ophthal.; b 1878; Keokuk Med. Col., o0; Butler Co.; A.M.A.

Albertson, Miriam Alberta; Fairmont; Gen. Prac.; b 1900; Uni. of Nebr., 1926; Fillmore Co.

Akers, William O.; Omaha; Gen. Prac.; Creighton Med. Col., M.D., 1902; Banner County Phys, and coroner, 1904; ward surgeon, Base Hospital No. 1; Field Hospital No. 353; M.O.R.C.; sanitary physician, Florence, 5 Years; former member A.M.A.

Albin, Walter Leonard; Lincoln; Ophthal., Otolo., Laryng., Rhin.; b 1876 ; St. Louis Uni., '02; Lancaster Co.; A. M. A.

Alexander, Clark Taylor; Omaha; Gen. Prac. b 1896; Uni. of Colo, 1925 ; Lieut., U.S.N.; Douglas Co.; A.M.A.

Alexander, Jeremiah Smyth; Omaha; Gen. Prac,; b 1878; Chicago Hom. Med. Col., 1000: Douglas Co.

Allen, James Gillan; Fremont; Gen. Prac.; b 1896; Uni. of Nebr., '24; Dodge $\mathrm{Co}$. 


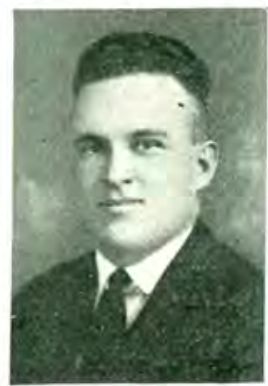

W. J. ADAMS

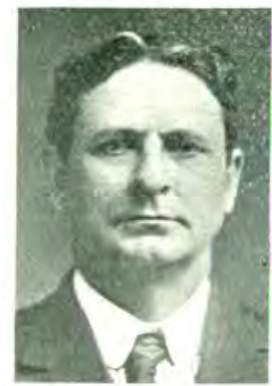

W. O. AKERS

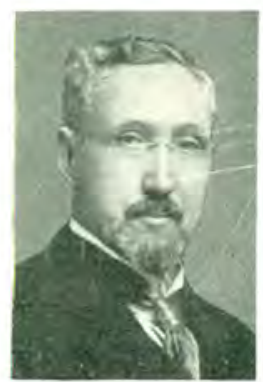

A. J. AMES

Allen. John F.; Omaha Internal Medicine; Tuberculesis; Uni. of Nebr. Med. Col., B.Sc. 1905, M.D., 1907; Asst. Prof. of Medicine, Uni. of Nebr.; special chest work, World War; Omaha-Douglas Co.; State; A.M.A.; Natl. T. Assn.; Phi Rho Sigma.

Allen. Silas Gilbert; Stanton; Gen. Prac.; b 1875; Uni. of Nebr., '1901; Stanton Co.

Allenburger, Christian Alexander; Columbus; Surg.; b 1870; Rush Med. Col., 1895;Platte Co.; A.M.A.

Allerton, Perry; Tilden; Gen. Prac. and Surg.; Uni. of Omaha, B.Sc., 1919; Uni. of Nebr., M D.; Pres, Madison Co. Med. Soc., 1926; M.R.C. city physician, 1927; Madison Co.; Missouri Valley Med. Soc.; State; A.M.A.; Phi Beta Pi; Elk; author of Peculiar Complication in a Case of Diabetes Insipidus, Nebr. State Med. J., 1025.

Allingham, Henry T.; South Omaha; Gen. Prac.; Creighton Med. Col., M.D., 1912; exemption board; Omaha-Douglas Co.; State A.M.A.

Ambrese, Addison Lee; Guide Rrck; Gen. Prac.; Uni. of Michigan, 1879 1882 ; practiced 23 years in Mich; World War; Co; State.

Ames, Albro Jcseph; Potter; Gen. Prac.; Creighton Med. Col., M.D., 1901; post-grad. study Chicago E. E. N and T., 1918; North Platte for 12 years; president of Lincoln Co. Med. Soc.; M.C., World War; Cheyenne Co.; State; Elk Civil Legion, Rifle and Golf Clubs.

Ames, Marie A.; North Platte; Gen. Prac.; b 1863; Creighton Uni., 1901; Lincoln Co.

Amick, Carl Gideon; Loup City; Gen. Prac.; b 1896; Uni. of Nebr., 1921; Sherman Co.; A.M.A.

Ammerman, Ulysses S.: Reynclds; Gen. Prac.; b 1865; Keckuk Med. Col., 1898; Jefferson Co.

Anderson, Allan Byford; Pawnee City; Gen. Prac.; Uni. of Nebr. Med Col., M.D.,1921; Pawnee Co.; State; A.M.A.

Anderson, Allen B. (retired); Pawnee City; Gen. Prac. and Surg.; Louisville Med. Sch.; past pres. Nebr. State Med. Soc.; local surgeon C.R.I.R.R.; Pawnee Co.; State; A.M.A. 


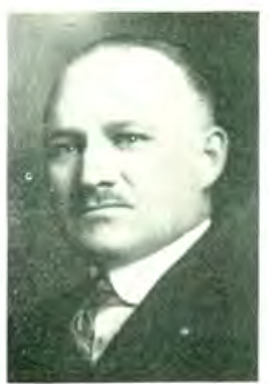

J. B. ANDERSON

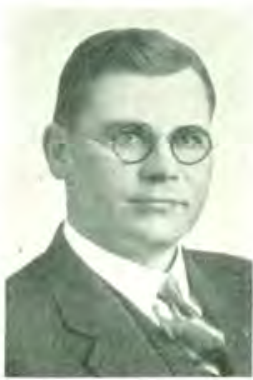

J. ANDERSON

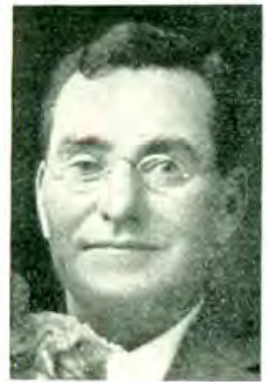

A. C. ARMITAGE

Anderson, Albert Wilfred; West Point; Surg.; b 1893; Creighton Uni., 1918; Cuming Co.; A.M.A.

Anderson, Harley E.; Omaha; Gen. Prac,; b 1900; Uni. of Nebr., 1925; Co.; A.M.A.

Anderson, James Burns; Gen. Prac.; b 1887; Creighton Uni.. 1910; Washington Co.

Anderson, J. B.; Lincoln; Gen. Prac,; York College; Creighton Med. Col., M.D., 1910; in Kennard 15 years.

Anderson, Arthur W.; Lexington; Gen. Prac.; Northwestern Med. Co., M.D., Co.; State A.M.A.; Kiwanis.

Anderson. August N.; Belvidere; Gen. Prac.; b 1867; Rush Med. Col., 1892; Thayer Co.; A.M.A.

Anderson, Joel; North Platte (formerly of Gothenburg); Gen. Prac.; Creighton Med. Col., M.D.; county advisory board, Bd. of Education at Gothenburg, 1926-1927; Dawson Co.; State; A.M.A.; Kiwanis; Community and Country Clubs.

Anderson. Maine C.; Omaha; Gen. Prac.; b 1896; Harvard Uni., 1924; Douglas Co.

Anderson, William Nance; Omaha; Internal Med.; Uni. of Nebr.; Uni. of Vienna; asst, prof. of medicine, Uni. of Nebr. Med. Col.; Major, M. C., 25 mo.; Douglas Co.; State; A.M.A.; Natl. Tuberculosis Assn.; Alpha Omega Alpha; Phi Rho Sigma; Omaha Club; Ch. of Commerce; author of many articles in medical journals.

Anderson, Victor; Bridgeport; Gen. Prac.; b 1867; Uni. Med. Col. of Kansas City, 1837; Morrill Co.

Andrews, Clayton Farrington; Lincoln; Surg.; b 1891; Uni. of Pa., 1916; Lancaster Co.; A.M.A.

Andrews, Gaylord McE.; Stella; Gen. Prac.; b 1871; Marion-Sims Col. of Med., 1898; Richardson Co.

Andrews, Henry Seeley; Minden; Surg.; b 1879; Uni. Med. Col. of Kansas City, 1909; Kearney Co.; A.M.A. 


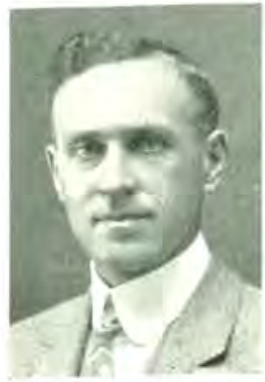

W. J. ARRASMITH

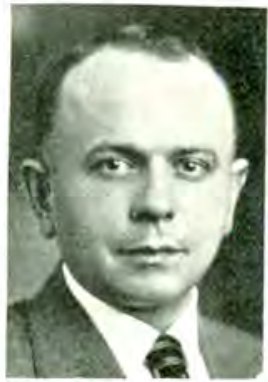

W. W. ARRASMITH

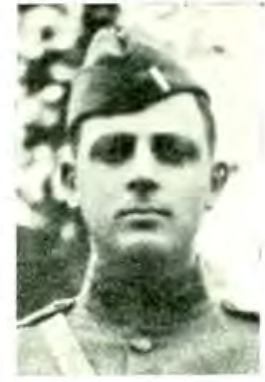

A. A. ASHBY

Andrews, Thomas J.; Fairbury; Gen. Prac.; Uni. of Mich., Ann Arbor, M.D., 1882; cxamining board Wcrld War; pension and insanity board.

Andrus, Frederick Moore; Lincoln; Surg.; Uni. of Nebr.; Cotner Med. Col.; post-grad. study in U. S. and European clinics; M.O.R.C. and Natl. Guard; Lancaster Co.; State; Mo.Valley Med. Soc.; A.M.A.; Lincoln golf and gun clubs; medical papers published.

Angle, Everett Edward; Lincoln; Urol.; Uni. of Nebr., A.B., 1918; Harvard Med. Sch., M.D., 1921: resident in dept. of urological surgery, New York Hosp., James Buchanan Brady Foundation in 1923; M.R.C., World War; Diplomate of natl. bd. of med. exam.; Lancaster Co.; State; A.M.A.; Am. Urol Assn.; Sigma Xi; son of Edward John Angle, M.D., Lincoln.

Angle, Edward John; Lincoln; Dermat.; Uni. of Wisc., B.Sc., 1886; Uni. of Nebr., 1898; Uni. of Cinn. (Med. Col. of O.), M.D., 1887; Uni. of Pa., M.D., 1895; post-grad. work in skin, genito-urinary diseases, N. Y. C.; prof. of skin and genito-urinary diseases, Uni. of Nebr. Med. Col., 19051910; derm., St. Elizabeth's Hosp.; Lancaster Co.; State; A.M.A.; Am. Urol. Assn.; Am. Col. of Physical Therapy; A.A.A.E.; Am. Acad. of Political and Soc. Sci.; Nebr. Acad. of Sci.; Royal Soc. of Arts, London; F. and A.M.K.T.; A.A.O.N.M.S.; Lincoln Uni.; Country, Rotary Clubs; edit. dept. in Western Med. Rev., 1902-1907; many articles on hygiene and medical subjects.

Archerd, John Wills; Grafton; Gen. Prac.; b 1857; Uni. of Nebr., 1891; Fillmore Co.

Archerd, John W.; Crookston; Gen. Prac.; Ohio Med. Col.; Omaha Med. Col., M.D., 1911; Past pres., Clay and Fillmore Co. Med. Societies.

Armitage, Albert C.; Haigler; Gen. Prac.; Keokuk Med. Col.; Co.; State; A.M.A.

Armstrong, Robert Burton; Papillion; Gen. Prac.; b 1865; Uni. of Nebr., 1894; Sarpy Co.

Arnholt, Milton; Lincoln; Urol.; b 1885; Uni. of Nebr., 1913; Lancaster Co.; A.M.A.

Arnold, Chas. Harrison; Lincoln; Surg.; b 1888; Chicago Col. of Med. and Surg., 1913; Lancaster Co.; A.M.A. 
Arnold, Merton O.; St. Paul; Gen. Prac.; b 1889; Uni. of Nebr., A.B., 1915; Northwestern Uni., 1919; Phi Ro Sigma; Ptolemy; Howard Co.; A.M.A.

Arrasmith, William J.; Grand Island; Surg., Diag.; Pre-medical, Uni. of Nebr.; Creighton Med. Col., M.D., 1913; Mayo Clinic 3 years; city charter convention; bd. of directors, Y. M. C. A.; Hall Co.; State; A.M.A.; Mo. Valley Med. Soc.; Phi Rho Sigma.

Arrasmith, Winfred Woodworth; Grand Island; Internal Med.; Uni. of Iowa; Northwestern Uni. Med. Sch.; past pres., Hall Co. Med. Soc.; U.S.N., World War; Hall Co.; State; A.M.A.; Assn. Am. Col. Phys.; Nu Sigma Nu; Acacia.

Asa, Athenus L.; Brock; Gen. Prac.; b 1879; Lincoln Med. Col., 1906; Nemaha Co.

Asa, Oran C.; Ong; Gen. Prac.; b 1871; Lincoln Med. Col., 1908; Clay Co.

Ash, Jos. Lafe; Omaha; Gen. Prac.; b 1900; Creighton Uni., 1925; Douglas Co.

Ashby, Albert Archie; Fairmont; Gen. Prac.; Hahnemann Med. Col., M. D., 1913; M.C., World War; Capt., M.O.R.C.; Fillmore Co.; State; A.M.A.

Altha, John Frank; Lincoln; Gen. Prac.; b 1871; Lincoln Med. Col,, 1907; Lancaster Co.

Arthur, Mattie Laughlin; Omaha; Gen. Prac.; Chicago Uni.; Uni. of Iowa; pres. Omaha Med. Women's Soc.; Douglas Co.; State; A.M.A.; Omaha and State Women's Assns.; Ch, of Com.

Atkinson, Ira E.; Lincoln; Gen. Prac.; b 1868; Uni. of Nebr., 1897; Lancaster Co.

Attwood, Norman Harry; Omaha; Gen. Prac.; Creighton Med. Col.; Inst. in Physiology, Creighton Dental Sch., 1921 to date; S.A.T.C. and Capt., M.C.; Ch. of Commerce.

Aukes, Ehme E.; Lincoln; Gen. Prac.; Gottingen, Germany, 1877; Volunteer med, service in war.

Avery, Hiram Henry; Omaha; Gen. Prac.; b 1890; Kansas City Hahnemann Med. Col., 1914; Douglas Co.

Avery, Wm. A.; Ulysses; Gen. Prac.; Columbia Uni., 1868; Butler Co.

Ayers, Clinton L.; Kearney; Ophthal., Otolo., Laryng.; b 1877; Lincoln Med. Col., 1906; post-grad., N. Y. Eye and Ear Infirmary, 1922-23; Uni. Vienna, Austria, Jan.-Feb., 1928; N. Y. Eye and Ear Infirmary, N. Y., March, 1928; Kearney, 1919.

Babcock, Jay Blaine; Lincoln; Gen. Prac.; b 1898; Uni. of Nebr., 1925; Lancaster Co.

Bachle, Edward P.; Liberty; Gen. Prac.; b 1882 ; Creighton Uni., 1906; Gage Co.; A.M.A.

Baer, Byron Howard; Ashland; Gen. Prac.; Uni. of Nebr. Med. Col.; Co.; State; A.M.A.; Nu Sigma Nu; Phi Delta Theta.

Baird, Chas. Glen; Beatrice; Ophthal., Otolo., Laryng., Rhin.; b 1887; St. Louis Uni. School of Med.; Gage Co.; A.M.A. 


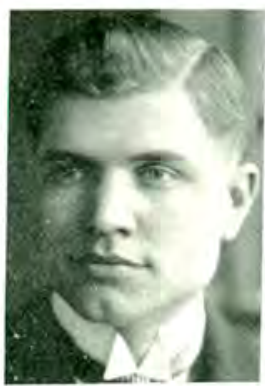

M. G. ARNOID

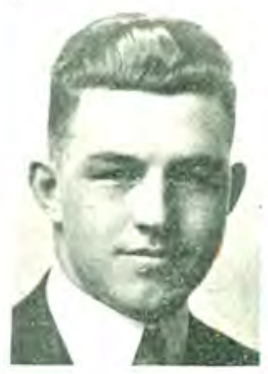

B. H. BAER

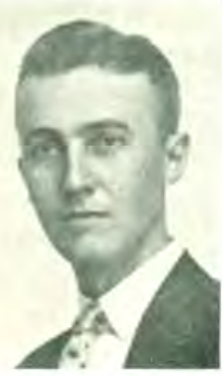

A. A. BALD

Baker, Bartow B.; Norfolk; Medico-Insurance; Washington Uni. Med. Col.; asst. med. dir., Elkhorn Life and Accident Ins. Co.

Baker, Frank Lawrence; Hildreth; Gen. Prac.; b 1885; Lincoln Med. Col., 1910; Franklin Co.

Balcom, Raymond D.; Genoa; Gen. Prac.; Uni. of Nebr. Med. Col.; Staff. Indian Sch. Hosp; M.O.R.C.; Co.; State; A.M.A.

Bald, Arno A.; Platte Center; Gen. Prac.; Uni. of Nebr. Med. Col; med. exam., draft board; county physician 12 years; Platte Co.; State; A. M. A.; Nu Sigma Nu; Delta Tau Delta.

Baldwin, Francis J.; Hay Springs; Proctol.; b 1867; Physio-Med. Col., Gieencastle, Ind., 1901; Sheridan Co. State.

Baldwin, Francis J.; Chadron; Proctol.; Blanchard Clinic; Holt Co.;

Banister, Wm. B.; Holdrege; Ophthal., Otolo., Laryng., Rhin.; b 1861; Hosp. Col. of Med., 1883; Col., U.S.A.; Phelps Co.; A.M.A.

Bantin, Clarence F.; Omaha; Gen. Prac.; Uni. of Nebr., B.Sc., 19?3, M.D., 1924; Sec. and Treas., Immanuel Hosp., Omaha; Staff, Uni. Hosp.; Sec., Nebr. Alpha Chapt.. Alpha Omega Alpha; Douglas Co.; State; A.M.A.; Nebr. and Iowa Pediatric Soc.; Nu Sigma Nu; author Diabetic Lipemia Retinalis, A.M.A., 2:1926.

Bantin, Elmer William; Omaha; Gen. Prac.; Pediat.; Uni. of Nebr., B.Sc., 1916; M.D., 1918; staff, Immanuel and University Hosps., Omaha; Douglas Co.; State; Nebr-Iowa Ped. Soc.; Nu. Sigma Nu.

Baptist, John; Omaha; Genito-Urol.; Indianapolis, Indiana ; Constantinople, Turkey; Douglas Co.; State; A.M.A.; Mo. Valley Med. Assn.

Barkey, Veteran Smith; Havelock; Gen. Prac.; b 1890; Lincoln Med. Col., 1917; Lancaster Co.

Barnes, Chester D.; Tecumseh; Roentgenol,; b 1866; Johnson Co.

Barns, Frank Milan; Albion; Eye, Ear, Nose and Throat, Diagnosis; Uni. of Nebr. Med. Col.; M.C., A.E.F., France; Co.; State; A.M.A.; Milit., U.S.A.; Radiol. Soc. 


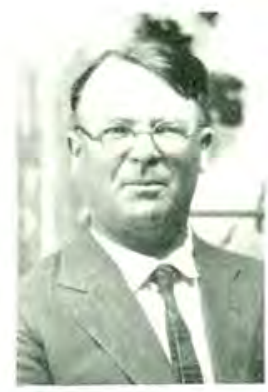

W. S. BARTHOLOMEW

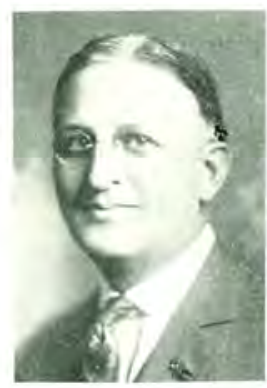

F. 0. BECK

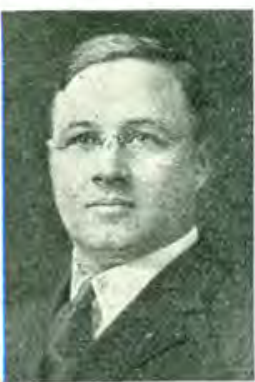

W. C. BECKER

Barnhart, Edgar Geoffry; Omaha; Urol.; b 1884; Creighton Uni., 1910; Douglas Co.; A.M.A.

Barr, Charles Cecil; Tilden; Gen. Prac.; Sioux City Med. Col,; New York post-grad. work; chief of surgical staff, Tilden Hosp.; Chmn., City Council 6 years, board of ed.; co-author Peculiar Complication of Diabetes Insipidus, Nebr. Med. J., 1924.

Barrett, Lawrence; Ashton; Gen. Prac,; b 1891; Creighton Uni., 1915, Sherman Co.

Barry, Charles Augustus; Norfolk; Gen. Prac.; Uni. of Nebr., Med. Col.; M.C., World War.

Barta, Frank Albert; Ord; Ophthal., Otolo., Laryng., Rhin.; b 1888; State Uni. of Ia., 1910; Valley Co.; A.M.A.

Bartek, Julius Geo.; Omaha; Gen. Prac.; b 1898; Creighton Uni., 1923; Douglas Co.

Bartholomew, William Sylvester; Lebanon; Gen. Prac.; Lincoln Med. Col.; served as 1st. Lieut., 1918-1920; Red Willow Co.; State; American Legion.

Bartholomew, Philip H.; Lincoln; Venereal Disease, Public Health; Uni. of Ill. Med. Col.; served, Mexican Border; Lieut. Col., M.C., 110 Med. Regt. N.N.G.; Maj., M.C., A.E.F.; Lancaster Co.; State; A.M.A.; Assn. Mil. Surgs.

Bartlett, Arthur L.; Spalding; Gen. Prac.; b 1880; Uni. of Nebr., 1903; Greeley Co.

Bartlett, Wm. Clarence; Alma; Gen. Prac.; b 1878; Central Med. Col. of St. Joseph, 1904; Harlan Co.; A.M.A.

Baskin, Morris Jacob; Alliance; Surg.; b 1895; Uni, of Colo., 1918; Bex Butte Co.; A.M.A.

Basten, C. Van Dyck; Kearney; Gen. Prac.; b 1859; State Uni. of Iowa, 1883; Buffalo Co.; A.M.A.

Bates, John B.; Verdigre; Gen. Prac.; b 1860; Col. of Phys. and Surg., Keokuk, 1890; Knox Co. 


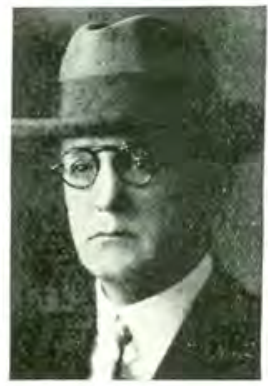

F. M. BELI

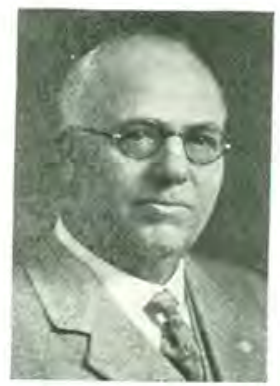

W. J. BIRKOFER

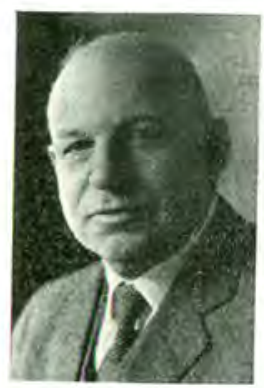

J. BIXBY

Beattie, Jasper; Bethany; Gen. Prac.; b 1867; Barnes Med. Col., St. Louis, 1894; Lancaster Co.

Beatty, John Ray; Butte; R'oentgenol.; b 1875; Uni. of Nebr., 1899; Boyd Co.

Beck, Frederick O.; South Omaha; Surg.; Col. Phys, and Surg., Uni. of Ill.; Douglas Co.; State; A.M.A.; Elks; Ch. of Commerce.

Becker, Wesley Charles; Lincoln; Obstet., Gynecol.; Uni. of Nebr., A.B., 1912; A.M. Med. 1914; Rush Med. Col., M. D. 1914; Rush Med. Col., M.D., 1915; Uni. of Vienna, 1926; chief of obstetrical department, Bryan Memorial Hospital.; president, Peoples Saving and Loan Assn.; M.C., World War; Capt., M.O.R.C.; Lancaster Co.; State; A.M.A.; Lions, Country Commercial Clubs.

Beede, Clark Eli; David City; Obstet.; b 1894; Uni. of Nebr., 1918; Butler Co.; A.M.A.

Bell, David W.; Blair; Gen. Prac.; Creighton Med. Col.; faculty, Creighton Med. Col., 1920-1924.

Bell, Hubert O.; York; Surg.; b 1889; Northwestern Uni., 1913; York Co.; A.M.A.

Bell, James R.; Fairfield; Obstet.; b 1872; Ensworth Med. Col., 1907; Clay Co.

Bell, James Stewart; York; Surg.; b 1889; Northwestern Uni., 1913; York Co.; A.M.A.

Bell, Firman M.; Grant; Gen. Prac.; Ensworth Central Med. Col.; pres., Keith-Perkins Co. Med. Soc.; local exam. bd., World Wâr; Keith-Perkins Co.; State; A.M.A.; Elks.

Bell, Nellie; Fremont; Gen. Prac.; b 1862; Kansas City Hom. Med. Col., 1895; Dodge Co.

Bennett, Abram Elting; Omaha; Neuro-psychiat. Uni. of Nebr., M.D.; Interne Philadelphia Gen. Hosp.; Nervous Infirmary, Philadelphia; Johns Hopkins Med. Sch.; Douglas Co.; State; A.M.A.; Alpha Omega Alpha; Phi Rho Sigma; author of many articles in New York M. J.; J.A.M.A.; Trained 
Nurse and Hosp. Rev.; Univ, of Nebr. Extension News; Arch. Int. Med,; Arch. Neurol. and Psychiat,; Nebr. Med. J.

Bennett, Jos. L.; Kearney; Gen. Prac,; b 1849; Eclectic Med. Col. of Cincinnati, 1874; Buffalo Co.

Bennie, J. W.; Clearwater; Gen. Prac.; Detroit Med. Col.; Co.; State; A.M.A.

Benson, Harry Wm.; Oakland; Ophthal., Otolo., Laryng., Rhin.; b 1876; Uni. of Nebr., 1903; Burt Co.; A.M.A.

Benthack, Peter L.; Chadron; Gen. Prac.; b 1867; Kansas City Hom. Med. Col., 1899; Dawes Co.

Benthack, Walter; Pierce; Gen. Prac.; b 1896; Uni, of Nebr., 1924; Pierce Co.; A.M.A.

Bentley, Ralph L.; Lincoln; Gen. Prac.; b 1855; Bennett Med. Col. of Chicago, 1881; Lancaster Co.

Bentley, Samuel N.; Lincoln; Gen. Prac.; b 1859; Uni. of Vt., 1884; Lancaster Co.

Berchtold, Victor Ernest; Santa Fe, New Mexico, formerly of Grand Island; Gen. Prac.; b 1901; Creighton Uni., 1925; Hall Co.

Benton, Joseph E.; Central City; Gen. Prac.; Uni. of Nebr. Med. Col., M.D., 1897; Merrick Co.; State; A.M.A.

Bentz, George Henry; Kearney; Gen. Prac.; Kansas City Med. Sch., M.D., 1902; Med. Dept., Nebr. Nat1. Guard, 1913-1917; Major, M.C., World War; Major, M.R.C. now; Buffalo Co.; State; A.M.A.; Kearney Ch. of Commerce; Cosmopolitan Clubs.

Berney, Paul William; Leigh; Gen. Prac; Creighton Med. Col.

Berry, William; Omaha; Pediat.; Starling Med. Col., M.D., 1888 (now med. dept., Ohio Uni.); post-grad, work in Chicago, New York and London, 1908 and 1927; Douglas Co.; State; Mo. Valley Med. Assn.; Nebr.-Iowa Pediat. Soc.; A.M.A.

Best, Rollin Russell; Omaha; Surg,; b 1897; Harvard Uni., 1922; Douglas Co.; A.M.A.

Betz, Wm. Henry; Omaha; Surg.; b 1867; Uni. of Nebr., 1900; Douglas Co.; A.M.A.

Billings, Robert Anderson; Comstock; Gen. Prac.; Chicago Hom. Sch.; Kansas City Hom. Sch.; county and city physician; U. S. Board of Pensions; Insanity $\mathrm{Bd}$; Am. Inst. of Homeopathy.

Bilon, Louis V.; York; Gen. Prac.; b 1897; Uni. of Nebr., 1925; York Co.

Birkhofer, William J.; Gothenburg; Gen. Prac.; charter member and past pres., Dawson Co. Med. Soc.; Past vice-pres., Nebr. State Med. Soc.; former mayor; Dawsen Co.; State; A.M.A.; Kiwanis, Ch. of Commerce.

Birkner, John Martin; Lincoln; Gen. Prac.; b 1855; Mo. Med. Col. of St. Louis, 1880; Lancaster Co. 


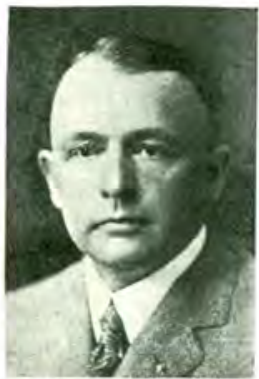

A. C. BLATTSPIELER

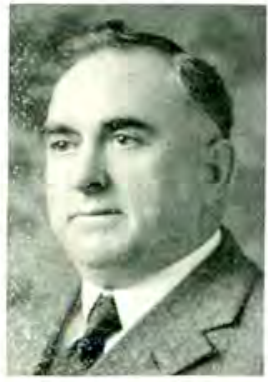

x. H. BLAKELY

Bitzer, Donald A.; Fairbury; Gen. Prac.; b 1903; Uni. of Nebr., 1926; Jefferson Co.

Bixby, Joseph; Geneva; Surg.; Rush Med. Col.; Uni. of Kansas Med. Col.; Fillmore Co.; State; A.M.A.; American Legion.

Black, Paul; Lincoln; Ophthal., Otolo., Laryng., Rhin.; Rush Med. Col., M.D.; M.C., World War; Co.; State; A.M.A.; F.A.C.S.; Am. Acad. of Ophthal. and Oto-Laryngol.

Blackman, Julian Raymond; Omaha; Roentgenol.; b 1878; Johns Hopkins Uni., 1906; Douglas Co.; A.M.A.

Blair, Edward S.; Wayne, 40 years; Gen. Prac.; Allegheny Col., M.A.; Uni. of Mich., M.D.; oldest practitioner in Wayne Co., there 34 years; member Wayne Co. Med. Scc.

Blakelcy, Nathan Hall; Auburn: Gen. Prac.; b 1869; Creighton Uni,, 1910.

Blattsp.eler, Arnoid Charles; Tobias; Gen. Prac,; Uni. ci Iowa; Northwestern Uni. Med. Schocl; Salline Co.; State.

Blcick, Louis C.; Omaha; Eye, Ear, Nose, Throat; Creighton Med. Col., M.D.. 1902; Intern, Fost-Grad. Hosp., Chicago, 1904; post-grad. study, Philadelphia, 1919 and European Clinics, 1900 and 1924; Capt., M.C., World War; Douglas Co.; State; A.M.A.

Bliss, Rodney Waldo; Omaha; Intern. Med,; Uni. of Nebr.; Rush Med. Col.; Harvard Med School; pres., Omaha-Douglas Co. Med. Soc., 1925; asst. prof. of medicine, Uni. of Nebr. Med. Col.; Douglas Co.; State.

Bloch, David Michael; Cedar Blufis; Gen. Prac.; b 1898; Uni. of Nebr., 1924; Saunders Co.

Block, Max; Omaha; Gen. Prac.; b 1895; Uni. of Nebr. Med. Col., 1919; Douglas Co.; A.M.A.

Blumer, Fredk. Wm.; Lincoln; Gen. Prac,; 5 1881; Lincoln Med. Col, 1908; Lancaster Co.

Boehr, Irwin I.; Long Pine; Gen. Prac,; b 1888; Northwestern Uni., 1924; Brown Co. 


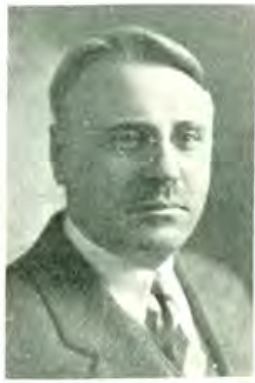

D. J. BOWMAN

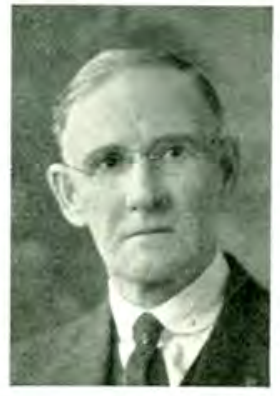

L. W. BOWMAN

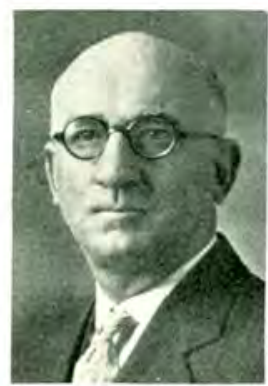

E. E. BOYD

Bogen, Louis Isaac; Lincoln; Gen. Prac., Electrotherap.; New York Uni. Med. Col.; Capt., M.C.; papers to American Physician and Clinical Med., Med. World.

Boggs, Chas. S.; Filley; Gen. Prac.; b 1857; Uni. of Nebr., 1884; Gage Co.

Boland, Frank Wm.; Howell; Gen. Prac.; b 1882; Creighton Uni., 1908; Colfax Co,

Boler, Thos. Danl.; Omaha; Urol.; b 1885; Northwestern Uni., 1908; Douglas Co.

Bonniwell, Harry Melvin; Axtell; Gen. Prac.; b 1870; American Medical Missionary Col., 1905; Kearney Co.

Boose, Wm. R.; Falls City: Gen. Prac.; b 1874; Rush Med. Col., 1904; Richardsen Co.

Beren. Albert J.; Hastings; Ophthal., Otolo., Laryng., Rhin.; b 1882; Washington Uni., St. Louis, 1906; Adams Co.; A.M.A.

Borghoff. John Alcysius; Omaha; Gen. Prac.; b 1895; Uni. of Nebr., 1920; Douglas Co.

Bewen, Geo. Sanford; Greeley; Gen. Prac.; b 1855; Long Island Col. Hosp., 1883; Greeley County.

Bowles, Edward Arthur; Hebron; Surg.; Detroit Hom. Col., 1903; Uni. of Ill,, 1905; Thayer Co.; A.M.A.

Bowles, Loetta Beamer; Hebron; Surg.; Uni. of Ill., 1006; Thayer Co.; A.M.A.

Bowman, Carrie Luella; Loup City; Gen. Prac.; b 188.3; Lincoln Med. Co.. 1912; Sherman Co.

Bowman, Delbert J.; Lincoln; b 1883; Gen. Prac.; Lincoln Med. Col., 1911; staffs, Bryan and Lincoln Hosps,; Lancaster Co.; State; Mo. Valley.

Bowman, Jchn Edward; Lcup City; Gen. Prac.; b 1878; Lincoln Med. Col., 1912; Sherman Co.

Bowman, Luther W.; Alliance; Gynecol.; b 1858; State Uni. of Iowa, 1886; Box Butte Co.; A.M.A. 
Bowser, Wm. Wolfe; Omaha; Gen. Prac.; b 1866; Uni. Med. Col. of Kansas City, 1911; Douglas Co.

Boyd, Earl Eugene; Central City; Gen. Prac.; Cotner Uni., A.B., 1902; M.D., 1906; Capt., M.R.C., World War; draft bd,; Merrick Co.; State; A. M.A.; Central City Lions Ch. of Commerce.

Boyden, Henry Blakeslee; Grand Island; Gen. Prac.; b 1889; Rush Med. Col., 1911; Hall Co.

Boyer, Wm. Ransom; Pawnee City; Surg.; b 1871; General Med. Col. of Chicago, 1884; Pawnee Co.; A.M.A.

Bradley, C. A.; Beatrice; Gen. Prac.; Col. of Phys. and Surgs., Keokuk, 1880; Gage Co.

Bradley, Edwin Bruce; Spencer; Gen. Prac,; Rush Med. Col.

Brainard, Jerry E.; Superior; Gen. Prac.; b 1865; Cleveland Uni. of Med. and Surg., 1889; Nuckolls Co.

Brannen, James L.; Greeley; Gen. Prac.; b 1869; Creighton Uni., 1901; Greeley Co.

Brandt, Emelia Hanigsen; Omaha; Internal Med. and Gynec.; Uni. of Nebr. Med. Co., 1918; public health lecturer, Y. W. C. A., 1919; Douglas Co.; State; A.M.A.; Natl. Womens Med. Soc; State Womens Med. Soc.; Mo. Valley Med. Assn.; Ch. of Commerce; College Club; Nu Sigma Phi.

Bratt, Mary; Arapahoe; Gen. Prac.; Uni. of Nebr. Med. Col.; Furnas Co.; State; A.M.A.; N.S.P.

Bray, Robert Ellis; Martinsburg; Gen. Prac.; Uni. of So. Dakota; Creighton Uni. Med. Col.

Breen, Adrian Louis; Carroll; Gen. Prac.; b 1873; England, 1894; Wayne Co.

Brendel, Jacob H.; Murray; Gen. Prac,; Lincoln Med. Col., 1903; Cass Co.

Brendel, J. W.; Avoca; Gen. Prac.; Lincoln Med. Col., 1901; Cass Co.

Brenn, Chas. P.; Western; Gen. Prac.; b 1883; Chicago Col. of Med. and Surg., 1906; Saline Co.; A.M.A.

Breuer, Charles H.; Lincoln; Surg., Gynecol,; Creighton Med. Col.; Chicago, Vienna; Capt., Nebr. M.C.; Lancaster Co.; State; A.M.A.; Am. Col. of Physical Therapy; author of Popular Hygiene and many medical articles.

Breuer, Miles J.; Lincoln; Internal Med.; Uni, of Texas, B.A., 1911; M.A., 1911; Uni. of Chicago Med. Dept. (Rush Med. Col.) M.D., 1915; pathologist, Bryan Memorial Hosp., Lincoln; acting asst. surg., U.S.P.H.S., 1919-1920; instr., materia medica, Uni. of Nebr. Dental Sch., 1916-1923; World War; Lancaster Co.; State; Am. Col. of Phys.; Am. Public Health Assn.; A.M.A.; Phi Beta Kappa; Sigma Xi, Phi Gamma Mu; Professional Men's Club; Boy Scouts; Y.M.C.A.

Bridges, Edson Lowell; Omaha; Internal Med,; Omaha Med. Col.; Northwestern Uni. Med. Sch.; N. Y. Policlinics; post-grad. study in Vienna, 


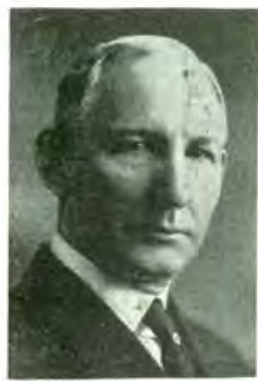

A. E. BUCHANAN

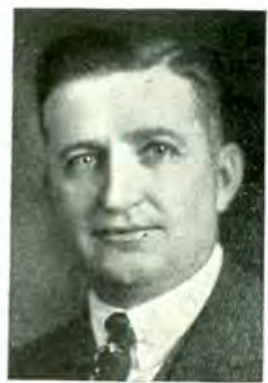

H. R. BROWN

Munich, Berlin, London; Professor of Medicine, Uni. of Nebr, Med. Col,; with Base Hosp. No. 49, Allery, France; Douglas Co.; State; A.M.A.; University, Omaha, Happy Hollow, Country Clubs.

Bridges, Willson Ortun. See Chapter on Pioneers and Medical Schools.

Briggs, Glenn W.; Decatur; Gen. Prac.; Creighton Med. Col.

Briggs, Walter H.; Ewing; Gen. Prac,; b 1876; State Uni, of Iowa, 1898; Holt Co.

Britt, Leonard E.; Omaha; Gen. Prac.; b 1878; Louisville Natl. Med. Col., 1909; Douglas Co.

Britt, Wm. H.; Creighton; Gen. Prac.; b 1874; State Uni. of Iowa, 1884; Knox Co.

Brooks, Earl Brisbin; Lincoln; Ophthal., Otolo., Laryng., Rhin.; Northwestern Uni,. 1905; Lancaster Co.; A.M.A.

Brown, Alfred Jerome; Omaha; Surg.; Yale Uni., A.B., 1899; Columbia Col. Phys, and Surg., M.D., 1903; asst. prof. of surgery, Uni. of Nebr. Med. Col.; staff, Uni., Clarkson, Swedish Covenant Hosps.; Major, M.C., World War, instructor in war surgery; State; West Surg. Soc.; Am. Surg. Assn.; A.M.A.; Phi Rho Sigma.

Brown, Andrew D.; Central City; Gen. Prac.; Uni. of Iowa; Rush Med. Col.; Uni. of Nebr. Med. Col.; Co.; State; Lion and Elk Clubs.

Brown, Chas. P.; Omaha; Gynecol.; b 1867; Uni. Med. Col. of Kansas City, 1900; Douglas Co.; A.M.A.

Brown, Dewey Franklin; McCook; Gen. Prac.; b 1898; Uni. of Nebr., 1924; Red Willow Co.

Brown, Ewing; San Pedro, Calif,; Public Health; Jefferson Med. Col., 1883 ; post-grad. work, John Hopkins Uni., 1904; Faculty, Omaha Med. Col,, 1883-1895; Uni. of Nebr., 1895-1904; now health officer for Los Angeles harbor District.

Brown, Harry Richard; Beatrice; Gen. Prac.; b 1883; St. Louis Uni. School of Med., 1907; Gage Co. 


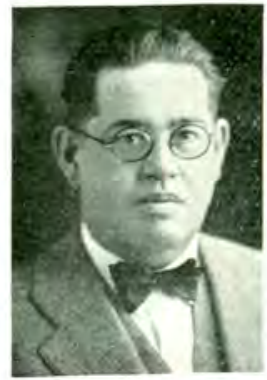

A. D. BROWN

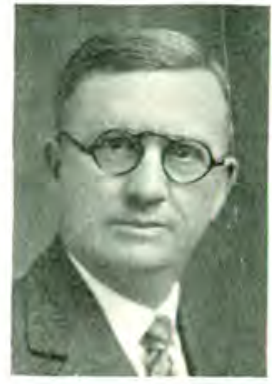

E. L. BRUSH

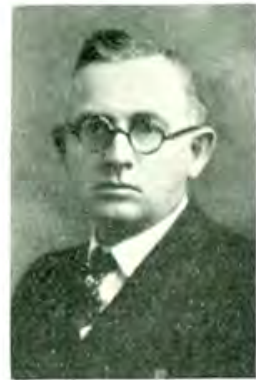

R. D, BRYSON

Brown, Joseph W.; Hastings; Gen. Prac.; Uni. of Iowa; Co.; State; Hastings K.P.; Eagles; Lions, M.W.A. Clubs.

Brown, Julius Philip; Stuart; Gen. Prac.; b 1890; Uni. of Nebr., 1924; Holt Co.; A.M.A.

Brown, Lione: Botleman; Stratton; Gen. Prac.; b 1896; Uni. of Nebr., 1922; Hitchcock Co.

Brownson, Hollis Lee; Plymouth; Gen. Prac.; b 1887; Jefferson Med. Col., 1920; Jefferson Co.

Bruce, Gerald J.; Mullen; Gen. Prac.; b 1895; Uni. of Nebr., 1922; Hooker Co.

Brush, Edward Lewis; Norfolk; Gen. Prac. and Surg.; Uni. of Iowa; Uni. of Nebr.; post-grad. study, Chicago, 1913; Harvard, 1916; New York, 1918 ; past pres., Madison Co. Med. Soc.; pres. in 1913, Elkhorn County Med. Soc.; chairman Advisory Board, Madison Co.; State; A.M.A.; Am. College of Surgeons; Norfolk County; Rotary.

Bryan, Albert Waite; Linceln; Gen. Prac.; b 1896; State Uni. of Iowa, 1020; Lancaster Co.; A.M.A.

Bryant, DeWitt Clinton; Claremont, Calif; (retired from active practice) Oculist and Aurist; Cleveland, A.M., M.D.; New York; London; Berlin; Vienna; former dean and prof. ophthalmology, Creighton Med. Col.; Los Angeles Co.; Mo. Valley Med. Assn.; Am. Col. of Surg.; one of the founders of the Am. Col. of Surg. and of Creighten Med. Col.

Bryson, Roy Douglas; Callaway; Surg.; Lincoln Med. Col., M.D., 1907; Councilor, 9th dist., Nebr. State Med. Assn.; M.C., World War; Custer Co.; State; Lincoln Rotary.

Buchanan, Albert Edward; Fremont; Gen. Prac.; Medical Col, of Virginia; chairman, state fund relief committee; Capt., M.C., World War; Major M.R.C ; state rehabilitation Com,; member gen. welfare com., Nebr. Am. Legion; bd. of education; past commander, Legion Post No. 20; Dodge Co.; State; A.M.A.; Elkhorn Valley; Sioux Valley and Mo. Valley Med. Assn.; Pi Mu; Sigma Alpha Epsilon; local societies. 
Buchanan, Rea; Lincoln; Gen. Prac.; b 1870; Lincoln Med. Col., 1911; Lancaster Co.

Buckley, Frederick Watson; Beatrice; Gen. Prac.; Northwestern Uni.; Base Hosp. No. 49, World War; Gage Co.; State; A.M.A.; Kiwanis.

Buie, John; Pender; Gen. Prac.; Omaha Med. Col.; M.C., World War; Co.; State; A.M.A.; Sioux Valley Med. Soc; Elkhorn Valley Med. Soc.

Burchard, Harry Dana; Falls City; Gen. Prac.; b 1882; Creighton Uni., 1908; Richardson Co.

Burdick, Harry Edwin; David City; Surg.; b 1876; Uni. of Nebr., 1899; Butler Co.; A.M.A.

Burford, James A.; Beatrice; Psychiat., Sociol.; Lincoln Med. Col.; Chicago Post-Grad. Med. Sch.; Northwestern Med. Col.; in private practice. 1897-1916; asst. supt., Nebr. Institute for Feeble Minded since July 1, 1927; Gage Co.; State; A.M.A.; R'otary.

Burgess, Frank Dooley; Ingleside; Gen. Prac,: b 1866; Uni. of Nebr., 1888; Adams Co.

Burke, Thos. N.; Elkhorn; Gen. Prac,; b 1875; Creighton Uni., 1904; Douglas Co.; State; A.M.A.

Burke, William A.; Omaha; Gen. Prac; Uni. of Iowa Med. Col., M.D.. 1801 ; Douglas Co.; State; A.M.A.:

Burlingame, Lyman R.; Omaha; Gen. Prac.; b 1853; Rush Med. Col., 1883 ; Douglas Co.

Burnham, Frank A.; Gen. Prac.; Uni. of Nebr.; Custer Co.; State

Burns, Bernard Chas.; Omaha; Gen. Prac.; b 1899; Creighton Uni., 1924; Douglas Co.

Burrell, Ramon Haddock; Creighton; Gen. Prac.; b 1874; Uni. of Mich. Med. Sch., 1900; Knox Co.; A.M.A.

Bushman, Louis B.; Omaha; Eye, Ear, Nose, Throat; London; Vienna: local aviation board during war; Douglas Co.; State; A.M.A.; Mo. Valley Med. Assn.; F.A.C.S.; Am. Acad.

Butler, J. S.; Superior; Gen. Prac.; b 1857; Western Reserve Uni., 1883; Nuckolls Co.

Byers, Jay Cleveland; Friend; Gen. Prac.; b 1892; Northwestern Uni., 1920; Saline Co.

Byers, Robert. Chas.; Fremont; Gen. Prac.; b 1877; Uni. of West. Ont. Med. Sch., London, 1903; Dodge Co.; A.M.A.

Byrne, James Raymond; Omaha; Gen. Prac.; b 1894; Creighton Uni,, 1917; Douglas Co.

Byrnes, M. Robt.; Crete; Ophthal., Otolo., Laryngol., Rhin.; b 1870 Grand Rapids Med. Col., 1907; Saline Co.; A.M.A.

Calbreath, Claude B.; Hastings; Surg.; Keckuk Med. Col., M.D., 1898; Capt., M.C., World War; Adams Co.; State; A.M.A.; Republican Valley Med. Soc. 


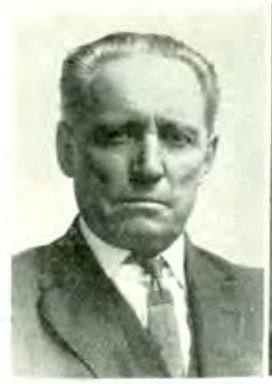

W. A, BURKE

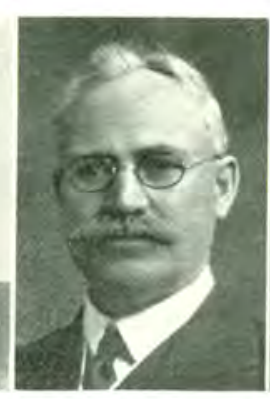

F. E. CALKINS

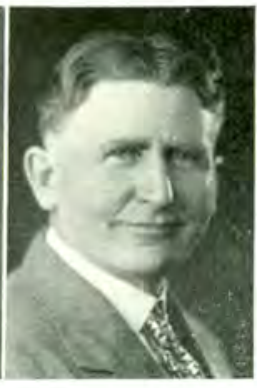

E. F. CARR

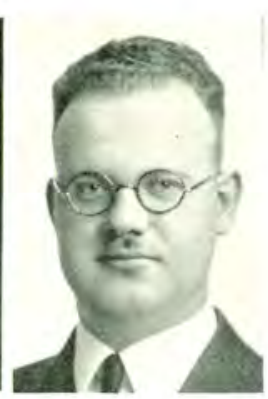

C. R. CARLSON

Calkins. Fred E.; Fremont; Gen. Prac. (retired); Uni. of Iowa Med. Col.; state med. director for Modern Woodman; member draft board; Dodge Co. physician; State.

Callaghan, Ambrose James; Snyder; Gen. Prac.; b 1892; Creighton Uni., 1918; Dodge Co.

Cameron, Alex D.; Kearney; Gen. Prac.; b 1862; Queen's Uni. Fac. of Kingston, 1882; Buffalo Co.

Cameron, Allan J.; Herman; Gen. Prac.; Toronto Uni., M.D., 1900; Capt., M.R.C., Fort Riley, Hcboken, Camp Crane; member advisory board, Washington Co.; Washington Co.; State; Mo. Valley Med. Assn.; Am. Col. of Physical Therapy.

Cameron, Hugh Campbell; Jehnston; Gen. Prac.; b 1876; Uni. of Toronto, 1900; Nemaha Co.; A.M.A.

Cameron, John James; Kearney; Gen. Prac.; b 1864; McGill Uni. Fac. of Med., Montreal, 1888; Bufialo Co.

Cameron, Joseph Robert; Bennet; Gen, Prac.; Creighton Med. Col.; Uni. of Ill., M.D.; Spanish War Veteran; Capt., med. service, Mexican Border, 1916; Furnas Co.; State.

Cameron, Wm. L.; Lincoln; Gen. Prac.; b 1855; Drake Uni., 1887; Lancaster Co.

Campbell, Chas. Harvey; Columbus; Ophthal., Otolo., Laryng., Rhin.; b 1876; State Uni. of Iowa, 1898; Platte Co.; A.M.A.

Campbell, Joseph New; Stamford; Gen. Prac.; Lincoln Med. Col.; Harlan Co.; State; Repubuican Valley Med. Soc.

Campbell, Philip Thes,; Omaha; Gen. Prac.; b 1898; Creighton Uni., 1922; Douglas Co.

Campbell, Robt. R.; Franklin; Gen. Prac.; b 1870; Keokuk Med. Col., 1894; Franklin Co.

Campbell, Samuel M.; Omaha; Gen. Prac.; b 1853; General Med. Col. of Chicago, 1881; Douglas Co. 
Campbell, Stuart Avery; Norfolk; Surg.; Uni. of Nebr. Med. Col.; N. Y. Post-Grad. Polyclinic; attg. surgeon, Lutheran Hosp., Norfolk; Co.; State; A.M.A.; F.A.C.S.

Campbell, Willian Allan; Glenvil; Gen. Prac,; Uni. of Nebr. Med. Col.; Clay Co.; State.

Carlson, Carl Robert; Wauneta; Gen. Prac.; Uni. of Nebr., M.D., 1924; Chase-Dundee-Hayes-Hitchcock Co.; State; A.M.A.; Interstate Post-Grad. Med. Assn. of N. A.; Phi Beta Pi; Phi Delta Chi; Mason.

Carothers, John W.; Lincoln; Surg.; b 1884; Lincoln Med. Col., 1913; Lancaster Co.; A.M.A.

Carothers, Paul Henry Jacob; Broken Bow; Surg.; b 1881; Lincoln Med. Col., 1910; Custer Co.; A.M.A.

Carpenter, Fredk. Denniston; Panama; Gen. Prac.; b 1873; Uni. of Md., 1907; Lancaster Co.

Carr, Emanuel Frederick; Stapleton; Gen. Prac,; Bennett Med. Col,; Co. Chmn., American R'ed. Cross; dist. surg, U.P. Ry, for 16 years; Capt., 372 M.C., U.S.A.

Carroll, Anthony Geo.; Bellwood; Gen. Prac.; b 1899; Creighton Uni., 1924; Butler Co.

Carroll, Raymond Patrick; Laurel; Gen. Prac.; b 1897; Creighton Uni., 1920; Cedar Co.

Carson, David H.; Grand Island; Ophthal., Otolo., Laryng., Rhin.; b 1876; Creighton, 1905; Hall Co.

Carter, Lew A.; O'Neill; Gen. Prac.; Kansas City Hahnemann Med. Col.; past pres., Holt Co. Med. Soc.; pres., bd. of education; Holt Co.; State; A.M.A.

Carveth, Walter Wm.; Lincoln; Gen. Prac.; b 1895; Uni. of Nebr., 1925; Lancaster Co.

Casady, Selmon A.; Beatrice; Gen. Prac.; b 1851; Keokuk Med. Col., 1891; Gage Co.

Case, Ernest Spencer; Curtis; Gen. Prac.; b 1872; Uni. of Nebr., 1895; Frontier Co,; A.M.A.

Case, James D.; Lincoln; Phys. and Surg.; Cotner Uni. Med. Col.; post-grad. study, Uni. of Chicago; Supt., State Hosp., Lincoln, 1918-1919; Supt. of State Health and Welfare dept., 1923-1924; formerly physician, Milford Industrial Home.

Casey, Frank Jos,; Omaha; Gen. Prac.; b 1895; Creighton Uni., 1924; Douglas Co,

Cashin, John Emerson; Omaha; Gen. Prac.; b 1870; Hosp. Col. of Med., Louisville, 1893; Douglas Co.

Cassidy, Waldron A.; Omaha; Oto-laryng.; Uni. of Denver, A. B.; Uni. of Nebr., M.D., 1918; assd. with Dr. Harold Gifford; Lieut., M.C., U.S.N.; Co.; State; A.M.A.; Alpha Omega Alpha; Nu Sigma Nu.

Cate, Wm. Andrew; Nelson; Gen. Prac.; b 1859; Chicago Hom. Med. Hosp., 1892; Nuckolls Co. 
Cauley, Anthony; Humphrey; Gen. Prac.; Creighton Med. Col.

Caulk, William H.; Lincoln; Gen. Prac.; Keokuk Col. Phys. and Surg., M.D., 1881; in gen. prac, in Nebr. since 1890.

Cerny, Jos.; Wilber; Gen. Prac.; b 1865; Jenner Med. Col., 1899; Saline Co.; A.M.A.

Chaloupka, Edward; Omaha; Gynecol.; Creighton Med. Col., M.D., 1905; Spanish War Veteran; Gynecol., St. Joseph's Hosp., Omaha.

Chaloupka, John Godiry; Omaha; Gen. Prac.; b 1896; Creighton Uni., 1922; Douglas Co.; A.M.A.

Chandler, Paul Austin; Hastings; Gen. Prac.; b 1896; Harvard Uni., 1924; Adams Co.

Chapman, Alma J.; York; Diseases of Women; Omaha Med. Col.; Phys., Ingleside Hosp.; S. and S. Home, Burkett, Nebr.; State Hosp., Lincoln; and supt., State Reformatory for women at York; Adams-Hall-LincolnYork Co.; State; Daughter of Veterans.

Chapman, Amy R.; Hastings; Obstet., Pediat.; Ann Arbor Uni.; Lincoln Med. Col.; Nebr. State Hosp. for Insane, Ingleside, 1924-1925; member, vol. med. Corps No. 393; Adams Co,; State; A.M.A.; W.R.C.

Chapman, Chauncey Franklin; Lincoln; Gen. Prac.; b 1862; Uni. of III., 1892; Lancaster Co.; A.M.A.

Chapman, Lille Forrest; West Point; Gen. Prac.; b 1892; Loyola Uni., 1919; Cuming Co.; A.M.A.

Charlton, Chas. Percy; Palmyra; Gen. Prac.; b 1887; Chicago Col. of Med. and Surg., 1913; Otoe Co.

Charlton, Geo. E.; Norfolk; Gen. Prac.; b 1882; Lincoln Med. Col., 1907; Madison Co.; A.M.A.

Chase, Warren T.; Loup City; Gen. Prac.; General Med. Col., Chicago, 1882; Sherman Co.

Chessir, J. Melsworth S.; Superior; Gen. Prac.; b 1871; Hering Med. Col., 1904; Nuckolls Co.

Christie, Burton Whitford; Omaha; Gen. Prac.; Uni. of Nebr., B.Sc., 1899; formerly asst. prof. of pediat., Uni. of Nebr. Med. Col.; pres., Douglas Co. Med. Soc., 1913; Spanish War Veteran; Douglas Co.; State; F.A.C.P.

Church, Anna Ferguson; North Platte; Gen. Prac.; b 1854; Northwestern Uni., 1882; Lincoln Co.

Churchill, Irving W.; Lincoln; Surg.; b 1893; Creighton Uni., 1917; Lancaster Co.; A.M.A.

Clapp, Raymond G.; Lincoln; Phys. Ed.; Yale Uni.; Keokuk; Col. Phys. and Surg.; Lancaster Co.; State; A.M.A.; Soc. of Dir. of Phys. Ed. in Cal.; Assn. of Uni. Prof.; Am. Phys. Ed. Assn.; Theta Delta Chi; Lincoln Uni. Club; papers on physical education.

Clark, Bennett Hillsman; Ashland; Gen. Prac.; b 1861; Uni. of Mo. 1880; Saunders Co.; A.M.A. 


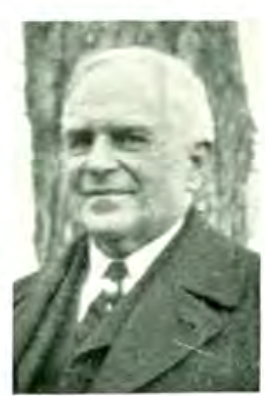

C. F. CLARK

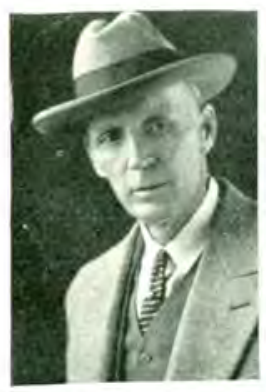

E. E. CONE

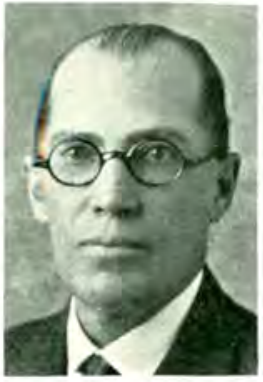

A. N. COMPTON

Clark, Chas. Ernest; Omaha; Gen. Prac.; b 1865; Rush Med. Col., 1884; Douglas Co.

Clark, Charles Fuller; Omaha; Gen. Prac.; Michigan Med. Col., M.D., 1881; Chicago Post-Grad. Col., 1891; Co.; State; A.M.A.; Dunlap, Nebr., $1881-1891$.

Clark, Eugene E.; Burwell; Gen. Prac.; Grand Island Col.; Uni. of Mo.; Jefferson Med. Col.; chief resident Sacred Heart Hosp., Allentown, Pa., 1920; Valley Co.; State; Phi Betta Pi.

Clark, Geo. A.; Elwood; Gen. Prac.; b 1870: Creighton Uni., 1908; Gosper Co.

Clark, George Leonard; Omaha; Gen. Prac.; b 1897; Uni. of Nebr., 1925 ; Douglas Co.

Clark, Guy Wilber; Bertrand; Gen. Prac; Fremont Normal, B. Sc.; Creighton Med. Col., M.D.; post-grad. work in Chicago; member war advisory board, Gosper and Frontier Co.; Co.; State; A.M.A.

Clark, Martha E.; Omaha; Gen. Prac.; b 1856; Gen. Med. Col. of Chicago, 1897; Douglas Co.

Clark, Mildred Naomi Johnson; Omaha; Gen. Prac,; b 1899; Uni. of Nebr., 1925; Douglas Co.

Clarke, Floyd Sweetland; Omaha; Pediat.; b 1875; Medico-Chirurgical Col.; Philadelphia; New York, Edinburgh; London; Vienna; prof. of pediat., Creighton Med. Col.; Co.; State; A.M.A.; Omaha Uni.; Happy Hollow; Professional Men's Club.

Clarke, Willard K.; Valentine; Gen. Prac.; b 1866; Uni. of Nebr., 1897; Cherry Co.

Clarke, Harry D.; Tamora; Gen. Prac,; b 1885 ; Creighton Uni., 1912; Seward Co.; A.M.A.

Clarke, Harvey Llewellyn; Fairbury; Gen. Prac.; New York Hom. Med. Col.; Uni. of Mich,. 1882; Jefferson Co.; State; Am. Institute of Homeopathy

Claussen, Julius Edward; Beatrice; Gen. Prac.; b 1855; Rush Med. Col., 1883; Gage Co. 
Clayton, Jeremiah Black; Omaha; b 1872; Uni. of Md., 1893; Col., M.C., U.S.A.; Douglas Co.; A.M.A.

Clements, Stanley Curtis; Lincoln; Gen. Prac.; b 1874; Minneapolis Col. of Phys. and Surgs., 1904; Lancaster Co.

Cline, Edgar; Auburn; Gen. Prac.; Creighton Med. Col.; Capt., M.C., Co.; State; Am. Legion.

Cloyd, Augustus D.; Omaha; Medico-Insurance; Louisville, St. Louis, Chicago, New York; Sovereign Phys. of Woodmen of World since 1898; med. Dir., Globe Life Insurance Co., Omaha, 1927; lecturer, Omaha Med. Col. and Med. Dept. of Uni. of Nebr., 1901-1912; formerly exam. surg., U.S. Pension Bureau; Ch. of Commerce; Happy Hollow Club; Articles on medicoinsurance.

Coe, Chas. Benj.; Wakefield; Gen. Prac.; b 1881; Creighton Uni., 1912; Dixon Co.

Colburn, William Orlin; Lincoln; Pediat.; Northwestern Uni. Med. Sch.; post-grad. study, New York Post-Graduate; Harvard; founder of Lincoln Children's Clinic; Head of Pediatric Dept., Lincoln Gen. Hosp.; Consult. ped., Bryan Memorial Hospital; Lancaster Co.; State; A.M.A.; Central States Pediatric Soc.; Lincoln Rotary; Ch. of Commerce.

Coleman, Fredk. David; Lincoln; Obstet.; b 1895; Uni. of Nebr., 1919; Lancaster Co.

Collins, Cornelius R'.; Omaha; Gen. Prac,; b 1872; Creighton Uni., 1900; Douglas Co.

Collins, Floyd M.; Mitchell; Gen. Prac.; Uni. of Nebr. Med. Col.; member staff, West Nebr. Methodist Hosp.; M.R.C.; Scotts Bluff Co.; State.

Collins, Richard Kenneth; Omaha; Obstet., Gynecol.; b 1896; Creighton Uni., 1922; Douglas Co.; A.M.A.

Colman, A. C.; Chappell; Gen. Prac.; b 1883; Lincoln Medical Col., 1007 ; Deuel Co.

Compton, A. N; Valentine; Gen. Prac.; Col. Phys. and Surg., St. Louis, 1898; Holt Co.; State; A.M.A.; Ch. of Commerce, Rotary.

Condon, Albert Paul; Omaha; Surg.; b 1868; Rush Med. Col., 1900 Douglas Co.; A.M.A.

Cone, Elbert E.; Oxford; Gen. Prac,; E. M. I. Cincinnati; one of four organizers, Furnas Co, Med. Soc., 1893; Furnas Co.; State; Republican Valley Co.

Conlan, Peter T.; Omaha; Obstet.; b 1870; Creighton Uni., 1898; Douglas Co.; A.M.A.

Conlee, Chas. C.; Cook; Gen. Prac; b 1884; Chicago Col. of Med. and Surg., 1915; Johnson Co.; A.M.A.

Conlin, Frank Matthew; Omaha; Gen. Prac.; b 1883; Rush Med. Col., 1907; Douglas Co.; ex-pres.; A.M.A.

Connolly, Earl A.; Omaha; Surg.; Creighton Med. Col.; instructor, Creighton Med. Col.; M.C., Gen. Hosp. No. 55; Co.; State; A.M.A. 
Connor, Walter John; Petersburg; Gen. Prac,; b 1897; Creighton Uni., 1923 ; Boone Co.

Conrad, Alexander A.; Crete; Gen. Prac.; Creight on Med. Col., M.D.; post-grad., Harvard; Interne, St. Vincent's Hosp., Portland; Ore.; Saline Co.; State; A.M.A.; Rotary; papers in Nebr. Med. Jour.

Conwell, Paul Larsh; Elgin; Gen. Prac.; b 1879; Creighton Uni., 1907; Antelope Co.

Cook, Arthur Ellsworth; Randolph; Gen. Prac.; b 1870; Sioux City Med. Col., 1898; councillor of 4th district; Co.; State; A.M.A.; Am. Ry. Surgeons; Elkhorn Valley Med. Soc.

Cook, Lyman Joseph; Omaha; Gen. Prac.; Uni. of Wisc.; Uni. of Illinois; Co.; state; A.M.A.

Cook, Sheldon Eli; Lincoln; Ophthal., Otolo., Laryng., Rhin.; b 1857; McGill Uni. Fac. of Med., Montreal, 1884 ; Lancaster Co.; A.M.A.

Cooper, Albert Lloyd; Scottsbluff; Gen. Prac.; Uni. of Nebr., B.Sc., 1917; M.D., 1919; president of 12 Councilor Dist., Med. Soc. of Nebr.; staff, West Nebr. Methodist Hosp.; Scotts Bluff Co.; State; A.M.A.

Cooper, Susan Rachel Merrill; Aurora; Pediat.; b 1876; Eclectic Med. Col., Cincinnati, 1902; Uni. of Ill. Col. of Med., 1906; Hamilton Co.; A.M.A.

Cope, Otis Merriam; Omaha; Gen. Prac,; b 1880; Uni. of Mich., 1904 ; Douglas Co.; A.M.A.

Copeland, Cecil Clare; Beaver City; Gen. Prac.; b 1868; Rush Med. Col., 1894; Furnas Co.

Cornelius, Wm. Roy; Cody; Gen. Prac.; b 1878; Col, of Phys. and Surgs., Baltimore, 1901; Cherry Co.

Covey, George Worthington; Lincoln: Gen. Prac.; b 1889; Columbia Uni., 1914; Lancaster Co.; A.M.A.

Cowan, Sam. D.; Falls City; Eye, Ear, Nose, Throat; Ensworth Med. Col., M.D., 1911; Intern, Illinois Charitable Eye and Ear Infirmary, Chicago, 1912-1913; war service, 1918-1919; Richardson Co.; State; A.M.A.; Com. Club.

Cowan, S. Harper; Deweese; Gen. Prac.; b 1868; Keokuk Med. Col., 1902; Clay Co.

Crabtree, Hillborn C.; Lincoln; Gen. Prac.; b 1882; Lincoln Med. Col., 1916; Lancaster Co.

Craft, William Thomas; Brunswick; Gen. Prac.; Omaha Med. Col.; Pierce-Antelope-Madison-Stanton Co.; State; A.M.A.; Elkhorn Valley Med. Soc.

Crawford, Andrew; Scottsbluff; Gen. Prac.; Omaha Med. Col.

Crawford, William N.; Rushville; Surg.; Creighton Med. Col.; county and city health officer; founder, Rushville Gen. Hosp., 1924; Capt., M.C. overseas.

Creighton, Ernest Albert; Red Cloud; Gen. Prac.; Western Uni., London, Canada; Capt., M.C., World War; Co.; State; A.M.A. 


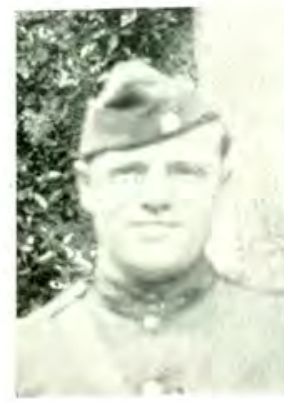

W. X. CRAWFORD

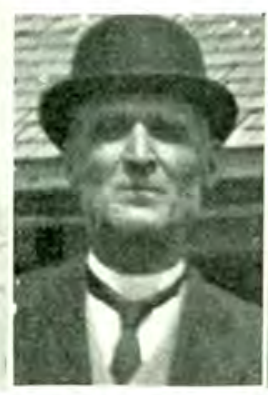

A. CRAWFORD

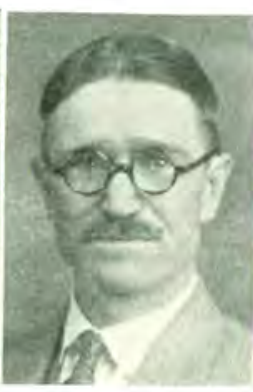

R. G. CRESSMAN

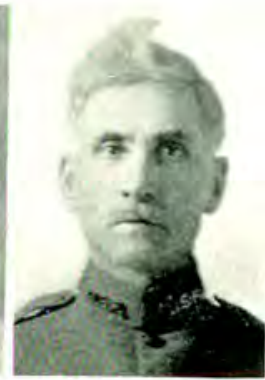

J. M. CURTIS

Cressman, Ralph G.; Hastings; Surg.; Bennett Med. Col., M.D., 1905; Lt.-Col., M.R.C., overseas; Adams Co.; State; A.M.A.; Rotary.

Criss, Clair C.; Omaha; Medico-Insurance; Creighton Med. Col; Commerce, Athletic, Field, Lakewood, Country Clubs.

Criss, Nell Leuis; Omaha; Gen. Prac.; b 1886; Creighton Uni. 1912; Douglas Co.

Cromwell, Philip I.; Arcadia; Gen. Prac.; b 1848; Albany Med. Col., 1870; Valley Co.

Crook, Roy; University Place; Surg.; b 1880; Creighton Uni., 1905; Lancaster Co.; A.M.A.

Crosby, Wm. L.; Beemer; Gen. Prac.; b 1866; Rush Med. Col., 1895; Cuming Co.

Cross, Clara B.; Omaha; Internal Med., Throat, Chest; Creighton Cincinnati; Loyola, M.D., 1913; Co.; State; A.M.A.; Mo. Valley Med. Assn.

Crowder, Earl Rankin; Omaha; Gen. Prac.; b 1899; Uni of Nebr., 1925 ; Douglas Co.

Crowley, Charles F.; Omaha; Teaching; Uni. of Mich.; Detroit; Creighton; Instructor, chemistry, Creighton Uni.; member, pre-war naval board; Am. Chem. Soc.; Am. Inst. of Chem. Engineers; Uni., Athletic, Happy Hollow Clubs.

Crudup, Charles Percy; Nebraska City; Gen. Prac.; Wake Forest College; Uni. of N. C.; Creighton Med. Col.; Allgemeine Krankenhaus, Vienna; Otoe Co.; State.

Cummins, Edgar D.; Lincoln; Gen. Prac; b 1864; Uni. of Nebr., 1889; Lancaster Co.

Cummins, Herschell B.; Seward; Ophthal.; b 1859; Uni. of Nebr., 1885; Seward Co.; A.M.A.

Curry, Chas. S.; Beatrice; Gen. Prac.; b 1873; Rush Med. Col., 1900; Gage Co.

Curtis, Elmer Elsworth; Neligh; Gen. Prac.; b 1888; Creighton Uni., 1911; Antelope Co. 
Curtis, Joseph Milton; Tecumseh; Gen. Prac.; Omaha Med. Col.; World War; city physician; Johnson Co.

Curtis, Louis Franklin; Omaha; Gen. Prac.; b 1878; Uni. of Ill., 1902; Douglas Co.

Curtis, Wesley L.; Lincoln; Eye, Ear, Nose, Throat; Omaha Med. Col.; Rush Med. Col.; prof. of anat., Omaha Med. Col., 1897-1903; surgeon, coast and geodetic survey, Philippine Isl.; pres., Lancaster Co.; State, A.M.A.; Acad. Ophthal. and Ocolaryng.; Kiwanis.

Cyphers, Fred B.; Duncan; Gen. Prac.; Uni. of Illinois, Co.; State.

Dailey, Eleanor Stallard; Omaha; Gen. Prac.; b 1854; Northwestern Uni., 1878; Douglas Co.

Dansky, Nathan; Omaha; Gen. Prac.; b 1895; Creighton Uni., 1919; Douglas Co.

Daubenheyer, Miles Fredk.; Omaha; Neurol., Psychiat.; b 1875; state Col. of P. and S., Indianapolis, 1907; Douglas Co.; A.M.A.

Davidson, Lawrence Leroy; Omaha; Gen. Prac.; b 1901; Uni. of Nebr., 1926; Douglas Co.

Davies, James Franklin; Callaway; Gen. Prac.; b 1870; Uni. of Nebr., 1893; Custer Co.

Davies, Rupert A.; Arlington; Gen. Prac. b 1875; Rush Med. Col., 1900; Washington Co.

Davies, Wm. John.; Fremont; Gen. Prac.; b 1862; Rush Med .Col., 1887; Dodge Co.; A.M.A.

Davis, Albert David; Omaha; Gen. Prac.; b 1898; Uni. of Nebr., 1921; Douglas Co.

Davis, Dallas D.; Liberty; Gen. Prac.; Uni. of Nebr.; M.R.C.; Gage Co.; State.

Davis, John Calvin, Jr.; Omaha; Eye, Ear, Nose, Throat; Uni. of Nebr., A.B., 1914; M.D., 1917; Post-Grad. Col. of New York, 1920; asst. Clinical prof. of oto-laryngology, Uni. of Nebr.; capt., M.C., 1919; Co.; State; A.M.A.; F.A.C.S.; Sicux Valley Acad.; Omaha and Co. Bluffs E. E. N. and T. Soc.

Davis, Herbert Haywood; Omaha; Surg.; b 1894; Johns Hopkins Uni., 1920; Douglas Co.; A.M.A.

Davis, Homer; Genoa; Gen. Prac.; b 1868; S. D. St. Col., B.S., 1891; M.S., 1897; Uni, of Nebr., M.D., 1900; post-grad., Chicago Post-Grad. Col. and Hosp., 1906-1910; N. Y. Pest-Grad. Col. and Hosp., 1916; Colo. School of Tuberculosis, 1926; Washington Uni., St. Louis, 1927; Major, M.C., Fort Riley, Fort Dodge and Camp Dex, 1917-1919; Co.; State; A.M.A.; F.A.C.P.; Genoa, 1900; physician, Genoa Indian School, 1903; U. P. R. A. Surg., 19021928; ex-pres., Nance Co. Med. Soc.

Davis, John Dwight; Genoa; Tuberculosis, Dis. of the Chest; Uni. of Ill.; Uni. of Nebr.; M.R.C.; Fellow at Mayo Clinic, 1928; Minn. State Med. Assn.; A.M.A 


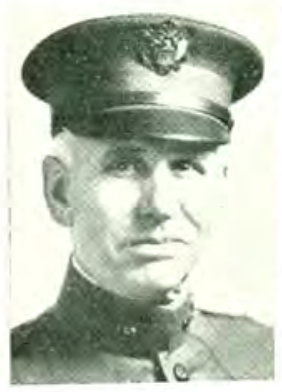

HOMER DAVIS

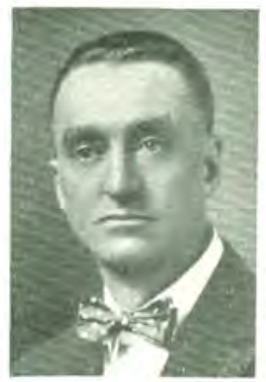

P. A. DE OGNY

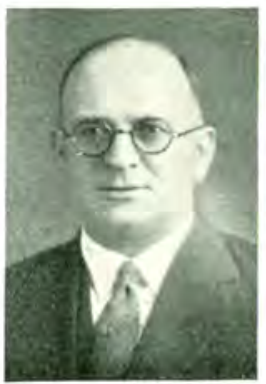

E. DODD

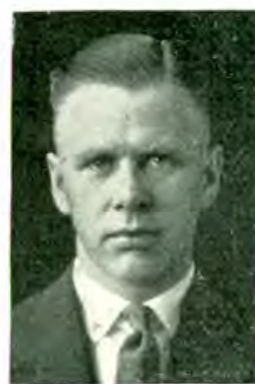

J. D. DAVIS

Davis, John Graham; Omaha; b 18\$2; State Uni. of Iowa, 1906; P. A. S.; Lieut., U.S.N.; Douglas Co.; A.M.A.

Davis, Jos. Edward; Albion; Gynecol.; b 1873; Uni. Med. Col. of Kansas City, 1900; Boone Co.

Davis, Wallace Clyde; Lincoln; Gen. Prac.; b 1866; Lincoln Med. Col., 1898; Lancaster Co.

Davis, William M.; Omaha; Gen. Prac.; St. Louis; former pension examiner at Chillicothe, Mo.; county physician; Co.; State; A.M.A.

Davis, Wm. Windle; Omaha; surg.; b. '85; Creighton Uni, '09; Douglas Co.; A.M.A.

Dayton, William Linsley; Lincoln; Eye, Ear, Nose, Throat; Chicago, New York, Berlin, Halle, London; former prof. of diseases of eye, Nebr. Med. Col. (in Lincoln); adjunct prof, of diseases of eye, Creighton Med. Col.; Lancaster Co.; State; A.M.A.; Am. Acad. Ophthal. and Oto-laryngol. (pres., 1917); Uni., Country Clubs.

Deardorf, Benj Miles; Clatonia; Gen, Prac.; b 1872; Jefferson Med. Col., Philadelphia, 1896; Gage Co.

DeBacker, Leopold Jos.; Hastings; Gen. Prac.; Creighton Uni., 1918; Adams Co.

Deck, Milton B.; Bennett; Gen. Prac.; Uni. of Md. School of Med. and Col. of Phys. and Surg., 1879; Lancaster Co.

Decker, Rudolph F.; Byron; Gen. Prac.; Wartburg Col., Clinton, Iowa, A.B.; Jefferson Med. Col., M.D., 1906; past pres., Thayer Co. Med Soc.; Sec., 7th Councilor Dist.; member village trustees; M.C.; Thayer Co.; State; A.M.A.

Deemer, Geo. Wm.; Chadron; Gen. Prac.; b 1865; Northwestern Uni. Med. Sch., 1894; Dawes Co.

Deering, Dave N.; Omaha; Gen. Prac.; b 1899; Uni. of Nebr., 1925; Douglas Co.

Deffenbaugh, Martin Henry; Fairmont; Gen. Prac.; b 1878; Lincoln Med. Col., 1904; Fillmore Co.; A.M.A.

Deffenbaugh, Nelle G. Carr; Fairmont; Gen. Prac.; b 1877; Gen. Med. Col. of Chicago, 1906; Fillmore Co. 
DeLanney, Leo A.; Omaha; Gen. Prac.; Creighton Med. Col.; M.C.; Co.; State; A.M.A.; Ch. of Commerce.

Delfs, Claus Gilbert; Shickley; Gen. Prac; b 1893; Creighton Uni., 1913; Filmore Co.

Demaree, Emma Warner; Buhl, Idaho (formerly Roca, Nebr.) ; Northwestern Uni., W.M.C., 1895; Lancaster Co.; State; Mo. Valley Med. Assn.

Demaree, H. C.; Buhl, Idaho (formerly of Roca, Nebr.;) Gen. Prac. (retired); Uni. of Mich.; Louisville Med. Col.; former member Co.; State.

DeMay, George Halley; Shelton; Gen. Prac,; b 1892; Creighton Uni., 1917; Buffalo Co.

DeMay, Griffith Alonzo; McCook; Gen. Prac.; b 1890; Uni. Med. Col. of Kansas City, 1913; Red Willow Co.; A.M.A.

Denison. Walcott: Omaha; b 1889; Washington Uni., St. Louis, 1914; Douglas Co.

DeOgny, Paul Albert; Milford; Gen Prac.; E.M.C., Cincinnati, Ohio; Spanish War veteran; C. B. and Q. Ry. surgeon; Co.; State; A.M.A.; Am. Assn. Ry. Surgs.; Ch. of Commerce.

Deppen, Earl Neagley; Lincoln; Gen. Prac; b 1896; Uni, of Cincinnati, 1920; Lancaster Co.; A.M.A.

Dermody, Leo A.; Omaha; Gen. Prac.; b 1884; Creighton Uni., 1908; Douglas Co.; A.M.A.

Dermody, Louis Arthur; Omaha; Gen. Prac.; b 1886; Creighton Uni., 1910; Douglas Co.

DesJardien, Alphonse Regist; Lincoln; Gen. Prac,; b 1873; Lincoln Med Col., 1910; Lancaster Co.

DesJardien, Gustave Adolph; Lincoln; Gen. Prac.; b 1884; General Med. Col.. Chicago, 1908; Lancaster Co.

Dever. Chas. Ray; Hastings; Gen. Prac.; b 1884; General Med. Col., Chicago, 1908; Lancaster Co.

Devers, Washington Irving; Upland; Gen. Prac.; b 1880; Northwestern Uni., 1912; Franklin Co.; A.M.A.

Devries, Joshua Shipley; Fremont; Gen. Prac.; Uni. of Nebr. Med. Col., 1888; post-grad.. New York Lying-In Hosp.; Jefferson Med. Col.; Dodge Co.; State; A.M.A.; Elkhorn Valley; Mo. Valley Med. Assn.

DeWitt, Charles Herman. Jr.; Malmo; Surg.; b 1896; Creighton Uni., 1910; Saunders Co.

Dewolf. Wm. Walter; Bennett; Gen. Prac.; b 1874; Lincoln Med. Col., 1808 ; Lancaster Co.

Dewey, Fred Girard; Coleridge; Gen. Prac,; Uni. of Ill. Med. Col., 1906; Cedar-Dixon-Thurston-Wayne-Dakota Co.; State; A.M.A.

Dewey, George Laurin; Cedar Rapids; Gen. Prac.; b 1862; Tulane Uni. of La. Sch. of Med.; Boone Co.

Dickinson, Louis Everett; Ravenna; Gen. Prac.; b 1878; Sioux City Col. of Med., 1904; Buffalo Co. 
Diehl, Olin Carl; Diller; Gen. Prac,; Creighton Med, Col.; Chicago Polyclinic; Jefferson Co.

Dierker, Joseph Bernard; Lawrence; Gen. Prac.; b 1879; Keokuk Med. Col., 1907; Nuckolls Co.

Diers, Louis H.; Seward; Gen. Prac.; Lincoln Med. Col., 1897; Seward Co.

Dieter, Leonard Daniel; Omaha; Gen. Prac.; b 1898; Creighton Uni., 1926; Douglas Co.

Dihel, Thos. Elmer K.; Oak; b 1862; Uni. of Louisville, 1893; Nuckolls Co.

Dishong, Gustave W.; Omaha; Nervous and Mental Dis.; Wesleyan Uni., Lincoln; Creighton Med. Col.; Cook Co. Hosp.; Psychopathic Inst., Kankakee, Ill.; Neurol. Inst., N.Y.C.; Natl. Hosp. for Paralyzed and Epileptic, London; chief neuropathic service, St. Joseph's Hosp.; consult., U. S. Vet. Bureau, Omaha; Capt., M.C.. Base Hosp. No. 49. France; Co.; State; A.M.A.; A.C.P.; Happy Hollow Club.

DiStefano, Carmelo; Omaha; Gen. Prac.; b 1895; Uni. of Nebr., 1925; Douglas Co.

Doane, Wm. Elden; North Bend; Gen. Prac.; b 1878; St. Louis Uni., 1906; Dodge Co.

Dodd, Clinton Quincy; Weston; Gen. Prac.; Creighton Uni., 1910; Saunders Co.; A.M.A.

Dodd, Edward; Cairo; Gen. Prac.; Keokuk Med. Col., 1903 Col. of Phys. and Surg., Keokuk, Iowa.

Dodge. Burton J.; Alma; Chronic Dis.; Keokuk Med. Col.; Chicago Polyclinic.

Dodge, Roy A.; Omaha; Obstet., Gynecol.; b 1877; Uni. of Nebr., 1901; Douglas Co.; A.M.A.

Doher, Thos. L.; Wilsonville; Gen. Prac.; b 1890; Lincoln Med. Col., 1914; Furnas Co.

Dorsey, Francis P.; Hartington; Gon. Prac.; Uni. of Md.; Louisville Uni.; member insanity board; Capt., M.C.; Cedar-Dixon-Thurston-Wayne-Dakota Co.; State; A.M.A.; Am. College of Physical Therapy.

Dorwart. Thomas Yule; Lexingten; Gen. Prac.; b 1897; Creighion Uni., 1923; Dawson Co.

Doty, Charles W.; Beaver Crossing; Rush Med. Col., 1888; former pres., Seward Co. Med. Soc.; state senator, 12 dist.. 1916-1917; food director; Y.M. C.A.; Red Cross; U. S. Public Health Service Reserve; Seward Co.; State.

Douglas, Geo. G.; Elmwood; Gen. Prac.; b 1863; Mo. Med. Col., 1891; Cass Co.; A.M.A.

Douglas, John Wesley; Lewiston; Gen. Prac.; b 1885; Lincoln Med. Col., 1908; Pawnee Co.

Douglas, Robert Raymond, Jr.; Clarks; Gen. Prac.; b 1889; Creighton Uni., 1911; Merrick Co. 


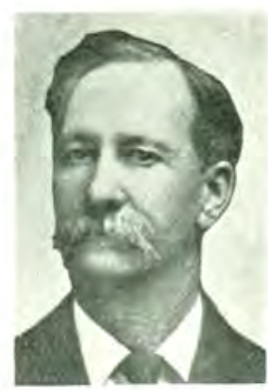

A. Downing

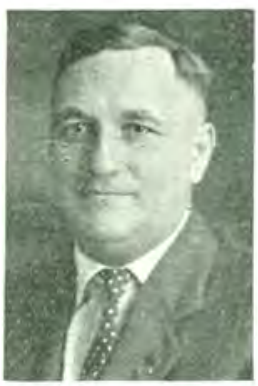

E. B. DOWNS

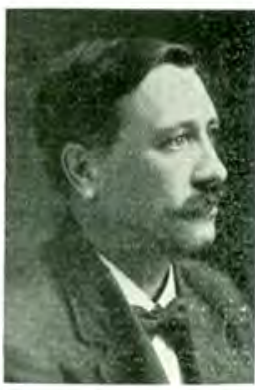

B. W. DRASKY

Douglas, Volney D.; Crab Orchard; Gen. Prac.; b 1878; Lincoln Med. Col., 1907; Johnson Co.

Douglas, William James; Atkinson; Gen. Prac.; Uni, of Nebr., M.D., 1900 ; councillor 8th Dist., Nebr. Med. Assn.; Capt., M.C.

Dovey, Edward Grovenor; Plattsmouth; Gen. Prac,; b 1890; Northwestern Uni., 1923; Cass Co.; A.M.A.

Dow, Andrew G.; Omaha; Pediat.; b 1893; Uni of Nebr., 1918; Douglas Co.; A.M.A.

Downing, Albert R.; Merna; Gen. Prac.; Quincy Med. Col., Quincy, Ill.; Custer Co.; State; A.M.A.

Downing, Jcs. Henry; Rising City; Gen. Prac.; b 1856; Rush Med. Col., 1882; Butler Co.

Downs, Ernest Boone; Sumner; Gen. Prac.; St. Louis, Mo.; U. S. Public Health; Capt., M.C.; Illincis State; A.M.A.; Author Insulin, Nebr. State Med. J., 1925.

Drasky, Bretislav William; Linwood; Gen. Prac.; Bellevue Hosp. Med. Col., N. Y. C.; Butler Co.; State; A.M.A.; Am. Assn. Ry. Surgeons.

Drew, Harry O.; Albion; Gen. Prac.; Creighton Med. Col.; Boone Co.; State; A M.A.; Lions; Commercial Club.

Drummond, Clarence C.; Norfolk; Nervous and Mental Dis.; Lincoln Med. Col., Cotner Uni.; Psychiat., Norfolk State Hosp.; Adams Co.; former member Indian Med. Missionary Assn.

Duffy, Francis M.; Gen. Prac.; Creighton Med. Col.; M.D.. 1923; A.M., 1927 ; Instructer, pathelogy and bacteriology, Creighton; formerly asst. phys., Cherokee Iowa State Hosp.; Co.; State; A.M.A.

Dugan, Wm. Francis; Campbell; Gen. Prac.; b 1881; Ill. Med. Col., 1903; Lincoln Med. Col., 1904; Franklin Co.

Duncan, Jchn W.; Omaha; Surg.; Creighton Uni. Med. Col.; post-grad. werk, Europe; Division surgeon, Mo. Pac. Ry.; U.S.M.C.; F.A.C.S.; Professional Mens' Club. 


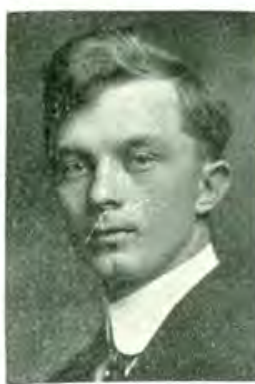

J. E. DUNX

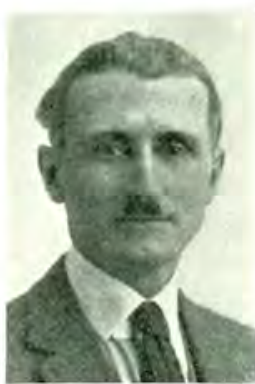

R. H. EASTON

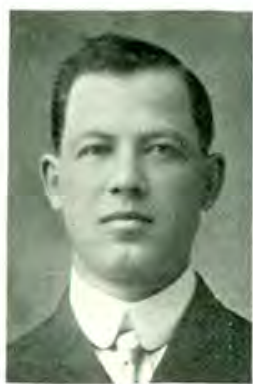

C. D. EBY

Dunham, Frank S., Omaha; Gen. Prac.; b 1868; Eclectic Med. Col., St. Louis, 1893; Douglas Co.

Dunn, Abner B.; Nebraska City; Gen. Prac.; b 1883; Geo. Washington Uni., 1909; Otoe Co.

Dunn. Arthur D.; Omaha; Internal Med.; Uni. of Chicago, Ph.B., 1895; Rush Med. Sch., M.D., 1902; post-grad., Vienna, 1904-1905, 1910; London, 1910; Zurich, 1013; Intern, Cook Co. Hosp., Chicago, 1902-1903; prof. of med., Creighton, 1907-1921; prof., clin. investigation, Uni. of Nebr., 1924; staff, St. Joseph's, 1908-1921, Clarkson, Wise Memorial; Co.; State; A.M.A.; Mo. Valley Med. Assn.; F.A.C.P.; Uni. (Omaha and Chicago), Omaha Club; Phi Rho Sigma; co-author of Uni. of Nebr. Hosp. Clinico-Path. Conf. reports published monthly in Nebr. Med. J.; and many other articles.

Dunn, Frank Lowell; Omaha; Gen. Prac.; b 1898; Harvard Uni., 1924; Douglas Co.;

Dunn, J. E.; Arnold; Gen. Prac.; Creighton Med. Col.; Co.; State; A.M.A.

DuVall. George Reese; Fairbury; Gen. Prac.; b 1882; Central Med. Col. of St. Joseph, 1904; Jefferson Co.

Dwire, Francis Belmont; Fort Crook; b 1877; Uni. of S. Cal., 1906; Maj., M.C., U.S.A.; Sarpy Co.; A.M.A.

Dwyer, Edward H.; Gordon; Gen. Prac.; b 1872; Barnes Med. Col., 1898; Sheridan Co.

Dwyer, Harold Vincent; Omaha; Gen. Prac.; b 1896; Creighton Uni., 1923 ; Douglas Co.

Dwyer, John R.; Omaha; Gen. Prac.; b 1883; Creighton Uni., 1912; Douglas Co.; A.M.A.

Dwyer, Timothy J.; Omaha; Gen. Prac.; b 1873; Creighton Uni., 1902; faculty, Creighton Cel.; staff, St. Catherine's and St. Joseph's Hosps.; Douglas Co.; died, May, 1928.

Easterday, Emma E. Meinhart; McCook; Gen. Prac.; b 1862; Cincinnati Col. of Med. and Surg., 1897; R'edwillow Co.; A.M.A. 
Easton, Cyrus Monroe; Davenport; Gen. Prac. (retired); Uni. of Mich.; Rush, M.D., 1872; practiced 37 years, Hebron, Nebr.; pet.sion examiner; Civil War Vet; former Co., State and A.M.A.

Easton, Robert Holmes; Eustis; Gen. Prac.; Uni. of Nebr. Med. Col.; post-grad., Chicago; served in Nebr. Natl. Guards, 1904; Dawson Co.; State; A.M.A.

Eby, Charles D.; Leigh; Gen. Prac,; Uni. of Nebr. Med. Col.; pres., Colfax Co. Med. Soc.; member, bd. education; Colfax Co.; State; A.M.A.

Eckles, Dora B.; York: Gen. Prac.; b 1873; Col. of Phys. and Surgs., Keokuk, 1898; York Co.

Eckles, Warren F.; York; Ophthal., Otolo., Laryng., Rhin.; b 1874; Col. of Phys. and Surg., Keokuk, 1898; York Co.

Edgington, Avington Adam; Omaha; Gen. Prac.; b 1865; State Uni. of Iowa, 1897; Douglas Co.

Edminston, Aaron W.; Omaha; Gen. Prac.; Rush Med. Col., M.D., 1880; practiced 44 years in Omaha.

Edmonds, Chas. Walton; Oconto; Gen. Prac.; b 1877; Marion-Sims Col. of Med., 1898; Custer Co.

Edmonds, Wm.; Nebraska City; Dermatol.; b 1871; Jefferson Med. Col. of Phila., 1900; Otoe Co.

Edstrom, Andrew J.; Stromsburg; Surg.; b 1878; Creighton Uni., 1915; Polk Co.; A.M.A.

Edwards, August G.; Omaha; Gen. Prac.; b 1867; Meharry Med. Col.. 1895 ; Douglas Co.

Edwards, Chas. B.; Overton; Gen. Prac.; b 1889; Creighton Uni., 1913; Dawson Co.; A.M.A.

Edwards, Fredk. Arthur; Omaha; Gen. Prac.; b 1874; Trinity Med. Col., Toronto, 1901; Douglas Co.

Edwards, Lee Wilson; Omaha; Gen. Prac.; b 1870; Uni. of Nebr., 1893; Douglas Co.

Egen, Lother Fredk.; Hastings; Gen. Prac.; b 1891; Creighton Uni., 1916; Adams Co.; A.M.A.

Egermayer, George Washington; Shubert; Gen. Prac.; Col. Phys. and Surg., Uni. of Ill.; Intern, St, Mary's Hosp., Chicago; former pres., Richardson Co. Med Soc.; school board; Richardson Co.; State; A.M.A.

Eggers, Harold Everett; Omaha; Gen. Prac.; b 1882; Rush Med. Col., 1909 ; Douglas Co.

Eiche, Fredk.; Lincoln; Gen. Prac; b 1866; Northwestern Uni., 1903; Lancaster Co.; A.M.A.

Eldredge, R. Bruce; Omaha; Pediat.; Uni. of Nebr. Med. Col.; Co.; State; A.M.A.; Nebr.-Iowa Pediatric Soc.

Elkner, Wm. Turner; Sidney; Gen. Prac.; b 1872; Milwaukee Med. Col., 1901; Cheyenne Co. 
Elias, Francis Leander; Wymore; Roentgenol, ; b 1883; Uni. of Kans., 1910; Gage Co,; A.M.A.

Elliott, Wordsworth M.; Lincoln; Otolo., Laryng., Rhin.; Toronto Uni., Canada; Capt., Canadian Army M. C.; Lancaster Co.; State.

Ellis, Paul H.; Omaha; Surg.; b 1876; Creighton Uni., 1899; Douglas Co.

Elmore, Chas. G.; Omaha; Gen. Prac.; b 1858; Uni, of Tenn., 1888; Douglas Co.

Elmore, John Q.; Gordon; Gen. Prac.; b 1851; Uni. of Tenn., 1888; Sheridan Co.

Elms, Julius K.; Lincoln; Gen. Prac.; b 1850; Chicago Hom. Med. Hosp., 1879; Lancaster Co.

Elston, Harry Richard; Gen. Prac., Diag. Urol.; Uni. of Nebr. Med. Col., 1923; Intern, Uni. Hosp., Uni. of Minn.; post-grad. study in cystoscopy, Mayo Foundation; served as Lieut., Infantry, 1918; Platte Co.; State; A.M.A.; Mo. Valley Med. Assn.

Elwood, Laird W.; Silver Creek; Gen. Prac.; Creighton Med. Col., 1914; M.C., A. E. F.; med. examiner for U. S. Vet. Bureau.

Emerson, Clarence; Lincoln; Surg.; b 1886; Rush Med. Hosp., 1911; Lancaster Co.; A.M.A.

Emery, Alpheus Lewellyn; Waverly; Gen. Prac.; b 1879; St. Louis Uni., 1902; Lancaster Co.

Emmert, Max; Omaha; Surg.; Uni. of Iowa, A.B., 1905; Johns Hopkins, M.D., 1909 ; vice-pres., Nebr. Childrens' Home; one of organizers, Nebr. Sect., Am. Col. of Surg., Omaha Surgical Club and Lions Club; Co.; State; A.M.A.; Professional Men's Club.

Emrich, Edward Linwood; Norfolk; Neurol., Psychiat.; b 1868; Rush Med. Col., 1892; Madison Co.; A.M.A.

England, John D.; Axtell; Gen. Prac.; b 1858; Bellevue Hosp. Med. Col., N. Y., 1887; Kearney Co.

Ensor, Rolland Renford: Omaha; Gen. Prac.; b 1892; Creighton Uni. 1916; Douglas $\mathrm{Co}$.

Ensor, Thomas H.; Omaha; Internal Med.; Uni. of Missouri; med. dept., Washington Uni., St. Louis, M.D., 1880; Mayor of Omaha (South Side) 1896-1900; Co.; State; A.M.A.

Erman. Jaceb Martin; Omaha; Gen. Prac.; Uni. of Illincis; Chicago Col. of Med. and Surq.; Loyola Uni.; M.C., A.E.F.; County; State; A.M.A.

Baltimore, 1903; Platte Co.; A.M.A.

Evans, Edward B.; Omaha; Urol.; b 1875; Baltimore Med. Col., 1897; Douglas $\mathrm{Co}$.

Evans, James North; Columbus; Gen. Prac.; Jefferson Med. Col.; 2 ycars, World War; Capt., Nebr. Natl. Guard; Co.; State.

Evans, Mcrris H.; Emerscn; Gen. Prac.; Columbus Med. Col., Columbus, Ohio, M.D., 1884; Volunteer M.R.C.; Dixon Co.; State; A.M.A.; Mo. Valley. 


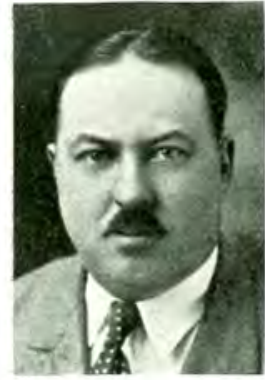

H. R. ELSTON

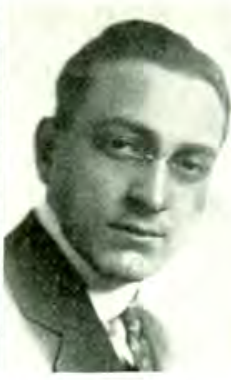

J. M. ERMAN
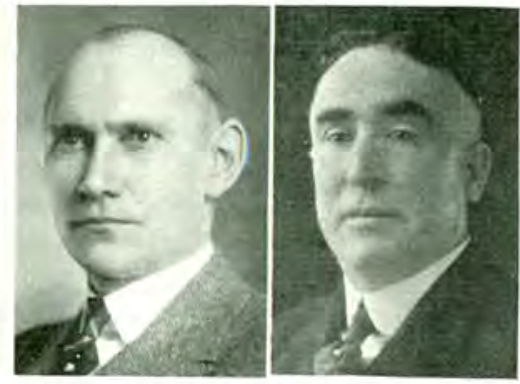

E. E. FARNSWORTH HENRY FARRELL

Evans, Wm. Samuel; Columbus; Surg.; b 1863; Col. of Phys. and Surg., Batlimore, 1903; Platte Co.; A.M.A.

Everett, Ernest Alfred; Lincoln; Gen. Prac.; b 1889; Northwestern Uni., 1924; Lancaster Co.; A.M.A.

Everett, Harry Harding; Lincoln; Surg.; b 1875; Northwestern Uni., 1900 ; Lancaster Co.; A.M.A.

Everett, Milton H.; Lincoln; Gen. Prac.; b 1847; Rush Med. Col., 1870; Jefferson Med. Col., 1885; Lancaster Co.

Everett, Oliver W.; Lincoln; Surg.; b 1881; Uni. of Nebr., 1904; Lancaster Co.; A.M.A.

Everitt, Neill J.; Omaha; Creighton Med. Col.; World War.

Ewing, Benj. Franklin; Omaha; Gen. Prac.; b 1897; Creighton Uni, 1923; Douglas Co.

Eychaner, Geo. Arthur M.; Omaha; Gen. Prac.; b 1901; Uni. of Nebr., 1926; Douglas Co.

Fahnestock, Charles L.; Lincoln; Ind. Surg.; Washington Uni., St. Louis; Capt., M.C.; surgeon, C. B. and Q. Ry, and Am. Express Co.; Lancaster Co.; State; A.M.A.

Fairall, Truman Edward: Tecumseh; Gen. Prac.; Uni. of Md., 1873; health officer and insane commisioner; M.C., World War; Co.; State; A.M.A.

Fairchild, Nora May; Omaha; Ophthal.; Uni. of Nebr., M.D., 1906; post-grad. in east and abroad; instructor in ophthal., Uni. of Nebr. Med. Col.; Co.; State; A.M.A.; Am. Acad. of Ophthal. and Oto-Laryng.; Altrusa Club.

Fall, Clifford Pervines; Beatrice; Surg.; Col. of Phys. and Surg., Chicago; pres., Nebr. State Bureau of Health; Spanish War Vet.; Gage Co.; State; A.M.A.; Mo. Valley Med. Assn.; Ry. Surg.

Fall, Norman Bryce; Madrid; Gen. Prac; b 1891; Uni. of Louisville, 1913 ; Perkins Co.; A.M.A.

Farmer, Lee Roy; Alliance; Gen. Prac.; b 1893; Natl. Uni. of Arts and Sciences, St. Louis, 1916; Box Butte Co. 
Farmer, Bennie Raymond; Ainsworth; Gen. Prac.; b 1901; Uni. of Nebr., 1925 ; Brown Co.

Farnham, Geo. O. W.; Lincoln; Gen. Prac.; Uni. of Vt., 1884; Lancaster Co.

Farnsworth, Albert Henry; Grand Island; Surg.; b 1875; Chicago Hom. Med. Hosp., 1900; Hall Co.

Farnsworth, Earle Edwin; Grand Island; Internal Med.; Uni, of Nebr.; Cornell; Uni. of New York; Harvard; pres., Hall Co. Med. Soc.; Hall Co.; A.M.A.; Phi Rho Sigma; Phi Delta Theta; Rotary.

Farr, Fred Franklin; Wauneta; Gen. Prac.; b 1878; Barnes Med. Col., 1898; Chase Co.

Farrell, Henry; Kearney; Eye, Ear, Nose and Throat, Public Health; Baltimore Med. Col., 1907; City Physician; Capt., M.R.C.; Co.; State; A.M.A.; Republican Valley Med. Soc.

Farrell, Robert. Francis; Omaha; Surg; b 1891; Creighton Uni., 1915; Douglas Co.; A.M.A.

Fasser, Alexander O.; Fremont; Surg. and Consult.; Yale Med. Sch., M.D., 1905; Uni. of Penn., M.Sc., 1923; Intern, New Haven Hosp. and New York Lying-In Hosp.; Res. Surg., Phil. Gen. Hesp.; house officer, Boston Floating Hosp; Vol, Surg., France, 1914; Capt., M.C., 1917; Co.; State; A.M.A.

Fast, William Sherman (deceased, 1926); Falls City; Internal Med., Nervous and Mental Dis.; Starling Col., Columbus, Ohio; Uni. of Berlin; supt. of Hosp. for Feeble Minded, Beatrice; supt., Hastings State Hosp. at Ingleside; Adams Co.; State; A.M.A.; Republican Valley Med. Soc.; Midwest Hosp. Assn.

Fate. Jesse C.; Weeping Water; Gen. Prac.; b 1840; Gen. Med. Col., Chicago, 1880; Cass Co.

Faulk, Andrew Jackson; Mitchell; Diag., Chronic Dis.; Sioux City Med. Col.; post-grad.; an organizer and first pres. of Scotts Bluff Co. Med. Soc.; Scotts Bluff Co.; State; A.M.A.

Faulk, Fred. W.; Omaha; Ophthal,; b 1865; Chattanooga Med, Col., 1807; Douglas Co.

Fees, Arthur Waldo; Blair; Gen. Prac,; Uni. of Iowa Med. Col.

Feese, Jean P.; Hastings; Gen. Prac.; Deane Col.; Beaumont Med., St. Louis, 1899; Uni. Med. Col., Kansas City, Mo., 1901; Capt., M.C.; Republican Valley Med. Soc.

Fegers, George William; Nebraska City; Surg.; Keokuk Med. Col.; Uni. of Iowa; Berlin; Vienna; former phys. and surg.. St. Mary's Acad. and Spaulding Institute, Nauvoo, Ill.; staff, St. Mary's Hosp.; U.S.M.C.; Otoe Co.; State; A.M.A.; Mo. Valley Med. Assn.

Fellers, Andrew B.; Palisade; Gen. Prac.; Uni. of Iowa; Uni. of Denver; county physician; Hayes Co.; State; A.M.A.

Fenner, Harry B.; Omaha; Gen. Prac.; Chicago Hom. Med. Col., 1884; Douglas Co. 


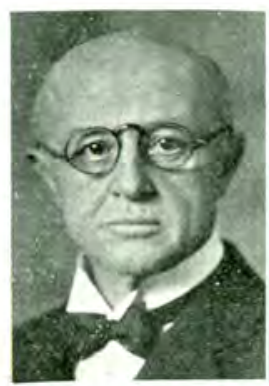

G. W. FEGERS

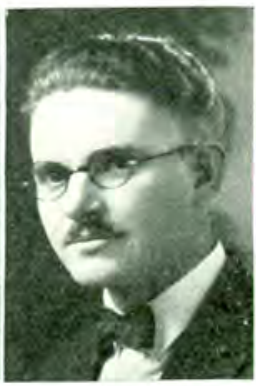

L. W. FORNEY

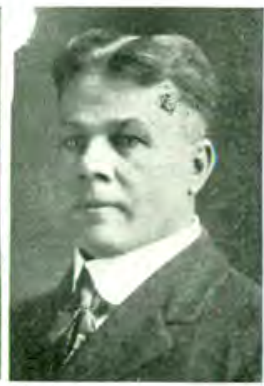

E. J. FLEETWOOD

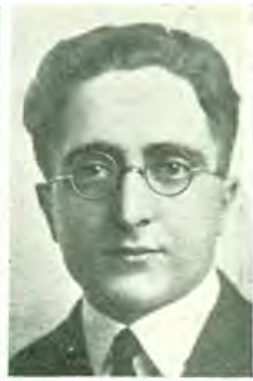

M. FLEISHMAN

Fetter, Earl Wm.; North Platte; Surg.; b 1885; Creighton Uni., 1909; Lincoln Co.

Findley, Palmer; Omaha; see end of chapter on Pioneers.

Finkle, Beverly Arthur; Lincoln; Surg.; b 1884; Chicago Col. of Med. and Surg., 1913; Lancaster Co.; A.M.A.

Finley, William F.; O’Neill; Gen. Prac.; Uni. of Minn.; Co.; State; A.M.A.

Finney, Everett B.; Lincoln; Surg.; Hahnemann Med. Col., Phila., 1888; staff, St. Elizabeth's and Bryan Memorial Hosp.; Am. Col. Surg.; Am. Inst. of Homeopathy.

Fitzgerald, Francis E.; Grafton; Gen. Prac.; Creighton Med. Col., 1901; former demonstrator of anatomy at Creighton Med. Col.

Fitzgibbon, Henry M.; Omaha; Surg.; b 1878; Creighton Uni., 1908; Douglas Co.

Fitzsimmons, Alex W.; Omaha; Gen. Prac.; Omaha Med. Col.; Co.; State; A.M.A.

Fitzsimmons, Jos. Ignatius; North Bend; Gen. Prac,; b 1899; Creighton Uni., 1924 ; Dodge Co.

Flanagan, May Louise; Lincoln; Neuro-Psychiat, at Green Gables Sanitarium; Hahnemann Med. Sch., Chicago; staff, Home for Dependent Children, 1901-1907; Lancaster Co.; State; A.M.A.; Nebr. Med. Women's Club.

Flansburg, Harry Ernest; Lincoln; Gen. Prac.; b 1885; Rush Med. Col., 1909; Lancaster Co.

Fleetwood, Edward J.; Lincoln; Gen, Prac.; Uni. of Nebr.; pres., Dixon Co. Med. Soc.; chmn. co. med. advisory bd.; Dixon Co.; State; A.M.A.

Fleishman, Max; Sanatorium, Colorado, formerly of Omaha; Tuberculosis; B.Sc.; Uni. of Nebr., M.D.; intern, Western Penn. Hosp., Pittsburgh; formerly asst. supt., Southwestern Minn. Tuber. San.., Worthington, Minn.; now res. phys., Jewish Consumptives' Relief Sanatorium, near Denver; Douglas Co. and Alleghany Co. Med. Soc.; Denver Med. Soc.

Fletcher, Asa E.; Omaha; Gen. Prac.; b 1882; Indiana Uni., 1911; Douglas Co. 


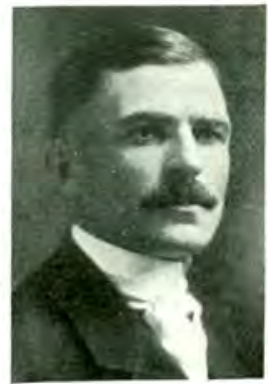

D. L. FLETCHER

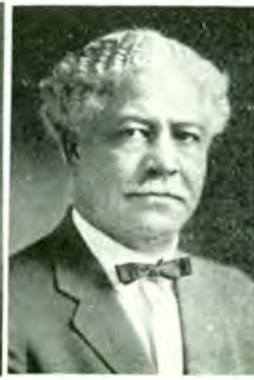

G. A. FLIPPIN

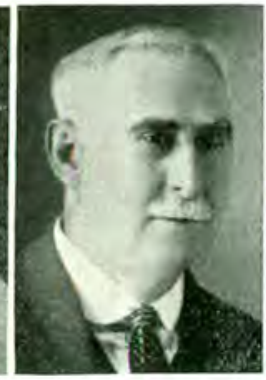

H. W. FRANCIS

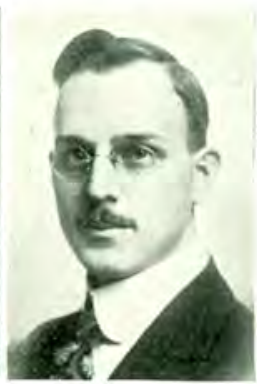

C. E. FREY

Fletcher, David Livingstone; Orchard; Phys., surg.; Sioux City Col. of Med.; Col. of Phys, and Surg., Chicago; co. coroner; Antelope Co.; State; A.M.A.

Fletcher, Wm. G.: Orchard; Gen. Prac.; b 1877; Uni. of Toronto, 1899; Antelope Co.

Flory, Orville H.; St. Edward; Kansas City Med. Col.;retired in 1903 to enter banking profession.

Flory, Paul J.; Pawnee City; Gen. Prac.; Uni. of Nebr. Med. Col.; U. S. Navy 2 years.

Flothow, Max Wm.; Omaha; Gynecol; b 1889; Creighton Uni., 1913; Douglas Co.;

Fochtman, Lloyd Henry; Cozad; Gen. Prac.; b 1890; Creighton Uni., 1914; Dawson Co.; A.M.A.

Fogarty. Chas. James; Omaha; Gen. Prac.; b 1900; Creighton Uni., 1926; Douglas Co.

Follman, John Christopher; Omaha; Gen. Prac,; b 1888; Natl. Uni. of Arts and Sciences, St. Louis, 1914; Douglas Co.

Foltz, Clarence Burden; Omaha; Surg.; b 1885; Creighton Uni., 1914; Am. R. R. Surg.; Douglas Co.; State; A.M.A.; Mo. Valley Med. Assn.; Ch. of Commerce; Triangle Club.

Foote, Dellizon A.; Omaha; Gen. Prac.; Chicago Homeopathic Med. Col., 1887; post-grad. work in Vienna and Berlin; intern in Joliet State Pen.

Foote, Eugene Clair; Hastings; Ophthal., Otolo., Laryng., Rhin.; b 1879; Creighton Uni., 1905; Adams Co.

Foote, Wm. Kellogg; Omaha; Gen. Prac.; b 1871; Chicago Hom. Med. Hosp., 1893; Douglas Co.

Ford, Michael J.; Omaha; Surg.; Creighton Med. Col., M.D.; Johns Hopkins Med. Sch.; first matriculant in present Creighton Med. Col. bldg.; founder of Creighton Med. Bulletin, first student publication; national president, Men's League for Boys; Douglas Co.; State; A.M.A. 
Fordyce, Claude C.; Falls City; Obstet., Gynecol.; Nebr. Uni., A.B., 1905; B Sc., 1907; scholar in zoology, Uni. of Nebr., 1907-1908; Washington Uni., St. Louis, M.D., 1910; many post-grad. clinics; vice-pres., Nebr. State Med. Assn., 1926-1927; Councilor, Nebr. State Med. Assn.; travel editor on Outdoor Life and Recreation Magazine, Denver; member, bd. of directors, Natl. Conf. on State Parks; visiting phys., Falls City Hosp.; Richardson Co.; State; A.M.A.

Forney, Lester Wayne; Mason City; Gen. Prac.; Uni. of Nebr. Med. Col., M.D., 1925; intern, Nebr. Methodist Hosp., Omaha; vice-pres., Custer Co. Med. Soc.; Custer Co.; State; A.M.A.; Alpha Kappa Alpha.

Fossler, John Jacob; Millard; Gen. Prac.; b 1877; Uni. of Nebr., 1907; Douglas Co.

Foster, Anthom A.; Omaha; Gen. Prac.; b 1889; Meharry Med. Col., 1921 ; Douglas Co.

Fouts, Frederick; Central City; Ophthal., Otolo., Laryng., Rhin.; b 1877; Creighton Uni., 1905; Merrick Co.; A.M.A.

Fouts, Roy W.; Omnha; Roentgenol., Physical Therap.; Uni. of Ill. Col. of Phys. and Surg., 1909; Sec., Am. Col. of Physical Therapy; past councillor and past vice-pres., Nebr. State Med. Assn.; instr. in anat. and demonstrator of dog and cadaver surg., Army Med. Sch., Chattanooga, Tenn., during World War; delegate from Nebr. to A.M.A., 1922-1928; attg. roentgenol., to Lord Lister Hosp. and U. S. Vet. Bur., Omaha; Douglas Co.; State; Am. Col. of Phys. Therapy; A.M.A.; papers on $\mathrm{x}$-ray diagnosis and therapy and physical therapy.

Fox, Chas. Herbert; Kearney; Ophthal., Otolo., Laryng., Rhin.; b 1874; McGill Uni. Fac, of Med., Montreal, 1895; Buffalo Co.

Fox, Clarence P.; Morrill; Gen. Prac.; b 1876; Chicago Hom. Med. Col., 1902; Scotts Bluff Co.

Francis, Harry Whiting; Bancroft; Gen. Prac.; Omaha Med. Col., 1896; first pres., Cuming Co. Med. Soc.; Capt., M.S.C.; Cuming Co.; State; A.M.A.; Elkhorn Valley Med. Soc.

Frandsen, Chas.; Omaha; Gen. Prac.; b 1888; Uni. of Nebr., 1918; Douglas Co.; A.M.A.

Franklin, Wm. Surman; Bayard; Gen. Prac.; b 1880; Creighton Uni., 1906; Morrill Co.

Franz, Francis Willard; Omaha; Gen. Prac.; b 1901; Creighton Uni., 1926; Douglas Co.

Frary, R'eginald Amos; Stanton; Gen. Prac.; Uni. of Nebr. Med. Col.; vice-pres., 1928 Madison-Stanton-Antelope-Pierce-Knox Co. Med. Soc.; M. C., World War.; Stanton Co.; State; A.M.A.

Frazier, G. J.; Santee; Gen. Prac.; Denver Uni. Med. Sch.; U. S. Indian Service; school physician at Santee Normal Training Sch,; deputy food administrator for Knox Co. during the war.

French, Albert Lincoln; Lincoln; Gen. Prac.; b 1859; Bowdoin Med. Sch., 1882; Lancaster Co.;

French, Oscar W.; Page; Gen. Prac.; Uni. of Nebr. Med. Col.; M.R.C. 


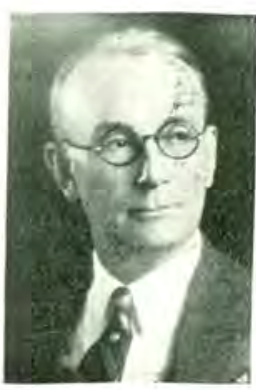

A. J. GARDNER

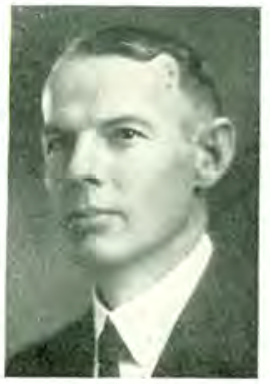

E. S. B. GEESAMAN

Frey, Clarence Elmer; Lincoln; Gen. Prac.; Cincinnati, Ohio; sec., Nebr. State Eclectic Medical Assn.; Lancaster Co.; State; A.M.A.; Interstate PostGrad. Med. Assn.

Freymann, John J.; Omaha; Surg., Gynecol.; Creighton Med. Col,; served in U. S. N.; Douglas Co.; State; A.M.A.

Frink, Frank L.; Newman Grove; Gen. Prac.; Louisville, Ky. Med. Col.; city mayor 8 years; Capt., M.R.C.

Fulton, Harry A.; Havelock; Gen. Prac.; b 1868; Uni. of Nebr., 1898; Lancaster Co.;

Funk, Harley E.; Culbertson; Gen. Prac.; 1882; Ensworth Med. Col., 1809; Hitchcock Co.

Furay, Edward St. Clair; Omaha; Gen. Prac.; b 1870; Creighton Uni., 1895; Douglas Co.

Furgason, Allen P.; Lincoln; Ophthal., Otolo., Laryng., Rhin.; b 1867; Northwestern Med. Col. of St. Louis, 1889; Lanctster Co.; A.M.A.

Gadbois, Arthur Emile; Norfolk; Ophthal., Otolo., Laryng., Rhin; b 1875; Creighton Uni., 1903; Madison Co.

Gafford, Chas. C.; Wymore; Gen. Prac.; Col. of Phys. and Surg., Keokuk, 1881; Gage Co.

Gairdner, Thos. M.; Waco; Gen. Prac.; b 1863; McGill Uni., Montreal, 1886; York Co.

Gandy, George G.; Humboldt; Gen. Prac.; Ensworth Med. Col.; Chicago Polyclinic; Uni. of Vienna, 1910.

Gardiner, John Francis; Omaha; Gen. Prac.; b 1897; Creighton Uni., 1922; Douglas Co.

Gardner, Albert J.; Orleans; Gen. Prac.; Uni. of Mich; Washington Uni.; med. examiner for Alliance and Sheridan Divisions of C. B. and Q. Ry.; Capt., M.R.C.; Harlan Co.; State; A.M.A.; Republican Valley Med. Soc.; Am. Assn. Ry. Surg.; Nu Sigma Nu; Ch. of Commerce; Rotary Club.

Gay, Benjamin F.; Stockville; Gen. Prac.; Uni. of Nebr. Med. Col.; began practice in Pierce Co., 1886; Tecumseh, Johnson Co., 1903; Stockville, Frontier Co., 1926; Johnson Co.; State Elkhorn Med. Soc. 
Geesaman, Edgar S. B.; Fort Calhoun; Gen. Prac.; Creighton Med. Col., M.D., 1912; intern, St. Joseph's Hosp., 1912-1913; on school bd., Washington Co.; State; Community Club.

Gelow, John E.; Grand Island; Ophthal., Otolo., Laryng., Rhin.; b 1879; Northwestern Uni., 1905; Hall Co.

Genung, Frank Clark; Waust (deceased July 26, 1924); Gen. Prac,; Phys, and Surg. Col, Chicago; Capt., World War; Tri-Co.; State; A.M.A.

Gerald, Herbert Franklin; Omaha; Pharmacol.; Harvard, Mass. Col. of Pharmacy, Ph.G., 1903; Tufts Med. Sch., M.D., 1909; Creighton Uni., B. Sc., 1927; Co.; State; A.M.A.; Am. Pharmaceutical Soc.; Nebr. Pharm. Assn.; Am. Assn. Adv, of Sci.;Professional Men's Club.

Gerrie, Wallace Anderson; Omaha; Gen. Prac. and Surg.; Uni. of Nebr.; St. Thomas Hosp., London, Eng.; M.R.C.; Capt., Nebr. Natl. Guard; Co,; State; A.M.A.; Mo. Valley; Elkhorn Valley Med. Soc.; University Club.

Gerish, Albert E.; Omaha; Gen. Prac.; b 1871; Col. of Phys, and Surg., Kansas City, 1903; Douglas Co.

Gerish, Nettie Luella; Omaha; Gen. Prac.; b 1884; Uni. of Cincinnati, 1915; Douglas Co.

Gever, John Conrad; Spaulding; Gen. Prac.; b 1892; Creighton Uni., 1920; Greeley Co.

Gibbon, William Davies; Dunbar; Gen. Prac.; Sioux City Med. Col.; Otoe Co.; State; A.M.A.; Nebr. City Country Club.

Gibbon, Wm. Henry; Harvard; Gen. Prac.; b 1899; Uni. of Nebr., 1925; Clay Co.; A.M.A.

Gibson, Luther Vernon; Lincoln; Gen. Prac.; b 1896; Uni. of Cincinnati, 1924; Lancaster Co.

Gifford, Sanford R.; Omaha; Ophthal.; Cornell, A.B., 1913; Uni. of Nebr., M.D., 1918; M.A. (Hon.), 1923; post-grad., Uni. of Freiburg and others; 1st Lieut., M.C., Base Hosp. No. 49, France; Am. Col. of Surg.; Am. Acad. of Ophthal.; Co.; State; see chapter on Scientific Achievement.

Gifford, Harold; Omaha; Ophthal.; Cornell Uni., B.Sc., 1879; Uni. of Mich., M.D., 1882; (Hon.) M.A., Uni. of Mich., (Hon.) LL.D., Uni. of Nebr., 1925; post-grad, N. Y., Erlangen Vienna, Zurich; Prof. Ophthal., Uni. of Nebr., 1903-1925; emeritus ophthal., Uni. of Nebr.; aural surg., Uni. State Hosp., Methodist Hosp.; editor Ophthalmic Record, 1887-1925; Co.; State; A.M.A.; Am. Acad. Ophthal, and Otolo.; see chapter on Scientific Achievement.

Gilbert, George Richardson; Omaha; Gen. Prac.; Uni. of Nebr., M.D., 1896 ; N. Y. Post-Grad. Med. Sch., 1897; Columbia Col. Phys. and Surg., 1897; Clin. inst., med. and surg., Omaha Med. Col., 1898-1901; Surg., U. P. Ry., 1898-1904 and 1911-1921; Capt., M.C.; author of numerous medical articles.

Gilborne, Henry; Clay Center; Gen. Prac.; b 1840; Hahnemann Med .Col., Philadelphia, 1872; Clay Co, 
Giliry, Ralph Atherton; Omaha; Gen. Prac.; b 1902; Uni. of Nebr., 1926; Deuglas Co.

Gill, James Ward; Chambers; Gen. Prac,; Cotner Uni. Med. Col.; vicepres., Northwest Nebr. Med. Soc.; M.R.C.; Co.: State; Northwest Nebr. Med. Soc.

Gillespie, Edward James; Fullerton; Gen prac.; b 1883; Creighton Uni., 1911; Nance $\mathrm{Co}$.

Gillespie, Paul Bernard; Fullerton; Gen. Prac.; b 1889; Creighton Uni,, 1917; Nance Co.

Gillespie, James Chas.; Falls City; Obstet.; b 1886; Uni. of Ill., 1910; Richardson Co.

Gillespie, Peter L.; Wymore; Pediat., Obstet,; New York Post-Grad. Med. Sch.; Creighton Med. Col.; Pres., Gage Co. Med. Soc., 1904; Gage Co.; State; A.M.A.

Gilligan, John Philip; O'Neill; Gen. Prac.; Albany, N. Y., New York City; Holt Co.; State; A.M.A. See Political Chapter.

Gilligan, John P., Jr.; Nebraska City; Gen. Prac.; b 1899; Uni. of Nebr., 1925 ; Otoe Co.

Gilmore, George Harrison; Murray; Gen. Prac.; Rush Med. Sch., 1895; Major, A.E.F.; Cass Co.; State; A.M.A.; author of medical papers, archeological articles and short stories.

Gilbert, Robert; Omaha; Gen. Prac.; Belfast, Dublin, Edinburgh; chief of staff, Wise Memorial Hosp., Omaha; Co.; State; A.M.A.; Mo. Valley Med. Assn.

Ginn. Arthur P.; Nebraska City; Gen. Prac.; b 1861; Uni. of Vt., 1883; Otoe Co,; A.M.A.

Giragosian, Vahan H. I,; Omaha; Gen. Prac.; b 1876; Reliance Med. Col., 19C9; Douglas Co.

Glatfelter, Harvey Edward; Central City; Gen. Prac.; b 1869; Uni. of Md. Sch. of Med, and Col. of Phys, and Surg., 1891; Merrick Co.; A.M.A.

Gleason, Bert Fuller; Randolph; Gen. Prac.; b 1879; Northwestern Uni., 1907; U. S. Army, 1917-1919; in Randolph 20 years; Cedar Co.; A.M.A.

Gleeson, John J.; Omaha; Gen. Prac.; b 1880; Creighton Uni., 1912; Douglas Co.; A.M.A.

Golden, Frank Patrick; Chadron; Gen. Prac.; b 1881; Creighton Uni, 1914; Dawes Co.

Gooden, David Wendell; Omaha; Gen. Prac.; Meharry Med. Col., Nashville, Tenn., M.D., 1909; pres.. C. C. Club; director, Omaha Urban League; medical examiner for fraternal orders.

Gooden, Chas. W.; Fairmont; Gen. Prac.; b 1870; Med. Col. of Ind., 1896; Fillmore Co.

Goodrich, Guy W.; Omaha; Gen. Prac.; Uni. of Nebr.; Co.; State; A.M.A.; Clin. Club. 


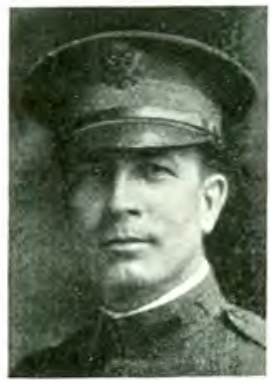

B. F, GLEASON

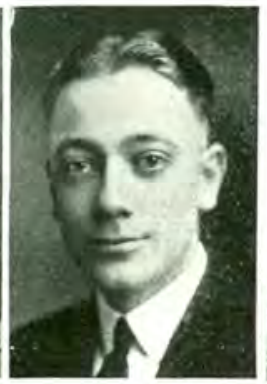

G. W. GOODRICH

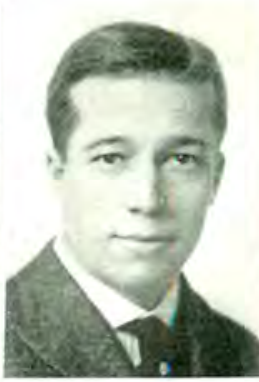

R. C. GRAM I.ICH

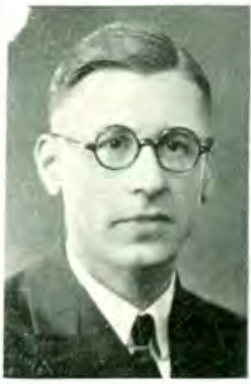

L. E. GROSSKOPFF

Goodrich, Guy Wm.; Omaha; Gen. Prac.; b 1899; Uni. of Nebr., 1925; Douglas Co.

Grace, Jos. Markey; Omaha; Gen. Prac.; b 1809; Creighton Uni., 1924; Douglas Co.; A.M.A.

Graham, Alfred Clifton; Nemaha;Uni. of Nebr..; M.R.C.; Franklin Co.; State; A.M.A.

Graham, Alice Winnefred, (Mrs. F. A.); Lincoln; Gynecol.; Creighton Med. Col.; Barnes Hosp., St. Louis; staff. St. Elizabeth's Hosp., Lincoln; Lancaster Co.; State; A.M.A.

Graham, Francis Andrew; Lincoln; Gynecol.. Surg.; O.M.C.; New York Polyclinic; Chicago Post-Grad. Col,; examiner for Lancaster Co. insanity bd.; Lancaster Co.; State; A.M.A.; Kiwanis.

Graham, James Robert; Allen; Gen. Prac.; Uni. of Nebr., M.D., 1903; pres., Isaac Walton League; Dixon Co.; State.

Graham, Wm. Wayne; Elgin; Gen. Prac.; b 1894; Uni. of Nebr., 1923; Antelope Co.

Gramlich, Ralph Clifford; Walthill; Gen. Prac.; b 1885; Uni. of Nebr., 1914; Local Surg. C. B. \& Q. R. R.; Thurston Co.; A.M.A.

Gray, Oscar Sylvester; Ayr; Gen. Prac.; b 1880; State Uni. of Iowa, 1904; Adams Co.

Green, Carl Raymond; Niobrara; Gen. Prac.; b 1898; Uni. of Nebr., 1925; Knox Co.

Green, Ralph Dennis; Beaver City; Gen. Prac.; Uni. of Nebr.; Jefferson Med. Col.; sec., Furnas Co. Med. Soc.; State.

Green, Wm. Mason; Harvard; Gen. Prac.; b 1874; Creighton Uni., 1901; Clay Co.

Greenberg, Abraham; Omaha; Surg., Obstet.; Uni. of Nebr. Med. Col., Neurol. Inst., N. Y. C.; staff, Wise Memorial Hosp.; assoc. staff. Clarkson Memorial Hosp.; Capt., A.E.F.; Co.; State; A.M.A.; Elkhorn Med. Soc.; Assn. Mil. Surgeons; Athletic, Highland, Country Clubs.

Greene, John Morton; Falls City; Gen. Prac.; b 1874; Uni. of Louisville, 1902; Richardson Co.; A.M.A. 
Grier, Maurice Edward; Omaha; Obstet. Gynecol.; Douglas Co.

Griess, Rudolph Otto; Hastings; Ophthal., Otolo., Laryng., Rhin.; b 1892; Uni. of Nebr., 1919; Adams Co.; A.M.A.

Griffin, Elmer J.; Omaha; Gen. Prac.; Creighton Med Col.; recruiting examiner.

Griffith, Anna M.; Omaha; Gen. Prac.; Creighton Uni., 1898; Douglas Co.

Griffiths, David Gurney; Lincoln; Neurol. Psychiat.; b 1875; Uni. of Nebr., 1902; Lancaster Co.; A.M.A.

Griggs, Earl Elmo; Scottsbluff; Gen. Prac.; Jefferson Med. Col.; Capt., A.E.F.; Scotts Bluif Co.; State; A.M.A.; American Legion; Isaac Walton League.

Griot, Arthur Jacob; Chadron; Gen. Prac.; b 1888; St. Louis Uni. Sch. of Med., 1912; Dawes Co.

Griot, George August; Chadron; Otol., Laryng, Rhin.; b 1880; St. Louis Uni. Sch. of Med., 1910; Dawes Co.

Gritzka, Christian T.; Talmage; Gen, Prac.; b 1873; Uni. of Nebr., 1901; Otoe Co.

Grodinsky, Manuel; Omaha; Surg., Urol.; Uni. of Nebr. Med. Col.; asst. prof. of anatomy; Uni. of Nebr.; staff, Nebr. University and Wise Memorial Hosp.; Co.; State; A.M.A.; Omaha Clinical Club; Alpha Omega Alpha; Sigma Xi; papers on Syphilis of the Lung; An experimental Study of the Sacral Nerves and the Sheaths; Sacral Anesthesia.

Grosback, Harry H.; Wauneta; Gen. Prac.; Eclectic Med. Col., Cincinnati, Ohio; first physician in Clear Co., 1886; member of Med. Advisory Bd., Wauneta; Tri-Co.

Grosskopff, Ludwig Edmund; Deshler; Gen. Prac.; Muenster Westph, and Bonn, Rhineland, Germany; served in 1914-1918, Germany; Co.; State; A.M.A.

Grothan, Ole; St. Paul; Surg.; Kentucky Sch of Med.; Rush Med. Sch.; Major, Spanish-American War; pres., State Board of Health, 18971901; Nebr. State Senate, 1887; Surgeon Gen., Nebraska, 1898.

Hadley, James E.; Cedar Bluffs; Gen Prac.; b 1860; Uni. of Nebr., 1882; Saunders Co.

Hahn, Oscar Herman; Hastings; Surg.; Ensworth Med. Sch., St. Joseph, Mo;. post-grad. study in East; staff, Mary Lanning Hosp.; Adams Co.; State; A.M.A.; Lions; Am. Legion.

Hall, Byron W.; Omaha; Gen. Prac.; b 1877; Uni. of Nebr., 1901; Douglas Co.; A.M.A.

Hall, Lynn Thompson; Omaha; Internal Med.; Drake; Iowa State; Harvard; asst. prof. of medicine, Uni. of Nebr. Med. Col.; staff, University and Wise Memorial Hosps.; U. P. R. R. med consultant; Major, A.E.F.; Co.; State; A.M.A.; Omaha Athletic; University Club.

Hall, M. Freeman; Neligh; Gen. Prac.; b 1871; Ensworth Med. Col., 1901; Antelope Co. 
Hall, Gilbert H.; Kearney; Proctol.; b 1872; Uni. and Bellevue Hosp. Med. Col., 1901; Buffalo Co.; A.M.A.

Hall, Jos. H.; Plattsmouth; Gen. Prac.; Rush Med. Col., 1878; Bellevue Hosp. Med. Col., 1882; Cass Co.

Hall, R'oy Ellsworth; Lyons; Gen. Prac,; b 1886; Creighton Uni., 1914; Burt Co.

Hamel, Eli Burton; Hastings; Proctol.; b 1874; St. Louis Uni., 1903; Adams Co.; A.M.A.

Hamilton, F. T.; Friend; Gen. Prac.; Hahnemann Med. Col., Chicago, M.D., 1904; city physician; bd. of education; Saline Co.; State; A.M.A.

Hamilton, Herschel P.; Omaha; Surg.; b 1859; Uni. of Louisville, 1887; Douglas Co.; A.M.A.

Hamilton, Howard B.; Omaha; Pediat.; Uni. of Illinois; post-grad. study in Europe; asst. prof. of pediat., Uni. of Nebr. Med. Col.; visiting pediatrist, University and Methodist Hosp.

Hammond, Margaret E.; Lincoln; Electrotherap.; Hahnemann Med. Col., Chicago; war work lecturer; Women's State Med.; Inst. of Homeopathy; Lincoln Med. Club.

Hancock, Ernest Wilberforce; Lincoln; Pediat.; b 1894; Northwestern Uni., 1917; Lancaster Co.; A.M.A.

Hand, Geo. J.; Alliance; Ophthal., Otolo., Laryng., Rhin.; b 1875; State Uni. of Iowa., 1904; Box Butte Co.

Haney, Wm. Porter; Omaha; Otolo., Laryng., Rhin.; b 1877; Rush Med. Col., 1901; Douglas Co.; A.M.A.

Hanisch, Louis Everett; Omaha; Surg.; b 1889; Uni. of Nebr., 1916; Douglas Co.; A.M.A.

Hanna, Edgar A.; Ansley; Gen. Prac.; b 1888; Ensworth Med. Col., 1895; Custer Co.

Hanna, Edwin B.; York; Gen. Prac.; b 1871; Chicago Hom. Med. Col.; York Co.; A.M.A.

Hansen, Alex Fredk. J.; Omaha; Gen. Prac.; b 1895; Uni, of Nebr., 1922; Douglas Co.; A.M.A.

Hansen, George M.; Madison; Gen. Prac.; Uni, of Nebr.

Hansen, Henry Chas.; Kearney; Gen. Prac.; b 1891; Chicago Col, of Med. and Surg., 1917; Buffalo Co.

Hansen, Nelson L.; Emerson; Gen. Prac.; Sioux City Med. Col., 1903; Co.; State; A.M.A.

Hansen, Niels P.; Dorchester; Gen. Prac.; b 1872; Uni. Med. Col. of Kansas City, 1900; Saline Co.

Hansen, Otto Theodore; Wausa; Gen. Prac.; Bennett Med. Col,, Chicago; Capt., M.C., World War.

Hanson, Daisy May; Lincoln; Gen. Prac,; b 1875; Rush Med. Col., 1906; Lancaster Co. 


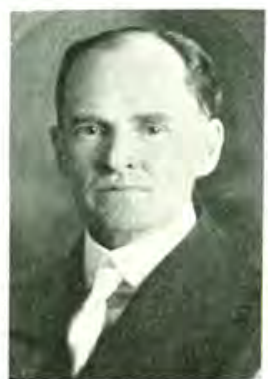

F. T, HAMHLTON

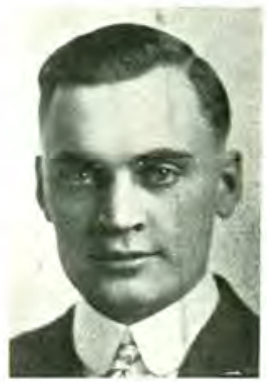

G, M. HANSEN

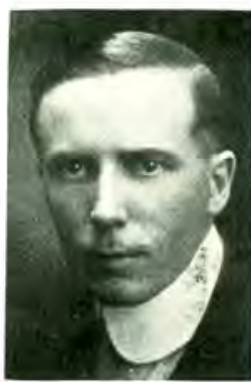

C. W. W. HARMS

Hap man, Harry; Minden; Abdominal Surg.; Rush Med. Col.; Buffalo Co.; State; A.M.A.; Am. Col. Surg.; Am. Ry. Surg.

Hardin, Arthur Bascon; McCook; Gen. Prac.; b 1865; Keokuk Med. Col., 1896; Barnes Med. Col., 1897; Redwillow Co.

Hardy, Clyde Clarence; Omaha; Roentgenol.; b 1897; Uni. of Nebr., 1922; Douglas Co.; A.M.A.

Harman, Leo Dow; Pawnee City; Gen. Prac.; b 1887; Creighton Uni., 1912; Pawnee Co.

Harms, Charles W. W.; Lincoln; Gen. Prac.; Uni. of Nebr., M.D., 1914; A.M. (zoology), 1912; Sigma Xi (zoology), 1914; dept. of student health, Uni. of Nebr.; war service 2 years

Harris, George A.; Valley; Physiotherap., Gen. Prac.; Creighton Med. Col.; Mexican Border Service; Co.; State; A.M.A.

Harris, Robley Duglison; Omaha; Gen. Prac.; St. Lou:s Col. of Phys. and Surgs., 1880; Douglas Co.

Harris, Squire Oliver; Kearney; Surg.; b 1879; Creighton Uni., 1910; Buffalo Co.; A.M.A.

Harris, Tenny Tennyson; Omaha; Roentgenol.; b 1882; Creighton Uni., 1910; Douglas Co.

Harrison, Uen Samuel; Neligh; Gen. Prac.; b 1890; St. Louis Uni., 1913 ; Antelope Co.

Harry, Robert Edward; York; Pediat.; Uni. of Nebr; Washington Uni. Post-Grad. School of Pediat., St. Louis.

Hart, George Emmet; Lyman; Gen. Prac.; Keokuk Uni. Med. Sch.; Scotts Bluff Co.

Hart, Raymond Lochary; Kearney; Internist; Uni .of Iowa; Buffalo Co. (ex pres.); State; Rotary; Ch. of Commerce.

Hartford, Thos. James; Omaha; Gen. Prac,; b 1901; Uni. of Nebr., 1925; Douglas Co.

Hartman, Jesse; Crete; Gen. Prac.; b 1872; Nebr. Col. of Med., 1909; Saline Co. 


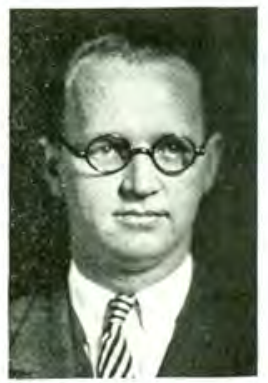

R. E. HARRY

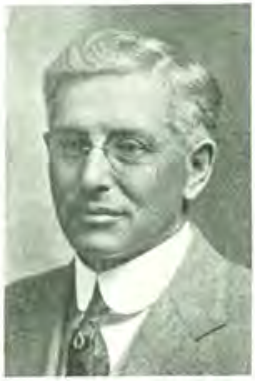

G. E. HART

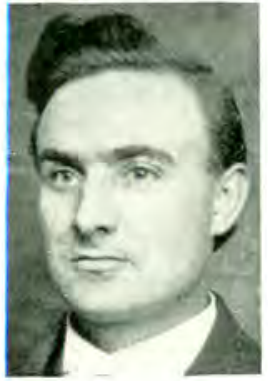

E. A. HARVEY

Hartwell, James E.; Crawford; Gen. Prac.; b 1852; Baltimore Med. Col., 1891; Dawes Co.; A.M.A.

Harvey, Andrew; Fremont; Gen. Prac.; Uni. of Nebr. Med. Col.; past Pres., Elkhorn Valley Med. Soc.; Co.; State; A.M.A. Elkhorn Valley Soc.

Harvey, Earle Alonzo; Fairfield; Gen. Prac.; b 1887; Eclectic Med. Uni., Kansas City, 1917.

Harvey, Harry Evans; Fairbury; Pediat; b 1892; Uni. of Nebr., 1920; Jefferson Co.; A.M.A.

Harvey, Walter Carlton; Gering; Gen. Prac.; Uni. of Nebr.; councillor, 12 dist.; staff, West. Nebr. Methodist Hosp.; Scotts Bluff Co.; State; A.M.A.; Commercial Club.

Haughey, Isaiah William; Aurora; Otolo., Ophthal., Laryng., Rhin.; Uni. of Iowa Med. Col.; M.R.C.; Hamilton Co.; State; A.M.A.

Hauser, Byron B.; Hooper; Proctol,; b 1871; Col. of Phys. and Surg., Baltimore, 1898; Dodge Co.; A.M.A.

Hauslein, Chas. Michael; Omaha; Gen. Prac.; b 1872; Rush Med. Col., 1900 ; Douglas Co.

Haverstock, Horace Teal; Lincoln; Eye, Ear. Nose, Throat; Hahnemann Med. Col., Chicago, M.D., 1907; N. Y. C.; Lancaster Co.; State; A.M.A.; $\mathrm{Ch}$. of Commerce.

Hawes, Geo, Fredk.; Omaha; Gen. Prac.; b 1891; Creighton Uni., 1914; Douglas Co.

Hawkins, Anthony; Omaha; Gen. Prac.; b 1884; Meharry Med. Col., 1913; Douglas Co.; A.M.A.

Hawkins, Robert Grossett, Sr.; Butte; Obstet., Gynecol.; Sioux Falls Col., Sioux Falls, Ia.; Creighton Med. Col., M.D.; Sacred Heart Hosp.; chmn., health board; Boyd Co.; State; A.M.A.

Hawley, A. N.; Norfolk; Eye, Ear, Nose, Throat; Cotner Uni. Med. Col.; Co.; State; A.M.A.; Kiwanis, Commercial Clubs.

Haworth, Dale Emmett; Wymore; Gen. Prac.; b 1894; Bennett Med. Col., 1915; Gage Co. 


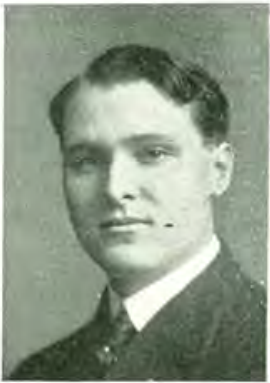

A. C. HAWKINS

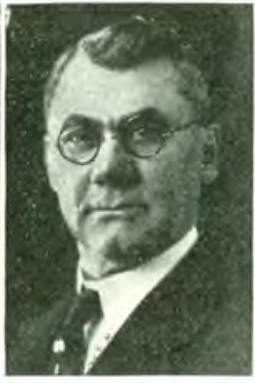

G. A. HEATH

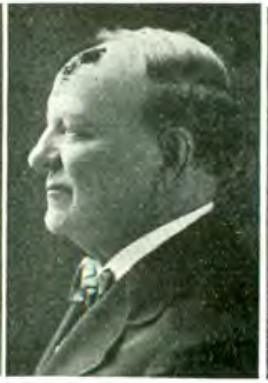

W. L. HEILMAN

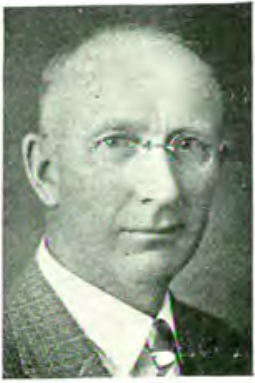

C. W. HICKEY

Hayes, Noah; Lincoln; Gen. Prac. (Retired); Georgetown, M.D.; Civil War Vet.; with Hall exped. to North Pole; Kansas Med. Soc.; A.M.A.

Hayes, Edward R.; Falls City; Gen. Prac.; b 1885; Ensworth Med. Col., 1906; Richardson Co.; A.M.A.

Hazen, Wm.; Creighton; Gen. Prac.; Knox Co.

Heacock, Frank Miles; Bancroft; Gen Prac.; b 1893; Creighton Uni., 1917; Cuming Co.; A.M.A.

Heagey, Francis Wenger; Omaha; Diag., Internai Med.; Princeton, A.B., 1908; Columbia Uni., M.D., 1912; Co.; State; A.M.A.; Am. Col. of Phys.; Ch. of Commerce; University, Country, Professional Men's Clubs; papers on Epidemic Encephalitis and other subjects.

Heath, Geo. A.; Fairbury; Gen. Prac.; Loyola Uni. Med. Col.; pres., Jefferson Co. Med. Scc.; State; A.M.A.; Rotary.

Heeren, Edna Susanne; Carroll; Gen. Prac.; b 1887; Barnes Med. Col. of St. Louis, 1911; Wayne Co.

Heider, Chas. Frank; Sutherland; Surg.; b 1894; Uni. of Nebr., 1921; Lincoln Co.

Heilman, W. Landis; Sterling; Gen. Prac.; Ensworth Med. Col., St Joseph, Mo., M.D., 1897; Co.; State.

Hein, Henry; Wilber; Gen. Prac.; Creighton Med. Col.; Saline Co.; State; A.M.A.

Heine, Clinton Daniel; Hooper; Gen. Prac.; b 1887; Rush Med. Col., 1915; Dodge Co.; A.M.A.

Heine, Wm. Howard; Fremont; Ophthal., Otolo., Laryng., Rhin.; b 1877; Uni. of Nebr., 1905; Dodge Co.; A.M.A.

Hellwig, J. W.; Omaha; Dermat,, Urol.; Creighton Med. Col.; postgrad., Europe; Co.; State; A.M.A.; Urol. Soc.; Athletic Club.

Hemphill, William Joseph; North Loup; Gen. Prac.; Chicago; staff, Hillcrest Sanatorium, Ord.

Henderson, Robt. G.; Falls City; Gen. Prac.; b 1872; Kansas City. Med. Col., 1900; Richardson Co. 
Hendrickson, Chas. W.; Amherst; Gen. Prac.; St. Louis Uni. Med. Dept., Ensworth Central, St. Louis; Loyola Uni., Chicago; interne, American Hosp., Chicago; Buffalo Co.; State.

Hendrickson, Mary A. Keller; Loup City; Gen. Prac.; Col. of Phys, and Surg., Keokuk, 1890; Sherman Co.

Henry, Edwin C.; Omaha; Brain Surg.; Creighton Med. Col.; Cornell Med. Sch.; Vienna; Berlin; Major, A.E.F.; staff, Lord Lister Hosp., Omaha; Co.; State; A.M.A.; Rotary; ex-pres., Douglas Co.; American Legion.

Henske, Joseph Aloysius; Omaha; Pediat.; Burns Uni., St. Louis, 1907; post-grad., Harvard, 1921; clinical tour in Europe; staff, City Hosp., St. Louis House surg., Mo. Pac. Hosp., Kansas City and St. Louis; Mo. Pac., Omaha; Assoc, with Dr. McClanahan; staff, Clarkson and Nebr. Methodist Hosps.; Nebr.-Iowa Ped. Soc.; papers on pediat.

Herney, Adam; Petersburg; Gen. Prac.; Ensworth Med. Col., 1893; Boone Co,

Herrmann, Walter Wesley; Omaha; Gen. Prac.; b 1898; Uni. of Nebr., 1926; Douglas Co.

Hess, Geo. J.; Wayne; Gen. Prac.; b 1868; Detroit Col. of Med. and Surg., 1894; Wayne Co.

Heumann, J. M. F.; Omaha (Benson); Gen. Prac.; Rush Med. Sch.; Co.; State; A.M.A.; Benson Commercial Club.

Hewitt, Hamilton W.; Lincoln; Gen. Prac.; (retired 1910) ; Uni. of Wisc., 1873; Rush Med. Sch., M.D., 1877; Practiced at Friend 37 years; Lancaster Co.; State; A.M.A.; Lincoln Ch. of Commerce.

Hewitt, Henry F.; Dunning; Gen. Prac,; b 1870; State Uni. of Iowa, 1897; Blaine Co.

Hickey, Charles W.; Bennington; Gen. Prac.; Creighton Med. Col.; Co,; State; A.M.A.

Hickman, Clarence Clyde; Lincoln; Surg.; b 1883; Rush Med. Col., 1910; Lancaster Co.; A.M.A.

Hickman, Joel Clyde; Geneva; Gen. Prac,; b 1887; Lincoln Med. Col., 1908; Fillmore Co.; A.M.A.

Higgins, Jos. E.; Grand Island; Ophthal., Otolo., Laryng., Rhin.; b 1878; Creighton Uni., 1904; Hall Co.

Higgins, Ralph P.; Ansley; Gen. Prac.; Uni. of Nebr.; M.C., A.E.F.

Hildreth, Mortimer L.; Lyons; Gen. Prac.; Rush Med. Col.; past pres., Nebr. State Med. Assn.; State; A.M.A.

Hill, J. Boston; Omaha; Gen. Prac.; Meharry Med. Col., 1904; Douglas Co.

Hill, James Stanley; McCook; Eye, Ear, Nose, Throat; Ohio Med. Uni., Columbus; public health service, 1918; Red Willow Co.; State; A.M.A.; Republican Valley; Ch. of Commerce.

Hille, Richard Walter; Arcadia; Gen. Prac.; b 1898; Uni. of Nebr., 1923; Valley Co. 


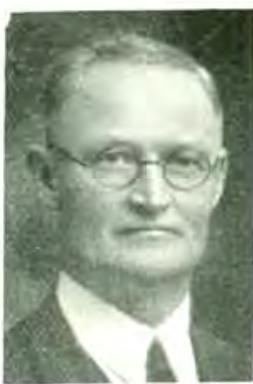

J. S, HILI.

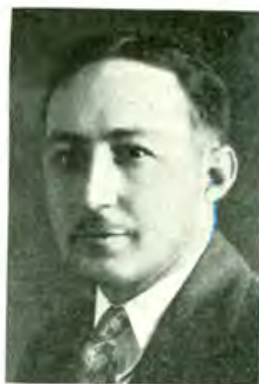

C. A. HOEFER

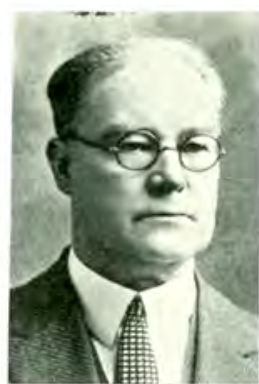

A. E. HOFF

Hillis, William Ervin; Syracuse; Gen, Prac,; Lincoln Med. Col., Cotner Uni., 1894; Chicago, 1903; Otoe Co.; State;

Hilsabeck, Lester Clyde; Gretna; Gen. Prac.; b 1883; Creighton Uni., 1910; Sarpy Co.

Hilton. David Clark; Lincoln; Surg.; Uni. of Nebr., A.B., 1900; A.M., 1901 ; Rush, M.D., 1903; Vienna, Paris; Capt., M.C.; Colonel, M.C.; Nebr. Natl. Guard; Lancaster Co.; (past pres.); State; A.M.A.; F.A.C.S.; chief surgeon, Bryan Memorial Hosp.; stalf, St. Elizabeth's Hosp; various papers on surgery and on Morphogenisis of the Liver; J. Am. Micros. Soc., 1903.

Hinchman, Jos. V.; Blair; Gen. Prac.; b 1846; Med. Col. of Ind., 1885; Washington Co.

Hinkle, Warren Irle; Barada; Gen. Prac.; b 1895; Uni, of Nebr., 1924; Richard Co.; A.M.A.

Hirschmann, Herman; Omaha; Obstet., Gynecel.; Baltimore Uni., 1903; Douglas Co.; A.M.A.

Hodnett, Wm. Perkins; Scottsbluff; Ophthal., Otolo., Laryng., Rhin., b 1883; Uni. of Colo., 1912; Scotts Bluff Co.; A.M.A.

Hoefer, Carl Archibald; Wisner; Gen. Prac.; Uni. of Nebr., 1924; U. S. N.; Madison Co.; State; A.M.A.; Phi Rho Sigma; American Legion.

Hoffmeister, George; Imperial; Gen. Prac.; Uni. of Nebr, 1916; Cantain M. C.

Hombach, Wm. Henry; Grand Island; Urol.; b 1889; Creighton Uni., 1913; Hall Co.; A M.A.

Hompes, Jos. Josiah; Lincoln; Ophthal., Otolo., Laryng., Rhin.; b 1883; Uni. of Nebr., 1908; Lancaster Co.

Hooper, Clifford Lecn; Oconto; Gen. Prac.; b 1882; Eclectic Med. Uni. Kansas City, 1907; Custer Co.

Hoops, Marcus; Springview; Obstet., Gynecol.; b 1879; Lincoln Med. Col., 1908; Kevapaha Co.

Hoover, Maurice A.; Kearney; Gen. Prac.; Indianapolis, 1881; Major, Spanish-American War; V.M.S.C.; U. S. Pension Poard (secretary). 
Hopkins, Saml. Rice; Omaha; Surg.; b. 1876; Rush Med. Col., 1900; Douglas Co.; A.M.A.

Hopper, Oscar C.; Stanton; Gen. Prac.; Uni. of Western Ontario, London, Ont.; Madison Co.; State.

Horn, Matthaus Henry; Bethany; Gen. Prac.; b 1871; Kansas Med. Col. of Topeka, 1900; Lancaster Co.

Hornbeck, Albert Russell; Omaha; Gen. Prac.; b 1884; Lincoln Med. Col., 1910; Douglas Co.; A.M.A.

Hostetter, Allen H.; Douglas; Gen. Prac.; b 1858; Rush Med. Col., 1868; Otoe Co.

Hostetter, Wm. A.; Omaha; Gen. Prac.; b 1866; Uni. of Nebr., 1894; Douglas Co.

Hotz, Harley James; Omaha; Gen. Prac.; Douglas Co.; A.M.A.

Houchen, H. R.; Utica; Gen. Prac.; b 1881; Lincoln Med. Col., 1905; Seward Co.

Houlton, Thos. Leo.; Omaha; Gen. Prac.; b 1894; Creighton Uni., 1920; Douglas Co.

Howard, Maurice C.; Omaha; Internal Med. Creighton Med. Col., Vienna; Creighton Uni. faculty; M.R.C.; Co.; State; A.M.A.

Howard, Sullivan; Elk Creek; Gen. Prac.; b 1865; Denver Col. of Med., 1892; Johnson Co.; A.M.A.

Howell, Wm. Lewellyn; Hyannis; Gen. Prac,; b 1887; Marquette Uni., 1913; Grant Co.

Howley, Ambrose N.; Norfolk; Ophthal., Otolo., Laryng.. Rhin.; Lincoln Med. Col., 1907; Madison Co.; A.M.A.

Hoxscy, Robert Patton; Beatrice; Phys., Nebr. Inst. for Feeble Minded; Doane Col., B. S., 1883; Col. Phys, and Surg., Chicago, M.D., 1901; Med. Dept., Uni, of Ill.

Hoyt, Saml. Norris; Omaha; Gen. Prac.; b 1879; New York Uni., 1893; Douglas Co.

Hoff, Albert Edward; North Bend; Internal Med.; Midland Col., Atchison, Mo.. A.B.; Ensworth Med., St. Joseph Mo., M.D.,; post-grad., Mayo Clinic; bd. of health; staff, Richmond and Military Ave. Hosp., Fremont; ex-pres., Dodge Co.; State; A.M.A.; elected as member of Am. Col. of Phys. in 1928.

Hoffman, Lloyd Oliver; Omaha; Obstet., Gynecol.; b 1895; Uni of Nebr., 1919; Douglas Co.; A.M.A.

Hohlen, Karl Siegfrid J.; Lincoln; Surg.; b 1886; Ensworth Med. Col., 1908; Lancaster Co.; A.M.A.

Hollenbach, Carl F.; Omaha; Gen. Prac.; Uni. of Nebr., M.D., 1918; U. S. N.

Hollenbeck, Frank Bradbury; Lincoln; Surg.; Rush Med. Col., M.D.; Major, M.R.C.; Lancaster Co.; State; A.M.A.; Mo. Valley Med. Assn.; Am. Col. of Surg.; Am. Ry. Surg. 
Hollister, Robert Russell; Omaha; Gen. Prac.; Harvard Med. Sch., M.D., 1902; Co.; State; A.M.A.; Mo. Valley Med. Assn.

Holm, Adolph Hjalmas; Wolbach; Obstet.; b 1874; Uni. of Nebr., 1905; Greeley Co.; A.M.A.

Holovtchiner, E.; Omaha; Gen. Prac.; Bern, Zurich (Switzerland), Berlin, Leipzig; Co.; State; A.M.A.; see Pioneer and Political Chapters.

Holst, John; Omaha; Eye, Ear, Nose, Throat; Omaha Col. of Pharm., Ph.G., 1903; Creighton, M.D., 1913; Post-grad. Copenhagen; Capt., M.C.; Co.; State; A.M.A.; Omaha-Council Bluffs Ophthal. and Laryng. Soc.

Holyman, Marcus B.; Naponee; Gen. Prac.; Lincoln Med. Col., 1904; Franklin Co.

Holyoke, Edgar Loomis; Lincoln; Gen. Prac. (retired); Iowa Uni, A.B.; prof., Nebr. Med. Col., At Lincoln; city phys., 1889-1903; staff, St. Elizabeth's Hosp., 1889-1903; state penitentiary physician, 1903-1908; U. S. Pension Examiner for 25 years; insanity board, six years.

Homan, Leo. Jos; Howell; Gen. Prac.; b 1893; Creighton Uni., 1925; Colfax Co.

Hubbard, C. S.; Mason City; Gen. Prac.; b 1865; Chicago Hom. Med. Hosp., 1900; Custer Co.

Hubbell, Abraham Turner; Wood River; Gen. Prac.; Northwestern Uni. Med. Col.

Hubbell, Harry W.; Gandy; Gen. Prac.; b 1861; Northwestern Med. Col., St. Joseph, 1890; Logan Co.

Hubenbrecker, John Carl; Morse Bluff; Obstet.; b 1891; Creighton Uni., 1915; Saunders Co.

Hufman, Robert Willard; University Place; Gen. Prac,; b 1859; Hering Med. Col., 1903; Lancaster Co.

Hughes, Dwight Otis; Fairbury; Gen. Prac.; Uni. of Nebr., M.D.; Navy, 1918; Jefferson Co.; State; A.M.A.

Hull, Charles A.; Omaha; Surg.; Uni. of Colo.; Berlin and Vienna; asst. prof., Uni. of Nebr.; C. B. and Q. Ry. Surg.; Major, A.E.F.; Co.; State; A.M.A.; numerous articles.

Hull, Solomon L.; Central City; Gen. Prac.; Rush Med. Col., M.D., 1889 ; pres., Merrick Co. Bd. of Pensions.

Hume, Harold Clay; Hayes Center; Gen. Prac.; b 1896; Uni. of Kans., 1925; Hayes Co.

Hummel, R'ay O.; Lincoln; Gen. Prac.; b 1880; Northwestern Uni., 1905; Lancaster Co.; A.M.A.

Humpal, Joseph J.; Omaha; Gen. Prac _; Creighton Med, Col., M.D., 1911 ; M.R.C., World War.

Humphrey, Hall H.; Daykin; Gen. Prac.; b 1888; Lincoln Med. Col., 1913; Jefferson Co.

Hunt, Katherine Moran, Omaha; Ophthal., Otolo., Laryng., Rhin.; b 1881; Uni. of Nebr., 1920; Douglas Co.; A.M.A. 


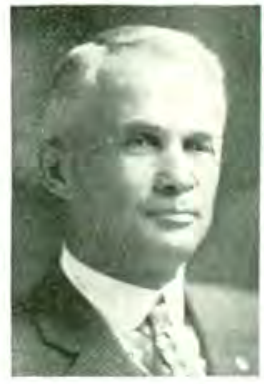

A. T. HUBBELL.

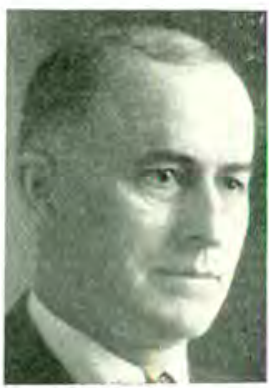

I. W. 1RVIN

Hustead, Charles D.; Aurora; Gen. Prac.; Uni. of Louisville Med. Dept.; pres., U. S. Pension Board; Air service (med.); Hamilton Co.; State; A.M.A.

Hustead, Charles Luke; Falls City; Surg.; Roentgenol; Creighton Uni. Med. Col.; New York Post-Graduate Med. Sch.; director, Falls City Hosp.; C. B. and Q. Ry. surgeon; Richardson Co.; State; A.M.A.; Am. Ry. Surg.; Interstate Post-Grad. Med. Assn.; Am. Col. of Physical Therapy; Isaac Walton League; Sportsman; Gun; Boy Scouts; contributor of: ThromboAngitis Obliterans of the Hand; Infectious Arthritis of the Elbow; Treatment of Carbuncles; Diverticulum of the Urinary Bladder.

Hutchison, Jos. W.; Central City; Gen. Prac.; b 1877; Creighton Uni., 1911; Merrick Co.

Hutten, Jesse H.; Omaha; Gen. Prac.; Howard Uni., 1898; Douglas Co.

Hyde, John Fay; Omaha; Obstet., Gynecol.; b 1885; Uni. of Nebr., 1907; Douglas Co.; A.M.A.

Hylton, J. H.; Brownville; Gen. Prac.; Lincoln Med. Col.

Hylton, William Nathanial; Gresham; Gen. Prac.; Uni. of Nebr.; York Co.; State; A.M.A.

Hynes, William P.; Greeley; Gen. Prac.; Creighton Med. Col.; M.C., A.E.F.; Greeley Co..

Ingham, Chas. T.; Wayne; Gen. Prac.; b 1869; Sioux City Col. of Med., 1893; Wayne Co.

Ingram, Jos. Everett; Nelson; Gen. Prac.; b 1883; Eclectic Med. Col. of Cincinnati, 1915; Nuckolls Co.

Inks, John A.; Shelby; Gen. Prac.; b 1856; Rush Med. Col., 1880; Polk Co.

Ira, Guy Bentley; Lynch; Gen. Prac.; b 1874; St. Louis Col. of Phys. and Surg., 1897; Boyd Co.; A.M.A.

Irvin, Isaiah W.; Auburn; Roentgenol.; b 1876 Lincoln Med. Col., 1905; Nemaha Co.; A.M.A.

Isaacs, David; Omaha; Ophthal., Laryng., Rhin.; b 1877; Uni. of Nebr., 1903 ; Douglas Co.; A.M.A. (deceased, 1927). 
Ivins, Richard Lynoesus; Crawford; Gen. Prac.; b 1886; Creighton Uni., 1908; Dawes Co.

Iwerson, John Christian; Omaha; Pediat.; b 1879; Uni. of Nebr., 1903; Douglas Co.

Jacobi, Stella Elora; Chapman; Omaha; Gen. Prac.; b 1859; Uni, of Mich., 1885; Douglas Co.

Jacobsen, Merlin Carl; Omaha; Gen. Prac.; b 1902; Creighton Uni., 1926; Douglas Co.

James, Chas. Stanton; Omaha; Ophthal., Otolo., Laryng., Rhin.; b 1877; Uni. of Nebr., 1899; Douglas Co.

James, Maurice C.; Columbus; Surg.; Jefferson Med. Col.; war service, 1918-1919.

Jarmin, Ernest Geo.; Minden; Gen. Prac.; b 1886; Lincoln Med. Col., 1908; Kearney Co.

Jefferson, Alfred; Omaha; Gen. Prac.; Omaha Med. Col.; physician to Nebr. State Sch. for Deaf; Co.; State; A.M.A.; Continental Club.

Jelinek, John A.; Bruno; Gen. Prac.; Creighton Med. Col.; Butler Co.; State; A.M.A.

Jenison, Andrew J.; Harvard; Uni, of Iowa Med. Sch.; food administrator, Clay Co.; Commissioner of Insanity; Co. Coroner; Legislature; City Mayor; school bd; Acting Postmaster; Clay Co.; State.

Jenkins, Harry Jerome; Omaha; Obstet.; b 1893; Creighton Uni., 1916; Douglas Co.; A.M.A.

Jensen, Frank; Newman Grove; Gen. Prac.; b 1880; Uni. of Nebr., 1903; Madison Co.; A.M.A.

Jensen, Jens Peter; Plainview; Gen. Prac.; Uni. of Nebr., 1903; Pierce Co.

Jester, Royal F.; Doniphan; Gen. Prac.; b 1890; Lincoln Med. Col., 1913; Hall Co.

Johnson, Amos Frank; Wausa; Gen. Prac.; b 1874; Creighton Uni., 1904; Knox Co.

Johnson, Chester Arthur; Valentine; Gen. Prac.; Uni. of Nebr.

Johnson, Chester Fredk.; Omaha; Gen. Prac.; b 1899; Uni. of Nebr., 1925; Douglas Co.

Johnson, Czar C.; Lincoln; Surg.; Creighton Med. Col.; Lieut. Col., A.E.F.; Lancaster Co.; State; A.M.A.; Am. Col. of Surg.

Johnson, Earle George; Grand Island; Surg.; Uni. of Nebr., A.B., A.M., Sigma Xi, 1911; Rush Med. Col.; post-grad, New York, London, Vienna; Capt., M. C.; Co.; State; A.M.A.; F.A.C.S.; Am. Assn. Ry. Surg.; Am. Legion; Rotary.

Johnson, Egbert G; Broken Bow; Eye, Ear, Nose, Throat; Uni. of Kans.; Okla; State Teacher Col., Emporia, Kans.; post-grad., Chicago, New York and Denver; Public Service Club.

Johnson, Frank Bruce; Lincoln; Gen. Prac.; b 1864; Keokuk Med. Col., 1884 ; Lancaster Co. 
Johnson, Frank W.; Fullerton; Gen. Prac.; Omaha Med. Col., 1894; city and county health officer; insanity commission 30 years; Co.; State; A.M.A.

Johnson, Henrietta Mae Washburn; Broken Bow; Gen. Prac.; b 1890; Uni. of Kansas Sch. of Med., 1923; Custer Co.

Johnson, Herman Frank; Omaha; Ortho. Surg.; b 1897; State Uni. of Iowa., 1922; Douglas Co.

Johnson, Homer H.; Lincoln; Gen. Prac.; b 1876; Lincoln Med. Col., 1904; Lancaster Co.

Johnson, John M.; Hartington; Surg.; b 1875; Creighton Uni., 1915; Cedar Co.

Johnson, Julius Andrew; Omaha; Gen. Prac.; b 1891; Uni. of Nebr., 1917; Douglas Co.

Johnson, Leslie Augustus; Plainview; Gen. Prac.; b 1886; Creighton Uni., 1912; Pierce Co.

Jehnson, Norman T.; Kearney; Physiotherap.; Uni. of West. Ontario, London, Canada, 1902; pcst-grad., Chicago, San Francisco; Kansas City, etc.; former vice-pres., Nebr. State Med. Assn.; ex-pres., Rep. Valley Med. Assn.; ex-secy., Franklin Co. Med. Soc.; ex-councillor, 10th dist., Nebr. State Med. Assn.; Co.; State; A.M.A.; Am. Assn. Medico-Physical Research; Ch. of Commerce; Country Club.

Johnson, Orville Dawson; Kearney; Surg.; Uni. of Nebr.; Co.; State; A.M.A.; Kiwanis.

Johnson, Rudolph Eugene; Wausa; Gen. Prac.; b 1892; Uni. of Nebr., 1918; Knox Co.; A.M.A.

Johnson, Walter Lawrence; Walthill; Gen. Prac.; b 1889; Uni. of Ill, 1915; Thurston Co.

Johnson, Wm .Thos., Jr.; Gothenburg; Obstet,, Gynecol.; b 1896; Uni. of Nebr., 1921; Dawson Co.; A.M.A.

Johnston, George Fredk; Alliance; Gen. Prac.; b 1891; Chicago Col. of Med. and Surg., 1917; Box Butte Co.

Johnston, Raymond S.; Hastings; Proctol.; b 1890; Creighton Uni., 1916; Adams Co.; A.M.A.

Jonas, August Frederick; Omaha; Surg.; Bennett Med. Col., Chicago, 1877; University Ludwig Maxmillian Munich Bavaria, 1884; see chapters on Pioneers and Achievements.

Jones, Agnes Houston, Denton; Gen. Prac; b 1876; Lincoln Med. Col, 1906; Lancaster Co.

Jones, Edward L.; Raymond; Gen. Prac.; b 1864; Lincoln Med. Col., 1905 ; Lancaster Co.

Jones, Robert Turner; Kearney; Surg.; b 1877; Creighton Uni., 1911; Bufffalo Co.; A.M.A.

Jones, Sherman J.; Hastings; b 1861; College of Phys, and Surg., Keokuk, 1891; Adams Co. 
Jones, Thos. Jefferson; St. Edward; Gen. Prac.; b 1867; State; Uni. of Iowa, 189,3; Boone Co.

Jones, Tyre Kinser E.; Lincoln; Gen. Prac.; b 1873; Lincoln Med. Col., 1905 ; Lancaster Co.

Jones, Wesley B.; Omaha; Gen. Prac.; b 1891; Meharry Med. Col., 1918; Douglas Co.; A.M.A.

Jones, Wm. Y.; Ponca; Gen. Prac,; b 1868; Uni, of Nebr., 1902; Dixon Co.

Judd, John Hewitt; Beatrice; Ophthal,, Otolo; Laryng., Rhin.; b 1899; Uni. of Nebr., 1924; Gage Co.; A.M.A.

Kadavy, Godfrey Joseph; Omaha; Gen. Prac,; Creighton Med. Col. Pharm., 1907; M.D., 1914; World War, 1918; Co.; State; A.M.A. see chapter on Achievements.

Kail, Carl; Lincoln; Roentgenol,; b 1885; Drake Uni., 1908; Lancaster Co.; A.M.A.

Kalar, James Riley; Anselmo; Gen. Prac.; Keokuk Med. Col., 1903; Custer Co

Kani, M. Alace; Omaha; Gynecol.; Chicago, 1903; pres., 1926; Omaha Women's Med. Soc.; Co.; A.M.A.; Nebr. State Women's Med. Assn.; Omaha Woman's Club.

Kantor, Dominic Benj.; Sargent; Gen. Prac.; b 1892; Uni. of Nebr., 1,923; Custer Co.

Karrer, Fred W.; Benedict; Gen. Prac.; b 1879; Uni. of Nebr., 1904; York Co.

Kaspar, Jos. Francis; Prague; Surg.; b 1876; Bellevue Hosp. Med. Col., 1900; Saunders Co.; A.M.A.

Kauffman, Emmanuel; Hardy; Gen. Prac.; 1860; Jefferson Med. Col. of Philadelphia, 1889; Nuckolls Co.

Kavan, Wenceslaus John; Clarkson; Surg.; b 1884; Creighton Uni., 1912; Colfax C.; A.M.A.

Kay, Zacheus LaFayette; McCook; Gen. Prac.; b 1849; Kentucky Sch. of Med., 1876; Red Willow Co.

Keane, John Lawrence; Omaha; Gen. Prac.; b 1896; Creighton Uni., 1926; Douglas Co.

Kee, Albert L.; Cambridge; Surg.; b 1876; Col. of Phys. and Surg., Baltimore, 1901; Furnas Co.; A.M.A.

Keetell, William Chas.; Lyons; Gen. Prac.; Creighton Med. Col.; intern, St. Joseph's Hosp., Omaha; Lyons Sch. Bd.; Co.; State; A.M.A.

Keith, Charles Worthington; Edgar; Gen. Prac.; Creighton Med. Col,; flight surg., Dept. of Commerce, Washington, D. C.; board of health; Clay Co.; State; A.M.A.

Keith, Wellington W.; Hastings; Gen. Prac.; b 1865; Lincoln Med. Col., 1902; Adams Co.

Keller, Fredk. A.; Falls City; Gen. Prac.; b 1878; Ensworth Med. Col,, 1902; Richardson Co. 


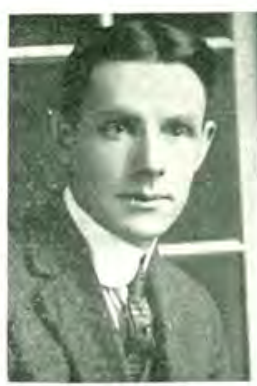

C. W KEITH

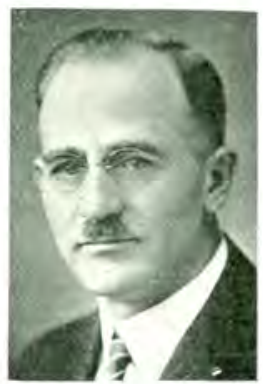

E. KELLEY

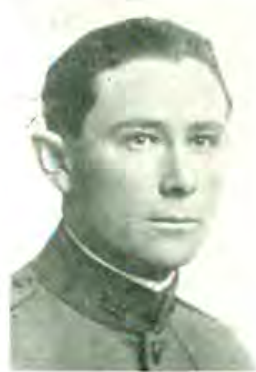

J. B. KILE

Kelley, Ernest; Omaha; Nervous and Mental Dis.; Creighton Med. Col.; Prof., nervous and mental diseases, Creighton; formerly on staff, Norfolk State Hosp.; Chief of staff, Lord Lister Hosp.; staff. St. Joseph's and attg. staff, St. Bernard's and Nicholas Senn Hosp.; Co.; State; A.M.A.; Mo. Valley Med. Assn.; Athletic, Happy Hollow Clubs.

Kelley, Walter Edwin; Ingleside; Pediat.; b 1866; Barnes Med. Col., 1903 ; Adams Co.

Kelly, James Francis; Omaha; R'oentgenol., Physical Therap.; Creighton Uni. Med. Col.; post-grad., Cornell and New York; assoc. prof., roentgenol., Creighton; staff, St. Catherine's and St. Joseph's Hosp.; Capt., M.C.; Am. Roentgen Ray Soc.; N. A. R'adiol. Soc.; Omaha Roentgen Ray Soc. (sec.); papers on technique.

Kelly, Perry Delphos; Nemaha; Gen. Prac.; b 1870; Ensworth Med. Col.; 1893; Nemaha Co.

Kennard, Henry Waters; Omaha; Gen. Prac.; b 1874; Uni. of Md., 1899; Douglas Co.

Kennedy, Charles Rex; Omaha; Surg.; Uni. of Nebr., M.D., 1905; prof. clin. surg., Uni. of Nebr.; surg., Nebr. Methodist Hosp.; Co.; State; A.M.A.; F.A.C.S.; Railway Surg.; Uni., Commercial, Athletic, Happy Hollow Clubs.

Kenner, Chas. Andrew; Omaha; Gen. Prac,; b 1861; Rush Med. Col., 1883; Douglas Co.

Kenner, Wm. Clinton; Omaha; Gen. Prac.; b 1868, Uni. of Nebr., 1894 ; Douglas Co.

Kenner, William Clinton, Jr.; Talmage; Gen. Prac.; Uni. of Nebr.; Otoe Co.; State; A.M.A

Kenney, Bernard Vincent; Dodge; Gen. Prac.; b 1896; Creighton Uni., 1922; Dodge Co.

Kennon, Clyde E.; Maxwell; Gen. Prac.; b 1879; Creighton Uni., 1906; Lincoln Co.; A.M.A.

Kerley, Quillen Avery; Randolph; Gen. Prac.; b 1872; Barnes Med. Col., 1900; Cedar Co. 
Kerr, Theodore Joseph; North Platte; Internal Med.; Uni. of Nebr.; dist. surg., U. P. Ry.; M.C., World War; Ch. of Commerce; Rotary.

Kerr, Robert Henderson; Alma; Ophthal., Otol., Laryng., Rhin.; b 1883; Uni. of Nebr., 1915; Harlan Co.

Keys, Jerome; Omaha; Gen. Prac.; b 1850; Eclectic Med. Col., Cincinnati, 1882; Douglas Co.

Kidder, Clarence Eugene; Hastings; Gen. Prac.; b 1881; Lincoln Med. Col., 1914; Adams Co.

Kiefer, J. J.; West Point; Gen. Prac.; St. Louis Med. Col., Uni. of Iowa Med. Col.; Cuming Co.; State.

Kile James Bernard; Eddyville; Gen. Prac.; Keokuk Col. of Phys, and Surg., M.D., 1906; M.C.; Dawsen Co.; State; A.M.A.

Kilian, Leo Julius; Wakefield; Gen. Prac.; Washington Uni., St. Louis, M.D., 1913; intern service, various St. Louis hospitals; asst. with Dr. Morris Neilsen, Blair, 4 yrs.; Capt., M.C., A.E.F.; Cedar-Dixon-Thurston-WayneDakota Co.; State; A.M.A.

Killins, Wendell A.; Omaha; Internal Med.; Uni. of Nebr., M.D., 1921; asst. to Dr. C. A. Roeder; Fellow Mayo Foundation; staff, Mayo Clinic 1926-1927.

Kindred, Homer Leander; Meadow Grove; Gen, Prac., Surg., E.E.N.T.; Kansas City Med. Col., M.D., 1802; post-grad., Chicago; Co.; State; A.M.A.

King, Dexter D.; York; Gen. Prac.; Uni. of Nebr.; Phys. to State 1.O.O.F. Home., York; York Clinic and Clinic Hosp.; Capt., M.C., A.E.F.; Co.; State; A.M.A.; Elkhorn Vally Rotary.

King, Frank Lambert; Omaha; Gen. Prac.; b 1860; Pulte Med. Col., 1888; Douglas Co.

King, Henry Eugene; Fullerton; Gen. Prac.; Creighton Med. Col.; pres., Nance Co. Med. Soc.; M. C.. World War; Nance Co.; State; A.M.A.; American Legion, Lions Club.

King, John W.; Hartington; Internal Med.; Inter-State Col. of Med., M.D., 1886; city phys., 1909 ; chief staff ,St. John's Hosp.; Ce.; State; A.M.A; Inter-State Post-Grad. Med. Assn, of North America; Mo. Valley Med. Assn.; Sioux Valley Med. Soc.; Am. Col. Phys. Therapy.

Kintner, Arthur Ruel; Nehawka; Gen. Prac.; b 1900; Uni. of Nebr., 1925; Cass Co.; A.M.A.

Kinyoun, Floyd H.; Omaha; Surg.; Drake Uni.; Creighton Med. Col.; Uni. of Vienna; Berlin; med. dir., Columbia Life Insurance Assn.; staff, Lord Lister 6 years; M.C., World War; see chapter on Achievements.

Kirchman, Robert Chas.; Wilber; Gen. Prac.; Notre Dame Uni.; Creighton Med. Col., M.D., 1919; M.R.C.; Saline Co.; State; A.M.A.; Phi Chi; American Legion.

Kirk, Esley Jos.; Omaha; Gen. Prac.; b 1898; Uni. of Nebr., 1926; Douglas Co. 


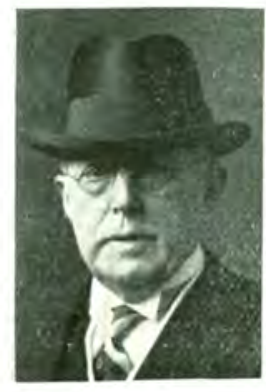

J. W, KING

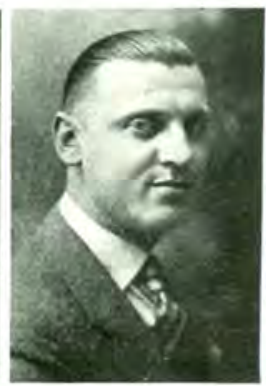

R. C. KIRCHMAN

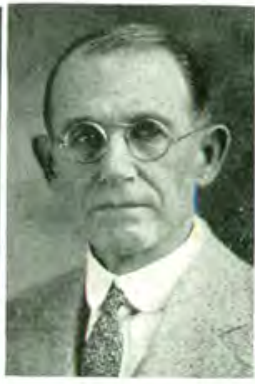

H. I. KINDRED

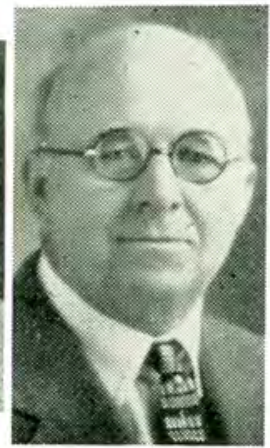

H, E, KING

Kirkpatrick, Chas, F.; Ashland; Pediat.; b 1858; Columbus Med. Col., 1882; Saunders Co.

Kirkpatrick, Milton Elder; Fullerton; Gen. Prac.; b 1894; Uni. of Nebr., 1920; Nance Co.

Kirckwood, Mary J.; Lincoln; Gen. Prac,; b 1894; Lincoln Med. Col., 1916; Lancaster Co.

Kleyla, John Raymond; Omaha; Internal Med.; Creighton Med. Col.; staff, Creighton Uni., St. Joseph's, St. Catherine's and Douglas Co. Hosp.; supervisor, Creighton Med. Disp.; M.C., air service.

Knode, A. R.; Omaha; Ear, Nose, Throat; Uni. of Nebr.; asst. prof., dept. oto-laryngology, Uni. of Nebr. Med. Col.; staff, Wise, Immanuel and Uni. Hosp.; Co.; State; A.M.A.

Knowles, Chas Erastus; Franklin; Gen. Prac.; b 1808; Creighton Uni., 1024; Franklin Co.; A.M.A.

Knox, Walter Eugene; McCcok; Gen. Prac.; b 1884; Tulane Uni. of La., 1909 ; Rcd Willow Co.;

Kcch, Lewis Alfred; Omaha; Gea. Prac.; b 1000; Uni. of Nebr., 1926; Douglas Co,

Kocbbe, Ezra Edwin; Columbus; Eye, Ear. Nose, Throat; Uni. of Mich.: U.S.N., 1916-1922.

Kocfoot, Theodore Henry; Broken Bow; Gen. Prac.; b 1890; Chicago Col. of Med. and Surg.; Custer Co.; A.M.A.

Koenig, Margaret Wilhelmina; Waterloo; Public Health, Social Worker; Creighton Med. Col.; Omaha 7 years; Lincoln Sanitary Dept., 6 months; Child Welfare Bureau, Lincoln; U. S. Children's Bureau, Washington, D.C., 14 months; Ark. State Board of Health, 1924-1927; assisted state dept. Wyoming and So. Dakota in maternity and infancy program; Lancaster Co.; State; A.M.A.; Am. Pub. Health Assn.; Waterloo Woman's Club; research for Ccld Harber Eugenical Assn.

Kohn, Krank; Beaver City; Gen. Prac.; b 1891; Uni. of Nebr., 1923; Furnas Co. 


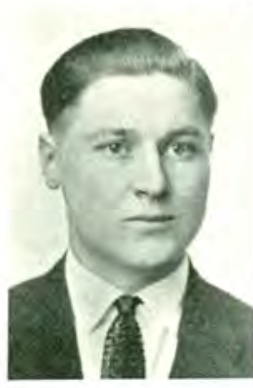

o. A. KOSTAL

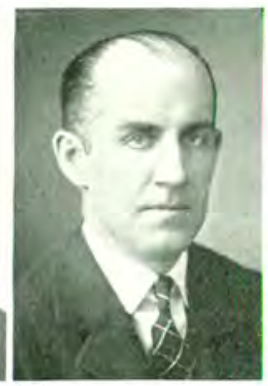

J. R. KLEYLA

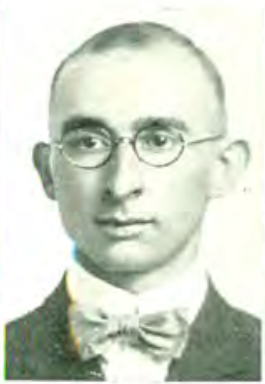

C. B. KOORY

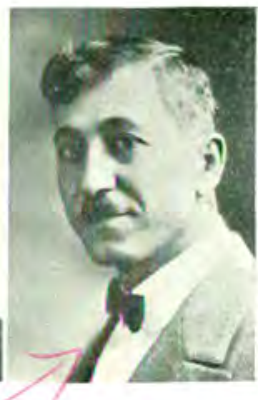

F. L. KRAMPART

Koory, Chickrey B.; Schuyler; Gen. Prac.; Creighton Med. Col.; Colfax Co.; State; A.M.A.

Koser, Martin Luther; Nebraska City; Gen. Prac.; b 1876; Jefferson Med. Col. of Philadelphia, 1903; Otoe Co.

Kostal, Otto Albin; Giltner; Gen. Prac.; Uni, of Nebr.; stafi, Ancon Hosp., Canal Zone, Panama; Mary Lanning Memorial Hosp; village board.

Koltar, Frank John; West Point; Gen. Prac.; b 1884; Uni. of Nebr., 1914; Cuming Co.

Koutsky, James Wm.; Omaha; Gen. Prac.; b 1896; Creighton Uni., 1921; Douglas Co.

Koutsky, John W.; Omaha; Surg.; b 1873; Creighton Uni., 1904; Douglas Co.; A.M.A.

Krampart, Frank L.; Imperial; Gen. Prac.; Uni. of Nebr., 1921; 1st Lt. M.R.; Local; Nebr. St.; A. M. A.

Krieg, Frank W.; Lincoln; Gen. Prac.; b 1867; Ensworth Med. Col., 1893; Lancaster Co.

Kriz, Rudolph Edmund; Lynch; Surg.; b 1892; Uni. of Nebr., 1917; Boyd Co.

Kroehler, Robt. A.; Omaha; Gen. Prac.; b 1900; Uni. of Nebr., 1925; Douglas Co.

Kruse, Fredk. W.; Weeping Water; Gen. Prac.; b 1863; Uni. of Nebr., 1902; Cass Co.

Kucera, Frank H.; Verdigre; Gen. Prac.; b 1879; Creighton -Uni., 1904; Knox Co.

Kueffer, Fred. Milton; Culbertson; Gen. Prac.; b 1876; Hom. Med. Col. of Mo., 1905; Hitchcock Co.

Kuhlman, Fred. Wm.; Omaha; Gen. Prac.; b 1892; Uni. of Nebr., 1925; Douglas Co.

Kully, Barney Maurice; Omaha; Oto-Laryng.; Creighton; post-grad., New York City; Vienna; asst. prof. of oto-laryng., Creighton Med. Col.; World War service; Co.; State; A.M.A.; Am. Acad. Oto-laryng.; Professional Men's Club. 


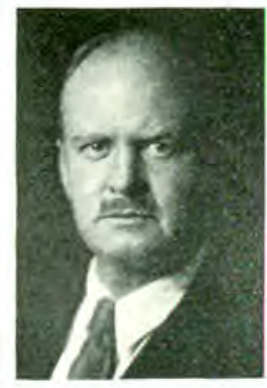

C. R. LAIRD

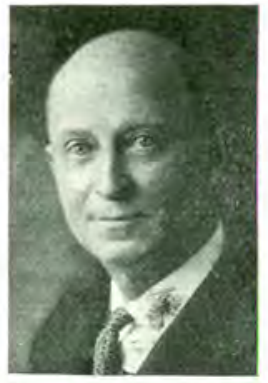

C. D. LANGRALL

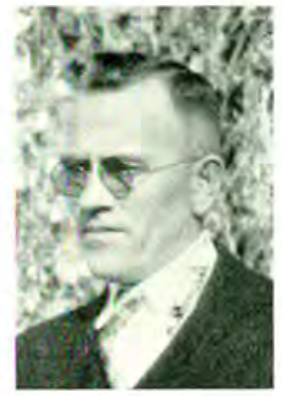

A. A. LARSEN

Laird, Ciaude Ross; Blue Hill; Gen. Prac.; b 1881; Creighton Uni., 1913; Webster Co.;

Lake, Liliburn Baker; Omaha; Gen. Prac,; b 1884; Uni. of Nebr., 1917; Douglas Co.

Lamb, Willie Edgar; Sprague; Gen. Prac.; b 18s1; Nebr. Uni., 1908; Lancaster Co.

Lambley, George W.; Ainsworth, since 1885; Gen. Prac.; Col. of Phys. and Surg., Keokuk, Iowa, M.D., 1883.

Landgraf, Ernest William; Omaha; Gen. Prac.; Creighton Med. Col., adj. surg., St. Joseph's Hosp.; World War service; Co.; State; A.M.A.

Landis, Henry Bruce; Broken Bow; Gen. Prac.; Central Med. Col, St. Joseph; M.C., World War; Co.; State; A.M.A.; Rotary.

Lang, Oscar Fredk.; Falls City; Surg.; b 1880; Northwestern Uni., 1909; Richardson Co.; A.M.A.

Langdon, J. Frederick; Omaha; Surg.; Creighton Med. Col.; assoc. prof., surg., Creighton; assoc. surg., St. Jcseph's and Douglas Co. Hosp.; staff, St. Catherine's Hosp.; Co.; State; A.M.A.; Am. Col Surg.; Ch. of Commerce, Athletic Club; papers in medical journals.

Langfield, Millard; Omaha; Bacteriolo., Chem.; Johns Hopkins Med. Sch.; supt. of laboratories, Cudahy Packing Co.; city bacteriologist; formerly prof. of bact. and clin. med., Creighton.

Langrall, Claude D. D. M. M. S.; Arcadia; Ensworth Med. Col.; Co.; State; A.M.A.; Mo. Valley Med. Assn.; Nebr. Acad. of Sci.; Am. Assn. for Adv. of Sci.

Langstaffe, George (deceased); formerly of Blair; Toronto Uni.; Col, of Phys, and Surg., Ontario, 1877; practiced near Toronto 23 years, Blair 27 years.

Lahphier, Bernard Anthony; Omaha; Gen. Prac.; b 1883; Creighton Uni., 1908; Douglas Co.

Lansing, Levinus A.; Wakefield; Gen. Prac.; Uni. of Buffalo, 1897; Dixon Co. 


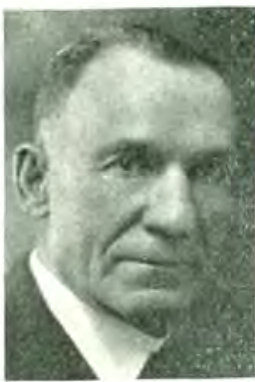

D. R. LEE

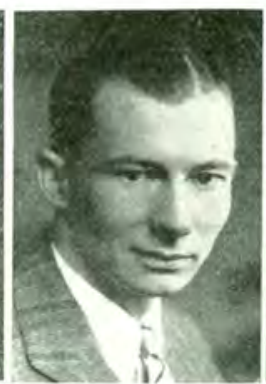

R. M, LEE

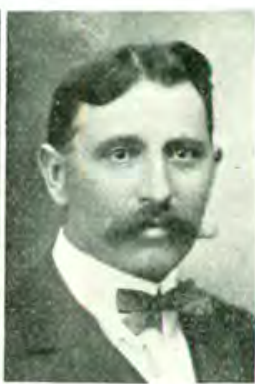

C. I. I.E MAR

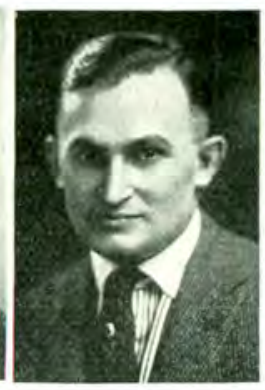

P. LE: EY

Larsen, Antonicus Andrew; Gurlcy; Gen. Prac.; b 1891; Uni. cf Nebr., 1018; Cheyenne Co.

Lathrep, Masen Ernest; Omaha; Gen. Prac.; b 1899; Uni. of Nebr., 1925; staff, County Hospital; Douglas Co.

Latta, James Oscar; Clay Center; Gen. Prac,; Lincoln Med. Col., Cotner Uni., Lincoln; Clay Co. insanity com.; Co. Phys.; past pres., Clay Co. Med. Soc.; State; A.M.A.

Latta, Elbert Johnston; Hastings: Internal Med. and Physictherapy; b 1870; Lincoln Med. Col.. 1894; post-grad., Chicago, Los Angeles; Adams Co.; State; A.M.A.; Kiwanis.

Lau Bach, Herbert George; Mitchell; Chronic Dis., Obstet.; Lincoln Med. Col., Uni. of Nebr.; U.S.P.H.S.V.D. Clinic, Hot Springs, Ark.; staff, Methodist Hosp., Scottsbluff.

Laughlin, Joseph Wilson; Elm Creak; Gen. Prac,; Uni. of Nebr. Med. Col.; pres., Buffalo Co. Med. Scc., 1926; S.gma Xi.

Lauvetz, Jos. F.; Wahoo; Gen. Prac.; Creighton Uni., 1905; Saunders Co.

Lawson, Thos. James; Ainsworth; Gen. Prac.; b 1866; Uni. of Nebr., 1896; Brown Co.

Laybourne, Ethel Mae; Lincoln; G.n Prac.; b 1884; Uni. cf Ill., 1910; Lancaster Co.

Lear, William Dale; Springview; G.n. Prac.; Uni. of Nẻr., B.Sc., M.D.; M.R.; Pres., Northwest. Nebr. Med. Assn.; Phi Rho Sigma.

Leary, Wm. Joseph; Omaha; Gen. Prac.; b 1880; Creighton Uni., 1905; Douglas Co.

Lee Amsbury; Pickrell; Gen. Prac ; b 1886; Crighton Uni., 1910; Gaze Co.

Lee, Daniel R.; Arcadia; Gen. Prac.; Uni. of Iowa; past-grad., Chicago; Co.; State; A.M.A.

Lee, Linford H.; Seward; Gen. Prac.; Uni. of Nebr. Med. Col.; World War; Co.; State; A.M.A.; Phi Rho Sigma; Am. Legion; Rotary Club. 
Lee, Robert M.; Ravenna; Gen. Prac.; Uni. of Nebr., M.D., 1924; Intern, Western Penn. Hosp., Pittsburgh; City Health Dept.; Buffalo Co.; State; A. M.A.; Phi Beta Pi; Community Club.

Leedom, Henry Flemin; Kearney; Gen. Prac,; b 1868; Ensworth Med. Col., 1893; Buffalo Co.; A.M.A..

Legg, Chas. Edwin; South Sioux City; Gen. Prac.; b 1874; Kansas City Hahneman Med. Col., 1904; Dakota Co.

Lehnhoff, Henry John; Lincoln; Internal Med.; Northwestern Med. Col., Chicago; Councillor from 2nd Dist.; State pres., 1927; Lancaster Co.; State; A.M.A.; Mo. Valley Med. Assn.; Ch. of Commerce; library board.

Leibee, John Ray; Beatrice; Gen. Prac.; b 1888; Creighton Uni., 1916; Gage Co.; A.M.A.

Leininger, Earl F.; McCook; Obstet. and Surg.; Uni. of Nebr., B.Sc., 1921, M.D., 1923; Phi Ci.

LeMar, Clair Leone; Osceola; Gen. Prac.; Uni. of Nebr.; Polk Co.; State; A.M.A.; Community Club.

Lemar, Fred Allard; Humphrey; Gen. Prac,; b 1874; Uni. of Nebr., 1902; Platte Co.

Lemere, Henry Bassett; Omaha; Eye, Ear, Nose, Throat; Uni. of Nebr, 1888; New York Eye and Ear Infirmary; prof. of Oto-Laryng., Uni. of Nebr.; Capt, A.E.F.; Co.; State; A.M.A.; F.A.C.S.; Acad. Ophthal, and OtoLaryng.; University Club.

Lennox, Geo. Banks; Omaha; Gen. Prac.; b 1889; Meharry Med. Col., 1918; Douglas Co.; A.M.A.

Levey, Phillip; Omaha; Medicine and Surg.; Yale; Creighton Uni.; Uni. of Vienna; staff, Nicholas Senn and Douglas Co. Hosp.; Co.; Mo. Valley Med. Assn; State; A.M.A.

Levine, Victor Emanuel; Omaha; prof., Biolog. Chem., Nutrition, Creighton Uni.; Col. of Phys. and Surg.; Columbia Uni.; Fordham Uni.; Beth Israel Hosp., N. Y. C., 1914-1916; Creighton Uni.; Am. Assn for Adv. ef Sci.; Royal Soc. Arts and Sci. (G. B.;) Am. Inst. Chem.; N. Y. Acad. of Sci.; Am. Geograph Soc.; Brit. Inst. Phil. Studies; Soc. for Exp. Biol. and Med.; 1924 pres., Am. Chem. Sec.; Nebr. Acad. Sci.; Am. P. H. Assn.; Am. Bact. Soc,; Hosp.; Diet Council; See chapter on Achievements.

Lewis, Alfred; Valentine; Gynecol; b 1858; Kansas City Med. Col., 1881; Cherry Co.; A.M.A.

Lewis, Geo. Evrie; Lincoln; Gen. Prac.; b 1807; Uni. of Nebr., 1925; Lancaster Co.

Lewis, Nelson Hiram; Benkleman; Gen. Prac.; Marquette Uni.; Uni, of Wisc.; Dundy Co.; State.

Lightenwallner, John B.; Omaha; Gen. Prac, (retired); Uni. of Penn.

Licber, Chas.; Sidney; Surg.; b 188:; Uni. of Nebr., 1908; Cheyenne Co.; A.M.A. 


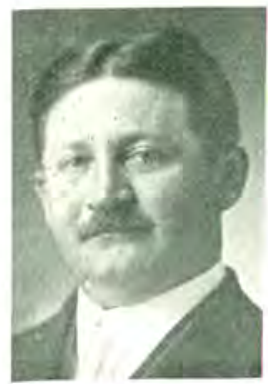

W. H. LOECHNER

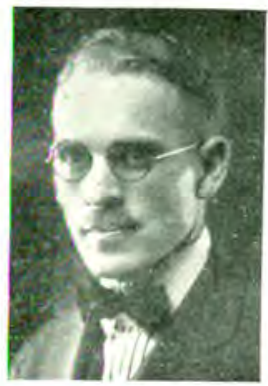

RALPH LUIKART

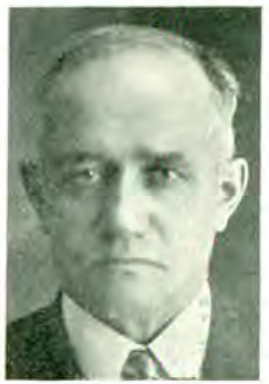

N. H. LEWIS

Lightner. Theodore; Hastings; Gen. Prac.; b 1856; Col. of Phys. and Surg., Baltimore, 1880; Adams Co.

Limburg, J. Irwin; Spencer; Surg.; Keokuk Med. Col.; Col. of Phys. and Surg.; World War, air service; Co. State.

Lindquest. Adolph Bernard: Omaha; Eye, Ear, Nose, Throat; Major, M.C., World War; staff, Immanuel Hosp.; Co.; State; A.M.A.; University Club; Ch. of Ccmmerce.

Line, Themas H.; Central City; Gen. Prac.; Uni, of Mich.; R'ush Med. Col., 1881; U, S. Pension Board; city and county physician; Co.; State; A.M. A; papers on public health; also History of A.F. and A. M.

Linquist, Arthur Lawrence; Omaha; Gen. Prac.; b 1882; Bennett Med. Col., 1006; Douglas Co.; A.M.A.

Liston. Oscar Earl; Elmwood; Gen. Prac.; b 1883; Uni, of Med. Col of Kansas City, 1910; Cass Co.; A.M.A.

Loechner, William Henry; Omaha (Benson); Gen. Prac.; Uni. of Nebr., 1901 ; pest-grad., Heidelberg, Vienna, Lcndon.

Logan, Johanna Elsie; Central City; Gen. Prac,; b 1859; Lincoln Med. Col., 1904; Merrick Co.

Lonergan, Paul Basil; Bloomfield; Gen. Prac.; Uni. of Maryland; World War service; Cedar-Dixen-Thursten-Dakota-Wayne Co.; State; A.M.A. Phi Beta $\mathrm{Pi}$.

Long, Francis A.; Madison; Gen. Prac.; Iowa Uni. Med. Sch.; pres., State Med Assn., 1906; founder and editor, Nebr. State Med. Journal since 1920; Madison Co.; State; A.M.A.; A.C.S.; Mo. Valley Med. Assn.; Elkhorn Valley Med. Soc.; various community clubs; numerous medical articles and editerials; see chapter on Publications.

Leng, Rachel A. Watkins; Holdrege; Neurol., Psychiat.; b 1870; Uni. of III., 1906; Phelps Co.

Longacre, Chester Horton; Lincoln; Gen. Prac.; b 1883; Uni. of Louisville, 1908; Cass Co. 
Longacre, Otto Earle; Rising City; b 1879; Baltimore Med. Col., 1906; Butler Co.

Loomis, John Julius; Lincoln; Gen. Prac.; b 1893; Loyola Uni., 1922; Lancaster Co.

Lorance, Benjamin F.; Auburn; Gen. Prac.; Uni. of Iowa Med. Col., 1887; post-grad. study, Polyclinic, Chicago; past pres., Nemaha Co. Med. Soc.: U. S. Pension Board, 1898-1927; Auburn board of education, 1908-1928; pres., Nebr. Assn. Sch. Bds, and Execut., 1927-1928; Nemaha Co.; State; A.M.A.

Lord, John Prentiss; Omaha; Gen. Prac.; Rush, 1882; New York PostGrad. Col., 1886; prof., Creighton Med. Col., 1893-1913; prof., orthopedic surg., Uni. of Nebr. Med. Col. since 1913; staff, Clarkson and Uni. Hosp.; ex-chief surg., Nebr. Orthopedic Hosp.; staff, Convalescent Home for Crippled Children; I. C. and C. R. I. and P. Rys.; Major, M.C.; F.A.C.S.; A.M.A.; State (pres. 1911); West. Surg Assn (pres 1910); Mo Valley Med. Assn. (pres. 1915-1916;) Omaha Med. Soc (pres. 1900); Am. Orthop. Assn.; Southwest. Iowa Med. Assn.; Elkhorn Valley Med. Assn.; Sioux City Med. Assn. (pres. 1921-1922); Rochester Clinic and Surgeons' Club; Los Angeles Orthop. Club (hon.); Am. Assn. Railway Surgeons; Natl. Assn for Study and Prevention of Tuberculosis; Omaha Surgeons' Club; Direct., Y. M. C. A.; Commercial, Rotary Clubs; many papers read before surg. and med. societies and published.

Love, Wm. S.; Wilber; Gen. Prac.; b 1850; Saline Co.

Lovell, Arthur Irving; College View; Gen. Prac.; Chicago Col. of Med. and Surg.; supt., Sanitarium, Graysville, Tenn., 4 years; staff, Madison, Wis, 4 years; health officer College View 8 years.

Lovely, Frank Thos.; Omaha; Gen. Prac.; b 1894; Creighton Uni., 1919; Douglas Co.

Lucas, Chas.; Shelton; Gen. Prac.; b. 1866 Georgetown Uni., 1803; Buffalo Co.

Lucic, Lucas Hugo; Omaha; Gen. Prac.; b 1901; Uni. of Nebr., 1926; Douglas Co.

Lucke, Robt. S.; Omaha; Gen. Prac.; b 1863; Rush Med. Col., 1884; Douglas Co.

Lueschen, Alvin G.; Columbus; Ophthal., Otol., Laryng., Rhin,; b 1880; Creighton Uni., 1904; Platte Co.

Luhman, Fredk. Walter; Pender; Ophthal,; b 1879; Rush Med. Col., 1902; Thurston Co.; A.M.A.

Luikart, Ralph; Omaha; Female Surg., Obstet.; Uni. of Nebr.; Uni. of Penn., M.D.; intern, Mass. Gen. Hosp. and Bellevue Hosp., N. Y.; supt., Creighton Med. Disp., 1918-1919; asst. prof., obstetrics, Creighton, to 1926; staff, Clarkson and Immanuel Hosp.; Capt., Serbian Red Cross, 1915; Co.; Omaha Clinical Club; State; A.M.A.; Am. Col. of Surg; Mo. Valley Med. Assn; Nu Sigma Nu; chmn., Goodfellowship Com., Ch. of Commerce; original article, Use of Luminal for Vomiting in Pregnancy, Am. J. Obstet.; Pyelitis Complicating Pregnancy, Nebr. State. Med. J.; General Advice to the Expectant Mother. 
Lukens, Issaiah; Tekamah ;Gen. Prac.; Jefferson Med. Col., Philadelphia; to Tekamah from Herman in 1897; mayor, city and co. health officer; vicepresident of state med assn., chairman, Burt County Red Cross During war: June, 1928.

Lurvey, Homer David; Omaha; Gen. Prac.; b 1883; Creighton Uni., 1912; Douglas Co. Clay Co.

Lusk, Wm. Albert; Trumbull; Gen. Prac.; b 1870; Uni. of Nebr., 1892;

Lutgen, Clifford A.; Auburn; Surg.; Lincoln Med. Col.; post-grad., Chicago, New York; Surg., Auburn Hosp.; Nemaha Co.; State; A.M.A.; Kiwanis.

Lutgen, Sidney Anson; Wayne; Surg.; Cotner Med. Col.; post-grad. study in surg., nose and throat in Chicago; owner, Wayne Hosp. and radio station; Northwestern Ky. Surg.; Tri. Co.; State; A.M.A.; Kiwanis.

Lutton, John Dudley; Laurel; Gen. Prac.; b 1870; Uni. of Nebr., 1924; Cedar Co.

Luxford, William James; Decatur; Gen. Prac.; Creighton Med. Col., 1909.

Lyman, Christine Elizabeth; Omaha; Gen. Prac,; b 1869; Creighton Uni., 1903 ; Douglas Co.

Lyman, Rufus Ashley; Lincoln; Pharmacist, Public Health; Uni. of Nebr., A.B., 1897; A.M., 1899; M.D., 1903; dean, Col. of Pharmacy and head of dept. of Student Health, Uni. of Nebr.; Lancaster Co.; State; A.M.A.; Nebr. Pharmaceutical; Am. Pharmaceutical Assn.; Am. Assn. Adv. of Sci.; papers on pharmaceutical education.

Lynch, Albert; Fairbury; Surg.; b 1860; Uni. of Mich. Med. Sch., 1901; Jefferson Co.

Lynch, Delia A.; Creighton Med. Col., M.D., 1909; examiner, Women's Benefit Assn. of Maccabees and Foresters; Omaha-Douglas Co.; State; A. M.A.; Omaha and State Med. Women's Assn.

Lynch, Edward Clarence; Litchfield; Gen. Prac.; b 1884; Creghton Uni., 1906; Sherman Co.

Lynch, Geo. Murray; Fairbury; Gen. Prac,; b 1884; Creighton Uní., 1924 ; Jefferson Co.

McAlcer, Elmer Cornelius; Omaha; Gen. Prac.; b 1899; Creighton Uni., 1925; Douglas Co.

MeArdle, Gecrge M.; Salem; Gen. Prac.; Creighton Med. Col.; staff, Douglas Co. Hosp., 1918-1019; Richardson Co. (vice-pres.); State; A.M.A.

Mc Arthur. Andrew J.; Broken Bcw; Gen. Prac.; b 1862; Missouri Med. Col., 1891 ; Custer Co.

McAvin, James S.; Omaha; Gen. Prac.; b 1889; Creighton Uni,, 1913; Douglas Co.

McCabe, Eugene Alphonsus; Ponca; Gen. Prac.; b 1896; Creighton Uni., 1920; Dixon Co.

McCarthy, Jos. Danl.; Elgin; b 1893; St. Louis Uni., 1916; Antelope Co.; A.M.A. 


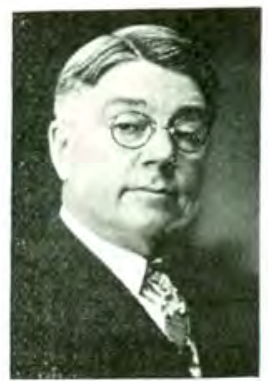

F. W. MC CAW

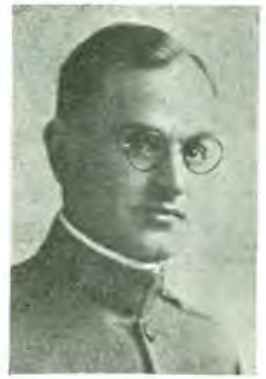

H. W, MC FADDEN

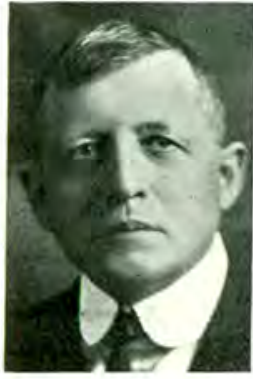

E. MC KINNEY

McCarthy, Timothy Francis; Lincoln; Gen. Prac.; b 1880; Creighton Uni., 1910; Lancaster Co.

McCaw, Fred. Warren; Colon; Gen. Prac.; Creighton Med. Col., M.D.; Saunders County; State; A.M.A.

McChesney, M Josephine; Osceola; Gen. Prac.; b 1856; State Uni. of Iowa, 1888; Polk Co.

McClanahan, Harry Monroe; Omaha, since 1889; Pediat.; Monmouth (ill.) Col., 1872-1875; Jefferson Med. Col., M.D.. 1878; post-grad., Vienna, London, Chicago, New York; prof., pediat Omaha Med. Col. since 1892; now Emeritus prof., dis. of children. Uni. of Nebr.; Douglas Co. (ex-pres.); State (pres. 1900-1902); A.M.A.; Am. Pediatric Soc.; Am. Soc. of Study and Prevention of Infant Mortality; Am. Teacher of Dis of Child. (pres. 1914-1915); A. C. P., Athletics and Kiwanis Clubs; contributes to many medical journals on pediat.

McClelland, Elmer E. E.: Alliance; Gen. Prac.; b 1861; Drake Uni., 1887; Box Butte Co.

McClelland, Elmer Edward Ellsworth, Jr.; Alliance; Gen. Prac.; b 1902; Uni. of Nebr., 1926; Box Butte Co.

McCleneghan, Saml.; Omaha; Obstet.; b 1880; Creighton Uni., 1907; Douglas Co.; A.M.A.

McCoy, John H.; Alliance; Gen. Prac.; Rush Med. Col., 1902; staff, St. Joseph's Hosp., Alliance; Mo. Natl. Guard; Box Butte Co.; State; A.M.A.

McCrann, Wm. Jos.; Omaha; Gen. Prac.; b 1855; Louisville Med. Col., 1883 ; Douglas Co.

McCrann, Wm. J. Jr.; Omaha; Gen. Prac.; Uni. of Louisville Med. Col.; intern, City Hosp., Louisville, 1912-1913; M. C., World War; Am. Legion.

McRea, Edward Lee; Table Reçk; Gen. Prac.; Uni. Med. Col., Kansas City, Mo., 1900; Co,; State; A.M.A.

McDermott, Bernard Aloysius; Omaha; Gen. Prac.; b 1879; Northwestern Uni., 1903; Douglas Co.

McDonald, Hugh Allan; North Platte; Gen. Prac.; b 1891; Temple Uni., 1920; Lincoln Co. 


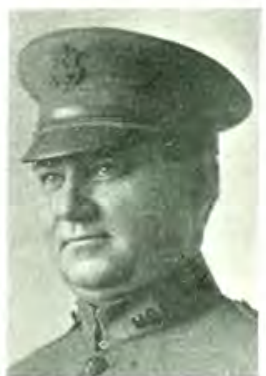

F. J. MC RAE

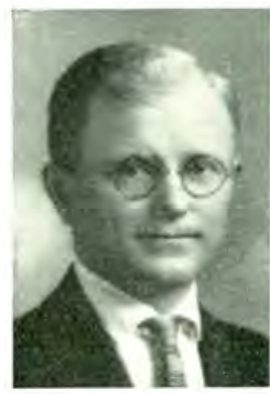

K. C. M'GREW

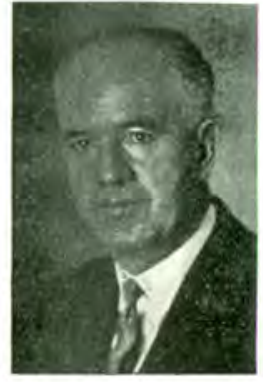

J. L. MAGILL.

McDowell, Milton Berlin; Chadron; Diag. and Gen. Prac.; Uni. of Nebr,; city phys.; Chadron Med, Soc,; Ch. of Commerce, Rotary.

McEuen, Oliver; Hemingford; Gen. Prac.; b 1866; St. Louis Col. of Phys, and Surg., 1889; Box Butte Co.

McFadden, Harry Weber; Greenwood; Gen. Prac.; Lincoln Med. Col., Cotner Uni., 1909; Capt., M.C., A.E.F.; ex-commander, American Legion; village council and school board; Cass Co.; State; A.M.A.

McGee, Harry Edwin; Omaha; Gen. Prac.; b 1895; Uni. of Nebr., 1919; Douglas Co,; A.M.A.

McGee, John Wm.; Omaha; Gen. Prac.; b 1901; Uni. of Nebr., 1925; Douglas Co.

McGirr, John I.; Beatrice; Ophthal.; b 1873; Uni. of Nebr., 1897; Gage Co.; A.M.A.

McGowan, Patrick Henry; Schuyler; Gen. Prac.; Creighton Med. Col.; vice-pres., Colfax Co. Med. Soc.; city and county phys.; M.C., World War; Colfax Co.; State; A.M.A.

McGrath, Benjamin R.; Grand Island; Surg.; Uni. of Illineis; M.C., A.E. F.; pres., Nebr. State Med. Assn., 1928; Hall Co.; State; A.M.A.; F.A.C.S.

McGrath, Wilmer D.; Grand Island; Internal Med.; Uni. of Nebr.; Rush Med. Col., M.D.; M.C., A.E.F.; Hall Co.; State; A.M.A.

McGraw, Harriet Goodman Kurtz; Tryen; Gen. Prac.; Bennett Med. Col., Chicago; County health officer; Lincoln Co.; State; A.M.A.; see chapter on Women Physicians.

McGraw, Fredk. A.; Deshler; Gen. Prac,; b 1866; Rush Med. Col., 1893; Thayer Co.; A.M.A.

McGrew, Kirby Clayton; Omaha; Gen. Prac.; b 1892; Uni. of Nebr., 1926; Douglas Co.

McGrew, K. C.; Ord; Gen. Prac.; Nebr. Wesleyan Uni., A.B., 1918; Uni. of Nebr. Med. Col., M.D., 1926; Intern, Swedish Mission Emmanuel Hosp., Omaha; post-grad. in diag. and surg., Grand Island Clin.; Phi Beta Pi.

McGrew, Wm. Raymond; Omaha; Gen. Prac.; b 1875; Keokuk Med. Col., 1903; Douglas Co. 
McGuire, Edward Thomas; Mead; Gen. Prac.; Lincoln Med. Col., M.D.; St. Louis and Chicago post-grad. clinics; pres., Nebr. State Eclectic Med. Assn.; pres., State Board of Med. Examination and Registration since 1919; State and Natl. Eclectic Assn.

McGuire, Louis David; Omaha; Surg.; b 1893; Creighton Uni., 1917; Douglas Co.

McIntyre, Backus M.; Winside; Gen. Prac.; Creighton Med. Col.; medical advisory board.

McIntyre, Wm.; Bethany; Gen. Prac.; Drake Uni., 1887; Lancaster Co.

McKee, Neal Patrick; Atkinson; Gen. Prac.; b 1890; Creighton Uni., 1914; Holt Co.

McKhann, Geo. Grassel; Lincoln; Gen. Prac.; b 1895; Uni. of Cincinnati, 1920; Lancaster Co.

McKinley, Jerome A.; York; Gen. Prac., Surg.; Uni. of Louisville, Ky.; county health board and U. S. Pension Examiner; Co.; State; A.M.A.

McKinney, Edward; Nebraska City; Gen. Prac.; Cleveland Ohio, Homeopathic and Dunham-Hering, Chicago; M.C., World War.

McKnight, Harnon P.; Virginia; Gen. Prac.; Omaha Med. Col.; Uni. of Missouri Med. Col.; Uni. of Iowa; surgeon, Northwestern Ry. 24 years; U. S Pension Board; regular army 5 years; Co.; State; A.M.A.

McLean, Robt. F.; Gibbon; Gen. Prac.; b 1883 ; Uni. of West. Ont., London, 1906 ; Buffalo Co.; A.M.A.

McLeay, Hugh Lawrence; Omaha; Roentgenol., Physiotherap.; Western Uni., Canada; Capt,, Canadian M.C. in World War.

McMahon, Charles Gilbert; Superior; Surg.; Uni. of Minn.; Co.; State; A.M.A.; F.A.C.S.; Kiwanis; articles on surgery in medical journals.

McMahon, Emmett; Omaha; Gen. Prac,; b 1892; Creighton Uni., 1920; Douglas Co.

McMartin, Charles; Omaha; Urol., Dermatol.; Grinell Col., Ph.B., 1902; Rush Med. Col., M.D., 1906; prof. of urology and dermatology, Creighton Med. Col.; Douglas Co.; State; A.M.A.; Uni., Athletic, Cr. of Commerce.

McMeekin, Hugh Ralston; Shelby; Gen. Prac; b 1900; Uni. of Nebr., 1925; Polk Co.

McMillan, Aaron Manasses; Omaha; Gen. Prac.; b 1805; Meharry Med. Col., 1923; Douglas Co.

McMillan, Gilbert A.; Elgin; Gen. Prac.; McGill Med. Col., Montreal, Can.

McNalley, James M.; Bellwood; Gen. Prac.; b 1885; Creighton Uni., 1912; Butler Co.

McNamara, Raymond B.; Crofton; Gen. Prac.; b 1889; Creighton Uni., 1915; Knox Co.

McNulty, Jos. Frank; Taylor; Gen. Prac.; b 1866; Uni. of Ill., 1893; Loup Co.; A.M.A. 


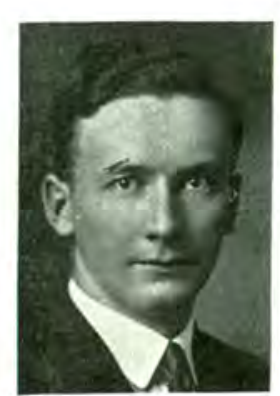

A. E. MAIL.LIARD

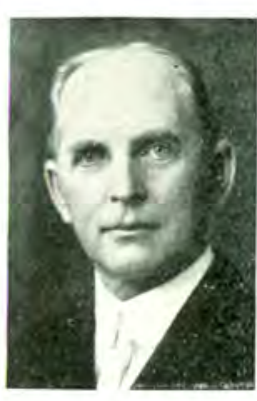

I. C. MALSTER

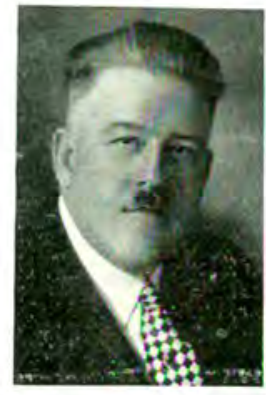

S. B. MACDIARMID

McPherson, Joseph Burns; Hastings; Eye, Ear, Nose, Throat; Creighton Med. Col.; Royal London Ophthalmic Hosp., London; Uni. of Vienna; Central London Throat and Ear Hosp., London; M.C., World War; Adams Co.; State; A.M.A.; Republican Valley Med. Assn.; Lions; Chamber of Commerce; Y. M. C.A.; Am. Legion.

McRae, Finlay J.; Albion; Gen. Prac.; Western Uni., London, Ontario, Canada, 1902; Capt., M. C., 1918-1919; Co.; State; Kiwanis.

McReynolds, Claude E.; Jansen; Gen. Prac,; b 1874; St. Louis Col. of Phys. and Surg., 1903; Jefferson Co.

MacVean, M. Martha; Nebraska City; Eye, Ear, Nose, Throat; Chicago; Philadelphia, Denver; health officer of city; juvenile officer of county; Cass Co.; State; A.M.A.

MacArthur, Hector J.; Omaha; Obstet., Gynecol.; b 1871; Uni. of Nebr., 1904 ; Douglas Co.

MacDiarmid, Stuart B.; Omaha; Gen. Prac; Creighton Med. Col,; Douglas Co.; State; A.M.A.; Mo. Valley Med. Assn.; Phi Rho Sigma; Ad Sell League and other civic organizations.

MacKinnon, Artemas I.; Lincoln; Surg.; b 1867; McGill Uni. Fac, of Med., Montreal, 1892; Lancaster Co.; A.M.A.

MacQuiddy, Ernest Lynn; Omaha; Gen. Prac ; b 1889; Uni. of Nebr., 1921 ; Douglas Co.; A.M.A.

Mace, John L.; Hastings; Gen. Prac.; Uni. of Tenn., Nashville, Tenn.; Co.; State; A.M.A.; Ch, of Commerce; Lions.

Mackechnie, Wm. D.; Indiancla; Gఃn. Prac.; b 1875; Uni. of West. Ontario Med. Sch., London, 1899; Red Willew Co.; A.M.A.

Margaret, Oswald Henry; Papillion; Gen. Prac.; Uni. of Nebr. Med. Col., 1900 ; Capt., M.C., 1918-1919.

Magill, J. L.; Holdrege; Gen. Prac.; Kansas City Uni. Med. Col.; New York Post-Grad. Sch.; secretary, Phelps Co. Med. Soc.; med. advisory board; Co.; State; A.M.A.; Republican Valley Med. Assn.; Rotary. 
Magill, Van Hooper; Curtis; Gen. Prac.; b 1898; Uni. of Kansas, 1924; Frontier Co.; A.M.A.

Magirl, R'obert F.; Jackson; Gen. Prac.; Creighton Med. Col., 1913; intern, St. Joseph's Hosp., Omaha.

Mahaffey, Andrew DeWitt; Valparaiso; Gen. Prac.; b 1865; Hahnemann Med. Col. of Kansas City., 1902; Saunders Co.

Maillard. Alfred Edward; Osmond; Gen. Prac.; Creighton Med. Col., B. Sc., M.D., 1925; 1st. Lieut., M.R.C.; Madison-Pierce-Stanton-Antelope Co.; State; A.M.A.; Phi Chi.

Main, Amos S.; Loup City; Keokuk Med. Col.

Malick, Uriah H.; Bloomington; Gen. Prac.; b 1851; College of Phys. and Surg., Keokuk, 1878; Franklin Co.

Malster, John Charles; Stromsburg; Gen. Prac.; Northwestern Pharmacy Col., Ph.G.; Jefferson Med. Col., Philadelphia, M.D.; state representative; chief examiner, Nebr. Mutual Life Assn., 10 years; past mayor and elected representative for Polk Co.. in 1926; U. P. and C. B. and Q. Ry., Surg.; Polk Co.; State; A.M.A

Manning, Ernest T.; Omaha; Pathol.; b 1877; Rush Med. Col., 1904; Douglas Co.; A.M.A.

Mantor, Harry L.; Sidney; Gen. Prac.; b 1881; Uni. of Nebr., 1909; Cheyenne Co.

Mantor, Hugh E.; Sidney; Surg.; b 1874; Uni. of Nebr., 1902; Cheyenne Co

Marble, Robert E.; Omaha; Ind. Surg.; Chicago, 1906; Creighton Uni.; Douglas Co.; State; A.M.A.

Mares. Anna M.; Omaha; Gen. Prac,; b 1869; Creighton Uni., 1903; Douglas Co.

Margolin, Morris; Omaha; Gen. Prac.; Uni. of Nebr.; Douglas Co.; A.M.A.

Marron, James G.; Brainard; Gen. Prac.; Bellevue Hosp. Med. Col., N. Y., 1887; Butler Co.

Marsteller, Arell LaFayette; Wilcox; Gen. Prac.; b 1882; Barnes Med. Col., 1906; Kearney Co.

Martin, James Wm.; Omaha; Gen. Prac.; b 1896; Creighton Uni, 1921; Douglas Co.; A.M.A.

Martin, Josiah Bonaparte; Plattsmouth; Gen. Prac. (deceased); Bennett Med. Col., Chicago; physician, State Masonic Home of Nebraska 20 years; Cass Co.; State.

Martin, Otis Wallace; Omaha; Gen. Prac.; Uni. of Nebr.; asst., clinical urology, Uni. of Nebr. Med. Col.; M.C., A.E.F.; Prognosis of Early Syphilis, Nebr. State Med. J., Dec., 1925.

Martin, Roy David; Hastings; Ophthal., Otolo., Laryng., Rhin.; b 1885; Uni. of Nebr., 1911; Adams Co.; A.M.A.

Martyn. David T., Sr.; Columbus; Gen. Prac.; b 1845; Northwestern Uni. Med. Sch., 1869; Platte Co. 
Martyn, David T., Jr.; Columbus; Gen. Prac.; b 1878; Creighton Uni., $1901 ;$ A.M.A.

Marvel, George H.; Lincoln; Internal Med.; Lincoln Med. Col,; Uni, of Ill; staff, Shoemaker Hospital, Lincoln; Hamilton Co.; State; A.M.A.

Marvel, Perry Otto; Giltner; Gen. Prac.; Lincoln Med. Col.; Eclectic Medical Soc; State; National.

Mason, Claude William; Omaha; Gen. Prac., Surg.; Uni. of Nebr., M.D., 1905 ; post-grad., London Sch. of Tropical Med., 1912; instr., Tropical Med., Uni. of Nebr. Med. Col.; Med. Miss., Presbyterian Church, 1906-1925, Siam, 1906-1913, China, 1917-1925; Omaha Bd. Education; Douglas Co.; State; A.M.A.

Matheny, Zellmond E.; Bellweed; Gen. Prac.; b 1873; Keokuk Med. Col., 1894; Butler Co.

Mathews, Alexander L.; Callaway, since 1886; Gen. Prac.; Eclectic Med. Institute, Cincinnati, 1882; lecturer on dermatology, Lincoln Med. Col., 18951897; Custer Co.; State.

Mathews, John T.; Omaha; Gen. Prac.; b 1853; Washington Uni., St. Louis, 1881; Douglas Co.

Matthai, Jacob Henry; Lincoln; Gen. Prac.; b 1889; Uni. of Md., 1916; Lancaster Co.

Mauer, Roy Thornell; Omaha; Surg,; b 1892; Uni. of Nebr., 1918; Douglas Co.

Maxey, Fred Wasco; Superior; Gen. Prac.; b 1876; Central Med. Col. of St. Joseph, 1905; Nuckolls Co,

Maxwell, Chas. H.; Dakota City; Gen. Prac.; b 1860; Rush Med.Col., 1883; Dakota Co.

Maxwell, James Taliaferro; Omaha; Ophthal., Otolo., Laryng., Rhin.; b 1882; Uni. of Nebr., 1912; Douglas Co.

Mayer, Charles F.; Burr; Gen. Prac., Surg.; Creighton Med. Col., 1904; Mayhew, John Mills; Lincoln; Gen. Prac.; b 1870; Uni. of Ill., 1895; Lancaster Co.

Medders, David A.; Omaha; Gen. Prac.; Uni. of Md., 1900; Douglas Co.

Medlar, Clyde A.; Verdon; Gen. Prac.; b 1879; Northwestern Uni., 1905 ; Richardson Co.

Meisenbach, Geo. W.; Plymouth; Gen. Prac.; b 1876; R'ush Med. Col., 1900; Jefferson Co.

Meisenbach, J. E.; Staplehurst; Gen. Prac.; Uni. of Nebr.; past pres., Seward Co. Med. Soc.; Co.; State; A.M.A.; Am. Col. of Physical Therapy.

Melcher, Wm. Henry; Omaha; Gen. Prac.; b 1893; Uni. of Nebr., 1920; Douglas Co.; A.M.A.

Melerian, Henry; Plainview; Gen. Prac.; b 1870; Rush Med. Col., 1896; Pierce Co.; A.M.A.

Mercer, Nelson S.; London, England, formerly of Omaha; Gen. Prac.; b 1874; Uni. of Nebr., 1898; Douglas Co. 


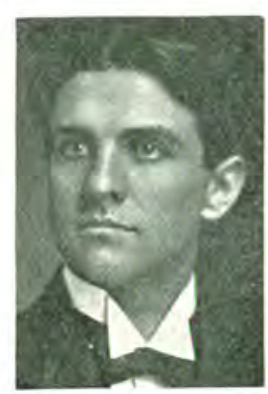

P. O. MARVEL

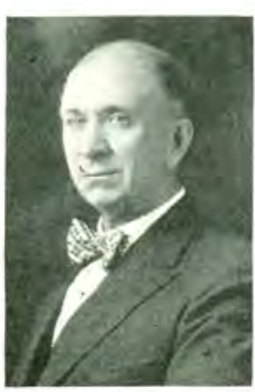

J. E. MEISENBACH

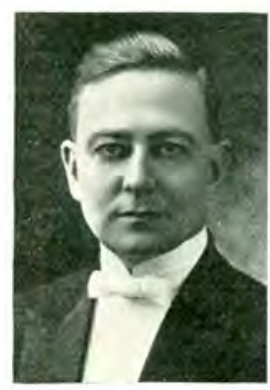

H. C. MILLER

Metheny, Fred Ray; Lincoln; Gen. Prac.; b 1887; St. Louis Col. of Phys. and Surg., 1919; Lancaster Co.

Methany, Saml.; Lincoln; Gen. Prac.; b 1864; Lincoln Med. Col., 1902; Lancaster.

Mettlen, James Harvey; Bloomfield; Gen. Prac.; b 1869; State Uni. of Ia., 1897; Knox Co.

Metzinger, J. J.; Fremont; Uni. of Iowa Med. Col., M.D., 1899; Dodge Co.; State.

Meyer, Julian Erdreich; Columbus; Gen. Prac.; b 1894; Jeferson Med. Col. of Philadelphia, 1917; Platte Co.; A.M.A.

Michalak, Jos. John; Omaha; Gynecol.; b 1895; St. Louis Uni., 1919; Douglas Co.

Miller, Arthur Lewis; Kimball; Surg.; b 1892; Loyola Uni., 1918; Kimball Co.; A.M.A.

Miller, Aura Jonas; Omaha; Gen. Prac.; b 1890; State Uni. of Ia., 1921; Douglas Co.

Miller, Bradford Walter; Omaha; Gen. Prac.; b 1902; Uni. of Nebr., 1926; Douglas Co.

Miller, Clinton James; Ord; Surg.; Uni. of Nebr. Med. Col., 1905; study in Chicago, Augustana Hosp., Wesley Hosp., 1916-1917; owner, Ord Hosp. since 1920; Valley Co.; State; A.M.A.

Miller, Ernest E.; David City; Gen. Prac.; b 1869; Creighton Uni., 1900; Butler Co.; A.M.A.

Miller, Glenn; Omaha; Surg.; Uni. of Nebr. Med. Col.; clin. asst. in surg., Uni. of Nebr. Med. Col.; surg. staff, Methodist Hosp. and Uni. Hosp.; Douglas Co.; State; A.M.A.; Field and Commercial Clubs.

Miller, Harold Baughman; Lincoln; Gen. Prac.; b 1861; Jefferson Med. Col., 1890; Lancaster Co.; A.M.A.

Miller, Harry C.; Omaha; Surg.; Creighton Med. Col.; Douglas Co.; State; A.M.A.; Am. Col. of Surg.; Mo. Valley Med. Assn.; Phi Beta Pi. 
Miller, James W.; Gibbon; Gen. Prac.; b 1859; Rush Med. Col., 1884; Buffalo Co.

Miller, Jay C.; Grisham; Gen. Prac.; b 1882; Lincoln Med. Col., 1915; York Co.

Miller, Jes. H.; Fremont; Gen. Prac.; b 1860; Uni. of Nebr., 1888; Dodge $\mathrm{Co}$,

Miller, Walter Chas.; Arapahoe; Gen. Prac.; b 1896; Uni. of Nebr., 1920; Furnas Co.

Mills, Bernard I.; Maywood; Gen. Prac.; b 1884; Lincoln Med. Col., 1908; Frontier Co.

Miner, Henry Rufus; Falls City; Chicago Hom. Col., 1894; pres., Schocl Board, 1911; pres., Nebr. State Hom. Soc.; delegate, 1908 to international tuberculosis congress.

Minnick, Clarence; Cambridge; Roentgenol.; b 1879; Northwestern Uni. Med. Sch., 1905; Furnas Cc.; A.M.A.

Minthorn, Martin Lloyd; Omaha; Gen. Prac.; b 1895; Rush Med. Col., 1921; Douglas Co.; A.M.A.

Misko, Geo. Harold; Lincoln; Gen. Prac.; b 1895; Northwestern Uni., 1920; Lancaster Co.

Mitchell, Edwin Jos.; Scottsbluff; Surg.; b 1880; Creighton Uni., 1913; Scotts Bluff Co.; A.M.A.

Mitchell, William Frank; Superior; Gen. Prac.; Ottawa Uni., Ottawa, Kansas., B.Sc., 1899 ; Uni. of Ill., Med. Dept., M.D., 1902; Co.; State; A.M.A.; Alpha Kappa Kappa.

Mnuk, Frank J.; Omaha; Gen. Prac.; b 1899; Uni. of Nebr., 1923; Douglas Co.

Mockett, Percy C.; Kimball; Gen. Prac.; b 1874; Denver Col. of Med., 1901; Kimball Co. A.M.A.

Moell, Jos. Franklin; Lincoln; Gen. Prac.; b 1878; Northwestern Uni., 1907; Lancaster Co.

Molseed, Clarence S.; Omaha; Surg.; b 1890; Creighton Uni., 1915; Douglas Co.

Molzahn, Albert J.; Hay Springs; Gen. Prac.; George Washington Uni.; M.C., World War; examiner, life insurance companies; Amer. Legion.

Molzahn, Edwrd T.; Omaha; Gen. Prac.; b 1877; Central Med. Col. of St. Louis, 1903; Douglas Co.

Montgomery, Asa Witter; Stella; Gen. Prac.; b 1872; Rush Med. Col., 1896; Richardson Co.;

Montgomery, W. P.; Hickman; Eye, Ear, Nose, Throat; Omaha Med. Col,; Chicago Eye, Ear, Nose and Throat Col.

Montgomery, Wm. P.; Pickrell; Gen. Prac.; b 1865; Uni. of Nebr., 1897; Gage Co.

Moody, Wilson Bridges; Omaha; Gen. Prac.; b 1892; Rush Med. Col 1919; Douglas Co.; A.M.A. 
Moon, Charles Franklin; Omaha; Obstet, and Gynecol.; Uni. of Nebr.; post-grad. in Halle a Saalle, Germany, Vienna, Freiburg, London, Dublin, Edinburgh, New York, Chicago; clinical asst. in obstet., Uni. of Nebr. Med. Col. and Hosp.; stafi, Clarkson and St. Catherine's Hosp.; Douglas Co.; State; A.M.A.; Clinical Club; Scoda Club.

Moon, Louis E.; Omaha; Proctol.; Uni. of Mich.

Moore, Cleland G.; Fremont; Surg.; Uni. of Maryland; staff, Richmond Hosp.; C. and N. W. Ry.; U. P. and C. B. and Q. Rys. mayor, Fremont, 1928; Lt., World War.; Dodge Co.; State; A.M.A.

Moore, Clyde Newton; Omaha; Gen. Prac.; b 1882; Lincoln Med. Col., 1911; Douglas Co..

Moore, Dudley A.; Winnebago; Gen. Prac.; b 1879; Sioux City Col. of Med., 1906; Thurston Co.

Moore, John Clyde; Omaha; Pediat.; Uni. of Nebr.; Asst. prof., pediat. Uni,. of Nebr. Med. Col.; Major, M.C.; Douglas Co.; State; A.M.A.; Nebr.Iowa Pediat. Soc.; Central States Pediat. Soc.; Alpha Omega Alpha; Phi Beta Kappa; Phi Rho Sigma; University Club.

Moore, Jes. C.; Omaha; Gen. Prac.; b 1851; St. Leuis Col, of Phys, and Surg., 1882; Douglas Co.

Moore, Milan Standish; Gothenburg; Gen. Prac.; Uni. of Nebr.; postgrad., Chicago; pres., Nebr. State Med. Assn., 1921; Mexican border, 1916, spent 2 years in World War A.E.F.; Dawson Co.; State; A.M.A.

Moore, Orville Milton; York; Surg. and Phys. Therap.; Bennett Med. Col., 1882; Grad. E. M. I., Cincinnati, 1883-4; post-grad., Pulte Med Col.; New York Post-Grad. Sch.; Chicago, Ill.; Western Physical Therapy Sch.; Am. Col. of Physical Therapy; senior member, York Clinic and Clinic Hosp.: past pres., Nebr. Eclectic Assn.; state bd. of health; past vice-pres., Western Physical Therapy Assn.; York Co.; State; A.M.A.; Am. Phys. Therap. Assn.; West. Phys. Therapy Assn.; Rotary.

Moore, Prentice Laurie; Omaha; Lieut., M.C.; b 1894; Uni. of Texas, 1918; Douglas Co.; A.M.A.

Moore, Wm. Alexander; Morrill; Gen. Prac.; b 1872; Columbian Med. Col., 1900; Scotts Bluff Co.

Morgan, Donald Hobart; McCook; Obstet.; b 1897; Uni. of Nebr., 1921; Red Willow Co.; A.M A.

Morrill, Ralph Marcellus; Lincoln; Gen. Prac.; b 1874 ; Bennett Med. Col., 1900; Lancaster Co.

Morrill, Wm. LeRoy; Sterling; Gen. Prac.; b 1873; Uni. of Nebr., 1895; Johnson Co.; A.M.A.

Morris, Don Frank; Lewellen; Gen. Prac,; b 1856; Uni. of Nebr., 1886; Garden Co.

Morris, Frank S.; McCool Junction; Gen. Prac.; b 1865; Med. Col. of Ind., 1887; York Co.; A.M.A.

Morris, Geo. Henry; Newman Grove; Surg.; b 1878; Uni. of Nebr., 1905; Madison Co. 


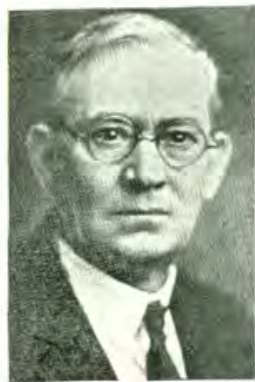

c. H. MORRIS

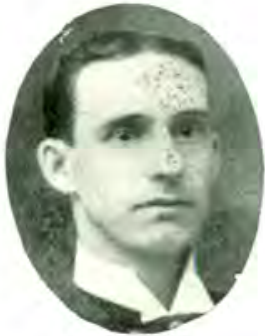

(.) A. MORRISON

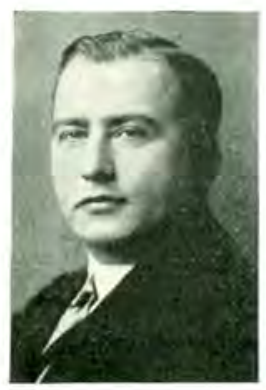

H. B. MUELLER

Morris, Geo. Henry; Oshkosh; Gen. Prac.; Keokuk Medical Col.; Col. of Phys. and Surg.; exemption board; Lincoln Co.; State.

Morrison, Geo. A.; Bradshaw; Gen. Prac.; b 1877; Uni. of Nebr., 1905; York Co,

Morrow, Carl William; Fort Calhoun; Gen. Prac.; Lincoln Med. Sch., 1913; Harvard Med. (Dr. Cabot's course in phys. diag., Mass Gen. Hosp.); M.C., A.E.F.; Furnas Co.; State.

Morrow, Frank Henry; Columbus; Surg.; b 1890; Uni, of Nebr., 1908; Platte Co.; A.M.A.

Morrow, Hamilton N.; Fremont; Gen. Prac.; Rush Med. Col., Chicago; health officer; Dodge Co.; State; A.M.A.; Mo. Valley Med. Assn.; Elkhorn Valley Med. Assn; Rotary.

Morrow, John H.; Merna; Gen. Prac.; b 1872; Lincoln Med. Col., 1902; Custer Co.; A.M.A.

Morrow, Joseph; Seward; Gen. Prac.; Eclectic Med. Col., Cincinnati; Owner, Morrow Hosp., Seward; C. and N. W. Ry. surgeon; Seward Co.; State.

Morrow, Lawrence; Tekamah; Gen. Prac.; b 1891; Creighton Uni., 1916; Burt Co.

Morse, Marie H.; Wisner; Gen. Prac.; Creighton Med. Col.

Morton, Herschel Burdette; Doniphan; Gen. Prac.; b 1898; Uni. of Nebr., 1925; Hall Co.

Moser, Reuben Allyn; Omaha; Gen. Prac.; b 1890; Uni. of Nebr., 1915; Douglas Co.; A.M.A.

Moss, Arthur Bryant; Lincoln; Gen. Prac.; b 1883; Jenner Med. Col., 1908; Lancaster Co.

Mountford, Forrest Alton; Davenport; Gen. Prac.; b 1898; Uni. of Nebr., 1924; Thayer Co.; A.M.A.

Moyer, Torrence Calvin; Lincoln; Gen. Prac,; b 1888; Uni. of Nebr., 1914 ; Lancaster Co.; A.M.A. 


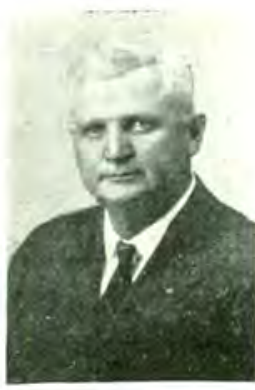

J. G. MUIR

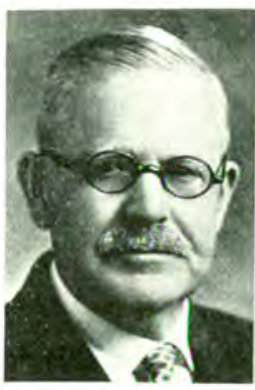

R. B. MULLINS

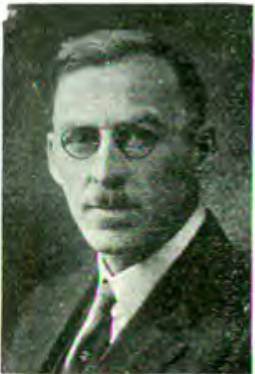

J. K. MULDOON

Mueller, Hanns Bernhard; Liricoln; Pediat.; Goettingen, Germany; Ann Arbor, Mich.; United States in 1923; staff, St. Elizabeth's and Bryan Memo. rial Hosps.; advisory pediatrician, Junior League.

Muir, James G.; Milford; Gen. Prac.; Lincoln Med. Col.; Lieut, M.C.; Seward Co; State; A.M.A.

Muir, Leonard; Alvo; Gen. Prac.; b 1874; Lincoln Med. Col., 1897; Cass Co.

Muldoon, John Kennedy; Omaha; Obstet., Gynecol.; Creighton Med. Col., 1908; Northwestern Uni.; Chicago Lying-In Hosp.; asst. prof. of obstet., Creighton Med. Col.; St. Joseph's Hosp.; Capt., M.O.R.C.

Mullen, Thomas Robert; Omaha; Eye, Ear, Nose, Throat; Creighton Med. Col.; post-grad. study, Uni. Col. Hosp., Lendon, England; Douglas Co.: State; A.M.A.

Mulligan, Harold Rowe; Hastings; Gen. Prac.; b 1890; Uni. of Nebr., 1920; Adams Co.

Mullikin, Doyle Beard; Chester; Gen. Prac.; b 1882; Uni. of Nebr., 1908; Thayer Co.; A.M.A.

Mullin, Richard Francis; Omaha; Gen. Prac.; b 1888; Creighton Uni., 1918; Douglas Co.

Mullins, Reuben B.; Fremont; Omaha Med. Col., M.D., 1898; Uni. of Maryland, D.D.S., 1905; practiced medicine, Gering, 1898-1901, dentistry at Fremont now.

Mullong, Chas. Robert; Norfolk; Surg.; b 1884; Sioux City Col. of Med., 1909; Madison Co.; A.M.A.

Munger, Arbor Day; Lincoln; Urol.; b 1890; Columbia Uni., 1915; Lancaster Co.; A.M.A.

Munger, Irvia Clarence; Lincoln; Obstet; Gynecol.; b 1875; III. Med. Col., 1900; Lancaster Co.; A.M.A.

Murdoch, Russell J.; Blair; Gen. Prac.; Uni. of Nebr. Med. Col., 1898; mayor of Blair, 4 years; Co.; State; A.M.A.

Murphy, Charles Middleton; Emerson; Gen. Prac.; Creighton Med. Col. 


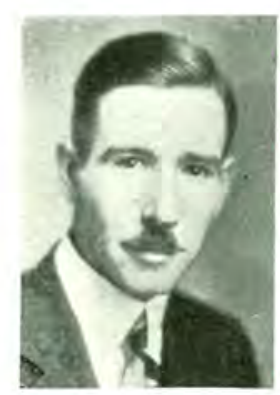

I. H. MURPHY

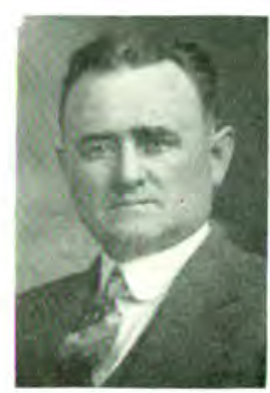

J. O. MLRPHY

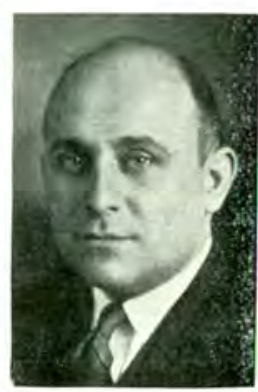

N. MUSKIN

Murphy, Francis Patrick; Omaha; Obstet; Creighton Med. Col.; asst. prof. of obstet., Creighton; stafi, St. Joseph's Hosp.; M.C. World War; Capt., M. C., World War; Capt., M.O.R.C.; Douglas Co.; State; A.M.A.

Murphy, James O.; Lincoln: Ind. Surg.; Uni. of Ill. Med. Col.; division surg., C. B. and Q. Ry.; M.C., World War; Major, M.R.C.; Davis Co.; Iowa State Med. Soc.; A.M.A.

Murphy, John Harry; Omaha; Pediat.; Creighton Med. Col.; A. B., 1910 ; A.M., 1913; M.D., 1915; Army Med. Sch., 1918; St. Vincent's Hosp., Portland, Ore.; St. Louis Children's Hosp; New York Post-Grad. Sch.; asst. prof.,diseases of children, Creighton Med. Sch.; M.C., 3 years; Douglas Co; State; A.M.A.; Central States Pediat Soc.; Am. Soc. Teachers Child. Diseases; Chamber of Commerce.

Murray, Floyd Joshua; Omaha; Gen. Prac.; b 1892; Uni. of Nebr., 1920; Douglas Co.; A.M.A

Muskin, Nathan; Omaha; Internal Med.; Uni. of Nebr., A.B., 1917; M.D., 1920; Mount Sinai Hosp.. N. Y., 1920-1922; staff, Wise Memorial Hosp.; Douglas Co.; State; A.M.A.; B'nai B'rith.

Myers, Henry Dey; Howells, Internal Med.; Drake Med. Sch.; dem. in anatomy 2 years; Dodge Co.; State; A.M.A.

Myers, Lloyd; Shelby; Gen. Prac.; b 1S01; Uni. of Nebr., 1918; Polk Co.

Nail, Frank Edgar; Riverton; Gen. Prac; b 1880; Ensworth Med. Col, 1007 ; Franklin Co.

Nason, Wm. Christopher; Omaha; Gen. Prac.; b 1879; Creighton Uni., 1908 ; Deuglas Co.

Neal, Will T.; Peru; Gen. Prac., Surg.; Rush Med. Col., Chicago; Am. Assn. Ry. Surg.

Neely, Abner D.; Lynch; Gen. Prac.; Marion-Sims Col. of Med., 1900; Boyd Co.

Neely, John Marshall, Sr.; Lincoln: Gen. Prac.; Uni. of Louisville, Med. Dept., Louisville, Ky.; staff, Missouri Pac. Ry. 18 years; Weeping Water Pension Board, 8 years; Lancaster Co.; A.M.A. 


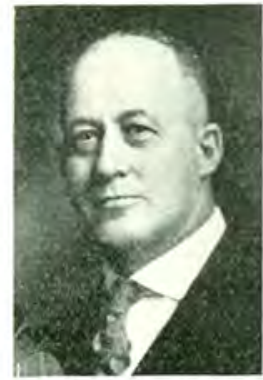

H. D. MYERS

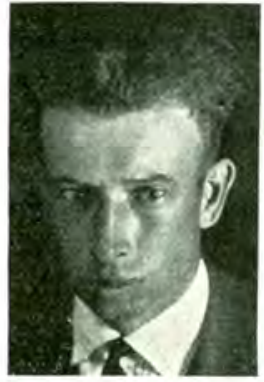

W. N. NELSON

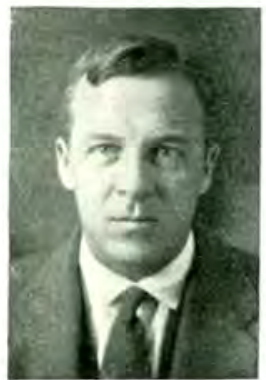

o. C. NICKUM

Neill, Chas. Wells; South Sioux City; Gen. Prac.; b 1885; Chicago Col, of Med, and Surg.; Dakota Co.

Nelson, Lloyd; Norfolk; Eye, Ear. Nose, Throat; Creighton; Manhattan Eye, Ear and Throat; M.C., World War; Madison Co.; State; A.M.A.; Am. Acad. of Ophthal. and Oto-Laryng.; R'otary.

Nelson, Frank Arleigh; Humboldt; Obstet, and Gynecol; b 1897; Uni, of Nebr,, 1923; Richardson Co.; A.M.A.

Nelson, William Harry; Ruskin; Gen. Prac.; Jefferson Med. Col.; Uni. of Ill.; Spanish-American War Vet.; Co.; State.

Nelson, William Newton; Hardy; Gen. Prac.; Uni. of Nebr. Med. Col., M.D., 1925; M.C., World War; Co.; State; A.M.A.

Nemec, Charles J.; Omaha; Gen. Prac. and Surg.; Creighton Med. Col., M.D., 1908; staff, Creighton Med. Col. and St. Joseph's Hosp.; Douglas Co.; State; A.M.A.

Neslund, Jehn W.; Cozad; Gen. Prac.; b 1882; Lincoln Med. Col., 1915; Dawson Co.

Neuhaus, George Emil; Omaha; Neuro-psychiat.; Bellevue Hosp. Med. Col., N. Y.; post-grad. study, Uni. of Berlin, Germany; Harvard Med. Sch.; Neurological Inst., N. Y.; Phipps Psychiatric Clinic, Johns Hopkins Med. Sch.; assoc. prof.. nerv, and mental diseases., Uni. of Colo Med. Sch., 19071910 ; prof. and head dept., nerv. and mental diseases., Uni. of Colo. Med. Sch., 1910-1922; lecturer, med. psychiatry, Creighton Med. Col.; Douglas Co.; State; A.M.A.; Am. Psychiatric Assn.; Am. Col. phys.; Central Neuropsychiat. Assn; Assn. for Research in Nerv. and Mental Diseases.; contributor to A.M.A.; Boston M. and S. J.; Colo. Med.; Nebr. Med. J.

Neumarker, Wm. Richard Carl; Columbus; Pediat.; b 1878; Central Med. Col. of St. Joseph, 1900; Platte Co.; A.M.A.

Neville, Dennis; Hildreth; Gen. Prac.; Ill. Med. Col., 1900; Franklin Co.

Neville, J. William; Utica; Phys. and Surg.; Uni. of Nebr., M.D., 1920; intern, San Francisco Co. Hosp.; Res. Phys., Calif. Sanatorium for Tuberculosis. 
Neumann, Ernest V.; Hollywood, Calif. (formerly in Wausa); Gynecol, Obstet.; Creighton Med. Col.; post-grad. study, Vienna, 1925; Los Angeles Co.; State; A.M.A.

Newell, Harry J.; Alexandria; Pediat,; b 1872; Creighton Uni., 1903; Thayer Co.; A.M.A.

Newell, Chas. Harold; Omaha; Surg.; b 1882; Creighton Uni., 1908; Douglas Co,; A.M.A.

Newman, James K.; Omaha; Gen. Prac. (retired); Uni. of Mexico, 1879; Omaha Douglas Co.; State; A.M.A.

Newman, Jefferson Clarence; Wallace; Gen. Prac.; b 1890; Chicago Col. of Med. and Surg., 1914; Lincoln Co.; A.M.A.

Newquist, Melvin Nathaniel; Bloomfield; Gen. Prac.; b 1897; Uni. of Nebr., 1924; Knox Co.

Newton, Geo. Henry; Fairbury; Gen. Prac.; b 1877; Uni. of Tenn., 1912; Jefferson Co.

Newton, R. A.; Walthill; Gen. Prac.; Uni. of Nebr., 1926; Alpha Kappa Kappa; Cedar, Dakota, Dixon, Thurston Co.

Newton, Raymond Alwyn; Hollinger; Gen. Prac.; b 1901; Uni. of Nebr, 1926; Furnas Co.

Nichelson, Frank Salter; St. Paul; Gen. Prac.; Surg.; Trinity Med. Col, Toronto, Canada, 1894; former Surg. Gen., Nebr. Natl. Guard; surg., U. P. Ry.; C. B. and Q. Ry.; Mexican Border, 1916; Major, M.R.C.; Howard Co.; State; A.M.A.

Nichols, Edwin Jr.; Scottsbluff; Gen. Prac,; b 1868; Starling Med. Col., 1894 ; Scotts Bluff Co.

Nichols, Harry Carl; Grand Island; Gen. Prac.; Creighton Med. Col., M.D., 1911; M.C., World War.; Co.; State; A.M.A.; Cosmopolitan, Woodland Golf Clubs.

Nichols, Robt.; Omaha; Gen. Prac.; b 1881; Eclectic Med. Uni., Kansas City, 1912; Douglas Co.

Nickum, Oliver Clarke; Seward; Diag., Internal Med.; Uni. of Nebr.; post-grad. study in Vienna; Seward Co.; State; A.M.A.; A.M.A. of Vienna.

Niehaus, Friedrich Wilhelm; Omaha; Clin. Path.; Uni. of Nebr.; intern, Clarkson Hosp.; St. Vincent's Bellevue Hosp., N. Y.; asst. prof. med., Uni of Nebr. Med. Col.; staff, Clarkson and St. Catherine's Hosp.; Capt., M.C., 1918-1919; Omaha-Douglas Co.; State; A.M.A.; Am. Soc. Clin. Path.

Nielsen, Juul Christian; Omaha; Gen. Prac,; b 1896; Uni, of Nebr., 1926; Douglas Co.

Nielsen, Marie Anna; Omaha and Blair; Gen. Prac.; Uni. of Nebr. Med. Col.; Uni. of Mich.; Copenhagen, London; Co.; State; Mo. Valley Med. Assn, ; Fed. Women's Club.

Nielsen, Mcrris; Blair; Gen. Prac.; b 1875; Uni. of Nebr., 1900; Wash ington Co.; ex pres., State; A.M.A. 


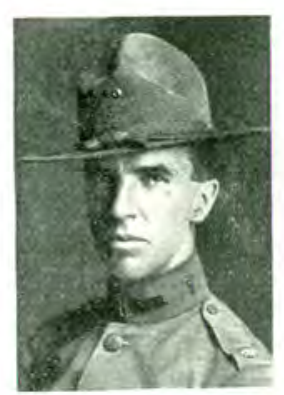

F. S. NICHELSON

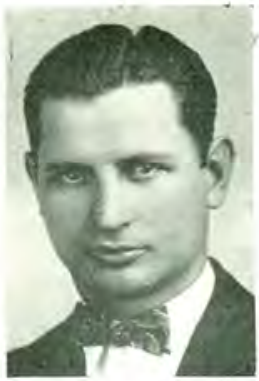

W. F. NOVAK

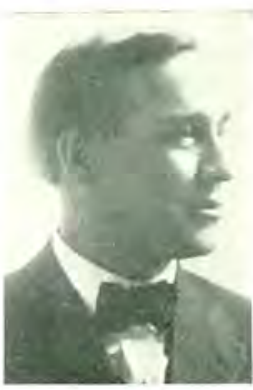

C. A, OAKS

Nilsson, John Rudolph; Omaha; Surg.; b 1878; Uni. of Nebr., 1901; Douglas Co.; A.M.A.

Noble, Lucian L.; Holmesville; Gen. Prac.; b 1871; Northwestern Med. Col. of St. Joseph, 1894; Gage Co.

Noble, Roy C.; Beatrice; Gen. Prac.; Uni. of Nebr. Med. Col.; vice pres., Gage Co. Med. Soc.; city phys.; served World War; Gage Co.; State; A.M.A.

Nolan, Wm. Jos.; Omaha: Gen. Prac.; b 1886; Dartmouth Med. Sch. 1909; Douglas Co.

Noonan, Eugene F.; Omaha; Gen. Prac.; b 1888; Creighton Uni., 1917; Douglas Co.

Northcross, Stephen Buchanan; Omaha; Gen. Prac.; Meharry Med. Col., 1918; Douglas Co.

Novak, Chas. E.; Humboldt; Gen. Prac.; b 1880; Rush Med. Col., 1903; Richardson Co.; A.M.A.

Novak, William Fred; Howells; Gen. Prac.; Uni. of Nebr.; World War service; Phi Chi.

Nowers, Walter E.; Kenesaw; Gen. Prac.; Creighton Med. Col.; Adams Co.; State.

Noyes, William W.; Ceresco; Gen. Prac.; Lincoln Med. Col., M.D., 1908; Co.; State; A.M.A.

Nye, Frank Hoyt; Plainview; Gen. Prac.; b 1866; Col. of Phys. and Surg., Keokuk, 1891; Pierce Co.; A.M.A.

Nye, Mark Alva; Omaha; Gen. Prac.; b 1872; Uni. of Nebr., 1904; Douglas Co.

Oaks, Charles A. (deceased, 1916); Hastings; Nervous and Mental dis.; Creighton Med. Col., M.D., 1902; post-grad., Fordham Uni., N. Y. C.; Adams Co.; State; A.M.A.

O'Brien, Donald James; Creston; Gen. Prac.; Creighton Med. Col.

O'Connell, James M.; Ponca; Pediat.; b 1853; Rush Med. Col., 1881; Dixon Co. 


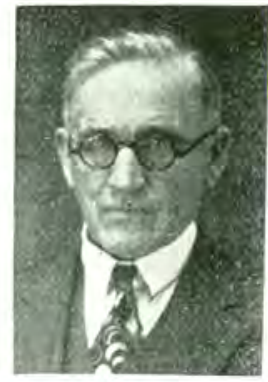

I. A. PACE

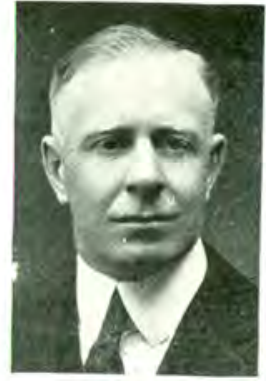

J. MC K. PACKER

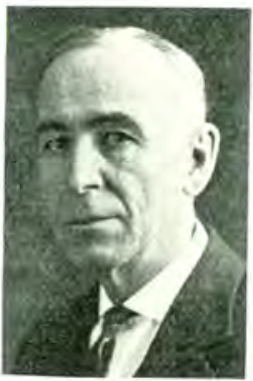

W. H. PALLETT

O'Conner, Wm. Edward; Omaha; Gen. Prac.; b 1871; St. Louis Col. of Phys. and Surg., 1895; Douglas Co.

O'Connor, D. Edward; Chappell; Gen. Prac.; b 1890; Kansas City Uni. of Phys. and Surg., 1919; Deuel Co.

Offerman, Arthur James; Omaha; Gen. Prac.; Creighton Med. Col., M.D., 1916; faculty, Creighton Med. Col.; staff, St. Joseph's Hosp.; M.C., A.E.F.

O'Hearn, John Jos,; Omaha; Gen. Prac.; b 1890; Creighton Uni., 1916; Douglas Co.; A.M.A.

Olney, Robt. Chas.; Lincoln; Surg.; b 1896; Eclectic Med. Col., Cincinnati, 1919; Lancaster Co.; A.M.A.

Olson, Ole; Lincoln; Surg. and Med.; Nebr. Med. Col.; World War service; Lancaster Co.; State.

Olson, Justus Edgar; Lexington; Surg.; Uni. of Nebr., M.D., 1910; post-grad., Chicago; M.C., A.E.F.; Dawson Co.; State; A.M.A.; Kiwanis; Ch. of Commerce.

O'Neill, Silverton Hollingsworth; Blue Hill; Gen. Prac.; b 1877; Col. of Phys. and Surg.; Baltimore, 1907; Webster Co.; A.M.A. A.M.A.

Osheroff, Samuel A.; Ericson; Gen. Prac.; Uni. of Nebr,; Co.; State;

Ostling, Evert H.; Lewellen; Gen. Prac.; Morningside Col.; World War; Lincoln Co.; State; A.M.A.

Overgaard, Anders P.; Omaha; Roentgenc1,; b 1879; Uni. of Nebr., 1900; Douglas Co. (pres., 1928); A.M.A.

Overmass, Saml. Edward; Gordon; Gen. Prac.; b 1871; Uni. of Ill., 1902; Clay Co.

Owen, Donald; Omaha; Ophthal., Otolo., Laryng., Rhin.; b 1894; Uni. of Nebr., 1918; Douglas Co.; A.M.A.

Owens, Chas. Austin, Jr.; Omaha; Gen. Prac.; b 1894; Uni. of Nebr., 1923; Douglas Co. 
Owen, Frank Stiles; Omaha; Eye, Ear, Nose, Throat; Uni. of Mich Med. Col.; emeritus prof., Oto-Rhin., Laryng.; Uni. of Nebr. Med. Col.; staff, University, St. Catherine's and Immanuel Hosp.; Omaha, Athletic. Uni. Clubs

Owen, Leonard Jos.; Lincoln; Dermat.; b 1892; Washington Uni., St. Louis, 1920; Lancaster Co.; A.M.A.

Oxford, Edwynn J.; Chambers; Gen. Prac.; Creighton Uni. Med. Col., M.D., 1905 ; city phys.; Holt Co.; State; A.M.A. Phi Rho Sigma.

Pace, Ira A.; Guide Rock; Gen. Prac.; Uni. of Vermont, 1891; Webster $\mathrm{Co}$,

Packer, J. McKinley; Ashland; Gen. Prac.; E. M. C., Cincinnati, Ohio; World War service.

Packwood, Wm. Ernest; Riverton; Gen. Prac.; b 1876; Bennet Med. Col., 1906; Franklin Co.

Paden, Frank A.; Hartington; Gen. Prac.; Central Col. of Phys. and Surg., Indianapolis; Hahnemann Med. Col., Chicago; staff, Methodist Hosp., Sioux City, Iowa; Co.; State; A.M.A.

Page, Clifford Seeley; Harrisburg; Gen. Prac.; b 1875; Vale Uni., 1896; Banner Co.

Pallet, William H.; Crete; Gen. Prac.; Uni. of Iowa; Kansas City Medical Col.. M.D., 1898; Capt., M.O.R.C.

Palmateer, Homer Royal; Madison; Gen. Prac.; b 1897; Uni. of Nebr., 1922; Madison Co.

Palmer, Claud; Bridgeport; Gen. Prac.; b 1872; Uni. of Nebr., 1906; Morrill Co.

Palmer, Daniel S.; Holdrege; Gen. Prac.; Cincinnati Eclectic Inst., 1889; city phys.; coroner; insanity commissioner, Phelps Co.; State.

Palmer, King Paige; Holdrege; Gen. Prac.; b 1892; Eclectic Med. Col., Cincinnati, 1918; Phelps Co.; A.M.A.

Panter. Robert Carpenter; Dorchester; Surg.; b 1882; Uni. of Nebr., 1904; Saline Co.; A.M.A.

Panter, Samuel Goodall; Lincoln; Dermat.; Bellevue Hosp., N. Y,; Uni. of Nebr. Med. Col.; Missouri Med. Col.; Washington Uni., St. Louis; former pres., Saline Co. Med. Soc.; board of health; Board of education.

Parks, Albert L.; Omaha; Gen. Prac.; b 1871; Rush Med. Col., 1897; Douglas Co.; A.M.A.

Parks, Chas. Wm.; Syracuse; Gen. Prac,; b 1888; Northwestern Uni., 1912; Otce Co.

Parsons, Antony; Valley; Gen. Prac.; Creighton Med. Col.; London Uni.; Medical Missionary to Belgian Congo, Africa; secy., board of education 13 years; Douglas Co.; State; A.M.A.

Parsons, John Wesley; Omaha; Gen. Prac.; b 1867; Col. of Phys. and Surg., Keokuk, 1891; Douglas Co.

Pass, Moses D.; Broadwater; Gen. Prac.; b 1862; Cleveland Med. Col., 1896; Kentucky Uni., 1899; Morrill Co. 
Patton, James McDowell; Omaha; Ophthal.; associate of Harold G. Gifford; Omaha Med. Col. and abroad; prof., ophthal., Uni. of Nebr. Med. Col.; Major. M.C., A.E.F.; Omaha Club; 1923; pres., Omaha-Douglas Co. Med. Assn.; State; A.M.A.

Patty, Marion B.; Chappell; Gen. Prac.; b 1871; Keokuk Med. Col., 1901; Deuel Co.

Paxton, Chas. Camren; Palmer; Gen. Prac.; b 1869; Kansas Med. Col., 1899; Creighton Uni., 1900; owner, Coolidge Hosp. at Palmer; M.C., World War; Merrick Co.

Pease, Bert Chas.; North Platte; Obstet., Gynecol.; b 1880; Bennet Med. Col. , 1905; Lincoln Co.

Pedersen, Andrew Meyer; Ruskin; Gen. Prac.; b 1887; Uni. of Nebr., 1920; Nuckolls Co.; A.M.A.

Pedersen, Hans Christian; Fremont; Surg.; b 1882; Uni. of Nebr., 1905; Dodge Co.; A.M.A.

Pedersen. Peter M.; Dannebrog; Gen. Prac.; b 1871; Uni. of Nebr., 1904; Howard Co.; A.M.A.

Peebler, Ora Fay; Omaha; Gen. Prac,; b 1881; Keokuk Med. Col., 1903; Douglas Co.

Pells, Edna; Grand Island; Chronic Dis.; Keokuk, Iowa; practiced in Illinois prior to Nebraska.

Pendell, George D.; Geneva; Beaumont Med. Col., St. Louis, Mo.; Fillmore Co,; State; A.M.A.

Penner, Henry G.; Beatrice: Roentgenol.; b 1872; Uni. of Nebr., 1904; Gage Co.

Penner, Louis Edward; Beatrice; Surg.; b 1874; Uni. of Nebr., 1904; Gage Co.

Pennington, Geo. E.; Broken Bow: Roentgenol.; b 1875; Ensworth Med. Col., 1902; Custer Co.; A.M.A.

Pennington, James Lewis; Thediord; Gen. Prac.; Barnes Med. Col., St. Louis, Mo.; Insanity Board; local surg., C. B. and Q. Ry.; city and Thomas Co. health officer.

Peters, Glen Elmo; Randolph; Gen. Prac,; Creighton Med. Col.; M.C., World War.

Peters, John Arthur; Springfield; Gen. Prac,; b 1873; Uni. of Nebr., 1902; Sarpy Co.

Peters, Roy Elliott; Wymore: Gen. Prac., Surg.; Loyola Uni., Chicago; U. S. N. Hosp, service 4 years.

Peterson, Alfred Olaf; Omaha; Internal Med., Physiotherap; b 1873; Uni. of Nebr., B.Sc., 1896; M.D., 1899; A.M., 1900; Sigma Xi; lecturer, Omaha Med. Col., 1896-1908; lecturer, Uni. of Nebr., 1908-1916; Co.; State; A.M.A.; A.A.A.S.; Happy Hollow, Carter Lake, Athletic Clubs.; author: Early Development of Liver in Pig. 


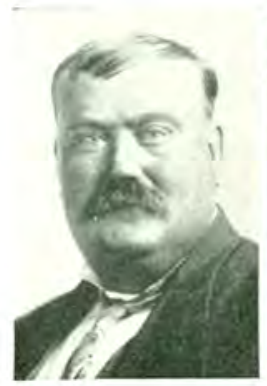

J. L. PENNINGTON

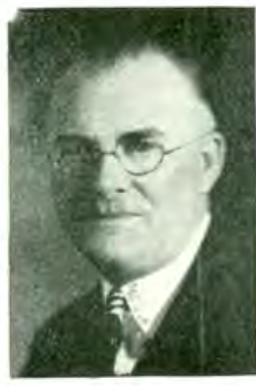

A. O. PETERSON

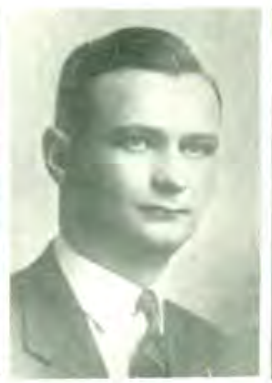

T. A. PETERSON

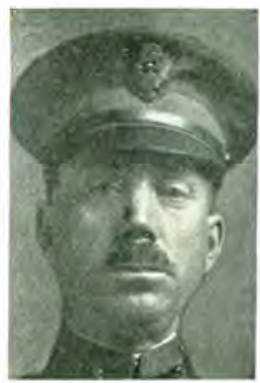

S. o. PITTS

Petersen, Emil Carl; Omaha; Gen. Prac.; b 1898; Uni. of Nebr., 1925; Douglas Co.

Peterson, Magnus Christian; Norfolk; Gen. Prac.; b 1893; Uni. of Nebr., 1925; Madison Co.

Peterson, Theo. A.; Holdrege; Gen. Prac.; Uni. of Nebr.; Swedish Covenant Hosp., Chicago; Co.; State; A.M.A.

Peterson, William C.; Henderson; Ophthal., Otolo., Laryng., Rhin.; b 1886; Creighton Uni., 1909; York Co.

Peyton, Wade Hamilton; Omaha; Gen. Prac.; Meharry Med. Col., 1923; Douglas Co.

Phelan, Leopold; Grand Island; Gen. Prac.; b 1863; Queen's Uni. Faculty of Med., 1890; Hall Co.

Philbrick, Inez Celia; Lincoln; Gen. Prac., Obstet.; Woman's Med. Col. of Penn., 1891; pres. 3 years, Nebr. Woman Suffrage Assn.; chmn., Woodrow Wilson Foundation; secy., city library; Lancaster Co.; State; A.M.A.; Lincoln, Nebr., Natl. Women's Med. Assn.; see chapter on Women Physicians.

Phillips, Clark L.; Dixon; Gen. Prac.; b 1885; Uni. of Nebr., 1912; Dixon Co.

Pickett, Ira N.; Odell; Gen Prac.; b 1852; Ind. Med. Col., 1878; Gage Co.

Pierce, Chauncy Merrill; Chadron; Gen. Prac.; b 1885; Northwestern Uni. Med. Sch., 1908; Dawes Co.

Pierce, Roscoe P.; Holbrook; Gen. Prac.; b 1871; Uni. of Louisville, 1895; Furnas Co.

Piersol, Marcus Rice; Cairo; Gen. Prac.; b 1871; Lincoln Med. Col., 1901; Hall Co.; A.M.A.

Pierson, Clarence A.; Beemer; Gen. Prac.; Northwestern Uni. Med. Sch., M.D., 1923; Co.; State.

Pilger, Walter Herman; Norfolk; Gen. Prac.; b 1879; Creighton Uni., 1905; Madison Co.

Pilsbury, Donald Marion; Omaha; Gen. Prac.; b 1902; Uni. of Nebr., 1926; Douglas Co. 
Pinckney, Chas. Edward; North Loup; Gen. Prac.; b 1882; Uni. of Nebr., 1915 ; Valley Co,; A.M.A.

Pinney, George L.; Hastings; Internal Med.; Sch., B.Sc., M.D.; acting supt., Ingleside State Hosp.; staff, Mary Lanning Memorial Hosp.; Adams Co.; State; A.M.A.; Repub. Valley Med. Soc.; A. C. of P.; Rotary; pres., Chamber of Commerce, Country Club.

Pitts, Sollis Oscar; Ogallala; Gen. Prac., Surg.; Denver Homeopathic Col., 1902; supt., Park Ave. Hosp., Denver; Lieut., M.C.; Am. Institute of Homeopathy.

Platt, Otis Russell; North Platte; Gen. Prac.; b 1891; Chicago Col. of Med, and Surg., 1916; Lincoln Co.

Platz, Ada; Beatrice; Dis. of Women and Children; Uni. of Nebr, M.D., 1900; Gage Co.; Nebr. Med. Women's Assn.; Professional Women's Club.; Y. W. C. A.

Plehn, Frank Wallace; Scottsbluif; Roentgenol.; Internal Med.; Normal Uni., Lebanon, Ohio; Ensworth Med. Col., St. Joseph; Uni. of Mo. Med. Col.; councillor, 12th dist., Nebr.; state board of health of Kansas, 18971898 ; surgeon, C. B. and Q. Ry.; pres. staff West Nebraska Methodist Hosp.; M. C., air service; Scotts Bluff Co.; State; A.M.A.; Rad. Soc. of No. America; see chapter on Politics.

Plumb, James Norris; York; Ophthal., Otolo., Laryng., Rhin.; b 1868; Rush Med. Col. 1891; York Co.

Polk, Lurton F.; Lincoln; Gen. Prac.; b 1858; Physio-Med. Col. of Ind., 1880; Lancaster Co.

Pollack, Fredolph A.; Norfolk; Gen. Prac.; b 1889; Creighton Uni., 1917; Madison Co.; A.M.A.

Pollard, Charles W.; Omaha; Obstet.; Dartmouth Col., 1895; M.D., Columbia Uni. Col, of Med., 1899; professor of obstet. and gynecol. Uni. of Nebr. Med. Col.; past president, Medical Arts Bldg. Assn,; owner, Omaha Maternity Hosp.

Porter, Elmer R.; Omaha; Surg.; b 1871; Uni. of Nebr., 1898; Douglas Co.; A.M.A.

Potter, George Benjamin; Omaha; Eye, Ear, Nose, Throat; Uni. of Nebr.; N. Y. Eye and Ear Infirmary; instr., Uni. of Nebr. Med. Col.; Co.; State; A.M.A.; Am. Acad. of Ophthal.

Potter, Harry Evan; Fairbury; Gen Prac.; b 1876; Uni. Med. Col. of Kansas City, 1900; Jefferson Co.; councillor, 7th dist. and 1927 pres., State; A.M.A.; delegates to 1924 Republican convention.

Potts, John Beekman; Omaha; Rhin., Oto-Laryng., Broncho.; assoc. with Dr. Harold Gifford; Uni. of Nebr. Med. Col.; asst. prof. of otolaryng., Uni. of Nebr.; Capt., A.E.F.; Co.; State; A.M.A.; Acad. Ophthal. and Oto-Laryng.; Am. Board of Oto-Laryng.; Triological Soc.; various papers on medical subjects.

Powell, E. Willard; Omaha; Surg.; Omaha Med. Col.; Washington Uni. Med. Col., St. Louis, Mo.;post-grad., New York, Chicago, Paris, Bern, Leip- 
zig, Berlin, Vienna, London; surg. to Evangelical Covenant and Douglas Co. Hosp.; Spanish-American War service; Co.; State; A.M.A.; Mo. Valley Med. Assn.; Elkhorn Valley Med. Soc.; Ch. of Commerce; Field Club; Died, June, 1928.

Powell, Lupher A.; Superior; Gen. Prac.; b 1861; Uni. of Pa., 1884; Nuckolls Co.

Powell, Milton J.; Fairbury; Ophthal., Otolo., Laryng., Rhin.; b 1881; Ensworth Med. Col., 1907; Jefferson Co.

Powell, Ward Hughes; Minden; Gen. Prac.; b 1882; Uni. of Nebr., 1913; Buffalo Co.; A.M.A.

Powers, Francis Irving; Omaha; Gen. Prac.; b 1902; Creighton Uni., 1926; Douglas Co.

Peynter, Charles W. M.; Omaha; Anatom.; Uni. of Nebr., B.Sc., M.D., 1902; post-grad., Vienna and Harvard; chmn. and prof. of anat. dept., Uni. of Nebr.; Co.; State; Am. Assn Adv. of Sciences; Am. Assn. Anat.; Soc. of Anat. of Great Britain; Am. Assn. Anthropologists; A.M.A.; Sigma Xi, Alpha Omega Alpha; Phi Rho Sigma; contributions to anthropology, teratology, embryology, neurology and anatomy.

Pratt, George C.; Omaha; Internal Med.; Rush Med. Col.; Co.; State; A.M.A.; F.A.C.P.; A.E.F.

Pratt, Willard Munson; Craig; Gen. Prac.; b 1807; Uni. of Nebr., 1923; Burt Co.

Premer, James Frederick; Benkelman; Gen. Prac.; Uni. of Nebr.; Dundy Co.; State; A.M.A.

Prendergast, James F.; Steinhauer; Gen. Prac.; b 1883; Creighton Uni., 1908; Pawnee Co.

Presnell, James Frederick; Lincoln; Army Surg. State Uni. of Iowa; Major, M.C.; Spanish War Vet.; A.M.A.; Ill. Med. Assn.; hon. mem.,

Prest, John, Elry; Lushton; Gen. Prac.; b 1878; Uni. of Nebr., 1904; York Co.

Preston, Sylvester Atkinson; Fremont; Gen. Prac.; Winnepeg Normal Sch., Canada, 1884; Uni. of Nebr., M.D., 1900; councillor, 5th dist., Nebr. State Med. Assn.; ex-pres. Dodge Co. Med. Soc.; Elkhorn Valley Med. Assn.; Dodge Co.; State; A.M.A.

Prichard, Geo. Winthrop; Omaha; Gen. Prac.; b 1879; Uni. of Nebr., 1908; Douglas Co.

Priest, Paul Herbert; Omaha; Gen. Urac.; b 1879; Uni. of Nebr., 1908; Douglas Co.

Priest, Paul Herbert; Omaha; Gen. Prac.; b 1879; Uni. of Nebr., 1908; Sioux Co.

Prince, Norman Call; Omaha; Roentgenol.; b 1884; Denver and Gross Col. of Med., 1907.

Protzman, Chas. E.; Lincoln; Gen. Prac.; Lincoln Med. Col., 1902; Lancaster Co. 


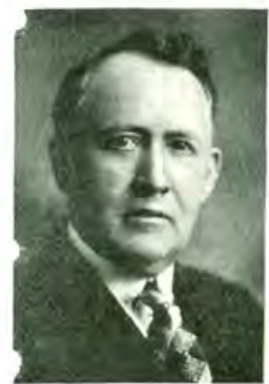

S. A. PRESTON

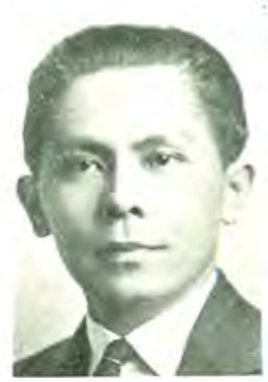

J. Y. RACINES

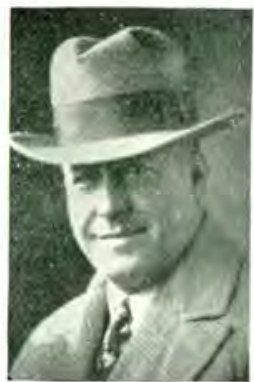

x. H. RASMUSSEN,

Pruner, Ambler Caskie; Omaha; Gen. Prac.; b 1890; Loyola Uni., 1916; Lieut., M.C., World War; Douglas Co.; A.M.A.; Phi Rho Sigma.

Pruner, William H., Jr.; Omaha; Surg.; Uni. of Nebr., A.B.,; Creighton Med. Col., M.D., 1907; Co.; State; Elkhorn and Mo. Valley Assns.; A.M.A.; Phi Rho Sigma.

Pugsley, Geo. Wm.; Bayard; Gen. Prac.; b 1880; Creighton Uni., 1907; Morrill Co.

Pulver, John Earle; Omaha; Gen. Prac.; Creighton Uni., 1908; Douglas Co.

Purviance, Walter Charles; Beatrice; Gen. Prac.; b 1875; Medico-Chirurgical Co. of Kansas City; Gage Co.

Putman, Lynn J.; Fremont; Ophthal., Otolo., Laryng., Rhin.; b 1886; Uni. of Md., 1909; Dodge Co.

Quigley, D. T.; Omaha; Radium; see chapter on Achievements.

Quigley, Willard Henry; Omaha; Dermat.; b 1891; Creighton Uni., 1914; Douglas Co.; A.M.A.

Quinn, John H.; Gothenburg; Gen. Prac.; b 1857; Rush Med. Col., 1880; Dawson Co.

Quirk, Howard William; Crete; Gen. Prac.; Western Reserve Uni., Cleveland; post-grad., New York, Chicago, Paris, London, Vienna, Berlin; secy., Saline Co. Med. Soc.; supt., Crete Hosp.; surg., Big 4 and C. B. and Q. Rys.

Racines, Juan Y.; Palmer; Gen. Prac.; Uni. of Philippines Med. Col.; Uni. of Nebr., M.D., 1925; Merrick Co.; State; A.M.A.

R'agan, Seth Ellsworth; Seward; Gen. Prac.; b 1872; Barnes Med. Col., 1897; Seward Co.

Ramey, Walter Newman; Lincoln; Surg.; b 1866; Eclectic Med. Col., Cincinnati, 1903; Lancaster Co.; A.M.A.

Ramsey, Andrew Jackson; Auburn; Gen. Prac.; b 1862; Ky School of Med., 1890; Nemaha Co.

Rance, William T.; Omaha; Gen. Prac.; Creighton Med. Col.; staff, Mo. Pacific Ry.

Rasmussen, Nelson H.; Scottsbluff; Surg.; Creighton Med. Col.; Scotts Bluff Co.; State; A.M.A.; F.A.C.S. 
Randall, Andrew LaRoy; Pleasanton; Gen. Prac.; Northwestern Uni., 1903; Buffalo Co.

Rasck, Alfred G.; Ainsworth; Gen. Prac.; b 1882; Loyola Uni., 1916; Brown Co.; A.M.A.

Ravitz, Sol E.; Omaha; Gen. Prac,; b 1896; Uni, of Nebr., 1920; Douglas Co.; A.M.A.

Raynor, Willis J.; Burkett; Internal Med.; Uni. of Ohio Med. Col., Cincinnati, M.D., 1880; supt., State Soldiers' and Sailors' Home Hosp.

R'ead, Paul Stowell; Omaha; Gen. Prac.; b 1898; Uni. of Nebr., 1926; Douglas Co.

Redfield, Josiah B.; North Platte; Surg., Roentgenol.; Uni. of Nebr.; eleventh councillor, Nebr. State Med. Assn.; city and county phys.; M.O.T.C., World War; Lincoln Co.; State; A.M.A.; Kiwanis Club.

Redfield, Willis J.; Omaha; Surg.; Creighton Med. Col.; post-grad., Vienna, New York Post-Grad. Hosp.; Chicago Polyclinic; Mayo Clinic; staff, Lord Lister Hosp.; Maj., M.C.; Lt. Col., M.O.R.C.; Co.; State; A.M.A.; Am. Assn. Military Surg.; Athletic Club.

Reed, Elmer Burkett; Lincoln; Gen. Prac.; b 1900; Uni. of Nebr., 1925; Lancaster co.

Reed, Hugh S.; Guide Rock; Gen. Prac.; Keokuk Med. Col., Keokuk, Ia,; Webster Co.; State; Commercial Club.

Reed, Orvill Clinton; Lexington; Ophthal., Otolo., Laryng., Rhin.; b 1892; Kansas City Hahnemann Med. Col., 1916; Dawson Co.; A.M.A.

Reed, Paul A.; Deshler; Gen. Prac.; Uni. of Nebr., B.Sc., 1923, M.D., 1924; Co.; State; Nu Sigma Nu.

Reed, Roland Ray; McCook; Gen. Prac.; b 1886; Uni. of Nebr., 1910; Red. Willow Co.; A.M.A.

Reed, Stanley G.; Omaha; Gen. Prac.; Northwestern Uni. Med. Col,; stafi, Lord Lister Hosp.; University, Field, Athletic Clubs.

Reed, Wilson Herbert: Omaha; Gen. Prac.; Creighton Med. Col.; Keokuk Med. Col.; surgeon, U, P. Ry.

Reeder, Grant Simpson; Fremont; Gen. Prac.; b 1885; Rush Med. Col., 1911; Dodge Co.; A.M.A.

Reeder, Wm. Jeremiah; Cedar Rapids; Gen. Prac,; b 1893; Creighton Uni., 1923; Boone Co.

Reese, Sidney Ober, Jr.; Lincoln; Obstet,; b 1891; Johns Hopkins Uni., 1916; Lancaster Co.; A.M.A

Reeves, Alfred E.; Farnam; Surg., Gen. Prac.; Ensworth Med. Col., 1904; post-grad., Chicago Polyclinic, 1911; Barnes Hosp., New York Post-Grad., Los Angeles Co. Hosp.; M.C., World War; owner Reeves Hosp.; Commercial Club.

Reeves, George I.; Belgrade; Gen. Prac.; Keokuk Uni. Med. Col.; Ensworth Uni. Med. Col,; organizer, Dawson Co. Med. Soc. 


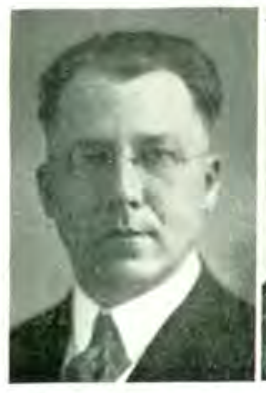

E, A. REILS

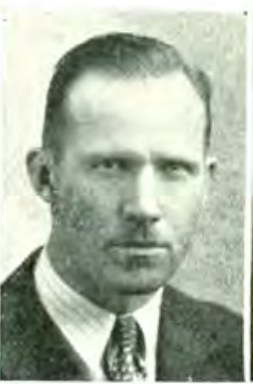

T. E. RIDIEL1.1.

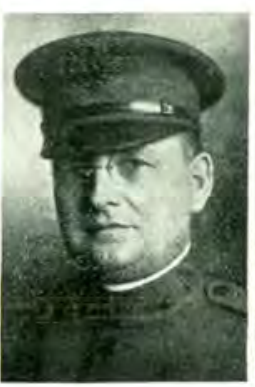

W. J. REDFIELD

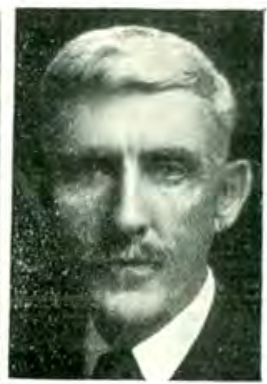

D. R. ROGERS

Recves, Geo. I.; Phillips; Gen. Prac.; b 1860; Ensworth Med. Col., 1902; Hamilton Co.

Reichstadt. Emil; Omaha; Gen. Prac.; b 1882; Creighton Uni., 1919; Douglas Co.

Reid, John D.; Pilger; Gen. Prac.; Uni of Nebr.; Stanton-Madison Co.; State; A.M.A.; Elkhorn Valley Med. Assn.

Reilly, John Victor; Grand Island; Pediat.; b 1881; Georgetown Uni., 1906; Hall Co.; A.M.A.

Reils, Edwin A.; Brainard; Uni, of Omaha, A.B., 1916; Uni. of Nebr., M.D., 1923.

Remy, George Oliver; Ainsworth; Gen. Prac., Surg.; Uni. of Ohio, M.D., 1877; eighth councillor dist.; oldest practitioner in Northwestern Nebraska; Brown Co.; State; A.M.A.; See Pioneer Chapter.

Reneker, Geo. Wirt; Falls City; Ophthal.; b 1864; Northwestern Med. Col, of St. Joseph, 1893; Richardson Co.

Reynolds, Crandall A.; Lincoln; Gen. Prac.; b 1880; Nebr. Col. of Med., 1908; Lancaster Co.

Reynolds, Robt. Wayne; Lincoln; Urol.; b 1882; Lincoln Med. Col., 1906; Lancaster Co.; A.M.A.

Rice, Allen T.; Beatrice; Gen. Prac,; Col. of Phys. and Surgs., Keokuk, 1881; Gage Co.

Rice, Chilton S.; Gen. Prac.; b 1855; American Eclectic Med. Col., 1893; Arthur Co.

Rice, Clarence E.; Odell; Gen. Prac.; Uni. of Nebr. Med. Col.; Gage Co.; State; A.M.A.; Phi Beta Pi.

Rice, Grover Cleveland; Bayard; Gen. Prac.; b 1888; Ensworth Med. Col., 1910; Morrill Co.

Rice, M. Raymond; Omaha; Surg.; b 1887; Creighton Uni., 1909; Douglas Co.

Rich, Max L.; Grand Island; Gen. Prac.; b 1871; Uni. of Nebr., 1893; Hall Co. 
Rich, Charles O'Neill; Omaha; Surg.; Medico-Chirurgical Col., Uni. of Penn., Philadelphia; asst. prof., surgery, Uni. of Nebr.; chair. med. advisory committee; Co.; State; A.M.A.; Am. Col. of Surg.; Uni. Club.

Rich, Riley Gilbert; David City; Gen. Prac,; Col. of Phys. and Surg., Chicago; Uni. of Ill. Med. Col.; surg., C. B. and Q. Ry.; Capt., M.C.; Co.; State; Am. Assn. Ry. Surg.; Commercial Club.

Richards, Benj. Franklin; Crawford; Obstet.; b 1874; Lincoln Med. Col., 1897; Dawes Co.

Richards, Roy Charlton; Newcastle; Obstet.; b 1877; Northwestern Uni., 1905; Dixon Co,; A.M.A.

Richardson, Ira Fredk.; Fremont; Gen. Prac.; b 1872; Kansas City Hahnemann Med. Col., 1903; Dodge Co.

Richardson, Louis; Waterloo; Gen. Prac.; Uni. of Nebr., 1890; Douglas Co.

Richardson, Sidney J.; Hershey; Gen. Prac.; b 1869; Chicago Hom. Med. Col., 1903; Lincoln Co.

Rickard, Wesley Grant; Lincoln; Gen. Prac.; b 1869; Bennett Med. Col., 1905; Lancaster Co.; A.M.A.

Riddell, Ted. E.; Scottsbluff; Surg., Diag.; Uni. of Nebr., A.B., M.D.; post-grad., London, Paris; secy., 12th councillor dist., Med. Soc.; M.R.C.; air service; Scotts Bluff Co.; State.

Rider, Eugene Edwin; Lincoln; Surg.; b 1881; Uni. Med. Col. of Kansas City, 1903; Lancaster Co.; A.M.A.

Rider, Harry Dewey; Havelock; Gen. Prac.; b 1898; Uni. of Nebr., 1925; Lancaster Co.

Rieth, Geo. Raymond; Omaha; Gen. Prac.; b 1888; Creighton Uni., 1918; Douglas Co.

Riley, Bryan Michael; Omaha; Internal Med.; Creighton Med. Col.; dir., med. dept., St. Joseph's Hosp.; prof., medicine, Creighton Med. Col.; Co.; State; A.M.A.; F.A.C.P.; Phi Rho Sigma.

Riley, Lincoln; Wisner; Gen. Prac.; Uni. of Iowa Med. Col.; county coroner; Capt., M. C., World War; Cuming Co.; State; A.M.A.

Riley, Wilber Kirk; Wisner; Gen. Prac.; Uni. of Nebr.; Capt., M.C.

Rix, Rudolph; Omaha; Gynecol.; b 1870; Creighton Uni., 1899; Douglas Co.; A.M.A.

Roark, Geo. L.; Omaha; Gen. Prac.; b 1881; Northwestern Uni., 1918; Douglas Co.; A.M.A.

Roberts, Douglas H.; Bethany; Gen. Prac.; b 1860; Lincoln Med. Col., 1896; Lancaster Co.

Robertson, Arthur Thos.; DuBois; Gen. Prac.; b 1877; Ensworth Med. Col., 1912; Pawnee Co.; A.M.A.

R'obertson, Geo. Edwin; Omaha; Gen. Prac.; b 1901; Uni. of Nebr.. 1926; Douglas Co. 


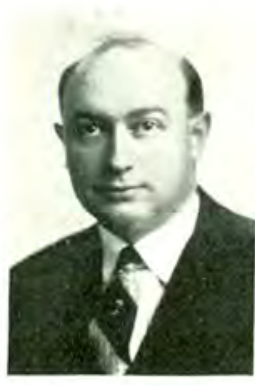

P. ROMONEK

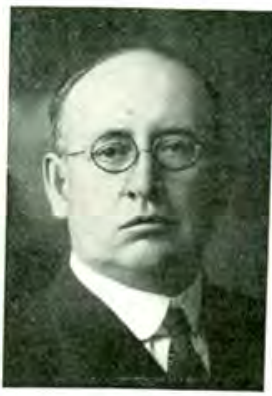

(ᄃ. H. ROOT

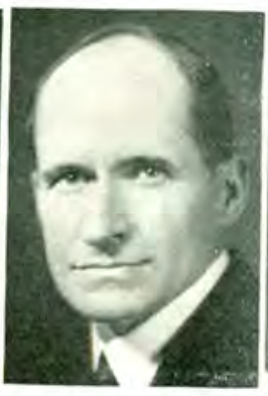

1.. W. RORKE

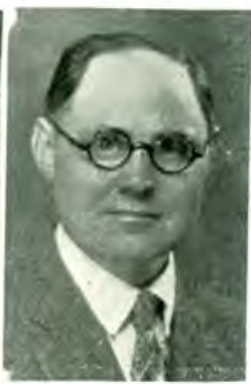

F. $\mathrm{X}$, RUDLOFF

Robertson, Wm. M.; Heldrege; Gen. Prac.; b 1876; Bennett Med. Col., 1001 ; Phelps Co.; A.M.A.

Robinsen, Emmett L.; Lincoln; Gen. Prac.; b 1851; Col. of Phys. and Surg., Keokuk, 1878; Lancaster Co.

Roche, Riley Edward; Sidney; Gen. Prac.; b 1890; Creighton Uni., 1916; Cheyenne Co.

Rodgers, Clarence Edwin; Osmond; Gen. Prac.; Uni. of Nebr. Med. Col.; intern, Methodist Hosp., Omaha; M.R.C.

Roe, G. L.; Beatrice; Gen. Prac.; Louisville Med. Col., 1879; Gage Co.

Roeder, Clyde Augustus; Omaha; Surg.; Yale Uni., M.D., 1907; surg. asst., Mayo Clinic, 1914-1016; asst. prof., surgery, Uni. of Nebr.; chief surg., Wise Hosp. and attg. surg.. University, Clarkson and Immanuel Hosp.; Co.; State; A.M.A.; A.C.S.; numerous articles on surgery.

Rogers, Dan'l. R'; Ragan; Gen. Prac.; b 1855 ; Jefferson Med. Col., 1880; Harlan Co.; A.M.A.

Rogers, Floyd Leslie; Lincoln; Gen. Prac.; b 1895; Northwestern Uni., 1922; Lancaster Co.; A.M.A.

Rolph, Edward L.; Kimball; Gen. Prac., surg.; Uni, of Louisville, Louisville, Ky.; Co.; State; A.M.A.

Romm, Abraham; Omaha; Gen. Prac.; Baltimore Uni., 1902; Douglas Co.; State; A.M.A.

Romonek, Philip; Omaha; Ophthal., Otolo., Laryng., Rhin.; Uni. of Loyalo, M.D.; post-grad., Prague, Vienna, Illinois; asst. prof., oto-laryngol., Uni. of Nebr.; staff, Uni. and Wise Memorial Hesp.; M O.R'C.; Co.; State; A.M.A.; Am. Med. Assn. Vienna (life member); Carter Lake Club.

Root, Benj. A.; York; Gen, Prac.; b 1875; Lincoln Med. Col., 1905; York Co.; A.M.A.

Root, Chas. Henry; Bassett; Gen. Prac.; b 1875; Uni. of Nebr., 1903; Rock Co.; A.M.A.

Rorke, Lee W.; Hastings; Radiol.; Cook Co. Hosp., Chicago; councillor, 10th dist.; Adams Co.; A.M.A.; Rad. Soc.; Ch. of Commerce; Rotary. 
Rosat, Lena Marguerite; Lincoln; Electrotherap.; Chicago; St. Louis; Med. Women's Club; A.I.H.

Rose, Wallace E.; Kearney; Pediat.; Uni. of Illinois; M.C., A.E.F.; Co.; State; A.M.A.; Kiwanis.

Rosenberg, Frank J.; Lexington; Gen. Prac.; b 1850; Eclectic Med. Col., Cincinnati, 1873; Dawson Co.

Ross, Arthur James, Jr.; Minatare: Gen. Prac.; b 1892; Uni. of Nebr, 1918; Scotts Bluff Co.; A.M.A.

Ross, Collin Henry; Omaha; Gen. Prac.; b 1863 ; Uni. of Nebr., 1898; Douglas Co.

Rcss, William Lytle, Jr.; Tacoma, Wash. (formerly Omaha); Urol.; Uni. of Nebr., B.Sc., 1914; Rush, M.D., 1916; Capt., M.C., World War; formerly clin. asst., urol., Uni. ef Nebr. Med. Col.; Co.; State; A.M.A.; Am. Urol. Assn.

Ross, William Lytle, Sr.; Omaha; Gen. Prac., X-Ray and Physiotherap.; Rush Med. Col., 1883; post-grad., Bellevue Med. Col., N. Y., 1887; pres., Omaha Radiol. Seciety; Co.; State; A.M.A.; Radiol Soc. of No. Amer.

Roth, Rollin G.; Curlew; Gen. Prac.; b 1872; Jenner Med. Col., 1900; Cherry Co.

Rowe, Edward W.; Lincoln; Roentgenol.; Uni. of Nebr., B.Sc.; Northwestern, M.D.; post-grad., Cornell; pres., Nebr. State Med. Assn., 1916; bd. education; M.C., A.E.F.; Lancaster Co.; State; A.M.A.; Radiol. Soc. of No, A. (pres., 1927); Am. Ricent. Ray Scc.; Kiwanis.

Reyal, Paul A.; Linceln; Neuro-psychiat.; Uni. of Iowa; post-grad., Johns Hopkins Hosp.; M.C., World War, 2 yrs.; Lancaster Co.; State; Am. Psychiat. Assn.; American Legien; Country Club.

Rubelman, Geo. J.; Tecumseh; Gen. Prac.; b 1854; Rush Med. Col., 1880; Johnsen Co.

Rubendall, Clarence; Omaha; Ophthal., Otolo., Laryng., Rhin.; b 1883; Uni. of Nebr., 1908; Douglas Co.; A.M.A.

Rubnitz, Abraham S.; Omaha; Clin. Path., Internal Med.; Gymnasium of Slutzk, Russia, 1908; Uni. of Nebr., A.B., 1915; M.D., 1916; assoc. instr., med., Uni. o Nebr. Med. Col.; staff, Wise Memorial Hosp. and Mercy Hosp., Co. Bluffs; Co.; State; A.M.A.; Am. Soc. of Clin. Path.

Rudloff, Francis X.; Battle Crcel; Gen. Prac.; Uni. of Nebr.; M.R.C.; Madisen Co.; State; A.M.A.; Commercial Club.

Rundle, Walter Gustavus; Orleans; Gen. Prac.; b 1876; Rush Med. Col., 1906; Harlan Co.; A.M.A.

Rundstrom, David A.; Curtis; Gen. Prac.; b 1878; Uni. of Nebr., 1902; Frontier Co.

Rush, Chas. Henderson; Lincoln; Gen. Prac.; b 1868; Lincoln Med. Col., 1894; Lancaster Co. 
Rush, Weaver Aldus; Beatrice; Gen. Prac.; b 1882; Uni. of Nebr., 1912; specialized in Radiology, 1916; U. S. Army, 1917-1919; Maj., U.S. A.R.C.; Beatrice since 1919; Radoiogist in Hepperlen Clinic and Lutheran Hosp.; Radiol. Sec. N.A.; A.M.A.; Gage Co.

Russell, Ralph Swisher; Omaha; Gen. Prac,; b 1900; Uni. of Nebr., 1925; Douglas Co.; A.M.A

Russum, Benjamin Carl; Omaha; Pathel.; Creighton, M.D.; Rush, postgrad.; prof., pathol. and bacteriol., Creighton; staff, St. Joseph's and Douglas Co. Hosp.; Capt., M.R.C., World War.

Ryan, McDonald; Danbury; Gen. Prac.; Col. of Phys, and Surg. Chicago; M.C., air service; Red Willow Co.; State.

Rydberg, Chas. A.; Litchficld; Gen. Prac.; b 1876; Lincoln Med. Col., 1903 ; Sherman Co.; A.M.A.

Ryder, Frank Dell; Grand Island; Gen. Prac.; Creighton, M.D., 1915; Major, M.C., 2 years; Hall Co.; State; A.M.A.; Rotary.

Ryerson, Edwin Ramah; Lincoin; Gen. Prac.; b 1878; Lincoln Med. Col., 1911; Lancaster Co.

Sachs, Adolph; Omaha; Internal Med.; Creighton Med. Col.; post-grad., Berlin, London, Munich; clinical prof. of medicine, Creighton; past pres., Douglas Co. Med. Soc,; Governor, Nebr. Col. of Phys.; Douglas Co.; State; A.M.A.; Am. Col. of Phys,; Ch. of Commerce; Athletic, Professional Men's Clubs; numereus articles in medical journals.

Sadler, Wm. M.; Hershey; Gen. Prac.; b 1875; Keokuk Med. Col., 1902; Lincoln Co.

Sage, Earl Cuddington; Omaha; Obstet., Gynecol,; Uni. of Nebr.; Washington Uni., St. Louis; instructor in obstetrics, Uni. of Nebr. Med. Col.; secy.treas., Omaha-Douglas Co, Med. Soc.; sccy.-treas,, Mo. Valley Med. Assn.; war service 2 years; Douglas Co.; State; A.M.A.; Am. Col. Surg.; University, Omaha Country Clubs.

Salter, Frank George; Pierce; Gen. Prac.; Trinity Uni. Med. Col., Toronto, Canada; pres., Stanton-Madison-Antelope-Pierce-Knox Co. Med. Soc.; city physician and county board of health; Co.; State; A.M.A.

Salter, Peter Harold; Norfolk; Surg.; Trinity Med. Cal., Toronto (now Toronto Uni.), 1884; L.R.C.P. and S., Edinburgh, Scotland, 1885; post-grad., London and Paris, 1885; Chicago, 1897; New Ycrk 1912; founder, Elkhorn Valley Med. Soc., 1895; pres., Nebr. State Med. Assn., 1910; Major, M.C., 1917-1918; M.S.P.A. and K Co. Med. Soc.; State; A.M.A.; Fellow Am. Col. of Surg.; Am. Assn. Ry. Surg.; Rotary.

Sample, Jos. R.; Omaha; Gュn. Prac.; b 1856; Lincoln Med. Col., 1897; Douglas Co.

Sample, Thos. E.; Omaha; Gen. Prac.; 1904 ; Douglas Co.

Sanders, John Alcysius; Omaha; Gen. Prac.; b 1884; Creighton Uni.. 1911 ; Deuglas Co. 


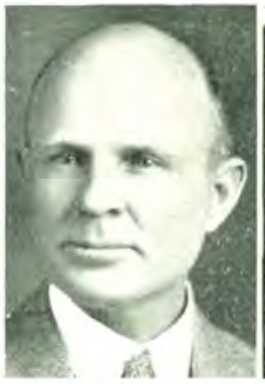

W. A. RUSH

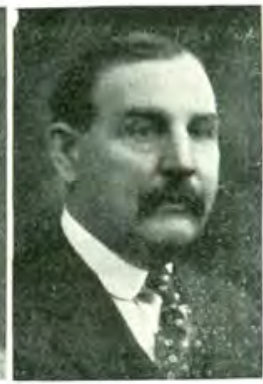

F. G. SALTER

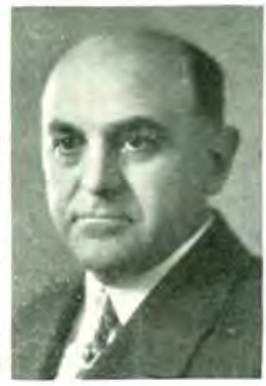

A. J. SANDERS

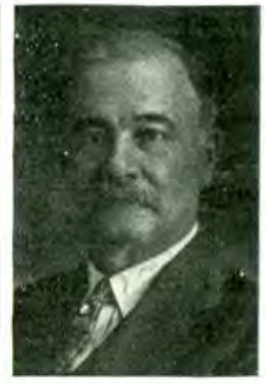

H. W. SAYLOR

Sanderson, David Douglas; Lincoln; Eye, Ear, Nose, Throat; St. Louis; Chicage; Lancaster Co ; State; A.M.A.; Am. Acad. Ophthal. and Otolaryng.; articles cn eye, sar, nose and throat.

Sands, Robt. Lyman; Omaha; Gen. Prac.; b 1804; Uni. of Nebr., 1910; Douglas Co.; A.M.A.

Sandusky, Wm.; Seward; Gen. Prac.; b 1881; Creighton Uni., 1910; Seward Co.; A.M.A.

Sauer, Leslie Earl; Tekamah; Gen. Prac.; b 1805; Uni. of Nebr., 1925; Burt Co.

Saville, Frank N.; Oakdale; Gen. Prac.; b 1875; Uni. of Nebr., 1909; Antelope Co.

Sawyer, Roy. H.; Lincoln; Gen. Prac.; b 1874; Lincoln Med. Col., 1902; Lancaster Co.

Sayler, Harvey Wesley; Brunning; Gen. Prac.; Kansas City Med. Col., M.D., 1897; county coroner, 1914-1915; pres., Thayer Co. Med. Soc., 1922; Vol. fire chicf 18 ycars; Co.; State; Commercial Club.

Sayre, Chas. Edward; Norfolk; Surz.; b 1862; Hering Med. Col., 1894; Uni, of Ill., 1897; Madison Co.

Schafer, Millard F.; Alcxandria; Proctcl.; b 1898; Uni. of Nebr., 1925; Thayer Co.

Schalek, Alfred; Omaha; Dermatol., Syphilol.; Uni. of Prague, Bohemia, M.D., 1890; until 1906, asst. prof., dermat., Rush Med. Col.; prof., Uni. of Nebr. Med. Col.; chief dermat., Uni. Hosp.; staff. Methodist and Swedish Immanuel Hesp.; Deuglas Co.; State; A.M.A.; Am. Dermat. Assn.; Chicago Dermat. Scc.; author Epitome of Skin Diseases (Lea an Febiger, 1905;) Fundcmentals of Dermatology (Lea and Febiger, 1926).

Schaufelberger, Freder ck J.; Los Angles, Calif. (formerly in Hastings for 39 years-retired); Jefferson Med. Col., M.D., 1884; former member, Adams Co.; State; A M.A.

Scheideggar, Elvin Franklin; Omaha; Gen. Prac.; b 189.3; Uni. of Nebr., 1924 ; Douglas Co. 
Schindel, Roscoe E.; Omaha; Gen. Prac.; b 1870; Baltimore Med. Col., 1807; Douglas Co.; A.M A.

Schleier, Frank J.; Omaha; Surg.; b 1876; Creighton Uni., 1904; Douglas Co.; A.M.A.

Schlumberger, Pierre Rhyner; Oakdale; Gen. Prac., Pediat.; Creighton Med, Col.; Madison Co.; State.

Schmitz, Wm. Howard; Omaha; Dermat., Urol.; b 1893; Creighton Uni., 1922; Uni. of Penn. Post-Grad. School, 1923-1925; faculty, Creighton Med. Col.; staff, St. Joseph's Hosp.; Douglas Co.; A.M.A.

Schneider, Albert Leo; Brady; Gen. Prac.; b 1887; Chicago Med. Sch., 1918; Intern, St. Francis Hosp., Colo. Springs, Colo., 1926; Intern, Swedish Mission and Emmanuel Hosp., Omaha; post-grad. course in diagnesis and surg., Grand Island Clin.; Phi Beta Pi.

Schock, Andrew Clarence; Sutherland; Surg.; b 1870; Northwest. Uni., 1907 ; Lincoln Co.; A.M.A.

Showengerdt, Frank Thec dore; Cortland; Gen. Prac,; Marian Sims Beaumont, St. Leuis, Mo.; Gage Co.; State; A.M.A.

Schrock, Jeseph Bensen; Scottsbluff; Internal Med, Oculist; Uni, of Nebr.; Lt., M.C., 1917-1918; secy.-treas., Scotts Bluff Co. Med. Soc., 19261927; Staff. West Nebr. Meth. Hosp.; Scotts Bluff Co.; State; A.M.A.; Lions Club.

Schreck, Robert D.; Omaha; Ortho. Surg.; Cornell Uni. Med. Col.; asst. prof., ortho. surg., Uni. of Nebr. Med. Col.; war service 2 years; Co.; State; A.M.A.; Am. Ortho. Assn.

Schulte, Hermann von Wechlinger; Omaha; Anat.; St. Paul's Sch., Trinity Col., A.B., 1897; Columbia Med. Col., M.D., 1902; post-grad., Presbyterian Hosp., N. Y. C.; Berlin; Dean of Creighten Med. Col.; see chapter on Medical Scheols.

Schultz, Herman H.; Woodmen, Colo.; (Sutton, Neb., 25 years); Tuberc,; Cotner Mcd. Col.; El Paso Co.; Colo. State; A.M.A.

Schwedhelm, Albert Jes.; Creighton; Gen. Prac,; b 1896; Creighton Uni., 1923; Knex Co.; A.M.A.

Schwertley, Fred J.; Omaha; Surg.; Chicago, New York, Montreal; staff, St. Jcseph's, St. Catherine's Hcsp. and Creighton Med. Col.; M.C.; Athletic Club.

Scefield, Henry B.; Atlanta; Gen. Prac.; b 1868; Northwestern Uni., 1896: Phelps Co.

Scctt. Frank Waldo; Omaha; Gen. Prac.; b 1887; Uni. of Nebr., 1910; Douglas Co.

Scoins, Wm. Harcld; Omaha; G:n. Prac.; b 1901; Uni. of Nebr., 1925; Deuglas Co.

Sears, Edgar A.; Decatur; Gen. Prac.; b 1859; Drake Unt., 1888; Burt Co.

Scasongood, Edward R.; (deceased Feb. 27, 1920); Naper; Gen. Prac., Surg.; Crcighton Pharm. Col. Ph.G., 1900; Med. Col., M.D., 1910; Boyd Co.; State; A.M.A. 

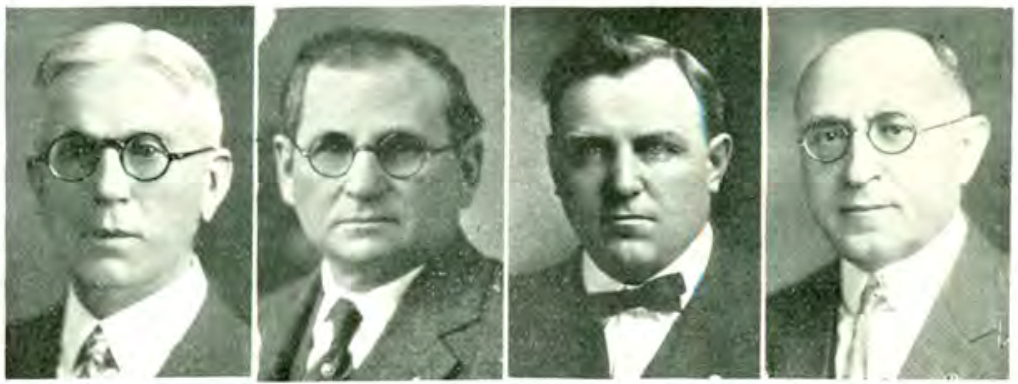

F. SCHAUFEI.BERGER

J. B. SCHROCK

F. T. SCHOWENGERDT

P. SHER

Seasongood, Robert R.; Naper; Gen. Prac.; Creighton Col. of Pharm., Ph.G., 1904; Med. Col., M.D., 1908; Holt Co.; State.

Secord, Dixie C.; Omaha; Gen. Prac.; b 1882; Uni. of West. Ontario, London, 19c6; Douglas Co.

Sedlacek, Frederick A.; Omaha; Gen. Prac,; Uni. of Illinois, Col. of Phys. and Surg., M.D., 1897; asst. health com., Omaha; Am. Red Cross, Siberia; Majcr, M.R.C.; Co.; State; A.M.A.; Veterans of Foreign Wars.

Seely, Henry H.; Harvard; Gen. Prac.; Middlebury, A.B.; Uni. of Vermont, M.D.; intern, Boston City Hosp.; Co.; State; A.M.A.; Am. Assn. Ry. Surg.; Am. Assn. Military Surg.

Selby, Claude A.; North Platte; Gen. Prac,; b 1888; Chicago Col. of Med. and Surg., 1915; Intern, St. Elizabeth's Hosp., 1915-1916; practised in Chicage and member of Health Dept., City of Chicago, 1916-1917; 1st Lt., M.C., 1st Nebr. Field Hesp., June 16, 1917; 166 Field Hosp.; 117 Sanitary Train, Rainbew Division., 18 mo , active service in A.E.F., Germany; North Platte, 1019; Councillor, 11th dis., Nebr. Med. Assn since 1920; Bd. of education; Am. Legion (pest commander, 1924; Alpha Kappa Kappa.

Seng, Gro. E.; Lincoln; Gen. Prac.; b 1882; Lincoln Med. Col., 1908; Lancasier Co.

Sevcrin, Mathew Jos,; Omaha; Gen. Prac.; b 1898; Creighton Uni., 1923; Douglas Cc.

Seward, Guy; Fr.mont; Gın. Prac.; Pittsburgh; St. Louis; vet., SpanishAmerican War, Werld War; Dodge Ce.; Sta.e; A.M.A.; Veterans of Foreign Wars; American Legion.

Seiver, Charlotte P.; Fremont; Dis. of Women and Children; Creighton Med. Ccl.; school phys., Frement; Dodge Co.; State; A.M.A.; Professional, Altrusa and Woman's Clubs.

Sexten, Thes. G.; Frement; Gen. Prac.; b 1843; Washington Uni. of Md., 1871; Dodge Co.

Shank, Frederick William; Oxford; Gen. Prac.; Uni. of Nebr.; Lincoln Med. Col.; Col. cf Phys, and Surgs., St. Louis; Furnas Co.; State; A.M.A.; Repub .Valley Med. Assn. 
Shaw, Lawrence Matt; Osceola; Gen. Prac.; b 1868; State Uni, of Iowa, 1889 ; Polk Co.

Shearburn, Edwin Webster; Fairbury; Gen. Prac.; b 1862; Chicago Hom. Med. Col., 1902; Jefferson Co.

Sheets, Chas. Henry; Cozad; Gen. Prac.; b 1894; Creighton Uni., 1916; Dawson $\mathrm{Co}$.

Shelden-Bitner, Mary Josephine; Fullerton; Gen. Prac.; b 1894; Uni, of Nebr., 1919; Nance Co.

Shepard, Chas. Angell; Omaha; Maj., M.C., U.S.A.; b 1871; Uni. of Buffalo, 1896; Douglas Co.; A.M.A.

Shepard, Chas. Carter; Ord; Gen. Prac.; b 1859; Hahnemann Med. Col. and Hesp. of Philadelphia, 1901: Valley Co.

Shepard, John C.; Rulo; Gen. Prac.; b 1854; Uni. of Louisville, 1876; Richardson Co.

Shepherd, William; Rulo; Gen. Prac., Surg.; Uni, of Nebr. Med. Col.; Lieut., M.C.; Richardson Co. (pres.); State; A.M.A.

Sher, Philip; Omaha; Gen. Prac.; Baltimore Uni.; Jefferson Med. Col., 1903 ; executive council of social agencies; active in Jewish Communal work; Co.; State; A.M.A.

Sherfey, Carl Wagner; Lincoln; Gen. Prac.; b 1876; Lincoln Med. Col, 1917; Lancaster Co.

Shoemaker, Chas. Alonzo; Lincoln; Gen. Prac.; b 18.51; Uni. of Nebr., 1886; Lancaster Co.

Shook, William Edward; Shubert; Gen. Prac.; Omaha Med. Col.; Uni. of IIl. Med. Dept.; past pres., Richardson Co. Med Soc.; ex-vice-pres., Nebr. State Med. Soc.; school bd., 18 years; Richardson Co.; State; A.M.A.

Shikc. William Earl: Gering; Gen. Prac.; b 1884; Cotner Ün1.. 1911: Scot.s Bluff Co, ; A.M.A.

Shramck, Chas, John; Omaha: Gen. Prac.; b 1896; Uni. of Nebr., 1926; Douglas Co.

Shramek, Jcs. M.; Omaha; Gen. Prac., Surg.; Creighton Med. Col., M.D., 1910; staff, St. Joseph's Hosp; M.C., World War; County; State; A.M.A.

Shreck. William A.; Bertrand; Gen. Prac.; Rush Med. Col.; Uni. of Louisville; Post-grad., New York Polyclinic; pres., school beard; Phelps Co.; State; A.M.A.; Republican Valley Med. Assn.

Sidwell, Lawrence T.; Kearney; Tuberculosis; Uni. of Nebr. Med. Col,; State Hcsp. for Tuberculosis; Co.; State; Rotary Commercial and Country Clubs.

Simanek, George F.; Omaha; Surg.; Creighton Med. Col.; chief surg., Creighten Med. Col. and St. Jeseph's Hosp.; Co.; State; A.M.A.; Am. Col. of Surg.; Ch. of Commerce.

Simecck, Jes.; Swanton; Gen. Prac.; b 1860; Rush Med. Col., 1894; Saline Co. 


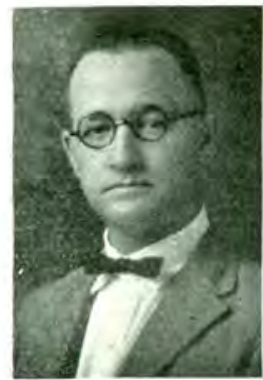

W. E. SHIKE

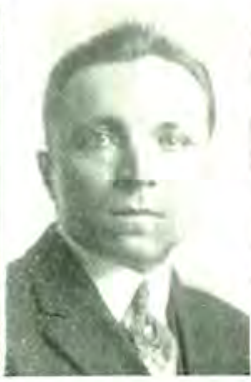

I. M. SHRAMEK

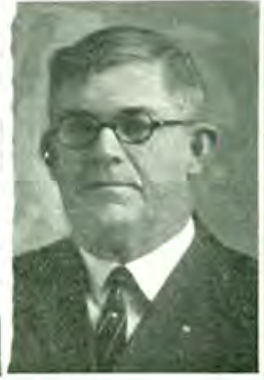

W. A. SHRECK

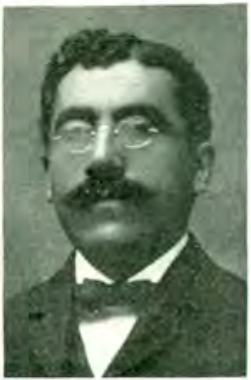

A. H. SISSAKIAN

Simmons, Eugene Earl, Omaha; Gen. Prac.; Uni. of Chicago; Uni. of Omaha; Uni. of Nebr. Med. College; instructor, Uni. of Nebr.; Navy service; med. director, Union Pacific Assurance Co.; Co.; State; A.M.A.

Simon, Frank; Oakland; Gen. Prac.; b 1862; Col. of Phys. and Surg., Baltimore, 1884 ; Burt Co.

Simon, Victor Lamont; Winside; Gen. Prac., Surg.; Chicago Col. Med. and Surg., 1913; N. Y. Polyclinic; New York Post-Grad.; intern, Toledo City Hosp.; M.C., A.E.F.; health officer; Wayne Co.; State; A.M.A.

Simpson, John Emerson; Omaha; Gen. Prac; b 1871; Creighton Uni., 1008; Douglas Co.

Sissakian, Avedis H.; Verdel; Gen. Prac.; Northwestern Uni., M.D., 1897; M.C.,World War; Nebr. since 1901.

Sixta, Lewis Henry; Schuyler; Gen. Prac., Refrac., Proctol.; Chicago Med. Col., 1889; post-grad., Prague, Vienna and Chicago; former pres., Colfax Co. Med. Soc.; former pres., bd. of education; insanity commission; Colfax Co.; State; A.M.A.

Skinner, Almeron O.; Beatrice; Pediat.; Lincoln Med. Col., M.D.; Pediat.; Lincoln Med. Col, M.D., Pediat. at Nebr. Inst. for Feeble Minded; M.C.; State; A.M.A.

Slagle. Charles E.; Alliance; Surg., Diag.; Uni. of Mich., D.D.S., 1896; Keokuk Med. Col., M.D., 1903; post-grad., New York, London, St. Louis; county phys.; staff, C. B. and Q. Ry.; chief, St. Joseph's Hosp., Alliance; 12th dist. counciller; Box Butte Co.; State; A.M.A.; F.A.C.S.; Mo. Valley Med. Assn.; Rotary and Country Clubs.

Slattery, Wm. H.; Lincoln; Gen. Prac.; St. Louis College of Phys. and Surg., 1902; Lancaster Co.

Sleeper, Lawrence Edward; Alliance; Ophthal., Otolo., Laryng., Rhin.; b 1877 ; Northwestern Uni., 1904; Box Butte Co.; A.M.A.

Sloan, Wm. T.; Potter; Gen. Prac.; b 1869; Lincoln Med. Col., 1898; Cheyenne. Co.

Sloss, Geo. A.; DeWitt; Gen. Prac.; Mich. Col. of Med. and Surg., 1899; Clay Co. 


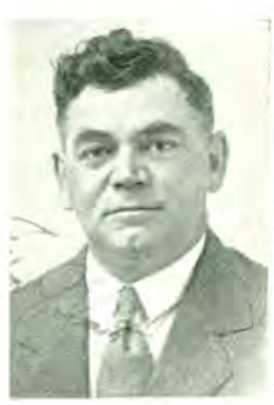

E. J. SMITH

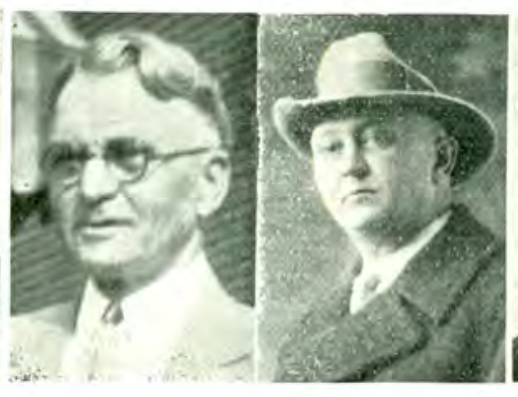

D. J. SMITH

H. C. SMITH

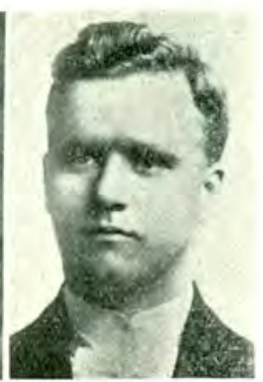

D. LA M. SMITH

Slusser, Frank Banks; Polk; Gin. Prac.; b 1868; Rush Med. Col. 1895; Polk Co.

Smart, Edward N.; Madison; Gen. Prac.; b 1856; Drake Uni., 1884; Madison Co.

Smersh, Otto G.; Omaha; Gen. Prac.; b 1880; Uni. of Nebr.. 1003; Douglas Co.

Smith, Arthur Andrew; Hastings; Surg.; b 1884; Rush Med. Ccl., 1912; Adams Co.; A.M.A.

Smith, Arthur Ernest, Rose-land; Gen. Prac.; b 1873; Uni. of Kansas, 1907; Adams Co.

Smith. Arthur Lawrence; Lincoln; Internal Med.; Rush Med. Col.; Uni. of Vienna; Spanish-American War; Lancaster Co.; State; A.M.A.; F.A.C.P.; Am. Col. Physical Therapy; Missouri Valley Med. Assn.

Smith, Azalia; Omaha; Gen. Prac.; Creighton Med. Col.; Nebr. Woman's Med. Assn.

Smith, Bert A.; Auburn; Ophthal., Otclo., Laryng., Rhin.; b 1888; Clicago Col. of Med. and Surg., 1913; Nemaha Co.; A.M.A.

Smith, Clinton H.; Big Spring; Gen. Prac.; b 1883; Lincoln Med. Col., 1916; Deuel Co.; A.M.A.

Smith, David J.; Osceola; Gen. Prac.; Uni. of Iowa; Omaha Med. Col., M.D., 1898; Polk Co.; State A.M.A.; Cemmunity Club.

Smith, Don La Motte; Wilsonville; Proct., Physical Therap.; Kansas City Uni. Med. Col., 1913; Co.; State; A.M.A.; Am. Col. Phys. Therapy

Smith, Eldon J.; Burwell; Gen. Prac.; Uni. of Nebr., M.D., 1905; postgrad., Chicago and New. York; Advisory board for three countries; Loup Valley; State; A.M.A.; Burl. R.R.; Phi Rho Sigma.

Smith, Hal Clarke; Franklin; Gen. Prac.; Proctologist; Lincoln Med. Col., 1904; post-grad, in Chicago, N. Y. and Europe; Capt, M.C.; Co.; State; A.M.A.; Republican Valley Med. Society; Am. Assn. Railway Surg.

Smith, Harry C.; Kearney; Gen. Prac.; b 1876; Uni. Med. Col. of Kansas City, 1903; Buffalo Co. 
Smith, Izatus L.; Syracuse; Gen. Prac.; Ky. Sch. of Med., 1890; Otoe Co.

Smith, James J.; Heathwell; Gen. Prac.; Creighton Med. Col.

Smith, James W. B.; Albion; Surg.; b 1877; Uni, of Nebr., 1903 Boone Co.

Smith, John G.; Wahoo; Gen. Prac.; b 1859; Ensworth Med. Col., 1891; Saunders Co.; A.M.A.

Smith, Richard Anderson; Omaha; Surg.; b 1889; Creighton Uni., 1915; Douglas Co.; A.M.A.

Smith, Rescoe Likes; Lincoln; Roentgenol.; b 1884; Creighton Uni., 1408; Lancaster Co.

Smrha, V. V.; Milligan; Gen. Prac.; b 1878; Creighton Uni., 1905; Fillmore Co.; A.M.A.

Snipes, James Johnston; Lincoln; Dermat; Tulane Uni. Med. Col., New Orleans; Capt., M.C.

Snowden, Charles Cook; Davenport; Gen. Prac.; Jefferson Med. Col., 1882; Thayer Co.; State; A.M.A.

Snyder, Frank A.; Lincoln; Gen. Prac.; b 1858; Northwestern Uni., 1881; Lancaster Co.

Snyder, Frank Grey; York; Surg.; b 1875; Barnes Med. Col., 1897; York Co.; A.M.A.

Soifer, Isidore; Omaha; Gen. Prac,; b 1894; Creighton Uni., 1926; Douglas Co.

Sommer, Edward Adam; Deshler; Gen. Prac.; b 1871; Starling Med. Col., 1898; Thayer Co.

Sonneland, Arthur M.; Norfolk; Phys., Surg.; Creighton, M.D., 1912; Lt., M.C., A.E.F.

Sparks, Martin L.; Bloomington; Gen. Prac.; b 1861; Louisville Med. Col., 1905; Franklin Co.

Speier, Aaron Schloss; Lincoln; Gen. Prac,; b 1898; Rush Med. Col., 1922; Lancaster Co.; A.M.A.

Spicer. Chas. Ralph; Hastings: Obstet.; b 1870; Rush Med. Col.; 1896; Adams Co.

Spivey, Clark Dwight; Anselmo; Gen. Prac.; b 1885; Uni. of Mich., 1909; Custer Co.; A.M.A.

Spchn, Marion Wilson; Chester; Gen. Prac.; b 1855; Keokuk Med. Col., 1891; Thayer Co.

Sprading, Clarence Richard; Hallam; Gen. Prac.; b 1891; Eclectic Med. Hosp., Cincinnati, 1916; Lancaster Co.

Spradling, Richard Hargrave; Lincoln; Nerv, and Mental Dis, Lincoln Med. Col., Cotner Uni.; dean, med. dept., Cotner Uni., 10 years; faculty, Cotner Uni., 13 years; asst. supt. and head physician, Lincoln State Hosp., 10 years; Lancaster Co.; State.

Srb, Jos. J.; Dwight; Gen. Prac.; b 1887; Creighton Uni., 1915; Butler Co.

Stadden, John C.; Ansley; Gen. Prac.; b 1888; Creighton Uni., 1913; Custer Co. 


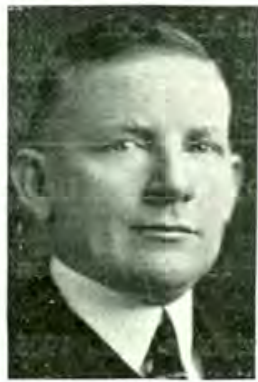

A. M. SONNELAND

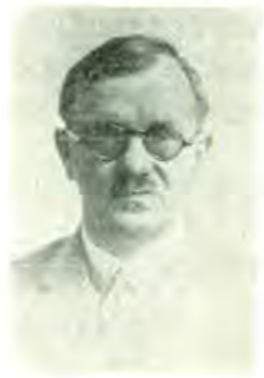

P. H. STAPENBECK

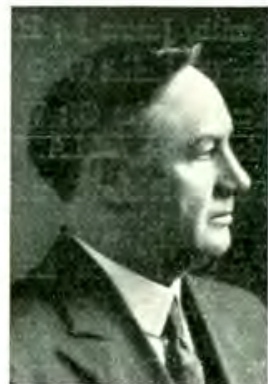

E. C. STEVENSON

Stanard, John Turner; Ulysses; Gen. Prac.; b 1887; Lincoln Med. Col.; 1909 ; Butler Co.; A.M.A.

Stander, Theodere Calvert; Omaha; Gen. Prac.; b 1908; Uni. of Nebr., 1926; Douglas Co.

Stansberry, Don C.; Geneva; Gen. Prac.; b 1860; Col. of Phys. and Surg., Keokuk, 1890; Fillmore Co.

Stanton, Donald Ion; Fort Crook; and Capt., M.C., U.S.A.; b 1890; Ensworth Med. Col., 1917; Sarpy Co.; A.M.A

Stapleton, Harvey Burr; Hickman; Gen. Prac.; b 1890; Creighton Uni., 1917; Lancaster Co.

Staples, Louis Henry; Omaha; Gen. Prac.; b 1853; Eclectic Med. Col., Cincinnati, 1884; Douglas Co.

Stappenbeck, Paul Henry; Brock; Gen. Prac.; Rush Med. Col.; Co.; State; A.M.A.

Stark, Lucien; Norfolk; Gen. Prac.: b 1882; Creighton Uni., 1903; Madison Co.

Starkey, Harvey Lee; Wood River; Gen. Prac.; b 1863; Barnes Med. Col., 1890; Hall Co.

Stastny, Olga; Omaha; Dis. of Women and Children; Uni.. of Nebr. M.D.; overseas service, France, Greese, CxechoSlavagia; Co.; State; A.M.A.; Med. Women's Natl. Assn.; International Assn. of Med. Women; see chapter on Women Physicians.

Stearns, Lester Miles; Kearney; Surg.; Uni. of Ill., Chicago; post-grad., Uni. of Vienna; Buffalo Co.; State; Am. Col. of Surgeons.

Stearns, R'obert James; Omaha; Gen. Surg., Urol.; Uni. of Nebr.; staff, University, Methodist, Immanuel Hosp.; pres., Omaha Council of Churches; M.C., World War.; Co.; State.

Steenberg, Donald Benj.; Aurora; Surg.; b 1890; Uni. of Pa. Sch. of Med., 1913; Hamilton Co.; A.M.A.

Steenberg, Edmond Kenneth; Aurora; Obstet.; b 1893; Harvard Uni. Med. Col., 1918; Hamilton Co.; A.M.A. 
Steenberg, Edmund A.; Aurora; Gen. Prac.; b 1865; Rush Med. Col., 1887; Hamilton Co.; A.M.A.

Steinberg, Abraham A.; Omaha; Gen. Prac., Ophthal.; Uni. of Omaha,

Stejskal, Francis Joseph; Crete; Gen. Prac.; Creighton, M.D., 1906; Lt., M.C.; Saline Co. (pres. 1927); State; A.M.A.

Stevenson, Earle Clement; Gothenburg; Surg.; b 1878; Nebr. Wesleyan, B.Sc., 1899; Uni. of Nebr., M.D., 1903; George Washington Uni., 1906; Sc, asst. in zoology Bur. Animal Industry, Dept. Agriculture, 1903-1904; acting chief of Laboratory, 1905-1906; assoc. with early investigations of hookworm infections in the South; author of various pamphlets on parasitic infections; captain, M.C., U.S.A., 1918; Co.; State; A.M.A.

Stewart, Alfred Jesse; Mitchell; Ophthal., Otolo, Laryng., Rhin.; b 1868; Gen. Med. Hosp. of Chicago, 1896; Uni. of Ill., 1906; Scotts Bluff Co.

Stewart, Benj. F.; Cambridge; Obstet.; b 1869; Keokuk Med. Col., 1905; Furnas Co.

Stewart, Earl M.; Eagle; Gen. Prac,; Col, of Phys. and Surg., Maryland Uni., Baltimore; secy., Chase-Dundy-Hitchcock-Haynes Med. Assn.; chmn., county Red Cross; Chase Co.; State.

Stewart, Edward Russ; Blair; Missouri Med. Col., St. Louis; Co.; State; A.M.A.

Stewart, Willis E; Stratton; Gen. Prac.; b 1875; Central Med. Col. of St. Joseph, 1900; Hitchcock Co.; A.M.A.

Stidworthy, Danl. Brocks; Homer; Gen. Prac,; b 1866; Sioux City; Col. of Med., 1894; Dakota Co.

Stiles, Harry H.; Lincoln; Gen. Prac.; b 1891; Lincoln Med. Col., 1916; Lancaster Co.

Stirling, Margaret Belle Crum; Burton; Gen. Prac.; b 1874; Med. Col. of Ind., 1898; Keyapaha Co.; A.M.A.

Stoakes, Wm. H.; Albion; Gen. Prac.; b 1855; State Uni. of Iowa, 1901 ; Boone Co.

Stoddard, Idelle Lydia Edmands; Omaha; Gen. Prac.; b 1863; Hom. Med. Col. of St. Louis, 1897; Douglas Co.

Stone, James G.; Sutton; Gen. Prac.; b 1882; Creighton Uni., 1906; Clay Co.; A.M.A.

Stonecypher, David Daniel; Nebraska City; Eye, Ear, Nose. Throat; Uni. of Nebr. Med. Col.; post-grad., Chicago Polyclinic; M.C., World War; Otoe Co.; State; A.M.A.; Phi Rho Sigma; Rotary; Am. Legion.

Stoops, James Norval; Scottsbluff; Ophthal, ; b 1881; Fort Worth Sch. of Med., 1906; Scotts Bluff Co.

Strate, Lester Kenneth; Hastings; Surg.; b 1890; Uni. of Colo., 1912; Adams Co.

Stratton, Asa B.; Exeter; Gen. Prac.; b 1861; Central Med. Col. of St. Joseph, 1895; Fillmore Co. 


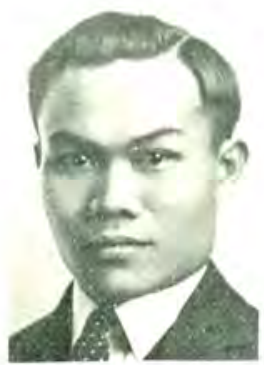

I. P. SUCGANG

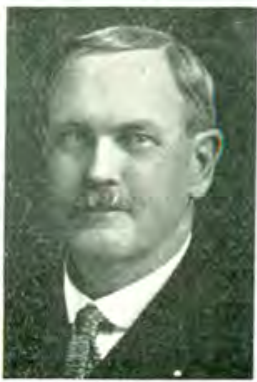

D. A. SUNDBURY

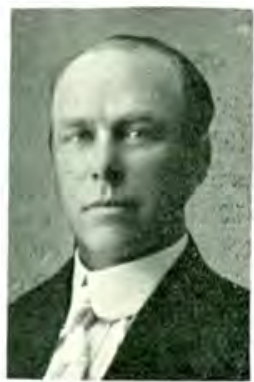

E. M. STEWART

Strciten, Harry H.; Chester; Gøn. Prac.; Cotner Uni; Co.; State.

Strickland, Will Redman; Omaha; Obstet.; b 1874; Natl. Uni. of Arts and Sciences, St. Lcuis, 1912; Douglas Co.; A.M.A.

Strough, George W.; Garland; Gen. Prac.; Omaha Med. Col., M.D., 1896; vet.. Spanish-American War and A.E.F.; Co.; State; A.M.A.

Stuart, Andrew E.; Cedar Bluffs; Gen. Prac.; b 1862; Detroit Col. of Med. and Surg., 1886; Saunders Co,

Stuckey, Royal Scott; Maywood; Gen. Prac.; b 1873; Uni. of Nebr., 1003 ; Frontier Co.

Sturdevant, Charles L.; Atkinson; Gen. Prac.; Eclectic Med. Col., Cincinnati; Co.; State; A.M.A.

Sucgang, Fellipe Parco; Bushnell; Gen. Prac.; Uni. of Washington; Uni. of Nebr. M. D.; Cheyenne-Kimball Co.; State; A.M.A.

Sullivan, G. Webster; St. Edward; Gen. Prac. and Surg.; Uni. of Nebr., M.D., 1908; Nu Sigma Nu; A.M.A.; Elkhorn Valley and Boone Co.; three months in clinics, Continental Europe.

Sullivan. Harry Thes,; Omaha; Gen. Prac.; b 1891; Creighton Uni., 1918; Douglas Co.

Sullivan, John Paul; Omaha; Gen. Prac.; b 1881; Creighton Uni., 1916; Douglas Co.; A.M.A.

Sullivan, M. M.; Spalding; Gen. Prac.; b 1878; Creighton Uni., 1903; Greeley Co.

Sullivan, Stephen W.; Lincoln; Gen. Prac.; b 1862; Marion Sims Col. of Med., 1899; Lancaster Co.

Sumner, Ella Pearson; Hastings; Gen. Prac.; Omaha Med. Col.; Franklin County coroner, 15 years; 10th councillor dist Adams Co.; State; A.M.A.; Republican Valley Med. Assn.; Woman's Club.

Sumney, Herbert Clayton; Omaha; Dermat., and Urol.; Jefferson Med. Col.; post-grad., London, Vienna, Paris; prof., Creighton Med. Col., 1894-1908; Capt. M.C., World War; Co.; State; A.M.A.; Am. Urol.; Am. Col. Surg.; 
Sundbury, Peter Albert; Holdrege; Gen. Prac.; Keokuk Med. Col., U. S. Pension Bureau 30 years; sch. bd. 28 years; surg., C. B. and Q. R. R.; Co.; State; A.M.A.; R'epublican Valley Med. Soc.; Assn. Ry. Surg.; Mo. Valley Med. Assn; R'otary.

Swab; Chas. Marion; Omaha; Ophthal.; b 1890; Creighton Uni., 1916; Douglas Co.; A.M.A.

Swab, Elizabeth; Omaha; Women's Med. Col., Philadelphia; Co.; State; A.M.A.

Swanson, Leenard A.; Hastings; Obstet., Pediat.; Uni. of Nebr.; Adams Co.; State; A.M.A.; Rotary; Ch. of Commerce; M.C.; Am. Legion.

Swartwood, Francis Marion; Adams; Gen. Prac.; b 1890; Lincoln Med. Col., 1915; Gage Co.

Sweney, Edward Edmond; Gilcad; Gen. Prac,; b 1873; Uni. Med. Col. of Kansas City, 1908; Thayer Co.

Swenson, Samuel August; Oakland; Gen. Prac.; Uni. of Nebr., 1908; M.C., Co.; State; A.M.A.; Sigma Xi.; A.A.O.N.M.S.; Ch. of Commerce.

Swift, C. H; Crofton; Gen. Prac.; Uni. of Iowa; Knox Co.; State; A.M.A.

Swoboda, Frank J.; Omaha; Gen. Prac.; b 1880; Uni. of Nebr. 1905; Douglas Co.

Swoboda, Jos. Phillip; Omaha; Gen. Prac.; b 1895; Creighton Uni., 1917 ; Douglas Co.

Swoboda, Louis; Omaha; Gen. Prac.; b 1860; Uni. of Nebr., 1896; Douglas Co.

Talboy, William R.; Newcastle; Gen. Prac.; Sioux City Med. Col.; former state representative; Ry. Surgeon; Co.; State; Sioux Valley Med. Assn.

Talcott, James M.; Omaha; Gen. Prac.; State Uni. of Iowa, 1896; Douglas Co.

Talcott, Norris D.; Greenwood; Sioux City Med. Col.; Co.; State.

Talcott, Vernon Vivaldo; Republican City; Gen. Prac.; b 1891; Uni. of Nebr., 1917; Harlan Co.

Tamisiea, John A.; Gen. Prac.; Creighton Med. Col.; M.C., British E. F.; Co.; State; A.M.A.; Athletic Club.

Tanner, Edward; Battle Creek; Gen. Prac.; Uni, of New York City, 1879; Madison Co.; State; A.M.A.

Tanner, Richard J.; Norfolk; Gen. Prac; b 1881; Lincoln Med. Col., 1909; Madison Co.

Tashjean, Armenag B.; Norfolk; Gen. Prac.; Bennett Med. Col., 1884; Rush Med. Col., 1895; Madison Co.; A.M.A.

Taylor, Chas. E.; Sargent; Gen. Prac.; Lincoln Med. Col., 1906; Custer Co,

Taylor, Guy R.; Hebron; Gen. Prac.; Creighton Uni., 1902; Thayer Co.

Taylor, Harry Allen; University Place; Gen. Prac.; b 1883; Uni. of Nebr., 1908; Lancaster Co.; A.M.A. 


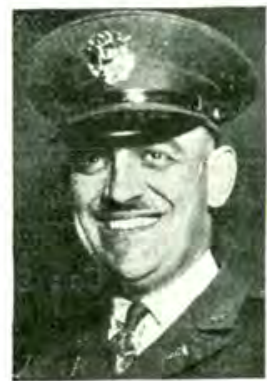

J. A. TAMISIEA

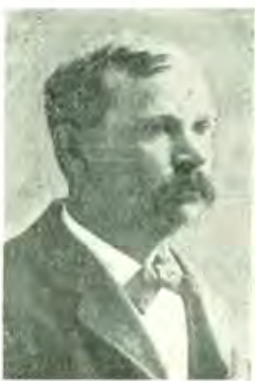

A. H. THOMAS

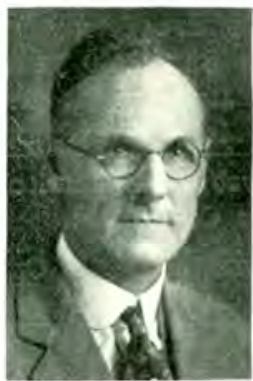

o. S. TOWNSEND

Taylor, Jesse Day; University Place; Gen. Prac.; b 1885; Uni. of Nebr., 1912: Lancaster Co.

Taylet, James R'odolph; Sidney; Surg.; b 1879; Uni. Col. of Med., Richmond; 1907; Cheyenne Co.; A.M.A.

Taylor, James Sherwoed; Fairbury; Surg.; b 1860; Louisville Med. Col., 1888; Jefferson Co.; A.M.A.

Tayior, Willis Harvey; Omaha; Obstet., Gynec.; staff, Methodist Hosp.; assoc. with Dr. A. B. Somers; Douglas Co.; A.M.A.

Tellesen, Chas. Clyde; Wynot; Gen. Prac,; b 1876; Rush Med. Col., 1909; Cedar Co.

Teal, Frederick F.; Lincoln; Eye, Ear, Nose, Throat, Homeopathic Med. Col., Chicago; Polyclinic, Philadelphia; ex-supt., Norfolk Hosp. for Insane; staff, Lincoln Gen. Hosp.; Lancaster Co.; State; A.M.A.; Am. Acad. Ophthal. and Otolaryng.; Nebr. Acad. of Ophthal. and Otolaryng.; Country Club; Ch. of Commerce; medical articles.

Terrell, Price; Omaha; Gen. Prac.; b 1891; Meharry Med. Col. of St. Joseph, 1809; Dawson Co.

Teter, Chas. E.; Lexington; Gen. Prac.; b 1870; Central Med. Col. of St. Joseph, 1899 ; Dawson Co.

Texley, Andrew; Carroll; Gen. Prac.; b 1872; Kansas City Homeopathic Med. Hosp., 1900; Barnes Med. Col., 1905; Wayne Co.

Thies, Edward Martin; Hartington; Gen. Prac.; Uni. of Iowa Med. Col.; M.C., World War; Co.; State; A.M.A.

Thomas, Alfred H. (deceased, 1927); Trenton, 41 years; Penn. Col., Oskaloosa, Iowa; Uni. of Iowa, M.D., 1883; Hitchcock Co.; State; A.M.A.

Thomas, Chas. W.; Barnston; Gen. 1 rac.; b 1883; Nebr. Col. of Med., 1909; Gage Co.; A.M.A.

Thomas, Fred. A.; Aurora; Gen. Pr.c. Lincoln Med. Col., 1905; 1919; Uni. of Nebr., 1923; staff, Uni. of Nebr. 1 4ed. Col.

Thomas, James Walter; Lincoln; Eye, Ear, Nose, Throat; Creighton Med. Col.; post-grad., Chicago, Europe; M.C., A.E.F. Lancaster Co.; State; A.M.A. 
Thomas, James White (deceased, 1908); Weeping Water since 1867; Cincinnati Med. Col.; see chapter on Politics.

Thomas, Martin Low; Palmyra; Gen. Prac.; b 1855; Natl. Uni. of Arts and Sciences, St. Louis, 1881; Otoe Co.

Thomas, Marion U.; Weeping Water; Gen. Prac.; Kansas City Uni. Med. Col.

Thomas, Valorous A.; Nelson; Gen. Prac.; Jefferson Med. Col., 1897; Nuckolls Co.

Thomas, Wm. M.; Edgar; Gen. Prac.; b 1869; Uni. Med. Col. of Kansas City, 1897; Clay Co.

Thompsen, Chester Quay; Omaha; Internal Med.; Harvard Med. Sch., M.D., Uni. of Nebr., B.Sc.; faculty, Uni. of Nebr. Med. Col.; staff, Clarkson, Swedish Mission and University Hosp.; M.R.C.; Co.; State; A.M.A.

Thompson, Irwin L.; West Point; Gen. Prac.; Uni. of Nebr. Col. of Med., B.Sc., 1906; M.D., 1908; Co.; State; A.M.A.; Phi Beta Kappa.

Thompson, John Clark; Lincoln; Gen. Prac.; b 1893; Rush Med. Col., 1919; Lancaster Co.; A.M.A.

Thompson, Jos. H.; Monroe; Gen. Prac.; b 1859; McGill Uni. Fac. of Med., Montreal, 1888; Platte Co.

Thompson, Richard Yoder; West Point; Gen. Prac.; b 1894; Cornell Uni., 1918; Cuming Co.

Thompson, Warren; Omaha; Internal Med.; Creighton. M.D., 1909: Uni. of Chicago, B.Sc.; Rush Med. Col., 1914; faculty, Uni. of Nebr. Med. Col.; staff, University, Evangelical Covenant, Wise Memorial, Clarkson Hosp.; Ontaha, Athletic, Happy Hollow Clubs.

Thomson, James Ellus M.; Lincoln; Ortho. Surg.; b 1889; Rush Med. Col., 1915; Lancaster Co.; A.M.A.

Thomson, John; Syracuse; Gen. Prac.; b 1871; Trinity Med. Col., Toronto, 1902; Otoe Co.

Thomsen, John Henry; Omaha; Gen. Prac.; b 1884; Creighton Pharmacy; Creighton Med. Col., 1914; pres., Nebr. Chapt., International Assn. of Inventors; owner Frederick Hosp.; Douglas Co.; State; A.M.A.; see chapter on Achievements.

Thurston, Eugene Dennis; Burwell; Gen. Prac.; College of Phys. and Surgs., Keokuk, Ia.; Uni. of Nebr. Med. Col., 1884.

Tiesing, Berthold S. G.; Columbus; Gen. Prac.; Uni. of Jena, Germany; Co.; State; A.M.A.; A.A.A.S

Tische, James Matthew; Wood Lake; Gen. Prac.; b 1877; Ky Sch. of Med., 1898; Cherry Co.

Tobkin, J. H.; Lindsay; Gen. Prac.; Creighton Med. Col.; E.V.M.S.; Community Club.

Tomlinson, Charles Creighton; Omaha; Dermat., Syphol.; Uni. of Nebr.; faculty, Uni. of Nebr. Med. Col.; staff, Uni., Douglas Co., Clarkson Memorial and Nebr. Methodist Hosp.; Co.; A.M.A. 


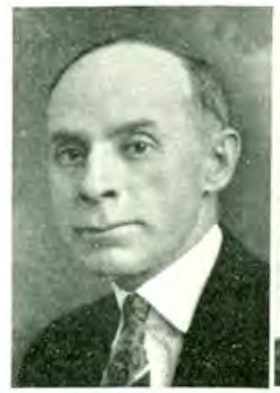

J. R. TAYLOR

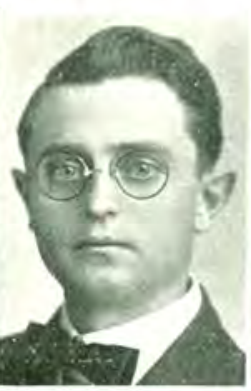

0. M. TROESTER

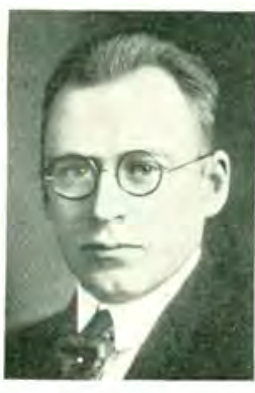

T. W. TORPY

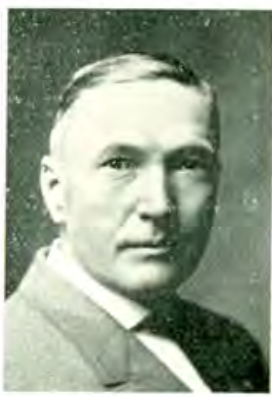

E. TANNER

Torbitt, Wm. F.; Bennett; Gen. Prac.; b 1853; Uni. of Md. Col, of Phys, and Surg., 1903; Lancaster Co.

Tornholm, Frank; Wahoo; Gen. Prac.; Uni. of Nebr.; co. phys.; secy., Saunders Co. Med. Soc.; councillor, 6th dist.; Saunders Co.; State; A.M.A.

Torpy, T. W.; Omaha; Surg.; b 1893; M.D., Neb. Uni. Sch. Med., 1919. M.D., 1893; Dean of Uni. of Nebr. Col. of Med., 1909-1913; see chapter on 1923; Cedar Co.; A.M.A.

Touvelle, Albert R.; Firth; Gen. Prac.; Med. Col. of Ohio, 1882; Larcaster Co.

Towne, Solon Rodney; Omaha; Ptiblic Health (retired); Dartmouth, A.B., 1872; M.D., 1875; health officer, Omaha and state; Co.; State; see chapter on Politics.

Townley, Frank Newcomer; Kenesaw; Gen. Prac.; b 1882; Lincoln Med. Col., 1910; Adams Co.; A.M.A.

Townsend, Adelbert; Minatare; Gen. Prac.; b 1871; Riush Med. Col., 1896; Scotts Bluff Co.

Townsend, Owen Stuart; York; Eye, Ear, Nose and Throat; b 1875; Rush Med. Col., M.D., 1807; surg. at Soldiers' and Sailors' Home, Grand Island, 1911-1913.

Traynor, Raymond L.; Omaha; Internal Med.; Creighton Uni., A.B., M.D., 1919; staff, St. Joseph's Hosp.; Assoc. with Dr. Adolph Sachs; Co.; State.

Triplett, John M.; Grand Island; Gen. Prac,; b 1867; Lincoln Med. Col., 1909; Hall Co.

Triplett, Thos. M.; Milford; Gen. Prac.; Homeopathic Med. Col. of Mo., 1878; Seward Co.

Troester, Otto Michael; Hampton; Gen. Prac.; Lincoln Med. Col.; Co.; State; A.M.A.

Trowbridge, James Allen; Superior; Ophthal., Otolo., Laryng., Rhin.; b 1875; Uni. Med. Col. of Kansas City., 1000; Nuckolls Co.; A.M.A.

Tucker, James C.; Beatrice; Eye, Ear, Nose, Throat; Uni. of Nebr., B.Sc., 1910; M.D., 1912; Uni. of Penn.; staff, Lutheran Hosp. and Hepperlin Clinic, Beatrice; M.C., World War; Am. Legion. 
Turner, James W.; Sterling; Gen. Prac.; Eclectic Med. Col., Cincinnati, 1893; Johnson Co.

Twinem, John S.; Nerth Platte; Gen. Prac.; b 1871; Chicago Hom. Med. Col., 1903; Lincoln Co.

Tyler, Albert F.; Omaha; Roentgenol.; b 1881; Creighton Uni., 1907; staff, Creighton Uni. and St. Joseph's Hosp.; Douglas Co.; A.M.A.; author: Effect of Heavy Radiation in Pleurae and Lungs, J. Radiol., 3:469-475, Nov., 1922; see chapter on Publications.

Tyler, Eugene M.; Auburn; Gen. Prac.; b 1863; Uni. of Tenn., 1885; Nemaha Co.; A.M.A.

Ulrich, Chas. Ferd.; Omaha; Gen. Prac.; b 1889; Creighton Uni., 1916; Douglas Co.; A.M.A.

Updegraff, Howard Leighton; Omaha; Surg.; b 1896; Uni, of Nebr, 1910; Douglas Co.; A.M.A.

Uren, Claude T.; Omaha; Otolo., Laryng., Rhin.; Uni. of Mich.; prof., Creighton Med. Col.; staff, St. Joseph's and Douglas Co. Hosps; Capt., M.C., World War; University and Country Clubs.

Uridil, Jes. E.; Hastings; Gen. Prac.; b 1891; Creighton Uni., 1913; Adams Co.; A.M.A.

Van Camp, Lee B.; Omaha; Urol,; b 1878; Uni. of Nebr., 1898; Douglas Co.; A.M.A.

Vance, John Harris; Omaha; Internal Med.; Jefferson Med. Col., Philadelphia; bd. of education; member executive committee, Uni. Omaha; Co.; State; A.M.A.; University Club; Izaak Walton League.

Vance, V. Verne; Peru; Gen. Prac.; Uni. of Nebr.; contract surgeon; Co.; State.

Vanden, Walter H.; Crookston; Gen. Prac,; b 1872; Med. Col. of Ohio. 1895; Cherry Co.

Vanderhoof, Thomas J.; Scottsblufi: Obstet.; pediat,; Lincoln Med. Col., M.D., 1908; M.C., A.E.F.; staff, Methodist Hosp.; Scotts Bluff Co.; State; A.M.A.; Rotary; Ch. of Commerce

Vanderslice, Augustus M.; Smithfield; Gen. Prac.; b 1868; Nebr. Col. of Med., 1909 ; Gasper Co.

Vandwer, Howard Asberry; Ogallala; Gen. Prac.; b 1895; Creighton Uni., 1921; M.R.C.; Keith-Perkins Co. (pres., 1927) ; State; A.M.A.; Rotary

Van Es, Leunis; Lincoln; Gen. Prac.; b 1868; Uni. of Ala.; 1898; Lancaster Co.

Van Fleet, Edward Amos; Omaha; Gen. Prac.; Uni. of Nebr. Med. Col., 1902; post-grad., London, Berlin; stafi, Immanuel Hosp., M.C., World War; Major, M.R.C.; Co.; State; A.M.A.; Apollo Club.

Van Metre, Richard Thompson; Fremont; Obstet. and Gynecol.; b 1879; State Uni. of Iowa, 1905; Dodge Co.; A.M.A.

Van Osdel, Saml. Arthur; Auburn; Ophthal., Otolo., Laryng., Rhin.; b. 1876; Ensworth Med. Col., 1902; Nemaha Co.; A.M.A. 


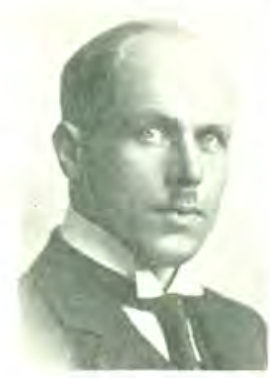

F. W. VENNEMANN

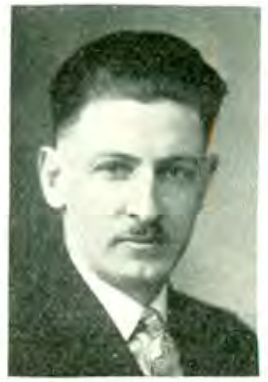

J. G. VETTER

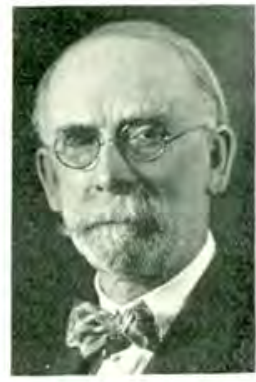

L. C. voss

Venneman, Fritz William; Lynch; Surg.; Bonn, Germany; M.C., World War.; Holt Co.; State;

Verges, Carl J.; Norfolk; Gen. Prac.; Hydro- and Physiotherap.; Germany, B.Sc and A.B., 1904; Hering Med. Col., Chicago, M.D., 1908; mayor, 1912-1914; city phys,; Madison Co.; State; Elkhorn Valley Med. Soc.; A.M.A.

Vetter, James George; Omaha; Gen. Prac.; Creighton Med. Col.; Staff, Creighton Med. Col. and St. Joseph's Hosp.; Lord Lister Hosp.; R.O.T.C.; Co.; State; A.M.A.; Athletic Club.

Vosika, Fred Gilbert; Clarkson; Gen. Prac.; b 1890; Creighton Uni., 1918; Colfax Co.; A.M.A.

Voss, Lorenzo C.; Columbus; Gen. Prac.; St. Louis Homeopathic Med. Col., M.D., 1888; pres., Platte Co. Med. Soc.; staff, Columbus Hosp.; Platte Co.; State; A.M.A.

Vrandenburg. Harry L.; York; Gen. Prac.; b 1853; General Med. Col., 1886; York Co.

Waddell, James Clyde; Beatrice; Gen. Prac,; b 1876; Uni. of Nebr., 1910; Gage Co.; A.M.A.

Wade, John Christopher; Oconto: Gen. Prac.; b 1870; Sioux City Col. of Med., 1897; Custer Co.

Waggener, John A.; Humboldt; Gen, Prac.; Louisville Med. Col., M.D., 1876; Chicago Clinic, 1900; staff, Soldiers' and Sailors' Home, Grand Island, 1915-1917; Richardson Co.; State; A.M.A.

Waggoner, Dickson R.; Hastings; Gen. Prac.; b 1884; Med. Col. of Ohio, 1871; Adams Co.; A.M.A.

Wagner, Geo. L.; Deshler; Gen. Prac.; b 1884; Lincoln Med. Col., 1914; Thayer Co.

Waite, Herbert Harold; Lincoln; Gen. Prac.; b 1868; Uni. of Mich., 1901 ; Lancaster Co.

Walden, Clifford W.; Beatrice; Surg.; b 1874; Creighton Uni., 1896; Gage Co.

Ch. of Commerce, Athletic Club. 
Walker, Arthur Bruce; Lincoln; Gynecol.; Creighton Med. Col.; Chicago Polyclinic, 1913; M.O.R.C.; Knife and Fork; contributions to Am. and German chemistry journals.

Walker, Daniel G.; Lindsay; Gen. Prac.; Col. of Phys, and Surg., Keokuk, Iowa, 1897; health officer; Co.; State; A.M.A.

Walker, David A.; Mullen; Gen. Prac.; b 1881; Keokuk Med. Col., 1902; Hooker Co.

Walker, George H.; Lincoln; Gen. Prac,; b 1881; Keokuk Med. Col., 1902; Hooker Co.

Walker, George H.; Lincoln; Gen. Prac.; Uni. of Nebr.; med. dir., Lincoln Liberty Life Ins. Co.; staif, Lincoln Sanitarium, Bryan Memorial Hosps.; M.C., A.E.F.; Lancaster Co.; State; A.M.A.; Commercial, Kiwanis, Professional Men's, University Clubs.

Walker, Harold Hill; North Platte; Opththal., Otolo., Laryng., Rhin.; b 1892; Uni. of Nebr., 1918; Lincoln Co.

Walker, Henry Chas.; Alliance; Gen. Prac.; b 1892; State Uni. of Iowa, 1925; Box Butte Co.

Walker. Wm. H.; Omaha; Gen. Prac.; Creighton Uni., 1901; Douglas Co.

Waller, Jos. E.; Arapahoe; Gen. Prac.; b 1852; Lincoln Med. Col., 1896; Furnas Co.

Wallin, Stanley Paul; Snyder; Gen. Prac,; b 1899; Uni. of Nebr., 1926; Dodge Co.

Walson, Chas. Moore; Omaha; Major, M.C., U.S.A.; b 1883; Jefferson Med. Col., 1906; Douglas Co.; A.M.A.

Walters, Stanley James: Omaha; Gen. Prac.; b 1902; Uni. of Nebr., 1926; Douglas Co.

Wanek, Anton E.; Loup Cíty; Gen. Prac,; b 1870; Creighton Uni., 1905 ; Sherman Co.; A.M.A.

Warner, Earl Albert; Blue Springs; Surg.; b 1875; Keokuk Med. Col, 1905; Gage Co.; A.M.A.

Warner, Ruth Ashley; Lincoln; Gen. Prac.; Uni. of Nebr.; faculty, Nebr. Wesleyan Uni. and Uni. of Nebr. Agricultural College; staff, Business and Prof. Women; pres., Lincoln Women's Medical Society.

Warner, Sophia E. Alice; Kearney; Obstet. and Gynecol.; b 189.3; Uni. of Nebr., 1923; Buffalo Co.

Warrick, James E.; Valentine; Gen. Prac.; b 1864; Col .of Phys. and Surg., 1888; Cherry Co.

Warta, Jos. J.; Omaha; Gen. Prac,; b 1877; Creighton Uni., 1912; Douglas Co.; A.M.A.

Waters, Theodore Hammond; Norfolk; Gen. Prac., Obstet; Hahnemann Med. Col., Chicago, M.D., 1901; Madison Co,; State; Kiwanis.

Watson, Claude R.; Mitchell; Surg.; b 1884; Ky. Sch. of Med., 1906; Scotts Bluff Co.; A.M.A. 
Watson, Claude; Nebraska City; Gen. Prac.; b 1855; St. Louis Med. Col., 1877; pres., Otce Co. Med. Soc.; pres., bd. of health and sch. bd.; physician to Institute for Blind; an organizer of Nebr. City Hosp.; in Nebraska City since 1881.

Watson. Eli Arthur; Grand Island; Surg.; b 1883; Creighton Uni., 1908; Hall Co.; A.M.A.; Phi. Rho Sigma; Lions

Way, Charles Willard; Wahoo; Gen. Prac.; Uni. of Nebr. Med. Col.., 1917 ; M.C., World War.; M.O.R.C.; pres., sch. bd., 1927; Saunders Co.; State; A.M.A.; Phi Rho Sigma; Lions.

Way, Frank Emerson; Waheo; Gen. Prac.; Boston Uni. Med. Sch., 1880; Saunders Co.; State; A.M.A.

Wearne, Frederick J.: Omaha; Surg.; Creighton Med. Col.; Uni. of Vienna; staff, Lord Lister Hosp.; surg., Omaha Fire Dept.; Co.; State; A.M.A.; Am. Assn. Ry. Surgeons; Field, Athletic Clubs.

Weaver, Ralph L.; Marquette; Gen. Prac.; Uni. of Nebr., A.B., 1923; M.D., 1925; County; State; A.M.A., Phi Chi.

Webb. Adin Hilton; Lincoln; Gen. Prac.; b 1887; Uni. of Nebr., 1916; Lancaster Co.; A.M.A.

Weber, Ernest Owen: Wahoo; Gen. Prac,; b 1876; Rush Med. Col., 1902; Saunders Co.; A.M.A.

Weekes, Thos Lindridge; Nebraska City; Surg.; b 1895; Northwestern surg.. Hillcrest Sanitarium; Am. Col. Phys. Therapy; Rotary.

Weekes, Charles W.; Ord; Surg.; post-grad., Chicago, Rochester; chief Uni., 1921; Otoe Co.; A.M.A.

Wegner, Ernest S.; Lincoln; Pediat,; Uni. of Nebr.; staff, Lincoln Gen. and Bryan Memorial Hosp.; Lancaster Co.; State; A.M.A.; Iowa-Nebr. Pediat. Soc.; Elkhorn Valley Med. Soc.; Rotary Club.

Weidensall, Clara Jean; Omaha; Gen. Prac.; b 1879; Uni. of Cincinnati, 1923; Douglas Co.

Weidman, Earl Vernon; Lincoln; Pediat.; b 1893; Uni. of Nebr., 1919; Lancaster Co.

Weinberg, Jos. Alexander; Omaha; Surg.; b 1894; Uni. of Nebr., 1919; faculty, Uni. of Nebr.; staff, Wise Memorial Hosp.; Douglas Co.; A.M.A.

Welch, Morton Gifford; Edison; Gen. Prac.; b 1888; Lincoln Med. Col., Clay Co.; A.M.A.

Welch, Jos, M.; Sutton; Gen. Prac.; b 1878; Rush Med. Col.. 1902; 1912; Furnas Co.

Welland, Jchann F. E.; Fremont; Gen. Prac.; b 1862; Uni. of Colo., 1904; Dodge Co.

Welsh, Wm. Leonard; Fairbury; Gen. Prac.; b 1872; Kansas Med. Col., 1898; Jefferson Co.

Wengert, Henry C.; Grand Island; Gen. Prac.; b 1875; Sioux City Col. of Med., 1901; Hall Co. 


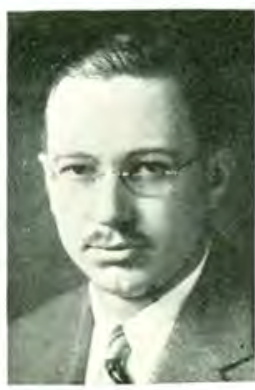

R. I. WEAVER

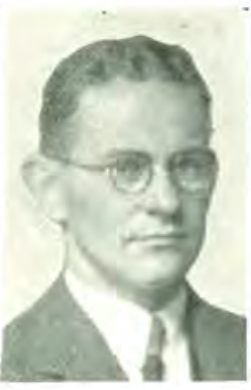

R. H. WHITHAM

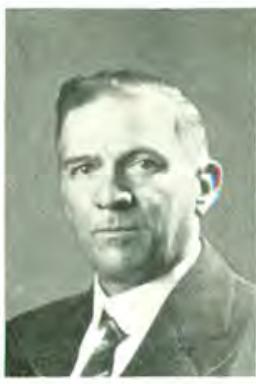

W. S. WIGGINS

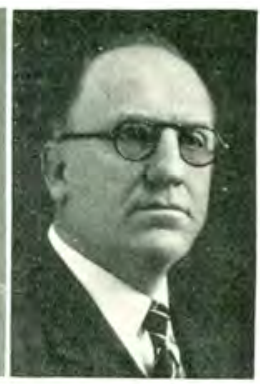

E. O. WILSON

Wertman, Harry J.; Milford; Gen. Prac.; b 1877; Rush Med. Col., 1903 ; Seward Co.

Westerhoff, John G. W.; Carleton; Gen. Prac.; b 1873; Uni. of Nebr., 1899; Thayer Co.

Westfall, Davis H.; Polk; Gen. Prac.; b 1874; Creighton Uni., 1902; Polk Co.

Westover, Raymond Paschal; Plattsmouth; Gen. Prac.; b 1893; Uni. of Nebr., 1918; Cass Co.

Weyer, Stephen Morris; Wakefield; Gen. Prac.; Uni. of Nebr.; Postgrad., Rush Med. and Wisconsin; Pres., Wakefield Welfare Assn.; surg., C. St. P. M. and O, Ry.; U, S. P, H. S. during war.

Wherry, William P.; Omaha; Eye, Ear, Nose, Throat; Uni. of Nebr.; staff, U. P. Ry., C. St. P. M. and O. Ry., St. Catherine's and Immanuel Covenant Hosp.; Omaha-Douglas Co.; (past-pres.); State (librarian 20 years); A.M.A; Am. Acad. Ophthal. and Oto-laryng. (exec. sec.); Am. Oto-RhinoLaryng. Soc.; bd. of examirers for Oto-laryng.; Am. Laryng. Assn.; K. C. Oto-Ophthal. Soc. (hon. member); F.A.C.S.; many papers on oto-rhinolaryngol, subjects, particularly sinus infections.

Weyrens, Jos. Peter; Scottsbluff; surg.; b 1877; Uni. of Minn., 1907; Scotts Bluff Co.

Whitcomb, Glen D.; Omaha; Gen. Prac.; Uni. of Nebr.; Creighton Med. Col.; Long Island Col. Hosp.; M.C., World War; Co.; State; A.M.A.

White, Gec. M.; Ingleside; Gen. Prac.; b 1871; Syracuse Uni., 1896; Adams .Co.; A.M.A.

White, Hosea J.; Ainsworth; Gen. Prac.; Col. of Phys, and Surg., Keokuk, 1885; Brown Co.

Whitehead, Emory I.; Alliance; Eye, Ear, Nose, Throat; St. Louis; post-grad., Chicago; Nebr. State Legislature, 1923; M.C., World War; Co.; State; A.M.A.

Whiteside, Geo. Henry Whitaker; Omaha; Gen. Prac.; b 1855; Harvard Uni., 1882; Douglas Co. 
Whitham, Roy Herbert; Lincoln; Gen. Surg.; Uni. of Nebr., A.B.; Harvard Med. Sch., M.D.; Intern, Mass. Gen. Hosp.; staff, Lincoln Gen. Hosp.; jr. member, Am. Col. of Surg.

Whittier, Geo. N.; Holdrege; Gen. Prac.; Gen. Med. Col. of Chicago, 1888; Phelps Co,

Wiedman, Earl Vernon; Lincoln; Pediat.; Uni. of Nebr. Med. Col,; staff, Bryan Memorial Hosp.

Wiggins, Herbert; Omaha; Gen. Prac.; b 1887; Uni. of Mich., 1913; Douglas Co.

Wiggins, William Shipman; Exeter; Gen. Prac.; Detroit, Mich.; pres., Fillmore Co. Med. Assn.; pres., sch. board; pres., Farmers and Merchants Bank; Fillmore Co.; State; A.M.A.; surg., C. B. and Q. Ry.

Wigton, Harrison Alonzo; Omaha; Nervous and Mental Dis.; Uni. of Nebr.; New York Post-Grad. Sch.; staff, Uni. of Nebr. Med. Col.; asst. supt., Nebr. Med. Col.; asst. supt., Nebr. Hosp for Insane, Lincoln, 2 years; trustee, Hastings Col.; staff, Immanuel, Methodist, Covenant, University Hosp.; Co.; State; A.M.A.; Kiwanis; articles on neurology.

Wilcox, Malcolm B.; Hastings; Eye, Ear, Nose, Throat; Northwestern Uni.; Uni. of Vienna; Co.; State; A.M.A.; Kiwanis; Ch. of Commerce

Wildhaber, Wm. Tell; Beatrice; Gen. Prac.; b 1891; Uni. of Nebr., 1917; Gage Co.

Williams, Benjamin Franklin; Lincoln; Neuro-psychiatrist; Iowa State Med. Col.; Cotner Uni., M.D., 1899; New York Neurological Inst.; Uni. of Pa.; supt., Nebr. State Hosp for Insane, 1908-1918; Capt., M.C.; Major, M.O.R.C., chmn., Bd. of Control of State Institutions; Lancaster Co.; State; A.M.A.; Rotary and Commercial Clubs; numerous articles on neuro-psychiatry.

Williams, Creighton David; Genoa; Gen. Prac.; b 1883; State Uni. of Iowa, 1906; Nance Co.; A.M.A.

Williams, Elijah C.; Bethany; Gen. Prac.; b 1881; Ensworth Med. Col., 1909.

Williams. J. B.; Beaver Crossing; Gen. Prac.; Creighton Uni.; Naval Med. Sch., Washington, D. C.; M. C., U.S.N. ; Seward Co.; State; A.M.A.

Williams, John P.; Lincoln; Eye, Ear, Nose, Throat; Northwestern Uni. Med. Col.; Capt., M.C., World War; Lancaster Co.; State; A.M.A.

Williams, Richard J.; Dunning; Gen. Prac.; Uni. of West. Ont. Med. Sch., London, 1895; Blaine Co.

Willis, James Mediord, McCook; Surg.; post-grad.; Rochester, Minn., Chicago; pres., Republican Valley Med. Soc.; 12th Councillor dist., 1926-1927; staff, St. Catherine's Hosp.; Co.; State; A.M.A.; Am. Radiol. Soc.; Kiwanis.

Wills. Claude LeRoy; Madison; Gen. Prac.; b 1875; Uni. of Nebr., 1906; Madison Co.

Wilmeth, Hal Drummond; Lincoln; Gen. Prac.; b 1891; Lincoln Med. Col., 1916; Lancaster Co.

Wilmeth, Ossie F.; Lincoln; Gen. Prac.; b 1889; Lincoln Med. Col., 1916; Lancaster Co.. 
Wilson, Arthur J.; Omaha; Gen. Prac.; b 1860; Creighton Uni., 1895; Douglas Co.

Wilson, Donald Jasper.; Omaha; Gen. Prac.; b 1899; Uni. of Nebr., 1925; Douglas Co.; A.M.A.

Wilson, Edward O.; Madison; Gen. Prac.; Creighton Med. Col., M.D., 1909 ; Pres., bd. of education; Commander, Legion post.

Wilson, Fredric L.; Stuart; Surg.; b 1890; Creighton Uni., 1917; Holt Co.

Wilson, James S.; Johnson; Gen. Prac.; b 1872; State; Uni. of Iowa, 1896; Nemaha Co.

Wilson, Jeremiah Calfer; Pleasant Dale; Gen. Prac.; b 1860; St. Louis Col. of Phys, and Surg., 1883; Seward Co.

Wilson, Millard Lewis; Falls City; Gynecol.; b 1866; Lincoln Med. Col., 1896; Richardson Co.; A.M.A.

Wilson, Oscar L.; Rushville; Gen. Prac.; b 1857; Med. Col. of Ind., 1879; Sheridan Co.

Wilson, Sydney S.; Nebraska City; (died, 1926); Gen. Prac. and Surg.; Uni. of Iowa, M.D., 1893; post-grad., Chicago Polyclinic; Col. of Phys, and Surg., New York; Vienna, London, Berlin; past vice-pres., Nebr. State Med. Soc.; chief surg., Nebr. City Hosp.; Otoe Co. (pres.); State; A.M.A.; Country Club.

Wilson, William H.; Lincoln; Public Health; Chicago, New York; formerly in state legislature; chief of state Bureau of Health; collaborating epidemiologist to U.S.P.H.S.; Lancaster Co.; State; A.M.A.; Ch. of Commerce; see chapter on Politics.

Wilson, Willis M.; Neriolk; Gen. Prac.; b 1859; Keokuk Med. Col., 1891: Madison Co.

Winston, John S.; Lodge Pole; Gen. Prac.; b 1850; Col. of Phys. and Surgs., Keokuk, 1890; Cheyenne Co.

Winter, Frederic William (retired); Adams; Gen. Prac.; Homeopathic. Med. Dept., Uni. of Iowa.; post-grad., Chicago Hahnemann; Wymore sch. bd.; Am. Inst. Hom.; Nebr. Hom. Med. Soc.

Winterson, Geo. Craggs; Omaha; Gen. Prac.; b 1878; Uni. of Md., 1902; Douglas Co.

Witter, Roy Verner; Bayard; Gen. Prac.; b 1874; Uni. of Nebr., 1900; Morrill Co.; A.M.A.

Woeppel, Fredk. Wm.; Wahoc; Gen. Prac.; b 1876; Creighton Uni., 1905; Saunders Cc.; (deceased, 1928).

Wohl, Michael Gershon; Omaha; Gen. Prac.; b 1 887; Medico-Chirurgical Col. of Philadelphia, 1912; Douglas Co.; A.M.A.

Wohl, Reisa B. Gillerson; Omaha; Gen. Prac.; b 1887; Germany, 1913; Douglas Co.; Women's Med. Soc.

Woicott, Robert Henry;Uni. of Nebr.; Lincoln; (retired); Uni. of Mich., M.D., 1893; Dean of Uni. of Nebr. Col. of Med., 1909-1913; see chapter on Medical Schools. 


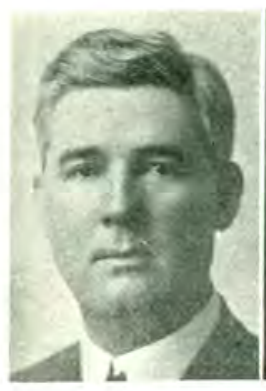

S. S. WILSON

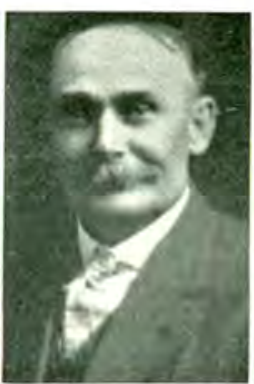

F. W. WINTER

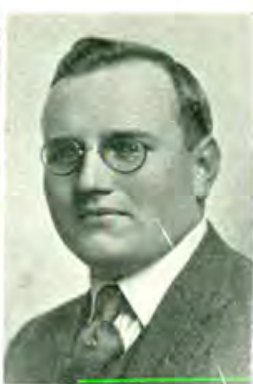

L. L. WOOD

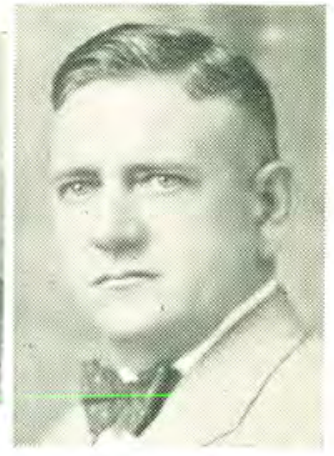

J. M. WOODARD

Wolfe, Katherine B.; Seattle, Wash. (formerly Lincoln); Gynecol., Public Health; Woman's Med. Col., Penn., M.D., 1887; dir. sch. health, Lincoln; Lancaster Co.; Child. Hygiene Sect.; A.M.A.; Council Child Hygiene Sect., A.P.H.A.; public health papers.

Wood, Irving C.; Omaha; Gen. Prac.; b 1857; Jefferson Med. Col., 1880; Douglas Co.; A.M.A.

Wocd, Lyle L.; Lyman; Gen. Prac.; Uni. of Nebr. Med. Col.; M.C., World War.

Wood, Merritt; Tekamah; Roentgenel; b 1877; Barnes Med. Col., 1903; Burt Co.; A.M.A.

Wcod, Walter Scott; Dawson; Gen. Prac.; Marion Sims Med. Sch., St. Leuis, M.D., 1896; post-grad., Harvard, 1017-1918; Holt Co.; State; A.M.A.

Wcodard, James Madiscn; Aurora; Gen. Prac,; b 1881; Uni. of Nebr.; Hamilton Co.; A.M.A.

Woodin. John G.; Grand Island; Gen. Prac.; b 1883; Uni. of Kans., 1908; Hall Co.

Woodrufi, Relland Cecil; Grand Island; Rcentgencl.; b 1888; Rush Med. Col., 1013; Hall Co.; A.M.A.

Woods, Fred J.; Linccln; Gen. Prac,; Lincoln Med. Col., 1898; Lancaster Co.

Wcods, Fred J.; Lincoln; Gen. Prac.; Lincoln Med. Col., 1898; Lancaster $\mathrm{Co}$.

Weeds, Royal; Lincoln; Gen. Prac.; b 1864; Rush Med. Col., 1889; Lancaster Co.

Woodward, James Mac.; Lincoln; Ophthal., Otolo., Laryng., Rhin.; b 1890; Uni. of Pa.. 1915; Lancaster Co.; A.M.A.

Woolis, Asa Lee; Alliance; Gen. Prac.; b 1874; Uni. Med. Col. of Kansas City, 1900; Box Butte Co.

Worthman, Edward H.; Louisville; Gen. Prac.; b 1875; Creighton Uni., 1900; Cass Co.; A.M.A. 
Wray, Frank Horace; Omaha; Gen. Prac.; b 1849; Col. of Phys. and Surg., Keokuk, 1887; Douglas Co.

Wright, Frank Taylor; Lincoln; Gen. Prac.; b 1875; Lincoln Med. Col., 1907; Lancaster Co.; A.M.A.

Wycoff, Ray Sheppard; Lexington; Surg.; b 1889; State Uni. of Iowa, 1919; Dawson Co.; A.M.A.

Yager, Wm. S.; Nebraska City; Gen. Prac.; b 1868; Bennett Med. Col., 1894; Otoe Co.

Yoder, Charles A.; Elm Creek; Gen. Prac.; Omaha Med. Col.; Lincoln Med. Col.; M.C., A.E.F.; Major, M.O.R.C.; Buffalo Co.; State; A.M.A.

Young, Alexander James; Omaha; Gen. Prac.; b 1890; Uni. of Nebr., 1915 ; Douglas Co.

Young, Frank B.; Gering; Kansas City Med. Col., M.D., 1900; Scotts Bluff Co.; (pres.); State; A.M.A.; staff, West Nebr. Meth. Hosp.; Lions. original studies in paleopathology; see chapter on Achievements.

Young, George Alexander; Omaha; Neuro-psychiat.; Chicago Hom. Med. Col., M.D., 1900; post-grad., London, Switzerland, New York; faculty, Uni. of Nebr. Med. Col.; staff, State Hosp. for the Insane, Lincoln and Norfolk, 1901-1908; Douglas Co. Insanity Board.; Co.; State; A.M.A.; Am. Psychopathological Assn.

Young, Glyndon A.; Norfolk; Pediat., Obstet; Uni. of Iowa, M.D.; city and county physician; Madison Co.; State; A.M.A.; Elkhorn Valley Med. Soc.; Kiwanis, Country, Gun Clubs; Y.M.C.A.

Young, James Melvin; Ingleside; Gen. Prac.; b 1869; Creighton Uni., 1898; Adams Co.

Young, Marcia Louise; Omaha; Gen. Prac.; b 1887; Hahnemann Med. Col. of the Pacific, 1916; Douglas Co.

Zarbaugh, Guy Frederick; Dalton; Gen. Prac.; Uni. of Nebr. Med. Col., 1925 ; Cheyenne Co. (secy.); State; A.M.A.

Zellers, Moses Theodore; Hooper; Ophthal., Otolo., Laryng., Rhin.: b 1861; Western Reserve Uni., 1889; Dodge Co.; A.M.A.

Zemer, Stanley Gillum; Lincoln; Ophthal., Otolo., Laryng., Rhin.; b 1883; Rush Med. Col., 1913; Lancaster Co.; A.M.A.

Ziegler, Chas. H.; Vesta; Gen. Prac.; b 1870; Starling Med. Col., 1894; Johnson Co.; A.M.A.

Zimmerer, Charles G.; Nebraska City; Gen. Prac.; Creighton Med. Col.; Otoe Co,; State; A.M.A.

Zimmerman, Charles Francis; Naper; Gen. Prac., Surg.; b 1866; Sioux City, Iowa.; Omaha; Chattanooga, Tenn., M.D., 1898; government phys. to Fioux Indians from 1904; Boyd Co.; State; registered pharmacist. 


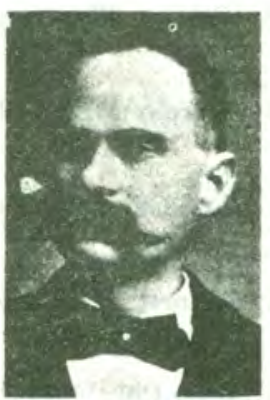

Zimmerer, Edmund Geo.; Lincoln; Gen. Prac.; b 1889; Creighton Uni., 1911; Lancaster Co.; A.M.A.

Zoerb, Edward Franklin; Scottsbluff; Gen. Prac.; Rush Med. Col.; Uni. of Minn.; Scotts Bluff Co.; State; Country Club.

Zulauf, Walter Christian; Belden; Gen. Prac.; b 1893; Uni. of Nebr., 1923; Cedar Co.; A.M.A.

C. F. ZIMMERMAN

\section{DIRECTORY OF NEBRASKA PHYSICIANS}

Notes and Errata

For name variants, see the Personal Name Index.

pp. 549-662 For a complete record of Nebraska physicians, see American Medical Directory . . . a register of physicians . . . Chicago; Press of the American Medical Association, 1906 -

p. 554

"Baldwin, Francis J." should read "Baldwin, Francis J.; Chadron; birth - 1867; Physio-Med. Col., Indianapolis, Ind.; 1901." Delete all other references to "Baldwin, Francis J."

p. 582

Add "Flippin, George Albert: Stromsburg: birth - 1868: University of Illinois College of Medicine:1900:licensed 1908."

p. 652 Delete entire six th line. 
Only broad subject categories in the field of medicine are identified. The index does include locations, organizations and inst itutions. In the case of variant spelling or name changes, the spelling or identity current in 1928, has been used as the main entry.

Oher usages are indicated by a.c. a. (i.e. also cited as) or by a "see" reference. Ilustrations are noted (e. g. p-489).

A.

ADAMS

148,659

ADAMS COUNTY

$91,119,138,146,392$.

$559,563,566,570,572$.

$577,580,582,587-589$,

$599-602,606,608,615$,

$621,625,630,636,544$,

$645,647,648,649,652-$

$654,657,661$

Medical Society, 393

ADDISON'S DISEASE

225, 226

AINSWORTH

$34,36,41,121,125$,

$146,186,321,502,580$, $605,633,634,657$

Hospital, 502

ALBION

$146,186,362,502,554$. $572,575,614,645,647$ Hospital, See Physician's Hospital

ALEXANDRIA

466, 624, 639

ALLEN

186,587

ALLIANCE

$91,120,146,147,149$ 。

$370,371,481,503,504$,

$555,579,589,611,643$,

$655,657,860$

Hospital, See St. Joseph's

ALMA Bospital, Alliance

$146,504,555,574,602$

Hospital, 504

ALPHA CHI

ALVo

of Phi Delta Epsilon, 388

621

AMERICAN

College of Physicians, Nebraska Section, 372

College of Surgeons, 527; a. c, a. American College of Surgery

Medical Association, 56, $61,104,106,210,377$

Surgical Association, 376

Surgical Institute, 60,

Cited as Omaha Medical and Surgical Institute; See notes following p. 76

AMHERST

593

AMPUTATION

34

ANATOMY

$260,290,304$

ANESTHESIA

90
ANSELMO

$421,600,645$

ANSIEY

$419,420,422,589,593$, 645

ANTELOPE COUNTY

$146,377,394,437,438$.

$569,570,582,587,588$,

$590,610,639$

ANTISEPSIS

$95,153,213,227$

ANTITOXIN

97

APPENDICITIS

90,107

ARAPAHOE

$38,504,560,618,655$

Hospital, See Republican Valley Hospital

ARCADLA

$128,148,363,570,593$, 605

ARCTIC EXPEDITIONS

See Expeditions, Arctic

ARLINGTON

$362,423,571$

ARNOL.D

$419,422,504,576$

Hospital, 504

ARTHUR COUNTY

146,634

ASEPTIC SURGERY

See Antisepsis

ASHLAND

$70,74,75,148,149$.

$150,193,203,256,269$,

$319,321,352,360,368$.

$405,553,566,603,627$

ASHTON

555

ATKINSON

$323,504,505,575,613$, 648

General Hospital, 504

Senitarium, 505

ATLANTA

$$
640
$$

AUBURN

$137,147,148,150,152$. $242,453,505,558,568$, $597,609,610,632,644$, 653

Hospital, 505

AURORA

$85,87,119,146,147$, $148,152,156,193,200$. $371,505,569,591,597$. $646,647,650,660$

Hospital, 505

AVOCÁ

146, 408, 560

AXTELL

187, 505, 506, 559, 578

Hospital, See Bethpage Mission
AYR

91,587

B.

BACTERIOLOGY

216,231

BANCROFT

$21,25,72,412,583,592$

BANNER COLNTY $148,395,627$

BARADA

451,594

BARNSTON

650

BARTLEY

148

BASSETT

147, 636

BATTLE CREEK $362,412,439,637,649$

BAYARD $583,632,634$

BEATRICE

$127,139,146,184,186,187$, $193,194,199,207,321,371$.

$372,450,533,553,560,561$. $563,565,567,570,579,595$, $600,607,612,625,628,630$.

$634,643,652,654,658$

Hospital, 507, See also:

Lutheran Hospital, Beatrice:

Mennonite Deaconess Home

and Hospital; Beatrice

Sanitarium; institute.for

the Feeble-Min ded

Sanitarium, 507, p-507

BEAVER CITY

$156,175,176,197,237,426$.

504, 509, 509, 569, 587, 603

Hospital, 508

BEAVER CROSSINC

$148,574,658$

BEEMER

112, 441, 509, 570, 629

Hospital, 509

BELDEN

662

BELGRADE

89,633

BELL CREEK

265

BELLE FONT AINE

2, 9,12

BELLEVUE

$23,33,45,46,65,76,77$,

$78,87,91,402,405$

College, 76, 269

Hospital, New York, 57

BELLWOOD

$565,613,616$

BELVIDERE

551

BENEDICT 


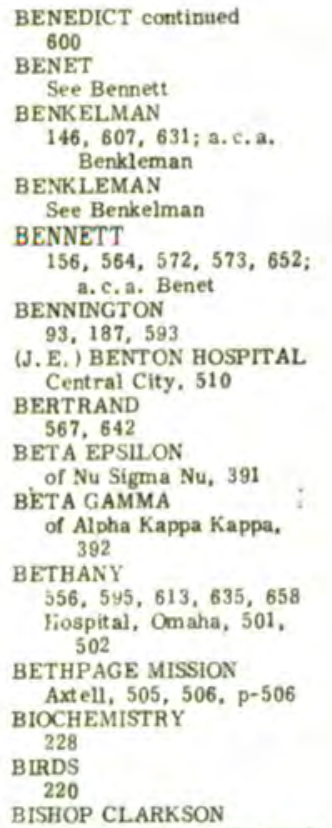

Memorial Hospital, Omaha, $58,97,171,225,268$, 275, $380,419,478$. $481-483, p-482,593$, $609,619,624,636$, 651

BLAINE COUNTY $146,395,439,593,658$ BLAIR

$21,71,84,147,150$,

$193,322,323,362,499$, $509,556,580,594,602$, $605,621,624,647$ Hospital, 509

BLOOMFIEL.D $122,123,193,199,608$, 617

\section{BLOOMINGTON}

$146,615,645$

BLUE HIL.L $473,605,626$

BLUE SPRINGS $193,522,655$

BLUE VALLEY HOSPITAL Hebron, 516

BONE AND BONES $219,222,223$

BOONE COUNTY

$146,395,569,572,573$, $575,593,600,633,645$, 647,648

Medical Society, 648

BOX BUTTE COLNTY

$146,396,555,559,579$ $589,599,611,612,643$. 655,660

BOYD COUNTY
BOYD COUNTY continued $30,146,396,556,591$. $597,604,622,640,661$

BOYD'S OPERA HOUSE 266

BOYS TOWN

See Father Flanagan's Boys Home

\section{BRADSHAW} 620

BRADY 640

BRAINARD 634

BRAYTON 193

BRIDGEPORT

$146,551,627$

BROADW ATER 504,627

BROCK 553,646

BRODSTONE Memorial Hospital, Superior, 537, p-537, 538

BROKEN BOW

$31,86,87,93,141,146$, $147,149,151,156,186$, $193,252,322,368,414$, $415,418,420,421,422$, $509,565,598,599,603$. $605,610,628$

Hospital, 509

BROWN COUNTY $146,396,502,558,580$, $606,633,634,657$

BROWNELL HALL Girls' School, 150

BROWNSVILLE See Brownville

BROWNVIL.LE $47,50,81,83,85,175$, $316,455,597$, a. c. a. Brownsville

BRUNSWICK 569

BRYAN Memorial Hospital, Lincoln, $142,481,521,594$. 621,656

BUDAPEST 114 , a. c, a. Buda-Pesth BUFFALO COUNT Y $87,146,555,557,564$, $573,583,589,590,593$. $599,606,607,609,613$, $618,631,633,644,646$, 655,661 Medical Society, 606

BUREAU OF HEALTH 143,144

BURKETT

509,633

Hospital, See Nebraska Soldiers' and Sailors' Home Hospital

BURLINGTON RAILROAD $61,80,108,119,124$. $131,139,351,399,400$ BURT COUNTY

$25,56,119,146,249$,
BURT COUNTY continued $397,557,589,610,620$, $631,639,640,643,660$ BURTON 647

BURWELL $146,567,644,651$

BUSHBURY 408

BUSHNEL.1. 250,648

BUTLER COUNTY $146,397,549,553,556$. $563,565,575,598,609$, $613,615-617,645,646$

BUTTE $146,193,556,591$

BYRON 467,572

\section{C.}

\section{CAIRO}

574,628

CAISSON DISEASE See Decompression Sickness

CALLAWAY $124,418,562,571616$, a.c. a. Gaflaway

CAMBRIDGE $369,426,510,600,618$. 647

Hospital, See Republican Valley Hospital, Cambridge CAMP COUNCIL BLUFFS 9, 11

CAMP DODGE 169

CAMP METTITT 169

CAMP MISSOURI 1, 3-5, 9, 477

CAMP RECOVERY 9

CARROLL $193,470,560,592,650$

CASS COUNTY $125,146,184,317,397$. $399,402,408,409,560$. $574,575,580,586,589$, $602,604,608,612,614$. $615,621,657,660$

Medical Society, 398

CEDAR BLUFFS $558,588,648$

CEDAR COUNTY $70,146,199,410,565,586$. $599,601,610,650,652$. 662

CEDAR RAPIDS $395,573,633$

CENTRAL CITY $37,93,94,122,123,146$, $148,157,193,442,510$, $557,560,583,586,596$, 597,608

Hospital, See J. E. Benton Hospit al

CENTRAL HOSPITAL Omaha, 101, 481

CERESCO 
CERESCO continued 625

CHADRON

$146,554,557,572,586$. $588,612,629$

CHAMBERS 586,627

CHAPMAN 598

CHAPPELL $92,146,568,626,628$ CHASE COUNTY $92,125,146,410,580$, 647

CHERRY COUNTY

$146,410,569,607,637$, $651,653,655$

CHESTER $466,621,648$

CHEYENNE COUNTY $93,146,411,550,577$, $606,607,615,636,643$, $648,650,659,661$

CHIEF BLACKBIRD 29

CHILD SAVING INSTITUTE Omaha, 275

CHILDREN'S HOME

(Immanuel), Omaha, 486

CHII D'S HOSPITAL \& HOME

(Clarkson), Ornaha, 58, 268,478 , a. c. a. Chúdren's Hospital

\section{CHLOROFORM} 51

CHOLERA $29,33,46,52$

CITY

Detention Hospital, Omaha, 502

Emergency Hospital, Omaha, 501

CLARKS

123,574

CLARKSON

600,654

Hospital, See Bishop Clark-

CLATONIA son Memorial Hospital

572

CLAY CENTER

$146,585,606$

CLAY COUNTY

$146,411,552,553,556$, $565,569,585,587,600$, $606,610,626,643,647$, 651,656

Medical Society, 552 . 606

CLAYTON

612

CLEARW ATER

557

CODY

569

COLERIDGE

573

COLFAX COUNTY

$146,559,577,596,600$.

$604,612,643,654$

Medical Society, 643

\section{COLLEGE VIEW}

$189,193,249,510,609$

Sanitarium and Hospital, 510

COLON

611

COLUMBUS

$70,87,90,120,147,149$ $157,324,370,371,481$. $511,550,564,578,603$, $609,615,616,617,620$, $623,651,654$

COLUMBUS HOSPITAL 481, 511, p-511, See Also: St. Mary's Hospital, Columbus

COMMUNITY CHEST 500

COMMLNITY HOSPTT AL Nebraska City, 526 Newman Grove, 528

COMSTOCK 422, 531,557

CONKLING HALL 56, 288

CONNELL MASK $102,158,159,254,304$

COOK

$33,83,250,568$

COOLIDGE HOSPITAL

Palmer, 531, p-532

CORTLAND

640

COTNER

Medical College, See Lincoln Medical College

University, See Lincoln Medical College

University Medical depart ment, See Lincoln Medical College

COUNCIL BLUFFS

lowa, 1, 9, 12; 20, 32 . $47,51,89,115,179$, $187,202,255,264$, $265,268,269,300$, $360,364,365,373$ 498

COUNTY HEALTH OFFICERS 146,147

COUNTY HOSPITAL COZAD

See Douglas County Hospltal

$121,582,642$

COZZENS HOT EL

66,479

CRAB ORCHARD

575

CRAIG

631

CRAWFORD

$131,150,193,195,511$. 591,635

Nebraska Hospital, See R. L. Ivins Hospital

(W. H. ) Crawford Hospital, Rushville, 535, p-534

\section{CREIGHTON}

$146,362,561,563,592$, 640

College of Medicine,
CREIGHTON cont inued

College of Medicine cont inued, See Creight on Iniver sity School of Medicine

Dental College, 223

Medical College, See Creightor University School of Medicine

Memorial Hospital, 296, 298

Memorial School of Nursing. 143

University, 268, 293, 298 , $301,+54,550,553,555$. $558,559,563,564,565-$ 587, 589-582, 594-601, 603-607, 609-611, 613, $615-618,621-626,629-$ $632,634-636,638-643$, $645-649,652-66$ ?

University School of Medicine, $68,95,99-101,105,107$ $108,111,112,114,116$. $123,125,126,142,159$. $207,219,220,222,223$, $225,226,230-232,236$, $237,242,246,249,252$. $254,268-270,273, \mathrm{p}-290$ 。 $292,293,296,298,301$. $302,304,308,311,332$. $378,384,385,387,407$, $413,550,551,553,555$ 607, 609-618, 620-636, $638-662 ;$ a. C.a. The John

A. Creighton Medical

College; The John A.

Creighton Medical College of Creighton Eniversity, Creight on liedical College, Creight on College of Medicine

\section{CRESTON} 625

CRETE

162, 459, 460, 563, 569, $590,627,632,647$

CROFTON

$148,613,648$

CROOKSION 552,653

CULBERTSON 584,604

CUMENG COLNTY

$146,412,570,583,592$, $602,604,635,651$

CURTIS

$124,146,565,615,637$

CUSTER COUNTY

$31,86,93,124,146,255$,

$256,414,420,422,562$,

$565,571,575,577,583$.

$589,594,596,599,600$,

$603,610,616,628,645$.

649

Medical Society, 93, 414, 415,583

CXECHO SL.AVAGIA

See Czechoslovakia

CZECHOSLOVAKLA

382; a.c. a. Czecho-Slovakia; CxechoSlavagia 
D.

\author{
DAKOTA CIT Y \\ $70,146,616$ \\ DAKOTA COUNTY \\ $146,198,470,607,616$. \\ 623,647 \\ DALTON \\ $411,511,661$ \\ Hospital, See Pioneer \\ Memorial Hospital \\ DANA COLLEGE \\ 498 \\ DANBURY \\ 638
}

DANISH LUTHERAN

Hospital, Omaha, 498, p-498, 499

DANNEBROG 628

DAVENPORT $81,120,121,466,577$, 620,645

DAVID CITY

$146,371,512,556,563$, 617,635

Hospital, 512

DAVIS COUNTY 622

DAWES COUNT Y

$146,557,572,586,591$, $598,629,635$

DAWSON COUNTY

$31,146,424,557,574$. $577,582,599,602,619$, $626,632,633,650,661$ Medical Society, 633

DAYKIN 596

DEACONESS' HOME

Omaha, 486

DEAF AND DUMB

Institute. Onaha, 53, 62

DECATUR

$24,119,561,610,640$

DECOMPRESSION SICKNESS 301

DENTAL INSTRUMENTS 224,254

DENT ISTRY Operative, 224

DENTON 599

DEPARTMENT OF PUBLIC WELFARE.

$$
515
$$

DERMATOLOGY

101

DESHLER

$466,467,588,612,633$, 645,654

DE SOTO

71

DEUEL COUNTY

$146,424,425,626,628$, 644

DEWEESE 569

DILLER

574

DIPHTHERIA
DIPHTHERIA cont inued $51,58,146,212,213$

DLXON 629

DIXON COUNTY

$146,470,568,573,574$, $578,581,587,600,605$, $610,625,629$

DOCTOR'S WIVES' CLUB 378

DODGE

423, 601

DODGE COUNTY

$72,125,146,423,556$, $562,564,571,573,574$. $581,591,595,601,617$ $620,622,628,631-633$. $835,641,653,655,656$, 661

Medical Society, 631

DONIPHAN

598,620

DORCHEST ER

$147,150,170,589,627$

DOUGLAS

595

DOUGLAS COUNTY

$43,52,66,68,71,72$,

$93,131,146,157,287$,

$335,549-551,553-561$,

563-591, 593-651, 653,

$655-661$

Hospital, Omahs, 115. $273,275,379,479$, 483, p-483, 484, 603 , $605,607,623,638$, 653

Medical Society, 68, 71, $329-331,544$

Medical Society Library, 270

Medico-Legal Association, 333,368

Poor Farm, 275

DUNBAR

585

DUNCAN

57

DUNDY COUNTY

$146,425,607,631$

DUNNING

$146,593,658$

DWIGHT

645

DYSENT ERY

65

B.

EAGLE

$125,408,422,647$

EDISON

656

EDDYVILLE

602

EDGAR

600,651

EDUCATION

Medical, See Chapter on Colleges, 259-314

Nursing, 142-143,
EDUCATION continued

Nursing continued, See also chapters on Colleges, 259314 and Hospitals, 477 $54 !$

EDW ARDS HOTEL

66

EIGHT MILE GROVE

$131,405,408$

ELGIN

$442,569,587,610,613$

ELK CREEK

448,595

ELKHORN

$73,148,563$

Life $\&$ Accident Insurance Co. . 554

River, 73

ELKHORN VALLEY

Medical Society, 32, 126 , $315,361,562,563,569$, $585,591,608,609,620$. $631,632,634,648,654$, 656,661

ELM CREEK

$146,606,661$

ELMWOOD

$126,127,403,404,408$,

$409,574,608$

ELWOOD

146,567

EMERSON

$578,589,621$

EPILEPSY

103

ERICSON

147,626

ESKIMOS

$228,234,236$; a. c. a. Esquimos :

ESQUIMOS

See Eskimos

ESTHER'S HOSPIT AL

Lincoln, 518

ETHER

80

EUSTIS

$148,514,577$

EVANGELICAL

Covenant Hospital, Omaha, $322,494-497$, p-495

Lutheran Bospital, York, 541

EWING

561

EXETER

$151,647,658$

EXPEDTTIONS

Artic, 234-237, 228

EYE AND EAR HOSPITAL Omaha, 96, 104, 480, 489; a.c.a. "small eye and throat hospital"

B.

FACTORYVILLE 408

FACULTY WOMEN'S CLUB 284

FALRBURY

$146,147,322,371,432$. 
FALRBL'RY continued

$466,512,552,558,567$.

$576,591,592,596,610$, $624,630,631,642,650$. 656

Hospital, See Iaylor Hospital

FAIR FIELD $141,143,556,591$

FAIRMONT $87,140,549,553,572$, 586

FALLS CITY

$81,84,141,147,151$,

$373,448,449,450,452$, $455,456,481,512,513$, $559,563,569,580,583$, $586,587,592,597,600$, $605,618,634,659$

Hospital, 451, 481, 512 . 513

FARNAM

514,633

Hospital, See Reeves Memorial Hospital

PATHER FLANAGAN'S Boys Home, 378

FATHER HAMILTON'S

Presbyterian Mission School, 24

PILLEY

559

FIII MORE COUNTY

$86-89,148,549,552$,

$553,558,572,573,586$,

$593,628,645-647,658$;

a. C. a. Filmore County

Medical Society, 55?

PILMORE COUNTY

See Fillmore County

FIRST NEBRASK A

Infantry (Civi 'War), 32. 48, 68, 154, 399, 402;

a.c.a, First Nebraska

Volunteers

Volumieers iSpanishAmerican War), 156

\section{PIRTH}

652

FLORENC

$49,51,70,149,316$,

402

FORD-PAXTON HOSPIT AL Omaha, 500

FORENSIC MEDICINE

$75,138,145,229,232$, 251

FOREST CIT

$$
57
$$

FOREST LAWN CEMETERY 46, 67

FORT ATKINSON

$$
1,9,23
$$

FORT CALHOUN

$$
1,22,70,71,151,620
$$

FORT CROOK

576,646

FORT KEARNEY

$54,56,153,154$

FORT LEAVENWORTH
FORT MONROE

162

FORT OMAHA

162

FORT OSAGE

$8,10,15$

FORT PIERRE

46

FORT RILEY

162

FORT ROBINSON

92

FRANKLIN

$564,580,603,644$

FRANKLIN COUNTY

$146,426,554,564,573$,

$575,587,596,603,615$, 627,645

PRAT ER NIT Y HOSPIT AL.

Tekamah, 539

FREDERICK HOSPIT AL Omaha, 500, p-500, 50: FREMONT

$33,34,73,62,146,147$. $150,156,267,270,318$, $319,321,364-366,378$, $423,441,469,514,549$, $556,562,563,564,573$, $591,617-621,628,631$, $632,633,641,653,656$ Hospitals, See Military Avenue Hospital and Richrn ond Hospital

Tribune, 130

PRIEND

$137,138,459,563,589$

PRONTIER COUNT Y

$146,426,565,584,615$. $618,637,648$

PULLERTON

$146,443,586,599,602$. 603,642

FURNAS COUNT

$38,125,146,426,427$. $560,564,568,569,574$ $600,603,618,620,624$, $629,647,655,656$

Medical Society, 426, 568 , 587

G.

\section{GAGE COUNTY}

$92,146,428,509,553$.

$559-561,563,565,567$,

$570,572,579,584,586$.

$591,600,606,807,612$,

$618,625,628-630,632$,

$634,638,640,650,654$, 655,658

GALLAWAY

See Callaway

GAND Y

146,596

GARDEN COUNT Y

$146,429,619$

GARDNER

120

GARFIELD COLNT

146

GARLAND
CARLAND continued 156, $6+8$

G.ASPER COUNTY

See Gosper Count y

GASTROENT ERETIS 90

GENEVA

$87-89,146,148,150,558$, $593,628,646$

GENOA

$34,372,314,554,571,658$ Indian School Hospual, $5: 4$

GERING

$147,186,-33,234,441$ 591,651

GIBBON

$90,418,613.618$

CIIEAD

$166,64 \%$

GIIMORE 57

GILTNER

604. 61

GiI ASCO RENERAL HOSPITAL Hast ing 5,316

GLEN'II. 565

GLENWOOD lowa, 366

GOOD SAMART AN HOSPT AL Kearney, 516 North Platte, 436 Crmaha, 58, 478

GOSPER COI NT) $146,429,567,653$

GOTHENBLRC

$150,151,156,551,557$. $599,619,632,647$

GORDON $576,578,626$

GRAFTON 552,581

GRAND ISLAND

$52,53,62,107,146,147$, $321,322,366,370,371$ $450,481,515,553,557$. $560,565,580,585,593$. $594,598,612,624,628$, $629,634,638,656,660$ General Hospital, 515, See also: St. Francis Hospita

CRANT

$14 i, 556$

GRANI COLNT

$146,429,595$

GREECE

646, a. c, a. Greese

GREELEY

$146,559,560,597$

GREEIEY COUNT Y

$146,197,549,555,559$.

$560,585,596,597,648$

GREEN GABLES SANIT ARIT.M Lincoln, 123, 139, 197. 200,518

GREENWOOD $157,193,408,409,612$, 649

GREESE

See Greece

GRESHAM 


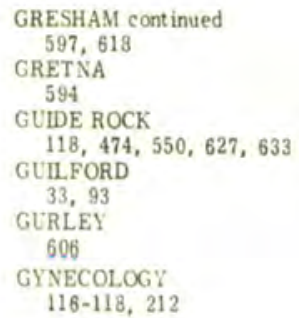

H.

\section{HAIGLER 552 \\ HALI COUNTY $146,429,553,560,565$, $580,585,593,594,598$, $612,629,634,638,646$, $652,656,660$ Medical Society, 553, 580 \\ HALLAM} 645

HAMILTON COLNTY $87,91,92,94,146,301$, $431,569,591,597,616$, $634,646,647,660$

HAMPTON 9!, 193

HANSCOM PARK $48,56,288$

HARBINE 127

HARDY 600,623

HARGRAVE 645

HARLAN COLNTY

$146,431,555,564,584$, $602,636,637,649$

HARRISBURG 395,627

HARRISON 147

HARTINGTON

$141,146,515,574,599$, $602,627,650$

Hospital, see St. John's Hospital

HARVARD

$149,151,568,585,587$, 598,641

HASTINGS

$39,90,92,96,138,142$, $146,147,152,156,186$, $187,194,213,247,266$, $270,319,323,363,384$, $392,450,472,473,482$, $516,559,562,563,566$, $570,572,573,577,580$, $582,588,599,600,602$, $608,608,614,615,621$, $625,636,639,644,645$, $647,648,649,653,654$ College, 80, 138, 142 Hospitals, See: Glasco General Hospital, Mary Lanning Memorial Hospital; Nebraska Sanitarium
HASTINGS continued Insane Asylum, 85, 87, 119,247

HAVELOCK $86,150,554,584,635$

HAY SPRINGS 554,618

HAYES CENT ER 596

HAYES COUNTY $146,431,580,596$

HEATHWELL 645

HEBRON $121,147,466,467,516$, $559,577,649$ Hospital, See Blue Valley Hospital

HELENA

$$
83
$$

HEMATOLOCY 304

HEMINGFORD 186,612

HEMORRHAGE 64

HENDERSON 629

HEPPERLEN CLINIC Beatrice, 127, 507, 533; a.c.a. Hepperlin Clinic

HERMAN 564

HERNDON HOUSE $45,54,66$

HER SHEY 635,638

HEYN-KENNEDY COMPANY 546

HICKMAN

618,646

HILDRETH 554

HILLCREST HOSPTTAL

\& Sanitarium, Seward, 536

HILLSWE HOSPIT AL York, 123

HIRAM L. SMITH LIBRARY 89

HITCHCOCK COUNTY $146,562,584,604,647$ HOLBROOK 629

HOLDREGE $37,124,140,147,151$, $237,426,445,504,508$, $614,627,629,636,649$, 658

HOLLINGER 624

HOLLINGSWORTH 626

HOLMESVILLE 625

HOLT COUNTY

$146,431,554,561,562$.

$565,568,586,613,627$,

$641,654,659,660$ HOME

for the Friendless, Lincoln.
HOME continued

for the Friendless, Lincoln, continued, $189,522,523$

Hospital, Strom sburg, 537 HOMER

$193,197,199,647$

HOOKER COUNTY

146,655

HOOPER

$148,423,591,661$

HOW ARD COUNTY

$146,553,628$

HOWELLS

$559,596,622,625$, a. c. a. Howell Humane Society, 46 HUMBOLDT

$86,149,447,451-453,455$, $456,584,623,625,654$, HUMPHREY $91,362,441,566,607$

HYANNIS

146, 504,595

I.

\section{IMMANUEL HOSPITAL}

Ornaha, 119, 255, 268, 481, $484-487, p-485,603,608$ $627,636,639,646,653$

IMPERIAL

$92,131,146,148,594,604$ INDIAN

Medicine, See Medicine, Indian

Physicians, See Physicians, Indian

INDLANOLA

614

INDIANS

$1,2,7,20-23,24-26,28-$

$31,33,57$

INFLUENZA

236,259

INGLESIDE

$193,563,601,657,661$

INSTITUTION

for the Feeble-minded, Beatrice, 450, 508

\section{INSURANCE}

250

INVENTORS

252-255

IOWA-NEBRASKA FERRY CO. 32

IRVINGTON

73,148

ISOLATION HOSP I AL Lincoln, 518

(R. L.) IRVINS HOSPITAI Crawford, 511

\section{J.}

\section{JACKSON \\ 615 \\ JANSEN \\ 614}

JEFFERSON COUNTY

$146,432,550,558,574$.

$576,591,592,596,610$, $614,616,624,631,650,656$ 
JEFFERSON COUNT Y cont inued Medical Society, 432

JENNINGS HOTEL 480

JOHNSON

564,659 , a. c. a. Johnston

JOHNSON COUNT Y

$33,83,86,146,407$.

$433,452,554,568,571$.

$575,584,595,619,637$, 653,661

JOHNSTON

See Johnson

K.

\section{KEARNEY}

$152,187,188,301,319$, $321,371,385,420,516$, $517,553,555,557,564$, $580,583,589,590,594$, $607,637,642,655$

KEARNEY COUNTY

$121,146,434,549,551$, $553,559,578,598,615$

KEARNEY HOSPTT ALS

See: Good Samaritan Hospital, Kearney; $\boldsymbol{X}$. Luke's Hospital; State Industrial School for Boys Hospital; Nebraska State Hospital for Tuberculosis

KEITH COUNTY

146,434

KENESAW

625,652

KENNARD

150,551

KEVAPAHA COUNTY

See Keya Paha County

KEYA PAHA COUNTY

$146,584,647$; a. c. a,

KDMBALL Kevapaha County

$518,618,636$

KIMBALL COI'NT Y

$146,437,617,648$

KIMBALL HOSPIT AL 518

KNOX COUNTY

$30,146,434,437,438$, $555,561,563,583,587$, $592,598,599,604,613$, $617,624,640,649$

KOLOUCH HOSPITAL.

Schuyler, 535

\section{LAKEWOOD COUNTRY CLUB} 45

LANCASTER COUNTY

$146,161,354,355,549$, $551-566,568-573,577-$ $581,583-585,587-589$, $591,593-596,598-600$, 603-607, 609-611, 613, $614,616-622,626,627$, $629-639,641-656,658-$ 662

Medical Society, 250, 354
MARY LANNING

Memorial Hospital, Hastings, 142, 516

LAPAROTOMY

90

L.ARYNGITIS

$B 0$

LAUREL

565,610

LAWRENCE

594

LEBANON

555

LEGISLATION

See Chapters on Colleges, 272-275 and Physicians in Politics, 130-152

\section{LEIGH}

$151,557,577$

LEWELLEN

619,628

TAYLOR E, LEWIS

Memorial Hospital, Superior, 537, p-538

\section{LEWISTON} 574

LEXINGTON

$30,31,422,551,574$. $626,633,650,661$

LIBERTY

$148,553,571$

LIBRARIES

$75,111,152,179,244=$ 246,270

LINCOLN CHAMBER OF COMMERCE 139,351

L.INCOLN COINTY

$33,84,146,436,550$, $566,581,592,801,611$, $612,620,624,626,628$, $630,633,640,653,655$

LINCOLN

General Hospitad, 481, $518-521, p-519,656$, 658

Hospital, 518

Hospital Association, 519. 520

Medical College, 140, 161, $181,247,249,252,311$ $313,441,553,554,555$, 558-560, 563-565, 572 , $574,594-600,602,503$ $606,610,612,613,616$. $617,618,620,621,623$, $625,629,634,635,636-$ $639,641-644,646,647$. $649,650,652-656,658-$ 661: a, $c, 2$, Cotner, Medical College; Cotner University; Cotner L'niversity Medical depertment; Lincoln Medical College of Cotner Lniversity

Medical College of Cotner University, See Lincoln Medical College

Medical Society, 93, 315, 349-354

Safe Deposit Company, 513
LINCOLN cont inued

Sanitarium, 518

School Board, 139, 14?

State Hospital, 182, 196

Sate Insane Asylum, 73, 79, 119,128

State Journal, 236, 239, 243

I rust Company, 512

LINDSAY

651,655

LINWOOD

575

LITCHFIELD

610,638

LODGEPOLE

504,659 , a, c, a. Lodige Pole

LOGAN COLNTY

$146,437,596$

LOGAV VALLEY HOSPITAL Pender, 534

LONG PINE.

558

LORD LISTER HOSPITAL.

Omaha, 114, 157, 487, p-487, $488,303,633,654,656$

LOUISVIILE

$403,408,409,680$

LOUP CIT 1

$147,550,559,586,393$

LOUP COUNT I

$146,437,613$

LOUP VAL.LEY

Medical Society, 315, 363

LUSHTON

631

LUTHERAN HOSPITAL

Beatrice, 507

Norfolk, 528, p-528, 529

Omaha, 488

LUTHERAN SCHOOL of Nur sing, Norfolk, 528

LYMAN 590,660

LYNCH

$597,622,654$

1. YCH GENERAL HOSPIT AL 524

LYONS

$203,589,593,600$

M.

MC COOK

$38,103,124,147,193$.

$237,257,363,371,504$,

$524,525,561,573,576$,

$590,593,600,607,619$,

633,658

Hospital, See St. Catherine's

Bospital

MC COOL JUNCTION 619

MC CREA PRIVATE HOSPIT AL Table Rock, 539

IC GIL.L UNIVERSITY

79; a. c. a. Magil University MC PHERSON COUNTY $146,181,437$

MACY

24

MADISON 
MADISON continued

$151,207,208,321,322$. $362,371,377,438-442$, $589,608,627,644,658$, 659

MADISON COLNTY

$122,146,377,437,438$, $550,566,578,584,594$, $598,608,619,621,629$, $637,639,640,646,649$. $654,655,658$

Medical Society, 437-442,

MADRID 550,562

579

MAGILL UNTVERSITY See McGill University

MALARLA 90,233

MALMO

573

MARQUETTE $37,93,94,656$

MARTINSBURG 560

UASKS

$96,102,158-159,254$, 304

MASON CITY

$418,422,583,596$

MAWOOD HOSPIT AL. Sromsburg, 536

MAXWELI.

601

MAYWOOD

618,648

MEAD

$144,150,367,613$, a. c. a. Meade

MEADE

See Mead

MEADOW GROVE 377,602

MEDICAL ARTS BUILDING

See Omaha Medical Arts Building

MEDICAL BUILDING ASSOCLATION 543

MEDICAL EDUCATION

See Education, Medical

MIEDICAL SOCIET Y

of Missouri Valley, 74, $96,105,107.108,114$ $203,255,264,265,315$, $360,361,544,550,552$ $554,559,562-564,570$, $573,578,579,582,595$, $601,602,605,607,609$, $614,620,630,632,638$, 643, 644: a, c, a. Missouri Valley Medical Society: Missouri Valley Medical Association

MEDICAL WOMEN'S CLUB of Lincoln, 200, 201

MEDICINE

Indian, 113

MEMORIAL HOSPITAL

Superior, 537, 538

MENTONITF. DEACONESS
MENNONITE DEACONESS HOME AND HOSPIT AL continued, Beatríce, 507 MERCER HOTEL $6 !$

MERCY HOSPITAL Omaha, 56 Council Bluffs, lowa, 637 MERNA

$421,422,575,620$

MERRICK COUNTY

$123,146,442,557,560$. $574,583,586,596,597$, $608,628,632$

Medical Society, 123, 442

ME TABOLISM

$229,230,289,290$

Invorn errors, 215

MICROSCOPE 223

MII.FORD

$129,185,464,465,523$.

$526,573,621,652$

Hospital, 464, 526

MILIT ARY AVENUE HOSPIT AL Fremont, 514

MILIT ARY MEDICINE $1-20,190,191,223,224$ 311 , See also Chapter on War Service, 153-175

MILLARD

$33,70,72,73,128,131$, $148,318,321,583$

MILLER

87

MILLER PARK 45

MILLIGAN

645

MILROY'S DISEASE 217,218

MINATARE $193,637,652$

MINDEN

$121,146,364,371,506$. $549,551,590,598,631$

MISSIONS \& MISSIONARIES 246-249

MISSOURI VALLEY

Medical Association, See Medical Society of Missouri Valley

Medical Society, See Medical Society of Missouri Valley

MITCHELL

$87,193,251,463,568$, $580,606,647$

MORRILL

$162,583,619$

MORRILL COUNTY

$146,551,583,627,632$,

634,659

MORROW HOSPITAL

Seward, 464, 536

MORSE BLUFF

34, 596

MULLEN

146,562

MURRAY

$408,409,560,586$
MYCOLOGX

215

N.

NANCE COUNTY

$146,243,443,586,602$.

$603,642,658$

Medical Society, 443, 571

NAPER

$30,640,641,661$

NAPONEE

596

NEBRASK A

Academy of Ophthaimology and Oto-Laryngology, 37.

Academy of Science, 74, 75, 232, 305, 605

Children's Home Society, 379 NEBRASKA CITY

$50,70-73,78,79,81,86$.

$128,147,148,150-152,193$.

$195,242,316,319,321,323$,

$364,399,477,527,570,576$,

$577,580,586,604,613,614$,

$647,656,659,661$

Hospital, 527, See also: Comm unity Hospitsl: St. Mary's Hospital

\section{NEBRASKA}

Department of Health and Welfare, 143

Federation of Women's Clubs, 28,29

Ferry Company, 47

Hospital Association, 143, 481

Hospital for the Insane, 152, 207

- Iowa Pediatric Society, 373, $554,557,577,593$

Masonic Home, Platt smouth, 535

Medical and Surgical Inst itute, Omaha, 478

Medical Society, 50, 52, 56, $63,207,315,316,323$, $330,399,477$

Medical Women's League, 199

Methodist Episcopal Hospital, Omaha, 480, 481, 488-491

Methodist Hospital, Omaha, $96,106,171,225,234$, $268,384,488-491, p-489$, $534,593,601,646,650$

Orthopedic Hospital, Lincoln, 108, 184, 185, 201 . $206,481,522-524$

Private Duty Nursing Association, 143

Public Health Association, 143

Radiological Society, 376

Railroad Surgeon's Society, 74, 203

Red Cross, 167

Sanitarium, College View, 510

Sanitarium and Benevolent Association, Hastings, 516 
NEBRASKA continued

School of Medicine, Preparatory, 262, 263

Soldiers' and Sailors' Home Hospital, Burkett, 450, 509, p-509, 510

State Association of Graduate Nurses, 143, 380

State Board of Health, $124,133,134,136$ $137-140,143$

State Capitol, Omaha, p-155

Sxate Dental Society, 225

State Eclectic Medical Society, 85, 311, 367

State Federation of Women's Clubs, 381

Sate Historical Society, 3, 46,129

State Homeopathic Medical Society, $363,364,522$

Sate Hospital for Tuberculosis, Kearney, 517 . p-516

State League of Nursing Education, 143

State Medical Association, 53, $56,61,65,67,79$, $82,108,114,126,137$, 156, 203, 209, 234, 258, $315,321-323,377,398$, $405,435,455,456,544$, $550,593,619$

Sate Medical Journal, 111 , $131,132,205,207,208$, $271,377,481,555,557$, $575,576,615,623$

State Medical League, 81

State Medical Library, 270 , 271

Qate Nurses Association, 380,381

Surgical andGynecological Association, 154

Tuberculosis Association, 376,379

University Hospital, 99, $136,142,143,481$ $483,534,603,609$, 627,651

Wesleyan University, 94, $142,313,314,655$

Women's Suffrage Association, 194

NEHAWYA

409,602

NELIGH

193, 362, 449, 570, 588, 590

NELSON

147, 565, 597, 651

NEMAHA CITY

455,601

NEMAHA COUNTY

$79,146,152,242,402$,

$444,452,553,564,659$

NEMAHA VALLEY

Medical Society, 456

NEUROSURGERY

259

NEWCASTLE
IEWCASTLE cont inued

635,649

NEWMAN GROIE

$150,362,528,584,5$ 으,

619

Hospital, See Community

Hospital, Newman Grove

NEWPORT

125

NICHOLAS SEXX HOSPITAL

257; a.c. a. Nicholas Sen Hospital

NIOBRARA

$33,50,587$

River, 92

NORDEN

125

NORFOLK

$81,82,115,122,123$

$126,141,147-150,151$,

$346,247,249,256,319$,

$321,323,361,362,370$,

$372,528-530,554,555$,

$562,565,566,575,578$,

$584,591,595,621,623$,

$629,630,638,639,645$,

$646,649,659,661$

City Hospital, 528

Genera! Hospital, 529, p-529, See also: Lutheran Hospital and School of Nursing; Verges Sanitarium

Insane Hospital, 122

National Bank, 82

State Hospital, 246

NORTH BEND

$70,324,423,574,581$, 595

NORTH LOUP

$363,592,630$

NORTH PLATTE

$33,84,124,142,146$,

$147,150,170,192,203$,

$222,243,250,252,322$

$371,372,435,436,500$,

$504,530,550,551,566$.

$581,602,611,628,630$,

$633,641,653$

Hospitals, See: Platte

Valley Hospital; Red

field-Dent Hospital;

Wurtele Hospital

NORTHWEST NEBRASKA

Medical Society, 586

NUCKOLLS COUNTY

$147,445,560,563,565$.

$566,574,597,600,616$,

$628,631,651,652$

NURSING

$141,142,143,171,202$

Education, See Education, Nursing

NUTRITION

$188,189,228,233,289$. 290

\section{O.}

OAK
OAKDALE

$362,639,640$

OAKLAND

$110,140,203,208,249$

357,643

OBSTETRICS

60, $76,105,116 \cdot 118,195$, 188

OCONTO

$193,255,420,577,394$, 654

ODELL

$92,322,629,634$

OGALLALA

$146,630,653$

OGDEN

61

ONAHA

Academy of Medicine, 100 . $106,218,323,232$

Academy of Vledicine and Surgery, 96

Ambulance Company, 106. $156,157,162$

Arrow, is

Bee, 491

Board of Education, 53, 96, 109, 150, 248

Board of Health, 1 th

Claim Club, 32, 48, is

Clinic, 61, 74, 203, 204

Club, 46

College of Nedicine, See Omaha Miedical College

-Council Bluffs OphthalmoIogical Society, 373

Couneil of Social Agencies, 290

-Douglas County Medical Asaociation, See Omaha . Douglas County Medical Society

-Douglas County Medical Society, 105-108, 111 . $209,210,218,269,290$, $303,315,322,323,333$, $334-337,379,484,+91$, $543,550,610,628,638$, 657; a. c, a. Omaha-Douglas County Medical Azsocie:ion

Douglas sounty Medical Societ Bulletin, 20 ?

General Hospital, 114

Health Department, 501

High School, 75

Mlustrated, jo

Maternity Hospital, 497, $p-497,498$

Medical and Surgical Institute, $66,479,480$

Medical Arts Building, 256. $361,378,543-5+5, p-545$

Medical Club, 203, 218, 323 . 332

Medical College, $52,53,50$. $61,63,65,68-70,7$, 76 . $80,97,99-101,104,106$, $107,109,112,114,115$, $128,154,171,178,187$. $190,197,203,210,216$, $218,261, p-261,263-265$, 
OMAHA continued

Medical College continued, $267-269,271,296,389$, $399,400,417,420,422$, $443,480,560,561,568$, $569,581,598,599,613$, $618,644,648,661$; a. c. a, Omaha College of Medicine; Omaha Medical School

Medical School, See Ornaha Medical College

Medical Society, 52, 53 , $56,59,69,70,96$, $100,115,145,182$, $272,316-318,323-$ $325,329,333,334$

Microscopic Society, 375

Pathological and Sanitary Society, 329, 374

Presbyterian Theological Seminary, 60

Public Library, 488

Public Library Museum, 59

Red Cross, 166

Republican, 205

Roentgen Ray Society, 211

School for the Deaf, 78

Society of Fine Arts, 246

Sreet Railway Company, 61

Surgical and Gynecological Association, 154

Surgical Club, 106, 244, 375

Symphony Orchestra, 289 Women's Press Club, 239

Women's Club, 376

Women's Medical Society, 201, 202

World-Herald, 24, 32, 45, $48,54,72,220,335$ $X$-Ray Society, 375,376

O'NEIL.I.

$146,148,150,151,322$, $362,408,565,581,586$

ONG 553

\section{OPHTHALMOLOGY}

$96,100,104,158,213-$ 216,254

ORCHARD

$146,530,582$

Hospital, 530

ORD

$137,147,193,198,199$, $321,363,468,530,531$, $555,612,617,642,656$ Hospital, $530,531, p-531$ ORLEANS

$431,584,637$

ORTHOPEDICS

74,108

OSCEOLA

$85,127,147,187,189$, $207,321,607,611,642$, 644

OSHKOSH

146,620

OSTEOPATHY

$133-135$
OTOE COUNTY

$147,317,566,570,576$,

$577,580,585,586,588$,

$594,595,601,604,627$.

$645,651,656,559,661$

Medical Society, 656

OTOLARYNGOLOGY 158

OVARIOTOMY

63,75, a.c. a. Ovaritomy

OVARTTOMY

See Ovariotomy

OVERTON

577

OXFORD

$426,568,641$

P.

PALEONTOLOGY 233

PALISADE

580

PALMER

$250,531,532,628,632$

Hospital, See Coolidge Hospital

PALMYRA 566, 651

PAPILLION $70,72,77,88,120,128$, $147,187,192,365,552$, 614

PAPPIO

73

PATHOLOGY

Surgical, 103

PAWNEE See Pawnee City

PAWNEE CITY

$80-82,89,90,140,141$,

$143,147,323,532-534$,

$550,560,582,590$; a.c.a. Pawnee

PAWNEE COUNTY

$90,147,550,560,574$, $590,631,635$

PAWNEE HOSPIT AL $532,533, p-533,534$ Association, 532

PAWNEE MEDICAL UNIT 534

PAWNEE RESERVATION 243

PAWNEE WAR 54,154

PAXTON HOTEL 332

PEDLATRICS

112

PENDER

$147,186,534,563,609$

Hospital, See Logan Valley Hospital

PERKINS COUNTY

147,579

PERU

$187,400,448,622,653$

PERU NORMAL.

89, 128

PET ERSBURG
PETERSBURG continued 569,593

PAGE

583

PHARMACOLOGY 227, 229

PHELPS COUNTY

$147,445,554,608,627$. 658

PHI BETA PI 388,390

PHI CHI

387

PHI RHO SIGMA

Eta Chapter, 38 ;

Iota Chapter, 389

PHIL.I.IPS

87, 634

PHYSICIANS HOSPIT AL. Albion, 502

PHYSICIANS

Indian, 30

Women, 25-29, See also: Chapter on Women Physicians, 174-202

PHYSIOLOGY

230,231

PICKRELL

606,618

(DR. SUSAN LA FLESCHE) PICOTTE MEMORIAL HOS. PITAL

PIERCE Walthill, 27, 540

$147,148,152,362,557,638$

PIERCE COUNTY

$122,147,377,437,438,557$, $584,598,599,616,625,638$ PILGER

362,634

PIONEER MEMORLAL HOSPITAL Dalton, 511

PLAINVIEW

$362,534,598,599,616,625$

General Hospital, 534

PLATTE CENTER

147,554

PLATTE COUNTY

$89,91,147,446,550,564$.

$578,579,607,609,615$.

$617,620,623,651,654$

Medical Soctety, 654

PLATTE RIVER 44

PLATTE VALLEY

Herald, 79

Hospital, North Platte, 530

PLATTSMOUTH

$50,70,79,80,128,131$, $147,149-152,154,239,251$, $256,316-318,320,321,324$, $352,364,398-400,403,406-$ $409,535,575,589,615,657$ Herald, 154, 402

Hospital, See Nebraska Masonic Home

PLEASANT DALE

129, 659

PLEASANTON

633

PLYMOUTH 
PLYMOUTH continued 562,616

PNEUMONLA $33,52,212$

POLK $495,644,657$

POLK COUNTY

$85,127,147,446,577$, $597,607,611,613,615$. $622,642,644,657$

(DR. ) POLLARD'S HOSPITAL See Omaha Maternity

PONCA Hospital

Nebraska, 146, 197, 600, 610,625

Indians, 29

POTTER $411,550,643$

PRAGUE 600,105

PRESBYTERLAN HOSPIT AL Omaha, 114, 159, 203. 480,488

PREVENTIVE MEDICINE 95

PSYCHLATRY

196, 197

PUBLIC HEALTH

$94,95,96,97,102$.

$107,116,130-152,188$,

$189,194-196,219$, See

also: Chapter on Physicians

in Politics, 130-152

PULSE

The, 210

R.

\section{RADIOLOGY}

$68,197,212,219,221$, 222

RADIUM HOSPITAL Omaia, 223, 243, 489, p-499, 500

\section{RAGAN}

$$
636
$$

RALSTON

$$
45
$$

RANDOLPH

$188,362,569,586,601$, 628

RAVENNA 573,607

RAYMOND 599

RED CLOUD $118,119,147,471,473$, $474,535,569$ General Hospital, 535

RED WILLOW COUNTY $147,447,555,561,573$, $576,590,593,600,603$. $614,619,633,638$; a.c. a. Redwillow County REDFIELD-DENT HOSPITAL North Platte, 530 REDWILLOW COUNTY See Red Willow County REEVES MEMORLAL HOSPITAL, Farnam,
REEVES MEMORLAL HOSPITAL, Farnam, continued, $514, \mathrm{p}-514$

REPUBLICAN CITY 649

REPUBLICAN RIVER 31

REPUBLICAN VALLEY

38

Hospital, Arapahoe, 38. 504

Hospital, Cambridge, 510

Medical Association, 315 , $363,563,564,568,580$. $584,593,599,614,641$, REYNOLDS $642,644,648,649,658$

186,550

RICHARDSON COUNTY

81, 102, 147, 174, 451, $452,454,455-457,551$, $559,563,569,577,583$, $586,587,592,600,605$. $610,616,618,623,625$. $634,642,659$ Medical Society, 451. 453, 455-457

RISLNG CITY $248,575,609$

RIVERTON 627

ROCA

$187,193,199,573$

ROCK COUNTY

147,636

ROEDER MATERNTTY HOME

AND HOSPITAL, Lincoln, 518

ROSELAND

644

RULO

451, 642

RUSHVILLE

$535,569,659$

Hospital, see Crawford RUSKIN Hospital, Rushville

623,628

$$
\text { S. }
$$$$
\text { Z. }
$$

ST. BERNARD'S HOSPITAL Council Bluffs, 268

ST. CATHERINE'S HOSPITAL

McCook, 524, 525, p-525, 526

Omaha, 302, $310,493$. $\mathrm{p}-493,494,576,601$. 603,605

ST : EDWARD

$128,395,582,600,648$

ST. ELIZABETH'S HOSPITAL.

Lincoln, 481, 518, 526 , $552,594,621$

ST. FRANCIS HOSPITAL

Grand Island, 53, 481, 515

School of Nursing, Grand Island, 515

ST. HELENA

70,266

ST. JOHN'S HOSPTT AL
ST, JOHN'S HOSPIT AL cont inued Hartingt on, 5:5

ST. JOSEPH HOME FOR THE AGED, West Point, 540

ST. JOSEPH'S HOSPIT AL Alliance, 481, p-502, 503 . 504

Omaha, 56, 58, 63, 69, 85. $100,142,268,290,294$. $296,298,301,303,308$, $310,477,478,481,494$. $566,576,600,603,605$, $621-623,626,635,638$, $642,653,654$

ST. LUKE'S HOSPIT AL Kearney, 516

Omaha, 502

ST. MARTIN'S CHURCH 45

ST, MARY'S HOSPITAL Columbus, 481, 514 Nebraska City, 527, p-527

ST. PACL.

$139,146,148,156,188$.

$553,588,624$

SALEM

$81,102,454,610$

SALINE COUNTY

$119,131,138,147,190$, $459-461,558,563,566$, $569,589,590,602,609$. $627,642,647$

Medical Society, 627

SALVATION ARMY

Women's Home and Hospital. Omaha, 500

SANTEE

Normal School, 30, 583

Reservation, 30, 583

SARGENT

422, 600,649

SARONVILLE

125

SARPY CENTER

87

SARPY COUNT Y

$21,57,77,78,88,89,147$. 256, 402, 552, 576, 594, 628,646

SARPY SCHOOL

89

SARTORLA

87

SAUNDERS COUNTY

$34,85,147,461,462,558$

$566,600,606,611,615$,

$645,648,652,656,659$

Medical Society, 198

SCALP

59

SCHUYLER

$146,147,250,535,604$,

612,643

Bospital, See Kolouch Hospital

SCOTTSBLUFF HOSPIT AL

See West Nebraska Methodist

Epi scopel Hospital

SCOTTS BLUFF COUNTY

$147,197,265,463,568$,

$569,580,583,588,590$,

$591,594,619,624,630$, 
SCOTTS BLLFF COUNTY

continued, 632, 635, 637 . $640,642,647,653$, 655,662 ; a. c. a. Scott sbluff County SCOTTSBLUFF

$143,147,156,178,192$, $248,463,481,503,535$. $536,569,594,606,618$, $624,632,635,640,647$. $653,657,662$

SCOTTSBLUFF COUNTY See Scotts Bluff County

SCRIBNER 273

SCURVY

2-16

SECOND NEBRASKA VOLUNTEERS, $77,78,161$

SENECA 455

SENN

Nicholas, Hospital, Omaha, SEW ARD 257, p-496, 497, 607

$139,141,536,570,574$, $606,620,624,639$

SEWARD COUNTY $129,147,464,567,574$. $595,620,621,624,632$, $639,657,659$ Medical Society, 616

SEW ARD BOSPITAL 464, 536, See al so: Morrow Hospital; Hullcrest Hospital and Sanitarium

SEYMOUR PARK

45

SHEL.BY

$597,613,622$

SHELTON

573, 609

SHERIDAN COUNTY $147,554,576,578,659$

SHERMAN COUNT $Y$ $147,465,550,555,559$, $593,610,638,655$

SHICKLEY 573

DR. SHOEMAKER'S HOSPITAL, Lincoln, 518

SHUBERT $151,451,455,577,642$ SIDNEY

$93,146,147,372,411$, $538,577,607,615,636$, 650

Hospital, See Taylor Hospital

SILVER CREEK 578

SIOUX COUNTY $92,147,465$

SIOUX VALLEY Medical Society, 562, 649

SMALLPOX $68,139,140,156,191$ 。 406

SMITHFIELD 653
SNYDER

564,655

SOLDIERS' AND SAILORS' HOME, Grand Island, 249

SOUTH BEND

408

SOUTH OMAHA

73, 550

Conservatory of Music, 252

Hospital Association, 488

SOUTH SLE GENERAL HOSPITAL, Omaha, 488

SOUTH SIOUX CITY 607,623

SOUTHEAST NEBRASKA Medical Society, 456

SPALDING

$555,585,648$; a. c, a. Spaulding

SPARKS

187

SPAULDING

See Spalding

SPENCER

$192,536,560$

Hospital, 536

SPINE

63

SPRAGUE

605

SPRING BANK

187

SPRINGFIELD

628

SPRINGVIEW

$125,146,594,606$

STAMFORD

564

STANTON

$147,362,550,583,595$

STANTON COUNTY

$122,147,377,437,466$.

550,569

STAPLEHURST

616

STAPLETON

$150,151,565$

ST ATE

Industrial School for Boys,

Kearney, 152, 516 Inst itute for the Blind, Nebraska City, 78

STEELE CITY 193

STELLA

455,618

STEWART MATERNITY HOSPITAL, 497

(DR.) STEW ART'S HOSPIT AL Sratton, 536

STOCK VILLE $124,148,179,584$

STRATTON

$536,562,647$

Hospital, See Dr. Stewart's Hospital

STROMSBURG

$149,150,536,577,615$

Hospitals, see: Home
STROMSBURG cont inued

Hospitals cont inued.

Hospital; Mawood Hospital

STUART

$537,562,658$

Hospital, See Wilson Hospital

SUMNER

575

SUPERIOR

$147,372,537,560,566$,

$613,616,631,652$

Hospital, See Brodstone Memorial Hospital

SURGERY

$89,103,104,105,106,197$. 302,303

SURGICAL PATHOLOGY

See Pathology, Surgical

SURPRISE

549

SUTHERLAND

592,640

SW ANTON

642

SWEDISH IMMANUEL HOSPITAL Omaha, 105

SWEDISH MISSION HOSPIT AL Omaha, 481, 494

SWBETW ATER 87

SWITZERLAND, 109, a.c. a. Switzland

SWITZLAND

See Switzerland

SYRACUSE

$123,186,193,594,627$,

645,651

T.

TABITHA HOSPIT AL

Lincoln, 122

TABLE ROCK

$132,140,149,186,534$,

539,611

Hospital, See McCrea Private Hospital

TALMAGE

588,601

TAMORA

147,567

TAYLOR

613

Hospital, Fairbury, 512

Hospital, Sidney, 538, p-538

TECUMSEH

$86,146,161,242,272,554$. $571,579,584,637$

TEKAMAH

$56,58,119,150,321,372$, $610,620,639$

Hospital, See Fraternity

Hospital

TEMPLE ISR AEL

491

THAYER COUNTY

$81,147,466,467,559,572$, $612,620,621,624,639$. $645,649,657$

Medical Society, 466, 639

THEDFORD 
THEDFORD cont inued 147,628

THERMOMETERS 68, 212

THIRD PRESBYTERIAN CHURCH

90

THOMAS COCNTY $147,468,628$

THURST ON COLNTY $147,198,470,587,599$, 609,619

THYROWD NEOPLASM 64

TIL.DEN

$151,362,377,441,539$, 550,555

Hospital, 539

TOBLAS

186, 558

TONSILITIS

58

TOXICOLOGY

228

TRANSPLANTATION 212

TRENTON

$146,151,650$

TRINTTY CATHEDRAL, 478

TROPICAL MEDICINE 158

TRUMBULL 610

TRYON

$146,181,193,194,437$. 612

TUBERC ULOSIS $75,124,302$

TUESDAY MUSICAL CLUB 252

TYPHOID

$88,90,161,191,218$

U.

ULYSSES
553,646
UNION
408
UNION PACIFIC

$32,43-45,54-56,60$, $61,68,68,84,85,87$, $100,101,106,107,115$. $124,128,130,155,162$, $238,242,323,477$

Bridge, $32,45,54,55$ Old Timers' Club, 443

UNIVERSITY

Hospital, Omaha, see Nebraska University Hospital

Medical Society of Lincoln, 373

UNIVERSTTY OF NEBRASKA

$74,76,80,84,113$

$161,189,190,216$.

217, 237, 248, 259,

$260,270,271,273$.

$289,311,373,419$,

$550-563,565-662$
UNIVERSTTY OF NEBRASKA cont inued

Base Hospital No. 49, 105. $106,156,157,166-171$, 217

Board of Regents, 104, 150

College of Medicine, 7, 56, $59,61,63,74,94,99$, $104,107,108,111,114$. $116,118,122,126,136$. $153,158,170,171,178$, 196, 207-209, 216, 218, $225,227,242,244,259$ $260,261,262, p-269$, $274,275,289,374,389$, $391,413,414,421,483$, $493,497,498,500,533$, $550-563,565-662$, a, c, a. University of Nebraska Medical College

Medical College of Medicine Library, 2, 111, 218, $244,246,270,271,335$

UNIVERSTI Y OF OMAHA

$76,97,105,116,225,550$

UNIVERSTTY PLACE

$141,147,570,596,650$

UPLAND

578

UPSILON NU

of Phi Chi, 389

UROLOGY

227

UTICA

585,623

$$
\text { v. }
$$

\section{VACCINATION}

$$
57,39
$$

VALENTINE

146, 567, 568, 598, 607, 655

VALIEY

$74,131,151,155,157$. $248,301,507,590,627$

VALLEY COUNTY

$147,468,555,567,570$,

$593,617,630,642$

Society, 198, 468

VALPARALSO

615

VERDEL

250,643

VERDIGRE

604

VERDON

$454,455,616$

VERGES SANITARIUM

Norfolk, 529

VESTA

661

VISITING NURSE ASSOCLATION

$380,382,384,485$

W.

WACO

421, 584

WAHOO
WAHOO cont inued

94, 128, 147, 203, 319, 323. $461,485,606,645,652$. 656,659

WAKEFIELD $568,602,605,657$

WALLACE

436, 62 ;

WALNIT HILL

33,61

WALTHILL

$27-29,181,387,599,624$

Hozpits?, See Dr, Susan La Flesche Picotle Memorial Hospital

Times, 29

WASBINGTON COLNTY

$71,147,202,317,469,564$, $571,585,394,624$

WATERBLR)

193

WATERLOO

$73,126,196,603,633$

WALNET A

$125,565,580,588$

WAUSA

$585,588,598,599,62 i$.

WAUST a. c. a. Waust

See Wausa

W AVERLY 578

W AYNE

$70,147,251,362,470,540$. $558,593,597,610$

WAYNE COUNTY

$147,470,558,560,592$, $593,597,643$

Medical Society, 558

WAYNE HOSPIT AL 251,540

WAYNE NORMAL COLLEGE 70

WAYNE ST ATE TEACHERS COLLEGE. 251

WEBSTER COLNTS $118,119,147,471,473$, $475,605,628,627,633$

WEEPINC WATER $84,126,148,150,406$. $408,409,580,804,822$, 651

WEST NEBRASKA Methodist Episcopal Hospital, 481, 535, p-535, 536

WEST POINT

$82,146,208,209,362$,

$402,412,414,540,551$.

$566,602,604,651$, a. e. a.

Westpoint

Hospital. See St. Joseph

WEST ERN Home for the Aged

131,560

Medical Review, 204, 206. 207,226

Surgical \& Gynecological

WESTON

574 


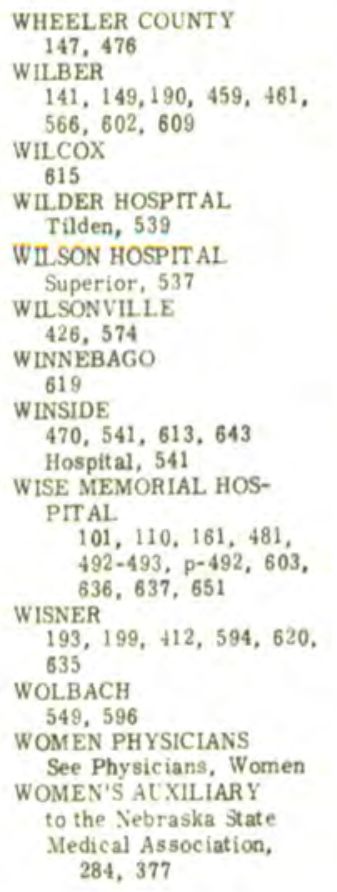

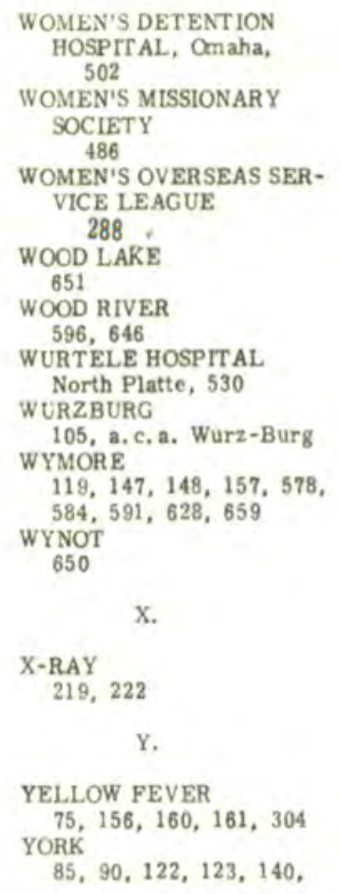

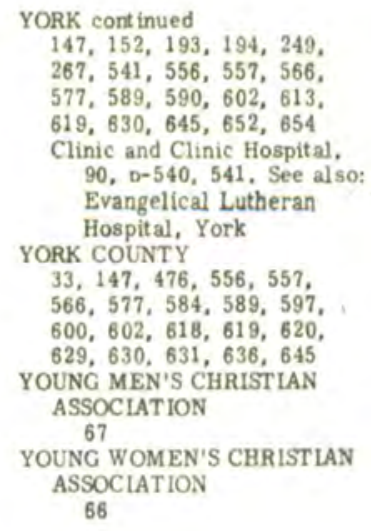


The personal name index includes all individuals mentioned in the text, even though some are only cited as members of a county medical society. If a port rait is included, that is so indicated (e.g. p-399).

In cases of variant spelling and usage, names are entered as they appear in: (a) various editions of the American Medical Directory, judged to be the best authority since it is the licensure identity; (b) educational records, or $(c)$ other original sources.

Such variant $b$ are indicated in alphabetical order as a. c. a. (i.e. also cited as) or by a "see" reference.

\section{A.}

\section{AARON}

Morris M. , 356

ABBOTT

Charles E., 434, 549

Edward Carson, 343, 549

Ephriam, 72

Hodson A., 341, 358, 434, 444,462

Keene, 70,72

Lulu, 143

Luther J., 41, 55, 70, 72, $p-72,73,78,130-131$, $148,152,267,318,319$, $321,357,423$

Luther (Mrs.) , 41, 72, 73

Ned, 70, 72, 78

Nicholas, 55, 72

ABEL

Nellis E. H., 345

ABERLY

H. J., 341

ABRAHAMSON

C. A. , 165

ABTS

Francis Joseph, 348

ABUNDI

Rolli, 338

ACK ERMAN

Emma M., 397, 414

ACKLEY

Francis M., 355

Winfleld, 91, 393

ADAIR

Ladie B. , 343

\section{ADAMS}

Arthur Benedict, 343, 549

Herbert William, 356, 411

Howard Chalfient, 442, 549

James (Mrs, ), 25

Roy Bennett, 208, p-320,

$322,355,358,521,549$

W. E. 341

W. R. (Mrs.), 383

William James, 307, 348,

ADAMSON $386,549, p-550$

Will iam J., 357, 468, 549

ADCOCK

Lee Campbell, 345, 549

ADOLPHUS

Joseph, Sr., 252

Joseph, 252

AGEE

James Clarence, 343, 425, 549

James W., 73, 74, 154, AGLER
AGLER cont inued

Frank Swarthout, 397, 549 AGNEW

Theodore M., 347

AHMANSON

John, 148, 340, 365

AIKEN

Charles C., 412

Henry L. , 207, 385, 387

Joseph Melanchton, 96 , $111,112, p-112,208$, 333, 337, 338, 341, 362

S. A., 427

ALLESWORTH

Lillie Jackson, 78

AINLAY

George W., 349

ATTKEN

Charles C., 343, 358, $433,447,462,467$, a. c.a. Aitken, Charies P.

AKERS

Willıam O. . 343, 345,

AKESON $549, \mathrm{p}-559$

James E., 173

AKIN

Henry L., 343

ALABASTER

F. A. . 313

ALBERTON

Percy, 443

ALBERTSON

Leland C. , 288, 392

Miriam Alberta, 549

ALBIN

Walter Leonard, 358, $429,521,549$

ALBRECHT

Florence M. , 171

Lillian, 171

ALBRIGHT

Robert S. , 428

William S., 447

ALBRO

Joseph A., 131

ALCORN

Ardelle Mabel, 393

AL.DEN

James M., 120, 148, 362

Winifred A. , 409

ALEXANDER

Benjam in J., 356, 408

Clark Taylor, 549

E. I., 338, 341, 435, a. C.a. Alexander, E. L.

H. W. 165

Jeremiah Smyth, 343, 549
ALEXANDER cont inued

Ray Alex, 396

S. , 428

W, R. , $\$ 28$

ALEY

Hector Sinclare, 356, 357, $410,429,432$, a. c. a.

ALGER Alley, Heetor Sinclair

Charles J., 146

ALGORTA

David Enrique, 347

Ruth, p- $-592,493$

ALKIRE

Irvan D. , 172

ALLEMAN

W. R., 165

ALLEN

Aust in R, , 357, 423

Edmund Turney, 137, 139 , $338,341,366,423,427$, $436,437,447,475$, a. c. a. Allen, Edmund Tunney

Edward H. . 356

Frank Leroy, 427

George V., 412, 414, 458

Henry, 427

James Gillian, 423, 549

James I., 424

John Frankl in, 227, 338, 345, $389,546,550$

John (Mrs, ), 378

L. B., 457,458

Robert A. , 410

Silas Gibert, 464, 466, 550

William E., 345

ALLENBLRGER

Christian Alexander, 370, 371, i46, 511,550

ALLERTON Perry, 162, 390, 438, 539, 550

Perry (Mrs, ), 377

ALIEY

Hector Sinclair, see Aley, Hector Sinclair

AL.LINGHAM!

Henry T., 550

ALLISON

Blake S., 396

Charles C.. 301, 302, p-302, $333,340,341,386,492$

C. E., 268 Nelle, 538

ALLYN

A. E., 508

ALMQUIST

Carl O. G. . 17 ?

ALSBACH

John, 427 


\section{ALTENBLRG}

M. A. , 338

ALTHA

John Frank, see Atha, John Frank

AMIBROSE

Addison Lee, 436, p-472, $473,475,550$

AMES

Alfred C. , 358, 411, 432. 467,475

Albro Joseph, 411, 424, $429,436,437,465$. $550, p-550$

Luther L., 432, 467

Marie Antoinette, 192. $424,429,436,550$, a. c.a. Ames, Marie E. AMICK

Carl Gideon, 465, 550

AMIMERMAN

Ulysses S., 550

William S., 432

AMY

Chauncey Willard, 186, 428

Harriet B, 186

ANDERS

Charles G. , 546

ANDERSEN

Louis N., 425

ANDERSON

Albert Wilfred, 414, 551

Allan Byford, 89-90, p-89. $392,534,539,550$

Allan Byford (Mrs. ), 377

Allen B., 89-90, p-89, $114,321,550$, a. c, a. Anderson, Allan B.

Arthur W. , 412, 424

August N. , 357, 467, 551

B. E., 338

Bennett C. . 333

Chauncey L. , 288

C. Raymond, 347

D. F., 411

Edward T., 410

Frank Russell, 359

Gene, 380

Harley E., 348, 546, 551

Huldah, 142

Irese Aphelia, 435

Irma, 274

J. B., 551, p-551

James A., 445

James Burns, 468, 55!

James C., 345, 397, 431, 446,447

James Elwood, 355, 428 , $429,432,458,467$. 475

Joel, 151, 424, 436, 551

John C. , 341

Maine C., 277, 349, 546, 551

M. T., 69, 324, 325

Oscar B., 172

O is L. . 391

P, E, T, 357, 462

Paul F., 172

S. W., 419
ANDERSON continued

Sadie L., 171

Thomas B., 420-422

T. J., 536

Victor, 411, 55!

Victoria, 14!

Waliam Nance, 277, 343 . 377,551

Willis S, , 422

ANDREW

G. M., see Andrews, G.M. ANDREWS

B. B, , 455, 458

Clayton Farrington, 359 . $371,520,521,551$

E. Benjamin, 271

Gaylord McE., 343, 434 , $442,444,458,457$. 458, 551, a. C, a. Andrew, G. M.

George Emory, 353, 356

Henry Seeley, 146, 434, $458,506,551$

H. T., 393

J. A., 140,148

J, P., 70, 71, 317, 324, 325

Katherine B., 171

Thomas J. , 147, 432, 552

ANDRUS

Frederick Moore, 359, 552

ANGLE

Edward John, 314, 357, 552

Everett Edward, 359, 552

S. D., 340

ANGLIN

Robert Stephen, 120, 338

ANGUS

George Alexander, 345

ANSON

Bess M., 171

ANTHONY

John C. , 428

ANTONY

Arthur Charles, 349

Joseph T., 467

APPL EGET

Eugent B., 355

ARBUCKLE

Georgia A., 256, 265 , 330,338

ARBUTHNOT

Charles M, , 467

Robert T., 427

ARCHERD

John Willis, 410,465 , 552, a.c. a. Archard: Archerd, John Wills

\section{ARDENEY}

J. J., 467

ARDIEL

Evan, 447

AREHART

Arthur A, , 397

ARENDT

Daniel C. , 172

ARK IN

Julis, 172

ARKWRIGHT

Richard M. , 288

ARMTT AGE
ARMITAGE continued

Albert Ciegle, 425, p-551. 552

ARMOUR

George E. , 396

ARMSTRONG

Frederick C., 468

G. C. , 427

H. G, 165

James R., 432

J. T. , 338, 428

Robert Burton, 508, 552

ARNALD

Harry Joseph, see Arnold, Harry $J$.

ARNHOLT

Milton, 552

ARNHOTT

Milt on F., 359

ARNOLD

A. A., 389

Charles Harrison, 358, 521 . 552

E. L., 338

Edward S., 172

Pannie, 85

B. B., 410

Harry Joseph, 340, 349, 446, a. c, a. Arnald

Harry L., 341

Merton 0., 553, p-554

William, 85, 329, 338, 341, 374

ARRASMITH

William J., 429, 442, 515 , p-552, 553

Winfred Woodworth, 429, $515, p-552,553$

ARRIES

Byron E. , D. D, S, 546

ARTHUR

Beatrice E. , 171

Mattie Laughlin, 186, 192, p-200, 200-202, 340 . $341,397,553$

ARTZ

Charles V., 393

ASA

Athenus L., 444, 553

Oran C. , 553

ASBURY

ASH

Levi M. , 397, 429

Joseph Lafe, 349، 553

Wilfred Anthony, 348

ASHBY

Albert Archie, p-552, 553

S. F., 140-14!

ASHER

Otto L. . 359

ASHTON

Thomas Butchinson, 123-124, 155, 358, 395; a. c. a.

ATHA Asht on, Thomas C.

John Frank, 345, 359, 553, a. C. a. Altha, John Frank ATKINSON

Ira E, J., 358, 425, 553

M. A. 338

ATTWOOD 
ATTWOOD continued Norman Harry, 345, 553, a. c. a. Atwood, Nor$\operatorname{man} \mathrm{H}$.

\section{ATWOOD}

Charles Herbert, 412

Henry Smith, 348

Moses, 427

ATZEN

Charles R., 345

Clarence Raymond, 467

AUKES

Ehme E., 428, 553

AUSPACHER

Carrie F., 340

AUSTIN

E. J., 394, 41 0, 435 , 470

Jack W, 172

AVERY

C. F. 389

Hiram Henry, 553

William A. , 553

AYARS

Henry Eugene, 446

AYERS

Clint on L., 411, 424, 432, 553

AYRES

George B., 262, 263 , $265,329,330,332$. 338

AZEE

James W, , 338

B,

\section{BABCOCK}

A. H. (Judge), 82

म. $\mathrm{C}, 343$

Jay Blaine, 359, 553

L. F., 59, 324

Welliam B., 92, 424

BACA

Harold W., 172

BACHLE

Edward P. , 429, 553

BACON

Frederick D. , 333, 338, 341,360 ; a. c. a. Bacon, Fredie

BAER

Almer in Webster, 396

Byron Howard, 347, 463,

BAGLEY

553, p-554

M. J., 434

BAILEY

Byron G. , 464

Benjamin Franklin, 138139, p-139, 140-141,

$151,205,208,252$, $322,355,356,473$, 518

H., 165

Hugh, 393, 411, 437

BAII ER

Lloyd E. , 343

BAIN

Clarence Lorimer, 349

BAIR
BAIR cont inued

William M. , 338, 356 , $397,411,425,427$. $432,445,458,462$. 470,475

BAIRD

C. W., 428

Charles Glenn, 429, 553, a. c. a. Baird, Charles Glen

Robert, 409

BAKER

Andrew J., 341, 357, 446

Bartow B., 124-125, 554

Clara, 171, 383

C. R., 451, 457

David L. , 432

Frank Lawrence, 462, 554.

Ira R. . 451, 457, 458

Jonathan H. , 428

Kenneth C., 288

Lewis L. , 341

Milan, 441

Ottway G., 328

S. M. , 431

BALCOM

Edward D., 444

Raymond D. , 514, 554

BALD

Arno Albert, 147, 446. 554, p-554

BALDRIDGE

S. T. . 338

BABDRIGE

H. M. (Mrs, ), 102, 221 BALDWIN

Beecher B., 410, 446

Caroline P., 186

Charles N., 341

Charles W.. 148, 338

Cyrus, 338

Earle Creighton, $\$ 10$

Francis J., 554

Grove, 249, 347, 387

BAL.1.

R. R., 489

BALLARD

Carl Herdin; 943

Charles E., 410

Charles F., 86, 150, 356

C. B. (Mrs, ), 379

W. $\mathrm{B},, 338$

BAMFORD

Samuel E. , 393

BANCROFT

Jesse, 31

Paul Martin, 277

William M., 30-31, p-31, 422

BANGHART

Edgar B., 345

BANISTER

Edwin Blair, 392

John Monro, 2, 157-158, p-157, 162, 277, 322, $338,345,370,546$; a. c. a, Banister, John Monroe

Willam B., 371, 446, 554

BANTIN

Clarence Frederick, 241,
BANTIN continued

Clarence Frederick continued, p-241, 277, 348, 373. 354

Elmer William, p-276, 277 373,554

BANT ING

F. G., 228

BANWELL

Edith, 171

W. B., 431

BAPTIST

John, p-249, 250, 554

BARAKAT

M. E. , 343, 410

BARBAT

Philip, 173

BARBER

Winlam Henry, 443

BARBOUR

Fredric L. . 338

BARCLAY

Arthur 0, 345

BARFOOT

Albert Fremont, 437

BARKER

Ira N. , 429

Joseph, 485

Pearl F., 517

BARKEY

Veteran Smith, 359, 554

BARKLEY

W, E., 519, 520

BARLOW

Maton T. (Mrs, ), 482

BARNARD

Esther E., 186

BARNES

A. S., 336

BARNETT

C. A., 442

BARNES

Charles, 345

Chester D. , 161, 554

Cokner, 16!

Cyrenins S., 443

Erskine M., 161, p-161. 345

BARNEY

Margaret C. Himrod, 192, 197

BARNHARDT

Bdgar Geoffry, 207, 343, 555

BARNHART

T. G. , 386

BARNS

Frank Milan, 343, 395, 465, 554

BARNSDALI

J. W. , 338

BARR

Arthur L., 345, 397

Charles Ceci1, 151, 395. 539,555

D. D., 410

E. E., $396,437,464,465$

Almer Louis, 347

BARRET

Lawrence, see Barrett, Lawrence 
BARRETT

E. L., 432

Edward D., 338, 428, 429, 443, 475

Lawrence, 465, 531, 555, a. c, a. Barret, Lawrence

William M., see Barritt, W. Marion

BARRINGER

G. R. , 444

BARRITT

W. Marion, 296, 333, 340,358 , a. c. a.

Barrett, William M.

BARRON

Howes Martin, 392

Thomas E., 341, 432, 462

BARROW

Thomas E, , 446

BARRY

Augustus C., 345, 438

Charles Augustus, 555

Michael Wtiliam, 348 , 546

William M. , 229, 307, 308

BARSTOW

James, 386

BARTA

Frank Albert, 468, 531 , 555 , a. c. в. Barta, Prank Elber:

L. C., 165

BARTEK

Julius George, 307, 348 . 555

BARTHOLOMEW

George F., 424, 442 . a. c. a. Barthalomew, Geo, F.

Philip H., 156, 359, 474, 475,555

William Sylvester, 447, $555, p=555$

BARTLET

David J., 425

BARTLETT

Grove W., 358, 414, 425 , a, c. a. Bortiett, G. W.

William Clarence, 431, 555

BARTLEY

Frank, 395

BARTLING

Dietrich L. , 435

BARTON

Guy C. , 485, 492

BARTOO

Albon E., 128, 148 , 363,468

BARUCH

Jacob B., 357

BARUCHT

F. E., 410

BASKIN

Morris Jacob, 396, 504, 555 , a. c. a. Baskins. Morris J.

BASON

W. T., 362
BASS

Cyrus, 70, 324, 325

BASTEN

C. Van Dyck, 516, 555

BASTRON

$$
\text { Carl H. , } 359
$$

BATES

Bret Verne, 446, 466

Charles Richard, 348

Dewitt, 459

Edward, 428, 459

Henry Y., 89, 412, 425 . 470

John B, 434, 555

Joseph, 89

BATHRICK

Byron, 428

BATIE

Lelia E., 171

BATTENDIERI

Domenico O., 343

BAUER

Peter L., 172

BAUGUESS

Harry, 432

BAUMER

John, 63

Theodore L. , 60, 63, p-63, 150, 325

T. W., 60

Willian,, 63

BAUMGARTNER

Conrad J. , 348

BAUSERMAN

Marshall P., 433

BAXT ER

Mark W., 152, 393

BAYER

Frederick A., 410

BAYL.ES

Stephen T., 476

BEACH

Glen O., 288

Samuel C. , 447

BEACHLEY

Belle, 374

John Vawter, see Beachly, John V.

John Victor, see Beachly, John V.

N, J., 351, 352

Victoria B, 171

BEACHLY

John Vawter, 357, 384, $385,432,462$, a. c. a. Beachley, John Victor, BEANS Beachley, John Vawter

W. E., 489

BEAR

Alexander, $81-82, \mathrm{p}-82$, $126,148-151,255,319$ 361,362

BEARD

Clyde Yeager, 437

Edwin A. , 464, 466

Frank Warnock, 428

J. R., 338

BEATTIE

David W. , 362, 394

Jasper, 359,556
BEATTY

John Ray, 146, 396, 556

BEAVER

Charles H. 358

BEBER

Meyer, 277

BECK

Frederick 0., 343, p-555, 556

Gerald Henderson, 347, 470

Louis H. , 473, 475

BECKER

Carrie, 186

Wesley Charles, 359, 522 , p-555, 556

BECKETT

James, 338

BEDAL

Mas shal D., 469

BEDELL

Charles V., 436

BEDWELL

Luyl Clare, 348

BEECHER

George Allen, 482

Rodner, 341, 414, 470

BEEDE

Clark Eli, 397, 556

BEEMBLOSOM

Z. E. 427

BEERY

Geno. Ethel, 358

BEGHTOL

James Vance, 39, 132, 137 -

$139, p-138,147,152$.

$352,355,363,392-393$

BEINRE

C. J. P. , 343, 411, 434

BEISEL

C. 165

BEIT ENNAN

Milton E. , 348

BELL

Albert T., 314

Allen, 435

David W., 556

Firman M. . 147, 556, p-556

Frank, 425

Hubert O. , 476, 556

H. S., 516

James R., 411, 556

James Stewart, 476, 556

Nellie, 192, 423, 425, 556

Peter Percy, 349

W. J., 341

BELLWOOD

H. H., 396, 503, a, c, a. Belwood, H. H.

Will S., 396

BELWOOD

B. H., see Bellwood, H.H.

BENDLAGE

George A., 348

BENEDICT

Edgar Pearl, 349

BENING

Herman, 412

BENJAMIN

Herman P., 345, 432

H. R., $69,324,328$

BENNER 
BENNER cont inued Stillman Marion, 428

BENNETT

Abram Elting, 277, 337 , $348,396,546,556$

Alice, 340

Alma S. , 443

Clyde R., 288

Gilbert P., 443

Joseph L., 516-517, 557

Isaiah, 427

Muton, G. E., 358, 429

William E., 288

W. S., 345

BENNIE

James Walter, 395, 557

BENSON

Anna L., 338

Harry William, 146, 397 , 557

BENT

Frank H. , 430, 431, 436

BENTHACK

Peter L., 446, 557

Walter, 348, 557

BENTLEY

Ralph L. , 311-312, 355 , 357,557

Samuel N. , 557

BENTON

Eugene A., 122, 123 p-123, 442

Joseph E., 123, p-123, $442,510,557$

BENTZ

George Henry, 358, 412 , BENZ $432,467,557$

Ferdinand L., 343

BERCHTOID

Victor Ernest, 348, 557

BERENS

Sylvester N. , 310

BERG

A. , 338

Emanuel, 495

BERGGREN

Andrew Leon, 435, 462

BERGMAN

Peter (Mr. \& Mrs, ), 495

BERKOFER

Wm. J., see Birkofer, Wm. J.

BERNARD

A. B., 73

BERNEY

Francis Joseph, 349

Paul William, 557

BERRY

John L., 338

William C. , 338, 360 , $373,464,546,557$

BERWICK

Thomas A., 340

BEST

C. H. , 228

Rollin Russell, 546, 557

BETHENY

Earl, 359

BETTENCOURT

Joseph L., 172
BETTER

James George, 347

BETTS

William Hy, 338

BETZ

William Henry, 557

BEYERMAN

Louis, 338, 458

BEYM ER

Charles Bishop, 349

BLART

C.M.G., 267, 331, 338, 360 , a, c. a. Biart

BLAS

C. M, C.

M. S. 462

B!CKNELL

George H., 115, p-115

BICKWELI

George H. 343

BIERMAN

Edward A. , 172

BIGGEF

D. P. , 338

BIGSBY

Edgar, 357

BIID

E. J., 431

BILLINGS

Frank, 270

Robert Anderson, 424, $468,531,557$

BIL.LS

C. J., 518,519

BILTON

Louis V., 348, 541, 557

BINNEY

Cascon henry, 338

Joseph H. , 443

BIRDSALL.

George Asa, 432, 466, 467

BIRKHAEUSER

Joseph E, , 338, 341, a.c.a. Birkhaenser, J. E. : Birkhauser, J. E.

BIRKOFER

William J., 150, 424, $436,514, p-556,557$. a. c. a. Berkofer, Birkefer; Birkhofer; Birkoffer

BIRKNER

John Martin, 357, 411, 557

BIRNEY

B. B., 341

BIRSS

Carrie A. (Mrs, ), 508

BISHOP

James C., 341

Jchn P., 432

BISSELL

Mary Taylor, 201

BITZER

Donald A., 432, 558

BIXBY

A. L., 239-240, 243-

244, $\mathrm{p}-244$

Alice $M, 171$

Bessie, 142
BLXBY continued

Joseph, 146, p-556, 558

BIXIEF

Willaim Grant, 357

BLACK

Axel J., 343

Benjamin H., 173

Edwin T., 432, 433

Emil, 397

George Huffman, 400-401. p-401

James, 70, 321, 324, 325

John, 398, p-398, 400-401

Paul, 371, 521, 558

BLACKBURN

Mathew H. , 428

Robert A., 338, 341, 396 . 411,427

BLACKMAN

Julian Raymond, 373, 393, 564,558

Julian (Mr5.), 379

Mary L. . 355

BLAINE

James J., 152

BLALR

Charles D., 426

Edward S., 470, p-470, 558

George A. 393

Sernuel F., 341, 423

Wiliam M. , 393, 414, 432, 434-436

BL.AK

Einer V., 396, 503

BLAKE

Benjamin F. M. , 343

BLAKELEY

Nathan Hall, 359, 445, 453 , $457,459,505,513,558$, p-558, a, c. a. Blakley;

Blakely: Blakeley, Nathan Holl

BL AKEMARE

William H. , 445

BLAKLEY

N. H., see Blakeley, N.H.

BLANCHARD

George L., 397

Lafayette W., 357, 429, 444

BLANCHE

Sister M. 515

BLATTSPIEL ER

Arnold Charles, 558, p-558

BLAZEK

Prank M., 435

BLEASON

Bert L. 410

BLEICK

Louis C. , 345, 435, 462, 558

BLEIWEISS

Martin H. , 345

BLENKNET

Theodore, 467

BLISS

Rodney Waldo, 337, 373,

$391,546,558$

Rodney (Mrs. ), 379

BLIZZARD

John William, 356

Sephen R., 355 


\section{BLOCH}

David Michael, 348, 463. 558 , a. c. a. Block, BLOCK David Michael

Max, 345, 558

Paul, 359

BLODGETT

Harry H. , 358

BLOMBERG

Mabel, 171

BLOME

Emma A. 171

Ernest R., 172

BLOOD

John, 445

BLOOMER Milo, 425

BLUM

A. A. 349

BLUMER

Adolph, 457

Frederick William, 558

BLYSTONE

M. C., 421, 422, 468

BLYTHIN

J. W., $145,338,341$

BOAL.

V. M. , 444

BOBURN

H, H., 433

BOCKME

Mastelle, 338

BODELSON

Helen B., 338

BODEMER

Herman Charles, 348. 390

BOEHLER

George M., 170, 546, a. c. a. Boehler, George N.

BOEHR

Irwin Isaac, 348, 397. 558

BOERBER

P. E. V., 446

BOERSTLER

George W., 338

BOGEN

Louts isaac, 343,358 , $424,426,465,559$, a. c. a. Bogan, Louis !

BOGGS

Charles Summer, 428, 559

Lewis B, , 427

BOHANXAN

Charles L., 411

BOLAND

Frank William, 435, 445, 559, a.c. a. Boland, Francis W.

Sarah J., 475

BOLER

Thomas Daniel, 306, 307. $343,386,546,559$, BOLIN a. c, a. Boler, Thomas J.

E. C. . 340

BOLLINGER

E. , 393, 397, 458
BOLLINGER continued

H. E., 432, 467

BON

Hattie C., 475

BONAVIEZ

Katherine E.K., 192

BOND

Elizabeth J., 468

BONESTEEL

S. A., $70,324,325$

William J., 429, 434

BONNELL

Dr., see Bunnell, T. A.

BONNTWELL

Harry Melvin, 359, 559

BOONE

Abner E., 345

George F, , 467

BOOSE

Wuliam R., 147, 450, 456, 458, 559

BOREN

Albert J., 359, 393, 475, 559

BORGHOFF

John Aloysius, 232, 307 . $308,347,546,559$.

a. c. a. Borghoff, John J.

J. A. (Mrs.), 379

BORCLINER

Francis L., 358

BORGLUM.

Francis L., 345, 465

F. M. 338

Gutzon, 365

Harriet, 380

J.M.H. , 341, 365, pe 365

Solon, 365

BORIEN

Schuyler C., 442

BORRE

Helge, 288

BORTLETT

Grove W., see Bartlett, G. W.

BOSWELL

Davis, 414

BOTHRICK

Byron, 432

BOUDURANT

Essie H., 357

BOUGARDT

Henry Francis, 347

BOURNI

J. H., 455

Joseph W., 343, 444, 458

BOWDEN

Isaac, 410

BOWEN

Arthur Hosmer, 355

Aurelius, 50, 70, 78 . $148,152,316,318,321$

Charles R., 173

George Sanford, 559

BOWER

Mary, 458

BOWERMAN

Adda, 186, 340, 432,

470 , a.c. a. Bowerman, E. Adda

BOW ERS
BOW ERS cont inued

O. B. 397

BOWLES

Arthur, 147

Edward Arthur, 467, 468, 516,559

Loetta Beamer, 468, 516, 559

BOWMAN

Carrie Luella, 192, 465, 559

Delbert J., 358, 522, 559, p-559

J. H., 462

John Edward, 465, 558

John W. . 355

Luther W., 396, 465, 466 , 504, 559, p-559

T. H., 73

W. L., 396, 466

BOWSER

William Wolfe, 343, 560, a.c.a BOYD Bowser, William Wolf

Charles Albert, 463, 464

Earl Eugene, 157, 358, 442, 560

Elsa, 142

James E., 48, 47, 87

Jay, 338, 343, 357

BOYDEN

Henry Blakeslee, 429, 515. 560 , a.c. a. Boyden, Henry D.

BOYER

William Ransom, 143, 323, $532,534,560$

W. R. (Mrs.), 377

BOYES

Joseph H., 466, 467

W. R. , 539

BOYLE

L. J. 165

BOYNE

Harry, 306

BRACELIN

M. Patrick, 338

BRACKETT

John W., 443, 446

BRADFORD

E., 470

Benry, 50, 315

BRADLEY

Clarence Austin, 428, 560

Edwin Bruce, 396, 560

Virginia A. , 412

BRADSHAW

H. N., 432

John F., 358, 475

BRADWAY

William, 338

BRADY

L. M. , 426, 427

Richard Randall, 348

BRAGG

George E., 355

T. A., 364

BRAIMEN

James L. , 462

BRAINARD

Jerry E. , 445, 560

BRAKETT 
BRAKETT cont inued J. W., 442

BRAMON

Marcus D., Jr., 173

BRANAMAN

George M., 343

BRANCHT

F. E. 343

BRANDEIS

Arthur D. (Mrs, ), 491

Emil, 492

E. John, 491

George, 543

Hugo, 492

Jonas L. (Mrs. ), 491

BRANDT

Emelia Halgsen, 192, 194, $p-194,196,200$ 。 $201,338,345,546$, 560 , a.c. a. Brandt, Emelia Hanigsen; Brandt, Emlly

Johanna M. , $35 \mathrm{C}$

Thyra L., 171

BRANNEN

James L., 146, 442, 560 , a. c. a. Brannon, J. L.

BRANNLAN

Edith M., 171

BRANNON

J. L., see Brannen, James L.

BRASH

George н., 139, 141 , $207,296,396,428$

BRATT

Mary, 427, 560, a. c, a. Bratt, Marry

BRAUCHT

F. E., 423

BRAUN

Josephine C. . 171

Minnie K., 171

BRAY

Robert Ellis, 560

BRECKENRIDGE

Charles F., 180

Mary Foster, 180, p-180

Mary J., 179, 186, 338, $341,366,428$

Wullam J., 411

BRECKS

Ida A., 171

BREDENSTINE

S. J., see Bridenstine, S. J.

BREEN

Adrian Louis, 517, 560

Mercedes, 274

BREENGARDT

B. A. 345

BR EHM

Paul Albert, 348

BRENDEL

J. W., 146,560

Jacob, see Brendell, Jacob H.

John F., 409

BRENDELI

Jacob H., 409, 560 .
BRENDELL continued

Jacob H. cont inued, a. c.a. Brendel, Jacob

BRENENSTALL

Harriet M, , 171

BRENIZER

James G., 86-87, 256. a, c. a. Brenzier, James G.

BRENN

Charles P., 560

BRENNAN

Raymond James, 347

Thomas J., 172

BRENZIER

James G., see Brenizer, James $G$.

BRERVURT

Harry S., see Brevoort, Harry S.

BRETHOWER

Evert Jan, 355, 356

BREUER

Charles Hugh, p-239, $240,460,560$

Miles John, $170, p-239$, $240,359,372,560$

Roland George, 359

BREVOORT

H. S., 358, 393-397。 $410,411,414,424$. $425,429,431,433$. $435,436,437,442$, 444, 446, 458, 462, $465,466,470,475$. a. c. a. Brervort, Harry S.; Brevort, H.S.

BREWER

Albert David, 357, 429

Charles H. , 341

BREWST ER

Elizabeth, 427

Frank A., 37-38, p-38, $156,237, p-238,427$, 504, 508-509, a.c. a. Brewster, F. F. A.

BRICKER

Frederick J., 338, 393, 429

BRIDENSTINE

S. J., 439, a. c. a. Bredenstine, S. J.

BRIDGMAN

W. B., 395, 465

W. E., 435

BRIDGES

Edson Lowell, p-167, $168,169,277,283$. $284,341,345,435$, 560

Willson Orton, 95, 97 , p-98, 99, 150, 208, $216,246,267,269$ 。 $272, p-276,277,288$ $321,322,330,333$, $334,337,338,341$. $360,461,478,492$. 561 , a. c, a. Bridges, Wilson 0 .

BRIGGS

Glenn W., 397, 561
BRIGGS continued

Harry Arthur, 424, 427

John S. , 174, 427

Phoebe A. Oliver, 174, 175. $p-175,176-177,197,426$ 427

Walter H., 432, 561, a. c, a. Brigs, W. H.

\section{BRLLHART}

Guy L., 393

BRINK

Chester A., 450, 456, 458, 468

H. J., 446

BRINTON

Mary Foster, 428

BRIST OL

L. D. , 141

Thomas Deloss, 467

BRITELL.

Oley A. , 443

BRITT

Leonard Edward, 343, 561

William Henry, 146, 434, 561

BRITTAN

Joseph E., 343, 358, 433, 444, a. c. a. Brittion, J, E.

BROCKETT

Jahn C., 468

BROCKHAN

Louise, 142

BRODSTONE

Evelyn, 538

Mathilde (Mrs. ), 538

BROMAN

R., 165

BROOKE

John R., 81, 454, 457, a. C. a. Brook, J. R.

BROOKS

Charles L., 457

Earl Brisbin, 358, 371, 521. $532,533,539,581$, a. c. a. Brook s, Earl V.

William Penn, 33, 83

BROSIUS

F. C., 338, 393, a. c, a. Brosins, F, C.

\section{BROTRHER}

Ferdinand, 428

BROTHERS

Howard D. , 266

BROWN

Mrs, , 504

Adolph L., 491

Alfred Jerome, 245-246. p-246, 277, 283, 372, $375,546,561$

Andrew D. , 442, 561, p-562, a. c. a. Browne, A. D.

Arthur C. F., 343

C. A., 444

C. E. 546

Charles E., see Browne, Charles E.

Charles Phillip, 345, 561

Dewey Franklin, 447, 361

Edward Verran, 470

Elmer, 345

Ewing, 266, p-266, 332, 337 , $338,343,360,361,561$ 
BROWN continued

Frank W., 425

G. M. , 442, 489

H. A., 411

Harold M. , 358, 425, 546

Harry Richard, 429, 432. $561, p=561$

J. J., 491

J. Marion, 447, 470

Joe R, 172

John P., see Brown, Julius Philip

Joseph Wesley, 393, 562

Julius Philip, 348, 432, 562 , a. c. a. Brown, John Philip

L. R., 470

Laura J. , 189, 192, 199 , 200,357

Lionel Botleman, 562

Mackenzic, 459

Mildred I. , 171

N. H., 423

Nathan H., 425

S. B., 390

Samuel L., 410

Thomas D., 338

Thomas H., 475

Turner, 433

W. M. , 333, 341, 338

William P., 338

BROWNE

A. D., see Brown, Andrew D.

Alfred M. , 343, 357

Charles E.. , 429, 458, a. c.a. Brown, Charles E.

Jesse P., $173^{\circ}$

William Preston, 355

BROW NRIGG

W. J., 341

BROWNSON

Hollis Lee, 432, 562

BROYLES

Franklin Hunt, 428 BROZ,

John Stephen, 347

BRUBAKER

J. C. , 356, 411, 429

BRUCE

Charles, 393

Jerald Joy, 347, 562 , a. c. a. Bruce, Gerald J. J. O., 393, 427, 435

BRUHN

Fred, 529

BRUMLEY

Samuel Henry, 345

BRUNER

James F., 338, 341

BRUNING

E. F., 390

BRUNNER

Henry, 34

BRUSB

Edward Lewis, 146, 323 . $362,372,438,562$, $\mathrm{p}-562$

BRYAN

Albert Waite, 359, 562

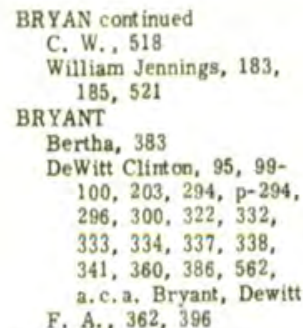

BRYSON

Charles W., 450, 457

Roy Douglas, 411, 420. $422,424,462,562$

W. G. , 340

BUCHÁNAN

Albert Edward, 151, 462, p-561, 562

Rea, 358, 563

BUCK

Frederick O., 359, 432

Frederick W. , 345, 424 , $425,429,430,433,434$, $436,437,442,446,447$, $462,465,468$

William W, 470

Willis E., 364, 434

BUCKLEY

Frederick Watson, 170 , $424,429,508,563$

S. Byron, 443

BUCKMAST ER

Raleigh A., 435

BUCKNER

Blijah D. , 355

BUDLER

Marie T., 171

BUEL

W. C. , $343,429,462$, 465

\section{BUFFINGTON}

George M. , 172

Joseph R., 148, 427

BUIS

John, 147, 534, 563 a. c.a. Buie, John

\section{BULLARD}

Ezekiel, 80-81

James H. , 338

John W., 80-81, 367, 539

BULLETT

Josephus G., 357

BULLOCK

Willard E., 172

BUMFORD

Sammie E., 359

BUMIZ

Frederick, 338

BUMP

Lewis W., 341

BUMSTEAD

Lucius J. , 355, 356

BUNCE

Arthur C., 343

BUNDY

Corydon D. , 468

William C., 410

BUNNELL
BUNNELL cont inued

T. A., 72, a. c. a. Bonnell, Dr.

BUNSBACK

Newton N., 428

BUNTEN

William A., 347

BUOL

George, 343

BURBANK

Frank Elbert, 434

Frederick Lisander, 340,356 . 417,425 , a. c. a. Burbank, F. E.

Lysander Tower, 255, 416 , 417,422

BURCH

Stella, 383

BURCHARD

Charles T., 141, 447-448, $449,450,456,457,458$

F. W. , 448

Harry Dana, 450, 458, 513. 563

BURDICK

Frank O., 468

H. C. , 397

Harry Edwin, 371, 563

J. R., 343

BURFORD

James A., 359, 434, 508, 517,563

BURGESON

Daniel LeRoy, 393

Edna F, P., 393

BURGESS

Charlotte, 143

Frank Dooley, 338, 395, 409, 465,563

BURGBER

A. E., $453,456,458$

BURKARD

Adrian F. , 343

BURKE

Donald, 306

Francis Paul, 435

Thomas N. , 563

William A., 343, 410, 446 , $458,470,563, \mathrm{p}-564$

BURLEY

Robert C., 173

BURLINGAME

Donald L. , 288

Lyman R., 345, 563

BURMAN

Guy Elmer, 434

BURNER

Henry R, 432

BURNET

Anne, 192, 352, 355

BURNETT

E. A., 273

Francis Kirk, 348

BURNHAM

Frank Ashael, 419, 422, 424, 504,563

Jane, 504

Philip S., 172

S. H. , 519

BURNS

Bernard Charles, 348, 563 
BURNS continued

C.

Ernest Madison, 347

Guy W., 341

Hiram D., 345

BURR

Chauncey S, , 338

W. A. , 363

BURRELL

Henry L. . 207, 296, 333. $338,386,470$

Ramon Haddock, 395, 435, 462,563, a. c. a.

Burrell, Roy D.; a. c, a, Burrell, Ray H.

BURROUGHS

Amelia E., 179, 181, 186 , $338,341,365$, a. c. a.

BURSTEIN Burrough, Amelia E.

Louis Lancelot, 470

BUSBY

J. A. Clark, 410

Lauren Fletcher, 277

BUSCHMAN

Elisa, 338

BUSH

John C. F., 203, 462.

a. c. a. Bush, J.F.C.

M. E. 301

Russell D. , 462

BUSHBY

Alonzo L., 431

BUSHMAN

Louis B., 305, 343, 372, 386,563 , a. c. a. Bushman, Lewis

BUTIN

Mary Ryerson, 183, 321

S. L., 183

BUTLER

Gover nor, 83

A. C. , 427

Edwin Miles, 355

Fletcher A. , 411, 412

J. S. , 563

Milton Micajah, 150, 406 , p-406, 409

T. R., 426,427

BUTT

Thomas F. , 356

BUTTERBAUGH

William S., 357, 434,

$$
444
$$

BUZICK

Edwin, 414, 428, 463, 464

BUZZA

Mildred Joy, 348

BYERS

George A., 425

Jay Cleveland, 563

John N., 425

Robert Charles, 423, 425,563

Samuel J. N. M. , 425

BYRN

H. H. , 431

BYRNE

James Raymond, 345, 563 BYRNES

M. Robert, 359,563

CALLFAS

\section{CABBLE}

W. H. , 435

CADWALLADEF

Charles, 414

CAKL

Franklis Ka, 340

CALBREATH

Claude B., 393, 563

CALDWELI

C. J. . 418

J. C. 475

J. Willard, 458

Ora M. . 393, 395, 397, $424,430,432,434$. $444,445,446,468$, 470 , a. c, a. Caldwell, Osa

CALKINS

Fred E., 423, 425, 564, p-564

\section{CALLAGHAN}

Ambrose James, 423, 425,564 , a. c, a. Callahan, Ambrose J.

CALLAND

Charles B. , 447

CALLENDER

J. A. , 343

James M. , 445, 468, 475

CALLEY

J. W. , 165

Jennie, 192, p-195, 343. 379

William Frederick, 104, 217, p-276, 277, 345, 372,546

CALLISON

Josephus M., 457

CAMEL

Elias George, 347

C.AMERON

A. C. 396

Alex D., 564

Allan J., 470, 564

Hugh Campbell, 564

John James, 564

Joseph Robert, 156, 359 , 427,564

Neal, 363

Wuliam L. , 358, 564

CAMPBELL

C. M., 366

Charles A., 458

Charles Harvey, 371 , $429,442,446,564$

Daniel W.. 449, 457

Henry, 357

John C. . 50, 315, 316

Joseph L. , 170

Joseph New, 431, 564

Phillip Thomas, 564

R. B. 447

Robert R., 564

Samuel Mount, 110, 338, 341,564

Stuart Avery, 341, 372, 528,565

T. F., 396, 411, 423,
CAMPBELL cont inued

T. F. cont inued, 425,429 , 468

W. W. 449,450

William Allan, 359, 412, 565

William C. , 362, 434

CANDY

A. L., 518

CANEEN

John E., 445

CANFIELD
J. M. , 435
L. G. , 356
O. B., 411

CANINE

T. C. , 432

CANTY

Charles Raymond, 348

CAPEK

Ernest, 343, 359, 425, 462, a. c, a. Capek, Ernst; Capet, Ernst

CAPELI

W. L., 341

CAPET

CARD

Ernst, see Capek, Ernest

Agnes, 192

CARLSAN

T. J., 165

CARLSON

C. C. . 513

Carl, 173

Carl Robert, 348, 410 , p-564, 565

George L., 412

Hüma C. 540

CARM AN

Frank D. , 546

CARMICHAEL

F. W. (Mrs.), 377

CARNAZZO

Sebast in John, 310

CARNEY

Balph B., 546

CAROTHE RS

John W. , 563

Paul Henry Jacob, 418-419, 509,565

CARPENT ER

D. W. , 45

E. M. 341

Frederick D. , 359, 395, 459。 565

CARR

Charles M. , 423, 425

E. Arthur, 141, 357

E. T., 436

Emanuel Frederick, 150, 151 . $436,437, p-564,565$

J. M. 536

John D. , 197

Robert Morgan, 428

CARRADINE

James S., 341

CARRALL

Frank, 425

CARRIG

Milton Henry, 348

CARRIKER

N. J. . 341 
CARROL

J. J. 387

CARROLL

Anthony Georige, 348, 565

James, 75

Raymond Patrick, 565

CARROTHERS

John Waller, 358

CARSCADDEN

Richard, 364

CARSON

David H. , 430, 565

W. T., 393

CARTER

A. H., 34!

Arthur L., 432

Guy D., 173

James 0, 264, 321, 329-

$331,338,350-352,355$, 357,361

John R. C., 396, 397, 437

Lew Arthur, 151, 432, 565

Marion, 186

Martin L., 430

William A., 430

CARVETH

Charles B., 434

Walter William, 348, 565

CASADY

Selmon A., see Cassaday, Selmon A.

CASE

Ernest Spencer, 128, 146, $148,179,426,565$.

a. c.a. Case, Ernest D. James D., 140, p-140, 357,565

Mary C., 186, 426

Sackett C., 128

Sackett C. (Mrs.) ) 179

W, E. , 177

CASEBEER

Howard M., 353, 354, 356,357

J. H. , 522

CASEY

Charles Oris, 359

Frank Joseph, 307, 348, $386,546,565$

CASHIN

John Emerson, 565

CASLEY

D, H. , 363

CASSELL

E. T., 393

CASSADY

Selmon A., 429, 431,

565 , a. c. a. Casady,

Selmon A.; Cassidy. Salmon A.

CASSIDY

George Alvin, 345, 359

Salmon A., see Cassady, Selmon A.

Waldron A., 104, 217. $277,345,546,565$, a. c.a. Cassidy,

CAST ER Waldran A.

John R., 475

CAST ERLINE
CAST ERLINE continued Ralph W. E., 301, 412 , 433, 475

T. E. . 411

CASTLE

Claude S., 429

CATANLA Nancy, 192

CATE

William Andrew, 445, 565

CAUGHLAN Gerald V. , 345

CAULEY

Anthony, 446, 566

CAULFIELD

Andrew Joseph, 434

CAULK

Wullam H., 359, 430, $432,471,566$

CAVE

J. C., 430

CECIL

J. M. , 458

CELOZOWSKY

F. A. , 387

CERNY

Joseph, 459, 566

CHADWICK

P. M. , 338, 341

CHAFFIE

George H. , 475

CHAIN

Leo William, 345, 347, a. c, a. Chain, Leo Williams

\section{CHALMERS}

Mary, 171

CHALOUPKA

Edward, 305, 307, 308, 345,566

Hugo R., 343

John Godfry, 307, 347,

566, a.c, a. Chaloupka, John Godfrey

CHAMBERLAIN

Andrew J., 393, 411, 432, 467, 475, a. c. a. Chamberline, A. J.

Henry G., 470

Josephine, see Chamberlin, Josephine

Robert W., 395

William E., 358

CHAMBERLIN

Josephine, 171, 274, 277, 382, a, c, a. Chamberlain, Josephine

Myron H. 240, 341

CHAMBERLINE

Andrew J., see Chamberlain, Andrew J.

\section{CHAMBERS}

Florence, 380

Oliver, 170, 343

W. C., 340

CHAMPNEY

Cecile R., 171

CHANDLER

Charles D., 357, 410

Paul Austin, 393, 566

CHAPEL
CHAPEL cont inued

A. , 50, 51, 55, 144, 154, 316

CHAPIN

Horace, 350, 352, 355

Madren, 171

CHAPMAN

Alma J., 192, 194, 201, 359. 430,566

Amy R., 566

Chauncey Franklin, 147, 358, $510,518,566$

H. R. 518

Lille Forrest, 412, 366

Mary B., 338

W. A., 393

W. H., 393

CHARLETON

Ada. 384

CHARLTON

Charles Percy, 358, 566

Cecil Floyd, 391

George E., 362, 426, 438, 566

CHASE

E. W. , 268, 333, 338, 341

Warren T., 566

CHEDECK

Benjamin H., 343, 435

CHEENEEGAVZYAN

H. M., 345

CHENOWITH

M. S., 396

W. S., 343

CHERRY

Alice, 470

Allan B., 470

Juliet E., 171

Walter S., 467, 539

CHESSHIR

J. Melwsorth S., 424, 445 , 566, a. c. a. Chessir

\section{CHIDESTER}

Thomes J., 131, 459

CHILCOAT

Julius J., 343

CHII.D

E. P., see Childe, E. P.

Nichlas, 430

CHILDE

Edward P, , 343, 355, 431, 435, a, c, a. Childs, E. P. : Child, E. P.

CHIL.DS

Mary E. D., 340

CHILES

Jesse Henry, 345

CHINLUND

Emil G., 143, 481, 485

CHOCK

King Chee, 347

CHRISTENSEN

C. H., 345

E., 430

CHRIST ER

Ralph, 462

CHRIST LANSEN

C. J., 424

Sophia, 338

CHRISTIE

Burt on Whit ford, 109, p-109, $156,337,338,343,373$, 389,566 
CHRISTIE cont inued

Joseph W., 310

R. C. , 442

William H., 96, 109, p-109, $151,152,267,331,333$. $337,338,341$

\section{CHRISTLIEB}

John M. , 288, a. c. a. Christliebe, J. M.

\section{CHRYSTAL}

R. J., 362

CHIZUM

G., 165

CHUBBUCK

Carelton K., 86, 433

CHURCH

Anna Ferguson, 192, 436. 566

Burt Thomas, 359

H. C. 389

Ira $\alpha$ is, 359, 468

CHURCHILL

Barbara, 347

Charles H. , 396

Irving W., 359, 566

CIZEK

B. J., 165

CLAASSEN

C. J. 377

CLAPP

Raymond G., 374, 566

CLARK

Albany Judson Emerson, $425,428,444,458$

Albert Lincoln, 434

Bennett Hillsman, 462 . 566

C. H., 73

Charles Ernest, 345, 397. 567

Charles Fuller, 333, 341 . $567, p-567$

Delbert A. 428

Eugene E., 531, 567

F. C. . 397

Frieda, 193, 345

George, 442, 373

George A., 394, 458, 587

George C. , 429

George Leonard, 146, 349, 567

Guy Wilbur, 445, 446, 567

Harry Douner, see Clarke, Harry D.

J. C. R. 57

J. A., 362

John L., 397

Martha E., 193, 341, 567

Mart in V. B., 468

Mary B., 446

Mildred Naomi Johnson, 200, 349, 567, a, c, a. Clarke, Mildred Johnson; Clark, Mildred T.

Munson H. , 50, 70-71, 315

Nellie L., 270

Perry J., 397, 470

Rebecca A. (Mrs.), 355

S. H. H., 61

Tracy, 444

Willard D., 427

\section{CLARK cont inued}

Willard Kingsley, 435, 567, a. c. a. Clarke, Willard K. ; Clark, William Kingsly

William McC. 355

\section{CLARKE}

Corwin Stanton, 432

Edward John, 310

Floyd Sweetland, 305, 373. 567

Floyd (Mrs, ), 379

H. S., Jr., 336

H. T., 78

Harry D., 147, 345, 465. 567, a, c, a, Clark, H. D,

Harvey Llewellyn, 432, 567

Harvey Llewellyn, Jr. , 437

Müdred Johnson, see Clark, Mildred N.

Willard Kingsley, see Clark, willard $\mathrm{K}$.

\section{CLARKSON}

Bishop Robert H., 478. 482

CLARY

Robert H. (Mrs. ), 478

Wiliam Henry, 359

CLATHNER

Wulam P. , 426

CL.AUSSEN

Julius Edward, 333, 340, $341,429,567$

Lorentz Andreas, 427

CLAYBAUGH

William R., 343

Will iam W., 338, 341, 358, a. c, a. Claybough, W.W.

CLAYTON

J. O, 546

Jeremiah Black, 568

W. A., 341

CLEARY

James A., 349, 444

CLEGG

Earl George, 437

CLEMENS

James Ross, p-287, 300, 345

Mary, 530

CLEMENTS

Stanley Curtis, 359, 521. 568

CLINE

Edgar, 444, 505, 568

CLOPPER

Eben C. , 458

CLOUGH

Francis E. , 396

CLOYD

Augustus David, 250, p-250, $341,349,377,451,458$, 568

COAKLEY

Leo P., 349

COATES

Lillian E., 193

COATS

Albert James, 359, 432

Charles C., 345
COBURN

H. H. 458

COCHRAN

Francis Bruce, 343

John $C_{1}, 433$

COCHRANE

A. P., 165

CODER

Harold Eastman, 392

$\mathrm{COE}$

Alma J., 186, 356

Charles M. , 338, 433

Charles Benjamin, 568

COFFIN

C. E. , $363,357,468$

COFFMAN

J. A., 430

Victor H. , 60, 63-66, p-64, $130,145,155,212,262$.

$263,318,320,321,324$

$325,328-330,335,338$,

341, 374, a. c. a. Coffmann

Victor (Mrs, ), 64, 325

COFFMANN

Victor H., see Coffrman, Y.H.

COFFROTH

H. J., 338

COGLEY

John Pbilip، 347

COHEE

Hal R. , 410

COLBURN

E. L. 425

William C., 359, 432

William Orlin, 373, 520, 568

COLE

Anna B., 193, 464, a. c. a. Cole, Anna M.; Cole, Anna A.

Arthur W., 338

F. H. (Mrs.), 482

James B., 357

R. D. 513

COLEBURN

Jennie, 408

COLEMAN

Albert C., see Colman, Albert $\mathrm{C}$.

Claudius B., 356

Frederick David, 397, 568

Oscar, 397

COL.LAMER

A. (Mrs, ), 504

COLLEIMO

Ugo A. D. , 343

COLLEN

Freman S. , 348

COLLETT

Wuliam S. (Mrs.), 72

COLLIER

Mary C., 63

COLI.INGS

W. T. $175,176,177$

COLLINGSWOOD

Franklin, 356

COLLINS

Charles F., 35 ?

Cornelius R., 343, 568

E. A., 356

E. P. 396

Floyd M. , 345, 464, 536, 568 
COLLINS continued

Georige W... 82, 83, 148, 149, 396

Harry A., 348

Richard Kenneth, 347, 568

COLLYER

Albert E., 394

COLMAN

Albert C., 358, 431, 568, a. c, a, Coleman,

COLSETH Albert C.

Peter, 484

COLVILLE

A. W. , 338

COMBS

M. R., 341

COMPTON

A. $\underset{568}{N}, 146,410, p-567$,

G. W, 338

I. L., 470

CONANT

Jesse Lyman, 469

CONAWAY

Aaron C., 343

H. $0.340,343,430$, 432 , a. c. a. Conway, H. 0 .

CONDON

Albert Paul, 257, 343, p-496, 497, 568

Albert Paul (Mrs.), 257

Charles Emmet, 345

CONE

Elbert E., 426, 427, $p-567,568$

CONERY

A. F., 395

CONEY

William Herbert, 410 CONKLING

Jetur Riggs, 55-56, p-56, $59,144,145,154,288$, $324,325,338$

Jetur (Mrs. ), 56, 288

CONLAN

P. J., 34 !

Peter T., 386, 568

CONLEE

Charles C., 434, 568

CONLEY

Anna M, 171

D. E., 546

CONLLN

Frank Mathew, 210, 269. $277,283,337,373$, 392, $483-484,546$, 568

Frank M. (Mrs.), 379

CONNALLY

Henry, 431

CONNELL.

James, 102

Karl Albert, 102, 158-159, $p-159,254,304,345$, 375,498

Ralph W., 95, 102, p-102, $145,159,338,341$

W. J., 159

CONNELLY
CONNELLY cont inued

Earl A., see Connolly, Earl A.

George W., 395

Vilvoy M., 425

CONNER

E. J., 349

Paul, 172

CONNOLLY

Charles R., 173

Earl A., 306, 307, 345, 568 , a. c. a. Connelly. Earl A.

Јames J., 173

CONNOR

Walter John, 359, 569

CONRAD

Alexander A. , 459, 460, $461, p=461,568$

Arthur C. . 162, 459-461, p 461 , a. c. a. Conrad, Arthur A.

James H., 411

John W., 447

Paul Edgar, 172, 347, 348

CONWAY

Florence M. , 171

B. O., see Conaway, H. O. CONWELL

Paul Larsh, 395, 569

William F., 362, 394, 449

COOK

A. J., 338, 341

Arthur Ellsworth, 362, 410,569

Charles V., 444

Columbus L., 444

Edwin Westbrook, 151 , p-407, 408, 409

Harold, 233

Henry, p-472, 473, 474, 475

Howard, 333, 338, 341

James (Captain), 233

Jesse Lee, 425

Lyman Joseph, 345, 546, 569

Sheldon E11, 204, 206,

COOKE $354,356,519,569$

Charles F. N., 92, 393

Isiah Ransom, 355

John, 92

COOLEN

Freeman S. , 397

COOLEY

Samuel C. , 355, 356

COOLIDGE

Charles, 531

COOPER

A. H. , 389

Albert Lloyd, 233, p-233,

$345,463,464,536,569$

Butler, 427

C. C. , 426

E. G. 436

Hachel M., 431

Herbert, 397

Paris G. , 469

Susan Rachel, 193, 200. 569
COPE

Otis Merriam, 277, 283, 569

COPELAND

Cecil Clare, 427, 568

Harold T., 172

J. A., 410

COPLEY

Jennie, 24

COPSEY

Herbert A., 120, p-120, $396,503,504$

CORBIN

Brice X., 387

Charles E. , 393

P. T., 433

CORELL

Walter W., 945

CORGUM

William, 362

CORMACK

Albert Orton, 435

CORNELIUS

Max, 301

William Roy, 410, 446, 569 CORNELL

E. Beryl, 382

CORNISH

J. V., 338

James B., 341

CORNWELL.

Willinm, 412, 458

CORR

R. (Miss), 373, 374

CORRAN

S. Harper, 411

COSMAN

Ethelbert, 338

COSNER

Robert L. , 444

COTES

A. B., 389

COTNER

Samuel V, , 313

COTTER

James, 355, 356

COULTER

Frank E., 126, 207, 296 , $333,337,338,341,386$ Jahn Stanley, 210, 389-370

COVELL

Walter W., 436

COVEY

George Washington, 170 ,

COVILLE

$345,359,520,521,569$

R. W. , 330

COWAN

Lee, 450, 459

S. Harper, 569

Sern David, 450, 457, 458 ,

COWDEN 513,569

A. M. , 427, 462

COWGILL

P. E., 489

W. M. , 357

COWIN

J. C., 264

COWLES

Edward J., 35 ? 


\section{COWLES cont inued}

John H, 429

COWPERTHWAIT

A. C., 364

COX

Aras B., 395, 439

Charles C. B. W., 395

H. M. , 394

Harry O., 343

J, G. , 452, 457

May E., 186, 338, 341

Omar, 358, 428

Roy Milo, 395

William C. . 343, 357

CRABBE

J. H., 84, p-84, 423, 462, a.c. a. Crabbs, J.H.; Crebbs, J.H.

\section{CRABTREE}

Hillborn C. , 359, 569, a.c. a. Crabtree,

CRADY Hilborn $\mathrm{C}$.

C. C. , 345

CRAFT

William Thomas, 395, 569

CRAIG

Daniel McCaughn, 45 ?

Jemes W. 434

L. R. , 464

Presley W., 2, 9

Vernon, 374

CRAIN

Charles H., 336

F. D., 356

CRAM

C. W. , 340, 341

Roy S., 288

CRAMB

Arthur Benjamin, 434

Edgar M. , 433

CRAMER

Fay E., 430

Lloyd, 345, 465

CRAMM

George W., 464

CRAN

George W, , 343

CRANDALL

Alice Huff, 186, 356

Frank Gailford, 347

Harry, 435

CRANDELL

A. A. , 546

CRANE

Gertrude F., 394

H. A. (Rev.), 489

Josiah, 50

Orla H. , 186, 396

CRAWFORD

Andrew, 333, 464, 470, $569, \mathrm{p}-570$

Joanna Disbro, 357

L. L., 416, p-416, 417, 421,422

Ralph B., 470

W. B., 535

William N. , 589, p-570

CREBBS

J. В., see Crabbe, J. В.

\section{CREIGHTON}

Edward, 63, 293-294

Ernest Albert, 471, p-471, $473,474,475,569$

John A., 290, 293, p-293, 294-296, 298, 308

Mary Lucretia, 159, 293294

Sarah Emily, p-293, 294, 298, 308

CRESSMAN

Ralph Gates, 156, 393, 570, p-570, a. c. a. Cressman, R. C.

\section{CREUTZ}

Fred J., 172

CRIM

Frank Dwight, 354, 356

CRDMS

Frank B., 353

CRISS

Clair C., 250, 345, 570

Nell Louis, 345, 570

\section{CROCKETT}

B. E, 343

CROFTON

Frank Everett, 338

CROGGS

Joseph, 356

CROLL

Mercer B., 338, 394, 414, 425

\section{CROMWELI}

Philip L. , 468, 570

CRONK

Harvey R., 340

CRONKE

Charles H., 467

CROOK

Charles V., see Crooks, Charles V.

Roy, 147, 359, 395, 435, 521,570

\section{CROOKS}

Charles V., 341, 395, $396,411,414,425$ $429,430,432,434$, $435-437,442,445$, $446,465,466,468$, 470, a. c. a. Crook, Charles

\section{CROSBY}

P. R., 345

William L. , 412, 570

William M., 414

CROSS

Alfred, 408

Anna, 193, 195, a, c. a. Cross, Anna Robinson

Clare B, Glines, 193, 198, $\mathrm{p}-198,345,570$, a. c, a. Cross, Clara B.; Cross, Clara Glines

E. D., 338

Guy B., 459

John Francis, 347, 393

CROUNSE

Lorenzo, 255

CROUSE

Clara, 171

CROWDER
CROWDER cont inued

Earl Rankin, 349, 393, 570

CROWELL

Eva, 17

G. M., 338

CROWL

Charles C. , 410

CROWLEY

Charles F., 219-220, 298 $300,301,570$

CROWNEY

Lawrence E., 348

CROZIER

Henry C. , 288

CRUDUP

Charles Percy, 147, 242, 444, 570

Edward A. , 242

Seth Jone 3, 242, 444

CRUMMER

Benjamin F., 95, 111, p-111 296, 300, 321, 331-333, $335,337,341,360,361$. 386

Henry LeRoy, 341

LeRoy, 16, 18, 111, 162 . $218,242,245, \mathrm{p}-245$. $279,233,337,373$

CRUTCHER

Willford H., 358, 432, 524

CULBERTSON

Hayes H. , 432

CULLENBERG

Sister OAive, 382, 485

CULLDMORE

Grant, 341, 393, 428

Thomas, 428

CULP

Pearl R., 171

CULVER

Emeral J., 465

F. S., 374

CUMMINGS

C. A. , 397

Edger D, , see Cummins, Edgar D,

Jesse Carl, 358

John A. , 343

CUMMINS

Edgar D. , 338, 359, 408, $409,521,570$, a.c. a. Cummings, Edger D. Herschell B., 139, 141 . $148,465,570$

\section{CUNNDNGHAM}

J. M. 356

CURRENT

Effie A. , 425, 434, 447

CURRY

Charles S, 428, 507, 570

William, 343, 357

CURTIS

Bimer Elsworth, 395, 570

John S., 428, 430

Joseph Milton, 242, 433. $462,470, p-570,571$

Louis Franklin, 348, 571

P., 165

Wesley L., 83, 161, 250, 341, p-353, 355, 359 , $371,432,433,521,571$ 


\section{CLSCADEN}

Alexander, 180

Gertrude Jones, 179-180, p-180, 186, 193, 333, 338,341 , a. c, a. Cuscaden, G. G. ; JonesCuscaden, Gertrude John A. , 180

Robert, 180

CUSHING

Mayor, 145

CUSHMAN

Henry C. , 462, 470

CUTSHALL

Ellsworth W., 429

CUTTER

Irving Samuel, 16, 167, $207,208,218,259$, $\mathrm{p}-259,280,275,358$

CYPHERS

Fred B. , 446, 571

CZERWINSK!

V. J., 165

CZESLAWSKI

Casimer, 173

D.

\section{DABNEY}

Franklin K. , 432

DAFFENBAUGH

Nellie C. G. , see Deffen-

DAFOE haugh, Nellte

P. V. R., 433

DAHL

K. G. Wm. (Mrs.), 506

K. G. Wm. , 505, 506

DAHLGREN

Roland W.. 348

DAHLSTROM

Ant on S., 343

DAIILEY

Edmund J., 546

Eleanor Stallard, 181. $186,193,198,330$. $331,333-334,338$, $341,360,171$, a. c. a. Dailey, Eleanor $\mathrm{T}$.

R., 165

William, 444

DALBY

Snyden R. , 356

DALE

David Harrison, 348

Earl Emanuel, 465

John, 489

DALES

J. A., 410

DALLAL.

Joseph M. , 310

Joseph John, 343, 410

DALLOW

E. , 145

DALLY

Mike H. , 172

DALRYMPLE

Frederick E., 412, 430 , 442,462

J. E., 425

DAMERELL
DAMERELL continued Robert, 119, 147, p-471. 472, 473, 475

DAMOUR

Ferdinand, 458

DANA

Irving R., 173

DANDY

George Brown, 343

DANIELS

D. R., 362

DANSKY

Nathan, 346, 571

DARGATZ

Fred Edward, 432, 467

DARLING

Enus Orin, 408, 4'75. a. c. a. Darling, Enos O.

\section{DARROW}

George E., 396, 437

R. H. , 338

DART

Seaman L., 469

DASSLER

DAU

P. H., 343, 446, 470

Neil J., 348

DAUBENHEYER

Miles Frederick, 349, 571

DAUGHERTY

Barbara, 186

James A., 172

DAUNS

C. W, O, 339

DAVEY

Roy William, 358

DAVIDSON

C. L. $395,463,471$

James M. , 470

Lawrence Leroy, 349, 571

\section{DAVIES}

Charles H. , 446

Emma J., 181, 338, 366

F, J., 420, 422

H. B., 181,366

James Franklin, 343, 424 , $425,433,442,446,571$

Rupert A. , 362, 470, 571

Stanley B., 172

Wiliam John, 362, 423, 571

DAVIS

A. H. , 489

Albert David, 347, 571

Byron Bennett, 95, 102 $104, \mathrm{p}-103,150,162$, $272,279,322,337$. $341,355,372,375$. 447,546

B. B. (Mrs.), 103,378

C. W., 66

Calvin J. , 111, 546

Claiburn D., 408

Clyde, see Davis, L. Clyde

Dallas D., 429, 571

Deane D. , 343

Delmar L., 343, 370, 375

Edwin, 170, 226, p-227. $228,279,284,341$, $346,372,546$, a. c. a. Davis, Edwin Greene;
DAVIS cont inued

Edwin continued, a, c. a. Davis, Edwin C. ; Davis, Edwin Van Ness

F. H. , 483

Frank, 356, 432

Frederick H. (Mrs.), 482. 483

Harry W, , 427

Herbert Haywood, 103, p-103, $104,279,346,546,571$

Homer, $372,444,571, p=572$

Huldah, 359, a.c. a. Davis. Hulda

Ida P., 193, 341, 395, 411, 432

J. M., 516

Jacob W. E. K., 338, 341

Jenkin W., 446

John C. , 338, 341

John Calvin Jr., 111, 279, 346,571

John Dwight, 444, 571, p-572

John Graham, 572

Joseph Edward, 146, 395, 572

Kenneth, 444

L. L. . 165, 341, 396

L. Clyde, 411, 465, a.c. a. Devis, Clyde

Mark, 427

Metta, 425

S. T., 341

Sam B, 514

Sumner, 430, 465, 468

T. L. (Mrs.) , 482

Thomas V., 358

Wallace Clyde, 357, 572

Walter L. , 357, 462

Wulliam Lester, 395

William M. , 333, 340, 341, 572

Willam T., 357, 411, 468

William Windle, 343,572

DAVISON

Almond D, , 172

DAWES

James W., 85

DAWSON

John O., 354-356

Terence Thomas, 310

DAY

Allie M. , 433

Charles M. 346

Clint on, $422,454,456,458$

DAYTON

G. M. , 338

William Lindsley, 204, 257, $314,349,350, \mathrm{p}-350$. $352,354,572$, a, c, a.

DEAL Dayton, William Linsley

Edwin Perle, 349

Wuliam Floyd, 389, 125

DEAN

Charles E., 427

Floyd Chapin, 393

Frank Wilson, 340, 341

George Almerian, 428

Highland Z., 464

Joe O. , 288 
DEAN cortinued Myrtle, 384, 522

DEANE

Seneca F., 462, 467

DEARDORF

Benjamin Miles, 428 , 572

DEARING

William H., 357, 408409, 428

DE BACKER

Leopold Joseph, 393, 572

DECATUR

Stephen (Mrs.), 78

DECK

Milton B. , 355, 356, 431,572

DECKER

Jay C., 343

Rudolph F., 467, 572

DEEMER

George William, 572

DEERING

Dave N. , 572

W. H. , 508

DEFFENBAUGH

Martin Henry, 430, 434, 572

Nelle G. Carr, 193, 430, 517,572 , a.c. a. Da!fenbaugh, Nellie C, G.

DE FOX

John, 435, 458

DE GARNAU

Wesley, 408

DE GARZON

Harry George, 432

DEIHL

O. C., See Diehl, O. C.

DE LAMATRE

C. W. , 491

DE LANEY

L.A.N., See DeLanney, Leo $A$.

DELANEY

Will lam A., 170

DE LANGLE

Charles P., 343

DELANNEY

E. L. P., 384

DE LANNEY

Leo A., 347, 444, 454,

458,573 , a. c, a. De-

Laney, L.A.N.

L. A. (Mrs.), 379

DELEHANT

Daniel LeRoy, 348

DELFS

Claus Gilbert, 346, 573, a. c.a. Delfs, Clans G,

DEL PUERTO

Jaun R. Y., 430

DEMAND

John, 357

DEMAREE

Emma Warner, 187, 193. 199-201, 269, 573, a.c. a. De Maree, Emma

Henry Clay, 187, 352, 355, 356,573 , a. c. a. DeMaree, H. C.
DEMAY

F., 523

DE MAY

George Halley, 427, 573

Griffith Alonzo, 447, 325 , 526,573

W. A., 447

DEMMER

George W., 146

DEMPSTER

Roy P., 470

William H. , 467

DEN

Emanuel Henry, 59, 60. 324,338

DENISE

Jacob Conover, 60-63, p-62, 144, 203, 261, $262,263,317,321$, $324,325,330,333$, $338,341,360,374$

Larimore C. , 60, 61

DENISON

Walcott, 572

DENNEY

L. D. , 475

DENNIS

Charles Warren, 357

Elmer Grant, 428

Frank F., 436

DENT

George B., 146, 371 , $372,435,436,530$

H., 165

Townsend E., 437

DENTON

W. A., 338

DEOGNY

P. D. , 465

DE OGNY

Paul Albert, p-572, 573

DEPPEN

Earl Neagley, 359, 520, 521,573

DERBY

Gladstone, 546

DERMODY

Leo A., 343, 573

Louis Arthur, 343, 386, 444, 573

DERMONDY

A. L. , 388

DERN

A. Jackson, 437, 445, 467

DESBROW

A., 433

DES JARDIEN

Alphonse Regist, 358, 573

Gustave Adolph, 358, 573

DETWILER

Augustus K, , 346

A. K. (Mrs.), 379

DETWEILER

J. S., 484

DEUEL

L., 165

DEVER

Charles Ray, 393, 444,

573 , a. c, a. Dever,

DEVERIS
DEIERIS continued

J. S., 338

DEVERS

W. E. YI. +75

Washington trving, 573

DEVIN

R. M., 165

DEVINE

John A. , 432

DE YORE

Samuel F, , 346

DEVRIES

Joshua Shipley, p-422, 423 , 470,573

DEWEY

Fred Girard, 410, 573

George Laurin, 573

Jay Reed, 347

Leonard A., 288

DE WITT

Charles H., Sr., +63

Charles Herman, Jr., 343, $425,462,573$, a.c. a.

DeWitt, Herman C., Jr.

DEWOLF

William Walter, 357, 573

DEXT ER

Henry, 464

DLAMANTENBERG

Nora, 355

DICK

Frederick N. , 435, 436

DICKEE

William Henry, 356

DICKINSON

Edna 0, 171

Louis Everett, 465, 573

William E., 359

DICKSON

James Charles, 279, 349

William Harrison, 346

DIDDOCK

W. T. (Mrs.), 25

DIEDRICH

Edward D., 263, 265, 339

DIEHL

Olin Carl, 384, 428, 432, 574 , a. c, a. Deihl, O. C.

DIERKER

Joseph Bernard, 445, 574

Otto Friedrich, 468

DIERK ING

H., 165

DIERS

Harry Frederick, 396

Louis Hi., 574

DIETER

Leonard Daniel, 349, 574

DIETERICHS

Frieda, 174

DIETRICH

C. H., 115, 120, 139, 155 ,

DIETZ

Gould, 162, 166

DIHEL

Thomas Elmer K. , 346, 433, 574

DILDINE

C. T., 320

DIL. 


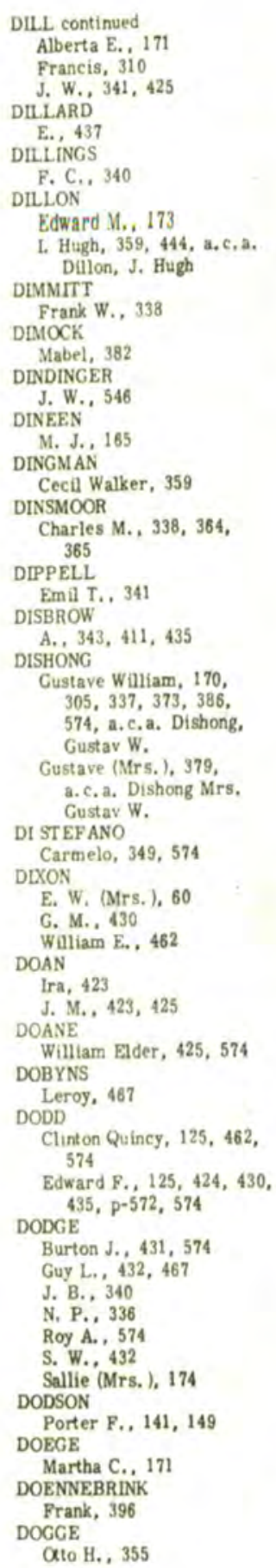

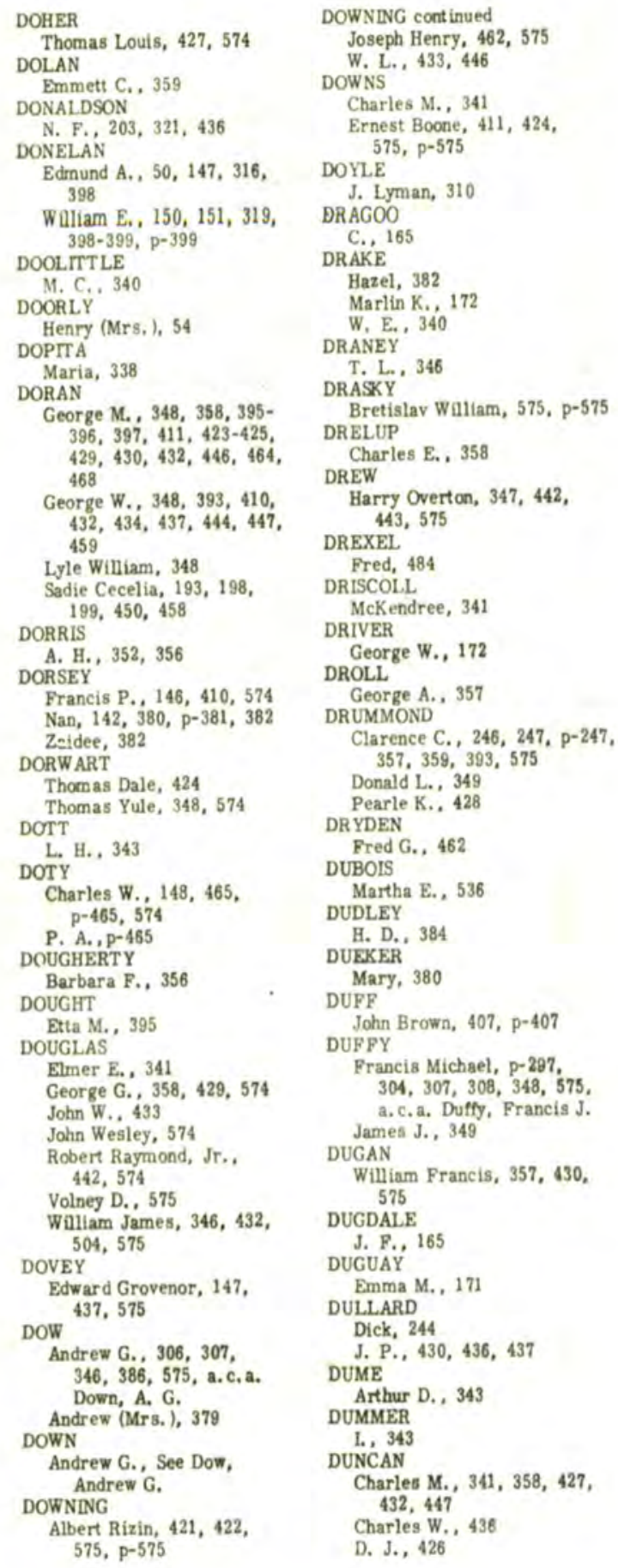


DUNCAN cont inued

J. K. L. . 343, 357, 414 , 425,447

John William, 305, 338 , $346,372,375,386$, 575

T. Nelson, 410, 462

DUNCANSON

James E. . 396, 434

DUNDY

May, 109

DUNGAN

Edward S. , 430

DUNHAM

Frank S., 343, 576

Lawrence Hilton, 310

DUNLAP

Sarah E. , 186

DUNN

A. C. 467

Abner B. , 393, 576

Arlo M. , 546'

Arthur David, 252, 279 , $283,284,289, \mathrm{p}-289$, $361,373,386,512$. 546,576

Arthur David (Mrs. ), 252. 379

Aust in Gibbons, 349

Frank Lowell, 349.546. 576, a.c. a. Dunn, F. Howell

J. Erman, 419, 422, 424 . $576, \mathrm{p}-576$

Mabel, 189, 200, 207, 358

Ray Olson, 435

W. G. , 338, 341

DUNSETH

Georgc Oliver, 424, 464, 465

DURANT

Thomas C. 45

DURHAM

Cecil B. , 346, 435

Harry, 330, 338

DURKEE

S. 165

DUTTON

C. E. 339

DU VALL

George Reese, 432, 467. 576

Grace M. Bliss, 193, 467

DU WE

Mabel, 538

DWIGGINS

Frank P., 358

DWIRE

Francis Belmont, 576

DWYER

Edward H., 411, 576

Harold Vincent, 348, 576

James C., 411

John R. , 346, 576

Timokyy J., p-297, 386 . 576

T. J. (Mrs, ), 379

DYDE

Charles B. 430

DYMENBERG

W. 338
DYSART

Joseph W. , 338

E.

EAKINS

F. C. , 411

EAREL

A. M. , 424

H. M. 357

John W. . 430

EARHART

W. J. , 364

EARLE

John W., 427

EARLY

R. O. , 358

R. J., 165

EASTERDAY

Emma S, Meinhardt, 193, 526,576 , a. c, a. Easterday, Emma E.; Eas terday, Emma $M$.

EASTMAN

Sydney, 444

EASTON

Cyrus Monroe, 120-121, $p=121,466,467,577$

Robert Holmes, 426 . $514, \mathrm{p}-576,577$

EATON

Joseph Sylvester, 356

Martin L. , 432

Thomas J., 480

EBERT

Joseph William, 347

EBENEF

F. W. , 339

EBY

Charles D., 151, 429 , $430, p-576,577$

ECHMrT Z

William Howard, 347

ECKLES

Dora B., 193, 577

Warren F., 476, 577

ECKRICH

Jerome Andrew, 310

ECKSTROM

Mabel, 171

EDDY

Alfred, 410

E. H. , 340,341

William, 59, 324

EDGAR

John F., 411

EDGECOMBE

Florence E., 171

EDGINGTON

Avington Adam, 341, 577

EDHOLM

K. R. J. (Mrs.). 376

EDLER

William, 346

EDMESTEN

L. L., 489

EDMISTON

Aaron Welch, 97, p-97, $332,333,339,341$. 345,577 , a. c. a. Edminston, A. W.

EDMONDS
EDMONDs continued

C. A., 343

C. B. . 430

Charles Walton, 424, 434 , 577

E. W. 424

Wuliam F., 470, 577

EDMCNDS

C. B., 358

EDSTROM

Alice D. , 288

Andrew J., 346, 537, 577

EDWARDS

August G. , 343, 577, a. c. a. Edwards, Augustus G.

C. W. , 444

Charles B. 577

Frederick Arthur, 343, 577

Isaac, 66, 339

James T. , 346

Laura A., 186, 341, 393. a. c.a. Edwards, Laura H. Lee Wilson, 343, 357, 396 444,577

EESTER

William G, 436

EGAN

L. F., 363

William Joseph, 349

EGBERT

Charles L., 371, 393, 411, 424

EGEN

Lother Frederick, 346, 393 , 412, 577, a.c. a. Egen, Lothar F,

EGERMAYER

George Washington, 151, 451, $455,457,459,577$, a. c. a. Egermeyer, G.W.

EGGERS

Harold Everett, 279, 546, 577

EGHIAAN

Setrak, 343.

EGLOFF

George E. , 411

EHLERS

Orrin Cecil, 279

EHRKE

Albert Adolf, 393

EICHE

Frederick, 314, 357, 577

EIGLER

Charles O. , 423, 425, 431

EIIS

Jens C. D., 341

EIKNER

William T. , 396, 430, 446

EISENBIESS

Albert, 430

ELDER

Alfred L. , 359, 397, 444، 458,467

John, 457

ELDREDGE

Robert Bruce, 279, 348 . $373,546,577$, a. $c$, a Eldrege, R. B.

Robert Bruce (Mrs.). 379

ELDREGE 


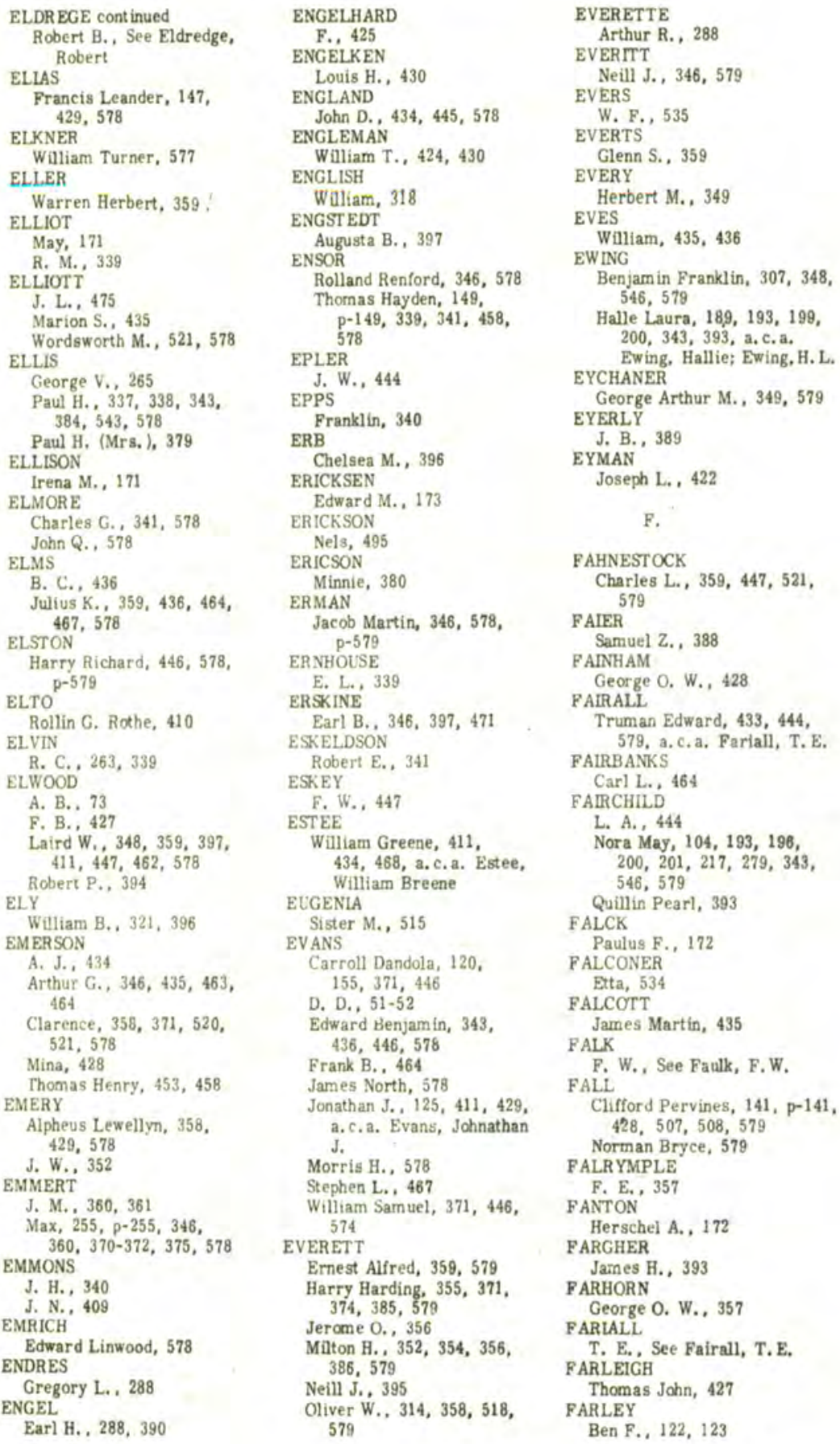


FARLEY cont inued Rosalie (Mrs.), 25

FARMER

Bennie Raymond, See Farner, Bennie Lee Roy, 504, 579 William, 432

FARNAM O. W., 354

FARNER

Bennie Raymond, 397 , 580 , a.c. a. Farmer, Bennie R.

FARNHAM

George O. W., 357, 580

FARNSWORTH

Albert Henry, 516, 580

Ambrose H., 394, 430

Earle Edw in, 430, 515, p-579, 680

H. B., 357

FARNUM

Mary C., 428

FARQUHAR

Elwood Miller, 464

FARR

Fred Franklin, 580

FARRELL

Henry, 147, p-579, 580

Robert Francis, 580

FARRINGTON

Owen $P, 346$

FART

Homer, See Fort, Homer

FARW ELL

Fletcher, 450

FASSER

Alexander Otto, 423, 580

FAST

J. S., p-152, 152

W. F. , $450,451,454$

William Kirk, 459

William Sherman, 393, $429,450,456,458$, 508,580

FATE

Jesse C., 580

FAUBLE

E., 165

G., 165

FAUCETT

John H., 444

FAUGHT

Arthur M., 464

FAULK

Andrew Jackson, 251, $463,464,580$

Fred W., 151, 343, 580, a. c. a. Falk, F.W.

FAULKNER
A. O. , 356

E. E., 357

FAUVER

Edward E., 444

FAWCETT

Silas H. , 84, 469

FEASE

Jean P., 193

FEEHAN

Wulliam J., 349

FEE
FEE cont inued

O. J., 520

FEES

Arthur Waldo, 425, 470, 580

FEESE

Jean P., 393, 580

FEGERS

George William, 580, p-581

FEII

N. P., 493

FELCH

Albert H., 428

PELLENSTEIN

David W., 339

FELLERS

Andrew B. , 431, 580

FELSHAW

Charles P., 355

FELT

Mary, 538

FENGER

P. N., 357

FENNER

Harry B., 342, 580

FENSCH

Albert, 343

FENSTER MACHER

C. H., 422, 424

FENTON

Thomas Charles, 356

FERGUSON

Allen Poff, 428

W. H., 518

W. H. (Mrs, ), 519, 520

PERN

H., 165

FERNLAND

P. O. A. , 339

FERRON

Eugent, 457

FERRY

Charles M., 432

FESS

Albert, 462

FETTER

Earl William, , 436, 581

FEURT

William Henry, 340

FICK

Hermann Andrew, 355

PIEGENBAUM

G. A., 339

FIELD

Dr, , See Fifield, Samuel N.

A. D. , 410

Susan Wilson, 198, 200 , 301,359

FIELDS

L. Seymour, 346

FIFFIN

Robert E., 357

FIFIELD

Samuel N., 73, a. c, a.

Field, Dr.

FILTER

C. F. W., 529

FINCH

Charles E., 426

F. D. , 425, 462

Walter M. 172
FINDLEY

David, 117, p-117

David Pressley, p-117, 118

Eldon Marshall, 359

Palmer, 116-118, $p-117$. $211,242,255,257,272$ $322,337,343,372,375$, 392,581

Park A. , 3 $43,358,420$ 433, $444,458,462$

Thomas Palmer, Jr., p-117, 118

William J., 117

FINKENSTEIN

Ervin 1. , 347, 430, a. c. a. Finkelstein, Irvin I.

FINKLE

Beverly Arthur, 359, 524 , 581

FDNLEY

Wülian F, 381

FINNEY

Everett B., 126, 356, 371, $521,524,581$

FINOCCHLARO

Maynard M. , 310

FINTELL

E. C. (Re: ) , 536

FISCHER

George G., 393

FISH

Waldo, 339

FISHBEIN

Morris, 95, 205

FISHBLAT'T

Albert S, 339, 355, 427. 430, 457

FISHER

E. $W ., 428$

Elmer E., 462

Oliver, 342

W, C, 431

Waldo C. , 339, 431

FISK

John B, , 475

FITCH

John M. , 430

Libbie M. , 270, 343

PITZGERALD

Francis E., 343, 581

J. T, , 165

Roger, 172

FTTZGIBBON

Henry M. , 345, 581

Thomas G. , 349

FITZSIMMIONS

Joseph L., See Fitzsimmons, Joseph

FITZSIMMONS

A. P., 272, 433

Alex W., 581

Joseph Ignatius, 348, 423 . FIX 581, a. c. a. Fitzsimmions

Georgia Arbuckle, 178, p-178, $179,186,197,265,464$

N. Guin, 179

FLAMM

Nimis H., 429

PLANAGAN

May Louise, 189, 193, 197. 


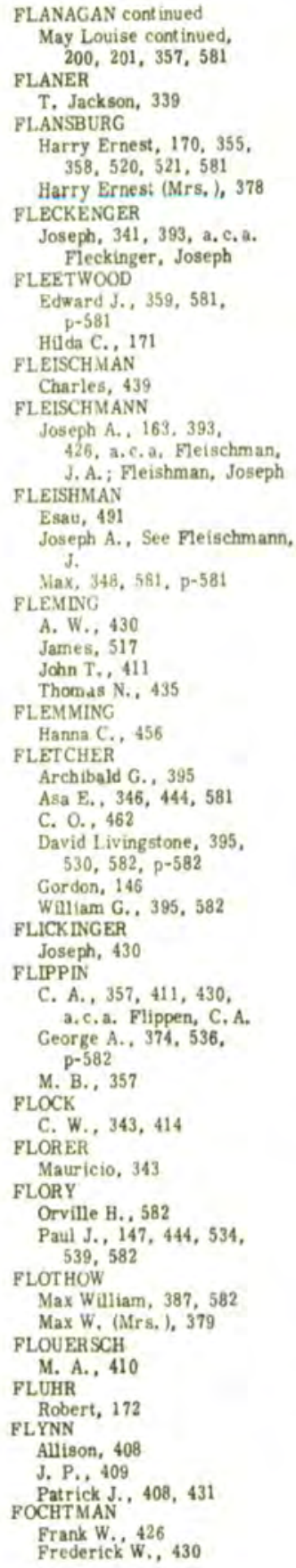

\author{
FOCHTMAN continued \\ John Henry, 121 \\ Lloyd Henry, 582 \\ FOGARTY \\ Charles James, 349, 444, \\ 582 \\ FOGELSTROM \\ E. A., 484 \\ FOLEY \\ J. J., 165 \\ S. J., 165 \\ FOLLETTE \\ William Mann, 393, 428, \\ $430,462,475$, a. c. a. \\ Follett, W. M. \\ FOLLMAN
}

John Christopher, 346, 582 FOLSOM

Artie, 358, 428, 432, 433, $442,444,467$

Clat ence Hugo, 348

Shirley Dair, 346

FOLTZ

Clarence Burden, 348, 582

C. B. (Mrs, ), 380

FOOTE

Dellizon A. , 339, 341, $364,366,372,489$, 582

Eugene Clair, 393, 582

James St ephen, 219-220, 222-223, p-222, 296. $300-302,386$

Willam Kellogg, 582

William R., 343

FORD

Michael Joseph, p-297, $300,343,385,500$ 。 582

\section{FORDYCE}

Charles, 314

Claude Powell, 241, p-241, $391,424,430,450$. $457,458,459,510$, 513,583 , a.c. a. Fordyce, Claude C.., Fordyce, Charles $\mathrm{P}$.

FORGRAVE

L. R.. 462

FORISTALL

Daniel Edgar, 457

FORNEY

Guy Virl, 359

Lester Wayne, 419, 432,

FORRY p-581, 583

Samuel, 2

FORSEN

John S., 447

FORT

Homer F., 410, 427, 436 437, 465, a.c.a. Fart,

Foss Homer

John B., 459

FOSSLER

Anna, 373,374

John Jacob, 583

FOST ER

Anthom A., 347, 583

E. W. , 346, 384, 385, 409
FOSTER continued

Harlan J., 393

Jennie, 179, 406-407, p-406

L. M. , 432

Phocbe, 427

Robert Hale, 345, 393, 394

Ursilla, 339

E. Wendell, 179, 406-407, p-406

William B., 340

FOSTERMAN

Elsie Muriel, 435

FOUCH

Ralph M. , 347, 390

FOUTS

Frederick, 442, 583

Roy W., 137, 162, 257. $323,338,369, \mathrm{p}-369$, $376,390,453,458,583$

FOWLER

Fred H., 343

John M. 428

FOX

Carrol, 135

Charles Herbert, 371, 442, 583

Clarence P., 463, 464, 583

Homer F., 462

Mary, 186

FRANCE

John M., 339, 34?, 428, 458,475

FRANCIS

Harry Whiting, 414, p-582, 583

William, 464

FRANCISCO

D. E., 343

FRANDSEN

Charles, 583

FRANK

Charles Harold, 434, 464, 536

Harold, 392

Samuel, 493

William W., 446

FRANKEL

Leopold, 358

FRANKLIN

Daniel, 346

Wellingt on A., 393, 475

William Surman, 434, 464 , 536,583

FRANZ

Francis Willard, 349, 583

FRARY

Reginald Amos, 583

FRAZIER

George J., 30, p-30, 396. 435,583

Margaret $0,435,520$

W. W. , 444, 462

FREDBERG

Hannt, 355

FBEDERICK

Ch. H. (Mrs.), 478

FREDERICKS

George M. , 349

FREDERICKSON

Vernie, 173

FREE 
FREE continued

George B. M. , 430

FREEBORN

Grant E. P. , 428

FREEDMAN

Stanley, 388

FREELAND

Harvey L., 143

FREEM

George B. M. , 432

FREEMAN

Agnes, 186, 427

Daniel, 427, 444

George M. , 340, 341, 430

Leonard, 511

FREIDELL

H. I. 389

FRENCH

Albert Lincoln, 358, 583

Benjam in F., 339, 356

Frederike, 500

G. W., 74

B. E., 391

Oscar W. , 432, 583

Viola M. , 186, 409

W. H. (Mrs, ), 535

FREW

James V., 172

FREY

Clarence Elmer, 359, 462, p-582, 584, a. c. a. Frey, Clarence L.

Bmer C. . 36?

FREYMANN

John J., 307, 308, 347 , $380,386,546,584$, a. c. a. Freyman, J. J.

FREYMAN

J. J. (Mrs.), 380

FRICKE

Albert A. , 345

FRIDENBERG

Eugene Lewis, 457

FRIEDAY

Louis S. , 462

Winliam G. , 462

FRIEDMAN

A., 341, 432

FRIES

Amos A., 158

FRIFFEN

Elmer J., 343

FRINK

Frank L. 150, 362, 584

FRISBIE

$$
\text { A. W. , } 465
$$

FRITSCHEL

Godfrey Constantine, 430, 444, a, c. a. Fritchel, G. C.

FRITZ

Glenn H. , 546

FROMMHOLTZ

Gertrude H. , 446

FROSH

Henry Benard, 359

FROST

Lincoln, 143

FUCHS

Gustave 0., 172

FUEST ER
FUEST ER cont inued

Richard, 343

FULKERSON

Walter C., 475

FLLIER

Blanche, 481, 491

Edgar M. . 173

Ellery G. , 434

Frederic Gurley, 203, $318,321,350,351$, 355

John A., Jr. , 343, 425

Mary Jane, 535

Merlin H. , 172

FULTON

Harry A., 323, 584

Henry A. . 470

Jacob Arthur, 467

John Blythe, 427, 428

Thomas Henry, 428

William, 355

FUNK

Harley E., 584

J. W. , 373, 374

FURAY

Charles E., 301, 342, 425

Edward F., 431

Edward St. Clair, 301, $410,411,465,584$

FURGASON

Allen P., 355, 356, 584

FURMAN

Mattie A., 393

FURNISE

Richard D., 348

G.

\section{GADBOIS}

Arthur Emile, 438, 441 $442,446,584$

GAFFORD

Charles C., 148, 427, 584

James Albert, Jr., 457

GAGE

E. E. , 343

Perry, 531, 532

W. V. , 447

GAH.AN

Myles J., 321, 340, 342 , $411,425,430$

GATRINGER

John M. , 430

GAIRDNER

T., 476

Thomas M., 391,584

GAITHER

Hilary, 444

GALBRATTH

William J. , 95, 100,101 , $268,294,296, p-297$, $301,302,332,339$. 342,360

GALE

James Burton, 22

John, 1-7, 9, 16, 20-24, 29,153

Mary, 1, 20, 23, 24

GALLIGAN
GALLIGAN cont inued

John H. , 430

GALLINGER

Ralph, 173

GALLISON

John S. . 355

GALLOWAY

A. . 393, 397, 429, 430

Harry S., 344

GAMBLE

Grank E. , 435

GANDY

George G., 86, 453, 456$458,513,539,584$

James Luther H., 86, 149 ,

$256,451-453,457$

\section{GANEY}

J. H., 384

GANNAWAY

Charles R. 432

GANOING

B. W. , 358

GANOUNG

Bloom W. , 358

GANT

Thomas S., 444

GANZEL

Charlote A., 526

GAPEN

Clark, 144, 145, p-145, $251,331,333,339$

GARBER

Cora, 524

Sulas, 414

GARCLA

Arturo, 437

GARDINEP

John Francis, 431, 546, 584, a. c, a. Gardener, J. F.

GARDNER

Albert J., 431, 584, p-584

Charles A., 344

Fletcher, $357,410,435$

Hyman W. , 435

Thomas A., 546

W. B. W. , 69, 324, 325

GARFIELD

Darley, 435

Walter T., 359

GARLOW

Samuel A. , 172

GARRET T

H. W. 458

GARRET SON

Peter H. , 356

GARRISON

Everett J., 172

W. H. , 358

William Patton, 429

GARTEN

Melchert H. , 352-356

GARVER

Bessie James, 186

GARW YI.IW

Wasyl, 173

GARY

Reginald A. , 348

GASSETT

William E. , 357

GASSLEIN

Richard J. , 429 


\section{GATES \\ C. F., 165}

GAULT

Curtis M., 248

Edwin Sartain, 359

GAWNE

W. Y. R., 148,442

GAY

Benjamin F., 124, 362 , $426,433,463,584$

GEBH ARDT

Albert A. , 346

GEE

Hoddard R., 339

GEER

F. H., 446

GEESAMAN

Edgar S, B., 151, 430 ,

470, p-584, 585, a, c. a. Geeseman, Edgar

GEESMAN

Edmund M. , 359

GEHRING

Henry, 207

GELOW

John E., 430, 515, 584

GENING

F, C., See Genung, F, C.

GENTRY

Max, 248

Willard Max, 348

GENUNG

Frank Clark, 434, 585 , a. c. a. Gening, F.C.

\section{GEOGLEIN}

Louise A. W. , 356

GEOMOETS

Henry N. , 288

GEORGE

A. B., 359, 429

Charles C. (Mrs, ), 246

L. E., 432

Lyra H., 189, 357

Oscar, 173

W, S., 432

William A. , 357

GERAGOSIAN

Vahan, H. J., 425

GERALD

Herbert Franklin, 301, $305,308,386,585$

Herbert F, (Mrs.), 380

GERDES

Henry, 508

GERDING

Ida L., 171

GERISCH

William W. T., 410

GERISH

Albert E., 346, 427,

444,585

Nettie Luella, 346, 585

GERRIE

Wallace Anderson, $p=276$, $279,346,389,585$

\section{GERVAIS}

W. A., 414

GERSTEIN

Harry, 165

Hime, 165

GETZLAFF
GETZLAF' F cont inued

Bruno J. F, , 411

GEUTSCH

D. C. . 339

F. H., 339

GEVER

John Conrad, 585

GIBBON

William Davies, 355, 408 , $414,428,585$

Wuliam Henry, 411, 585 GIBBS

D. C. , 339

Wellington Smith, 76, p-76, $151,263,264,330$, $333,339,342$, a. c, a. Gibbs, W. T.

GIBSON

C. A. W., 430

Luther Vernon, 359, 585

Paul W. , 410

GIDEON

E. D., 536

GIESE

Charles O., 445

GIEVER

John C., 346, 423

GIFFEN

Robert Emmett, 356

GIFFORD

Harold G. , 95, 96, 104, $115,203,207,211$, $213-216, \mathrm{p}-214,217$. $251,254,257,267$, $268,270,272,279$. $288,321,331,333$, $334,335,337,339$, $360,361,372,390$, $480,489,546,585$

Sanford R., $170, \mathrm{p}-214$, 216-217, 279, 338 . $372,546,585$

Willis B., 365

GIGGINS

J. E., 515

GILBERT

George Richardson, 162 , $342,463,464,585$

H. D. 319

GILBORNE

Henry, 585

GII.CHRIST

Charles, 357

GILES

A. P., 339

GILFILLAN

Margery Jane, 393

GILFRY

Ralph Atherton, 470, 586

GILKERSON

Milo J. , 397

GILL

James Ward, 431, 586

John P., 173

GILLESPIE

Edward James, 444, 586

Floyd Burke, 346

J. C. . See Gillisple, J, C,

Paul Bernard, 387, 444, 586

Peter L., 429, 586
GILLET

S. B., 333

GILLETTE

Leslie B., 339

GILLIGAN

F., 165

John Philip, Sr., 146, 148 ,

$150,151,322-323, p-322$ 。 $362,422,586$

John Philip, Jr., p-322, $323,349,431,586$

GILLISPIE

James Charles, 450, 457. 459,586 , a.c. a. Gillespie, J. C.

Orville Floyd, 462

GLMAN

D. L., 339

Helen C. , 186

GIL.MORE

Arthur Hale, 445

George Harrison, 241, p-241, $408,409,586$

Robert F., 96, 110, p-110, $331,333,339,342,586$

Thomas H. , 409

GILSHANNON

Bernard J., 347

GINN

Arthur P., 332, 339, 342 , 586

GIRAGOSLAN

Vahan H. J., 346, 446, 586, a. c. a. Giragosian, Veham: a.c.a. Giragosian, \#ohan

GISH

Jacob, 145, 146

GIST

F. J., 343

GIVEN

Howell B., 356, 430

GLAMMEIER

Carolyn A., 171

GLASCO

Anna (Mrs.), 516

J. Luther, 444

John M. , 339, 342

GLASIER

Mina B. , 186

W. H., 340

GLASS

Virgil S., 349

GLATFELTER

Harvey Edward, 442, 586

GLATHAR

A. W., 390

GLEASON

Bert Fuller, 586, p-587

GLEESON

John Joseph, 306, 346, 586, a. c. a. Gleason, J.J.

GLESSNEF

Edmund M. , 434

GLICK

M. S. , 339

GLOVER

Samuel G., 469

GLUCK

Hanna S., 338

Isidor, $114,339,342$, a. c, a. Gluck, Isadore 
GLYNN

L. M. , 165

GODDLN

Gibert W. , 172

GOEBEL.

Clarence Joseph, 348

GOERSS

Franz C. A., 340

GOETZ

Harry, 165

James Samuel, 116, p-116, $279,346,492$

GOFF

John L., 465

GOLDBERRY

Alice W. , 358

GOLDEN

Frank Patrick, 586

GOLDING

Carl Ernest Louis, 80, 399

Daniel G., 80, 340, 342 , 399,425

GOLDSBERRY

Alice W., 397

GOLDSMITH

H., 165

GOLDSTONE

Joe, 348

GONTERMAN

Emery Oliver, 395

GOODE

J. F., 475

GOODELL

Charles F., 355

L. E., 459

GOODEN

Charles W., 393, 411, $427,462,586$

David Wendell, 346, 586

GOODING

Joseph, 165

GOODON

Frank Earl, See Gordon, F. E.

GOODRICH

Guy William, 348, 390, $586, p-587$

Jullus L. , 411, 437, 468

L. C., 457

GOODSHELLER

George J., 358

GOODSON

Catherine M., 359

Fent on Noah, 358

GOODWIN

Charles E., 444

Grover G. , 347

GORDER

John W., 462

GORDON

Frank Carl, 465

Frank Earl, 344, 357,

$397,410,412,414$,

$424,425,427,430$,

$434,435,442,445$,

$447,458,462,466$,

468,510 , a. c. a.

Goodon, Frank Ear1

Frank Edward, 464
GORDON cont inued

George O. , 424, 436

William, 343

GOREHAM

Salem E., 346

GORMAN

D. D. , 353

GOULD

John, 410

R. M., 165

GOULDING

Francis J., 410

GRABE

Elizabeth, 186, 428

GRABEL

Frank, 430, 446

GRABIN

Charles S., 359, 412, 414,431

GRABS

Elton B., 425, 436

GRACE

Joseph Markey, 348, 587

William J., 301

GRADDY

Lynn B., 95, 96, 104, $329-331,339,374$,

GRAFF 480, 489

Leo W., 387

GRAHAM

Alfred Clifton, 347, 389, 445,587, a. c. a. Graham, Alford

Alice Winnefred G., 193. 587

C. 505

Dales Young, 268, 340, 342

Donald A., 396

Elisha Barker, 41, 92-93, 256

E. B. (Mrs.), 41, 92-93

Francis Andrew, 314 , 356,587

James M., 424

James Robert, 587

James W., 288

Joseph H., 423

W. H., 339

William Wayne, 348, 587

GRAINGER

H. B., 519,520

GRAMLICH

Ralph Clifford, 346, 587.

GRAN p-587

Albert O., 340

GRANDY

Margaret, 538

GRANT

Richard S., 172

Thomas, 423,425

GRANTHAM

Elizabeth A., 343

GRAPER

Frank, 173

GRAU

Eugene C., 348

GRAY

E., 165
GRAY cont inued

Ethed L. B. , 393

George E. , 467

J. Hamilton, 356, 364

John Worth, 393

Oscar Sylvester, 393, 587

Richn rd, 462

William H. , 444

GREBE

Jacob, 432

William, 3 to

GREBS

Elt on B., 343

GREEN

C. C., See Green, Clarence C.

Carl Rarmond, 435, 387

Clarence C., 426, 427; a. c. a. Green, C. C.

Hiram Adelbert, 393

J. Alonzo, See Greene, Jared Alonzo

James, See Greene, James

John M. , 457,458

Orson W... 356

Ralph, 446

Ralph Dennis, 175, 426, 427, 445, 587

Sarah Elizabeth, 186, 355, $411,442,468$

T. L. , 536

William Mlason, 354, 356, 587

GREENBERC

Abraham, 170, p-170, 346 . 546,587

Ben, 288

Maynard M. , 388

Meyer, 388

GREENE

James Leon, 128, 354, 356, a. c. a. Green, James

Jared Alonzo, 339, 408, 457 , a. c, a. Greene, Jered A.; Green, J. Alonzo

John Morton, 457, 587

Sarah S., 393

GREENFIELD

John W., 358

GREENLICH

A. B., 475

GREENMAN

John W., 393

GREER

Flavius J., 422

GREGG

A. E., 470

H. L. 442

William B., 397

GREY

Miton, 356

GRIEC

William, 355

GRIER

Maurice Edward, 306, 308, $346,546,588$

GRIESS

Rudolph Oto, 389, 393, 411. 588

GRIFFIN

Elmer J., 547, 588 
GRIFFIN cont inued
J. H. , 425, 434, 442

GRIFFITH

\section{A. B., 497}

Anna M. , 193, 342, 588

D. G. , See Griffiths, D. G.

W. G., 358

GRIFFITHS

David Gurney, 414, 430, $450,455,458,508$. 510,588 , a. C. a. Griffith, D. G.

G. W. , 450

GRIGGS

Earl Elmo, 464, 536, 588

GRIGSBY

R. A., 464

GRIMES

Richard S. , 355, 356

GRIMIM

Peter G. , 397, 412, 470

GRINNELL

Josiah R., 430

GRIOT

Arthur Jacob, 397, 588

George August, 588

GRIST

Albert J., 430

George A. , 430

GRITZKA

Christian T., 432, 588

GRODINSKY

Manuel, p-278, 279. $346,547,588$

GRONST AL

Knute S., 172

GROSBACK

Harry H., 125, 588

GROSS

David, 388

GROSSAND

W. A., 387

GROSSKOPFF

Ludwig Edmund, p-587, 588

\section{GROSSMAN}

George Paul Albrecht, $69-70, p-69,96,212$ $296,329,330,333$, $339,342,374$

John H. 273

\section{GROT E}

Larie Lois, 182, 193 $196-197, p-197,200$

GROTHAN

Georgiana, 187-188, 204 Ole, 139, p-139, 148, $156,188,588$ S., 517

GROUX

Benjam in, 340

GRUBB

Albert L., 467

GRUBS

Elt on B. , 395, 396, 410 , $433,458,464$

GUENTHER

August Ernest, 279, 374

GUILD

W. H. , 238-239

GULICK
GULICK cont inued

Henry, 339, 442

GULTERY

J. D. , 462

GUMAER

James Ira, 427

GUNN

J. A., $344,427,447$

W. H. 341

GURNEY

Charles E., 390

GUST AVSON

S. V., 484

GUTHRIE

J. W. 503

GUTTERY

J. D. 359

W. D., 425, 466

GUY

Multon Phillippi, 356

GWALTNEY

Sylvester, 446

GWIN

Howell B., 342, 393

GYDESON

Mary E. C., 266

H.

HAARUP

Jens Sorenson, 342, 425, $428,444,446,462$. a, c. a. Haarup, Jans; Haart;, Jens; Haarup, Jens Sorensen; Harrup. Jens Sorrenson

HABENICHT

John A., 435, 459, 460

HACKETT

J. F., 357

Rabley, 428

HADFELLD

E. J., 341

HADLEY

James Elmon, 263, 265 , $357,442,462,470$, 588

Sherman J., 425, 470

HAFFNER

H. , 165

HAGAN

D. S. , 468

HAGER

R., 165

HAGEY

W, H. H. , 362

HAGG ARD

John A., 357

HAGGLUND

Maris C., 339, 346

HAGLIN

J. E., 165

BAHN

Bess Hasom, 193

Frederick M., 346

Gustav, 344

O. M. 393

Oscar Herman, 393, 394 , 588

HAINES

Frances E, 346
HAKES

Charles W., 424

HALDEMAN

Frederick, 137, 139, 198 , $263,265,321,363,468$, a. c. a. Haldeman, Frederick E.

HALE

Albert E., 310

James Henry, 432

Sarah A. Scott, 186, 357, 411

HALL

Almira M. , 186, 422, 468. a, c, a. Hall, Almire

Byron W., 344, 588

E. T. 342

Elbert A., 357, 475

Fred G, 458

Geb, 455

Gilbert H., 344, 411, 424, $427,458,589$, a. c. a. Hall, G. H.

James, 404-405

J. N., 512

Joseph H., 256, 398, 404$405, p-405,589$

Lynn Thompson, I63, p-163, $279,346,588$

M. Freeman, 395, 588

O. A. 432

Philip L., 72, 131, p-131, 462, a. c, a. Hanl, Phllip L.

Roy Ellsworth, 397, 444, 589

Sacy B. , 344, 358, 389, 430, $436,437,446$, a. c. a. Hall. Sacey

Theron Root, 428

Will C. , 373, 374

HALLADAY

A. S., 444

HAMBLE

Virgil Ross, 459

HAMEI

Eli Burton, 146, 393, 394, 467,589

HAMER

Eulis Passmore, 91

HAMERLAND

Myrtle H. , 171

HAMII

R. A, 442

HAMILTON

Augustus, 410

F. T. . 589, p-590,

Geol L., 344

Herschel P., 333, 334, 337, $339,344,372,386,589$

Hariet S. , 346

Howard Brownlee, 279, 284, $344,373,589$

Martha A., 434

HAMMER

L. W, 430

HAMMOND

Ernest D. , 384, 385, 387, a. c. a. Hammond, Ernest E. ; Hammond, E. W,

J. C., 344

Margaret E., 189, 193, 197, 
HAMMOND cont inued Margaret E. cont inued, $199,201,359,589$

HAMPTON

R. M. , 503

William A. , 91

HANCHETT

Alfred P., 344

J. P., 339, 366, a. c. a. Hanchett, J, C.

W. H. , 339, 363-365

HANCOCK

Avery C., 410

Ernest A., 356

Ernest Wilberforce, 520, 589

Mary B., 410

HAND

George J., 147, 396 , $503,504,589$

Harold M. , 310

HANEY

William Porter, 306, 308, $346,372,384-386$

HANEY 547,589

William P. (Mrs.), 380

HANIGAN

C. P., 339

HANISCH

E. C. , 146,346

Louis Everett, 488, 547. 589

HANNA

Edgar A. B., 81, 420, $422,468,589$

Edwin B., 476, 589

H. O. $449,450,456$

William Robert, 470

HANNAH

B. C., 436

HANNAWALD

Ludwig. 425

HANNICUTT

William P., 359

BANOCK

E. M. 522

BANSCOM

A. J. . 48,56

HANSEN

Alex Fredk. , 589

Charles Avery, 359, 465

Daisy May, 189, 193 ,

199-201, 589, a. c. a.

Hanson, Datsy

Elmer Marion, 349

George Marcus, 348, $589, p-590$

Henry Charles, 468, 589

Homer A. . 446

Maria, 339

Marian, 414

Nelson L., 589

Niels P., 397, 433، 434, 444, 589

Niels Marius, 349

Otto Theodore, 435, 588

Robert W., 425, 476

X. F. 498

HANSER

Byron B. , 470
HANSON

Carl P. , 173

D. E., 390

Daisy, See Hansen, Daisy

Harold G. , 547

Marius, 344

HANTHORN

R. A. ${ }^{426}$

HAPEMAN

Harry, 121, p-121, 371. 434,590

HARBAUGH

Dorotha T, 358

HARDCAST LE

Dr. 70

HARDEMAN Sam, 397

HARDEN

A. B., See Hardin, A. B.

HARDEST Y

George W. , 426

HARDIN

Arthur Bascon, 427, 447, 590 , a. c. a. Barden, A. B.

HARDLANNERT E. F., 547

HARDWICK Anna E. , 141, 523

HARDY

Clyde Clarence, 347, 547, 590

J. M. , 430, 470

Joseph B, , 466

Wuliam E., 172, 518

HARE

John D., 356, 447

HARLAN

A. C. , 426, 447

Ira $F ., 444,458$

HARMAN

Leo Dow, 534, 539, 590, a. c. a. Harmon, L. D.

Mart in F., 358

HARMON

L. D., See Harman,

HARMS Leo D.

Albert O., 428

Charles W. W. 346, 359 ,

HARPER $521,590, p-590$

Glenn C. , 394

R. G. , 165

William A., 428

HARRAL

C. E., 165

HARRAN

Orlando, 428

HARRIGAN

C. $\mathrm{P}, 332,333,360$

HARRDMAN

E. H. , 107

S. S. , 424

HARRINGTON

Ernest F., 358

H, E, 445

John C. , 349

Lewis A., 172

HARRIS

Chester F. A. , 339, 408, 458
HARRIS cont inued

David, 457

Earl Alexander, 3 ty

George A., 157, $301,386$. $428,507,590$

Homer C. (Miss)، 384, p-384

O. O. 432

O. V.. 469

R. C. +432

Roy B., 344

Robley Dugl ison, 344, 590

Squire Oliver, 590

Tenny Tenny son, 344, 368 . 388,590

Wuliam J., 428

William D. , 348

HARRISON

Edwin M. . 344

George E., 342

J. C., 341

James N., 430

ten Samuel, 395, 590

HARRUP

Jens $\mathrm{S}$, , See Haarup, Jens $\mathrm{S}$.

HARRY

Robert Edward, 476, 541, 590, p-591

HART

Benjam in F., 356

C. L., 266, 339, 364-366

Charles Seymour, 355, 365

Fay, 165

George Emmet, 464, 590, p-591

Girard R, , 427

B., 165

John F., 447

K., 165

Leonard, 344

Raymond Lochary, 590

HARTE

H. D., 165

BART ENDORP

Paul Van H. , 310

HARTENSEN

Albert G. . 430

HARTENST EIN

A. G., 517

HARTFORD

Thomas James, 348, 590

HART JE

Harry Ferdinand, 347

HARTMAN

Jesse, 467, 475, 590

HARTWELL

James E., 131, 150, 151 . 591

HARTWIG

H., 394

HARVEY

Andrew, 362, 397, 423. 425, 591

Earle Alonzo, 424, 467, $591, p-391$, a, c. a. Harvey, Earl A.

Harry Evans, 346, 432, 591

Henry M. 424, 450, 459

Walter Carlton, 536, 591

HASCALL

Vtncent Charles, 279

BASEMEIER 
HASEMEIER cont inued Jacob A., 403, p-403

HASH

Berthal R., 173

HASHAW

J. B., 339

HASKELL

Cosa Dell, 468

HASKETT

J. W. , 458

HASLAM

George James, 125-126,

$202,242,257,423$

Thomas Powell, 348

HASLEIN

Charles M., 425

HAST EAD

Edwin Louis, 346

HAST INGS

Byron, 55

$\mathrm{HATCH}$

Homer B. , 436

Kenneth, 165

William Henry, 355

HATFIELD

H., 515

HATHORN

John E., 148, 447

HAUGH

Harry H. , 424

HAUGHEY

Isaiah William, 409, 591

HAUSER

Byron B., 423, 591

Byron T., 172

HAT'SLEIN

Charles Michael, 344 , $423,547,591$, a. c. a. Hauslien, C.M.

HAVERLY

H. T. , 387

HALERSTOCK

Horace Teal, 359, 591

HAVLICEK

Theodore Leo, 310

HAWES

George Fredk., 591

Samuel E., 420, 422, 432

William John, 429, 432

HAWK

Jonathan B., 430

Nell E. . 171

HAWKINS

A. C., p-592

Anthony L.., 346, 591, a. c. a. Hawkins, Anthony L. R.

Robert Crossett, Sr. 396,591 , a. c. a. Hawkins, Robert Grossett, Sr.

HAWLEY

A. N., 591

Ambrose H. , 358

HAWORTH

Dale Emmett, 429, 591

HAWTHORN

Robert A., 475

HAWTHORNE

Johnston A., 428

HAY

Jacob C., 410
HAY cont inued

John T., 94, 314, 354, 355

HAYDEN

Clara May, 193, 394

H. R. 427

HAYES

C. W. , 339, 342, 366

Charles Bernard, 348, 394,459

D. D. 341

Edward R. . See Hays, Edward R.

Helen, 236

Hezekiah, 342

Noah, 234-235, p-234, $359,432,592$

P. W. 355

HAYMAN

Edward C., 344, 358, 430

HAYNES

Alfred P. , 462

Arthur Haisler, 459

HAYS

Edward R., 147, 306, 373, $450,452,456,457,458$. 513,592, a. c.a. Hayes, Edward R.

Isaac, 2

P. W, $450,452,457$

Peter M., 458

HAYSMER

Elam Dolphus, 393, 394

HAZARD

Charles M. , 450, 458

HAZELTON

John M. , 489

HAZEN

John T., 172

Wulliam, 434, 592

HAZLE

M. M. , 444

HAZLETT

Joseph D., 310

HEACOCK

Frank Miles, 412, 592.

J. M., 387

HEADRICK

Charles M., 344, 355, $394,395,397,425$. $433,446,466,470$, a. c. a, Headrich, C. M.

\section{HEAGEY}

Francis Wenger, 303-304, $\mathrm{p}-303,306,307,346$ $373,377,380,547,592$

Francis W. (Mrs. ), 380

HEALD

H. C., 344

HEALEY

M. J., 547

HEAR

Henrietta, 339

HEATER

Olin, 173

HEATH

George A., 149, 432, 592, p-592

HEATON

William D. , 462

HEBENSTREIT T
HEBENSTREITT continued

Austin J., 346

HECKLER

J. W. , 458

HEDLUND

Axel E., 397, 411, 511

Ward Willard, 358, 394, 446

HEEREN-MORRIS

Edna Susanne, 193, 470 , 592 , a. c, a. Heeren,

Edna E. ; Heeren, Edna

Susanna

HEFFINGER

H. W. , 389

HEFLIN

J. F., 484

William J., 430

HEIDER

Charles Frank, 436, 592

HEILMAN

William Landis, 433, 592 . p-592, a. c. a. Heilmann, W. L.

HEILMANN

Hans, 341

William L., See Beilman, W. L.

HEIN

Henry, 592

HEINE

Clint on Daniel, 423, 425. 592, a. c. a. Heine, Clint on David

Wuliam Howard, 423, 425, 592

HEINZ

Alice Amen, 274

Theo. E. 288

HEISE

Carl G. , 346

HELLWIC

John W., 344, 592

HELVIE

Charles A., 462

HEMPHILL

William Joseph, 468, 592

HEMSTEAD

Werner, 265

$\mathrm{HENCH}$

John Madison, 344

HENDERSLOT T

Willie W. 339

HENDERSON

Fannie D. , 446

Richard C. , 348

Robert G. . Jr. ,424, 450 , $456-458,592$

Thomas, 341, 342

HENDRICKSON

Charles W., 592

Mary A. Keller, 193, 465, 593

HENNING

3. Russell, 172

HENNY

William H, 468

HENRICH

Melvin C. , 310

HENR Y

C. E. 342

Charles A., 33, 46-47, p-46, 
HENRY continued

Charles $\mathrm{A}$. continued, 52 . $55,339,466,467$

Edwin C., 157, p-157. $254,301,337,369$, $386,487,593$

Margaret A. (Mrs.), 487

W. P, , 47

Walter $0 ., 114,333,341$, 342,386

HENSCHELE

William Henry, 358

HENSEL

L. M. , 341

HENSEY

Ben W., 358

HENSHAW

E. E., 344

HENSKE

Joseph Aloysius, 113, 256,

HENSLEY $373,547,593$

J., 339

HEPPERLEN

Harry M. , Jr, , p-128, 428

Harry M. , Sr. , 127, $\mathrm{p}-128,371,432,507$

HERBERT

Walter M. , 172

HERMAN

Walter T., 173

HERMSEN

Paul John, 410

HERNEY

Adam, 466, 467, 593

HERREN

Carl E., 358

HERRMANN

Walter Wesley, 349, 593

HERSCHEY

J. B., 458

HER SCHMAN

Charles E., 396, 503, a. c. a. Hershman, C.E,

\section{HER SHEY}

D. W., $130,317,318$,

450, a. c, a, Hershey, D. F.

HERSHMAN

C. E., See Herschman, C. E.

HERSHNER

Charles S., 394, 430. $434,465,475$

HERTZMAN

J. F., 339, 341, 342

J. F. L. D. (Mrs.). 263

HERVEY

David S., 173

HESKETT

J. W., 458

HESS

George J., 432, 470, 593

HEUMANN

Johann M. F., 346, 593

HEUSKE

Joseph Aloysins, 346

HEWETSON

B. L. $267,333,339$, 342 , a.c, a. Hewelson. H. L.; Hewitson, H.
HEWETT

Etta E., See Hewitt, Etta E.

Henry F, , See Hewitt, H. F,

HEWT

David A., 445

BEWITSON

H., See Hewetson, H, L.

HEWITT

Etta E. , 193, 396, 397, 430 , a. c. a. Hewett, Etta E. ; Hewitt, Etta C.

Ham liton W., 459, 593

Henry F., 395-397, 593, a. c. a. Hewett, Henry F. HICKEY

Charles W., 338, 344, 462, p-592, 593

HICKMAN

Clarence Clyde, 371, 520 , 521, 593

Hortie, 173

Joel Clyde, 593

HICKOK

H. S., 466,467

HIGGINS

John M. 173

Joseph E., 430, 468́, 593

Ralph P. , 420, 422, 424 , 593

HILDEBRAND

Guy H. , 394

HIL.DINGER

Albert Leo, 310

HILDRETH

Mortimer L., 203, 204, $317, \mathrm{p}-317,321,397$, 593

W. H., 361

HIIL

A. E., 414

A. T. , 397

Charles P., 356, 428

Erasmus M., 358

J. Boston, 346, 593

J. G., 342

James S anley, 344, 434,

HILLE $447,593, D-594$

Richard Walter, 392, 424. 593

HILLIS

Madalene S., 270, 279 . a. c. a. Hillis, Madeline William Ervin, 594

HIL.LKOWITZ

Philip, 504

HILLS

Frank, 489

John Z., 467

HIDSABECK

Lester Clyde, 594

HiLTON

David Clark, 251, p-251, $314,355,357,371$, 521,594

HDMMELFARB

Max, 349

HIMROD

Margaret C., 342, 395

HINCHEY

Frank, 342
HINCHMAN

Joseph Y.., +30, 444, 450, $458,466,467,470,510$, 594

HINKLE

Thomas C., 410

Warren Irle, $451,457,459$, 594, a, c, a. Hinkle, Warren Irl

HINTZ

Alvis F., 467

HINZ

A. F., 339

A. T. 467

HIPPLE

A. Hugh, 547

HLRCHMAN

J. I., 34?

HLRSCH

D. L., 537

E. K, , 537

HIRSCHMIANN

Herman, 344, 594

$\mathrm{HITCHCOCK}$

Gilbert Monell, 33, 52, 54

John W., 356, 410, 426, 427

Phineas, 54

HLAIR

Peter J., 172

HOAGLAND

Newton J., 442

HOAGLCND

Earnest A., 173

HOBB

W. R., 342

HOBBS

Noah R., 402, p-403

Phillip M. , 428

HOCTOR

Emmett Francis, 348

BODGE

Beatrice, 274, 279

HODGES

C. H. (Mrs, ), 538

HODGETTS

Alfred, 489

HODGINS

V. M., 165

HODNETT

Wuliam Perkins, 463, 464 . 536,594

HOEFER

Carl Archibald, 348, 594, $p=594$

HOEPFER

James F. X., 288

HOEHEN

Edward, 446

HOFF

Albert Edward, 423, 425, 462, p-594, 595

HOFFMAN

Carl A. , 342

E. H., 339,342

Fred, 513

J. $0 ., 431$

Lloyd Oliver, 547, 585

Oscar S., 95, 100, 101 , $p-101,116,162,332$, $335,339,342,492$

Paul H. , 173 
HOFFMAN cont inued

Samuel S., 427

Wayne W., 173

HOF FMEIER

Frank S., 457

HOFFMEIST ER

Fred A., p-91, 92, 131, 148,427

George, p-91, 146, 346 , 410,594

HOFFZIGER

Armand, 345

HOGAN

D. S., 468

HOGE

Wilmer B. , 339, 430

HOGEBOOM: Richard, 77

HOGLE

George W., 429

HOHLEN

Karl Siegfried J., 355 , $358,371,394,521$, 595 , a.c. a. Hohlen, Karl Siegfrid J.

\section{HOLBROOK}

Charles A., 396, 412, 467

Myron, 173

HOLCOMB

Stlas, 73, 119, 185

Thomas J., 429

HOLDEN

Horace T., 342

HOLDREGE

G. W. , 221

Harry A. , 221

HOLDREDGE

Leta, 384

HOLKE

Henry J. , 346, 414, 427 446,459 , a. c, a. Holk, Henry J.

HOLLAR

$$
\text { Lulu, } 383
$$

HOLLENBACK

Carl Francis, 346, 595, a. c.a. Hollenbach, C. F. HOLLENBECK

Frank Bradbury, 354, 357, $371,521,595$

HOLLERAN

George C., 310

HOLLIDAY

Andrew S, 50, 316

J. V., 342

HOLLISTER

George, 46

Robert Russell, 391, 547, 596

HOLLOPET ER

Charles Marion, 428

HOLM

Adolph Hjalmas, 442, 596

HOLMES

Abby Virginia, 192, 342

Edgar Rea, 394

H. P. . 341

Jesse, 355

HOLMQUIST

Anna S., 341
HOLMQUIST continued

G. , 341

H. L., 342

HOLMS

L. C., 445

HOLOVTCHINER

Elias, 96, 109-110, p-110, $151,333,339,596$

HOLSCLAW

Charles V., 397, 411

HOLST

John, Jr, , 346, 596

HOLTKE

Henry J. , 430

HOLTMAN

Amadens A., 344

HOLYMAN

Marcus B., 596

HOLYOKE

Edgar Loomis, 145, 314 $353, p-353,355,596$.

HOMAN

Leo. Jos. , 423, 596

HOMBACH

Leo James, 348

William Henry, 430, 515, 594

HOMPES

Joseph Josiah, 141, 355, HOOK $358,371,521,594$

Norman, 356

HOOPER

Clifford Leon, 396, 594 HOOPS

F. C., 428

Marcus, 397, 594

HOOVER

A. L. , 353

Jonas, 355,356

John Bower, 434

Ladd E. , 349

Maurice A., 594

Raymond K., 347

HOPKINS

Alfred G., 341, 342, 397

B. S., 314

Cary M. , 341, 342, 432

Howard L. , 288

J. C., 344

Salein H., 342

Samuel Rice, 372, 393 , 595

Silas, 307

HOPPER

Oscar C. , 147, 342, 423, 425,595

William N., 173

HORER

Hugh, 425

HORN

Matthaus Henry, 359, 595, a. c. a. Horn, Matthius H. HORNBACH

Walter P., 432

HORNBECK

Albert Russell, 359, 409, 595

HORNE

Brose S. , 346

H. 165
HORNE cont inued

Mary, 374

HORNER

Grace Dowler, 435

HORTON

C. J., 430

W. H. , 342, 470

HOSCHOUER

George Dexter, 358

HOSKING

Milton C., 173

HOSKINSON

Joseph E., 173

HOSMAN

Thomas E., 356, 458

HOST ETTER

Allen H. , 595

Peter, 339

William A., 342, 595

HOTTELMANN

Otto, 355, 434

HOT2

Edward Janus, 347

Harley James, 349, 595

HOUCHENS

Homer R., 465, 595

HOUGH

J. Walter, 346

HOUGHTON

Frederick W., 344, 470 HOULTON

Thomas Leo, $307,338,347$. 595 , a. c. a. Houlton, Thomas F.

HOUSEL

Charles L., 424

HOUSER

James A., 458

HOUSH

Charles R., 172

HOUSTON

I. M. , $450,455,456$

HOUTZ

William G., 118, 356

HOUZVICKA

Oto August, 310

HOVER

Hugh, 344, 394, 410, 432,

HOVEY $435,446,462,467$

Ford, 491

Sarah L. K. , 356

HOVOCKA

Joseph Hogn, 348

HOWARD

George W. , 355, 427

Isaac D. , 411

Mary A., 186, 355, 394

Maurice C. . p-299, 303, 306. $346,387,547,595$

Paul R., 359, 396, 425, a. c. a. Howard, Paul K.

Richard E., 358

Sullivan, 433, 442, 465, 595

William Samuel, 396

HOWCROFT

C. . 73

HOWE

M. F., 339

R. M. , 341, 470

HOWELL 
HOWELL cont inued

G. R., 165

John W. S., 425, 444, 462,467

Maude, 512

William Lewellyn, 146 , $504,595$.

HOWES

G. Frederick, 470

J. C. v. C., 339

Luther Alan, 394

P. G. , 531

Seth F. . 430

HOWLAND

Lutber H. 394

HOWLEY

Ambrose N. , 358, 438, 595, a.c. a. Howley, Androse N.

H. 165

HOXIE

Frank, 342

Derrick Antill, 348, 392 HOXSEY

Robert Patton, 410, 429. HOYE $474,475,595$

Emma, 357

HOYT

Andrew W., 475

Andros W., 359, 447

D. E. F., 365

S. W., Jr., 342

Samuel Norris, 595

HRBECK

Cyril J., 173

HUBBARD

C. S., $394,424,596$

H. B. 374

Scott L. , 475

Seth L., 358, 394, 424,

HUBBEL $428,434,445,465$

C. G., 432

HUBBELI

Abraham Turner, 596, p-597

Harry W., 146, 437, 596

HUBENBECKER

John Carl, 462, 596, a. c. a. Hubenbrecker, J. C.

HULBERTA

Sister M., 515

HULBERTINA

Sister M. , 511

HUDDLESTON

R. H. . 73, 339

HUDSON

Edward A., 427

Hosea, 424

Walter Burris, 394

HUELFF

John H. E., 339, 355

HUESTIS

Charles B., 347, 348

HUFF •

Alice Em 1ly, 265, 352, 356

S. G. 427

HUFFMAN

Harry Gusten, 347

HUFMAN
HUFMAN continued

Robert Wward, 357, 458. 596, a.c. a. Hufman,

HUGG Robert $\mathrm{H}$.

Thomas, 173

HUGHES

A. L. , 547

Dwight Otis, 348, 432,

445, 596

M. A. , 332

Talbert Webb, 468

HUGHS

Price Whlliam, 457

HUGHSON

James A., 339

HULL

Alva Rufus, 344

Charles Aaron, 162, p-167, $168,169,280,337,342$. $372,375,547,596$

E. Ruth, 443

Everett B., 173

J. W. N. , 455, 457, 458, a.c.a. Hull, Joseph A. M. : Eull, Joseph A. W.; Hull, Joseph Addis on W.

Solom on L.. 442, 596

HULLHORST

Carl. 90

Charles G. A. , 355, 356

HULLHORT

Fredrick, 462

HULST

Mary Mitchell (Mrs.), 87

HUMBARTA

Sister M. , 383

BUMF

Harold Clay, 431, 596

HUMMEL.

Ray O., 358, 596

HUMPAL

Joseph J., 344, 596, a.c, a. Humpal, Jọseph Tohn

HUMPHREY

Amy R., 189, 200, 358

Hall H. , 432, 596

Ira K., 358,432

R. S. , 432, 462, 467

William Armine, 339, 364, $366,409,428$

HUMPHREYS

G. L. . 321

HUNCAT E

James B. , 409

HUNGERF ORD

David A., 119

HUNT

Katherine Moran, 200, $202,346,547,596$

Laura, 358

Loren E., 172

T. S., 431

Wilber N. , 442

HUNTER

Charles E. , 342, 432

Chester Ernest, 428

James D., 172, 449, 456, 457

Mont gomery, 344
HCRD

Marcus Charles, 396

HLRFORD

S. G. +30

HL'RKA

Robert, 455

HLRLBL'T

Nrs, 206

E. T, M1. 363, 343

HURLEY

Daniel J. , 349

HURST

Warren Thomas, 424

HURTIC

Henry George, 425

HURTZ

Harriet G. . 358

HUSTEAD

Charles Dela:o, 147, 156 $157,431,597$, a. c. a.

Husted, C. D.

Charles Luke, 450, p-450, $457,458,512,513,597$

E. L. . 423

HLSTED

Otto Maxwell, 347

HUSTON

Irvin E., 339

Isaac M., 458

HUTCHINSON

Charles B., 357

Mary E. B., 357, 46 ?

W. F, 344

HUTCHISON Joseph W., 146, 344, 442 . 597

William N., 173

HUTH

A., 165

HUTTEN

Jesse H., 342, 597, a. c. a. Huttor, J, H.

BYDE

H. W. $, 333,339,374$

John Fay, 344, 597

R. S., 96

Winifred W., 274, 342

HYLAND

Clarence M., 346, 396, 442

HYLTON

James H. , 445, 597

Waliam Nathanial, 476, 597

BYNES

William Patrick, 410, 597

$$
1 .
$$

IMPEY

Charles C., 101, 102, p-102, $339,344,481,547$

Chester C. 101, p-102, 481

Francis, 102, p-102

INCE

Guss, 173

INCHES

Charles, 321, 423, 425

INGHAM

Charles Thomas, 147, 410 , 471, 597, a.c. a. Ingham, C. 1.

George W., 341 


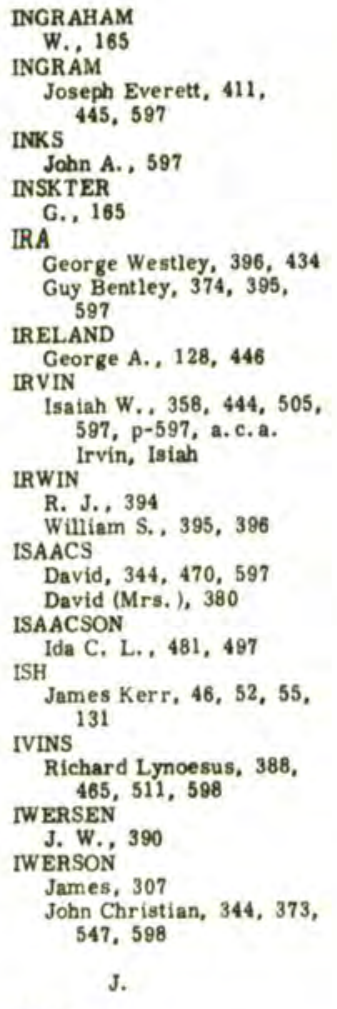

JACK

John Barnes, 344, 428, 444

JACKMAN

Charles B., 396

JACKSON

A. H. , 319

Annie D. , 430

Bernard M. , 344, 397 , $432,435,437$

Frances M. W. 365

George L., 355

Jabez N., 78

John D. , 430

John Ernest, 348, 392

JACOBI

Stella Elora Chapman, $193,196,-598$, a. c, a.

JACOBS Jacobi, Stella F. C.

Charles W., 339

J. C. 146

Stephen W., 356

JACOBSEN

Mertin Carl, 598

JAENIKE

Ríchard Carl Albert, 347 . 442 , a. c. a. Jaenike, R. C.

\section{JAGO}

Arthur Herbert, 333, 341, 342

JAHR

Herman Mandel, 209-210, p-210, 280, 289, 348, 373,547 , a.c. a. Jahr,

JAMES Herman Milton

Charles Stanton, 280, 345, $372,547,598$

Louis A. , 173

Maurice Clayton, 446, 598

Peter E., 344, 475

W. J. , 357

JAMIESON

Thomas H., 467

JAMISON

Sarah E., 171

JANNEY

James Garfield, 458

JANSO

Herman, 344

JANSS

Henry, 430

John, 430

Peter, 428, 430, 432, 434, $444,458,467$, a. c. a. Jauss, $\mathrm{P}$.

JANSSEN

William, 467

JANY

Max, 414

JARMIN

Ernest George, 359, 434, JAUSS 506,598

P., See Janss, Peter

JEFFERIES

Moses, 451, 457, a. c. a. Jeffries, Moses

JEFFERS

B. F., 425

JEFFERSON

Alfred, 344, 598

Thomas E., 457

JEFFREYS

Reuben S., 428, 432

JEFFRIES

Moses, See Jefferies, Moses

JEFFRYS

William Thomas, 432

JELINEK

John A., 598

JELSMA

H. P., 433

JENISON

Andrew J., p-149, 149151

JENKINS

Harry Jerome, 306, 307, $346,386,598$

John E., 338

JENKS

H., 165

JENNINGS

Henry B. , 386

J. $M,, 423,427,434$

JENISON

Andrew J., 411, 598 ,
JEN1SON cont inued

Andrew J. cont inued, a. c, a. Jennison, A. J.

JENSEN

A. , 165

Arnold Larson, 348

C. G. (Mrs. ), 538

Frank, 362, 438, 528, 598

Hans Peter, 54, 67-69, p-67, $108,212,222,296,324$, $332,333,339$

Jens Peter, 395, 598

Robert Percival, p-67, 68-69, 429

JESPERSEN

Thomas, 339

JESPERSON

Iven, 358

Lydie, 358

JESS

Irene H., 171

JESSE

R., 165

JESSEN

Johann H., 425, 444, 446, a. c, a. Jessne, Johann $\mathrm{H}$. J. M. 425

JESSNE

Johann H., See Jessen, J.H. JESSON

H. C., 365

JESTER

Charles W., 430, 444

Royal F., 430, 598

JETER

Calvin D., 173

JEWETT

Lawrence B., 172

JINDRICH JOB

George W., 172

Clatilla B., 424

JOHANSSON

Elna, 485

JOHNSON

A., 165, 296

Agnes M. . 193

Aldis Adelbert, 346

Aldis A. (Mrs.), 380

Alfred, 424, 465, 467

Amos Frank, 425, 446, 468 , 598

Andrew, 127-128, 341, 342, 428,508

Anthony, 485

Arthur C., 307, 386

B. F., 339

Barton Willard, 357, 428, a. c. a. Johnson, Barton Wulliard

Belle R., 186, 356, 410 , 458 , a. c, a. Johnson. Belee R.

Carl, 495

Carl A., 172

Chester Arthur, 397, 410, 598

Chester Frederick, 348, 598

Czar Clinton, 156, 161, 359 . $371,435,598$

D. W, 341 
JOHNSON cont inued

Earle George, 371, 430. 598 , a.c.a. Johnson, Earl G.

Edward, 444

Egbert Guy, 252, 424, 598

Ellen Marie, 171

Emily A. , 171

Ernest D. L., 346

F, V, 430, 445

Frank Bruce, 359, 427 . 521,598

Frank W.. 146, 443, p-443, 444, 599

George W. , See Johnston, G. W.

George Stephen, 359

Henrietta Mae Washburn, 599

Henry A. , 385, 387, 397

Herman Frank, 108, 280, $348,431,547,599$, a. c.a. Johnson, Herman H.

Homer H. , 599

Huldah D. , 171

Iven Godfrey, 346

John F., 443, p-443, 444

John M. , 410, 484, 515 , 599

Joseph Cadleigh, 468

Jultus Andrew, 172, 346, 599 , a. c. a. Johnson, Julius $\mathrm{H}$.

L. C. 395

Leland A., 172

Leslie Augustus, 410, 599

Lillian R. . 171

M. A. D. , 339

Myron V., 173

Norman T., 599

Olaf B. . 495

Orville Dawson, 424, 599

R. B. , 165

R. S., See Johnston, Raymond S.

Robert, 440

Rudolph Eugene, 346, 435, 599

Russell W. . 359

Samuel Wesley, 458

W. P., 141, 166

Walter Lawrence, 599

Will K., 356, 410, 458

William Adams, 428

William Burton, 462

William H. 356, 428 , $434,462,464$

Wnliam Thomas, Jr., 140, $348,473-475,532,599$

Wuiam W. . 425

Zaremba, 71

JOHNST ON

Andrew P., 263

George Frederick, 599

George W. , 87, 320, 394, a. c. a. Johnson, G.W.

Henry E. , 357

James A., 397

James Franklin, 359

Raymond S., 346, 387,
JOHNSTON cont inued

Raymond 5. continued,

394,599 , a. c. a. Johnson, R. S.

William R. , 344

JONAS

August Frederick, 95 , $105-106,154,162$. $167,182,207,216$. $244,257,268,272$, p-276, 280, 321, 331, $333,334,337,339$, $341,360,361,370$, $372,375,460,480$, 492, 599

Francisced, 329

Metha Helfritz, 182, 187. $198,331,333,334$, 339

\section{JONES}

Agnes Houst on, 193, 358 . 437,599

Benjamin F. , 462

Charles H. . 447

E. R., 446

Edward L., 599

Edward T. . 358

George, 394

-Cuscaden, Gertrude. See Cuscaden-Jones

Glenn Albert, 346

1. D. , 409

John Collins, 332, 333 $339,342,427,432$ 467 , a.c. a. Jones, John 0.

J. S. 451

James D. 470

Lauren, 344, 395, 411

Leroy, 464

Lewellyn L., 394

M. L. . 166

McMillan, 344

Morris Edward, 356

Newell, 344, 442

Newell (Mrs.). 380

R. H. , 166,341

Richard H. , 446

Robert F., 411

Robert Turner, 424, 599

Sherman J., 393, 394, 434,599

Thomas Jefferson, 442, 600

Tyre Kinser, 397, 600

Vincent Leo, 346

Walter M. , 429

Wesley B., 347, 600

Will Owen, 205

Wuliam Clay, 358

William W., 427

Wiliam Y. 410, 600

IONSON

Elin, 341

JORDAN

Charles M. . 339

Harry (Mrs.), 59

JORGENSEN

William A. , 172

JORTER

E. J., See Porter, E. J.
JOY

Douglas A., 339

JOYCE

John B., 410

JOYNER

Navill, 434, 506

JLBEL.

Hette, 33 ?

JUDD

John Hewitt, 429, 600

Walter Henry, 248, p-248, 348

JLDKINS-DAVIES

Dora M. , 187, 193,269 $342,394,433,444$, a. c, a. Judkins, Dora M. Davies; Judkins, Dora M.

JULIAN

Edward I. , 394, 411

H. M. 430

JUNGCLACS

William X. , 172

JURGENSEN

Nohne C., 172

K.

KADAVY

Godfrey Joseph, 252-253.

KAIL. $p=253,348,600$

Carl, 600

KAI.AL.

Elizabeth, 171

F. J. B. , 346,430

KALAR

James Riley, 424, 435, 466. 600

Sarah B. , 193, 435

KANDEL

Phoebe M., 142, 143, 381 . 384

KANE

Joseph John, 347

KANI

M. Alace Mantz, 193, 199 . 200-202, 345, 600, a. c, a. Kani, Alace; Kani, M. Alice Mantz

KANTOR

Dominic Benjamin, 172, 390. $422,424,600$, a. c. a. Kantor. Dominik B.

KARASS

Hubert D. 345, 394, 435 , $462,466,470$, a. c. a. Kardss, H. D. ; Karass. Herbert D.

W. D. 414

KARDSS

Hubert D., See Karass. Hubert D,

KARGACIN

Thomas J., 348

KARRER

Fred W. , 389, 476, 600

KART EN

Joseph W. , 339, 342

KASPAR

Joseph Francis, 462, 600

KATOR 
KATOR continued

S. B., 199

KATSKEE

Edwin, 359

KATSUKI

David I., 288

KAUFFMAN Emmanuel, 600

KAUFMAN

A. J., $346,411,412$

KAUP

A. F., 428

KAUPP

A. T., 432

KAVAN

Wenceslaus John, 600

KAVON

KAY

$$
\text { E. Georgia, } 171
$$

James, 444

Zacheus LaFayette, 525 , 526,600

KEANE

John Lawrence, 600

KEARNS

A. J., 465

$\mathrm{KEE}$

Albert L., 427, 510, 600

Azalia, 346

KEEFE

Harry L. , 29

KEEGAN

John Jay, 259-260, p-259,

$271,273,280,338$,

$347,375,547$

J. Jay (Mrs.), 378

KEELER

C. C., 450,456

KEENAN

George, Jr., 338

Leo W., 310

KEENE

Edwin R., 462, 476

KEENEY

W. H. , 462

KEEP

F. E., 395

KEETTEL

Waliam Charles, 397. 600 , a. c, a. Keetell W. C.

KEHLER

Charles F., 475

John Ellis, 427

KEHY

James Francis, 346

KEICKBAUM

C. T., 427

KEIFER

John J., See Kiefer, John J.

KEIPER

George Frederick, 122 , $148,152,362$

KEITH

Charles Worthington, 251, $600, p-601$

James B. , 344, 397, 425, $434,462,470$

M. Allen, 536

Mellvile Cox, 355
KEITH continued

Wellington W. , 394, 411. 426,600

KELLAR

A. , See Keller, Alvin Henry

F. A. , See Keller, Frederick $A$.

\section{KELLENBURGER}

Emerson K. , 355

KELLER

Alvin Henry, 266, 450, 456,467, a. c. a.

Kellar, A.

Anthony, 457, 458

Frederick A. 456, 458, 600 , a.c. a. Kellar. F. A.

Lydia H., 536

Samuel L., 468

Tresa, 383, 502, a. c, a. Keller, Theresa

\section{KELLE}

Albert W., 357

Bernard S. , 435

Charles Joseph, 395

Ernest, 306, 308, 339. $345,385-387,601$, p-601

Ernest (Mrs.), 380

Fannie, 383

H. D. , 344

James Francis, 306, 333, $339,342,376,386$, $459,547,601$, a. c, a.

Kelley, Jas, A. A.; Kelley, J.A.; Kelly, James F.; Kelly, James A. A.

John F., see Kelly, John F, Morriss DeWitt, 348

Peter C. 430

R. D. , 166

Thomas, $333,339,342$, a, c. a. Kelly, Thos,

Walter Edwin, See Kelly, Walter Edwin

\section{KELLISON}

Maud E., 536

KELLOGC

Carmelita, 310

KELLY

E. A. 330

James A. A., See Kelley, James $F$.

James F., See Kelley, James $F$,

John, Jr, . 547

John Franklin, 342, 425 , a. c. a. Kelley, John F.

Perry Delphos, 431, 444, 601

Thos., See Kelley, Thomas

Walter Edwin, 393, 467, 601 , a.c. a. Kelley. Walter Edwin

KELMAN

W. J. , 341

KELSO

James, 339, 356

KEMP

T. J. , 374
KEMPER

W. G. , 332, 339

KENASTON

James A. , 403-404, p-404

KENNARD

Henry Waters, 601

KENNEDY

Alfred, 546

Charles Fremont, 428

Charles Rex, p-278, 280 . $283,344,372,375,392$. 601

C. R. (Mrs, ), 380

Howard, 508

Sallie F., 410

W, V, , 395

KENNEL

A. C., 446

KENNER

Charles Andrew, 342, 357 , 601

William Clinton, 601

William Clint on, Jr., 344, $348,434,601$

\section{KENNEY}

Bernard Vincent, 347, 601

Cassius C. . 355, 356, 457 , a, c, a, Kenny, Cassins C.

Eugene W., 348

James, 173

W. H. , 458

KENNON

Clyde E., 601

Olen A., 173

KENNY

Cassins C., See Kenney, Cassius C.

KENSINGTON

Milo Leonard, 339, 341 , $342,428,430,467,475$,

KEN a, c. $\mathrm{a}, \mathrm{Kensington,} \mathrm{Nilo} \mathrm{L}$.

Asen H. , 444

Clifford Foster, 280

James M. , 358, 394

Oren H. , 458

KENYON

M. J. 397

$\mathrm{KEOGH}$

Frank S. , 296, 298

Patrick S., 294, 296, 300, 332,339

KEPNER

Raymond Brandt, 359, 447

KERGAN

James F. C., 358

KERLEY

Quillen Avery, 410, 601

KERLIN

KERN

Lloyd W. , 172

W. B., 394, 430

KERNS

A. B, , 536

KERR

Charles Lemoire, 433, 450. 458

David R, , 269

Robert Henderson, 504, 602

Theodore Joseph, 436, 602

W. H. $450,456,457,458$ 
KESSEL.

John Jonas, 467

KESSINGEF

James William, 356, 432,458

KESTEL

John E. . 348

KESTER

M. Addie, 187

KETCHUM

Marshall P., 357

KETTRING

Joshua A., 355

KEYES

E. C. , 462

Gene, 383

Jean E., 529

Jerome M. , 312, 313 , $341,342,602$, a.c. a. Keys, J. R.

KEYTON

Russell S., 173

KICHBAUM

Charles R. . 462

KIDDER

Clarence Eugene, 394 602

KIEFER

John J. , 146, 397, 410 , $412,414,432,444$.

467, a. c, a. Kelfer.

KIELING J. J.; Kieffer, J. J.

W. W. . 444

KIESSLING

Elna Laura, 435

KIEZAKOVA

Josephine, 341

KILBRIDE

Edwin Albin, 348

KILBURN

Alice, 510

KIDEE

Henry Ambrose, 347

KILE

James Bernard, p-610, 602

KILLAN

Leo Julius, 470, 602

KIL.LINS

Wendell Allensworth,

KIMBALI $58,347,547,602$

Archie P. , 462

Thomas, 61

KIMBERLING

Herbert C. 432

KIMMEL

John Patton, 435

KINDRED

Homer Leander, 342 . $377,458,602, \mathrm{p}-603$ Homer Leander (Mrs.), 377

KINE

John William, 458, 470 KING

C. DeWitt, 357

D. L. . $p-539$

David Morgan, 455, 458

Dexter D., 476, 541, 602
KING continued

E. Eugene, 444

Elizabeth B., 187, 462, 468

F. M. , 166

Frank Lambert, 344, 356 , $394,411,430,434,444$, 445,602

Henry Eugene, 442, 443, 602, p-603

John D. . 339

John S. . 341

John W. . 342, 410, 602, p-603

Sophia, 339

KINGSLAND

Samuel, 339

KINNAMON

A. M. , 432

KINNEY

John Fitch, 71, 477

John Fitch (Mrs.) , 71, 477

Stephen F., 71

KINSELEY

Arthur 1., 429

KINSEY

Ben W., 344, 394-397. $410,424,429-431$, $433,436,445-447$. $458,462,475$

Katherine E., 346

KINSLER

J. T. 339

James 1. , 342

KINTNER

Arthur Ruel, 602

KINYON

H. E., 444

KINYOUN

Floyd H., 254, p-253, $346 ; 602$

KIRBY

Tupper, 425, 432

KIRCFMAN

Robert Charles, 423, 462, 602, p-603

KIRCKWOOD

Mary J. , See Kirkwood, KIRK Mary J.

A. F. . 516

Esley Joseph, 426, 602

Nathan, 408

William, 408

KIRK E

William, 428

K IRKEGAARD

Smith C. . 349

KLRKPATRICK

Charles F, , 462, 603

Muo, 342

Milton Elder, 339, 360 , 444,603

KIRKTWOOD

Mary J, , 193, 603, a.c. в. Kirckwood, Mary J.

R. C. . 517

KIRSCHSTEIN

H. J., 213

KIRSHENB AUM

Jacob, 173
KLASS

Henry, 17

KLAVON

Loneta, 274

KLEYLA

John Raymond, 232, 305. $307,338,346,386,547$, 603, p-604

KLICK

John Joseph, 344

KLIMEK

F. M. , 166

KLINE

Phillip. 346

KLING

David G. , 432

KLINKER

Joseph M., 395, 468

KLOPP

A. 166

KLUSSMAN

M. Pauline, 344

KNAPP

Frances Crothers, 429

William M. , 204, 319,321 , $353,354,356$, a. c. a, Knapp, W, w.

KNEELY

John G. , 428

KNIE

J. IV. , 446

KNIGHT

Frank M. , 396

Ralph Thomas, 358

KNODE

Archibald Roy, 113, 280 , 547,603

R. C. . 464

Ray A., 344

Robert Samuel, 96, 113-114, $\mathrm{p}-113,333,339$

KNOLLENBERG

William H. , 425

KNOWLES

Charles Erastus, 603

H. S. , 339, 366

S. H. , 339,410

KNOX

W. W. , 339

Walter Eugene, 447, 525 . 526,603

KOBAK

Disraeli, 210

$\mathrm{KOCH}$

Earnest, 173

Lewis Alfred, 424, 603

Wesley A., 344

KOCUM

Joseph, 172

KOEBBE

Eara Eduin, 157, 446, 603 KOEBER

P. E. . 462

KOEFOOT

Theodore Henry, Ii6, it6, 603

KOEHLER

Albert, 172

B. F., 476

KOELTER

Max, 395 
KOENIC

Albert H., 344

George, 449, 457, 458

Margaret Wilhelmina, 193, 196, p-196, 199, 201. 603

KOERBER

P. E. , 465

KOHENST AMM

L. J., 333

KOHLER

H. F., 432

KOHN

Frank, 172, 427, 603, a, c. a. Kohn, Krank Isaac, 491

KOHNST AMM

Lorenzo J. , 339

KOLDA

Felix Oliver R., 347, 387

KOLLE

Carrie M. , 171

KOLOUCH

F. G., 535

KOLTAR

Frank John, See Kotlar, F. J.

KONESTRICK

J. D. . 427

KONTERWITZ

Harry K., 288

KOORY

Chickrey B, , 604, p-604

KORACH

Leo, 172

KORTH

William Marcus, 349

KORY

Roscoe Conklin, 446

KOSER

Martin Luther, 604

KOST AL.

Otto Albin, 249, 348. 604, $\mathrm{p}-604$

KOTLAR

Frank John, 412, 414, 604 , a. c. a. Koltar. Frank John

\section{KOUNTZE}

Augustus, 45

Herman, 493

Herman (Mrs, ), 478

May Burns, 288

KOUTSKY

James William, 347, 604

John W., 344, 604

KOZISEK

Marie, 537

KRAFFT

Arthur A., 173

KRAHULIK

Lambert, 348

KRAL

Marie, 339

KRAMPERT

Frank L., 410, 604, p-604

KRASS a. c.a. Krampart, F. L.

Herbert D., 431

KRAUSE

Emule, 356
KRAUSE continued

J. Carl, 355

KRAUSNICK

Martha, 171

KRAYBILL

Harold M., 172

KREECORIAN

K. M. . 426

KREIG

Frank W, , See Krieg, Frank W.

KRET ZIER

Harry Hamlin, 348

KRETZLEF

Harry H., 390

KREYMBORG

O. Clair, 349

KRICK

H. A., 430

KRICKBAUM

Charles 1., 91

KRIEG

Frank W., 428, 433, 604 a. c. A. Kreíg, Prank W.

KRINC

Orlen R., 172

KRIZ

Rudolph Edmund, 396 . 524, 604

\section{KROEHLER}

Robert Andrew, 349, 604

KRUEGER

Frederick W, 468

Karl E. , 423

KRUSE

Frederick W., 344, 433, 436, 462, 604

KUCERA

Frank H., 344, 435, 604

KUEBLER

Leon A., 172

KUEFFER

Fred. Milton, 604

KUEGLE

Frederick H. , 345, 394, $412,414,425,430$. a. c.a. Kuegele; Kuegle. Frederick W.

\section{KUGLER}

Earnest F, , 173

KUHLMAN

Charles G. , 339

KUHLMANN

Frederick W., 348, 604

KULLY

Barney Maurice, 232, 303 $306,308,338,347$. $387,547,604$, a. c. a. KUNCL Kully, Bernard M.

Joe, 288

K UNKEL.

Gerald M. , 349

KUNTZA

Margaretha, 339

KUNZ

Father Andrew, 524-525

KUNZE

Herman, 432, 465

KUSS

Joseph A., 173
LABREE

J., 69, 324

LACERT

G. A. , 458

LACEY

T. B., $300,360,361$, a. c, a. Lacy, T. B.

LAFFERTY

Allan B., 394

Allan M. , 414, 425, 435,

$446,462,466,468, a, c$, a. Lafferty, Allen M.

LAFFLER

Gilbert, See Loffler, Gilbert

LA FLESCHE

Francis, 24

Joseph, 1, 23-24

Susan, 1, 20, 24-29, p-25, $\mathrm{p}-27,30$

Suzette, 24-26

LA FOLLETTE

George W., 428

LAGERKRANS

Adolph, 397

LAGES

John R. W., 409

LAIRD

Claude Ross, 473, 475, 605, p-605

J. W. 342

LAKE

Fred W., 344

Lilburn Baker, 346, 605,

a. c, a. Lake, Liliburn Baker

Sidney A., 467

LAMB

Harry Elmer, 446

J. E. 462

Walle Edgar, 358, 605

LAMBERT

M. V., 532

T. R., 531

LAMBLEY

George W., 146, 396, 605

LAMMERS

Harold Van, 410

LAMPHERE

G. H. , 389, 390

LAMPHIER

Vernard E., See Lanphier, V. A,

LANCER

John J., 463

LANDGRAF

F., 387

LANDGRAFF

Ernest Waliam, 307, 346, 605

L.ANDIS

Henry Bruce, 422, 424, 605

LANE

James, 339, 342

Milton, 182, 187, 204, 321, $351-353,355$

O. F., 450,451

Sophronia McC., 182, 187. 352,355, a. c. a. Lane. Sophonia 
LANE cont inued

Thomas H., 355, 357

LANG

Benjamin F., 356, 408

Emil. 508

Matthew S., 173

Oscar Fredk., 605

LANGAERE

Otto E. , 397

LANGDON

Frederick J., 305

John Frederick, p-297, $344,372,386,547$, 605

J. Frederick (Mrs, ), 380

LANGE

Emil, 433

Oscar F. , 458

LANGEL

A. M. , 342

LANGFELD

Millard, 115-116, 147 . 344,605 , a. c. a. Langfield, $M$.

LANGFORD

Earl K. , 236-237, p-236

W. I. (Mr. Mrs, ), 236

LANGHORN

Charles, 390

LANGRALL

Claude D., 605, p-605

S., 468

LANGST AFF

George A. . 147, 470, 605 , a, c, a, Langstaffe, G.

LANGSTON

Rufus K. , 468

LANKTON

Freeda M. , 181, 187, 339. 342, 364,366 , a. c. a.

Lankton, Freda; Lankton, Frieda M.

\section{LANNON}

W. H. . 342

LANPHIER

Vernard Anthony, 306. $386,411,605$, a. c, a. Lanphier, Bernard A. : Lamphier, V. E.

\section{LANSING}

Levinus A. , 358, 605

LANSPA

Joseph A., 288

LANYON

Searl Henry, 347

William H., 339

LAPIERRE

Jean Thomas, 348

LA PORTE

E. J., 547

LAPPENS

A. J., 433

LARABEE

Joseph M., See Larrabee, J. M.

LARIMER

$$
\text { J. F. } 339
$$

LARRABEE

Joseph M. , 339, 433, a. c. a. Larabee. Joseph M.
LARSEN

Antonious Andrew, p-605, 606

Carl Edward, 346

\section{LARSH}

Napoleon B. , 70, 79, 148, $150,152,317,321$

\section{LARSON}

Andrew G. , 344

Jonns, 424, 434, 446

Jonathan M. , 345

Pearl W. , 171, 492

Sadie F, , 488

LASHLER

Horace, 430

LATHROP

Mason Earnest, 348, 606 , a.c.a. Lathrop, Mason Ernest

\section{LATTA}

Elbert Johnson, 359, 393 , 394,606

James Oscar, 146, 411

John Stephens, 280

Orra Iona, 467

Samuel E., 355

William Story, 266, 311 $313,352,355,356$

\section{LATT AN}

$$
\text { L. F, , } 433
$$

LAU

J. , 73

LAUBACH

George Frederick, 87-88, p-98

Herbert George, 87-88, p-88, 464, 536, 606 . a, c. a. Lau Bach

\section{LAUGHLIN}

Joseph Wilson, 146, 606

L.AUGHRAN

Charles H. , 464

LAUGRALL C. D. D. M. M. , 464

LAUVETZ Joseph F, , 462, 606

LAVENDER

William R., 267, p-276, $333,339,341,342$

\section{LAWRENCE}

Charles T., 467, 475

Elmer Y., 436 Emma J. . 198, 450

LAWRENZANA D. Antonio, 346

L.AWRIE Mason C., 172

LAWS John, 339

LAWSEN Ray, 547

LAWSON

Thomas James, 2, 9-11, 397,606

LAWTON

W. H. (Mrs.), 72

LAYBOURNE Ethel Mae, 606

LAZEAR Jesse W. , 75

LAZURE
LAZURE cont inued May Allen, 22

LEA

W. O., 362

LEAHY

F. Emmet, 388

John Emmett, 42 :

LEAKE

E. N., 425

LEAMING

Daniel Mack, 394

LEAR

William Dale, 146, 348, 606

LEARD

Samuel E., 342

LEARNED

John Barr, 242

Myron, 242

LEARY

Wiliam Joseph, 344, 606

LEAVITI

Ruben D. , 288

LEBOLD

Edward Alonzo, 349

LECHNER

T. J. , 166

LEE

Amsbury, 606

Daniel F., 344, 389

Daniel R. , 363, 468, 531 , 606, $\mathrm{p}-606$

Edward Wallace, 52, 108-109, $203,339,342$

Lawrence D, 349

Linford H. , 347, 606

Nicholas, 532

R. C., 342

Robert M., p-606, 607

Vera M., 193, 358

W. A. , 395, 434

William F., 428, 475

William Ross, 428

LEEDOM

Henry Flemin, 608

LEEPER

Dwight D., 456, 458

Thomas W. . 397

LEFTWICH

$$
\text { O. T. . } 394
$$

LEGC

Charles Edwin, 431, 507

LEHMANN

C. H. (Mrs.), 63

LEHNHOF

Henry John, 141-142, p-142, $322,354,361,374,518$, $\mathrm{p}-521,607$

LEIBEE

John Ray, 387, 607

LEIGH

Lucy, 274

LEININGER

Earl F, , 447, 526, 607

LEISENRING

Henry George, 70, 266 , $362,410,470$, a. c, a. Leisenring, Harry G. Liesenring. Henry G.

Peter S. , 70, 144, 262-264. $268,330,333,339,342$, 360,361 , a. c. a. Liesen- 
LEISENRING continued

Peter S, continued, ring, P. S. ; Liensenning. P. S.

LEISURE

Clyde E., 231, 310

Joseph S. , 394

LE MAR

Clair Leone, 446, p-606, 607

LEMAR

Fred Allard, 357, 446, 607

\section{LEMERE}

Henry Bassett, p-276, $280,338,344,372$, 547,607 , a.c. a.

Lemere, H. M.; Le-

LEMLEY mere, Harry

George, 346

LENNEMANN

Ernest, 231, 310

LENNOX

George Banks, 347, 607

LENZ

Minna, 339

LEONARD

Alta (Mrs.), 534

Earl Renshaw, 429

Edward F., 344

LEONHARDT

John Sinclair, 356

LESCHINSKY

George, 515

LESH

Charies W., 172

LESLIE

James D. , 350, 355

LEVEY

Philip, 346, p-606, 607, a. c.a. Levey, Phillip; Levy, Philip

Simon A. , 434

LEVINE

Victor Emanuel, p-228, 228-230, 232, 236 .

LEVY $301,305,388,607$

Ike, 172

Louis (Mrs. ), 491

Philip, See Levey, Philip LEWELLAN

Chester Elmer, 358

LEWIS

Alfred, 411, 607

Arta, 384

Carl A. , 173

Edwin, 344

Emlen, 363, 365

Ernest Verdon, 280

Frank L. , 428

F. Stanton, 339

George Evrie, 607

George Kenneth, 435

Grace M. , 424

J. A. 339

James T., 288

M. D. , 341

Minerva, 355

Nelson Hiram, 425, 607, p-608
LEWIS cont inued

O. P., 166

Raym ond G., 391

W. R. , 396, 397

William B., 173

William F., 344, 395

Wilmer O., 390

LIBERT

J. W. 387

LICHT ENW ALLNER

John G. . 346, 607, a. c, a.

\section{LIEBEE} Lightenwallner, J.B.

J. R., 429

LIEBER

Charles, 344, 607

Philip, 339, 342

LIENSENNING

P. S. , See Leisenring, P. S.

LIESENRING

Henry G., See Leisenring, H. G.

P. S., See Leisenring, P. S.

LIFFLER

Gubert, See Lofner, Gabert

\section{LIGHT}

Samuel E., 349

LIGHTENWALLNER

John B., See Lichtenwallner, J.

LIGHT FOOT

Frank, 344

LIGHTNER

Theodore, 608

LIGHTON

W. R. , 375

LIGHTY

E. 387

LII.IEDAHL

Frank E., 342, 435, a.c. a. Lillerahl, Frank E.

\section{LILJEROTH}

Anna, 339

LILLERAHL

Frank, See Liliedahl. Frank

LILLIE

Park A., 395

LIMBURG

John Irwin, 396, 536, 608

LIMOS

Walter P. . 172

LINCOLN

William H. , 355

LINDBERG

Cora Dell, 193

LINDQUEST

Adolph Bernard, 344, 358, 389,608 , a. c. a. Lindquist, A. B.

LINDQUIST

G. A. , 484

LINDSAY

S. W. , 489

LINDSTEDT

Hildegard M. , 171

LINDT

Harriet L. , 193
LINE

Thomas Henry, 37, p-37, 93-94, 430, 442, 444, 608

LING

Frank B., 345, 358, 394

LINGENFELDER

Julius, 344, 430

LINK

Harvey, 33, 70-73, p-71, $131,148,318,319,321$. $329,339,342$

LINN Oliver C. , 356

E. S. , 166

Elbert E. , 430

LINQUIST

Arthur Lawrence, p-162,

LINSLEY $163,346,348,608$

Claude H. , 288

LIPE

Wilbur P. , 346

LIPP

Michael Joseph, 347

LIPPINCOTTE

Maybelle, 171

LISTON

Oscar Earl, 608

LTCHFIELD

E. A. 547

LTTTLE

C. O., 387

Charles Francis, 3:7

Charles W.. 357, 358

Clement Botsford, 122, 123 , 434

John T., 231, 306

L., 442

P. J., 344, 410, 435

Ralph B., 172

Thomas Coe, 123, 386, 435

Thomas W. W., 396

LITTLEJOHN

J. Martin, 344

LIVINGSTON

David Selery, 457

John Stuart, 394, 400, p-400, 409, a. c, a. Livingston, John Stewart

Robert Ramsay, 70, 79-80, $150,150,152,154,262$. $263,265,317,318,319-$ $320,321,324,325,352$, $399-400, p-400,405,408$, 409 , a. c. a. Livingstone, R. $\mathrm{R}$.

Robert R., Jr., 400, p-400

Theodore Philip, 239, 400, $p-400,408,409$

LIVINGSTONE

R. R., See Livingston, R. R. LLOYD

G. F., 266

$\mathrm{LOCH}$

Bessie, 533

LOCKWOOD

Ira M. , 224

Ira Hiram, 358

Jessie King, 383

LOECHNER 
LOECHNER cont inued

William Henry, 344, 608, p-608

\section{LOFFLER}

Gilbert Dennis, 346, 410 , $411,424,427,429$. $430,433,435,444$, 446, 465, 468, 470, a. c. a. Loffer; Liffler;

LOFTUS Laffer

Harry, 388

LOGAN

Charles J., 397, 447, 470

Johanna Elsie, 193, 424, $430,442,447,462$, 608 , a.c. a. Logan, Jhanna: Logan, Johanns:

LOMBARD

M. S. , 344

LONERGAN

Paul Basil, 608

LONEY

James Stephen, 344

LONG

Arthur N. , 457

E. E. 462

Francis A. 126, 207-209, $\mathrm{p}-208,257,321,322$, $361,362,371,377,608$

Francis A. (Mrs, ), 209, $377, p-377$

John Henry, 344, 359, 465

Kelon H. 458

Louis C., 344, 355, 356

Rachel A., 608

Thomas H., 441

William E. , 346

LONGACRE

Chester Horton, 608

Otto Earle, 358, 465, 609

LONGDON

Harrison A., 358

LONGLEY

F. H., 435,436

LONGSHORE

Anna, 341

LONNQUIST

C. A. (Rev.), 506

LONGQUEST

Elias B., 464

LONSDALE

James A., 341

LOOFBOURPOW

Thad. L., 444

LOOMIS

F. E., 395,462

Gilbert C. , 172

John Julius, 359, 521, 609

Maurice M. , 172

William B., 36

LOOSBROCK

John Francis, 446

LOPER

Asbury N. , 356

LORANCE

Benjam in Franklin, p-122, $122,146,150,242$,

LORD
LORD cont inued

John Prentis5, 95-96, 106 , $108, \mathrm{p}-108,207,212$,

$222,257,280,296$.

$321,331,333,334$,

$337,339,342,361$,

$372,375,376,386$.

$523,524,547,609$

John Prentiss (Mrs. ), 377

LORGER

C. , 166

LORKE

Louis Robert, 429, a. c. a. Lorkee, L. R.

LOUER

Carrie, 380, 492

LOUGHBRIDGE

R. R. , 128-129

LOUGHRIDGE

William H., 357

William K. , 346

LOVE

A. J. (Mrs.), 491

C. A. 428

Don L. , 518

George S., 342, 470

W. A., 470

William S., 609

LOVEJOY

Esther Pohl, 190, a. c. a. Lovejoy. Esther Pohn

Ferold D., 349

LOVELEY

Frait' N. , 445

LOVELI.

Arthur Irving, 249, 358, 609

F. B., 433

Joseph, 9, 16, 18, 19

LOVELY

Frank Thomas, 387, 425, 609, a. c. a. Lovely, F. E.

James Phillip, 348

LOVIG

Thomas O., 470

LOWE

DeWitt Stratton, 310

Enos, 32, p-32, 47-49, $54,55,154,319,323-$ 325

Fred B. (Mrs. ), 48

Jesse, 47

William, 434

LOWER

Raymond Alan, 349

LOWRY

Hamilton B. , 204, 246. $266,314,321,352$, $354,355,361$

H. P. , 356

LUCAS

A. C. 396

Charles, 394, 411, 430, 609

John H. , 458

Voorhees, 435, 436

LUCE

Roscoe P. , 349

LUCIC

Lucas Hugo, 349, 609
LCCKE

Richard Ot:o, 347

Robert S., 339, 342, 609

LUDDEN

James L., 344

LUDNNGTON

Horace, 339, 342

Paul H. 342, 492

LUDWIG

Otto Paul, 348

LUENINGHOENER

Mathilda Anna, 202

LUEPKE

John F.. 434

LUESCHEN

Alvin G. , 446, 609

LUHMAN

Frederick Walter, 397, 609

LUIK ART

Ralph Herbert, 161, 252. $372,547, p-608,609$, a. c. a. Luikhart, R.

Ralph (Mrs. ), 380

LUIKHART

R., See Luikart, R.

LUJA

C. F., 448

LUKENS

Isaiah, $150,372,397,470$. 539,610 , a. c. a. Lukens, Issaiah

LUKOWSKY

J. F., 349

LULL

Claude Charles, 429

LUND

A., 166

LUNDBERG

Frederick Otto, 435

LUNDBY

John L. . 344

LUNDHOLN

Martin C. O. . 173

LUNDY

Fred L. 345

LURVEY

Homer David, 346, 471, 610

LUSK

William Albert, 411, 462 , 610

LUTES

Charles H., 433

LUTGEN

Anson S. , 433, 444, 471

Clifford A., 444, 505, p-505, 610

S. B., 444

Sidney Anson, 251, 470, 540 . 610

LUTTON

John Dudley, 359, 410, 610

LUTZ

Mary Alice, 355

LLXFORD

William james, 397,462 , 610

LYLE

Charles F., 447

LYMAN

Christine Elizabeth, 344, 610

Elizabeth C. 193 
LYMAN cont inued

Henry S. , 344

Laura Wilson, 514

Rufus Ashley, 344, 358, $374,391,610$

LYNCH

Albert, 371, 433, 610

B. H., 166

Delia Adalene, 193, p-202, 344,610

Edward Clarence, 344 . 425, 610

George Murray, 348, 433, 610

Lawrence A., 346

LYNN

W, H., 394

LYON

Robert, 355

LYONS

Charles W., 427

M.

MC ADAM

Robert, 394

MC AFFREE

F. S., 536

MC ALEER

Elmer Cornelius, 610

MC ALLISTER

Julius S., 446

MC ALTEE

J. S., 387

MC ARDLE

George M. , 346, 457, $459,513,610$

Leroy, 346

MC ARTHUR

Andrew J., 418, 422, 610

Hector J., 614

MACASA

Demetric C. , 348

MACAULEY

Bernard J., 395

MC AVIN

James D., 346

James S, , 280, 610

MC CABE

Eugene Alphonsus, 610

Florence, 143, p-381, 381,383

Fordyce Hiram, 369, 411, 427, a. c, a. McCabe, F. W.

Nicholas, 124, 150, 435, 436

MC CAGUE

William L. , 484

IC CAHAN

Hannah C., 187, 198, 333, $341,342,434,445$, 458

MC CALL

Henry B., 172

MC CAN

W. H. 425

MC CANLEY

Paul B. , 446

MC CANN

W. J., 342
MC CARTHY

J. A., 232

Joseph Daniel, 346, 395, 438,610

Joseph Satolli, 347

M. S., 344

Timothy Francis, 358, 611

William F,, 348

MC CAW

Fred Warren, 462, p-611, 611

Hugh E. , 344, 436, 467

MC CHESNEY

Charles E., 410

M. Josephine, 187, 193 , 446,611

MC CLANAHAN

Harry Monroe, 95, 112$113, p-113,248,268$ $280,283,321,332$, $333,335,339,342$, $373,547,611$

W. S, , 339

MC CLANE

Joseph DeG., 355, 410

MC CLEAN

James, 434

MC CLELLAN

Isador A. 428

MC CLELLAND

Elmer E. E., 611

Elmer Edward Ellsworth, Jr. , 395, 396, 611

Hugh K., 457, 475

Jennie, 54

William, 54, 55, 59-60, $154,318,324,325$. $329,339,374,431$

MC CLENEGHAN

Samuel, 500, 611

Samuel (Mrs. ), 380

MC CLINTICK

Howard B. , 172

MC COHN

W. G. , 410

MC COLLESTER

Seth M. , 475

MC CONAUGHY

Robert, 140, 321

MC CONNAHA

John, 409, 470

MAC CONNELL

C. W. , 341

MC CONNELL

George W., 467

John B., 449, 457

MC CONOUGHEY

Freeman E., 347, 359

MC CORMICK

Marion S., 457

MC COY

Emily, 339

Hiram Foster, 339, 342, 457

John Cresop, 339

John H. , 396, 433, 504, 611

William Byron, 358

MC CRACKEN

Robert E., 442
MC CRANE

H. F., 54 ?

MC CRANN

Patrick M., 346

William Joseph, 252, 428, 611

William J., Jr., 152, 611

MC CRAW

W. Joseph, Jr., 346

MC CREA

E. L., $529, p-539$

F. M. 342

John L., 408

MC CREARY

J. C., 536

MC CULLACH

Jennie A. , 410

MC CULLOUGH

J. Stewart, 357

MC DADE

Charles Webster, 470

Zeoria Owen, 470

MC DANIEL

Virgil Sprague, 350

MC DERMOTT

Alza Stewart, 310

B. У., 431

Bernard Aloysius, 344, 611

William 0., 432

MC DEVITT

James Andrew, 467

MAC DIARMID

Stuart B., 344, 385, 387, $614, p-614$

MC DONALD

Ambrose A. , 476

Charles M., 339

Grundy E., 396

Hugh Allan, 431, 611

Isobel Cunningham, 193, $197-198,359$, a. c, a. McDonald, Isabel

James F. (Mrs. ), 380

James Francis, p-230, 230 $232,301,305$

James L. , 431

Louisa Boyer Smallwood, 185, $193,200,354$, a. c. a. McDonald, Louise Smallwood

Norman A., 185

Robert Cameron, 321, 333, 339,423

Robert E., 425

MC DONNELL

Joseph, 333, 342

MC DONOUGH

Frank J., 348, 423

MC DOWELI

Charles H., 342

Milton Berlin, 389, 410, 612

MACE

John Larence, 393, 411, 614

MC ELWEE

A. , 32, 48-50, 55, 316

B. F., 433,434

MC EUEN

Oliver, 396, 612, a. c. a.

McEwen, $\mathrm{O}$.

MC FADDEN

Harry Weber, 157, 409, 423, 
MC FADDEN continued

Harry Weber continued, p-61i, 612

MAC FARLAND

D. D. 166

MC FAYDEN

Grant L., 172

MC FREE

George B. , 410

MC GARVEY

Marie, 433

MC GAVERN

H. S., 342

MC GEE

Edwin Miller, 356, 397 $411,414,433,457$. 467

Harry Edwin, 346, 612 John William, 348, 612

Thomas Jonathan, 467

MC GIBBON

F. S., 462

MC GINLEY

Dean Stephen E., 482

MC GIRR

John I. , 428, 612, a.c. a. McGirr, John Ervin

MC GOVERN

Bernard E., 347

H. S. , 339,342

MC GOW AN

James P., 349

Patrick Henry, 146, 147, 346,612

MC GRATH

Benjamin R., p-319, 322, $370,371,430,515,612$

J., 166

Mathew P.. 173

Wilmer D. . 430, 515, 612

MC GRAVEY

Marie Peak, 429

MC GRAW

Frederick A., 612

Harriet Goodman Kurtz, $146,181, \mathrm{p}-181,193$, $194,437,612$

Joseph, 181

MC GRAY

M. E., 476

MC GREEVY

Margaret, 142

MACGREGOR

John R. , 434

MC GREGOR

William, 356, 430

MC GREW

Frederick A. , 424, 468

J. E., 339,342

K. C. , 612, p-612

Kirby Clayton, 612

S, W. , 148

William Raymond, 346 , 612

MC GUIRE

Edward Thomas, 141 , $144,150,462,613$, a. c, a. MsGuire, E. T. Louis David, 307, 338. $346,386,613$, a. c. a. McGuire, Louis B.
MC GLIRE continued

Louis D. (Mrs. ), 380

MACHOI

Herbert L., 170

MC INTYRE

Backus M. , 470, 613

Byron, 470

William, $312,358,613$

MC ISAAC

Fred C. , 346

MACK

Alonzo E., $342,346,386$

Lucinda, 344

MC KAY

Mary A., 171

MAC KAY

ง. H. 122

MC KEAN

James W., 112, 248, 339

MC KECHNTE

N. , 445

MAC KECHNIE

William D., 447, 614, a. c. a. MacKechnie,

MC KEE W. R.; Mackechnie

James L. , 355, 356

Neal Patrick, 431, 504 . 613

MC KEEBY

Fred E., 475

G. E., 475

MC KELLIPS

Ward, 172

MC KENNA

L. F., 267, 330, 332 , $333,339,342,360$, 547

MC KENZIE

George, 467

H. E., 410

R. W. 424

MC KHANN

George Grassel, 359, 613

MC KIBBIN

F. S., 357

Harriet A., 339

MC KIBBON

James Wesley, 427

MC KINLEY

Ethel May, 193, 424

J. C. $147,446,476,541$

Jerome A., 613

MC KINNEY

Edward, p-611, 613

MC KINNON

Artemas I. , 354, 355, 361, 371,614

A. S. , 356

Nellie H. , 171

MC KIRAHAN

J. R. , 430,434

MC KNELLY

William von, 310

MC KNIGHT

Harmon P., 156, 396, 397 $425,429,431,446$, 613 , a.c. a. McKnight, MC LAIN Harnon P.: McKnoght

James J. , 489
MC LANE

Samuel Gerald, 394

MC LAUGHLIN

A. T. , 480

Allie P., 491

James, 73, 339

Mildred M. , 171

MC LEAN

Edward H., 346

James, 430

Robert F., 613

MC LEAY

H. L., 437

Bugh Lawrence, 613

MC LEOD

Fred L., 444

Julius Martin, $314,357,428$

MC MAHON

Charles Gilbert, 372,445 , 538,613

D. B. 444

Edward E. , 346

Emmett, 307, 613, a. c, a. McMahon, E. Emmet

MC MANIZAL

J. M. , 339

MC MANUS

L. W, , 166

MC MARTIN

Charles, p-299, 305, 345. $372,386,613$

Charles (Mrs.). 380

MC MEEKIN

Bugh Ralston, 424, 613

MC MENAMY

J. W., 66, 339, 479-480, a. c.a. McMenarry, J.w.

MC MILLAN

Aaron Manasses, 348, 613

Edward C. , 444

Gilbert A., 394, 613

T. C. 444

MC MLLiN

John H. , 172

MC MULLEN

J. J. 547

Mother M. Agatha, 503

MAC MURPHY

Harriet (Mrs. ), 20-22

MC NALLEY

James M., 613

MC NAMARA

Gerald A., 173

Raym ond B., 410, 435, 613

MC NAUGHT

L. H. . 511

MC NEN

Andrew, 457

MC NULTY

Joseph Frank, 394, 420 , $424,435,437,613$, a, c, a. McNutty, J.F.

MC PHADEN

Archibald C., 410

MC PHERSON

Joseph Burns, 344, 393, 394, 614

MC PHERY

S. P., 425

MAC QUIDDY

Ernest Lynn, 280, 347, 389, 
MAC QUIDDY continued Ernest Lynn cont inued, 390,614

\section{MACRAE}

Donald, Jr., 264-265

Donald, Sr. , 264, 360

MC RAE

Finlay F., 445, p-612, 614

MAC RAE

Gertrude B., 171

MC REA

Edward Lee, 611

MC REYNOLDS

C. F., 437

Claude E., 614

MC SHANE

G., 166

John A. , 242

MC SLAY

James H., 344

MC SWIGART

Henry, 475

MC TAGGART William Bernard, 310

MACUA

F. M. , 339

MAC VEAN

M. Martha, 193, 195 , 199,614 , a. c, a. Mc-

MACY Vean, Martha E.

T. E., 428

MADDEN

John, 543

P. R., 357

MADDLNG

. Henry C., 426

MADISON

Amos B., 346

George L., 433

MAGARET

O. H. , 344

MAGDELENE

Sister, 515

MAGEE

M. J., 5

MAGIERA

Estelle A., 348

MAGILL.

J. L., 446, 466, 467 , p-612, 614

Van Hooper, 426, 615

MAGIRL

Robert F., 615

MAGNUS

Occipitus, 385

MAHAFFEY

Andrew DeWitt, 462, 615

MAIKA

$$
\text { H. F., } 536
$$

MAIKEN

William Henry, 341, 409

MAILLARD

Alfred Edward, 359,

MAIN $p-614,615$

Amos S., 465, 615

MAINARD

E. H., 536

MALCOM
MALCOM continued

Alexander B., 50, 51, 316

MALEE

John Joseph, 348

MALICK

F. A., 444

Uriah H. , 615

MALLOY

Ellsworth Francis, 310

Floyd James, 310

Jnseph Francis, 347

MALOK

Johann, 355

MALONE

Francis F, 358, 444

MALONEY

Edward Stephen, 310

R. S., Sr. , 457

MALSTER

John Charles, 149, 150. 446, p-614, 615

R. M. , 342

MALTER

Alfred, 339

MALZACHER

John Warner, 392

MANARY

Henry C., 357, 467

MANDEL.

Charles, 349

MANG

Lilian, 171

MANGIN

John M. , 341

MANN

Nettie Holden, 342

MANNING

Charles B. , 352, 353, 356

Ernest T., 145, 344, 547, 615

Francis Edgar, 466

MANSFELDE

Alex S. von, 70, p-74, $74-76,149,150,203$ 204, 206-207, 256, 262. $264,319-321,361,368$ $405,461,462$, a. c, a. von Mansefelde

Alex S. von (Mrs.), 75, a. c.a. von Mansefelde

Belle von, 75 Jo von, 75

MANTER

H. W.., 283

MANTOR

Harry L., 345, 358, 411, 512,615

Hugh E., 372, 615

MAPLES

F. A., 396

MARBLE

R. R. . 394

Robert E., 344, 346, 615

MARES

Anna M. . 193, 344, 615

MARGARET

Oswald Henry, 147, 614

MARGOLIN

Morris, 348, 615

MARKLEY

L. R., 266
MARRON

James G., 397, 615, a, c, a. Marran, J. G.

MARROW

Bert E., 445

Charles D., 462

MARSELUS

Henry E., 445

MARSH

Howard, 456, 458

Jesse J. P. , 356

MARSHALL

Alice, 377

C. R., 387

L. T., 166

Mary J., 171

MARSTELLER

Arell Lafayette, 434, 615

F. L., 393

MARTIN

Clement Leon, 348, 396

Edith, 251

Edwin W., 423, 425

Elizabeth, 395

G, E., 442

J. B., $409, p-409$

J. E., 442

James A., 434

James William S., 307, 347, $386,412,547,615$

John K., 288

Josiah Bonaparte, 251, p-409, 615

Otis Wallace, 163, p-163, $280,346,547,615$

Robert S., p-472, 474

Roy David, 393, 411, 615

Selma M., 171

T. S., 458

Thomas Laughlin, 458

W. R., 296, 341,342

William C., 346

William J., 357

William P., 344

MARTYN

David T., Sr. , 87, 446, 615

MARTYN

David T., Jr., 446, 616

MARVEL

George H., 431, 616

Perry Oto, 431, 616, p-617

MASAU

George Edward, 397

MASN

Ernest A., 547

MASON

Bessie P., 193, 447

Claude William, 151, 248, $\mathrm{p}-248,280,347,616$. a. c, a. Mason, Claude M.

George Edward, 359

O. P. , 46

Rufus D., 342, 376

T. J., 424

W. T., 341, 342, 446

Walter E., 547

MASSER

Charles B., 433

MASSEY

T, E., 433 
MASSHART

J. C. , 357

MASTIN

Orville C., 394, 447, 462,475

MATHENY

Earl, 430

Zellmond E., 359, 394 , $397,430,436,616$

MATHERS

A. N., 536

MATHERSON

Angus, 458

MATHEW

Zellmond B., 344

MATHEWS

Alexander L., 124, p-124, $418,420,422,616$

George A., 465

H. L., 444

I. F. 339

John T., 333, 342, 616

MATHEWSON

Harley P., 69, 261, 264, $317,318,321,324$. $325,329,355,374$

MATHIESEN

J. A. . 512

MATOUSEK

William Joseph, 396

MATSON

Daniel, 356

Reuben Carl, 349

MATTHAI

Jacob Henry, 616

Jay H., 524

MATTHEWS Alexander L., p-124, 422

MATTICE

Richard Ira, 339

MATTSON

C., 166

MAUER

Roy Thornell, 616

MAUL

Herman Gustave, 394

MAULICK

N. H. 426

MAXEY

Fred Wasco, 616

MAXSON

John Kinion, 355

MAXWELL

Carolyne E. , 433

Charles H. , 146, 616

Eugene B., 349

James F., 346

James Taliaferrc, 390 , 547,616

T. Meredith, 346

William C. . 3.39

MAYER

Charles F., 616

M. E. . 529

MAYERS

T. J., 357

MAYFIELD

Eugene, 508

MAYHEW

John Mills, 252, 323, $372,374,520$
MEAD

Hamilton, See Meade, Hamilton

Maud, 187, 269

MEADE

Hamilton, 339, 408, a, c, a. Mead, $\mathrm{H}$.

MEADLAR

C. A., See Medlar, C.A.

MEADOWS

James W., 172

MECHAM

Stephen A., 355

MECHAN

John W., 412

MECHTENBERG

William Rudolph, 280

MEDDAR

Clyde A., See Medlar, Clyde A.

MEDDERS

David Albert, 344, 616

David A. (Mrs. ), 380

MEDILL

J. W. , 344

MEDLAR

Clyde A. , 444, 455, 457, $467,513,616$, a. c. a. Meadlar, C. A. : Meadler: Meddar

MEDUNA

Lloyd R., 172

MEEREDITH

Ernest L., See Meredith, Earnest

MEIER

R. L. . 374

MEIKLEJOHN

Pearle, 171

MEINHARDT

Emma T. , 447, 449

MEISENBACH

George W., 433, 616

J. E., $465,616, p-617$

MELCHER

William Benry, 338, 347, 616

MELCHERS

F. W., 342

MELCHIORSEN

William, 346

MELERIAN

Henry, 394, 616

MELGAARD

Bennett A., 395

MELLINGER

F. S. , 547

MELLOR

W. R., 519,520

MELVIN

J. L., 444

MERAGER

O. S. 344

MERCER

Nelson S. , 61, 547, 616 . a. c. a. Mercer, Nelson $\mathrm{H}$.

Samuel David, 33, 59, $60-61, p-60,130,257$, $261-264,270,317,319$. $321,324,325,330,339$,
MERCER continued

Samuel David continued, 342,477

Wilson S., 342

MERCH.ANT

H. A. , 547

MEREDTTH

Earnest Louis, 424, 434, 462 , a.c. a. Meeredith, Ernest L.

George W.. 148, 346, 359, 462

MERRIAM

L. A. , 321, 329-331, 333 , $334,337,339,342,360$, 374,480

Sidney Addison, 96, 346

MERRII I

C. S., 341

S. , 339

MERRTT T

Edythe D. , 516

MERRIWEATHER

Charles N. , 394

MERR YMAN

T. J. . 356

MESCROPIAN

Messiah, $346,358,411$.

a. c.a. Mesraprian, M.

MESSENGER

H. E., 341

METHANY

S., See Metheny, S.

METHENY

Fred Ray, 359, 616

Harry Bohn, 359, 464

Samuel, 357, 358, 367, 617, a.c.a. Methany, S.

METTLEN

James Harvey, 435, 617, a. c. a. Mettlin, J, H.

METSINGER

J. J., See Metzinger, J.J.

METZ

Phillip H. , 342, 446

METZNNGER

George R., 390

John J., 423, 425, 617 a, c, a, Metsinger

MEYER

Carl A., 346

Julian Erdreich, 446, 617

Max, 101

MEYERS

F. A., 339

J. T., 390

Thomas L., 131

MICEK

Joseph F., 172

MICHAEL

Luther, 420

Mary Mills, 355, 394

MICHALAK

Joseph John, 349, 617

MICHEL

Alfred, 446

MICHELS

Nicholas A, 304-306, p-304 MICK

W. B. , 376

MICKEY 


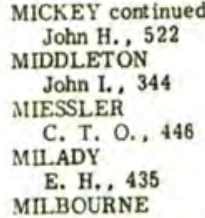

Percy Elmore, 359, 434, 467, a. c. a, Milbourn, P. E.

MILEN

Theodore, 344, 358, $414,433,434,445$. 462

MIL.IARD

Alfred, 484

Anna, 382

Ezra, 45

Mary, 104

MILLBERC

L. M. , 166

MILLEN

S. C. H., 342

W. M. , 342

MILLENER

Frederick H., 238-239, $p=238,346$

MILLER

A. J., 337, 341

Allen F. , 410

Arthur Lewis, 411, 437. $468,518,617$

Aura Jonas, 280, 283. $284,338,349,617$. a. c. a. Miller, Aura

D. : Miller, Aura James

Bradford Walter, 617

Brownlow P., 391

C. E., 166

C. L., 166

Clint on James, 468, 530-

$531, p-530,617$

D. E. (Mrs.), 288

D. H., 288

D. W. 358

Earl Edgar, 348, 390. 410 , a.c.a. Miller, Earle E.

Ernest E. . 617

Erwin Phelps, 347

F. W. , 385

George L. , 32, p-43, 43$46,48,50,51,55,66$. $70,144,147,315,316$, $324,325,484$, a, c. a. Maller, G, F.

George W. , 408

Glen, 280

Glenn Henry, 346, 617

Harold Baughman, 122 , $314,357,396,617$

Harry C. , 346, 357, 372. $547,617, p-617$

Harry C. (Mrs.) 380

Henry Gratton, 339, 426

Herman R. , 462

Hilma C. Swanson, 193

Hjalmer R. , 342

Irving, 346
MILLER cont inued

Jacob M. , 394, 434

James A., 498

James E., 344, 518-520

James P., 344

James T., 445

James W.., 418, 422, 433 , 618

Jay C, , 339, 476, 618

Joseph H., 464, 618

Leonard N. , 344

Lorin, 43

Lucins V., 346

Maggie E., 209

R. N. . 357

Robert C., 394

Robert Glen, 437

Ruben Lewis, 339

Samuel S., 402-403

Thomas D., 433

Uda M., 518

Walter Charles, 426, 427, 618

William K., 396

MIL.LHOUSE

John H. . 424

MILLIGAN

Arthur Augustus, 428

MILLIKEN

Charles, 357, 468

William, 357, 429, 430, 464

MILLS

Bernard I. , 426, 618

E. H. Birch (Mrs. ), 187

George M., 187

MILNER

George S., 339

MILNES

G. S., 333, 342, a. c. a. Milnes, Geo, J.

MILROY

William Forsyth, 95, 100 , $106,203,217-218$, $\mathrm{p}=217,250,257,267$, $272,280,322,331-334$, $337,342,360,361$. 373,480

William F. (Mrs. ), 380 MINER

H. E., 462

Henry Rufus, 151, 411, $450,457,458,513$, 618

J. M. , 475

MINGUS

Forest Mae, 467, 475 . a. c.a. Mingus, Forrest M.

MINIKUS

Edward, 173

MINKLER

James Delzon, 427, 433

MINNICK

Clarence, 426, 442, 447 . $510,531,618$, a.c. a. Minnich, C.S.

MINTER

R. M. 424

MINTHORN

Mart in Lloyd, 347, 389 ,
MINTHORN cont inued

Martin Lloyd continued, 618 MINTON

Edward W. , 362, 394

MISKO

George Harold, 359, 381 , $389,423,618$

MITCHEL

Leopold (Lt. Col.), 168

MITCHELL

Albert Roscoe, 204, 320 , $321,349-353,354,355$, 359,371

Charlotte Ann, 349

Edwin Joseph, 395, 463, 464, 536,618

Elizabeth, 87

G. N. 396

Robert S. , 475

Thomas Edward (Major), 87

William Frank, 445, 537 。 618

MLASKA

L. J., 547

MNUK

Frank J., 348, 618

MOATES

Guy Hart, 348, 390

MOCKETT

Percy C. , 411, 437, 618

MOELL

Joseph Franklin, 359, 445 , 467,618

\section{MOELLER}

Christian, 428

MOFFATT

Francis J. , 466

MOFFET

Villa Gatley, 343, 344

MOHR

Lauisa (Mrs.). 339

MOHUN

Meade, 349

MOKLER

V. A, 429

MOLSEED

Clarence S. , 306, 307, 346 . 386,618

MOLZAHN

Albert J. . 618

Edward T., 618

MONAU

Lawrence, 395

MONEL.I.

Gilbert C. , 33, 52-55, p-54, $60,144,150,317,321$. 324,325

MONGTOMERY

W. P., See Montgomery, W. $P$.

MONOLLEY

E. H., 387

MONROE

Byron F., 342, 469

Henry P., 475

MONT EITH

Robert, 263, 265

MONTGOMERY

Asa Witter, 456-458, 513, 618 
MONTGOMERY continued

Charles F. 342

Enoch A. , 433

John R., 437, 441, 447, 464

Kathleen, 435

William P. , 358, 428, 618 , a.c.a. Mont gomMOODY ery, W. P.

Edith J., 383

James W. , 433

Willson Bridges, 280 . 348,618, a. c, a.

MOOMAW Moody, Wilson B.

Leon A., 311

MOON

Charles Franklin, 281, $346,547,619$

Louis Edwin, 306, 307, MOORE $346,372,547,619$

C. R., See Moore, Richard Channing

Cleland G., p-149, 150 , $345,423,425,619$

Clyde J., See Moore, John Clyde

Clyde Newton, 373, 424, $434,436,463,464$, 619

Clyde (Mrs. ), 380

Dudley A., 619

Edwin A., 341, 446 , a.c. a. Moore, Edwin B.

Emily J., 519, 520

Frances A. (Mrs.), 478

George F., 425

Harris Carrahan, 359

John Clyde, 110, 170. $203,281,339,345$

547,619 , a. c. a.

Moore, Clyde J.

John E., 346, 396, 397

John L. , 424

John W. 462

J. V., 386

Joseph C. . 96, 110, 112 , 342, 619

Milan Standish, 156. $p-318,322,437,468$, 619, a.c. a. Moore, Miles Standish

Orville Milton, 85,86 , $\mathrm{p}-86,90,476,541$. 619

Prentice Laurie, 344, $357,430,433,619$

Richard Channing, 58-59, p-59, 112, 144, 154, 257, 261-264, 268, $270,319-321,324$, $325,329,330,332$, $333,336,337,339$, $342,361,374$, a.c. a. Moore, C. R.

Robert E., 519, 520

Russell L., 355, 356

Sarah Woll, 183
MOORE continued

Servet us V., 33, 85-86, $p-85,148,152$

T. V., 387

William Elijah, 47, 434

W. F., 341

William Alexander, 411. 464,619

MOOREHEAD

Harold B. , 346

MORAN

Clarence S., 310

MORANVILLE

Calvin F., 118, 396, 473, 475

C. T. 475

James W., 118, 425, 475

MOREFIELD

Albert, 394, 447

MOREHOUSE

Eli M., 410

MORELAND

John J. , 394

MORELOCK

Josephine, 357

MOREY

Claris B., 173

MORGAN

Bertha E. . 437

Clifford Veryl, 281

Donal Hobart, 390,447 , 619 , a.c. a. Morgan, Donald $\mathrm{H}$.

Sidnar, 357

W. , 3, 5, 7

MORGUER

D. Omar, 339

MORGULIS

Sergius, 281, 283, 289, $\mathrm{p}-28 \mathrm{~s}$

MORLAN

Clarence H. , 346

MORLARTY

James Timothy, 348

MORLARITY

Pierre C., 342

MORILI

E. L. See Morrill, E. L.

MORISETTE

Mayo G. , 171

MORISON

Charles C. , 344

MORITZ

John R., 288, 389

MORNING

J. F., 462

MORRAN

Anna, 539

MORRELL.

Ralph Marcellus, 357. 619

MORRILL

E. L., 384, 385, a. c. a. Morill, E. L.

J. E., 358

Walter L. , 427, 433, 144

William LeRoy, 619

MORRIS

A. B., 344, 358,397

Claudius H., 418-422

Don Frank, 355, 423, 428 ,
MORRIS continued

Don Frank continued, 619

E. H. , 389, 390

Frank S., 476, 619

George E., 172

George Henry, 146, 423, $446,528,619,620$ 。 p-620, a. c.a. Morriss, G. H.

Homer D., 467

J. Russell, 452, 456

Minor, 396,504

Russell, 457, 458

Stephen S. L. . 355

U. H. 428

Willis G. , 428, 464

MORRISON

Arlo A. , 288, 389

George A. , 476, 620, p-620

H. M. 458

Harold F., 359

J. F., 160

Milton, 462

MORRISS

George H. , See Morris, G. H.

MORROW

Bert, 465

Carl William, 427, 445, 620

Frank Henry, 370, 371, 391, $392,446,620$

Hamilton N. , 362, 423, 620

John H. , 421, 422, 424, 620

Joseph, 465, 536, 620

Lawrence, 435, 620

Milton, 357

Samuel, 467

T. N. 423

Wren, 409, 435, a. c, a. Morrow, Uren

W. N. 397

MORSE

Esther M. 288

Marie B. , 193, 199, 620

R. H., 414

MORSMAN

Leslie W. . 344

MORTLOCK

J. S, 425,470

MORTON

G. M. , 410

Herschel Burdette, 349, 620

J. Serling, 91, 399, 527

Robert B. , 342, 462

MOSENA

James M. , 475

MOSER

Reuben Allyn, 281, 283, 346 , 547,620

Moskovitz

Julius M. , 348

MOSS

Arthur Bryant, 358, 620

Elizabeth A., 433

MOSSER

Charles B. , 467

MOSSES

E. Neff, 342

MOSSEY

T. E. , 431

MOSSHART 
MOSSHART continued

C. J. 427

Joseph C. , 467

MOSSMAN

Seth, 435

Thomas M., 288

MOSTELLER

Edward C., 410, 434, 444,458 , a.c. a.

Mostelles, E. C.

MOTE

John O'Herbin, 355, 428

MOULINERE

Father, 526

MOUNSEY

J. C. 387

MOUNTFORD

Forrest Alton, 468, 620

MOWER

Thomas G., 2, 4, 5, 7, $9,11-10,153,477$

MOWERY

Charles R., 387

MOYER

Charles C., 314, 357

Ralph Emerson, 435, 463

Torrence Calvin, 520, 521, 620

MOYLAN

Joseph, 173

MOZEE

Benjamin B., 355

William T., 355, 359, $394,427,429,433$

MUCK

William H., 344

MUDDING

H. C., 357

MUELLER

Hanns Bernhard, 359 , p-620, 621, a.c. a. Mueller, Hans B.

MUIR

Daniel H. , 352, 353, 355

G., 166

James G. , 41 0, 465, p-621, 621

Leonard, 621

MUIRHEAD

A. L., 141, 207, 225$226, \mathrm{p}-225,300,301$, $344,396,397,442$, 470

A. L. (Mrs, ), 378

MUKEL.

George Earl, 432

MULDOON

J. V., 547

John Kennedy, 306, 308, $386,621, \mathrm{p}-621$

MULHOLLAND

Edward J., 347

MULLEN

Clifford John, 348

R. B. 408

R. W., 424

Thomas Robert, 344, 621

MULLER

Carl, 434

Herman R., 475

Otto Von, 341, 434,
MULLER continued

Oto Von continued, a.c. a. Muller, Von Otto

MULLIGAN

Arthur M. , 288

Harold Rowe, 393, 394 , 621

MULLIKIN

Doyle Beard, 468, 621

MULLIN

R. B., See Mullins, R. B. Richard Francis, 621

MULLINAX Clay Eli, 393, 394, 431 MULLINS

C. L. $31,141,156,268$, $322,368,369,414-$ 417, $\mathrm{p}-416,420-422$

Reuben B., 424, 425, 464, $621, \mathrm{p}-621$, a. c. a. Mullin, R. B.

MULLONG

Charles Robert, 435, 528 , 621

E. G. , 528

MULMANE

Orin Everett, 355

MUNCH

Otto L., 349

MUNFORD

William B., 425

MUNGER

Alfred C., 172

Arbor Day, 354, 359, 371 , $520,522,621$

C. Herbert, 431, 444

Irvia Clarence, 359,433 , 520,621

MUNK

Eric, 342

George Wesley, 467

MUNRO

Henry S., 345, 359, 394 , 411,429

MUNSELL.

Elmore Y., 457

L. S., 457

MUNSON

Elizabeth B, K., 193

Herbert O. , 345, 445

MUNTER

Craig Wilson, 348

MURDOCH

Russell John, 150, 470, 621 , a. c. a. Murdock, R. J.

MURDOCK

Edgar Paul, 396, 423

Harry M. , 349

P.. 504

R. J., See Murdoch, R. J.

MURPHY

Archibald, 397

Bradford J., 347

Charles Middleton, 349, 621

F. L., 430

Francis Paul, 339, 346

Frank Patrick, p-299, 306$307,386,547,622$, a.c. a Murphy, Francís. P.
MURPHY continued

Frank P. (Mrs. ), 380

Harry J., 306, 386

Howard R., 249, 313, 424, 427,447

J. C. M., 414

James Orville, 359, 622 , p-622, a, c, a. Murphy. James Orvil

John B. , 351

John Harry, 346, 547, 622 . p-622

John Harry (Mrs, ), 380

Lew Paul, 446

Louise, 144

Rex Leo, 424

Thomas J., 349

William Keon, 310

William M. , 345

MURRAY

Bthel, 171

F. X. 339

Floyd Joshua, 281, 346 , 622

Ralph Whitman, 433

MUSGRAVE

Rhoda U. , 288

MUSKIN

Nathan, 347, 547, 622, p-622

MÜSSER

Urías S., 467

MYERS

Benjam in L. , 345

Evans M. , 357

Henry Dey, 622, p-623

Joha Tennyson, 281, 283, 396,547

L. E., 446, 547

Lille (Mrs. ), 492

Lloyd, 622

Thomas L., 85

William Alfred, 358

William F., 355

MYLAR

Wilber K. 437

N.

NAF FZIGER

Armand, 470

NAGELMANN

C. Bernard, 410

NAIl

Frank Edgar, 622

NALTY

Walter Cyril, 348

NANCE

Albinus, 85

NARNSDALL

J. W. , 366

NASON

William Christopher, 344, 622

NASSTROM

Anna C., 171

NAUGHTIN

Patricia L., 172

NAULTENS

Alfred F., 430, 475, a. c. a. Naultens, Alfred A.

NAULTEUS 
NAULTEUS cont inued Francis, 394, 433

NEAL

B. E., $344,425,445$

Florence, 270

George H., 450, 457

Halbert F., 444

John D. , 172

John F., 444

Will T., 344, 444, 622

NEEDHAM

Charles Thayr. 346, 431

NEEF

C. , 425

NEELY

Abner D. , 596, 622, a. c. a. Neeley, Abner John G. . 433, 470, 471

John Marshall I, 126 127, $p-127,462,521$, 622

John Marshall II, 126 127, p-127, 359, 409 John Marshall III, 126, p-127

Joseph, 126-127, p-127

NEFP

C. . 426,446

Enoch, 344, 397, 411. $414,425,433,434$, 437, 444, 464, a.c. a. Neff, Erroch

NEIGH

John Wesley, 429

NEIL

Wiliam, 458

NEILL

Charles Wells, 623

S. H. O., 475

NEILSON

Amelia, 339

Arthur L., 346

NEISUS

Frank Anthony, 232, 310

NELSEN

H. A., 547

NELSON

Carl D. , 358, 435

Cedric Henry, 348

Charles, 341

Frank Arleigh, 348, 453 , $457,459,513,623$

Fred A., 344

Jesse W., 173

John Price, 356

Lloyd L., 438, 623

P. A., 495

William Harry, 156, 445, 623

William Newton, 349, 623 , $p-623$

NEMEC

Charles J., 305, 344, 623

NEMZEK

William Peter B., 348

NESBIT

Andrew D., 321, 397

NESLUND

John W, 623

NETHARTON

S. O., 475
NETTLETON

J. H. , 426, +37

NEUHAUS

George Emil, 307, 347, $373,547,623$

George Emil (Mrs.), 380

NEUMANN

Ernest V.. 435, 624

NEUMARKER

William Richard Carl, 446,623

NEVILLE

Dennis, 412, 445, 623

J. William, 465, 623

Joseph, 96, 146, 267, $329,333,339,342$. 374

NEVISON

Vida, 384

NEWBECKER

Minerva M., 193, 198 , $199,342,357,468$, a, c. a. Newbecker M. Minerva

NEWCOM

Floyd Leskey, 470

NEWCOMB

Arthur P., 172

NEWELL

C. Homer, 395

Charles Harold, 345, 624

Charles Harold (Mrs.). 380

Harry J., 467, 624

Henry J., 46 ?

NEWHAUS

G. B., p-299

NEWHOUSE

Marshall B., 353, 356

NEWK IRK

A. B. , 449, 450, 456, 457

Adamson B., Jr, , 457

Howard R., 394

NEWMAN

James K., 624

Jefferson Clarence, 436, 628

John Russell, 435

Julius M. , 173

Som, 491

NEWQUIST

Melvin Nathaniel, 348 435,624

NEWSOME

W. W., 427

NEWTON

George Henry, 433, 624 NICE

Benjamin, 339

NICHELSON

Frank Salter, 624, p-625

NICHOLAS

Dr., 55

Alfted, 531, 532

NHCHOLS

Arthur L. , 475

Charles L., 342

Edwin, Jr., 464, 536, 624

G. L, $339,341,342$

George W., 470
SICHOLS cont inued

Harry Carl, 430, 431, 465 , 624, a.c. a. Nichols,

Henry C.

Robert, 346, 624

William Thomas, 356

NICHOLSON

Clyde Gordon, 172, 348

George P. , 347

J. J., 166

Martha, 17

NICKEL

Mable A., 428

NICKERSON

E. J., 339

John E. , 42 ?

NICF.UM

Oliver Clarke, 347, 465, p-623, 524

NICOI

John Harvey, 444

NICOLA

Benjamin Eugent, 359, 510

NICOLL

Surgeon Mate, 8, 15

NIEDERST

Richard H., 346

NIEHALS

Frederick Wilhelm, 281, 346 , 547, 524, a. c. a. Niehaus, Friedrich W.; Niehans, Freiderich W.

NIELSEN

Juul Christian, 349, 624

Marie Anna, 193, 344, 470, 624, a, c. a. Nielson, Marie

Morris, p-318, 322, 323, $362,410,470,624$, a. c. a. Nielson, Morris

NIELSON

Marie See Nielsen, Marie Morris Sce Nielsen, Morrib NIEMAN

Gustave, 425, 434, 470

NIGRO

Dominie M. , 346

NI-KU-M!

$1,7,20-24, p-21$

NILLSSON

J. R. See Nilsson, J. R.

NII SON

Nils G. . 172

NII.SSON

Gustav N. , 288

John Rudolph, 170, 255, 281. $344,372,390,625$, a. c. a. Nilisson, J. R.

NITTLER

W. 168

NOBL

Lucian L., 42B, 625, a, c, a. Noble, Lucien NOB

Roy Cecil, 146, 429, 508, 625

Amon Thatcher, 355

NOL.AN

Thomas J., 425

William Joseph, 346, 431, 625

William J. (Mrs, ), 380

NOON

Joseph Edward, 339

NOONAN

Eugene F., 306, 386, 437 , 
NOONAN continued

Eugene $\mathrm{F}$. cont inued, 547, 625, a. c. a. Noonan, Eugent

NORALL.

Burton T., 424

NORCROSS

Jasper P. . 87, 125, 350, 355 , a.c. a. Norcross, Jaspar

NORDELL

E. B. 166

NORDSTROM

S. G. , 339

NORDWALL

C. Olaf H. 345

NORGARD

R., 166

NORLANDER

H. , 166

NORMAN

Eugene F., 346

NORRIS

George H. , 429

Henry, 531

Urban H. , 265, 396, 408 , 444,458

W. H., 446

NORTH

Zeno N. . 348

NORTHCROSS

Stephen Buchanan, 346, 625

NORTHMAN

Edward W., 409

YORTON

Charlotte Moore, 182-183, $\mathrm{p}-183,187,352,355$, 356

Christine Hazel, 183

Christopher, 183

NOVAK

Charles E. . 453, 457, $458,513,539,625$

F. J. 369

William Fred, 625, p-625 NOWERS

Walter E. , 393, 394, 625 NOWICKIGE

L. A. , 433

NOWICKIYO

Andrezeja, 356

NOY

M. J. , 515

NOYES

William W. . 625

NUNN

Richard, 339

NUSBAUM

David H. , 344

NUTTING

Will Wallace, 346

NUTZMAN

Charles L., 349

NYE

Frank Hoyt, 362, 394, 625

Mark Alva, 345, 462, 625 NYSTROM

Harry R., 173

J. Oscar, 344 o.

OAKS

Charles A., 427, 625 . p-625

Charles W., 435, 445, 447

OAKES

C. M. Jr. 349

OBERG

O. H. 166

OBERLIES

L. C. 508

OBERMAN

Arthur E., 410, 467

O'BRIEN

Donald James, 348, 625

Edward James, 310

Thomas J., 349

OCHILTREE

H. M. 433

O'CONNELL

John Thomas, 431, 387

James (Rev.), 294

James M., 146, 625

John L., 172

O'CONNER

Wm. Ed. , See O'Connor, Wm. E.

O'CONNOR

Claire Addison, 349

D. Edward, 146,626

H. K. , 344

James JoBeph, 387

Jeremiah A., 410

Thomas P. . 346, 356

William Edward, 346, 626, a. c, a. O'Conner, Wm. E.

ODEGAARD

Ethel, 383

ODELL

Charles M. . 339

ODILIA

Sister, 526

O'DONNELL

Hugh Joseph, 431

OFFERMAN

Arthur James, 307, 346. 626

OFFERSON

Kristine, 342

O'GORMAN

Daniel D, , 356

O'HAVER

Paul C. . 444

O'HEARN

John Joseph, 307, 347 . 626

OHLENSCHLAEYER

M. . 341

O'KEEFE

J. . 362

M. G. , 388

O'KEY

A. E., 444

O'LEARY

Arthur J. , 339, 356

J. J. , 166

O'LINN

D. H. , 319

OLIVER

Edward B., 397, 428,
OLIVER cont inued

Edward B. continued, 435. $458,466,470$

Margaret E., 171

OLNEY

Robert Charles, 359, 521. 626

OLSEN

Charles Northfield, 435

David G. 434

OLSON

Axel E. . 495-496

David G. , 357, 445

Fred, 173

Justus E., See Olsson, Justus E.

Lilly, 171

Ole, $358,521,626$, a.c. a. Olson, Olle

Stanley O. , 173

OLSSON

Justus Edgar, 170, 626 a. c. a, Olson, J. E.

O'MALLEY

Mollie, 171

O'NEAL

Oren, 357

O'NEIL

Owen S., 349, 414, 415, 433, a. c. a. O'Nelll, Owen; Oneil

O'NEILI

H. S. , 531

Mary, 381

Owen. See O'Neil, Owen

Raymond Thomas, 310

Silverton Hollingsworth, 394 , $468,473,626$, a. c, a.

O'Neill, Sylverston; O'Neill, Silverst on

OPPERMANN

Adolph, 444

O'RIELLY

Robert, 344

O'ROURKE

Joseph Leo, 349

M. J. , 341

Paul Vincent, 349

ORR

Alice C., 274, 339

Hiram Winnett, 156, 161, 206 -

207. p-206, 246, 322, 354.

$357,370,371,373,374$,

$385,519,520,523,524$

William G. , 470

ORTMAN

OSA

John Wessel, 348

Oran C. , 411

OSBORN

Francis M., 430

OSBORNE

Prank, 429, 508

OSHEROFF

Samuel A., 147, 346, 476 , 531,626, a.c. a. Osherhoff

OST ERHOLM

Albin N., 495, 496

OSTERT AG

Frank S., 173 


\section{OSTLING}

Evert Harwood, 429, 626, a. c. a. Ostling. Everett

O'SULLIVAN

Eva F., 172

Kathleen, See Sullivan, H. Kathleen O'Connor

Margaret J., 547

O'TOOLE

T. F, 387

OTOUPALIK

Hugo M., 172

OTTERBOURG

M. A. 430

OV ERGAARD

Anders P., 322, 337, $\mathrm{p}-337,346,362,425$. 547,626 , a. c, a. Overgaard, Andrew P.

Anders P. (Mrs. ), 378, 380

OVERHOLT

F., 342

OVERMASS

Samuel Edward, 468, 626

OVERTON

Ralph V., 433, 435

OVIATT

C. W. , 475

James C. Willam, 355. 467

OWEN

Charles Austin, Jr., 626

Donald R., 114, 346, 547, 626

Frank Styles, 95, 114 , $258,281,288, \mathrm{p}-320$. $322,323,333,342$, $372,492,547,627$, a.c.a. Owen, Frank Stiles

Leonard Joseph, 359, 627

OWENE

Margaret (Mrs.). 493

OWENS

Charles Austin, 281, 348 , 547

OWINGS

C. T. 395,475

OXFORD

Charles, 342, 414, 425

Edwin F., 425, 432, 627. a. c. a. Oxford, Edwynn

\section{P.}

PACE

Ira A., 473, 474, 475. p-626, 627, a. c. a. Pace, Ira $\mathrm{T}$.

Jerome G. , 359, 411, 427

Jerome Van H, 347

PACKARD
F. A., 516
L. R., 385
William, 408, 464

PACKER

John McKinley, 462, p-626, 627

PACKWOOD
PACKWOOD cont inued

William Ernest, 427, 627

PADDLEFORD

James F., 345, 397

PADDOCK

James A. , 428

PADEN

$$
\text { Frank A., 410, } 627
$$

PAGE

Clifford Seeley, 627

Walter T., 483

PAGELER

J. H. , 341

PAGELSEN

M. Emily, 340

PAGLER

J. H. , 340

PAINE

Bartlett Lewis, 353, 364

Jesse Lee, 424

PAINTER

Hettie Kersey, 202, 355

Lorene, 193, 198, 199. 201,359 , a.c. a.

Painter, Jeorene;

Painter, Lenore

PALLETT

William H., p-626, 627 . R. c, a, Pallet, W. H.

PALMATEER

Homer R. , 347, 442, 627

PALMER

Charles Edward, 371

Claud E., 146, 511, 627

Daniel S., 445, 627

Hiram R., 358, 424, 465

King Paige, 147, 446, 627

Romain H., 468

W. A. , 408

William H. , 469

PAMPEL

Byron L. , 428

PANGLE

G. W. , 340

PANKAU

Joseph Bernard, 349, 394, 437

PANTEP

Judson C. , 339

Robert Carpenter, 147 . 170,627

Samuel Goodall, 151, 359 459, p-459, 468, 627

PAPE

Eugene William, 349

PARCELL

George H. , 342

W. , 450

PARCHEN

Henry William, 344, 395 .

PARDUM $425,435,457,469,47$

John R., 475

PARIZEK

Frank Joseph, 424

PARK

B. F., 344

Durward Belmont, 346

E. M. , 342

PARKER

Arthur A., 329, 330, 332,
PARKER cont inued

Arthur A. continued, 333 . $339,342,374$

Charles T, 356

David W. , 173

Garner F., 465

John A., 47, 344

Joseph S., 547

Stephen Thomas, 347

PARKINSON

George H. , 426

PARKS

Albert L., 345, 627, a. c. a. Park5. Tilbert L.

Charles William, 358, 627

Durard B., 170

J. J., 166

Tilbert, See Parks, Albert

PARSELI.

George H. , 339, 364, 365

PARSONS

Antony, 151, 248, 338, 346. 425, 627, a.c. a. Parsons. Anthony

Forest l.ee, 396

John Wesley, 341, 342, 627

William H., 340

PASS

Moses D., 344, 436, 468, 627

PATEE

H. E., 340

PATRICK

P. F., 457

PATTEN

J. L. See Patton, J. L.

PATTERSON

Chester L., 172

Edwin S., 428

Franklin, 425, 432

Frederick B., 425

H. C. , 166

Harriet, 143

PATTON

David H. R., 344

J. C. 458

J. L., 411, 428, 433, 446, 475, a. c. a. Patten, J. L.

James McDowell, 104, 115, $170,213,216, \mathrm{p}-216,281$. 283, 337, 346, 371, 372, 543,628

James McDowell (Mrs, ). 380 Paul H. . 221

PATTY

John B., 458

Marion B., 424, 428, 628

PAUGH

George R. W. , 356

PAXTON

Charles Camren, 429, 442, 62 z

Green C. . 166, 450, 451, $453,457,458$

PAYNE

Walter S., 395, 462

William N. 173

PAYNTER

Chas. W. M. , See Poynter. Charles

Horace M. , 341

PEABODY 
PEABODY cont inued John Dent, 58, 212, 296 , 333,339

James H., 55, 56-58, $\mathrm{p}-57,59,79,130,154$ $212,261,296,317-318$, $321,324,330,332,337$, $339,360,361$

James H. (Mrs. ). 57

PEACE

Charles P. 173

PEARCE

Francis J. , 433

PEARSON

Emmet Albert, 392

Orlando, 341

William H. , 394, 465

PEASE

Bert Charles, 384, 437, 628

PECK

Edward Porter, 34, 52

George William, 341, 342

James Porter, 32-33, 34 , $\mathrm{p}-51,50-52,55,59$, $144,212,261,316$, $318-319,321,324$, 325,339

PECKHAM

Anna P., 344

PEDERSEN

Andrew Meyer, 445, 628

Hans Christian, 628

Peter M. , 628

PEEBLER

Ora Fay, 348, 628, a. c.a. Peebler, Ara F.

PEEBLES

G. Hial, 203, 263, 264, $268,321,353,356$

PEERY

Matt, 448

PEIER

Aaron S. 359

PEIRCE

Carleton Barnhart, 281, 349 , a. c. a. Pierce. C. B.

PELIKAN

Charles Carl, 288

Edward Robert, 397

PELLETTIERE

E. Victor, 310

PELLS

Edna Smith, 193, p-202, 430,628

PENDELI

George D. , 628

PENDRY

A. S. , 469

PENFOLD

H. J. , 203

PENNER

Henry G. , 433, 628

Louis Edward, 429, 433, 628

PENNEY

Myron, 434

PENNINGTON

George E, 424, 628

James Lewis, 147, 395 ,
PENNINGTON continued James Lewis cont inued, $424,428,431,468$, 628, $\mathrm{p}-629$

W. R. , 424

PEPPERS

Aust in W., 444

PERKINS

Clark (Mrs.), 144

PERCIVAL

John A., 462

Joseph P., 460

PERKINS

M. A. 394,411

Philip M. , 344

PERKY

J. F., 184

Lenore, See Webster. Lenore

PERLEE

B. S., 423

Byron L., 425, 470

PERRIN

E., 186

PERRY

Dane, 434

Warren, 433

PERSON

Syl, 466

William H. , 466

PEST AL

Joseph, 424, 462

PETE

Francis, 344

PETER

Robert, 355

PETERS

A. T. , 391

Claude Ferdinand, 348

Glen Elmo, 435, 628

John Arthur, 628

Matilda Katherine, 274

Roy Elliott, 157, 429, 628

William Robert, 170,362 . 438,466

PETERSEN

Alvin A., 173

Fmil Car1, 281, 348, 629, a, c, a. Peterson, E. C. Fred, 499

J. C. See Peterson, J.C.

\section{PETERSON}

Alfred Olaf, 342, 374, $628, \mathrm{p}-629$

Arthur E, 288

Carrie M., 508

Emil Carl, See Petersen. Emil C.

Hans, 446

John Chaney, 288, 389 , a. c.a. Petersen, J.C.

LeRoy Thermon, 453, 459

Magnus Christian, 349. 629

Mahlon Bluford, 446

Marcus Albin, 435

N. J., 495

Royal F., 173

T. P., 166

Theodore A., 424, 446. $629, \mathrm{p}-629$
PETERSON continued

Victor E. , 172

W. A., 394

William C. , 476, 629

PETITT

Marshall, 395, 396, 397。 $410,424,426,464$

PETR

Francis, 433

PETTENGILL

Somers, 469

PETTIT

Roswell T., 370

H. W. , 340

PEYTON

Wade Hamilton, 348,629

PFEIFFER

PHAR

W. W. , 9

PHELAN

Leopold, 341, 430, 515, 629

PHII BRICK

Guy Sterling, 346

Inez Celia, 183, 188-189, p-188, $190,193,194$, $199-201,354,356,523$, 524,629

PHILERICK

G. C. , 387

PHILIPS

A. B., 475

PHILIPSON

J. A. 358

PHIL.LIPS

Clark L., 629

Fredericka A., 470

Frieda A., 270

Herbert Lester, 349

Isaac H. , 455, 462, 468

Robert Alan, 349

W. B, 387

W. H. , 344,470

Warren M. 447

PHILLIPSEN

J. A., 411, 468

PHIPOT

Cory Allen, 433

PHILPOTT

C. H. , 338

PHINNEY

Julian E., 355, 465

PICKARD

Vida, 381

PICKENS

Edgar A. , 359

PICKETT

A. M. , 428, $433,458,467$, 475

C. L, , 433, 458

Cyrus, $395,421,422$

Ira N. , 427, 629

J. J., $421,422,442$

W. E. 344

PICOTTE

Caryl, 26

Henry, 1, 26

Pierre, 26

Susan (also LaFlesche, PIEL 
PIEL cont inued

W. A. , 543

PIEPER

Sophia, 498

PIERCE

Albert L. , 344

Albert S., 394

Alman N. , 428

Carleton, See Peirce, Carleton

Chauncy Merrill, 629

Chester A., 394

Floyd, 394

Roscoe P. . 427, 629

Russell K., 173

W. L. , 397

PIERSOL

Marcus Rice, 430, 629

PIERSOLL

T. J. , 394

PIERSON

Clarence A., 412, 414,

PIKE 509,629

Frank, 344

PILGER

Walter Herman, 629

PILLSBURY

Donald Marion, 349, 629

PILSBURY

Lawrence B. , 357, 391

\section{PINCKNEY}

Charles Edward, 346, 424, $468,531,630$; a. c. a. Pinkney, C. E.

PINK ERTON

\section{F. C. 384}

Jane Wheeler (Mrs, ), 492

W. J., $344,436,462$

PINKNEY

C. E., See Pinckney. Charles E.

PINNEY

C. H. , 60, p-60, 145 , 262,324

George LeRoy, 393, 394, 630

PINTO

Alva Sherman, 75, 97,

$144,145,147,156$,

$160-161, \mathrm{p}-160,302$, $304,336,344,501$

A. S. (Mrs.), 378, 380

PIPER

Edward Fiffin, 355

PITTMAN

C. W. , 430

PITTOCK

Harry J., 393, 394

PITTS

James D., 467

Sollis Oscar, 430, 434. 442, p-629, 630, a. c. a. Pitts, Solles C.; Pitts,

PITZER Sollis C.

\section{E. , 540}

William H. , 527

PIUS

Sister M. . 525

PIXLEY

W. A. , 221
PLANK

Joseph Raymond, 310

William, 427, 447

PLATT

Otis Russell, 437, 630

Owen D. , 433

PLATZ

Ada, 193, 194, p-194, $199,200,358,429$. 508,630

Charles H. , 374, 446, 463

PLEHN

Frank Wallace, 143, p-143.

PLOOF

$178,463,464,536,630$

Julius, 408

PLUMB

James Norris, 147, 476, 630

POE

Caswell T., 430

POGUE

George A., 355

POINTS

J. J. , 93

POL.ANSKY

Bess, 171

POLCAR

Joseph, 491

POLK

Lurt on Franklin, 355, 630

POLLACK

Fredolph A., 630

POLLARD

Charles Whitney, p-278, $281,283,342,382$ $391,392,543,630$

Julian A. , 409, 458

POMERENE

L. W. (Mrs.), 523

POPE

Max Robert, 435

POPPLETON

A. J., 46

A. J. (Mrs.), $₫ 78$

PORT ER

Bowen, 340, 408

C. W. 431

E. J. , 344, 424, 430 , 436 , a. c. a. Jorter. E. J.

Elmer R., 342, 630

Horace P. . 457

S. Dale, 387

POSKA

Abraham, 357

POSPISIEL

Joseph, 344

POTTER

A. A., 395

George Benjamin, 281, 345,630

Harry Evan, 146, p-319, $322,323,424,432$, 433,630

Laird L. , 172

POTTER

A. A. , 394, 396, 397 . $410,412,414,424-$ $428,430,431,433-$ $437,444-447,458$ 。
POTTERF cont inued $462,464-468,470,475$

POTTS-LONGSHORE

Anna M. , 342, 356, 357. $425,428,430$, a. c. a. Potts, Anna Mary S. Potts, Anna $\mathrm{M}$. L.

POTTS

Franklin, 340

J. W. 340

John Beekman, 104, 170 , p-170, 217, 28i, 345 . $372,389,630$

Madje J., 193, 424

POULSON

P. W. 364,366

PCWELI

Ernest Willard, 254, p-254, $256,342,362,543,630$

E. Willard (Mrs.), 380

George B. , 436

Lupher A. , 429, 433, 467, 631

Lyle Stephenson, 349

Milt on J. . 433, 631

R. D. , 166

Ward Hughes, 434, 631

POWELS

Ena, 344

POWERS

Francis Irving, 349, 631

POYNTER

William A., 260

Charles William McCorkle, $7,207,242,260,281$ $283,357,374,389$. PRATT 631, a. c. a. Paynter

G. G., 414

George Peyton, 223-224, 281 , $283,284,289,338,346$. 373,631 , a. c. a. Pratt, Goorge C.

Willard Munson, 392, 631

PREMER

James Frederick, 146, 425, 447,631

PRENDERGAST

James F., 344, 631

PRENTICE

George M. , 411

PRENTISS

H. J. , 391

PRESCOTT

Kenneth Eugene, 288, 392

PRESNELL

J. Will, 410

James Frederick, 331, 333. 340,631 , a. c.a. Presnell J. I.

Norval Eddy, 409

PRESSON

Butler, 428

PREST

John, 424, 631

PRESTON

Robert Louis, 288

Sylvester Atkinson, 146, 362. $414,425,440-441,631$, p- 632

Sylvester A. (Mrs.). 378

PRETTYMAN 
PRETTYMAN continued Charles W. , 433, 458 PRICE

Charles Ramsey, 348 Harry Mervin, 355, 427 PRICHARD

George Winthrop, 281 , $344,391,392,631$, a. c. a. Pritchard, G. W.

George Winthrop (Mrs.). 380

Harry, 414

PRICHETT

G. S., 466

PRIES

Rudolph F. , 342

PRIEST

Paul Herbert, 348, 465. 631

Wendell H. , 465

PRIMASING

Raym ond J., 349

PRINCE

Norman Call, 346, 631

PRINGLE

George Wilson, 358

PRINTY

Josephine, 458

PRITCHARD

G. W., See Prichard, G. W.

PRITCHETT

G. L., 432, 433

PROCHAZKA

Emil, $42 B$

PROCTOR

Is abel, 359

PROTZMAN

C. A. 357

Charles E., 631

Thomas Blair, 392

William, 352, 355, 356 , a. c. a. Proutzman, W.

PROUDFOOT

Charles P. , 428

PROUTY

Edgar L., 173

S. B., 344

PROUTZMAN

William, See Protzman, W.

PROVENCHER

Norbert, 340

PRUNER

Ambler Caskie, 346 , $469, \mathrm{p}-469,632$

William H. , Sr. , 469, $\mathrm{p}-469,470$

William H. , Jr., 150 , $344,469, p-469,632$ William H. (Mrs.), 380 PUGH

Elizabeth, 171

George F., 446

PUGSLEY

George William, 345 . $464,536,632$, a. c, a. PLHEK Puglsey, G. W.

George Julius, 410, 428,

\section{PUHEK cont inued}

George Julius continued, 430 , a. c. a. Punek, Géo. Julian

George J., 340

PULVE

John E. , 345

PULVER

John Earle, 632

PURCUPILE

Benjamin H. , 173

PURDUM

E. F., 426

PURINGER

Albert, 430

PURIS

Abram M., 346

PURNELL

W. W, 342

PURVIANCE

Walter Charles, 429, 447, 632

PUTMAN

F. L., 388

Lynn J., 346, 425, 632, a. c. a. Putnam, L. J.

Seymour, 342, 356, 394

PUTNAM

Lynn J., See Putman,

PUTT Lynn J.

Dr., 510

William F., 446

William T. , 358, 394, 411 , PYLE 430 , a.c. a. Putt, W. M. T.

Bert W., 288

\section{Q.}

QUEEN

Wesley, 355, 356, 395 , 411,425 , a. c. a. Queen, QUICK Wesely

Mary S., 174, 457

QUIGLEY

Daniel Thomas, 222, 243, p-243, 281, 370, 372 $435,436,499,632$

Daniel T. (Mrs.). 380

Willard Henry, 346, 632

QUINBY

S. J., 342

QUINCY

Fred B. , 396

Mary A. (Mrs. ), 187, 193, $198,269,461,462$

QUINN

John H. , 427, 632

QUINTEN

John F., 434

QUIRK

Howard William, 459, 632

QUIST

Esther, 171

QUIVEY

M. B., 536
RAAPKE

Henry (Mrs.), 68

RABEN

Emil, 444

RABER

Donald D. , 345

RABKIN

Irving, 348

RACE

William F., 342, 357, 395 . $397,414,424,425,430$, $432,433,437,442,465$. 468,470 , a. c. a. Race, William $\mathrm{T}$.

RACINES

Juan Y., 250, 442, 632, p-632

RAEMER

Mrs., 539

R.AFTER

Martin B. , 340

RAGAN

E. S. , 465

Seth Elisworth, 632

RAINES

Robert F., 427, 475

RAINEY

James M. , 342

RAINS

G. D. , 166

RALPH

John B. , 95, 108, 144, 145 . $330,332,340,342$

Roy, 108

RALSTON

Adda Wiley, 196, 201, a. c. a. Ralston, Ada W.

Furman Paul, 349

Roy Raymond, 281

William Wilson, 355

RAMALEY

L. Guy, 409, 428, 433, 458, 467 , a. c. a. Ramaly, S, Guy: Ramaly, A. L. Guy;

RAMEY Ramalay, L. Guy

Walter Newman, 357, 358,

RAMOS 428,632

Frank, 173

RAMSEY

Andrew Jackson, 344, 505 . 632

Wuliam H., 344

RANCE

William Thomas, 307, 347 , 386,632

RAND

Silas Charles, 464

RANDALL

Dr. 510

Andrew LaRoy, 633

George W. , 427, 433, 458, 467

Hiram L., 449-450, 457

H. R. , 340

Maxin, 340

S. J., 347

RANKIN

Charles G. , 433

RANSOM

Frank T., 272, 335 
RANSOM continued

Penn W., 342, a, c. a, Rasnom, Penn W.

RARRITZ

Sol E., 347

RASCK

Alfred G, , 397, 633

RASGORSHEK

Robert H., 288

RASMUSSEN

Henry A., 346

Nelson H., 147, 346, 463, $464,536,632, p-632$

V. 1., 166

RASNOM

Penn W., See Ransom, Penn W.

\section{RATER}

David Leo, 348

RATHBUN

Clarence A., 434

G. H. : 425

RATHBURN

I. , 433

RATHKE

Carl A. , 172

RAVER

Charles A., 470

RAVITZ

Sol E., 281, 633

RAWLINS

John Windsor, 402, p-402

RAWSON

$$
\text { C. L., } 499
$$

RAY

Adam R., 411

Napoleon B. , 475, 458,

\section{RAYMOND}

Alfred, 333,340 , a. c. a. Reymond, Alfred

E. A., 340

RAYNOR

Wilis J.. 430, 444, 510 . 633

\section{RAZEE}

S. R., 426

REA

Benjamin, 394, 397, 428, $433,444,465,467$, 470,475

W. D., $394,411,424$, $427,430,434,436$, 445,447

\section{READ}

Francis Thomas, 458

N. C. (Miss), 25

Paul Stowell, 349, 633

READY

Frank Lane, 410

REAGAN

Seth C. . 467

REBERT

Michael A. , 330, 333. 342

REDELFS

Lommert H. , 172

REDELLS

John W., 173

REDFIELD

Josiah Beckley, 147, 252 , $436,530, \mathrm{p}-530,633$
REDFIELD continued

Willis J., p-156, 347, $430,436,633, \mathrm{p}-634$

\section{REDMAN}

Harden B. , 428, 458, a. c. a. Redman, Hardin

\section{REDMOND}

Franklin H. , 424

Henry, 458

REED

Caroline, 467

David James, 433

David W. 357

Eleanor Capitola, 187 . $193,400, \mathrm{p}-401,402$. 444

Elmer Burkett, 349, 521 , 633

Eva A., 357

Francis B., 319, 398, 400 . p-401, 402

Hugh S. , 474, 475, 633

J., 166

James Erwin, 355

Orville Clint on, 394,424 464,633 , a. с, a. Reed, Orvill C.

Paul Ancil, 348, 468, 633

Purl Elmer, 349

Roland Ray, 147, 447, 525. 526,633

Sanford P., 173

Sanley Goodrich, 346, 633, a, c, a, Reed, Stanily G.

Thomas A., 342, 470

Wilson Herbert, 633

REEDER

Grant Simpson, 147, 425, 633

William Jeremiah, 348, 633

REES

Henrietta, 239

REESE

Alfred I., 173

Sidney Cber, Jr., 359, 520 . 633

REEVES

Albert E., 514

Alfred E., 358, 412, 633

Arthur, 475

G. S., 434

George 1. , 358, 633, 654

Labon P., 340

W. C. , 332

REEVIS

William C., 340

REGAN

John H. , 430

M. R. 470

REICHENBACH

H. A. 389

REICBST ADT

REID

Emil, 347, 634

David J., 427

John Dick, 362, 397, 466 , 634

REIHART

Oliver F., 346

REILLY

Charles J., 429
REILLY cont inued John Victor, $430,515,634$

REIIS

Edwin August, 348, 397, 634, p-634

REINSCH

Ernest Robert, 348, 390

RELLER

William Edward, 340

REMILLARD

Louis 0,173

REMY

Charles E., 121, 397

George Oliver, p-35, 34-37. $41-42,121,240-241,396$. 397,634

RENEKER

George Wirt, 451, 456, 457 . $458,513,634$

RENNER

F., 317

RENNY

Charles E., 344

RENWICK

Robert W., 342

RETTENMAIER

Albert J. , 349

RETZER

Robert, p-299, 300

REUS

John, 173

REUTTER

Garfield A. , 458

REX

L. E., 384

REYMOND

Alfred, See Raymond, Alfred REYNISH

David J., 411

REYNOLDS

Bertha, 200

C. C. 357

Crandall A. , 166, 321, 634, a. c. a. Reynblds, C.O. :

Reynolds, C. J.

Ezra E. , 408, 428, 433

H. J., 166

M. F., 466

Nathan Oyler, 358

O. C., 314,321

Robert Wayne, 358, 634

William T., 467

RHODE

Margaret W., 344

RHODES

Clara, 381, 508

Frank V., 173

L. G., 353,356

Mae, 374

R. H. , 408

RICE

Allen F., 447

Allen T., 428, 444, 475, 634

Chilton S., 634

Clarence Edward, 347, 429, 634

Grove: Cleveland, 433, 634

Moses Raymond, 345, 634

Rose H. , 344

William Jackson, 78 
RICH continued

Charles O'Neill, 282, 344, $372,386,635$

Josephine Agnes, 340

Lewis P. , 433

Max L., 412, 414, 424 , $430,433,434,442$. 465,634

Riley Gilbert, 635

\section{RICHARDS}

Benjamin Franklin, 635

Carl E., 467

Dickinson C., 347

G. B. 362

James, 341, 344

Roy Chariton, 635

RICH ARDSON

$$
\text { C. T. } 344
$$

Delmar D. 344

Ira Frederick, 425, 635

Louis, 341, 342, 466 , 635

Lyman, 66

N. S. . 55

O. D., 162

Sidney J. , 436, 635

RICHETTS

M. O., 340

RICHMOND

$$
\text { S. W. , } 408
$$

RICK

$$
\text { L., } 433
$$

RICKARD

Wesley Grant, 358, 521, 635

RICKETTS

M. O., 333

RIDDELL

Cecilia B., 358

RIDDILE

J. P., See Riddle, J.P.

RIDELL

Ted Eugene, 156, 348 . 463, 464, 536, p-634, 635, a. c, a. Riddell,

RIDDLE Ted Eugent

Joseph P. , 394, 430, a. c. a. Riddile, J.P. RIDER

Roscoe Conklin, 347

Eugene Edwin, 359, 445, 521,635

Harry Dewey, 635

Larry Dewey, 359

RIEBE

P. (Mrs.), 341

RIES

Christian, 340

RIETH

George Raymond, 347 . RIGG 635

James Paul, 288, 392

RIGGERT

Leonard O. , 170, 847

RIGGS

Ira L. , 374

Robert M., 427

RIGHTER

Frederick B., 266, 355,
RIGHTER continued

Frederick B. cont inued,

a. c. a. Righter, B. F.

\section{RIGHTMIRE}

George, 427

RIIS

C. , 333

RILEY

Andrew W. . 111, 112 , $\mathrm{p}-112,296,300,331$, $333,340,342$

Bryan Michael, p-299, $301,305,344,373$, 386,635

Lincoln, 166, 412, 414, 635

R. P., 186

Wilber Kirk, 412, 414, 635

RINEHART

Jacob S., 447

RING

Hogan J., 430

RINGWALT

Theodore (Mrs.), 482, 483

RIPPERTON

Aust in Edgar, 437

RIPPEY

$$
\text { I. N. . 59, 323, } 324
$$

RIS

$$
\text { Josefa, } 340
$$

RISER

Frederic L. , 356, 396

RITCHIE

William, 483

RiX

Rudolph, 302, 344, 386, 635

Rudolph (Mrs, ). 380

RIZK

Joseph Joseph, 359

ROARK

George L.. 349, 635

ROBB

Howard H., 173

H. M. , 166

ROBBINS

Ermma E. , 394, 468

Ida, 519,520

Leonard H. , 317-319, 321, $350,351,352,355$,

ROBERT

M. A. 340

ROBERTON

Wulliam, See Robertson, William

\section{ROBERTS}

Douglas H. , 357, 635

George, 434

Harry W. . 173

J. G. 394

Jack, 173

Palmer W., 444

ROBERT SON

A. E., 424,465

Arthur Thomas, 397, 635

Edward U., 344

George Edwin, 349, 536, 635

James (Mrs. ), 403

Lucretia, 50

Reuben L., 342
ROBERTSON continued

Richard, 173

William McC., 147, 425, 445 , 636 , a. c. a. Roberton, W. ROBINSON

A., 166

Adrian M. , 310

Alex Van Grant, 408, 428

Amy R., 193, 357, 394

Byron E., 422

C. M. , 430

Charles A., 470

Charles O., 344, 425

Emmett L. . 395, 442, 636

F. , 166

J. W., 475

L. Sidney B., 359, 517

Louis Luster, 349

Ole E., 447

Raymond E., 435

Reuben, 114,342

Richard F. , 345, 397, 470

W. Clark, 344, 442

W. S. , 296

ROBY

Imogen L., , 270

$\mathrm{ROCHE}$

Riley Edward, 146, 147, 411 , $437,511,636$

ROCK

Andrew V., 387

ROCKWELL

Orville, 358

RODGERS

Clarence Edwin, 636

Floyd Lessilie, See Rogers, Floyd Leslie

W. O.. 333, 340, 342

ROE

G. L., $146,427,428,508$, 636 , a. c, a. Roe, George Lowny; Roe, George Leroy John W. , 340, 342

ROEDEI

John C. , 173

ROEDER

Augustus A. , 52-53, p-53, $59,144,147,270,317$, 324, a, c. a. Roeder, August

Clyde Auguatus, 53, p-53, $270,282,283,284,317$, $345,372,375,430,492$, 636

George, 52, 53, p-53, 270 , 430

Gustav, 53

H. T. (Mrs.), 518

Julius A. , 52-53, 270, 342 ROEMER

C. O., 340

ROGERS

A. J. , 475

Clarence J., 359

Daniel R. , p-634, 636

Eva M. . 171

F. E. 389

Floyd Leslie, 359, 520, 521 , 636 , a. c. a. Rodgers. Floyd Lesslie

H. Stanley, 346 
ROGERS continued

Herbert M. (Mrs. ), 382$383, p-383$

John B. ., 434

ROGGENSEES

Anna L., 171

$\mathrm{ROH}$

C. F. , 433

ROHLFF

E. L.. 344

Oscar B., 172

ROHLFING

Celina, 507

ROHRBACH

Mother M. Theresa, 504

ROHRING

Fred (Mrs.), 77, 192

ROHWER

Roland T., 348

ROLLINS

G. E. , 475

ROLPH

Caroline LaM., 397

Edward L. , 146, 411. 437,636

\section{ROMINE}

James Perry, 357, 433

ROMIUR

James P., 414

ROMM

Abranam, 344, 636

ROMONEK

Phillip, 282, 348, 636 , p-636, a. c. a. Romonek,

RONDOT Philip

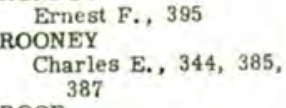

ROOP

John Valentine, 427

Josiah, 427

ROOT

Allen D., 24, 459

Anson L., 131, 312, 405-406

Benjamin A. , 430, 476 , 636

Charles Henry, 147, 636 , p-636

Henry D. , 408

Joseph Cullen, 349

Ralph R. , 173

Russell Dayton, 424

ROPER

Kenneth Lawrence, 348 RORK

Lee Wallace, 363,393 , $394,427,433,636$, p-636, a. c. a. Rorke, L. W.

ROSAT

Lena Marguerite, 185-186, $\mathrm{p}-186,193,197,200$, $201,358,637$, a. c. a. ROSE Rosat, Lina

\section{F. W. 394}

Leo Dow, 347, 390

Robert William, 310
ROSE cont inued

W. C., 340

Wallace E., 517, 637

ROSEN

Robert, 227

ROSENBERG

Frank J., 637

Jacob, 342

Mary Elizabeth, 199, 270. ' 942

ROSENBLADT

Fritz, 348, 498

ROSENSTEEL

H. W. , 357

ROSENSTEIN

J. (Mrs. ), 491

ROSENTHAL

George W., 342

ROSEWATER

Charles, 95, 105, p-105. $296,332,333,340$, 342,492

Edward, 60, 105

ROSICKY

Rose, 34

ROSS

A. G. . 536

Arthur James, Jr., 347, 464,637

Collin Henry, 347, 637

George W., 340

Grant J., 355, 408, 428

L. Phil, 397

William Lytle, Jr., 331, $347,376, p-376,637$

William Lytle, Sr., 333. $340,342,376, p-376$, 637

ROSSMAN

Orion, 508

ROTH

Rollin G. . 637

ROUNDS

Lorenzo, 444

ROUSE

H. 166

ROUSH

Arza J. , 467

ROWE

Edward W. , 135, 142-144

$151,170,257, \mathrm{p}-317$.

$322,355,358,430$.

$521,522,637$

Edward W. (Mrs.). 377

J. P, 373,374

ROWLAND

Charles, 301

ROWLEY

L. B. 349

ROYAL

Paul A. , 359, 637

ROYCE

W. T. , 430

ROZELL

Jennie B. . 433

RUBELMAN

George J., 146, 433, 637 , RUBEN

a. c.a. Rubelmann, G.J.

Henry John, 355

RUBENDALL.
RLBENDALL continued

Clarence, 114, 282, 344, 358,637

Clarence (Mrs.), 377

RUBLN

Lewis A., 173

RUBNITZ

Abraham S., 282, 347, 637

RUDAT

Emma H. , 171

RUDLOFF

Francis X. . p-636, 637 RUEL

H. J., 352,356 , a. c. a. Rueb, H. J.

RUESINC

Joseph, 540

RUMERY

Arthur C. , 418, 424, a. c. a. Rummery, A. C.

RUNDLE

Walter Gustavus, 431, 637

RUNDSTROM

David A. , 436, 637

RUNNER

Frank F. , 340

RUNTY

Harvey Daniel, 392

RUNYAN

Mabel A. , 359

Nellie A. , 427

RUPERT

Willam H. , 358, 427

RUPP

Benjam in D. , 462

RUSCHE

Carl F., 347, 348

RUSH

Charles Henderson, 358 , $450,458,637$

Weaver Aldus, 429, 638,

RUSK p-639

Helen, 384

RUSL.AND

Muriel, 171

RUSSELL

Ralph Swisher, 349, 638 RUSSUM

Benjamin Carl, 232, 304, $305,338,346,386,387$. 638 , a.c.a. Russum, Carl Benjamin Carl (Mrs.), 380 RUTH

Gordon A. , 173

RUTH ERFORD

Charles, 173

W. G, 340

RUZIKA

D. J., 344,425 , a. c. a.

RYALL Ruzuka, D. J.

RYAN

Almon James, 469

Martin Joseph, 348

McDonald, 427, 447, 638

R. C. 166

Ralph M. , 410, 446

Will is J. R., 344

RYDBERG 
RYDBERG cont inued Charles A. , 465, 638

RYDER

Frank Dell, 147, 346 $397,430,515,638$

RYERSON

Edward Ramah, 358, 638

Edwin R. , 358, 433, 521

RYMAN

Eugene Miles, 344, 359, 411

\section{S.}

SABIN

Alexander C., Jr, , 345, $394,395,396,397$. $410,424,425,427$. $434,435,442,466$

Alexander C. , 355, 394, $412,414,426,428$, $431,434,436,444$. $445,446,462,467$, 468,475 , a. c. a. Sabine; Sabin, Alexander $A$.

Almer Lee, 356, 410 , $414,425,428,430$, 435, 444-446, 458, $466,467,470$, a. c. a. Sabina, A. L.

Clarence W. , 288, 390

Margaret Loomis, 187 . 193,355

SABINA

Almer L., See Sabin, Almer $\mathrm{L}$.

SACHS

Adolph, 301, 303, p-303 $305,337,345,373$, 386,638

Adolph (Mrs. ), 379, p-379, 380

SACKETT

C. C. 410

SADILEK

Olga, 190

SADLER

W. W., 424, 425, 437

William M. , 638

SAFFOLD

Benjam in W., 343

SAFFORD

William G. , 357

SAGE

Almond B. , 430

Earl Cuddington, 282. $334,337,347,361$.

SATKI $372,544,638$

Arthur K., 288

SALIBURY

F. Scott, See Salisbury, F. S.

SALIN

Edith M. , 381

SALISBURY

Frederick Scott, 429 , 533 , a. c. a. Salibury, F. S,

George R., 408
SALLEN

William A., 431

SALTER

Frank George, 147, 438, 529, 638, p-639

Peter Harold, 126, 249, $321,361,362,370$,

SALVIE $372,529,638$

A. C. , 410

SAMMONS

S. A., 414, 464, 470

SAMPLE

Joseph R. . 347, 394, 411,638

Thomas E. , 347, 437, 638

SAMSON

Charles, 397, 423

Frank Edgar, 457

SAMUEL

J. B., 457

SAMUELSON

P., 166

SANDERS

A. J., 394, 422, 425, $430,442,446,462$, $p-639$

Guy, 166

John Aloyisus, 638

John W., 427

Samuel F., 445

SANDERSON

David Douglas, 359, 475. 639

SANDMAN

Elizabeth H. , 171, 508

SANDS

Robert Lyman, 347, 433. 468, 639

SANDUSKY

William, 465, 639

SAPERT

Ernest, 431

SAPP

Clinton E., 343

SAPPINGTON James C. . 435

SARPY

Peter, 21-23, 46, 78

SASSADY

S. A. , 436

SATTERFIEID

Cornelius E., 343, 433

SAUER

Leslie Earl, 173, 348 , 639 , a. c, a. Sauer, Lesslie E.

SAUNDERS

A. J., 444

Frank B. , 172

Alvin, 49

Jno, A. 347

SAUP

J. , 166

SAVAGE

E. P. 155

James W., 262

SAVIDGE

M. , 166

SAVILLE

F. F., 340
SAVILLE continued

Frank N., 395, 639

J. J. , 97, 145, 146, 213 343

SAWYER

A. H. , 340

Lizzie White, 187, 411

Roy H., 146, 357, 639

SAXENBERGER

Leopold F., 365, 428, 430, 444,457 , a. c. a. Saxenburger, L. F.; Saxenberger, F.

SAYLES

David McCoy, 429, 468, a. c. a. Saylee, D. M.

\section{SAYLOR}

Harvey Wesley, 467, 539. $\mathrm{p}-639$

SAYRE

Charles Edward, 632

SCALLON

P. J., 430

SCANLAN

William, 340

SCANLON

G. C. 387

SCHAFER

Leander Herman, 349

Louis A., 343

Millard Franklin, 468, 639

SCHALEK

Alfred, 242, 282, 639

SCHALLER

Frank W., 347

SCHANM

Lydia L., 347

SCHATA

Karl D, 172

SCHAUFELBERGER

Franklin, 393, 394

Frederick J., 394, 639, p-641, a, c, a, Schauffelberger, F.

SCHAUM

Lydia, 193

SCHEIDEGGFR

Elvin Franklin, 282, 348 , 639 , a. c. a. Scheideggar, E.

SCHEIOT

J., 166

SCHEMEL

H. K. , 340

Karl, See Schiemel, Karl

SCHENK

Cyrenins, 475

SCHERER

Frederick, 340

Luther D., 437

SCHETTLER

G. O. , 343

SCHIEMEL

Karl, 414, 425, 470, a. c. a. Schemel, K.

SCHIL.DKNECHT

William H., 400, 401, p-401, 406

SCHILLER

A. E., 370

SCHINDEL

C. M. , 343 
SCHINDEL continued

Roscoe E., 640

SCHIRMER

E. W. 444

SCHIVEDHELM

Albert J. , 435

SCHLANK

Charles (Mrs. ), 491

SCHLEIER

Frank J. , 305, 345, 386 , 640

SCHLOSSER

Cecil T., 173

SCHLOTT ERLEACH

Peter $W,, 458$

SCHLUMBERGER

Pierre Rhyner, 395, 640

SCHMIDT

Hyacynthum, 408

Mathilda Maria, 270

Roas (Mrs, ), 341

SCHMIT T

Henry J. , 173

SCHM TTTROTH

V. J., 166

SCHMITZ

William Howard, 307 . 640

William Howard (Mrs.), 380

SCHNECKENBURGER

E. 340

SCHNEIDER

Albert Leo, 640

G. , 166

SCHNELLER

E.. $410,444,462,467$. 470

$\mathrm{SCHOCH}$

Andrew Clarence, 396. 437,640 , a. c. a. Schock, A. C.

SCHOFIELD

H. B., 437

SCHOOLING

H. Guy, 429

SCHOWENGERDT

Frank Theodore, 429 , $640, p-641$

SCHRECK

W. A., 445

SCHROCK

Joseph Benson, 424, 463. $464,536,640, \mathrm{p}-641$

Robert D. , 108, 282, 347, 640

SCHROEDER

Ralph Leonard, 282, 390

SCHR UMPF

Ottilie, 512

SCHUDDER

Royal, 468

SCHUELKE

Emma, 541

SCHUELLER

E., 344, 395

SCHULKE

Julius, 409

SCHULTE

Hermann von Wechlinger, $252,290,291, p-291$.
SCHCLTE continued

Hermann von Wechlinger continued, 293, 300, $301,305,338,640$

SCHULTZ

Herman H., 412, 640

SCHUNK

Clara Margaret, 193, 394

H. P., 475

SCHURMAN

Alma L., , 171

SCHWEDHELM

Albert Joseph, 348, 640

SCHWERTLEY

Frederick J, , 307, 347, 386,640

SCOFIELD

A. E. , 362

Henry B., 640

SCOINS

William Harold, 348,640 , a. c.a. Scoins, William Sarold

SCONCE

Ethel M. , 171

SCOTT

Frank Waldo, 345, 640

James Andrew, 355, 396

L. M. , 340

Martin, 5

Michael J., 345, 386

W. R., 396

SCRUGGS

S. , 470

S. J., 394, 411, 470

SCUDDER

Charles R. , 173

SEALEY

Henry Jeptha, 348, 392

SEAMAN

Charles O., 410

Warren L., 428

SEARCH

James W. , 265, 340, 343

SEARCY

George Harris, 358

SEARLES

Aust in D. , 343

Frank L., 342, 357

Libbie McNerny, 270, 345,357 , a, c. a. Searles,

SEARS Libbie McMerny

Edgar A., 397, 640

H. That cher, 341

John L., 424, 468

S. 166

SEASONGOOD

Edward R. , 396, 640

Robert R. , 396, 641

SECLOR

F. P., 448

SECORD

Dixie C. , 641

SECREST

John Farley, 458

SEDLACEK

Bretislav, 348, 390, a.c. a. Sedlacek, Bretislaw

Frederick A., 147, 162 , $252,345,641$
SEDWICK

William A., 343

SEECK

Elfrieda L., 171

SEELY

Henry Hamblin, 411, 641, a.c.a. Seeley, H.H.

SEEMAX:

W. O., $3+5$

SEEVERS

C. T. . +14

SEIP

William H. , 356

SEISON

W. P. , 166

SEITZEK

J., 166

SEIVER

Charlotte Pollcck, 193, 195 p-195, 200, 425, 641. a. c. a. Siever, C. ; Sevier, C. P.

SELBI

Claude A., $250,322,436$, 641

SELLMEIER

Bernard L., 143, 310, a. c, a. Sellmeyed, B. L.

SELLON

George 1. . 424

SENG

George E., 358, 429, 641

Omer 1. 390

SEVERE

Columbus Delano, 430,434

SEVERIN

Matthew Joseph, 348, 641

SEVIER

Charlotte, See Seiver.

Charlotte

SEWARD

Guy, 397, 423, 641

SEXON

Mattie, 88

SEXTON

Thomas C. $423,425,469$, 641 , a.c.a. Sexton. Thos. G.

SEIBERT

Frank T. , 345, 386

SEYMOLR

Horatio, 45

James H., 32, 48, 49, 50, $\mathrm{p}-50,55,147,148,154$

SHAEFEER

L. A. . $3 \pm 0$

SHAFER

George J. , 465

SHAFFER

C. P., 458

George H. , 344

Theodore L., 170

SHANAHAN

Edrm ond F., 345

SHANEYFELI

Kathryn (Mrs. ), 505

SHANK

Frederick William, 359, 426 , 641

John W. , 480

SHANNON 
SHANNON cont inued

W. C. (Mrs.), 482, 483

SHAPERE

A. D. , 447

SHARP

Charles Arthur, 410

SHAW

Alfred Jackson, 355

B. F., 343

C. E. (Mrs.) , 538

J. S. 266

Lawrence Matt, 147, 207, $321,446,642$

William Waring, 449, 456, 457

Wiliam John, 348

SHAWLEY

W. T. 437

SHAYLER

Ernest V., 482

SHEARBURN

Edwin Webster, 433, 642

SHEARER

William Lete, 224-225, $\mathrm{p}-224,254,282,347$ $370,372,375,380$

Waliam L. (Mrs.). 378, 380

SHEEH Y

Toseph P. 347

SHEETS

Charles Elmer, 395

Charles Henry, 347, 424, 642

SHEIBLEY

Anna L., 171

SHELDON

Addison E. . 3, 3

Edward L., 475

H. P. , 463

J. M. 389

SHELDON-BIT NER

Mary Josephine, 193. 464,642

SHELLECK

C. W., 475

SHELLEY

B. T. $33,48,50,315$

Benneville Y., 434

H. A., 340

SHELLHORN

B. F., 444

SHELTON

Herbert P. , 464

SHEPARD

C. J. , 343

C. S., 394, 444, 475

a. c. a. Sheppard, C.S. ; Shephard, C. S.

Charles Angell, 642

Charles Carter, 147, 468, $642, a, c, a$. Shepherd, C. C.

John C., See Shepherd, John

S. Julta, 171

W. B. , See Shepherd, W, B.

SHEPHARD

C. S., See Shepard, C. S.
SHEPHERD

C. C, See Shepard, Charles C.

John C. , 451, 457, 458, 513,642 , a. c, a. Shepard, J. C.

J. S., 457

J. T. 448

William, 434, 451, 457, 513,642 , a. c. a. Shepard, W. B.

SHEPMAN

Alfred, 343

SHEPPARD

C. S., See Shepard, C. S.

SHEF

Philip, 345, p-641, 642

SHERER

Robert R., 475

SHERFEY

Car1 Wagner, 359, 642

SHERIDAN

Allen V., 395, 424

SHERMAN

Edward M. , 357

Rollin G. 173

Warren H. , 357. 428, 433. 458

SHERRADEN

W. H. , 543

SHERRIL.L

J. E. , 433

SHERWOOD

Ephriam, 340, 342

R. G. , 347

SHIDLER

George P., 90, 541

George W.., 90

SHIELDS

Jacob S., 445

Will iam D. , 347, 356, 445

SHIKE

William Ear1, 147, 441, $463,464,536,642$, p-643

SHILLINGTON

Maurice A., 347

SHIPHERD

T. M. . 518

SHIPLEY

H. McGregor, 347

SHIPMAN

Alfred, $340,407,425$. $434,442,444$

SHIREY

Ralph W., 173, 348

SHIRLEY

H. B. , 468

SHIRMER

E. William, 457

SHIVELY

Jay Daw, 358

SHIVELEY

Eva M., See Shivley, Eva $M$.

Virginia, 193

SHIVLEY

Eva McGee, 189, 193, 358, a. c. a. Shively, Emma McG.; Shiveley

SHOCKEY
SHOCKEY cont inued

B. M. , 430

SHOEMAKER

Charles Alonzo, 356, 358 , 518,642

George P., 427

O. P. , 411

SHOFF

Franklin, 434

Oscar F. , 434

SHOOK

Anna M. . 536

Charles F., 347

Willam Edward, 151, 255 $444,451,456-458,513$, 642

SHORTS

Philip R. 340

SHOULAIN

Francis Edgar, 348

SHOUSE

Edwin, 347

SHOW ENGERDT

Frank Theodore, 640

SHRAMEK

Charles John, 349, 642

Joseph M., 305, 642, p-643

SHRECK

William A., 445, 642, p-643 SHRIMP

A, J. , 394

SHRIVER

F. M. , 341

J. M. 340

Michael E., 424

SHULL

Harrison 1., 444

Henry B. , 433

SIBBALD

George, 424

SIBBERNSEN

Albert (Mrs. ), 303

SIBERTS

Paul R., 436

SICKINGER

Charles E. , 173

SIDLES

H. F. (Mrs.), 351

SIDWELL

Lawrence T., 359, 394, 429، $508,517,642$

SIEVER

Charlotte, See Seiver, Charlotte

SIFTON

James W. , 396

SIGAFOOS

James Frank, 345

SIGEL

Charles H. , 343, 425, 462

SIGGINS

Ernest L., 340, 343, 408, 478

John Jacob, 341, 356

SIGLER

Charles H. , 356

Marion I., 429

SILVER

Charles C. , 445

SIMAN

Paul F, , 471 
SIMAN cont inued

Victor Lamont, 471, 541, $643, a, c, a$. Simon, V. L.

SIMANEK

Edward J., 173

George F., 301, 303, 305, $338,345,372,642$

\section{SIMECEK}

Joseph, 642

SIMMONS

B. B., 447

Charles H., 357

Eugene Earl, 282, 347, 643

George H. , 187, 188 , 204-206, p-204, 210 , $349,352,354,355$

Jacob, 425

Margaret E., 187, 188 , $206,353,356,357$

SIMMS

John S., 170, 436

SIMON

Abram, 491

Frank, 397, 425, 442 , 643

Lincoln G., 437

Victor Lamont, See Siman, Victor

SIMONS

Devilo P., 447

Levi A., 340, 343

SIMONSON

Jacob, 355

Lafe, 532

SIMPSON

Bryant Robert, 429

John Emerson, 345, 643

Surgeon Josiah, 16

S. R., 341

SLMS

Charlie A, Starr, 427

Florence P., 394

George P., 349

Lesslie B., 394

SINAMARK

Andrew, 425

SINCLAIR

Frank P. , 301

Isaac P., 340, 345, 355 , 357, 408, 446

SINGER

Harold D., 345, 386 , a.c.a. Singer, Harold T.

SIRCA

Dionisie Mathew, 349

SISSAKIAN

Avedis H., 250, 435, 643, SISSON p -643 , a. c. a. Sissikian

W. H. H. , 66,364

William J., 427

SITZER

George D., 408, $412,425$. $428,430,467$, a. c. a.

SIVERS Sitzen, G, D.

SIXT A
SLXT A continued Lew is Henry, 643

SKEEN

Earl D. , 345

SKELTON

Harry Alexander, 396

SKIDMORE

Clarence E., 467

Sylvester D. , 355, 356 , a.c. a. Skidmore, S.S. SKINNER

Almeron O. , 358, 426. 429,643

Leander Z., 411

SLABAUGH

Warner H. , 331, 337, 340 , 343

SLAGLE

Charles Eyster, 146, 370 . $371,396,503, p=503$, 504,643

SLATTERY

Peter A., 462

William B. . 357, 643

SLEDGE

-.- 166

SLEEPER

Lawrence Edward, 396, 643

SLIMMER

Abraham, 492

SLORN

Arthur N. , 410

William T., 357, 411, 429, 643

SLOCUMB

M. G. , 345

SLOMAN

Edward E. , 114-115, 333. 340,342

SLOMINSKI

Ladislaus, 340,356 , a.c. a. Slomanski, L. ; Slomiuski, L.

SLOP

Herbert J. , 428

SLOSS

Altha, 193, 428, 433, a. c.a. Sloss, Aetha

George A., 428, 643

Herbert J., 433

SLOWN

Cyril Leland, 392

SLUSSER

Frank Banks, 434, 436 . 446,644

SLUTZKY

Ben, 388

SMALLEW

Wesley, 467

SMALLWOOD

Louise Boyer, 187, 356 , a. c. a. Smallwood. Louisa B.

SMART

Edward N., 440, 644

Nellie H., 171

SMERNOFF

Louis Noah, 347,426 , 446 , a. c. a. Smeroff. L. N.

Meyer, 349
EVEROF

Louis X., See smernolf, Louis $\mathrm{X}$.

SIIERSH

Otro G. , +25, 64

S.MILEY

Jonathan, 340

Thomas B., 41 4

SMITH

Arthur C. 11. , 166, 353, 410

A. P. 166

Andrew Jackson, Fis, 411 . $45+, 45:$

Anthony J., 430, 436

Arthur Andrew, 358, 371 . $303,394,644$

Arthur D. , $\$ 30$

Arthur Ernest, 394, 432 . 468,644

Arthur Lawrence, 156, 359, 372,644

Austin, 410

Azalia, $193, p-196,201$, 202, 644

Benjamin R. , 467

Bert A. , 445, 505, 644

Bertha E., 394

Carl W. , 173

Clarence R. , 357

Clint on H. , 423, 644

D. W. C. , 437

David Finley, 427

David J., 446, 644, p-644

Don La Wotte, 427, 644 . p-644

Draper (Mrs. ), 376

E. B., 221

E. H. , 444

Edwin L., 430

Eldon J., 531, 644, p-644

Ella Pearson, 269

Elmer Burton, 340, 394, a. c.a. Smith, Elmer E.

Floyd, 8t

Franklin B. , 340

George Hartford, 410

George W., 166, 345

G. M. , 356, 396, 457

George L. , 462

Gertrude Reid, 142, 383

Greene McClure, 427

H. R. 166

Hal Clarke, $345,397,444$, 644, p-644, a.c. a. Smith, Hal Clark

Harry C. 433, 517, 644

Henry F., 340

Henry J. , 430

Herbert H. 428, 433

Hiram L. , 88-89, 148, 150

Izatus L., 645

J. E. , 340

Joseph F., 390, 410, 412

James J., 434, 645

James W. B., 340, 502, 645

Jerome $\mathrm{H}, 288$

Jessie, 171

John E., 340, 473

John Francis, 114, 123

John G. $343,462,645$

John W., 394 
SMITH cont inued

L. , 166

Leander Bannatyne, 33$34,83-84, p-83,423$, a.c.a. Smith, Leonard Bannatyne

Levi Nelson, 433

N. Spalding, 428, 458 , a. c. a. Smith, N. Spaulding

Nina Ream, 193, 198. 199

R. O., 422

Ralph, 396

Richard Anderson, 348, 645

Roscoe Likes, 358,376 . 395,645

Samuel D., 430

Samuel J., 357, 428

Seymour H., 345

Vern, 172

Victor B., 83

W., 166

William H. , 396, 430

Zella, 172

SMITHHEISLER

James R, , 345, 435, 446

SMITS

Gladys G. (Mrs. ), 520

SMMER

Edward Adam, See Sommer, Edward A.

SMRHA V. V., 645

SNELL

Charles R. , 434

SNIPES

James Johnst on, 358, 645

SNOOK

William Henry, 356, 475

SNOW

John E., 347

Lillian L. . 358

SNOWDEN

Charles Cook, 81, 466, 467,845

1. W., 81

SNYDER

Charles W. , 345

Frank A. , 357, 433, 645

Frank Grey, 476, 645

J. Elmer, 411

$\mathrm{SOHM}$

Herbert A., 387

SOHOLNi

Rev. A. O., 498

SOIFER

Irvin, 388

Isidore, 349, 645

SOLDER

W. W. , 436

SOLLIS

Delmar Bryant, 359

SOLOMON

A. K. , 166

F. F., 340

J. J., 343

SOMERS

Andrew Bartholomew, 95, 106-108, p-107,
SOMERS cont faued

Andrew Bartholomew continued, 140, 145, 282 , $331,333,334,337$, $340,342,360,361$

SOMMER

Christian N. , $3+5$

Edward Adam, 345, 394, $395,396,462,468$, 645 , a. c. a. Sommers, E. A. ; Smmers, Edward Adam

Edwin Adam, 359

SOMMERS

E. A., See Sommer, E. A. Frank Mead, 428

SONG

Mary M., 187

SONNELAND

Arthur M., 438, 645, p-646

SONNENBURG

J. (Mrs. ), 491

SOPER

James, 430

Joseph, 345, 425

Lyman White, 356

SORBER

M. , 166

SORENSON

Carl Gustaf, 340

Regnar M. , 288

SOTTERFIELD

Cornelius E., 357

SOUKUP

Rosalie (Mrs.), 34

SOULE

Isaac, 462

SOW ERS

A. H. , 319, 321

SPAHR

Charles E., 355, 356, a. c. a. Spahs, C. E. : Spahn, C. E.

\section{SPALDINC}

Samuel Kennedy, 95, 96$97, p-97,140,145$, $146,151,161,213$, $296,300,330,333$, $334,337,340,343$, a. c. a. Spaulding, S. K.

W. Clyde, 340

SPANGLER

Milton Howard, 433

SPARLING

W. R, 411

SPARKS

Martin L., 146, 645

SPATZ

Joseph E., 141, 411

SPAULDING

S. K., See Spalding, S. K.

SPEALMAN

John F. . 357

J. S., 519

SPEAR

George E., , 357, 394

SPEARMAN

Harry H. , 172

SPEARS

Franklin, 355

SPEIER
SPEIER continued

Aaron Schloss, 645

SPENCE

Edith H. S., 193

George Franklin, 433

SPENCER

D. B., 365

Dudley Carlton, 356

E. S. B., 340

Noal W. , 348

SPERES

Conrad, 340

SPERRY

Willia Peek, 355

SPICER

C. B., 393

Charles Ralph, 394, 645 . a.c. a. Spicer, Sharles Ralph

SPICKELMIER

L. J. . 447, 475

SPIEGEL

Emil R., 173

SPINNEY

A. B., 340

SPIRA

Moritz, 340

SPIVEY

Clark Dwight, 359, 421, 422, 424,645

SPOHN

Marion Wilson, 467, 645

SPRADINC

Clarence Richard, 645

SPRADLING

Richard Hargrave, 313,645

SPRAELLINC

Frank Lee, 462

SPRAGUE

C. C. , 366

Charles D. , 110-111, p-110, 340,342

Charles G. , 340, 342, 364, 368

Charles H. , 111

C. W., 508

J., 166

John Perley, 392

SPURRIER

Elfie Viola, 435

SQUIRES

U. H., 466,487

SRB

Adolph F., 306, 307, 347

Gilbert J. , 310

Joseph J, , 397, 645

ST AADE

S. W., 345

ST ACK

Thomas E., 343, 362, 421 , $422,427,433,446,470$

ST ADDEN

John C. , 420, 422, 424, 430, 645

ST AFFORD

Elon, 428

STAHLY

Edward H. , 359

STAHR

Harry Sophus, 359, 390

STALCROP 
STALCROP cont inued

H. G. , 464

STALEY

Wilber A., 427

ST ANARD

John Turner, 646

ST ANDER

Theodore Calvert, 646

ST ANDEREN

John F., 345

ST ANDISH

Aust in D'Arcy, 355

ST ANGLAND

E. C. , 69

ST ANHONE

Redingt on, 355

STANLEY

J. B., 517

ST ANSBERRY

Don C. , 646

STANSBURY

Eugene M. , 430, 446

ST ANTON

Donald Ion, 646

STAPENBECK

P. H., See Stappenbeck, P. H.

ST APLEFORD

A. D. , 475

STAPLES

Louis Henry, 344, 646

ST APLETON

Harvey Burr, 347, 359 , 646

ST APPENBECK

Paul Henry, 445, 646, p-646, a. c, a, Stapenbeck, P. H.

ST ARBUCH

D. W. , 444

ST ARING

Jennie, 340

STARK

C. V., 343

H. S., 536

Lucien, $410,429,646$

ST ARKEY

Harvey Lee, 430, 646

Roy D., 173

ST ARKIE

Caraline, 340

ST ARNER

Gettis E. , 340

ST ARR

Calvin, 184, 187, 427

Julia Cornelia Candee, $184,187,193,428$

ST ASTNEY

Charles S., 190

ST ASTNY

Olga, 152, 190-192。 p-190, 193, 194, $196,199,202,282$, 646

\section{ST AW ARD}

John T., 397

STEARNS

Lester Miles, 371, 517 . 646

Robert James, 282, 347, 646
STEAIENSON

Leigh C., 173

STEBSGAARD

Niels C. J., 434

STECH

M. James, 435

STEEL

C. H., See Steele, Charles $\mathrm{H}$.

Nathaniel, 355

STEELE

Charles H., 410, 470, a.c.a. Steel, C. H. J. T., 393, 394

STEEN

Charles C., 445, 536 , a. c. a. Steen, C. G.

ST EENBERG

Donald Benjamin, 371 . 431, 646

Edmond Kenneth, 431 , 646

Edmund A., 146, 647

STEINBERG

Abraham Abe, p-278, $282,348,647, a, c$, a. Stelnberg, A. C.

STEINEF

W. F., 344

STEJSKAL

Francis Joseph, 647

STELLATE

Martin J. , 172

STELLE

Truman Young, 359

STELNBERG

A. C., See Steinberg. A. A.

STEPHENS

F. E., $343,356,462$, 470

I. C. , $357,462,467$

Lottie, 444 .

STEPHENSEN

Ora S., See Stephenson. Ora L.

STEPHENSON

Charles I., 444, 458

Ora L., 187, 343, 458, 468 , a. c. a. Stephensen, Ora A.

W. н. С. . 263, 340, 343

William James, 431

ST ERNHILL

Isaac, 388

STEVEN

Robert Alexander, 349

STEVENS

Charles A., 446

Charles C. , 430, 436

Dawl, 426

George A. , 345

Henry M., 340

I. S., $397,422,435,442$, 444,458

James Franklin, 313, 314, $353,356,358,458$

Wade, 38,238

STEVENSON

A. L. 430

Andrew V., 464
STEVENSOX cont inued

Earl Clement, p-5 46

Waldo W. . 172

ST EVER

Emma Watkins, 197, 394

STEW ARD

S. M. (Mrs. ), 411

P. LaFayette, See Stewart, Pierre L.

STEWART

Alfred Jesse, 463, 647

Benjam in F. , 424, 426, 427 , 510,647

Charies, 444

Charles F., 79, 139, 152

Charles R., 426

Charles W., 437

Earl M. , 647, p-648

Edward Russ, 470, $6 i 7$

Ellen, 142

Fletcher Clark, 348, 392

George, 408

Howard Coke, $43 t$

James L. $5 ., 434,445$

M. , 433

Nellie E. , 497

Pierre LaFayette, 345,434 . $444,446,458,467,468$, a. c. a. Steward, P.:

Stewart, Pierre Lafayette; Stewart, Piere L. ; Stewart, Pierce 1 .

S. J., 508

Willis E. , 425, 536, 647

STIDWORTHY

Daniel Brocks, 647

STIEN

A. L. . 444

STIERS

A. L., $396,411,443,458$, 462,475, a.c. a. Stires, A. $\mathrm{L}$.

STILES

Harry H. , 359, 647

STLLE

Alfred, 88, a.c.a. Stilley

STILLMAN

Charles B. , 89, 149, 446

E.. 365

W. D. , 364

STIMSON

Lucy, 539

STINTEV ANT

Lazelle, B., See Sturdevant, Lazelle B.

STIRES

A. L., See Stiers, A. L.

ST IRLING

Margaret Belle Crun, 647

ST TTES

George K. , 433

STIVERS

Charles C., 345, 358, 394$397,410,411,414,424$, $425,427,429,433,434$, $435,443,444,447,458$, $462,465,466,467,468$, 470,475 , a. c. a. Stivers, Charles S.; Sivers, Chas. E.

STOAKES 
STOAKES cont inued

William H. , 647

Frank E., 412, 424, 430,

445,465, a. c. a. Stokes, F. E.

STOCKDALE

$$
\text { B. A., 345, } 462
$$

STOCKER

Charles F., 359

STOCKERT

C. Frederick, 462

ST OCKFELD

Paul, 355

STOCKMAN

J. W.., p-472, 475

STOCKTILL

Henry B. , 173

STODDARD

Idelle Lydia Edmands, 647

John, 442

STODDART

Archibold C. , 340

STODDEN

Frank J., 347

STOGSDIL

James, 468

STOKES

Arthur Charles, 115, 167. p-167, 168, 170-171, $250,272,288,362$, 372,374

A. C. (Mrs.), 380

Charles S., 345

F. E., See Soaks, F. E.

STOKES

James, 50, 315

STONE

Clement A. , 430

Ira G. , 356, 462

James G., 411, 466, 647 .

M. L., 491

Melville W., 33, 84-85, $319,321,462$

Robert Marsena, 95, 96, $329,331,334,335$,

$341,342,360,374$

Robert W., 340

Thomas W., 343

Ulric D. , 356, 428, 433 ,

444 , a.c. a. Stone,

Ulrich; Stone, Urlic D. ;

Stone, Uric D.

STONEC YPHER

David Daniel, 445, 647

STONEY

F. J. W., 357

STONGER

R. , 166

STOOKEY

Vespasian, 457

STOOPS

Eunice R., 193

James Norval. 463, 464, 536,647

Roy Philson, 463, 464

STOPPENBECK

Paul, 505

STORKAN

Louis J., 411

STOR2
STORZ continued

Louis H., 172

STOUFFER

John Wesley, 355

STOUT

Burn Thompson, 349

James K. , 340, 343

STOWES

Carrie S., 357

STRADER

George L., 512

STRAIGHT

John W., 341, 342, 394 , 426 , a. c, a. Straigh, J. W.

STRAIN

John S., 434

STRANGLAND

E. C. , 324

STRATE

Lester Kenneth, 393, $394,412,647$

STRATTON

Asa B, 647

Rex B., 467

STRAUB

Caroline, 340

STRETTON

Harry H. , 357, 466, 467, 648

STRICKLAND

William Redman, 347,648

STRINGFELLOW

Emanuel, 430

STRONG

Jesse F., 451, 458

Judd A. , 411, 464

Mary, 182, 331, 333, 334, $340,342,360$

STROUGH

George W., 156, 357, 428, 465,648

STROUSE

H. G. 345

STROY

Herbert Eric. 348

STRUBLE

Carl K. , 394

STUART

A. E., 423

A. F., 462

Andrew E. , 423, 648

Samuel J., 357, 394

STUCKART

Theodore, 310

STUCKEY

Royal Scott, 426, 427. 431,648

STUDLEY

Louis W., 428

STUFF

Lillian B., 142

STUMP

Alberta (Mrs.). 383

STURDEVANT

Charles L. , 343, 355 , $432,505,648$, a, c, a. Sturt evant; Sturdivant J. L., 357

Joseph Sylvester, 408 $428,442,446,467$.
STURDEVANT continued

Joseph Sylvester continued, 475 , a. c. a. Sturdivant;

Sturdivant, Josiah S.

LaZelle Brantly, 358, 391, a, c, a. Stint evant, Lazelle B.; Surdevant, Lozell B.

STURDIVANT

J. S., See Sturdevant, J. S.

C. L., Sce Sturdevant, C. L.

G. O. , 432

STURTEVANT

C. L., See Sturdevant, C. L. STUTZMAN

Thomas B., 467

\section{SUCGANG}

Felipe Parco, 250, 430, 437, 648 , p-648; a. c. a. Sucgang,

SUCHA Fellipe P.; Sucgang, Felix

William A. , 307

William L., 170, 305, 386 , 394, 431

SUCHART

J., 166

SUEPER

Mary, 310

SULLIVAN

George Webster, 391, 648

H. Kathleen O'Connor, 193, 201 , a. c. a. O'Sullivan, Kathleen; Sullivan, Kathleen $\mathrm{O}^{\prime}$ Connor

H. Rathben, 193

Harry Thomas, 347, 648

J. T., 387

John Paul, 347, 648

M. M. , 648

Minnie M., 172

Stephen W., 648

SUMMER

Ella P., See Sumner, Ella P.

SUMMERS

Hy S., 362, 412, 414

Hattie M. , 144

John B., 457

John E., Jr. , 54, 65, 153$154, \mathrm{p}-153,242,267,321$ $331-334,337,340,342$, $360,361,386$

John Edwards, Sr., 55, 65, $95,153-154, p-153,197$ $203,213,216,269,282$. $283,343,372,375,376$, 484,492

J. E., Jr., (Mrs.), 478

SUMENER

Ella Pearson, 187, 193, 194 , $393,394,426,648$, a. c. 8. Summer, E. P.

SUMNEY

Herbert Clayton, 249, p-249, $341,372,377,386,648$

Herbert Clayton (Mrs.). 377. $378, p-378$

SUNDBERG

Rudolph H., 348

SUNDBURY

Peter Albert, 151, 445, p-648, 649

SUSSDORF 


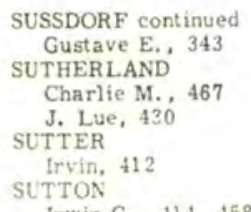

Irwin C. , 414, 458, 475 , a.c.a. Sutton, Erwin c.

SUZDORF

Gustave E. $3+0$

SVENSON

E. O., 340

SVIT AK

Emma L., 172

SVOBODA

Frank Charles, 349

SWAB

Charles Marion, 307 , $308,347,386,649$, a.c. a. Swab, Chas, F.

Elizabeth Marie Moyer, $307,308,349,380$, 649

SW AGGART

Luman B. , 525, 526, a.c.a. Swaggert, L. B.

\section{SW AMBOM}

Alaric R., 173 .

SWAN

M. R., 142

Van N. , 434

SW ANBOM

L. J., 536

SWANEY

L. Alice, 345

SWANSON

J. , 166

Leonard A., 359, 393, 649

Myrl R., 172

SWARD

Erick M. P. 397

Ernest Joel Const ant ine, $140,248-249,358,397$. a. c. a. Sword, Ernest J. C.

SW ARTWOOD

Francis Marion, 649

SWARTZ

Caroden Leroy, 457

Charles M, 357

SWARTZLANDER Fred, 333, 340, 342

Louis C. , 345

SWEANEY

Leverett, 343, 458

SWEENEY

Edward E. , 345, 429, $444,458,649$, a.c. a. Sweeney, Edward Edmond; Sweeney, Edward Emmet

George, 434

SWEET

J. H., 527

SWENSON

Carl G. , 341, 342

Samuel August, 397, 435, 649
SWETLAND

Agnes V., 187, 193, 341 . 343,436 , a. c, a. Swetland, Agnes D.

James, 187

SWETMAN

James M., 329-330, 340, 343

SWIFT

Charles Henry, 435, 649

Charles L. . 437

SWIGART

Henry Mc, , 394, 510. a. c.a. Swygert, Dr.

\section{SWOBODA}

Frank J., 649

Joseph Phillip, 347, 649

Louis, 256, 343, 460, 649

SWOPE

Oscar C. . 429

SWORD

Ernest J. C., See Sward, Ernest J. C.

\section{SW YGERT}

Dr., See Swigart, Henry $\mathrm{Mc}$.

SYDENHAM

Phaip T. , 433

\section{T.}

TABER

$$
\text { R., } 166
$$

TABOR Sidney J. , 409

IAGGART

Artbur T., 166, 341, 343

Samuel R. , 288

TALBOT

A. R., 521

Robert C., 33, 93, 149 , $151,415, \mathrm{p}-415,418$ 421

Willis E. , 147, 156, 415, $\mathrm{p}-415,421,424$, a. c. a.

TALBOY Talbot, Willis A

Henry J. , 432

William R., 649

TALCOTT

Dan De R. . 435

James Martin, 148, 649

Norris D. . 409, 649

Vernon Vivaldo, 347, 431.

TALLON 435,649

Fred D. , 536

TAMISIEA

John Alexander, 347, 649. p-650, a. c. a. Tamisea. J. A.

TANCOCK

J. A., 170

TANNER

Edward, 362, 412, 649, p- 652

Howard H., 172

Mary E., 187

Richard J., 414, 425, 446, $466,471,649$

Webster, 444
TANNER cont inued

William T. . 356, 410,430 , 475

Willis C. , $345,424,465$

Willis G. , 411

TANY

Edward R., 345

TARBOX

Jennie E., 431

TARNER

Will iam, 340

I ASHJEAN

Amenag B, $362,640, a, c, a$, Tashjean, A. D.

TAUBLIN

Jerome B. . 409

TAYLOR

Alexander, 74

Aurelius P. , 356

Charles E. , 424, 649

Fred L., 394

Cuv R., 424, 444, 458, 467 . 649

Harold H. R., 173

Harry Allen, 358, 391, 392, 521,649

J. S. 51 ?

James Rodolph, 650 , p-652

James Sherwood, 133, 650

Jesse Day, $358,521,650$

Samuel B. , 469

Thomas L. , 345,434

Timion L., 358

Willis Harvey, 282, 650

TEAL.

Fred R., 115, 151

Frederick F., 151, 359, 371. $391,520,521,650$

\section{TEETERS}

John Lewis, S18, 520, a, c, a. Teeters, L. L.; Teeters, J. J.

TELLESEN

Charles Clyde, 410.650

TEMPLE

C. H., 357

IENNEY

E. S., 141

TERRELI.

Price, 348, 630

TERRY

J. D. 453

P. A., 341

TETER

Charles E., 396, 424, 650

Daniel P. 343

TEXLEY

Andrew, $433,465,470,650$

THAW

Harry K. , 24

Mary Copley (Mrs, ), 24

THAYER

John Mt, 85, 118, 137, 154

P., 166

THEIS

Harold H., 517

THIES

Edward Martin, 650

THODE

Martina C., 172, 482

THOMAS 
THOMAS continued

Albert, 462

Alfred H., 146, 151, 650 , $p-650$

Amos, 282

Charles W. , 358, 429, 458,650

F. S., 268

Fred A., 650

James F, , 467

James H. , 431

James Walter, 148, 408, 409,650

James W., Jr. , 359

James White, 84, 409, 651

John L., 359

M. W. , 462

Marion U., 357, 409, 475. 651 , a,c.a. Thomas, Marion W.

Martin Low, 409, 651

Valorous A., 147, 651

W. W. , 429

Wellington A., 430, 445 , a. c.a. Thomas, Willingt on $A$.

William M. , 508, 651

Y. A., 445

THOMLON

John Davis, 340

THOMPSON

Anna Isabelle, 435

Charles F, 414, 470

Chester Quay, 282, 348, $413, p-413,651$

Daniel W. , 358, 46?

Edgar Samuel, 412, 414

F, , 166

F. B., 433

Frank C. , 444

B. S. +34

Harry H. , 425, 464

Irwin L., $412,414,651$

J. E. M. , See Thomson, James E. M.

John Clark, 359, 434, $475,521,651$, a, c. a. Thompson, Jhn

John W. 359, 411, 467

Joseph H. , 394, 444, 446,651

kenneth L., 347

Kimball E. . 412, 413. $\mathrm{p}-413,414$

Levi H. 414

Mary (Mrs.). 541

Ralph M. 288

Richard Yoder, 413, p-413. 651

Theos Jefferson, 282

Thomas D., 412, 412-414, $p-413$

Thomas, 414

Warren Y., 282, 347, 413, p-413, 651

William A., 59, 343, 433

THOMS

Adolph N. , 429

THOMSEN

John Henry, 253-254, p-253, $347,500-501,651$
THOMSEN cont inued

J. E. M. (Mrs.), See Thomson, Mrs. James

\section{THOMSON}

Bertha Mangon, 249, 313

James Ellus M., 170, 359 , $371,522,651$, a, c. a. Thomson, James M, : Thompson, J. E. M. James E. M. (Mrs.). 377 , a. c, a. Thomsen, Mrs. James E. M.

John, 651

Ray T., 390

THORNTON

Albert H. , 396

H. , 166

J. W. , 384

Lorenzo R., 358, 428

Thomas H. , 387

THORP

Charles W. , 436

Harry S. 508

Lewis Edward, 457

THORPE

Agnes Cecelia, 193, 197, 347,464

H., 166

THRALI

W. R. , 32, 48-49, 50 , $55,147,316$

THULIN

Herman F. , 345

THURBER

Samuel W., 355

THLRSTON

Eugene Dennis, 146, 363 , $437,468,651$

W. B., 443

THURTON

Wilson B, 123

TLBBETTS

Thomas D., 427

TIBBLES

Suzette, 24

Thomas H. , 24, 26

TIESING

Berthold Charles G. 446,651 , a. c, a. Tiesing. Bartholdi; Tiesing, Berthold S. G.

\section{TIFFANY}

John S., 431

John W.', 458

TILDEN

George, 60, 66, p-66, 130 , $261,318,324,325,332$. 340

George (Mrs. ), 66

L. C., 340

TINLEY

M. A., 389

Mary L., 187,269

TIPTIN

T. W. (Senator), 49

TIPTON

G. Dean, 347

TISCHE

James Matthew, 343, 397. $410,431,651$

TOBIAS
TOBLAS continued John M. , 464

TOBIN

Frank J., 347, 387

T., 166

TOBKIN

J. H., 412, 651

TOBKINS

Joseph N., 414

TODD

William, 428

TOLLMAN

James Perry, 392

TOLSON

Benjamin F. , 343

TOMBLIN

Jerome Burt, 355

TOMKINS

Helen, 382

TOMLINSON

Charles Creight on, p-278, $282,283,338,345,391-$ $392,512,651$

TONEY

S. C. 340

TOOMEY

Francis Elmer, 349

TOOTHAKER

Sylvester R., 467

TORBITT

W. T. 357

William F., 652

TOREN

Julius A., 447

TORJUSON

Theodore B., 345

TORNHOLM

Frank, 147, 323, 463, 652

TORPY

Thomas W, , 306, 307, 347, $387,652, \mathrm{p}-652$

TOUVELLE

Albert R, 652

TOWLE

John W, 81

TOWN

Solon Rodney, 139, 140, p-140, $251,282,331,333,340$ 。 $360,376-377,652$

TOWNLEY

Frank Newcomer, 393, 394, 434,652

TOW NSEND

Adelbert, 395, 423, 427 , $435,443,446,464,466$ 652 , a. c. a. Townsend, A. jelbert

Albert, 431,444

G. L., 156

Guy Walter, 432

ina, 274

Louis J. , 410, 425

Owen Stuart, 249, p-650, 652

W. R., 434,467

TRACY

Fred F., 343

Jonathan F., 340, 470

T. S., 349

TRAIN

George Francis, 66, 479

TRAYNOR 
TRAYNOR cont inued Raymond L., 306, 307 . 349,652

TREADGALD

Elight, 357

TREYNOR Jack Vernon, 283, 373

TRIGC

$$
\text { D. S., } 255
$$

TRIMBLE

Chester, 348

TRIPLETT

John M. , 411, 431, 652

Thomas M. , 356, 652

TR LPPLETT

F. M. , 429

TROESTER

Otto Michael, 431, 652 . $\mathrm{p}-652$

TROMMHOLZ

Gert rude H. , 356

TROSTLER

Isador S., 435

TROTTER

William M. , 450, 456, 458

TROUP

Ralph Leslic, 347

TROUT

A. L., 427

TROWBRIDGE

Dempsey L. , 424, 429, $431,434,475$

James Allen, 445, 652

TRUE

George B, M. , 475

TRUEBI.OOD

B. T. , 431,432

TRUELSEN

Emil E., 173

TRUELSON

Thomas, 345

TRUEX

Howard E., 357

TRUTTT

Alva C. . 434

G. W. C. , 433, 467

TRUMBOWER

J. W., 340

TRUTCHER

John Barr, 429

TUBBS

Hazel, 143

TUCKER

F. W. , 356

James C. , 397, 652

James E., 429

Myra, 274, 383

TULLEYS

I. $W_{.75} 471, p-471,472$. 475

TURNER

Arthur K., 425

David J. , 428

H. J. . 433

James Harvey, 348

James W., 428, 434, 653

John J., , 355

Louis, 340, 356, 394, 428, $431,433,434,467$. 470
TCRNER cont inued

William Duncan, 392

TWINEM

John S., 436, 653, a. c, a. Twinem, John W.

TYLEE

Augustus A. , 428

TYLER

Albert F., 208, 210, p-210, $221,252,257,305,337$ $338,345,368,370,376$. 386,653

Albert F. (Mrs.), 378, 379 , p-379, 380

Eugene M. $444,505,653$

T. M. . 539

TYNDAL

J. H., 354

V.

ULBER

Hattie, 340

ULLRICH

Charles William, 340, 458

ULRICH

Charles Ferd, 307, 410, 653

UNDERBERG

E. C. 466

UNDERBURG

F., 166

UPDEGRAFF

Eimer J., 115, 345

Howard Leighton, 853

UPJOHN

Erastus N., 33, 77

Mary H., 77, p-77, 187, 192, 343, a. c. a. Upjohn. Mary L.

William C. , 77, p-77, 187 . 192,343

UPTON

E. J., 345,458

UREN

Claude T., 305, 308, 372 。 653

Claude T, (Mrs, ), 380

URIDII

Joseph E., 393, 473, 653, a. c.a. Uridell, J. E.

URQUHART

Thomas H., 394

VALENTINE

Linville F. , 288

VALLICOLT

Oscar J. , 431

VALLIER

Thomas, 443

VAN ALTA

Eleaner, 340

T. 166

VAN BUREN

E. $, 318,320$

Frederick A., 345

VAN CAMP

Ira, 70, 340, 343, 478

Lee B. , 70, $146,345,653$
VANCAMP

J. A., 433,458

J. H. +44

VANCE

Brookes, 105

Evangelyne F., 172

John Harris, 96, 105 p-105, 151, 16? 332 , $337,340,343,543$

Joseph A. , 357

V. Verne, $444,505,653$, a.c.a. lance, 1. Veone

William Brooks, $3+8$

VANDEN

Walter H. , 410,653

VANDERHOF $\mathrm{F}$

b. W. 436

I ANDERHOOE

Thomas 3., 394, 46., p-463, $464,536,653$

$\checkmark A N D E R P O O L$

Merrill M., 172

VANDERSLICE

Augustus .M., 355, 653, a.c.a. Van Dersilice, A.M.

Edwin R., 357, 317

VANDEY ER

H. A. See $\mathrm{l}$ andiver, H. A.

VANDER WYST

P. G. H. 464

VAN DE WALKER

Jaines G. , 467

VANDIVER

Charles E. , 437, 463, 464, 475

Howard Asberry, 146, 387

434, 653, a.c. a. Vandever, H. A. : Vandwer, H. A.

L. E. , $423,424,436$

VAN LACKUM

H. J., See Von Lackum, H. J.

VANDOLAH

Benjamin F., 355

VAN DOREN

S. H., 340

William, 397

$\checkmark A N$ DYKE

George Henry, 428

James, 343

VANDWER

Howard Asberry, See Vandiver, H. A.

VAN ES

Leunis, 653

VAN FIEET

Edward Amos, 252, 345, 653

VAN GIESON

H. C. , 267, 268, 331, 332 . $333,340,343$, a. c. a. lan Grisen, H. C.

VAN HUMMELL

D. 340

VAN KEUREN

Jno, 345, 410, 444, a, c, a. Van Kuren, Jno.; Van Keurew, Jno.

VAN METRE

Richard Thompson, 425, 653

VAN NESS

Isaac I., 340 
IAN NESS cont inued Sherman, 268, 333

VAN NUYS

M. M. (Mrs.), 187, 270

VAN OSDEL

Samuel Arthur, 347, 444, 451, 456, 458, 505, 653 , a.c. a. Van Orsdel, S. A.

IAN SICKLE

Abijah R., 364, 384

VAN STOCK

C. L. 525

VAN IALIN James C. , 288

VAN YALKENBURG F. P. 467

VAN IELSAR W. W. , 434

VAN YELSON W. W. . 410

VAN VELSOR Daniel J. , 410

Henry V., 410

VASINA

Ant on F., 173

VASKO

John RaJph, 349

VAUGHN

Frank Wesley, 396

Leona P., 429

VAUGHT

D., 166

VAXTON

E. J., 434

VENABLE.

Joseph, 50, 315

VENNEMANN

Fritz Willtam, 348, 396. $654, p-654, a . c . a$.

Venneman, $F$. W.

\section{VERCOE}

Walter L, 347

VERGES

Car1 J., 147, 150, 256 。 $529-530,654$

VERPORTEN

M. H. , 340

VETTER

James George, 386, 654,

VICTOR p- 654

Henry C. , $35 \overline{6}$

VIEREGG

Frank Ray, 394

VOGEL

John A. , 431

YOLKMANN

Catherine, 355

VON EGERT

Albert, $34 \mathrm{i}$

VON LACKUM

Herman J., 345, a, c, a. Van Lackum, H.J.

Peter, 340,343 , a. c.a. Von Leckum, P.; Von Locuk un

VOORHEES

I. M., 394

voos

Fred William, 433
VOSE

L. O. , 144

William H. , 446

VOSIK A

Fred Gilbert, 654

voss

Lorenzo C. , 446, 654, p-654

VRADENBURG

Harry L., 411, 654, a. c.a. Vrandenburg. H. L.

W,

WACHTER

S. , 166

WADDELL

James Clyde, 170,372 , $429,507,532,539$. 654

W ADE

J. T., 470

John Christopher, 420, 424, 654

Mary (Mrs.), 24

WAECHTER

Marie, 529

W AGG ENER

Hewitt A., 345, p-448, 453 , a. c. a. Waggoner, H. A.

John A., 447, p-448, 452 $453,455-458,513,654$, a. c. a. Waggoner, J. A.

John Todd, 429, p-448, 453, 458, a. c. a. Waggoner, John Todd

William R., p-448, 453 , $458,468,470$, a.c. a. Waggoner

WAGGONER

Dickson R., 654

Hewitt A., See Waggener, H. A.

J. A., See Waggener, J. A. John Todd, See Waggener, John $\mathrm{T}$.

W. R., See Waggener, W. R.

WAGNER

Carl P. , 288

George L. , 394, 431, 434, 468,654 , a. c. a. Wagner, Gerge

Leo M., 414

May Melle, 172

WAIT E

F. W. , 340

Herbert Harold, 354, 374, 654

Hubert H. 358

Ira Willis, 426,467 , a. e, a. Waits, L. W.

WAKEMAN

Margaret, 529

WALDEN

Clifford W. , 302, 428 , 654, a. c, a. Waldon, C. W.

Delinzo A. , 302, 321, 427. 428, a. c, a. Waldon, D. A.

WALDMAN
WALDMAN continued Joseph Sterling, 433

WALDON

Clifford W., See Walden, Clifford

D. A., See Walden, D. A.

WALFORD George B. , 411

WALIZER

E. R. , 426

WAL.KEF

A. E., 429, 458

Arthur Bruce, 242, 359, 655

Charles Wesley, 467

Daniel G. , 446, 655

David A. , 146, 655

Edward, 432

G. R. , 389

George Hemab, 170, 358 , $445,521,655,8$. с. a. Walker, Geo. F.

H., 166

Harold Hill, 347, 436, 437. 655

Henry, 504

Henry Charles, 396, 655

Joel Edward, 356

John Greenleaf, 457

Robert C. , 340, 343, 443

Sarah M. 458

W ALL

Wlliam H. , 345, 655

Vict or Juble, 433

WALLACE

James Marvin, 468

Robert Bruce, 404, p-404

WALLER

James E., 357

Joseph E., 427, 456, 655

Joseph S. , 458

W ALLERIUS

Raymond M., 348

WALLIN

Stanley Paul, 423, 655

WALLINGFORD

C. C. , 436

WALSH

Jno. E., 343

WALSON

Charles Moore, 306, 855

WALSWORTH

Henry J., 427

WALTERS

Hamlin J., 345

Stanley James, 349, 655

WALTHER

C. F., 458

WALTMEY ER

John Tassey, 454, 458

WALTON

Charles Archibald, 358

J. C. , 395, 453, 466

M. Wilson, 428

W AL TOR

C. J., 431

WAMSLEY

Lafayette B., 419, 422

WANDBORC

Carl M. , 173

WANEK

Ant on E., 147, 465, 655 
WARD

Alonzo, 410, 424, 427, $434,436,444,445$. 464,476

Augustus, 443

Carl Fletcher, 349

Earl F., 424

G. B. , 356

Henry B., 266, 374

John Scott, 410

Joseph D., 343

Mary Winifred, 193, 198

Sylvia M., 187, 425

T. R., 340,343

William Frederick, 434

William W, , 345

WARDER

W. Scott, 345

WARE

Edward M., 429

WARNER

Albert S. , 395

Charles J. , 343

Earl Albert, 429, 655

Esther (Mrs.), 187

Merle F, 347, 468

Ruth Ashley, 189, 193, 200. 201, 359, 521 . 655

Sophia E. Alice, 193, 655

WARNOCK

Thomas W., 428

WARREN

Hamilton, 340, 341, 343

Mannie V., 340

WARRICK

James E. , 394, 445, 655

WARSHAWSKY

Morris M. . 173

W ART A

John J. . 306, 308, 468

Joseph J., 347, 424, 468,

WAS 655

Louis, 356

WASHBURN

F. A, (Mrs.), 509

WATERBURY

T. N., $416,417, p-417$

WATERMAN

John M, , 408

Louise (Mrs.) ) 38.3

WATERS

A. R., 357, 458

Chester Hill, 283, 372, 375,392

Ely Hoge, 426, 427, 447

John Marion, 428

Orthello, 407, 447, a. c, a. Waters, Chello; Waters, Orthelo

Theodore Hammond, 655

WATKE

Fred M. , 307, 308, 348

WATK INS-LONG

Radiel, 446

WATSON

Amanda C. , 340

Claude, 656

Claude R., 463, 464, 536, 655
WATSON cont inued

Eli Arthur, 431, 394, 656

Harvey S., 427

John D. , 340, 432, a. c. a. Watson, J.D. W. . 166

WATTHALI

John G. . 425

WATTLES

G. W. , 162

WAUGH

Flora (Mrs. ), 402

WAY

Charles W., 347

Chester F., 173

Frank Emer son, 463, 656 J. H. 363

WAYMAN

John F., 355

WAYNICK

I. W. , 421

Joseph B., 363, 468

WEAR

John W. , Jr. , 347, 389 , 390,395 , a. c. a. Wear, I. W. Jr.

WEARNE

Frederick J., 302, 343, 492,656

WEATHERLY

A. L., 518,519

WEAVER

John B., 340, 343, a. c. a. Weaver, Kno. B.

Ralph L. . 656, p-657

WEBB

Adin Bilton, 656

C. I., 341

Joseph L., 427, 429 (de-

lete "Jr." on p. 429)

Joseph L., Jr., 467

Walter E., 173

WEBER

Charles L. . 396

Ernest Owen, 431, 462. 656

George Car1, 343, 14 , 423,468

Howard R. , 340, 343

Juluus Albert, 349

WEBSTER

A. A. $493,395,396,470$

E. D., 47

F. W. 170

James Thomas, 454, 457

Jahn Potter, 308

John R. , 372, 308

Joseph R., 184, 185

Lenore Perky, 184-165, p-184,

- 200, 356, 522, 523

Lyman A. , 428

Nell. 383

Ralph, 345

William W., 288, 390

WEDEMAN

E. V., 373

WEEK ES

Charles W., 656

Thom as Lindridge, 656

WEETER

George, 431
WEETH

Charles G. , 347

WEGMAXX

Casper, p-471, 473, 475

William M., 394, p-471, 473, 475

WEGNER

Andrew J., 173

Carl R., 349

Erne st S. , 347, 359, 389 , $520,522,541,656$, a. c. a. Wegner, Ernest E.

Walter Robert, 349

WEIDENSALL

Clara Jean, 656

WEIDERANDERS

E. W. I. , 446

WEIDMAN

Earl Vernon, 656

WEIGAND

G. L., 347

WEIGEL

Bernard John, 394

WELLAND

Johann F. E., 425

WEINBERG

Joseph Alexander, 283, 347 , 656

WEIRICK

G. A. , 394, 427, 431, 445 , 467, a.c,a. Weirick, G. H.

WEISE

Henrick, 343

WEISS

Johannes G. A., 426, 431, $433,444,468$

Rudolph Otto, 347

Victor Johannes, 349

WEKESSER

Henry Peter, 358, 391

WELBES

Michale Aloysius, 348

WELCH

Albert C. , 425

J. Stanley, 314, 354, 358, $370,371,374,392,521$ Joseph M. , 411, 656

Marie, 142

Morton Gifford, 425, 656

William W. . 357

WELLAND

Johann F. E. . 856

WELLER

Hedwig, 172

WELLES

Angela Prentis5, 257

WEILS

F. A. $359,424,428,434$

George F., 476

H. L. 412,414

Louis W. . 475

Milton F., 458

Myrta A, , 193, 345, a. c.a.

Wells, Myrle A.

O. O., 427,428

Thos, 288

William J., 358

William Leonard, 656

WELSHEIMER

John M. , 428 
WENBERC

H. , 166

WENGARD

Edward V. , 340

WENGERT

Henry C. , 656

WENSTRAND

D. E. W. , 385

WENTZ

Anna E., 340

WENZLICK

George J., 470

WERBER

William T, 347

WERNER

Walter A., 173

WERRICK

G. A. , 341

WERTENBAKER

C. P. 140

WERTENBERGER

W. W, 458

WERTHELMER

Samuel, 493

WERTMAN

Harry J., 465, 657

WESSELOWSK!

Julius, 458

WESSELS

Pauline F., 519, 520

WESSLEY

Will am David, 283

WEST

Benjamin F., 343, 357 . 425,434

WESTBRCOK

E. S. (Mits.), 59

WEST ERDAHL

Viva E., 172

WEST ERFIELD

J., 166

WESTERHOFF

John G. W. , 433, 467, 468

WESTERMAN

Louige, 519, 520

WERTMAN

Willard, 173

WERTZ

George D. , 41 1

WESLËY

Frank, 435

WESTER VELD

C. H. 536

WESTER VELT

E. T. , 509

WESTFALL

Davis H., 446, 657

WESTOVER

Raymond Paschal, 409, 535,657

WETHERBEE

Harlow F, , 173

WEYER

Stephen Morris, 347, $397,471,657$

WEYMULLER

Charles Augustus, 347

Louis Ernest, 349

WEYRENS

Joseph Peter, 396, 464,
WEYRENS cont inued

Joseph Peter cont inued,

$503,536,657$, a. c. a.

Weyrens, W. P.

WHALEN

Edwin J., 170

Joseph F., 349

WHALEY

Ada Mae, 193, 269, 424

WHEELER

Clayton E. , 347

WHELAN

WHliam P. , S. J., 219 , $242,296,298,300$, $301,303,306$

WHERRY

William Penaluna, 283, $322,0-322,337,345$. $372,389,543,657$

W, P, (Mr5, ), 380

WHIEBE

H. 433

WHLEN

Theodore, 466

WHIPPLE

Mrs., 263

WHITCOMB

F. F., 543

Glen D. , 347, 657

G. D. (Mrs,), 380

WHITE

Alexander L., 345

Cleveland James, 359

George Manly, 393, 394, $443,467,657$

Hosea J, 657

John T., 431

Mary B., 428

Nora O'Connor, 514

Robert M., 172

Sherman A., 374

Victor (Mrs.), 59

W. S. , 343

WHIT EHEAD

Emory Ira, 194, 396, 445, $446,458,504,657$

J. T., 536

WHIT EHORN

Edward E., 445

WHIT EMAN

James K., 411

WHITESIDE

George Henry W. , 345, 657

WHITHAM

Roy Herbert, 359, 520 . p-657, 658

WHITING

Fred W., 434

WHITMAN

Frank S., 345

WHIT MORE

B. F., 333

David, 448

W. F. 394

WHITMYRE

John P., 345

WHITNEY

Samuel D, 458

WHITT AKER

J. B., 347,443

WHITTEN
WHITT EN cont inued

E. M. , 73

R. M. , 321

WHITTIER

George N., 445, 658

Jackson, 118

WICKERSHAM

James C. , 469

WIDEANDERS

E. F. S., 426

WIEDEANDERS

Fannie H. , 426

WIEDMAN

Earl Vernon, 521, 658

WIEK

Marie, 383

WIELAND

Frank W., 437

WIEP

David K., 340

Edward A. , 394

WIERICK

G. A., 411

WICGINS

Caryl Williams, 348

Herbert, 347, 858

William Shipman, 358, 459, p-657, 658

WIGHTMAN

Wullam C., 470

WIGLESWORTH

Tandy, 425

WIGTON

Harrison Alonzo, 283, 390, 658

WIL BFRFORCE

Ernest, 358

WIICOX

B. A., 491

Fred, 467

George W., 536

Malcom B., 393, 437, 658

William P., 330, 333, 340, 350

WILD

Wuiam F., 141

WIL.DHABER

William Tel1, 429, 658

WILKINS

Theoda, 340

WII.KINSON

A. D. $353,354,357,361$, 519

George P., 204, 333, 334, $340,360,388,375,396$, $397,410,435,437,464$ Grace E. , 172

WILLARD

Walliam Albert, 283, 374

William G, 340, 366

WILLBERGER

J. L. 340

WILLIAMS

Benjamin Franklin, 152, 387 , $508,522,658$

Charles M., 356, 428, 434, 475

Charles Rollin, 359

Creighton David, 444, 658

Davis, 427

Eli M. , 410, 422 
WILLIAMS cont inued

Elijah C. , 444, 658

G. W. , 340, 366

Henry C. . 345, 357, 394, $411,444,446,462$

John A., 340

James Benjamin, $35 \%$, 465,658 , a. c. a. Williams, J. B.

Jotn J., 410, 428, 470

John P. 314, 340, 357, 658

Josephus J., 265, 322, 394 , a.c. a. Williams, Joseph

Mattheu A., 345

Mildred C., 193

N. A., 444

Richard J., 146, 395 , 421,658

William G. . 424, 464

WILLIAMSON

A. L., 458

George W., 341, 343, 470

Iram N., 451, 456, 457

WILLIS

Bennet G., 345

Charles Henry, 391, 429

Claude L., See Wils, Claude L.

James Medford, 363, 396. $427,447,451,456,458$, $462,526, p-526,658$

WILLMARTH

Edwin H., 288

WILLS

Claude Lenoy, 421, 424, 442,658 , a. c. a. Wills, Claude LeRoy; Willis, Claud Leroy

WILLSON

Hugh McGregor, 340, 356

WILLY

John C. , 446

WILMETH

Frank Lincoln, 125, 257, $313,357,367,518$

Hal Drummond, 658

Ossie F. 658

W. L. , 345

WILMOT

Frank Aloezo, 359

WILMOTB

Marion E., 288

WILSEY

Frank, 526

WIISON

Alva, 357

Arthur Julian, p-299, 301, $343,435,659$

Claude S., 314

Donald Jasper, 348, 659

Edward 0., 151, 441, $p-857,659$

Edwin S, 468

Egerton E. , 432

Eli M. , 84, 449, 450

Fredric L., 387, 432, 659 , a.c.a. Wilson, Fredric 0.; a.c.a. Wilson, Frederick L.
WILSON continued

George W. , 426

Henry L., 435, 468

J. O., 495

James S., 444, 650

Jeremiah Calfer, 359, 394 , 659 , a. c. a. Wilson. Jeremias Calfe

Jesse D. , 347,424

L. L., 232, 349

M. A., 345

Marion Orr, 470

Malard Lewis, 394, 410. $450,456,457,458$, $462,513,659$, a. c. a. Wilson, M. M.

Oscar L. , 659

Samuel, 50, 315

Sydney S. , 151, 659, p-660

William A., 433

William F., 476

William H., 131, 132, p-132, $134-136,140,143,144$. $149,340,358,428,659$ Will is M. , 426, 659

WILTE

William, 358

WIITSE

Edward H. , 458

WIMER

Henry, 467

WINDMEYER

Connie, 172

WINGETT

J. M. , 536

WINICK

George A., 475

WINNETT

Hudson Josiah, 93, 131, p-131, 149, 206, 207, $353,354,355,357$, 519

WINSHIP

Dugald C. , 355

WINSTON

John S., 411; 426, 659

WINT ER

Frederick William, 119 , 427,659 , p-660, a. c. a. Winter, Frederic W.

WINT ERSON

George Craggs, 473, 475, 659

WIRT

Hiram E., 422

WIRTH

Edward, 340, 343, 424,

WISE 464

David, 420, 422

Isaac M. 491

WISER

F. C. $450,456,458$

WISHART

Irene L., 172

WISNER

William $0 ., 345,425,436$

WITHROW

Taylor N. , 172

WITTE

S. H., 263
WITTER

Roy Verner, 464, 536, 659

WITTWER

C. C. , $i 56$

wo

Edward C., 458

Gee-Chung, 20t, it0, a.c. a.

Wo Gee Chung: Wo, C. G. WOEPPEL

Frederick William, 659

WOHI.

Mirhael Gershon, 347,639

WOLH

Reisa B. Gillerson, 199. 659 , a.c. a. Woh, Rose

WOHLNER

Paul, 173

WOITISHEK

Frank J., 345

WOLCOT T

R. H., 374

Rebecca B. , 433

Robert Henry, 271, p-278, 659

W. E. , 375

WOLF

Clifford Robert, 310

F., 166

WOLFE

Arthur E., 458

Harry K. , 189

Katharine H. K., $189, \mathrm{p}-189$, $201,356,660$, a. c. a.

Wolfe, Katherine B.

Wolfe, Katherine Brandt: Wolfe, Kathryn

WOLFGANG

W. E. . 410

WOLLGAST

Catherine, 141, 142, a. c. a. Wollgast, Katherine

WOLTMAN

Frederick K. , 437

WOMERSLE)

Edward Everett, 100, 101, $330,332-334,340,368$

WOMERSLEY

Ernest A. , 343

WONDER

Ezra, 427

WONDERS

Max Eugene, 348

WOOD

Amelia T., 193

Ch. T., JiO

George Angus, t27

Irving $C ., 660$

James Madison, 355

Leonard S. , 347

Lyle L., $348,390,443,464$, $660, \mathrm{p}-660$

Merritt, 397, 680, a.c.a. Wood, Merit

N. E., 467

Orlando Scott, 66-67, $p=67$, $139,340,343,364$

P. R. , 436

Robert Liston, 457

Ruth VI, 187, 353, 35t, 355 , 356 , a.c. a. Wods, Ruth

Walter Scott, 454, 459, 660 
WOODARD

Daniel Samuel, 119, 148, 152

J. H. , 266, 312

James Madison, 431, 660 , p-660

WOODBURN

John Martin, 340

WOODIN

John G., 431, 660

WOODRTFE

Baker, 426

Dare, 431, 433, 447

Rolland Cecil, 431, 515, 660

WOODS

Fred J., 428, 660

Harold Harrison, 429

Joshua Depoits, 467

Ozro Theo, 348

Royal, 359, 425, 660

Ruth M. . See Wood, Ruth st.

Thomas C., 377

WOODWARD

J. C., 347

James H. , 355

James Mac, 521, 660, $p-660$

Quinby A., 470

Stilman, 429

Thad H. , 356

WOOL.1S

Asa Lee, 396, 504, 660

WOOLLEY

Paul G., 207, 345, 374

WOOLSEY

A. , 319

WOOLWORTH

J. M. (Mr5, ), 478

WOOSTER

Dorothy, 172

WORDWALI

C. Olaf H. , 345

WORLEY

Howard A., 340, 343.

365,366 , a.c. a.

Worley, H. S.

Ivan H. . 173

Kathryn F.. 508

WORRALL

Lowell D. , 173

WORSTER

Willam Wilis, 358

WORTH

Charles Mansfield, 447

WORTHINGTON

George W., 478

WORTHMAN

Edward H. , 660

WORTHY

Melvina, 340

WRAY

Frank Horace, 345, 431. 661

WREN

Claude, 347

WRIGHT

A. S. , 55, 66, 363, 364

Ethel M., 172

Frank J., 431
WRIGHT continued

Frank Taylor, 358, 462, 521,661

G. B., 166

James H., 172

Lucius Gould, 411, 429, 433,476, a. c. a. Wright, Lucins $\mathrm{G}$.

William Elza, 349

WUESTHOF F

Leopold W., 394, a. c. a. Wuesteholf, L. W.

WURTELE

$$
\text { Fred J., 436, } 530
$$

WUSO

$$
\text { H. G. } 340
$$

WYANDT

Helen, 274, 283

WYATT

Merlin B., 345, 391

WYCOFE

Ray Sheppard, 424, 661

WYERHORST

Joseph, 431

WYNEGAR

David E., 288

Y.

YAGER

William Seth, 343, 661

YARD

$$
\text { Alfred G. , } 173
$$

YATES

Henry W., 58

Henry W. (Mrs. ), 478

Walter Sidney, 347,410 , 425,435

YEAKELE

William K., 345

YODER

Charles A., 423, 661

YOUNG

Alexander G., See Young,

G. Alexander

Alexander James, 661

Blaine Augustus, 411

Douglas B. , 396

Francis H. 357

Francis N., 470

Frank Booth, 233, p-233, $463,464,536,661$

George Alexander, p-278, $283,338,347,661$, a.c, a, Young, Alexander G.

George Alexander (Mrs.), 380

Glydon A., 661

J. M. 166

James Melvin, 661

Josiah, 358, 396, 446

Justiv J., , 467

Marcia Louise, 193, 195 , 347,661

Raymond A., 431, 445

William R., 424

YOUNGERMAN

John, 434

YOUNGMAN

J. W., $427,434,467$
YOUNGS

Fred M. , 335

YOUNGSTEDT

Magnus, 356

$\mathrm{z}$.

\section{ZAHORCHAK}

Joseph A., 288

ZALAZOWSKI

Frank L. . 347

ZARBAUGH

Guy Frederick, 411, 512, 66 .

H. R. (Mrs, ), 512

ZARP

$$
\text { E., } 166
$$

ZAWORSKY

Edward A., 345

ZELLERS

Moses Theodore, 148, 423, 661 ZEMER

Stanley Gillum, 359, 520, 521, 661

\section{ZIEGENHAGEN}

Jacob L. A., 465

ZIEGLER

Charles H., 428, 434, 661, a. c. a. Zieler, Chas. H.

Isidor, 493

William G. , 410

ZIELER

Chas. H., See Ziegler, Chas. B.

ZIELIE

J. M. , 457

ZIEROT'

Leroy L., 288

ZIMMERER

Charles G. , 661

Edmund George, 372, 518 , 662

ZIMMERMAN

Charles Francis, 387, 395 , 661, p-662

ZOERB

Edward Franklin, 444, 464, 662, a.c.a. Zoers, E, F.; ZOLL Zoerb, Edwin Franklin

Frank C., 470

ZULAUF

Walter Christian, 397, 410 , 414,662 